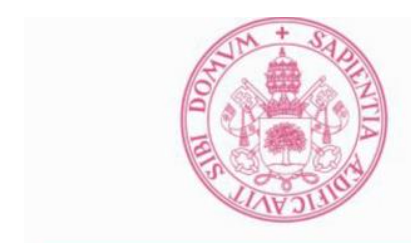

Universidad deValladolid

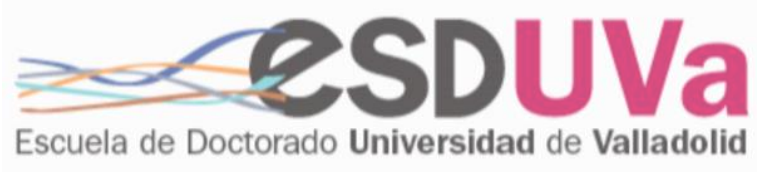

PROGRAMA DE DOCTORADO EN DERECHO

TESIS DOCTORAL:

\title{
DERIVACIÓN DE RESPONSABILIDAD AL ADMINISTRADOR SOCIAL DE DEUDAS DE SEGURIDAD SOCIAL DE LA SOCIEDAD DE CAPITAL
}

\author{
Presentada por:
}

Antonio Fernández Díez, para optar al grado de Doctor por la Universidad de Valladolid, Departamento de Derecho Mercantil, Trabajo e Internacional Privado

Directores de la Tesis:

Elías González-Posada Martínez

Ana María Murcia Clavería

Año 2021 



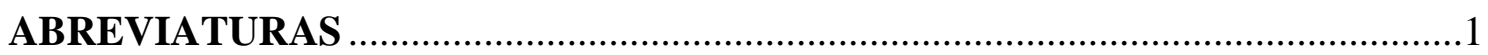

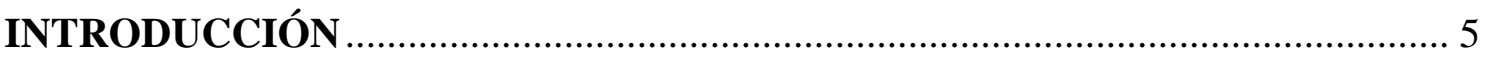

I PARTE:

RESPONSABILIDAD DEL ADMINISTRADOR EN DAÑOS Y EN DEUDAS DE SEGURIDAD SOCIAL

I CAPÍtULO:

RESPONSABILIDAD DEL ADMINISTRADOR EN DAÑOS Y EN

DEUDAS DE SEGURIDAD SOCIAL DE LA SOCIEDAD DE CAPITAL

I.- Los distintos supuestos de responsabilidades del administrador

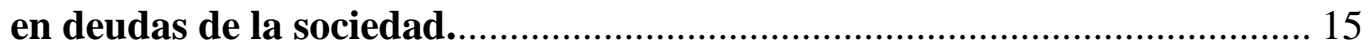

1. Responsabilidad ex lege por deudas de la sociedad....................................... 17

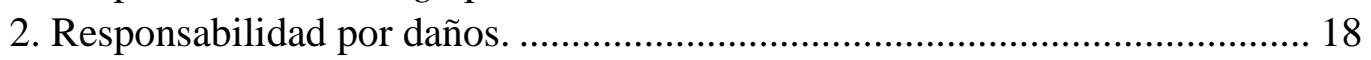

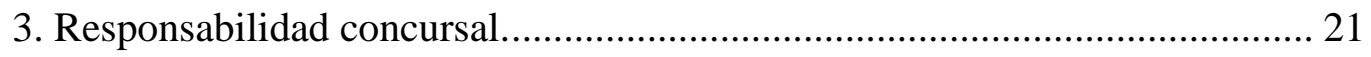

4. Responsabilidad por uso fraudulento de la personalidad jurídica. ................ 22

II.- La responsabilidad ex lege del administrador en deudas

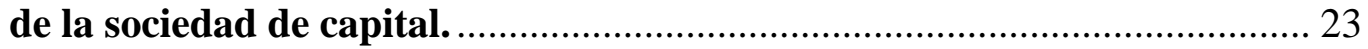

1. Principales supuestos normativos de responsabilidad solidaria del

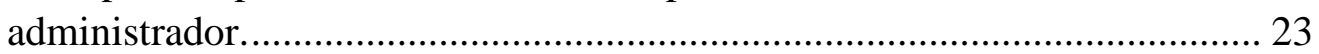

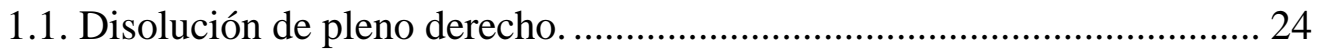

1.2. Disolución por causa legal o estatutaria................................................. 25

1.3. Falta de inscripción registral en plazo de la escritura de elevación del nuevo capital mínimo legal....................................... 27

2. Otros supuestos de responsabilidad solidaria o subsidiaria del socio

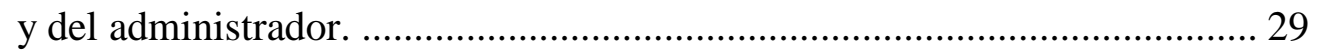

2.1. Sociedad en formación........................................................................... 30

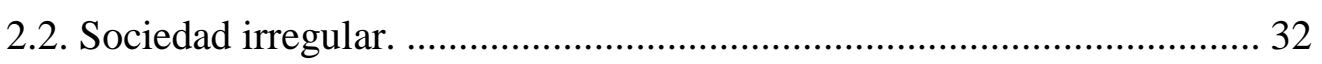

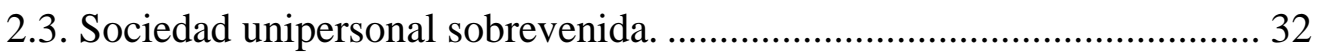

2.4. Responsabilidad en las transformaciones societarias........................... 33

III.- Deudas de Seguridad Social de la sociedad de capital exigibles al administrador.

1. Deudas por cotizaciones a la Seguridad Social y por cuotas

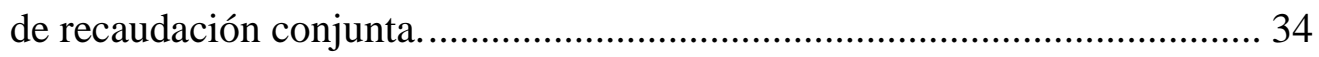

2. Deudas de la sociedad de capital por prestaciones de Seguridad Social. ....... 40

2.1. Deudas por prestaciones ante incumplimientos de normas de prevención de riesgos laborales. 
2.2. Deudas por responsabilidad empresarial en el reintegro de prestaciones indebidamente percibidas............................................... 46

2.3. Deudas de prestaciones de pago directo de la empresa.......................... 48

2.4. Deudas por prestaciones por incumplir la empresa obligaciones de encuadramiento y cotización a la Seguridad Social............................... 50

2.4.1. Responsabilidad por falta de alta o afiliación

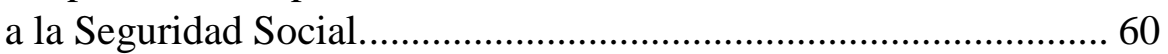

2.4.2. Responsabilidad por falta de cotización a la Seguridad Social. ...... 65

3. El recargo de prestaciones.

4. Responsabilidad del administrador en la deuda por sanciones de Seguridad Social de la sociedad de capital.

\section{CAPÍt ULO: \\ RESPONSABILIDAD POR DAÑOS DEL ADMINISTRADOR \\ EN DEUDAS DE SEGURIDAD SOCIAL. ACCIÓN SOCIAL E INDIVIDUAL DE RESPONSABILIDAD.}

I.- Fundamento y diferenciación jurídica de la acción social y

la acción individual de respondabilidad.

1. Fundamento y régimen jurídico de la responsabilidad por daños. ................. 81

2. Antecedentes normativos de la responsabilidad por daños

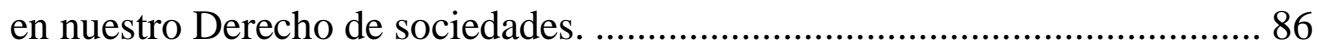

3. Diferenciación de la acción social y la individual........................................ 90

3.1. Diferenciación por el patrimonio perjudicado. ...................................... 90

3.2. Diferenciación por el régimen de sujetos legitimados

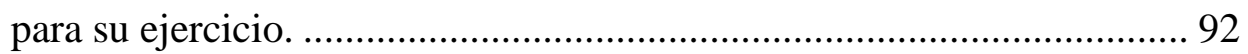

3.3. Diferenciación por el sujeto beneficiario de la acción. .......................... 93

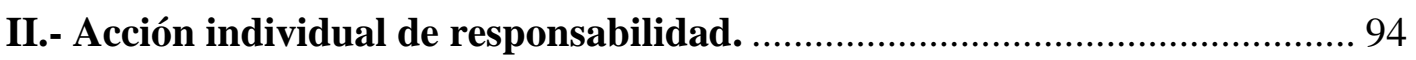

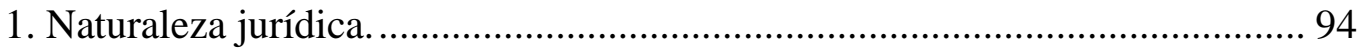

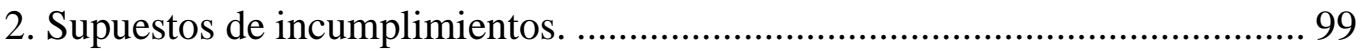

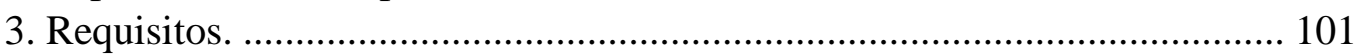

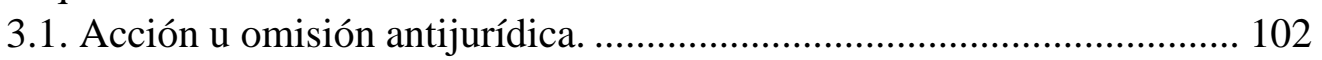

3.2. Culpabilidad o imputabilidad de la conducta del administrador........... 107

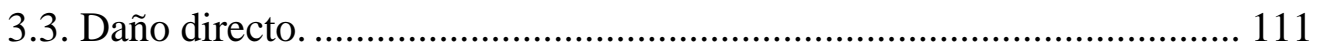

3.4. Relación de causalidad entre la acción y el daño................................ 113

4. Ámbito subjetivo de la acción individual de responsabilidad. ..................... 114

4.1. Administradores responsables............................................................ 114

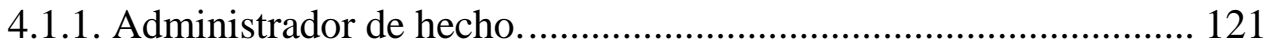

4.1.2 Administrador persona jurídica. ............................................... 129

4.1.3. Personal de alta dirección y apoderados generales....................... 139

4.1.4. Administradores responsables en los grupos de sociedades.......... 142

4.1.5. Administradores de sociedades mercantiles de capital del Estado..................................................................... 146

4.2. Imputabilidad de la responsabilidad y su exoneración......................... 155

4.3. Prescripción de la responsabilidad. ....................................................... 161 
III.- Acción individual de responsabilidad e incumplimiento de obligaciones sociales.

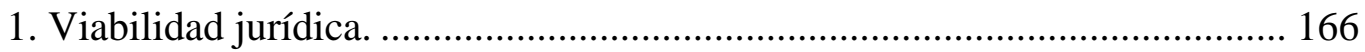

2. Acción individual por incumplimiento de deberes de una ley imperativa y su aplicabilidad a la Seguridad Social.

3. Acción individual ante incumplimientos dolosos del administrador de las obligaciones de la Seguridad Social.

3.1. Acción individual por incumplimiento de la obligación social en supuestos de graves deficiencias en la contabilidad social.

3.2. Acción individual ante la deliberada preterición y perjuicio de determinados acreedores

3.3. Acción individual por infracciones de las obligaciones de Seguridad Social.

4. Acción individual de responsabilidad por incumplimientos de deberes disolutorios y concursales.

4.1. Tipología de responsabilidades de los administradores por incumplimientos de esos deberes.

4.2 Acción individual o acción social en las crisis patrimoniales irreversibles de la sociedad.

4.3. Cierre de hecho y acción individual.

4.4. Acción individual por el impago de deudas de Seguridad Social en crisis patrimoniales societarias.

\section{IV.- Acción individual de responsabilidad por incumplimiento \\ de obligaciones laborales y de Seguridad Social.}

Daño al crédito de la Seguridad Social.

1. El crédito laboral y de Seguridad Social como objeto de la acción individual.

2. Tramitación administrativa o judicial de la acción individual de responsabilidad por los organismos públicos de la Seguridad Social.

3. Créditos de Seguridad Social.

3.1. Créditos del trabajador.

3.1.1. Prestaciones de responsabilidad directa empresarial. Recargo de prestaciones.

3.1.2 Prestaciones por incumplimiento de obligaciones de prevención de riesgos laborales.

3.1.3. Responsabilidad por incumplimiento de obligaciones de encuadramiento y cotización.

3.2. Créditos de las entidades gestoras y recaudadoras de la Seguridad Social.

3.2.1. Créditos por cotizaciones a la Seguridad Social.

3.2.2. Créditos por prestaciones de responsabilidad empresarial.

4. Jurisdicción competente ante una deuda de origen laboral y de

Seguridad Social.

4.1. Créditos Laborales y de Seguridad Social del trabajador. 
4.2. Créditos de las entidades gestoras de la Seguridad Social.................. 255

4.2.1. Créditos por cotizaciones a la Seguridad Social.......................... 255

4.2.2. Créditos por prestaciones de responsabilidad empresarial. ........... 256

V.- Relación entre acción individual y responsabilidad por deudas del administrador por crisis disolutoria.

1. Relación general de ambas acciones de responsabilidad ante acreedores privados

2. Relación entre la acción individual de responsabilidad por daños y la responsabilidad solidaria por deudas del administrador en materia de Seguridad Social.

VI.- Acumulación de la acción individual frente al administrador y la acción contra la sociedad por incumplimento de la obligación.

VII.- Efectos de la declaración del concurso de acreedores de la sociedad en la acción individual de responsabilidad.

\section{PARTE:}

LA DERIVACIÓN EX LEGE DE DEUDAS DE SEGURIDAD SOCIAL DE LA SOCIEDAD DE CAPITAL AL ADMINISTRADOR SOCIAL

\section{III' CAPÍTULO:}

DERIVACIÓN DE RESPONSABILIDAD POR CAUSA DE DISOLUCIÓN DE PLENO DERECHO

I.- Regulación legal y antecedentes normativos.

II.- Responsabilidad del administrador social.

\section{CAPÍTULO:}

\section{DERIVACIÓN DE RESPONSABILIDAD POR INCUMPLIMIENTOS DE}

DEBERES DISOLUTORIOS Y CONCURSALES

I.- La responsabilidad solidaria del administrador por causa legal de disolución.

1. Régimen Jurídico de la responsabilidad y sus antecedentes normativos..... 293

1.1. Régimen jurídico.

II.- Fundamento y naturaleza jurídica de la responsabilidad por deudas..... 314

1. Fundamento de la responsabilidad por deudas.

2. Naturaleza jurídica de la responsabilidad por deudas 


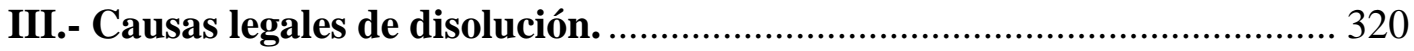

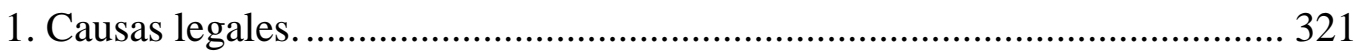

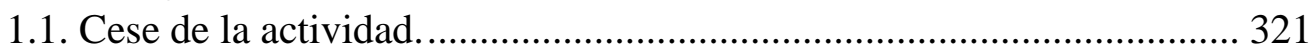

1.2. Conclusión del objeto social. .............................................................. 323

1.3. Imposibilidad de conseguir el fin social............................................ 325

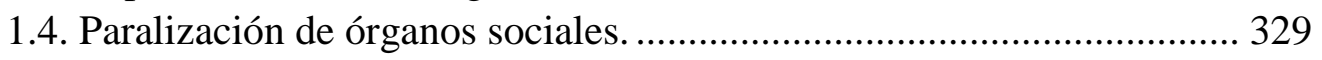

1.5. Reducción del capital social por debajo del mínimo legal.................... 331

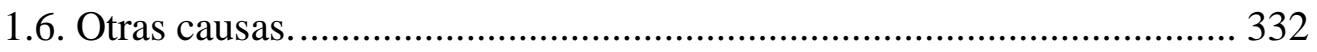

2. Especial referencia a la disolución por pérdidas cualificadas. …................. 336

2.1. Régimen jurídico y finalidad de la causa de disolución........................ 336

2.2. Relación entre el patrimonio neto y el capital social. .......................... 341

2.3. Efectos de la crisis sanitaria del Covid-19 en la causa de disolución. .. 348

IV.- Presupuestos objetivos de responsabilidad. Deberes incumplidos.......... 351

1. Acaecimiento y conocimiento de la causa de disolución. ........................... 353

1.1. Acaecimiento de las diversas causas de disolución. ............................ 355

1.2. Acaecimiento de las pérdidas cualificadas.......................................... 357

2. Deber de convocar la Junta o solicitar el concurso....................................... 362

2.1. Convocatoria de la Junta General...................................................... 362

2.2. Solicitud del concurso de acreedores ..................................................... 374

2.2.1. Solicitud de medidas preconcursales........................................... 380

3. Deber de solicitar la disolución judicial o el concurso. ................................ 383

3.1. Solicitud de la disolución judicial. .................................................... 383

3.2. Solicitud del concurso de acreedores y medidas preconcursales. ......... 390

4. Medidas alternativas. Remoción de la causa de disolución........................... 392

4.1. Adopción por la Junta y su plazo de ejecución. .................................... 393

4.2. Determinación de las medidas de remoción.......................................... 398

5. Cumplimiento tardío de los deberes generadores de responsabilidad. ......... 405

6. La falta de solicitud de concurso como presupuesto de

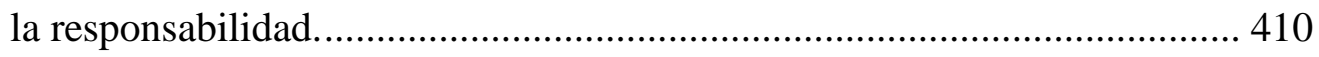

V.- Ámbito objetivo de responsabilidad. Deudas de Seguridad Social anteriores y posteriores. .......................................................................... 413

VI.- Ámbito subjetivo de la responsabilidad.................................................. 429

1. Administradores responsables. Delimitación de los sujetos responsables. .. 429

1.1. Administrador de hecho. .............................................................. 432

1.2. Administrador persona jurídica........................................................ 434

1.3. Personal de alta dirección y gerentes. ................................................. 439

1.4. Apoderados generales y otros representantes voluntarios.................... 441

1.5. Administrador fallecido................................................................... 442

1.6. Administrador de la sociedad dominante y responsabilidades

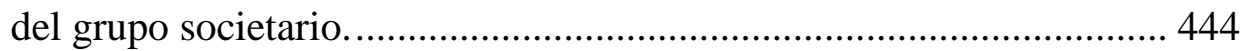

1.7. Consejero empleado público de la sociedad de capital estatal............. 453

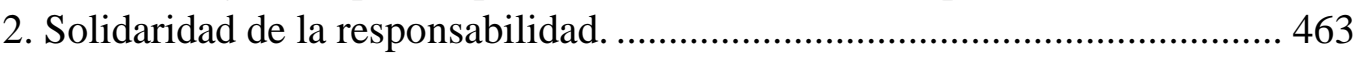

3. Nacimiento, duración y extinción de la responsabilidad.............................. 468 
3.1. Nombramiento, aceptación e inscripción registral.............................. 468

3.2. Cese y caducidad del cargo. Efectos de la inscripción registral............ 470

3.3. Efectos de la sucesión de administradores en la

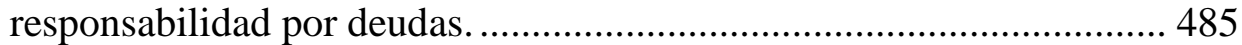

4. Exoneración de responsabilidad. Imputabilidad del administrador............... 490

5. La buena fe en la moderación o exención de responsabilidad del administrador en la responsabilidad solidaria por deudas del art. 367 de la LSC.

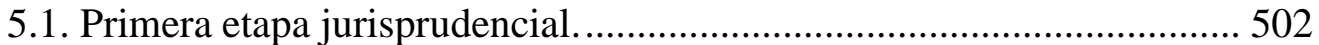

5.2. Segunda etapa jurisprudencial............................................................ 503

VII.- Ámbito temporal de la responsabilidad y su prescripción.................... 504

VIII.- Subsistencia de las deudas de Seguridad Social de la sociedad

disuelta, liquidada y extinguida. Sujetos responsables.

1. Responsabilidad del liquidador y de los socios de la sociedad disuelta y extinguida.

2. Responsabilidad en la sociedad extinguida. Sentencia del

TS 324/2017, de 24 de mayo.

IX.- Efectos de la declaración del concurso de acreedores de

la sociedad en la responsabilidad del administrador.

\section{Vo CAPÍtULL:}

OTROS SUPUESTOS DE DERIVACIÓN DE RESPONSABILIDAD AL ADMINISTRADOR DE DEUDAS DE LA SOCIEDAD DE CAPITAL

I.- Responsabilidad en la sociedad en fase de constitución........................... 539

1. Régimen jurídico de la responsabilidad.................................................... 539

2. Derivación administrativa de responsabilidad............................................ 552

3. Antecedentes normativos de la responsabilidad......................................... 566

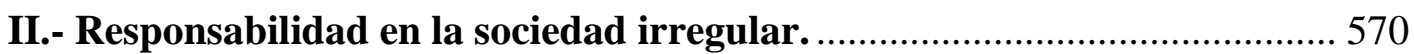

1. Régimen jurídico de la responsabilidad..................................................... 570

2. Derivación administrativa de responsabilidad.......................................... 578

3. Antecedentes normativos de la responsabilidad....................................... 583

III.- Responsabilidad en la Sociedad unipersonal sobrevenida. ....................584

1. Régimen jurídico de la responsabilidad....................................................584

2. Derivación administrativa de responsabilidad........................................... 587

3. Antecedentes normativos de la responsabilidad...................................... 589

IV.- Responsabilidad en las transformaciones societarias.............................589

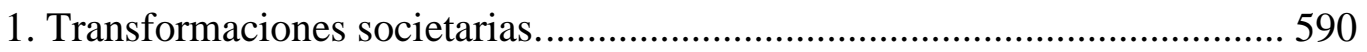

1.1. Transformación de sociedades con responsabilidad limitada en sociedades de responsabilidad ilimitada. 
1.2. Transformación de sociedades con responsabilidad ilimitada en sociedades de responsabilidad limitada............................................. 594

2. Derivación administrativa de responsabilidad............................................. 595

\section{V.- Responsabilidad del administrador social por}

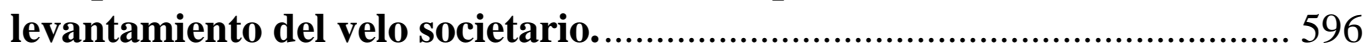

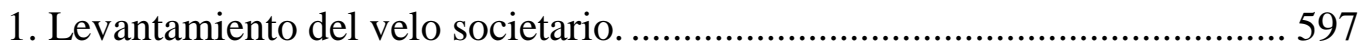

2. Responsabilidad del socio de control-administrador.................................. 602

VI.- Responsabilidad concursal no derivable del administrador social de la sociedad en concurso de acreedores.

VII.- La insuficiente regulación de la responsabilidad del administrador social en las deudas de Seguridad Social de la sociedad de capital.

1. Régimen jurídico de responsabilidad de los administradores por incumplimientos de disposiciones de Seguridad Social.

2. Régimen jurídico de responsabilidad de los administradores por incumplimiento de los deberes orgánicos de la legislación de sociedades.

3.- Régimen de responsabilidad en los grupos de sociedades: empresa grupo y grupo patológico.

\section{CAPÍTULO:}

\section{PROCEDIMIENTO ADMINISTRATIVO DE DERIVACIÓN DE DEUDAS DE SEGURIDAD SOCIAL AL ADMINISTRADOR SOCIAL}

I.- Derivación administrativa de la responsabilidad al administrador social.

1. La declaración y la derivación administrativa de responsabilidad.

Autotutela administrativa

1.1. Declaración y derivación administrativa de responsabilidad. 635

1.2. Autotutela administrativa.

2. Régimen jurídico de la derivación administrativa de responsabilidad al administrador social.

3. Antecedentes normativos.

3.1. Irretroactividad de la reforma de la Ley 52/2003, de 10 de diciembre.

II.- Competencia para derivar la responsabilidad del administrador en el procedimiento administrativo de recaudación.

1. Derivación de deudas por cuotas al administrador social.

1.1. Distribución de competencias entre la TGSS y la ITSS. 684

2. Derivación de deudas por prestaciones al administrador social. 696

2.1. La derivación del recargo de prestaciones. 
III.- Aspectos comunes esenciales del procedimiento administrativo de derivación de responsabilidad.

1. Normativa reguladora del procedimiento administrativo de

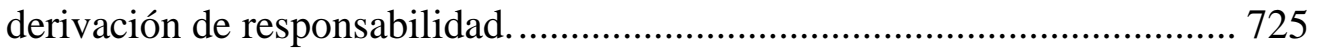

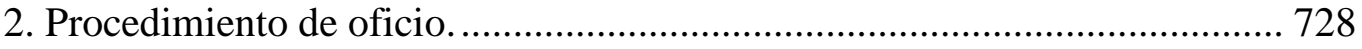

3. Carácter contradictorio del procedimiento. Comunicación de inicio y audiencia al administrador social.

4. Medidas cautelares en el procedimiento de derivación de responsabilidad.

5. Motivos de oposición del administrador social a la derivación administrativa de responsabilidad.

6. Prejudicialidad penal. Efectos del proceso penal en la derivación de deudas.

7. La caducidad del procedimiento administrativo de derivación de responsabilidad.

7.1. Caducidad de la derivación de la TGSS........................................... 756

7.2. La caducidad de la actividad previa de comprobación de la ITSS........ 757

7.3. Caducidad del procedimiento de derivación iniciado con acta de liquidación.

8. La ejecutividad y la no suspensión del pago de la deuda objeto de la derivación administrativa de responsabilidad.

9. Suspensión del procedimiento de derivación de responsabilidad por aplazamiento de la deuda de la sociedad de capital.

\section{IV.- Derivación administrativa de responsabilidad solidaria}

y subsidiaria.

V.- Procedimiento derivación de responsabilidad de deudas por la

Tesorería de la Seguridad Social.

\section{VI.- Derivación de responsabilidad de deudas por cuotas por la} inspección de trabajo y Seguridad Social: actas de liquidación, requerimientos de cuotas e informes.

1. Actuaciones de la Inspección de Trabajo y Seguridad Social en materia de liquidación de cuotas de Seguridad Social.

2. Actividad inspectora previa de comprobación, naturaleza jurídica y contenido.

3. Acta de liquidación de cuotas de derivación de responsabilidad. ................. 798

3.1. Requisitos generales de las actas de liquidación.

3.2. Requisitos particulares de las actas de derivación de responsabilidad.

3.3. Presunción de certeza de las actas de la Inspección.

3.4 Tramitación del acta de liquidación, resolución y recursos.

3.4.1. Tramitación del acta de liquidación.

3.4.2. Resolución.

3.4.3. Recursos. 
5. Informe a la TGSS en materia de derivación de responsabilidad................. 842

6. Informe al Ministerio Fiscal. ...................................................................... 845

CONCLUSIONES Y PROPUESTA DE LEGE FERENDA .................................849

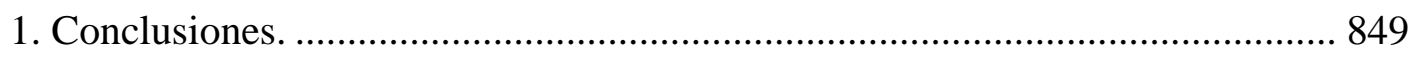

2. Propuestas de lege ferenda en la responsabilidad del administrador y en la derivación de responsabilidad............................................................ 855

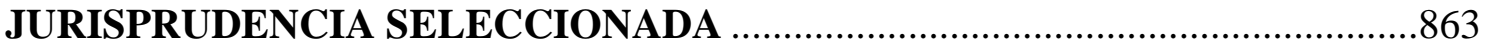

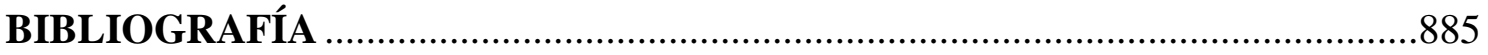





\section{ABREVIATURAS}

- Art.: Artículo.

- Arts.: Artículos.

- BOE: Boletín Oficial del Estado.

- BORNE: Boletín Oficial del Registro Mercantil.

- CE: Constitución Española.

- C. Civil: Código Civil.

- CEE: Comunidad Económica Europea.

- DGITSS: Dirección General de la Inspección de Trabajo y Seguridad Social.

- DGRN: Dirección General de Registros y el Notariado.

- DOUE: Diario Oficial de la Unión Europea.

- D.F.: Disposición final.

- D.T.: Disposición Transitoria.

- ERE: Expediente de regulación de empleo.

- FOGASA: Fondo de Garantía Salarial.

- INSS: Instituto Nacional de la Seguridad Social.

- IPREM: Indicador público de rentas de efectos múltiples.

- ISM: Instituto Social de la Marina.

- ITSS: Inspección de Trabajo y Seguridad Social.

- LC: Ley Concursal de 2003.

- LEC: Ley de Enjuiciamiento Civil.

- LETT: Ley de Empresas de Trabajo Temporal.

- LGP: Ley General Presupuestaria.

- LGT: Ley General Tributaria.

- LJCA: Ley Reguladora de la Jurisdicción Contencioso-Administrativa.

- LJV: Ley de Jurisdicción Voluntaria.

- LOITSS: Ley Ordenadora del Sistema de Inspección de Trabajo y Seguridad Social.

- LOPJ: Ley Orgánica del Poder Judicial. 
- LPACAP: Ley del Procedimiento Administrativo Común de las Administraciones Públicas.

- LPAP: Ley de Patrimonio de las Administraciones Públicas.

- LRJSP: Ley del Régimen Jurídico del Sector Público.

- LPRL: Ley de Prevención de Riesgos Laborales.

- LRJS: Ley Reguladora de la Jurisdicción Social.

- LSA: Texto Refundido de la Ley de Sociedades Anónimas.

- LSC: Texto Refundido de la Ley de Sociedades de Capital.

- LSRL: Ley de Sociedad de Responsabilidad Limitada.

- OEITSS: Organismo Estatal Inspección de Trabajo y Seguridad Social.

- O.M.: Orden Ministerial.

- Rcud: Recurso de Casación de Unificación de Doctrina

- R.D.: Real Decreto.

- RDGRN: Resolución de la Dirección General de Registros y el Notariado.

- Rec.: Recurso.

- RGCSS: Reglamento General sobre Cotización y liquidación de otros derechos de la Seguridad Social.

- RGIASS: Reglamento General de Inscripción de empresas, afiliación, altas, bajas y variación de datos de los trabajadores en Seguridad Social.

- RGRSS: Reglamento General de Recaudación de la Seguridad Social.

- RGSS: Régimen General de la Seguridad Social.

- RISOS: Reglamento General sobre Procedimiento para la Imposición de Sanciones por Infracciones del Orden Social y para los Expedientes Liquidatorios de cuotas de Seguridad Social.

- RM: Registro Mercantil.

- ROFITSS: Reglamento de Organización y Funcionamiento de la Inspección de Trabajo y Seguridad Social.

- RRM: Reglamento del Registro Mercantil.

- SEPE: Servicio Público de Empleo Estatal.

- SLD: Sistema de liquidación directa.

- SSTC: Sentencias del Tribunal Constitucional.

- SSTS: Sentencias del Tribunal Supremo.

- STC: Sentencia del Tribunal Constitucional. 
- STS: Sentencia del Tribunal Supremo.

- STJUE: Sentencia del Tribunal de Justicia de la Unión Europea.

- TGSS: Tesorería General de la Seguridad Social.

- TJUE: Tribunal de Justicia de la Unión Europea.

- TRLC: Texto Refundido de la Ley Concursal.

- TRLET: Texto Refundido de la Ley del Estatuto de los Trabajadores.

- TRLGSS: Texto Refundido de la Ley General de la Seguridad Social.

- TRLISOS: Texto Refundido de la Ley de Infracciones y Sanciones en el Orden Social. 



\section{INTRODUCCIÓN}

\section{Justificación y finalidad.}

Con la presente tesis doctoral pretendemos abordar la problemática jurídica y las deficiencias con que se encuentra el operador jurídico, especialmente la Tesorería General de la Seguridad Social y el Organismo Estatal Inspección de Trabajo y Seguridad Social, para reclamar o derivar a los administradores sociales la responsabilidad en el pago de las deudas a la Seguridad Social de la sociedad de capital, sean deudas por prestaciones o por cotizaciones.

A diferencia de otros órdenes normativos en los que se prevé expresamente la responsabilidad solidaria o subsidiaria del administrador social en el pago de obligaciones de la sociedad de capital, como sucede en materia tributaria, en nuestro Derecho de Seguridad Social no existen disposiciones que impongan directamente al administrador un régimen propio y específico de responsabilidad en el pago de las deudas con la Seguridad Social de la sociedad de capital. No existen referencias directas y expresas a los administradores sociales en materia de responsabilidad por deudas de Seguridad Social de la sociedad de capital.

Ante esa ausencia de regulación expresa de la responsabilidad del administrador social, trataremos de examinar qué instrumentos jurídicos nos ofrece el Derecho de la Seguridad Social para derivar o extender la responsabilidad al administrador social en el pago de deudas con la Seguridad Social de la sociedad de capital, teniendo en cuenta que es el administrador quien tiene atribuida la dirección, gestión y representación de la sociedad en el tráfico jurídico, por lo que participa muy activamente en la generación de las deudas de Seguridad Social de la sociedad de capital, correspondiendo al operador jurídico reflexionar acerca de la posibilidad de extender esa responsabilidad utilizando instrumentos normativos indirectos de derivación de la responsabilidad.

Es esa ausencia de un régimen propio y específico de responsabilidad del administrador social en las deudas de Seguridad Social de la sociedad de capital, la que nos permitirá ir ofreciendo al operador jurídico instrumentos indirectos de reclamación de deudas de Seguridad Social. 
Son escasas las contribuciones doctrinales dedicadas al estudio de esta modalidad de derivación administrativa de responsabilidad del administrador social, por lo que con esta tesis deseamos contribuir a profundizar en su estudio, coadyuvando a poner claridad en un asunto de tanta relevancia para los administradores sociales y para las Instituciones de la Seguridad Social.

Esta investigación tiene como finalidad esencial alumbrar los posibles instrumentos jurídicos que ofrece nuestro ordenamiento para exigir la responsabilidad por deudas, poniendo de manifiesto las carencias existentes, para finalizar proponiendo las reformas de lege ferenda que subsanen esas deficiencias técnicas, y concluyendo con la necesidad de abordar la regulación de un sistema propio y específico de responsabilidad del administrador social en las deudas de Seguridad Social de la sociedad de capital por incumplimientos imputables de las obligaciones con la Seguridad Social de la sociedad de capital, que permita cubrir el vacío normativo actualmente existente.

\section{Objetivos e interés de la investigación.}

Ante la ausencia de una regulación directa de la responsabilidad del administrador social en el pago de las deudas con la Seguridad Social de la sociedad de capital, examinaremos qué posibilidades nos ofrecen los apartados 3 y 4 del artículo 18 del Real Decreto Legislativo 8/2015, de 30 de octubre, que aprueba el Texto Refundido de la Ley General de la Seguridad Social -en adelante TRLGSS-, para fundamentar jurídicamente la responsabilidad del administrador social en el pago de esas deudas.

El núcleo esencial de nuestra investigación se centrará en la derivación administrativa de responsabilidad partiendo del precitado artículo 18 apartados 3 y 4 del TRLGSS. Procedimiento de derivación administrativa de responsabilidad que ofrece mayor eficiencia y celeridad en la gestión recaudatoria, frente a una eventual reclamación judicial, al estar regido por los principios de ejecutividad y ejecutoriedad propios de la autotutela administrativa.

En primer lugar, trataremos de identificar los supuestos normativos que permitan fundamentar jurídicamente la responsabilidad ex lege del administrador, solidaria o subsidiaria, en las deudas de Seguridad Social de la sociedad de capital, para exigir su pago mediante la derivación administrativa de responsabilidad. En el artículo 18.3 del TRLGSS se regula, de modo indirecto, el régimen jurídico de derivación de responsabilidad solidaria o subsidiaria del administrador en el pago de las deudas de la 
Seguridad Social de la sociedad de capital, sean deudas de cotizaciones o de otros recursos económicos de Seguridad Social (responsabilidad ex lege en deuda ajena). Esa disposición legal es una norma de remisión en blanco de la responsabilidad en materia de deudas de Seguridad Social, ya que no determina expresamente las terceras personas responsables, ni los supuestos en que nace la responsabilidad solidaria o subsidiaria en el pago de las deudas de Seguridad Social de la sociedad de capital, obligándonos a acudir a otros órdenes normativos, principalmente al Derecho mercantil, y dentro de él al Derecho de sociedades, lo que exige analizar el alcance material, objetivo, subjetivo y temporal de los supuestos de responsabilidad del administrador social atribuibles a su actuación orgánica, para determinar su aplicación en las deudas de Seguridad Social de la sociedad de capital.

En segundo lugar, en el art. 18.4 del TRLGSS se prevé exigir la responsabilidad en el pago de deudas por cotizaciones de Seguridad Social, no al empresario formal, sino al empresario real, lo que nos permitirá exigir en vía administrativa la responsabilidad al administrador-socio de control en los supuestos de uso fraudulento de la personalidad jurídica de la sociedad de capital (teoría del levantamiento del velo), y en los supuestos de empresa grupo o grupos patológicos, o al empresario plural en el ámbito de las Administraciones Públicas.

La responsabilidad ex lege en deuda ajena del administrador social en el pago de las deudas por cotizaciones o por prestaciones de Seguridad Social de la sociedad de capital del artículo 18.3 del TRLGSS, a través del procedimiento administrativo de recaudación, nos obligará a dilucidar, en atención a la naturaleza de las diversas deudas de Seguridad Social y a la función gestora o inspectora desarrollada, cuándo la derivación de responsabilidad será competencia de la Tesorería General de la Seguridad Social -en adelante TGSS-, del Organismos Estatal de Inspección de Trabajo y Seguridad Social -en adelante OEITSS-, y de las entidades gestoras de la Seguridad Social. En la derivación de deudas por cotizaciones, analizaremos cuándo la competencia es de la TGSS, y cuándo es de la ITSS. De igual modo, en deudas por prestaciones, trataremos de fijar postura acerca de cuándo la derivación de deudas al administrador social deberá ser competencia de la entidad gestora de las prestaciones, y cuándo de la TGSS, para lo que consideramos elemento decisorio si con la derivación de responsabilidad nos hallamos ante un acto de gestión de prestaciones o ante un acto 
de gestión recaudatoria, mereciendo una reflexión aparte la competencia para derivar, en su caso, el recargo de prestaciones.

La reclamación de la responsabilidad del administrador social mediante la derivación administrativa de responsabilidad que nos permite el artículo 18 apartados 3 y 4 del TRLGSS, no agota otras posibles vías de reclamación de deudas de Seguridad Social de la sociedad de capital al administrador social.

Conjuntamente con la derivación administrativa de responsabilidad existirán otros dos supuestos de responsabilidad del administrador que podrán ser de aplicación para reclamar determinadas deudas de Seguridad Social de la sociedad. Por un lado, estará la reclamación de responsabilidad por daños a través de la acción individual de responsabilidad, y, por otro lado, la responsabilidad concursal impuesta al administrador en el proceso concursal de la sociedad de capital. Responsabilidades ambas que serán objeto de análisis teniendo en cuenta que no serán la fuente principal y directa de reclamación de las deudas de Seguridad Social, por dos razones. En primer lugar, porque no son objeto de reclamación en el procedimiento administrativo de recaudación, sino que deberán ser exigidas en vía judicial, por lo que no serán de aplicación los principios de ejecutividad y ejecutoriedad de los actos administrativos. En segundo lugar, porque, para que pueda obtenerse la declaración de responsabilidad por daños o de la responsabilidad concursal, se exige mayor carga probatoria que la exigida en la derivación de responsabilidad "ex lege" en deuda ajena. Consecuencia inmediata de ello será que la TGSS se sirva de la derivación administrativa de responsabilidad para reclamar al administrador social la responsabilidad en las deudas de la sociedad, no recabando prácticamente la responsabilidad por daños, y beneficiándose sólo indirectamente de la responsabilidad concursal cuando sea parte de la masa pasiva del concurso de la sociedad y se haya declarado por el juez mercantil la responsabilidad concursal del administrador, participando con el resto de los acreedores en el disfrute del beneficio derivado de la condena a la cobertura del déficit patrimonial con cargo a los administradores impuesta en la sentencia de calificación del concurso.

\section{Grado de innovación.}

Con esta tesis se aborda un tratamiento unitario y con vocación totalizadora de los distintos supuestos de responsabilidad del administrador en las deudas de Seguridad Social de la sociedad de capital, que admite actualmente nuestro ordenamiento jurídico, 
con dedicación preferente a la derivación administrativa de responsabilidad, para terminar abogando por las reformas necesarias que permitan ir avanzando en un sistema propio de responsabilidad por incumplimientos imputables del administrador de las obligaciones con la Seguridad Social de la sociedad de capital.

Desde el año 2004, y como reacción a la jurisprudencia que excluía la autotutela administrativa, el legislador introdujo un régimen indirecto y general de responsabilidad de terceros en deudas de Seguridad Social (art. 18.3 del TRLGSS), que ha permitido derivar al administrador social la responsabilidad en las deudas de la sociedad de capital acudiendo al Derecho de sociedades. Ello no obstante, queda un siguiente hito en el camino a recorrer para la extensión de la responsabilidad del administrador social en esas deudas, que culminará con la regulación del régimen específico de responsabilidad del administrador por incumplimiento de las obligaciones de Seguridad Social, tal y como ya han hecho otros ordenamientos internos reguladores de la exacción de recursos públicos, como el Derecho tributario, régimen específico que acabaremos proponiendo en esta tesis doctoral.

\section{Alcance y contenido de la investigación.}

Para delimitar y enmarcar correctamente el actual régimen jurídico de la derivación administrativa de responsabilidad al administrador social en el pago de las deudas de Seguridad Social de la sociedad de capital, delimitaremos los distintos supuestos de responsabilidad en los que puede incurrir el administrador social regulados en el Derecho mercantil, para determinar su naturaleza jurídica, su ámbito material de aplicación, y poder concluir acerca de la procedencia o improcedencia de la derivación administrativa de la deuda en cada una de esas modalidades de responsabilidad.

Para este cometido analizaremos cuatro supuestos de responsabilidad del administrador, que tendrán naturaleza, fundamento legal y régimen jurídico distinto: a) la responsabilidad "ex lege" por deuda ajena impuesta legalmente al administrador social; b) la responsabilidad por daños que podrá ser recabada mediante la acción individual de responsabilidad; c) la responsabilidad concursal del administrador; y d) la responsabilidad por el uso fraudulento de la personalidad jurídica de la sociedad de capital.

Para tener un exhaustivo conocimiento del contenido y del alcance de la responsabilidad del administrador social en el pago de las deudas de Seguridad Social de la sociedad de 
capital, deberemos examinar qué tipo de deudas serán susceptibles de reclamación al administrador social. Si sólo se reclamarán las deudas por cotizaciones, si se extiende a las deudas por prestaciones de responsabilidad empresarial, o también a otros recursos económicos de Seguridad Social, como el recargo de prestaciones de Seguridad Social y las deudas pecuniarias por infracciones de Seguridad Social impuestas a la sociedad de capital.

\section{Estructura de la investigación.}

La investigación se estructura en dos partes con una introducción, seis capítulos, unas conclusiones con propuestas de lege ferenda, una selección de las sentencias más relevantes de la numerosa jurisprudencia utilizada, y finalmente la bibliografía consultada. La primera parte, se dedica al estudio genérico de los diversos supuestos legales de responsabilidad del administrador, y a la responsabilidad por daños (capítulos primero y segundo respectivamente). La segunda parte de la tesis (capítulos tercero al sexto), estará destinada al estudio de los supuestos de responsabilidad ex lege del administrador social en las deudas de Seguridad Social de la sociedad de capital, mediante la derivación administrativa de responsabilidad.

En el capítulo primero se hará una reseña general acerca de los diversos supuestos legales de responsabilidad en que podrán incurrir los administradores sociales, analizando cuáles serán las deudas de Seguridad Social de la sociedad de capital que podrá reclamarse a los mismos.

En el capítulo segundo se destina al examen en profundidad de la responsabilidad por daños, y dentro de la misma, a la acción individual de responsabilidad, en cuanto instituto jurídico que permitirá reclamar judicialmente al administrador el daño directo causado con su actuación orgánica en los créditos de la Seguridad Social. Acción individual de responsabilidad que podrá ser viable jurídicamente en los supuestos de daño directo causado a los derechos de crédito de la Seguridad Social, especialmente en tres supuestos. En primer lugar, cuando el daño a esos créditos sea debido a comportamientos dolosos de los administradores, por incumplir de modo deliberado y persistente las obligaciones con la Seguridad Social de la sociedad de capital en materia de encuadramientos, afiliaciones, altas y cotizaciones a la Seguridad Social. En segundo lugar, en supuestos de preterición del pago de deudas de Seguridad Social atendiendo otras deudas de menor prelación. Y, en tercer lugar, en los supuestos de cierre de hecho 
de la empresa consecuencia del cual se deja pendiente de pago un número importante de deudas de Seguridad Social.

El grueso de la investigación los constituye la parte segunda de la tesis que se dedicará a la derivación administrativa de las deudas de Seguridad Social de la sociedad de capital al administrador social, en sus aspectos sustantivos (capítulos tercero al quinto, ambos inclusive) y adjetivo o procedimental (capítulo sexto).

En el capítulo tercero se abordará la responsabilidad del administrador social en las deudas de Seguridad Social en los supuestos de disolución de pleno derecho de la sociedad.

El capítulo cuarto se dedicará a estudiar con profusión el supuesto que generará una mayor derivación de deudas de Seguridad Social al administrador, que es la responsabilidad solidaria en las deudas de la sociedad de capital ante la concurrencia de una causa legal de disolución, analizando las diversas causas de disolución, especialmente la de pérdidas cualificadas y su relación con la insolvencia como causa de concurso, los presupuestos objetivos de responsabilidad, así como los ámbitos subjetivos, materiales y temporales de responsabilidad por deudas.

En el capítulo quinto se abordarán otros supuestos legales de derivación administrativa de deudas de Seguridad Social al administrador social, como la responsabilidad en la sociedad en formación, en la sociedad irregular, en las transformaciones societarias; la responsabilidad del administrador por levantamiento del velo societario; y concluiremos con la necesidad de avanzar hacia un régimen propio y específico de responsabilidad del administrador en deudas de Seguridad Social de la sociedad, complementario al actualmente existente.

El capítulo sexto se dedicará íntegramente al estudio del procedimiento administrativo de derivación de responsabilidad al administrador social de las deudas por cotizaciones y por prestaciones de la sociedad de capital, determinando los organismos o entidades públicas con competencias en la derivación de responsabilidad.

Se concluirá esta tesis con una serie de conclusiones y con varias propuestas de "lege ferenda", con las que se pretenden ofrecer posibles soluciones para ampliar y mejorar el régimen jurídico de la derivación administrativa de responsabilidad de los 
administradores en las deudas con la Seguridad Social de la sociedad de capital, ante las deficiencias legales y vacíos normativos advertidos.

Finalmente recogeremos una selección de sentencias, especialmente del Tribunal de Justicia de la Unión Europa, del Tribunal Constitucional y del Tribunal Supremo, que destacamos como más relevantes en la investigación, de entre la numerosa jurisprudencia consultada y analizada a lo largo de la tesis doctoral.

\section{Fuentes y metodología de la investigación.}

Para la elaboración del trabajo de investigación se partirá de la normativa vigente (método jurídico sistemático), acudiendo a los antecedentes normativos para su contextualización (método de investigación histórica), dedicando una atención preferente a nuestro ordenamiento jurídico de Seguridad Social y de Sociedades, acudiendo cuando sea preciso a otras ramas del Derecho en las que se imponga la responsabilidad del administrador, como el Derecho tributario, con la finalidad de realizarse un estudio comparativo del diverso alcance de la responsabilidad (método analítico e interdisciplinario).

Igualmente, tendrá un tratamiento relevante en esta investigación el estudio de la jurisprudencia en cuanto fuente complementaria del nuestro ordenamiento jurídico, así como la doctrina judicial en ausencia de aquélla.

Prestaremos a la doctrina científica atención destacable, ya que, por un lado, en ausencia de jurisprudencia ayudará al operador jurídico en la interpretación e integración jurídica, orientando al legislador, y por otro lado, porque nos permitirá analizar el alcance, deficiencias o insuficiencias tanto del ordenamiento jurídico como de la jurisprudencia, para proponer cambios normativos al legislador (método jurídico doctrinal).

Igualmente, se expondrá la doctrina administrativa relevante en materia de derivación de responsabilidad de deudas con la Seguridad Social.

La mención al Derecho comunitario (método jurídico comparativo) tendrá carácter residual en el núcleo esencial de la investigación, al no existir instrumentos normativos supranacionales o comunitarios reguladores de la responsabilidad en las deudas de Seguridad Social de los administradores sociales, ni armonización de los sistemas de recaudación de recursos de los sistemas de Seguridad Social, reseñando la colaboración 
de los Estados de la Unión Europea en la ejecución de los títulos ejecutivos de Seguridad Social. 

I PARTE:

\section{RESPONSABILIDAD DEL ADMINISTRADOR EN DAÑOS Y EN DEUDAS DE SEGURIDAD SOCIAL}

\section{CAPÍtULO:}

\section{RESPONSABILIDAD DEL ADMINISTRADOR EN DAÑOS Y EN DEUDAS DE SEGURIDAD SOCIAL DE LA SOCIEDAD DE CAPITAL}

\section{I.- LOS DISTINTOS SUPUESTOS DE RESPONSABILIDADES DEL ADMINISTRADOR EN DEUDAS DE LA SOCIEDAD.}

En nuestro ordenamiento de Seguridad Social no existe una regulación propia acerca del régimen jurídico de responsabilidad del administrador social en las deudas de Seguridad Social de la sociedad de capital, pese a ser éstos quienes en último término dirigen y organizan, directa o indirectamente, las relaciones laborales en el ámbito de la empresa, con lo que, en buena medida, determinados incumplimientos laborales y de Seguridad Social de la sociedad de capital serán atribuibles a la actuación orgánica de aquéllos.

Ante esta ausencia de un régimen jurídico propio de responsabilidad de los administradores, en nuestro ordenamiento jurídico hemos de acudir a la actual regulación del artículo 18 apartados 3 y 4 del TRLGSS para poder atribuir una responsabilidad solidaria o subsidiaria al administrador social en el cumplimiento de obligaciones de Seguridad Social propias de la sociedad de capital. Preceptos normativos que establecen una regulación genérica de responsabilidad solidaria o subsidiaria de sujetos distintos al empresario real o formal.

En el artículo 18.3 del TRLGSS nos encontramos con una norma que, partiendo de la responsabilidad directa de la empresa sociedad de capital, establece genéricamente otros posibles sujetos responsables solidarios o subsidiarios de deudas con la Seguridad Social, cuando una disposición con rango de ley imponga a terceras personas una responsabilidad en el pago de las deudas u obligaciones por concurrir determinados 
hechos, omisiones o actos jurídicos generadores de responsabilidad, siempre que no se hayan excluido expresamente las obligaciones de Seguridad Social. Estamos ante una norma de remisión en blanco en materia de responsabilidad solidaria o subsidiara en las deudas de Seguridad Social, que nos obligará a acudir al régimen jurídico de responsabilidad establecido en sectores normativos ajenos al Derecho de la Seguridad Social, principalmente al Derecho mercantil y de sociedades, que no necesariamente se rigen por sus mismos principios inspiradores, siendo necesario analizar la jurisprudencia dictada por el orden jurisdiccional civil.

Finalmente, en el artículo 18.4 del TRLGSS se contempla una especificación de la doctrina del levantamiento del velo en el pago de la obligación de cotizar a la Seguridad Social, al establecerse que la deuda podrá ser reclamada a quien realmente reciba la prestación laboral de los trabajadores por cuenta ajena, aunque no sea quien consta como empresario en los registros administrativos de la Seguridad Social.

Al recogerse en el artículo 18.3 del TRLGSS un sistema de responsabilidad solidaria o subsidiaria por remisión a otros órdenes jurídicos distintos al Derecho de la Seguridad Social, para delimitar y enmarcar correctamente el régimen jurídico de la derivación administrativa de responsabilidad al administrador social de las deudas con la Seguridad Social de la sociedad de capital, habrán de delimitarse los distintos supuestos de responsabilidad en los que puede incurrir el administrador social en aplicación de otras ramas del Derecho, principalmente del Derecho de sociedades.

Los apartados 3 y 4 del artículo 18 del TRLGSS no agotan todos los posibles supuestos de responsabilidad en que puede incurrir el administrador social en las deudas de la sociedad de capital, aunque sí nos explicitarán los supuestos legales en que la deuda podrá ser exigible al administrador social en el procedimiento administrativo de recaudación de los recursos de la Seguridad Social.

Existirán otros posibles supuestos de responsabilidad del administrador en las deudas de Seguridad Social de la sociedad de capital, lo que nos obliga a identificarlos y analizarlos, para determinar su naturaleza jurídica, su ámbito material de aplicación, y poder concluir acerca de la procedencia o improcedencia de la derivación administrativa de la deuda y su importancia cualitativa o cuantitativa en la reclamación de deudas al administrador social. 
Para este cometido distinguiremos cuatro supuestos de responsabilidad del administrador, que tendrán naturaleza, fundamento y régimen jurídico distinto.

\section{Responsabilidad ex lege por deudas de la sociedad.}

Un primer supuesto de responsabilidad del administrador será la responsabilidad "ex lege" por deuda ajena impuesta legalmente al administrador social, ante determinados incumplimientos de las obligaciones del cargo que se estiman especialmente nocivos para el acreedor social y para el correcto tráfico jurídico en que se desenvuelven las sociedades de capital. Nos encontraremos ante una previsión legal expresa de atribución de responsabilidad al administrador en el pago de las deudas de la sociedad de capital, y, por ende, en las deudas de Seguridad Social, que operará como medio de garantía de los acreedores sociales ante el incumplimiento de deberes legales esenciales por parte de los administradores (supuesto típico de responsabilidad-garantía ex lege del administrador por deuda ajena).

Cuando una disposición legal de cualquier ámbito normativo, imponga una responsabilidad ex lege al administrador social en el pago de deudas de la sociedad de capital, esa responsabilidad podrá ser exigida para reclamar deudas de Seguridad Social acudiendo al procedimiento administrativo de la derivación de responsabilidad (art. 18.3 del TRLGSS).

Los principales supuestos de responsabilidad ex lege del administrador en las deudas de la sociedad de capital son los previstos en los arts. 360 y 367 del Real Decreto Legislativo 1/2010, de 2 de julio, por el que se aprueba el Texto Refundido de la Ley de Sociedades de Capital - LSC- ${ }^{1}$, cuando la sociedad de capital se halle en causa de disolución, sea causa de disolución de pleno derecho (art. 360 de la LSC) o causa legal de disolución (art. 367 de la LSC), y el administrador haya incumplido con sus deberes legales de promover la disolución, o medidas alternativas de remoción de la causa disolutoria. En ambos preceptos se impone una responsabilidad solidaria del administrador en el pago de determinadas deudas de la sociedad de capital.

Otros posibles supuestos de responsabilidad ex lege resultarán de aquellos preceptos de la legislación de sociedades que impongan algún tipo de responsabilidad al administrador o a los socios en el proceso de constitución societaria o como consecuencia del control societario sobrevenido, siendo los supuestos más relevantes,

\footnotetext{
${ }^{1}$ BOE 3.7.2010
} 
los tres siguientes. En primer lugar, la responsabilidad por deudas en la sociedad en formación o constitución societaria ${ }^{2}$. En segundo lugar, la responsabilidad por deudas en la sociedad de capital irregular ${ }^{3}$. En tercer lugar, la responsabilidad por deudas en la sociedad unipersonal sobrevenida ${ }^{4}$. Como veremos al estudiar estas responsabilidades, en la sociedad irregular y en la sociedad unipersonal sobrevenida, la responsabilidad no será tanto del administrador, sino del socio, aunque en el tráfico mercantil la figura de socio-administrador normalmente tiene lugar en las sociedades de pequeño capital y en las sociedades familiares, en las que con más frecuencia se producen los impagos de deudas de Seguridad Social.

Finalmente, en el Derecho de sociedades se prevén otros supuestos de responsabilidad solidaria o subsidiaria del socio o del administrador, que son de menor importancia y trascendencia a efectos de esta investigación. En primer lugar, estará la responsabilidad en general de los socios por las deudas sociales en los procesos de transformaciones societarias. En segundo lugar, la responsabilidad que se imputa a los socios y administradores por la realidad y valoración de las aportaciones no dinerarias de los socios, que, al ser responsabilidades fundamentalmente internas, ante la sociedad, no tendrán relevancia a efectos del nacimiento de deudas de Seguridad Social. En tercer lugar, estarán aquellas responsabilidades anejas al proceso de constitución societaria, que, igualmente, no serán objeto de estudio por no afectar a las deudas de Seguridad Social, al ser esencialmente responsabilidades internas y muy excepcionalmente externas. En estos tres supuestos de posibles responsabilidades, más que de responsabilidad de los administradores, en puridad cabría hablar fundamentalmente de responsabilidades de los socios por las deudas sociales, y en menor medida de los administradores sociales.

\section{Responsabilidad por daños.}

Un segundo supuesto diferente de posible responsabilidad del administrador social será la responsabilidad por daños causados al acreedor de la sociedad de capital en el ejercicio de su cargo. Responsabilidad que será exigible a través de dos acciones judiciales, la acción social de responsabilidad y la acción individual de responsabilidad.

\footnotetext{
${ }^{2}$ Arts. 36 a 38 de la LSC.

${ }^{3}$ Arts. 39 y 40 de la LSC.

${ }^{4}$ Art. 14 de la LSC.
} 
La acción social de responsabilidad tiene como finalidad recomponer el daño causado al patrimonio social, no el daño causado directamente al acreedor, reconociéndose para su ejercicio sólo una legitimación subsidiaria de segundo grado al acreedor social, al poderla entablar sólo cuando la sociedad o los socios no la hayan ejercitado, y siempre que el patrimonio social sea insuficiente para la satisfacción de sus créditos. Al ser una legitimación subsidiaria de segundo grado, al no tener como finalidad obtener el acreedor la reparación directa de su crédito, y al exigirse que se acredite insuficiencia del patrimonio de la sociedad, el acreedor optará por la acción individual de responsabilidad, ya que con ella se pretende el cobro del crédito impagado por la sociedad de capital, siendo muy escasa la utilización de la acción social de responsabilidad, e inexistente en materia de deudas de Seguridad Social. Razón por la que nos centraremos en el estudio de la acción individual de responsabilidad.

Mediante la acción individual de responsabilidad regulada en el art. 241 de la LSC se exigirá al administrador la responsabilidad extracontractual por ilícito orgánico, en aquellos supuestos en que éste cause un daño directo al acreedor social, que, a nuestros efectos, tendrá lugar cuando el impago de la deuda de Seguridad Social, en que se concretará el daño, sea consecuencia de una conducta antijurídica y culpable del administrador en el ejercicio del cargo, mediando relación de causalidad entre la conducta y el daño. Nos hallamos ante supuestos de responsabilidad directa por daños, como una modalidad de responsabilidad extracontractual especial por ilícito orgánico del administrador, contraída en el ejercicio del cargo societario en nombre de la sociedad, responsabilidad distinta de la que pueda tener ante actuaciones personales extraorgánicas, que se regirán por la responsabilidad extracontractual común de los arts. 1902 y siguientes del Código Civil.

Mediante la acción individual de responsabilidad se exige al administrador social la reparación de los daños que cause en el derecho de crédito, siempre que sean evaluables económicamente. Analizaremos qué créditos de Seguridad Social pondrán ser exigidos al administrador, si se circunscriben a los créditos por cotizaciones, o si por el contrario se extienden a otros créditos impagados, como los derivados de prestaciones de Seguridad Social de responsabilidad empresarial, el recargo de prestaciones $^{5}$, o las

\footnotetext{
${ }^{5}$ En el art 12.4 del Real Decreto 1415/2004, de 11 de junio, se excluye ab initio el recargo en la derivación administrativa de responsabilidad por deudas, salvo que conste directamente impuesto en la resolución de la entidad gestora. Hemos de preguntarnos si esa limitación es aplicable en el ejercicio de la acción individual de responsabilidad.
} 
indemnizaciones por daños causados al trabajador con motivo de un accidente de trabajo o enfermedad profesional. Aludiremos, aunque no sea un crédito de Seguridad Social, al crédito que pueda ostentar una entidad pública, como el Fondeo de Garantía Salarial -FOGASA-, por los créditos anticipados al trabajador, preguntándonos si producida la subrogación ante la empresa responsable, cabe su reclamación al administrador social al amparo de la acción individual de responsabilidad.

Analizaremos si esta responsabilidad podrá reclamarse al administrador en vía administrativa, por derivación de responsabilidad al amparo del art. 18.3 del TRLGSS, o si por el contrario, al no ser una responsabilidad solidaria ex lege, sino una responsabilidad por daños, las entidades gestoras, la Tesorería General de la Seguridad Social -en adelante TGSS-, o las mutuas colaboradoras con la Seguridad Social deberán entablar la acción individual de responsabilidad prevista en el art. 241 de la LSC, ante los tribunales, y en ese supuesto ante qué orden jurisdiccional, si ante el civil a través de los Juzgados Mercantiles ${ }^{6}$, si ante el social de reclamarse el pago de prestaciones económicas de Seguridad Social ${ }^{7}$, o, ante el contencioso-administrativo de reclamarse el pago de deudas por cuotas y demás cuotas de recaudación conjunta ${ }^{8}$. Competencia jurisdiccional que, tuvo en los años noventa del siglo pasado, un interesante debate jurídico que finalmente se ha superado.

Esta responsabilidad por daños deberemos diferenciarla claramente de la responsabilidad solidaria prevista en los arts. 360 y 367 de la LSC. En estos dos últimos preceptos nos encontramos ante un supuesto de responsabilidad ex lege por deudas de la sociedad ante el incumplimiento de ciertos deberes del administrador ante la concurrencia de alguna causa de disolución. Por el contrario, en la acción individual de responsabilidad del art. 241 de la LSC el administrador responde por los daños directos que culpablemente cause al acreedor en la ejecución del cargo, teniendo naturaleza indemnizatoria, exigiendo del acreedor una mayor carga probatoria respecto a la responsabilidad ex lege, ya que deberá acreditarse una conducta antijurídica, culpable, un daño directo y la relación de causalidad entre la conducta y el daño.

\footnotetext{
${ }^{6}$ Art. 86 ter apartado 2, a) de la Ley Orgánica 6/1985, de 1 de julio, Reguladora del Poder Judicial -en adelante LOPJ.

${ }^{7}$ Art. 2 apartados b), y o), de la Ley 36/2011, de 10 de octubre, Reguladora de la Jurisdicción Social -en adelante LRJS.

${ }^{8}$ Art. 3 apartado f) de la LRJSS, en relación con los arts. 1 a 3 de la Ley 29/1998, de 13 de julio, de la Jurisdicción Contencioso-Administrativa, -LJCA-.
} 
Acción individual de responsabilidad que será objeto de estudio en el capítulo II de esta tesis.

\section{Responsabilidad concursal.}

Un tercer supuesto de responsabilidad del administrador en el pago de deudas de Seguridad Social de la sociedad de capital, es la llamada responsabilidad concursal, que es aquélla que puede ser impuesta al administrador social en el concurso de acreedores de la sociedad, especialmente cuando el juez del concurso entienda que el administrador social con su conducta ha contribuido a generar o agravar la insolvencia de la sociedad, en los supuestos de concurso calificado de culpable abierta la fase de liquidación. Responsabilidad concursal regulada en el artículo 456 del Real Decreto Legislativo 1/2020, de 5 de mayo, por el que se aprueba el Texto Refundido de la Ley Concursal en adelante TRLC- ${ }^{9}$.

En la medida en que el administrador de una sociedad de capital insolvente, cuyo concurso de acreedores de la mercantil se califique como culpable, pueda ser condenado a responder del déficit patrimonial, nos encontraremos ante un supuesto en que la Seguridad Social podrá obtener a través del administrador, y dentro del proceso concursal, la parte del crédito no satisfecha con el reparto de la masa activa. Se dispondrá de un instrumento jurídico para que el administrador social asuma dentro del concurso la deuda de Seguridad Social no cubierta con el reparto de la masa activa.

No nos hallamos ante un supuesto de derivación administrativa de deudas de Seguridad Social del art. 18.3 del TRLGSS, por cuanto esa responsabilidad no puede exigirse en vía administrativa, sino que sólo nace si se impone como condena en la sentencia de calificación del concurso de acreedores de la sociedad de capital.

Se hará mención a la misma dentro del estudio de la acción individual, para reflexionar sobre la coordinación y condicionamiento de ambas modalidades de reclamación de deudas al administrador, dedicando a su estudio un apartado específico dentro del capítulo V de esta tesis.

Será objeto de análisis, si la declaración del concurso de acreedores de la sociedad de capital paraliza o suspende el ejercicio de la acción individual de responsabilidad contra el administrador, para reclamarle el daño o perjuicio causado en las deudas de

\footnotetext{
${ }^{9}$ BOE del 7.5.2020.
} 
Seguridad Social de la mercantil. Por otro lado, ante la previsión del TRLC ${ }^{10}$ de que la declaración de concurso de acreedores de la sociedad, paraliza y suspende las acciones judiciales de los acreedores reclamando la responsabilidad ex lege de los administradores, dilucidaremos, si al preverse sólo la paralización de acciones procesales de reclamación de la responsabilidad, ha de incluirse la derivación administrativa de deudas con la Seguridad Social, o si por el contrario, el procedimiento administrativo recaudatorio ante el administrador no se ve afectado por la declaración del concurso de la sociedad.

\section{Responsabilidad por uso fraudulento de la personalidad jurídica.}

Un cuarto y último supuesto de posible responsabilidad del administrador social, será la responsabilidad ante el uso fraudulento de la personalidad jurídica de la sociedad de capital. Esta responsabilidad tiene su origen en una previa labor creativa jurisprudencial de superación del ropaje formal de la personalidad jurídica de la sociedad mercantil, para extender el ámbito de los sujetos responsable de la obligación de cotizar a la Seguridad Social a otros sujetos o personas físicas o jurídicas relacionadas con aquélla en determinadas situaciones. Estos supuestos de responsabilidad de creación jurisprudencial se enmarcan en la prohibición del fraude de ley y del abuso del derecho de los arts. 6.4 y 7.2 del Código Civil.

Una primera modalidad de uso fraudulento de la personalidad jurídica de la sociedad de capital tiene lugar cuando el administrador-socio de control o socio único de la sociedad de capital (normalmente en las sociedades de escasa entidad patrimonial y societaria, en que suele aunarse la doble condición de socio dominante y administrador), ejerza realmente la actividad empresarial a título personal, pero bajo el ropaje formal de la personalidad jurídica de la sociedad con la finalidad de eludir fraudulentamente ante los acreedores la responsabilidad personal patrimonial ilimitada (teoría del levantamiento del velo $\left.{ }^{11}\right)$. Doctrina del levantamiento del velo que nos permite penetrar en el sustrato material real de la sociedad para desconocer y superar su constitución formal aparente.

En esta modalidad de responsabilidad trataremos de delimitar si cabe una derivación administrativa de deudas con fundamento legal en el artículo 18.3 del TRLGSS, o en el

\footnotetext{
${ }^{10}$ Arts. 136.1. $2^{\circ}$ y 139.1 del TRLC.

${ }^{11}$ Sentencias del TS, Sala Civil, 30 de diciembre de 2015 -Rec. 2002/13; 17 de marzo de 2015 -Rec. 767/2013-; de 14 de octubre de 2010 -Rec. 2253/2006-; 28 febrero de 2008; 19 de septiembre de 2007; y STS, Sala Social, 20 de junio de 2018 -Rec. 168/17-, entre otras.
} 
artículo 18.4 del TRLGSS. De ser de aplicación el art. 18.4 del TRLGSS se analizará si la revisión de los actos instrumentales de inscripción de la empresa y las altas de los trabajadores en Seguridad Social, será condición previa y necesaria de la reclamación de la deuda al administrador.

Un segundo supuesto de extensión jurisprudencial del círculo de sujetos responsables lo hallamos en los grupos de empresa, a través de dos figuras jurídicas de creación jurisprudencial, por un lado, la conocida como la simple empresa grupo, y, por otro lado, los grupos societarios patológicos. Supuestos ambos que, a efectos de las deudas laborales y de Seguridad Social nos van a permitir desconocer la personalidad jurídica y la limitación de responsabilidad patrimonial de una concreta entidad mercantil, la que formalmente se presenta como empleadora, para extender la responsabilidad solidaria a todas las sociedades integrantes del grupo. Responsabilidad que no será objeto de estudio, con independencia de aludirse a ella al abordarse el ámbito subjetivo de la responsabilidad por daños y por deudas en los capítulos segundo y cuarto de esta investigación.

La responsabilidad en los supuestos de abuso de la personalidad jurídica societaria será analizada en el Capítulo V de esta tesis.

\section{II.- LA RESPONSABILIDAD EX LEGE DEL ADMINISTRADOR EN DEUDAS DE LA SOCIEDAD DE CAPITAL.}

\section{Principales supuestos normativos de responsabilidad solidaria del administrador.}

Con carácter general son cinco los supuestos legales de responsabilidad solidaria o subsidiaria del administrador social y de los socios en las deudas de la sociedad de capital: a) la responsabilidad por causa de disolución de pleno derecho -art. 360 de la LSC-; b) la responsabilidad por causa legal o estatutaria de disolución -art. 367 de la LSC-; c) la responsabilidad del administrador durante el proceso de formación de la sociedad -arts. 36 a 38 de la LSC-; d) la responsabilidad en la sociedad irregular -art. 39 de la LSC-; y e) la responsabilidad en la sociedad unipersonal sobrevenida -art. 14 de la LSC-.

Hay un sexto supuesto, la responsabilidad solidaria del administrador social por no haber inscrito antes del 30.6.1992 en el Registro Mercantil la escritura elevando el 
capital social al mínimo legal. Responsabilidad establecida legalmente en el año 1989 que actualmente está ya periclitada, al haber tenido vigencia transitoria, y por haber quedado disueltas las sociedades afectadas y cancelados sus asientos registrales de (DT. $3^{\text {a }}$ del Real Decreto Legislativo 1564/1989, de 22 de diciembre, por el que se aprobó el Texto Refundido de la Ley de Sociedades Anónimas - en adelante LSA- ${ }^{12}$, y DT. $3^{\text {a }}$ y $6^{\text {a }}$ de la Ley 19/1989, de 25 de julio, de Reforma parcial y adaptación de la Legislación Mercantil a las Directivas de la Comunidad Económica Europea (CEE) en materia de Sociedades ${ }^{13}$ ), por lo que no será objeto de estudio, salvo la mera referencia que realizamos en este apartado.

Todos los supuestos de responsabilidad ex lege en deuda ajena permitirán la derivación administrativa de responsabilidad dentro del procedimiento de recaudación de los recursos de la Seguridad Social.

En este capítulo se hará una reseña general de esos distintos supuestos legales de responsabilidad por deuda ajena, siendo objeto de estudio en los capítulos III al V de esta investigación.

\subsection{Disolución de pleno derecho.}

La sociedad de capital se disolverá ipso iure, de pleno derecho, cuando haya transcurrido un año desde que se adoptó por la Junta general de accionistas el acuerdo de reducción del capital social por debajo del mínimo legal, como consecuencia del cumplimiento obligatorio de una ley, sin que se hubiere inscrito en el Registro Mercantil la escritura de transformación en otro tipo societario que permitiese tener ese capital social inferior, la escritura de aumento del capital social al mínimo legal, o en su defecto la escritura de disolución de la sociedad (art. 360 de la LSC). En esos supuestos, transcurrido un año desde la adopción del acuerdo de reducción del capital sin que se hubiere inscrito el aumento del capital, la transformación societaria, o la disolución, los administradores responde de modo solidario con la sociedad de las deudas sociales, entre ellas de las de Seguridad Social, y solidariamente entre sí (art. 360.1, último párrafo de la LSC). No se determinan, sin embargo, qué deudas integran la responsabilidad, si son sólo las posteriores al incumplimiento, las posteriores a la

${ }^{12}$ BOE del 27.12.1989, Disposición actualmente derogada por la LSC.

${ }^{13}$ BOE del 27.7.1989. 
adopción del acuerdo de reducción de capital social, o todas las deudas, sean anteriores o posteriores al incumplimiento o a la adopción del acuerdo de reducción del capital.

Dedicaremos el capítulo III de esta investigación a estudiar la derivación de responsabilidad del administrador social por causa de disolución de pleno derecho.

\subsection{Disolución por causa legal o estatutaria.}

Existe una responsabilidad solidaria del administrador social en el pago de deudas de Seguridad Social de la sociedad de capital cuando ante la concurrencia de alguna de las causas disolución previstas en el art. 363 de la LSC, los administradores incumplan los deberes legales establecidos en los arts. 365 y 366 LSC: no promover la disolución, no solicitar el concurso de acreedores, de proceder, o no promover la adopción de medidas alternativas que permitan superar o remover la causa de disolución.

Este es el supuesto más importante de responsabilidad solidaria del administrador en las deudas sociales, que permitirá derivar administrativamente las deudas de Seguridad Social al administrador, siendo la causa de pérdidas cualificadas -las que disminuyen el patrimonio neto por debajo de la mitad del capital social-, la más relevante cualitativa y cuantitativamente de la derivación de responsabilidad.

Responsabilidad solidaria recogida en el art. 367 de la LSC que no se extiende a todas las deudas de Seguridad Social, sino sólo a las deudas generadas a partir del acaecimiento de la causa legal de disolución. Establecida esa limitación temporal en las deudas objeto de responsabilidad, acto seguido, se recoge una presunción iuris tantum, en virtud de la cual se presumen de fecha posterior todas las deudas reclamadas, por lo que será el administrador quien deberá acreditar qué deudas no podrán ser objeto de derivación administrativa por ser de fecha anterior a la causa de disolución. Presunción que viene a operar como una presunción de concurrencia de la causa de disolución en la fecha de generación de la deuda, correspondiendo al administrador acreditar que la deuda es anterior o, lo que es igual, que la causa disolutoria es posterior.

En la regulación inicial de esta responsabilidad el administrador respondía de todas las deudas sociales, fueren anteriores o posteriores a la causa de disolución. Se limitó la responsabilidad a las deudas posteriores a la causa de disolución mediante la Ley 19/2005, de 14 de noviembre ${ }^{14}$, sobre la Sociedad Anónima Europea domiciliada en

\footnotetext{
${ }^{14}$ Con vigencia desde el 16.11.2005.
} 
España, al dar nueva redacción al artículo 262.5 de la LSA y al artículo 105.5 de la Ley 2/1995, de 23 de marzo ${ }^{15}$, de Sociedades de Responsabilidad Limitada -en adelante LSRL-, introduciendo también la presunción iuris tantum.

Régimen jurídico de responsabilidad actualmente vigente y que está recogido en el artículo 367 de la $\operatorname{LSC}^{16}$.

Los deberes disolutorios que deben cumplir los administradores para no responder solidariamente de las deudas de la sociedad se recogen en los arts. 365 y 366 de la LSC. En virtud de esos preceptos los administradores sociales deben cumplir con dos deberes legales. En primer lugar, deberán convocar dentro de los dos meses siguientes al conocimiento de la causa de disolución, la Junta general de accionistas para la adopción de medidas encaminadas a la remoción de la causa, y de no ser ello posible, para la adopción del acuerdo de disolución, o para que se solicite el concurso de acreedores de ser la sociedad insolvente. En segundo lugar, y con carácter subsidiario, solicitar la disolución judicial en el plazo de dos meses siguientes a la celebración de la Junta o a la fecha prevista para su celebración, si el acuerdo de ésta hubiere sido contrario a la disolución, sin haberse removido la causa, o si no se hubiese adoptado el acuerdo o no se hubiese constituido la Junta de accionistas, o bien solicitar el concurso de acreedores de existir causa de insolvencia.

En la responsabilidad de deudas de Seguridad Social por causa legal de disolución del art. 367 de la LSC, analizaremos detenidamente, de modo especial, la causa de disolución por pérdidas cualificadas, y su relación con la insolvencia como causa de concurso. Dentro de esta responsabilidad del administrador social, será objeto de estudio si esa responsabilidad solidaria nace sólo si hay causa de disolución, vaya o no acompañada de causa de insolvencia, o si por el contrario, nacería también cuando exista sólo causa de insolvencia sin concurrir causa legal de disolución, ya que pueden

\footnotetext{
${ }^{15}$ Con vigencia desde el 1.6.1995.

16 "Artículo 367. Responsabilidad solidaria de los administradores.

1. Responderán solidariamente de las obligaciones sociales posteriores al acaecimiento de la causa legal de disolución los administradores que incumplan la obligación de convocar en el plazo de dos meses la junta general para que adopte, en su caso, el acuerdo de disolución, así como los administradores que no soliciten la disolución judicial o, si procediere, el concurso de la sociedad, en el plazo de dos meses a contar desde la fecha prevista para la celebración de la junta, cuando ésta no se haya constituido, o desde el día de la junta, cuando el acuerdo hubiera sido contrario a la disolución.

2. En estos casos las obligaciones sociales Reclamadas se presumirán de fecha posterior al acaecimiento de la causa legal de disolución de la sociedad, salvo que los administradores acrediten que son de fecha anterior".
} 
suceder tres situaciones distintas en la sociedad de capital, en primer lugar, puede haber causa de disolución sin causa de insolvencia, en segundo lugar, causa de insolvencia sin causa de disolución, y en tercer lugar, pueden concurrir conjuntamente ambas causas. Debemos responder si en todos esos casos sería aplicable la responsabilidad solidaria del administrador social, o si, por el contrario, sólo se declarará cuando haya causa de disolución, vaya o no acompañada de causa de insolvencia. De igual modo, deberemos determinar si la solicitud de medidas preconcursales, cuando concurra causa de disolución por pérdidas y causa de insolvencia, es obligación alternativa que exonere de la responsabilidad del art. 367 de las LSC, ya que en ese precepto no se alude a las mismas.

Dedicaremos el capítulo IV de esta investigación al estudio de esta responsabilidad solidaria del administrador en el pago de las deudas de Seguridad Social por incumplimiento de los deberes disolutorios.

\subsection{Falta de inscripción registral en plazo de la escritura de elevación del nuevo capital mínimo legal.}

Finalmente, en la Ley 19/1989, de 25 de julio, se estableció una nueva responsabilidad solidaria del administrador social en las deudas de la sociedad anónima, de la sociedad comanditaria por acciones, y de la sociedad responsabilidad limitada, que era consecuencia de haberse elevado en esa disposición legal el capital social mínimo de esas sociedades, ya que para las sociedades anónimas y comanditarias por acciones se establecía un capital mínimo de diez millones de pesetas, y para las sociedades de responsabilidad limitada se fijaba en quinientas mil pesetas. Para la adaptación de los estatutos sociales y para la elevación del capital social a ese nuevo capital mínimo legal, en su Disposición Transitoria $3^{\mathrm{a}}$, se fijaba un plazo que finalizaba el 30.6.1992, para que las sociedades anónimas, las comanditarias por acciones y las de responsabilidad limitada, elevasen su capital social a esos nuevos importes mínimos legales, o para que antes de esa fecha se transformasen en otros tipos societarios que permitiesen mantener esos capitales inferiores. Si llegado el 30 de junio de 1992 no se hubiesen adaptado los estatutos y no se hubiere elevado el capital social al mínimo legal, o en su defecto, no se hubiesen transformado en otros tipos societarios, los administradores y, en su caso, los liquidadores, responderán personal y solidariamente entre sí, y con la sociedad, de las deudas sociales. Responsabilidad sin limitación alguna, por todas las deudas de la 
sociedad, sean anteriores o posteriores al incumplimiento de la obligación de adaptación estatutaria y de elevación del capital social.

Responsabilidad solidaria por no elevarse el capital social al mínimo legal, que para las sociedades anónimas se recogió posteriormente en la Disposición Transitoria $3^{\mathrm{a}}$ de la anterior $\operatorname{LSA}^{17}$,

Para las sociedades de responsabilidad limitada y comanditarias por acciones, continuaban siendo de aplicación las Disposiciones Transitorias $3^{\mathrm{a}}$ y $6^{\mathrm{a}}$ de la Ley 19/1989, de 25 de julio. En virtud de esos preceptos legales, por un lado, los administradores sociales respondían de las deudas sociales si antes del 30 de junio de 1992 no elevaban el capital social a los mínimos legales de quinientas mil pesetas -para las sociedades de responsabilidad limitada-, o de diez millones de pesetas -para las comanditarias por acciones- (disposición transitoria tercera); y por otro lado, las sociedades de responsabilidad limitada y comanditarias por acciones quedaban disueltas de pleno derecho si no presentaban en el Registro Mercantil la adaptación del capital social mínimo legal antes del 31.12.1995 (Disposición Transitoria Sexta), sin perjuicio de subsistir la responsabilidad personal y solidaria de administradores, gerentes, directores generales y liquidadores por las deudas contraídas en nombre de la sociedad.

Con la posterior entrada en vigor de la LSRL, ya no podía constituirse ninguna sociedad de responsabilidad limitada con capital social inferior a 500.000 pesetas. Esa LSRL deroga la Disposición Transitoria Sexta de la Ley 19/1989, de 25 de julio, en lo relativo a la disolución de pleno derecho de la sociedad de responsabilidad limitada por no haber elevado antes del 31.12.1995 el capital social al mínimo legal de 500.000 pesetas $^{18}$, y en sus disposiciones transitorias segunda y tercera, fijó un nuevo plazo de tres años, desde su entrada en vigor, para que las sociedades existentes adaptasen sus estatutos o escrituras sociales a la nueva regulación, y de no hacerlo se les negaba el acceso al registro a partir del vencimiento del plazo transitorio (31.5.1998). La responsabilidad

\footnotetext{
${ }^{17}$ En esa Disposición Legal se establecía:

"1. Antes del 30 de junio de 1992, las sociedades anónimas deberán adaptar sus Estatutos a lo dispuesto en esta Ley, si estuvieran en contradicción con sus preceptos.

2. Las sociedades anónimas que tengan un capital inferior a 10.000.000 de pesetas deberán, en el plazo señalado en el apartado anterior, haber aumentado efectivamente su capital hasta, al menos, esa cifra o transformarse en sociedad colectiva, comanditaria o de responsabilidad limitada.

3. Transcurridos los plazos a que se refieren los apanados anteriores sin haberse adoptado e inscrito las medidas en ellos previstas, los administradores y, en su caso, los liquidadores responderán personal y solidariamente entre sí y con la sociedad de las deudas sociales".

${ }^{18}$ Disposición Derogatoria Segunda.
} 
solidaria de los administradores para las sociedades de responsabilidad limitada y comanditaria por acciones continuó en vigor mediante la Disposición Transitoria $3^{\text {a }}$ de la Ley 19/1989, de 25 de julio.

Responsabilidad actualmente no recogida en la LSC, por cuanto ya no existen sociedades con capitales inferiores al haberse cancelado los asientos registrales, y haberse extinguido las mismas. Actualmente se contempla para las sociedades constituidas conforme a la LSC, la especialidad de sociedad de responsabilidad limitada en régimen de formación sucesiva del art. 4 bis, para la constitución inicial con capital inferior al mínimo legal.

Responsabilidad solidaria que, por el tiempo transcurrido y por no hallarse en actividad ninguna sociedad afectada, determina la inaplicabilidad práctica de esta responsabilidad solidaria en deudas de Seguridad Social.

\section{Otros supuestos de responsabilidad solidaria o subsidiaria del socio y del administrador.}

Existen otros supuestos en la LSC en los que se prevé una responsabilidad solidaria o subsidiaria de los socios, y en menor medida de los administradores, ante determinadas situaciones societarias.

- Un primer grupo de supuestos están asociados a los procesos de constitución regular de la sociedad, y a los momentos previos a la adquisición de la plena personalidad jurídica, a través de las figuras de la sociedad en formación y de la sociedad irregular. Supuestos que ya no serán tan relevantes en materia de deudas de Seguridad Social, a diferencia de la responsabilidad derivada de la concurrencia de causas legales de disolución o de disolución de pleno derecho.

- En un segundo grupo de supuestos se prevé la responsabilidad de los socios, y por ello de los socios-administradores, en los procesos de transformación de la sociedad de capital en otros tipos societarios.

- En tercer lugar, hay una serie de disposiciones legales contemplando la responsabilidad de los socios, y puntualmente del administrador, por la realidad y la adecuada valoración de aportaciones no dinerarias, que no tienen trascendencia en materia de deudas de Seguridad Social, por lo que no son objeto de estudio en esta tesis. 
Todos estos supuestos los calificamos de menores, al tener menor incidencia en materia de deudas de Seguridad Social, salvando la especialidad de la responsabilidad de los socios por transformaciones societarias. La responsabilidad asociada a los procesos previos de constitución de la sociedad no tendrá mucha repercusión en materia de deudas de Seguridad Social, ya que, si la actividad se inicia por los administradores una vez otorgada la escritura y antes de la inscripción registral, salvo pacto en contra, están autorizados ope legis para realizar el objeto social constitutivo de la actividad empresarial (art. 37.3 de la LSC), por lo que se reducen los posibles supuestos de responsabilidad del administrador social en las deudas durante la fase de formación o constitución de la sociedad. No por ello puede descartarse que nazca la responsabilidad solidaria de determinadas personas ante la Seguridad Social si ha habido actividad empresarial a nombre de la futura sociedad, en cuyo caso, podrá iniciarse la derivación administrativa de responsabilidad ante las personas responsables mientras no conste la inscripción registral.

Expongamos brevemente cuáles son esos supuestos en los que los socios y los administradores pueden resultar responsable solidarios o subsidiarios en el pago de las deudas de Seguridad Social, y cuyo régimen jurídico será objeto de estudio más detallado en el Capítulo V de esta investigación.

\subsection{Sociedad en formación.}

En la sociedad en formación -período previo a la inscripción en el Registro Mercantil de las escrituras de constitución de la sociedad- se prevén las siguientes responsabilidades:

- En primer lugar, durante el período de formación de la sociedad responderá el patrimonio formado por los socios, solidariamente con los socios por la parte del capital social pendiente de desembolsar (art. 37 LSC), por los cuatro siguientes actos: $1^{\circ}$ Por los actos y contratos indispensables para la inscripción de la sociedad, de los que normalmente no nacerán deudas de Seguridad Social. $2^{\circ}$ Por los actos realizados por los administradores dentro de las facultades que les confieren las escrituras para la fase anterior a la inscripción. $3^{\circ}$ Por los estipulados por un representante designado en virtud de un mandato específico de todos los socios. De estos dos últimos supuestos, pueden surgir deudas de Seguridad Social si se ha iniciado la actividad laboral. Y en $4^{\circ}$ lugar, por todos los actos y contratos 
derivados del desarrollo del objeto social ejecutados por los administradores sociales, ya que, salvo disposición en contrario de los estatutos o de las escrituras, se entienden autorizados ope legis para el pleno desarrollo del objeto social y para realizar toda clase de actos y contratos, de haber iniciado la mercantil las operaciones sociales en la fecha de otorgamiento de las escrituras públicas. Si se permite al administrador social el inicio de las operaciones sociales, la sociedad en formación puede inscribirse como empresa en Seguridad Social y dar de alta a los trabajadores por cuenta ajena, por lo que surgen obligaciones y deudas de Seguridad Social, de las que responderá el patrimonio formado por los socios, solidariamente con los socios por la parte del capital suscrito y no desembolsado durante la fase de constitución, cesando esa responsabilidad una vez se inscriba la sociedad en el Registro Mercantil (arts. 37 y 38 de la LSC).

- En segundo lugar, por los actos y contratos realizados por un tercero en nombre de la sociedad en formación, siempre que no sea el administrador social autorizado, responde esa persona de modo personal y con todo su patrimonio de las deudas de la sociedad del período de formación, salvo que se acepten por la sociedad en el plazo de tres meses siguientes a la inscripción de las escrituras de constitución en el Registro Mercantil. Si se formalizasen contratos de trabajo y se iniciasen operaciones constitutivas del objeto social, pueden nacer deudas de Seguridad Social, que serán exigibles a esa persona o apoderado material actuante, como veremos capítulo $\mathrm{V}$ de esta tesis. Si esa persona hubiere sido autorizada por todos los socios para realizar esos actos y contratos, responderá solidariamente el patrimonio formado y los socios por la parte del capital no desembolsado. Cesa la responsabilidad de esa persona si la sociedad se inscribe en el Registro Mercantil antes del año y acepta dentro de los tres meses siguientes los contratos formalizados.

Normalmente, la actividad la iniciarán los administradores, y no terceros al amparo del art 36 de la LSC, ya que los administradores están autorizados ope legis para el inicio de la actividad (art. 37.3 LSC).

Para el estudio de esta responsabilidad nos remitimos al apartado I del capítulo V de esta investigación. 


\subsection{Sociedad irregular.}

Estaremos ante una sociedad irregular, cuando haya constancia de que no será inscrita en el Registro Mercantil, o cuando haya transcurrido un año desde el otorgamiento de la escritura de constitución sin que se hubiere solicitado la inscripción en ese Registro. En ambas situaciones, para el pago de las deudas contraídas en el ejercicio de la actividad, se aplican las normas de la sociedad colectiva, si desarrolla una actividad mercantil, o en otro caso las disposiciones legales de la sociedad civil (art. 39 de la LSC). Si la sociedad irregular se califica como mercantil, responderán los socios de modo personal e ilimitado, y solidariamente entre ellos de las deudas sociales, pero de modo subsidiario respecto a la sociedad (arts. 127, 128 y 237 del Código de Comercio). Por el contrario, de ser calificada como entidad civil responderá la sociedad con su patrimonio, y de modo subsidiario los socios en proporción a su participación en el capital, previa excusión de los bienes sociales (art. 1698 del Código Civil, según la doctrina científica $\left.{ }^{19}\right)$. El problema será determinar si responderá de las deudas sociales el administrador social que no fuese socio, ya que en la sociedad colectiva se impone la responsabilidad solidaria sólo a los socios, porque sólo pueden ser administradores los socios colectivos, no cabe un administrador que no sea socio (art. 129 del Código de Comercio). Cuestión ésta que deberemos resolver al estudiar este tipo de responsabilidad legal.

Para el estudio de esta responsabilidad nos remitimos al apartado II del Capítulo V de esta investigación.

\subsection{Sociedad unipersonal sobrevenida.}

En la sociedad unipersonal sobrevenida se prevé la responsabilidad del socio único cuando se incumplan ciertos deberes registrales. Una vez que transcurran seis meses desde que el único socio se hace con la totalidad del capital social, sin haberse inscrito en el Registro Mercantil el carácter unipersonal de la sociedad, el socio responde de modo personal y solidario con la sociedad de todas las deudas de Seguridad Social contraídas a partir del momento en que el único socio adquiere la totalidad del capital social (art. 14 de la LSC). Responsabilidad que se extiende a todo el período de

${ }^{19}$ DÍEZ-PICAZO Y PONCE DE LEÓN, L. y GULLÓN BALLESTEROS, A.: Sistema de Derecho Civil, Vol. II, $2^{\mathrm{a}}$ edición, Tecnos, 1979, p. 512. 
unipersonalidad, cesando la misma en la fecha en que se inscriba extemporáneamente en el registro el carácter unipersonal.

Para el estudio de esta responsabilidad nos remitimos al apartado III del Capítulo V de esta tesis.

\subsection{Responsabilidad en las transformaciones societarias.}

Las sociedades de capital en que los socios tienen una responsabilidad limitada al capital suscrito, pueden transformarse en sociedades personalistas (sociedades colectivas y comanditarias simples), en que los socios responden de las deudas sociales con su propio patrimonio, pero de modo subsidiario respecto a la sociedad.

Cuando una sociedad de capital se transforma en sociedad personalista en que los socios responden de las deudas sociales, responderán en la misma forma de las deudas anteriores a la transformación (art. 21.1 de la Ley 3/2009, de 3 de abril, sobre modificaciones estructurales de las sociedades mercantiles ${ }^{20}$ ).

Por el contrario, cuando una sociedad personalista se transforme en una sociedad de capital, salvo que los acreedores sociales hayan consentido expresamente la transformación, subsistirá la responsabilidad personal de los socios de las deudas contraídas con anterioridad a la transformación de la sociedad. Esta responsabilidad prescribirá a los cinco años a contar desde la publicación de la transformación en el Boletín Oficial del Registro Mercantil (art. 21.2 de la Ley 3/2009).

Responsabilidad en deudas de Seguridad Social que será objeto de análisis en el capítulo $\mathrm{V}^{\mathrm{o}}$ de esta tesis.

\section{III.- DEUDAS DE SEGURIDAD SOCIAL DE LA SOCIEDAD DE CAPITAL EXIGIBLES AL ADMINISTRADOR.}

La sociedad de capital podrá tener deudas de Seguridad Social de distinta naturaleza, lo que nos obligará a su previa identificación, para poder determinar cuáles podrán ser reclamadas al administrador social, cuando se exige la responsabilidad por daños a éste a través de la acción individual de responsabilidad, que se analiza el Capítulo II, y, cuáles serían exigibles en vía administrativa mediante la derivación administrativa de responsabilidad, cuando se declara la responsabilidad solidaria o subsidiaria del administrador o del socio, tanto en los supuestos de responsabilidad ex lege por deudas

\footnotetext{
${ }^{20} \mathrm{BOE}$ 4.4.2009.
} 
(art. 18.3 del TRLGSS), como en los supuestos de abuso de la personalidad jurídica societaria mediante la doctrina del levantamiento del velo, en aplicación de los apartados 3 y 4 del art. 18 del TRLGSS.

Las deudas objeto de gestión recaudatoria de la Seguridad Social que integran sus recursos económicos, son las determinadas con carácter general en el art. 1 del Real Decreto 1415/2004, de 11 de junio, por el que se aprueba el Reglamento General de Recaudación de la Seguridad Social -en adelante RGRSS-.

En función de esos diversos recursos económicos de la Seguridad Social, podrán generarse las siguientes deudas de Seguridad Social de la sociedad de capital, que podrán agruparse en dos grandes grupos, por un lado, deudas por cotizaciones, y, por otro lado, deudas por prestaciones de Seguridad Social.

\section{Deudas por cotizaciones a la Seguridad Social y por cuotas de recaudación conjunta.}

Dentro de las deudas por cotizaciones habrán de incluirse los recursos previstos en el artículo 1 apartado 1 letras a, c, n. ñ, p, y apartado 2 del RGRSS: $1^{\circ}$ ) cuotas de Seguridad Social, de desempleo, fondo de garantía salarial y formación profesional; $2^{\circ}$ ) aportaciones para el sostenimiento de servicios comunes cuando la empresa colabore voluntariamente en la gestión, que se liquidan mensualmente en el sistema de liquidación directa; $3^{\circ}$ ) reintegro de prestaciones indebidamente deducidas en las liquidaciones de cuotas; y $4^{\circ}$ ) recargos, intereses y costas que procedan sobre los conceptos anteriores.

A estos recursos habrán de añadirse las deudas por bonificaciones indebidas del subsistema de formación profesional para el empleo, cuyos costes compensan las empresas, dentro de los límites máximos autorizados, mediante la aplicación de una bonificación en las liquidaciones mensuales de cuotas a la Seguridad Social. Bonificación que es un recurso económico que se financia con cargo a las cuotas de formación profesional (arts. 6, 9, 17, 18, 19, 24 y 25 de la Ley 30/2015, de 9 de septiembre, por la que se regula el Sistema de Formación Profesional para el empleo en el ámbito laboral ${ }^{21}$, y Real Decreto 694/2017, de 3 de julio, por el que se desarrolla la Ley 30/2015, de 9 de septiembre ${ }^{22}$ ). El control de estos beneficios en las cotizaciones

\footnotetext{
${ }^{21}$ BOE 10.9.2015.

${ }^{22}$ BOE 05.7.2017.
} 
sociales corresponde al Servicio Público de Empleo Estatal -SEPE-, conjuntamente con la Fundación Estatal para la Formación en el Empleo, y el OEITSS o lo que es lo mismo la Inspección de Trabajo y Seguridad Social -en adelante ITSS-. Será la ITSS la que tiene la competencia de gestión liquidataria, reclamando las bonificaciones indebidas una vez se haya dictado resolución del SEPE declarando la improcedencia, en todo o en parte, de la bonificación deducida en las liquidaciones mensuales a la Seguridad Social (art. 18 Real Decreto 694/2017, de 3 de julio).

Las cuotas de Seguridad Social y las cuotas de recaudación conjunta se devengan por meses naturales vencidos (art. 16 del Real Decreto 2064/1995, de 22 de diciembre, por el que se aprueba el Reglamento General sobre Cotización y Liquidación de otros Derechos de la Seguridad Social -en adelante RGCSS-), siendo su plazo reglamentario de ingreso el mes siguiente a su devengo, salvo autorización en plazos diversos en los supuestos reglamentariamente establecidos (art. 56 del RGRSS, Sentencia del TS Sala Contencioso-Administrativa 128/2021, de 3 de febrero -Rec. 4110/2019-).

Esas cuotas han de ser liquidadas e ingresadas por la sociedad de capital en plazo reglamentario, mediante la autoliquidación o mediante el sistema de liquidación directa -SLD-, o fuera de plazo, antes de su reclamación administrativa (arts. 22 y 29 del TRLGSS). La falta reglamentaria de ingreso en plazo reglamentario determina su reclamación administrativa por la TGSS o por la ITSS.

Las deudas por cotizaciones pueden tener su origen en las siguientes causas. En primer lugar, deudas por una falta total de cotización, sea por no ingresarse en plazo reglamentario las cuotas mensuales por todos o alguno de los trabajadores que se hallen en alta en Seguridad Social, se haya o no cumplido con la obligación de autoliquidación o comunicación mensual de datos para la práctica de la liquidación por el sistema de liquidación directa; o sea, por falta de alta en Seguridad Social de los trabajadores (arts. 19, 29, 33 apartados 1.a y b, 34.1.a, 139, 140, 141, 142, 146 y 147 TRLGSS). En segundo lugar, deudas por diferencias de cotización, las que pueden ser debidas a diferencias en las bases, en tipos de cotización (arts.19, 33.1.c, 34 apartado 1.b, 145, 146 y 147 del TRLGSS), o por la aplicación indebida de deducciones, bonificaciones, compensaciones o reducciones, (arts. 19, 20, 33 apartados 1.a y d, y 34 apartados 1.b y d del TRLGSS), incluyendo las bonificaciones del subsistema de formación profesional para el empleo. 
Las deudas por cotizaciones a la Seguridad Social, y por cuotas objeto de recaudación conjunta (desempleo, formación profesional y fondo de garantía salarial) de la sociedad de capital (art. 18.3 y 142.1 del TRLGSS), una vez expirado el plazo reglamentario de ingreso se reclamarán administrativamente. Reclamación de la deuda por cuotas a la sociedad que se llevará a cabo a través de dos títulos jurídicos o actos administrativos, por un lado, mediante la llamada "reclamación de deuda" por la TGSS, o mediante acta de liquidación de cuotas de la ITSS (arts. 33 y 34 del TRLGSS, art. 20 del RGCSS, y arts. 62 y 65 del RGRSS). En esas reclamaciones administrativas se aplicarán los correspondientes recargos, y comenzará el devengo de intereses de demora (arts. 30 y 31.2 del TRLGSS y arts. 6.2, 10 y 11 del RGRSS). Los intereses de demora exigibles serán los que vaya devengado el principal de la deuda y el recargo desde el vencimiento del plazo reglamentario de ingreso (art. 31.2 del TRLGSS). Intereses de demora y costas del procedimiento que serán exigibles en el período de recaudación ejecutiva (arts. 31.1 y 38.7 del TRLGSS y arts. 11 y 127 del RGRSS).

Cuando el descubierto de cotización a la Seguridad Social sea total, la reclamación de la deuda a la sociedad de capital corresponderá a la TGSS mediante la llamada "reclamación de deuda", si estamos ante una falta de cotización por los trabajadores que se hallasen en alta en Seguridad Social en el código de cuenta de cotización de la sociedad (art. 33 apartados a y b del TRLGSS). Cuando la deuda por descubierto total tenga su origen en la falta de afiliación o de alta de los trabajadores en Seguridad Social, será reclamada a la sociedad por la ITSS $^{23}$, mediante la expedición de un acta de liquidación de cuotas (art. 34 apartado a, del TRLGSS).

Cuando la competencia sea de la TGSS en los supuestos de falta de cotización total por los trabajadores en situación de alta en Seguridad Social en la sociedad de capital, la ITSS podrá remitir a la TGSS una propuesta de liquidación cuando haya comprobado las bases de cotización reales, para que se reclamen las cuotas por bases reales y no por bases estimadas (art. 35 del TRLGSS y arts. 62.3 y 65.2 del RGRSS). Propuesta de liquidación cuya finalidad es facilitar a la TGSS las bases individuales de los

\footnotetext{
${ }^{23}$ Inspección que administrativamente tienen la condición jurídica de Organismo Autónomo Estatal, que fue creado con la denominación de Organismo Estatal Inspección de Trabajo y Seguridad Social OEITSS-, por la Ley 23/2015, de 21 de julio, Ordenadora del Sistema de Inspección de Trabajo y Seguridad Social -BOE del 22.7.2015-, y regulado por el Real Decreto 192/2018, de 6 de abril, por el que se aprueban los estatutos del Organismo Autónomo Organismo Estatal Inspección de Trabajo y Seguridad Social -BOE del 7.4.2018-.
} 
trabajadores $^{24}$, lo que tendrá efectos recaudadores y prestacionales, porque, por un lado, permitirá la reclamación de la deuda con datos reales, y, por otro lado, permitirá conocer a las entidades gestoras de la Seguridad Social las bases de cotización individualizadas a efectos de futuras prestaciones. Propuesta de liquidación que tendrá efectos indirectos en la derivación de responsabilidad, ya que permitirá que conste una deuda de la sociedad de capital por bases reales, que será la que se derivará posteriormente al administrador social.

Si las deudas de Seguridad Social fuesen debidas a diferencias de cotización, por haberse aplicado bases y tipos de cotización inferiores a los debidos, o por reducciones, bonificaciones o deducciones indebidas, la competencia para su reclamación a la sociedad de capital corresponderá a la TGSS a través de la reclamación de deuda, siempre que la diferencia resulte directamente de la liquidación mensual o de los datos transmitidos por el sistema de liquidación directa, y no deba realizarse una valoración jurídica acerca de su carácter cotizable. Por el contrario, para la reclamación de cualquier diferencia de cotización a la sociedad de capital, en la que se tenga que efectuar una valoración jurídica acerca del carácter cotizable a la Seguridad Social -sean diferencias en bases, en tipos de cotización, en reducciones, deducciones o bonificaciones-, la competencia para su reclamación corresponde a la ITSS mediante acta de liquidación de cuotas (arts. 33.1.c y 34.1.b, del TRLGSS, en relación con los arts. 62.1.c y 65.1.b del RGRSS). Finalmente, la reclamación de las bonificaciones indebidas del subsistema de formación profesional para el empleo ante la sociedad de capital, se reclamarán mediante acta de liquidación de cuotas de la ITSS (34.1.d del TRLGSS).

Si la empresa redujese las cuotas mensuales de Seguridad Social mediante la aplicación indebida de deducciones por prestaciones de pago delegado improcedentes, la deuda que se genera será una deuda por diferencias de cotización ${ }^{25}$, aunque el recurso sea un

\footnotetext{
${ }^{24}$ MERCADER UGUINA, J. R. y SÁNCHEZ GRANDE, A.: “Anotaciones al Reglamento general sobre procedimiento sancionador y liquidatorio del orden social (Novedades del RD 928/1998, de 14 de mayo)", Relaciones Laborales, no 20, Sección Legislación, Quincena del 16 al 31 octubre 1998, p. 1109, Tomo 2, Editorial La Ley, edición digital, https://laleydigital-laleynext-es.ponton.uva.es/Content/Documento.aspx?params, p. 10; MERCADER UGUINA, J. R.: Los Procedimientos Administrativos en materia de Seguridad Social, Aranzadi Thomson Reuters, 2017, pp. 175-176.

25 Artículo 17 del RGCSS, y art. 60 del RGRSS, en relación con la Resolución de 13 de abril de 2010 (BOE del 22.4.2010), de la Secretaria de Estado de la Seguridad Social, sobre colaboración de las entidades gestoras, la Tesorería General de la Seguridad Social y las Mutuas Colaboradoras, en las
} 
recurso de prestaciones indebidas, con lo que forma parte de la gestión recaudatoria de la Seguridad Social la reclamación a la sociedad de capital de los importes indebidamente deducidos (Sentencias del TS, Sala Social, de 30 de septiembre de 2002 -rcud. 223/2002- ${ }^{26}$ ). Es una deuda de cotización de la empresa, por haber minorado ésta las cotizaciones mensuales a la Seguridad Social, y será objeto de reclamación a la sociedad de capital por la TGSS mediante reclamación de deuda, si la diferencia resulta directamente de la autoliquidación practicada por la empresa o de los datos comunicados por el sistema de liquidación directa (art. 33 apartado c del TRLGSS), o por la Inspección de Trabajo y Seguridad Social, mediante acta de liquidación de cuotas por diferencias de cotización de ser deducciones indebidas o fraudulentas en el pago delegado de la incapacidad temporal, (art. 34 apartado b del TRLGSS).

Potestativamente, la ITSS está facultada para reclamar el pago de cuotas a la sociedad de capital antes de extender el acta de liquidación de cuotas, emitiendo un requerimiento de pago a la empresa para los supuestos de las deudas por falta de alta, diferencias de cotización, o para requerir el pago al responsable solidario por derivación de responsabilidad (art. 34.1 párrafo segundo del TRLGSS). De no efectuarse el pago en el plazo establecido en el requerimiento, se extenderá el acta de liquidación de cuotas y el acta de infracción, salvo en la derivación de responsabilidad al administrador social en que no cabe acta de infracción (art. 34.1 párrafo segundo del TRLGSS).

La reclamación de las cuotas a la sociedad de capital, sea mediante reclamación de deuda o acta de liquidación, incluirá el recargo aplicable. Recargo que será diferente en función de si la sociedad cumplió o no con la obligación de comunicar en plazo reglamentario los datos de cotización necesarios para que la TGSS pudiese efectuar el cálculo de la liquidación a ingresar.

actuaciones de control de compensaciones en los documentos de cotización de pago delgado de la prestación de incapacidad temporal.

${ }^{26}$ En esa Sentencia de 30 de septiembre de 2002, que cita anteriores Sentencias de 26 de junio de 2002 y 3 de julio de 2002, señala, "La obligación de pago de la prestación de incapacidad temporal, sea como pago delegado, ya como responsable directo, corresponde al empleador. Cuestión diferente a este pago, como ha ocurrido en el caso que nos ocupa, es que pueda existir una deducción indebida de cotizaciones por parte del empleador; acto indebido que puede dar lugar, como materia incluible en la gestión recaudatoria, a que la Mutua reclame ante la Tesorería General de la Seguridad Social la deuda por el importe de las deducciones practicadas, conforme a lo dispuesto en el artículo 8 del Real Decreto 1637/95, de 6 de octubre". La referencia al Real Decreto 1637/1995, de 6 de octubre, antiguo Reglamento General de Recaudación de la Seguridad Social, debe entenderse al actual Real Decreto 1415/2004, de 11 de junio, por el que se aprueba el Reglamento General de Recaudación de la Seguridad Social.

La Sentencia del TS, Sala Social, 500/2020, de 23 de junio -rcud. 4375/2017-, cita la Sentencia de 30 de septiembre de 2002, pese a desestimar el Recurso interpuesto por falta de contradicción. 
De no haberse cumplido con la obligación formal del art. 29 del TRLGSS de comunicar en plazo reglamentario los datos necesarios para la práctica de la liquidación de cuotas o con la transmisión de autoliquidaciones (supuestos del art. 33.1.a, b y d del TRLGSS), el recargo aplicable en la reclamación de la deuda de la TGSS de conformidad con el art. 30.1.b del TRLGSS, será: a) del 20 por ciento de la deuda, de abonarse las cuotas antes de la terminación del plazo de ingreso establecido en la reclamación de deuda, o b) del 35 por ciento de la deuda, si se abonasen las cuotas debidas a partir de la terminación de dicho plazo de ingreso. Recargo del 20 por ciento que es aplicable a las actas de liquidación de cuotas de la ITSS.

En el supuesto de reclamación de deuda de la TGSS por diferencias de cotización que resultan de los datos de cotización comunicados en plazo reglamentario (supuesto del art. 33.1.c del TRLGSS), el recargo de la reclamación de deuda será: a) del 10 por ciento de la deuda, si se abonasen las cuotas debidas dentro del primer mes natural siguiente al del vencimiento del plazo reglamentario para su ingreso, o b) del 20 por ciento de la deuda, si se abonasen las cuotas debidas a partir del segundo mes natural siguiente al del vencimiento del plazo para su ingreso.

Una vez transcurra el plazo reglamentario de ingreso de las cuotas de Seguridad Social, sea una deuda por descubiertos totales, por diferencias de cotización o por bonificaciones indebidas del subsistema de formación profesional para el empleo, ha nacido una deuda de Seguridad Social, que será susceptible de ser reclamada al administrador social, de concurrir los supuestos legales determinantes de responsabilidad, bien mediante la acción individual de responsabilidad del art. 241 de la LSC, que veremos en el Capítulo II, o bien mediante la derivación administrativa de deuda dentro del proceso de recaudación, al amparo del art. 18 apartados 3 y 4 del TRLGSS.

La derivación administrativa de responsabilidad por cuotas de Seguridad Social, dentro del procedimiento de recaudación de los recursos económicos de la Seguridad Social, en virtud del principio de autotutela administrativa (art. 18 apartados 3 y 4 del TRLGSS), podrá formalizarse a través de dos títulos jurídicos diversos, en función del sujeto legitimado para iniciar el procedimiento. $\mathrm{O}$ bien, mediante resolución de derivación de responsabilidad de la TGSS, en la que se declare la responsabilidad solidaria o subsidiaria del administrador, que se complementará con la expedición de la correspondiente reclamación de la deuda por derivación, en la que constará el importe 
de la deuda, los conceptos, los hechos y la fundamentación jurídica de la responsabilidad, así como los recargos, intereses y costas de ser una responsabilidad solidaria (art. 33.2 del TRLGSS, y art. 12 apartados 2 y 4, en relación con el art. 62.2 del RGRSS), o bien el acta de liquidación de cuotas por derivación de responsabilidad expedida por la ITSS (arts. 34.1.c del TRLGSS, art. 65.1.c del RGRSS y art. 32.1 del Real Decreto 928/1998, de 14 de mayo, que aprueba el Reglamento General sobre Procedimiento para la Imposición de Sanciones por Infracciones del Orden Social y para los Expedientes Liquidatorios de cuotas de Seguridad Social -RISOS-27), que veremos en el último capítulo de esta tesis.

Para evitar que el coste de la reclamación pueda ser superior a las cuotas adeudadas, se establecen unos importes mínimos para poder iniciarse el procedimiento de reclamación administrativa de la deuda, sea de una única deuda o de la agrupación de varias existente contra el mismo deudor (art. 116.2 del TRLGSS y arts. 7 a 13 de la Orden 116.2 y arts. 7 a 13 de la Orden TAS/1562/2005, de 25 de mayo ${ }^{28}$, que desarrolla el RGRSS). El importe mínimo que puede ser objeto de recaudación administrativa se fija en una cuantía que no exceda del 3\% del IPREM mensual, vigente en el momento de la respectiva liquidación, salvo en los casos de responsabilidad por sucesión mortis causa en los que dicha cuantía se fija en el 20\% del IPREM mensual.

\section{Deudas de la sociedad de capital por prestaciones de Seguridad Social.}

Las deudas por prestaciones de responsabilidad empresarial son un recurso económico de la Seguridad Social, cuya relación se recoge en el art. 1 apartados d, g, k, m, ñ, p, del RGRSS. Deudas por prestaciones de responsabilidad empresarial, que precisan una previa resolución administrativa firme de la entidad gestora declarando la responsabilidad de la empresa (arts. 55.2 y 167.4 del TRLGSS). Una vez se ha declarado por la entidad gestora de la prestación la responsabilidad de la empresa, nace una deuda de Seguridad Social de la sociedad de capital que será exigible a ésta en el procedimiento administrativo de recaudación de los recursos de la Seguridad Social (arts. 1, 2, 69, 70, 75, 78 y 80 del RGRSS).

Las principales deudas por prestaciones de la empresa, a efectos de esta investigación, surgirán al amparo de los recursos económicos establecidos en el art. 1 apartados d), g)

\footnotetext{
27 BOE 3.6.1998.

${ }^{28}$ BOE 1.6.2005.
} 
y m) del RGSS (prestaciones y pensiones de responsabilidad empresarial, recargo de prestaciones, y reintegro de prestaciones indebidamente percibidas), todas ellas podrán ser objeto de derivación administrativa de responsabilidad al administrador en el procedimiento de recaudación, con la peculiaridad establecida para el recargo de prestaciones que analizaremos en el apartado III. 3 de este capítulo. Deudas de la sociedad que podrían, en su caso, ser exigibles al administrador social mediante la acción individual de responsabilidad.

Las prestaciones económicas de Seguridad Social que podrá percibir un trabajador en nuestro sistema jurídico, de conformidad con los arts. 42 y 161 a 234 del TRLGSS, serán las siguientes: a) prestaciones periódicas como son la incapacidad temporal, nacimiento y cuidado de menor, riesgo durante el embarazo, riesgo durante la lactancia natural, ejercicio corresponsable del cuidado del lactante, cuidado de menores afectados por cáncer u otra enfermedad grave, pensión temporal de orfandad o de viudedad temporal; b) prestaciones vitalicias como son la pensión de incapacidad permanente (total, absoluta y gran invalidez), la pensión de jubilación, y las de muerte o supervivencia y c) prestaciones a tanto alzado, como la prestación de incapacidad parcial o total, en este caso para menores de 60 años que opten expresamente por ese tipo de prestación, o en favor de los familiares por accidente de trabajo y enfermedad profesional, o la indemnización por lesiones permanentes no invalidantes.

De exigirse la responsabilidad empresarial en el pago de prestaciones en el procedimiento administrativo de derivación de responsabilidad, habrán de distinguirse dos momentos procedimentales distintos y conexos ante la empresa empleadora. Por un lado, la declaración de la responsabilidad de la sociedad de capital por concurrir alguno de los supuestos legalmente establecidos, cuya competencia corresponde a la entidad gestora de la prestación, al Instituto Nacional de la Seguridad Social -INSS-, e Instituto Social de la Marina -ISM-, o al SEPE si son prestaciones de desempleo, salvo en el Régimen del Mar, en que el ISM es entidad gestora también de las prestaciones de desempleo $^{29}$. Por otro lado, una vez declarada la responsabilidad de la sociedad de capital, la competencia para la gestión recaudatoria encaminada a hacer efectiva la realización de la deuda de Seguridad Social ante la empresa corresponde a la TGSS (art. 1.1 apartados d, g, k, m, y arts. 69, 70 y 75 del RGRSS).

29 Artículos 55.2, 167.4, 294 y 295 TRLGSS, y artículo 43 de la Ley 47/2015, de 21 de octubre, reguladora de la protección social de las personas trabajadoras del sector marítimo-pesquero -BOE 22.10.2015-. 
Para que pueda ser reclamada la responsabilidad de la sociedad de capital, en cuanto empleadora y directamente responsable de la prestación, se precisa la previa declaración de la responsabilidad empresarial por la entidad gestora mediante resolución administrativa firme, en la que se podrá igualmente declarar la responsabilidad de otras empresas que pudieran resultar responsables de la prestación, como sucede en las contratas, subcontratas, cesión ilegal, empresas de trabajo temporal, o en la sucesión de empresa $^{30}$. En el art. 69.3 del RGRSS, se señala que, si bien la responsabilidad de la sociedad de capital como empresario en el pago de la prestación ha de ser declarada en resolución administrativa firme, se permite que, "asimismo será necesaria resolución previa que agote la vía administrativa de la entidad gestora competente que declare la responsabilidad solidaria, subsidiaria o mortis causa en orden a las prestaciones de las que sean responsables las empresas por prestaciones a su cargo".

Declaración de responsabilidad de la entidad gestora que adquiere firmeza en vía administrativa una vez se haya resuelto la reclamación previa que es exigible como trámite pre procesal antes de demandar a aquélla ante el orden jurisdiccional social (art. 71 de la LRJS). La reclamación previa en materia de prestaciones de Seguridad Social se mantiene en vigor, a diferencia de la reclamación previa a la vía civil o laboral que se suprimió por la Disposición Final Tercera de la Ley 39/2015, de 1 de octubre, del Procedimiento Administrativo Común de las Administraciones Públicas -LPACAP_ ${ }^{31}$. Reclamación previa que tiene un doble carácter o naturaleza ${ }^{32}$, administrativa en cuanto la entidad gestora tiene la posibilidad de volver a reconsiderar su decisión ante de ser demanda, y preprocesal al ser requisito previo para la admisión de la demanda.

Para que la TGSS pueda iniciar el procedimiento recaudatorio de las prestaciones de responsabilidad empresarial, la entidad gestora deberá remitir a la Tesorería General de la Seguridad Social todas las resoluciones y los acuerdos firmes en vía administrativa, que declaren la responsabilidad de la empresa sociedad de capital, con indicación expresa de la fecha de su notificación a ésta, conjuntamente con todos los datos necesarios para que ese Servicio Común pueda efectuar el cálculo del importe del

${ }^{30}$ Art. 69.3 del RGRSS. En relación con los arts. 167.4, 168 del TRLGSS, arts. 42, 43 y 44 del Real Decreto Legislativo 2/2015, de 23 de octubre, por el que se aprueba el Texto Refundido de la Ley del Estatuto de los Trabajadores -TRLET-, y art 16 de la Ley 14/1994, de 1 de junio, que regula las Empresas de Trabajo Temporal -LETT -, BOE de 2.6.1994.

${ }^{31}$ BOE del 2.10.2015.

32 ALBERT EMBUENA, V.: La Incapacidad Permanente Contributiva. Aspectos Sustantivos y Procesales, Tirant lo Blanch, 2017, edición digital, https://biblioteca-tirant-com.ponton.uva.es/cloudLibrary/ebook/search, pp.190-192. 
capital coste a ingresar, de los intereses de capitalización y de los recargos correspondientes (art. 69.3 del RGSS). Esas resoluciones firmes de la entidad gestora serán recurribles ante la Jurisdicción Social (art. 2 apartado o) de la LRJS).

Recibidas esas resoluciones de la entidad gestora, la TGSS recaudará esa deuda por prestaciones a la sociedad de capital emitiendo la reclamación de deuda por prestaciones (art. 70 del RGRSS), que incluirá los siguientes conceptos (art. 69.1 del RGRSS): a) El importe del valor actual del capital coste de las pensiones de las que hayan sido declaradas responsables, haya mediado o no anticipo por parte de la Seguridad Social; b) Los intereses de capitalización; c) El importe correspondiente a las prestaciones de cuantía fija o periódica no vitalicia y a tanto alzado, incluidas aquellas que hayan de ser satisfechas directamente a los beneficiarios por la entidad colaboradora o el empleador, en caso de impago, haya mediado o no anticipo por parte de la Seguridad Social; d) El recargo del cinco por ciento por falta de aseguramiento, si procediere. Los intereses de capitalización se liquidarán e ingresarán junto con los capitales coste sobre los que recaen. Asimismo, los recargos por falta de aseguramiento de la que hubiesen sido declarados responsables de pago los empresarios se liquidarán e ingresarán junto a los capitales coste de pensión.

Emitida la reclamación de deuda, la sociedad de capital debe efectuar su ingreso en plazo reglamentario que finaliza el último día hábil del mes siguiente a su notificación (art. 70.1 del RGRSS). Transcurrido el pazo reglamentario sin haberse atendido el pago, y una vez sea firme en vía administrativa la reclamación de deuda emitida, se inicia el procedimiento de ejecución dictándose la providencia de apremio ${ }^{33}$. Actos de gestión recaudatoria que, una vez firmes en vía administrativa, son impugnables ante la Jurisdicción Contencioso-Administrativa (art. 3 letra f LRJS y arts. 1 y 2 de la LJCA) ${ }^{34}$.

${ }^{33}$ Arts. 69 y 70 del RGRSS. Para prestaciones de desempleo, la reclamación de la deuda en vía voluntaria ante la empresa responsable, la inicia la entidad gestora de Desempleo, y de no atender el pago la empresa, la Recaudación Ejecutiva se realizará por la TGSS (art. 295 TRLGSS).

34 Desde las Sentencias del TS, Sala Contencioso-Administrativa, de 31 de enero de 2000 -Rec. 6603/1997 y 4886/1997-; y de 1 de febrero de 2000 -Rec. 1311/1998 y 1369/1998-, se ha distinguido, entre impugnación de la resolución de la entidad gestora que declara la responsabilidad empresarial en el pago de una prestación, que es impugnable ante la Jurisdicción Social, y el acto posterior de gestión recaudatoria de la TGSS, reclamando el pago del capital coste, que es recurrible en vía ContenciosoAdministrativa. En igual sentido el TS, Sala de Conflictos de Competencias en Auto no 36/1998 de 3 noviembre -Rec. 36/1998-. Existe una dualidad competencial entre la Jurisdicción Social y la Contencioso-Administrativa, correspondiendo a la primera la facultad exclusiva de pronunciarse sobre la declaración de responsabilidad empresarial, y a la segunda todo lo relativo a la impugnación o incidencias derivadas del acto de liquidación y recaudación, de modo que únicamente cabe impugnar en esta segunda vía la cuantificación material del capital fijado partiendo, no obstante, de los criterios 
No se iniciará tampoco la reclamación de estas deudas por prestaciones cuando sus importes sean inferiores al 3\% del IPREM, salvo en los casos de responsabilidad por sucesión mortis causa en los que dicha cuantía se fija en el 20\% del IPREM mensual (art. 116.2 del TRLGSS y arts. 7 a 13 de la Orden TAS/1562/2005, de 25 de mayo). Declarada la responsabilidad empresarial surge una deuda de Seguridad Social de la sociedad de capital, que, en su caso, podría ser exigible también al administrador social.

Deuda de prestaciones que podrá ser única y exclusivamente de la sociedad ante el trabajador, cuando no proceda el pago anticipado por la entidad gestora, o ser una deuda de la empresa ante la entidad gestora de proceder el pago anticipado de ésta al trabajador en virtud de automaticidad absoluta o relativa de la prestación.

De ser una deuda de responsabilidad exclusiva de la empresa, el trabajador podría reclamar la responsabilidad también al administrador social si concurren los presupuestos legales determinantes de la responsabilidad de éste, bien mediante la acción individual de responsabilidad del art. 241 de la LSC, o bien mediante la acción procesal de responsabilidad del administrador en las deudas sociales (arts. 36 a 39, 360 y 367 de la LSC).

De ser una deuda con régimen de automaticidad absoluta o relativa, surgirá una deuda de la sociedad de capital con la entidad gestora o la mutua, que podrá ser reclamada también, en su caso, al administrador social mediante la derivación administrativa de la responsabilidad dentro del procedimiento administrativo de recaudación (art. 18.3 del TRLGSS y arts. 1, 12, 13, 69, 70, 75, 78 y 80 del RGRSS), o mediante la acción individual de responsabilidad (art. 241 de la LSC).

Las prestaciones con el beneficio de automaticidad absoluta -alta de pleno derecho o en palabras de un sector doctrinal alta preferente ${ }^{35}$-, son las prestaciones de desempleo, las prestaciones derivadas de contingencias profesionales (accidentes de trabajo y enfermedades profesionales), así como en su caso, la asistencia sanitaria por contingencias comunes y por nacimiento y cuidado de menor (antigua maternidad). Tienen el tratamiento y naturaleza de contingencias profesionales, las prestaciones de

establecidos por el INSS (Sentencias de esa Sala del TS 31 de enero de 2000 -Rec. 6603/1997 y 4886/1997-; 1 de febrero de 2000 -Rec. 1311/1998 y 1369/1998-; 22 de marzo de 2002, Rec. 9037/1996- ; 12 de marzo del 2001; 25 de septiembre del 2002; y 18 de marzo del 2003 -Rec. 1128/1998-).

35 AA.VV. (PEDRAJAS MORENO, A.; SALA FRANCO, T.; y VALLEJO ORTE, A.): La incapacidad permanente y las lesiones no invalidantes, Tirant Lo Blanch, 2010, p. 37. 
riesgo por embarazo y riesgo por lactancia de la mujer trabajadora, de conformidad con los arts. 186 a 189 del TRLGSS, por lo que, a efectos de la acción protectora, tienen la consideración de altas de pleno derecho, siendo de aplicación el principio de automaticidad de prestaciones (art. 29.2 del Real Decreto 84/1996, de 26 de enero) ${ }^{36}$.

Seguidamente procedemos a examinar las principales deudas por prestaciones de la sociedad de capital que podrían ser objeto de reclamación al administrador social: a) deudas por prestaciones ante incumplimientos de normas de prevención de riesgos laborales; b) deudas por responsabilidad empresarial en el reintegro de prestaciones indebidamente percibidas; c) deudas de prestaciones de pago directo de la empresa; d) deudas por prestaciones por incumplir la empresa obligaciones de encuadramiento y cotización a la Seguridad Social.

\subsection{Deudas por prestaciones ante incumplimientos de normas de prevención de riesgos laborales.}

Serán tres los supuestos fundamentales en que podrá surgir la responsabilidad empresarial en el pago de prestaciones de Seguridad Social por el incumplimiento de sus obligaciones en materia de prevención de riesgos laborales.

- En primer lugar, las prestaciones causadas por enfermedad profesional sin haber tenido el trabajador los reconocimientos médicos obligatorios, previos al acceso al empleo o periódicos durante la relación laboral, cuando vengan establecidos en disposiciones en materia de prevención de riesgos laborales, que dará lugar a que se declare la responsabilidad empresarial en el pago de la prestación (art. 244.2 del TRLGSS). Será responsabilidad de la empresa la prestación, sin perjuicio de que anticipe el pago la entidad gestora o la mutua colaboradora, en caso de impago por la empresa responsable, al ser una prestación por contingencias profesionales en que rige la automaticidad en el pago (arts. 166.4 y 167.3 del TRLGSS). Al anticiparse el pago surge una deuda de la empresa ante las Instituciones de la Seguridad Social que podrá reclamarse, en su caso, al administrador social mediante la derivación administrativa de responsabilidad (art. 18.3 del TRLGSS), o mediante el ejercicio de la acción individual de responsabilidad (art. 241 de la LSC).

${ }^{36}$ CARPENA NIÑO, J.M.: "La responsabilidad empresarial en materia de Seguridad Social por infracotizaciones", Revista del Ministerio de Trabajo y Asuntos Sociales, edición digital Recogida en el Foro del conocimiento de la ITSS núm 74, 2008, p. 18 de 26. 
- En segundo lugar, surge la responsabilidad empresarial cuando acaezca un accidente de trabajo incumpliendo la empresa la orden de paralización de trabajos por riesgos graves e inminentes para los trabajadores impuesta por la Inspección de Trabajo y Seguridad Social, en cuyo caso, se estima que los accidentes se producen como si no hubiere concertado la empresa la protección por la contingencia (art. 242 de la LGSS). Es de responsabilidad de la empresa la prestación, sin perjuicio de que, al ser una prestación de contingencias profesionales, anticipe el pago la entidad gestora o mutua colaboradora (art. 166.4 del TRLGSS). De ese anticipo surge una deuda por prestaciones de la sociedad de capital ante las Instituciones de la Seguridad Social, que podrá reclamarse, en su caso, al administrador social mediante la derivación administrativa de responsabilidad (art. 18.3 del TRLGSS), o mediante el ejercicio de la acción individual de responsabilidad (art. 241 de la LSC).

- Un tercer supuesto, es la responsabilidad por el recargo de prestaciones, al que dedicaremos un apartado específico más adelante (apartado III. 3).

\subsection{Deudas por responsabilidad empresarial en el reintegro de prestaciones indebidamente percibidas.}

Podrá surgir una responsabilidad en el pago de prestaciones cuando se haya producido una percepción indebida de una prestación por el trabajador, y la sociedad haya sido colaboradora necesaria para esa obtención indebida, en cuyo caso, la mercantil responde subsidiariamente con el trabajador de la devolución de la prestación indebida, salvo que acredite buena fe en su actuación (art. 55 del TRLGSS).

El reintegro de prestaciones al trabajador beneficiario sólo podrá ser reclamado en vía administrativa, cuando proceda jurídicamente la revisión de oficio por la entidad gestora, ya que, en otro caso, deberá reclamarse al trabajador el reintegro de la prestación indebida ante el orden jurisdiccional social (art. 146 de la Ley 36/2011, de 10 de octubre, Reguladora de la Jurisdicción Social -en adelante LRJS-).

Sólo cabe la revisión de oficio en vía administrativa por la entidad gestora de prestaciones reconocidas, en los siguientes supuestos ${ }^{37}$. En primer lugar, cuando se rectifiquen errores materiales, de hecho y aritméticos. En segundo lugar, cuando la revisión sea debida a omisiones o inexactitudes en las declaraciones del beneficiario

\footnotetext{
${ }^{37}$ Art. 146 de la LRJS.
} 
para obtener la prestación. En tercer lugar, si se trata de revisión de actos de prestaciones o subsidios por desempleo, o de la prestación por cese de actividad de los trabajadores autónomos, siempre que se efectúe dentro del plazo máximo de un año desde la resolución administrativa. En cuarto lugar, cuando se trata de revisar los actos de reconocimiento del derecho a una prestación de muerte y supervivencia, motivada por la condena al beneficiario mediante sentencia firme por la comisión de un delito doloso de homicidio en cualquiera de sus formas, si la víctima hubiera sido el sujeto causante de la prestación, en cuyo caso la revisión que podrá efectuarse en cualquier momento.

Una vez se declare por la entidad gestora la responsabilidad del trabajador en el reintegro de la prestación indebidamente percibida nace la responsabilidad subsidiaria de la empresa empleadora, si con su acción u omisión contribuyó a la percepción indebida, (art. 55.2 del TRLGSS). Según este precepto legal, del reintegro de la prestación responde subsidiariamente con el trabajador perceptor quien, por acción u omisión, haya contribuido a hacer posible la percepción indebida ${ }^{38}$.

Nacida esa deuda por prestaciones de la sociedad de capital, en los supuestos legales determinantes de la responsabilidad del administrador, podría ser exigida a éste, si concurren los presupuestos legales de la acción individual de responsabilidad del art. 241 de la LSC, o de la derivación administrativa de la deuda al amparo del art. 18.3 del TRLGSS.

Un supuesto distinto, es la responsabilidad solidaria o directa de la empresa empleadora, prevista en los arts. 23.2 y 43.3 del Real Decreto Legislativo 5/2000, de 4 de agosto, por el que se aprueba el Texto Refundido de la Ley sobre Infracciones y Sanciones en el

\footnotetext{
${ }^{38}$ En este sentido en el Anexo de fecha 9 de marzo de 2016 de la Instrucción Conjunta de fecha 4.3.2013 de la Dirección General de la Inspección de Trabajo y Seguridad Social y de la Dirección General del Servicio Jurídico de la Seguridad Social para establecer un marco de coordinación en el ámbito de los ilícitos penales contra la Seguridad Social, se señala en su página 32, “el artículo 55. 1 del TRLGSS, RDL 8/2015, establece que los trabajadores y demás personas que hayan percibido indebidamente prestaciones de la Seguridad Social vendrán obligadas a reintegrar su importe. Salvo buena fe probada, también responden, con carácter subsidiario los que hayan contribuido, por acción u omisión, a hacer posible la percepción indebida. En consecuencia, la Administración tiene facultades para revisar de oficio y reclamar las prestaciones indebidamente percibidas en vía administrativa, o revisar los actos declarativos de Derechos en vía judicial, a tenor de lo dispuesto en el artículo 146 de la Ley Reguladora de la Jurisdicción Social -LRJS-. Por tanto, con carácter general, conviene Recordar que el Derecho administrativo contempla la posibilidad de proceder a la revisión de sus actos; esta facultad revisora responde a sus propias reglas, independientes del Derecho penal y del administrativo sancionador; y sólo en determinados supuestos, siempre excepcionales, la revisión de los actos administrativos guardará relación con la comisión de un ilícito penal”.
} 
Orden Social -en adelante TRLISOS- ${ }^{39}$, para la devolución o reintegro de prestaciones de Seguridad Social indebidamente percibidas por trabajadores por infracciones muy graves de la empresa, que es una deuda de naturaleza sancionadora. No podría exigirse al administrador social el reintegro de estas prestaciones indebidas, que como sanción accesoria o directa se haya impuesto a la sociedad de capital en el procedimiento administrativo sancionador del orden social, por tener ese reintegro la naturaleza de sanción administrativa, no siendo un acto administrativo de revisión de prestaciones reconocidas. Es una responsabilidad solidaria (art. 23.2 del TRLISOS) o directa de la empresa (art. 43.3 del TRLISOS) en el reintegro o devolución de una prestación indebidamente percibida, por haber participado la sociedad de capital en la comisión de la infracción.

\subsection{Deudas de prestaciones de pago directo de la empresa.}

Con carácter general, la responsabilidad del pago de las prestaciones de la Seguridad Social corresponde a la entidad gestora o colaboradora (arts. 45, 165 y 281 de la LGSS). No obstante, existen tres supuestos en que la responsabilidad del pago de la prestación es directa de la empresa, y con sus propios recursos económicos.

- El primer supuesto, es la prestación de incapacidad temporal por contingencias comunes de los días $4^{\circ}$ a $15^{\circ}$ ambos inclusive, de conformidad con el art. 173.1, $2^{\circ}$ párrafo del TRLGSS ${ }^{40}$. No obstante, pese a ser una prestación de pago directo y con los propios recursos económicos empresariales, al hallarnos ante una prestación pública de Seguridad Social, de no abonar la empresa esa prestación del

${ }^{39}$ BOE del 8.8.2000.

"Artículo 2. Sujetos responsables de la infracción.

Son sujetos responsables de la infracción las personas físicas o jurídicas y las comunidades de bienes que incurran en las acciones $u$ omisiones tipificadas como infracción en la presente Ley y, en particular, las siguientes:1. El empresario en la relación laboral. 2. Los empresarios, trabajadores por cuenta propia o ajena o asimilados, perceptores y solicitantes de las prestaciones de Seguridad Social, las entidades de formación o aquellas que asuman la organización de las acciones de formación profesional para el empleo programada por las empresas, de forma individual o en agrupación de empresas y los solicitantes y beneficiarios de las ayudas y subvenciones públicas de formación profesional para el empleo, las Mutuas Colaboradoras con la Seguridad Social y demás entidades colaboradoras en la gestión, en el ámbito de la relación jurídica de Seguridad Social, así como las entidades o empresas responsables de la gestión de prestaciones en cuanto a sus obligaciones en relación con el Registro de Prestaciones Sociales Públicas y demás sujetos obligados a facilitar información de trascendencia Recaudatoria en materia de Seguridad Social”. (....).

${ }^{40}$ Responsabilidad directa de la empresa que se estableció a través del Real Decreto-Ley 5/1992, de 21 de julio. La STC 37/1994, de 10 de febrero, consideró compatible el precepto cuestionado con el art. 41 CE, fundamentalmente, porque el carácter público del sistema de Seguridad Social, no queda cuestionado por la incidencia en él de fórmulas de gestión o responsabilidad privadas, de importancia relativa en el conjunto de gestión del sistema. 
$4^{\circ}$ al $15^{\circ}$ día de baja, encontrándose en alta en Seguridad Social el trabajador reuniendo la carencia exigible, anticipará el pago la entidad gestora o colaboradora, la cual tendrá posteriormente un derecho de crédito para reintegrarse de ese pago ante la empresa ${ }^{41}$.

- El segundo supuesto de pago directo por la empresa de una prestación económica de Seguridad Social, tiene lugar cuando la empresa haya asumido la colaboración voluntaria en la gestión de la prestación de incapacidad temporal por contingencias profesionales, en virtud de la cual abonará directamente la prestación de incapacidad temporal por esas contingencias a sus trabajadores ${ }^{42}$. Ante el impago de la prestación de incapacidad temporal por la empresa que haya asumido la colaboración voluntaria en la gestión de la incapacidad temporal, reuniendo los requisitos legales el trabajador para su percepción, asume la responsabilidad subsidiaria ante éste la entidad gestora o colaboradora, por ser una prestación por contingencias profesionales en que rige el principio de automaticidad ${ }^{43}$.

- El tercer supuesto de responsabilidad directa de la empresa, es el recargo de prestaciones, que se analizará posteriormente.

Cuando proceda el anticipo o pago subsidiario de la prestación por las entidades gestoras nace una deuda por prestaciones de la sociedad de capital, que podrá reclamarse ante el administrador social mediante la derivación administrativa de responsabilidad (art. 18.3 del TRLGSS), o mediante el ejercicio de la acción individual de responsabilidad (art. 241 de la LSC).

${ }^{41}$ SSTS, Sala Social, 390/2016, de 9 de mayo, -Aranzadi RJ 201612695- que cita a las STS 15 junio 1998 -Rec.3519/1997- y 15 mayo 2001 -Rec.3546/2000-.

${ }^{42}$ Art 102.1 apartados a y b del TRLGSS, en redacción dada por la D.F. $2^{\mathrm{a}}$ del Real Decreto Ley 28/2018, de 28 de diciembre. Con la entrada en vigor el 1.1.2019 del Real Decreto Ley 28/2018, se suprime la colaboración voluntaria en la gestión de la incapacidad temporal por contingencias comunes, indicándose que cesarán el 31.3.2019 en esa colaboración voluntaria, las empresas que antes del 31.12.2018 tuvieren Reconocida esa colaboración en la gestión, con independencia de seguir efectuando el pago de los procesos Reconocidos antes del cese (DT. $4^{\text {a }}$ del Real Decreto Ley 28/2018, de 28 de diciembre).

${ }^{43}$ En este sentido la STS, Sala Social, 15 mayo 2001 -RJ 2001/5214-, establece la responsabilidad subsidiaria del Instituto Nacional de la Seguridad Social -INSS-, respecto del subsidio por incapacidad temporal que no abona a su trabajador la empresa insolvente, y que venía obligada al haber asumido el pago en régimen de colaboración voluntaria. La STS 17 septiembre 2001 -RJ 2001/8444-, sigue ese criterio respecto del subsidio de incapacidad temporal cuando se ha extinguido el contrato de trabajo. La Sentencia del TS, Sala Social, de 8 noviembre 2001 -RJ 2001/9873-, cuando la empresa haya asumido la colaboración voluntaria en la gestión de la Incapacidad Temporal, insiste en que su obligación, no excluye la obligación del INSS de anticipar el importe de la prestación, sin perjuicio de su Derecho a repetir contra la empresa incumplidora, criterio que es reiterado en SSTS 23 enero 2002 -Rec. 249/2001-, 1 junio 2004 -RJ 2004, 5385-. 


\subsection{Deudas por prestaciones por incumplir la empresa obligaciones de encuadramiento y cotización a la Seguridad Social.}

Cuando en la fecha en que se produce el hecho causante de una prestación de Seguridad Social de un trabajador de la sociedad de capital, la mercantil hubiere incumplido sus obligaciones instrumentales con la Seguridad Social en materia de afiliación o alta del empleado, o de cotización a la Seguridad Social, por la entidad gestora se declarará la responsabilidad empresarial en el pago de la prestación (arts. 45, 165, 167, 168 y 281 del TRLGSS).

Con carácter general, cuando nazca el derecho a una prestación de Seguridad Social, corresponde abonar su pago a las entidades gestoras o colaboradoras, siempre que el trabajador en la fecha del hecho causante se encontrase en alta o situación asimilada al alta y reuniese los períodos de cotización exigidos -de ser una prestación causada por enfermedad común, ya que no exigen períodos de carencia las prestaciones causadas por contingencias profesionales o por accidentes no laborales- (arts. 45, 46, 165, 166, $167 \mathrm{y}$ 281 del TRLGSS). Pero, si en la fecha del hecho causante de la prestación la empresa incumpliese sus obligaciones en materia de inscripción, afiliación, alta o cotización a la Seguridad Social surge la responsabilidad empresarial en el abono de la prestación de Seguridad Social (arts. 167 y 281 del TRLGSS), declaración de responsabilidad empresarial que se recogerá, en su caso, en la resolución administrativa expresa de la entidad gestora (art. 167.4 del TRLGSS), aunque puede suceder que si no se reúnen los requisitos para el nacimiento de la prestación se deniegue la misma obligando al trabajador a reclamar judicialmente, para que en la sentencia se declare la responsabilidad empresarial.

Frente a la resolución administrativa de declaración de la responsabilidad empresarial en la prestación, la sociedad de capital afectada está legitimada ${ }^{44}$ para impugnarla en reclamación previa a la vía judicial social ante la propia entidad gestora, y posteriormente mediante demanda ante el orden jurisdiccional social. Legitimación activa que se ha reconocido por la jurisprudencia ${ }^{45}$ en función del derecho a la tutela

\footnotetext{
${ }^{44}$ AA.VV. (PEDRAJAS MORENO, A.; SALA FRANCO, T.; y VALLEJO ORTE, A.): La incapacidad permanente y las lesiones no invalidantes, op. cit., p. 53, quienes citan la STS de la Sala Social de 14 de octubre de 1992.

45 SSTS, Sala Social, de 14 de octubre de 1992 (Ponente: DESDENTADO BONETE, A.), 20 de mayo de 2009 -rcud. 2405/2008-, 4 de abril de 2011 -rcud. 556/2010-; 30 de enero de 2012 -rcud. 2720/2010-, entre otras.
} 
judicial efectiva, por afectarle directamente en su patrimonio, incluso cuando sin haber sido condena por responsabilidad empresarial le afecte en la relación jurídico laboral que mantiene con el trabajador -efectos reflejos de la sentencia-

Acerca de la naturaleza jurídica de la responsabilidad empresarial en el pago de prestaciones, por el incumplimiento de las obligaciones instrumentales de inscripción de empresas, afiliación, alta y cotización a la Seguridad Social, se han sostenido diversas teorías. Para una primera interpretación doctrinal ${ }^{46}$, estaremos ante una responsabilidad específica de Seguridad Social, ya que de incumplirse esas obligaciones de Seguridad Social hay un desplazamiento de responsabilidad en el pago de la prestación de la entidad gestora o mutua colaboradora a la empresa, sin perjuicio en su caso del adelanto de prestaciones al trabajador por la entidad gestora o mutua. Para un segundo sector doctrinal ${ }^{47}$, estamos ante una responsabilidad civil consecuencia del incumplimiento de una obligación legal. Para una tercera teoría ${ }^{48}$, esta responsabilidad tiene naturaleza administrativa, y más concretamente sancionadora.

Ante ese debate doctrinal acerca de la naturaleza jurídica, DESDENTADO BONETE ${ }^{49}$ aboga por suprimir la responsabilidad en prestaciones de la empresa, para que se abonen

${ }^{46}$ ALMANSA PASTOR, J. M.: Derecho de la Seguridad Social, Tecnos, 6a edición, Madrid, 1989, pp. 354-355; AA.VV. (MONEREO PÉREZ, J. L. et altri): Manual de Seguridad Social, Tecnos, $16^{\mathrm{a}}$ edición, 2020, p. 229.

${ }^{47}$ GALA DURÁN, C.: La responsabilidad empresarial por incumplimiento de las obligaciones de afiliación, alta y cotización a la Seguridad Social, editorial Aranzadi, Pamplona, 1997, pp. 189-191. Para esta autora nos hallamos ante una responsabilidad civil regida por una ley especial, por la Ley General de la Seguridad Social, responsabilidad objetiva y no basada en la culpa.

${ }^{48}$ BLASCO PELLICER, A. A.: La responsabilidad empresarial en el pago de Prestaciones de Seguridad Social, editorial Aranzadi Thomson Reuters, 2005, pp. 123-128; MARTínEZ LUCAS, J. A.: "La configuración jurídica de la responsabilidad empresarial en orden a las prestaciones de la Seguridad Social”, Revista Española del Derecho del Trabajo, Cívitas, núm. 78, 1996; SALA FRANCO, T.: "El régimen jurídico del Derecho a prestaciones de la Seguridad Social (Un estudio de la responsabilidad empresarial por falta de afiliación, alta y cotización)”, RISS, núm. 6, noviembre-diciembre 1974, pp. 1477-1478. Carácter sancionador que se atribuye en el voto particular formulado por los magistrados Salinas Molina y Marín Correa, en la Sentencia de 1 de febrero de 2000 -rcud. 694/1999-, Sentencia que niega ese carácter sancionador y la aplicación del principio non bis in ídem. Vulneración del principio non bis in ídem y carácter sancionador de la responsabilidad empresarial del voto particular, que SEMPERE NAVARRO califica como (sic) "un drástico planteamiento de que todo el sistema de responsabilidad empresarial establecido en la Ley General de la Seguridad Social puede incurrir en inconstitucionalidad por infracción del art. 25 de la Constitución"; SEMPERE NAVARRO, A. V.: "La responsabilidad empresarial en contingencias profesionales tras la STS 1 febrero 2000 ", Aranzadi Social, núm. 4/2000, BIB 20001349, edición digital https://insignis-aranzadidigitales.ponton.uva.es/maf/app/document?srguid, p. 14 de 16.

49 DESDENTADO BONETE, A.: "Responsabilidades por el incumplimiento de las obligaciones en materia de actos de encuadramiento en la Seguridad Social", Actualidad Laboral, núm. 4, quincena del 16 al 29 febrero de 2004, pp. 395 y ss, y núm. 5, quincena del 1 al 15 marzo 2004, pp. 523 y ss., editorial La Ley, edición digital,

https://laleydigital-laleynext-es.ponton.uva.es/Content/Documento.aspx?params, ref. La Ley $313 / 2004$, p. 15 de 24 , señalando que "en términos de política legislativa, sería conveniente abordar 
por la Seguridad Social al ser lo propio de un sistema público de Seguridad Social, pero a cambio deberá tratarse con mayor severidad las sanciones administrativas por el incumplimiento de esas obligaciones de encuadramiento en Seguridad Social.

En todo caso, no estamos ante una sanción administrativa a efectos de la derivación administrativa de responsabilidad, no siendo de aplicación el art. 12.4 del RGRSS, por cuatro razones. En primer lugar, porque la responsabilidad no se impone dentro de un procedimiento sancionador, sino dentro de un procedimiento de reconcomiendo de prestaciones de Seguridad Social, no actuando la entidad gestora como autoridad revestida de imperium o poder coercitivo. En segundo lugar, porque si no se resuelve en plazo el procedimiento administrativo de reconocimiento de prestaciones por la entidad gestora, no opera la caducidad como ocurre en todo procedimiento sancionador (arts. 25 y 95 de la LPACAP), sino que se entiende desestimada la prestación por silencio administrativo (art. 129.3 del TRLGSS). En tercer lugar, porque el importe de la prestación no incrementa los recursos económicos del erario público, sino que va destinado a compensar o reintegrase del pago de la prestación efectuado al trabajador beneficiario. En cuarto lugar, porque no rige el principio non bis ídem, imponiéndose la responsabilidad en la prestación aunque la empresa haya sido sancionada administrativa o penalmente por incumplir las obligaciones determinantes de la responsabilidad en la prestación (Sentencia del TS, Sala Social, 1 de febrero de 2000 -rcud. 694/1999_ ${ }^{50}$ ). En quinto lugar, porque no rige en el procedimiento administrativo de reconocimiento de prestaciones y de declaración del sujeto responsable el principio de presunción de inocencia.

Ante la responsabilidad de la empresa por incumplimiento de las obligaciones de encuadramiento y cotización a la Seguridad Social, cuando rija el principio de automaticidad absoluta o relativa (arts. 166.3, 167.3 y 281 del TRLGSS), la entidad gestora o colaboradora anticipará la prestación al trabajador, por lo que nacerá una deuda con la Seguridad Social de la empresa por esa prestación anticipada. El pago

una reforma que prescinda de la responsabilidad empresarial en materia de prestaciones, reforzando el sistema sancionador administrativo en la línea de la Legislación Tributaria”.

${ }^{50}$ En esa Sentencia se indica en su Fundamento de Derecho $2^{\circ}$ que "el principio non bis in ídem, siendo un principio ligado al ius puniendi estatal es de difícil aplicación, a la luz de la doctrina constitucional sobre el mismo (SSTC 234/1991 y 164/1995), a la responsabilidad empresarial", rechazando que la responsabilidad empresarial pudiera vulnerar ese principio, como se apuntó en una anterior Sentencia de la Sala de fecha de 8 de mayo de 1997 -Rec. 3824/1996- en la que, como nuevo argumento para eximir la responsabilidad empresarial ante una prestación por contingencias comunes, se razonaba que para evitar vulnerarse el principio non bis ídem, si la falta de cotización no ha tenido efectos en la relación de protección se debía exonerar a la empresa de responsabilidad en la prestación. 
anticipado de la prestación tendrá como límite máximo el importe equivalente a dos veces y media el indicador público de rentas de efectos múltiples (IPREM) vigente en el momento del hecho causante (art. 167.3 del TRLGSS).

No teniendo esa deuda por prestaciones naturaleza de sanción administrativa, podrá ser exigida administrador social cuando estemos ante una responsabilidad ex lege en deudas de la sociedad de capital (art. 367 de la LSC), o cuando el incumplimiento de las obligaciones con la Seguridad Social de la sociedad de capital sea imputable a conducta orgánica del administrador social (acción individual de responsabilidad).

Son causas que determinan la responsabilidad de la empresa, si en la fecha del hecho causante de la prestación concurre alguna de las siguientes circunstancias:

a) Que el empleado afectado no se hallare afiliado y/o en alta en Seguridad Social en la empresa, ni en situación asimilada al alta (arts. 45, 165 y 167 del TRLGSS), siempre que no se produzca el alta de oficio con efectos retroactivos a un momento anterior al hecho causante.

b) Que la empresa no se encontrase al corriente en el pago de las cotizaciones a la Seguridad Social (arts. 45, 165 y 167 del TRLGSS), salvo que hubiere aplazamiento o fraccionamiento en el pago concedido por la TGSS, y se cumpla regularmente con el mismo. De hallarse en alta en Seguridad Social y reunir la carencia exigible, en función del principio de automaticidad relativa, anticipa el pago de la prestación la entidad gestora o colaboradora.

Otros supuestos conexos en que la empresa puede resultar responsable de prestaciones, acontece cuando vía garantía legal se imponga normativamente una responsabilidad solidaria o subsidiaria respecto a un trabajador de otra empresa, en situaciones de contratas, subcontratas, cesión ilegal de mano de obra, sucesiones de empresa, o en puestas a disposición de trabajadores por empresas de trabajo temporal, y que no son objeto de estudio a efectos de esta investigación, aunque conviene reseñarlos, por ser fuente de una posible reclamación a la empresa garante que no es parte del contrato de trabajo 51 .

El incumplimiento de las obligaciones empresariales de altas y cotizaciones a la Seguridad Social determinará responsabilidad de la empresa en el pago, previa fijación

\footnotetext{
${ }^{51}$ Arts. 42, 42 y 44 del TRLET, en relación con los arts. 168 del TRLGSS, y art.16 de la LETT.
} 
de los supuestos de imputación. Responsabilidad que debería haber sido objeto de desarrollo reglamentario (art. 167 párrafos 2 y 3 del TRLGSS). Desarrollo reglamentario que no ha tenido lugar, ni con la vigente ley, ni tampoco con los anteriores textos refundidos de la Ley General de la Seguridad Social aprobados por Decreto 2065/1974, de 30 de mayo, y por el Real Decreto Legislativo 1/1994, de 20 de junio.

Ante esa falta de desarrollo, partiendo de la Disposición Transitoria 2. ${ }^{a}$ del Real Decreto 1645/1972, de 23 de junio (derogada), que disponía que, "en tanto se dicten las disposiciones de desarrollo del nuevo régimen de la responsabilidad empresarial, se aplicarán las normas contenidas en los artículos 94, 95, 96 y 97 de la Ley de la Seguridad Social de 21 abril 1966", nuestra jurisprudencia ${ }^{52}$ ha venido aplicando con el carácter de norma reglamentaria esos preceptos de la Ley de Seguridad Social de 21 de abril de $1966^{53}$.

Aplicación que no ha sido literal, habiéndose realizado una interpretación más flexible y beneficiosa para el trabajador, para permitir una interpretación más acorde con la configuración de la Seguridad Social como servicio público esencial (art. 41 de nuestra Constitución-CE-), que tiende a garantizar prestaciones suficientes ante situaciones de necesidad. Interpretación integradora de esos preceptos que se ha admitido partiendo la jurisprudencia constitucional que convierte a la Seguridad Social en una función estatal para cubrir suficientemente las situaciones de necesidad, aunque la amplitud de la "cobertura suficiente" vendrá condicionada por las disponibilidades económicas, al poder fijarse el nivel y las condiciones de nacimiento de las prestaciones en función de las necesidades del momento presupuestario ${ }^{54}$.

Ante la falta de desarrollo reglamentario del TRLGSS en materia de responsabilidad empresarial, vamos a partir de la regulación de la Ley de Seguridad Social de 21 de abril de 1966, con el carácter de disposición reglamentaria, adaptando sus mandatos literales a la interpretación flexible y más favorable para el trabajador realizada por

\footnotetext{
${ }^{52}$ Se ha acudido a esos preceptos en SSTS, Sala Social, de 26 de enero de 2004 (RJ 2004, 4092), (Rec. 4535/02); 16 de febrero de 2005 (RJ 2005, 3492), (Rec. 136/04); 27 de abril de 2005 (RJ 2005, 5058), (Rec. 2130/04); 12 de mayo de 2005 (RJ 2005, 5045), (Rec. 2434/04); 8 de junio de 2006 (RJ 2006, 3413), (Rec. 871/05); 22 de enero de 2007 (RJ 2007, 2201), (Rec. 4450/05); 22 de febrero de 2007 (RJ 2007, 2788), (Rec. 1618/05); 2 de julio de 2007 (RJ 2007, 6125), (Rec. 686/06 ); y 22 enero 2009 (RJ 2009\1038), entre otras muchas.

${ }^{53}$ Decreto 907/1966, de 21 de abril, que aprueba el Texto Articulado de la Ley 193/1963, de 28 de diciembre, sobre Bases de la Seguridad Social -BOE del 22.4.1966-

${ }^{54}$ SSTC 77/1995, de 22 de mayo y 65/1987, de 21 de mayo, entre otras.
} 
nuestra jurisprudencia, pudiendo extraerse las siguientes conclusiones en materia de responsabilidad en el pago de prestaciones de Seguridad Social ${ }^{55}$ :

a) Falta de alta y automaticidad absoluta de prestaciones: si los trabajadores no están en situación de alta en la Seguridad Social, la empresa será la responsable del pago de la prestación, pero si se trata de contingencias profesionales (accidente de trabajo y enfermedad profesional), rige el principio de «automaticidad» (arts. 166.4 y 167 del vigente TRLGSS), de manera que la mutua o la entidad gestora ha de anticipar las prestaciones, sin perjuicio de repetir contra el empresario (responsable directo). Empresa responsable que ha de ingresar el capital coste de la pensión o prestación periódica en la Tesorería General Seguridad Social, calculado según lo establecido en la Orden TAS/4054/2005, de 27 de diciembre ${ }^{56}$. Para las prestaciones de desempleo rige igualmente el alta de pleno derecho y automaticidad, pagando directamente la entidad gestora, el SEPE o el ISM (arts. 166.4 y 281 del TRLGSS), sin perjuicio de repetir la misma frente a la empresa incumplidora de sus obligaciones de alta y cotización a la Seguridad Social. Opera igualmente el alta de pleno derecho a efecto de las prestaciones riesgo durante la lactancia, riesgo durante el embarazo, en que asume el pago la entidad colaboradora con la Seguridad Social (la mutua), y en la asistencia sanitaria por enfermedad común, nacimiento de menor (antigua maternidad) y accidente no laboral (arts. 166.4, 186 a 189 y 281 del TRLGSS, en relación con el art. 29.2 del Real Decreto 84/1996, de 26 de enero).

b) Si se trata de prestaciones de incapacidad temporal por contingencias comunes, el defecto de alta del trabajador impide la entrada en juego del principio de «automaticidad» para la prestación. La empresa responde directamente de la prestación de incapacidad temporal por contingencias comunes, no anticipando el pago la entidad gestora o colaboradora, y no respondiendo subsidiariamente el

${ }^{55}$ SSTS, Sala Social, de 14 de junio de 2000 -rcud. 3096/99-; 9 de abril de 2001 -rcud. 3860/99-; 26 de enero de 2004 -Rec. 4535/02-; 17 de noviembre de 2004 -rcud. 5997/03-; 12 de mayo de 2005 -RJ 2005/5045-; 16 de febrero de 2005 -RJ 2005/3492; 8 de noviembre de 2006; 20 de febrero de 2007 RJ 2007/2470-; 2 de julio de 2007 -rcud. 686/06-; 10 de julio de 2007 -rcud. 4168/06-; 22 de enero de 2009 -rcud. 3858/07-; 17 de febrero de 2009 -rcud. 4230/07-; 21 de mayo de 2009 -rcud. 1515/08-; 15 de noviembre de 2009 -rcud. 2864/06 -; y 16 de diciembre de 2009 -rcud. 4356/08-.

${ }^{56}$ Que desarrolla los criterios técnicos y aprueba las nuevas tablas de mortalidad que han de aplicarse para determinar el importe de los capitales coste de las pensiones u otras prestaciones de carácter periódico del Sistema de la Seguridad Social, BOE 28.12.2005. 
INSS/ISM o la mutua ante la insolvencia patronal, naciendo de este modo un crédito del trabajador ante la empresa ${ }^{57}$.

c) Automaticidad relativa de prestaciones. La automaticidad relativa o anticipo opera sin excepción respecto de los trabajadores que se encuentran en alta en Seguridad Social, aunque las empresas hayan incurrido en descubiertos o infracotizaciones ${ }^{58}$. Si la empresa no se encontrase al corriente en el pago de cotizaciones, anticipa el pago la entidad gestora o colaborada para las prestaciones de jubilación, incapacidad permanente, muerte y supervivencia, incapacidad temporal. Ante el pago anticipado de una prestación de incapacidad temporal por contingencias comunes, si la responsabilidad de la empresa fuese por descubiertos de cotización estando en alta el trabajador, de cubrir la contingencia la mutua y resultar ésta insolvente, garantiza el pago subsidiariamente el INSS, pero si quien ha sido declarada insolvente es la empresa, la mutua no puede resarcirse del pago ante el INSS ya que esa garantía o responsabilidad subsidiaria de la entidad gestora sólo opera ante contingencias profesionales (Sentencia del TS, Sala Social, de 7183/2006, de 8 de noviembre -rcud. $3392 / 2005-)$ o ante incapacidad permanente por accidente no laboral ${ }^{59}$. Anticipo de prestaciones que procede aunque la empresa hubiere desaparecido o no pudiera ser objeto de apremio (art. 167.3 del TRLGSS).

d) Automaticidad relativa o anticipación del pago prestaciones en que ya no exigen la situación de alta. En prestaciones como jubilación, muerte y supervivencia, incapacidad permanente absoluta o gran invalidez, que se causan desde una situación de no alta, si hubo períodos anteriores de falta de alta determinantes de una menor prestación, surge la responsabilidad empresarial por la diferencia de la prestación, ya que la falta de alta de períodos anteriores al hecho causante incide en la cuantía de la pensión, pero al no exigirse actualmente la situación de alta para esas prestaciones, procede el anticipo por la entidad gestora, sin perjuicio de que ésta reclame el pago posteriormente a la empresa responsable ${ }^{60}$.

57 SSTS, Sala Social, de 8 de noviembre de 2006 -rcud. 3392/2005; 20 de febrero de 2007 -RJ 2007/2470-; y 22 de enero de 2009 -RJ 2009\1038, entre otras.

${ }^{58}$ STS, Sala Social, de 22 de enero de 2016 -rcud. 1931/2014-.

59 Art. 94.4 del Decreto de Seguridad Social de 21.4.1966, y SSTS, Sala Social, de 28 de septiembre de 1995 -rcud. 3000/1994-; de 8 de noviembre de 2006 -rcud. 3392/2205-; y 15 de noviembre de 2009.

60 SSTS, Sala Social, de 17 de marzo de 2006 -rcud. 832/2005- y 16 de diciembre de 2009 -rcud. 4356/2008-. 
e) Descubiertos totales de cotización. Tratándose de trabajadores en alta, el principio de automaticidad relativa, o en mejor técnica jurídica, el principio de anticipación del pago opera sin excepción, aunque a la fecha del hecho causante las empresas estén incursas en descubiertos totales de cotización, sin perjuicio de repetir lo pagado contra la empresa, ya que ésta no se exonera de responsabilidad con la anticipación del pago por la entidad gestora o colaboradora.

Los descubiertos totales de cotización se entienden producidos cuando no se ingresen las cuotas una vez se haya iniciado el tercer mes siguiente a fecha de devengo de las cuotas, o lo que es igual, a partir del inicio del segundo mes siguiente a la fecha en que expire el plazo reglamentario establecido para el pago de las cotizaciones (art. 94.2.b de la Ley de 21 de abril de 1966). Como las cuotas deben ingresarse dentro del mes siguiente a su devengo, nace la responsabilidad empresarial el día primero del tercer mes siguiente al devengo de las cuotas, en caso de falta de pago.

f) Que en las situaciones de infracotización o cotización por bases inferiores, la diferencia de la prestación sería de responsabilidad de la empresa, porque el incumplimiento afecta a la cuantía de la prestación, (art. 94.2.c. de la Ley de Seguridad Social de 21.4.1966), y en función del principio de moderación la responsabilidad ha de ser proporcional a la incidencia del incumplimiento en la prestación. Al hallarse en alta en Seguridad Social el trabajador, anticipa el pago la entidad gestora o colaboradora ${ }^{61}$.

g) En los supuestos de sucesión empresarial la nueva empresa responde de modo solidario de las prestaciones de Seguridad Social de que fuere responsable la anterior empresa, por incumplimientos de obligaciones de altas y cotización a la Seguridad Social, entendiéndose que una prestación se ha generado con anterioridad a la sucesión, no sólo si ha sido reconocida antes de la misma, sino si se ha generado durante el período previo de servicios en la anterior empresa, aunque se declare su derecho con posterioridad, como acontece con las diferencias de prestaciones por

${ }^{61}$ SSTS, Sala Social, de 21 de enero de 1987 -número Sentencia 236/1987-; 29 de marzo de 1993 -rcud. 298/1992-; 10 de diciembre de 1993 -rcud. 3113/1992-; 17 de enero de 1998 -rcud. 3083/1992-; y 27 de marzo de 2019 -rcud. 2137/2017-. 
infracotización anterior a la sucesión, o prestaciones de enfermedad profesional que se gesta progresivamente en el tiempo ${ }^{62}$.

h) La responsabilidad empresarial sólo nacerá cuando el trabajador tenga derecho a las prestaciones por reunir la carencia necesaria, o cuando no se reúna la carencia como consecuencia del propio incumplimiento empresarial, esto es, cuando de haber cumplido la empresa con sus obligaciones de alta y cotización, el trabajador hubiere completado el período de carencia exigible ${ }^{63}$. La responsabilidad empresarial cuando no se alcanza la carencia por falta de alta y cotización durante una parte de la relación laboral origina el nacimiento de la responsabilidad empresarial, pero se aplica el principio de proporcionalidad para determinar el importe a cargo de la empresa, teniendo en cuenta el período de falta de alta y cotización de la empresa en relación con el período total que debió haberse cotizado, siempre que con ese período incumplido se hubiere reunido la carencia exigible (Sentencia del TS, Sala Social, 750/2019 de 5 noviembre -rcud. 1610/2017- ${ }^{64}$ ). Es por ello, que si el trabajador,

${ }^{62}$ SSTS, Sala Social, 23 de marzo de 2015 -rcud. 2057/2014-; 27 de marzo de 2019 -rcud. 2137/2017-; y 7 de mayo de 2020 -rcud. 169-2018-.

${ }^{63}$ BLASCO LAHOZ, J. F. y LÓPEZ GANDÍA, J.: Curso de Seguridad Social, publicación electrónica, Tirant Lo Blanch, $10^{a}$ edición, 2018, edición digital, https://biblioteca-tirant-com.ponton.uva.es/cloudLibrary/ebook/info/9788491906575, p. 328.

${ }^{64}$ En esa Sentencia sobre una jubilación anticipada, se señala, "La doctrina de la Sala en materia de imputación de responsabilidades en los supuestos de falta de alta en la Seguridad Social y de cotización a ella en los casos de contingencias comunes por aplicación del principio de proporcionalidad se ha ido flexibilizando, incluso en los casos de falta de alta, siendo muestra de ello nuestras Sentencias de 27 de febrero de 1996 (RJ 1996, 1511), (R. 1896/1995), 14 de diciembre de 2004 (RJ 2005, 1729), (R. 5291/2003) y 1 de junio de 2006 (RJ 2006, 6054), (R. 5458/2014), entre otras, cuya doctrina han recopilado y ampliado las más recientes de 25 de septiembre de 2008 (RJ 2008, 6600) (R. 2914/2007), 7 de julio de 2009 (RJ 2009, 6071), (R. 2612/2008), 29 de octubre de 2009 (R. 4447/2008), 27 de abril de 2010 (R. 2580/2009), entre otras (...). Así, en la ya citada STS/IV 1-junio-2006 (Recurso 5458/2004) se recuerda, sobre el que denomina "módulo de la responsabilidad", que "Tal criterio se complementa con el de proporcionalidad en la responsabilidad, tanto en los supuestos de descubiertos de cotización temporales como en los que traen causa en cotización inferior a la debida (STS de 17/01/98) (RJ 1998, 738), (Rec. 3083/92), de forma que la responsabilidad empresarial por defectos de cotización ha de ser proporcional a su incidencia sobre las prestaciones (SSTS 28/09/94), (RJ 1994, 9714) -Rec. 2552/93-; 16/01/01 (RJ 2001, 773) -Rec. 4043/99-; 03/07/02 (RJ 2002, 9199) -Rec. 2901/01-; 22/07/02 (RJ 2002, 9520) -Rec. 4499/01-; y 19/03/04 (RJ 2004, 2940) -Rec. 2287/03-), incluso en el supuesto de incumplimientos que impiden al trabajador cubrir el periodo de carencia (STS 25/01/99) (RJ 1999, 2476), (Rec. 500/98), atendiendo a "la parte proporcional correspondiente al periodo no cotizado" sobre el total de la prestación (SSTS 20/07/95), (RJ 1995, 6718) -Rec. 3795/94-, para Jubilación; 01/06/98 (RJ 1998, 4936) -Rec. 223/97-, para Jubilación; 25/01/99 (RJ 1999, 2476) -Rec. 500/98-, para Jubilación; y 14/12/04 (RJ 2005, 1729) -Rec. 5291/03-, para subsidio por desempleo para mayores de 52 años). De esta manera, no sólo se ha liberado de responsabilidad a la empresa cuando los descubiertos son ocasionales, sino que cuando se le ha de imputar responsabilidad por descubiertos reiterados -sean temporales o por cotización inferior a la debida-, se hace responsable a la empresa y al INSS pero en proporción a la influencia que el defecto de cotización haya tenido en la cuantía de la prestación (SSTS 28/09/94), (RJ 1994, 9714) Rec. 2552/93-; 20/07/95 (RJ 1995, 6718) -Rec. 3795/94-; 27/02/96 (RJ 1996, 1511) -Rec. 1896/95-; y 31/01/97 (RJ 1997, 648) -Rec. 820/96-) (...). En el supuesto analizado en la STS/IV 25-septiembre- 
computando los períodos de falta de alta o cotización incumplidos por la empresa, en ningún caso hubiese reunido los requisitos para el nacimiento del derecho a la prestación, al no surgir ésta, no nace responsabilidad empresarial alguna, ya que faltaría el presupuesto de tener o poder tener derecho a la prestación ${ }^{65}$. Paralelamente, si pese al incumplimiento empresarial el trabajador ha completado el derecho a la prestación total, por reunir en prestaciones derivadas de enfermedad común toda la carencia general y específica, de modo que pese al incumplimiento no se percibiría mayor prestación, no nace correlativamente ninguna responsabilidad empresarial.

i) Que cuando la responsabilidad empresarial en el pago de la prestación sea por contingencias profesionales y se declare la insolvencia de la empresa, la mutua que ha anticipado el pago al trabajador podrá reclamar la responsabilidad subsidiaria al INSS/TGSS, al haber asumido estas entidades las funciones de garantía del antiguo Fondo de Garantía de Accidentes de Trabajo ${ }^{66}$. Garantía que se extiende a las prestaciones de incapacidad permanente por accidente no laboral (art. 94 apartados 4 y 5 de la Ley de 21 de abril de 1966). El INSS/TGSS responde ante la insolvencia empresarial sin necesidad de que para ello deba constar también la insolvencia de la mutua $^{67}$, como garantes públicos subsidiarios por prestaciones por contingencias

2008 (RJ 2008, 6600) -Rec. 2914/2007-, se trataba de determinar el alcance de la responsabilidad empresarial por falta de alta y cotización de un trabajador, en un concreto periodo de tiempo, que determinó el no reconocimiento del Derecho a la pensión de jubilación y si era posible que la imputación de aquella fuera proporcional al periodo descubierto, a lo que se dio una respuesta positiva, argumentándose, con invocación de la STS/IV 14-diciembre-2004 (RJ 2005, 1729) -Rec. 5291/2003- y las precedentes que en la misma se citaban, que "La Sala ya se ha pronunciado sobre la cuestión debatida en sus Sentencias de 20-julio-1995 (RJ 1995, 6718), 1-junio-1998 (RJ 1998, 4936), 20-diciembre-1998 (RJ 1999, 441) y 25-enero-1999 (RJ 1999, 2476). En la primera Sentencia citada, el alcance de la responsabilidad se modera -en unas circunstancias ciertamente excepcionalesatendiendo a la parte proporcional correspondiente al período no cotizado sobre el total de la prestación, que era una pensión de jubilación".

${ }^{65}$ En Sentencia del TS, Sala Social, de 22 de mayo de 2020 -rcud. 54/2018- se ha reconocido el Derecho a la jubilación con declaración de responsabilidad empresarial, sin perjuicio de su anticipo por la entidad gestora, cuando el trabajador no completa la carencia porque se anuló la inscripción de la empresa y las altas de los trabajadores correspondiente a un período de varios años, al ejercer la empresa una actividad para la que era obligatoria contar con una preceptiva autorización administrativa de la que carecía.

${ }^{66}$ Disposición Final $1^{\text {a }}$, apartado. 3.3 y Disposición Transitoria $1^{\mathrm{a}}$.1. del Real Decreto Ley 36/1978, de 16 noviembre -BOE del 18.11.1978-, que extinguió el Fondo de Garantía de Accidente de Trabajo (siendo asumidas sus obligaciones por la entidad gestora o servicio común en que se integró; el art. 1.2 del RD 2318/1978, de 15 septiembre -BOE del 28.9.1978-, que atribuyó la naturaleza de Servicio Común a la TGSS, y el Real Decreto 255/1980, de 1 de febrero -BOE del 12.2.1980- que atribuye a la TGSS la titularidad del patrimonio único de la Seguridad Social.

67 FERNÁNDEZ DOMÍNGUEZ, J. J. y FERNÁNDEZ FERNÁNDEZ, R.: Incumplimientos empresariales en los actos de encuadramiento y responsabilidad de la mutua, Laboral Prácticos Abdón Pedrajas, Tirant Lo Blanch, 2007, p. 109, (sic), quienes señalan que opera la responsabilidad 
profesionales. Como garantes subsidiarios, en su caso, responderán también en el caso más excepcional de que correspondiendo el pago con cargo directo de la mutua esta resultare insolvente.

Cuando proceda el anticipo de prestaciones por la entidad gestora o colaboradora, ante el incumplimiento empresarial de sus obligaciones con la Seguridad Social, como hemos reseñado, el importe no podrá exceder de la cantidad equivalente a dos veces y media el importe del indicador público de rentas de efectos múltiples vigentes en el momento del hecho causante, o el importe del capital coste necesario para el pago anticipado (art. 167.3 del TRLGSS). Compartimos el criterio doctrinal ${ }^{68}$ de que no debería operar ese límite del anticipo de la prestación en caso de insolvencia del empresario declarado responsable, porque al hallarnos ante una prestación de Seguridad Social que debe estar revestida de la garantía de suficiencia, la entidad gestora debería abonar íntegramente la prestación.

Analicemos los dos grandes incumplimientos que general responsabilidad empresarial en el pago de las prestaciones, responsabilidad por faltas de alta y por descubiertos de cotización.

\subsubsection{Responsabilidad por falta de alta o afiliación a la Seguridad Social.}

Con carácter general, para que la entidad gestora o colaboradora reconozca al trabajador una prestación de Seguridad Social, es preciso que se halle en alta o en situación asimilada al alta en el momento en que se produce el hecho causante, salvo que rija el principio de automaticidad o sea una prestación en la que ya no se exige la situación de alta o asimilada al alta. Para determinar la responsabilidad de la empresa por incumplimiento de esas obligaciones instrumentales, habrá de tenerse en cuenta dos $\operatorname{aspectos}^{69}$, por un lado, el plazo para cumplir con esas obligaciones, y por otro lado, los efectos retroactivos de las altas de oficio. Plazo que será previo al inicio de la actividad

subsidiaria del INSS/TGSS "sin necesidad de declaración de insolvencia alguna -sólo será imprescindible constatar las dificultades económicas del empleador-“, citando las Sentencias del TS 11 julio 1994, 8 marzo, 28 septiembre y 30 diciembre 1995 o 16 julio y 22 octubre 1996.

Las SSTS, Sala Social, de 22 de octubre de 1996 -rcud. 686/1996-; 16 de julio de 1996 -rcud. 2389/1995-; 30 de diciembre de 1995 -rcud. 112/1995-; de 28 de septiembre de 1995 -rcud. 3000/1994-; 8 de marzo de 1995 -rcud. 843/1994-; lo que señalan es que para que opere la responsabilidad subsidiaria del INSS/TGSS, como sustitutos del Fondo de Garantía de Accidentes de Trabajo, no se precisa la declaración de insolvencia de la mutua, pero sí de la empresa responsable.

${ }^{68}$ BLASCO LAHOZ, J. F. y LÓPEZ GANDÍA, J.: Curso de Seguridad Social, edición digital, 2018, op. cit., p. 332.

${ }^{69}$ AA.VV. (MONEREO PÉREZ, J. L. et altri): Manual de Seguridad Social, op. cit., p. 233. 
empresarial para la inscripción, y al inicio de la prestación laboral de servicios para el alta y afiliación a la Seguridad Social ${ }^{70}$.

Es doctrina unificada del $\mathrm{TS}^{71}$ que si constase como hecho probado en una sentencia firme del orden social, que un trabajador ha prestado servicios a una empresa durante un período de tiempo sin alta, ese trabajador tiene derecho a que se anote en el fichero de afiliación de la TGSS la situación de alta en la Seguridad Social durante el período correspondiente, aunque la empresa obligada no haya cotizado, y con independencia de las acciones que proceda ejercer por parte de la Tesorería General de la Seguridad Social contra ella por las cuotas no pagadas y no prescritas, aunque por el período no cotizado surja la responsabilidad empresarial, pudiendo el trabajador afectado solicitar a la TGSS que modifique los períodos de alta en Seguridad Social, tanto en el registro de afiliación como en el informe de vida laboral expedido.

Lo que caracteriza el incumplimiento de las obligaciones empresariales de encuadramiento en materia de responsabilidad en prestaciones, frente al incumplimiento de los descubiertos de cotización, según DESDENTADO BONETE ${ }^{72}$, es que "no es susceptible de moderación en su apreciación, ni de proporcionalidad en su aplicación, porque el incumplimiento de la obligación del alta determina siempre la responsabilidad de la empresa y una responsabilidad total por la prestación causada". No obstante, como veremos seguidamente, esa responsabilidad ha dejado de ser total en ciertas situaciones, como ante una falta de alta de períodos anteriores al hecho causante.

Para poder determinar cuándo surge la responsabilidad empresarial por prestaciones por falta de alta en Seguridad Social del trabajador, debemos analizar las situaciones especiales, así como la flexibilización de este requisito que ha realizado la jurisprudencia, ya que afectará al nacimiento de la responsabilidad empresarial y al subsiguiente crédito contra el administrador social.

Si la falta de alta o afiliación del trabajador a la Seguridad Social genera responsabilidad empresarial en el pago de las prestaciones, no obstante, hay que hacer las siguientes puntualizaciones o especialidades. En primer lugar, no nace la responsabilidad

\footnotetext{
${ }^{70}$ Arts. 138 a 140 del TRGSS, en relación con los arts. 5 y 32.3 del R.D. 84/1996, de 26 de enero, por el que se aprueba el Reglamento General sobre inscripción de empresas y afiliación, altas, bajas y variaciones de datos de trabajadores en Seguridad Social -BOE del 27.2.1996-, en adelante RGIASS.

${ }^{71}$ SSTS, Sala Contencioso-Administrativa 15 de marzo de 2016 -Rec. 2253/2014- y 1244/2020, de 1 de octubre de 2020 -Rec. 4525/2018-.

72 DESDENTADO BONETE, A.: "Responsabilidades por el incumplimiento de las obligaciones en materia de actos de encuadramiento en la Seguridad Social ”, op. cit., p. 6 de 24.
} 
empresarial, pese a la falta de alta, cuando con anterioridad al hecho causante se han ingresado en plazo reglamentario las cuotas de Seguridad Social correspondientes al período de falta de alta, ya que en ese supuesto, el alta retrotrae sus efectos a la fecha de ingreso de las primeras cuotas $^{73}$. Los efectos retroactivos serán a la fecha de ingreso de las $\operatorname{cuotas}^{74}$, no a la fecha de inicio del mes de devengo de las cotizaciones, lo que genera la responsabilidad empresarial de la prestación si el alta es posterior al hecho causante, aunque las cuotas se ingresen en plazo reglamentario, que sería el supuesto típico de alta al día siguiente del hecho causante ingresándose las cuotas en plazo reglamentario. En segundo lugar, con relación a las altas practicadas de oficio como consecuencia de la actuación inspectora, el alta retrotrae sus efectos a la fecha de tal actuación o la fecha de presentación de la correspondiente denuncia, salvo que se hubiere extendido acta de liquidación o requerimiento de pago por la ITSS, en cuyo caso, el ingreso de las cuotas del acta retrotrae sus efectos a la fecha de inicio del período de liquidación ${ }^{75}$. En tercer lugar, el alta de oficio por la Tesorería General de la Seguridad Social retrotrae sus efectos a la fecha en que conozca la situación de falta de alta $^{76}$. En cuarto lugar, si la falta el alta es debida a un error empresarial, sin voluntad de incumplir, por haber cursado indebidamente la baja del trabajador por error continuando cotizando por él a la Seguridad Social, no existe responsabilidad empresarial ${ }^{77}$, pero paralelamente, si no existe error y la empresa ha procedido indebidamente a dar de baja al trabajador antes del hecho causante, es responsable del pago de la prestación ${ }^{78}$. En quinto lugar, si el alta en Seguridad Social ha sido posterior al hecho causante, la empresa es responsable del pago al ser un supuesto puro de falta de alta ${ }^{79}$. En sexto lugar, si la falta de alta es de un período anterior al hecho causante de la prestación, supuesto de retraso en el alta anterior a ese hecho causante, se aplica el régimen jurídico de la responsabilidad por falta de $\operatorname{cotización}^{80}$, rigiendo la moderación y

${ }^{73}$ Art. 35.1.1 ${ }^{\circ}$ del Real Decreto 84/1996, de 26 de enero, y Sentencia del TS, Sala Social, de 26 de junio de 2000 -rcud. 4169/1999-.

74 DESDENTADO BONETE, A.: "Responsabilidades por el incumplimiento de las obligaciones en materia de actos de encuadramiento en la Seguridad Social”, op. cit., p. 7 de 24.

75 Art. 35.1. $2^{\circ}$ del Real Decreto citado 84/1996, y SSTS del TS, Sala Social, de fechas 27 de febrero de 1996 -RJ 1996/1511-; de 1 de junio de 1994 -rcud. 3415/1993-; 31 de enero de 1997 -RJ 1997\648-.

${ }^{76}$ Art. 35.1. $2^{\circ}$ del Real Decreto citado 84/1996.

77 STS, Sala Social, de 26 de junio de 2000 -RJ 2000\5967-.

${ }^{78}$ STS, Sala Social, 7 de diciembre de 2005 -RJ 2006\406-.

${ }^{79}$ STS, Sala Social, de 4 de junio de 2000 -RJ 2000\5116-.

${ }^{80}$ SSTS, Sala Social, SSTS de 20 de julio de 1995- Rec. 3795/94-; 1 de junio de 1998 - Rec. 223/97-; 25 de enero de 1999 -Rec. 500/98-; 1 de junio de 2006 -rcud. 5458/2004- ; 25 de septiembre de 2008 rcud. 2914/2007-; 25 de septiembre de 2008 -rcud. 2914/2007-; 14 de diciembre de 2004 -rcud. 5291/2003-; STS 25 de septiembre de 2008 -rcud. 2914/2007-; 10 de marzo de 2009; 7 de julio de 
proporcionalidad en la atribución de la responsabilidad empresarial ${ }^{81}$. En séptimo lugar, si la falta de alta del trabajador es debido a error de la Tesorería General de la Seguridad Social, queda exonerada la empresa de responsabilidad ${ }^{82}$. En octavo lugar, no existe falta de alta durante el período de salarios de tramitación si la empresa solicita el alta e ingresa las cuotas dentro del mes siguiente a la notificación de la sentencia, del auto judicial, o acta de conciliación que condena o acuerda la obligación de pago de los salarios de tramitación ${ }^{83}$.

Por otro lado, nuestra jurisprudencia ha venido atenuando o flexibilizando la exigencia del requisito de alta para generar prestaciones de Seguridad Social, mediante una interpretación humanizadora que pondera las circunstancias de cada caso concreto con el fin de evitar supuestos no justificados de desprotección.

Dentro de esa opción flexibilizadora del requisito de alta, se ha considerado que la baja en la Seguridad Social ha de entenderse con carácter provisional durante los noventa días siguientes al cese, período de noventa días en que el trabajador puede acogerse a un Convenio Especial, conservando, por tanto, durante ese período los derechos que pudieran devengarse como consecuencia del tiempo que duró la afiliación y la cotización a la Seguridad Social (Sentencia del TS, Sala Social, de 8 de marzo de 2017 rcud. $\left.2686 / 2015-{ }^{84}\right)$.

2009 -rcud. 2612/2008-; 29 de octubre de 2009 -rcud. 4447/2008-; 10 de marzo de 2009; 27 de abril de 2010 -rcud. 1756/2009-; y núm 212/2018, de 27 de febrero -rcud. 3448/2015-; 22 de julio de 2020 -rcud. 737/2018-.

81 BEJARANO HERNÁNDEZ, A.: "Responsabilidad empresarial por falta de alta del trabajador y anticipo de prestaciones de la Seguridad Social", Relaciones Laborales, n. ${ }^{\circ}$ 20, Sección Doctrina, Quincena del 16 al 31 octubre 1996, p. 340, Tomo 2, Editorial La Ley, edición digital https://laleydigital-laleynext-es.ponton.uva.es/Content/Documento.aspx?params, p. 6.

82 SSTS, Sala Social, de 27 de enero de 2009 -RJ 2009\1833-, 13 de febrero de 2007 -RJ 2007/ 3256-.

83 Art. 56.1.4 del R.D. 1415/2004, de 11 de junio, y Sentencia del TS, Sala Social, de 29 de mayo de 1997 -rcud. 3974/1996-, 22 de julio de 2004 -rcud. 4037/2003-; 5 de julio de 2006 -rcud. 1090/2005-, entre otras.

84 Flexibilización que según la Sentencia se realiza "mediante una interpretación humanizadora que pondera las circunstancias de cada caso concreto con el fin de evitar supuestos no justificados de desprotección. (...) Esta línea jurisprudencial, -como recuerda, entre otras, STS/IV 26-enero-1998 (rcud. 1385/1997) y reitera la STS/IV 25-julio-2000 (rcud. 4436/1999) <<iniciada ya con anterioridad a la casación unificadora (entre otras, SSTS/Social 4-IV-1974, 2-VII-1974, 6-III-1978, 27-X-1979, 14-IV-1980, 24-VI-1982, 11-XII-1986, 15-XII-1986, 2-II-1987, 21-III-1988, 12-VII-1988 y 13-IX1988) y que ha tenido fiel reflejo en ésta (entre otras, STS/IV 19-XII-1996 -Recurso 1159/1996-), estableció, como recuerda la citada STS/Social 15-XII-1986, la doctrina relativa a que el alta ha de referirse al momento en que sobrevino la contingencia determinante de la situación protegida (SSTS/ Social 14-IV-1980 y 24-VI-1982), o aquella otra que, tras analizar la normativa afectante al Convenio Especial, considera que la baja en la Seguridad Social ha de entenderse con carácter provisional durante los noventa días siguientes al cese, en los que el trabajador puede acogerse al Convenio Especial, conservando, por tanto, durante ese período los Derechos que puedan serle legalmente atribuidos en relación al tiempo que duró la afiliación y la cotización a la Seguridad Social 
Con igual finalidad se ha reconocido el derecho al anticipo de prestaciones jubilación o incapacidad permanente por la entidad gestora o colaboradora, aunque el trabajador no se hallare en alta en Seguridad Social en la fecha del hecho causante (Sentencias de TS, Sala Social, de 16 de diciembre de 2009 -rcud. 4356/2008-), siempre que reuniese el resto de requisitos para devengar la prestación (edad, períodos mínimos de cotización y carencia específica), con el límite de que la cuantía anticipada no podrá superar dos veces y medio el importe del indicador público de rentas de efectos múltiples -art. 167.3 del TRLGSS-, partiendo del argumento de que la jubilación y la invalidez absoluta y gran invalidez se pueden causar desde una situación de no alta en Seguridad Social.

Del mismo modo se ha flexibilizado el requisito de hallarse en alta en Seguridad Social, cuando sin solución de continuidad se extingue una situación de incapacidad temporal a la fecha en que el trabajador ya no estaba en alta en Seguridad Social, y al día o días siguientes se produce una nueva baja por nacimiento o cuidado de menor (antigua maternidad $)^{85}$. También se ha flexibilizado el requisito de alta a la fecha del hecho causante de una incapacidad temporal, cuando la baja médica tiene lugar el último día de finalización de una excedencia voluntaria, incorporándose al día siguiente a la empresa, reconociéndose la prestación por considerar que el día siguiente a la baja médica en que se produce la incorporación al trabajo sigue la situación de imposibilidad material de trabajar (Sentencia TS, Sala Social, 1043/2018, de 12 de diciembre -rcud. 4142/2016-). En cambio, no se ha flexibilizado el requisito de falta de alta cuando sin solución de continuidad se extingue una situación de incapacidad temporal en la fecha en que el trabajador ya no estaba en alta en Seguridad Social, y al día siguiente se produce una nueva baja médica, no reconociéndose la prestación por falta de alta o

(SSTS/Social 27-X-1979 y 15-XII-1986); doctrinas a las que es dable adicionar la que interpreta con flexibilidad el requisito de estar inscrito como demandante de empleo "tanto más cuanto que reunía los requisitos para obtener la pensión cuando los padecimientos se produjeron" (STS/Social 11-XII1986), añadiendo que <<Pudiendo concluirse en esta línea, y siguiendo la doctrina marcada en la referida STS/IV 19-XII-1996, que el requisito del alta y las situaciones asimiladas a ella han sido interpretados de modo no formalista por esta Sala, estimando en general que sí concurría la situación de alta, cuando se inicia el acontecer que conduce al hecho causante y es fundadamente explicable que se hayan descuidado los resortes legales prevenidos para continuar en alta, entonces el requisito ha de entenderse por cumplido >. (...) Doctrina jurisprudencial flexibilizadora que ha sido aplicada por la Sala en otras prestaciones, en especial en las de muerte y supervivencia (entre otras, SSTS/IV 27mayo-1998 -rcud. 2460/1997-, y 23 de mayo de 2000 -rcud. 3039/1999- (Sentencia del TS, Sala Social, 197/2017, de 8 de marzo)".

85 SSTS, Social, de 20 de enero de 1995 -RJ 1995/1146-, 19 de febrero de 1997, y núm. 90/2018 de 2 febrero -RJ 20181744-. 
situación asimilada al alta, ya que no se encontraba tampoco percibiendo prestaciones de desempleo ${ }^{86}$.

Es también doctrina flexibilizadora, la que interpreta de modo laxo y no riguroso, la situación asimilada al alta consistente en hallarse inscrito como demandante de empleo tras la finalización de percepción de prestaciones por desempleo ${ }^{87}$.

De incumplirse la obligación de inscripción de empresa, afiliación o alta en Seguridad Social del trabajador, siempre que no rija el principio de automaticidad o de flexibilización del alta, nace un crédito de prestaciones del trabajador ante la empresa (arts. 45, 165, 167, 195.4, 205.3, 219.1, 224.1 y 281 del TRLGSS). Ante ese crédito de prestaciones de Seguridad Social del trabajador ante la sociedad de capital, el empleado podría reclamar la responsabilidad del administrador social, si concurren los requisitos para ejercitar la acción individual de responsabilidad o para reclamar la responsabilidad solidaria ex lege por deudas de los arts. 360 y 367 de la LSC.

Por el contrario, de proceder el pago anticipado de la prestación por la entidad gestora (automaticidad absoluta), nace una deuda por prestaciones de la empresa ante las entidades gestoras de la Seguridad Social, que podrá reclamarse al administrador mediante la derivación administrativa de la responsabilidad (art. 18.3 del TRLGSS), o en su caso, mediante la acción individual de responsabilidad (art. 241 de la LSC).

\subsubsection{Responsabilidad por falta de cotización a la Seguridad Social.}

Finalmente, con relación al supuesto de responsabilidad empresarial por descubiertos totales de las cotizaciones mensuales a la Seguridad Social, hemos de indicar que los descubiertos de cotización tienen que producirse o mantenerse en la fecha del hecho causante de la prestación y haber transcurrido el tercer mes siguiente al devengo de la cuotas impagadas -o lo que es igual, haberse iniciado el segundo mes siguiente a haber expirado el plazo reglamentario de ingreso-, y ello porque las cotizaciones ingresadas fuera de plazo, pero antes del hecho causante, computan para la efectividad de las prestaciones (Sentencia del TS, Sala Social, 27 de febrero de 1996 -rcud. 1896/1995-).

86 SSTS, Sala Social, de núm. 90/2018 de 2 febrero -rcud. 679/2016-, citando las Sentencias de 18 de septiembre de 2002 y 19 de septiembre de 2003. En igual sentido, ante falta de alta de un período que impide la carencia para la jubilación anticipada la sentencia del TS, Sala Social, 750/2019 de 5 noviembre -rcud. 1610/2017-.

87 SSTS/Social, de 27 de mayo de 1998 -rcud. 2460/1997-; 23 de mayo de 2000 -rcud. 3039/1999-; de 7 de noviembre de 2018 -rcud. 3549/2016-; 23 de octubre de 2018 -rcud. 3599/2016-; 25 de septiembre de 2018 -rcud. 761/2017-; 8 de marzo de 2017 -rcud. 2686/2015-; 20 de febrero de 2018 -rcud. 1845/2016-; 2 de abril de 2019 -rcud. 2885/2017-, entre otras muchas. 
Por el contrario, carecen de eficacia las cotizaciones ingresadas con posterioridad al hecho causante (Sentencias del TS, Sala Social, 22 de febrero de 2001 -rcud. 3033/2000- y 24 de marzo de 2001 -rcud. 794/2000-).

Se considera que se está al corriente en el pago de las cuotas, cuando éstas hayan sido objeto de aplazamiento o fraccionamiento por resolución de la TGSS, siempre que se cumplan las condiciones establecidas (art. 31.3 del RGRSS).

Como regla general, si el trabajador se hallase en situación de alta en Seguridad Social en la empresa, aunque ésta no estuviese al corriente en el pago de las cotizaciones, la entidad gestora o la mutua viene obligada a anticipar el pago de la prestación, sin perjuicio de su derecho a repetir lo pagado contra la empresa responsable ${ }^{88}$.

Ante los descubiertos de cotización se ha moderado la responsabilidad empresarial. Moderación de responsabilidad que opera de modo diferente según estemos ante prestaciones que exijan o no períodos previos de cotización ${ }^{89}$. Cuando la prestación sea por contingencias comunes, se reconoce la existencia de responsabilidad empresarial, cuando los descubiertos de cotización afectan a la relación de protección, pero si no afectan a la relación de protección porque el trabajador tiene completada la carencia exigida, no existirá responsabilidad prestacional de la empresa. Por el contrario, si fruto de los descubiertos no se tiene la carencia general o específica, o cuando teniendo la carencia la prestación resulte inferior de la que correspondería de no haber descubiertos de cotización, surge la responsabilidad de la empresa por la diferencia de prestación (principio de proporcionalidad en la moderación de la responsabilidad empresarial), aunque de hallarse en alta el trabajador anticipará el pago la entidad gestora ${ }^{90}$. Por el

${ }^{88}$ SSTS, Sala Social, de 14 de junio de 2000 -rcud. 3096/99-; 9 de abril de 2001 -rcud. 3860/99-; 17 de noviembre de 2004 -rcud. 5997/03-; 8 de noviembre de 2006; 2 de julio de 2007 -rcud. 686/06-; 10 de julio de 2007 -rcud. 4168/06-; 22 de enero de 2009 -rcud. 3858/07-; 17 de febrero de 2009 -rcud. 4230/07-; 21 de mayo de 2009 -rcud. 1515/08-; 15 de noviembre de 2009 -rcud. 2864/06-; 16 de diciembre de 2009 -rcud. 4356/08; y 22 de enero de 2016 -rcud. 1931/2914-.

89 SSTS, Sala Social, 8 de noviembre de 2006 -rcud. 3392/2205-; 26 de febrero de 2008 -rcud. 2341/2006-; 8 de julio de 2009; 11 de noviembre de 2009; 16 de diciembre de 2009 -650/2009-; y 23 de abril de 2010 -2216/2009-; entre otras muchas.

${ }^{90}$ SSTS, Sala Social, de 20 de julio de 1995; 8 de mayo de 1997; 1 de junio de 1998; 20 de diciembre de 1998; 25 de enero de 1999 -Rec. 500/1998-; 17 septiembre 2001 -Rec. 1904/2000-; 29 de octubre 2001 -Rec. 199/2001-; 3 de julio de 2002 -rcud. 2901/2001-; 14 de diciembre de 2004 -rcud. 5291/2003-; 26 de febrero de 2008 -rcud. 2341/2006-; 25 de septiembre de 2008 -rcud. 2914/2007-; 22 de enero de 2009 -rcud. 3858/2007-; 22 de julio de 2020 -rcud. 737/2018-, entre otras).

Sobre el contenido de la aplicación del principio de moderación de la responsabilidad empresarial, la Sentencia del TS, Sala Social, 750/2019, de 5 de noviembre -rcud. 1610/2017-, nos resume la jurisprudencia en los siguientes términos: “Así, en la ya citada STS/IV 1-junio-2006 (Rec. 5458/2004) se recuerda, sobre el que denomina "módulo de la responsabilidad", que "Tal criterio se complementa con el de proporcionalidad en la responsabilidad, tanto en los supuestos de descubiertos de cotización 
contrario, si la prestación es de contingencias profesionales, al no exigirse periodos de cotización o carencia (art. 165.4 del TRLGSS) y no afectar los descubiertos totales a la relación de protección, nuestra jurisprudencia acude a la hora de fijar la responsabilidad empresarial a examinar si el impago denota ánimo rupturista o no de la empresa con la Seguridad Social, de modo que de haber ánimo rupturista, por ser los descubiertos prolongados en el tiempo en relación con el período de prestación de servicios, se declara la responsabilidad de la empresa, sin perjuicio de anticipar al trabajador la prestación la entidad gestora o la mutua ${ }^{91}$.

En los supuestos de diferencias de cotización que sean consecuencia de declararse unas bases de cotización inferiores a las debidas, se genera una responsabilidad empresarial por la diferencia de prestación si los períodos afectados por la deficiente o menor cotización integraban la base reguladora de la prestación, porque esa menor cotización ha repercutido de modo directo en importe final de la prestación reconocida, sin perjuicio de su anticipo por la entidad gestora o colaboradora al hallarse el trabajador en alta en Seguridad Social, entendiéndose que no cabe moderación de responsabilidad, ya que esa moderación va ínsita en el propio contenido de la responsabilidad, al ser una responsabilidad de la prestación por la diferencia ${ }^{92}$.

temporales como en los que traen causa en cotización inferior a la debida (STS de 17/01/98 (RJ 1998, 738) -Rec. 3083/92-), de forma que la responsabilidad empresarial por defectos de cotización ha de ser proporcional a su incidencia sobre las prestaciones, incluso en el supuesto de incumplimientos que impiden al trabajador cubrir el periodo de carencia, atendiendo a "la parte proporcional correspondiente al periodo no cotizado" sobre el total de la prestación. De esta manera, no sólo se ha liberado de responsabilidad a la empresa cuando los descubiertos son ocasionales, sino que cuando se le ha de imputar responsabilidad por descubiertos reiterados -sean temporales o por cotización inferior a la debida-, se hace responsable a la empresa y al INSS pero en proporción a la influencia que el defecto de cotización haya tenido en la cuantía de la prestación".

${ }^{91}$ SSTS, Sala Social, de 8 de mayo de 1997 -Rec. 3824/1996.; 27 de mayo de 2004 -rcud. 2843/2003-; 16 de mayo de 2007 -rcud. 4263/2005-; de 15 de enero de 2008 -rcud. 3964/2006-; 26 de febrero de 2008 -rcud. 3383/2006-; 11 de noviembre de 2009 -rcud. 513/2009-; 16 de diciembre de 2009 -rcud. 650/2009-; 23-4-2010. En la Sentencia de 16 de diciembre de 2009, en que los descubiertos alcanzaron 25 meses, señala con relación a la concurrencia del ánimo rupturista con la Seguridad Social de la empresa que, "en STS de 30 de septiembre de 2008 (rcud. 3535/2006) en relación a las responsabilidades que pueden derivarse del accidente de trabajo, la doctrina de la Sala es constante al afirmar que la citada responsabilidad está en función de la duración de los descubiertos, pero en atención al período de seguro correspondiente al trabajador afectado, de forma que no solo haya de atenderse a la duración del incumplimiento, sino primordialmente en proporción al período de aseguramiento". Por otro lado, los incumplimientos a tener en cuenta para valorar la existencia de dicha responsabilidad empresarial, son únicamente los producidos antes del acaecimiento del accidente laboral y no los posteriores (Sentencia del TS, Sala Social, de 16 de mayo de 2007).

92 SSTS, Sala Social, de 21 de enero de 1987 -número Sentencia 236/1987-; 29 de marzo de 1993 -rcud. 298/1992-; 10 de diciembre de 1993 -rcud. 3113/1992-; 17 de enero de 1998 -rcud. 3083/1992-; 29 de septiembre de 1994 -Rec. 2552/1993-; 20 de julio de 1995 -Rec. 3795/1994-; 27 de febrero de 1996 Rec. 1896/1995-; 31 de enero de 1997 -Rec. 820/1996-; de 16 de junio de 2005 -rcud. 3332/2003-; 18 
Con carácter general cuando la diferencia de cotización a la Seguridad Social no sea debida a bases de cotización, sino a la aplicación de tipos de cotización inferiores a los debidos, como sucedería, entre otros supuestos, al aplicar una tarifa de primas por contingencias profesionales distinta a la pertinente, al no haberse declarado correctamente la actividad u ocupación del trabajador por conducta empresarial deliberadamente rebelde e intencional -ocultación o falseamiento de datos-, debe declararse la responsabilidad empresarial a pesar de que las diferencias de cotización no afecten de forma directa a la relación de protección ${ }^{93}$. Responsabilidad que se cifra en proporción a las menores cuotas ingresadas, sin perjuicio de que se reclamen las cotizaciones no prescritas a la empresa ${ }^{94}$.

Cuando se anticipe al trabajador la prestación de responsabilidad empresarial por descubiertos o diferencias de cotización hallándose aquél en situación de alta en Seguridad Social ${ }^{95}$, nacerá una deuda de la sociedad de capital ante las entidades gestoras de la Seguridad Social, que podrá ser objeto de reclamación al administrador social mediante la derivación administrativa de la deuda en el procedimiento de recaudación (art. 18.3 del TRLGSS), o mediante la acción individual de responsabilidad (art. 241 de la LSC).

Paralelamente, surgirá un crédito del trabajador que puede ejercitar ante la empresa, y en su caso, ante el administrador social mediante la acción individual de responsabilidad

de noviembre de 2005 -rcud. 5352/2004-; 1 de junio de 2006 -rcud. 5458/2004-; 4 de octubre de 2006 -rcud. 1798/2005-; 9 de abril-2007 -Rec. 143/2006-; 5 de noviembre de 2019 -rcud. 1610/2017-.

93 SSTS, Sala Social, de 18 de febrero de 2008 -rcud. 1263/2007-; 26 de febrero de 2008 -rcud. 3383/2006-; 13 de octubre de 2009 -rcud. 4063/2008-, entre otras. En la Sentencia de 13 de octubre de 2008, en el Fundamento de Derecho Segundo, se señala que "la ocultación o falseamiento deliberados en la declaración de las circunstancias que hayan motivado un ingreso de cuotas o primas inferiores al procedente" (art. 94.2.c. LSS/1966) al supuesto del $\mathrm{n}^{\circ} 5$ del art. 92 de la propia disposición reglamentaria, donde se establece que "la cotización efectuada con arreglo a una base inferior a la que corresponda al trabajador surtirá efectos por la cuantía efectivamente ingresada, sin perjuicio de la responsabilidad empresarial que corresponda de acuerdo con lo dispuesto en el artículo 94". Es decir, sólo en el caso de que conste expresamente acreditada una conducta empresarial deliberadamente rebelde e intencional será posible atribuir al empresario incumplidor responsabilidad prestacional, a pesar de que las diferencias cotizatorias no afecten de forma directa a la relación de protección".

Responsabilidad que tiene su fundamento en la ocultación o falseamiento deliberados de la empresa, BLASCO LAHOZ, J. F.: Las Contingencias Profesionales de la Seguridad Social, Tirant lo Blanch, 2019, p. 288.

94 Sobre la responsabilidad por infracotización véase MUÑOZ MOLINA, J.: Responsabilidad empresarial en materia de prestaciones de la Seguridad Social, ed. Tirant Lo Blanch, 1999, pp. 26 y ss; y CARPENA NIÑO, J. M.: "La responsabilidad empresarial en materia de Seguridad Social por infracotizaciones", op. cit.

95 Art. 95 de la Ley de Seguridad Social de 1966, y Sentencias TS, Sala Social, 22 de enero de 2016 rcud. 1931/2014- y 27 de marzo de 2019 -rcud. 2137/2017-. 
o la responsabilidad ex lege por deudas, por el importe no anticipado por la entidad gestora, esto es, en lo que exceda de dos veces y media el IPREM en la fecha del hecho causante, o en su caso, del importe del capital coste necesario para el pago anticipado (art. 167.3 del TRLGSS).

\section{El recargo de prestaciones.}

Un supuesto de responsabilidad directa de la empresa ante el trabajador o sus causahabientes, sin que quepa el anticipo por las entidades gestoras o colaboradoras ${ }^{96}$, surge cuando se declare por la entidad gestora el derecho del trabajador a percibir el recargo de prestaciones (art. 164 del TRLGSS). Recargo de la prestación que podrá imponerse dentro de una horquilla que oscila entre un $30 \%$ y un $50 \%$ del importe de la prestación causada cuando la prestación fuere debida a accidente de trabajo o enfermedad profesional, teniendo como causa el incumplimiento empresarial de la normativa de prevención de riesgos laborales. Recargo de responsabilidad exclusiva de la empresa infractora de las disposiciones de prevención de riesgos laborales que hayan motivado el hecho causante de la prestación.

La responsabilidad de la empresa empleadora incumplidora en el recargo de la prestación, no es óbice para que puedan concurrir también responsabilidades de otras empresas en los supuestos de descentralización productiva, cesión ilegal de mano de obra, trabajadores en misión de una empresa de trabajo temporal, y de sucesión en actividad empresarial (arts. 42 y 43 del TRLET, arts. 16 de la LETT y 168 del TRLGSS). En la descentralización productiva responde la empresa incumplidora, la principal y la subcontratista, incluso en contratas distintas a la propia actividad de la principal, si los incumplimientos son imputables a ambas ${ }^{97}$. Responderá igualmente la empresa causante del daño cuando en el lugar de trabajo concurran varias empresas, aunque no sea la empleadora del trabajador, siempre que haya causado el daño incumpliendo la normativa de prevención de riesgos laborales.

\footnotetext{
96 Art. 16 de la Orden de 18 de enero de 1996, de aplicación y desarrollo del Real Decreto 1300/1995, de 12 de julio, sobre Incapacidades Laborales de la Seguridad Social -BOE del 26.1.1996-.

${ }^{97}$ SSTS, Sala Social, de 18 de septiembre de 2018 -rcud. 144/2017- en que no concurría propia actividad, y para el resto de contratas, Sentencias de 7 de octubre de 2008 -rcud. 2426/2007-; 18 enero 2010 rcud. 3237/2007-; 20 marzo 2012 -rcud. 1470/2011-, entre otras.
} 
La empresa o empresas declaradas responsables deberán ingresar el importe del recargo de la prestación ante la $\operatorname{TGSS}^{98}$, ya que el beneficiario es el trabajador o sus causahabientes de haber fallecido como consecuencia del accidente o la enfermedad profesional.

Recargo prestaciones cuya naturaleza jurídica ha sido objeto de debate en la doctrina y en la jurisprudencia, habiéndose defendido su naturaleza sancionadora ${ }^{99}$, indemnizatoria, cláusula penal de origen legal, indemnización sancionadora, prestacional de Seguridad Social ${ }^{100}$, siendo mayoritaria la doctrina que aboga por su carácter híbrido al conjugar aspectos sancionadores, indemnizatorios-reparadores y preventivos $^{101}$.

${ }^{98}$ Art. 164 del TRLGSS, en relación con art. 75 del Real Decreto 1415/2004, de 11 de junio, RGRSS, art. 1.1. del Real Decreto 1300/1995, de 21 de julio, en materia de Incapacidades Laborales del Sistema de Seguridad Social, y art. 16 de la Orden de 18.1.1996 que desarrolla en Real Decreto anterior.

99 AA.VV. (SALA FRANCO, T., BLASCO PELLICER, A. A. y SALCEDO BELTRÁN, M. ${ }^{a}$ C.): Derecho de Prevención de Riesgos Laborales, op. cit., 2014, p. 305.

100 DE ALCÁNTARA Y COLÓN, J. M.: "El Recargo de prestaciones. Un análisis práctico". Jurisprudencia de Información Laboral, Estudios n ${ }^{\circ}$ 7, 2007, pp. 11-12, para quien tendrá naturaleza prestacional por ser competencia de la entidad gestora de prestaciones su reconocimiento, su intervención.

101 MONEREO PÉREZ, J. L.: "El Recargo de prestaciones por incumplimiento de las medidas de seguridad e higiene en el trabajo", Cívitas, 1992, Madrid pp. 28 y ss., que señala que es una sanción compleja intimidatoria; MONEREO PÉREZ, J. L. y SÁNCHEZ PÉREZ, J.: 'El Recargo de prestaciones y la nueva doctrina jurisprudencial. Una reflexión crítica a propósito de las Sentencias del Tribunal Supremo de 4 y de 23 de marzo de 2015", Trabajo y Derecho, № 12, diciembre 2015, Editorial Wolters Kluwer, edición digital,

https://laleydigital-laleynext-es.ponton.uva.es/Content/Documento.aspx?params, para quienes tienen naturaleza híbrida al conjugar una dimensión punitiva y reparadora; FERNÁNDEZ-COSTALES MUÑIZ, J.: Prevención de riesgos laborales y empresa: obligaciones y responsabilidades, Aranzadi Thomson Reuters, 2019, pp. 331-344; SEMPERE NAVARRO, A. V. y MARTÍN JIMÉNEZ, R.: "El recargo de prestaciones: puntos críticos”, Revista del Ministerio de Trabajo y Asuntos Sociales, n. ${ }^{\circ}$ 53, 2004, publicado en el foro del conocimiento de la ITSS, https://itss.laley.es/Content/DocumentoTDC.aspx?params, Ref. La Ley 14641/2009, p. 12, para quienes en el recargo confluyen elementos propios de las indemnizaciones junto a otros caracterizadores de las sanciones, como también aspectos típicos de las cláusulas penales civiles; MOLINA NAVARRETE, C: "Otra vez a vueltas con el problema de la configuración jurídica del recargo de prestaciones por omisión de las medidas sobre prevención de riesgos: la nueva modernidad de una institución jurídica clásica". Revista Española de Derecho del Trabajo, no 79, septiembre/oct. 1996, pp. 791-792, 803-806 y 825-827; CABEZA PEREIRO, J.: "Sobre el recargo, a la luz de la moderna jurisprudencia”, en AA.VV. (Dir.: BORRAJO DACRUZ, E.): Accidentes de Trabajo y Mutuas, La Ley, Madrid, 2008, p. 285, que habla de naturaleza plural del recargo camaleónica; DUQUE GONZÁLEZ, M.: "El recargo de prestaciones como manifestación de la acción de regreso de la Seguridad Social (I): su incardinación en el sistema de protección social y su coordinación con el sistema de responsabilidad civil", Revista Española de Derecho del Trabajo, núm. 220/2019, edición digital https://insignis-aranzadidigital-es.ponton.uva.es/maf/app/document?srguid, p. 6, para quien es un híbrido entre una indemnización punitiva en forma de prestación, por un lado, y un derecho de repetición del asegurador (la Seguridad Social) frente al asegurado y/o tomador (empresario) por el otro; MÉNDEZ SEBASTIÁN, P.: "La cuadratura del círculo procesal de las responsabilidades por accidente de trabajo. En particular, la vinculación entre las decisiones judiciales sobre recargo, sanción e Indemnización por daños”, Trabajo y Derecho, núm. 55, julio 2019, Smarteca, https://laleydigital-laleynext-es.ponton.uva.es/Content/Documento.aspx?params, p. 21, para quien el 
En la jurisprudencia inicialmente se admitió su naturaleza sancionadora ${ }^{102}$, para posteriormente defenderse su naturaleza híbrida ${ }^{103}$ al aunar aspectos sancionadores, indemnizatorios-reparadores y preventivos. Recargo de prestaciones que para la jurisprudencia mayoritaria ostenta naturaleza compleja, por presentar tres finalidades diversas (preventiva, sancionadora y resarcitoria), ya que, por un lado tiene una innegable faceta prestacional (resarcitorio-indemnizatoria), por cuanto que el beneficiario no es el erario público, como ocurre con las sanciones, sino el trabajador causante de la prestación de Seguridad Social o sus derechohabientes, que ven incrementada la misma en el porcentaje que se reconozca, y por otro lado, tiene una función preventivo/punitiva, ya que se impone la responsabilidad de pago al empresario infractor de la normativa de prevención de riesgos laborales que motivó el accidente de trabajo o la enfermedad profesional de la que trae causa la prestación recargada ${ }^{104}$.

Para la reciente doctrina del Tribunal Supremo ${ }^{105}$, el recargo de prestaciones no tiene sólo una naturaleza punitiva, sino que ostentando una triple naturaleza - preventiva,

recargo tiene naturaleza sancionadora para el empresario e indemnizatoria prestacional para el trabajador.

102 SSTS, Sala Social, de 20 de marzo de 1997 -Rec. 2730/96-; 11 de julio de 1997 -Rec. 719/1997-; 10 de diciembre de 1998 -Rec. 4078/97-; sanción con finalidad preventiva en SSTS, Sala Social, 9 de octubre de 2001 -rcud. 159/2001-; 14 de febrero de 2001 -rcud. 130/2000-; 21 de febrero de 2002 rcud. 2239/2001-; y 22 de abril de 2004 -rcud. 4555/2002-; 21 de julio de 2006 -rcud. 2031/2005-; y 28 de febrero de 2019 -rcud. 508/2017-, en la que sin abordar la naturaleza del Recargo, deja clara la necesidad de que concurra la culpa empresaria en el incumplimiento, pese a admitir posteriormente la aplicación del art. 96.2 de 1 LRJS, lo que ha llevado a señalar a MÉNDEZ SEBASTIÁN que en esa Sentencia el "carácter sancionador que se sostiene sin paliativos" (MÉNDEZ SEBASTIÁN, P.: "La cuadratura del círculo procesal de las responsabilidades por accidente de trabajo. En particular, la vinculación entre las decisiones judiciales sobre Recargo, sanción e Indemnización por daños”, op. cit., p. 6).

103 SSTS, Sala Social, de 17 de julio de 2013 -rcud. 1023/2012-; 23 de marzo de 2015 -rcud. 2057/2014-; 14 de abril de 2015 -rcud. 962/2014-; 5 de mayo de 2015 -rcud. 1075/2014-; 13 de octubre de 2015 rcud. 2166/2014-; 2 de noviembre de 2015 -rcud. 3426/2014-; 25 de febrero de 2016 -rcud. 846/2014; y 18 de mayo de 2016 -rcud. 1042/2014-.

${ }^{104}$ SSTS, Sala Social, de 8 de marzo de 1993 -rcud. 953/92-; 14 de febrero de 2001 -rcud. 130/2000-; 21 de febrero de 2002 -rcud. 2239/2001-; La STS, Sala Social, 28 de febrero de 2019 -rcud. 508/2017-, excluyó la imputabilidad de la empresa, en accidente de un trabajador por imprudencia temeraria, no del accidentado, sino del encargado de la empresa responsable de la supervisión y vigilancia de las medidas preventivas adoptadas por la empresa.

105 Para la Sentencia del 23 de marzo de 2015, “a los efectos de la sucesión en la responsabilidad derivada del Recargo ha de primar la faceta indemnizatoria sobre la sancionadora o preventiva; o lo que es igual, de forma opuesta a nuestros precedentes, entiende ahora la Sala -tras meditada Reconsideración del tema- que la consecuencia inducible de las previsiones del art. 123.2 han de ceder frente a las derivables del art. 127.2 LGSS. Criterio que, como veremos, es del todo coincidente con doctrina comunitaria que significa la Sentencia del TJUE arriba indicada y que más adelante referiremos en detalle". La cursiva es nuestra. La referencia al art. 127.2 debe entenderse al actual art. 168.2 del TRLGSS.

En igual sentido admitiendo la transmisión del recargo las posteriores sentencias del TS, Sala Social, de 14 de abril de 2015 -rcud. 962/2014-; 5 de mayo de 2015 -rcud. 1075/2014-; 2 de noviembre de 2015 -rcud. 3426/2014-; 15 de diciembre de 2015 -rcud. 1258/2014-; 10 de diciembre de 2015 -rcud. 
sancionadora y resarcitoria-, prima el aspecto indemnizatorio-prestacional ${ }^{106}$ sobre los aspectos punitivos, al ser parte de la propia prestación de Seguridad Social, por lo que es transmisible y derivable en los supuestos de sucesión de empresa, de modo especial en la fusión por absorción, en la transformación societaria, en la escisión societaria, y en la cesión del activo y pasivo de una sociedad a otra (Sentencia del TS, Sala Social, de 23 de marzo de 2015 -2057/2014-, que sigue la doctrina de la Sentencia del TJUE de 5 de marzo de 2015 -asunto C-343/13- ${ }^{107}$ ). A partir de la Sentencia del TJUE, nuestra jurisprudencia admite la transmisión del recargo en la sucesión empresarial, no sólo para el recargo ya reconocido antes de la sucesión, sino también cuando ante una enfermedad de evolución lenta (silicosis, asbestosis) se ha contraído durante la exposición al riesgo en la empresa anterior, manifestándose posteriormente ${ }^{108}$.

Primacía de tratamiento prestacional que resulta de las siguientes características. En primer lugar, el recargo está regulado en el art. 164 del TRLGSS, dentro del Título II, Capítulo IV cuya rúbrica es "normas generales en materia de prestaciones ${ }^{109}$. En segundo lugar, la competencia para el reconocimiento del recargo corresponde al INSS/ISM, como cualquier otra prestación económica contributiva de Seguridad Social $^{110}$. En tercer lugar, el procedimiento para imponer el recargo es, como para cualquier otra prestación, el previsto en el R.D. 1300/1995, de 21 de julio y en la O.M. de 18 de enero de $1996^{111}$. En cuarto lugar, porque las notas esenciales de toda prestación recogidas en los arts. 44 y 162 del TRLGSS son de aplicación al recargo de

1012/2014-; 8 de junio de 2016 -rcud. 1103/2015-; 21 de diciembre de 2016 -rcud. 3373/2015-, Sentencias que se separan expresamente de la anterior doctrina del TS, en la que negaba que el Recargo se transmitiese en la sucesión de empresas, como era el caso de las sentencias de 18 de julio de 2011 -rcud. 2502/10-, y de 28 de octubre de 2014 -rcud. 2784/2013.

106 SSTS, Sala Social, de 14 de abril de 2015 -rcud. 962/2014-; 5 de mayo de 2015 -rcud. 1075/2014-; 2 de noviembre de 2015 -rcud. 3426/2014-; 15 de diciembre de 2015 -rcud. 1258/2014-; 10 de diciembre de 2015 -rcud. 1012/2014-; 8 de junio de 2016 -rcud. 1103/2015-; 21 de diciembre de 2016 -rcud. 3373/2015-.

En palabras de la Sentencia del TS de 21 de diciembre de 2016 -rcud. 3373/2015-, "destaca el tratamiento legal de indudable carácter prestacional".

107 Procedimiento prejudicial a instancias de un órgano judicial portugués sobre la interpretación de la Directiva 78/855 CEE, actualmente derogada y sustituida por la Directiva 2011/35/UE. En esa sentencia se sienta como doctrina que, si en la fusión por absorción la nueva empresa se hace cargo del activo y pasivo de la anterior, y en el pasivo se incluye una deuda por sanciones laborales impuesta a la anterior sociedad, la sucesora responde del importe de esa deuda que es parte del pasivo transmitido.

${ }^{108}$ SSTS, Sala Social, de 8 de junio de 2016 -rcud. 1103/2015-; 14 de septiembre de 2016 -rcud. 90/2015; 20 de abril de 2017 -rcud. 1826/2015-.

${ }^{109}$ SSTS, Sala Social, de 23 de marzo de 2015 -rcud. 2057/2014-.

${ }^{110}$ SSTS, Sala Social, 23 de marzo de 2015 -rcud. 2057/2014; de 14 de abril de 2015 -rcud. 962/2014-; y 21 de diciembre de 2016 -rcud. 3373/2015-

${ }^{111}$ SSTS Pleno de 17 de julio de 2013-rcud. 1023/12-, 21 de diciembre de 2016 -rcud. 3373/2015-. 
prestaciones $^{112}$. En quinto lugar, el recargo de prestaciones ha de ser objeto de capitalización en la TGSS, susceptible de recaudación en vía ejecutiva, como cualquier otra prestación para su abono mensual al trabajador conjuntamente con la prestación que complementa $^{113}$. En sexto lugar, el plazo de prescripción del recargo es el mismo que el establecido legalmente para las prestaciones, el de cinco años previsto en el art. 53.1 del TRLGSS $^{114}$ En séptimo lugar, se aplica al recargo la retroactividad de 3 meses en las solicitudes extemporáneas de las prestaciones de Seguridad Social del art. 53 del TRLGSS ${ }^{115}$. En octavo lugar, que la lógica consecuencia de la atribución de tal naturaleza prestacional no puede ser otra que la aplicación de las normas que disciplinan las prestaciones ${ }^{116}$.

Por otro lado, no estamos ante una pura y exclusiva naturaleza sancionadora del recargo según la jurisprudencia, por varias razones. En primer lugar, porque la falta de audiencia a la empresa en el expediente administrativo del recargo, a diferencia del procedimiento sancionador no conlleva la nulidad, siempre que haya tenido posibilidad de efectuar alegaciones y aportar pruebas, sea en vía administrativa o en el posterior proceso judicial $^{117}$. En segundo lugar, la presunción de inocencia no es aplicable al recargo de prestaciones, lo que es propio de las sanciones y no del régimen jurídico de las prestaciones de Seguridad Social ${ }^{118}$, señalando algún autor ${ }^{119}$ que con ello, (sic) "lo que se plantea al Tribunal Supremo, es la posibilidad de eximir del recargo de prestaciones a

112 SSTS, Sala Social, de 23 de marzo de 2015 -rcud. 2057/2014-, de 14 de abril de 2015 -rcud. 962/2014; 5 de mayo de 2015 -rcud. 1075/2014-; 21 de diciembre de 2016 -rcud. 3373/2015-.

${ }^{113}$ SSTS, Sala Social, de 27 de marzo de 2007 -rcud. 639/2006 -; de 14 de abril de 2007, -rcud. 756/2006; de 26 de septiembre de 2007 -rcud. 2573/2006 -; de 23 de marzo de 2015 -rcud. 2057/2014-; de 21 de diciembre de 2016 -rcud. 3373/2015-

114 SSTS, Sala Social, de 9 de febrero de 2006 -rcud. 4100/2004-; de 17 de julio de 2013 -rcud. 1023/2012-; 19 de julio de 2013 -rcud. 2730/2012-; 12 de noviembre de 2013 -rcud. 3117/2012-; 23 de marzo de 2015 -rcud. 2057/2014-; 21 de diciembre de 2016 -rcud. 3373/2015-; 11 de mayo de 2018 -rcud. 3012/2016-; y 18 de septiembre de 2018 -rcud. 2367/2016-.

115 SSTS, Sala Social, 13 de septiembre de 2016 -rcud. 3770/2015-; 15 de septiembre de 2016 -rcud. 3272/2015-; 11 de mayo de 2018 -rcud. 3012/2016-; 18 de septiembre de 2018 -rcud. 2367/2016-; 13 de octubre de 2020 -rcud. 3270/2018-.

116 STS, Sala Social, 21 de diciembre de 2016 -rcud. 3373/2015-.

117 SSTS, Sala Social, de 27 de febrero de 2008 -rcud. 21/2007-; 9 de mayo de 2008 -rcud. 605/2007-; 28 de mayo de 2008 -rcud. 814/2007-; 30 de junio de 2008 -rcud. 4162/2006-; 22 de septiembre de 2008 -rcud. 189/2008-; 11 de diciembre de 2008 -rcud. 4408/2007-; 23 de diciembre de 2008 -rcud. 2284/2007-; 11 de febrero de 2009 -rcud. 4439/2007-; 22 de diciembre de 2010 -rcud. 1136/2009-; 12 de mayo de 2014 -rcud. 635/2013-; 18 de mayo de 2017 -rcud. 1720/2015-, ya que sólo sería anulable la resolución si se produce indefensión, como es propio de todo acto administrativo al amparo del art. 48.2 de la LPACAP.

118 SSTS, Sala Social de 30 de junio de 2003 -rcud. 2403/2002-; 16 de enero de 2006 -rcud. 3970/2004-; de 30 de junio de 2008 -rcud. 4162/2006-; 15 de octubre de 2014 -rcud. 3164/2013-

${ }^{119}$ DUQUE GONZÁLEZ, M.: "El recargo de prestaciones como manifestación de la acción de regreso de la Seguridad Social (I): su incardinación en el sistema de protección social y su coordinación con el sistema de responsabilidad civil ”, edición digital, op. cit., p. 19 de 47. 
la empresa por no haberse demostrado la relación de causalidad entre los incumplimientos y el accidente, debido a que no se supo exactamente qué es lo que ocurrió”. En tercer lugar, el expediente administrativo del recargo no se paraliza por la tramitación de causa penal por los mismos hechos ${ }^{120}$, no siendo aplicable el principio non bis in ídem. En cuarto lugar, si expira el plazo máximo para dictar resolución expresa por la entidad gestora, se produce el silencio administrativo negativo como acece en las prestaciones de Seguridad Social (art. 129.3 del TRLGSS y art. 14.3 de la Orden 18 de enero de 1996 sobre Incapacidades Laborales), y no la caducidad como es lo propio del procedimiento sancionador (arts. 21 y 25 apartado 1.b de la LPACAP) ${ }^{121}$. En quinto lugar, que el reconocimiento del recargo de prestaciones no exige que la conducta empresarial determinante del incumplimiento de las normas de prevención esté tipificada como infracción en el TRLISOS ${ }^{122}$. En sexto lugar, que en la tramitación administrativa del recargo la entidad gestora no ejercita una función sancionadora, sino que interviene como mera gestora de prestaciones ${ }^{123}$. En séptimo lugar, el recargo no es una sanción, porque se puede imponer a la empresa cuando se cause una prestación de contingencias profesionales por incumplimiento de sus obligaciones de prevención de riesgos laborales, sin necesidad de que la conducta esté tipificada en el TRLISOS ${ }^{124}$.

En la doctrina del Tribunal Supremo acerca de la naturaleza del recargo, DUQUE GONZÁLEZ ${ }^{125}$, señala que hubo una primera etapa en que se defendió la naturaleza sancionadora del recargo, para finalmente en una segunda, que comienza en el año 2015, se decanta en favor de su naturaleza prestacional.

${ }^{120}$ SSTS, Sala Social, de 17 de mayo de 2004 -Rec. 3259/2003-; 8 de octubre de 2004 -rcud. 4552/2003; 25 de octubre de 2005 -Rec. 3552/2004-; 18 de octubre de 2007 -Rec. 2812/2006-; 13 de febrero de 2008 -Rec. 163/2007-; 15 de septiembre de 2009 -rcud. 171/2009-; 17 de julio de 2013 -Rec. 1023/2012-, en que se declara inaplicable el art. 16.2, último párrafo que establecía esa paralización.

${ }^{121}$ SSTS, Sala Social, de 17 de mayo de 2004 -rcud. 3259/2003-; 9 de octubre de 2006 -rcud. 3279/2005-; 5 de diciembre de 2006 -rcud. 2531/2005-; 21 de noviembre de 2006 -rcud. 1079/2005-; 12 de febrero de 2007 -rcud. 5542/2005-; 18 de octubre de 2007 -rcud. 2812/2006-; 26 de mayo de 2008 -rcud. 4755/2006-; 17 de julio de 2013 -rcud. 1023/2012-; 19 de julio de 2013 -rcud. 2730/12; 12 de noviembre de 2013 -rcud. 3117/2012-.

122 SSTS, Sala Social, de 4 de marzo de 2014 -rcud. 788/2013-; 26 de abril de 2016 -rcud. 149/2015-; y 14 de marzo de 2017 -rcud. 1083/2015-.

${ }^{123}$ SSTS, Sala Social 3 de julio de 2007 -rcud. 1330/2006-; 12 de julio de 2007 -rcud. 1145/2006-; 23 de marzo de 2015 -rcud. 2057/2014-; 21 de diciembre de 2016 -rcud. 3373/2015-.

${ }^{124}$ SSTS, Sala Social, de 4 de marzo de 2014 -rcud. 788/2013-; 26 de abril de 2016 -rcud. 149/2015-; 14 de septiembre de 2016 -rcud. 846/2015-; 14 de marzo de 2017 -rcud. 1083/2015-. E incluso que puede anularse la sanción sin que ello determine la nulidad del Recargo porque, pudo haber incumplimiento de disposiciones de prevención de riesgos laborales que no necesariamente han de estar tipificadas como infracción administrativa, STS 14 de septiembre de 2016 -rcud. 846/2015-.

${ }^{125}$ DUQUE GONZÁLEZ, M.: "El Recargo de prestaciones como manifestación de la acción de regreso de la Seguridad Social (I): su incardinación en el sistema de protección social y su coordinación con el sistema de responsabilidad civil”, edición digital, op. cit., p. 5 de 47. 
El recargo de prestaciones no tiene una pura y exclusiva naturaleza sancionadora, recogiendo palabras de MÉNDEZ SEBASTIÁN ${ }^{126}$, porque los principios del Derecho administrativo sancionador no son aplicables según nuestra jurisprudencia al procedimiento administrativo de reconocimiento del recargo de prestaciones, al tener éste (sic) "una naturaleza híbrida, con una determinante carga indemnizatoria/prestacional", concluyendo esta autora que el recargo tiene carácter indemnizatorio prestacional para el trabajador y sancionador para la empresa $\mathrm{o}$ naturaleza de indemnización punitiva empresarial.

Son argumentos en contra de la pura naturaleza sancionadora, según SEMPERE NAVARRO ${ }^{127}$, que en el beneficiario del importe del recargo no es la Administración de Seguridad Social sino el trabajador accidentado; porque de tener naturaleza sancionadora si se sanciona a la empresa en el procedimiento administrativo sancionador, no podría por los mismos declararse el recargo de prestaciones al impedirlo el principio non bis in ídem; y porque si fuese una sanción sólo procedería el recargo de ser los hechos subsumibles en las infracciones tipificadas en el TRLISOS.

Recargo de prestaciones que el trabajador podría reclamar al administrador social ejercitando la acción individual de responsabilidad (art. 241 de la LSC), o la acción de la responsabilidad solidaria en deudas, en los supuestos de los arts. 360 y 367 de la LSC, de concurrir los requisitos legales exigidos a esas dos modalidades de responsabilidad.

Si el recargo de prestaciones no tiene una pura y exclusiva naturaleza sancionadora, sino híbrida por incorporar en su propia configuración jurídica elementos sancionadores, indemnizatorios y prestacionales, y especialmente cuando la jurisprudencia ${ }^{128}$ considera que prima el factor indemnizatorio prestacional, puede permitirnos abogar jurídicamente por la necesidad de reformar la actual limitación de la derivación del recargo de prestaciones dentro del procedimiento administrativo de recaudación establecida en el art. 12.4 del RGRSS. Será objeto de estudio en el capítulo VI apartado II.2.1 la posible

126 MÉNDEZ SEBASTIÁN, P.: "La cuadratura del círculo procesal de las responsabilidades por accidente de trabajo. En particular, la vinculación entre las decisiones judiciales sobre recargo, sanción e indemnización por daños”, 2019, op. cit., pp. 2 y 11-12.

127 SEMPERE NAVARRO, A. V. y MARTÍN JIMÉNEZ, R.: "El recargo de prestaciones: puntos críticos", op. cit., p. 6.

${ }^{128}$ SSTS, Sala Social, de 23 de marzo de 2015 -rcud. 2057/2014-; 14 de abril de 2015 -rcud. 962/2014-; 5 de mayo de 2015 -rcud. 1075/2014-; 13 de octubre de 2015 -rcud. 2166/2014-; 2 de noviembre de 2015 -rcud. 3426/2014-; 25 de febrero de 2016 -rcud. 846/2014-; y 18 de mayo de 2016 -rcud. $1042 / 2014-$. 
derivación de recargo de prestaciones al administrador social, y qué entidad de Seguridad Social será la competente para la derivación de esa deuda, si la TGSS o la entidad gestora.

\section{Responsabilidad del administrador en la deuda por sanciones de Seguridad Social de la sociedad de capital.}

Un principio esencial del Derecho penal, y consiguientemente del Derecho administrativo sancionador, es el principio de personalidad de la infracción y la sanción $^{129}$, lo que supone que sólo serán sujetos responsables de las infracciones administrativas las personas físicas, jurídicas o entidades sin personalidad expresamente determinadas por una disposición con rango de ley, bien sea como responsables directos de la infracción o en virtud de responsabilidad solidaria o subsidiaria ${ }^{130}$.

Sujetos responsables de las infracciones de Seguridad Social son las personas o entidades recogidas con carácter taxativo o numerus clausus $^{131}$ en el art. 2 del TRLISOS, donde no se han incluido a los administradores sociales, ni como sujetos responsables directos de la infracción, ni como sujetos responsables solidarios o subsidiarios de la misma.

Para que el administrador social pudiera ser sujeto responsable de una infracción del orden social de la sociedad de capital, debería una disposición con rango de ley calificarle como sujeto responsable directo (arts. 25, 27 y 28 de la Ley 40/2015, de 1 de octubre, de Régimen Jurídico del Sector Público -LRJSP_ ${ }^{132}$ ), al aplicarse los principios inspiradores del orden penal, con ciertas matizaciones, al procedimiento administrativo sancionador, al ser ambos manifestaciones del ordenamiento punitivo del Estado ${ }^{133}$,

${ }^{129}$ Art. 28 de la Ley 40/2015, de 1 de octubre, de Régimen Jurídico del Sector Público, en relación con el art 2.2 TRLISOS, y art. 12.4 del Real Decreto 1415/2004, de 11 de junio -RGRSS-.

${ }^{130}$ SSTC 18/1981, de 8 de junio; 120/1996 de 8 julio; 82/2019 de 17 junio; 93/2018 de 17 septiembre; 59/2014 de 5 mayo; 146/1994, de 12 de mayo.

${ }^{131}$ CAMINO FRÍAS, J. J.: "Un fenómeno emergente del fraude social: las empresas ficticias. Actuación de la Inspección de Trabajo y Seguridad Social”, Trabajo y Derecho, n. 3, Sección Práctica Jurídica y Despachos Profesionales, editorial Wolters Kluwer, Ref. La Ley, edición digital https://laleydigitallaleynext-es.ponton.uva.es/Content/Documento.aspx?params, p. 12, quien señala que "bien es cierto que puede parecer que la relación de sujetos responsables que contiene el artículo 2 puede tener un carácter enunciativo (..., en particular), mas lo prolijo de la enumeración que contiene en sus catorce apartados - con las sucesivas ampliaciones de que ha sido objeto para posibilitar la sanción a determinados sujetos-, entendemos que ha de llevarnos a la conclusión de que no cabe la sanción de aquellos que no figuran en la relación".

132 BOE del 2.10.2015.

${ }^{133}$ SSTC 18/1981, de 8 de junio -Aranzadi RTC 1981/18-; 120/1996 de 8 julio -Aranzadi RTC 1996/120; 82/2019 de 17 junio -Aranzadi RTC 2019/82-; 93/2018 de 17 septiembre -Aranzadi RTC 2018/93-; 59/2014 de 5 mayo -Aranzadi RTC 2014/59-. 
rigiendo dentro de esos principios el de legalidad, tipicidad, y de personalidad de la infracción y la sanción ${ }^{134}$. De igual modo, se precisaría una disposición con rango de ley para declararle responsable solidario o subsidiario de una sanción administrativa impuesta a la sociedad de capital ${ }^{135}$.

Pese a ser un recurso económico de la Seguridad Social, del importe de las sanciones impuestas a la sociedad de capital por infracciones en materia de Seguridad Social (art. 1 apartado f del RGRSS), responde sólo la sociedad de capital en el procedimiento administrativo sancionador, no pudiendo exigirse al administrador la sanción por derivación administrativa de responsabilidad (art. 12.4 del RGRSS). Para que pueda derivarse una deuda por sanciones impuestas a la sociedad de capital al administrador social, se precisaría que por disposición legal se haya previsto expresamente la derivación de responsabilidad en las sanciones, porque la derivación administrativa de responsabilidad para el pago de una sanción por infracciones administrativas debe sujetarse a los principios que presiden el ejercicio del ius puniendi del Estado ${ }^{136}$.

Tampoco se le podría exigir la sanción al administrador social ejercitando la acción individual de responsabilidad, porque el daño se causaría en el patrimonio social.

Defendía la responsabilidad del administrador social en infracciones del orden social NICOLÁS BERNAD ${ }^{137}$, quien pese a reconocer que con carácter general debe excluirse la responsabilidad del mismo por el principio de personalidad de la pena, admitía que podía ser sujeto pasivo del acta de infracción en tres supuestos, en las actas de infracción por obstrucción, en las infracciones muy graves laborales con vulneración de derechos fundamentales tipificadas en el artículo 8 apartados 5, 6. 8. 10, 11, 12 y 13 del TRLISOS, y cuando por levantamiento del velo se le impute la condición de empresario, supuesto éste que sería el único admisible, por ostentar la condición de empresario en la relación laboral.

SSTS, Sala Contencioso-Administrativa, de 10 de noviembre de 1986 -RJRJ 1986/6647-; 18 junio de 1984 -Aranzadi RJ 1984/3637-; 24 septiembre 1984 -Aranzadi RJ 1984/4306-; 22 febrero de 1989 -RJ 1989/1462-; 26 enero 2015 -Aranzadi RJ 2015/299-; Sentencia de 20 enero 1997 -Aranzadi RJ 1997/535-; 16 junio 1997 -Aranzadi RJ 1997/5442-; entre otras muchas.

${ }^{134}$ STC 76/1990, de 26 de abril; 146/1994; 146/1994, de 12 de mayo; 246/1991, de 19 de diciembre.

${ }^{135}$ STS, Sala Civil, 316/2020, de 17 de junio -Rec. 4270/2017-, SSTS, Sala Contencioso-Administrativa 1033/2019, de 10 de julio; 88/2017, de 24 de enero; 1421/2016, de 15 de junio -Rec. 1916/2015-; 6 de julio de 2015 -Rec. 3418/2013-; 8 de noviembre de 2010 -Rec. 4941/2007-.

136 SSTS, Sala Contencioso-Administrativa, de 8 de noviembre de 2010 -Rec. 4941/2007-; 6 de julio de 2015 -Rec. 3418/2013-; 1421/2016, de 15 de junio -Rec. 1916/2015-

${ }^{137}$ NICOLÁS BERNAD, J. A.: "La responsabilidad de los administradores sociales ante la Inspección de Trabajo”, Revista de Derecho Social, núm. 17/2002, p. 92. 
En el art. 31 del Código Penal ${ }^{138}$ se recoge la condición de sujeto penalmente responsable del administrador de hecho o de derecho por los ilícitos penales que pueda cometer la sociedad de capital, con independencia de que también se haya reconocido a ésta sujeto responsable en vía penal (art. 31 bis del Código Penal ${ }^{139}$ ). Responsabilidad penal de la sociedad regulada en los arts. 31 bis al 31 quienquies, ambos inclusive, y en los delitos contra la Seguridad Social en el art. 310 bis del Código Penal.

En el Derecho sancionador del orden social el administrador de la sociedad de capital no es sujeto responsable directo de las infracciones o sanciones (art. 2 del TRLISOS), ni sujeto responsable de la sanción por derivación de responsabilidad en la sanción, a diferencia del Derecho tributario en el que se prevé una responsabilidad del administrador conjuntamente con la sociedad de capital.

En la legislación tributaria se prevé que la responsabilidad en las sanciones por infracciones tributarias se pueda exigir, no sólo al sujeto obligado principal o responsable principal, sino también a otras personas en calidad de responsables solidarios o subsidiarios dentro del procedimiento administrativo de derivación de responsabilidad en las deudas por sanciones (arts. 41, 181 y 182 de la Ley 58/2003, de 17 de diciembre, que aprueba la Ley General Tributaria -LGT-). En el Derecho tributario el administrador social responderá en calidad de responsable solidario o subsidiario, ya no sólo de las deudas tributarias, sino también de las sanciones por infracciones administrativas tributarias ${ }^{140}$. Responsabilidad en la deuda ajena que se reclamará mediante la derivación administrativa tributaria de responsabilidad.

En el orden social no cabe esa derivación administrativa de responsabilidad en las sanciones pecuniarias impuestas a la sociedad de capital (art. 12.4 del RGRSS), sea la sanción principal por multa del art. 40 del TRLISOS, la sanción directa de devolución de prestaciones del art. 43.3 del TRLISOS, o las sanciones accesorias de los arts. 23.2, 46 y 46 bis del TRLISOS -importes indebidos de bonificaciones, deducciones en la cotización, etc.-.

${ }^{138}$ En el art. 31 se establece "el que actúe como administrador de hecho o de Derecho de una persona jurídica, o en nombre o representación legal o voluntaria de otro, responderá personalmente, aunque no concurran en él las condiciones, cualidades o relaciones que la correspondiente figura de delito requiera para poder ser sujeto activo del mismo, si tales circunstancias se dan en la entidad o persona en cuyo nombre o representación obre".

139 BOE del 23.7.2010.

140 Vid.: VILLAR EZCURRA, M.: "La responsabilidad tributaria", en el AA.VV. (Coord.: ROJO FERNÁNDEZ-RÍO, A. y BELTRÁN SÁNCHEZ, E.): La responsabilidad de los administradores de las sociedades mercantiles, $6^{\mathrm{a}}$ edición, Tirant Lo Blanch, Valencia, 2016, pp. 589-649. 


\section{CAPÍtUlo:}

\section{RESPONSABILIDAD POR DAÑOS DEL ADMINISTRADOR EN DEUDAS DE SEGURIDAD SOCIAL. ACCIÓN SOCIAL E INDIVIDUAL DE RESPONSABILIDAD.}

Como hemos señalado en el capítulo anterior el administrador social está sujeto con carácter general a tres tipos de responsabilidad ante los acreedores ${ }^{141}$, responsabilidad por daños, por deudas y responsabilidad concursal.

En virtud de la responsabilidad por daños los administradores de las sociedades de capital responderán de los daños que causen en el ejercicio de su cargo a la sociedad, a los socios y a los acreedores sociales. Responsabilidad por daños que es exigible mediante dos acciones procesales, la acción social de responsabilidad y la acción individual de responsabilidad (arts. 236 a 241 bis de la LSC).

En este capítulo analizaremos la responsabilidad por daños, como forma de exigir la responsabilidad ante el daño a los créditos de Seguridad Social de las entidades gestoras y de la TGSS. Nuestra investigación se centrará en el estudio de la acción individual de responsabilidad, ya que la acción social carece de virtualidad para obtener directamente el pago de deudas de Seguridad Social, por dos razones esenciales. En primer lugar, por las limitaciones que se establecen en la legitimación de su ejercicio. En segundo lugar, y de modo principal, porque la finalidad de la acción social no es recomponer el patrimonio perjudicado del acreedor social, sino el patrimonio de la propia sociedad, con lo que, normalmente el acreedor social tenderá a ejercitar la acción individual de responsabilidad con la que sí podrá obtener la satisfacción de su crédito.

Al ser la acción individual de responsabilidad un instituto jurídico que permitirá al acreedor de la sociedad de capital obtener del administrador social la reparación o

${ }^{141}$ ESTEBAN VELASCO, G.: "Algunas reflexiones sobre la Responsabilidad de los Administradores frente a los Socios y los Terceros: Acción individual y acción por no Promoción o Remoción de la disolución”, en Revista Derecho de Sociedades, número 5, 1995, pp. 47-50; GARRETA SUCH, J. M.: La responsabilidad civil, fiscal y penal de los administradores de sociedades, Editorial Marcial Pons, $3^{a}$ edición, Madrid, 1996, pp. 127-220; SÁNCHEZ CALERO, F.: Los Administradores en las Sociedades de Capital, $2^{\mathrm{a}}$ edición, Aranzadi Thomson Cívitas, 2007, pp. 303 y ss; VALPUESTA GASTAMINZA, E. M.: Comentarios a la Ley de Sociedades de Capital, $3^{\mathrm{a}}$ edición, Bosch Wolters Kluwer, 2018, pp. 622 a 625. 
indemnización del daño antijurídico directo sufrido con motivo del incumplimiento de obligaciones legales, pretendemos dilucidar si mediante la acción individual de responsabilidad pueden las entidades gestoras de prestaciones y la TGSS perseguir la satisfacción de sus créditos.

La finalidad de nuestra investigación al analizar esta responsabilidad por daños del administrador social, irá encaminada a determinar en qué condiciones, y en qué supuestos, podrán las entidades gestoras de la Seguridad Social obtener la satisfacción de los créditos resultantes de las obligaciones legales contraídas por la sociedad de capital, mediante el ejercicio de la acción individual de responsabilidad cuando el incumplimiento de esas obligaciones legales sea imputable al administrador, ya que, el mero incumplimiento de obligaciones sociales, sean legales o contractuales, no es presupuesto del ejercicio de la acción individual de responsabilidad. Nos centraremos de modo especial en tres supuestos: a) en los incumplimientos dolosos de los administradores de las obligaciones imperativas en materia de afiliación, altas, bajas y cotización a la Seguridad Social; b) en los supuestos de preterición en el pago de los acreedores de Seguridad Social cuando se dejan de atender esas obligaciones, cumpliéndose por el contrario con otras de menor prelación, con un daño evidente a los derechos de Seguridad Social; y c) en la posible aplicación de esta acción individual de responsabilidad ante situaciones de crisis empresariales, especialmente ante un cierre de hecho sin ordenada liquidación. Analizaremos igualmente cómo afecta la situación concursal de la sociedad de capital a la reclamación de deudas de Seguridad Social mediante la acción individual de responsabilidad.

Antes de adentrarnos en el estudio de esos posibles supuestos en que la acción individual de responsabilidad puede ser de aplicación en la reclamación de obligaciones de Seguridad Social, para tener un conocimiento acerca de las posibilidades, condiciones y límites con que se encontrarán esas entidades de Seguridad Social, conviene tener un previo conocimiento de la naturaleza de la acción individual de responsabilidad, de los presupuestos y requisitos necesarios que han de concurrir para su ejercicio, y especialmente ante determinados incumplimientos de obligaciones de Seguridad Social.

Determinada la naturaleza y régimen jurídico general de la acción individual de responsabilidad, analizaremos cómo afecta la situación concursal de la sociedad de 
capital a la reclamación de deudas de Seguridad Social mediante la acción individual de responsabilidad, y si ésta puede exigirse dentro del procedimiento administrativo de recaudación en aplicación del art 18.3 del TRLGSS, o si las Administraciones de la Seguridad Social deben acudir ante los tribunales ejercitando la acción individual de responsabilidad como cualquier otro acreedor.

\section{I.- FUNDAMENTO Y DIFERENCIACIÓN JURÍDICA DE LA ACCIÓN SOCIAL Y LA ACCIÓN INDIVIDUAL DE RESPONDABILIDAD.}

\section{Fundamento y régimen jurídico de la responsabilidad por daños.}

Corresponde a los administradores sociales de las sociedades de capital la gestión y dirección ordinaria de la empresa -relaciones internas o ad intra-, (arts. 209 y 225 a 231 de la LSC), así como la representación de la misma ante terceros en el tráfico jurídico relaciones externas o ad extra- (artículos 233 y 234 de la LSC).

Para que la gestión y dirección de los negocios de la sociedad de capital vaya en beneficio de la propia sociedad, y no de terceros o de los propios administradores, se les imponen a éstos una serie de deberes legales que son fruto de la posición fiduciaria de los mismos ante la sociedad. Deberes que, siguiendo a LLEBOT MAJÓ ${ }^{142}$, a partir de la reforma de la Ley 31/2014, de 3 de diciembre, por la que se modifica la Ley de Sociedades de Capital para la mejora del gobierno corporativo ${ }^{143}$, pueden reducirse a dos, en los que de alguna forma se subsumen o se reconducen los otros. Por un lado, está el deber de diligencia en la gestión empresarial para la consecución del objeto social en el tráfico económico, y, por otro lado, está el deber de lealtad con la sociedad en la gestión del objeto social ${ }^{144}$. Deberes que se han positivizado en los artículos 225 y siguientes de la LSC. El deber general de diligencia se recoge en los arts. 225 y 226 de la LSC, precepto éste en que se consagra por influencia del Derecho anglosajón la

${ }^{142}$ LLEBOT MAJÓ, J. O.: "Deberes y Responsabilidades de los Administradores", en AA.VV. (Dir.: ROJO FERNÁNDEZ-RÍO, A. y BELTRÁN SÁNCHEZ, E.): La Responsabilidad de los Administradores de las Sociedades Mercantiles, edición electrónica, pp. 10 y ss.

143 BOE 4.12.2014.

144 Sobre estos deberes Vid.: LLEBOT MAJÓ, J. O.: "Deberes y Responsabilidades de los Administradores", op. cit., pp. 13 y ss.; RODRÍGUEZ ARTIGAS, F.: "El deber de diligencia", en AA.VV. (Coord.: ESTEBAN VELASCO, G.): El gobierno de sociedades cotizadas, Madrid 1999, pp. 419 y ss; QUIJANO GONZÁLEZ, J. y MAMBRILLA RIVERA, V.: "Los deberes fiduciarios de diligencia y lealtad, en particular los conflictos de interés y las operaciones vinculadas", en AA.VV. (Coord.: RODRÍGUEZ ARTIGAS, F.): Derecho de Sociedades Anónimas Cotizadas: estructura de gobierno y mercados, Thomson Reuters Aranzadi, Vol. II, 2006, pp. 915 a 990; PÉREZ CARRILLO, E. F.: "El deber de diligencia de los administradores de sociedades", $R d S$, núm. 14, 2000, pp. 275 y ss. 
protección de la discrecionalidad empresarial en la toma de decisiones razonables para la consecución del objeto social (business judgment rule) ${ }^{145}$. El deber de lealtad se recoge en el art. 227 del mismo cuerpo legal, del que emanan otros deberes regulados en los arts. 228 a 229 de la LSC $^{146}$ que especifican supuestos del deber genérico de lealtad (evitación de situaciones de conflicto de intereses con la sociedad, de reserva y confidencialidad, etc.), que no son objeto de estudio en este trabajo. Son esos dos grandes deberes de diligencia y lealtad en el ejercicio del cargo de la administración social, los que sirven de fundamento y justificación para que la sociedad, los socios y los acreedores exijan la responsabilidad de los administradores mediante las acciones sociales o individuales de responsabilidad.

El incumplimiento de esos deberes de gestión diligente -conforme a los parámetros de un ordenado comerciante-, y leal -como fiel representante de la sociedad-, generará la responsabilidad de los administradores ante la sociedad, los accionistas y los acreedores (artículos 232 y 236 a 241 bis de la LSC).

Con fundamento en esos deberes y con la obligación del administrador de actuar con respeto a la ley y a los estatutos sociales, en el Derecho de sociedades se configura la acción de responsabilidad exigible a aquéllos como una institución jurídica específica $^{147}$, con entidad y régimen jurídico propio con respecto a la responsabilidad por daños del Derecho civil, pasando del parámetro de conducta de un buen padre de familia, al parámetro de diligencia de un ordenado empresario y de un representante leal. Instituto jurídico específico que no impide que sus presupuestos se nutran, en buena medida, de las fuentes de la responsabilidad extracontractual aquiliana del artículo 1902 de nuestro Código Civil, que tiene como principio alterum non laedere.

El régimen jurídico de la responsabilidad por daños exigible al administrador ante la sociedad, los socios y los acreedores o terceros, se regula el Título VI, Capítulo V, bajo la denominación genérica de "La responsabilidad de los administradores" (arts. 236 a 241 bis de la LSC). En ese capítulo se contemplan dos acciones de responsabilidad diversas, por un lado, la acción social de responsabilidad que se regula en los artículos

\footnotetext{
${ }^{145}$ VALPUESTA GASTAMINZA, E. M.: Comentarios a la Ley de Sociedades de Capital, op. cit., pp. 595-596; SÁNCHEZ CALERO, F.: Los Administradores en las Sociedades de Capital, op. cit., p. 311.

146 VALPUESTA GASTAMINZA, E. M.: Comentarios a la Ley de Sociedades de Capital, op. cit., p. 592.

147 GARRETA SUCH, J. M.: La responsabilidad civil, fiscal y penal de los administradores de sociedades, 1996, op. cit., pp. 166-167.
} 
238 a 240 de la LSC, y por otro, la acción individual de responsabilidad en el art. 241 de la LSC. Son disposiciones comunes aplicables a ambas acciones las prescripciones recogidas en los arts. 236, 237 y 241 bis, según nos indica VALPUESTA GASTAMINZA $^{148}$ siguiendo a la doctrina mayoritaria. En el art. 236 de la LSC se establecen los presupuestos o requisitos de la acción de responsabilidad. En el art. 237 de la LSC se impone el carácter solidario de la responsabilidad de ser varios los administradores, pese a que, excepcionalmente y frente a una reiterada y mantenida doctrina jurisprudencial, en alguna sentencia aislada ${ }^{149}$, analizando el art. 133.3 el Real Decreto Legislativo 1564/1989, de 22 de diciembre, que aprobó el Texto Refundido de la Ley de Sociedades Anónimas -en adelante LSA- ${ }^{150}$, del que trae causa el art. 237 de la LSC, se consideró no aplicable a la acción individual. Actualmente, no existen dudas acerca de la plena aplicabilidad del art. 237 de la LSC a la acción individual de responsabilidad. Finalmente, el art. 241 bis, que regula la prescripción de la acción social e individual de responsabilidad, precepto introducido por la Ley 31/2014, de 3 de diciembre.

Nos hallamos ante una responsabilidad del administrador por los daños que cause a la sociedad, a los socios, o a los terceros por actos contrarios a la ley, los estatutos, o incumpliendo los deberes inherentes al cargo. Responsabilidad "esencialmente subjetiva" ${ }^{151}$, teniendo como causa la culpa. Para que surja la responsabilidad civil del administrador es preciso que realicen un acto ilícito que cause un daño, que será patrimonial o extrapatrimonial $^{152}$.

En función del sujeto que sufra el daño, sea la sociedad o sean los socios o los terceros acreedores, se prevén dos acciones de responsabilidad, la acción social de responsabilidad regulada en los arts. 238 a 240 de la LSAC, y la acción individual de responsabilidad prevista en el art. 241 de la $\operatorname{LSC}^{153}$.

\footnotetext{
148 VALPUESTA GASTAMINZA, E. M.: Comentarios a la Ley de Sociedades, op. cit., 2018, pp. 638639.

149 TS, Sala Civil, Sentencia núm. 598/2010 de 14 octubre -RJ 2010/8866-.

${ }^{150}$ BOE del 27.12.1989.

151 GARRETA SUCH, J. M.: La responsabilidad civil, fiscal y penal de los administradores de sociedades, 1996, op. cit., p. 111.

152 ESTEBAN VELASCO, G.: “Algunas reflexiones sobre la Responsabilidad de los Administradores frente a los Socios y los Terceros: acción individual y acción por no Promoción o Remoción de la disolución”, 1995, op. cit. p 48.

153 ESTEBAN VELASCO, G.: “La acción individual de responsabilidad”, en AA.VV. (Coord.: ROJO FERNÁNDEZ-RÍO, A. y BELTRÁN SÁNCHEZ, E.): La responsabilidad de los administradores de las sociedades mercantiles, Tirant Lo Blanch, 6ª edición, 2016, Valencia, pp. 190-194; SÁNCHEZ
} 
En la acción individual de responsabilidad nos interesa la figura del acreedor social, al tener esta condición las entidades gestoras de la Seguridad Social y la TGSS, ya que serán titulares de créditos derivados de obligaciones legales en materia de Seguridad Social, sean obligaciones por prestaciones de responsabilidad empresarial o deudas por cotizaciones.

La acción social de responsabilidad procede cuando el administrador en el ejercicio del cargo causa un daño a la sociedad, daño directo a la sociedad que puede originar, a su vez, un daño reflejo o indirecto a los socios y/o a los acreedores ${ }^{154}$. Acción social cuya finalidad es recomponer el patrimonio social perjudicado. No obstante ser una única acción procesal ${ }^{155}$, son tres los sujetos legitimados, uno principal que es la sociedad y otros subsidiarios, los socios si no ejercita la sociedad la acción y los terceros acreedores si no ejercita la acción ninguno de los otros dos legitimados. Es una acción personal, declarativa y de condena ${ }^{156}$

Si el administrador en el ejercicio del cargo causa un daño directo al socio o al acreedor, éstos podrán ejercitar la acción individual de responsabilidad, cuya finalidad es obtener la reparación del perjuicio causado a su derecho, que en el caso del acreedor social podrá ser el crédito que ostenta contra la sociedad, esto es, la satisfacción del crédito frustrado ${ }^{157}$. La acción individual de responsabilidad según GARRETA SUCH"158 es "la acción que todo perjudicado directo tiene contra quien, como administrador, incumplió

CALERO, F.: Los Administradores en las Sociedades de Capital, op. cit., pp. 304-307; GARRETA SUCH, J. M.: La responsabilidad civil, fiscal y penal de los administradores de sociedades, 1996, op. cit., pp. 127-130.

${ }^{154}$ GARRIGUES, J.: Curso de Derecho Mercantil, Tomo I, $7^{\mathrm{a}}$ edición, Madrid 1976, p. 491; BROSETA PONS, M.: Manual de Derecho Mercantil, 4a edición, Tecnos, 1981, pp. 262-263; JIMÉNEZ SÁNCHEZ G. J.: Lecciones de Derecho Mercantil, Tecnos, 1992, pp. 200-201; GARRETA SUCH, J. M.: La responsabilidad civil, fiscal y penal de los administradores de sociedades, 1996, op. cit., pp. 127-132; SÁNCHEZ CALERO, F.: Los Administradores en las Sociedades de Capital, op. cit., pp. 320-321, 366 y ss y 409 y ss; ESTEBAN VELASCO, G.: "La acción individual de responsabilidad", 2016, op. cit., p. 190; VALPUESTA GASTAMINZA, E. M: Comentarios a la Ley de Sociedades, op. cit., pp. 628-629.

155 GARRETA SUCH, J. M.: La responsabilidad civil, fiscal y penal de los administradores de sociedades, op. cit., pp. 130-131.

156 GARRETA SUCH, J. M.: La responsabilidad civil, fiscal y penal de los administradores de sociedades, op. cit., p. 130.

${ }^{157}$ ESTEBAN VELASCO, G.: "Algunas reflexiones sobre la Responsabilidad de los Administradores frente a los Socios y los Terceros: Acción individual y acción por no Promoción o Remoción de la disolución”, 1995, op. cit. p 48; GARRETA SUCH, J. M.: La responsabilidad civil, fiscal y penal de los administradores de sociedades, op. cit., pp. 131-132 y 163 y ss; SÁNCHEZ CALERO, F.: Los Administradores en las Sociedades de Capital, op. cit., 2007, p. 410; ESTEBAN VELASCO, G.: "La acción individual de responsabilidad", op. cit., pp. 194 y ss.

158 GARRETA SUCH, J. M.: La responsabilidad civil, fiscal y penal de los administradores de sociedades, op. cit., p. 164. 
su obligación y causó un daño". En el art. 241 de la LSC se alude a terceros ${ }^{159}$, en cuyo vocablo ha de incluirse al acreedor social perjudicados mencionado explícitamente en el art. 236.1 de la LSC, en virtud de una interpretación sistemática de ambos preceptos jurídicos. Referencia a los terceros que se realiza para aclarar que, con la acción individual se pretende reparar el daño causado por el administrador en el ejercicio de su cargo, no sólo al acreedor sino a todo aquél que resulte perjudicado, tenga o no relación contractual con la sociedad. La referencia a los terceros del art. 241 de la LSC, no implica exclusión del acreedor social, sino que es un concepto con contornos más amplio para no limitar la acción individual únicamente al acreedor, como pudiera desprenderse de una lectura aislada y no sistemática del art. 236 de la LSC.

El acto del administrador puede causar daño directo al patrimonio de la sociedad que podrá motivar el ejercicio de la acción social de responsabilidad, pero puede ocasionar también simultáneamente un daño directo al patrimonio del socio o del acreedor (acción individual de responsabilidad), en cuyo caso, podrían ejercitarse simultáneamente ambas acciones por los sujetos legitimados. Acciones que nuestra jurisprudencia ${ }^{160}$ admite que podrán acumularse en la demanda por el acreedor social. MUÑOZ PAREDES ${ }^{161}$, considera que la acción individual y la social serían difícilmente acumulables al ser incompatibles entre sí, especialmente en el cierre de hecho de la empresa, ya que en la acción social el beneficiario es la sociedad y en la acción individual el acreedor. Defiende la procedencia de su acumulación SÁNCHEZ CALERO $^{162}$, para quien, no obstante su admisibilidad, comoquiera que el beneficiario de la acción social es directamente el patrimonio social, esa acción carece de interés para el acreedor, quien ejercita con más frecuencia la acción individual de responsabilidad porque su éxito redunda en su patrimonio. Consideramos que, aunque se admita teóricamente su acumulación, de realizarse se hará siempre una acumulación subsidiaria de la acción social con respecto a la acción individual, ya que de estimarse ésta el acreedor obtiene la reparación directa del crédito dañado.

${ }^{159}$ ESTEBAN VELASCO, G.: "Algunas reflexiones sobre la Responsabilidad de los Administradores frente a los Socios y los Terceros: Acción individual y acción por no Promoción o Remoción de la disolución”, 1995, op. cit. p. 48; GARRETA SUCH, J. M.: La responsabilidad civil, fiscal y penal de los administradores de sociedades, op. cit., p. 164; SÁNCHEZ CALERO, F.: Los Administradores en las Sociedades de Capital, op. cit., pp. 320-321, 366 y 409.

${ }^{160}$ SSTS, Sala Civil núm. 540/2005, de 7 de julio -Rec. 43/1999-; núm. 667/2009, de 23 de octubre -Rec. 199/2005-, y núm. 396/2013, de 20 de junio -Rec.1421/2011-, entre otras muchas.

161 MUÑOZ PAREDES, A.: "Tratado judicial de responsabilidad de los administradores. La responsabilidad societaria”, Thomson Reuters Aranzadi, $1^{\text {a }}$ edición 2015, Vol. I., p. 79.

${ }^{162}$ SÁNCHEZ CALERO, F.: Los Administradores en las Sociedades de Capital, op. cit., pp. 404 y 424. 
Tiene más importancia para las entidades gestoras y recaudatorias de la Seguridad Social la acción individual de responsabilidad, ya que con ella podría satisfacerse directamente el crédito de Seguridad Social ante el administrador social cuando haya resultado perjudicado por la conducta ilícita de éste, mientras que con la acción social se reintegra el patrimonio de la mercantil, por lo que de ejercitar alguna acción se optará por la acción individual, pudiendo acumular subsidiariamente la acción social.

\section{Antecedentes normativos de la responsabilidad por daños en nuestro Derecho de sociedades.}

La responsabilidad por daños del administrador social se introdujo de modo muy incompleto en el art. 156 del Código de Comercio ${ }^{163}$, precepto actualmente derogado.

Regulación muy incipiente de la responsabilidad de los administradores que eran concebidos como mandatarios sujetos a un contrato de mandato con la sociedad, sin ser concebido como órgano permanente y estructurado de la sociedad (teoría del órgano).

El primer hito histórico en la regulación de las sociedades mercantiles lo tendremos en los años 1951 y 1953, en que se aprueban respectivamente las leyes de sociedades anónimas y de responsabilidad limitada, configurándose la responsabilidad de los administradores como una responsabilidad orgánica, separándose de la mera figura del mandato.

Habrá que esperar hasta la 1951 para disponer de una regulación específica de las sociedades anónimas, desgajada del Código de Comercio, al aprobarse la Ley de 17 de julio de 1951, sobre Régimen Jurídico de las Sociedades Anónimas ${ }^{164}$. En el art. 79 se regulaba con carácter general la responsabilidad de los administradores. En ese precepto se establecían los presupuestos de la responsabilidad, indicándose que debían desempeñar el cargo con la diligencia de un ordenado comerciante y de un representante leal, respondiendo ante la sociedad, los socios, y los acreedores del daño que causen por malicia, abuso de facultades o negligencia grave, y contemplándose que se exonerarían de responsabilidad los administradores que hubieren salvado su voto en los acuerdos

163 Aprobado por Real Decreto de 22 de agosto de 1885 (publicado en La Gaceta de Madrid del 16.10.1885), en cuyo precepto se establecía en su redacción originaria (sic): "Los administradores de las compañías anónimas son sus mandatarios, y, mientras observen las reglas del mandato, no estarán sujetos á responsabilidad personal ni solidaría por las operaciones sociales; y si, por la infracción de las Leyes y estatutos de la compañía, o por contravención a los acuerdos legítimos de sus juntas generales, irrogaren perjuicios y fueren varios los responsables, cada uno de ellos responderá a prorrata".

${ }^{164}$ BOE 18.7.1951. 
causantes del daño. Responsabilidad que se vehiculaba a través del ejercicio de dos acciones. Se regulaba en el art. 80 la acción social para exigir el daño que causen al patrimonio social, y en el art. 81 la acción individual para la reparación del daño que causen con su actuación a los socios o a los terceros ${ }^{165}$. Paralelamente para las sociedades de responsabilidad limitada se promulgó la Ley de 17 de julio de 1953, sobre Régimen Jurídico de las Sociedades de Responsabilidad Limitada ${ }^{166}$, dedicándose el art. 13 a regular en un único precepto los presupuestos de la responsabilidad y los dos instrumentos de su ejercicio, la acción social y la individual.

Un segundo momento histórico vino representado por la Ley 19/1989, de 25 de julio, de Reforma parcial y adaptación de la Legislación Mercantil a las Directivas de la Comunidad Económica Europea en materia de Sociedades ${ }^{167}$. Disposición legal que reformó la Ley de Sociedades Anónimas de julio de 1951 y la Ley de Responsabilidad Limitada de 1953. Se modifica el art. 79 de la Ley de Sociedades Anónimas de 1951, para recoger los presupuestos de la responsabilidad de los administradores, indicándose que los administradores responden frente a la sociedad, los accionistas y los acreedores del daño que causen por actos contrarios a la Ley, los estatutos o los realizados sin la diligencia con la que deben desempeñar el cargo. Al regularse el requisito de culpabilidad de la conducta del administrador ya no se habla de malicia, abuso de facultades o negligencia grave. En la delimitación de la antijuridicidad de la conducta del administrador se alude por primera vez a los actos contrarios a la Ley en mayúsculas, y a los actos contrarios a los estatutos sociales. La diligencia con la que deben desempeñar el cargo se identificaba con la de un ordenado empresario y representante leal. Se introducía por primera vez la responsabilidad solidaria de los administradores en términos muy similares a los actuales. Finalmente, se modificaba la redacción de la acción social de responsabilidad del art. 80, sin alterarse la redacción de la acción individual del art. 81. Paralelamente, se modifica la Ley de Sociedades de Responsabilidad de 1953, pasando a regularse la responsabilidad, no en el art. 13, sino en el art. 11 donde ya se pretendía una mayor homogenización con la sociedad anónima, al remitirse al régimen fijado en la Ley de Sociedades Anónimas, salvo las peculiaridades fijadas en aquella Ley.

\footnotetext{
${ }^{165}$ En el art. 81 se establecía "No obstante lo dispuesto en los artículos precedentes, quedan a salvo las acciones que puedan corresponder a los socios y a los terceros por los actos de los Administradores que lesionen directamente los intereses de aquéllos".

166 BOE del 18.7.1953.

167 BOE del 27.7.1989.
} 
El tercer momento histórico será la aprobación de dos nuevos textos reguladores de las sociedades anónimas y de responsabilidad limitada. Para las sociedades anónimas, y en virtud de la habilitación dada al Gobierno en la D.F $1^{\text {a }}$ de la Ley 19/1989, de 25 de julio, se aprueba el Real Decreto Legislativo 1564/1989, de 22 de diciembre, por el que se aprueba el Texto Refundido de la Ley de Sociedades Anónimas. Texto Refundido que derogaba la Ley de 17 de julio de 1951. Al ser un Texto Refundido no se modifica el régimen jurídico de la responsabilidad, procediéndose a regularizar, aclarar y a armonizar la legislación existente. En el art. 133 se recogían los presupuestos de la responsabilidad con el mismo régimen jurídico de la Ley 19/1989. Dedicando el art. 134 a la acción social de responsabilidad y el art.135 a la acción individual de responsabilidad, y ésta con idéntico contenido a la Ley de 1951, añadiendo el sustantivo indemnización al término acción ${ }^{168}$. Para las sociedades de responsabilidad limitada se aprueba la Ley 2/1995, de 23 de marzo, de Sociedades de Responsabilidad Limitada ${ }^{169}$, que en su art. 69 sigue la técnica jurídica de remitirse en materia de responsabilidad del administrador a la legislación de sociedades anónimas, impidiendo que en los estatutos se pudiera modificar la mayoría establecida en la ley para ejercitar la acción social por la Junta General.

Mediante la Ley 26/2003, de 17 de julio, por la que se modifican la Ley 24/1988, de 28 de julio, del Mercado de Valores, y el Texto Refundido de la Ley de Sociedades Anónimas, aprobado por el Real Decreto Legislativo 1564/1989, de 22 de diciembre, con el fin de reforzar la transparencia de las sociedades anónimas cotizadas ${ }^{170}$, se reforma el art. 133 del Texto Refundido de la LSA, para, entre otros aspectos relevantes, incluirse por primera vez al administrador de hecho como sujeto responsable.

El último momento histórico en la regulación de la responsabilidad por daños de los administradores lo encontramos en el Real Decreto Legislativo 1/2010, de 2 de julio, que aprueba el Texto Refundido de la Ley de Sociedades de Capital ${ }^{171}$-LSC- En este nuevo Texto Refundido se unifica en un único cuerpo normativo la regulación de las tres modalidades de sociedades de capital, esto es, de la sociedad anónima, de la

\footnotetext{
${ }^{168}$ En el art. 135 se establecía, "No obstante lo dispuesto en los artículos precedentes, quedan a salvo las acciones de indemnización que puedan corresponder a los socios y a los terceros por actos de Administradores que lesionen directamente los intereses de aquéllos".

169 BOE del 24.3.1995.

170 BOE del 18.7.2003.

${ }^{171}$ BOE del 3.7.2010. Texto Refundido aprobado en virtud de la autorización otorgada al Gobierno en la Ley $3 / 2009$, de 3 de abril, sobre modificaciones estructurales de las Sociedades Mercantiles.
} 
sociedad de responsabilidad limitada y de la sociedad comanditaria por acciones, derogándose la anterior LSA de 1989, y la Ley de Responsabilidad Limitada de 1995.

En el art. 236 de la LSC se regulan los presupuestos de responsabilidad de los administradores ${ }^{172}$, donde se alude a que los administradores de hecho o de derecho responden frente a la sociedad, los socios y los acreedores de los daños que causen por actos contrarios a la ley, los estatutos, o por los realizados incumpliendo los deberes inherentes al ejercicio del cargo. Se habla del administrador de hecho ${ }^{173}$, y en los actos contrarios a la ley se refiere a ésta en minúsculas, con relevancia en su interpretación, como veremos. Finalmente se alude en términos más generales a actos realizados incumpliendo los deberes inherentes al cargo. Precepto 236 que se modificó sustancialmente por la Ley 31/2014, de 3 de diciembre, por la que se modifica la Ley de Sociedades de Capital para la mejora del gobierno corporativo ${ }^{174}$, para recoger su actual régimen jurídico, incluyendo dentro del requisito de la culpabilidad en materia de responsabilidad, la alusión al dolo o la culpa, con la presunción de culpa para los actos contrarios a la ley o los estatutos. Por otro lado, se regula la responsabilidad del administrador persona jurídica y la responsabilidad del personal de alta dirección. La acción social se regula en los arts. 238 a 240, y la acción individual en el art. 241, siendo común a ambas acciones los arts. 236 y 237. El art. 241 de la acción individual de responsabilidad, permanece con la redacción que tenía en el Texto Refundido de la Ley de Sociedades Anónimas de 1989, suprimiéndose las expresiones "no obstante lo dispuesto en los artículos precedentes”, que se recogía desde la Ley de 1951.

Finalmente, mediante la Ley 31/2014, de 3 de diciembre, se añade el art. 241 bis sobre la prescripción de la responsabilidad de los administradores, poniendo fin a la aplicabilidad del art. 949 del Código de Comercio en materia de responsabilidad por daños del administrador social.

\footnotetext{
${ }^{172}$ Presupuestos de responsabilidad que ya con la anterior legislación se consideraba de aplicación a la acción individual de responsabilidad. Vid.: SÁNCHEZ CALERO, F.: Los Administradores en las Sociedades de Capital, op. cit., pp. 414 a 416; GARRETA SUCH, J. M.: La responsabilidad civil, fiscal y penal de los administradores de sociedades, op. cit., pp. 109-111; CALBACHO LOSADA, F.: El ejercicio de acciones de responsabilidad contra los administradores de la sociedad anónima, Tirant Lo Blanch, Valencia, 1999, pp. 350-361.

173 Introducido por la Ley 26/2003, de 17 de julio.

174 BOE 4.12.2014.
} 


\section{Diferenciación de la acción social y la individual.}

Con carácter general, la responsabilidad de los administradores por el daño causado por actos u omisiones imputables que sean contrarios a la ley, a los estatutos sociales, o que se realicen incumpliendo los deberes inherentes al desempeño del cargo, será exigible judicialmente a través de las dos acciones referidas: la acción social de responsabilidad y la acción individual de responsabilidad. Mediante la acción social de responsabilidad se repara el daño causado por el administrador al patrimonio social, mientras que con la acción individual de responsabilidad se tiende a resarcirse el daño causado directamente al socio o al acreedor ${ }^{175}$.

La diferenciación entre ambas acciones viene determinada, en primer lugar, en función de cuál sea el patrimonio perjudicado objeto de recomposición, en segundo lugar, por tener distintas finalidades, y, en tercer lugar, en función de la diversa legitimación conferida para su ejercicio ${ }^{176}$.

\subsection{Diferenciación por el patrimonio perjudicado.}

Cuando la gestión de los administradores sociales de la sociedad de capital cause un daño al patrimonio social, los mismos responden ante la sociedad mediante la llamada acción social de responsabilidad regulada en los artículos 238 a 240 de la LSC. Acción social cuya finalidad es restablecer el patrimonio social, siendo ese patrimonio de la sociedad el beneficiario de su ejercicio ${ }^{177}$. Este daño al patrimonio social puede generar también un daño indirecto a los socios y a los acreedores, en la medida en que ven disminuidas sus garantías ante un menor patrimonio de la sociedad ${ }^{178}$. El bien jurídico protegido con la acción social es el patrimonio social ${ }^{179}$

175 GARRIGUES, J.: Curso de Derecho Mercantil, op. cit., p. 491; BROSETA PONS, M.: Manual de Derecho Mercantil, op. cit., pp. 262-263; ESTEBAN VELASCO, G.: "Algunas reflexiones sobre la Responsabilidad de los Administradores frente a los Socios y los Terceros: Acción individual y acción por no Promoción o Remoción de la disolución”, 1995, op. cit., p. 48; GARRETA SUCH, J. M.: La responsabilidad civil, fiscal y penal de los administradores de sociedades, op. cit. p. 128. SÁNCHEZ CALERO, F.: Los Administradores en las Sociedades de Capital, op. cit., pp. 320-321, 366 y ss y 409 y ss; ESTEBAN VELASCO, G.: "La acción individual de responsabilidad”, op. cit., p. 190; VALPUESTA GASTAMINZA, E. M.: Comentarios a la Ley de Sociedades, op. cit., pp. 628-629.

${ }^{176}$ MUÑOZ PAREDES, A.: La responsabilidad de los administradores societarios, $1^{\text {a }}$ edición, Aranzadi, 2018, pp. 13 y ss.

177 SÁNCHEZ CALERO, F.: Los Administradores en las Sociedades de Capital, op. cit., pp. 365 a 367. ESTEBAN VELASCO, G.: “La acción individual de responsabilidad”, op. cit., pp. 189-190.

178 GARRETA SUCH, J. M.: La responsabilidad civil, fiscal y penal de los administradores de sociedades, op. cit. pp. 128-129.

179 GARRETA SUCH, J. M.: La responsabilidad civil, fiscal y penal de los administradores de sociedades, op. cit. p. 164. 
$\mathrm{Si}$, por el contrario, la acción u omisión del administrador causa un daño directo a los acreedores sociales, éstos pueden ejercitar la llamada acción individual de responsabilidad regulada en el artículo 241 de la LSC, cuya finalidad es recomponer el patrimonio perjudicado del socio o del acreedor (Sentencia del TS, Sala Civil, 396/2013, de 20 de junio). El bien jurídico protegido es el patrimonio individual del socio o acreedor perjudicado ${ }^{180}$. Acción individual aplicable a las Sociedades de Garantía Recíproca $^{181}$, a las Sociedades Cooperativas ${ }^{182}$, y a las Sociedades Laborales y Participadas $^{183}$. Con el ejercicio de la acción individual se pretende resarcirse el daño causado directamente al acreedor. En nuestro caso a las entidades gestoras y a la TGSS.

La diferenciación de la acción social y de la acción individual de responsabilidad de los administradores, viene establecida en la doctrina científica ${ }^{184}$ y jurisprudencia ${ }^{185}$, en función de cuál sea patrimonio perjudicado objeto de recomposición.

180 GARRETA SUCH, J. M.: La responsabilidad civil, fiscal y penal de los administradores de sociedades, op. cit. p. 164.

181 Art. 44 de la Ley 1/1994, de 11 de marzo, sobre Régimen Jurídico de las Sociedades de Garantía Recíproca.

182 Art. 43 de la Ley 27/1999, de 16 de julio, de Cooperativas.

183 Disposición Final Tercera de la Ley 44/2015, de 14 de octubre, de Sociedades Laborales y Participadas.

184 Entre otros: JIMÉNEZ SÁNCHEZ, G. J.: Lecciones de Derecho Mercantil, op. cit., p. 201; GARRIGUES, Joaquín: Curso de Derecho Mercantil, Tomo I, $7^{\text {a }}$ edición, Madrid 1976, p. 491; BROSETA PONT, M.: Manual de Derecho Mercantil, op. cit., p. 263; ESTEBAN VELASCO, G.: "Algunas reflexiones sobre la Responsabilidad de los Administradores frente a los Socios y los Terceros: Acción individual y acción por no Promoción o Remoción de la disolución”, 1995, op. cit., p. 48; GARRETA SUCH, J. M.: La responsabilidad civil, fiscal y penal de los administradores de sociedades, op. cit. pp. 127-132; ESTEBAN VELASCO, G.: "La acción individual de responsabilidad", op. cit., p. 190; DÍAZ ECHEGARAY, J. L.: Deberes y Responsabilidades de los Administradores de las Sociedades de Capital, editorial Thomson Aranzadi, $2^{\mathrm{a}}$ edición, 2006, p. 347.

185 SSTS, Sala Civil, de 12 de julio de 1984; 21 de mayo de 1985; 12 de abril de 1989; 4 de febrero de 1999; 741/1999, de 21 de septiembre -Rec. 438/1995-; 1194/2000, de 29 de diciembre -Rec. 3393/1995-; 397/2001, 19 de abril -Rec. 301/1996-; 1124/2003, de 20 de noviembre -Rec. 302/1998-; 1178/2003, de 17 de diciembre -Rec. 280/1998-; 261/2007, de 14 de marzo -Rec. 262/2000-; 1168/2008, de 27 de noviembre -Rec. 815/2004-; 396/2013, de 20 de junio; 395/2012, de 18 de junio; 446/2014, de 3 de septiembre -Rec. 2681/2012-, entre otras muchas.

El Tribunal Supremo, en la Sentencia de la Sala Civil núm. 1168/2008, de 27 de noviembre -RJ 2008/6323-, señala recogiendo doctrina jurisprudencial precedente que:

"La acción como individual (...) presenta un ámbito material diferente del que caracteriza a la social, siendo hábil la individual para indemnizar los probados perjuicios que de modo directo afecten a los intereses de terceros o de los propios socios, pero no para amparar pretensiones reequilibradoras del patrimonio social, en cuanto estas se encuentran reservadas a la acción social. El referido pronunciamiento es plenamente conforme con la doctrina de esta Sala, que en torno a la distinción entre la acción individual a que se refiere el artículo 135 LSA -actual 241 LSC- y la social del 133.4 actual 238 LSC-, tiene señalado que «Mientras el objeto de la acción social es restablecer el patrimonio de la sociedad, mediante la acción individual se trata de reparar el perjuicio en el patrimonio de los socios o terceros» (Sentencia de 4 de noviembre de 1991, citada en la de 14 de marzo de 2007, entre muchas más), siendo así que la acción social busca restablecer el patrimonio tras el daño «social», entendido como el sufrido por la propia sociedad titular de la acción -aunque afecte indirectamente a sus socios y acreedores, a quienes también se legitima para su ejercicio-, mientras 


\subsection{Diferenciación por el régimen de sujetos legitimados para su ejercicio.}

Es precisamente en función de los afectados de modo directo o indirecto en su patrimonio, por lo que se prevé una triple legitimación para el ejercicio de la acción social de responsabilidad contra los administradores, con la finalidad de restablecer el patrimonio social o de resarcir el quebranto patrimonial causado a la sociedad por la conducta ilícita del administrador. Están legitimados para ejercitar o plantear la acción social de responsabilidad ante los tribunales:

- En primer lugar, la propia sociedad, previo acuerdo de la Junta General de accionistas (art. 238 de la LSC) (legitimación directa, o en palabra de SUÁREZLLANOS GÓMEZ ${ }^{186}$ legitimación de primer orden), sin que se exija una modalidad determinada de Junta General según GARRETA SUCH ${ }^{187}$. El acuerdo se adoptará por mayoría ordinaria, sin que puedan establecer una mayoría cualificada o reforzada $^{188}$ (arts. 238, 198 y 201 de la LSC). Acuerdo que podrá adoptarse aunque no se hallare incluido en el orden del día (art. 238.1 de la LSC), pretendiéndose con ello que los administradores teniendo la competencia para convocar y establecer el orden de día, no impidan su ejercicio ${ }^{189}$.

- En segundo lugar, y en defecto de la Junta General (legitimación subsidiaria de primer grado- salvo que sea por incumplimiento del deber de lealtad, en cuyo caso la legitimación es directa y no subsidiaria-), los socios que representen el 5\% del capital social, o el 3\% del capital en las sociedades anónimas cotizadas (arts. 168, 239 y 495.2.a, de la LSC). El ejercicio de la acción social por los socios, salvo por

que la acción individual es una acción personal, que se dirige a la reparación de los perjuicios causados, «directa e individualmente, a los intereses de los accionistas y de los terceros» (Sentencias de 12 julio 1984, 21 mayo 1985, 12 de abril de 1989, 4 de noviembre de 1991 y 14 de marzo de 2007)”. Las referencias al artículo 135 LSA, deben entenderse al actual 241 LSC y la del art. 133.4 al art. 238 LSC.

186 SUÁREZ-LLANOS GÓMEZ, L.: "Responsabilidad de los administradores en la sociedad anónima", Anuario de Derecho Civil, Vol. 15, n 4, 1962, p. 928, quien distingue entre legitimación de primer orden, la que tiene la sociedad, y de segundo orden, la que ostentan los socios y los acreedores.

187 GARRETA SUCH, J. M.: La responsabilidad civil, fiscal y penal de los administradores de sociedades, op. cit. p. 134, para este autor el acuerdo se podrá adoptar en junta ordinaria o extraordinaria, aunque lo normal es que sea en la junta que apruebe las cuentas anuales.

188 GARRETA SUCH, J. M.: La responsabilidad civil, fiscal y penal de los administradores de sociedades, op. cit. p. 134; Con anterioridad, se pronunciaban en ese sentido Garrigues, en GARRIGUES, J. y URÍA GONZÁLEZ, R.: Comentario a la Ley de Sociedades Anónimas, Tomo II, $3^{\mathrm{a}}$ edición revisada y puesta a día por MENÉNDEZ MENÉNDEZ, A. y OLIVENCIA RUIZ, M., Madrid, 1976, p. 175.

${ }^{189}$ POLO SÁNCHEZ, E.: "Los administradores y el Consejo de Administración de la Sociedad Anónima (arts. 123 a 143 de la LSA)”, en Comentario al Régimen Legal de las Sociedades Mercantiles, T. VI, editorial Cívitas, Madrid, 1992, p. 319. 
infracción del deber de lealtad, sólo podrá tener lugar si no se ejercita la acción por la sociedad. La legitimación activa la ostentan, tanto el socio que tiene ese porcentaje del capital social, como los que sin tenerlo, lo alcancen conjuntamente, ya que se alude a poseer ese porcentaje del capital, individual o conjuntamente ${ }^{190}$. Legitimación que se reconoce a los accionistas porque el daño causado directamente a la sociedad puede, de modo reflejo, provocar también daños a los socios, al disminuir el valor de las acciones o participaciones sociales de las que es titular el socio, dando lugar a que no se repartan dividendos, o se repartan en menor medida (Sentencia del TS núm. 396/2013, de 20 de junio).

- Finalmente, en defecto de los anteriores -legitimación subsidiaria de segundo o de último grado-, están legitimados para su ejercicio los acreedores siempre que el patrimonio social resultare insuficiente para la satisfacción de sus créditos, y la sociedad o los socios no hubieren ejercitado esa acción social (art. 240 LSC). El acreedor ejerce la acción social en nombre propio, pero en interés ajeno, para reintegrar el patrimonio de la sociedad, lo que sólo indirectamente podría contribuir a su posterior satisfacción del crédito ${ }^{191}$.

\subsection{Diferenciación por el sujeto beneficiario de la acción.}

Finalmente, en función del sujeto beneficiario por el ejercicio de esas acciones, que estará relacionado con el patrimonio perjudicado por el administrador, ha de indicarse que con la acción social es la sociedad la directamente beneficiada con su ejercicio, mientras que con la acción individual será el socio o el acreedor social ${ }^{192}$.

Siendo la finalidad de la acción social reintegrar el patrimonio social, lo que sólo indirectamente servirá de garantía a los terceros acreedores, no vamos a detenernos en su estudio, ya que no es un medio para obtener de modo directo la reparación del crédito de Seguridad Social por las entidades gestoras de la Seguridad Social.

190 GARRETA SUCH, J. M.: La responsabilidad civil, fiscal y penal de los administradores de sociedades, op. cit. p. 153, este autor, antes de la actual redacción, defendía la legitimación, tanto del accionista que individualmente tuviere esa participación en el capital, como de quienes la alcanzasen conjuntamente, en cuyo caso, deberían ejercer la acción conjuntamente mediante Litis consorcio activo necesario.

191 GARRETA SUCH, J. M.: La responsabilidad civil, fiscal y penal de los administradores de sociedades, op. cit. p. 160.

192 ESTEBAN VELASCO, G.: “Algunas reflexiones sobre la Responsabilidad de los Administradores frente a los Socios y los Terceros: Acción individual y acción por no Promoción o Remoción de la disolución”, 1995, op. cit., p. 48; GARRETA SUCH, J. M.: La responsabilidad civil, fiscal y penal de los administradores de sociedades, op. cit. p. 164. 
Para nuestra investigación nos interesa la acción individual de responsabilidad que pueden utilizar las entidades gestoras de la Seguridad Social contra el administrador social para obtener el resarcimiento del daño causado a su crédito.

Es la acción individual de responsabilidad ante el administrador social un primer instrumento jurídico, aunque no el principal, para la exigencia de responsabilidad ante el incumplimiento de la sociedad de capital de las obligaciones con la Seguridad Social, siempre que sea imputable a un comportamiento ilícito del administrador social, ya que la mercantil, en cuanto persona jurídica, actúa en el tráfico jurídico a través de sus órganos de administración ${ }^{193}$.

Será la acción individual de responsabilidad un instituto jurídico válido para exigir la reparación de un daño causado al patrimonio de la Seguridad Social, aunque no tendrá carácter principal, sino más bien residual, como veremos, básicamente por dos factores, en primer lugar, porque es una acción procesal que impide la derivación administrativa de responsabilidad prevista en el art. 18.3 del TRLGSS, y en segundo lugar, por la mayor carga probatoria exigida, ya que debe acreditarse el daño directo en el crédito de la Seguridad Social y la relación de causalidad entre el daño y la conducta del administrador.

\section{II.- ACCIÓN INDIVIDUAL DE RESPONSABILIDAD.}

\section{Naturaleza jurídica.}

Para la comprensión del significado de la acción individual de responsabilidad hemos de precisar que, en principio la sociedad responderá ante los terceros de los daños causados por actuaciones ilícitas del administrador social en el ejercicio de sus funciones, por imputarse a aquélla los actos realizados por éste en el ejercicio de su actividad orgánica ${ }^{194}$. La imputación de los actos de los administradores a la sociedad, en virtud de la teoría del órgano, no puede llevarse hasta sus extremos de modo que

193 GARRETA SUCH, J. M.: La responsabilidad civil, fiscal y penal de los administradores de sociedades, op. cit. p. 167.

194 ESTEBAN VELASCO, G.: “Algunas reflexiones sobre la Responsabilidad de los Administradores frente a los Socios y los Terceros: Acción individual y acción por no Promoción o Remoción de la disolución”, 1995, op. cit., pp. 52-53. 
impida a los terceros acreedores perjudicados exigir la responsabilidad del administrador, cuando éstos con su conducta culposa causen un daño ${ }^{195}$.

Si de las deudas sociales responde la sociedad de capital con su propio patrimonio, cuando el perjuicio del derecho de crédito del acreedor social sea debido a una conducta ilícita y culpable del administrador, la sociedad seguirá siendo la única deudora obligada al pago, pero de no ser atendido, el acreedor social podrá reclamar judicialmente al administrador la reparación del daño causado a su derecho de crédito. El acreedor de la sociedad dispondrá de la acción individual de responsabilidad para exigir al administrador social la reparación de daño causado a su crédito, especialmente cuando la mercantil no ha cumplido con la obligación social contraída por conducta culposa de aquél. El acreedor tendrá la acción contra la sociedad para reclamar el pago de la deuda social y una acción contra el administrador para la reparación de daño causado al crédito, acciones que podrán acumularse procesalmente. La reclamación contra el patrimonio del administrador social mediante la acción individual de responsabilidad, en el caso de eventual insolvencia de la sociedad, podrá ser más fructífera que la reclamación ante la $\operatorname{sociedad}^{196}$. La acción individual de responsabilidad abre una vía de reclamación ante el administrador por incumplimientos de sus obligaciones legales, principalmente ante comportamientos de especial gravedad, que serán objeto de análisis en el apartado III de este capítulo.

En la doctrina se han mantenido tres interpretaciones sobre la naturaleza jurídica de la acción individual de responsabilidad.

Para una primera interpretación estaremos ante una responsabilidad siempre de naturaleza contractual ${ }^{197}$, añadiendo el calificativo de "societaria".

Una segunda le otorga un carácter contractual o extracontractual, en función de quien ejercite la acción y del tipo de infracción de los administradores ${ }^{198}$. En esta segunda

${ }^{195}$ ESTEBAN VELASCO, G.: "Algunas reflexiones sobre la Responsabilidad de los Administradores frente a los Socios y los Terceros: Acción individual y acción por no Promoción o Remoción de la disolución”, 1995, op. cit., p. 53; GARRETA SUCH, J. M.: La responsabilidad civil, fiscal y penal de los administradores de sociedades, op. cit., p. 168.

${ }^{196}$ ESTEBAN VELASCO, G.: "Algunas reflexiones sobre la Responsabilidad de los Administradores frente a los Socios y los Terceros: Acción individual y acción por no Promoción o Remoción de la disolución”, 1995, op. cit., p. 53.

${ }^{197}$ LLEBOT MAJÓ, J. O.: "El sistema de la responsabilidad de los administradores", en $R d S$, nº 7, 1996, pp. 51 y 60.

198 GARRIGUES, J. y OLIVENCIA RUIZ, M., en GARRIGUES, J. y URÍA GONZÁLEZ, R.: Comentario a la Ley de Sociedades Anónimas, Vol. II, $3^{\text {a }}$ edición, Madrid, 1976, p. 197; 
interpretación, podemos encontrar dos variantes. Una de ellas acepta el carácter extracontractual de la acción cuando es ejercitada por terceros y un carácter contractual cuando es ejercitada por socios. La segunda variante ${ }^{199}$ acepta el carácter extracontractual cuando es ejercitada por terceros, pero en cambio con relación al ejercicio de la acción por el socio se señala que puede ser contractual o extracontractual, considerando a grandes rasgos, que es contractual cuando el socio la ejercita ante un incumplimiento del administrador en su actividad orgánica (ad intra, pero no representativa ad extra), contraída en el ámbito interno de la sociedad, que afecta o perjudica a un derecho que el socio ostenta como parte del contrato de sociedad, como percibir dividendos, mientras que será de naturaleza extracontractual cuando el acto se realiza fuera del ámbito de sus competencias orgánicas pero investido de su función. Para SÁNCHEZ CALERO ${ }^{200}$, ante los socios la acción tiene naturaleza contractual y será extracontractual cuando el socio asuma la posición de tercero, no de accionista; carácter extracontractual que para él tiene la acción ejercitada por un tercero u acreedor. Para DÍAZ ECHEGARAY ${ }^{201}$, cuando es ejercitada por el socio, la responsabilidad es contractual cuando existe una obligación previa del administrador y es extracontractual cuando ésta no exista; siendo en todo caso, extracontractual con respecto a los terceros o acreedores. Para GARRETA SUCH ${ }^{202}$, la responsabilidad es de naturaleza contractual, cuando tiene su origen en una actuación orgánica del administrador, y será extracontractual, cuando la actuación no se realice exclusivamente y dentro de la relación orgánica que el administrador mantiene con la sociedad, sea quien sea el perjudicado por la acción.

RODRÍGUEZ ARTIGAS, F.: Consejeros delegados, Comisiones Ejecutivas y Consejos de Administración, Madrid 1978, p. 406; SÁNCHEZ CALERO, F.: Los Administradores en las Sociedades de Capital, op. cit., pp. 419 a 422.; DÍAZ ECHEGARAY, J. L.: La responsabilidad civil de los administradores de la sociedad anónima, Madrid, 1995, p. 283; y en Deberes y responsabilidades de los administradores de la sociedad de capital, op. cit., 2006, p. 354.

${ }^{199}$ POLO SÁNCHEZ, E.: "Los administradores y el Consejo de Administración de la Sociedad Anónima (arts. 123 a 143 de la LSA)”, op. cit. pp. 374 y 375; SÁNCHEZ CALERO, F.: Los Administradores en las Sociedades de Capital, op. cit., p. 420.

200 SÁNCHEZ CALERO, F .: Los Administradores en las Sociedades de Capital, op. cit., p. 420.

${ }^{201}$ DÍAZ ECHEGARAY, J. L.: La responsabilidad civil de los administradores de la sociedad anónima, 1995, op. cit., p. 283; y en Deberes y responsabilidades de los administradores de la sociedad de capital, op. cit., 2006, p. 354.

202 GARRETA SUCH, J. M.: La responsabilidad civil, fiscal y penal de los administradores de sociedades, op. cit. pp. 171-172. 
Una tercera interpretación ${ }^{203}$, que es la mayoritaria y que nosotros seguimos, considera que esta acción tiene siempre carácter extracontractual, con independencia de que quien ejercite la acción, sea un socio o un tercero, ya que no existe vinculación jurídica del socio o del tercero con el administrador, sino con la sociedad. Como señala ESTEBAN VELASCO 204 , "no puede negarse ese carácter extracontractual de la responsabilidad por el hecho de que la relación jurídica que la sociedad ha concertado o mantiene con el acreedor perjudicado haya sido a través del administrador", y ello, decimos nosotros, porque el contrato surte efectos y se concierta en nombre de la sociedad por el administrador -teoría del órgano-. En esta responsabilidad extracontractual del administrador nos encontramos con una conducta ilícita del mismo en su actividad orgánica que causa un daño al acreedor de la sociedad -en su derecho de crédito-. Estamos ante una responsabilidad extracontractual por acto ilícito orgánico ${ }^{205}$, que tiene su origen en el ejercicio del cargo orgánico de administrador social, respondiendo los integrantes del órgano, pero no el órgano como tal ${ }^{206}$.

Con carácter general la actual jurisprudencia considera que nos encontramos ante un supuesto específico de responsabilidad extracontractual por daños, de índole orgánica $^{207}$, y no ante una responsabilidad contractual al faltar una relación jurídica

203 RUBIO GARDA-MINA, J.: Curso de Derecho de sociedades Anónimas, Madrid, 1964, p. 267; QUIJANO GONZÁLEZ, J.: "La responsabilidad civil de los administradores de la Sociedad Anónima, aspectos sustantivos”, Universidad de Valladolid, 1985, p. 141; QUIJANO GONZÁLEZ, J.: "La responsabilidad civil de los administradores de la sociedad anónima en el Texto Refundido de 22 de diciembre de 1989”, Boletín Informativo del Colegio de Abogados de Valladolid, 1990, núm. 4, pp. 22 y ss.; QUIJANO GONZÁLEZ, J.: "Acción individual de responsabilidad de Administradores e ilícito orgánico (a propósito de la Sentencia del Tribunal Supremo, de 4 de noviembre de 2019)", RDCP, n. ${ }^{\circ}$ 32, enero 2020, pp. 4 a 16; VICENT CHULIÁ, F.: Compendio Crítico del Derecho Mercantil, Madrid, 1991, p. 660; DE LA CÁMARA ÁLVAREZ, M.: "La Administración de la Sociedad Anónima”, RJN, 1992, núm. 4, pp. 151 y ss.; ESTEBAN VELASCO, G.: “Algunas reflexiones sobre la Responsabilidad de los Administradores frente a los Socios y los Terceros: Acción individual y acción por no Promoción o Remoción de la disolución ”, 1995, op. cit., pp. 56-57 ; SUÁREZ-LLANOS GÓMEZ, L.: "La responsabilidad por deudas de los administradores de la sociedad anónima”, en Estudios jurídicos en Homenaje del profesor Aurelio Menéndez, Madrid, 1996, Vol. II, p. 2502; MARÍN DE LA BÁRCENA GARCIMARTÍN, F.: La acción individual de responsabilidad de los administradores de las sociedades de capital (art. 135 LSA), Madrid, 2005, pp. 229 y ss.; CALBACHO LOSADA, F.: El ejercicio de las acciones de las acciones de responsabilidad contra los administradores de la sociedad anónima, op. cit., p. 338; ESTEBAN VELASCO, G.: "La acción individual de responsabilidad”, op. cit., pp. 208 y 209; MORALES BARCELÓ, J.: La responsabilidad de los administradores de las sociedades mercantiles en situación de pérdidas y de insolvencia, editorial Tirant Lo Blanch, 2013, edición digital, https://bibliotecatirant-com.ponton.uva.es/cloudLibrary/ebook/show/9788490330821\#ulNotainformativaTitle p. 450.

204 ESTEBAN VELASCO, G.: “La acción individual de responsabilidad”, op. cit., p. 208.

${ }^{205}$ ESTEBAN VELASCO, G.: "La acción individual de responsabilidad”, op. cit., p. 210.

${ }^{206}$ SÁNCHEZ CALERO, F.: Los Administradores en las Sociedades de Capital, op. cit., p. 319.

207 SSTS, Sala Civil, núm. 737/2014, de 22 de diciembre -Aranzadi RJ 2014/6885-; 242/2014, de 23 de mayo -RJ 2014/2943-; 131/2016, de 3 de marzo, entre otras. 
directa entre el administrador y el acreedor perjudicado. Responsabilidad extracontractual con un régimen jurídico específico (arts. 236 a 241 bis de la LSC), diferente al régimen jurídico general civil de la responsabilidad extracontractual aquiliana del artículo 1902 del Código Civil.

La acción individual de responsabilidad en la legislación de sociedades de capital, tiene la naturaleza jurídica de responsabilidad extracontractual por ilícito orgánico del administrador, en cuanto la contrae éste por actuaciones realizadas en el ejercicio del cargo, y en la medida en que causa un daño a un tercero, en nuestro caso al acreedor. Para diferenciar cuándo la actuación del administrador es propia de un acto orgánico y cuándo de acto personal, DESDENTADO BONETE ${ }^{208}$, acude a la construcción que se ha realizado en el Derecho administrativo en materia de imputación de los actos del órgano a la Administración en cuanto persona jurídica, para concluir que existirá acto orgánico del administrador que genera responsabilidad, tanto sean actos de gestión como si son de representación; tanto nos encontremos con actuaciones realizadas en beneficio de la entidad mercantil como cuando exista un abuso o desviación de poder; tanto en actuaciones en que el administrador ejercita correctamente su competencia como cuando exceda las mismas, pero de una forma que no perturbe la recognoscibilidad del acto como correspondiente a la actuación de la sociedad.

La naturaleza jurídica de la acción, sea contractual o extracontractual, carece de relevancia actualmente porque su régimen jurídico es el mismo, la ejercite el socio o un tercero, y no afecta al plazo de prescripción de la responsabilidad al haberse regulado expresamente en el art. 241 bis de la LSC ${ }^{209}$.

En la Sentencia 242/2014, de 23 de mayo, el TS, nos indica al respecto que, "La acción individual de responsabilidad de los administradores por actos llevados a cabo en el ejercicio de su actividad orgánica y no en el ámbito de su esfera personal, en cuyo supuesto entraría en juego la responsabilidad extracontractual, del art. 1902 CC -plantea especiales dificultades para delimitar los comportamientos de los que deba responder directamente frente a terceros, delimitando el ámbito de la responsabilidad que incumbe a la sociedad, que es con quien contrata, de la responsabilidad de los administradores que actúan en su nombre y representación. En este último caso, pues, la acción individual de responsabilidad supone una especial aplicación de responsabilidad extracontractual integrada en un marco societario, que cuenta con una regulación propia (art. 135 LSA -241 LSC), que la especializa respecto de la genérica prevista en el art. 1902 CC (SSTS de 6 de abril de 2006, 7 de mayo de 2004, 24 de marzo de 2004, entre otras). Se trata, de una responsabilidad por "ilícito orgánico", entendida como la contraída en el desempeño de sus funciones del cargo".

208 DESDENTADO BONETE, A. y DESDENTADO DAROCA, E.: Administradores sociales, altos directivos y socios trabajadores. Calificación y concurrencia de relaciones profesionales, responsabilidad laboral y encuadramiento en la Seguridad Social, Editorial Lex Nova, Valladolid, 2000, pp. 164 y 165.

209 Precepto introducido por la Ley 31/2014, de 3 de diciembre, por la que se modifica la Ley de Sociedades de Capital para la mejora del Gobierno Corporativo. 
No obstante, cabría atribuirle cierta relevancia, que en parte no será tal, a efectos de tramitación procesal de la acción, en la medida en que si se concibiese como de naturaleza contractual, especialmente ante el ejercicio de la misma por los trabajadores sujetos de una relación jurídico laboral, o de naturaleza obligacional "ex lege" para las entidades recaudadoras o gestoras de la Seguridad Social, pudiera atribuirse la competencia para su conocimiento al orden social o contencioso-administrativo, aspecto éste objeto de estudio más adelante en este capítulo (apartado IV.4).

\section{Supuestos de incumplimientos.}

La tipología de supuestos que pueden motivar el ejercicio de la acción individual de responsabilidad contra el administrador social, por los sujetos legitimados, en función de qué y a quién se haya causado el daño, puede ser de lo más variada, pero siguiendo a ESTEBAN VELASCO ${ }^{210}$, podemos optar por su criterio de ordenación, reconduciéndolos a cuatro grupos o supuestos posibles:

$1^{\text {o }}$.- En primer lugar, estarían los supuestos de lesión de intereses de terceros que no están en una previa relación jurídica con la sociedad (ilícitos de empresa, entre los que cita daños a la salud o integridad física, al medio ambiente, etc.). En estos ilícitos de empresa, no hallaremos el fundamento para una posible acción individual de responsabilidad contra el administrador por incumplimientos imputables de las obligaciones de Seguridad Social de la sociedad de capital.

$2^{\circ}$.- En segundo lugar, la lesión de intereses de los socios por intromisión en las relaciones societarias del socio con la sociedad, en que incluye cualquier infracción de los derechos del socio en su relación intraorgánica. Supuesto que es igualmente ajeno al propósito de nuestra investigación

$3^{\circ}$.- En tercer lugar, la intromisión lesiva en el proceso de formación de voluntad de los terceros, acreedores o socios, que incluye supuestos de informaciones falsas o incorrectas sobre la situación patrimonial de la sociedad que induzcan a la adquisición de acciones, concertación de contratos, pese a estar realmente la sociedad en situación de dificultades económicas o insolvencia no declarada, por falseamiento o incorrecta llevanza de la contabilidad. Supuesto igualmente

${ }^{210}$ ESTEBAN VELASCO, G.: "Algunas reflexiones sobre la Responsabilidad de los Administradores frente a los Socios y los Terceros: Acción individual y acción por no Promoción o Remoción de la disolución". 1995, op. cit., pp. 59-61; ESTEBAN VELASCO, G.: "La acción individual de responsabilidad", op. cit., pp. 221 y ss. 
intrascendente para nuestra investigación, al ir ésta dirigida a determinar la procedencia del ejercicio de la acción individual ante el incumplimiento de las obligaciones empresariales con la Seguridad Social, con lo que carecen de relevancia los posibles perjuicios a los acreedores en la fase de formalización del vínculo contractual con la mercantil, ya que los créditos de Seguridad Social que pueden exigirse al administrador, ante impago de la sociedad deudora, tienen naturaleza "ex lege" y no contractual, bien sean créditos por cotizaciones o por responsabilidad empresarial en el pago de prestaciones de la Seguridad Social. Únicamente los defectos sustanciales en la llevanza de contabilidad o su falta de llevanza, podrán utilizarse en la reclamación de los créditos dañados de la Seguridad Social cuando ese perjuicio haya sido la causa directa de los incumplimientos contables, como veremos más adelante en el apartado tercero de este Capítulo.

$4^{\text {o. }}$ - En cuarto lugar, intromisiones lesivas en la fase de ejecución de relaciones jurídicas existentes entre la sociedad y los acreedores, que es la que tiene más relevancia para nuestra investigación, porque la acción individual de responsabilidad en estos supuestos pretende la reparación de daño directo causado en los créditos por incumplimiento de obligaciones con la Seguridad Social, especialmente ante un propósito deliberado de eludir esas obligaciones mediante comportamientos dolosos, o ante una desordenada liquidación de la sociedad con ejecución de actos que coloquen a la sociedad en situación de insolvencia o absoluta despatrimonialización, con el consiguiente perjuicio para los derechos económicos de los trabajadores y de la Seguridad Social. A este supuesto dedicaremos especial atención en este Capítulo en sus apartados III y IV, que constituirán el núcleo esencial de la responsabilidad por daños del administrador en materia de Seguridad Social.

Antes de entrar a analizar el posible ámbito de aplicación de la acción individual de responsabilidad ante el impago de las obligaciones de Seguridad Social de la sociedad de capital, que sean consecuencia directa de un comportamiento culposo del administrador, debemos examinar los requisitos propios de toda acción individual de responsabilidad. 


\section{Requisitos.}

Como responsabilidad extracontractual que es, precisa la concurrencia acumulativa de varios requisitos ${ }^{211}$-artículo 236.1 de la LSC-: a) acción u omisión antijurídica del administrador, esto es, contraria a la ley, a los estatutos sociales, o incumpliendo los deberes inherentes al desempeño del cargo; b) que se cause un daño directo al acreedor; c) que medie relación de causalidad entre la acción-omisión y el daño causado al acreedor; y d) la culpabilidad, que la conducta sea atribuible o imputable al administrador en el ejercicio del cargo a título de culpa o dolo.

Concurriendo esos requisitos surge la responsabilidad del administrador, sin que quede exonerado por el hecho de que el acuerdo o el acto lesivo haya sido adoptado, autorizado o ratificado por la Junta General de accionistas (art. 236.2 de la LSC). Esa circunstancia, si bien no exime de responsabilidad, sí podría ser un elemento a valorar para moderar la misma ${ }^{212}$.

Cuando la sociedad de capital incumpla sus obligaciones con la Seguridad Social por actos $\mathrm{u}$ omisiones del administrador, $\mathrm{y}$ esos incumplimientos sean imputables a comportamientos culposos, especialmente cuando concurra dolo, podrán las entidades gestoras ejercitar la acción individual de responsabilidad. Los actos u omisiones de los que nacerá la responsabilidad del administrador por incumplimientos de obligaciones de Seguridad Social, serán normalmente por omisiones, por no cotizar a la Seguridad Social, o no cotizar en la cuantía debida, así como por no solicitar, en tiempo y forma, las afiliaciones y altas de los trabajadores.

Para poder determinar en qué condiciones podría ejercerse la acción individual de responsabilidad por las entidades gestoras, o por la TGSS, contra el administrador social, ante el incumplimiento de las obligaciones con la Seguridad Social de la sociedad de capital, conviene que previamente conozcamos qué requisitos han de concurrir para ejercitar la acción individual, para partiendo de los mismos, valorar posteriormente su posible aplicación ante los incumplimientos de esas obligaciones. Requisitos que las entidades gestoras y recaudadoras de la Seguridad Social habrán de acreditar en la reclamación de daños contra el administrador social.

${ }^{211}$ SSTS, Sala Civil, 716/2018, de 19 de diciembre -Rec. 3648/2015-; 253/2016 de 18 de abril -RJ 2016/1342-; 261/2007, de 14 de marzo; 242/2014, de 23 de mayo; 446/2014, de 3 de septiembre, entre otras.

${ }^{212}$ VALPUESTA GASTAMINZA, E. M.: Comentarios a la Ley de Sociedades, op. cit., p. 630. 


\subsection{Acción u omisión antijurídica.}

La nota de ilicitud o antijuridicidad en nuestro derecho regulador de la responsabilidad extracontractual general o aquiliana del artículo 1902 del Código Civil, no se recoge expresamente en ese precepto, ya que se habla de daño causado por culpa o negligencia, pero no se alude al carácter ilícito o injusto del comportamiento causante del daño. Ante la ausencia de referencia expresa a ese requisito de la responsabilidad aquiliana, se han mantenido tres interpretaciones acerca de la concurrencia o identificación del mismo, según un primer punto de vista, la antijuridicidad se predicaría del acto productor del daño, para una segunda posición, lo antijurídico no ha de ser la acción, sino el daño causado; y según la tercera perspectiva, la culpabilidad o imputabilidad sustituiría a la antijuridicidad $^{213}$.

Con carácter general en nuestra doctrina y jurisprudencia tradicional se ha entendido que, cuando menos, ese comportamiento ilícito de la responsabilidad extracontractual del Código Civil, deviene del principio "alterum non laedere". Para determinada jurisprudencia ${ }^{214}$ este requisito "suele diluirse en el marco de la valoración de la acción u omisión en términos de culpa o negligencia".

Cuestión distinta es la configuración de la responsabilidad extracontractual del administrador social en nuestro Derecho de sociedades, donde sí se alude expresamente al requisito de antijuridicidad. La responsabilidad extracontractual del administrador social en el Derecho de sociedades es un supuesto específico de la responsabilidad aquiliana prevista con carácter general en el Código Civil. La antijuridicidad de la conducta viene determinada por una antijuridicidad distinta de la del Derecho civil común ${ }^{215}$.

La antijuridicidad viene contemplada expresamente en el artículo 236 de la LSC, donde se habla de actos u omisiones contrarios a la ley, a los estatutos sociales o realizados incumpliendo los deberes inherentes al desempeño del cargo de administrador. Mientras que cumplir con las obligaciones impuestas al administrador por la ley y los estatutos es

${ }^{213}$ Vid.: DÍEZ-PICAZO Y PONCE DE LEÓN, L. y GULLÓN BALLESTEROS, A.: Sistema de Derecho Civil, 1979, op. cit., p. 618.

214 SSTS, Sala Civil, 206/2003, de 10 de marzo -Rec. 2256/1997-; 261/2007, de 14 de marzo -Rec. 262/2000; 1117/2008, 10 de diciembre -Rec. 2492/2002.

215 GARRETA SUCH, J. M.: La responsabilidad civil, fiscal y penal de los administradores de sociedades, op. cit., pp. 131-132; SALDAÑA VILLOLDO, B.: La acción individual de responsabilidad. Su significado ...." op. cit., p. 127. 
una obligación de resultado, cumplir con los deberes inherentes al cargo, con los deberes de diligencia y lealtad, es una obligación de medios ${ }^{216}$.

El primer supuesto de antijuridicidad está constituido por los actos contrarios a la ley. En la LSC se habla de ley en minúscula, frente a la redacción que se recogía en el artículo 133 del Real Decreto Legislativo 1564/1989, de 22 de diciembre, en que se aludía a Ley en mayúsculas. Cambio que no es baladí y que tenía su trascendencia jurídica. En el art. 236 de la LSC se habla de la ley y en el art. 225 se alude a las leyes en plural, con lo que, la cuestión a dilucidar será, ¿qué ha de entenderse por ley? ¿Sólo disposición legal en sentido estricto? De ser esa la conclusión, ¿sólo la Ley de Sociedades o cualquier ley, con independencia de la rama jurídica que infrinja el administrador en su actuación orgánica? Finalmente, ¿podría considerarse que la referencia a la ley es para comprender a toda norma jurídica, cualquiera que fuere su rango y orden normativo, incluyendo la normativa de Seguridad Social?

Con anterioridad a la actual LSC, SÁNCHEZ CALERO, defendía la concepción más restrictiva partiendo de la LSA de 1989, al entender la referencia a la ley limitada sólo a la vulneración de la propia Ley de Sociedades Anónimas y sus normas complementarias $^{217}$.

Nuestra doctrina mayoritaria se ha pronunciado por la acepción de ley en sentido amplio, como equivalente a norma jurídica cualquiera que sea su rango y orden normativo $^{218}$. Seguimos esta doctrina, ya que en ese precepto se habla de infracción de la ley, ley en minúsculas y sin exigirse que sea de esta ley. La referencia a la ley ha de ser interpretada en sentido amplio, como infracción de toda disposición normativa

216 SÁNCHEZ CALERO, F.: Los administradores en las Sociedades de Capital, 2007, op. cit., p. 311.

217 SÁNCHEZ CALERO, F.: “Administradores (arts. 123 a 143)”, en Comentarios a la Ley de Sociedades Anónimas, dirigida por SÁNCHEZ CALERO, Editoriales de Derecho Reunidas, Madrid, T. IV, 1994, p. 250, y en Los Administradores en las Sociedades de Capital, op. cit., p. 325.

218 QUIJANO GONZÁLEZ, J.: La responsabilidad civil de los administradores de la Sociedad Anónima, aspectos sustantivos", 1985, op. cit., p. 170; ALONSO UREBA, A.: "Presupuestos de responsabilidad social de los administradores de una sociedad anónima”, RDM, núm. 198, octubre-diciembre 1990, p. 676; MARÍN DE LA BÁRCENA GARCIMARTÍN, F.: "La acción individual de responsabilidad de los administradores de sociedad anónima frente a socios y terceros (artículo 135)”, RdS, núm. 13, 1999, p. 309; NICOLÁS BERNAD, J. A.: "La responsabilidad de los administradores sociales ante la Inspección de Trabajo”, op. cit., p. 81; DÍAZ ECHEGARAY, J. L.: Deberes y responsabilidades de los Administradores...,op. cit., p. 222; POLO SÁNCHEZ, E.: "Los administradores y el Consejo de Administración de la Sociedad Anónima (arts. 123 a 143 de la LSA)", op. cit., p. 289; Se "comprende cualquier vulneración de la normativa societaria y de otras normas imperativas o prohibitivas, como ya concluía la mejor doctrina bajo la anterior legalidad, según MUÑOZ PAREDES, A.: $L a$ responsabilidad de los administradores societarios, op. cit., p. 19; y Tratado judicial de la responsabilidad, op. cit., p. 55; VALPUESTA GASTAMINZA, E. M.: Comentarios a la Ley de Sociedades de Capital, op. cit., p. 627. 
cualquiera que sea su rango (Ley, Real Decreto Ley, Real Decreto, Convenio Colectivo, etc..). Para nosotros, bajo esa denominación se alude a infracción de disposiciones normativas imperativas o prohibitivas que impongan una obligación u omisión a los administradores en el ejercicio de su cargo, sean o no de la rama del Derecho de sociedades, y cualquiera que fuere su rango normativo, incluyendo en la rama social del Derecho al Convenio Colectivo estatutario, como fuente de obligaciones normativas, ya que en nuestro Derecho laboral ese convenio es fuente de derecho objetivo con eficacia normativa y erga omnes ${ }^{219}$, extensión al convenio colectivo que admite directamente MERCADER UGUINA y SUÁREZ CORUJO ${ }^{220}$, e indirectamente admiten la infracción del convenio, DESDENTADO BONETE y DESDENTADO AROCA ${ }^{221}$, quienes partiendo de ley como norma estatal, señalan que se incluye el Convenio por ser una norma a la que la ley confiere obligatoriedad.

Dentro de la acción antijurídica se han de incluir las infracciones de las obligaciones de la sociedad de capital, establecidas en la normativa Laboral y de Seguridad Social, porque el cumplimiento de los administradores de las obligaciones legales y de los deberes inherentes al cargo, conlleva respetar las prescripciones legales y reglamentarias impuestas a los empresarios ${ }^{222}$.

Acepción amplia de ley como disposición normativa cualquiera que sea su rango y orden normativo, que ha prevalecido en nuestra jurisprudencia ${ }^{223}$, al admitirse la responsabilidad por incumplimientos de las obligaciones legales de la sociedad de capital establecidas en el orden social, en el Derecho del Trabajo y de la Seguridad Social.

219 Artículo 3.1.b., del Real Decreto Legislativo 2/2015, de 23 de octubre, que aprueba el Texto Refundido del Estatuto de los Trabajadores.

${ }^{220}$ MERCADER UGUINA, J. R, y SUÁREZ CORUJO, B.: "La responsabilidad laboral y de Seguridad Social de los Administradores Sociales”, en AA.VV. (Coord.: ROJO FERNÁNDEZ-RÍO, A. y BELTRÁN SÁNCHEZ, E. M.): La responsabilidad de los administradores de las sociedades mercantiles, $6^{\text {a }}$ edición, 2016, Tirant Lo Blanch, Valencia, p. 553.

221 DESDENTADO BONETE, A. y DESDENTADO DAROCA, E.: Administradores Sociales, Altos Directivos y Socios Trabajadores..., op. cit., p. 179.

${ }^{222}$ ESTEBAN VELASCO, G.: “Algunas reflexiones sobre la Responsabilidad de los Administradores frente a los Socios y los Terceros: Acción individual y acción por no Promoción o Remoción de la disolución”, 1995, op. cit., p. 59.

${ }^{223}$ Se han admitido reclamaciones de responsabilidad ante al administrador social, ejercitándose acciones individuales de responsabilidad y acciones por deudas, en numerosas resoluciones judiciales, citando como representativas las siguientes, Sentencias TS, Sala Social, 28 de febrero de 1997 -Aranzadi RJ Ar. 4220/1997-; 28 de octubre de 1997 -RJ 7680/1997-; 13 de abril de 1998 -RJ 1998/4577-; 21 de julio de 1998 -RJ 6211/1998-; 9 de noviembre de 1999 -RJ 1999\8520-; 9 de junio de 2000 -RJ 200015109-; 8 de mayo de 2002 -RJ 2002\7541-; y Auto 4/1996, de 8 de marzo -Rec. 7/1995- de la Sala Especial de Conflictos de Competencias del TS. Sentencias del TS, Sala Civil, 460/2010, de 14 de julio; 826/2011 de 23 noviembre; 455/2017, de 18 de julio; 420/2019, de 15 de julio (entre otras). 
Por otro lado, la antijuridicidad consistente en la infracción de los estatutos sociales, normalmente tendrá más trascendencia para la acción social de responsabilidad, o para la acción individual de los socios, y menos para la acción a ejercitar por las entidades gestoras o la TGSS, por establecer fundamentalmente obligaciones del administrador en el ámbito interno, ad intra, como se desprende de las materias objeto de su regulación en el art. 23 de la LSC, siendo los efectos jurídicos ad extra menores, salvo en cuestiones relacionadas con el tráfico económico, como la determinación del objeto social o actividad. Ello no excluye que, de afectar la vulneración o incumplimiento a los terceros acreedores, éstos estarán legitimados para el ejercicio de la acción individual invocando la infracción estatutaria.

Normas estatutarias que no pueden oponerse a disposiciones normativas imperativas o prohibitivas, teniendo consiguientemente un carácter complementario ${ }^{224}$, de suplementariedad, cubriendo vacíos normativos, o desarrollando disposiciones normativas heterónomas.

Pese a aludirse sólo a los estatutos, DÍAZ ECHEGARAY considera que surge la responsabilidad, no sólo por la infracción de los estatutos, sino también del Reglamento de Régimen Interno del Consejo de Administración ${ }^{225}$, Reglamento que es obligatorio para las sociedades cotizadas (art. 528 de la LSC). Por el contrario, VALPUESTA GASTAMINZA $^{226}$ considera que la infracción de normas internas, como los reglamentos de actuación del Consejo de Administración, podrían encuadrarse más bien en actuaciones contrarias al deber de diligencia.

Finalmente, el otro elemento de la antijuridicidad es el incumplimiento de los deberes inherentes al cargo. En la medida en que los deberes inherentes al cargo están recogidos en la propia LSC, se ha venido sosteniendo que este tercer presupuesto de responsabilidad resulta innecesario, porque si estos deberes están regulados en la LSC, nos hallaremos en definitiva ante actos contrarios a la ley ${ }^{227}$. Por eso se ha podido decir

${ }^{224}$ QUIJANO GONZÁLEZ, J.: "La responsabilidad civil de los administradores de la Sociedad Anónima, aspectos sustantivos", 1985, op. cit., p. 171.

${ }^{225}$ DÍAZ ECHEGARAY, J. L.: Deberes y responsabilidades de los administradores de la sociedad de capital, op. cit., p. 224.

226 VALPUESTA GASTAMINZA, E. M.: Comentarios a la Ley de Sociedades de Capital, op. cit., p. 627.

227 DÍAZ ECHEGARAY, J. L.: Deberes y responsabilidades de los administradores, op. cit., p. 226; SÁNCHEZ CALERO, F.: Los Administradores en las Sociedades de Capital, op., cit, pp. 326-327. 
que, la actuación conforme a la ley y con atención a los deberes inherentes al desempleo del cargo, actúan como vasos comunicantes 228 .

Para valorar la acción antijurídica del administrador deberá tenerse en cuenta el principio de discrecionalidad del art. 226 de la LSC, donde se establece que las decisiones estratégicas y de negocio, encaminadas a la consecución del objeto social, están sujetas a la discrecionalidad empresarial, para evitar que ante el riesgo de verse sometido a la responsabilidad por daños el administrador no adopte decisiones razonables para la consecución del objeto social aunque entrañen un riesgo, ya que éste es inherente a la actividad empresarial, por lo que deberá valorarse si las decisiones de negocio se han adoptado de buena fe, en defensa del interés societario y habiendo recabado previamente la información necesaria ${ }^{229}$.

En la responsabilidad exigible al administrador social a través de la acción individual de responsabilidad del artículo 241 de la LSC, el acto u omisión antijurídica contrario a la ley, y por incumplimiento de los deberes del cargo, normalmente implicará incumplimientos de obligaciones normativas del orden social que pesen sobre la sociedad en sus relaciones con trabajadores, con las entidades gestoras y con la TGSS. Responsabilidad que podrá nacer ante omisiones culposas del administrador de las obligaciones de contenido económico de Seguridad Social de la sociedad de capital. Responsabilidad que normalmente surgirá del incumplimiento de las obligaciones de solicitar, en tiempo y forma, las afiliaciones y las altas en Seguridad Social de sus trabajadores (arts. 16, 139 y 140 del TRLGSS), de donde nacerán deudas por cotizaciones y eventualmente por prestaciones de responsabilidad empresarial (arts. 34.1.a, 142, 165, 167 y 168 TRLGSS), así como por incumplir las obligaciones de cotización a la Seguridad Social, sean descubiertos totales de cotización o diferencias de cotización por ocultación fraudulenta de partidas que integran la base de cotización (arts. 18, 22, 28, 29, 141, 142 y 144 a 153 del TRLGSS), o por infracción de la normativa reguladora de la prevención de riesgos laborales determinantes de la responsabilidad empresarial en prestaciones (arts. 164 y 242 a 244 del TRLGSS).

${ }^{228}$ SALDAÑA VILLOLDO, B.: La acción individual de responsabilidad. Su significado..., op. cit., p. 130.

229 SÁNCHEZ CALERO, F.: Los Administradores en las Sociedades de Capital, op., cit, p. 311; MUÑOZ PAREDES, A.: Tratado judicial de la responsabilidad de los administradores, op. cit., pp. 55-77; VAlPUESTA GASTAMINZA, E. M: Comentarios a la Ley de Sociedades de Capital, op. cit., pp. 595-596. 


\subsection{Culpabilidad o imputabilidad de la conducta del administrador.}

Conjuntamente con la antijuridicidad de la acción, ésta ha de ser imputable al administrador a título de dolo o culpa (negligencia). Como señala MARÍN DE LA BÁRCENA GARCIMARTÍN ${ }^{230}$, conviene no confundir entre incumplimiento y culpa, que en el campo de la responsabilidad se reconducen a ilicitud de la conducta y a su imputabilidad, o en palabras de QUIJANO GONZÁLEZ 231 , “debe distinguirse entre el juicio de ilicitud o antijuridicidad de la conducta del administrador, que se proyecta sobre el acto dañoso como valoración objetiva, y el juicio de culpabilidad que se proyecta sobre la actitud del sujeto antes de examinar las categorías concretas de culpabilidad".

Pese a no aludirse a este requisito de culpabilidad en el art. 241 de la LSC, se encuentra recogido con carácter general en la responsabilidad por daños en el art. 236 de la LSC, aplicable a la acción individual de responsabilidad y en la acción social de responsabilidad $^{232}$. En ese precepto se establece que el administrador responde por los actos u omisiones antijurídicos imputables a título de dolo o culpa, presumiéndose "iuris tantum" la concurrencia de la culpa en los actos contrarios a la ley o a los estatutos sociales, estableciéndose una inversión de la carga de la prueba para que sea el administrador quien acredite su falta de culpabilidad (STS, Sala Civil, 417/2006, de 28 de abril -Rec. 3287/1999-), con lo que la carga probatoria de la culpabilidad por el accionante quedaría reconducida básicamente al incumplimiento de los deberes inherentes al cargo, pero incluso en estos supuestos podría operar una especie de inversión de la carga de la prueba.

En el art. 237 de la LSC se establece una presunción de culpa colectiva cuando el órgano de administración adopta la forma de Consejo de Administración, en virtud de la cual el administrador podrá exonerarse de responsabilidad probando que no le es imputable la conducta causante del daño, por concurrir las circunstancias eximentes que permiten destruir la presunción iuris tantum de responsabilidad solidaria de todos los

${ }^{230}$ MARÍN DE LA BÁRCENA GARCIMARTÍN, F.: "La acción individual de responsabilidad de los administradores de sociedad anónima frente a socios y terceros (artículo 135)", 1999, op. cit., p. 309.

${ }^{231}$ QUIJANO GONZÁLEZ, J.: "La responsabilidad civil de los administradores de la Sociedad Anónima, aspectos sustantivos", 1985, op. cit., p. 215.

${ }^{232}$ SÁNCHEZ CAlero, F.: Los Administradores en las Sociedades de Capital, op. cit, p. 317; ESTEBAN VELASCO, G.: "La acción individual de responsabilidad", op. cit., pp. 218-220; VALPUESTA GASTAMINZA, E. M. : Comentarios a la Ley de Sociedades de Capital, op. cit., p. 644. 
integrantes del órgano de administración ${ }^{233}$. Presunción de culpa colectiva que tiene su fundamento en el principio de personalidad e individualización de la responsabilidad ${ }^{234}$. Inversión del onus probandi que, antes de haberse recogido expresamente en la legislación societaria, ya defendía QUIJANO GONZÁLEZ ${ }^{235}$, para quien, por facilidad probatoria debería ser el administrador quien habría de acreditar que ha actuado con la diligencia debida para probar su falta de culpabilidad, sin tener que obligarse al acreedor a probar la culpa. Para MARÍN DE LA BÁRCENA GARCIMARTÍN"236 "la responsabilidad del administrador se derivará del incumplimiento, presumiéndose iuris tantum la culpa, y si el demandante acredita el incumplimiento del deber de diligencia, se invertirá la carga de la prueba al administrador social para probar que el incumplimiento no le es subjetivamente imputable".

En el art. 236 de la LSC, dentro del elemento subjetivo del injusto se habla de dolo y la culpa. El dolo es la voluntad deliberada y consciente de causar un daño, de modo que, según QUIJANO ${ }^{237}$, “en materia de la responsabilidad de los administradores, significa que concurre el dolo cuando el administrador, con intención de causar un daño patrimonial, realiza un acto que sabe es adecuado para ese resultado y cuyas consecuencias conoce y prevé, incluyendo el dolo eventual, en que previendo posibles efectos perjudiciales, los asume de producirse".

La característica del dolo es la conciencia y voluntad de producir una transgresión jurídica, esto es, de infringir un derecho o un deber; mientras que la culpa o negligencia es la falta de diligencia debida ${ }^{238}$, incluyendo la culpa leve o simple. El dolo implica un

${ }^{233}$ SÁNCHEZ CALERO, F.: Los Administradores en las Sociedades de Capital, op. cit., pp. 330-331 y 339; DÍAZ ECHEGARAY, J. L.: Deberes y responsabilidades de los Administradores de sociedades de Capital, op. cit., pp. 266-267; ALFONSO SÁNCHEZ, R.: "Obligaciones básicas derivadas del deber de lealtad", en AA.VV. (Coord.: HERNANDO CEBRIÁ, L.): Régimen de Deberes y Responsabilidades de los administradores en las sociedades de capital, Bosch, 2015, p. 224; GRIMALDOS GARCÍA, M. I.: "Presupuestos y extensión subjetiva de la responsabilidad. Solidaridad: artículos 236 y 237. Otras acciones por infracción del deber de lealtad: artículos 227.2 y 232", en AA.VV. (Coord.: HERNANDO CEBRIÁ, L.): Régimen de Deberes y Responsabilidades de los administradores en las sociedades de capital, Bosch, 2015, pp. 341-344.

${ }^{234}$ SÁNCHEZ CALERO, F.: Los administradores en las sociedades de Capital, op. cit., pp. 319-320, 330-331 y 339.

${ }^{235}$ QUIJANO GONZÁLEZ, J.: La responsabilidad civil de los administradores de la Sociedad Anónima, aspectos sustantivos", 1985, op. cit., pp. 244-248 y 367-368.

${ }^{236}$ MARÍN DE LA BÁRCENA GARCIMARTÍN, F.: "La acción individual de responsabilidad de los administradores de sociedad anónima frente a socios y terceros (artículo 135)", $R d S, 1999$, núm. 13, p. 311.

${ }^{237}$ QUIJANO GONZÁLEZ, J.: La responsabilidad civil de los administradores de la Sociedad Anónima, aspectos sustantivos", 1985, op. cit., pp. 216-217.

${ }^{238}$ CASTÁN TOBEÑAS, J.: Derecho Civil Español Común y Foral, Tomo $1^{\circ}, 12^{\mathrm{a}}$ edición, Edit. Rius, Madrid, 1978, pp. 658 y ss. 
mayor grado de voluntariedad e intencionalidad en la infracción de un deber, frente a la culpa en sentido estricto, por lo que conlleva mayor reproche social y jurídico. Según ESTEBAN VELASCO ${ }^{239}$, el dolo se entiende como consciencia del significado del acto ilícito y voluntad de realizarlo, y la culpabilidad como omisión de la diligencia debida.

La culpa en sentido estricto conlleva o implica dos rasgos esenciales, la previsibilidad y la evitabilidad de la acción o de las consecuencias de la acción. Existe culpa cuando algo ha podido ser previsto por persona diligente y no lo ha sido, de modo que es culpable quien pudo prever el hecho matriz del daño y no lo previó, entendiéndose la previsibilidad como previsibilidad objetiva. Por el contrario, existe evitabilidad cuando previsto el daño se adoptan medidas necesarias para evitarlo, de modo que la previsibilidad puede referirse tanto a la acción dañosa como a las consecuencias de la $\operatorname{misma}^{240}$.

PEÑA LÓPEZ considera que "la calificación como culposa de la conducta de una persona depende esencialmente de que ésta haya realizado o no un comportamiento objetivamente menos diligente que aquél que le exige el Derecho"241.

Al mencionarse la culpa, de conformidad con la doctrina ${ }^{242}$ y la jurisprudencia ${ }^{243}$ es suficiente actualmente la concurrencia de culpa leve o lata, la simple negligencia u omisión de la diligencia debida, ya no es necesario que concurra la culpa grave que se recogía en el art. 79 la Ley de Sociedades Anónimas de 17 de julio de 1951 donde se hablaba de daño causado por malicia, abuso de facultades o negligencia grave. Se puso fin a lo que la jurisprudencia calificaba como "franquicia de imprudencia leve" 244.

$\mathrm{Al}$ exigirse la culpa leve, se admite una mayor exigencia en la actuación orgánica de los administradores ante los terceros acreedores, lo que es consecuencia de una mayor

\footnotetext{
239 Para ESTEBAN VELASCO, G.: “La acción individual de responsabilidad”, op. cit., pp. 218-219.

${ }^{240}$ DÍEZ-PICAZO Y PONCE DE LEÓN, L. y GULLÓN BALLESTEROS, A.: Sistema de Derecho Civil, op. cit., p. 637.

241 PEÑA LÓPEZ, F.: La culpabilidad en la responsabilidad civil extracontractual, Ed. Comares, Granada, 2002, p. 442.

242 Entre otros, JIMÉNEZ SÁNCHEZ, G. J.: Lecciones de Derecho Mercantil, op. cit., p. 201; SALDAÑA VILLOLDO, B.: La acción individual de responsabilidad. Su significado..., op. cit., p. 121; ESTEBAN VELASCO, G.: "La acción individual de responsabilidad", op. cit., pp. 218 a 220; SÁNCHEZ CALERO, F.: Los Administradores en las Sociedades de Capital, op. cit, p. 327.

${ }^{243}$ SSTS, Sala Civil, de 30 de marzo de 2001, 19 de noviembre de 2001, 30 de diciembre de 2012, entre otras muchas.

244 SSTS, Sala Civil, de 13 de octubre de 1986, 12 de abril de 1989, 16 de junio de 1992, entre otras interpretando el alcance del elemento subjetivo del injusto de la Ley de 1951.
} 
profesionalización y tecnificación de esa figura en las actuales relaciones económicas de producción. Exigencia de culpa leve, de negligencia simple, que no enerva la discrecionalidad de las decisiones estratégicas y de negocio.

La exigibilidad de dolo o culpa como presupuesto de la responsabilidad por daños, conlleva que no nazca la misma si se acredita que no hay imputabilidad por hallarnos ante un caso fortuito del art. 1105 del Código Civil ${ }^{245}$.

Al exigirse dolo o culpa, y pese a la presunción de culpa colectiva del art. 237 de la LSC, no nos hallamos ante una responsabilidad objetiva o sin culpa según la doctrina ${ }^{246}$ y la jurisprudencia ${ }^{247}$.

La responsabilidad será exigible a las personas integrantes del órgano de administración, y no al órgano mismo, de ser un Consejo de Administración, o de ser varios los administradores, en virtud del principio de personalización e individualización de la responsabilidad ${ }^{248}$.

Ante incumplimientos de obligaciones legales con la Seguridad Social de la sociedad de capital, imputables a los administradores en el ejercicio del cargo, como sucederá con infracciones de los deberes de afiliación, altas y cotización, nos hallaríamos ante posibles actos antijurídicos culposos/dolosos, de los que se podrá derivar el ejercicio de una acción individual de responsabilidad, especialmente ante incumplimientos dolosos, cuando exista una voluntad deliberada de incumplir esas obligaciones, como sucedería en caso de la falta de cotización que no sea fruto de una situación objetiva de dificultad económica habiendo cumplido otras obligaciones legales como solicitud de concurso de haber insolvencia, o como acontecería ante situaciones de clara preterición en el pago de las obligaciones legales con la Seguridad Social, atendiendo por el contrario otras obligaciones legales o contractuales, y finalmente, ante el cierre de hecho de la empresa.

245 MARÍN DE LA BÁRCENA GARCIMARTÍN, F.: "La acción individual de responsabilidad de los administradores de sociedad anónima frente a socios y terceros (artículo 135)", 1999, op. cit., p. 310; VAlPUESTA GASTAMINZA, E. M.: Comentarios a la Ley de Sociedades de Capital, op. cit., pp. 626-627.

246 MARÍN DE LA BÁRCENA GARCIMARTÍN, F.: "La acción individual de responsabilidad de los administradores de sociedad anónima frente a socios y terceros (artículo 135)”, 1999, op. cit., p. 310; ESTEBAN VELASCO, G.: "La acción individual de responsabilidad”, op. cit., pp. 219 a 220; VAlPUESTA GASTAMINZA, E. M.: Comentarios a la Ley de Sociedades de Capital, op. cit., pp. 626-627.

${ }^{247}$ Sentencias del TS, Sala Civil; 138/2002 de 25 de febrero -RJ 2002/1908-; 448/2004 de 27 de mayo; $864 / 2004$, de 22 de julio, entre otras.

248 SÁNCHEZ CALERO, F.: Los administradores en las sociedades de capital”, op. cit., pp. 319-320 y 406. 
Supuestos de posible aplicación de la acción individual que analizaremos en el apartado III de este capítulo.

\subsection{Daño directo.}

Nos encontramos ante el requisito más relevante y decisivo para la viabilidad de la acción individual por el acreedor, y a efectos de nuestra investigación, ante el elemento determinante y más problemático de una eventual aplicación de la acción individual de responsabilidad frente al administrador social por una entidad gestora o por la TGSS.

Para que sea viable la acción individual de responsabilidad no es suficiente que la conducta del administrador sea antijurídica y culpable, sino que es requisito esencial y necesario que se cause un daño que deba resarcirse ${ }^{249}$. El daño en el ejercicio del cargo es presupuesto de la responsabilidad.

Ahora bien, a diferencia de la acción social de responsabilidad, este daño ha de ser directo al acreedor o al tercero (daño primario $^{250}$ ), y no meramente reflejo del daño causado al patrimonio de la sociedad (daño secundario), aunque éste cause de modo indirecto un daño al acreedor al disminuir la garantías del pago.

Daño directo en el patrimonio del acreedor que es en definitiva el elemento diferenciador entre la acción social y la acción individual de responsabilidad según nuestra doctrina ${ }^{251}$. Requisito de daño primario o directo en el patrimonio del acreedor que se ha exigido igualmente en nuestra jurisprudencia ${ }^{252}$. Daño directo que no puede

${ }^{249}$ QUIJANO GONZÁLEZ, J.: "La responsabilidad civil de los administradores de la Sociedad Anónima, aspectos sustantivos", 1985, op. cit., p. 204; ALCALÁ DÍAZ, Ma . A.: “Acción individual de responsabilidad frente a los administradores (STS de 21 de mayo de 1992) ”, RdS, núm. 1, 1993, p. 172.

${ }^{250}$ Por todos, GARRIGUES, J.: Curso de Derecho Mercantil, op. cit., p. 491; SÁNCHEZ CALERO, F.: Los administradores en las Sociedades de Capital, op. cit., p. 321.

${ }^{251}$ ESTEBAN VELASCO, G.: "La acción individual de responsabilidad”, op. cit., pp. 194-195; DÍAZ ECHEGARAY, J. L.: Deberes y Responsabilidades de los Administradores, op. cit., p. 343; SÁNCHEZ CALERO, F.: “Administradores (arts. 123 a 143)”, op. cit., p. 322; SÁNCHEZ CALERO, F.: Los administradores en las Sociedades de Capital, op. cit., pp. 409 a 412; GARRETA SUCH, J. M.: La responsabilidad civil, fiscal, penal de los Administradores de las sociedades, op. cit., pp. 127 y ss; MARÍN DE LA BÁRCENA GARCIMARTÍN, F.: "La acción individual de responsabilidad de los administradores de sociedad anónima frente a socios y terceros (artículo 135)”, 1999, op. cit., p. 312; ESTEBAN VELASCO, G.: "Algunas reflexiones sobre la Responsabilidad de los Administradores frente a los Socios y los Terceros: Acción individual y acción por no Promoción o Remoción de la disolución”, 1995, op. cit., p. 62; QUIJANO GONZÁLEZ, J.: “La responsabilidad civil de los administradores de la Sociedad Anónima, aspectos sustantivos ”, 1985, op. cit., p. 205.

252 Por todas, SSTS, Sala Civil, de 21 de mayo de 1985; 26 de febrero de 1993; 388/2001, de 19 de abril; 1168/2008, de 27 de noviembre; 667/2009, de 23 de octubre; 312/2010, de 1 de junio; 396/2013 de 20 de junio; 150/2017, de 2 de marzo -Rec.2118/2014-.

La Sentencia n 388/2001, de 19 de abril -Rec. 3931/1997-, es ilustrativa al respecto, señalando que la acción individual tiende, no a la indemnización de los daños indirectamente causados al acreedor, a 
consistir en la insolvencia de la sociedad (Sentencia del TS, Sala Civil, 417/2006, de 28 de abril).

Este requisito del daño directo no siempre será fácil de acreditar en los supuestos de impago de créditos u obligaciones legales en situaciones de crisis patrimoniales irreversibles, ya que, en principio, no estaremos ante un daño directo al acreedor de una obligación legal cuando afecta al conjunto de los acreedores sociales por insuficiencia del patrimonio social. Esto no significa dejar desprotegido al acreedor cuando el comportamiento del administrador social vaya dirigido claramente a provocar el incumplimiento de las obligaciones sociales, abocando a la sociedad a una situación de descapitalización y despatrimonialización.

La acción individual de responsabilidad podrá tener su justificación cuando la sociedad termina en una situación de absoluta despatrimonialización Por incumplimientos imputables de los administradores, lo que suele suceder cuando ante dificultades económicas de la sociedad, en lugar de proceder a la ordenada disolución, se continúa irresponsablemente con la actividad en una especie de huida hacia adelante que aboca en el vaciamiento patrimonial o en último término en un cierre de hecho ${ }^{253}$. Esos comportamientos ilícitos, quedarían dentro del campo de aplicación de la acción individual de responsabilidad, con independencia de que sean también constitutivos de la responsabilidad por deudas del art. 367 de la LSC, por incumplirse los deberes de ordenada disolución de la sociedad, en cuyo caso, el acreedor dispondrá de dos vías para la satisfacción de sus créditos.

En las crisis patrimoniales sin ordenada liquidación cobrará su sentido la acción individual para reclamar las deudas de Seguridad Social anteriores a la causa de disolución, complementando a la derivación administrativa de responsabilidad por las deudas posteriores (arts. 18.3 del TRLGSS y 367 de la LSC).

No nos planteará dificultad la prueba del daño directo a los derechos económicos de la Seguridad Social en situaciones de insuficiencia patrimonial de la sociedad, cuando nos hallemos ante incumplimientos de las obligaciones legales que generen deudas de

través del patrimonio de la sociedad (daños secundarios), sino a repararle e indemnizarle de los daños directamente sufridos por el demandante en su patrimonio (daños primarios).

253 ESTEBAN VELASCO, G.: “Algunas reflexiones sobre la Responsabilidad de los Administradores frente a los Socios y los Terceros: Acción individual y acción por no Promoción o Remoción de la disolución”, 1995, op. cit., pp. 61 y 64. MARÍN DE LA BÁRCENA GARCIMARTÍN, F.: “La acción individual de responsabilidad de los administradores de sociedad anónima frente a socios y terceros (artículo 135)", 1999, op. cit., p. 315. 
Seguridad Social, como serían los incumplimientos de solicitar en plazo reglamentario las altas en Seguridad Social de los trabajadores, la obtención fraudulenta de reducciones, bonificaciones de cuotas de Seguridad Social. Se acreditará daño directo al patrimonio de la Seguridad Social cuando el incumplimiento de las obligaciones de Seguridad Social sea consecuencia de conductas antijurídicas típicas de fraude a la Seguridad Social (ocultación de las retribuciones abonadas o de las horas extraordinarias para eludir su cotización a la Seguridad Social, etc.) que se analizarán en el apartado III. 3.3 de este capítulo.

Igualmente, se acreditará el daño directo, cuando existiendo bienes y circulante, y ante la proximidad de una situación de dificultades económicas y financieras, el administrador opta por no cumplir con las obligaciones económicas de la Seguridad Social, atendiendo por el contrario, otras deudas legales o contractuales de menor prelación o preferencia, con clara e injustificada preterición de los derechos de la Seguridad Social. Supuesto importante para nuestro estudio, que será objeto de análisis más adelante (apartado III. 3. 2 de este capítulo).

\subsection{Relación de causalidad entre la acción y el daño.}

Finalmente para que tenga éxito la acción individual de responsabilidad del acreedor, frente al administrador social, debe probar aquél la relación de causalidad entre la acción u omisión del administrador y el daño causado al patrimonio del acreedor ${ }^{254}$.

Es factor básico a la hora de acreditar la relación de causalidad entre la conducta del administrador y el daño causado, analizar si la conducta ha tenido la relevancia necesaria para la producción del daño, acudiendo por ello nuestra jurisprudencia a la teoría de la causalidad adecuada o eficiente ${ }^{255}$.

Para una adecuada apreciación de la causalidad habrá de acudirse, en primer lugar, a comprobar la existencia de causalidad física, y, en segundo lugar, valorar la concurrencia de causalidad jurídica ${ }^{256}$.

${ }^{254}$ SSTS, Sala Civil, 396/2013, de 20 de junio; 15 de octubre de 2013 -Rec. 1268/2011-; 395/2012, de 18 de junio; 312/2010, de 1 de junio; 667/2009, de 23 de octubre; 242/2014, 23 de mayo; 864/2004, de 22 de julio; 723/2001, de 17 de julio, entre otras muchas.

${ }^{255}$ SSTS, Sala Civil, 648/1998 de 3 de julio; Sentencia núm. 399/2009 de 12 junio; Sentencia 1012/2006 de 5 octubre.

${ }^{256}$ En Sentencia del TS, Sala Social, 815/2010, de 15 de diciembre, al respecto se indica: "la relación de causalidad se reconstruye, en una primera fase, mediante la aplicación de la regla de la "conditio sine qua non ", conforme a la que toda condición, por ser necesaria o indispensable para el efecto, es causa 
La acreditación de la relación de causalidad entre la acción y el daño directo en los derechos económicos de la Seguridad Social, no tendrá especiales dificultades una vez se haya acreditado el daño directo, así como el acto antijurídico del administrador, ya que hay una relación de causa efecto entre el incumplimiento de las obligaciones legales del orden social y el daño acaecido en el patrimonio económico de la Seguridad Social. La dificultad residirá en acreditar el daño directo en el patrimonio de la Seguridad Social, como algo distinto al daño al patrimonio social de la mercantil, en situaciones de crisis patrimoniales no buscadas.

Requisitos de la acción individual que han de acreditar las entidades gestoras y la TGSS cuando pretendan exigir el pago de las deudas de Seguridad Social de la sociedad.

\section{4. Ámbito subjetivo de la acción individual de responsabilidad.}

\subsection{Administradores responsables.}

La acción individual de responsabilidad como instituto jurídico a disposición de los acreedores de la sociedad de capital para exigir la responsabilidad a los administradores por los daños directos causados a los derechos de crédito con sus conductas ilícitas, se regula en los arts. 236 a 241 bis de la LSC, dentro del Título VI, Capítulo V, intitulado "la responsabilidad de los administradores", cuyo primer precepto, el art. 236, lleva por rúbrica "Presupuestos y extensión subjetiva de la responsabilidad".

En el art. 236 apartados 1, 3, 4 y 5 de la LSC se regula el ámbito subjetivo de la acción individual de responsabilidad, en cuyo apartado primero se señala que los sujetos pasivos de esta acción son los administradores sociales, aludiéndose posteriormente al administrador de hecho (apartado $3^{\circ}$ ), al administrador persona jurídica (apartado $5^{\circ}$ ), y a altos cargos cuando no haya delegación permanente de funciones (apartado $4^{\circ}$ ). Se habla de los administradores en general en el apartado $1^{\circ}$, por lo que habrá de partirse de las distintas formas en que puede constituirse el órgano de administración, ya que éste puede estar integrado por una única persona, o por varias, en cuyo caso, las mismas pueden actuar de modo solidario o bien de modo mancomunado, o finalmente puede

del resultado; así como la de la "equivalencia de condiciones", según la cual, en el caso de concurrencia de varias, todas han de ser consideradas iguales en su influencia causal si, suprimidas imaginariamente, la consecuencia desaparece también. Afirmada la relación causal según las reglas de la lógica, en una segunda fase se trata de identificar la causalidad jurídica, para lo que entran en juego criterios normativos que justifiquen o no la imputación objetiva de un resultado a su autor, en función de que permitan otorgar, previa discriminación de todos los antecedentes causales del daño en función de su verdadera dimensión jurídica, la calificación de causa a aquellos que sean relevantes o adecuados para producir el efecto". 
constituirse como órgano colegiado, como Consejo de Administración, pudiendo nombrarse en su seno uno o varios Consejeros Delegados o una Comisión Ejecutiva (art. 210.1 de la $\operatorname{LSC}^{257}$ ).

La forma de organización de la administración de la sociedad de capital deberá constar en los estatutos sociales, con indicación del número de administradores, o al menos, el número máximo y mínimo de miembros integrantes, así como el plazo de vigencia del cargo (art. 23.e de la LSC). En la escritura pública de constitución de la sociedad se hará constar la identidad de las personas que se encarguen inicialmente de la administración de la sociedad (art. 22.1.e de la LSC). Toda alteración del modo de organizarse la administración social se elevará a escritura pública y se inscribirá en el Registro Mercantil (art. 210.4 de la LSC).

Ante la eventualidad de haberse constituido el órgano de administración por varias personas, o de haberse nombrado un Consejo de Administración, la responsabilidad exigible mediante la acción individual, no es una responsabilidad del órgano, sino de las personas que integran el mismo ${ }^{258}$, sean personas físicas o jurídicas, en virtud de lo que SÁNCHEZ CALERO ${ }^{259}$ ha denominado la personalización e individualización de la responsabilidad.

El ámbito subjetivo de responsabilidad se extiende a todos las personas físicas o jurídicas que integran el órgano de administración, sea cual sea la forma de su organización (arts. 212.1, 212 bis y 236 de la LSC), y que estén en el ejercicio del cargo. En virtud de la presunción de la culpa colectiva ${ }^{260}$ del art 237 LSC, no será tanto el acreedor el que deba probar la culpa de todos y cada uno de sus integrantes, sino que hay una inversión de la carga probatoria debiendo ser los administradores quienes han

\footnotetext{
257 "Artículo 210. Modos de organizar la administración. 1. La administración de la sociedad se podrá confiar a un administrador único, a varios administradores que actúen de forma solidaria o de forma conjunta o a un consejo de administración. 2. En la sociedad anónima, cuando la administración conjunta se confíe a dos administradores, éstos actuarán de forma mancomunada y, cuando se confie a más de dos administradores, constituirán consejo de administración. 3. En la sociedad de responsabilidad limitada los estatutos sociales podrán establecer distintos modos de organizar la administración atribuyendo a la junta de socios la facultad de optar alternativamente por cualquiera de ellos sin necesidad de modificación estatutaria. 4. Todo acuerdo que altere el modo de organizar la administración de la sociedad, constituya o no modificación de los estatutos sociales, se consignará en escritura pública y se inscribirá en el Registro Mercantil”.

${ }^{258}$ SÁNCHEZ CALERO, F.: Los Administradores en las Sociedades de Capital, op. cit., pp. 312 y 319.

${ }^{259}$ SÁNCHEZ CALERO, F. : Los Administradores en las Sociedades de Capital, op. cit., p. 319.

${ }^{260}$ SÁNCHEZ CALERO, F. : Los Administradores en las Sociedades de Capital, op. cit., pp. 312 y 319 ; DÍAZ ECHEGARAY, J. L.: Deberes y responsabilidades de los Administradores de Sociedades de Capital, op. cit., p. 266.
} 
de acreditar que no les es imputable el acto dañoso ${ }^{261}$. Con ello se facilita el ejercicio de la acción individual por los acreedores, al no exigirse a éstos probar la culpa de todos y cada uno de los miembros del órgano de administración ${ }^{262}$. Presunción de culpa que tiene relevancia en el supuesto de existir una pluralidad de administradores, o de hallarnos ante un Consejo de Administración ${ }^{263}$. Por otro lado, al ser una responsabilidad personal de los integrantes del órgano de administración, no será exigible la responsabilidad a los administradores suplentes mientras no ocupen realmente el cargo ${ }^{264}$, salvo que ante una vacante accedan al ejercicio efectivo de las funciones gestoras.

Los responsables son todos los administradores, en los supuestos de ser más de uno, por haber varios administradores solidarios, mancomunados, o por haberse constituido un Consejo de Administración. De haberse nombrado Consejeros Delegados o una Comisión Ejecutiva, nombramiento que recaerá entre miembros integrantes del consejo, (art. 249 de la LSC), no quedan exonerados de la responsabilidad el resto de los miembros del órgano de administración, salvo que acrediten que no han participado en el acto lesivo, en su acuerdo, o que hicieron todo lo posible para evitar el mismo ${ }^{265}$.

${ }^{261}$ SÁNCHEZ CALERO, F.: Los Administradores en las Sociedades de Capital, op. cit., p. 331.

${ }^{262}$ DÍAZ ECHEGARAY, J. L.: Deberes y responsabilidades de los Administradores de Sociedades de Capital, op. cit., p. 266.

${ }^{263}$ SÁNCHEZ CALERO, F.: Los Administradores en las Sociedades de Capital, op. cit., pp. 319 y 320.

${ }^{264}$ QUIJANO GONZÁLEZ, J.: "Principales aspectos del estatuto jurídico de los administradores: nombramiento, duración, retribución, conflicto de intereses separación; los suplentes", en $R d S$, número extraordinario, 1994, La Reforma del Derecho de Sociedades de Responsabilidad Limitada, p. 675; CALBACHO LOSADA, F.: El ejercicio de las acciones de responsabilidad contra los administradores de la sociedad anónima, op. cit., p. 503; RODRÍGUEZ RUIZ DE LA VILLA, D. y HUERTA VIESCA, M. I.: La responsabilidad de los administradores por las deudas de las Sociedades de Capital (en las Leyes de Sociedades Anónimas, de Sociedades de Responsabilidad Limitada, de Sociedad Limitada Nueva Empresa, Concursal, General Tributaria $y$ de Responsabilidad Medioambiental), $2^{\mathrm{a}}$ edición, Aranzadi, 2008, p. 54.

${ }^{265}$ SSTS, Sala Civil 647/2006 de 23 junio -RJ 2006/3744-; 225/2008, de 1 de diciembre -Rec. 80/2001-; 460/2010, de 14 de julio -RJ 2010/6040-; y 826/2011 de 23 noviembre -Rec. 1753/2007-, entre otras. En la Sentencia 225/2008, de 1 de diciembre -Rec. 80/2001-, se señala que "procede, en suma, apreciar la responsabilidad de los administradores, para la que resulta indiferente que determinadas funciones del Consejo de Administración hayan sido delegadas en concretos miembros del mismo. El art. $133 \mathrm{LSA}$ se refiere como titulares de la responsabilidad que en él se establece a los «administradores» (o «miembros del órgano de administración»: art. 133.3 LSA). Esta cualidad la ostentan los nombrados como tales por la Junta General (art. 123 LSA). En consecuencia, los legitimados desde el punto de vista de la exigencia de responsabilidad son quienes ostentan esta condición, independientemente de que determinadas facultades del consejo de administración hayan sido delegadas en consejeros concretos, puesto que éstos actúan por mandato de los administradores o como gestores de éstos, y sólo cabe eximir a aquellos de responsabilidad en el caso de que, como prescribe el artículo 133.3 LSA, prueben que, no habiendo intervenido en la adopción y ejecución del acuerdo lesivo, desconocían su existencia o, conociéndola, hicieron todo lo conveniente para evitar el daño o, al menos, se opusieron expresamente a aquél". Las referencias a los arts. 133 debe entenderse a 236 de la LSC y las del art. 123 al art. 214 de la LSC. 
El primer presupuesto para que surja la responsabilidad es ostentar la condición de administrador social, que nace con el nombramiento y la aceptación del cargo, y se extingue por el cese o pérdida de vigencia del mismo.

Para que el administrador sea sujeto pasivo de la acción individual de responsabilidad, la primera condición será que esté en el ejercicio del cargo en la fecha en que se produce el acto u omisión que ha causado el daño al acreedor, lo que implica que haya sido nombrado administrador por la Junta General y haya aceptado el cargo, sin que la inscripción en el Registro Mercantil del nombramiento sea constitutiva ${ }^{266}$ (art. 214 de la LSC, y art. 9.1 del $\mathrm{RRM}^{267}$ ). En la inscripción del nombramiento se deberá hacer constar la identidad de los nombrados, la fecha del nombramiento, el plazo de vigencia del cargo, y en su caso, de ser un Consejo de Administración el cargo para el que, en su caso, hubiese sido nombrado (art. 138 del RRM). La inscripción en el Registro Mercantil del nombramiento deberá tener lugar dentro de los diez días siguientes a la aceptación del cargo (art. 215.2 LSC).

El nombramiento surte efectos desde la aceptación (art. 214.3 de la LSC), sin que la fecha de la aceptación pueda ser anterior al nombramiento (art. 141 RRM), pero sí posterior. La aceptación podrá ser expresa o tácita, resultando ésta de actos concluyentes de ejercicio de funciones propias del cargo ${ }^{268}$. Una vez acepte el cargo deberá inscribirse el nombramiento en el Registro Mercantil (art. 215 LSC, arts. 94.1. $4^{\circ}$ y 138 a 143 del RRM), a medida que se vaya produciendo la aceptación y dentro del plazo de los diez días siguientes a ésta (art. 215 LSC y art. 141 del RRM). Pese a aludirse sólo al nombramiento como acto objeto de inscripción, la aceptación ha de comunicarse igualmente, por varias razones, en primer lugar, porque es un dato para determinar la vigencia del cargo, que sí es objeto de inscripción (art. 138 RRM), en segundo lugar, porque la inscripción del nombramiento deberá realizarse dentro del plazo de diez días desde la aceptación del cargo (art. 215.2 de la LSC), permitiéndose que la inscripción pueda realizarse a medida que se vayan aceptando los cargos por los

266 CALBACHO LOSADA, F.: El ejercicio de las acciones de responsabilidad contra los administradores de la sociedad anónima, op. cit., p. 509.

${ }^{267}$ En el art 9 se recoge el principio de publicidad del registro, en función del cual, los actos sujetos a inscripción sólo surtirán efecto ante terceros de buena fe, desde la publicación de la inscripción.

“Artículo 9. Oponibilidad.1. Los actos sujetos a inscripción sólo serán oponibles a terceros de buena fe desde su publicación en el «Boletín Oficial del Registro Mercantil». Quedan a salvo los efectos propios de la inscripción".

268 CALBACHO LOSADA, F.: El ejercicio de las acciones de responsabilidad contra los administradores de la sociedad anónima, op. cit., p. 508; DÍAZ ECHEGARAY, J. L.: Deberes y responsabilidades de los Administradores de sociedades de Capital, op. cit., p. 404. 
interesados, con lo que la aceptación deberá constar en la comunicación dirigida al registro (art. 141.1 del RRM), y en tercer lugar, porque la fecha de la aceptación del cargo no podrá ser anterior a la fecha de nombramiento, con lo que para su fiscalización deberá comunicarse esa circunstancia al registro (art. 141.2 RRM). Esa comunicación de la aceptación no exige que deba constar la aceptación del interesado de modo fehaciente, con lo que podría comunicarse una aceptación que no ha tenido lugar, al no exigirse la firme del aceptante para la inscripción del nombramiento, pudiendo constar como administrador de derecho alguien que no lo sea y que podría ser, en principio, sujeto pasivo de la acción de responsabilidad.

La responsabilidad del administrador nacerá, cuando nombrado y aceptado el cargo, en el ejercicio del mismo cause un daño al acreedor social, con independencia de que se haya inscrito en el Registro Mercantil el nombramiento y la aceptación del cargo, porque la inscripción del nombramiento de administrador no es constitutiva, pero su ausencia sí tendrá efectos ante terceros, en función del principio de publicidad material registral, tanto en su aspecto positivo (principio de legitimación registral), por cuanto que, su contenido se presume exacto y válido, produciendo sus efectos mientras no se inscriba la declaración judicial de su inexactitud o nulidad (art. 7 del RRM), como en su dimensión negativa (principio de oponibilidad), en virtud del cual, los actos sujetos a inscripción sólo serán oponibles a terceros de buena fe desde su publicación en el Boletín Oficial del referido Registro (art. 9.1 RRM).

En virtud del principio de publicidad material del registro, que admite prueba en contrario, en principio, sujeto pasivo de la acción individual de responsabilidad será el administrador que conste inscrito en el Registro Mercantil en el momento de causarse el daño. Si quien conste inscrito no hubiere llegado a ser administrador, por no haber aceptado el cargo, ni ejercerlo, desconociendo la inscripción de su nombramiento, con independencia de otras posibles responsabilidades administrativas o penales, le correspondería al inscrito probar un hecho negativo, no ser administrador social, con la consiguiente dificultad de acreditarse hechos negativos, por lo que PRADOS CUTILLAS $^{269}$, aboga por exigir que conste la firma del aceptante del cargo en la certificación del nombramiento, en lugar de admitir como suficiente la simple

269 PRADES CUTILLAS, D.: La responsabilidad del administrador en las sociedades de capital en la jurisprudencia del Tribunal Supremo, Editorial Tirant Lo Blanch, edición digital, 2014 https://biblioteca-tirant-com.ponton.uva.es/cloudLibrary/ebook/show/9788490338469, pp. 226-227. 
manifestación del hecho. Paralelamente, y, al contrario, esa inscripción registral no impide que pueda ser sujeto pasivo de la acción individual de responsabilidad quien sea auténtico administrador de derecho, pese a la falta de inscripción registral del nombramiento, lo que se podría acreditar, previa actuación inspectora, cuando el administrador nombrado ejerza el cargo tras la aceptación pese a la falta de inscripción del nombramiento. Estaríamos, en ese caso, ante un administrador de derecho, no ante un administrador de hecho, porque ha sido nombrado por la Junta General, ha aceptado el cargo y ejerce sus funciones.

Si para entablar la acción de responsabilidad la TGSS o la entidad gestora de la prestación, quieren conocer la identidad de los administradores, podrán recabar esa información en el Registro Mercantil, ya que son objeto de inscripción, el nombramiento y los ceses de los administradores de las sociedades de capital, constando las fechas de vigencia del cargo, las dimisiones, revocaciones y la caducidad del cargo (arts. 31 a 35 de la LSC, y arts. 94.1.4 $, 138,143,144,145,147,148,175.1 .5^{\circ}, 191$ y 192 del RRM). Identidad de los administradores que podrá conocerse igualmente, a través del modelo oficial del impuesto de sociedades presentado en la Agencia Estatal de Administración Tributaria, ya que debe constar la identidad de los administradores en cada declaración anual del impuesto, según la Orden Ministerial anual que aprueba el modelo de declaración del impuesto.

Las funciones del cargo del administrador social comprenden dos ámbitos, las relaciones internas o intrasocietarias, donde rige el poder de gestión ${ }^{270}$, y las relaciones externas ante terceros, que se rige por el poder de representación ${ }^{271}$, ámbito éste en que se producirá el acto dañoso objeto de reclamación por la acción individual, en nuestro

${ }^{270}$ En que se aplican las reglas del art. 201 de la LSC, donde todos los administradores están llamados a la gestión y dirección de la sociedad, sean varios administradores solidarios, mancomunados, o un Consejo de Administración, en este supuesto con adopción de acuerdos por mayoría de los asistentes.

${ }^{271}$ En las relaciones externas ante terceros el poder de representación de los administradores se rige por las reglas establecidas en el art. 233.2 de la LSC. En primer lugar, en el caso de nombrarse un administrador único, el poder de representación corresponderá a éste. En segundo lugar, en caso de ser varios administradores solidarios, el poder de representación corresponde a cada administrador, el que con su actuación vincula a la sociedad y al resto de los administradores, sin perjuicio de lo que pudiera haberse pactado en los estatutos sociales, o de lo acordado por la junta sobre distribución de facultades, que tendrán un alcance meramente interno. En tercer lugar, en la sociedad de responsabilidad limitada, si hubiera más de dos administradores conjuntos o mancomunados, el poder de representación se ejercerá mancomunadamente al menos por dos de ellos en la forma determinada en los estatutos, y si la sociedad fuera anónima, el poder de representación se ejercerá mancomunadamente. En cuarto lugar, en el caso de Consejo de Administración, el poder de representación corresponde al propio consejo, que actuará colegiadamente. No obstante, los estatutos podrán atribuir el poder de representación a uno o varios miembros del consejo a título individual o conjunto, pudiendo nombrar Consejeros Delegados o una Comisión Ejecutiva (art. 249 de la LSC). 
supuesto, el incumplimiento de las obligaciones encuadramiento y de cotización a la Seguridad Social, o de abonar prestaciones de Seguridad Social por responsabilidad empresarial.

En el caso de la administración mancomunada existe una disociación entre la titularidad del poder de gestión ${ }^{272}$, o relaciones internas societarias, y la titularidad del poder de representación en las relaciones externas con terceros ${ }^{273}$.

Esta responsabilidad por daños del administrador social es aplicable a los liquidadores, ya que en el art. 375.2 de la LSC, se señala que "serán de aplicación a los liquidadores las normas establecidas para los administradores que no se opongan a lo dispuesto en este capítulo", entre las que están las que regulan la responsabilidad por daños. Igualmente es aplicable a los administradores concursales y sus delegados (art. 98 del Real Decreto Legislativo 1/2020, de 5 de mayo, por el que se aprueba el Texto Refundido de la Ley Concursal -TRLC- ${ }^{274}$-).

Analicemos brevemente las diversas situaciones que pueden presentarse en la organización o gestión del órgano de administración, con la finalidad de determinarse si son sujetos pasivos de la acción individual de responsabilidad. Nos referimos a los administradores de hecho, al administrador persona jurídica, al personal de alta dirección, a los apoderados, a la administración en los grupos de sociedades y a los administradores de las sociedades mercantiles estatales.

${ }^{272}$ El poder de gestión se rige por las reglas del art. 210 de la LSC, que como se señala en la Sentencia 424/2019, de 16 de julio -Rec. 3784/2016-, en el caso de hallarnos ante administradores mancomunados, le corresponde al conjunto de los administradores mancomunados, que, por tanto, habrá de ejercitarse por todos ellos de forma conjunta.

${ }^{273}$ El poder de representación o actuación externa ante terceros, se rige por las reglas de los arts. 233.2.c) LSC y 185.3.c) RRM, de modo que, en la sociedad de responsabilidad limitada, si hubiera más de dos administradores mancomunados, el poder de representación se ejercerá mancomunadamente al menos por dos de ellos en la forma determinada en los estatutos, y en el caso de la sociedad anónima, el poder de representación se ejercerá mancomunadamente por sus miembros. Según la Sentencia del TS, Sala Civil, 424/2019, de 16 de julio -Rec. 3784/2016-, "la mancomunidad parcial, se prevé legalmente solo respecto de la representación, pero no en cuanto a la gestión, salvo que los estatutos establezcan que los administradores con poder mancomunado pueden gestionar de forma solidaria los asuntos internos de la compañía (lo que últimamente ha sido admitido por la DGRN, por ejemplo, en la Resolución de 4 de mayo de 2016)".

${ }^{274}$ BOE del 7.5.2020.

"Artículo 98. Acción individual de responsabilidad.

1. Quedan a salvo las acciones de responsabilidad que puedan corresponder al concursado, a los acreedores o a terceros por actos u omisiones de los administradores concursales y auxiliares delegados que lesionen directamente los intereses de aquellos.

2. Las acciones de responsabilidad a que se refiere el apartado anterior prescribirán a los cuatro años, contados desde que el actor hubiera tenido conocimiento del daño o perjuicio por el que Reclama y, en todo caso, desde que los administradores concursales o los auxiliares delegados hubieran cesado en su cargo". 


\subsubsection{Administrador de hecho.}

Son sujetos pasivos de la acción individual de responsabilidad no sólo los administradores de derecho o administradores formales, sino también los administradores de hecho.

La responsabilidad del administrador de hecho se reconoce expresamente para la responsabilidad por daños, para la acción social e individual de responsabilidad, en el primer inciso del art. 236.3 de la LSC, al señalarse que "la responsabilidad de los administradores se extiende igualmente a los administradores de hecho". Responsabilidad del administrador de hecho introducida por primera vez en la regulación de la responsabilidad por años de los administradores, mediante la Ley 26/2002, de 17 de julio, por la que se modifican la Ley 24/1988, de 28 de julio, del Mercado de Valores, y el Texto Refundido de la Ley de Sociedades Anónimas, aprobado por el Real Decreto Legislativo 1564/1989, de 22 de diciembre, con el fin de reforzar la transparencia de las sociedades anónimas cotizadas ${ }^{275}$.

Extendido el ámbito subjetivo de la responsabilidad por daños al administrador de hecho, y ante la ausencia legal de su definición jurídica, asumió esta tarea la doctrina administrativa registral, la doctrina científica y la jurisprudencia.

Inicialmente nuestra doctrina científica perfiló dos grandes categorías de administradores de hecho, por un lado, el administrador con cargo caducado, y por otro, el que ejerce las funciones sin título jurídico válido. Para SÁNCHEZ CALERO ${ }^{276}$, el administrador de hecho es una figura con perfiles difusos, en el que se han de incluir a los administradores con cargo caducado, así como a aquellos, que sin título válido gestionan la sociedad. DÍAZ ECHEGARAY ${ }^{277}$, agrupaba a los administradores de hecho, en dos grandes bloques, por un lado, las personas que ejerzan las funciones en ausencia de un nombramiento, y por otro, quienes ejerzan las funciones con nombramiento irregular o caducado. En el primer grupo incluía al socio de control, al socio único de la sociedad unipersonal, a los apoderados con amplísimas facultades, a la gestión indirecta en los grupos de sociedades, y diversos supuestos de traslación de la gestión a órganos extra-institucionales. En el segundo grupo incluía a los

\footnotetext{
${ }^{275}$ BOE del 18.7.2002.

${ }^{276}$ SÁNCHEZ CALERO, F.: Los administradores en las sociedades de capital, op. cit., p. 314.

277 DÍAZ ECHEGARAY, J. L.: Deberes y responsabilidades de los Administradores de Sociedades de Capital, op. cit., pp. 250-251.
} 
administradores nombrados en una deliberación inválida, al administrador cesado, al administrador de hecho con nombramiento implícito, o al nombrado sin observarse los requisitos de publicidad formal, o al ejercicio de las funciones sin la aceptación del cargo. Finalmente, el profesor QUIJANO ${ }^{278}$, señaló dos grandes supuestos o categorías del administrador de hecho, "por una parte, estarían los que ocupan el cargo de administrador, pero su nombramiento adolece de algún vicio jurídico, y por otro lado, estarían, los que sin ocupar formalmente el cargo, ejercen de modo real las funciones del órgano de administración, sea sustituyendo a los administradores de derecho, o sea influyendo de modo decisivo sobre los mismos". Con esta concepción ya se apuntaba la figura de lo que posteriormente se ha llamado el administrador de hecho oculto.

La construcción de la figura del administrador de hecho tuvo en nuestro ordenamiento un origen registral ${ }^{279}$, ya que en aras de garantizar la continuidad de la empresa, y especialmente para evitar la paralización de los órganos sociales, ante la caducidad del cargo de los administradores por expiración del plazo de vigencia, se admitió la validez de la convocatoria de la Junta General por los administradores con cargo caducado, como un supuesto de prórroga de hecho del nombramiento de los administradores. Con posterioridad esta figura evoluciona ${ }^{280}$ para extender sus contornos a todos aquellos supuestos de ejercicio efectivo del cargo, pese a no tenerse un nombramiento válido o sin título jurídico, y acabar incluyendo a quien, sin ejercer el cargo directamente, ejerce una influencia decisiva sobre el administrador formal o de derecho, limitándose éste a cumplir las instrucciones recibidas de aquél, el llamado administrador "oculto o en la sombra".

Nos apunta esa evolución doctrinal de la figura del administrador de hecho HERNANDO CEBRIÁ ${ }^{281}$, quien señala que, (sic) “inicialmente la doctrina conceptuó

${ }^{278}$ QUIJANO GONZÁLEZ, J.: La responsabilidad civil de los administradores de la Sociedad Anónima, aspectos sustantivos", Universidad de Valladolid, 1985, p. 351.

${ }^{279}$ MARTÍNEZ SANZ, F. y BARTLE AGUSTÍN, M.: "Los administradores responsables”, en AA.VV. (Coord.: ROJO FERNÁNDEZ-RÍO, A. y BELTRÁN SÁNCHEZ, E.): La responsabilidad de los administradores de las sociedades mercantiles, $6^{\mathrm{a}}$ edición, 2016, Tirant Lo Blanch, Valencia, p. 67; RODRÍGUEZ SÁNCHEZ, S.: "La delimitación de la figura del administrador de hecho", en $R d S$, núm. 301, 2016, edición digital https://insignisaranzadidigitales.ponton.uva.es/maf/app/document?srguid=i0ad82d9b0000017448ff865bd89df112\& marginal=BIB $12016185617 \&$ docguid=I06c70da0, pp. 3-4. Ambos citan como primera resolución registral que admite la validez de la convocatoria de la junta por administradores con cargo caducado, la resolución de la Dirección General de los Registros y del Notariado de 24 de junio de 1968.

${ }^{280}$ RODRÍGUEZ SÁNCHEZ, S.: "La delimitación de la figura del administrador de hecho”, en RdS, núm. 301, 2016, edición digital, p. 4.

${ }^{281}$ HERNANDO CEBRIÁ, L.: “¿Sociedad dominante administradora de hecho? Más allá del velo 
como administrador de hecho a aquel que no podía ser considerado como administrador de derecho porque su designación o aceptación se hallaba afectada por algún vicio de nulidad, incapacidad o inhabilitación; para extenderse luego al administrador de derecho con mandamiento caducado; y, por último, a la persona que ejerza las labores de gestión sin la cobertura legal exigida al administrador de derecho".

Estos supuestos quedarían actualmente incluidos dentro del concepto legal amplio de administrador de hecho del art. 236.3 de la LSC, al contemplarse en su último inciso al administrador oculto o en la sombra, esto es, a quien no siendo el administrador de derecho, no obstante, influye de modo determinante en éste mediante la impartición de instrucciones directas de carácter permanente.

El concepto y la delimitación de la figura del administrador de hecho ha tenido también un origen jurisprudencial. En la Sentencia del TS, Sala Civil, núm. 721/2012, de 4 de diciembre -Rec. 1139/2010-, en su fundamento de derecho sexto, puede leerse, (sic) "ante el silencio de la norma sobre qué debe entenderse por administrador de hecho, esta Sala ha declarado que lo son quienes, sin ostentar formalmente el nombramiento de administrador y demás requisitos exigibles, ejercen la función como si estuviesen legitimados prescindiendo de tales formalidades, pero no a quienes actúan regularmente por mandato de los administradores o como gestores de éstos, pues la característica del administrador de hecho no es la realización material de determinadas funciones, sino la actuación en la condición de administrador con inobservancia de las formalidades mínimas que la Ley o los estatutos exigen para adquirir tal condición (Sentencias 261/2007, de 14 marzo; 55/2008, de 8 de febrero; 79/2009, de 4 de febrero; 240/2009, de 14 de abril; 261/2007, de 14 de marzo). Es decir, cuando la actuación supone el ejercicio efectivo de funciones propias del órgano de administración de forma continuada y sin sujeción a otras directrices que las que derivan de su configuración como órgano de ejecución de los acuerdos adoptados por la junta general”.

En nuestra jurisprudencia se ha ido perfilando la figura del administrador de hecho con la clara finalidad de evitar situaciones de fraude de ley en la aplicación del régimen de responsabilidad de los administradores, nombrándose administradores formales a personas insolventes que no ejercen las funciones, las que son desempeñadas realmente por terceros utilizando torticeramente y en fraude de ley otros vínculos jurídicos como 
un apoderamiento general (administradores efectivos no formales), para sustraerse del riguroso régimen de responsabilidad a que se hallan sometidos los administradores (Sentencia del TS, Sala Civil, 55/2008, de 8 de febrero -Rec. 5168/2000-). Este es un supuesto de administrador efectivo no formalmente designado que ha de ser diferenciado del administrador oculto. El administrador efectivo no designado se reviste de otra condición jurídica diversa, presentándose como apoderado o con otro título jurídico, ejerciendo realmente las funciones de administración por lo que no sería verdaderamente un administrador oculto. Hemos de reservar esta última noción para quien, desde fuera del cargo, ejerce una influencia decisiva sobre el administrador de derecho, administrador de derecho que es quien actúa y se manifiesta ante terceros, a diferencia del primer supuesto, en que quien actúa es el tercero revestido de ropaje jurídico distinto al de administrador.

Igualmente, se atribuyó en la jurisprudencia la condición de administrador de hecho al socio con control mayoritario o socio único de la sociedad de capital, sea persona física o jurídica, como se hizo en la Sentencia del TS, Sala Civil, 828/2001, de 24 de septiembre -Rec. 1895/1996-, en que se asignó esa condición a la sociedad que adquirió todas las acciones de otra mercantil, convirtiéndose en único socio sin haberse nombrado a nadie administrador.

Finalmente, en la doctrina judicial se admitió la condición de administrador de hecho a quien ejerce una influencia decisiva y continuada sobre el administrador de derecho figura del administrador oculto-.

Ante esos antecedentes doctrinales y jurisprudenciales, en el actual art. 236. 3 de la LSC, según redacción dada por la Ley 31/2014, de 3 de diciembre, se incluye bajo la denominación de administrador de hecho, "tanto la persona que en la realidad del tráfico desempeñe sin título, con un título nulo o extinguido, o con otro título, las funciones propias de administrador, como, en su caso, aquella bajo cuyas instrucciones actúen los administradores de la sociedad".

En virtud del concepto legal, son administradores de hecho los que realmente desempeñan la administración de la sociedad, de modo continuado y sin título jurídico, sea directamente, o sea indirectamente por ejercer una influencia decisiva en el administrador de derecho. 
Con esta reforma se introduce una definición legal del administrador de hecho, recogiéndose las propuestas de la Comisión de Expertos en Materia de Gobierno Corporativo creada por Acuerdo del Consejo de Ministros de 10 de mayo de 2013, y que ya se mencionaba en el "Informe de la Comisión Especial para el Fomento de la Transparencia y Seguridad en los Mercados y en las Sociedades Cotizadas", de 8 de enero de 2003, conocido como Informe Aldama. En el Informe Aldama, ya se aludía "a los administradores de hecho -a aquellas personas que en la realidad del tráfico desempeñan sin título, o con título nulo o extinguido- las funciones de administración”; a los "administradores ocultos, bajo cuyas instrucciones suelen actuar los administradores de la sociedad"; y "a los accionistas de control".

Con la definición legal de administrador de hecho se recoge un concepto amplio y flexible, incluyendo al que realmente actúe como administrador, careciendo de título válido -quien ejerce directamente el cargo-, y al que imparte las instrucciones a seguir por el administrador formal de derecho -quien indirectamente ejerce el cargo $^{282}$-. En esta figura del administrador de hecho quedarán comprendido ${ }^{283}$ (sic) "tanto a la persona que, sin estar legitimada para el cargo, desempeña directamente las funciones propias que competen, tanto al órgano de administración como a la persona que ejerce ese cometido indirectamente, mediante el dictado de instrucciones de gestión a los administradores formalmente nombrados por la sociedad".

Con la definición legal queda zanjado el debate acerca de si se incluye al administrador oculto $^{284}$, porque se comprende tanto a quien ejerce el cargo de la administración de modo directo, como a quien lo ejerza de modo indirecto impartiendo instrucciones al administrador formal.

Dentro de la amplia definición legal del administrador de hecho quedarían incluidas tres subespecies que se venían apuntando en la doctrina y la jurisprudencia, el administrador

282 GRIMALDOS GARCÍA, M. I.: "Presupuestos y extensión subjetiva de la responsabilidad. Solidaridad: artículos 236 y 237. Otras acciones por infracción del deber de lealtad: artículos 227.2 y 232 ”, op. cit., p. 321.

283 BRENES CORTÉS, J.: "Responsabilidad del representante persona física del administrador persona jurídica y su posible configuración como administrador de hecho", Revista Derecho Mercantil, ${ }^{\circ}$ 310, 2018, Aranzadi, Comentarios de Jurisprudencia, edición digital, p. 2, quien matiza que "ambas categorías no se corresponden exactamente con la tradicional distinción entre administrador de hecho y administrador oculto".

${ }^{284}$ RODRÍGUEZ SÁNCHEZ, S.: "La delimitación de la figura del administrador de hecho", 2016, op. cit., edición digital, pp. 10-11, precisando que esa doble delimitación no se corresponde exactamente con lo que se ha venido denominando administrador de hecho y administrador oculto. 
de hecho notorio o aparente, el administrador oculto, y el administrador efectivo sin título jurídico o con título nulo o extinguido ${ }^{285}$. Se incluyen dentro de la noción legal del administrador de hecho, al administrador notorio ${ }^{286}$, el que sin título jurídico válido, ante terceros se manifiesta ejerciendo las funciones de administración, al administrador oculto $^{287}$, aquél que realmente ejerce las funciones del cargo, impartiendo las instrucciones al administrador formal, con la finalidad de sustraerse de la responsabilidad legal prevista para los administradores, para lo que coexiste con el administrador de derecho quien sería un mero testaferro o subordinado, y, las personas que ejercen las funciones del órganos sin título jurídico válido, los nombrados de forma irregular, tácita, incluyendo a los que permanecen en el ejercicio de sus funciones tras la caducidad del cargo, sin ser prorrogados o sustituidos ${ }^{288}$, que en puridad actualmente quedarían incluidos dentro de la categoría general de administrador de hecho notorio, del que realmente ejerce el cargo. En los supuestos de ejercicio de las funciones del órgano de administración tras el cese formal o caducidad del cargo, en nuestra jurisprudencia $^{289}$ se ha declarado la responsabilidad del mismo en calidad de administrador de hecho.

Administrador de hecho oculto es aquél que sin ocupar formalmente el cargo ejerce una influencia decisiva y continuada sobre el administrador de derecho, controlando la

285 GRIMALDOS GARCÍA, M. I.: "Presupuestos y extensión subjetiva de la responsabilidad. Solidaridad: artículos 236 y 237. Otras acciones por infracción del deber de lealtad: artículos 227.2 y 232”, op. cit., pp. 311-317.

286 GRIMALDOS GARCÍA, M. I.: "Presupuestos y extensión subjetiva de la responsabilidad. Solidaridad: artículos 236 y 237. Otras acciones por infracción del deber de lealtad: artículos 227.2 y 232”, op. cit., p. 314; MARTÍNEZ SANZ, F. y BARTLE AGUSTÍN, M.: “Los administradores responsables”, 2016, op. cit., pp. 70-73; HERNANDO CEBRIÁ, L.: “Sociedad dominante administradora de hecho? Más allá del velo corporativo", op. cit., p. 5.

287 GRIMALDOS GARCÍA, M. I.: "Presupuestos y extensión subjetiva de la responsabilidad. Solidaridad: artículos 236 y 237. Otras acciones por infracción del deber de lealtad: artículos 227.2 y 232”, op. cit., pp. 314-315; MARTÍNEZ SANZ, F. y BARTLE AGUSTÍN, M.: "Los administradores responsables”, 2016, op. cit., pp. 70-73; HERNANDO CEBRIÁ, L.: “¿Sociedad dominante administradora de hecho? Más allá del velo corporativo”, op. cit., p. 5; RODRÍGUEZ SÁNCHEZ, S.: "La delimitación de la figura del administrador de hecho", 2016, op. cit., edición digital, pp. 10-11, para quien, queda incluido dentro del administrador de hecho notorio, "un supuesto típico de administración oculta: el sujeto que desarrolla su actuación como administrador bajo el ropaje formal de cualquier otro título, con la intención de ocultar su verdadera condición a los terceros. La incorporación en esta categoría del sujeto que accede al cargo bajo la apariencia de otro título representa la ruptura de la frontera que tradicionalmente ha separado al administrador de hecho del administrador oculto".

288 GRIMALDOS GARCÍA, M. I.: "Presupuestos y extensión subjetiva de la responsabilidad. Solidaridad: artículos 236 y 237. Otras acciones por infracción del deber de lealtad: artículos 227.2 y 232", op. cit., pp. 315-317.

289 SSTS, Sala Civil, 228/2008 de 25 de marzo -Rec. 219/2001-; 240/2009, de 14 de abril -Rec. 1504/2004-, entre otras. 
gestión social en la sombra ${ }^{290}$, como podría suceder en determinadas situaciones ante un socio de control y ante el socio único en las sociedades unipersonales" ${ }^{291}$.

El administrador de hecho notorio y el administrador oculto son las dos grandes categorías de la figura del administrador de hecho, y las que, con más frecuencia, podrán ser los sujetos pasivos de la acción individual de responsabilidad. Menos interés tiene actualmente la figura del administrador con cargo caducado, por cuanto que, ya en la regulación vigente (art. $222 \mathrm{LSC}^{292}$ y art. 145.1 $\mathrm{RRM}^{293}$ ), se reducen los supuestos de administradores de hecho por caducidad del cargo al prorrogarse éste hasta que se proceda a elegirse nuevos administradores por la Junta General, o en su defecto, hasta que transcurra el plazo para la celebración de la junta que ha de aprobar las cuentas anuales, por lo que, a partir de ese momento nos encontraríamos en puridad ante un administrador de hecho notorio de continuar ejerciendo las funciones del cargo (Sentencias del TS, Sala Civil, 240/2009, de 14 de abril -Rec. 1504/2004-; 123/2010, de 11 de marzo -Rec. 1239/2005-).

Partiendo de nuestra doctrina jurisprudencial ${ }^{294}$ podemos señalar que son tres los rasgos esenciales de la figura del administrador de hecho: la funcionalidad, la continuidad y la

${ }^{290}$ BRENES CORTÉS, J.: "Responsabilidad del representante persona física del administrador persona jurídica y su posible configuración como administrador de hecho", 2018, op. cit., p. 10. RODRÍGUEZ SÁNCHEZ, S.: "La delimitación de la figura del administrador de hecho", 2016, op. cit., edición digital, p. 5.

${ }^{291}$ RODRÍGUEZ SÁNCHEZ, S.: "La delimitación de la figura del administrador de hecho”, 2016, op. cit., edición digital, p. 5.

292 "Artículo 222. Caducidad. El nombramiento de los administradores caducará cuando, vencido el plazo, se haya celebrado junta general o haya transcurrido el plazo para la celebración de la junta que ha de resolver sobre la aprobación de las cuentas del ejercicio anterior".

293 "Artículo 145. Caducidad del nombramiento. 1. El nombramiento de los administradores caducará cuando, vencido el plazo, se haya celebrado la Junta General siguiente o hubiese transcurrido el término legal para la celebración de la Junta que deba resolver sobre la aprobación de cuentas del ejercicio anterior".

294 SSTS, Sala Civil, 721/2012, de 4 de diciembre; 421/2015, de 22 de julio -Rec. 1701/2013-; y 224/2016, de 8 de abril -Rec. 2535/2013-.

En la Sentencia 224/2016, de 8 de abril -Rec. 2535/2013- sobre el concepto y rasgos definitorios del administrador de hecho, señala, "La única definición que existe en nuestro Derecho positivo sobre la figura del administrador de hecho se recoge, a efectos de extensión de la responsabilidad societaria, en el art. 236.3 de la Ley de Sociedades de Capital (LSC), conforme al cual: «tendrá la consideración de administrador de hecho tanto la persona que en la realidad del tráfico desempeñe sin título, con un título nulo o extinguido, o con otro título, las funciones propias de administrador, como, en su caso, aquella bajo cuyas instrucciones actúen los administradores de la sociedad». Aunque dicho precepto no sea de aplicación directa al caso, nos puede servir de orientación para delimitar los perfiles de esta figura. La Sentencia de esta Sala núm. 421/2015, de 22 de julio, con remisión a la Sentencia 721/2012, de 4 de diciembre, resume la jurisprudencia en la materia, al decir: «esta Sala ha declarado que lo son [administradores de hecho] "quienes, sin ostentar formalmente el nombramiento de administrador y demás requisitos exigibles, ejercen la función como si estuviesen legitimados prescindiendo de tales formalidades, pero no a quienes actúan regularmente por mandato de los administradores o como gestores de éstos, pues la característica del administrador de hecho no es la 
autonomía. La funcionalidad, implica el ejercicio de los poderes o funciones propias del órgano de administración, bien de modo directo -caso del administrador de hecho notorio-, o bien de modo indirecto, bajo las instrucciones de un tercero ajeno administrador de hecho oculto-. La continuidad o habitualidad, que ese ejercicio de las funciones gestoras, directas o indirectas, debe ser algo continuado y sistemático, duradero en el tiempo, no algo episódico o esporádico. La autonomía, que se ejerza un poder autónomo de decisión, sin sujeción a otras instancias o poderes externos, tanto en la gestión directa -administrador notorio-, como en la indirecta -administrador oculto-.

Rasgos definitorios que en la doctrina se han identificado con las notas de "funcionalidad, intensidad cualitativa-cuantitativa de la gestión, y autonomía"295, o como "autonomía, habitualidad y el carácter decisorio de la intervención" ${ }^{296 .}$

Será sujeto pasivo de la acción de responsabilidad el administrador de hecho por lesión directa del derecho de crédito por cuotas o prestaciones de Seguridad Social (art. 236.3

realización material de determinadas funciones, sino la actuación en la condición de administrador con inobservancia de las formalidades mínimas que la Ley o los estatutos exigen para adquirir tal condición" (Sentencias 261/2007, de 14 de marzo; 55/2008, de 8 de febrero; 79/2009, de 4 de febrero; 240/2009, de 14 de abril; y 261/2007, de 14 de marzo). Es decir, cuando la actuación supone el ejercicio efectivo de funciones propias del órgano de administración de forma continuada y sin sujeción a otras directrices que las que derivan de su configuración como órgano de ejecución de los acuerdos adoptados por la junta general» Conforme a esta jurisprudencia, la noción de administrador de hecho presupone un elemento negativo (carecer de la designación formal de administrador, con independencia de que lo hubiera sido antes, o de que lo fuera después), y se configura en torno a tres elementos caracterizadores: i) debe desarrollar una actividad de gestión sobre materias propias del administrador de la sociedad; ii) esta actividad tiene que haberse realizado de forma sistemática y continuada, esto es, el ejercicio de la gestión ha de tener una intensidad cualitativa y cuantitativa; y iii) se ha de prestar de forma independiente, con poder autónomo de decisión, y con respaldo de la sociedad".

En la Sentencia del TS, Sala Civil, 721/2012, de 4 de diciembre -Rec. 1139/2010-, ya se apuntaba que el administrador de hecho, implica "el ejercicio efectivo de funciones propias del órgano de administración de forma continuada y sin sujeción a otras directrices que las que derivan de su configuración como órgano de ejecución de los acuerdos adoptados por la junta general".

295 RODRÍGUEZ SÁNCHEZ, S.: “La delimitación de la figura del administrador de hecho”, 2016, op. cit., edición digital, p. 8.

Para este autor, el elemento funcional, lo identifica con la persona que realiza las tareas que legal y estatutariamente correspondan al órgano de administración. La intensidad cualitativa supone que el administrador de hecho ejerce efectivamente el cargo del órgano de administración. La intensidad cuantitativa exige que la actividad de administración sea además habitual, es decir, constante y continuada; y el poder autónomo de decisión, implica que el administrador de hecho goza de un auténtico poder sin subordinación a las instrucciones de un tercero.

${ }^{296}$ MARTÍNEZ SANZ, F. y BARTLE AGUSTÍN, M.: “Los administradores responsables”, 2016, op. cit., pp. 74 a 78. Para estos autores, para acreditar esa condición habrá de partirse de una serie de indicios, como serían, en primer lugar, la actuación de esa persona mediante poderes amplios -sin que el poder general sea en sí mismo, prueba suficiente, debiendo concurrir otros hechos que denoten que es esa persona la que dirige y gestiona la sociedad-, en segundo lugar, el hecho de ser una sociedad de base familiar, en las que el administrador de hecho controla al administrador de Derecho, y en tercer lugar, el control de la totalidad del capital social o su amplia mayoría, citando la Sentencia del TS, Sala Civil, 828/2001, de 24 de septiembre, en que se reconoció la condición de administrador de hecho al único socio, por carecer la sociedad unipersonal de administrador de Derecho. 
de la LSC), partiendo de las notas definitorias en ese precepto legal y de los rasgos caracterizadores en la jurisprudencia.

\subsubsection{Administrador persona jurídica.}

Administradores de una sociedad de capital podrán ser tanto las personas físicas como las personas jurídicas (art. 212.1 LSC). De nombrarse administrador a una persona jurídica, es obligatorio que ésta designe a una sola persona física para el ejercicio permanente de las funciones propias del cargo (art. 212 bis de la LSC).

Según RDGRN de 20 de septiembre de $2019^{297}$, que cita anteriores Resoluciones de 11 de marzo de 1991, 3 junio de 1999; 22 de septiembre de 2010, 18 de mayo de 2012, la persona jurídica administradora actúa a través de la persona física designada, y el nombramiento de la misma tiene un triple régimen jurídico: a) en primer lugar, es la persona jurídica designada administradora, y no la sociedad administrada, quien tiene la competencia para nombrar a la persona física o natural que ejercita las funciones propias del cargo; b) en segundo término, por exigencias prácticas y operativas ha de ser una única la persona física designada, no siendo válida la designación de varias ni aunque existan administradores solidarios o mancomunados en la administradora; y c) por último, esa persona física actuará en nombre de la persona jurídica administradora y con carácter permanente para el ejercicio estable de las funciones inherentes al cargo de administrador.

Para poder inscribirse en el Registro Mercantil la condición de administrador de la persona jurídica, haciendo constar su identidad o razón social (art. 215 de la LSC y arts. 138 y 141 del RRM), habrá de inscribirse la identidad de la persona física designada para ejercer las funciones (art. 143 RRM). La identidad del representante designado debe inscribirse al mismo tiempo que el nombramiento de la persona jurídica administradora en la hoja de la sociedad administrada, y si el designado pertenece al órgano de administración de la persona jurídica administradora, bastará con presentar la certificación correspondiente del acuerdo expedida por el órgano de la persona jurídica administradora que sea competente al efecto; mientras que en otro caso, la designación debe figurar en escritura pública de poder (RDGRN de 20 de septiembre de $2019^{298}$ ). Para la inscripción de la identidad de la persona física designada debe constar la

\footnotetext{
${ }^{297}$ BOE del 13.11.2019.

${ }^{298}$ Publicada en el BOE del 13.11.2019.
} 
aceptación del interesado (RDGRN de 20 de septiembre de 2019 ${ }^{299}$ ). Paralelamente, la revocación de esa persona física representante no surtirá efectos hasta que no se designe a la persona física que la sustituya, debiéndose inscribir en el Registro Mercantil a la nueva persona física nombrada (art. 212 bis. 2 de la LSC). En caso de reelección del administrador persona jurídica, el representante anteriormente designado continuará en el ejercicio de las funciones propias del cargo, en tanto no se proceda expresamente a su sustitución (art. 143.2 RRM).

QUIJANO $^{300}$, antes de regularse legalmente la responsabilidad y la condición de administrador de la persona jurídica, ya distinguía claramente la figura de la persona jurídica administradora, que para ejercer el cargo ha de actuar a través de una persona física que la represente, de aquella otra situación en la que una persona jurídica que no es administradora, tiene votos suficientes, por su importante participación en el capital social, para elegir a alguno de los administradores de la sociedad. Mientras en el primer supuesto la condición de administrador recae sobre la persona jurídica, en el segundo supuesto la condición de administrador la ostenta la persona elegida, defendiendo la traslación de la responsabilidad a la persona jurídica administradora de los actos de su representante, bien sea haciéndola responder directamente con derecho de regreso sobre

\footnotetext{
${ }^{299}$ Según esta Resolución, se exige que conste la aceptación como requisito para practicarse la inscripción de la designación de la persona física, porque, "así resulta del artículo 236 de la Ley de Sociedades de Capital, que en su apartado 5 (introducido por la Ley 31/2014, de 3 de diciembre, por la que se modifica la Ley de Sociedades de Capital para la mejora del gobierno corporativo, que en este punto sigue una orientación análoga a la de legislaciones como la francesa -artículos L225-20 y L225-76 del «Code de Commerce»- y belga -artículo 2:55 del «Code des Sociétés»-, en cuanto disponen que el representante designado queda sometido a las mismas condiciones e incurrirá en las mismas responsabilidades que si ejercieran el cargo de administrador en nombre propio), establece que: «La persona física designada para el ejercicio permanente de las funciones propias del cargo de administrador persona jurídica deberá reunir los requisitos legales establecidos para los administradores, estará sometida a los mismos deberes y responderá solidariamente con la persona jurídica administrador». Y si esta asimilación puede presentar problemas de interpretación, en cuanto podría dudarse si abarca únicamente los requisitos subjetivos para ser administrador así como los deberes de diligencia, lealtad y de evitar situaciones de conflicto de intereses, así como las responsabilidades inherentes al cargo pero no los requisitos formales como es la aceptación, lo cierto es que del artículo 212 bis, apartado 2 «in fine», de la misma ley se desprende inequívocamente la necesidad de aceptación por el representante persona física designado como requisito para su inscripción en el Registro, toda vez que del artículo 215 al que se remite resulta que sólo una vez aceptada se podrá presentar a inscripción esa designación y, además, ésta deberá presentarse dentro de los diez días siguientes a la fecha de la aceptación. Por lo demás, esta previsión normativa es lógica si se tiene en cuenta la dificultad o imposibilidad que existiría para exigir la responsabilidad al designado representante persona física de la sociedad administradora mientras no constare la aceptación de aquél, especialmente por ejemplo en caso incumplimiento del deber de diligencia, no ya por los actos que pudiera realizar - de la que resultaría la aceptación tácita de la designación- sino como consecuencia de la omisión de actuaciones debidas".

300 QUIJANO GONZÁLEZ, J.: La responsabilidad civil de los administradores de la Sociedad Anónima, aspectos sustantivos, 1985, op. cit., pp. 348-350.
} 
el representante, o bien declarando a la persona física responsable solidaria con la persona jurídica administradora.

De haberse nombrado administrador a una persona jurídica, bien sea administrador único, o administrador conjuntamente con otras personas, todos ellos serán sujetos pasivos de la acción individual de responsabilidad (art. 326 de la LSC), en función de la presunción de culpa colectiva del art. 237 de la LSC, salvo que con posterioridad alguno acredite que a él no le es imputable el daño por concurrir circunstancias exonerantes ${ }^{301}$. Lo decisivo será determinar si la persona física designada para ejercer las funciones del cargo, asume la responsabilidad por daños al amparo de la acción individual de responsabilidad (arts. 241 y 236 de la LSC), y cómo se articula esa responsabilidad respecto a la persona jurídica administradora.

En la Ley 31/2014, de 3 de diciembre, se introduce un nuevo apartado 5 al art. 236 de la LSC, que viene a resolver esta cuestión al establecer que la persona física designada para el ejercicio permanente de las funciones propias del cargo de administrador persona jurídica "está sometida a los mismos deberes y responderá solidariamente con la persona jurídica administrador".

Precepto legal que recoge el régimen jurídico general de responsabilidad del administrador persona jurídica, aplicable a la responsabilidad por daños y a la responsabilidad por deudas del art. 367 LSC, por lo que se ha criticado la inclusión de ese régimen jurídico en el art. 236 de la LSC, abogándose, en mejor técnica jurídica, por su inclusión dentro del art. 212 bis de la LSC $^{302}$.

Con la introducción de este nuevo precepto legal, se cumple el propósito manifestado en la Propuesta de la Comisión de Expertos en materia de Gobierno Corporativo, de fecha 14 de octubre de 2013, que abogaba por extender el régimen de responsabilidad de los administradores a las personas asimiladas.

Con anterioridad a la previsión legal de esta responsabilidad solidaria la responsabilidad recaía directamente en la persona jurídica administradora, sin que el acreedor pudiera reclamarla a la persona física designada, y sólo excepcionalmente, se utilizaban dos vías o instrumentos jurídicos para poder exigir la responsabilidad a la persona física, por un

${ }^{301}$ DEL VAL TALENS, P.: El administrador persona jurídica en las sociedades de capital, Editorial Marcial Pons, Madrid, 2017, p. 355.

302 BRENES CORTÉS, J.: "Responsabilidad del representante persona física del administrador persona jurídica y su posible configuración como administrador de hecho”, op. cit., Véase su nota 34. 
lado la teoría del levantamiento del velo y por otro lado la figura del administrador de hecho de concurrir los requisitos de ambas instituciones ${ }^{303}$.

Con la introducción de este precepto legal la persona física designada para el ejercicio permanente de las funciones del cargo de la persona jurídica administradora, responde de modo solidario con ésta de los daños que se causen a los terceros acreedores ${ }^{304}$. En virtud de esa responsabilidad solidaria, el tercero acreedor perjudicado podrá reclamar la totalidad del daño indistintamente a la persona jurídica administradora, a la persona física designada, o a ambos conjuntamente, teniendo dos patrimonios para resarcirse del daño, incrementando sus garantías de $\operatorname{cobro}^{305}$. Con la previsión legal de esta responsabilidad solidaria, se pretende evitar que se acuda a la figura del administrador persona jurídica, como un medio de elusión de responsabilidades, especialmente de la persona física designada. En el art. 236.5 de la LSC estamos ante una presunción de culpa colectiva, ante una solidaridad pasiva externa de la persona jurídica administradora y el representante persona física, sin exigir un consorcio pasivo necesario $^{306}$.

La persona física designada responde solidariamente con la persona jurídica administradora de los daños directos que cause aquélla a los acreedores en el desempeño del cargo de la administración persona jurídica (art. 236.5 LSC). La responsabilidad que asume la persona jurídica por el daño causado por el representante, lo será por existir culpa directa al actuar éste siguiendo instrucciones de la persona jurídica, o por culpa in vigilando, en los casos de no haber impartido instrucciones. No se olvide que la persona física designada es quien ejerce de modo permanente las funciones que como administrador tiene atribuida la persona jurídica administradora, estando sometida a los mismos deberes que todo administrador (art. 236.5 LSC).

${ }^{303}$ BRENES CORTÉS, J.: "Responsabilidad del representante persona física del administrador persona jurídica y su posible configuración como administrador de hecho”, 2018, op. cit., pp. 2 y. 5.

304 MARTÍNEZ SANZ, F. y BARTLE AGUSTÍN, M.: "Los administradores responsables", op. cit., p. 95; Vid. BRENES CORTÉS, J.: "Responsabilidad del representante persona física del administrador persona jurídica y su posible configuración como administrador de hecho", op. cit., 2018; RODRÍGUEZ DÍAZ, I.: "Cómo opera la responsabilidad solidaria del representante con el administrador persona jurídica”, Diario La Ley, $N^{o}$ 9304, Sección Tribuna, 22 de noviembre de 2018, edición digital, https://diariolaley.laleynext.es/Content/Documento.aspx?params=H4sIAAAAAAAEAMtMSbF1CTE AAiMLE0sTY7Wy1KLizPw8WyMDQwtDQwMjtbz81NQQF2fb0ryU1LTMvNQUkJLMtEqX_OSQ yoJU25Ki01S11KT8_GwUg-LhBqSm, pp. 3 y ss.

305 DEL VAL TALENS, P.: El administrador persona jurídica en las sociedades de capital, 2017, op. cit., p. 350.

306 DEL VAL TALENS, P.: El administrador persona jurídica en las sociedades de capital, 2017, op. cit., pp. 350-354. 
Cuando la persona jurídica sea uno de los integrantes de un órgano de administración pluripersonal, la persona jurídica en su condición de administradora y la persona designada responden solidariamente entre ellos (art. 236.5 LSC), por cuanto es la persona física la que ejerce las funciones del cargo. Pero no sólo esto, sino que, al mismo tiempo, ambos, formando un todo - un polo unitario de la pluralidad de administradores-, responden solidariamente con el resto de los administradores de los perjuicios causados a los acreedores (arts. 237 LSC). Solidaridad que se manifiesta en dos planos, por un lado, porque la persona jurídica administradora responde solidariamente con la persona física designada, -relación interna-, y, por otro lado, porque la persona jurídica como miembro del órgano de administración, conjuntamente con la persona física designada, al integrar a estos efectos una unidad, responden también solidariamente ante los acreedores con el resto de los integrantes del órgano solidaridad pasiva externa-, de modo que al responder la persona jurídica con el resto de los administradores, y al existir una responsabilidad solidaria de ella con la persona física designada, todos, en último término, están llamados a responder solidariamente.

Matiza esta conclusión RODRÍGUEZ DÍAZ ${ }^{307}$, quien señala que la persona física responde solidariamente con la persona jurídica administradora, pero no en teoría con el resto de los administradores, aunque concluye que "en la práctica ambos planos se entremezclan respondiendo solidariamente absolutamente todos frente al tercero perjudicado, quien podrá dirigir su acción contra cualquiera de ellos: si la persona jurídica responde solidariamente con los demás administradores y de la misma manera con su representante, éste también responderá solidariamente con aquellos” (sic).

Cuestión diversa sería que concurriera alguna causa de exoneración de responsabilidad en alguno de los administradores, en cuyo caso, éste podría ser excluido de la responsabilidad solidaria, lo que planteará qué efectos tiene esa exoneración en la persona física en cuanto representante de la persona jurídica administradora. En definitiva, corresponde determinar si, para que se exoneren de responsabilidad el representante y el administrador persona jurídica ante los terceros acreedores, ha de concurrir causa de exoneración en ambos, o, si por el contrario, es suficiente con que concurra en uno de ellos, con lo que quedaría exento de responsabilidad aquél en el que concurriese la causa de exoneración, sea el representante o la persona jurídica

307 RODRÍGUEZ DÍAZ, I.: “Cómo opera la responsabilidad solidaria del representante con el administrador persona jurídica”, op. cit., 2018, p. 6. 
administradora. Si la causa de exoneración concurriese en la persona jurídica administradora, deberíamos preguntarnos si cabría la posibilidad de que fuere responsable ante los terceros sólo la persona física y no el administrador persona jurídica. Si la persona jurídica en cuanto administrador acreditase la concurrencia de alguna causa de exoneración, quedaría liberada de responsabilidad la persona jurídica ante el acreedor sólo si al representante no le fuese imputable tampoco el daño, ya que las causas de exoneración son aplicables en la relación de los administradores con los acreedores -relación externa-. Pero si el daño fuese imputable a la persona física representante, la persona jurídica no quedaría exonerada, ya que, en cuanto administrador forma un todo unitario con el representante persona física, por lo que, la persona jurídica responde solidariamente con el resto de los administradores, sin perjuicio de la acción de repetición que tenga sobre el representante que hubiere actuado de modo culposo desconociendo sus instrucciones. Todo ello, porque la persona física designada "responde solidariamente con la persona jurídica administradora" (art. 236.5 LSC), y está sometida a los mismos deberes que los administradores, de modo que su responsabilidad arrastra la responsabilidad de la persona jurídica administradora. Para RODRÍGUEZ DÍAZ ${ }^{308}$, “el representante sólo responde solidariamente con los demás administradores cuando la persona jurídica representada también lo hace, pero no en caso contrario".

DEL VAL TALENS ${ }^{309}$, defiende la teoría de la individualización de la culpa del administrador persona jurídica y de su representante, porque alguno de los incumplimientos fiduciarios serán imputables a uno u otro, de modo que la declaración de responsabilidad del no infractor sería atribuible a la omisión del deber de vigilancia mutua, pero la dificultad reside en la apreciación de las causas de exoneración del art. 237 de la LSC, en la relación de solidaridad del art. 236.5 de la LSC de la persona jurídica administradora y su representante, ya que las causas de exoneración del art. 237 de la LSC están concebidas para la solidaridad pasiva externa de los administradores, y no tanto para la solidaridad pasiva del administrador persona jurídica y su representante, porque ambas presunciones de solidaridad responden a relaciones fiduciarias diversas. Para esta autora, la solidaridad del art. 236.5 de la LSC, no es incompatible con la

308 RODRÍGUEZ DÍAZ, I.: “Cómo opera la responsabilidad solidaria del representante con el administrador persona jurídica”, op. cit., 2018, p. 6.

309 DEL VAL TALENS, P.: El administrador persona jurídica en las sociedades de capital, 2017, op. cit., pp. 353-355, 357-361 y 384-385. 
individualización de las culpas, concluyendo que, ante reclamaciones de responsabilidad, ambos se beneficiarán de dos tipos de circunstancias exoneratorias del art. 237 de la LSC, ya que (sic) "el voto favorable del acuerdo lesivo o la ausencia injustificada de la reunión por parte del representante también perjudican al titular, al tiempo, que la abstención con oposición expresa y las medidas adoptadas para minimizar el daño podrán ser aducidas por el principal” ya que, la persona jurídica no podrá alegar que no intervino o no conoció el acuerdo lesivo, porque quien actúa materialmente es el representante, y porque con relación a las causas de hacer lo suficiente para evitar el daño, o de haberse opuesto al mismos, quien habrá votado es el representante, y quien podrá impugnar el acuerdo lesivo será éste, aunque en ambos casos su ejercicio se imputa a la persona jurídica administradora.

Esto nos lleva a plantear claramente la cuestión que dejamos antes apuntada, y es, si cuando el daño lo causa la persona física sin culpa de la persona jurídica administradora, sin que cupiese ni tan siquiera la culpa in vigilando, por ejemplo, por haber impartido expresamente instrucciones a la persona física de no ejecutar o acordar el acto causante del daño sin haber podido destituir a tiempo a la persona física, hemos de preguntarnos, si también responde la persona jurídica administradora en esos supuestos tan excepcionales, o por el contrario, si sólo respondería la persona física con el resto de administradores de hallarnos ante un órgano pluripersonal de administración.

Cabrían tres respuestas, en primer lugar, una respuesta negativa, entendiendo que no respondería la persona jurídica, porque al concurrir causa de exoneración en ella, la persona jurídica administradora no respondería ante el tercero acreedor, respondiendo sólo el resto de los administradores y la persona física representante, y ésta por no concurrir en ella causa de exoneración (art. 237 LSC). Sería una teoría de la individualización de la culpa llevada a sus extremos, en virtud de la cual respondería sólo la persona física, pero no la persona jurídica por concurrir en ella causa de exoneración, con lo que éstas se podrían apreciar separadamente en la persona jurídica y en su representante. Interpretación que rechazamos, porque, llevaría a exonerar de responsabilidad a la persona jurídica administradora, y hacer responsable sólo a la persona física, que no tiene la condición de administrador, conjuntamente con el resto de los administradores, cuando la causa de exoneración ha de concurrir en el administrador, y cuando éste es persona jurídica forma un todo inseparable con su representante, no se entiende uno sin el otro. No se olvide que la persona física responde 
solidariamente con la persona jurídica administradora (art. 236.5 LSC), de modo que, si ésta no responde, no debería responder la persona física, ya que la condición de administradora es de la persona jurídica.

Para una segunda interpretación, para que responda la persona jurídica cuando la culpa sea imputable sólo a la persona física representante, al no poder hacer responsable sólo a la persona física se defiende que la responsabilidad de ésta arrastra la responsabilidad de la persona jurídica, cuando menos por culpa in vigilando. En definitiva, no cabría la exoneración de la persona jurídica, ya que siempre se aplicaría la culpa in vigilando ${ }^{310}$. Pero con esta interpretación, de imputar la responsabilidad a la persona jurídica por culpa in vigilando, no se contempla o responde al hecho muy excepcional, pero no imposible, de que no concurriese incluso la culpa in vigilando en un concreto acto dañoso.

Cabe una tercera interpretación, que defendemos, entender que sí sería responsable la persona física designada y la persona jurídica en cuanto administradora, ya que éstas forman "un todo", una unidad ante terceros, por lo que, la persona jurídica no podría ser ajena al daño si proviene de su representante. Ambos son un "polo unitario", un todo, también cuando exista pluralidad de administradores, de modo que, la causa de exoneración del art. 237 LSC debe concurrir conjuntamente en la persona jurídica y en su representante ${ }^{311}$. De este modo, si existe culpa de la persona física sin causa de

310 RODRÍGUEZ DÍAZ, I.: "Cómo opera la responsabilidad solidaria del representante con el administrador persona jurídica”, op. cit., 2018, p. 6, para quien, (sic) "demostrada la culpabilidad del representante, ipuede quedar exonerada la persona jurídica representada? La posibilidad de individualizar la culpa y de quedar liberada cuando no se ha participado en el supuesto dañoso, nos permite afirmar que la responsabilidad de la persona jurídica se sustentaría entonces en la culpa in vigilando pero, ¿y si por difícil que sea, el administrador persona jurídica demuestra que cumplió rigurosamente con su deber de vigilancia? ¿Podríamos en este caso sostener la posible existencia de una responsabilidad solidaria entre el representante y el resto de administradores responsables frente al perjudicado? Por supuesto que no, puesto que el representante solo responde solidariamente con la persona jurídica y con los demás administradores cuando ella forma parte del grupo de los responsables, mezclándose así los planos señalados. El representante solo responde solidariamente con los demás administradores cuando la persona jurídica representada también lo hace, pero no en caso contrario. Ello nos conduce a aseverar que, en un supuesto de responsabilidad colectiva, cuando el representante es culpable y no lo es la persona jurídica por no haber tomado parte en el supuesto dañoso, necesariamente ha de responder por culpa in vigilando para que opere la solidaridad frente a terceros con todas las garantías necesarias. Por ello, podríamos decir que, en este caso, el destino del representante y de la persona jurídica están irremediablemente unidos".

311 "HERNÁNDEZ SAINZ, E.: La Administración de sociedades de capital por personas jurídicas. Régimen Jurídico y responsabilidad, Aranzadi, 2014, edición digital, https://insignis-aranzadidigitales.ponton.uva.es $/ \mathrm{maf} / \mathrm{app} /$ document? startChunk=1\&endChunk=2\&nstid=marginal\&stid=marginal\&in fotype=biblos\&marginal=BIB $\backslash 2014 \backslash 9$ p. 13, quien con anterioridad a la introducción de la responsabilidad solidaria de la persona física y la persona jurídica, ya señalaba que, "la responsabilidad del ente moral se rige por las previsiones de la LSC y conforme al artículo 237 LSC sólo podría exonerarse si no hubiese intervenido en la adopción y ejecución del acuerdo o acto lesivos. 
exoneración de ésta, la persona jurídica administradora responde con el resto de administradores y con la persona física designada ante los terceros que han sufrido el daño. Cuestión distinta será cómo opera la vía de regreso entre los distintos administradores, en cuyo caso, en el supuesto excepcional de laboratorio que hemos planteado, la cuota unitaria que corresponde "al todo formado por administrador persona jurídica y persona física designada" debería ser asumida de modo íntegro por la persona física culpable, por lo que la persona jurídica administradora mediante una acción de reintegro exigiría a la persona física el pago íntegro de la cuota unitaria correspondiente a ambos. Estaríamos ante un posible supuesto en el que, en puridad, no habría imputabilidad de la persona jurídica administradora al concurrir causa de exoneración en la misma, pero sí en la persona física representante, y si defendemos que la persona física sólo responde si hay responsabilidad de la persona jurídica, exoneraríamos también a esa persona física que consumó un acto lesivo, lo que no es coherente con la responsabilidad por daños. Por ello debemos entender que hay imputabilidad de la persona jurídica administradora, cuando el acto lesivo le sea atribuible, o la persona física o a la persona jurídica, o bien a ambos conjuntamente, y que para que opere la exoneración del art. 237 LSC, no ha de ser imputable el daño a ninguno de los dos, porque en estos casos la condición de administrador es un todo formado por la persona jurídica de modo indisoluble a la persona física. BRENES CORTÉS ${ }^{312}$ señala al respecto, que, "tanto la persona jurídica administradora como el representante persona física tienen la consideración de administradores, están sujetos a su disciplina jurídica y, en consecuencia, se le puede exigir su responsabilidad solidaria sin necesidad de investigar si concurriría alguna circunstancia que permitiera imputar a uno solo la responsabilidad derivada de la actuación que ha causado el daño que debe ser indemnizado".

Si ante terceros eximimos a la persona jurídica haciendo responsables solidarios al resto de los administradores con la persona física designada, desconoceríamos que en el art. 237 LSC se establece presunción de la solidaridad o responsabilidad de los

No puede considerarse que no intervino en la acción u omisión si ésta proviene de su propio representante voluntario".

312 BRENES CORTÉS, J.: "Responsabilidad del representante persona física del administrador persona jurídica y su posible configuración como administrador de hecho”, 2018, op. cit., p. 19, quien señala que, "tanto la persona jurídica administradora como el representante persona física tienen la consideración de administradores, están sujetos a su disciplina jurídica y, en consecuencia, se le puede exigir su responsabilidad solidaria sin necesidad de investigar si concurriría alguna circunstancia que permitiera imputar a uno solo la responsabilidad derivada de la actuación que ha causado el daño que debe ser indemnizado". 
administradores, condición que ostenta la persona jurídica en cuanto un todo con la persona física, con lo cual, incluiríamos en una responsabilidad solidaria en función del art. 237 LSC, a alguien que, por sí sólo, no es administrador. La persona física responde de modo solidario con la persona jurídica administradora ante terceros, en virtud del art. 236.5 de la LSC, pero a su vez, esta responsabilidad solidaria depende de que sea operativa la responsabilidad solidaria del art. 237 de la LSC, de modo que la exoneración de la persona jurídica al amparo del art. 237 LSC, opera plenamente cuando el acto dañoso no sea imputable ni a la persona física ni a la persona jurídica. Con ello, evitamos que responda ante los terceros, sólo la persona física con el resto de los administradores.

Al existir solidaridad pasiva externa el acreedor podrá reclamar contra todos los responsables solidarios, o contra alguno de ello, sin ser obstáculo, en este caso, las ulteriores reclamaciones ante el resto de los responsables hasta obtener la reparación del daño (art. 1144 del Código Civil). El acreedor puede libremente elegir a quién exige la reparación de la integridad del daño (ius eligendi), si a la persona jurídica administradora, si a la persona física representante, si al resto de los administradores, o si a todos conjuntamente, ya que en la relación externa de los responsables con el acreedor la solidaridad opera plenamente ${ }^{313}$, aunque los diversos responsables no estén ligados del mismo modo o condición (art. 1140 del Código Civil), sin que la reclamación entablada contra alguno de ellos, impida al acreedor reclamar contra el resto hasta la integra reparación del daño (ius variandi). Sujetos pasivos de la acción individual de responsabilidad, lo serán todos los administradores, y en el caso de ser alguno una persona jurídica, sujetos pasivos lo serán los administradores y el representante persona física ${ }^{314}$, teniendo el ius eligendi y el ius variandi el acreedor, para reclamar el total de la reparación del daño a todos o al cualquiera de ellos.

Cuestión distinta es cómo opera la solidaridad interna, entre los corresponsables, ya que el pago realizado por uno de ellos abre la vía de regreso para exigir al resto su parte alícuota de responsabilidad. Ante la especialidad de que alguno de los administradores sea una persona jurídica, surge la cuestión de aclarar cómo opera el reparto de cuotas, si es sólo entre los administradores sin incluirse al representante-cuota única, o sí, por el

313 RODRÍGUEZ DÍAZ, I.: "Cómo opera la responsabilidad solidaria del representante con el administrador persona jurídica", op. cit., 2018, p. 8.

314 DEL VAL TALENS, P.: El administrador persona jurídica en las sociedades de capital, 2017, op. cit., p. 367. 
contrario, el daño ha de repartirse incluyendo en la parte de cuota no sólo a la persona jurídica sino también a la persona física representante. Nuestra postura es entender que al existir entre los administradores una responsabilidad solidaria externa (art. 237 de la LSC), el reparto de cuotas será entre ellos, entre los que ostenten la condición de administradores, sin computarse a la persona física, de modo que, en la persona jurídica administradora, su cuota es única, no se duplica con la persona física, ya que ésta forma un todo con la persona jurídica en la relación inter-administradores ${ }^{315}$.

\subsubsection{Personal de alta dirección y apoderados generales.}

El personal de alta dirección no mantiene una relación de integración orgánica con la sociedad, como es la propia de los administradores, sino que está vinculado mediante una relación laboral de carácter especial ${ }^{316}$.

En el art. 1.2 del Real Decreto 1382/1985, de 1 de agosto, por el que se regula la relación laboral de carácter especial del personal de alta dirección, se establece que, "se considera personal de alta dirección a aquellos trabajadores que ejercitan poderes inherentes a la titularidad jurídica de la Empresa, y relativos a los objetivos generales de la misma, con autonomía y plena responsabilidad sólo limitadas por los criterios e instrucciones directas emanadas de la persona o de los órganos superiores de gobierno y administración de la Entidad que respectivamente ocupe aquella titularidad".

Al ejercitar los poderes inherentes a la titularidad de la sociedad bajo las instrucciones del órgano de administración, a priori podrían causar daño directo con sus actuaciones en los derechos de crédito de los acreedores de la sociedad de capital $^{317}$, y a nuestros efectos en los derechos económicos de la Seguridad Social, por lo que, al no ser administradores sociales no podría exigírseles la responsabilidad por daños, por cuanto que en el art. 236.1 de la LSC se señala que los administradores sociales responden ante terceros del daño que causen.

Igualmente podrán causar daño a los acreedores de la sociedad de capital los apoderados, especialmente los que ostentan poderes generales o lo más amplios de

\footnotetext{
315 En igual sentido de defender la cuota única, DEL VAL TALENS, P.: El administrador persona jurídica en las sociedades de capital, op. cit. p. 355.

${ }^{316}$ Real Decreto 1382/1985, de 1 de agosto, por el que se regula la relación laboral de carácter especial del personal de alta dirección -BOE del 12.8.1985-.

317 GRIMALDOS GARCÍA, M. I.: "Presupuestos y extensión subjetiva de la responsabilidad. Solidaridad: artículos 236 y 237. Otras acciones por infracción del deber de lealtad: artículos 227.2 y 232”, op. cit., p. 328.
} 
gestión y representación (apoderados generales), quienes no están sujetos a una relación laboral, sino que en terminología del Código de Comercio vendrían a ser los factores ${ }^{318}$, vinculados por una relación de representación o mandato con la sociedad. Pero al no ser administradores, quedarían excluidos de la aplicación del régimen de responsabilidad de los administradores.

Pese a que tanto el personal de alta dirección como los apoderados pudieran ejercitar funciones de la más alta dirección y, en consecuencia, pudieran causar daño a terceros, al no tener la condición de administradores quedaban excluidos del régimen de responsabilidad aplicable a éstos, respondiendo sólo los administradores ante los acreedores mediante la acción individual de responsabilidad, salvo que se acreditase que nos hallásemos ante verdaderos administradores de hecho de la sociedad ${ }^{319}$.

Ésta ha sido la situación legislativa y jurisprudencial hasta que se amplió el ámbito subjetivo de las personas sometidas a la responsabilidad por daños de los administradores en la sociedad de capital, para incluirse no sólo a los administradores, sino también a personas asimiladas, a todos aquellos que tengan atribuidas facultades de la más alta dirección de la sociedad, cualquiera que sea su denominación, donde hemos de incluir al personal de alta dirección y a los apoderados generales ${ }^{320}$.

Con la reforma del art. 236 de la LSC, por la Ley 31/2014, de 3 de diciembre, se ha ampliado el ámbito subjetivo de la responsabilidad por daños del administrador social, introduciéndose un nuevo apartado 4, donde se establece expresamente que, “cuando no exista delegación permanente de facultades del consejo en uno o varios consejeros delegados, todas las disposiciones sobre deberes y responsabilidad de los administradores serán aplicables a la persona, cualquiera que sea su denominación, que tenga atribuidas facultades de más alta dirección de la sociedad, sin perjuicio de las acciones de la sociedad basadas en su relación jurídica con ella".

Con esta reforma legal se ha hecho eco el legislador del contenido del Informe Aldama, en el que se proponía la extensión de los deberes de lealtad de los administradores, y de

${ }^{318}$ QUIJANO GONZÁLEZ, J.: La responsabilidad civil de los administradores de la Sociedad Anónima, aspectos sustantivos, op. cit., pp. 328 y ss; MARTÍNEZ SANZ, F. y BARTLE AGUSTÍN, M.: "Los administradores responsables", op. cit., p. 90.

319 SSTS, Sala Civil, 760/2002, de 16 de julio -Rec. 304/1997-; 222/2004 de 22 de marzo -Rec. 1556/1998-; 261/2007, de 14 de marzo -Rec. 262/2000, entre otras.

320 GRIMALDOS GARCÍA, M. I.: "Presupuestos y extensión subjetiva de la responsabilidad. Solidaridad: artículos 236 y 237. Otras acciones por infracción del deber de lealtad: artículos 227.2 y 232”, op. cit., p. 328. 
la consiguiente responsabilidad a "los altos ejecutivos de la sociedad, aunque no ostentasen la condición de consejeros".

Extensión del régimen de responsabilidad a este personal que ya se defendía en la doctrina científica ${ }^{321}$, por cuanto que personas que realizan cometidos muy similares a los de los administradores, con un alto grado de autonomía, no deberían quedar excluidos de iguales obligaciones y responsabilidades.

Con el actual art. 236.4 de la LSC se ha venido a clarificar la responsabilidad por daños del personal de alta dirección y de los apoderados generales, quienes responderán al igual que los administradores, debido al contenido de sus poderes de dirección, gestión o representación, siempre que concurran dos circunstancias. En primer lugar, que estemos ante un órgano de administración constituido en forma de Consejo de Administración, no en otro caso, por el carácter sancionador o restrictivo que tiene esta responsabilidad, lo que impide una aplicación extensiva de sus preceptos. En segundo lugar, que en el Consejo de Administración no haya delegación permanente de funciones, en uno o varios consejeros delegados o en una comisión ejecutiva ${ }^{322}$, ya que, pese a la omisión u olvido por el legislador de la comisión ejecutiva, entendemos que debe incluirse por existir identidad de razón. Si hubiere delegación de funciones dentro del Consejo de Administración, el personal directivo estaría sujeto a las directrices de los consejeros delegados, por lo que ya no ocuparía igual posición funcional y societaria, y no estaría sujeto a este régimen de responsabilidad. Para que sea exigible la responsabilidad a ese personal ejecutivo no consejero, es necesario que concurran esos dos requisitos de modo acumulativo.

Con este reconocimiento legal, el personal de alta dirección y los apoderados generales (personal ejecutivo no consejero) quedan sometidos a las mismas responsabilidades que los administradores. No obstante, si ese personal de alta dirección o esos apoderados

${ }^{321}$ QUIJANO GONZÁLEZ, J.: La responsabilidad civil de los administradores de la Sociedad Anónima, aspectos sustantivos", op. cit., pp. 328-333 y 372, quien ya proponía que se declarare expresamente aplicable el régimen de responsabilidad, previsto para los administradores, al Director General, así como la responsabilidad solidaria de administradores, apoderados y directores generales; Igualmente, JUSTE MENCÍA, J.: "La posición del equipo directivo en la estructura de gobierno de la sociedad cotizada: la responsabilidad de los Consejeros ejecutivos y miembros de la Alta Dirección", en AA.VV. (Dir.: RODRÍGUEZ ARTIGAS, F.; ALONSO UREBA, A.; FERNÁNDEZ DE LA GÁNDARA, L.; VELASCO SAN PEDRO, L. A.; QUIJANO GONZÁLEZ, J.; y ESTEBAN VELASCO, G.): Derecho de Sociedades Anónimas cotizadas, Vol. II, Elcano, 2005, pp. 1036 y 1047.

322 GRIMALDOS GARCÍA, M. I.: "Presupuestos y extensión subjetiva de la responsabilidad. Solidaridad: artículos 236 y 237. Otras acciones por infracción del deber de lealtad: artículos 227.2 y 232”, op. cit., p. 328. 
fuesen calificados como verdaderos administradores de hecho, la responsabilidad exigible no sería la del art. 236.4 de la LSC, sino la responsabilidad del administrador de hecho del art. 236.3 de la $\operatorname{LSC}^{323}$, con lo que no se limitaría su responsabilidad a los supuestos de administración organizada en forma de Consejo de Administración.

\subsubsection{Administradores responsables en los grupos de sociedades.}

Inicialmente cada sociedad integrante de un grupo societario tiene sus propios órganos de administración, siendo esos administradores los sujetos responsables ante los acreedores de cada una de las sociedades integrantes del grupo, en función de la personalidad jurídica de cada entidad, sin que exista comunicación de responsabilidades intra-grupo, sin poderse predicar una responsabilidad solidaria de las sociedades del grupo, salvo que pudiéramos recurrir a la doctrina jurisprudencial del levantamiento del velo, o nos encontrásemos ante la empresa grupo o grupos patológicos o, finalmente, salvo que pudiera atribuirse a la sociedad dominante, y/o, a sus administradores la condición de administradores de hecho de las sociedades dominadas.

En el tráfico jurídico es muy frecuente la presencia de grupos de sociedades que se hallan bajo una misma dirección unitaria, en busca de maximizar su eficiencia en la consecución del objeto social del grupo, y/o de los objetos o actividades sociales de las sociedades integrantes del grupo, bien sean grupos con estructura jerárquica, o bien sean grupos con una estructura de coordinación u horizontal.

El grupo de sociedades tiene amparo jurídico en los derechos de propiedad y de libertad de empresa de los artículos 33 y 38 de la Constitución Española, que permite a la sociedad dominante ejercer la política de gestión general fijando la estrategia de las sociedades del grupo ${ }^{324}$.

Los grupos societarios no han sido objeto de una regulación jurídica general de su régimen jurídico, encontrando una definición de los mismos en el art. 42.1 del Código de Comercio, al que se remite el art. 18 de la LSC. Se define al grupo de sociedades

323 SSTS, Sala Civil, 222/2004, de 22 de marzo -Rec. 1556/1998-; 261/2007, de 14 de marzo -RJ 2007\1793-; 501/2007, de 7 de mayo -Rec. 2225/2000-; y 240/2009, de 14 de abril, -Rec. 1504/2004-, entre otras.

324 VICENT CHULIÁ, F.: “Grupos de sociedades y conflictos de intereses", en Revista de Derecho Mercantil, núm. 280, 2011, edición digital,

https://insignis-aranzadidigitales.ponton.uva.es/maf/app/document?srguid=i0ad82d9a000001744955ae86ecf341d 3\&marginal=BIB 12 011\1486\&docguid=I09fd9020, p. 1. 
cuando una sociedad dominante ejerce el control sobre otras u otras sociedades dependientes.

El grupo de sociedades es plenamente válido en nuestro ordenamiento jurídico, aunque no tengamos una regulación general de su régimen jurídico, sin que la existencia de una dirección unitaria implique una comunicación de responsabilidades solidarias entre las sociedades del grupo ${ }^{325}$.

Que no exista una regulación general sobre las responsabilidades en los grupos societarios, no quiere decir que los acreedores sociales queden desprotegidos, ya que éstos podrán defender sus derechos e intereses legítimos acudiendo a la aplicación general de las normas del Derecho de sociedades para exigir la responsabilidad de la sociedad dominante por las instrucciones impartidas a los órganos sociales de la sociedad filial ${ }^{326}$.

Al ser los grupos societarios inocuos jurídicamente, salvo situaciones de fraude a terceros, la cuestión será cómo coordinar los intereses de la sociedad dominante o los intereses del grupo, con los intereses de las sociedades dominadas, si al seguirse las instrucciones de la matriz se puede causar un perjuicio a la sociedad filial, con posible daño a sus acreedores.

Al no hallarse reconocido el interés del grupo como preeminente sobre los intereses de las filiales, ni regulada la responsabilidad de la sociedad dominante o de sus administradores por instrucciones impartidas a los administradores de la sociedad dominada o filial, cuando esas instrucciones pueden causar perjuicio en la filial, se viene aplicando el principio de ventajas compensatorias, de modo que serían lícitas las instrucciones de la matriz, cuando pudiendo causar un daño en la filial, ese daño quede compensado por las ventajas de estar integrada en el grupo la sociedad dependiente ${ }^{327}$, pero, y esto es lo importante, siempre que con ello no se perjudique a los acreedores de la filial, ya que en ese caso, si los administradores de la filial causan daño a sus

${ }^{325}$ SSTS, Sala Social, de 21 de diciembre de 2000 -Rec. 4383/1999-; 26 de diciembre de 2001 -Rec. 139/2001-; de 30 de abril de 1999 -Rec. 4003/1998- y STS, Sala Contencioso-Administrativa, 1661/2018, de 22 de noviembre -Rec. 2507/2016-.

${ }^{326}$ VICENT CHULIÁ, F.: "Grupos de sociedades y conflictos de intereses", op. cit., edición digital, p. 5.

${ }^{327}$ Vid. al respecto MARTÍNEZ-GIRÓN MACHUCA, P.: "Algunas reflexiones sobre la responsabilidad de los administradores en los grupos de sociedades tras la sentencia del Tribunal Supremo de 11 de diciembre de 2015", en AA.VV. (Coord.: BRENES CORTÉS, J.; Dir.: DÍAZ MORENO, A.; y VÁZQUEZ CUETO, J. C.): Estudios sobre la responsabilidad de los administradores de las sociedades de capital a la luz de sus Recientes reformas legislativas y pronunciamientos judiciales, Thomson Reuters Aranzadi, 2018, $1^{\mathrm{a}}$ edición, pp. 161 a 265. 
acreedores siguiendo las instrucciones de la sociedad matriz, es razonable plantearse la posible responsabilidad de la matriz y sus administradores ante los mismos, en primer lugar, como administradores de hecho de la filial ${ }^{328}$, o en segundo lugar, como coautores del daño, en función de la doctrina jurisprudencial de la solidaridad impropia por coparticipación en un resultado dañoso causado por acto ilícito (Sentencias del TS, Sala Civil, 670/2010, 4 noviembre, -Rec. 422/2007- y 187/2008, de 28 de febrero, entre otras).

Doctrina de las ventajas compensatorias que se recoge en la Sentencia del TS, Sala Civil, 695/2015, de 11 de diciembre -Rec. 2141/2013- ${ }^{329}$, de la cual pueden extraerse

${ }^{328}$ DÍAZ ECHEGARAY, J. L.: Deberes y responsabilidades de los Administradores de Sociedades de Capital, 2006, op. cit. pp. 293-301; SÁNCHEZ CALERO, F.: Los Administradores en las Sociedades de Capital, 2007, op. cit. pp. 361-363; VICENT CHULIÁ, F.: "Grupos de sociedades y conflictos de intereses", op. cit., edición digital, p. 3; MARTÍNEZ SANZ, F. y BARTLE AGUSTÍN, M.: "Los administradores responsables”, 2016, op. cit., pp. 87-90; HERNANDO CEBRIÁ, L.: “¿Sociedad dominante administradora de hecho? Más allá del velo corporativo", op. cit., pp. 25-31; MARTÍNEZGIRÓN MACHUCA, P.: "Algunas reflexiones sobre la responsabilidad de los administradores en los grupos de sociedades tras la Sentencia del Tribunal Supremo de 11 de diciembre de 2015", op. cit., pp. 161-178; MORENO SERRANO, E.: "La responsabilidad de la sociedad matriz como administrador de hecho”, en AA.VV. (Coord.: BRENES CORTÉS, J.; Dir.: DÍAZ MORENO, A.; y VÁZQUEZ CUETO, J. C.): Estudios sobre la responsabilidad de los administradores de las sociedades de capital a la luz de sus recientes reformas legislativas y pronunciamientos judiciales, Thomson Reuters Aranzadi, 2018, 1ª edición, pp. 259-264; RODRÍGUEZ SÁNCHEZ, S.: "La delimitación de la figura del administrador de hecho", 2016, op. cit, edición digital, p. 14.

${ }^{329}$ En el Fundamento de Derecho Tercero, se señala, "La integración de la sociedad en un grupo societario, incluso aunque lo sea en concepto de sociedad filial o dominada, no supone la pérdida total de su identidad y autonomía. La sociedad filial no solo conserva su propia personalidad jurídica, sino también sus concretos objetivos y su propio y específico interés social, matizado por el interés del grupo, y coordinado con el mismo, pero no diluido en él hasta el punto de desaparecer y justificar cualquier actuación dañosa para la sociedad por el mero hecho de que favorezca al grupo en que está integrado. El administrador de la sociedad filial tiene un ámbito de responsabilidad que no desaparece por el hecho de la integración en un grupo societario, pues tal integración no deroga sus obligaciones de gestión ordenada, representación leal, fidelidad al interés de la sociedad, lealtad y secreto que le incumben como tal administrador social y que vienen referidos a la sociedad de la que es administrador, no al grupo societario ni a otras sociedades integradas en el grupo. El interés del grupo no es absoluto y no puede justificar un daño a la sociedad filial que suponga un perjuicio injustificado a los acreedores y socios externos de la sociedad filial. El administrador de la sociedad filial que realiza una actuación que causa un daño a la sociedad que administra no queda liberado de responsabilidad por el simple hecho de que tal actuación haya sido acordada por quien dirige el grupo societario. El administrador no puede escudarse en las instrucciones recibidas de la dirección unitaria del grupo a que pertenece la sociedad que administra. El administrador de Derecho de la sociedad filial tiene su ámbito propio de autonomía de decisión que no puede verse afectado por una especie de "obediencia debida" a las instrucciones del administrador del grupo que perjudique injustificadamente los intereses de la sociedad que administra, por los que ha de velar. Aunque lo anterior bastaría para rechazar el argumento del recurso, debe recordarse que la Audiencia Provincial ha declarado que el recurrente participa en el círculo de control del grupo de sociedades y tuvo intervención activa en la decisión de crear una nueva sociedad en Francia y desviarle la clientela francesa que tenía la sociedad española. Ciertamente, la existencia de un grupo de sociedades supone que, cuando se produzcan conflictos entre el interés del grupo y el interés particular de una de las sociedades que lo integran, deba buscarse un equilibrio razonable entre un interés y otro, esto es, entre el interés del grupo y el interés social particular de cada sociedad filial, que haga posible el funcionamiento eficiente y flexible de la unidad empresarial que supone el grupo de sociedades, pero impida a su vez el expolio de las 
las siguientes conclusiones: $1^{\circ} \mathrm{El}$ administrador de la sociedad filial tiene un ámbito de responsabilidad que no desaparece por el hecho de la integración en un grupo societario; $2^{\circ}$ el interés del grupo no es absoluto, no está por encima del interés de las sociedades del grupo, por lo que no puede ser causa justificante de un daño a la filial o a sus acreedores; $3^{\circ}$ deben cohonestarse los intereses de las sociedades del grupo, sirviendo como criterio de validación la doctrina de las ventajas compensatorias, cuando el conjunto de operaciones globales del grupo reporta un beneficio para los socios externos y los acreedores; $4^{\circ}$ que la técnica de las ventajas compensatorias tendrán como límite, que las instrucciones de la sociedad matriz no pueden comprometer la viabilidad y la solvencia de la filial.

El reconocimiento legal de la responsabilidad del administrador de hecho nos va a permitir exigir la responsabilidad de la sociedad dominante y de sus administradores, en cuanto puedan ser calificados como administradores de hecho de la sociedad dominada $^{330}$, responsabilidad que podrán asumirla de modo exclusivo o compartirla

sociedades filiales y la postergación innecesaria de su interés social, de manera que se proteja a los socios externos y a los acreedores de cualquier tipo, públicos, comerciales o laborales. Ese equilibrio puede buscarse en la existencia de ventajas compensatorias que justifiquen que alguna actuación, aisladamente considerada, pueda suponer un perjuicio para la sociedad. Tales ventajas no tienen que ser necesariamente simultáneas o posteriores (esto es, simultáneamente o tras la actuación perjudicial para la filial se produce otra beneficiosa que compensa el daño), sino que ha podido ser también previa (por ejemplo, que previamente a la actuación perjudicial hubiera existido un beneficio patrimonial apreciable, generado por el grupo a favor de su sociedad filial o derivado de la pertenencia de la sociedad al grupo, que hay que tomar en consideración cuando posteriormente se produce la actuación que perjudicó a la sociedad filial). Se trata de realizar un balance de las ventajas facilitadas o las prestaciones realizadas en ambas direcciones (de la sociedad al grupo y del grupo a la sociedad) y concluir si existe o no un resultado negativo para la sociedad filial. Las ventajas o prestaciones realizadas por el grupo a favor de la sociedad filial deben ser verificables, sin que sean suficientes meras hipótesis, invocaciones retóricas a "sinergias" o a otras ventajas faltas de la necesaria concreción, que carezcan de consistencia real, aunque sí pueden consistir en oportunidades de negocio concretas, dotadas de valor patrimonial, como pueden ser las inherentes a una cesión de clientela. En todo caso, han de tener un valor económico, y guardar proporción con el daño sufrido por la sociedad filial en la actuación por la que se exige responsabilidad, en este caso, exclusivamente al administrador de la sociedad filial. Asimismo, han de resultar debidamente justificadas, pues de no serlo habrá que entender producido el daño directo para la sociedad filial de la que deriva la responsabilidad del administrador demandado. El argumento del interés de grupo y la alegación de los beneficios que, en abstracto, supone la integración en un grupo societario, si no van acompañados de una justificación razonable y adecuada de que la actuación del administrador resultó además provechosa para la sociedad filial, no excluye la existencia de un daño directo del que el administrador debe responder". La cursiva es nuestra.

Doctrina de las ventajas compensatorias que se recoge en Sentencia del TS, Sala Civil, 407/2017 de 27 junio, en que una sociedad filial, posteriormente declarada en concurso, constituye una hipoteca en garantía de un préstamo bancario concedido a la matriz, con garantías cruzadas entre las sociedades, considerando que no es una cesión gratuita de la concursada, partiendo de las ventajas compensatorias.

${ }^{330}$ VICENT CHULIÁ, F.: “Grupos de sociedades y conflictos de intereses”, op. cit., edición digital, p. 3, que en los grupos patrológicos apunta la posible condición de administrador de hecho de la sociedad dominante; MARTÍNEZ-GIRÓN MACHUCA, P.: “Algunas reflexiones sobre la responsabilidad de 
con los administradores de la sociedad dominada ${ }^{331}$. Como regla general será compartida, porque no es causa eximente del incumplimiento de los deberes legales inherentes al cargo de los administradores de la sociedad dominada, la circunstancia de haberse visto obligados a seguir las instrucciones de los administradores de la sociedad matriz $^{332}$.

La figura del administrador de hecho de la sociedad dominante será el instrumento jurídico para hacer responsable a la sociedad dominante o a los administradores de la sociedad dominante de los daños causados en los créditos de Seguridad Social frente a la sociedad dominada.

\subsubsection{Administradores de sociedades mercantiles de capital del Estado.}

Las Administraciones Públicas, y entre ellas la Administración General del Estado, podrán acogerse a las formas de organización del Derecho privado, y más concretamente del Derecho de sociedades para la gestión de determinados bienes y servicios de interés público, o para intervenir en el mercado como un agente económico más. Sociedades mercantiles estatales que forman parte de la llamada Administración Institucional o sector público institucional (art. 2.2, apartado c y 3.2, apartado b de la Ley 47/2003, de 26 de noviembre, General Presupuestaria-LGP- ${ }^{333}$, art. 166.1, c y 2 de la Ley 33/2003, de 3 de noviembre, del Patrimonio de las Administraciones Públicas LPAP- $^{334}$, y arts. 2.2, apartado b, 84.1, apartado c de la Ley 40/2015, de 1 de octubre, de Régimen Jurídico del Sector Público -LRJSP- ${ }^{335}$ ).

La sociedad de capital de titularidad o participación de la Administración General del Estado forma parte del sector público empresarial (art. 3.2 LGP y art. 2.2 de la LRJSP), rigiéndose por las disposiciones normativas del tipo societario elegido, así como por la LRJSP, la LPAP, o la LGP en lo expresamente establecido para la sociedad de capital estatal (art. 113 de la LRJSP y arts. 166.2 y 167.2 de la LPAP). Se hallan sometidas igualmente al Derecho público administrativo en materia presupuestaria, contable, de

los administradores en los grupos de sociedades tras la sentencia del Tribunal Supremo de 11 de diciembre de 2015", op. cit., p. 167, para quien podrá atribuirse en los grupos de sociedades la condición de administrador de hecho a la sociedad dominante y a sus administradores; RODRÍGUEZ SÁNCHEZ, S.: "La delimitación de la figura del administrador de hecho”, 2016, op. cit., edición digital, p. 14.

${ }^{331}$ SÁNCHEZ CALERO, F.: Los Administradores en las Sociedades de Capital, 2007, op. cit., p. 363.

${ }^{332}$ STS, Sala Civil, 695/2015 de 11 diciembre -Rec. 2141/2013-.

${ }^{333}$ BOE del 27.11.2003.

${ }^{334}$ BOE del 04.11.2003.

335 BOE del 02.10.2015. 
selección de personal, de control económico-financiero y de contratación (art. 113 de la LRJSP y art. 166.2 LPAP).

Se califican como sociedades mercantiles estatales aquellas sociedades mercantiles sobre la que se ejerce control por la Administración General del Estado. Entendiéndose que se tienen el control por el Estado, a) cuando la Administración del Estado o alguna de las entidades que integran el sector público institucional estatal, incluidas las sociedades mercantiles estatales, ostenten una participación directa superior al 50 por 100 en el capital de la sociedad, o b) cuando sin tener la mayoría del capital, tengan el control societario al amparo de lo establecido en el art. 42 del Código de Comercio (art. 111.1 de la LRJSP y art. 166.1.c. de la LPAP).

El régimen jurídico específico de responsabilidad por daños de los administradores en las sociedades mercantiles estatales está recogido en los arts. 166, 178 y 179 de la LPAP y_en los arts. 115 y 116 de la LRJSP.

La primera regla específica en materia de responsabilidad por daños de los administradores, es la recogida en los artículos 166.2, 178 y 179 de la $\operatorname{LPAP}^{336}$ y artículo 116 apartados 5 y 6 de la LRJSP ${ }^{337}$. En virtud esos preceptos, en las sociedades

336 “Artículo 166 (...) 2. Las sociedades mercantiles estatales, con forma de sociedad anónima, cuyo capital sea en su totalidad de titularidad, directa o indirecta, de la Administración General del Estado o de sus organismos públicos, se regirán por el presente título y por el ordenamiento jurídico privado, salvo en las materias en que les sean de aplicación la normativa presupuestaria, contable, de control financiero y de contratación".

"Artículo 178. Instrucciones.

1. En casos excepcionales, debidamente justificados, el Ministro al que corresponda su tutela podrá dar instrucciones a las sociedades previstas en el artículo 166.2, para que realicen determinadas actividades, cuando resulte de interés público su ejecución.

2. Cuando las instrucciones que imparta el ministerio de tutela impliquen una variación de los Presupuestos de Explotación y Capital de acuerdo con lo dispuesto en el Real Decreto Legislativo 1091/1988, de 23 de septiembre, por el que se aprueba el Texto Refundido de la Ley General Presupuestaria, el órgano de administración no podrá iniciar la cumplimentación de la instrucción sin contar con la autorización del órgano competente para efectuar la modificación correspondiente"

"Artículo 179. Responsabilidad.

Los administradores de las sociedades a las que se hayan impartido instrucciones en los términos previstos en el artículo anterior actuarán diligentemente para su ejecución, y quedarán exonerados de la responsabilidad prevista en el artículo 133 del Real Decreto Legislativo 1564/1989, de 22 de diciembre, por el que se aprueba el Texto Refundido de la Ley de Sociedades Anónimas si del cumplimiento de dichas instrucciones se derivaren consecuencias lesivas". La referencia al art. 133 debe entenderse a los arts. 236 y siguientes de la LSC”.'

337 “Artículo 116. Tutela.

1. Al autorizar la constitución de una sociedad mercantil estatal con forma de sociedad anónima, de acuerdo con lo previsto en el artículo 166.2 de la Ley 33/2003, de 3 de noviembre, el Consejo de Ministros podrá atribuir a un Ministerio, cuyas competencias guarden una relación específica con el objeto social de la sociedad, la tutela funcional de la misma. 
mercantiles estatales, con forma de sociedad anónima, cuyo capital sea en su totalidad de titularidad directa o indirecta de la Administración General del Estado o de sus organismos públicos dependientes, los administradores están sometidos a las instrucciones que les dicte el Ministerio al que estén adscritas las sociedades, de modo que, si causan un daño a terceros al seguir en su actuación orgánica esas instrucciones, los administradores están exentos de la responsabilidad por daños prevista en los arts. 236 a 241 bis de la LSC.

En virtud de esas disposiciones legales los administradores sociales de las sociedades anónimas estatales, en que la Administración General del Estado ostente la totalidad del capital social, están exentos de la responsabilidad por daños de los arts. 236 y siguientes de la LSC, si en su actuación orgánica causan daños siguiendo las instrucciones del Ministerio o Autoridad de la que dependan (art. 116 de la LRJSP y arts. 166.2, 178 y 179 de la LPAP). La responsabilidad por daños ante terceros se imputará a la Administración tutelante de la sociedad. En cambio, si causan el daño sin haber seguido las instrucciones impartidas por la autoridad tutelante, al no quedar exentos de responsabilidad, se les podría exigir la responsabilidad por daños de los arts. 236 y ss de la LSC. Algún sector doctrinal estima que la exoneración de responsabilidad operaría cuando estemos ante órdenes legales, no si las órdenes impartidas fuesen manifiestamente ilegales, ya que si el daño lo han causado siguiendo órdenes ilegales

2. En ausencia de esta atribución expresa corresponderá íntegramente al Ministerio de Hacienda y Administraciones Públicas el ejercicio de las facultades que esta Ley y la Ley 33/2003, de 3 de noviembre, otorgan para la supervisión de la actividad de la sociedad.

3. El Ministerio de tutela ejercerá el control de eficacia e instruirá a la sociedad respecto a las líneas de actuación estratégica y establecerá las prioridades en la ejecución de las mismas, y propondrá su incorporación a los Presupuestos de Explotación y Capital y Programas de Actuación Plurianual, previa conformidad, en cuanto a sus aspectos financieros, de la Dirección General del Patrimonio del Estado si se trata de sociedades cuyo capital corresponda íntegramente a la Administración General del Estado, o del organismo público que sea titular de su capital.

4. En casos excepcionales, debidamente justificados, el titular del departamento al que corresponda su tutela podrá dar instrucciones a las sociedades, para que realicen determinadas actividades, cuando resulte de interés público su ejecución.

5. Cuando las instrucciones que imparta el Ministerio de tutela impliquen una variación de los Presupuestos de Explotación y Capital de acuerdo con lo dispuesto en la Ley 47/2003, de 26 de noviembre, el órgano de administración no podrá iniciar la cumplimentación de la instrucción sin contar con la autorización del órgano competente para efectuar la modificación correspondiente.

6. En este caso, los administradores de las sociedades a las que se hayan impartido estas instrucciones actuarán diligentemente para su ejecución, y quedarán exonerados de la responsabilidad prevista en el artículo 236 del Real Decreto Legislativo 1/2010, de 2 de julio, por el que se aprueba el Texto Refundido de la Ley de Sociedades de Capital, si del cumplimiento de dichas instrucciones se derivaren consecuencias lesivas". 
responderán del mismo, por entender que no cabe obediencia ante una orden ilegal, sino que deberán oponerse a ese acuerdo o impugnarlo ${ }^{338}$.

Exención de responsabilidad que opera sólo cuando la sociedad estatal haya adoptado la forma de sociedad anónima, no si fuese una sociedad de responsabilidad limitada, implicando un trato discriminatorio del administrador de este último tipo societario.

Exoneración sólo de la responsabilidad de los art. 236 y siguientes de la LSC (responsabilidad por daños), pero no se ha exonerado a esos administradores de la responsabilidad por deudas del art. 367 de la LSC, ni tampoco de la responsabilidad concursal de cobertura de déficit patrimonial del art. 456 del TRLC, por aludirse en el art. 116.6 de la LRJSP y en art. 179 de la LPAP únicamente a la responsabilidad del art. 236 de la actual LSC.

Exención de responsabilidad por daños del art. 236 y siguientes de la LSC que no es directamente aplicable en la Administración Institucional autonómica o local, salvo regulación expresa en su propia normativa, ya que art. 179 de la LPAP y art. 116 de la LRJSP no tienen la condición de legislación básica (Disposición Final 2. ${ }^{a}$ de la LPAP y Disposición Final 14.2 apartado c, de la LRJSP), sin que en la legislación local se contemple igual privilegio, al haber una remisión al Derecho privado (art. 85 ter de la Ley 7/1985, de 2 de abril, Reguladora de las Bases del Régimen Local $^{339}$ ).

338 RECALDE CASTELLS, A.: “Artículo 161. Intervención de la junta general en asuntos de gestión» Comentario de la reforma del régimen de las sociedades de capital en materia de gobierno corporativo (Ley 31/2014). Sociedades no cotizadas”, Cívitas, Cizur Menor, 2015, apartado 3.2, pp. 32 y ss; citado por HERNÁNDEZ SAINZ, E.: "El nuevo régimen de responsabilidad de los consejeros de sociedades mercantiles estatales: ¿hacia la irresponsabilidad por la gestión de sociedades públicas?”, $R d S$, núm. 47, 2016, edición digital,

https://insignis-aranzadidigital-es.ponton.uva.es/maf/app/document?srguid-, p. 12.

${ }^{339}$ BOE del 3.4.1985:

Artículo 85 ter.

“1. Las sociedades mercantiles locales se regirán íntegramente, cualquiera que sea su forma jurídica, por el ordenamiento jurídico privado, salvo las materias en que les sea de aplicación la normativa presupuestaria, contable, de control financiero, de control de eficacia y contratación, y sin perjuicio de lo señalado en el apartado siguiente de este artículo.

2. La sociedad deberá adoptar una de las formas previstas en el Texto Refundido de la Ley de Sociedades de Capital aprobado por el Real Decreto Legislativo 1/2010, de 2 de julio, y en la escritura de constitución constará el capital que deberá ser aportado por las Administraciones Públicas o por las entidades del sector público dependientes de las mismas a las que corresponda su titularidad.

3. Los estatutos determinarán la forma de designación y el funcionamiento de la Junta General y del Consejo de Administración, así como los máximos órganos de dirección de las mismas". 
La segunda regla específica, es la recogida en el art. 115 de la LRJSP ${ }^{340}$, en virtud de la cual, en las sociedades mercantiles estatales, cuando el órgano de administración adopta la forma de Consejo de Administración, y el cargo de consejero designado por la Administración General del Estado lo asuma un empleado público, éste no responde de los daños causados a terceros en su actuación orgánica, siendo imputable la responsabilidad directamente a la Administración del Estado, sin perjuicio de que ésta pueda exigir la responsabilidad del empleado público al amparo del art. 36 de la LRJSP, cuando el daño en los bienes o derechos de la Administración se hubiera causado concurrido dolo, culpa o negligencia graves.

En el art. 115.1 de la LRJSP se establece que "la responsabilidad que le corresponda al empleado público como miembro del consejo de administración será directamente asumida por la Administración General del Estado que lo designó".

Exoneración del consejero empleado público que en iguales términos se prevé en el art. 2.13 Real Decreto-Ley 25/2020, de 3 de julio, de medidas urgentes para apoyar la reactivación económica y el empleo ${ }^{341}$. Cuando en virtud de esta disposición la Administración General del Estado entre en el capital social de empresas estratégicas, como medida temporal de apoyo a la solvencia de las mismas, a través del Fondo de apoyo a la solvencia de empresas estratégicas, y designe como consejeros del órgano de administración en la empresa participada a empleados públicos, ese consejero queda exento de responsabilidad prevista en la legislación societaria o concursal por asumirla directamente la Administración de Estado, sin perjuicio de que la Administración a

340 "Artículo 115. Régimen de responsabilidad aplicable a los miembros de los consejos de administración de las sociedades mercantiles estatales designados por la Administración General del Estado.

1. La responsabilidad que le corresponda al empleado público como miembro del consejo de administración será directamente asumida por la Administración General del Estado que lo designó.

2. La Administración General del Estado podrá exigir de oficio al empleado público que designó como miembro del consejo de administración la responsabilidad en que hubiera incurrido por los daños y perjuicios causados en sus bienes o Derechos cuando hubiera concurrido dolo, o culpa o negligencia graves, conforme a lo previsto en las leyes administrativas en materia de responsabilidad patrimonial."

${ }^{341}$ BOE del 6.7.2020:

Artículo 2, apartado 13: “La responsabilidad que en los casos previstos en las leyes le pudiera corresponder, en su caso, al empleado público como miembro de los consejos de administración de las empresas objeto de participación en su capital social, será directamente asumida por la administración. El Consejo Gestor podrá exigir de oficio al empleado público la responsabilidad en que hubiera incurrido por los daños y perjuicios causados en sus bienes o Derechos cuando hubiera concurrido dolo, o culpa o negligencia grave, conforme a lo previsto en las leyes administrativas en materia de responsabilidad patrimonial". Igual exención en el art. 17 del Real Decreto Ley 5/2021, de 12 de marzo, de medidas extraordinarias de apoyo a la solvencia empresarial en respuesta a la pandemia de la COVID -BOE del 13.3.2021- 
través del Fondo se resarza del daño causado a la misma, exigiendo la responsabilidad patrimonial del consejero empleado público. Disposición legal que exonera de responsabilidad al consejero empleado público que participa en el Consejo de Administración de la empresa privada estratégica, sin que necesariamente tenga que tener ésta la condición de sociedad mercantil estatal.

Exención de responsabilidad del consejero empleado público prevista en el art. 115.1 de la LRJSP que se aplica plenamente a la responsabilidad por daños de los arts. 236 a 241 bis de la LSC. Algún sector doctrinal ${ }^{342}$, estima que esta exención es aplicable a la responsabilidad por daños y a la responsabilidad concursal del art. 456 del TRLC, pero no a la responsabilidad por deudas del art. 367 de la LSC. Discrepando de esa interpretación remitiéndonos al Capítulo IV, apartado VI.1.6 de esta tesis.

La exigencia de la responsabilidad trasladada a la Administración General del Estado del art. 115.1 de la LRJSP, según interpretación doctrinal ${ }^{343}$ deberá instrumentalizarse jurídicamente a través del cauce procedimental de la responsabilidad patrimonial de la Administración del Estado, por el procedimiento administrativo de los arts. 32 y siguientes de la LRJSP. Responsabilidad de la Administración al amparo de los arts. 236, 237 y 241 de la LSC, que según esa interpretación no podría reclamarse ante los Juzgados de lo Mercantil, sino en vía administrativa por el procedimiento de la responsabilidad patrimonial de la Administración de los arts. 32 y siguientes de la LRJSP.

Asumiendo la Administración General del Estado la responsabilidad patrimonial, para la doctrina ${ }^{344}$ que limita esta exención a la responsabilidad por daños, en el art. 115.2 de

${ }^{342}$ HERNÁNDEZ SAINZ, E.: "El nuevo régimen de responsabilidad de los consejeros de sociedades mercantiles estatales: ¿hacia la irresponsabilidad por la gestión de sociedades públicas?”, op. cit., edición digital, pp. 30 y ss.

${ }^{343}$ HERNÁNDEZ SAINZ, E.: "El nuevo régimen de responsabilidad de los consejeros de sociedades mercantiles estatales: ¿hacia la irresponsabilidad por la gestión de sociedades públicas?”, op. cit., edición digital, pp. 30 y 31.

Según esta autora, en ese art. 115 de la LRJSP se (sic) "configura un anómalo supuesto de responsabilidad de la Administración en la que ésta responde conforme a parámetros privados, en concreto, conforme a los parámetros de la responsabilidad de los administradores de sociedades mercantiles, pero quedando sometida la acción para la exigencia de responsabilidad a las reglas procedimentales administrativas y siendo resueltas las controversias en última instancia por la Jurisdicción Contencioso-Administrativa".

${ }^{344}$ En los párrafos 1 y 2 del art. 36 de la LRJSP, se establece:

“Artículo 36. Exigencia de la responsabilidad patrimonial de las autoridades y personal al servicio de las Administraciones Públicas.

1. Para hacer efectiva la responsabilidad patrimonial a que se refiere esta Ley, los particulares exigirán directamente a la Administración Pública correspondiente las indemnizaciones por los daños y perjuicios causados por las autoridades y personal a su servicio. 
la LRJSP se estaría reproduciendo lo que con carácter general se establece en el art. 36.2 de la LRJSP con prácticamente el mismo alcance, esto es, que la Administración podrá exigir al empleado público consejero la responsabilidad que haya tenido que asumir ella, cuando ese consejero haya actuado con dolo, culpa o negligencia grave, responsabilidad que se exige "conforme a lo previsto en las leyes administrativas en materia de responsabilidad patrimonial".

En este artículo 115 de la LRJSP se establece una exoneración de responsabilidad del empleado público consejero de cualquier tipo de sociedad mercantil de capital estatal, sea anónima o de responsabilidad limitada, cuando concurran las siguientes circunstancias:

a) En primer lugar, esta exoneración de responsabilidad acontece cuando estemos ante una sociedad de capital que tenga la condición de sociedad estatal al amparo del art. 111 de la LRJSP y art. 166.1.c de la LPAP. Esto es, sociedades de capital en que la Administración del Estado posea, directa o indirectamente, una participación social superior al 50\% del capital social, o en las que pese sin ostentar la mayoría del capital, posea el control societario en los términos del art. 42 del Código de Comercio.

b) En segundo lugar, cuando el órgano de administración tenga la forma de Consejo de Administración. No se entiende muy bien la razón por la que se circunscribe sólo a una concreta forma de organización del órgano de administración, ya que si el órgano de administración es unipersonal o está formado por dos o más administradores solidarios o mancomunados, quedarían sujetos al régimen general de responsabilidad de la LSC, pese a ser igualmente los administradores designados por la Administración empleados públicos, por lo que, si la razón de ser de la exoneración de responsabilidad, es para exonerar al empleado público y hacer responsable a la Administración, existe igual razón de ser, sea cual sea la forma de

\footnotetext{
2. La Administración correspondiente, cuando hubiere indemnizado a los lesionados, exigirá de oficio en vía administrativa de sus autoridades y demás personal a su servicio la responsabilidad en que hubieran incurrido por dolo, o culpa o negligencia graves, previa instrucción del correspondiente procedimiento.

Para la exigencia de dicha responsabilidad y, en su caso, para su cuantificación, se ponderarán, entre otros, los siguientes criterios: el resultado dañoso producido, el grado de culpabilidad, la responsabilidad profesional del personal al servicio de las Administraciones Públicas y su relación con la producción del resultado dañoso. (...)”.
} 
organizarse el órgano de administración. HERNÁNDEZ SAINZ ${ }^{345}$ critica esa restricción sólo a los supuestos en que el órgano de administración se constituya como Consejo de Administración, por ser discriminatoria y no tener razón de ser.

c) En tercer lugar, que el consejero designado por la Administración del Estado sea un empleado público, con lo que no habría exoneración si para ese cargo se designa a una persona que no tenga la condición de empleado público. Término de empleado público que debe interpretarse en sentido literal y no extensivo, por lo que no quedarían excluidos de responsabilidad los altos cargos que no tengan la condición de empleados públicos ${ }^{346}$. De conformidad con los arts. 1, 2, 3 y 8 del Real Decreto Legislativo 5/2015, de 30 de octubre, por el que se aprueba el Texto Refundido de la Ley del Estatuto Básico del Empleado Público ${ }^{347}$, tienen la condición de empleados públicos: los funcionarios de carrera, los funcionarios interinos, el personal laboral, el personal estatutario de los servicios de salud, y el personal eventual al servicio de cualquiera de las Administraciones públicas siguientes: a) La Administración General del Estado; b) Las Administraciones de las Comunidades Autónomas y de las ciudades de Ceuta y Melilla; c) Las Administraciones de las Entidades Locales; d) Los organismos públicos, agencias y demás entidades de derecho público con personalidad jurídica propia, vinculadas o dependientes de cualquiera de las Administraciones Públicas; e) Las Universidades Públicas.

d) En cuarto lugar, que el consejero sea designado por la Administración General del Estado, lo que incluye a los consejeros nombrados por la Administración del Estado por ser la sociedad unipersonal, o cuando siendo una sociedad mixta, el consejero sea designado por esa Administración estatal por el sistema de representación proporcional o por el sistema de cooptación, o si la elección de ese consejero haya dependido del voto favorable de los representantes de la Administración General del

\footnotetext{
345 HERNÁNDEZ SAINZ, E.: "El nuevo régimen de responsabilidad de los consejeros de sociedades mercantiles estatales: ¿hacia la irresponsabilidad por la gestión de sociedades públicas?”, op. cit., edición digital, pp. 23-24.

${ }^{346}$ HERNÁNDEZ SAINZ, E.: "El nuevo régimen de responsabilidad de los consejeros de sociedades mercantiles estatales: ¿hacia la irresponsabilidad por la gestión de sociedades públicas?”, op. cit., edición digital, p. 26.

${ }^{347}$ BOE del 31.10.2015.
} 
Estado por lo que no quedarán excluidos de la exoneración los consejeros designados por socios distintos a la Administración General del Estado ${ }^{348}$.

e) En quinto lugar, que es suficiente con que la sociedad mercantil tenga la condición de sociedad estatal, sin exigirse que ostente la Administración la totalidad de capital social (a diferencia de la exención de responsabilidad prevista en el art. 179 de la LPAP), por lo que se incluyen a las sociedades mixtas, aquellas de las que forman parte del capital entidades privadas, con lo que hay una diversidad de regímenes de responsabilidad aplicables a los administradores, pudiendo afectar al principio de igualdad $^{349}$ y no discriminación, ya que los consejeros que representen a la Administración y sean empleados públicos están exentos de responsabilidad, pero en cambio, sí responderían por daños, por un lado, los consejeros de otros socios privados que no hayan sido designados por la Administración, o los consejeros en representación del Estado que no tengan la condición de empleado público.

Esta exoneración de responsabilidad del empleado público miembro del Consejo de Administración nombrado por la Administración del art. 115 de la LRJSP, sólo es de aplicación directa a las sociedades mercantiles estatales, y no a las Administraciones Autonómicas o Locales, ya que las disposiciones del Capítulo V del Título II, los arts. 111 a 117 de la LRJSP, no tienen la condición de legislación básica (Disposición Final 14, apartado 2.c de la LRJSP). Por lo tanto, en principio, las sociedades locales y autonómicas se someterían al régimen del Derecho de sociedades ${ }^{350}$, salvo que se establezca una regulación específica en la normativa reguladora del sector público institucional empresarial de las Comunidades Autónomas. Para las Entidades Locales son de plena aplicación los arts. 236 y siguientes de la LSC, al no haberse previsto ninguna regulación específica en materia de responsabilidad de los administradores, ya

${ }^{348}$ HERNÁNDEZ SAINZ, E.: "El nuevo régimen de responsabilidad de los consejeros de sociedades mercantiles estatales: ¿hacia la irresponsabilidad por la gestión de sociedades públicas?”, op. cit., edición digital, p. 28.

349 NAVARRO FRÍAS, I.: “Sociedades públicas: Derecho Mercantil vs Derecho Administrativo. En particular, deberes y responsabilidad de los administradores de sociedades públicas estatales", $R d S$, núm 56, 2019, edición digital,

https://insignis-aranzadidigital-es.ponton.uva.es/maf/app/document?srguid, p. 30; HERNÁNDEZ SAINZ, E.: "El nuevo régimen de responsabilidad de los consejeros de sociedades mercantiles estatales: ¿hacia la irresponsabilidad por la gestión de sociedades públicas?”, op. cit., edición digital, p. 16.

350 HERNÁNDEZ SAINZ, E.: "El nuevo régimen de responsabilidad de los consejeros de sociedades mercantiles estatales: ¿hacia la irresponsabilidad por la gestión de sociedades públicas?”, op. cit., edición digital, p. 42; NAVARRO FRÍAS, I.: "Sociedades públicas: Derecho Mercantil "vs" Derecho Administrativo. En particular, deberes y responsabilidad de los administradores de sociedades públicas estatales", op. cit., p. 30. 
que en el art. 85 ter de la Ley 7/1985, de 2 de abril, Reguladora de las Bases del Régimen Local, hay una remisión genérica a la legislación de sociedades.

Al sustraer al consejero empleado público del régimen de responsabilidad previsto en la LSC, creándose un trato diverso entre los integrantes del Consejo de Administración en las sociedades mercantiles estatales mixtas, ya que a unos consejeros se les aplicaría el régimen de responsabilidad de los administradores de la LSC, y a otros no -a los empleados públicos designados por la Administración General del Estado-, un sector de la doctrina científica ${ }^{351}$ ha abogado por la derogación de este art. 115 de la LRJSP.

\subsection{Imputabilidad de la responsabilidad y su exoneración.}

Como hemos señalado en el apartado II.3.2 de este capítulo, en el art. 236 de la LSC, aplicable a todos los supuestos de responsabilidad por daños del administrador, sea en la acción individual de responsabilidad o en la acción social de responsabilidad ${ }^{352}$, se establece que el administrador responde por los actos $\mathrm{u}$ omisiones antijurídicos imputables a título de dolo o culpa, presumiéndose "iuris tantum" la concurrencia de la culpa en los actos contrarios a la ley o a los estatutos sociales, con lo que la carga probatoria de la culpabilidad por el accionante quedaría reconducida básicamente al incumplimiento de los deberes inherentes al cargo, pero incluso en estos supuestos podría operar una especie de inversión de la carga de la prueba derivada del art. 237 de la LSC.

Al estar ante una responsabilidad por culpa, se precisa que la conducta antijurídica causante del daño directo al acreedor sea imputable a título de dolo o culpa, lo que planteará problemas de prueba si se exige al acreedor que acredite la culpa de todos y cada uno de los integrantes del órgano de administración, cuando éste es de composición plural, especialmente si estamos ante un órgano colegiado, ante un Consejo de Administración. La culpa cuando estemos ante un administrador individual, no plantea especiales problemas, pero sí cuando estemos ante un órgano o

${ }^{351}$ NAVARRO FRÍAS, I.: "Sociedades públicas: Derecho mercantil "vs". Derecho administrativo. En particular, deberes y responsabilidad de los administradores de sociedades públicas estatales", op. cit., p. 30

352 SÁNCHEZ CAlero, F.: Los Administradores en las Sociedades de Capital, op. cit, p. 317. ESTEBAN VELASCO, G.: "La acción individual de responsabilidad", op. cit., pp. 218-220. VALPUESTA GASTAMINZA, E. M.: Comentarios a la Ley de Sociedades de Capital, op. cit., p. 644. 
administración pluripersonal ${ }^{353}$, ya que en esos supuestos, especialmente ante órganos colegiados, en que se adoptan los acuerdos por mayoría, sería un óbice al ejercicio de la acción individual de responsabilidad exigir al acreedor social que acredite la culpa en todos y cada de los integrantes del órgano.

No todos los supuestos de administración pluripersonal nos plantearán este problema de dificultad de individualización de la responsabilidad, ya que en la administración solidaria cada administrador actúa individualmente, sin requerir el concurso del resto, por lo que la individualización de la culpa será más problemática en la administración mancomunada y los órganos colegiados -el Consejo de Administración- ${ }^{354}$.

Para solventar esa dificultad probatoria, ya el profesor QUIJANO ${ }^{355}$, proponía que debería reconocerse en nuestro ordenamiento un vínculo de solidaridad en la responsabilidad de los integrantes del órgano causante de daño, de modo que la solidaridad sería una consecuencia de la colegialidad en materia de responsabilidad, engendrando la colegialidad una presunción de culpa, que podrá eludirse a través de la exoneración individual de la responsabilidad, a través de la acreditación de que el acto no les es imputable.

Para salvar esas dificultades probatorias y cohonestar el principio de culpa personal exigible en la responsabilidad por daños, con el carácter colegiado del órgano de administración, se establece en el art. 237 de la LSC una presunción iuris tantum de responsabilidad colectiva o solidaria de todos los integrantes del órgano de administración, de modo que los integrantes del órgano puedan a título personal acreditar que el acto o acuerdo dañoso no les es imputable, por concurrir una causa de exoneración de su responsabilidad ${ }^{356}$. Presunción que tiene su justificación, en que si

${ }^{353}$ QUIJANO GONZÁLEZ, J.: La responsabilidad civil de los administradores de la Sociedad Anónima, aspectos sustantivos", op. cit., pp. 249-253; SÁNCHEZ CALERO, F.: Los administradores en las sociedades de capital, op. cit., pp. 336-340; DÍAZ ECHEGARAY, J. L: Deberes y responsabilidades de los Administradores de Sociedades de Capital, op. cit. pp. 264-266.

${ }^{354}$ QUIJANO GONZÁLEZ, J.: La responsabilidad civil de los administradores de la Sociedad Anónima, aspectos sustantivos", op. cit., p. 251; SÁNCHEZ CALERO, F.: Los Administradores en las Sociedades de Capital, op. cit., p. 338; DÍAZ ECHEGARAY, J. L: Deberes y responsabilidades de los Administradores de sociedades de Capital, op. cit. pp. 264-267.

${ }^{355}$ QUIJANO GONZÁLEZ, J.: La responsabilidad civil de los administradores de la Sociedad Anónima, aspectos sustantivos", op. cit., pp. 252-253 y 263-266.

${ }^{356}$ QUIJANO GONZÁLEZ, J.: "Responsabilidad de los administradores por no disolución de la sociedad (art. 262.5 TRLSA), (Sentencia de la Audiencia Provincial de Burgos de 24 de julio de 1995)", en $R d S, \mathrm{n}^{\circ}$ 5, 1995, 1995, pp. 274-275; SÁNCHEZ CALERO, F.: Los administradores en las sociedades de capital, op. cit., pp. 336-337; DÍAZ ECHEGARAY, J. L.: Deberes y responsabilidades de los Administradores de sociedades de Capital, op. cit. pp. 264-267; ESTEBAN VELASCO, G.: "La 
bien será fácil saber quiénes son los integrantes del órgano, en cambio será más difícil determinar quiénes participaron en la reunión del órgano o quiénes votaron a favor del acuerdo $^{357}$.

Cuando el órgano de administración es colegiado nos hallamos ante una responsabilidad solidaria de los integrantes del mismo, respondiendo todos ellos ${ }^{358}$, salvo que alguno acredite que el daño no le es imputable por concurrir alguna causa de exoneración del art. 237 de la LSC.

Como señaló QUIJANO ${ }^{359}$, con anterioridad al reconocimiento legal expreso de la solidaridad en la responsabilidad de los integrantes del órgano de administración colegiado, "la exoneración cumple la función de detener la presunción de culpa, excluyendo indirectamente la responsabilidad solidaria”.

En virtud de esa presunción de responsabilidad colectiva solidaria, la solidaridad juega en dos ámbitos ${ }^{360}$. Por un lado, es una solidaridad pasiva externa, de modo que ante el acreedor o perjudicado, todos los integrantes del órgano responden de modo solidario, salvo acreditación de causa de exoneración, respondiendo de la integridad del daño, pudiendo el acreedor reclamar la reparación de daño a todos los integrantes o a alguno, sin que la reclamación efectuada contra unos, impidan ulteriores reclamaciones al resto, en virtud del ius variandi (arts. 1137 y 1144 del Código Civil). Pero por otro lado, una vez se repara el daño por alguno de los responsables solidarios, éste tiene la acción de regreso para exigir al resto de los responsables la parte que les corresponda, en función del grado de participación en la producción de daño ${ }^{361}$, y de no acreditarse esa diversa participación, será a prorrata de todos ellos (art. 1138 del Código Civil) ${ }^{362}$.

acción individual de responsabilidad", op. cit., pp. 278-280; GRIMALDOS GARCÍA, M. I.: "Presupuestos y extensión subjetiva de la responsabilidad. Solidaridad: artículos 236 y 237. Otras acciones por infracción del deber de lealtad: artículos 227.2 y 232 ”, op. cit., pp. 341-343.

${ }^{357}$ SÁNCHEZ CALERO, F.: Los Administradores en las Sociedades de Capital, op. cit., p. 339.

${ }^{358}$ QUIJANO GONZÁLEZ, J.: La responsabilidad civil de los administradores de la Sociedad Anónima, aspectos sustantivos, op. cit., pp. 252-253; SÁNCHEZ CALERO, F.: Los Administradores en las Sociedades de Capital, op. cit., pp. 336-337; DÍAZ ECHEGARAY, J. L: Deberes y responsabilidades de los Administradores de Sociedades de Capital, op. cit. pp. 265-266.

${ }^{359}$ QUIJANO GONZÁLEZ, J.: La responsabilidad civil de los administradores de la Sociedad Anónima, aspectos sustantivos, op. cit., p. 267.

${ }^{360}$ SÁNCHEZ CALERO, F.: Los Administradores en las Sociedades de Capital, op. cit., pp. 336-337; DÍAZ ECHEGARAY, J. L.: Deberes y responsabilidades de los Administradores de Sociedades de Capital, op. cit. pp. 265-266.

${ }^{361}$ QUIJANO GONZÁLEZ, J.: La responsabilidad civil de los administradores de la Sociedad Anónima, aspectos sustantivos, op. cit., p. 264-266; ESTEBAN VELASCO, G.: "La acción individual de responsabilidad”, op. cit., p. 278. Para QUIJANO GONZÁLEZ, la solidaridad es aplicable tanto a la 
En nuestra jurisprudencia ${ }^{363}$ es reiterada la doctrina que reconoce el carácter solidario de la responsabilidad de los integrantes del órgano, o de los administradores pluripersonales.

De existir consejeros delegados o comisiones ejecutivas si con sus actos $\mathrm{u}$ omisiones causan el daño, serán los que deban responder del mismo, sin perjuicio de que el resto de los miembros integrantes del Consejo de Administración puedan también incurrir en responsabilidad por culpa in vigilando ${ }^{364}$, ya que la delegación, en principio, es una excepción a la solidaridad de los integrantes del consejo con relación a las facultades delegadas, pero sin llegar a excluirse la responsabilidad del resto de los administradores del consejo ya que continúa vigente, por un lado, respecto a las facultades indelegables, y por otro también, con relación a las potestades delegadas en que incurrirán en responsabilidad principalmente por culpa in vigilando, in eligendo, o in instruendo ${ }^{365}$. Cuando exista delegación de facultades dentro del Consejo de Administración, de modo que la gestión ordinaria de la marcha de la sociedad se encomiende a órganos delegados, sean consejeros delegados o comisiones ejecutivas elegidas dentro de los miembros del Consejo (arts. 249 y 249 bis de la LSC), según SÁNCHEZ CALERO ${ }^{366}$, "por los actos lesivos realizados por los miembros del órgano delegado sin intervención del consejo de administración, serán imputables a los administradores delegados, estando en principio, libres de responsabilidad respecto a ellos los administradores no delegados", y ello por los principios que informan la responsabilidad extracontractual por culpa, en virtud de lo cuales responden quienes causaren el daño de modo culpable y mediando relación de causalidad entre el acto y daño generado, pero en último

hora de establecerse la responsabilidad como en la reparación de daño, sin perjuicio de que en la vía de regreso, cada uno de ellos asuma el quantum de indemnización que corresponda al grado de su participación en la producción del daño; ESTEBAN VELASCO, G.: "La acción individual de responsabilidad”, op. cit., p. 278.

${ }^{362}$ DÍAZ ECHEGARAY, J. L.: Deberes y responsabilidades de los Administradores de sociedades de Capital, op. cit., pp. 268-269, este autor a falta de previsión expresa en la normativa de sociedades, es de aplicación el art. 11348 del Código Civil, de modo que se reparte a prorrata el importe entre todos los administradores.

363 SSTS, Sala Civil, 1003/2002, de 28 de octubre -Rec. 1085/1997-; 516/2003, de 26 de mayo -Rec. 3144/1997-; 2/2004, de 22 de enero -Rec. 2280/1998-; 261/2007, de 14 de marzo -Rec. 262/2000-.

${ }^{364}$ POLO SÁNCHEZ, E.: “Los administradores y el Consejo de Administración de la Sociedad Anónima (arts. 123 a 143 de la LSA)", op. cit., pp. 291 y ss; ESTEBAN VELASCO, G.: "La acción individual de responsabilidad”, op. cit., p. 279; IGLESIAS PRADA, J. L.: Administración y delegación de facultades en la Sociedad Anónima, Editorial Tecnos, 1971, p. 359; QUIJANO GONZÁLEZ, J.: La responsabilidad civil de los administradores de la Sociedad Anónima, aspectos sustantivos”, op. cit., pp. 301-320.

365 QUIJANO GONZÁLEZ, J.: La responsabilidad civil de los administradores de la Sociedad Anónima, aspectos sustantivos, op. cit., pp. 301-320.

${ }^{366}$ SÁNCHEZ CALERO, F.: Los Administradores en las Sociedades de Capital, op. cit., p. 350. 
término también responderá el resto de los miembros del órgano de administración, cuando conociendo el acto dañoso no hiciesen nada por evitarlo, al ser obligación de todos estar debidamente informados sobre la marcha de la sociedad (art. 225.3 de la LSC), con lo que no será fácil acreditar la causa de exoneración de desconocer el acto dañoso.

Para nuestra jurisprudencia ${ }^{367}$, la delegación de facultades en consejeros delgados o comisiones ejecutivas no exonera al resto de los miembros del órgano de administración. En la Sentencia 205/2008, de 1 de diciembre -Rec. 80/2001-, se señala que en la responsabilidad de los administradores es indiferente que determinadas funciones del Consejo de Administración hayan sido delegadas en otros miembros del mismo, porque quienes responden son los administradores, condición que ostentan los nombrados como tales por la Junta General al actuar los delegados por mandato de los delegantes, pudiéndose eximir de responsabilidad en el caso de que, no habiendo intervenido en la adopción y ejecución del acuerdo lesivo, desconozcan su existencia o, conociéndola, hubieren hecho todo lo conveniente para evitar el daño o, al menos, se opusieron expresamente a aquél (art. 237 de la LSC).

Ante esa presunción de responsabilidad colectiva de los administradores, conviene analizar brevemente los supuestos legales de exoneración de responsabilidad. Para SÁNCHEZ CALERO ${ }^{368}$ estos supuestos de exoneración serían reconducibles a tres, de conformidad con el art. 237 de la LSC. En primer lugar, no haber intervenido en la adopción y ejecución de acuerdo dañoso, por desconocer su existencia. En segundo lugar, cuando conociendo su existencia, hicieron todo lo conveniente para evitar el daño. Y, en tercer lugar, cuando se haya opuesto expresamente al acuerdo.

Dentro del primer supuesto, de no haber participado en la "adopción y ejecución del acuerdo", para ese autor se incluyen los supuestos en que por causa justificada o no imputable no ha podido acudir a la reunión del consejo en que se adoptó el acuerdo, siempre que no tuviere por otros medios conocimiento, anterior o posterior, de su existencia, y, siempre que de haberlo conocido hubiere hecho todo lo posible por evitar

\footnotetext{
${ }^{367}$ SSTS, Sala Civil 647/2006 de 23 junio -Rec. 4192/1999-; 205/2008, de 1de diciembre -Rec. 80/2001-; 460/2010, de 14 de julio -Rec. 945/2006-; y 826/2011 de 23 noviembre -Rec. 1753/2007-, entre otras. ${ }^{368}$ SÁNCHEZ CALERO, F.: Los Administradores en las Sociedades de Capital, op. cit., p. 343.
} 
el daño ${ }^{369}$. Se ha criticado que con esta causa se pretenda exonerar al administrador que desconozca el acuerdo, cuando, en todo caso, está obligado a informarse diligentemente sobre la marcha de la sociedad, y de los acuerdos adoptados, y en consecuencia una vez debe conocer el acuerdo, ha de hacer todo lo posible por evitar el acto dañoso ${ }^{370}$.

La segunda causa de exoneración de haber hecho todo lo posible para evitar el daño ante el acuerdo adoptado, implicaría una actitud proactiva de oposición que no se limita a votar en contra, sino que exigiría que no llegue a ejecutarse el acuerdo, siendo un medio idóneo la impugnación judicial ${ }^{371}$ del acuerdo del órgano de administración por el administrador que se opuso a él, ya que se les confiere legitimación para la impugnación de los acuerdos del consejo, hayan o no votado a favor (art. 251 de la LSC). Sería causa de exoneración, si pese a haber votado a favor del acuerdo posteriormente se impugna judicialmente el mismo, por entender que para que opere la responsabilidad se exige de modo conjunto haber intervenido en la adopción y en la ejecución ${ }^{372}$, de modo que si no se participa en la ejecución por impugnarse y pedirse la suspensión cautelar no se incurre en responsabilidad. Sería supuesto de exoneración, no solo la impugnación del acuerdo, sino también un requerimiento o notificación formal del administrador a la sociedad para impedir su ejecución, así como una comunicación dirigida por el administrador a las entidades públicas de control o supervisión ${ }^{373}$, para evitar que se consume el acto dañoso (Banco de España, Comisión Nacional de Mercado de Valores, Tesorería General de la Seguridad Social, etc.).

Finalmente, la tercera causa de exoneración, consistente, en "al menos haberse opuesto de modo expreso al acuerdo", implica haber votado en contra, pero no sólo eso, sino exigir que se deje constancia en el acta de la reunión de esa circunstancia ${ }^{374}$. Es una causa que, viene a suavizar el rigor de la regla general de presunción colectiva de

${ }^{369}$ SÁNCHEZ CALERO, F.: Los Administradores en las Sociedades de Capital, op. cit., pp. 343-344. DÍAZ ECHEGARAY, J. L.: Deberes y responsabilidades de los Administradores de Sociedades de Capital, op. cit., p. 271.

370 DÍAZ ECHEGARAY, J. L.: Deberes y responsabilidades de los Administradores de Sociedades de Capital, op. cit., p. 272.

${ }^{371}$ POLO SÁNCHEZ, E.: "Los administradores y el Consejo de Administración de la Sociedad Anónima (arts. 123 a 143 de la LSA)”, op. cit., p. 305; SÁNCHEZ CALERO, F.: Los Administradores en las Sociedades de Capital, op. cit., p. 346.

${ }^{372}$ SÁNCHEZ CALERO, F.: Los Administradores en las Sociedades de Capital, op. cit., p. 346.

${ }^{373}$ SÁNCHEZ CALERO, F.: Los Administradores en las Sociedades de Capital, op. cit., pp. 344-345.

${ }^{374}$ QUIJANO GONZÁLEZ, J.: La responsabilidad civil de los administradores de la Sociedad Anónima, aspectos sustantivos, op. cit., p. 268; SÁNCHEZ CALERO, F.: Los Administradores en las Sociedades de Capital, op. cit., pp. 344-345. 
responsabilidad, por lo que se ha criticado $^{375}$ que en sí misma sea eximente ya que debería exigirse que se haga algo más que haber votado en contra y hacer constar en acta la oposición.

\subsection{Prescripción de la responsabilidad.}

La acción individual de responsabilidad contra los administradores prescribe a los cuatro años, a contar desde el día en que la acción ha podido ejercitarse, según establece el art. 241 bis de la $\mathrm{LSC}^{376}$, precepto introducido por el artículo único 22 de la Ley $31 / 2014$, de 3 de diciembre. Se opta claramente por la actio nata como momento inicial del cómputo del plazo de cuatro años frente a la regulación anterior del art. 949 del Código de Comercio, que fija el plazo de 4 años a computar desde el cese en el cargo.

Con el reconocimiento legal expreso del principio de la actio nata, en el nuevo art. 241 bis en la LSC, el dies a quo del cómputo del plazo de prescripción de la acción se inicia, no desde la fecha de realización del acto dañoso por el administrador, sino desde que se manifiestan sus efectos perjudiciales ${ }^{377}$, desde que el daño se manifiesta y es conocido por el perjudicado, que podrá o no coincidir con su realización, ya que en los arts. 1968.2 y 1969 del Código Civil, que contiene el régimen jurídico general de la actio nata, el dies a quo del plazo de prescripción de la responsabilidad por daños nace desde el momento en que la acción puede ejercitarse, desde que el perjudicado conoce el daño, al señalarse en el art. 1968.2 del Código Civil desde que lo supo el agraviado.

El dies a quo se computará, según SALDAÑA VILLOLDO ${ }^{378}$, respecto de cada acto del administrador, desde que el perjudicado esté en condiciones de ejercitar la acción de responsabilidad, lo que implica que conozca que han acaecido los hechos determinantes de la responsabilidad, la conducta antijurídica y el daño en su patrimonio. Como señala FERNÁNDEZ SEIJO ${ }^{379}$, el tercero acreedor perjudicado "puede tener problemas para

375 DÍAZ ECHEGARAY, J. L.: Deberes y responsabilidades de los Administradores de Sociedades de Capital, op. cit., p. 273.

376 "Artículo 241 bis. Prescripción de las acciones de responsabilidad.

La acción de responsabilidad contra los administradores, sea social o individual, prescribirá a los cuatro años a contar desde el día en que hubiera podido ejercitarse".

${ }^{377}$ ESTEBAN VELASCO, G.: "La acción individual de responsabilidad”, op. cit., p. 281.

${ }^{378}$ SALDAÑA VILLOLDO, B.: "Nuevos problemas de la responsabilidad de los administradores: la acción social y la responsabilidad por deudas tras la Ley 3/2014", en AA.VV. (Coord.: EMBID IRUJO, J. M. y NIETO CAROL, U.): Estudios de Derechos de Sociedades, Tirant Lo Blanch, Valencia, 2019, pp. 145-146.

379 FERNÁNDEZ SEIJO, J. M.: "La prescripción de las acciones de responsabilidad", en AA.VV. (Coord.: ROJO FERNÁNDEZ-RÍO, A. y BELTRÁN SÁNCHEZ, E.): La responsabilidad de los administradores de las sociedades mercantiles, $6^{\mathrm{a}}$ edición, 2016, Tirant Lo Blanch, Valencia, p. 707. 
identificar la acción u omisión imputable al administrador, sin embargo, sí que identificará el momento en que se produce el efectivo perjuicio".

El dies a quo o día inicial de cómputo del plazo de cuatro años de prescripción de la responsabilidad se situará en el momento en que el acreedor disponga o conozca la existencia de todos los elementos fácticos o jurídicos para litigar, para exigir la responsabilidad, en definitiva, desde que conozca el daño (Sentencias del TS, Sala Civil, 1049/2008, de 11 de noviembre -Rec. 974/2004-, y 261/2007, de 14 de marzo Rec. 262/2000-) $)^{380}$. Para nuestra jurisprudencia ${ }^{381}$, disponer de todos los datos fácticos y jurídicos que permitan el ejercicio de la acción, incluye conocer la identidad de la persona responsable, de modo que si se conoce el importe del daño o de la deuda objeto de reparación, pero se desconoce la identidad del sujeto responsable, hasta que no se tenga constancia de esa identidad no se inicia el cómputo del plazo de prescripción de la acción.

De igual modo, cuando la conducta antijurídica causante del daño, sea fruto de una conducta continuada no se iniciaría hasta que hayan concluido esos actos continuados dañosos ${ }^{382}$.

${ }^{380}$ En la Sentencia 1049/2008, de 11 de noviembre -Rec. 974/2004-, se alude a que el dies a quo de la actio nata exige, para que la prescripción comience a correr en su contra, que la parte que propone el ejercicio de la acción disponga de los elementos fácticos y jurídicos idóneos para fundar una situación de aptitud plena para litigar, al indicarse, "como se recuerda en la Sentencia de esta Sala de 14 de marzo de 2007, la prescripción, según ha reiterado la jurisprudencia, debe ser interpretada restrictivamente (STS de 15 de julio de 2005). El dies a quo o día inicial para el ejercicio de la acción por responsabilidad extracontractual es aquél en que puede ejercitarse la acción, según el principio actio nondum nata non praescribitur [la acción que todavía no ha nacido no puede prescribir], al que se acoge el CC (STS 27 de febrero de 2004). Este principio exige, para que la prescripción comience a correr en su contra, que la parte que propone el ejercicio de la acción disponga de los elementos fácticos y jurídicos idóneos para fundar una situación de aptitud plena para litigar".

En la Sentencia $261 / 2007$, de 14 de marzo -Rec. 262/2000-, se sitúa ese dies a quo en el momento en que el acreedor conoció el daño, cuando por el cierre y desaparición de la empresa el acreedor vio frustrado su crédito, momento en el que el acreedor dispone de todos los elementos facticos y jurídicos para accionar.

${ }^{381}$ Como señala la Sentencia del TS, Sala Civil, 350/2020, de 24 de junio -Rec. 4442/2017-, "la redacción del artículo 1969 del Código Civil no admite duda acerca de que el tiempo para la prescripción de acciones "se contará desde el día en que pudieron ejercitarse" y lógicamente no puede ejercitarse la acción cuando no se conoce la identidad de aquél o aquéllos frente a los que ha de dirigirse, con independencia de que el perjudicado cuente desde antes con los datos objetivos referidos a la cuantía del daño o perjuicio causado. Así lo establece esta sala en las sentencias citadas por el Recurrente núm. 25/2015, de 2 de febrero, y 725/2014, de 18 de diciembre; así, como en fecha más Reciente núm. 94/2019, de 14 de febrero".

${ }^{382}$ SSTS, Sala Civil, 1049/2008, de 11 de noviembre -Rec. 974/2004- y 261/2007, de 14 de marzo -Rec. 262/2000-,en las que se señala que, "la jurisprudencia ha matizado la regla del artículo 1968.2 CC en el caso de que los daños hayan sido causados por comportamientos continuados permanentes (SSTS de 12 de diciembre de 1980, 12 de febrero de 1981, 6 de mayo de 1985,17 de marzo de 1986 y 24 de junio de 1996, entre otras) y ha exigido para el inicio del plazo una verificación total de los daños 
Si el daño se causa a un crédito que es litigioso, el plazo de prescripción de la responsabilidad nacería a partir de la sentencia firme que reconoce la deuda y/o el crédito (Sentencia del TS, Sala Civil, 1049/2008, de 11 de noviembre -Rec. 974/2004${ }^{383}$ ), pero, puede también el juez que conoce la acción individual de responsabilidad, apreciar con carácter prejudicial la existencia y realidad de la deuda, sin que sea exigible un proceso judicial previo de reconocimiento o ejecución (Sentencias del TS, Sala Civil, 261/2007, de 14 de marzo -Rec. 262/2000- ${ }^{384}$ ).

La carga de la prueba del momento en que se inicia el cómputo del plazo de prescripción corresponde al administrador, a quien la alega, que será normalmente del beneficiado con la prescripción, de modo que la falta de concreción, la indeterminación o las dudas sobre del día inicial no deben resolverse en principio en contra de la parte a cuyo favor juega el derecho reclamado (Sentencia del STS, Sala Civil, 227/2006, de 9 de marzo -Rec. 2418/1999-, con cita de las sentencias de 10 de marzo de 1989 y 3 de diciembre de 1993).

producidos, al entender que sólo con ella el perjudicado está en condiciones de valorar en su conjunto las consecuencias dañosas y de cifrar el importe de las indemnizaciones que puede Reclamar por concurrir una «situación jurídica de aptitud plena para el ejercicio de las acciones», según la expresión utilizada por la STS de 21 de abril de 1986".

${ }^{383}$ En la Sentencia 1049/2008, de 11 de noviembre, se señala "Como se Recuerda en la Sentencia de esta Sala de 14 de marzo de 2007 (...). En la citada Sentencia de la Sala se consideró que la acción no pudo ejercitarse antes, como mínimo, del momento en que las deudas de la sociedad fueron declaradas mediante sentencia firme y, en su ejecución, se procedió infructuosamente al embargo de bienes de la sociedad administrada por los demandados, así como que su ejercicio estaba subordinado no solamente al conocimiento de la inviabilidad económica de la empresa, sino también, como mínimo, a la constancia de la insolvencia de la sociedad como factor demostrativo de la imposibilidad de hacer efectivos los créditos contra ella".

${ }^{384}$ En la Sentencia 261/2007, de 14 de marzo, se indica "La STS de 25 de octubre de 2005 ha Reconocido la eficacia prejudicial (en el proceso en que se ventila la responsabilidad de los administradores) de la sentencia que condena a la sociedad. Pero esto no significa que la condena de la sociedad sea presupuesto indefectible para la exigencia de la responsabilidad, como declara la STS de 30 de noviembre de 2005. En suma, no resulta imposible el ejercicio simultáneo de la acción contra la sociedad y contra los administradores en aquellos casos en los cuales puede determinarse con certeza la existencia del perjuicio desde el mismo momento de la Reclamación contra aquélla (STS de 28 de noviembre de 2006). Hay que analizar, por consiguiente, las circunstancias del caso para determinar el momento en que el daño se hallaba suficientemente establecido para permitir el ejercicio de la acción".

Dicho lo anterior, acaba reiterando esa sentencia que "Las circunstancias del caso examinado llevan a la conclusión de que el principio actio nata [acción nacida] impide considerar que la acción pudo ejercitarse antes, como mínimo, del momento en que las deudas de la sociedad fueron declaradas mediante sentencia firme $y$, en su ejecución, se procedió infructuosamente al embargo de bienes de la sociedad administrada por los demandados, pues sólo entonces quedó acreditado el daño (la imposibilidad de realizar los créditos con cargo al patrimonio social) y nada permite afirmar que antes de este momento pudiera asegurarse la imposibilidad por parte de la sociedad de hacer frente a dichas deudas con su propio patrimonio, especialmente teniendo en cuenta que existe una valoración de existencias anterior en dos años por un importe superior a la deuda". 
Con anterioridad a esta regulación expresa de la prescripción de la acción individual de responsabilidad del art. 241 bis de la LSC, en la doctrina y en la jurisprudencia se plantearon dos dudas. En primer lugar, cuál era el plazo de prescripción, si el plazo de cuatro años del art. 949 del código de Comercio, o el plazo de un año de las acciones de responsabilidad extracontractual del art. 1968.2 del Código Civil. Y en segundo lugar, cuál era el dies a quo. Se respondieron ambas cuestiones concluyendo que era aplicable el art. 949 del Código de Comercio, tanto para la duración del plazo de prescripción de la acción (cuatro años), como para la determinación del dies a quo (el cese en el cargo $)^{385}$.

En cambio, para la acción individual de responsabilidad contra el administrador concursal, fijándose el mismo plazo de prescripción de cuatro años, en su cómputo se admiten dos momentos de inicio, que serán desde que la acción pudo ejercitarse, y en todo caso, desde que cesó en el cargo (art. 98 del TRLC ${ }^{386}$ ), una especie de refundición acumulativa de los arts. 241 bis y 949 del Código de Comercio.

Aclaradas esas dudas sobre el plazo de prescripción y su cómputo, los problemas interpretativos consistirán actualmente en determinar la posible aplicación del art. 241 bis de la LSC a la responsabilidad por deudas del administrador del art. 367 de la LSC,

${ }^{385}$ Opta por esta solución, zanjando la discusión, el TS, Sala Civil, en Sentencia 749/2001, de 20 de julio -Rec. 1495/1996-. Resume la postura definitivamente adoptada la sentencia del TS, Sala Civil, 669/2008, de 3 de julio -Rec. 4186/2001-, al señalar, "esta Sala en Sentencia de 20 de julio de 2001 tuvo la ocasión de poner fin a cierta fluctuación que se había venido registrando en sus sentencias en torno al plazo de prescripción aplicable a las acciones de responsabilidad de los administradores sociales, entendiendo, con designio de unificación de doctrina, que el plazo de las individuales, que se funden en el artículo 135 LSA, debe ser también el de cuatro años que establece el artículo 949 del Código de Comercio", para concluir "esta doctrina ha venido siendo aplicada desde entonces por esta Sala en Sentencias de fechas 1 marzo, 26 de mayo y 5 octubre 2004, 25 de marzo, 15 junio y 22 de diciembre de 2005, 2 de febrero, 6 marzo y 26 de mayo de 2006, 30 de enero, 21 de febrero, 8, 12 y 14 de marzo y 14 de mayo de 2007, por citar algunas de entre las más Recientes".

Y con relación al dies a quo se opta por el cese en el cargo, salvo que no conste inscrito en el RM, en cuyo caso, para los acreedores de buena fe se computa la acción desde la inscripción registral (SSTS, Sala Civil, 664/2006 de 26 junio -Rec. 4434/1999; 208/2009, de 1 de abril -Rec. 2198/2003-; Sentencias de 13 de abril de 2000 -RJ 2000/1829-; 2 de abril de 2002 -RJ 2002/2666); 28 de mayo de 2005 -Rec. 4720/1998-; 26 de mayo de 2006 -RJ 2006/3319-; 951/2007 de 25 septiembre -Rec. 4052/2000-; 669/2008, de 3 de julio -Rec. 4186/2001-; 1145/2008, de 27 de noviembre -Rec. 1050/2003-; 123/2010, de 11 de marzo -Rec. 1239/2005-, entre otras).

386 “Artículo 98. Acción individual de responsabilidad.

1. Quedan a salvo las acciones de responsabilidad que puedan corresponder al concursado, a los acreedores o a terceros por actos u omisiones de los administradores concursales y auxiliares delegados que lesionen directamente los intereses de aquellos.

2. Las acciones de responsabilidad a que se refiere el apartado anterior prescribirán a los cuatro años, contados desde que el actor hubiera tenido conocimiento del daño o perjuicio por el que Reclama y, en todo caso, desde que los administradores concursales o los auxiliares delegados hubieran cesado en su cargo". 
cuestión que será objeto de análisis en el Capítulo IV, apartado VII, al que nos remitimos.

Con la actual regulación el plazo de cuatro años se computa desde que la acción pudo ejercitarse, con lo que el acto dañoso lo causará el administrador ejerciendo el cargo, ni antes ni después de la vigencia de su cargo, salvo que tras el cese continuase como administrador de hecho (Sentencias del TS, Sala Civil, 240/2009, de 14 de abril -Rec. 1504/2004-, 123/2010, de 11 de marzo -Rec. 1239/2005- ${ }^{387}$ ). En la sociedad anónima la duración del cargo la establecen los estatutos sociales, sin que pueda exceder de seis años, aunque cabe que sea reelegido una o varias veces, por iguales períodos de duración máxima (art. 221.2 LSC). Por el contrario, los administradores de las sociedades de responsabilidad limitada son elegidos por tiempo indefinido, salvo que los estatutos hubieren fijado un plazo máximo, en cuyo caso podrían ser reelegidos una o más veces por períodos de igual duración (art. 221.1 LSC). Con relación al cese por expiración del plazo de vigencia temporal del cargo, puntualizar que, la caducidad no opera de modo automático a la fecha de expiración de la duración pactada, sino que el cargo del administrador caduca cuando vencido el período de vigencia se haya celebrado la Junta general que haya nombrado al nuevo administrador, o, en su defecto, cuando haya transcurrido el plazo para la celebración de la junta que ha de aprobar las cuentas anuales (art. 222 LSC), que debe reunirse dentro de los primeros seis meses siguientes a la finalización del ejercicio social (art. 164 LSC), todo ello, para evitar la paralización del órgano de administración.

La acción individual de responsabilidad no se suspende o paraliza por el hecho de haberse abierto un proceso concursal contra la sociedad de capital (arts. 136 apartado $1.2^{\circ}$ y 139.1 del TRLC a contrario sensu, y Sentencia del TS, Sala Civil, 737/2014, de 22 de diciembre -Rec. 1261/2013-). La ley concursal no prevé ningún efecto suspensivo de la declaración de concurso en la acción individual, "de tal forma que puede ser ejercitada por los terceros perjudicados, ante el juez mercantil que corresponda, al

\footnotetext{
${ }^{387}$ En la Sentencia del TS, Sala Civil, 123/2010, de 11 de marzo -Rec. 1239/2005-, se señala con relación a la continuidad en el ejercicio de las funciones de administrador tras la caducidad del cargo, en cuanto administrador de hecho: "Continuidad en el ejercicio de sus funciones como administradores de hecho. Esta Sala se ha pronunciado en el sentido de que el cese del nombramiento por caducidad del administrador no constituye requisito suficiente para entender producido el cese del mismo si se prueba que existió una continuidad en el ejercicio de sus funciones como administrador de hecho, permaneciendo en sus funciones de administración y representación orgánica de la sociedad (STS 2309-2008, RC 2803/2003), y ha considerado que se da esa continuidad si existe un proceso abierto en el que es parte la sociedad (STS 14 de abril de 2009, RC 1504/2004)".
} 
margen del concurso de acreedores" (Sentencia del TS, Sala Civil, 737/2014, de 22 de diciembre).

Aunque la declaración de concurso de acreedores de la sociedad de capital no suspende el ejercicio de la acción individual de responsabilidad, en cambio, ese concurso de acreedores sí interrumpe la prescripción de la acción individual contra los administradores sociales (art. 155.3 del TRLC y Sentencia del TS, Sala Civil, 737/2014, de 22 de diciembre -Rec. 1261/2013-), volviendo a correr el plazo de prescripción nuevamente desde el momento de la conclusión del concurso (art. 155.4 del TRLC). Al ser un plazo de prescripción, la interrupción significa que, concluido el concurso se reinicia el plazo de cuatro años para reclamar la responsabilidad ${ }^{388}$, por lo que se amplía el período en que se va a poder exigir la responsabilidad del administrador social, pero siempre por actos dañosos causados durante su cargo, no por otros posteriores.

Finalizamos señalando que interrumpe el plazo de prescripción de cuatro años de la acción individual de responsabilidad, el ejercicio de acciones penales por los mismos hechos, o por ilícitos penales que puedan tener influencia en el ejercicio de la acción individual o social de responsabilidad (Sentencia del TS, Sala Civil, 221/2018, de 16 de abril -Rec. 3050/2015- ${ }^{389}$ ).

\section{III.- ACCIÓN INDIVIDUAL DE RESPONSABILIDAD E INCUMPLIMIENTO DE OBLIGACIONES SOCIALES.}

\section{Viabilidad jurídica.}

A través de la acción individual de responsabilidad se impone a los administradores sociales el deber de indemnizar a los terceros acreedores, por los actos u omisiones que

\footnotetext{
${ }^{388}$ FERNÁNDEZ SEIJO, J. M.: “La prescripción de las acciones de responsabilidad”, op. cit., p. 707.

${ }^{389}$ En este sentido, con relación a la acción social de responsabilidad, en Sentencia del TS, Sala Civil, 221/2018, de 16 de abril -Rec. 3050/2015-, se señala que, "conforme a la doctrina de esta sala contenida, entre otras, en la STS 657/2010, de 3 de noviembre, es suficiente con que el hecho objeto de investigación en el juicio penal pueda tener una influencia determinante en el juicio civil para que se produzca la interrupción del cómputo de la prescripción. No es necesaria la identidad de objetos entre ambos procesos (penal y civil), sino la conexión entre los hechos denunciados en la jurisdicción penal y el objeto del proceso civil. En los procesos penales se denunció la intervención de la administradora en la apropiación indebida de fondos de la sociedad, hecho que constituye, en esencia, el objeto de la acción social de responsabilidad que se plantea en el procedimiento civil. Por lo que debe considerarse que el plazo de prescripción de dicha acción quedó interrumpido por la pendencia de las causas penales. En el presente caso, la notificación de la desestimación del Recurso de apelación se realizó con fecha 14 de abril de 2008, por lo que aún no habían transcurrido los 4 años del plazo de prescripción de la acción en el momento de la interposición de la demanda".
} 
lesionen directamente los derechos de crédito de éstos por actuación orgánica antijurídica (en el artículo 241 de la LSC).

La cuestión esencial que nos vamos a plantear consiste en determinar si ante el incumplimiento de la sociedad de sus obligaciones legales por actos $\mathrm{u}$ omisiones imputables a los administradores, podrían los acreedores de la sociedad de capital exigir a éstos la responsabilidad por el impago de la deuda o crédito. Si las entidades gestoras y de recaudación de la Seguridad Social podrían exigir el pago de las obligaciones legales al administrador, y en qué condiciones o circunstancias sería posible, valorando la dificultad de este medio de reclamación frente a otras vías previstas legalmente, especialmente ante una eventual exigibilidad de la deuda acudiendo a la reclamación solidaria por deudas de los arts. 360 y 367 de la LSC.

Para responder a esta pregunta ha de partirse de la premisa de que nos hallamos ante sociedades de capital, en las que será el patrimonio de la sociedad quien responde de sus obligaciones ante los acreedores, ya que rige la responsabilidad limitada de los socios, quienes no responden de las deudas sociales (art. 1 de la LSC). Son principios básicos del funcionamiento de las sociedades de capital, por un lado, la autonomía patrimonial respecto a los socios, la responsabilidad del patrimonio social por las deudas de la mercantil, no rigiendo la responsabilidad personal ilimitada, y por otro lado, la personalidad jurídica propia y diferenciada ${ }^{390}$.

Con carácter general podemos afirmar que no puede recurrirse indiscriminadamente a la vía de la responsabilidad individual de los administradores ante el impago de cualquier deuda social, ya que ello supondría contrariar los principios fundamentales de las sociedades de capital, como son la personalidad jurídica de las mismas, su autonomía patrimonial y su exclusiva responsabilidad por las deudas (Sentencia del TS, Sala Civil, número 150/2017, de 2 de marzo -Rec. 2118/2014-).

Por otro lado, al ser la sociedad de capital una persona jurídica cuya manifestación de voluntad en el tráfico jurídico, se expresa o manifiesta a través de sus órganos sociales, especialmente a través del órgano social que ejerce la dirección y gestión de la entidad mercantil (administrador o Consejo de Administración), las obligaciones contraídas por

390 SSTS, Sala Civil, 457/2008, de 30 de mayo -Aranzadi RJ 2008/4166-; de 20 de junio de 2013 -RJ 2013/5187-; 150/2017, de 2 de marzo -Rec. 2118/2014-, entre otras muchas. 
los administradores en nombre de la sociedad, surtirán efectos entre el tercero contratante y la sociedad ${ }^{391}$.

Ante esa naturaleza jurídica de las sociedades de capital con responsabilidad limitada de los socios a las aportaciones sociales, respondiendo el patrimonio social de las deudas sociales, la conclusión será que ante el mero incumplimiento por la sociedad de sus obligaciones no responderán los socios ni los administradores con su patrimonio, ya que no cabe apreciar el daño directo que exige la acción individual por el mero hecho de incumplirse una obligación de la sociedad de capital ${ }^{392}$.

Debemos dilucidar cuándo podría el acreedor exigir la responsabilidad patrimonial al administrador por la vía del artículo 241 de la LSC, cuando el incumplimiento de la obligación social fuere debido a actos antijurídicos y culpables del administrador con causación de un daño directo al acreedor, lo que podría acaecer ante incumplimientos dolosos de las obligaciones de Seguridad Social, y ante incumplimientos en situaciones de graves desarreglos económicos o de insuficiencias patrimoniales graves imputables a conductas negligentes del administrador.

La posibilidad de emprender la acción individual de responsabilidad ha cobrado mayor relevancia tras la Ley 38/2011, de 10 de octubre, que reforma la Ley Concursal, por cuanto que la declaración de concurso no suspende ni paraliza el ejercicio de la acción individual de responsabilidad frente al administrador social (artículos 132.1, 136.1.2 139.1 y 155 del TRLC), y tras la Ley 19/2005, de 14 de noviembre, sobre la sociedad anónima europea domiciliada en España ${ }^{393}$, para reclamar las deudas anteriores a la concurrencia de una causa legal de disolución, especialmente desde que la responsabilidad por deudas del administrador se limitó a esas deudas posteriores

En nuestra doctrina ${ }^{394}$ ha sido mayoritaria la oposición al ejercicio de la acción individual de responsabilidad ante el incumplimiento de las obligaciones sociales de la sociedad de capital, por graves que puedan ser los comportamientos del administrador

\footnotetext{
${ }^{391}$ Arts. 1, 19, 20, 33 y 209 de la LSC, arts. 116 y 118 a 122 del Código de Comercio, y artículos 35, 38, 1101 y 1257 del Código Civil.

${ }^{392}$ SSTS, Sala Civil, 207/2008, de 14 de marzo -Rec. 74/2001-, que cita al respecto las Sentencias de esa sala de fechas 2 de julio de 1998, 20 de julio de 2001 y 6 de marzo de 2003.

${ }^{393}$ BOE del 15.11.2005.

${ }^{394}$ MARÍN DE LA BÁRCENA GARCIMARTÍN, F.: La acción individual de responsabilidad de los administradores de las sociedades de capital (art. 135 LSA), editorial Marcial Pons, Madrid, 2005, pp 181-183, 328-331; POLO SÁNCHEZ, E.: Los administradores y el Consejo de Administración de la Sociedad Anónima (arts. 123 a 143 de la LSA)", op. cit., p. 373 y ss. DÍAZ ECHEGARAY, J. L.: La responsabilidad civil de los administradores de la sociedad anónima, op. cit., p. 489.
} 
en la ejecución de las mismas, ya que éstos no responden de esos incumplimientos porque no estamos ante una responsabilidad en deudas.

El incumplimiento por la sociedad del crédito en situaciones de dificultades económicas, inicialmente ha de excluirse de la acción individual de responsabilidad por la dificultad de probar el daño directo al patrimonio del acreedor, cuando en esas situaciones de dificultades económicas normalmente el daño se causa por los administradores en el patrimonio social susceptible de la acción social y no de la acción individual de responsabilidad ${ }^{395}$.

La acción individual de responsabilidad por su propia naturaleza tiene como finalidad reparar el daño causado a los acreedores, y no garantizar el cobro de las deudas de la sociedad al no ser una responsabilidad en deudas, no obstante, habrá situaciones en que el daño directo puede consistir en hacer imposible el pago de una deuda social de un concreto acreedor por actuación directa, ilícita y culpable del administrador social, en cuyo supuesto el daño se cifra en la deuda impagada, permitiendo el ejercicio de la acción individual de responsabilidad, sin que en ese caso se vea alterada la naturaleza o la función de la acción individual que se utiliza para indemnizar un daño, que, en este caso, consiste en el impago de una deuda ${ }^{396}$.

De igual modo, si como norma general el mero incumplimiento de la obligación social, en sí mismo, no genera ninguna responsabilidad del administrador social, otra cosa será cuando ese incumplimiento sea debido a una conducta dolosa o maliciosa del administrador que cause perjuicio al acreedor según QUIJANO ${ }^{397}$. Ante conductas dolosas del administrador que abocasen a situaciones de insuficiencia patrimonial, frustrando el pago de una deuda, cabría examinar, en cada caso en concreto, el ejercicio de esa acción individual de responsabilidad.

El sector mayoritario de la doctrina ve difícil el ejercicio de esta acción en situaciones de crisis empresariales para que el acreedor pueda obtener el pago del crédito ante el

\footnotetext{
${ }^{395}$ ESTEBAN VELASCO, G.: “La acción individual de responsabilidad”, op. cit., pp. 248 a 252.

396 QUIJANO GONZÁLEZ, J.: “Acción individual de responsabilidad de Administradores e ilícito orgánico (a propósito de la Sentencia del Tribunal Supremo, de 4 de noviembre de 2019)”, 2020, op. cit., p. 6 de 16 .

${ }^{397}$ QUIJANO GONZÁLEZ, J.: "La responsabilidad civil de los administradores de la sociedad anónima en el Texto Refundido de 22 de diciembre de 1989”, op. cit., pp. 23 y ss; ESTEBAN VELASCO, G.: “La acción individual de responsabilidad”, op. cit., p. 251; QUIJANO GONZÁLEZ, J.: “Acción individual de responsabilidad de Administradores e ilícito orgánico (a propósito de la Sentencia del Tribunal Supremo, de 4 de noviembre de 2019)", 2020, op. cit., p. 9 de 16.
} 
incumplimiento de la obligación de la sociedad de capital, por la dificultad de apreciarse el daño directo en el patrimonio del acreedor como algo distinto al daño del patrimonio social, y la relación de causalidad entre conducta del administrador y el impago del crédito. No obstante, habría supuestos en que podría apreciarse la viabilidad de la acción individual y no de la acción social. Así, para MARÍN DE LA BÁRCENA GARCIMARTÍN ${ }^{398}$, en el incumplimiento de las obligaciones contractuales por el administrador podría apreciarse la concurrencia del daño directo y no un daño reflejo del daño al patrimonio social, cuando el administrador imparte órdenes de no pagar a determinados acreedores, sin sufrir daño el patrimonio social, antes al contrario, por lo que ante esa conducta dolosa el administrador responderá de los daños causados al acreedor conjuntamente con la sociedad, consiguiéndose un reforzamiento de la tutela del crédito al gozar el perjudicado con la garantía de dos patrimonios el de la sociedad y el del administrador incumplidor. Igualmente MARÍN DE LA BÁRCENA GARCIMARTÍN ${ }^{399}$, considera que de hallarse la sociedad en situación de insolvencia inminente de debe informar a los acreedores acerca de la misma, ya que de otro modo podría incurrir en responsabilidad por daños ante el acreedor al causarle a éste un daño directo que no es reflejo del daño al patrimonio social, por lo que éstos, (sic) "deben ser situados en la misma posición que estarían de no haber celebrado el contrato, es decir, indemnizados por el interés negativo, no por el interés positivo (v. gr. ganancias dejadas de obtener y que se habrían obtenido de haberse ejecutado totalmente el contrato) una vez descontada la cuota que recibirían como acreedores concursales con cargo a la masa".

De igual modo, ESTEBAN VELASCO ${ }^{400}$, parte de la regla general de que cuando el incumplimiento de la sociedad es debido a su situación de desarreglo económico, contribuyendo el administrador con su mala gestión a la insolvencia de la mercantil, la responsabilidad, en principio, sería exigible vía acción social de responsabilidad, pero pueden existir supuestos en que, ante el incumplimiento de la sociedad de la obligación

\footnotetext{
398 MARÍN DE LA BÁRCENA GARCIMARTÍN, F.: "La acción individual de responsabilidad de los administradores de sociedad anónima frente a socios y terceros (artículo 135)”, 1999, op. cit., pp. 313315.

399 MARÍN DE LA BÁRCENA GARCIMARTÍN, F.: "Deberes y responsabilidades de los administradores ante la insolvencia de las sociedades de capital”. RdS, núm. 24, 2005, edición digital, https://insignis-aranzadidigitales.ponton.uva.es/maf/app/document?srguid=i0ad82d9b000001742f355b4068993575\&marginal=BIB 20051750\&docguid=I5b4f746090, p. 30.

${ }^{400}$ ESTEBAN VELASCO, G.: “La acción individual de responsabilidad”, op. cit., pp. 251-252.
} 
de pagar un crédito social, se aprecie responsabilidad del administrador vía acción individual, citando el supuesto de preterición de unos acreedores respecto a otros, contemplado en la Sentencia de TS, Sala Civil de 27.11.2014 que cita.

Ante esas posturas doctrinales examinemos cuál es la posición de nuestra jurisprudencia.

Nuestra doctrina jurisprudencial ${ }^{401}$, en términos generales, había venido declarando que, ante el incumplimiento de la sociedad de sus obligaciones sociales, especialmente ante insuficiencia patrimonial, no cabría la acción individual de responsabilidad, porque la acción individual de responsabilidad, como la social, no es una responsabilidad por deudas sociales sino por daños causados.

En esa jurisprudencia el mero incumplimiento de las obligaciones sociales no genera "per se" responsabilidad del administrador, ya que, el impago de esas deudas no puede identificarse necesariamente con un daño directo de los administradores a los acreedores sociales, a menos que el riesgo comercial quiera eliminarse por completo del tráfico entre empresas, se pretenda desvirtuar el principio básico de que los socios no responden personalmente de las deudas sociales (Sentencias del Tribunal Supremo, Sala Civil, 467/2005 de 20 de junio -RJ 2005/6425-), o se quiera convertir a los administradores a través de la acción individual de responsabilidad en garantes de las deudas sociales ${ }^{402}$.

El mero incumplimiento de la obligación no es suficiente para la acción individual de responsabilidad, exigiéndose "un comportamiento del administrador, distinto del mero acto de no pagar el crédito, que constituya un ilícito orgánico (conducta antijurídica por infringir la Ley, los estatutos o no ajustarse al estándar o patrón de diligencia exigible a un ordenado empresario) al que pudiera imputarse la causación directa del perjuicio sufrido por el tercero, que es la falta de cobro de un crédito" (Sentencia TS, Sala Civil, 571/2019, de 4 de noviembre-Rec. 4162/2016-).

\footnotetext{
${ }^{401}$ SSTS, Sala Civil, Sentencia núm. 864/2004 de 22 de julio -RJ 2004/4694-, y núm. 409/2005 de 26 de mayo -RJ 2005/6302-, entre otras muchas.

${ }^{402}$ SSTS, Sala Civil, 457/2008, de 30 de mayo -RJ 2008/4166-; 242/2014, de 23 de mayo; 253/2016, de 18 de abril; 472/2016, de 13 de julio; y 718/2018, de 19 de diciembre.
} 
De igual modo, el daño directo que es exigible en la acción individual no puede consistir en la insolvencia de la sociedad ${ }^{403}$. La falta de cumplimiento de la obligación social por insuficiencia patrimonial de la sociedad, ab initio, no genera responsabilidad del administrador social al amparo del art. 241 de la LSC, ya que una eventual dificultad económica de la empresa en el momento de contraer una obligación, entra dentro de los parámetros ordinarios de la actividad lucrativa de mercado ${ }^{404}$. Es reiterada la doctrina jurisprudencial $^{405}$ que afirma que el mero impago ante deficiencias patrimoniales, si no va acompañado de otros incumplimientos orgánicos, no es suficiente para que tenga éxito esta acción individual, porque cuando un acreedor ejercita una acción individual de responsabilidad frente al administrador de una sociedad por el daño causado por el impago de un crédito, es muy fácil caer en el riesgo de identificar la falta de pago de las deudas de la sociedad por insolvencia, con la infracción de los administradores de la ley o de los deberes inherentes a su cargo. Tal errónea concepción convertiría la responsabilidad de los administradores en objetiva y se produciría una confusión entre la actuación en el tráfico jurídico de la sociedad y la actuación de su administrador.

En los supuestos en que quepa plantearse que el impago de la obligación social ante una insuficiencia patrimonial de la sociedad, puede ser motivo del ejercicio de una acción de responsabilidad, cuando concurra un acto ilícito orgánico del administrador que haya determinado el impago, la cuestión esencial será determinar si procede la acción social de responsabilidad, la acción individual, o las dos.

No obstante, la anterior doctrina jurisprudencial que marca las líneas generales de la responsabilidad de la sociedad por las deudas sociales, con exclusión inicial de la responsabilidad de los administradores, en la más reciente jurisprudencia se ha venido abriendo tenuemente la vía de la acción individual de responsabilidad del administrador, ante ciertos incumplimientos de las obligaciones sociales, cuando concurran especiales y graves incumplimientos del administrador social. Si con carácter general, puede afirmarse que por vía del art. 241 de la LSC, no puede exigirse al administrador social el pago de toda deuda u obligación legal impagada de la sociedad de capital, sí que hemos

${ }^{403}$ SSTS TS, Sala Civil, 571/2019, de 4 de noviembre -Rec. 4162/2016-; 150/2017, de 2 de marzo -Rec. 2118/2014-; 1168/2008, de 27 de noviembre; 207/2008, de 14 de marzo -Rec. 74/2001-; 417/2006, de 28 de abril.

404 SSTS, Sala Civil, 87/2004, de 16 de febrero -RJ 2004/648-; 150/2017, de 2 de marzo -Rec. 2118/2014-; 580/2019, de 5 de noviembre -Rec. 579/2017-; y 612/2019, de 14 de noviembre -Rec. $1318 / 2017-$.

405 SSTS, Sala Civil, 150/2017, de 2 de marzo -Rec. 2118/2014; 274/2017, de 5 de mayo -Rec. 3298/2014-; y 612/2019, de 14 de noviembre -Rec. 1318/2017. 
encontrados cuatro supuestos en que se ha admitido la responsabilidad del administrador para el pago de la deuda social. En primer lugar, en casos de incumplimientos de obligaciones societarias, cuando no se han cumplido con mandatos impuestos por una norma imperativa, como ha acaecido en los supuestos de incumplimientos societarios ante el comprador de una vivienda en fase de construcción sin haberse garantizado la devolución de cantidades económicas entregadas a cuenta. En segundo lugar, en casos de preterición en el pago de determinados créditos, atendiendo por el contrario otros créditos. En tercer lugar, cuando por actuación dolosa del administrador no se ha atendido el pago de una obligación social. En cuarto lugar, ante el incumplimiento de los deberes disolutorios en crisis patrimoniales irreversibles cierre de hecho de la empresa sin ordenada liquidación societaria-. En esos cuatro supuestos, claro está, siempre que se acrediten judicialmente todos los requisitos constitutivos de la acción individual

Para la jurisprudencia más reciente que ha admitido la acción individual en supuestos de claros incumplimiento de deberes orgánicos, incluso en situaciones de crisis patrimoniales, como sucede ante un cierre de hecho, se ha advertido acerca de la necesidad de evitar el riesgo de la aplicación indiscriminada de esa acción individual, por lo que invita a ser prudentes y rigurosos en la aplicación de la doctrina contenida en esas sentencias ${ }^{406}$.

A tres supuestos de incumplimientos de obligaciones sociales en situaciones excepcionales, como son los incumplimientos de obligaciones impuestas en normas imperativas, los incumplimientos dolosos, y los incumplimientos de deberes disolutorios, especialmente ante el cierre de hecho, dedicaremos los próximos apartados (apartados 2, 3 y 4), en la medida en que pueden ser situaciones de claros incumplimientos de las obligaciones de Seguridad Social.

\section{Acción individual por incumplimiento de deberes de una ley imperativa y su aplicabilidad a la Seguridad Social.}

Si los incumplimientos de una obligación imperativa ex lege impuesta a la sociedad de capital, fuese un posible presupuesto para el ejercicio de la acción individual de responsabilidad, nos podría orientar acerca de las posibilidades de esta acción de

${ }^{406}$ SSTS, Sala Civil, 253/2016, de 18 de abril, 472/2016, de 13 de julio, y 716/2018, de 19 de diciembre Rec. 3648/2015-. 
responsabilidad ante el incumplimiento de obligaciones legales imperativas con la Seguridad Social.

Si en determinadas condiciones el incumplimiento de una norma imperativa impuesta a la sociedad de capital, puede ser un presupuesto para el ejercicio de la acción individual de responsabilidad, el incumplimiento de obligaciones imperativas de Seguridad Social podrá ser un argumento discursivo necesario, pero no suficiente para su ejercicio. Podrá ser utilizado el incumplimiento de las obligaciones imperativas de Seguridad Social como elemento discursivo adicional cuando estemos en presencia de otros supuestos en que claramente se ha venido admitiendo la procedencia de esta acción individual, como serían la preterición de acreedores, los incumplimientos dolosos y los cierres de hecho sin ordenada liquidación.

Examinemos en qué condiciones se ha admitido en la jurisprudencia el ejercicio de esta acción individual ante incumplimientos de normas imperativas.

En la reciente jurisprudencia ${ }^{407}$ se ha admitido la acción individual ante el impago de obligaciones o deudas impuestas en una norma legal imperativa ${ }^{408}$-cual es garantizar la devolución de las cantidades entregadas a cuenta por la compra de una vivienda habitual-, en la medida en que el incumplimiento imputable del administrador ha generado un daño directo al comprador, la parte más débil de la relación jurídica. Doctrina que ha de ser objeto de aplicación prudencial, sin que nos permita entender que, en todo caso, y ante cualquier incumplimiento de una norma imperativa impuesta a la sociedad de capital, pueda exigirse automáticamente el pago al administrador, porque entonces estaríamos ante una responsabilidad por deudas, más que ante una responsabilidad por daños.

${ }^{407}$ SSTS, Sala Civil, número 131/2016, de 3 de marzo -RJ 2016/801-; número 242/2014, de 23 de mayo RJ 2014/2943-; y número 60/2019, de 29 de enero -Rec. 506/2016-

En las Sentencias 242/2014 y 131/2016, se establece que "el art. 241 LSC permite una acción individual contra los administradores, cuando en el ejercicio de sus funciones incumplen normas específicas que se imponen a su actividad social y tienden a proteger al más débil, en este caso, al comprador de una vivienda que anticipa su precio antes de serle entregada, y sufre directamente el daño como consecuencia del incumplimiento de sus obligaciones (...). Pero en el presente caso, la responsabilidad directa de los administradores proviene del carácter imperativo de la norma que han incumplido y de la importancia de los intereses jurídicos protegidos por dicha norma. Ello supone que incumbe a los administradores asegurarse del cumplimiento de esta exigencia legal, y que su incumplimiento les sea directamente imputable». A tal efecto, ha de tenerse presente y resaltarse que la conducta imputable a los administradores sociales demandados no es el incumplimiento de una obligación contractual de la sociedad que administran, sino la infracción de un deber legal de carácter imperativo".

${ }^{408}$ Impuesta en la Ley 57/1968 y por la Disposición Adicional Primera de la Ley 23/1999. 
En estas sentencias se admite el ejercicio por el acreedor de la acción individual, entendiendo que la responsabilidad de los administradores proviene del carácter imperativo de la norma incumplida y de la importancia de los intereses jurídicos protegidos por la misma, como es garantizar el derecho de la parte más débil de la relación jurídica, el derecho que la norma imperativa establece en favor de su beneficiario. Pero no se impone la responsabilidad por el mero incumplimiento de una obligación legal, porque en tal caso los convertiríamos en garantes de deudas, y estamos ante una responsabilidad por daños.

Los requisitos de norma imperativa e importancia de los bienes jurídicos protegidos concurren en la normativa reguladora de la Seguridad Social, ya que son disposiciones imperativas cuyo bien jurídico protegido -mantenimiento de un sistema público de prestaciones suficientes y su financiación-, tiene carácter público y relevancia constitucional (art. 41 de la Constitución Española).

El incumplimiento de una norma imperativa de Seguridad Social podría ser un argumento en favor de la viabilidad de la acción individual ante el incumplimiento de obligaciones de Seguridad Social, partiendo de esa doctrina jurisprudencial que admite su procedencia ante el incumplimiento de una norma imperativa establecida para la defensa de la parte más débil de una relación, en nuestro caso el trabajador, por la especial relevancia del interés jurídico protegido con la norma imperativa.

Doctrina que podrá ser de utilidad para reclamar el daño directo, cuando el incumplimiento de las disposiciones imperativas de Seguridad Social vulneran el derecho del trabajador beneficiario de una prestación de Seguridad Social, como sucede cuando nazca la responsabilidad empresarial en el pago de una prestación por incumplimiento imputable del administrador de las obligaciones instrumentales de afiliación y altas en Seguridad Social, ya que resulta directamente perjudicado el trabajador, la parte débil de la relación jurídica de Seguridad Social, porque ante la falta de alta o afiliación la responsabilidad en prestaciones por contingencias comunes es de la empresa, sin que anticipen el pago las entidades gestoras, pudiendo disponer el trabajador de la acción individual de responsabilidad para reclamar el pago ante el administrador, y no sólo a la sociedad de capital deudora.

Esta doctrina jurisprudencial, de extrapolarse al ámbito social, permitiría argumentar la aplicación del ejercicio de la acción individual de responsabilidad ante el 
incumplimiento de obligaciones laborales y de Seguridad Social imperativas, por el carácter tuitivo de las normas imperativas laborales, encaminadas a proteger la parte más débil de contrato de trabajo -el trabajador-, y en buena medida, también, ante el incumplimiento de las obligaciones imperativas de la normativa de Seguridad Social, para proteger a la parte más débil de la relación jurídica de Seguridad Social -el trabajador de la relación triangular trabajador, empresa, Instituciones Públicas de Seguridad Social-.

Doctrina que podrá ser un argumento de refuerzo o adicional cuando estemos en presencia de incumplimientos en los que sí se ha admitido más nítidamente la acción individual de responsabilidad -el cierre de hecho, la preterición de acreedores y los incumplimientos dolosos del administrador-, y se reclamen por la TGSS créditos por faltas de alta, por defraudación en la cotización, o por descubiertos de cotizaciones sin haberse cumplido en plazo reglamentario las obligaciones de comunicación de las retribuciones abonadas y las bases de cotización para que la TGSS facture el importe de la liquidación de cuotas mensuales (art. 29 del TRLGSS); o cuando las entidades gestoras reclamen créditos por prestaciones anticipadas en supuestos de responsabilidad empresarial por los incumplimientos imputables de los administradores de las obligaciones instrumentales de afiliación, altas y cotización (art. 164.3, último párrafo del TRLGSS).

El incumplimiento de la obligación de comunicación mensual de las bases de cotización de los trabajadores a la TGSS (art. 29 del TRLGSS), genera deudas por cotizaciones a la Seguridad Social que se reclamarán por bases de cotización estimadas, no por bases reales de cotización (art. 35 TRLGSS), con el consiguiente daño al patrimonio de la Seguridad Social, pero también con daño a los trabajadores, ya que al no tener las bases de cotización las entidades gestoras para el cálculo de prestaciones de Seguridad Social, actuales o futuras, han de acudir a la técnica de integración de lagunas partiendo de las bases mínimas de cotización (arts. 45, 161, 197.4, 209.1.b y Disposición Adicional $1^{\text {a }}$ del TRLGSS).

Doctrina que como elemento adicional de argumentación podrá utilizarse cuando las deudas por cotizaciones sean consecuencia de incumplimientos fraudulentos, reiterados, dolosos o deliberadamente rebeldes, imputables a conducta orgánica de administrador, como veremos en el próximo apartado. 
Admisión de la acción individual por infracción de norma imperativa que, como se cuida de señalar el Tribunal Supremo, debe aplicarse con cautela, evitando una aplicación expansiva que conllevase a una imputación de la responsabilidad del administrador por el mero incumplimiento de obligaciones o disposiciones normativas de "ius cogens", ya que no pueden convertirse los administradores en garantes de las deudas sociales.

Critica la posibilidad de generalizar esa doctrina del Tribunal Supremo, sobre el incumplimiento de normas imperativas, MUÑOZ PAREDES ${ }^{409}$, por cuanto con ello se sentaría un precedente peligroso, ya que imputar a un administrador el incumplimiento de una obligación que es de la sociedad, sería desconocer la personalidad diferenciada de la sociedad, pudiendo llevar a convertir a los administradores en garantes de las deudas sociales. Para este autor, para que opere la responsabilidad del administrador, la cuestión no estaría tanto en si se infringe una norma imperativa, sino en si el incumplimiento es imputable al administrador, y para esa imputabilidad considera que ha de ponderarse la posible concurrencia de factores objetivos y subjetivos que pudieran escapar al razonable control del administrador, poniendo como ejemplo, que difícilmente puede imputarse al administrador de una empresa promotora un defecto técnico de construcción, o al administrador de una empresa de instalación de redes telefónicas una deficiencia del cableado, pero que en pequeñas empresas en que suele aunarse el control social y administrador social en una misma persona, sería razonable concluir que ese administrador debe cerciorarse de que la sociedad cumpla con sus obligaciones, ya que de no hacerlo pueden asumir responsabilidad solidaria. Reproche éste, que consideramos no sería aplicable ante el incumplimiento deliberado del administrador de una norma imperativa Laboral o de Seguridad Social.

Ya hace unos años MARÍN DE LA BÁRCENA GARCIMARTÍN ${ }^{410}$ apuntaba que de existir un interés jurídicamente protegido por la norma jurídica infringida, ese interés podría, con ciertas dificultades de las que era consciente, fundamentar una acción individual de responsabilidad, especialmente en caso de incumplimiento de deberes disolutorios, al indicar que (sic) "no obstante, debemos señalar la posibilidad -que de momento no descartamos aunque no se nos oculta la dificultad de conciliarlo con el tenor literal del art. 135 de la LSA- de tener en cuenta como punto de vista directivo del

${ }^{409}$ MUÑOZ PAREDES, A.: Tratado judicial de la responsabilidad..., op. cit., pp. 291-292.

${ }^{410}$ MARÍN DE LA BÁRCENA GARCIMARTÍN, F.: "La acción individual de responsabilidad de administradores de sociedad anónima frente a socios y terceros (artículo 135)”, 1999, op. cit., p. 317. 
sistema de acciones de responsabilidad otros criterios como el interés jurídicamente protegido por la norma en cuya infracción se fundamenta la responsabilidad”.

\section{Acción individual ante incumplimientos dolosos del administrador de las obligaciones de la Seguridad Social.}

Con carácter general los administradores no responden por el mero impago de las obligaciones sociales $^{411}$, pero el incumplimiento de obligaciones sociales en determinadas situaciones sí podrá fundar el ejercicio de esa acción. ESTEBAN VELASCO $^{412}$, se ha detenido en el estudio de los supuestos de la intromisión ilegítima del administrador en el cumplimiento de la obligación social como un posible presupuesto de la acción individual.

Teniendo presente que del mero incumplimiento de la obligación social no surge la responsabilidad por daños de administrador, conviene que nos detengamos en el análisis de los incumplimientos dolosos de las obligaciones sociales donde sí puede ser viable el ejercicio de la acción individual. Esos posibles comportamientos dolosos, los agrupamos en tres supuestos, en primer lugar, los incumplimientos en situaciones de graves deficiencias en la contabilidad social, en segundo lugar, los incumplimientos de la obligación social debidos a la preterición deliberada de determinados acreedores, y, en tercer lugar, los incumplimientos dolosos derivados de infracciones de las obligaciones legales de Seguridad Social, que lesionen los derechos económicos o el patrimonio de la Seguridad Social.

Los incumplimientos por preterición en el pago de deudas con la Seguridad Social, y los incumplimientos derivados de infracciones de las obligaciones legales de Seguridad Social, serán los supuestos más relevantes para el ejercicio de la acción individual de responsabilidad ante el incumplimiento de la sociedad de capital de sus obligaciones con la Seguridad Social.

Analizamos brevemente los tres supuestos de incumplimientos dolosos referidos.

411 GARRETA SUCH, J. M.: La responsabilidad civil, fiscal y penal de los administradores de sociedades, op. cit., p. 177.

412 ESTEBAN VELASCO, G.: “Algunas reflexiones sobre la Responsabilidad de los Administradores frente a los Socios y los Terceros: Acción individual y acción por no Promoción o Remoción de la disolución”, 1995, op. cit., pp. 59-68; ESTEBAN VELASCO, G.: "La acción individual de responsabilidad", op. cit., pp. 248-272. 


\subsection{Acción individual por incumplimiento de la obligación social en supuestos de graves deficiencias en la contabilidad social.}

Ha sido en reclamaciones concursales donde se han planteado fundamentalmente los efectos que ha podido tener la no llevanza, o la llevanza con graves irregularidades de la contabilidad empresarial.

Los administradores de la sociedad de capital son los sujetos obligados a formular y llevar la contabilidad de la empresa (art. 253 de la LSC). Contabilidad integrada por las cuentas anuales, los balances trimestrales de comprobación, y el libro diario (art. 28 del Código de Comercio).

Las cuentas anuales comprenden el balance, la cuenta de pérdidas y ganancias, un estado sobre los cambios en el estado del patrimonio neto, un estado de flujos efectivos y la memoria (art. 34 del Código de Comercio, art. 254 de la LSC, y Real Decreto 1514/2007, de 16 de noviembre, por el que se aprueba el Plan General de Contabilidad ${ }^{413}$ ). Estos documentos forman una unidad, y deben ser redactados con claridad, mostrando la imagen fiel del patrimonio, la situación financiera y los resultados de la empresa (art. 34.2 del Código de Comercio y art. 254.2 de la LSC).

La llevanza de la contabilidad por el administrador social no sólo es una carga sino que es una obligación legal, que no sólo sirve al empresario para conocer su situación financiera y patrimonial, sino también a otros estamentos sociales ${ }^{414}$, al imponerse la obligación de su depósito en el Registro Mercantil para general conocimiento. Es por ello que, esa contabilidad es una garantía también para los acreedores de la sociedad, y entre ellos, para los acreedores de Derecho público, como son las entidades gestoras de la Seguridad Social y la TGSS, especialmente para el cumplimiento de obligaciones empresariales de cotización a la Seguridad Social.

Ante esa obligación legal de llevanza de una contabilidad ordenada y veraz, examinemos brevemente si la ausencia de la contabilidad, su llevanza desordenada, las irregularidades graves en la misma, o la falta de depósito en el Registro Mercantil, son circunstancias esenciales para acreditar la responsabilidad del administrador mediante el ejercicio de la acción individual, o, si por el contrario, tendrá el único efecto de invertir

\footnotetext{
413 BOE del 20.11.2007.

414 GARRETA SUCH, J. M.: La responsabilidad civil, fiscal y penal de los administradores de sociedades, op. cit., pp. 187-188
} 
la carga de la prueba en el administrador para tener que acreditar que el daño en el patrimonio del acreedor no es debido a ese incumplimiento legal.

Como nos recuerda MARÍN DE LA BÁRCENA GARCIMARTÍN ${ }^{415}$, para un sector destacado de la doctrina alemana y española, pese a no ser mayoritario, los terceros no pueden exigir responsabilidad por la infracción de los deberes contables, ya que los deberes de diligencia en la llevanza de la contabilidad, son deberes ante la sociedad, no ante terceros, y su incumplimiento sólo puede generar daños al patrimonio social. MARÍN DE LA BÁRCENA GARCIMARTÍN ${ }^{416}$, admite que puede ser origen de la acción individual de responsabilidad el incumplimiento del deber de ordenada llevanza de contabilidad, porque "los administradores no sólo responden frente a terceros cuando causan inmediatamente un daño como consecuencia de un actuar precedente generador de riesgos (responsabilidad por injerencia), sino también cuando incumplen el deber de velar por que la sociedad cumpla con sus deberes de protección frente a terceros (responsabilidad por asunción)", ya que éstos confiarán que los administradores cumplirán, con la diligencia de un ordenado empresario, con las obligaciones que la ley les impone, entre ellas con las obligaciones en materia de contabilidad que tienen a su cargo, teniendo la acción individual de responsabilidad, como razón de ser, la protección de esa confianza.

En materia de la exigencia de responsabilidad al administrador mediante la acción individual del artículo 241 de la LSC, destacamos como relevante la Sentencia del TS, Sala Civil, núm. 737/2014, de 22 de diciembre -RJ 2014/6885-417, en la que se examinaba la acción individual ante el impago de pedidos por una gran cadena de venta de electrodomésticos, habiendo sobrevalorado las existencias en su contabilidad en los últimos años.

415 MARÍN DE LA BÁRCENA GARCIMARTÍN, F.: "Deberes de contabilidad y acción individual de responsabilidad. (STS $1^{\text {a }}$ de 22 de diciembre de 2014)", en $R d S$, núm. 44, 2015, edición digital,

https://insignis-aranzadidigitales.ponton.uva.es/maf/app/document?rediRect=true\&srguid=i0ad82d9a000001742f3173216e 214e65\&marginal=BIB $2015 \backslash 1608 \&$ docguid=Ia068b680f25011e4af82010000000000\&ds $=$ ARZ_LEGIS_CS\&infotype=arz_biblos;\&spos $=1 \&$ epos $=1 \& \mathrm{td}=1 \&$ predefinedRelationshipsT ype $=$ documentRetrieval $\&$ fromTemplate $=\&$ suggestScreen $=\& \&$ selectedNodeName $=\&$ selec mod=false \&displayName $=$, p. 5.

416 MARÍN DE LA BÁRCENA GARCIMARTÍN, F.: "Deberes de contabilidad y acción individual de responsabilidad. (STS $1^{\text {a }}$ de 22 de diciembre de 2014)", 2015, edición digital, op. cit., p. 6.

${ }^{417}$ Sentencia comentada por MARÍN DE LA BÁRCENA GARCIMARTÍN, F.: "Deberes de contabilidad y acción individual de responsabilidad (STS $1^{\text {a }}$ de 22 de diciembre de 2014)”, 2015, op. cit. 
En esta sentencia se aborda la cuestión acerca de si la conducta antijurídica de llevanza desordenada o con irregularidades graves de la contabilidad, sería un comportamiento antijurídico de los administradores susceptible de causar un daño directo y causal en el crédito de los acreedores sociales. La aportación de esta sentencia será doble. En primer lugar, no excluye la acción individual de responsabilidad ante el incumplimiento del deber de ordenada llevanza de contabilidad- Y, en segundo lugar, establece cuándo el incumplimiento de esos deberes contables puede causar un daño directo al acreedor, cuanto se comprometa la confianza que el acreedor asume ante la información contable conocida, ya que partiendo de ella no adopta medidas adecuadas de protección de su crédito.

La sentencia anterior sienta como regla general que los errores o desajustes en la contabilidad publicada en el Registro Mercantil, per se, no son aptos para el ejercicio de la acción individual de responsabilidad, cuando señala que "las diferencias, errores o desajustes en la contabilidad de una sociedad publicadas en el Registro Mercantil para información general, no parece que sean en sí mismas aptas, adecuadas causalmente, para una acción individual contra sus administradores, que exige una acción u omisión singular directamente orientada hacia el acreedor perjudicado (art. 241 de la LSC)". Dicho lo anterior, no obstante abre la puerta al ejercicio de la acción individual cuando esa alteración contable ha generado una confianza en el acreedor, que le ha llevado a no adoptar medidas preventivas para asegurar el cobro del crédito, medidas que habría adoptado de tener conocimiento cabal de la situación contable. Si la irregularidad contable, la relevancia de las inexactitudes que afectaban a la imagen de solvencia de la compañía, va a impedir que el acreedor, confiando en su realidad o fiabilidad, no adopte medidas o garantías de protección del crédito, que de conocer la situación contable real hubiese adoptado, podrá acreditarse en esos supuestos que el impago de la obligación de la sociedad tiene como causa el incumplimiento de las obligaciones contables.

Para la Sentencia 737/2014, de 22 de diciembre, el daño directo propio de toda acción individual se identifica con el impago parcial del crédito, entendiendo que ese impago "es un perjuicio directo en la medida en que, como se afirma en la doctrina, la conducta ilícita de los administradores les haya llevado a confiar en la situación patrimonial aparente y a seguir contratando sin recabar especiales garantías para prevenir del riesgo de incumplimiento de la sociedad”, Finalmente, la relación de causalidad la estima concurrente, "porque la conducta ilícita de los administradores privó a los acreedores 
demandantes de una información que les hubiera permitido adoptar medidas con las que evitar o aminorar el riesgo de impago".

Doctrina que se mantienen en la Sentencia del TS, Sala Civil, 571/2019, de 4 de noviembre -Rec. 4162/2016-, al considerar que el incumplimiento orgánico del administrador consistente en irregularidades graves en contabilidad podrá ser origen de la acción individual de responsabilidad, aunque se desestima el recurso de casación, porque al reclamarse al administrador social la deuda dejada de percibir de la masa activa del concurso de la sociedad, se considera que si en el proceso concursal en que el acreedor fue parte no se apreció que las irregularidades contables pudieran calificar el concurso como culpable, sin que se impugnase la calificación, no cabría imputar posteriormente el incumplimiento orgánico de las graves irregularidades en la contabilidad como conducta antijurídica causante de un daño para ejercitar la acción individual. La importancia de esta sentencia, consiste en seguir la línea de la sentencia anteriormente referida, de no excluir la acción individual para los incumplimientos de los deberes de llevanza de contabilidad, cuando concluye afirmando "por lo que no existió un ilícito orgánico consistente en un defecto grave en la llevanza de la contabilidad susceptible de haber provocado que naciera el crédito de la demandante que luego resultó impagado" (la cursiva es nuestra). Se está reconociendo que la falta de ordenada contabilidad puede ser incumplimiento de un deber de diligencia que cause daño directo al acreedor, al poder tener relación de causalidad con el impago, que ya la Sentencia de 22 de diciembre de 2014, lo situaba en haber privado ese incumplimiento a los acreedores de una información esencial que les hubiera permitido adoptar medidas para evitar o aminorar el riesgo del impago. La crítica que hace QUIJANO ${ }^{418}$ a esta sentencia, es que de la misma no puede extraerse una regla general de equivalencia vinculante tanto para la calificación del concurso como para la procedencia de la acción individual de responsabilidad, cuando haya irregularidades en la contabilidad, ya que (sic) "aceptar que, si no hay ilícito orgánico suficiente para declarar el concurso como culpable, tampoco lo hay para ejercer la acción individual de responsabilidad, supondría también aceptar la regla inversa, esto es, que, si no hay base para la acción individual, tampoco debe haberla para la calificación culpable", cuando los intereses protegidos en

${ }^{418}$ QUIJANO GONZÁLEZ, J.: "Acción individual de responsabilidad de Administradores e ilícito orgánico (a propósito de la Sentencia del Tribunal Supremo, de 4 de noviembre de 2019)”, op. cit., pp. $15-16$. 
el concurso son colectivos, que exige una mayor rigidez en la apreciación de la ilicitud, y en la acción individual se protege el interés del acreedor particular perjudicado.

MARÍN DE LA BÁRCENA GARCIMARTÍN ${ }^{419}$ comentando la Sentencia del TS, Sala Civil, núm. 737/2014, de 22 de diciembre, puntualizará que, en la acción individual de responsabilidad, no bastará con atribuir la antijuridicidad a la infracción de una norma, como la contable, porque no es suficiente con un comportamiento antijurídico, sino que "es necesario establecer una conexión de imputación objetiva con el resultado dañoso. Si la antijuridicidad de la conducta se basa sólo en la infracción de la norma y el daño causado no entra dentro de su ámbito de protección entonces no será posible acreditar la relación de causalidad (e imputación objetiva) entre la infracción de la norma y el daño causado", razón por la que, habrá que fundamentar la acción (sic) “en la infracción de un deber objetivo de cuidado y no sólo en la infracción de las normas sobre ordenada llevanza de la contabilidad. En el desempeño del cargo, los administradores deben velar por que la sociedad se comporte correctamente en el tráfico y esto implica informar a los terceros sobre las circunstancias que razonablemente pueden considerarse esenciales para la aceptación de los contratos que suscriben con la sociedad o evitar que se proyecte en el mercado una imagen patrimonial falsa. La conexión de imputación objetiva descansará en estos casos en la previsibilidad o adecuación. Si era previsible para los administradores que la información que facilitaban las cuentas (o no facilitaban) podría distorsionar la imagen patrimonial hasta el punto de generar una distorsión en la confianza de los suministradores a crédito el daño resultaría objetivamente imputable".

Con estas resoluciones judiciales ya no podrá afirmarse siempre que la conducta antijurídica de no llevar una ordenada contabilidad, no pueda ser objeto de la acción individual, ya que, si ese incumplimiento impide tener al acreedor una imagen correcta de patrimonio y la situación financiera, lo que le ha impedido anticipar o adoptar medidas para garantizar el pago, esa conducta antijurídica del administrador puede ser causa de la acción individual.

Doctrina jurisprudencial que para la TGSS puede ser de utilidad ya que si la desordenada contabilidad, las deficiencias graves en la llevanza de la contabilidad, ha podido impedir que la TGSS adopte medidas cautelares destinadas a asegurar el cobro

${ }^{419}$ MARÍN DE LA BÁRCENA GARCIMARTÍN, F.: "Deberes de contabilidad y acción individual de responsabilidad. (STS $1^{\text {a }}$ de 22 de diciembre de 2014)”, 2015, edición digital, op. cit., p. 12. 
de las deudas de Seguridad Social, concurriría una conducta antijurídica del administrador que causa un daño directo en el patrimonio de la Seguridad Social, en el crédito de la Seguridad Social no asegurado, mediando relación de causalidad. Ese incumplimiento orgánico del administrador impide a la TGSS conocer la real situación patrimonial y financiera, evitando que ésta adopte medidas cautelares, como embargos preventivos, retención de devolución de ingresos, etc., previstas en el art. 37 del TRLGSS, donde se establece que "para asegurar el cobro de las deudas con la Seguridad Social, la Tesorería General de la Seguridad Social podrá adoptar medidas cautelares de carácter provisional cuando existan indicios racionales que, en otro caso, dicho cobro se ve frustrado o gravemente dificultado".

La falta de presentación o depósito de las cuentas en el Registro Mercantil, en sí misma, tampoco sería constitutiva de la acción individual de responsabilidad, ya que se precisaría acreditar ante esa conducta antijurídica el nexo de causalidad y el daño directo en el impago sufrido por el acreedor. Así en la sentencia del TS, Sala Civil, núm. 286/2005, de 26 de abril -Rec. 4282/1998-, ante la falta de presentación en el Registro Mercantil de las cuentas anuales de los ejercicios 1992 y 1993, se indica que “conforme declara la sentencia de 17 de junio de 2004, este incumplimiento que por Ley se impone a los administradores no es bastante para ser considerado como causa de daño o perjuicio alguno para los acreedores que demandan”. En igual sentido Sentencia núm. 467/2005 de 20 de junio -Rec. 183/1999-.

En la Sentencia del TS, Sala Civil, 202/2020, de 28 de mayo -Rec. 3365/2017-, se justifica la obligación de los administradores sociales de depositar las cuentas en el Registro Mercantil, por ser relevante la información que contiene la contabilidad de una empresa para los terceros en general, y especialmente para los que se relacionan jurídicamente con la sociedad de capital. El incumplimiento del deber legal de depositar las cuentas provoca un doble efecto, por un lado, dará lugar al cierre registral (art. 282.1 LSC con las excepciones previstas en el párrafo 2 de dicho precepto), y, por otro lado, está sujeto al régimen sancionador previsto en el art. 283 LSC, en virtud del cual se podrán imponer sanciones por Instituto de Contabilidad y Auditoría de Cuentas.

Como bien se ha indicado con profusión, sólo prosperará la acción individual cuando el daño al acreedor sea un daño directo, y no un daño reflejo consecuencia de la disminución del patrimonio de la entidad mercantil por falseamiento grave de la contabilidad, con lo cual, hemos de ser conscientes que la viabilidad de la acción 
individual de responsabilidad, tiene un carácter excepcional, ya que en la mayoría de los supuestos, lo pertinente sería la acción social de responsabilidad, ya que el daño originario se producirá en el patrimonio social, debiéndose acreditar suficientemente que estamos ante un daño directo al acreedor, desconectado de un posible daño patrimonial social. Es en esa zona de confluencias del daño, donde se juega el éxito o el fracaso de la acción individual de responsabilidad.

En la responsabilidad solidaria del art. 367 de la LSSC -disolución por pérdidas- se ha admitido desde hace tiempo, la inversión de la carga de la prueba del demandante perjudicado al administrador, por la mayor facilidad probatoria del art. 217.7 de la LEC, como veremos en el Capítulo IV al examinar la responsabilidad solidaria del administrador por deudas de la mercantil.

Para la acción individual se ha aceptado en la jurisprudencia ${ }^{420}$ la inversión de la carga de la prueba al demandado en virtud del art. 217.7 de la LEC, por mayor facilidad probatoria ante el cierre de empresa.

En virtud de esta jurisprudencia la no llevanza de una contabilidad ordenada y su falta de depósito en el Registro Mercantil, en los supuestos de cierres de hecho, al ejercitarse la acción individual podrá tener, cuando menos, el efecto de invertir el onus probandi en el administrador para tener que acreditar que los incumplimientos de las obligaciones de llevanza de la contabilidad y de ordenada liquidación de la sociedad no han sido los causantes del daño al acreedor, si éste realiza una argumentación razonada ante de la falta de prueba directa por ausencia de contabilidad. GARRETA SUCH ${ }^{421}$ criticando la Sentencia del TS, Sala Civil, de 21 de mayo de 1992, en que ante un cierre de hecho se exonera de responsabilidad a los administradores, por no apreciar la relación de causalidad entre la infracción del deber de diligencia de los administradores y el daño

${ }^{420}$ STS, Sala Civil, 253/2016, de 18 de abril -Rec. 2754/2013-y 472/2016 de 13 julio -Rec. 2307/2013-. En esas Sentencias se señala ante un cierre de hecho que "debe atribuirse a dicho administrador la carga de la prueba de aquellos hechos respecto de los que tiene mayor facilidad probatoria (...) El ilícito orgánico que supone el cierre de hecho ha podido impedir el cobro del crédito de quien ejercita la acción individual. En este contexto, la prueba de la inexistencia de bienes y Derechos o el destino de lo adquirido con la liquidación de los existentes, corresponde al administrador y no puede imputarse al acreedor demandante, en aplicación de la regla contenida en el apartado 7 del art. 217 LEC. Frente a la dificultad del acreedor demandante de probar lo contrario (que había bienes y que fueron distraídos o liquidados sin que se destinara lo obtenido al pago de las deudas), dificultad agravada por el incumplimiento del administrador de sus deberes legales de llevar a cabo una correcta liquidación, con la información correspondiente sobre las operaciones de liquidación, el administrador tiene facilidad para probar lo ocurrido, pues se refiere a su ámbito de actuación".

421 GARRETA SUCH, J. M.: La responsabilidad civil, fiscal y penal de los administradores de sociedades, op. cit. p. 217. 
sufrido por el acreedor, señala que "el incumplimiento de las obligaciones del administrador hace imposible para el acreedor la medición de la relación de causalidad, que la desaparición de la empresa no puede favorecer a quien la provoca", especialmente añadimos, cuando no se ha llevado contabilidad en orden ni se ha de depositado en el Registro Mercantil.

Concluimos señalando que, el incumplimiento de la llevanza de contabilidad por los administradores sociales, las graves irregularidades en la misma, o su falta de depósito en el Registro Mercantil, podrá tener dos efectos en las deudas de Seguridad Social ante el ejercicio de una eventual acción individual de responsabilidad. En primer lugar, cuando confiando en la veracidad de la información que la contabilidad manifestaba se haya impedido la adopción de medidas cautelares o de garantías para asegurar el pago por la TGSS, previstas en el art. 37 del TRLGSS (embargo preventivo, retención de pago de devoluciones, etc.), podría argumentarse que ello ha motivado un daño directo en el crédito no garantizado de Seguridad Social ${ }^{422}$. En segundo lugar, ante la ausencia de contabilidad o la falta de su depósito en el Registro Mercantil, si el acreedor realiza una argumentación razonada sobre el impago del crédito como consecuencia de esos incumplimientos, podrá tener el efecto de invertir el onus probandi para que sea el administrador quien tenga que acreditar que los incumplimientos contables y/o el cierre de hecho no han sido la causa del impago o del daño al acreedor, porque pese a esos incumplimientos contables o registrales el impago se hubiera producido de igual modo por la situación patrimonial de la sociedad -principio de facilidad probatoria del art. 217.7 de la LEC- ${ }^{423}$.

\subsection{Acción individual ante la deliberada preterición y perjuicio de determinados acreedores.}

Cuando la conducta del administrador causa daño a un acreedor por haberse satisfecho en su perjuicio la deuda de otros acreedores no preferentes, cabe la posibilidad de admitir la acción individual, en la medida en que nos hallemos ante un daño directo al acreedor perjudicado, y no ante un daño reflejo o indirecto derivado del daño al patrimonio social. Para ESTEBAN VELASCO ${ }^{424}$ cuando se paga a unos acreedores en detrimento de otros, con vulneración del principio de paridad de trato, de la par conditio

\footnotetext{
${ }^{422}$ SSTS, Sala Civil, 737/2014, de 22 de diciembre y 571/2019, de 4 de noviembre.

${ }^{423}$ SSTS, Sala Civil, 253/2016, de 18 de abril -Rec. 2754/2013 -; 472/2016 de 13 julio-Rec. 2307/2013-; 202/2020, de 28 de mayo -Rec. 3365/2017-.

${ }^{424}$ ESTEBAN VELASCO, G.: "La acción individual de responsabilidad”, op. cit., p. 262.
} 
creditorum, de haber con posterioridad situación de insolvencia, cabría la acción individual de responsabilidad, al existir un daño directo en el patrimonio del acreedor, que se cifraría en la cuota que se ha dejado de obtener por los otros pagos indebidos.

Nos encontraremos ante actos dolosos, no meramente culposos del administrador, quien deliberadamente perjudica al acreedor frente a otros de igual o peor derecho. Para MARÍN DE LA BÁRCENA GARCIMARTÍN ${ }^{425}$, en el incumplimiento de las obligaciones contractuales por el administrador podría apreciarse la concurrencia del daño directo al acreedor y no un daño reflejo, cuando el administrador imparte órdenes de no pagar a determinados acreedores por no sufrir daño el patrimonio social, antes al contrario. Para este autor, ante esa conducta dolosa el administrador responde de los daños causados al acreedor conjuntamente con la sociedad, consiguiéndose un reforzamiento de la tutela del crédito al gozar el perjudicado con la garantía de dos patrimonios el de la sociedad y el del administrador incumplidor. Igualmente, QUIJANO $^{426}$ menciona la preterición deliberada del acreedor como supuesto de comportamiento doloso o malicioso susceptible de ser reparado mediante la acción individual de responsabilidad.

En nuestra jurisprudencia podemos encontrar algunas sentencias que en estos supuestos admiten la acción individual de responsabilidad. El Tribunal Supremo, Sala Civil, en la Sentencia núm. 650/2014, de 27 de noviembre -Rec. 623/2013-, declara la responsabilidad del administrador y posterior liquidador por el daño causado a un acreedor (crédito de un trabajador por cuenta ajena frente a la sociedad) al que se ha preterido deliberadamente en el pago frente a otros acreedores que sí han visto satisfechos sus créditos. Igualmente, en la Sentencia núm. 1207/2004, de 13 de diciembre -Rec. 3367/1998-, en la venta de un inmueble, se admite la acción individual de responsabilidad porque la conducta del administrador ha perjudicado a determinados acreedores. Por otro lado, en la Sentencia núm. 274/2017, de 5 de mayo -Rec. 3298/2014-, y en un contexto de práctica liquidación de hecho de la sociedad, ésta paga a un acreedor una suma elevada con relación a su patrimonio que ha impedido el pago a otros acreedores. En definitiva, en esos supuestos estaríamos ante incumplimientos

\footnotetext{
${ }^{425}$ MARÍN DE LA BÁRCENA GARCIMARTÍN, F.: "La acción individual de responsabilidad de los administradores de sociedad anónima frente a socios y terceros (artículo 135)”, 1999, op. cit., p. 314.

426 QUIJANO GONZÁLEZ, J.: "Acción individual de responsabilidad de Administradores e ilícito orgánico (a propósito de la Sentencia del Tribunal Supremo, de 4 de noviembre de 2019)", 2020, op. cit., p. 9 de 16.
} 
dolosos de los administradores en que cabría la posibilidad de exigir la responsabilidad por daños de concurrir el resto de requisitos previstos en el art. 241 de la LSC: acción u omisión antijurídica, daño directo al acreedor y existencia relación de causalidad.

En la Sentencia núm. 650/2014, de 27 de noviembre sobre la acción individual de responsabilidad se debatió si era un hecho constitutivo de responsabilidad por daños, la conducta del administrador social y posterior liquidador excluyendo a un trabajador de recibir el importe obtenido de la venta de las acciones de una sociedad, habiéndose reconocido ese derecho del trabajador en sentencia previa de la Jurisdicción Social que fue conocida por la sociedad demandada y el administrador social. Se admitió la procedencia de la acción individual de responsabilidad del administrador y posterior liquidador por haberse causado un daño directo al trabajador preterido en el pago del importe de la venta de las acciones ${ }^{427}$.

Se aprecia en esta sentencia el daño directo determinante de la acción individual de responsabilidad cuando se paga a unos acreedores con olvido o preterición de otro acreedor con igual derecho, de otro trabajador que pese a haber cesado en la empresa por incapacidad tenía derecho al importe de venta de las acciones. Ello por cuanto el daño es directo al acreedor omitido, y porque esa conducta no causa daño en el patrimonio social ya que éste no resultó perjudicado con el crédito omitido.

En la otra Sentencia núm. 1207/2004, de 13 de diciembre -RJ 2005/265- se condena a los administradores sociales mediante la acción individual de responsabilidad por haber incumplido la sociedad administrada un contrato de compraventa consistente en la entrega de una vivienda para que, previa demolición, se levantarse un bloque de pisos,

\footnotetext{
${ }^{427}$ Se razona del siguiente modo en el Fundamento de Derecho $5^{\circ}$ : "El Tribunal de apelación consideró responsable a don Evaristo, pues entendió que, como administrador, había actuado negligentemente al no haber incluido al demandante entre las personas con derecho a participar en el reparto del precio de las acciones. Comportamiento que le pareció tanto más reprochable cuando Garantía Rentería, SL fue creada, precisamente, para asegurar a los trabajadores de Papresa, SA la satisfacción de sus derechos contra la misma. Y, además, que don Evaristo, como liquidador, teniendo conocimiento de la conciliación intentada por el repetido acreedor, había actuado como si la sociedad no tuviera ninguno y procedido a repartir, entre los socios de la sociedad disuelta, la cuota de liquidación (...). En todo caso, a la vista del supuesto descrito por el Tribunal de apelación hay base suficiente para entender que el ahora recurrente incumplió el deber de diligencia que, como administrador, le imponía el tipo de actividad para la que se había constituido la sociedad; y que, además, como liquidador, contribuyó con otra conducta a la reafirmación del daño, pues, teniendo por aquellas fechas noticia de la reclamación de don Lázaro , incumplió la norma del artículo 120 de la Ley 2/1995 (RCL 1995, 953), que le prohibía abonar la cuota de liquidación sin la previa satisfacción de su crédito contra la sociedad -o sin consignar su importe-. En contra de lo que se afirma en el primer motivo, se trata de un daño resultante, en adecuada relación causal, de dos conductas distintas una, de mayor eficiencia, ejecutada por el administrador y, otra, realizada por la misma persona, ahora como liquidador".
} 
con el compromiso de que los propietarios del solar recibiesen un piso y dos plazas de garaje, compromiso no atendido, ya que la sociedad compradora del inmueble, que no llegó a ejercer actividad inmobiliaria alguna para la que se había constituido, procedió posteriormente a vender el solar una empresa constructora, ocultando el compromiso que habían adquirido para la entrega del piso y las dos plazas de garaje. Ejercitada la acción de resarcimiento contractual al amparo del art. 1124 del Código Civil se condena a la primera empresa compradora del inmueble que se había comprometido a la entrega del piso, y solidariamente a sus administradores al estimarse la acción individual de responsabilidad del art. 241 de la actual LSC -anterior art. 135 de la LSA-. En la sentencia se absuelve a la empresa constructora adquirente posterior del inmueble por desconocer el compromiso de la entrega del piso y las plazas de garaje. Condena a los administradores por incumplimiento deliberado, intencionado, del crédito asumido por la sociedad. En el fundamento de derecho primero se indica: "En los supuestos de incumplimientos contractuales a cargo de la sociedad sí cabe que los administradores resulten responsables conforme al artículo 135 , y aquí, por lo probado, llevaron a cabo actividades negociables que representan un comportamiento calificado certeramente por el Tribunal de Apelación de negligencia grave, concurriendo la necesaria relación de causalidad entre las actuaciones de los recurrentes, suficientemente explicada, y los daños y perjuicios causados a los demandantes, determinante de responsabilidad solidaria (Sentencia de 10-12-1996, así como las de 25-5-1992, 22-6-1995, 31-7 y 25-91996, 28-6-2000 у 30 у 31-12-2002)".

Finalmente, en la Sentencia del TS, núm. 274/2017, de 5 de mayo -Rec. 3298/2014- se condena a la administradora social al pago del importe del crédito impagado al haberse producido una salida injustificada y elevada de dinero del activo social en un contexto de liquidación de hecho de la empresa, consistente en el pago injustificado e inexplicado de $83.000 €$ a otro acreedor, lo que supuso un perjuicio para los demás acreedores sociales (entre ellos para la demandante), pues privó a la sociedad de un activo (una elevada cantidad de numerario, como dice textualmente la sentencia), que podría haberse empleado en pagar el crédito de la demandante y que al haber salido indebidamente del haber social, a modo de liquidación desordenada y por vía de hecho, impidió dicho abono. Con lo que se apreció la relación de causalidad entre ese pago indebido a un tercero y el impago del acreedor reclamante. 
Para NICOLÁS BERNAD ${ }^{428}$ un perjuicio derivado del fraude o negligencia grave en el desempeño del cargo del administrador, sería la falta de pago de obligaciones con la Seguridad Social por haberse pagado a otros acreedores sin respetarse las preferencias de los créditos públicos del art. 1924 del Código Civil.

En virtud de esa jurisprudencia podría reclamarse el pago de deudas con la Seguridad Social mediante el ejercicio procesal de la acción individual de responsabilidad, cuando deliberadamente se desatiende el pago de esas deudas, sean de cotizaciones o prestaciones de responsabilidad empresarial, pero de modo especial cuando se elude el pago de las cuotas mensuales de la sociedad de capital pagándose por el contrario otras deudas sociales de menor prelación o preferencia (arts. 25 y 162 del TRLGSS, en relación con el art. 1924.11 del Código Civil). Deudas atendidas que, incluso en supuestos de insolvencia, podrían tener menor preferencia que la que tienen los créditos de Seguridad Social, de conformidad con los arts. 25 y 162 del TRLGSS, y arts. 242, $244,245,269,270.280,281$ y 429 a 435 del TRLC.

Cuando la sociedad en los períodos previos a la que acaezca una causa de disolución o de insolvencia, por actuación orgánica de los administradores atiende el pago de determinadas obligaciones sociales pretiriendo el pago reiterado de deudas de Seguridad Social, especialmente de deudas por cotizaciones, se podrá reclamar el pago de las deudas anteriores al advenimiento de causa de disolución ejercitando la acción individual de responsabilidad ante el administrador, ya que estamos ante un daño directo en el patrimonio de la Seguridad Social, que no es reflejo de un daño al patrimonio social, y que resulta del incumplimiento de las obligaciones legales de Seguridad Social, por haberse preterido su pago atendiendo otras obligaciones que podrán tener incluso menor prelación en caso de insuficiencia patrimonial. En esos supuestos la acción individual de responsabilidad será una vía de reclamación al administrador de deudas anteriores al advenimiento de la causa de disolución, ya que, para las deudas posteriores el instituto jurídico de reclamación más efectivo contra el administrador social será la derivación administrativa de responsabilidad de las deudas de la sociedad al amparo del art. 367 de la LSC.

Para las deudas de Seguridad Social no satisfechas por la sociedad por preterición, aunque la mercantil sea declarada en concurso de acreedores, se podrá ejercitar la

${ }^{428}$ NICOLÁS BERNAD, J. A.: "La responsabilidad de los administradores sociales ante la Inspección de Trabajo", op. cit., pp. 75 y 87. 
acción individual por las entidades gestoras de la Seguridad y por la TGSS para reclamar el pago del administrador social, teniendo en cuenta que esta acción individual no queda paralizada o suspendida por el hecho de haberse declarado el concurso der acreedores -como se expone los apartados II. 4.3 y VII de este Capítulo-. El daño directo se cifrará en el importe impago de las deudas si la acción individual se resolviere con anterioridad a la conclusión del concurso, o en la parte no satisfecha dentro del proceso concursal de haber finalizado previamente éste.

\subsection{Acción individual por infracciones de las obligaciones de Seguridad Social.}

Supuesto paradigmático de conducta dolosa del administrador susceptible de fundamentar el ejercicio de la acción individual de responsabilidad, es el incumplimiento de obligaciones imperativas de Seguridad Social, estén o no tipificadas en la ley de Infracciones y Sanciones del orden social -TRLISOS-, cuando como consecuencia del incumplimiento se generen deudas con Seguridad Social por la sociedad de capital, y ese incumplimiento sea atribuible al administrador social a título de dolo o culpa grave.

De las deudas de Seguridad Social que nazcan de la infracción de obligaciones de Seguridad Social que debe cumplir la sociedad de capital, podrá resultar responsable el administrador social a través de la acción individual de responsabilidad ${ }^{429}$. Responsabilidad que surgirá especialmente cuando estemos ante incumplimientos reiterados, fraudulentos o con voluntad deliberadamente rebelde de incumplir las obligaciones con la Seguridad Social.

Podrá responder el administrador de las deudas de Seguridad Social que se deriven de esos incumplimientos o de las infracciones de Seguridad Social, pero no de las sanciones administrativas por las infracciones del orden social al impedirlo el principio de personalidad de la sanción. En todo caso, si la sanción administrativa fuere imputable a conducta del administrador el daño directo se producirá en el patrimonio social, lo que no permite el ejercicio de una acción individual de responsabilidad.

En el procedimiento administrativo sancionador en el orden social el único sujeto responsable de la infracción de las obligaciones de Seguridad Social y de la correlativa sanción administrativa es el empresario, en nuestro caso, la sociedad de capital, pero no

${ }^{429}$ NICOLÁS BERNAD, J. A.: "La responsabilidad de los administradores sociales ante la Inspección de Trabajo", op. cit., pp. 82 a 93. 
el administrador social (art. 2 del TRLISOS), a diferencia de lo que ocurre en otros órdenes normativos en que se ha declarado expresamente la responsabilidad del administrador en las infracciones y sanciones de la sociedad, al reconocerse la responsabilidad penal del administrador o la responsabilidad derivada del administrador en el procedimiento administrativo en el pago de las sanciones tributarias impuestas a la sociedad de capital.

El administrador social no tendrá la condición jurídica de sujeto responsable del procedimiento administrativo sancionador, y, por lo tanto, tampoco será el destinatario de la sanción. Cuestión distinta será que la sociedad pueda ejercitar la acción social de responsabilidad contra el administrador para resarcirse del daño patrimonial que le ha causado la sanción.

En virtud del principio constitucional de legalidad rige el principio de personalidad de la infracción y la sanción en el procedimiento administrativo sancionador. De las consecuencias de las infracciones administrativas responderán las personas o entidades a las que se les atribuya legalmente la condición de sujetos responsables de la infracción, siempre que el incumplimiento sea por acción u omisión dolosa o culposa (art. 28 de la LRJSP).

Si de las infracciones de Seguridad Social responde sólo la sociedad de capital en el procedimiento administrativo sancionador, ante la falta de reconocimiento legal expreso de la responsabilidad del administrador social por las infracciones y las sanciones, no cabrá imponerles o exigirles la sanción administrativa ni por derivación administrativa de responsabilidad (art. 12.4 del RGRSS) ni ejercitando la acción individual de responsabilidad ${ }^{430}$, porque ha declarado reiteradamente el $\mathrm{TC}^{431}$ que los principios

${ }^{430}$ NICOLÁS BERNAD, J. A.: "La responsabilidad de los administradores sociales ante la Inspección de Trabajo", op. cit., p. 91.

${ }^{431}$ Desde la STC 18/1981, de 8 Junio el Tribunal Constitucional, ha venido declarando, no solo la aplicabilidad a las sanciones administrativas de los principios sustantivos derivados del art. 25.1 CE (principios de legalidad, tipicidad de infracciones, sanciones, sujetos responsables), considerando que «los principios inspiradores del orden penal son de aplicación con ciertos matices al Derecho administrativo sancionador, dado que ambos son manifestaciones del ordenamiento punitivo del Estado» (FJ 2), sino que también ha proyectado sobre las actuaciones dirigidas a ejercer las potestades sancionadoras de la Administración las garantías procedimentales ínsitas en el art. $24 \mathrm{CE}$, en sus dos apartados, no mediante una aplicación literal, sino «en la medida necesaria para preservar los valores esenciales que se encuentran en la base del precepto, y la seguridad jurídica que garantiza el art. 9 de la Constitución, si bien ha precisado que no se trata de una aplicación literal, dadas las diferencias entre uno y otro orden sancionador, sino «con el alcance que requiere la finalidad que justifica la previsión constitucional» (ibídem). En relación con esa operación de traslación de las garantías del art. $24 \mathrm{CE}$ al procedimiento administrativo sancionador, que viene condicionada a que se trate de garantías que resulten compatibles con la naturaleza de dicho procedimiento, se ha ido elaborando 
inspiradores del ordenamiento penal son aplicables al procedimiento administrativo sancionador, con determinadas matizaciones, al ser ambos manifestaciones del ordenamiento punitivo del Estado, rigiendo dentro de esos principios el de legalidad y tipicidad en materia de infracciones, sanciones y de los sujetos responsables.

Si los administradores sociales no responden de las sanciones administrativas por infracciones del orden social, en cambio, sí que podrán ser responsables de las deudas de Seguridad Social que sean consecuencia del incumplimiento de obligaciones con la Seguridad Social de la sociedad que se deriven de las infracciones de Seguridad Social, cuando ese incumplimiento sea atribuido a la actuación orgánica del administrador social por conducta culposa, dolosa, fraudulenta, o con voluntad deliberadamente rebelde de incumplir.

Esta responsabilidad mediante la acción individual no nacería del mero incumplimiento de las obligaciones sociales en materia de Seguridad Social ya que es jurisprudencia ${ }^{432}$ reiterada que, para la admisibilidad de la acción individual cuando la sociedad no abona sus deudas, se precisa algo más que el mero impago, al tenerse que identificar un comportamiento del administrador distinto del mero acto de no pagar, que constituya un ilícito orgánico causante del daño directo sufrido por el tercero por la falta de cobro de su crédito.

Ese comportamiento distinto al mero incumplimiento de la obligación de pago de obligaciones, como criterio justificativo de la acción individual, lo incardinamos en el incumplimiento culposo, deliberado, reiterado o doloso de obligaciones imperativas de Seguridad Social, de modo especial de las obligaciones instrumentales de afiliación, alta, cotización (arts. 15, 16, 18, 138, 139. 140 y 142 del TRLGSS), o de la obligación de la comunicación de las bases de cotización a través del sistema de liquidación directa

progresivamente en numerosas resoluciones una consolidada doctrina constitucional, en la que se citan como aplicables, sin ánimo de exhaustividad, el Derecho de defensa, que proscribe cualquier indefensión; el Derecho a la asistencia letrada, trasladable con ciertas condiciones; el Derecho a ser informado de la acusación, con la ineludible consecuencia de la inalterabilidad de los hechos imputados; el Derecho a la presunción de inocencia, que implica que la carga de la prueba de los hechos constitutivos de la infracción recaiga sobre la Administración, con la prohibición absoluta de utilizar pruebas obtenidas con vulneración de Derechos Fundamentales; el Derecho a no declarar contra sí mismo; o, en fin, el Derecho a la utilización de los medios de prueba adecuados para la defensa, del que deriva la obligación de motivar la denegación de los medios de prueba propuestos (por todas, SSTC 18/1981, de 8 junio; 77/1983, de 3 de octubre; 7/1998, de 13 enero; 76/1990, de 26 de abril; 14/1999, de 22 febrero; 157/2000, de 12 de junio; y 218/2005, de 12 de septiembre, entre otras muchas). Doctrina que ha seguido el TS en sus Salas Sociales y Contencioso-Administrativa.

432 SSTS, Sala Civil, 571/2019, de 4 de noviembre -Rec. 4162/2016-; 150/2017, de 2 de marzo; y 274/2017, de 5 de mayo. 
(art. 29 TRLGSS)-. Incumplimientos dolosos de los que resultarán deudas por cotizaciones y por prestaciones con la Seguridad Social.

Será atribuible el incumplimiento al administrador a título de culpa cuando: a) no hubiese realizado los actos necesarios, que sean de su incumbencia, para el cumplimiento de las obligaciones de Seguridad Social, b) hubiere consentido el incumplimiento de sus subordinados, c) hayan adoptado acuerdos o instrucciones que den lugar a las infracciones, o cuando las han posibilitado. Actuación imputable del administrador por ser el incumplimiento de las obligaciones atribuible directa o indirectamente a la actuación rectora o gestora del administrador social, de llevar personalmente la gestión de esos actos administrativos (por ejemplo, si es el representante en el sistema RED para la trasmisión de las altas, bajas, y cotizaciones a la Seguridad Social), o cuando sin llevarla personalmente los incumplimientos sean debidos a instrucciones $\mathrm{u}$ órdenes expresas impartidas, o por no haber adoptado las medidas pertinentes para que no se produzcan esos incumplimientos reiterados de las obligaciones legales con la Seguridad Social -culpa in vigilando-.

Sería posible el ejercicio de la acción individual de responsabilidad para reclamar las deudas de Seguridad Social que nazcan de la comisión de las siguientes infracciones graves o muy graves de la sociedad, imputables a título de dolo o culpa a actuación orgánica del administrador:

$1^{\circ}$.- Las deudas de cuotas a la Seguridad Social y de cuotas de recaudación conjunta, debidas a las infracciones de falta de inscripción de la empresa en Seguridad Social, de identificación de centros de trabajo, o de faltas de afiliación o alta de los trabajadores en el sistema de la Seguridad Social (arts. 22 apartados 1, 2, 10, 11, 12, 13 y 16, y art. 23 apartado 1. a) del TRLISOS ${ }^{433}$ ). Cuando consecuencia de esos

433 "Artículo 22. Infracciones graves. Se consideran infracciones graves las siguientes:

1. Iniciar su actividad sin haber solicitado su inscripción en la Seguridad Social; no comunicar la apertura y cese de actividad de los centros de trabajo a efectos de su identificación; no comunicar las variaciones de datos $u$ otras obligaciones establecidas legal o reglamentariamente en materia de inscripción de empresas, incluida la sucesión en la titularidad de la misma, e identificación de centros de trabajo, así como en materia de comunicación en tiempo y forma de los conceptos retributivos abonados a sus trabajadores, o su no transmisión por los obligados o acogidos al uso de sistemas de presentación por medios informáticos, electrónicos o telemáticos.

2. No solicitar la afiliación inicial o el alta de los trabajadores que ingresen a su servicio, o solicitar la misma, como consecuencia de actuación inspectora, fuera del plazo establecido. A estos efectos se considerará una infracción por cada uno de los trabajadores afectados.

(...)

10. La solicitud de afiliación o del alta de los trabajadores que ingresen a su servicio fuera del plazo establecido al efecto, cuando no mediare actuación inspectora, o su no transmisión por los 
incumplimientos se hayan devengado y sean exigibles deudas por cotizaciones a la Seguridad Social se reclamarán a la sociedad mediante la extensión de acta de liquidación de cuotas por la Inspección de Trabajo y Seguridad Social (art. 34 apartado 1. a) del TRLGSS). Esas deudas por cotizaciones de la sociedad, de haber sido declaradas incobrables en el procedimiento administrativo de recaudación, podrían ser susceptibles de reclamarse al administrador social mediante la acción individual de responsabilidad.

Se incluyen también las deudas por cotizaciones a la Seguridad Social cuando por el número de trabajadores afectados estemos, no ante infracciones administrativas por falta de alta, sino ante un delito contra los trabajadores tipificado en el art. 311 del Código Penal si la falta de alta afecta: a) al menos al veinticinco por ciento, en las empresas o centros de trabajo que ocupen a más de cien trabajadores, b) al cincuenta por ciento, en las empresas o centros de trabajo que ocupen a más de diez trabajadores y no más de cien, o c) a la totalidad de los trabajadores, en las empresas o centros de trabajo que ocupen a más de cinco y no más de diez trabajadores.

obligados o acogidos a la utilización de sistemas de presentación por medios informáticos, electrónicos o telemáticos.

11. No comprobar por los empresarios que contraten o subcontraten con otros la realización de obras o servicios correspondientes a la propia actividad de aquéllos o que se presten de forma continuada en sus centros de trabajo, con carácter previo al inicio de la prestación de la actividad contratada o subcontratada, la afiliación o alta en la Seguridad Social de cada uno de los trabajadores que estos ocupen en los mismos durante el periodo de ejecución de la contrata o subcontrata, considerándose una infracción por cada uno de los trabajadores afectados.

12. No proceder dentro del plazo reglamentario al alta y cotización por los salarios de tramitación y por las vacaciones devengadas y no disfrutadas antes de la extinción de la relación laboral. A estos efectos se considerará una infracción por cada uno de los trabajadores afectados.

13. El incumplimiento de la obligación de comunicar a la entidad gestora de la prestación por desempleo, con carácter previo a su efectividad, las medidas de despido colectivo o de suspensión o reducción de jornada, en la forma y con el contenido establecido reglamentariamente, así como la no comunicación, con antelación a que se produzcan, de las variaciones que se originen sobre el calendario inicialmente dispuesto, en relación con la concreción e individualización por trabajador de los días de suspensión o reducción de jornada, así como en este último caso, el horario de trabajo afectado por la reducción.

(...)

16. Comunicar la baja en un régimen de la Seguridad Social de trabajadores por cuenta ajena pese a que continúen la misma actividad laboral o mantengan idéntica prestación de servicios, sirviéndose de un alta indebida en un régimen de trabajadores por cuenta propia. A estos efectos se considerará una infracción por cada uno de los trabajadores afectados".

"Artículo 23. Infracciones muy graves. 1. Son infracciones muy graves:

a) Dar ocupación como trabajadores a beneficiarios o solicitantes de pensiones u otras prestaciones periódicas de la Seguridad Social, cuyo disfrute sea incompatible con el trabajo por cuenta ajena, cuando no se les haya dado de alta en la Seguridad Social con carácter previo al inicio de su actividad". 
Se incluirían también dentro de este grupo las deudas por cotizaciones que deba asumir la sociedad de capital por responsabilidad solidaria o subsidiaria por incumplimientos imputables al administrador en supuestos de falta de alta en otras empresas clientes en los supuestos de subcontratas, cesión ilegal de trabajadores, sucesión de empresas (arts. 42, 43 y 44 del TRLET y arts. 18, 142.1 y 168 apartados 1 y 2 del TRLGSS), o de puesta a disposición de trabajadores de una ETT o Centro Portuario de Empleo (arts. 1 y 16.3 de la LETT). Deudas por faltas de alta de los trabajadores en esas otras empresas clientes cuando la responsabilidad solidaria o subsidiaria de la sociedad de capital fuese imputable a comportamiento culposo del administrador social, y especialmente si ha sido por conducta dolosa.

$2^{\circ}$.- Las deudas por cuotas a la Seguridad Social y por las cuotas de recaudación conjunta, que tengan su origen en las infracciones de falta de cotización o por diferencias de cotización a la Seguridad Social, incluyéndose las deudas por bonificaciones indebidas del subsistema de formación profesional para el empleo (infracciones tipificadas en el art. 22 apartados 3, 9, 15 y en el art. 23 apartado 1. b, f, h, i, k, y apartado 2 del TRLISOS ${ }^{434}$. El apartado 2 del art. 23 citado para la

434 “Artículo 22. Infracciones graves. Se consideran infracciones graves las siguientes: (...)

3. No ingresar, en la forma y plazos reglamentarios, las cuotas correspondientes que por todos los conceptos Recauda la Tesorería General de la Seguridad Social o no efectuar el ingreso en la cuantía debida, habiendo cumplido dentro de plazo las obligaciones establecidas en los apartados 1 y 2 del artículo 26 del Texto Refundido de la Ley General de la Seguridad Social, siempre que la falta de ingreso no obedezca a una declaración concursal de la empresa, ni a un supuesto de fuerza mayor, ni se haya solicitado aplazamiento para el pago de las cuotas con carácter previo al inicio de la actuación inspectora, salvo que haya recaído resolución denegatoria (...)

9. Obtener o disfrutar indebidamente cualquier tipo de reducciones, bonificaciones o incentivos en relación con el importe de las cuotas sociales que corresponda, entendiendo producida una infracción por cada trabajador afectado, salvo que se trate de bonificaciones de formación profesional para el empleo y reducciones de las cotizaciones por contingencias profesionales a las empresas que hayan contribuido especialmente a la disminución y prevención de la siniestralidad laboral, en la que se entenderá producida una infracción por cada empresa y acción formativa (...)

15. Incumplir, las entidades de formación o aquellas que asuman la organización de las acciones formativas programadas por las empresas, los requisitos de cada acción formativa establecidos por la normativa específica sobre formación profesional para el empleo, cuando haya dado lugar al disfrute indebido de bonificaciones en el pago de cuotas, salvo cuando la infracción sea calificada como muy grave de acuerdo con el artículo siguiente. Dichas entidades responderán solidariamente de la devolución de las cantidades indebidamente bonificadas por cada empresa y acción formativa. Se entenderá una infracción por cada empresa y por cada acción formativa".

“Artículo 23. Infracciones muy graves.1. Son infracciones muy graves:

b) No ingresar, en la forma y plazos reglamentarios, las cuotas correspondientes que por todos los conceptos recauda la Tesorería General de la Seguridad Social, no habiendo cumplido dentro de plazo las obligaciones establecidas en los apartados 1 y 2 del artículo 26 del Texto Refundido de la Ley General de la Seguridad Social, así como actuar fraudulentamente al objeto de eludir la responsabilidad solidaria, subsidiaria o mortis causa en el cumplimiento de la obligación de cotizar o en el pago de los demás recursos de la Seguridad Social.(...). 
responsabilidad solidaria en devolución de bonificaciones por acciones de formación de las entidades de formación). Sean deudas por falta de cotización total -por no cotizar por todos o algunos trabajadores-, o por diferencias de cotización, sean diferencias en bases, en tipos de cotización, o por aplicación indebida o fraudulenta bonificaciones, reducciones, compensaciones, o incentivos en las cuotas de Seguridad Social y cuotas de recaudación conjunta.

El impago de cotizaciones de la sociedad cuando sea debida a crisis patrimonial habiendo cumplido con otras obligaciones legales, como haber comunicado los datos necesarios a la TGSS para la práctica de la liquidación, haber solicitado aplazamiento en el pago de cuotas, haber solicitado el concurso de acreedores, o haber promovido la disolución de la sociedad, impedirán el éxito de la acción individual de responsabilidad.

Se incluirán igualmente en estos incumplimientos dolosos o con culpa grave las deudas por falta de cotización o diferencias de cotización que deba asumir la sociedad de capital por responsabilidad solidaria o subsidiaria en supuestos de contratas, subcontratas, cesión ilegal de trabajadores, o sucesión de empresas, cuando los incumplimientos sean imputables al administrador (arts. 42, 43 y 44 del TRLET, y arts. 18, 142.1 y 168 apartados 1 y 2 del TRLGSS), o por responsabilidad subsidiaria o solidaria de la empresa usuaria en las deudas de Seguridad Social de la ETT y de los Centros Portuarios de Empleo respecto a los trabajadores puestos a su disposición (arts. 1, y 16.3 de la LETT).

f) Efectuar declaraciones o facilitar, comunicar o consignar datos falsos o inexactos, que ocasionen liquidaciones, deducciones o compensaciones fraudulentas en las cuotas a satisfacer a la Seguridad Social, o incentivos relacionados con las mismas. (...)

h) Incurrir los empresarios, las entidades de formación o aquellas que asuman la organización de las acciones formativas programadas por las empresas, en el falseamiento de documentos o en la simulación de la ejecución de la acción formativa, incluida la teleformación, para la obtención o disfrute indebido de bonificaciones en materia de formación profesional para el empleo. Se entenderá una infracción por cada empresa y por cada acción formativa.

i) Incumplir la obligación de suscribir el convenio especial en los supuestos establecidos en el artículo 51.9 del Estatuto de los Trabajadores (...)

k) Retener indebidamente, no ingresándola dentro de plazo, la parte de cuota de Seguridad Social descontada a sus trabajadores o efectuar descuentos superiores a los legalmente establecidos, no ingresándolos en el plazo reglamentario.

2. (...) En las infracciones señaladas en el apartado 1.h), las entidades de formación o aquellas que asuman la organización de las acciones formativas programadas por las empresas y los solicitantes o beneficiarios de subvenciones y ayudas públicas, responderán solidariamente de la devolución de las cantidades disfrutadas de forma indebida por cada acción formativa". 
Deudas por cuotas que podrán reclamarse al administrador social aunque los hechos sean constitutivos de delito (de los arts. 307 y 307 bis del Código Penal ${ }^{435}$ ), ya que de esas infracciones penales surgirán también deudas de Seguridad Social por cotizaciones que se dejaron de ingresarse, y que podrían ser reclamadas a aquél a través de la acción individual de responsabilidad de ser consecuencia de un comportamiento doloso del administrador social.

$3^{\circ}$.- Deudas por prestaciones de responsabilidad empresarial de la sociedad de capital, declaradas por la entidad gestora (art. 167 del TRLGSS), cuando se hayan causado por incumplimientos imputables del administrador en materia de afiliación, altas, y cotización a la Seguridad Social, haya sido o no la falta de alta, de afiliación o de cotización objeto de sanción administrativa a la sociedad por la comisión de infracciones tipificadas en el art. 22 apartados 2 y 3 y el art. 23 apartado b) del TRLISOS.

Las deudas por prestaciones de responsabilidad empresarial declaradas por la entidad gestora podrían ser reclamadas al administrador social, cuando por conducta imputable de éste nazca la responsabilidad empresarial en el pago de esas prestaciones rigiendo el principio de automaticidad o pago anticipado de la entidad gestora, especialmente en los supuestos de incumplimientos reiterados, dolosos o con voluntad deliberadamente de rebelde de incumplir el administrador social las obligaciones instrumentales de afiliación, alta y cotización a la Seguridad Social, si la sociedad no ha capitalizado ante la TGSS el importe del capital coste de pensión o prestación por insolvencia, en cuyo caso se produce un daño directo en el patrimonio de la Seguridad Social. De regir el principio de automaticidad, surgirá el derecho de crédito de la entidad gestora o colaboradora ante la empresa declarada responsable. Se incluiría la responsabilidad solidaria o subsidiaria que resultasen de contratas o subcontratas, sucesión de empresa, cesión ilegal de trabajadores y ETT, cuando por insolvencia empresarial no se haga efectivo el pago anticipado al trabajador ante la TGSS (arts. 42, 43 y 44 del TRET y art. 16 de la LETT).

$4^{\mathrm{o}}$.- Deudas por percepción de prestaciones indebidas. Se incluye en este supuesto el reintegro de la prestación que sea consecuencia de la revisión de la resolución

435 Existe delito cuando el importe de la cantidad defraudada por cotizaciones, por bonificaciones o reducciones de cuotas, sean superiores a 50.000 euros, durante cuatro años naturales, agravándose las penas si el importe defraudado excede de 120.000 euros. 
administrativa a instancias de la entidad gestora mediante el proceso de revisión administrativa (art. 55 del TRLGSS) o de revisión ante la Jurisdicción Social (art. 146 LRJS), cuando esa entidad compruebe que el beneficiario ha percibido indebidamente una prestación de Seguridad Social, en cuyo caso, del reintegro de la prestación responde subsidiariamente con el trabajador perceptor quien, por acción u omisión, haya contribuido a hacer posible la percepción indebida, salvo que acredite buena fe. Sujeto cooperador necesario de la percepción indebida que pudo ser imputable a conducta orgánica del administrador social, justificando el ejercicio de la acción individual de responsabilidad, y con mayor fundamento si la sociedad resultare insolvente ${ }^{436}$.

Deudas por prestaciones indebidas impuestas a la sociedad de capital en el procedimiento administrativo sancionador por la comisión de infracciones muy graves de la sociedad de capital consistentes en: $1^{\circ}$ ) dar ocupación a perceptores de prestaciones incompatibles con el trabajo, sin solicitar el alta en Seguridad Social, $2^{\circ}$ ) obtención indebida de prestaciones concurriendo fraude, connivencia $\mathrm{o}$ simulación de relación laboral con los trabajadores, o $3^{\circ}$ ) incrementos indebidos de bases de cotización que generan prestaciones superiores a las debidas (art. 23 apartados 1. a), c), e) y j) y 2 del TRLISOS).

De esas prestaciones indebidas responde solidariamente la empresa con el trabajador para su devolución, cuando estemos ante las infracciones empresariales del art. 23 apartados 1, a), c), y e) y art. 23.2 del TRLISOS, salvo que en la infracción muy grave del art. 23 apartado 1.c) no hubiere mediado dolo o culpa del empleado, en cuyo caso responde sólo la empresa de la devolución (art. 43.3 del TRLISOS).

\footnotetext{
${ }^{436}$ En este sentido en el Anexo de la Instrucción Conjunta de fecha 4.3.2013 de la Dirección General de la Inspección de Trabajo y Seguridad Social y de la Dirección General del Servicio Jurídico de la Seguridad Social para establecer un marco de coordinación en el ámbito de los ilícitos penales contra la Seguridad Social, de fecha 9 de marzo de 2016, se señala, "el artículo 55. 1 del TRLGSS, RDL $8 / 2015$, establece que los trabajadores y demás personas que hayan percibido indebidamente prestaciones de la Seguridad Social vendrán obligadas a reintegrar su importe. Salvo buena fe probada, también responden, con carácter subsidiario los que hayan contribuido, por acción u omisión, a hacer posible la percepción indebida. En consecuencia, la Administración tiene facultades para revisar de oficio y reclamar las prestaciones indebidamente percibidas en vía administrativa, o revisar los actos declarativos de Derechos en vía judicial, a tenor de lo dispuesto en el artículo 146 de la Ley Reguladora de la Jurisdicción Social -LRJS-. Por tanto, con carácter general, conviene recordar que el Derecho administrativo contempla la posibilidad de proceder a la revisión de sus actos; esta facultad revisora responde a sus propias reglas, independientes del Derecho penal y del administrativo sancionador; y sólo en determinados supuestos, siempre excepcionales, la revisión de los actos administrativos guardará relación con la comisión de un ilícito penal”.
} 
Deudas por responsabilidad solidaria en la devolución de prestaciones aplicable en contratas y subcontratas (artículo 23.2 del TRLISOS).

En todos estos supuestos de responsabilidad en prestaciones la principal dificultad para el ejercicio de la acción individual de responsabilidad, está en acreditar el daño directo al patrimonio de la Seguridad Social, que no sea reflejo de un daño al patrimonio social, ya que los incumplimientos del administrador han motivado que la sociedad asuma ex novo el pago de una prestación, que no nace de la mera relación jurídica general de la empresa con la Seguridad Social, sino del incumplimiento del administrador de otras obligaciones instrumentales del orden social, con lo que se genera un daño al patrimonio social. Ahora bien, el daño directo se causa a la Seguridad Social, siendo reflejo o consecuencia de aquél el daño en el patrimonio de la sociedad y condicionado a que se haya constatado o aflorado la conducta empresarial constitutiva del fraude a la Seguridad Social, ya que de no ser comprobada la infracción no existirá lesión al patrimonio social y sí, en todo caso, en el patrimonio de la Seguridad Social al ser indebida la prestación.

La doctrina jurisprudencial que admite la acción individual ante incumplimientos de normas imperativas, analizada en el apartado III.2 de este capítulo, podría servir de fundamento adicional para el ejercicio de la acción individual del art. 241 de la LSC, especialmente ante las deudas por cotizaciones de Seguridad Social, siempre que el incumplimiento de las obligaciones de instrumentales con la Seguridad Social -faltas de alta de trabajadores, o no comunicar los datos necesarios para la facturación de la liquidación en el sistema de liquidación directa-, sea imputable al administrador, especialmente a título de dolo.

Cabría el ejercicio de esta acción individual antes las deudas por cotizaciones a la Seguridad Social derivadas de las infracciones graves o muy graves del TRLISOS, al concurrir los requisitos constitutivos de la misma. En primer lugar, porque estaremos ante actos u omisiones antijurídicas que infringen una disposición imperativa laboral o de Seguridad Social impuesta a la sociedad, cumplimiento de obligaciones que se inserta en ámbito competencial de los administradores. En segundo lugar, porque concurre la culpa, especialmente ante conducta dolosa existiendo voluntad deliberada de incumplir, teniendo en cuenta que se presume la culpabilidad por actos contrarios a la ley (art. 237 LSC). En tercer lugar, porque esa conducta antijurídica causa un daño directo en los derechos económicos de la Seguridad Social, que no es reflejo de un daño 
al patrimonio social, ya que el cumplimiento de las obligaciones laborales y de Seguridad Social no puede considerarse causante de un daño en el patrimonio social, al ser una obligación de Derecho público que surge de las relaciones laborales desarrollas en el ámbito de la empresa, que en todo caso ha de atender la sociedad con su patrimonio. El único daño al patrimonio social serían los recargos, intereses de demora, costas del procedimiento, pero no el importe de la deuda de Seguridad Social liquidada, ya que ésta debió ser satisfecha en plazo reglamentario, siempre que la falta de pago sea imputable a conducta orgánica de administrador, y no sea debida a una situación patrimonial deficiente de la sociedad, en cuyo supuesto se precisa haber cumplido otras obligaciones como haber solicitado aplazamientos, concurso de acreedores, promoción de la disolución, etc. En cuarto lugar, porque hay relación de causalidad entre el daño y la acción u omisión antijurídica de los administradores.

Esos incumplimientos culpables y dolosos tendrán una clara relación causal con el daño directo al patrimonio de la Seguridad Social, cuando se incumpla conjuntamente la obligación del pago mensual de cotizaciones y la obligación instrumental de comunicación mensual de las bases de cotización de los trabajadores a la TGSS al través del sistema de liquidación directa (art. 29 del TRLGSS), al generarse deudas por cotizaciones a la Seguridad Social que se reclamarán por bases de cotización estimadas, no por bases reales de cotización (art. 35 TRLGSS), con el consiguiente daño también a los trabajadores beneficiarios de prestaciones al tener que reconocerse éstas acudiéndose a la técnica de integración de lagunas, partiendo de las bases mínimas de cotización (arts. 45, 161, 197.4, 209.1.b y Disposición Adicional 1ª del TRLGSS).

Por el contrario, no serían exigible mediante la acción individual de responsabilidad las deudas de Seguridad Social consistentes en la pérdidas o exclusiones de los beneficios a la cotización que se hayan impuesto a la sociedad de capital en el procedimiento administrativo sancionador como sanciones accesorias por infracciones graves o muy graves (arts. 46 y 46 bis del TRLGSS). No son exigibles al administrador porque el daño directo se produce en el patrimonio de la sociedad.

\section{Acción individual de responsabilidad por incumplimientos de deberes disolutorios y concursales.}

Cabrá la acción individual ante vaciamientos patrimoniales de la sociedad, crisis patrimoniales y cierres de hecho sin ordenada liquidación. 
En alguna reciente sentencia del Tribunal Supremo $^{437}$ se afirma que, en determinados supuestos, la imposibilidad del cobro de los créditos por los acreedores sociales puede ser debido a un daño directo imputable a los administradores sociales, precisándose para ello que concurran circunstancias muy excepcionales y cualificadas: a) sociedades que por la realización de embargos han quedado sin bienes y han desaparecido de hecho, pese a lo cual los administradores, en su nombre, han seguido contrayendo créditos; b) concertación de servicios económicos por importe muy elevado justo antes de la desaparición de la empresa; c) desaparición de facto de la sociedad con actuación de los administradores que ha impedido directamente la satisfacción de los créditos de los acreedores; d) vaciamiento patrimonial fraudulento en beneficio de los administradores o de sociedades o personas con ellos vinculados que imposibilitan directamente el cobro de los créditos contra la sociedad, etc.

En la Sentencia núm. 1178/2003 de 17 de diciembre -RJ 2004/195-, el Tribunal Supremo admite la acción individual cuando la actuación del administrador social ha provocado una disminución patrimonial que impide a la sociedad hacer frente a sus deudas, en la medida en que la conducta negligente del administrador único, resultó gravemente perjudicial para la situación económica de la sociedad, al aumentar el endeudamiento de la misma, y provocar con ello un daño al acreedor, con evidente relación causal entre la situación económica de la sociedad y el daño. Según esa sentencia, para que los terceros acreedores puedan accionar han de acreditar que su crédito ha sido perjudicado, y ello sólo se producirá cuando el título es válido y eficaz, y la deuda habiendo vencido resulte líquida y exigible.

Cuando se ha admitido la acción individual en situaciones de despatrimonialización de la sociedad, por impago de deudas sociales, se exige la prueba rigurosa de que el impago cause un daño directo al patrimonio del acreedor, que no sea reflejo de un daño al patrimonio social, ya que de ser así estaríamos ante la acción social de responsabilidad.

La acción individual de responsabilidad en las situaciones de crisis o vaciamientos patrimoniales de la sociedad puede ver reducido su campo de aplicación por dos vías, en primer lugar, por ser de aplicación la acción social de responsabilidad si el daño directo del administrador recae en el patrimonio de la sociedad, y, en segundo lugar, porque de

\footnotetext{
${ }^{437}$ Sentencia TS, Sala Civil, 150/2017, de 2 de marzo -Rec. 2118/2014-.
} 
concurrir una causa de disolución el acreedor acudirá a reclamar la responsabilidad por deudas prevista en los arts. 360 y 367 de la LSC, que le ofrece mayores garantías de obtener el pago del administrador, al exigirse menor carga probatoria, que en el caso de ser deudas de Seguridad Social será la reclamación preferente por las ventajas de su reclamación en el procedimiento administrativo recaudatorio.

Podrá defenderse la acción individual de responsabilidad en deudas de Seguridad Social ante situaciones de crisis económica o deficiencias patrimoniales, ya que la conducta antijurídica y culpable del administrador se pone de relieve en el incumplimiento de las obligaciones de solicitar las altas en Seguridad Social de los trabajadores o de no ingresar las cotizaciones, incluso cuando se cumple la obligación instrumental de comunicación de las bases de cotización en el sistema de liquidación directa (infracción grave del art. 22.3 del TRLISOS), porque la difícil situación económica o tener elevadas deudas no son hechos constitutivos de fuerza mayor que exima de responsabilidad, si adicionalmente no se han cumplido obligaciones como haber solicitado el concurso de acreedores ante el impago de cuotas de tres meses anteriores (art. 2.4.5 ${ }^{\circ}$ TRLC), o un aplazamiento en el pago de las cotizaciones adeudadas (Sentencia del TS, Sala Social, 691/2019, de 8 de octubre -Rec. 2/2017-438). Con ello, se pone de relieve la necesidad de la empresa de cumplir con las obligaciones de solicitar aplazamientos ${ }^{439}$, o el concurso de acreedores ante el impago de cuotas de tres mensualidades (art. 2.4.5 ${ }^{\circ}$ del TRLC). La dificultad sería determinar si esos incumplimientos de no solicitar el aplazamiento de pago o el concurso de acreedores serían constitutivos de un daño directo al patrimonio social, y estimamos que se produciría ese daño directo cuando de

${ }^{438}$ En esa Sentencia interpretando el alcance de las tres circunstancias eximentes de la infracción grave del art 22.3 del TRLISOS, se indica, "la alegación de una evidente situación de cúmulo de deudas no puede servir para aplicar tales eximentes. De un lado, no pueden servir para afirmar la concurrencia de fuerza mayor, la cual se define tradicionalmente como un acontecimiento extraordinario, irresistible e imprevisible, y que no hubiera sido posible evitar aun aplicando la mayor diligencia. Por otra parte, resulta atribuible a la propia empresa una conducta negligente al no instar el concurso de acreedores en base a la situación que ella misma pretende ahora hacer valer para eludir la sanción que, por la falta de satisfacción de su responsabilidad, se le impone (arts. 1.1, 2 y 5 de la Ley 22/2003, de 9 de julio, Concursal). Lo mismo cabe decir de la inacción en aras a un eventual aplazamiento de la deuda de Seguridad Social (art. 23 LGSS y arts. 31.1 y ss. del RD 1415/2004, de 1 de junio, por el que se aprueba el Reglamento General de Recaudación de la Seguridad Social). Es la propia empresa la que ignora el uso de instrumentos tendentes a dar salida jurídica a la alegada crisis, manteniendo conscientemente el endeudamiento". La cursiva es nuestra.

En igual sentido STS, Sala Social, 65/2021, de 19 enero -Rec. 3/2020-.

${ }^{439}$ Nuestro ordenamiento de Seguridad Social prevé el aplazamiento o fraccionamiento en el pago de deudas de Seguridad Social devengadas, cuya concesión le permitiría considerar a la empresa al corriente en el pago de las obligaciones de Seguridad Social, de modo que se evita una eventual responsabilidad empresarial por prestaciones por impago de las deudas de cotizaciones aplazadas (art. 31.3 RGRSS). 
haberse cumplido con esas obligaciones legales no se hubieren producido los impagos, correspondiendo la carga de la prueba al administrador social y no a la TGSS, porque es la sociedad a través del órgano de administración quien no cumple con esas otras obligaciones legales que permitirían dar salida jurídica a la crisis, para evitar mantener o incrementar el endeudamiento. Daño directo al patrimonio de la Seguridad Social que no es daño reflejo de un daño al patrimonio social, si el incumplimiento es de la obligación de solicitar las altas o afiliaciones a la Seguridad Social.

\subsection{Tipología de responsabilidades de los administradores por incumplimientos de esos deberes.}

En estas situaciones de crisis patrimoniales de la sociedad de capital pueden concurrir tres responsabilidades del administrador, la responsabilidad por deudas ante una causa de disolución del art. 367 de la LSC, la responsabilidad concursal para responder del déficit patrimonial de la masa activa del concurso (art. 456 del TRLC) y la posible aplicación de la acción individual de responsabilidad.

Ante la concurrencia de una causa de disolución la responsabilidad del administrador se podrá exigir a través de dos institutos jurídicos, en primer lugar, mediante la responsabilidad por deudas de los arts. 360 y 367 de la LSC, y, por otro lado, mediante la acción individual de responsabilidad, principalmente ante situaciones de cierre de hecho empresarial. Ejercicio de la acción individual ante situaciones de crisis patrimoniales, de despatrimonialización de la sociedad, que tendrá un carácter más residual frente a la responsabilidad ex lege por deudas de los arts. 360 y 367 de la LSC

Ante el incumplimiento de los deberes disolutorios previstos en los arts. 364 a 366 de la LSC, en el art. 367 de esa disposición legal se impone ex lege una responsabilidad solidaria a los administradores para el pago de las deudas de la sociedad posteriores al acaecimiento de la causa de disolución. Responsabilidad solidaria que será la vía preferente, pero no única ni excluyente, para exigir la responsabilidad del administrador en deudas de Seguridad Social, al encontrarnos ante una responsabilidad solidaria ex lege por deuda ajena de mayor efectividad, que no exige la concurrencia de los requisitos propios de la responsabilidad extracontractual por daños del art. 241 de la LSC (acción u omisión antijurídica, culpable, que causa daño directo, y la relación de causalidad entre el daño y la conducta), ya que en esa responsabilidad solidaria del art. 367 de la LSC es suficiente con probar la existencia de una deuda, la concurrencia de 
causa de disolución y el incumplimiento de los deberes disolutorios impuestos legalmente al administrador ${ }^{440}$ (para un conocimiento de esta responsabilidad por deudas nos remitimos al Capítulo IV de esta investigación).

Al responder sólo de las deudas posteriores, adquiere relevancia la acción individual de responsabilidad a efectos de reclamar la responsabilidad por las deudas anteriores, y de modo particular ante un cierre de hecho de la empresa. En nuestra jurisprudencia se ha venido admitiendo que si, como consecuencia del incumplimiento de los deberes disolutorios impuestos a los administradores, se produce un daño directo al acreedor, y queda acreditada la relación de causalidad entre el daño y la omisión de los mismo, así como el dolo o la culpa, no hay ningún obstáculo jurídico para que pueda entablarse la acción individual de responsabilidad.

La acción individual de responsabilidad no se excluye ante incumplimientos de deberes disolutorios, aunque ese incumplimiento sea también causa de la responsabilidad por deudas del administrador social ${ }^{441}$.

La reclamación de la responsabilidad por deudas y la responsabilidad por daños de la acción individual de responsabilidad son compatibles, complementarias y no excluyentes, siendo posible su acumulación procesal.

La crisis concursal se caracteriza frente a la crisis disolutoria en que el deudor se encuentra en estado de insolvencia, con riesgo actual o futuro de impago de los créditos, al poder ser la insolvencia actual o inminente (art. 2.3 del TRLC). La "insolvencia actual" es aquella situación en la que el deudor "no puede cumplir regularmente sus obligaciones exigibles" (art. 2.3 del TRLC), y la "insolvencia inminente" tiene lugar cuando el deudor prevé que no podrá cumplir regular y puntualmente sus obligaciones (art. 2.3 del TRLC). La insolvencia implica imposibilidad de cumplimiento regular por

${ }^{440}$ SSTS, Sala Civil, de 20 de febrero de 2004 -RJ 2004/838- y de 23 de febrero de 2004 -RJ 2004/1138-, entre otras muchas).

${ }^{441}$ La STS, Sala Civil, número 464/2008, de 30 de mayo -Rec. 1219/2001-, señala "La Jurisprudencia de esta Sala ha admitido que, en régimen de concurso ideal, la situación de insolvencia de una sociedad en la que los administradores han incumplido su obligación de promover la disolución, además de ser determinante de la responsabilidad a que se refiere el artículo 262.5 LSA, pueda dar paso a la responsabilidad individual, por la vía de la acción llamada "individual" del artículo 135 LSA, cuando la insolvencia de la sociedad provocada por la negligencia de los administradores causa una lesión directa a los acreedores (SSTS 11 de diciembre de 1991, 10 de diciembre de 1996, 11 de noviembre de 1997, 17 de diciembre de 2003, 20 de febrero de 2004, 27 de octubre de 2006, etc.) pues, como decía la STS 14 de marzo de 2007, la responsabilidad por los actos de los administradores comprende la acción y la omisión". Las referencias a los artículos 265.5 y 135 de la LSA, deben entenderse realizadas actualmente a los arts. 367 y 241 de la LSC.

En similares términos la STS, Sala Civil, 716/2018, de 19 de diciembre -Rec. 3648/2015-. 
la sociedad de sus obligaciones que para PULGAR EZQUERRA ${ }^{442}$ hay que conectar con una situación de desbalance o iliquidez definitiva y no temporal, porque éstas dificultarían pero no imposibilitarían el cumplimiento.

El daño directo al acreedor propio de la acción individual no puede consistir en la insolvencia de la sociedad (SSTS, Sala Civil, 417/2006, de 28 de abril y 150/2017, de 2 de marzo -Rec. 2118/2014-). Para la STS de 2 de marzo de 2017, en caso de que el acreedor haya sufrido daños como consecuencia de la insolvencia de la sociedad deudora, la acción que puede ejercitarse, como regla general, no será la individual, sino la social que permite reintegrar el patrimonio de la sociedad. Para que proceda la acción individual debe causarse un daño directo al acreedor no siempre fácil de apreciar en situaciones concursales.

Ante la concurrencia de una causa de insolvencia, el administrador podrá incurrir en responsabilidad concursal si se le condena a la cobertura del déficit patrimonial en caso de concurso de acreedores de la sociedad, calificado de culpable si por su conducta imputable ha generado o agravado la situación de insolvencia. Responsabilidad concursal que se analizará en el Capítulo V apartado VI de esta tesis.

Nos detenemos ahora en la viabilidad de la acción individual de responsabilidad que pueda emprender el acreedor ante el administrador, por impago de la sociedad de deudas anteriores a la concurrencia de la causa de disolución, cuando aquél haya incumplido sus deberes orgánicos y exista un daño directo al derecho de crédito concurriendo el resto de los requisitos de esta clase de acción de responsabilidad.

Con la finalidad de determinar la procedencia o improcedencia de la acción individual de responsabilidad en situaciones de crisis patrimoniales, haremos una breve introducción acerca de qué acción es la adecuada ante el incumplimiento de los deberes disolutorios y concursales, respecto a las deudas contraídas, si la acción social o la acción individual. Para esta investigación acudiremos a la doctrina científica y a la jurisprudencia, dedicando un apartado propio a hacer una mención específica al cierre de hecho de la empresa, al ser el incumplimiento paradigmático de los deberes de una ordenada liquidación de la sociedad.

${ }^{442}$ PULGAR EZQUERRA, J.: "El presupuesto objetivo de apertura del concurso de acreedores”, en: GARCÍA VILLAVERDE, R.; ALONSO UREBA, A.; y PULGAR EZQUERRA, J. (directores): Derecho Concursal. Estudio Sistemático de la Ley 22/2003 y de la Ley 8/2003 para la Reforma Concursal, Editorial Dilex, Madrid, 2003. pp. 67 y 75. 
De estimarse procedente la acción individual de responsabilidad para las deudas anteriores al incumplimiento de deberes disolutorios o para las deudas existiendo causa concursal en la sociedad, se nos abre la puerta para poder reclamar a los administradores el impago de obligaciones con la Seguridad Social devengadas, siempre que acreditemos que esas conductas causen daño directo en el cobro de esos créditos.

\subsection{Acción individual o acción social en las crisis patrimoniales irreversibles de la sociedad.}

Ante crisis patrimoniales que pueden tornarse irreversibles, según MARÍN DE LA BÁRCENA GARCIMARTÍN ${ }^{443}$ podemos encontraremos con situaciones empresariales en que, concurriendo causas de disolución o concurso, los administradores continúan con la actividad sin remover la causa y sin cumplir con los deberes de una ordenada disolución-liquidación, en algunos casos, en espera de solventarse la crisis al considerarla coyuntural, cuando deviene posteriormente en irreversible, y en otros, por situarse los administradores en una auténtica huida hacia adelante abocando a una despatrimonialización total de la mercantil, incumpliendo los más elementales deberes ante una situación de crisis empresarial.

Dejemos apuntada la posibilidad de que los administradores pueden asumir la responsabilidad extracontractual por daños en contrataciones en situaciones de crisis irreversible de la sociedad. El TS, en Sentencia de la Sala Civil, 43/2010, de 12 de febrero -Rec. 1850/2005-, señala “como afirma la Sentencia de esta Sala no 87/2004, de 16 febrero, en los supuestos de responsabilidad por deudas sociales, los administradores efectivamente pueden incurrir en responsabilidades, pero para ello es preciso, en el marco de la responsabilidad por daño a los acreedores, que la contratación se hubiera llevado no precisamente en situación de dificultades económicas de la sociedad, lo que entra en el ámbito de la normalidad comercial, sino más bien de crisis irreversible con acreditada falta de capital".

La responsabilidad por daños podrá ser reclamada ante situaciones de crisis irreversibles o insolvencia de la sociedad, pero para ello se precisa, no solo que se haya incumplido una obligación de la sociedad, sino que ese incumplimiento vaya acompañado de otros ilícitos orgánicos del administrador, o en palabras del Tribunal Supremo (Sala Civil,

443 MARÍN DE LA BÁRCENA GARCIMARTÍN, F.: “La acción individual de responsabilidad de los administradores de sociedad anónima frente a socios y terceros (artículo 135)”, 1999, op. cit, p. 315. 
Sentencia 571/2019, de 4 de noviembre -Rec. 4162/2016-), "es necesario identificar un comportamiento propio del administrador, distinto del mero acto de no pagar el crédito, que constituya un ilícito orgánico (conducta antijurídica por infringir la Ley, los estatutos o no ajustarse al estándar o patrón de diligencia exigible a un ordenado empresario) al que pudiera imputarse la causación directa del perjuicio sufrido por el tercero, que es la falta de cobro de un crédito".

La primera cuestión a esclarecer es si, ante las situaciones de crisis irreversibles o de despatrimonialización de la sociedad, generando el impago de los créditos anteriores, cabría la acción individual, o si lo pertinente sería la acción social de responsabilidad. Examinaremos, en primer lugar la jurisprudencia, para posteriormente, destacar brevemente las interpretaciones doctrinales mantenidas al respecto, ya que ante situaciones de crisis patrimoniales irreversibles de la sociedad se han planteado dudas sobre la procedencia de la acción individual de responsabilidad, tanto en la doctrina como en la jurisprudencia, por considerarse "ab initio" que los daños causados serían principalmente en el patrimonio social y sólo de modo reflejo en los acreedores. Dejaremos para un apartado propio el supuesto de cierre de hecho de la empresa.

Partimos de la premisa de que en la acción individual de responsabilidad el presupuesto básico viene constituido por la existencia de un daño directo, que no significa que se derive de modo automático de toda situación de crisis patrimonial o insolvencia de la sociedad $^{444}$.

Partiendo de nuestra Jurisprudencia, nos encontramos con pronunciamientos en los que se aprecia la concurrencia de los requisitos de la acción individual de responsabilidad, y por el contrario, en otras sentencias en función de los hechos probados se concluye que la acción adecuada sería la acción social de responsabilidad.

Antes de relacionar las sentencias del Tribunal Supremo que se han decantado por la acción individual o la acción social, partiremos de la consolidada doctrina delimitadora del ejercicio de una u otra acción, en función de cuál sea el bien jurídico protegido, resumida en la Sentencia del TS, Sala Civil, 485/2018, de 11 de septiembre -Rec. 2365/2015-. En la acción social de responsabilidad el daño patrimonial directo que los administradores puedan causar a la sociedad puede, de modo reflejo, provocar también

${ }^{444}$ SSTS, Sala Civil, de 10 de diciembre de 1996, 21 de noviembre de 1997 citadas por la Sentencia 1055/2006, de 9 de enero -Rec. 2048/1999-, entre otras. 
daños a los acreedores, porque dada la función de garantía que el patrimonio social tiene para el acreedor, el quebranto patrimonial provocado por la conducta ilícita del administrador supone la disminución, o incluso la desaparición de esa garantía frente a los acreedores. Pero para que proceda la acción individual se precisa que la conducta del administrador cause un daño directo al derecho de crédito del acreedor, que no sea reflejo de un daño al patrimonio social. Si el daño es reflejo del daño al patrimonio social sólo puede ejercitarse la acción social de responsabilidad, en cuyo caso, la indemnización que se obtenga reparará el patrimonio social y, de reflejo, el individual del acreedor.

Siendo factor esencial para apreciar la acción individual de responsabilidad el daño directo al acreedor y la relación de causalidad entre el daño y la conducta del administrador, en situaciones de crisis patrimoniales surge el problema de poder acreditar si estamos ante un daño directo al acreedor independiente de un eventual daño al patrimonio social, por cuanto que en esas situaciones el daño normalmente se produce en el patrimonio de la sociedad.

En situaciones de despatrimonialización podremos encontrarnos sentencias en ambos sentidos, unas han admitido la acción social ${ }^{445}$ y otras la acción individual ${ }^{446}$, en función de que el daño directo se cause en el patrimonio social o en patrimonio del acreedor. En cambio, al no concurrir un daño directo en el acreedor se ha denegado por el Tribunal Supremo la acción individual en otras sentencias ${ }^{447}$.

Se ha admitido la acción individual en situaciones de crisis patrimonial de la sociedad en las siguientes sentencias del TS, Sala Civil:

- En la Sentencia 388/2001, de 19 de abril -Rec. 3931/1997- se aprecia la acción individual ejercitada por un acreedor, por una gestión contraria no sólo a las más elementales directrices de la vida societaria, sino a las propias exigencias legales, ya

445 SSTS, Sala Civil, 132/2009, de 2 de marzo -Rec. 1644/2004-; 667/2009, de 23 de octubre -Rec. 199/2005-; 396/2013, de 20 de junio -Rec.1421/2011-; y 150/2017, de 2 de marzo, entre otras.

${ }^{446}$ SSTS, Sala Civil, 388/2001, de 19 de abril -Rec. 3931/1997-; 1103/2002, de 25 de noviembre -Rec. 1425/1997-; 1191/2003, de 15 de diciembre -Rec. 348/1998-; 87/2004, de 16 de febrero -Rec. 1345/1998-; 261/2007, de 14 de marzo -Rec. 262/2000-; 1207/2004, de 13 de diciembre -Rec. 3367/1998-; núm. 950/2005 de 30 noviembre -RJ 2006135-; núm. 1049/2008, de 11 de noviembre Rec. 974/2004-; núm. 670/2010, de 4 de noviembre -Rec. 422/2007-. A todas estas, hay que añadir las dictadas en los últimos años en supuesto de cierre de hecho de la sociedad, a las que aludiremos posteriormente en el apartado 3.4.3.

447 SSTS, Sala Civil, 1200/2004 de 7 de diciembre -RJ 2004/7914-; 409/2005 de 26 de mayo -RJ 2005/6302-; 467/2005 de 20 de junio -RJ 2005/6425-, entre otras. 
que no se elaboraron anualmente las cuentas, ni se realizó auditoría a la empresa, y con tales actuaciones han generado culpablemente una insolvencia que ha llegado a ser calificada de fraudulenta. Se aprecia daños directos al patrimonio del acreedor (daños primarios).

- En la STS 1103/2002, de 25 de noviembre -Rec. 1425/1997- se enjuició la virtualidad de la acción individual de responsabilidad ante un cese sin ordenada disolución o liquidación, continuándose la actividad bajo otra forma societaria, concluyendo que el daño causado al acreedor era un daño resarcible mediante el ejercicio de la acción individual de responsabilidad, condenándose por el importe del crédito reclamado, no por ninguna teórica cuota de liquidación del patrimonio social deficitario resultante.

- En la STS, Civil, núm. 1191/2003, de 15 de diciembre -Rec. 348/1998- para que pueda apreciarse la acción individual de responsabilidad deberá haber existido un patrimonio que de haberse liquidado ordenadamente hubiese permitido satisfacer los créditos.

- En la STS núm. 261/2007, de 14 de marzo -Rec. 262/2000- se examina el incumplimiento de deberes disolutorios, siendo los hechos los siguientes. Se había procedido a la venta y alzamiento de todos los activos de la sociedad de forma arbitraria, concurriendo causa de disolución por pérdidas, con ausencia de cuentas anuales, e inexistencia de actividad social con la consiguiente imposibilidad manifiesta de realizar el fin social. No existía capital que hiciese viable la consecución del fin social. Se carecía de instalaciones, maquinaria, al alzarse los únicos bienes conocidos, y de mano de obra al haber procedido al despido de toda la plantilla. No se solicitó la baja de la Sociedad registralmente, sin constar en el Registro Mercantil documentación alguna a partir del año 1993, bien sean las cuentas anuales o cualquier otro acuerdo que debiera ser inscrito. Afirma que la carga de la prueba de la insolvencia de la sociedad no se puede hacer recaer sobre el acreedor, pues éste no tiene por qué conocer cuáles son los bienes de aquél y no cabe exigirle una labor de investigación o indagación más allá de lo que puede advertirse fácilmente por los signos externos o consulta de un registro, ya que, por el contrario, es el deudor quien fácilmente puede desvirtuar la afirmación de insolvencia mediante la indicación de bienes de su propiedad susceptibles de 
realización, por lo que a él incumbe la carga de la prueba. Aprecia la acción individual por incumplimiento de deberes disolutorios, porque la desaparición de la empresa sin haberse practicado la oportuna liquidación comporta una vulneración de la ley que puede llevar consigo un perjuicio para los titulares de créditos pendientes que, de esa forma, no han podido controlar la liquidación de la mercantil ni el destino final de su patrimonio. Esta doctrina se continuará y perfilará en la reciente jurisprudencia referida a los cierres de hecho.

Esta última sentencia es muy importante en materia de reclamación de deudas de Seguridad Social, ya que en situaciones de desaparición de la empresa sin ordenada liquidación y sin presentación de cuentas anuales, la carga de la prueba de la insolvencia de la sociedad no recae sobre las entidades recaudadoras o gestoras de la Seguridad Social, que no tiene por qué conocer cuáles son los bienes de la mercantil, y no cabe exigirles una labor de investigación o indagación más allá de lo que puede advertirse fácilmente por los signos externos o por consulta de un registro, correspondiendo al administrador desvirtuar la afirmación de insolvencia mediante la indicación de bienes de la sociedad.

De la práctica totalidad de estas sentencias en que se estima la acción individual de responsabilidad en crisis patrimoniales, que pueden ser concurrentes con causas de disolución o concurso, se condena por los importes de los créditos no satisfechos al acreedor, aunque en alguna se remita a la determinación del importe a ejecución de sentencia. Sólo en la acción individual ejercitada por los socios en la STS 670/2010, de 4 de noviembre -Rec. 422/2007-, se condenaba por la cuota parte del patrimonio que le correspondería por su participación en el capital social.

- Finalmente, con relación a la admisión de la acción individual de responsabilidad contra los administradores por incumplimiento de deberes previos a la solicitud del concurso, en la Sentencia del TS, Sala Civil, 737/2014 de 22 diciembre -Rec. 1261/2013-, se analiza la petición de los acreedores demandantes que reclaman la parte insatisfecha del crédito tras el reparto de la masa activa en el proceso concursal, ejercitando posteriormente la acción individual contra los administradores. Se trataba de contratos concertados para la entrega de mercancías para la campaña navideña de 2004/2005, cuando la empresa recogía en las cuentas depositadas en el Registro Mercantil graves irregularidades, ocultando a los 
acreedores la situación real de su patrimonio. Ante esas graves irregularidades contables que impidieron conocer la situación patrimonial real de la sociedad, se condena a los administradores al pago del $40 \%$ del importe de los créditos impagados, porque esas irregularidades contables hicieron confiar a los acreedores en poder cobrar sus créditos, ya que, de haber conocido la real situación patrimonial de la sociedad, no hubieren concertado el contrato o hubiesen adoptado medidas encaminada a asegurar el cobro del crédito.

Doctrina que ha ido admitiendo con ciertas restricciones la acción individual ante crisis patrimoniales, pero eso sí, cuando concurran incumplimientos muy relevantes de los administradores que aboquen a la imposibilidad de poderse satisfacer los créditos, que concluirá con la reciente jurisprudencia sobre los cierres de hecho.

Para nuestra doctrina científica mayoritaria ante supuestos de despatrimonialización de la sociedad se considera que el daño directo se produce en el patrimonio social, y sólo de modo reflejo en el acreedor, de modo que procedería, más que la acción individual de responsabilidad, la acción social de responsabilidad ${ }^{448}$.

Para un sector de nuestra doctrina en muchas de las sentencias, para admitir la acción individual de responsabilidad, según ESTEBAN VELASCO ${ }^{449}$, se había realizado una interpretación expansiva del daño directo que debe revisarse, porque debe ponerse el acento en exigir la prueba de la relación de causalidad entre los deberes omitidos y el daño sufrido.

En este sentido, SALDAÑA VILLOLDO ${ }^{450}$, analizando la evolución de la jurisprudencia señala que para admitir la acción individual de responsabilidad en supuestos de incumplimientos de deberes disolutorios, se fue flexibilizando el concepto de daño directo, cuando lo más adecuado en esas situaciones era la procedencia del ejercicio de la acción social.

448 MARÍN DE LA BÁRCENA GARCIMARTÍN, F.: La acción individual de responsabilidad de los administradores de las sociedades de capital (art. 135 LSA),2005, op. cit., p. 350, y en "Deberes y responsabilidades de los administradores ante la insolvencia de las sociedades de capital ", 2005, op. cit., edición digital, pp. 16 y 17; ESTEBAN VELASCO, G.: "La acción individual de responsabilidad”, op. cit., pp. 258-259; SUÁREZ-LLANOS GÓMEZ, L.: "La responsabilidad por deudas de los administradores de la sociedad anónima”, op. cit., 1996, p. 2503.

${ }^{449}$ ESTEBAN VELASCO, G.: "La acción individual de responsabilidad”, op. cit., p. 263.

${ }^{450}$ SALDAÑA VILLOLDO, B.: "La acción individual de responsabilidad. Su significado....”, op. cit., pp. 333 a 349. 
No obstante, procediendo en principio la acción social de responsabilidad, SALDAÑA VILLOLDO $^{451}$ distinguía dos situaciones en los supuestos de impago al acreedor por insuficiencia patrimonial de la sociedad, sin haberse liquidado ordenadamente la misma -incluyendo el supuesto de cierre de hecho-. En primer lugar, si al momento del cierre de hecho la sociedad careciese absolutamente de patrimonio habría un incumplimiento de deberes del administrador, pero no se habría producido un daño al derecho de crédito del acreedor, ya que en ese momento sería imposible su pago, con lo que al no existir relación de causalidad entre la conducta del administrador y el impago no cabría la acción individual. En segundo lugar, si en el momento del cese fáctico sin ordenada liquidación existieren bienes para satisfacer, en todo o en parte, al acreedor, el incumplimiento del deber orgánico del administrador de una ordenada liquidación causaría un daño a aquél, que se cifraría en la parte del crédito no abonado, existiendo relación de causalidad que permitiría ejercitar la acción individual de responsabilidad.

La despatrimonialización de la sociedad por incumplimiento del administrador de los deberes concursales, en principio sería un supuesto propio de la acción social de responsabilidad, porque la disminución patrimonial de la sociedad difícilmente podría generar un daño directo al derecho de crédito, como algo distinto del daño al patrimonio social $^{452}$. No obstante, sí habrá supuestos que entrasen en el campo de aplicación de la acción individual de responsabilidad. Serían subsumibles en la acción individual de responsabilidad, aquellos actos que atenten directamente al principio de paridad de trato de los acreedores, como los pagos a unos acreedores excluyendo a otros, o los actos de realización de pagos prohibidos, pagos que no dañan el patrimonio social ya que reducen el pasivo, pero sí daña a la masa de acreedores y ese daño viene representado por la diferencia entre lo pagado y la cuota ${ }^{453}$. De igual modo, se justificaría una acción individual de responsabilidad cuando en situaciones de insuficiencia patrimonial los administradores destinan la totalidad de los activos para realizar pagos a determinados acreedores, especialmente a entidades financieras cuando ellos han avalado personalmente, porque estos pagos no lesionan el patrimonio social pero sí privan al resto de acreedores de poder cobrar la cuota que les hubiere correspondido por sus

\footnotetext{
451 SALDAÑA VILLOLDO, B.: “La acción individual de responsabilidad. Su significado...”.op. cit., pp. 341 y 342.

452 SUÁREZ-LLANOS GÓMEZ, L.: "La responsabilidad por deudas de los administradores de la sociedad anónima”, op. cit., p. 2503.

${ }^{453}$ ESTEBAN VELASCO, G.: "La acción individual de responsabilidad”, op. cit., p. 262.
} 
derechos de crédito, daños a la cuota que serían directos y ejercitables vía art. 241 de la $\mathrm{LSC}^{454}$.

MARÍN DE LA BÁRCENA GARCIMARTÍN ${ }^{455}$ critica que la jurisprudencia identifique el daño directo al acreedor con el importe del crédito, cuando el importe de la indemnización de la acción individual en situaciones de insolvencia "no coincidirá siempre con el crédito que tiene el acreedor perjudicado con la sociedad pues lo que debe indemnizar el administrador es el interés contractual negativo, no por el interés positivo, una vez descontada la cuota que recibirían como acreedores concursales con cargo a la masa". Por el contrario, MORALES BARCELÓ ${ }^{456}$, identifica el daño causado por el impago por causa del administrador, con el importe de la deuda de la sociedad.

Concluimos afirmando que procederá la acción individual de responsabilidad en situaciones de despatrimonialización de la sociedad por incumplimiento de los deberes de ordenada liquidación, siempre que se cause un daño directo al acreedor, que no sea mero reflejo de un daño al patrimonio social, lo que sucede cuando pudieran existir bienes para satisfacer en todo o parte el crédito de haberse cumplido con las obligaciones orgánicas de ordenada liquidación, corriendo la carga de la prueba por facilidad probatoria en el administrador social. Daño directo que se cifrará en el importe de la deuda dejada de cobrar por conducta imputable del administrador social, que en unos casos será por el total de la deuda, si de no haber mediado los incumplimientos que causan el daño directo se hubiere cobrado toda la deuda con cargo al patrimonio social, o en otro caso, por la parte cuota correspondiente.

\subsection{Cierre de hecho y acción individual.}

Siendo el supuesto paradigmático de incumplimiento de las obligaciones de ordenada liquidación societaria, vamos a dar un tratamiento específico al cierre de hecho de la empresa, por ser una circunstancia de acaecimiento frecuente en situaciones de crisis económica. Cierre en virtud del cual la sociedad cesa en su actividad incumpliéndose todos los deberes exigidos en el tráfico económico-jurídico, sin liquidarse la sociedad y

${ }^{454}$ RODRÍGUEZ ARTIGAS, F. y MARÍN DE LA BÁRCENA GARCIMARTÍN, F.: "La acción social de responsabilidad", en AA.VV. (Coord.: GUERRA MARTÍN, G.): Responsabilidad de los administradores de sociedades de capital, Madrid, 2011, pp. 164 y ss.

455 MARÍN DE LA BÁRCENA GARCIMARTÍN, F.: "Deberes y responsabilidades de los administradores ante la insolvencia de las sociedades de capital”, 2005, op. cit., edición digital, p. 30.

${ }^{456}$ MORALES BARCELÓ, J.: La responsabilidad de los administradores de las sociedades mercantiles en situación de pérdidas y de insolvencia, edición digital, op. cit., p. 457. 
sin solicitar, en su caso, el concurso de acreedores, desapareciendo del domicilio social, y en la mayoría de los casos, incumpliendo deberes con la Administración Tributaria y con la Seguridad Social, al no dar de baja la actividad ni a los trabajadores, dejando cuantiosos descubiertos de cotización.

Para que el ilícito orgánico que supone el cierre de hecho (incumplimiento de los deberes de disolución y liquidación de la sociedad), pueda dar lugar a una acción individual de responsabilidad es preciso que el daño ocasionado sea directo al acreedor y no reflejo del daño al patrimonio social. Es necesario que el ilícito orgánico incida directamente en la insatisfacción del crédito.

Se ha reconocido en nuestra jurisprudencia ${ }^{457}$ que el cierre de hecho puede ser un supuesto que permita al acreedor social el ejercicio de la acción individual de responsabilidad, porque los administradores no pueden limitarse a eliminar la sociedad sin más, ya que deben liquidarla legalmente para salvaguardar los intereses de terceros en el patrimonio social, por lo que, la no liquidación en forma legal del patrimonio social es susceptible de producir daño a terceros. Otra cosa será determinar cómo ciframos el faño directo, si será por el importe del crédito impagado, o por el importe del mismo que se pudiera haber obtenido de una ordenada liquidación -cuota teórica de liquidación-. Como podemos observar, en las sentencias mayoritarias se venía cifrando ese daño en el importe del crédito insatisfecho, pero en alguna se parte del daño cuota proporcional sobre el importe del crédito no obtenido del reparto de la masa activa del concurso de acreedores (STS, Sala Civil, núm. 737/2014 de 22 diciembre, -RJ 201416885-). Si estamos ante una responsabilidad por daños, podría plantarse si, ante el cierre de hecho, de haberse liquidado en forma la sociedad el acreedor hubiere cobrado en todo o en parte, reconduciendo el daño directo a la existencia o inexistencia de bienes, de modo que, el daño sería por el importe de los bienes que existiesen en el momento del cierre sin ordenada liquidación, en cuyo caso, sí podría hablarse de teórica cuota de liquidación, de ser los bienes de importe menor.

${ }^{457}$ SSTS, Sala Civil, STS 397/2001, de 19 de abril -Rec. 301/1996-; 1103/2002, de 25 de noviembre Rec. 1425/1997-; STS núm. 1191/2003, de 15 de diciembre -Rec. 348/1998-; STS 255/2006, de 22 de marzo -Rec. 2254/1999-; STS núm. 261/2007, de 14 de marzo -Rec. 262/2000-; 670/2010, de 4 de noviembre -Rec. 422/2007-, entre otras muchas. En las Sentencias 397/2001, de 19 de abril y 255/2006, de 22 de marzo, se afirma que el cierre de hecho sin ordenada liquidación en situación de insolvencia, produce un daño al acreedor, sin entrar a valorar si de haberse disuelto y liquidado la sociedad en forma, habría obtenido el acreedor el pago de su crédito, circunstancia esta, que en la última jurisprudencia adquiere relevancia en el ejercicio de la acción individual, como veremos posteriormente. 
Nuestra reciente jurisprudencia ${ }^{458}$ del Tribunal Supremo, Sala Civil, sí ha admitido la acción individual de responsabilidad del administrador ante situaciones de cierre de hecho, sin ordenada liquidación, partiendo de las siguientes consideraciones:

- En primer lugar, que cierre de hecho es un incumplimiento de los deberes legales relativos a la disolución de la sociedad y a su liquidación, lo que constituye un ilícito orgánico grave del administrador.

- En segundo lugar, que para que ese ilícito orgánico pueda dar lugar a una acción individual de responsabilidad es preciso que el daño ocasionado al acreedor sea directo; que el ilícito orgánico incida directamente en la insatisfacción del crédito.

- En tercer lugar, que el daño directo al acreedor se producirá si, de haberse realizado la correcta disolución y liquidación, se hubiese atendido el pago del crédito, o lo que es lo mismo, hubiese podido el acreedor percibir su crédito, total o parcialmente. Esto es, que el cierre de hecho impidió el pago del crédito. Con lo que el pago sería por una teórica cuota de liquidación.

- En cuarto lugar, que la prueba de que el pago se hubiese producido no le corresponde al acreedor, a éste le corresponde en su demanda realizar un "mínimo esfuerzo argumentativo" al respecto, correspondiendo al administrador social la carga de la prueba de la situación patrimonial de la sociedad, la ausencia de bienes para atender el pago, esto es, que el impago se hubiere producido igualmente de haberse disuelto ordenadamente la sociedad ${ }^{459}$. Con anterioridad a esta nueva

${ }^{458}$ SSTS, Sala Civil, núm. 253/2016, de 18 de abril -Rec. 2754/2013-; 472/2016, de 13 de julio -RJ 2016/3191-; 129/2017, de 27 de febrero -Rec. 2604/2014-; 274/2017, de 5 de mayo -Rec. 3298/2014-; 580/2019, de 5 de noviembre -Rec. 579/2017-; y 612/2019, de 14 de noviembre -Rec. 1318/2017.

${ }^{459}$ En la Sentencia 472/2016 de 13 julio -RJ 2016/3191-, se concluye que "El administrador demandado no ha procedido a la disolución de la sociedad ni a la consiguiente liquidación de sus activos. Y el propio administrador, en su contestación, Reconoce que la sociedad tenía cuatro vehículos susceptibles de ser embargados. Por lo que, cuando menos estos bienes debían haber sido liquidados, para hacer pago de las deudas sociales. Frente a la alegación contenida en la demanda de que el administrador no ha procedido a la liquidación ordenada de los activos de la sociedad y que ello ha impedido el cobro de los créditos de la demandante, máxime cuando se demoró su exigibilidad mediante la emisión de unos pagarés que resultaron finalmente impagados, correspondía al administrador justificar que la disolución y liquidación ordenada de la sociedad no hubiera servido para pagar los créditos de la demandante, ordinariamente por la insuficiencia de activo. Si partimos de la base de que el administrador venía obligado a practicar una liquidación ordenada de los activos de la sociedad y al pago de las deudas sociales pendientes con el resultado de la liquidación, y consta que existían algunos activos que hubieran permito pagar por lo menos una parte de los créditos, mientras el administrador no demuestre lo contrario, debemos concluir que el incumplimiento de aquel deber legal ha contribuido al impago de los créditos del demandante. En consecuencia, resulta procedente la estimación la acción de responsabilidad y condenar al administrador demandado al pago del perjuicio sufrido por la demandada como consecuencia del cierre de hecho de la sociedad deudora, que ha 
jurisprudencia, en supuestos de crisis empresarial y partiendo del art. 217.7 de la LEC, se venía admitiendo por facilidad y disponibilidad probatoria, el traslado de la carga de la prueba al administrador, especialmente cuando no se han presentado las cuentas anuales $^{460}$.

- En quinto lugar, la nueva doctrina no podrá ser objeto de aplicación expansiva, sino que deberá hacerse una prudente aplicación de la misma, alertando sobre los riesgos de una aplicación no estricta, indeseada, porque correríamos el riesgo de atribuir a los administradores una responsabilidad por el impago de las deudas sociales, cuando no es esa la mens legis (STS, Sala Civil, 716/2018, de 19 de diciembre -Rec. 3648/2015-).

Para esta nueva línea jurisprudencia, se parte de la regla general de que con el cierre de hecho se daña primariamente el patrimonio social, pero que ello no excluye que en determinadas circunstancias se pueda perjudicar directamente al acreedor, producir un daño originario y no derivado. Para que el cierre de hecho pueda dar lugar a una acción individual es preciso: que el ilícito orgánico incida directamente en la insatisfacción del crédito, por lo que debe existir un incumplimiento nítido de un deber legal al que pueda anudarse de forma directa el impago de la deuda social, cifrándose ese daño directo en el hecho de que de haberse realizado la correcta disolución y liquidación hubiera sido posible obtener el cobro del crédito, total o parcialmente, lo que no exige al acreedor una prueba de los bienes, sino un mínimo esfuerzo argumentativo, un discurso razonado de que con el cierre se ha impagado el crédito, ya que la carga de la prueba sobre el montante patrimonial le corresponda al administrador social por el principio de facilidad probatoria $^{461}$.

supuesto el incumplimiento de los deberes de liquidación ordenada de la sociedad. Perjuicio que, en este caso, a falta de prueba en contrario, viene representado por el importe de los créditos que, como consecuencia de aquel ilícito orgánico, la demandante no pudo cobrar".

${ }^{460}$ Partiendo de la STC 140/1994 de 4 de mayo, en Sentencias del TS, de 8 de marzo -RJ 1996/1936-; 28 de noviembre de 1996 -RJ 1996/8590-; 28 de febrero de 1997 -RJ 1997/1392-; 30 de julio de 1999 RJ 1999/6358-; 29 de mayo de 2000 -RJ 2000/3944-; 8 de febrero de 2001 -RJ 2001/2048-; 18 de febrero de 2003 -RJ 2003/2214-; y 17 de julio de 2003.

461 Admite la acción individual de responsabilidad del art .241 de la LSC contra los miembros del Consejo Rector de la empresa deudora que era una cooperativa, la Sentencia del Tribunal Supremo, Sala Civil, 129/2017, de 27 de febrero -Rec. 2604/2014-. Igualmente, en la Sentencia del TS, núm. 274/2017, de 5 de mayo -Rec. 3298/2014-, se condena a la administradora social al pago del importe del crédito impagado, por cuanto que se había producido una salida injustificada y elevada de dinero del activo social en un contexto de liquidación de hecho de la empresa, al haberse pagado de modo indebido e inexplicado $83.000 €$ a otro acreedor, lo que supuso un perjuicio para los demás acreedores sociales, privando a la sociedad de un activo (una elevada cantidad de dinero), que podría haberse 
Según MUÑOZ PAREDES ${ }^{462}$, en esta jurisprudencia se sientan expresamente tres conclusiones básicas. En primer lugar, que el incumplimiento de deberes disolutorios y liquidatorios, es un ilícito orgánico grave del administrador. En segundo lugar, que para que prospere la acción individual de responsabilidad se debe acreditar que, de haberse realizado la correcta disolución y liquidación, el acreedor hubiera podido cobrar su crédito, en todo o en parte. En tercer lugar, que en el ejercicio de la acción individual debe hacerse un esfuerzo argumentativo para mostrar la incidencia directa del incumplimiento de un deber legal cualificado en la falta de cobro de aquellos créditos, sin perjuicio de que el administrador tenga la carga de la prueba acerca de la situación patrimonial de la sociedad.

En nuestra doctrina científica ${ }^{463}$ no faltan voces que abogan por evitar una indebida utilización de la acción individual de responsabilidad por deudas anteriores a la causa de disolución, tras la limitación en el año 2005 de la responsabilidad solidaria del art. 367 de la LSC para las deudas posteriores al advenimiento de la causa de disolución. En igual sentido MUÑOZ PAREDES ${ }^{464}$, quien partiendo de esas sentencias del TS, afirma que asistimos a un auténtico renacer de la acción individual, por dos razones, en primer lugar, por no suspenderse con la tramitación del concurso de acreedores, y, en segundo lugar, por haberse reducido la responsabilidad por deudas del art. 367 de la LSC a las deudas posteriores a la causa de disolución.

Con carácter general en la doctrina se ha venido criticando el uso desmedido de la acción individual ante el cierre de empresa. DÍAZ ECHEGARAY ${ }^{465}$ había criticado un uso excesivo por los acreedores de la acción individual en supuestos de crisis disolutorias y de insolvencia, cuando se ven en la imposibilidad de obtener el pago de la sociedad en situaciones de cierre de la empresa, cuando lo más indicado sería acudir a exigir la responsabilidad por deudas regulada actualmente en el art. 367 de la LSC. VALPUESTA GASTAMINZA ${ }^{466}$ pese a criticar el recurso a la acción individual en supuestos de crisis patrimoniales de la sociedad, por ser de aplicación la acción social y no la acción individual, no obstante, al haber desaparecido la empresa, no tendría mucha

empleado en pagar el crédito de la demandante y que, al haber salido indebidamente del haber social, a modo de liquidación desordenada y por vía de hecho, impidió dicho el pago.

${ }^{462}$ MUÑOZ PAREDES, A.: La responsabilidad de los administradores societarios, op. cit., p. 32.

${ }^{463}$ Entre otros: ESTEBAN VELASCO, G.: "La acción individual de responsabilidad", op. cit., p. 257; DÍAZ ECHEGARAY, J. L.: Deberes y Responsabilidades.., op. cit., pp. 359 a 362.

${ }^{464}$ MUÑOZ PAREDES, A.: Tratado judicial de responsabilidad..., op. cit., p. 298.

${ }^{465}$ DÍAZ ECHEGARAY, J. L.: Deberes y responsabilidad...., op. cit., pp. 359 a 364.

${ }^{466}$ VALPUESTA GASTAMINZA, E. M.: Comentarios a la Ley de Sociedades de Capital op. cit., p. 646. 
eficacia la acción social al ser difícil articular una reclamación contra una sociedad desparecida.

\subsection{Acción individual por el impago de deudas de Seguridad Social en crisis patrimoniales societarias.}

En la medida en que se prevé la acción individual de responsabilidad contra el administrador social, ante el impago de una obligación de la sociedad de capital en situaciones de crisis patrimoniales de la mercantil, podríamos estar ante una vía adecuada para reclamar al administrador social la responsabilidad por daños resultantes del impago de deudas con la Seguridad Social de la mercantil.

Partiendo de la reciente jurisprudencia que admite el ejercicio de la acción individual para reclamar las deudas impagadas, cuanto la frustración del pago sea debida directamente al cierre de hecho de la empresa, concluimos que las entidades gestoras y la TGSS podrán exigir mediante esa acción las deudas de Seguridad Social pendientes de pago, correspondiendo al administrador acreditar que el impago se hubiere producido de igual modo de liquidarse ordenada y legalmente la sociedad. Responsabilidad que se extiende a los importes de las deudas insatisfechas, salvo que el administrador social acredite que los únicos bienes existentes al cierre de hecho son de importe inferior, en cuyo caso la condena se limitará a ese importe, al cifrarse en el mismo el daño causado.

Acción individual de responsabilidad ante el cierre de hecho que podrán utilizar las entidades gestoras y la TGSS para reclamar el pago de deudas con la Seguridad Social anteriores a la una eventual causa de disolución, al no poder ser exigidas éstas mediante la derivación administrativa directa de responsabilidad al amparo del art. 367 de la LSC y art. 18.3 del TRLGSS.

Acción individual de responsabilidad que procedería también en situaciones de despatrimonialización de la sociedad, ante pretericiones en el pago de las deudas de Seguridad Social, habiéndose satisfecho otras de menor prelación, o cuando estemos ante incumplimientos dolosos del administrador de las obligaciones con la Seguridad Social, especialmente ante deudas por cotizaciones o prestaciones debidas a faltas de altas en Seguridad Social, deudas por deficiencias de cotización por actuación fraudulenta (ocultación de retribuciones, obtención fraudulenta de reducciones o bonificaciones, etc.). 
Al poderse acreditar los requisitos de esa acción individual, especialmente el daño directo, que no es reflejo de un daño al patrimonio social, en situaciones de cierre de hecho, preterición de pagos de deudas de Seguridad Socia, y ante deudas generadas por incumplimientos dolosos de obligaciones instrumentales de Seguridad Social, no vemos inconvenientes jurídicos para ejercitar la acción individual de responsabilidad, aunque hasta la fecha ha sido un instrumento prácticamente inexplorado por la Seguridad Social, por dos razones. En primer lugar, debido a la mayor carga probatorio de la acción de responsabilidad frente a otras reclamaciones administrativas, y, en segundo lugar, por el procedimiento que ha de seguirse para su reclamación, que examinaremos en el siguiente apartado.

\section{IV.- ACCIÓN INDIVIDUAL DE RESPONSABILIDAD POR INCUMPLIMIENTO DE OBLIGACIONES LABORALES Y DE SEGURIDAD SOCIAL. DAÑO AL CRÉDITO DE LA SEGURIDAD SOCIAL.}

\section{El crédito laboral y de Seguridad Social como objeto de la acción individual.}

Si el administrador social ha de indemnizar el impago de los créditos que el acreedor ostente frente a la sociedad de capital, siempre que hayan sido insatisfechos como consecuencia directa de una conducta antijurídica del mismo, concurriendo todos los requisitos constitutivos de la acción individual de responsabilidad, no plantea prima facie, mayor problema la admisión de los créditos laborales y de Seguridad Social, como títulos jurídicos fundantes de la acción individual de responsabilidad de los administradores sociales al amparo de lo previsto en el art. 241 de la LSC.

Se ha admitido mayoritariamente en la doctrina ${ }^{467}$ y jurisprudencia ${ }^{468}$ que el crédito objeto de indemnización puede ser fruto de una relación jurídica contractual (civil,

${ }^{467}$ LEFEBVRE, F.: Responsabilidad de los administradores, Madrid 1999, pp. 87 y ss; DESDENTADO BONETE, A. y DESDENTADO DAROCA, E.: Administradores sociales, Altos Directivos y Socios Trabajadores..., op. cit., pp. 145 a 190; NICOLÁS BERNAD, J. A.: "La responsabilidad de los administradores sociales ante la Inspección de Trabajo”, op. cit., pp. 73-99; GALA DURÁN, C.: La responsabilidad laboral y de Seguridad Social de los administradores de las sociedades mercantiles, Editorial Bosch, 2007, pp. 12-20; MARTíN JIMÉNEZ, R. y MATEOS BEATO, A.: La responsabilidad de empresas y Administradores con la Seguridad Social, op. cit., pp. 175 y ss.

${ }^{468}$ STS, Sala Social, de 8.5.2002 -RJ 2002/7541- y STS, Sala Civil, núm. 650/2014, de 27 noviembre -RJ 01416489-, entre otras. Entre los créditos procedentes de obligaciones legales citamos las STS, Sala Civil, números 131/2016, de 3 de marzo de 2016 -RJ 2016/801- y 242/2014, de 23 de mayo de 2014 RJ 2014/2943-, donde se admitió la acción individual ante el incumplimiento de una obligación legal, cual era garantizar cantidades entregadas a cuenta en la compraventa de inmuebles. 
laboral, mercantil, etc.), o consecuencia del incumplimiento de una obligación legal de la sociedad.

En el orden social podrán existir créditos laborales de los trabajadores ante la sociedad de capital empleadora, que podrán ser reclamados, en su caso, al administrador mediante la acción individual de responsabilidad, y créditos de Seguridad Social que podrán tener tanto el trabajador como las entidades de la Seguridad Social.

Los créditos laborales que podrá exigir un trabajador será todo tipo de créditos con contenido o valoración económica que le adeude la sociedad de capital, y que no se hayan satisfecho por conducta del administrador, sean salarios adeudados o indemnizaciones derivadas de cualquier título jurídico vinculado con la relación laboral (por extinción de la relación laboral, por movilidad geográfica o modificación sustancial de condiciones de trabajo, por pactos de dedicación exclusiva o por no competencia post-contractual, por compensación de gastos consecuencia de la relación laboral, compensación por vacaciones no disfrutadas con anterioridad a la extinción de la relación laboral, indemnización por daños causados por incumplimientos de la normativa de prevención de riesgos laborales, por vulneración de derechos fundamentales, entre otros); ayudas de asistencia social derivadas de la acción social empresarial $^{469}$. En definitiva, créditos laborales ${ }^{470}$ de contenido pecuniario.

Serán también créditos derivados de la relación laboral las indemnizaciones por daños causados al trabajador en su integridad física o salud, como consecuencia de la falta de medidas de seguridad y salud en el trabajo ${ }^{471}$. Créditos por daños cuya indemnización podrá ser objeto de cobertura por la empresa con entidades aseguradoras privadas ${ }^{472}$.

${ }^{469}$ CAROLINA DURÁN, C.: La responsabilidad laboral y de Seguridad Social, op. cit., p. 15.

470 Auto 4/1996, de 8 de marzo - Rec. 7/1995- de la Sala Especial de Conflictos del TS ; Sentencias de la Sala Social del TS, de fechas 28 de febrero de 1997 -Rec. 2928/1996-; 21 de julio de 1998 -Rec. 102/1998-; 28 de octubre de 1997 -Rec. 3485/1996-; 31 de diciembre de 1997 -Rec. 1858/1997-; 13 de abril de 1998 -Rec. 925/1997-; 9 de noviembre de 1999 -Rec. 2252/1998-; 8 de mayo de 2002 Rec. 3079/2001-, entre otras muchas; Sentencias del TS, Sala Civil, núm. 650/2014 de 27 noviembre RJ 01416489-; y 460/2010, de 14 de julio, entre otras.

${ }^{471}$ Indemnizaciones al amparo del artículo 42 de la Ley 31/1995, de 8 de noviembre, de Prevención de Riesgos Laborales, y del art. 168.3 del TRLGSS, en que se admite la compatibilidad de la prestación de Seguridad Social con la indemnización de daños civiles causados por el empresario o por terceros en el ámbito de la relación laboral. Supuesto típico de daños de terceros, son los accidentes de circulación durante la prestación laboral (accidentes en misión), o al ir o volver al trabajo (in itinere).

${ }^{472}$ En Sentencia del TS, Sala Social, 12 de noviembre de 2019 -rcud. 2356/2017-, se declara que, salvo previsión expresa en contrario de las condiciones de la póliza, los trabajadores asegurados serán todos lo que ostenten esa condición jurídico-laboral, aunque no se hallasen en alta en Seguridad Social en la empresa, al no ser ese alta elemento constitutivo de la relación laboral. 
Para la cuantificación del importe de la indemnización nuestra jurisprudencia ${ }^{473}$ ha acudido al baremos de accidentes de tráfico ${ }^{474}$. Baremo que fue modificado por la Ley $35 / 2015$, de 22 de septiembre, de reforma del sistema para la valoración de los daños y perjuicios causados a las personas en accidentes de circulación ${ }^{475}$.

A parte de los trabajadores puede igualmente ser titular de un crédito laboral frente a la sociedad de capital, que pudiera ser objeto de la acción individual de responsabilidad, el Fondo de Garantía Salarial ${ }^{476}$, cuando se pretenda exigir al administrador el pago de una deuda salarial o indemnizatoria asumida por ese organismo y de la que fuere responsable la sociedad de capital $^{477}$. Puede ser titular de créditos laborales, por cuanto que, una vez efectúe el pago al trabajador de los salarios adeudados o de las indemnizaciones por extinción de la relación laboral pendientes de pago por la sociedad de capital empleadora, por haber sido declarada la empresa insolvente en vía judicial, o por hallarse en concurso de acreedores de haber abonado los créditos laborales de los trabajadores incluidos en la lista de acreedores del concurso, el FOGASA se subroga en los derechos que tenía el trabajador ante la sociedad de capital. De concurrir los requisitos de la acción individual de responsabilidad, y no haber obtenido el resarcimiento de la masa pasiva del concurso, podrá ejercitar la acción individual de responsabilidad contra el administrador social, de considerar que el impago empresarial

${ }^{473}$ STS, Sala Social, de 23 de junio de 2014 -rcud. 1257/2013-; 13 de octubre de 2014 -rcud. 2843/2013-; de 20 de noviembre de 2014 -rcud. 2059/2013-; y 17 de febrero de 2015 -rcud. 1219/2014-; 12 de septiembre de 2017 -rcud. 1855/2015-; 10 de enero de 2019 -rcud. 3146/2016-; y 7 de febrero de 2019 -rcud. 1680/2016-, que cambian la anterior doctrina que había sentado la sala social, que del montante total de la indemnización deducía lo pagado en concepto de prestaciones de Seguridad Social, aunque no el importe del recargo de prestaciones, para ahora tener en cuenta los distintos daños causados, y minorar del lucro cesante las prestaciones de Seguridad Social, pero sin esas prestaciones minoren otros daños como el daño moral.

${ }^{474}$ Recogido en el Título IV del Texto Refundido de la Ley sobre Responsabilidad Civil y seguro en la circulación de vehículos a motor, aprobado por el Real Decreto Legislativo 8/2004, de 29 de octubre, BOE del 5.11.2004-.

${ }^{475}$ BOE del 23.9.2015.

476 Sobre las acciones de subrogación del FOGASA ante el administrador social, Vid.: NICOLÁS BERNAD, J. A.: "Acciones por subrogación del FOGASA en supuestos de despatrimonialización empresarial", Revista General Del Derecho del Trabajo y Seguridad Social, no 48, 2018, pp. 33-69.

477 Art. 33 del TRLET, en relación con el Real Decreto 505/1985, de 6 de marzo, sobre organización y funcionamiento del Fondo de Garantía Salarial, especialmente su art. 31 que legitima al Fondo para ejercitar cuantas acciones estime pertinentes para el reembolso de cantidades abonadas de que fuere responsable un tercero. Dentro de esa legitimación procesal, se ha admitido en un proceso de despido en que no comparece la empresa, ni la administradora social, para que el FOGASA, pueda solicitar, al amparo del art. 110.1.a) de la LRJS, que opta por la indemnización, y no por la readmisión, pese a no ser la empresa empleadora, si esta se halla desaparecida, si está incursa en procedimientos concursales, o si ha cesado en la actividad y no ha comparecido en juicio, y siempre que el trabajador no haya solicitado la extinción por cierre de la empresa al amparo del art. 110.1.b) de la LRJS, ya que en ese caso prevalece la opción del trabajador (Sentencias del TS, Sala Social, de 5 de marzo de 2019 -rcud. 620/2018-; 4 de abril de 2019 -rcud. 4064/2017-; 13 de febrero de 2020 -rcud. 2009/2018-; y 11 de marzo de 2020 -rcud. 2903/2018-). 
de los salarios o indemnizaciones legales ha sido consecuencia directa de una conducta culpable o dolosa de éste en la generación de la insolvencia empresarial, ya que al amparo del art. 31 del Real Decreto 505/1985, se legitima al Fondo para ejercitar cuantas acciones estime pertinentes para el más rápido reembolso de cantidades abonadas.

Acción individual de responsabilidad que, como veremos en el apartado VII del capítulo, no se suspende de hallarse la sociedad de capital en concurso de acreedores, por lo que puede entablarse fuera del juez del concurso, una vez que el Fondo haya abonado a los empleados los créditos por salarios o indemnizaciones, sin esperar al resultado del proceso concursal.

Finalmente, dentro de los créditos de Seguridad Social han de distinguirse, por un lado, los créditos de los trabajadores de la sociedad de capital, y, por otro lado, los créditos de las entidades gestoras y de la TGSS. El trabajador podrá exigir los créditos por prestaciones de responsabilidad de la empresa sociedad de capital, cuando sean de pago directo de la empresa sin proceder el pago anticipado de las entidades gestoras o colaboradoras, por ser de pago directo de la empresa, siempre que concurran los presupuestos de la responsabilidad por daños del administrador. Será igualmente el trabajador titular del crédito por el recargo de prestaciones, que no es objeto de anticipación por la entidad gestora, sino de responsabilidad directa de pago de la empresa (art. 164.2 del TRLGSS y art. 16.4 de la Orden 18 de enero de 1996, que desarrolla el Real Decreto 1300/1995, de 21 de julio, sobre Incapacidades Laborales del Sistema de Seguridad Social ${ }^{478}$ ).

Los créditos que tendrán los Organismos Públicos de Seguridad Social, en términos generales, los reconducimos a dos grandes grupos, créditos por cotizaciones y créditos por prestaciones. Los créditos por prestaciones de la entidad gestora serán por las prestaciones de responsabilidad empresarial que ésta ha anticipado al trabajador en virtud del principio de automaticidad relativa o absoluta. Créditos por prestaciones de responsabilidad empresarial que, en vía administrativa reclama la TGSS dentro del procedimiento de recaudación, previa resolución de la entidad gestora declarando la responsabilidad empresarial y de los demás responsables solidarios o subsidiarios (art. 67.4 TRLGSS y arts. 69 a 71 del RGRSS).

${ }^{478}$ BOE del 9.2.1996. 


\section{Tramitación administrativa o judicial de la acción individual de responsabilidad por los organismos públicos de la Seguridad Social.}

Nos corresponde determinar si las deudas de Seguridad Social de la sociedad de capital, que pretendan exigirse al administrador social al amparo de la acción individual de responsabilidad, pueden o no ser objeto de reclamación administrativa directa en virtud del procedimiento administrativo de recaudación de los recursos económicos de la Seguridad Social; o si por el contrario, la entidad gestora de Seguridad Social y la TGSS han de ejercitar la acción individual ante los tribunales competentes, por no ser de aplicación la derivación administrativa de responsabilidad al amparo de los arts. 18.3 y 142.1 del TRLGSS.

No procede la derivación administrativa de deuda, porque no nos encontramos ante un supuesto de responsabilidad ex lege del administrador por deuda ajena, sino ante una responsabilidad por daños que debe apreciarse en vía judicial, donde se ha de acreditar y probar que concurren todos los requisitos propios de ese tipo de responsabilidad. En este sentido la Guía Operativa de actuación en materia de derivación de responsabilidad a los administradores de sociedades mercantiles capitalistas en materia de deudas de Seguridad Social, dictada por la Dirección General de la Inspección de Trabajo y Seguridad Social, de fecha septiembre de $2017^{479}$, establece en el apartado de consideraciones previas sobre la actuación de comprobación e investigación (página 7), que, en materia de acciones de responsabilidad por daños de los arts. 236 y siguientes de la LSC, (sic) "en este supuesto es necesaria la declaración judicial de responsabilidad que declare la culpabilidad y la relación de causalidad. No se puede efectuar la declaración de responsabilidad mediante expediente administrativo. En este supuesto cabe la posibilidad de informar a TGSS de la actuación empresarial llevada a cabo por el administrador en perjuicio de la TGSS en su condición de acreedora de la sociedad. La TGSS está facultada para acudir a la vía judicial para que declare la responsabilidad del administrador por su actuación y los daños causados".

Mantiene el mismo criterio de que no puede derivarse la responsabilidad por daños de la acción individual de responsabilidad del art. 241 de la LSC, la Subdirección General de Ordenación e Impugnaciones de la Tesorería General de la Seguridad Social, en

\footnotetext{
${ }^{479}$ La Ley 193/2017
} 
Consulta de 12 de marzo de 2007 (Exp. 1605/2006), que citan MERCADER UGUINA y SUÁREZ CORUJO ${ }^{480}$.

Entendemos que no resulta de aplicación la derivación administrativa de responsabilidad del art. 18.3 del TRLGSS, para exigir la responsabilidad por daños prevista en el art. 241 de la LSC, por varias razones. En primer lugar, porque en el art. 241 de la LSC se regula una modalidad de acción judicial de resarcimiento por daños causados, y no se establece ninguna responsabilidad solidaria, subsidiaria o mortis causa para el pago de deudas ajenas, que es el presupuesto habilitante para la derivación administrativa de responsabilidad en el art. 18.3 del TRLGSS. En el art. 18.3 del TRLGSS se permite la derivación de responsabilidad en el pago de deudas de Seguridad Social, cuando la responsabilidad solidaria venga impuesta a un tercero en una norma con rango de la ley, en nuestro caso a los administradores. Es necesario que la ley prevea expresamente la responsabilidad solidaria del administrador en las deudas de la sociedad ante determinados hechos, omisiones, negocios u actos jurídicos, como sucede con los supuestos normativos contemplados en los arts. 360 y 367 de la LSC. No es ese el caso, del supuesto normativo regulado en el art. 241 de la LSC, donde se habla de acciones de indemnización por daños causados, de modo que no se establece ninguna responsabilidad solidaria por deudas, sino que se regula una acción procesal a ejercitar por los acreedores para el resarcimiento de daños. En el art. 241 de la LSC, estamos ante una responsabilidad por daños, no por deudas. En segundo lugar, porque al hallarnos ante una modalidad de acción procesal, ésta es competencia exclusiva de los Juzgados y Tribunales en ejercicio de su función jurisdiccional (art. 117.3 de la CE y arts. 1 a 4 de la Ley Orgánica 6/1985, de 1 de julio, del Poder Judicial). En tercer lugar, por la propia naturaleza de la responsabilidad, que al ser responsabilidad por daños precisa que un tercero (Jueces y Tribunales), y no el acreedor, aprecie la concurrencia de los requisitos de esa responsabilidad.

Un sector doctrinal ${ }^{481}$ entendió en su día que la TGSS podría derivar la responsabilidad exigible al administrador social mediante la acción individual en el procedimiento

${ }^{480}$ MERCADER UGUINA, J. R. y SUÁREZ CORUJO, B.: "La responsabilidad laboral y de Seguridad Social de los Administradores Sociales”, op. cit., p. 579.

${ }^{481}$ GALA DURÁN, C.: La responsabilidad laboral y de Seguridad Social de los administradores de las sociedades mercantiles, op. cit., pp. 190 y ss; NICOLÁS BERNAD, J. A.: "La responsabilidad de los administradores sociales ante la Inspección de Trabajo”, op. cit., pp. 98-99; LLOMPART BENNÀSSAR, M.: "La responsabilidad en el ámbito laboral y de Seguridad Social”, publicado en la monografía La responsabilidad de los administradores de sociedades de capital, $1^{\mathrm{a}}$ edición, editorial 
administrativo de recaudación, sin tener que acudir necesariamente ante los tribunales del orden civil.

GALA DURÁN ${ }^{482}$, admitía la derivación administrativa de responsabilidad al administrador social, con apoyo en el art. 135 de la anterior LSA ${ }^{483}$-actual art. 241 de la LSC-, para quien, al no estar excluidas las deudas de Seguridad Social en los anteriores arts. 262 y 135 de la $\mathrm{LSA}^{484}$, concluía que partiendo de esos dos preceptos mercantiles podía reclamarse al administrador por la TGSS y en vía administrativa las deudas de Seguridad Social, sin diferenciar la diversa naturaleza de responsabilidad en los casos de la responsabilidad por deudas del art. 367 de la LSC y de la responsabilidad por daños del art. 241 de la LSC. NICOLÁS BERNAD ${ }^{485}$ defendía igualmente la competencia de la ITSS para extender acta de liquidación en supuestos de deudas de Seguridad Social de la sociedad imputable al administrador, en los supuestos de acción individual de responsabilidad. LLOMPART BENNÀSSAR, admite la derivación de responsabilidad no sólo para la responsabilidad ex lege por deudas del administrador social prevista en el art. 367 de la LSC, sino también de modo expreso para la acción individual de responsabilidad del art. 241 de la LSC, pero ante la dificultad de acreditarse los elementos determinantes de esa acción individual acaba concluyendo que (sic) “a la TGSS le resultará más difícil iniciar la derivación de responsabilidad en los supuestos de ejercicio de la acción individual, debido a las exigencias legales requeridas para el ejercicio de este tipo de responsabilidad. En efecto, en este caso, la TGSS debe contar con datos suficientes para poder imputar la responsabilidad de la deuda que tiene la sociedad al administrador. En otro caso, tan solo le resta ejercer judicialmente la acción individual”.

No consideraban aplicable la derivación administrativa de responsabilidad a través del procedimiento recaudatorio de la Seguridad Social, MARTÍN JIMÉNEZ y MATEO BEATO $^{486}$, para quienes es preciso que la responsabilidad solidaria del administrador

La Ley, Madrid, marzo 2011, La Ley 22232/2011, edición digital, https://laleydigital-laleynextes.ponton.uva.es/Content/Documento.aspx?params, pp. 19 de 44.

482 GALA DURÁN, C.: La responsabilidad laboral y de Seguridad Social de los administradores de las sociedades mercantiles, op. cit., pp. 190 y ss.

${ }^{483}$ Actual art. 241 de la LSC.

${ }^{484}$ Actuales arts. 367 y 241 de la LSC, respectivamente.

${ }^{485}$ NICOLÁS BERNAD, J. A.: "La responsabilidad de los administradores sociales ante la Inspección de Trabajo", op. cit., pp. 98-99.

${ }^{486}$ MARTÍN JIMÉNEZ, R. y MATEOS BEATO, A.: La responsabilidad de empresas y Administradores con la Seguridad Social, op. cit., p. 213. 
esté fijada expresamente en una ley, y en el art 133 de la LSA ${ }^{487}$ no se hablaba de una responsabilidad solidaria, concluyendo que en este caso no estaría justificada una resolución administrativa exigiendo la responsabilidad al administrador, ya que para ello se exige que la responsabilidad solidaria esté expresamente declarada en una ley. En igual sentido, excluyen la acción individual de responsabilidad del art. 241 de la LSC, de la derivación administrativa de responsabilidad MERCADER UGUINA Y SUÁREZ CORUJO ${ }^{488}$.

Al no ser aplicable la autotutela administrativa (derivación de responsabilidad) para exigir al administrador social la responsabilidad por daños del art. 241 de la LSC, los diversos sujetos titulares de los derechos de crédito de la Seguridad Social deberán entablar ante los tribunales la acción individual de responsabilidad. En el apartado IV. 4 de este capítulo examinaremos ante qué jurisdicción debe entablarse la acción individual de responsabilidad para la reparación de los daños causados a los créditos contraídos con la Seguridad Social y con los trabajadores.

Serían sujetos beneficiarios y acreedores de los créditos de Seguridad Social susceptibles de ser reclamados mediante la acción individual de responsabilidad, las siguientes Entidades de Derecho Público:

- En primer lugar, la Administración de la Tesorería General de la Seguridad Social TGSS- $^{489}$ en deudas por cotizaciones, en cuanto sujeto activo de la gestión recaudatoria de los créditos por cuotas de Seguridad Social y otras contingencias de recaudación conjunta.

- En segundo lugar, el Servicio Público de Empleo Estatal-SEPE-490, o el Instituto Social de la Marina -ISM- ${ }^{491}$ en Régimen Especial del Mar, por los derechos de crédito cuando se pretenda exigir el reintegro de prestaciones de desempleo

\footnotetext{
487 Actual art. 236 de la LSC.

${ }^{488}$ MERCADER UGUINA, J. R. y SUÁREZ CORUJO, B.: "La responsabilidad laboral y de Seguridad Social de los Administradores Sociales”, op. cit., p. 579.

${ }^{489}$ Arts. 21, 74, 103 y 104 del vigente TRLGSS; art. 1 apartado 1, letras a), d), y g) y apartado 2, art. 2 y art. 83 del Real Decreto 1415/2004, de 11 de junio; arts. 1 y 2 del R.D. Real Decreto 696/2018, de 29 de junio, por el que se aprueba el Reglamento General de la Gestión Financiera de la Seguridad Social; art. 6 de la Ley 30/2015, de 9 de septiembre, de Formación Profesional para el Empleo; y las diversas disposiciones legales sobre bonificaciones en materia de empleo, que se financian con Recursos del Servicio Público de Empleo Estatal, frente a las reducciones de cuotas que son con cargo a la Tesorería General de la Seguridad Social.

490 Arts. 294 y 295 del TRLGSS.

${ }^{491}$ Art. 295 del TRLGSS, y art. 44 de la Ley 47/2015, de 21 de octubre, reguladora de la protección social de las personas trabajadoras del sector marítimo-pesquero.
} 
adelantadas al trabajador en virtud del principio de automaticidad de prestaciones, y que sean de responsabilidad empresarial por incumplir ésta sus obligaciones de alta y cotización. Cuestión distinta será la reclamación administrativa a la empresa dentro del procedimiento de recaudación de los recursos de la Seguridad Social, ya que la reclamación de las prestaciones por desempleo de responsabilidad empresarial, corresponde en vía voluntaria a la entidad gestora y en vía ejecutiva a la TGSS $^{492}$ (arts. 167.3 y 295 del TRLGSS, y arts. 31 y 32 del Real Decreto 625/1985, de 7 de abril, que desarrolla las Prestaciones por Desempleo ${ }^{493}$ ). Cuando se pretenda exigir el pago de esa prestación al administrador social al amparo de la acción individual de responsabilidad del art. 241 de la LSC, la competencia para acudir ante los tribunales la ostenta el Servicio Público de Empleo Estatal o el ISM, que son los titulares del derecho de crédito.

- En tercer lugar, el Instituto Nacional de la Seguridad Social-INSS- o el ISM ${ }^{494}$, para reclamar el pago de prestaciones de Seguridad Social de que fuere responsable la empresa, una vez se anticipó el pago al trabajador beneficiario por las entidades gestoras de la Seguridad Social en virtud del principio de automaticidad de prestaciones. Cuestión distinta es la gestión recaudadora en vía administrativa de las prestaciones de Seguridad Social de responsabilidad de la empresa, cuando la responsabilidad de la sociedad de capital se ha declarada por resolución firme de la entidad gestora (INSS, ISM), ya que corresponde a la TGSS, en cuanto Caja única de la Seguridad Social ${ }^{495}$, la competencia de la gestión recaudatoria mediante el procedimiento de recaudación de la Seguridad Social. Ahora bien, cuando en virtud del principio de automaticidad relativa o absoluta, la entidad gestora anticipa el pago al trabajador de una prestación de responsabilidad de la empresa, esa entidad se subroga en los derechos y acciones frente al empresario responsable (art. 167.3 del

492 Arts. 281 y 295 de la LGSS y art. 69.3 del Real Decreto 1415/2004, de 11de junio, y arts. 31 y 32 del Real Decreto 625/1985, de 2 de abril, que aprueba el Reglamento de Protección por Desempleo.

493 BOE 7.5.1985, según redacción dada por el Real Decreto Ley 16/2014, de 19 de diciembre, por el que se regula el Programa de Activación para el Empleo -BOE del 20.12.2014-.

${ }^{494}$ Arts. 66, 74 y 167.3 y 167.4 del TRLGSS, art. 1 apartado 1 letras d) y g), del Real Decreto 1415/2004, de 11 de junio, que aprueba el RGCSS, y arts. 42 y 43 de la Ley 47/2015, de 21 de octubre, reguladora de la protección social de las personas trabajadoras del sector marítimo-pesquero.

495 Arts. 74, 103, 104, 109 y 110 del TRLGSS, art. 1 del Real Decreto 1314/1984, de 20 de junio, sobre estructura y competencias de la TGSS, y Real Decreto 696/2018, de 29 de junio, por el que se aprueba el Reglamento General de la Gestión Financiera de la Seguridad Social. La TGSS ostenta la titular de todos los créditos y derechos económicos de la Seguridad Social, del patrimonio único de la Seguridad Social, en definitiva, de la Caja Única de todos los Recursos financieros del Sistema de la Seguridad Social. Arts. 1.1.d y 69 del RGRSS. 
TRLGSS), al ser el titular del crédito. Si se pretendiese reclamar ese crédito, no por el procedimiento administrativo de recaudación, sino en vía judicial, la entidad gestora de la prestación estaría legitimada para ejercitar la acción individual de responsabilidad frente al administrador social. Así en el art. 167.3 del TRLGSS, se señala "los derechos y acciones que, por subrogación en los derechos y acciones de los beneficiarios, corresponden a aquellas entidades gestoras, mutuas o servicios frente al empresario declarado responsable (...)", para concluir que," cuando, en virtud de lo dispuesto en este apartado, las entidades gestoras, las mutuas y, en su caso, los servicios comunes se subrogasen en los derechos y acciones de los beneficiarios, aquellos podrán utilizar frente al empresario responsable la misma vía administrativa o judicial que se hubiera seguido para la efectividad del derecho y de la acción objeto de subrogación". Quien es titular del crédito es la entidad gestora, pese a que, en el procedimiento administrativo de recaudación, la gestión recaudadora de la prestación ante la empresa responsable corresponde a la TGSS, pero cuando se pretende ejercitar la acción individual ante los tribunales, no estamos dentro del procedimiento de gestión recaudatoria. Cuestión distinta será que el crédito obtenido se ingrese en la cuenta financiera de la TGSS al ser el servicio que se unifican todos los recursos financieros de la Seguridad Social (art. 74 del TRLGSS).

- Finalmente, señalar que las Mutuas Colaboradoras de la Seguridad Social ${ }^{496}$, participan en la gestión de las prestaciones de contingencias profesionales accidente de trabajo, enfermedad profesional-, de prestaciones por incapacidad temporal de contingencias comunes, de riesgo durante el embarazo, de riesgo durante la lactancia, o en la prestación por reducción de jornada de los padres para atender a un hijo menor de edad afectado de cáncer u otra enfermedad grave. Al ser entidades colaboradoras, no pueden declarar la responsabilidad empresarial en el pago de prestaciones, ya que, la competencia para la declaración administrativa de esa responsabilidad, y de otros posibles sujetos responsables solidarios o subsidiarios, corresponde a la entidad gestora (art. 167.4 del TRLGSS). Cuando abone la mutua directamente la prestación al trabajador, como en la incapacidad temporal, riesgo por embarazo, lactancia, o en virtud del principio de automaticidad en el pago en prestaciones por contingencias profesionales en que debe capitalizar

\footnotetext{
${ }^{496}$ Arts. 80 a 84 del TRLGSS y arts. 61 a 84 del Real Decreto 1993/1995, de 7 de diciembre.
} 
su importe en la TGSS, por esos pagos directos o por los importes capitalizados, si la responsabilidad en el pago de la prestación era de la empresa, la mutua se subrogan en los derechos y acciones que tenía el beneficiario frente a la empresa (arts. 80.2, 82, 84.2, 187, 189 y 167.3 del TRLGSS), con lo que tendrían una posible acción individual de responsabilidad, en su caso, ante el administrador social, aunque de ser una prestación de contingencia profesional, la mutua ante la insolvencia de la empresa, reclamará la responsabilidad subsidiaria del INSS/ISM/TGSS como subrogados en el Fondo de Garantía de Accidentes de Trabajo, vía preferente para resarcirse de su pago, por lo que esa acción individual, tendrá menor relevancia y operatividad para la mutua.

No obstante, la empresa responsable debe ingresar en la TGSS el capital coste de la prestación, con independencia del pago anticipado por la entidad gestora o la mutua (art. 167 del TRLGG y art. 69 del RGRSS).

De concurrir una conducta antijurídica del administrador social en los hechos que dieron lugar a la responsabilidad empresarial, especialmente ante conductas dolosas, como hemos reseñado en el apartado III de este capítulo, nace un derecho de crédito que, al ser perjudicado por actuación del administrador, podría percibirse ejerciendo la acción individual de responsabilidad ante la jurisdicción competente (jurisdicción que examinaremos en el apartado IV.4 de este Capítulo).

Ante una prestación derivada de enfermedad profesional, la determinación de la entidad gestora o colaboradora que asuma la gestión y el pago, plantea más problemas, ya que pueden devenir responsables del pago ante el trabajador o los causahabientes beneficiarios varias entidades responsables. Las prestaciones con origen en una enfermedad profesional, a diferencia de lo que sucede con el accidente de trabajo, si bien se exterioriza en un momento determinado, se ha venido desarrollando a lo largo del tiempo de forma silente, por la exposición del trabajador a determinadas sustancias, elementos o condiciones de trabajo, lo que impide que pueda concluirse siempre que la entidad responsable del pago es la aseguradora del momento en el que se manifiesta la enfermedad $^{497}$. De concurrir en el tiempo de modo sucesivo diversas mutuas

${ }^{497}$ Sentencias del TS, Sala Social, de 4 de julio de 2017 -rcud. 913/2016- y 10 de julio de 2017 -rcud. 1652/2016-. 
aseguradoras y el INSS ${ }^{498}$, nuestra jurisprudencia considera que la responsabilidad en el pago de la prestación derivada de esa contingencia, corresponde a las mutuas que sucesivamente han tenido la cobertura del riesgo en la empresa y al INSS/ISM si la contingencia se fue generando con anterioridad al año 2008, en proporción al tiempo en que el trabajador estuvo expuesto al riesgo de contraer la enfermedad en cada una de las entidades, que no es identificable necesariamente con proporcionalidad en el tiempo de aseguramiento en cada una de las entidades gestoras o colaboradoras. Así en la reciente jurisprudencia se declaró la responsabilidad compartida del INSS y la mutua demandante en el abono de la pensión de viudedad en proporción al tiempo de exposición al riesgo durante los aseguramientos sucesivos, en el INSS (anterior a 2008) y a la mutua posterior a $2008^{499}$. De este modo, beneficiarios de créditos por contingencias de enfermedad profesional pueden ser diversas mutuas, o mutuas y el INSS, éste para exposición a riesgos de enfermedad profesional anteriores a 2008 , aunque la competencia para la declaración de la responsabilidad empresarial es del INSS o ISM (art. 167.4 del TRLGSS y art. 1 apartado e) del Real Decreto 1300/1995, de 21 de julio - sobre Incapacidades Laborales ${ }^{500}$ ).

Cuando de una contingencia profesional, como un accidente de trabajo, se deriven sucesivamente en el tiempo distintas prestaciones (asistencia sanitaria, incapacidad temporal, incapacidad permanente), para determinar la responsabilidad de la mutua o entidad gestora, habrá de estarse al momento en que acaece el accidente, y no a la fecha de los sucesivos hechos causantes de las diferentes prestaciones (Sentencia del TS, Sala Social, 705/2019, de 10 de octubre -rcud. 3494/2017-).

No podría ejercitar esa acción individual de responsabilidad el Organismo Estatal de la Inspección de Trabajo y Seguridad Social (OEITSS), al no ser el sujeto titular del

${ }^{498}$ Con anterioridad al 1 de enero de 2018 era el INSS o el ISM las únicas entidades aseguradoras de las Prestaciones de Incapacidad Permanente, o de muerte y supervivencia derivadas de Enfermedad Profesional, ya que con efectos del 1 de enero de 2008, la Disposición Final 8.2 de la Ley 51/2007, de 26 de diciembre, modificaba el art. 68.3 de la anterior TRLGSS de 1974, atribuyendo a las Mutuas la cobertura de todas las prestaciones derivadas de enfermedad profesional, y no sólo de Incapacidad Temporal o período de observación.

${ }^{499}$ Sentencias del TS, Sala Social, de 10 de julio de 2017 -rcud. 1652/2016-; de 22 de noviembre de 2017 -rcud. 3345/2016-; 13 de marzo de 2018 -rcud. 1209/2016-; 12 de junio de 2018 -rcud. 1740/2017-; 8 de enero de 2019 -rcud. 2590/2016-; 21 de marzo de 2019 -rcud. 3901/2017-; de 21 de marzo de 2019 -rcud. 3901/2017-; 22 de julio de 2020 -rcud. 102/2018-; 17 de septiembre de 2020 -rcud. 723/2018-; 13 de octubre de 2020 -rcud. 3947/2017-; salvo que durante la cobertura de la mutua posterior al 1.1.2008 no hubiere habido exposición al riesgo de Enfermedad Profesional (Sentencias TS, Sala Social, de 26 de febrero de 2019 -rcud. 1343/2017-; 26 de marzo de 2019 -rcud. 1281/2017-); y 17 de septiembre de 2020 -rcud. 723/2018- .

${ }^{500}$ BOE del 19.8.1995. 
crédito, ya que ese organismo autónomo únicamente colabora con la TGSS en materia de liquidación y recaudación de cuotas de Seguridad Social y de demás recursos de recaudación conjunta -Desempleo, Fondo de Garantía Salarial y Formación Profesional, así como con el Instituto Nacional de la Seguridad Social y con el Servicio Público de Empleo Estatal o ISM, en el control de la compatibilidad de prestaciones de Seguridad Social y de desempleo ${ }^{501}$. En este sentido la Guía Operativa de actuación en materia de derivación de responsabilidad a los administradores de sociedades mercantiles capitalistas en materia de deudas de Seguridad Social, dictada por la Dirección General de la Inspección de Trabajo y Seguridad Social, de fecha septiembre de 2017, establece que debe emitirse informe a la TGSS sobre la actuación empresarial llevada a cabo por el administrador social, por ser esa Tesorería la acreedora de las cotizaciones a la Seguridad Social y quien podrá ejercitar las acciones procesales.

\section{Créditos de Seguridad Social.}

\subsection{Créditos del trabajador.}

Los créditos de Seguridad Social que puede tener el trabajador por cuenta ajena ante la sociedad de capital, serán los generados por prestaciones de la Seguridad Social de las que sea responsable la empresa cuando no proceda el pago anticipado por la Entidad Gestora.

La responsabilidad empresarial en el pago de prestaciones podrá tener tres causas o títulos jurídicos. En primer lugar, por ser una prestación de pago directo de la empresa y con sus propios recursos. En segundo lugar, por ser una prestación generada por incumplimiento de obligaciones en materia de prevención de riesgos laborales. En tercer lugar, por ser prestaciones de responsabilidad empresarial al incumplirse las obligaciones en materia de afiliación, altas y cotización a la Seguridad Social, sin que proceda el anticipo por la entidad gestora (artículos 45, 166, 167, 168 y 281 del TRLGSS).

Cuando la prestación se haya generado procediendo la declaración de la responsabilidad empresarial, si en virtud del principio de automaticidad absoluta o relativa de la prestación, deba asumir ex lege el pago la entidad gestora y/o la mutua colaboradora, el

${ }^{501}$ Arts. 21, 133, 135 , 296, 297 y 302 del TRLGSS, en relación con los arts. 1, 12 apartado 1.c) de la Ley 23/2015, de 21 de julio, LOITSS. 
trabajador no tendría un derecho de crédito directo frente a la empresa, ya que, la prestación se la abonará por pago anticipado la entidad gestora o colaboradora.

Las prestaciones con el beneficio de automaticidad absoluta de pago para el trabajador son las prestaciones de desempleo, las prestaciones derivadas de contingencias profesionales, así como la asistencia sanitaria por contingencias comunes o por nacimiento y cuidado de menor (antigua maternidad). Tienen el tratamiento y naturaleza de contingencias profesionales las prestaciones de riesgo por embarazo y riesgo por lactancia de la mujer trabajadora de conformidad con los arts. 186 a 189 del TRLGSS, por lo que a efectos de la acción protectora tienen la consideración de altas de pleno derecho en las que es de aplicación la automaticidad de prestaciones (art. 29.2 del Real Decreto 84/1996, de 26 de enero).

Consecuencia de ese pago anticipado será que surge una deuda de Seguridad Social de la empresa ante las entidades gestoras y la TGSS, al proceder el reintegro del pago anticipado (arts. 45, 162.2 y 166.4, en relación con los arts. 167 y 281 de la vigente LGSS). En virtud del pago anticipado al trabajador, esas prestaciones no constituirán objeto de un crédito de Seguridad Social del trabajador ante la empresa y el administrador. Serán más bien créditos de la entidad gestora o colaboradora ante la empresa, y, en su caso, ante el administrador social.

La responsabilidad del pago de las prestaciones de la Seguridad Social, cuando el trabajador reúnen los requisitos generales y/o específicos de la prestación, previstos en los arts. 45 y 165 de la LGSS (alta en Seguridad Social y carencia general y específica, en su caso) corresponde ${ }^{502}$ : a) a la TGSS, previo reconocimiento del derecho a la prestación efectuado por la entidad gestora (INSS o ISM), para todas las prestaciones económicas excepto las de desempleo y las prestaciones temporales que abone la mutua; b) la Mutua Colaboradora con la Seguridad Social, que abona las prestaciones temporales en las que tiene reconocida la competencia para su pago con cargo a sus recursos, como son las prestaciones de riesgo por embarazo, riesgo durante la lactancia, prestación por reducción jornada para atender al cuidado de un menor afectado de cáncer u otra enfermedad grave, y prestaciones de incapacidad temporal por contingencias comunes o profesionales, si la empresa concertó la cobertura con la

${ }^{502}$ Arts. 45, 66.1.a), 74, 103, 104, 80.2, 82, 83.1, 84, 102.1.c), 165, 167, 186.4, 189, 192, 294, 295, 296 y Disposición Adicional 8a del TRLGSS; arts. 42 y 43 de la Ley 47/2015, de 21 de octubre; y arts. 1 y 2 del Real Decreto 696/2018, de 29 de junio, por el que se aprueba el Reglamento General de la gestión financiera de la Seguridad Social. 
mutua, aunque para las prestaciones de incapacidad temporal, colabora la empresa obligatoriamente en la gestión mediante el pago delegado, reintegrándose posteriormente del mismo la empresa mediante la deducción del importe pagado de las cuotas mensuales a la Seguridad Social; y c) al Servicio Público de Empleo Estatal o ISM, si son prestaciones de desempleo.

Analicemos las prestaciones que siendo a cargo de la empresa, podría reclamar el trabajador al administrador social ejercitando la acción individual de responsabilidad.

\subsubsection{Prestaciones de responsabilidad directa empresarial. Recargo de prestaciones.}

Con carácter general existen tres supuestos en que la responsabilidad del pago de la prestación es directa de la empresa y con sus propios recursos económicos, no correspondiendo inicialmente el pago a la entidad gestora o colaborada.

- El primer supuesto, es la prestación de incapacidad temporal por contingencias comunes de los días $4^{\circ}$ a $15^{\circ}$ día ambos inclusive de conformidad con el art. $173.12^{\circ}$ párrafo del TRLGSS. Al regir el principio de pago anticipado, el trabajador no tendría un derecho de crédito frente a la empresa, por lo que no estaríamos ante una prestación que pudiera ser objeto de reclamación por el empleado al administrador de la sociedad mediante la acción individual de responsabilidad. Sólo nacería un derecho de crédito del trabajador si la empresa no hubiere solicitado su alta en Seguridad Social, lo que será objeto de análisis en el posterior apartado 3.1.3.

- El segundo supuesto de pago directo de una prestación, es cuando la empresa asume la colaboración voluntaria en la gestión de la prestación de incapacidad temporal por contingencias profesionales, pero al ser una prestación por contingencias profesionales, ante el impago de la prestación de incapacidad temporal por la empresa, anticipará el pago la entidad gestora o colaboradora, con lo que no nace un derecho de crédito del trabajador que pudiera reclamar judicialmente a la sociedad o al administrador social, en este caso mediante la acción individual de responsabilidad. 
- El tercer supuesto en que la responsabilidad es directa de la empresa, sin que quepa el anticipo por las entidades gestoras o colaboradoras ${ }^{503}$, es el recargo de prestaciones (artículo 164 del TRLGSS). Recargo de prestaciones que la empresa o empresas declaradas responsables, deberán ingresar su importe ante la TGSS ${ }^{504}$, ya que el beneficiario es el trabajador o sus causahabientes de haber fallecido como consecuencia del accidente o la enfermedad profesional.

En este supuesto al ser una prestación con cargo exclusivo de la empresa, sin que quepa anticipo alguno por la entidad gestora o colaborada, sí nacerá un derecho de crédito del trabajador ante la sociedad de capital, que, en su caso, podría reclamar ante el administrador social de concurrir los requisitos de la acción individual de responsabilidad del art. 241 de la LSC. Son escasas las demandas resueltas mediante sentencia en que el trabajador ejercita la acción individual ante el administrador por incumplimiento orgánicos, pudiendo citar, a título de ejemplo, la sentencia de la Audiencia Provincial de Córdoba, número 188/2018, de 12 de marzo -RJ Aranzadi 2018/6360-, en que se admitió la demanda de un trabajador que reclama al administrador social mediante la acción individual el recargo de prestaciones, pero entrando a conocer del fondo de la petición, se desestima la responsabilidad por daños del administrador por no haber argumentado ni acreditado el trabajador de qué manera los incumplimientos de aquél han determinado que no haya podido cobrar su crédito de la sociedad. Por el contrario, encontraremos más pronunciamientos judiciales en el orden jurisdiccional social acerca de la responsabilidad del administrador en el recargo de prestaciones, pero no será en ejercicio de la acción individual de responsabilidad, sino reclamando la responsabilidad del mismo por incumplimientos imputables de la normativa de prevención de riesgos laborales causantes de la prestación, especialmente mediante la aplicación de la doctrina del levantamiento del velo por estimar que el administrador social es el verdadero empresario, como veremos en el Capítulo VI, apartado II.2.1.

${ }^{503}$ Art. 16.3 de la Orden de 18 de enero de 1996 (BOE del 26/01/1996), de aplicación y desarrollo del Real Decreto 1300/1995, de 21 de julio, sobre Incapacidades Laborales del Sistema de la Seguridad Social.

${ }^{504}$ Art. 164 del TRLGSS, en relación con el art. 75 del Real Decreto 1415/2004, de 11 de junio; art. 1.1 del Real Decreto 1300/1995, de 21 de julio, en materia de Incapacidades Laborales del Sistema de Seguridad Social; y art. 16 de la Orden de 18.1.1996, que desarrolla en Real Decreto anterior. 
De estos tres supuestos en que la prestación de Seguridad Social es de responsabilidad directa de la empresa, sólo en el recargo de prestaciones tendrá el trabajador un derecho de crédito directo ante la empresa -por no regir el anticipo en el pago- que, en su caso, podría reclamar ante el administrador social de concurrir los requisitos de la acción individual de responsabilidad del art. 241 de la LSC.

\subsubsection{Prestaciones por incumplimiento de obligaciones de prevención de riesgos} laborales.

En primer lugar, las prestaciones causadas por enfermedad profesional sin haber tenido el trabajador los reconocimientos médicos obligatorios, previos al acceso al empleo o periódicos durante la relación laboral, cuando vengan establecidos en disposiciones en materia de prevención de riesgos laborales, determinará que se declare la responsabilidad empresarial en el pago de la prestación (art. 244.2 del TRLGSS). No nacerá un derecho de crédito del trabajador ejercitable mediante la acción individual de responsabilidad, porque al ser una prestación por contingencias profesionales con pago anticipado, surgirá una deuda de la sociedad de capital ante la Seguridad Social.

De igual modo, ante la responsabilidad empresarial por acaecer un accidente de trabajo y haber incumpliendo la empresa la orden de paralización de trabajos, impuesta por la Inspección de Trabajo y Seguridad Social ante riesgos graves e inminentes para los trabajadores, pese a ser la prestación de responsabilidad de la sociedad de capital, al considerarse como si no se hubiere concertado la protección de las contingencias profesionales (art. 242 del TRLGSS), no nace un derecho de crédito del trabajador susceptible de ser ejercitado mediante la acción individual de responsabilidad ante el administrador social, ya que procediendo el pago anticipado por la entidad gestora o mutua, por ser una prestación de contingencias profesionales, surgirá una deuda de la sociedad de capital ante la Seguridad Social.

\subsubsection{Responsabilidad por incumplimiento de obligaciones de encuadramiento $y$ cotización.}

Si la sociedad de capital no ha cumplido con sus obligaciones con la Seguridad Social en materia de afiliación o alta del empleado, o de cotización a la Seguridad Social, y se ha causado una prestación, nace la responsabilidad empresarial en el pago de la misma que será declarada por la entidad gestora en resolución administrativa firme (arts. 45, 165, 167 y 281 del TRLGSS). 
Entremos en el análisis de las causas que determinan que la empresa sea responsable del pago de una prestación por incumplimiento de sus obligaciones con la Seguridad Social. Causas que, si son imputables a la conducta antijurídica del administrador social, permitirán reclamar la responsabilidad por daños a éste al amparo del art. 241 de la LSC.

Como se ha indicado en el Capítulo I, apartado II.2.4 de esta tesis, son causas que determinan la responsabilidad de la empresa, si en la fecha del hecho causante de una prestación, a) el empleado afectado no se hallare afiliado y/o en alta en Seguridad Social en la empresa, ni en situación asimilada al alta (arts. 45, 165 y 167 del TRLGSS), o b) la empresa no se encontrase al corriente en el pago de la de las cotizaciones a la Seguridad Social (arts. 45, 165 y 167 del TRLGSS), salvo que hubiere aplazamiento o fraccionamiento en el pago concedido por la TGSS, y se cumpla regularmente con el mismo. De hallarse en alta en Seguridad Social, en función del principio de automaticidad relativa, anticipa el pago de la prestación la entidad gestora o colaboradora, por lo que el trabajador no tendrá un crédito directo sobre la empresa.

El incumplimiento de las obligaciones empresariales de altas y cotizaciones a la Seguridad Social determinará la responsabilidad de la empresa en el pago (art. 167, párrafos 2 y 3 del TRLGSS), responsabilidad empresarial que no siempre va a generar un derecho de crédito directo del trabajador ante la empresa, que pudiera permitir el posterior ejercicio de la acción individual de responsabilidad.

Como señalamos en el Capítulo I, apartado III.2.4, y siguiendo a nuestra jurisprudencia podemos extraer las siguientes conclusiones en materia de responsabilidad en el pago de prestaciones de Seguridad Social $^{505}$ :

a) Si ante la falta de alta en Seguridad Social se causase una prestación en que rija el principio de automaticidad absoluta o alta de pleno derecho, anticipará el pago la entidad gestora o mutua colaboradora, sin perjuicio de repetir contra el empresario responsable (arts. 166.4 y 167 del vigente TRLGSS), y, si el empresario fuese declarado insolvente, de ser contingencias profesionales, la

\footnotetext{
505 Sentencias del TS, Sala Social, de fechas 14 de junio de 2000 -rcud. 3096/99-; 9 de abril de 2001 rcud. 3860/99-; 26 de enero de 2004 -Rec. 4535/02-; 17 de noviembre de 2004 -rcud. 5997/03-; 12 de mayo de 2005 -RJ 2005/5045-; 16 de febrero de 2005 -RJ 2005/3492-; 8 de noviembre de 2006; 20 de febrero de 2007 -RJ 2007/2470-; 2 de julio de 2007 -rcud. 686/06-; 10 de julio de 2007 -rcud. 4168/06-; 22 de enero de 2009 -rcud. 3858/07-; 17 de febrero de 2009 -rcud. 4230/07-; 21 de mayo de 2009 -rcud. 1515/08-; 15 de noviembre de 2009 -rcud. 2864/06-; y 16 de diciembre de 2009 -rcud. $4356 / 08$.
} 
mutua reclamará la responsabilidad subsidiaria del INSS/ISM -responsable subsidiario, en tanto que sucesor del Fondo de Garantía de Accidentes de Trabajo(arts. 166.4, 186 a 189 y 281 del TRLGSS, en relación con el art. 29.2 del Real Decreto 84/1996, de 26 de enero).

Al anticipar el pago la entidad gestora o colaboradora, no nace un derecho de crédito del trabajador para ejercitar la acción individual de responsabilidad. Si nacería ese derecho de crédito por el importe superior al límite que asume la entidad gestora, por los importes superiores a dos veces y media el indicador público de rentas de efectos múltiples (IPREM).

b) Si se trata de prestaciones de contingencias comunes, que exijan el requisito de hallarse en situación de alta, como ante una Incapacidad Temporal, el defecto de alta del trabajador impide la aplicación del principio de automaticidad, siendo la empresa la única responsable de la prestación, por lo que surgirá un derecho de crédito del trabajador ante la empresa. Deberá tenerse en cuenta la flexibilización del requisito de situación de alta admitido en nuestra jurisprudencia, y examinado en el Capítulo I, apartado III.2.4 de esta tesis. De concurrir los requisitos legales exigibles en la acción individual de responsabilidad, el trabajador podría reclamar el pago de la prestación ante el administrador social.

c) Automaticidad relativa de prestaciones. Cuando se causa una prestación hallándose el trabajador en alta en Seguridad Social en la empresa, de no hallarse ésta al corriente en el pago de sus cotizaciones, la responsabilidad será empresarial, procediendo el pago anticipado por la entidad gestora o mutua ${ }^{506}$. Anticipo de prestaciones que procede, aunque la empresa hubiere desaparecido o no pudiera ser objeto de apremio (art. 167.3 del TRLGSS).

Al anticipar el pago la entidad gestora o colaboradora no nace un derecho de crédito del trabajador para ejercitar la acción individual de responsabilidad. Si nacería por el importe superior al límite que asume la entidad gestora, por los importes superiores a dos veces y media el indicador público de rentas de efectos múltiples (IPREM).

En definitiva, tendrá el trabajador un derecho de crédito contra la sociedad de capital, que permitirá ejercitar ante el administrador la acción individual de responsabilidad, en

\footnotetext{
${ }^{506}$ Sentencia del TS, Sala Social, de 22 de enero de 2016 -rcud. 1931/2014-.
} 
dos situaciones, en primer lugar, cuando la responsabilidad sea exclusiva de la empresa sin que quepa anticipo alguno por la entidad gestora o colaboradora, y, en segundo lugar, cuando ante el pago anticipado el importe de la prestación se superior a dos veces y media el IPREM, por el importe de la diferencia.

\subsection{Créditos de las entidades gestoras y recaudadoras de la Seguridad Social.}

Distinguimos dos tipos de créditos que pueden tener las entidades gestoras, Colaboradoras o la TGSS ante la empresa sociedad de capital, por cotizaciones o por prestaciones.

En la recaudación administrativa de deudas por cotizaciones y por prestaciones de responsabilidad de la empresa, se establecen unos importes mínimos, para poder iniciarse la reclamación ante el deudor, con la finalidad de evitar que el coste de su reclamación pueda ser superior al crédito con derecho a percibir, resulte de una única deuda o de la agrupación de varias existente contra el mismo deudor. Importe mínimo del 3\% del IPREM mensual, salvo en la responsabilidad mortis causa que es del $20 \%$ (art. 116.2 del TRLGSS y arts. 7 a 13 de la Orden TAS/1562/2005, de 25 de mayo ${ }^{507}$, que desarrolla el RGRSS). Importes que, con mayor razón, no deberán ser objeto de reclamación mediante la acción individual de responsabilidad en vía judicial.

\subsubsection{Créditos por cotizaciones a la Seguridad Social.}

Ante la falta de pago de las cotizaciones a la Seguridad Social en el plazo reglamentario de ingreso -mes siguiente al de devengo-, nace un derecho de crédito de la TGSS contra la sociedad de capital, que será exigible en vía administrativa a través del procedimiento recaudatorio, sea mediante reclamación de deuda por la TGSS, o acta de liquidación de la Inspección de Trabajo y Seguridad Social ${ }^{508}$.

Deudas por cotizaciones que pueden tener su origen en descubiertos totales de cotización, o en diferencias de cotización cuando se han ingresado o declarado cuotas por importes inferiores a los debidos.

Si la deuda de cotización a la Seguridad Social fuere debida a conducta antijurídica y culpable del administrador social, la TGSS podría ejercitar la acción individual de responsabilidad contra éste. No obstante, en la práctica la TGSS no hace apenas uso de

\footnotetext{
${ }^{507}$ BOE 1.6.2005.

508 Arts. 22, 28, 29 y 33 a 36 del TRLGSS, y arts. 56 a 66 del Real Decreto 1415/2004, de 11 de junio, RGRSS.
} 
esa atribución, no sólo por la dificultad probatoria que conlleva la acción individual de responsabilidad, sino por ser un medio más lento, y en esa medida, menos eficiente, que la derivación administrativa de deuda al administrador social al amparo del art. 367 de la LSC y del art. 18 apartados 3 y 4 del TRLGSS. Ahora bien, en los supuestos en que no sea aplicable la responsabilidad por deudas del art. 367 de la LSC, de hallarnos ante supuestos que permitan el ejercicio de la acción individual de responsabilidad por conducta imputable del administrador, como la preterición del pago de deudas de Seguridad Social, el cierre de hecho, o deudas derivadas de conducta dolosa o con culpa grave del administrador (no solicitar en plazo de modo reiterado las altas en Seguridad Social, diferencias de cotización por conducta fraudulentas -ocultar retribuciones, aplicación fraudulenta de bonificaciones, reducciones de cuotas-, etc.)-, siempre quedaría abierta la vía de la acción individual de responsabilidad.

No hemos encontrados sentencias del TS en las dos últimas décadas acerca del ejercicio de acciones individuales de responsabilidad de la TGSS contra el administrador social, lo que denota un claro abandono de esta vía, especialmente desde que entra en vigor la derivación administrativa de responsabilidad ante el administrador en el pago de deudas de Seguridad Social (actual art. 18.3 del TRLGSS), introducida mediante la Ley 52/2003, de 10 de diciembre, para los supuestos de responsabilidad ex lege por deudas.

\subsubsection{Créditos por prestaciones de responsabilidad empresarial.}

Los derechos de crédito de las entidades gestoras de la Seguridad Social o colaboradoras contra la empresa en materia de prestaciones de Seguridad Social, que podrían ser exigidos al administrador social de concurrir los requisitos de la acción individual de responsabilidad, los agruparíamos en ocho grandes grupos o supuestos.

- En primer lugar, cuando en virtud del principio de automaticidad plena o absoluta de prestaciones, la entidad gestora anticipe el pago al trabajador, en cuyo caso nace un derecho de crédito contra la empresa responsable, ya que esa entidad tiene el derecho a repercutir lo pagado (art. 167 del TRLGSS).

- En segundo lugar, cuando la prestación de incapacidad temporal sea con cargo a los recursos económicos de la sociedad de capital, estando el trabajador en alta en Seguridad Social reuniendo la carencia exigida, sin que la empresa efectúe el pago de la prestación, en cuyo supuesto procederá la entidad gestora a su pago adelantado, con lo que nace un derecho de repetición contra la empresa sociedad de 
capital, lo que tendrá lugar en dos situaciones. Por un lado, las prestaciones de incapacidad temporal derivadas de contingencias profesionales cuando la empresa tenga reconocida la colaboración voluntaria (art. 102, apartado a) del TRLGSS). Y, por otro lado, el pago de la prestación de Incapacidad Temporal por Contingencias Comunes del $4^{\circ}$ al 15 día de baja médica (art. 173.1 del TRLGSS), estando el trabajador en situación de alta o asimilada al alta para las contingencias comunes.

- En tercer lugar, cuando en la fecha del hecho causante de una prestación existan descubiertos de cotización a la Seguridad Social, hallándose en situación de alta en Seguridad Social el trabajador reuniendo la carencia exigida, surge la responsabilidad empresarial en el pago de prestaciones (automaticidad relativa). Ahora bien, al anticipar el pago la entidad gestora, nacerá un derecho de crédito de ésta ante la empresa sociedad de capital (art. 167.3 del TRLGSS). Como regla general, si el trabajador está de alta en Seguridad Social en la empresa, la entidad que asegura las contingencias comunes (INSS/ISM o mutua colaboradora) viene obligada a anticipar el pago de la prestación, sin perjuicio de su derecho a repetir contra la empresa lo pagado, rigiendo el principio de proporcionalidad en la moderación de la responsabilidad ${ }^{509}$.

- En cuarto lugar, cuando por falta de alta y de cotización del trabajador en periodos determinados anteriores al hecho causante, se haya generado una prestación de cuantía inferior, en cuyo supuesto y en virtud del principio de proporcionalidad, por la superior prestación a que tendría derecho el trabajador, nace la responsabilidad empresarial, y si anticipa el pago la entidad gestora, podrá reclamarse a la empresa. Nace de este modo, un derecho de crédito de la entidad gestora sobre la sociedad de capital.

- En quinto lugar, cuando existan diferencias de cotización a la Seguridad Social, por excluirse indebidamente de la base de cotización retribuciones sujetas a cotización, surgirá la responsabilidad empresarial por la diferencia de la prestación a que hubiere tenido derecho el trabajador de haberse incluido en la base de cotización esa retribución. Al hallarse en alta el trabajador, en virtud del principio de automaticidad

\footnotetext{
${ }^{509}$ Sentencias del TS, Sala Social, de fechas 14 de junio de 2000 -rcud. 3096/99-; 9 de abril de 2001 rcud. 3860/99-; 17 de noviembre de 2004 -rcud. 5997/03-; 8 de noviembre de 2006; 2 de julio de 2007 -rcud. 686/06-; 10 de julio de 2007 -rcud. 4168/06-; 22 de enero de 2009 -rcud. 3858/07-; 17 de febrero de 2009 -rcud. 4230/07-; 21 de mayo de 2009 -rcud. 1515/08-; 15 de noviembre de 2009 rcud. 2864/06 -; y 16 de diciembre de 2009 -rcud. 4356/08-
} 
relativa de la prestación, anticipa el pago la entidad gestora o colaboradora, por lo que nace un derecho de crédito de éstas contra la empresa para resarcirse de ese pago anticipado.

- En sexto lugar, nacerá un derecho de crédito cuando por flexibilización del requisito de alta en Seguridad Social, y en virtud del principio de proporcionalidad, nazca responsabilidad de la empresa por la parte proporcional de la superior prestación. Al anticipar el pago la entidad gestora de esa superior prestación nace un derecho de crédito de la ésta contra a empresa.

- En séptimo lugar, en los supuestos de prestaciones causadas por enfermedad profesional sin haber tenido el trabajador los reconocimientos médicos previos al acceso al empleo, o periódicos durante la relación laboral, cuando estén establecidos como obligatorios en disposiciones en materia de prevención de riesgos laborales (art. 244.2 del TRLGSS). Surgirá la responsabilidad empresarial en el pago de la prestación, pero al ser una contingencia profesional anticipa el pago la entidad gestora o la mutua colaboradora. Por ese anticipo nace un derecho de crédito frente a la empresa incumplidora.

- En octavo lugar, cuando acaezca un accidente de trabajo incumpliendo la empresa la orden de paralización de trabajos por riesgos graves e inminentes para los trabajadores, impuesta por la Inspección de Trabajo y Seguridad Social, en cuyo caso, se estima que los accidentes se producen como si no se hubiere concertado por la empresa la protección por la contingencia, siendo ésta la responsable (art. 242 del TRLGSS). Surge un derecho de crédito ante la empresa responsable al anticipar el pago la prestación la entidad gestora o colaboradora.

Ante todos esos incumplimientos de la empresa, y una vez anticipa la entidad gestora o colaboradora la prestación al trabajador, surge un derecho de crédito contra la sociedad de capital. Ante esa deuda por prestaciones de la sociedad de capital, de estimarse que la misma es fruto de una conducta antijurídica y culpable del administrador social, cabría ejercitar la acción individual de responsabilidad.

El problema jurídico con que nos podremos encontrar al ejercitar la acción individual para resarcirse del pago de las prestaciones, como en toda acción individual, radicará en la acreditación del daño directo al patrimonio de la Seguridad Social como daño distinto y no reflejo de un daño al patrimonio de la sociedad. 


\section{Jurisdicción competente ante una deuda de origen laboral y de Seguridad Social.}

El administrador social al poder causar con su conducta antijurídica un daño directo en el crédito social del trabajador, sea un crédito laboral o un crédito de Seguridad Social, así como en los créditos que las entidades gestoras o recaudadoras de la Seguridad Social tengan contra la sociedad de capital, principalmente ante deudas por cotización o por prestaciones anticipadas al trabajador en virtud del principio de automaticidad, hemos de determinar ante qué orden jurisdiccional han de accionar los trabajadores, las entidades gestoras o la TGSS para ejercitar la acción individual de responsabilidad.

Distinguimos igualmente la competencia judicial en función de hallarnos ante créditos laborales y créditos de Seguridad Social.

\subsection{Créditos Laborales y de Seguridad Social del trabajador.}

En nuestro ordenamiento jurídico se atribuye a la Jurisdicción Social la competencia para conocer las cuestiones litigiosas que se promuevan entre los trabajadores por cuenta ajena y sus empleadores como consecuencia del contrato de trabajo, así como las acciones que pudieran entablar los trabajadores contra el empresario y contra aquellos a quienes se les atribuya legal, convencional o contractualmente la responsabilidad por los daños originados en el ámbito de la prestación de servicios, o que tengan su causa en accidentes de trabajo o enfermedades profesionales, todo ello salvo las competencias atribuidas al Juez Mercantil en el concurso de acreedores ${ }^{510}$.

Por otro lado, compete al orden jurisdiccional civil, y dentro de él a los Juzgados de lo Mercantil en primera instancia, conocer las cuestiones que se promuevan al amparo de la normativa reguladora de las sociedades mercantiles y cooperativas, salvo las que expresamente por ley se atribuyan a otro orden jurisdiccional (arts. 9.2, 86. ter, apartado 2. a) de la LOPJ).

Ante esa duplicidad de órdenes jurisdiccionales, el civil para las reclamaciones derivadas de la legislación de sociedades de capital, a través de los Juzgados de lo Mercantil, y el social para conocer las reclamaciones de los trabajadores contra su empleador, y especialmente ante la previsión legal expresa de extensión de la

\footnotetext{
${ }^{510}$ Art. 2 apartados a) y b), y 3.2.d) de la Ley 36/2011, de 10 de octubre, que aprueba la Ley Reguladora de la Jurisdicción Social -en adelante LRJS-, en relación con los artículos 9.5, 59, 75, 92 y 93 de la Ley Orgánica 6/1985, de 1 de julio, del Poder Judicial-LOPJ-, y arts. 44, 52, 54, y 169 a 191 del TRLC.
} 
Jurisdicción Social para conocer de "las reclamaciones de los trabajadores contra aquellos a los que se atribuya legal, convencionalmente o contractualmente responsabilidad por daños originados en el ámbito de la prestación de servicios" del art. 2.b) de la LRJS, surge la duda de determinar ante qué orden jurisdiccional debe entablarse la acción, ya que por una lado, la acción individual de responsabilidad contra el administrador social de la sociedad de capital es una acción de responsabilidad por daños, que tiene como presupuesto la infracción de deberes de la normativa societaria (arts. 236 a 241 de la LSC), y por otro lado, la naturaleza del crédito dañado del acreedor es un crédito laboral.

En defensa de la atribución a la Jurisdicción Social podrían invocarse cinco razones. En primer lugar, que la reclamación al administrador tiene como título jurídico el crédito laboral, esto es una reclamación del trabajador de un crédito laboral que no ha sido satisfecho por la sociedad de capital empleadora, aunque la insatisfacción haya sido fruto de una actuación antijurídica del administrador. Crédito contractual, por cuanto la relación jurídico laboral comprende tanto la deuda como la responsabilidad que se derivase del mismo, y ambas cuestiones son competencia del orden social. En segundo lugar, porque la reclamación al administrador de la deuda laboral por incumplimiento imputable al mismo, no conlleva que se nove la naturaleza jurídica del crédito, ya que éste sigue siendo laboral, contractual, aunque ex lege pueda exigirse también al administrador por incumplimientos imputables al mismo, por lo que, siendo la deuda reclamada de origen laboral, contractual, corresponde a esa jurisdicción su conocimiento. En tercer lugar, porque cabría entender que el crédito por daños reclamado con la acción individual de responsabilidad es cuestión prejudicial del proceso social, ya que el daño directo tiene como presupuesto el impago de la deuda por la sociedad. En cuarto lugar, porque la jurisprudencia ha admitido el carácter solidario de la condena de la acción individual de responsabilidad al acumularse con la acción principal contra la sociedad ${ }^{511}$, y se afectaría a la solidaridad si el trabajador tuviere que demandar a la sociedad ante el orden social y al administrador ante el orden civil. En quinto lugar, porque expresamente en el art. 2 apartado b) de la LRJSS, se atribuyen al orden social "las reclamaciones de los trabajadores contra el empresario o contra aquellos a los que se atribuya legal, convencionalmente o contractualmente responsabilidad por daños originados en el ámbito de la prestación de servicios”, esto

${ }^{511}$ STS, Sala Civil, núm. 253/2016, de 18 de abril -RJ 2016/1342-; y núm. 242/2014 de 23 de mayo -RJ 2014/2943-. 
es, las reclamaciones atribuidas legalmente, cualquiera que sea la rama del derecho, incluida la mercantil, contra aquéllos que causen daños originados en el ámbito del contrato de trabajo, en que se incluirían a los administradores sociales de la sociedad de capital. Este último criterio legal de atribución al orden social, podría ser la vis atractiva a esta jurisdicción, en una interpretación gramatical y teológica de este orden como jurisdicción especializada y garantista del trabajador ${ }^{512}$, y en virtud del cual ha pasado al orden social la competencia que se arrogaba el orden civil sobre la responsabilidad civil por daños derivados de accidentes de trabajo, y estamos ante una responsabilidad de igual naturaleza, responsabilidad por daños de un tercero -el administrador- fruto de una relación laboral.

En defensa de atribuir la competencia al orden civil y concretamente a los Juzgados de lo Mercantil, caben apuntarse cinco motivos. En primer lugar, que la condición de título o crédito laboral es el que tiene el trabajador contra la sociedad de capital, al no ser el administrador social parte del contrato de trabajo, crédito laboral que no podrá exigirse al administrador social, sino que si se reclama a éste, no será ejercitando un derecho contractual laboral, sino exigiendo la reparación del daño directo causado en el crédito del trabajador, al ser la acción del art. 241 de la LSC de naturaleza extracontractual y no contractual. En segundo lugar, porque el título y la causa de pedir del trabajador al administrador tiene como fundamento un título jurídico derivado de una ley mercantil, estamos ante una indemnización con fundamento jurídico en el Derecho de sociedades, aunque el origen de crédito dañado sea una deuda laboral. En tercer lugar, porque legalmente no se atribuye en la normativa laboral ninguna responsabilidad solidaria o subsidiaria del administrador con la sociedad en el pago de las deudas laborales y de Seguridad, y cuando se reclama el pago de un crédito laboral dañado por el administrador social se está exigiendo el resarcimiento del daño causado, naciendo una responsabilidad y una deuda indemnizatoria propia del administrador, con título de

512 Han defendido su competencia diversas Salas del Orden Social de los Tribunales Superiores de Justicia, entre las que citamos a título de ejemplo Sentencias del TSJ, Sala Social, de Madrid, 21 de marzo de 1996; 12 de abril de 1996; 16 de abril de 1996; 13 de mayo de 1996; 23 de mayo de 1996; 24 de junio de 1996; 2 de septiembre de 1996; 2 de diciembre de 1996. TSJ, Sala Social, de Cataluña, 4 de julio de 1995; 30 de diciembre de 1995; 27 de junio de 1996; 27 de enero de 1997. TSJ, Sala Social, de Castilla-La Mancha, de 29 de abril de 1995; 29 de marzo de 1996; 18 de abril de 1996; 21 de febrero de 1997. TSJ, Sala Social, del País Vasco 22 de noviembre de 1994. TSJ, Sala Social, de Cantabria, de 6 de junio de 1995 y 13 de mayo de 1996, fundamentalmente abogando por la vis atractiva del Orden Laboral ante una reclamación derivada del contrato de trabajo, que incluye tanto la deuda como las posibles responsabilidades derivadas colateralmente de la relación laboral, sin que se nove la naturaleza jurídica de contractual a extracontractual, y/o defendiendo el carácter de cuestión prejudicial de la reclamación del daño al administrador. 
pedir distinto al de la deuda laboral de la sociedad, de modo que incluso el importe reclamado al administrador podrá ser de importe diferente, incluso inferior al crédito laboral, de apreciarse que el daño causado fuere menor. En cuarto lugar, porque el crédito por daños no es cuestión prejudicial del orden social, ya que no estamos ante un crédito laboral en que para su valoración haya de acudirse previamente a una disposición mercantil, sino al contrario, nos hallamos ante un crédito mercantil que tiene sustantividad propia respecto al crédito laboral de origen, porque la cuestión mercantil de responsabilidad del administrador es la cuestión principal y no accesoria respecto a otra laboral que haya de dilucidarse. En quinto lugar, no es aplicable el art. 2.b) de la LRJS, porque en este precepto se alude a "las reclamaciones de los trabajadores contra el empresario o contra aquellos a los que se atribuya legal, convencionalmente o contractualmente responsabilidad por daños originados en el ámbito de la prestación de servicios", para atribuir al orden social el conocimiento de la responsabilidad en daños causados en el ámbito de la prestación laboral (fundamentalmente supuestos de los arts. 164 y 168 del TRLGSS), y aquí el daño lo causa el administrador por su actuación orgánica sin que sea un daño por incumplir disposiciones del orden social, al ser la causa de pedir de la acción individual de responsabilidad una norma del Derecho de sociedades, y no del Derecho laboral.

Nuestra doctrina científica mercantilista ${ }^{513}$ ante la dualidad competencial, se ha decantado claramente por la competencia del orden civil-mercantil, partiendo esencialmente de considerar que la acción de reclamación de un crédito laboral del trabajador contra la sociedad es contractual, mientras que la acción del trabajador contra el administrador es extracontractual, siendo la causa petendi de índole mercantil, ya que la responsabilidad reclamada está regulada en la normativa de sociedades de cuyo conocimiento es competente la Jurisdicción Civil a través de los Juzgados de lo Mercantil, siendo la cuestión principal planteada la reclamación del daño lo que exige apreciar la concurrencia de todos los requisitos legales exigibles, no teniendo la acción individual carácter prejudicial de la acción contractual laboral, ya que para decidir sobre ésta no es condición necesaria abordar previamente la responsabilidad del administrador.

${ }^{513}$ SALDAÑA VILLOLDO, B.: La acción individual de responsabilidad..., op. cit., pp. 396 a 407. 
Por el contrario, la doctrinal laboralista ${ }^{514}$ defendía la competencia de la Jurisdicción Social.

DESDENTADO BONETE y DESDENTADO DAROCA ${ }^{515}$ consideran que acudir a dilucidar si las pretensiones ejercitadas al amparo del actual art. 241 de la LSC, son principalmente cuestiones laborales o mercantiles, para atribuir la competencia a uno $\mathrm{u}$ otro orden, es en definitiva un criterio inseguro. Para estos dos autores, el problema viene dado porque siendo la reclamación de contenido netamente laboral, la misma se dirige contra la sociedad y el administrador, y si ante la sociedad el vínculo es laboral, ante el administrador la situación es más compleja, de modo que si la norma incumplida es laboral, aunque sea mercantil la que impone la responsabilidad, lo razonable sería defender la competencia del orden social, mientras que si la norma infringida es también mercantil, la cuestión es más dudosa y habría que decidir para resolverla si predomina el objeto de la pretensión o el fundamento de la misma.

Defendía la competencia de la Jurisdicción Social CAVAS MARTÍNEZ ${ }^{516}$, quien la justificaba partiendo de tres argumentos. En primer lugar, porque (sic) "no parece lógico que dependa del concreto precepto de la LSA en que se base la reclamación de responsabilidad del administrador la competencia uno u otro orden jurisdiccional. En segundo lugar, porque, el hecho de que el administrador haya incumplido obligaciones impuestas por la Legislación Mercantil no obsta a que la reclamación verse sobre un crédito laboral y la competencia sea del orden social. En tercer lugar, porque se desnaturaliza la solidaridad, cuando ésta viene impuesta legalmente, porque se obliga a demandar por separado a los deudores y responsables solidarios, cuando la solidaridad implica poder demandar a todos, o alguno, a elección del acreedor, y la acción contra la

514 DESDENTAdo BONETE, A. y DESDENTADO DAROCA, E.: Administradores Sociales, Altos Directivos y socios trabajadores..., op. cit., pp. 207 y 208; CAVAS MARTÍNEZ, F.: "La responsabilidad patrimonial de los socios y administradores sociales en el ámbito laboral ”, en Revista Doctrinal Aranzadi Social, núm. 9/2002, BIB 1998\1260, edición digital, https://insignisaranzadidigital-es.ponton.uva.es/maf/app/document?rediRect=true\&srguid, $\quad$ p. 14; CANABATE POZO, R.: "Jurisdicción competente para determinar la responsabilidad de los administradores de una sociedad de responsabilidad limitada derivada del despido de un trabajador (Comentario a la STSJ de Navarra de 18 junio 1999)", Revista Doctrinal Aranzadi Social, Vol. párrafo. II 40, BIB 1999\1542, edición digital,

https://insignis-aranzadidigital-es.ponton.uva.es/maf/app/document?rediRect=true\&srguid, p. 7; LLOMPART BENNÀSSAR, M.: "La responsabilidad en el ámbito laboral y de Seguridad Social”, op. cit., edición digital, pp. 12-13 de 44.

515 DESDENTADO BONETE, A. y DESDENTADO DAROCA, E.: Administradores Sociales, Altos Directivos y socios trabajadores..., op. cit., pp. 207 y 208.

516 CAVAS MARTÍNEZ, F.: "La responsabilidad patrimonial de los socios y administradores sociales en el ámbito laboral”, op. cit., edición digital, p. 14. 
empresa se podría ejercitarse, por su naturaleza laboral, ante el orden jurisdiccional social, de modo que sólo en ésta podría reclamarse simultáneamente contra empresa y administrador social, y de impedirlo, se está negando la solidaridad".

CAÑABATE POZO $^{517}$ defendía la competencia del orden jurisdiccional social porque si la responsabilidad del administrador es una responsabilidad solidaria con la sociedad, se perjudica el carácter solidario cuando se obliga al trabajador a demandar a la sociedad ante el orden social y al administrador ante el civil.

En favor de la atribución de la competencia al orden civil apuntamos como precursora, la sentencia núm. 435/1995, de 9 mayo (Recurso n 485/1992, RJ 1995-3629) del TS, Sala Civil, que ante la ausencia de una atribución legal expresa a un concreto orden judicial, y partiendo de la "vis atractiva" del artículo 9.1 de la LOPJ, con motivo de una reclamación laboral de un artista en espectáculos públicos sujeto a relación laboral, declaró la competencia del orden civil contra la empresa por la cláusula residual de competencia de la misma para todas aquellas cuestiones no atribuidas a otro orden judicial. Sentencia importante para atribuir la competencia en ausencia de previsión legal expresa.

Legalmente se ha atribuido la competencia a los Juzgados de lo Mercantil para conocer las demandas en que se planteen cuestiones reguladas en la legislación de sociedades mercantiles (art. 86, ter apartado 2. a) de la LOPJ).

A efectos de determinar la jurisdicción competente en nuestra jurisprudencia se han distinguido dos supuestos. Un primer supuesto es el de la responsabilidad por daños de la acción individual de responsabilidad del actual art. 241 LSC. Un segundo supuesto es el de la responsabilidad por deudas del administrador, distinguiendo aquí, a su vez, entre responsabilidad por deudas ante una causa legal de disolución (art. 367 de la actual LSC), o responsabilidad solidaria por deudas impuesta en la D.T. $3^{\mathrm{a}}$ de la LSA por no haber elevado la sociedad con anterioridad al 30.6.1992 el capital social al importe mínimo legal de diez millones de pesetas (supuesto éste actualmente inexistente por pérdida de vigencia).

517 CAÑABATE POZO, R.: "Jurisdicción competente para determinar la responsabilidad de los administradores de una sociedad de responsabilidad limitada derivada del despido de un trabajador (Comentario a la STSJ de Navarra de 18 junio 1999)", op. cit., edición digital, p. 7. 
Cuando se reclama la responsabilidad por deudas por causa de disolución del art. 367 de la LSC, y cuando se ejercite la acción individual de responsabilidad del art. 241 de la LSC, la jurisprudencia ha atribuido la competencia a la Jurisdicción Civil ${ }^{518}$. Buena parte de esa jurisprudencia se ha dictado sobre la responsabilidad solidaria por deudas, pese a aludirse también expresamente a la acción individual de responsabilidad, como ocurre en la Sentencia de fecha 9 de noviembre de 1999 -Rcud. 2252/1998-. Se reconoció expresamente la competencia del orden civil para conocer la acción individual en la STS, Sala Social, de 8 de mayo de 2002 -Rec. 3079/2001-519, que parte de las argumentaciones sentadas por la jurisprudencia para declarar la competencia de ese orden para conocer acerca de la responsabilidad solidaria por deudas del actual art. 367 de la LSC, que referiremos más abajo.

Se ha negado en esa doctrina jurisprudencial la competencia del orden jurisdiccional social por varios motivos. En primer lugar, porque si bien las deudas de la empresa son laborales; no tienen esa condición las deudas por responsabilidad del administrador, las que son societarias. En segundo lugar, porque para decidir sobre la responsabilidad laboral de la empresa es innecesario decidir sobre la responsabilidad del administrador, al no ser ésta una cuestión prejudicial de la acción laboral, sino posterior a ésta. En tercer lugar, porque debe distinguirse entre las cuestiones prejudiciales laborales, como todas aquellas que van a identificar a los empresarios reales, a cedentes o cesionarios, antecesores o sucesores en términos de los artículos 42, 43 y 44 del Estatuto de los Trabajadores, cuyas responsabilidades como empresarios precisa de una decisión prejudicial que les identifique en tal condición; de aquellas otras en las que se trata de extender a otros sujetos responsabilidades que les alcanzan por títulos jurídicos no

\footnotetext{
${ }^{518}$ Auto 4/1996, de 8 de marzo -Rec. 7/1995- de la Sala Especial de Conflictos de Competencias del TS, y por la Sala Social del TS, en Sentencias de 28 de febrero de 1997 -RJ Ar. 4220/1997-; 28 de octubre de 1997 -RJ 7680/1997-; 13 de abril de 1998 -RJ 1998/4577-; 21 de julio de 1998 -RJ 6211/1998-; 9 de noviembre de 1999 -RJ 1999\8520-; 9 de junio de 2000 -RJ 2000\5109-; y 8 de mayo de 2002 -RJ 200217541-. Igualmente, en reclamaciones de deudas por la TGSS, antes de que se introdujese el art. 18.3 del TRLGSS actual, mediante la Ley 52/2003, de 10 de diciembre, las Sentencias del TS, Sala Contencioso-Administrativa, de 18 de junio de 2002 -Rec. Interés de Ley 3424/2001-; 15 de octubre de 2003 -RJ 2003\8582-; 21 de julio de 2003 -RJ 2003\6939-; 31 de marzo de 2003 -RJ 2003\3485-. Por la Sala Civil, del TS, se ha venido declarando reiteradamente, la competencia del orden civil para conocer acerca de la responsabilidad por deudas laborales del administrador social, en virtud del art. 367 LSC, en una ya consolidada jurisprudencia, citando como pronunciamientos más reciente, las Sentencias 460/2010, de 14 de julio; 826/2011, de 23 noviembre; 455/2017, de 18 de julio; y 420/2019, de 15 de julio.

519 En igual sentido, ha conocido acerca del ejercicio de la acción individual de responsabilidad para reclamar créditos laborales de los trabajadores impagados por la sociedad empleadora, la Sentencia del TS, Sala Civil, de no 1200/2004, de 7 de diciembre; y Sala Social del TS, la Sentencia de 7 de enero de 2000 -rcud. 3973/1998-.
} 
laborales, sino mercantiles, como es la responsabilidad del administrador establecida en la legislación societaria, que al no poder calificarse como una cuestión prejudicial laboral, porque su decisión no afecta ni condiciona la pretensión laboral, la competencia no es del orden social, sino del orden jurisdiccional civil.

Por otro lado, se ha atribuido la competencia al orden social para conocer sobre la responsabilidad solidaria del administrador por deudas laborales establecida en la D.T. $3^{a}$ de la antigua $L S A^{520}$, de no haberse elevado el capital social, antes del 30.6.1992, al importe mínimo del capital fijado para toda sociedad anónima. La responsabilidad solidaria está actualmente sin contenido por pérdida de vigencia de ese precepto y por prescripción de las acciones que pudieran ejercerse por ese motivo, en función del tiempo transcurrido.

Doble atribución de competencia de responsabilidad solidaria por esos dos motivos, que se confirmaba en la STS, Sala Social, de 21 de julio de 1998 -RJ 6211/1998-, de modo que es competente la Jurisdicción Civil para conocer tanto de la responsabilidad por deudas, como de la acción individual de responsabilidad del administrador, y sólo sería competente la Jurisdicción Social para conocer de la responsabilidad por deudas del administrador social por no haberse elevado el capital social al mínimo legal que se estableció en la Disposición Transitoria $3^{\mathrm{a}}$ de la anterior LSA.

Se atribuye la competencia a la Jurisdicción Social por falta de adaptación del capital social al mínimo legal establecido en la nueva legislación de sociedades, entendiendo que es la naturaleza de los créditos sociales que han de satisfacerse la determinante de la competencia, por cuanto la responsabilidad de los administradores en este supuesto, es un refuerzo de los derechos de quienes se relacionaron con el ente social, cuya exigencia debe realizarse ante el Tribunal competente para decidir la cuestión principal, que es la determinante de la calificación de la naturaleza de la acción ejercitada. Doctrina que en sí misma sería aplicable también a las acciones de responsabilidad por deudas o por daños del trabajador contra el administrador social. Sentado lo anterior, en la Sentencias del TS, Sala Social, de 28 de octubre de 1997 -RJ 7680/1997-521, se

${ }^{520}$ STS, Sala 4a , de 28 de octubre de 1997 -RJ 7680/1997-; 31 de diciembre de 1997 -Rec. 1858/1997-; 31 de marzo de 1999 -Rec. 3073/1998-; 20 de septiembre de 1999 -Rec. 1339/1998-; 12 de abril de 2000 -rcud. 4605/1998-.

${ }^{521}$ Se argumenta la competencia en los siguientes términos (sic): "en las demandas que iniciaron este procedimiento se ejercitaba una pretensión contra la sociedad anónima a la que los demandantes prestaban sus servicios, para que se decretara la extinción indemnizada del contrato, como consecuencia del incumplimiento contractual consistente en falta de pago del salario. Para tal acción, 
declara que con esa doctrina no se aparte de la jurisprudencia que admite la competencia general del orden civil, por ser supuestos distintos, porque en la responsabilidad por daños del art. 241 de la LSC y en la responsabilidad por deudas del administrador del art. 367 de la LSC, estamos ante responsabilidad por incumplir unas obligaciones societarias, como los deberes de ordenada disolución, y para fijar estas responsabilidades es necesario analizar los supuestos de hecho determinantes de las responsabilidades del administrador establecidos en la legislación de sociedades, y esa cuestión no es accesoria de la deuda laboral, por lo que la competencia será del orden civil.

En definitiva, diríamos nosotros que para la aplicación de la responsabilidad de la D.T. $3^{\mathrm{a}}$ de la LSA, no se precisa ninguna valoración jurídico mercantil, sino que estamos tan

promovida dentro de la rama social del Derecho, son competentes los Tribunales del Orden Social (arts. 9.5 de la Ley Orgánica del Poder Judicial y art. 1 de la Ley de Procedimiento Laboral actualmente LRJS-). La pretensión se planteó, asimismo, frente a los administradores sociales para que, de la posible deuda derivada del éxito de la acción anterior, se declare su responsabilidad solidaria, por haber incumplido un mandato de la Ley de Sociedades Anónimas, que les obligaba a adecuar los estatutos sociales a la nueva normativa rectora de estas sociedades. Y es evidente que, aunque esta responsabilidad encuentre su fundamento en preceptos mercantiles, ajenos a la rama social del Derecho, la causa de pedir, sigue siendo laboral, por mas que la extensión de responsabilidad a los administradores sociales se base en la infracción de mandatos de la Ley Reguladora de las Sociedades Anónimas. La Disposición Transitoria Tercera de esta Ley estableció una responsabilidad de los administradores sociales que, no cumplieran el mandato de aumentar el capital al mínimo de diez millones de pesetas, colocando a la sociedad en situación de no poder satisfacer los créditos a sus acreedores. Y deberá ser la naturaleza de los créditos sociales que se hayan de satisfacer la determinante de la competencia de los Tribunales que hayan de decidir sobre el conjunto, pues la responsabilidad de los administradores respecto a las deudas sociales, en este supuesto, es un refuerzo de los derechos de quienes se relacionaron con el ente social, cuya exigencia debe realizarse ante el Tribunal, que deba decidir la cuestión principal que es la determinante de la calificación de la naturaleza de la acción ejercitada. La interpretación que en esta Sentencia se realiza no contradice la expuesta en la de 24 febrero 1997 (RJ 1997\4220) (Recurso 2928/1996), pues, en dicha resolución la Sala se pronunció declarando que la responsabilidad del administrador único derivada de la no disolución del ente social, no era cuestión prejudicial respecto a las deudas salariales reclamadas en el litigio. Para decidir sobre la responsabilidad de la empresa es innecesario un previo pronunciamiento sobre la responsabilidad del administrador, que será una cuestión no prejudicial, sino posterior a la estricta y realmente laboral. Contestaba así la resolución judicial a la argumentación del recurrente. Por otra parte, no son iguales los supuestos contemplados en ambas resoluciones. En este litigio se resuelve sobre la responsabilidad de los administradores que, incumpliendo el mandato de elevar el capital al mínimo legalmente establecido, colocan a la sociedad en situación de dudosa solvencia, en perjuicio de los terceros que mantuvieron relaciones jurídicas con el ente social en la confianza de que cumple los mínimos legalmente establecidos. Es así esta responsabilidad solidaria de los administradores una garantía para quienes contrataron con la sociedad y es exigible ante los Tribunales que conozcan de las deudas sociales insatisfechas. En el caso regulado en el art. 262 de la Ley de Sociedades Anónimas (caso contemplado en la Sentencia de 24 febrero 1997) se establece una responsabilidad de los administradores que incumplen la obligación de disolver la sociedad (mediante la consiguiente convocatoria de junta de accionistas o declaración judicial) en los supuestos establecidos. Para fijar estas responsabilidades es necesario un previo pronunciamiento sobre si concurren o no los supuestos de hecho que la Ley señala como determinantes del deber de disolver la sociedad. Pronunciamiento que ha de ser realizado por los Tribunales competentes en materia mercantil, pues tal determinación no es accesoria respecto a las obligaciones sociales". Las referencias al art. 262 de la LSA deben entenderse realizadas al actual art. 367 LSC-. 
sólo ante una cuestión de hecho, fáctica, que se reduce a constatar si se la elevado o no el capital social a una fecha determinada, que es el hecho determinante de la responsabilidad, siendo la cuestión principal la naturaleza del crédito reclamado y no el hecho determinante de la responsabilidad, siendo éste cuestión accesoria apreciable en el orden social, sin vulnerarse la competencia propia del orden civil.

Dentro de la jurisprudencia que atribuye la competencia al orden civil para la acción individual de responsabilidad y para la responsabilidad por deudas del administrador social, destacamos el voto particular del magistrado Fernando Salinas emitido a la Sentencia del TS, Sala Social, de 13 de abril de 1998 -rcud. 925/1997-, que abogaba por la competencia del orden social. Defiende que se extienda a esas dos responsabilidades la doctrina sobre la competencia del orden social establecida para la responsabilidad del administrador de la Disposición Transitoria $3^{\text {a }}$ de la LSA, por no elevar en el plazo legal el capital social mínimo exigido, partiendo de que el crédito laboral es fruto de la relación contractual del trabajador con la sociedad mercantil, por lo que el administrador sería así, en cierto modo, parte del contrato de trabajo, en la medida en que actúa en nombre y representación de aquélla, con lo que podría decirse que es una culpa no extracontractual sino contractual. Apoya el sentido de su voto en tres argumentos: “a) aunque la responsabilidad solidaria de los administradores puede encontrar su fundamento en preceptos mercantiles, la causa de pedir sigue siendo laboral; b) la responsabilidad de los administradores respecto a las deudas sociales, en este supuesto, es un refuerzo de los derechos de quienes se relacionaron con el ente social, de lo que es dable deducir que tal responsabilidad legalmente establecida constituye una garantía (cuestión accesoria) que se adiciona al propio contrato de trabajo (cuestión principal) concertado con la sociedad cuyos administradores actúen ilícitamente, siendo esa garantía una cuestión accesoria respecto a la cuestión principal que la constituyen los derechos de naturaleza laboral de los trabajadores de la sociedad; c) la consecuencia es que deberá ser la naturaleza de los créditos sociales que se hayan de satisfacer la determinante de la competencia de los Tribunales que hayan de decidir sobre el conjunto y que la exigencia de la garantía adicional o refuerzo debe realizarse ante el Tribunal, que deba decidir la cuestión principal que es la determinante de la calificación de la naturaleza de la acción ejercitada".

Concluimos señalando, que admitida la jurisprudencia reseñada, al no haber sido corregida, se sigue defendiendo la competencia de la Jurisdicción Civil ante 
reclamaciones contra el administrador en que se acumulan las acciones del art. 241 de la LSC de la responsabilidad por daños y la del art. 367 LSC de la responsabilidad por deudas, para exigirle el pago de créditos laborales, como en las recientes Sentencias del TS, Sala Civil, 460/2010, de 14 de julio; 826/2011, de 23 noviembre; 650/2014, de 27 noviembre -RJ 014\6489-; 455/2017, de 18 de julio; 420/2019, de 15 de julio (entre otras), así como en la doctrina judicial menor, que entre otras muchas, citamos la Sentencia de AP de Córdoba núm. 188/2018, de 12 de marzo (Aranzadi RJ 2018/6360), sobre acción individual reclamando el trabajador el recargo de prestaciones al administrador.

Ante la incompetencia del orden jurisdiccional social para conocer las demandas de los trabajadores para exigir la responsabilidad del administrador en el pago de deudas laborales, sean al amparo del art. 241 o del art. 367 y concordantes de la LSC, y ante la eventualidad de que nuestra consolidada jurisprudencia ${ }^{522}$ pudiera estar vulnerando el Derecho comunitario, por el Juzgado de lo Social nº 30 de Barcelona, mediante Auto de fecha 14.4.2016 (Procedimiento 2155/2013), se eleva una cuestión prejudicial ante el Tribunal de Justicia de la Unión Europea, planteado expresamente las siguientes cuestiones: (sic) “ 1 a) el acreedor de la sociedad mercantil que reclame su crédito laboral ante los órganos judiciales españoles de la Jurisdicción Social, ¿tiene derecho a ejercitar simultáneamente ante el mismo tribunal la acción directa frente a la empresa para el reconocimiento de la deuda laboral $\mathrm{y}$, de forma acumulada, la acción frente al administrador societario como responsable solidario? 2a) La jurisprudencia del TS ¿infringe los artículos la Directiva 2009/101/CE al considerar que los tribunales españoles de la Jurisdicción Social no pueden aplicar directamente para el crédito laboral las garantías previstas en tal directiva? $3^{\mathrm{a}}$ ) La jurisprudencia del TS, ¿conculca la normativa comunitaria al forzar al acreedor laboral a duplicar los procedimientos jurisdiccionales -primero ante la Jurisdicción Social para obtener el reconocimiento del crédito laboral frente a la empresa y después ante la Jurisdicción Civil/Mercantil para obtener la garantía solidaria del administrador societario?".

La referencia a la Directiva 2009/101/CE, actualmente se halla derogada y sustituida por la Directiva 2017/1132, de 14 de junio (DOUE, serie L, de 30.6.2017), sobre Aspectos del Derecho de Sociedades.

522 SSTS, Sala Social, de 8 de febrero de 1997, 13 de abril de 1998, 17 de enero de 2000, 9 de junio de 2000, y 8 de mayo de 2002, entre otras muchas. 
El Tribunal de Justicia de la Unión Europea, resuelve la cuestión prejudicial en Sentencia, Sala Cuarta, de 14 de diciembre de $2017^{523}$, en el procedimiento prejudicial con el número de asunto C-243/16, respondiendo negativamente a las cuestiones planteadas por el Juzgado de lo Social $n^{\circ} 30$ de Barcelona, y concluye que, ni los preceptos de las Directivas invocadas, ni los artículos señalados de la Carta de Derechos Fundamentales de la Unión Europea, confieren a los trabajadores que sean acreedores de una sociedad anónima, a raíz de la extinción de su contrato de trabajo, el derecho a ejercitar ante la Jurisdicción Social la competencia para declarar la responsabilidad contra el administrador de esa sociedad. De este modo, se estima que la jurisprudencia del TS que residencia en la Jurisdicción Civil la competencia para declarar la responsabilidad del administrador ante créditos laborales de la sociedad de capital, sean por ejercicio de la acción individual de responsabilidad, o por reclamación de la responsabilidad solidaria por deudas del art. 367 de la LSC, no vulnera el Derecho comunitario invocado.

Ante la Sentencia del TJUE, que resuelve la cuestión prejudicial, estimando que la jurisprudencia del TS no vulnera el Derecho de la Unión Europea, ello no obstante, el Juzgado de lo Social 30 de Barcelona, mediante Auto 75/2018, de 14 de mayo (Iuris Aranzadi 2018\166855), amparándose en el art. 6.1 de la Carta Europea de Derechos Humanos, en la jurisprudencia del TEDH sobre el derecho la tutela judicial si dilaciones indebidas, y el art. 240.2 de la LRJS, concluye que "en buena lógica jurídica los órganos de la Jurisdicción Social son competentes para resolver la eventual declaración de responsabilidad del demandado incidental -del administrador social de la sociedad anónima- con fundamento en los preceptos de la Ley de Sociedades de Capital, y entrando a resolver el fondo de la cuestión declara la responsabilidad solidaria del administrador al amparo del art. 240.2 de la LRJS, cuando en ese precepto se autoriza,

${ }^{523}$ El fallo de la Sentencia es el siguiente: "La Directiva 2009/101/CE del Parlamento Europeo y del Consejo, de 16 de septiembre de 2009, tendente a coordinar, para hacerlas equivalentes, las garantías exigidas en los Estados miembros a las sociedades definidas en el artículo 48 [CE], párrafo segundo, para proteger los intereses de socios y terceros, y en particular sus artículos 2 y 6 a 8 , y la Directiva 2012/30/UE del Parlamento Europeo y del Consejo, de 25 de octubre de 2012, tendente a coordinar, para hacerlas equivalentes, las garantías exigidas en los Estados miembros a las sociedades definidas en el artículo 54 [TJUE], párrafo segundo, con el fin de proteger los intereses de los socios y terceros, en lo relativo a la constitución de la sociedad anónima, así como al mantenimiento y modificaciones de su capital, en particular sus artículos 19 y 36, deben interpretarse en el sentido de que no confieren a los trabajadores que sean acreedores de una sociedad anónima, a raíz de la extinción de su contrato de trabajo, el derecho a ejercitar, ante la misma Jurisdicción Social que la competente para conocer de la acción declarativa de su crédito salarial, una acción de responsabilidad contra el administrador de esa sociedad". 
en el caso de títulos ejecutivos contra entidades sin personalidad jurídica, a despachar ejecución frente a los socios, los partícipes, miembros o gestores que hayan actuado en el trafico jurídico o frente a los trabajadores en nombre de esa entidad.

Auto desafortunado jurídicamente por dos razones esenciales. Por un lado, porque aplica la extensión del título ejecutivo apoyándose en un precepto procesal laboral que se refiere exclusivamente a entidades sin personalidad jurídica, que no es el caso de la sociedad de capital empleadora, que era una sociedad anónima y por lo tanto tenía personalidad jurídica propia. Por otro lado, es criticable también ese Auto del Juzgado 30 de Barcelona de fecha 14.5.2018, porque, considera que acaece la causa de disolución de haber cesado la empresa durante más de doce meses en la actividad, sin haberse cumplido por el administrador los deberes disolutorios, ya que la sociedad cesa en la actividad entre mediados y finales de 2013, con lo que en diciembre de 2014, concluye el auto, existe la causa de disolución del cese de actividad durante un año, por lo que a partir de ese momento responde el administrador de las deudas sociales; pero olvida ese auto, que responde de las deudas generadas con posterioridad al acaecimiento de la causa de disolución (art 367 LSC), y la sentencia que reconoce la deuda laboral es del 17.11.2013, por lo que si la sentencia que declara la deuda es anterior a la causa de disolución, con más motivo lo será la deuda laboral impagada y reconocida en la sentencia.

\subsection{Créditos de las entidades gestoras de la Seguridad Social.}

Para reclamar al administrador social los créditos de Seguridad Social de la sociedad de capital, sean por cotizaciones o por prestaciones, mediante el ejercicio de la acción individual de responsabilidad, debemos determinar ante que órgano jurisdiccional deberá presentarse, si ante el civil, si ante el social de ser prestaciones, o si ante el contencioso-administrativo de ser deudas por cotizaciones.

\subsubsection{Créditos por cotizaciones a la Seguridad Social.}

De los créditos por cotizaciones a la Seguridad Social que ostenta la TGSS contra la sociedad de capital por incumplir éstas sus obligaciones legales con la Seguridad Social 
(art. 21 del TRLGSS), agotada la vía administrativa, conocerá la Jurisdicción Contencioso-Administrativa ${ }^{524}$.

Cuestión distinta será exigir el pago de la deuda de cotización a la Seguridad Social, no a la empresa sociedad de capital, sino al administrador social en ejercicio de la acción individual de responsabilidad.

Será jurisdicción competente para conocer la acción individual de responsabilidad frente al administrador social por deudas de cuotas de Seguridad Social de la sociedad de capital, la Jurisdicción Civil a través de los Juzgados de lo Mercantil, al tener competencia para conocer las demandas que se promuevan al amparo de la normativa reguladora de las sociedades mercantiles y cooperativas, salvo en aquellas cuestiones que expresamente por ley se atribuyan a otro orden jurisdiccional ${ }^{525}$.

Doctrina jurisprudencial que se mantiene en vigor para exigir la TGSS la reclamación de deudas por cotizaciones al administrador ejercitando la acción individual de responsabilidad.

\subsubsection{Créditos por prestaciones de responsabilidad empresarial.}

Con carácter general la competencia para reclamar a la empresa sociedad de capital el reintegro de prestaciones abonadas por pago anticipado al trabajador, cuando la responsabilidad de pago es de la empresa, corresponde al orden jurisdiccional social (art. 2 apartado o), de la Ley 36/2011, de 10 de octubre -LRJS-). En ese precepto se declara que conoce esa Jurisdicción "en materia de prestaciones de Seguridad Social, incluidas la protección por desempleo y la protección por cese de actividad de los trabajadores por cuenta propia, así como sobre la imputación de responsabilidades a

${ }^{524}$ Art. 3.f) de la Ley 36/2011, de 10 de octubre -LRJS-, en relación con los arts. 1 a 3 de la Ley 29/1998, de 13 de julio, Reguladora de la Jurisdicción Contencioso-Administrativa -en adelante LJCA-, así como el art. 46 del Real Decreto 1415/2004, de 11 de junio, que aprueba el Reglamento General de Recaudación de la Seguridad Social -RGRSS-, los arts. 1 y 2 de la Ley 39/2015, de 1 de octubre, del Procedimiento Administrativo Común de las Administraciones Públicas -LPACAP- y el art. 9.4 de la LOPJ.

525 Arts. 9.2, 86 ter, apartado 2.a) de la LOPJ, en relación con el art. 3.a) de la Ley 29/1998, de 13 de julio, LJCA, y el art. 3.f) de la Ley 36/2011, de 120 de octubre, de la LRJS.

SSTS, Sala Social, 28 de febrero de 1997 -RJ Ar. 4220/1997-; 28 de octubre de 1997 -RJ 7680/1997-; 13 de abril de 1998 -RJ 1998/4577-; 21 de julio de 1998 -RJ 6211/1998-; 9 de noviembre de 1999 -RJ 199918520-; 9 de junio de 2000 -RJ 2000\5109-; y 8 de mayo de 2002 -RJ 2002\7541-. Igualmente, en Reclamaciones de deudas por la TGSS, SSTS Sala Contencioso-Administrativa, de 18 de junio de 2002 -Rec. Interés de Ley 3424/2001-; 15 de octubre de 2003 -RJ 2003\8582-; 21 de julio de 2003 -RJ 2003\6939-; y 31 de marzo de 2003 -RJ 2003\3485-. 
empresarios o terceros respecto de las prestaciones de Seguridad Social en los casos legalmente establecidos".

El procedimiento de reclamación de la entidad gestora de una prestación anticipada al trabajador, y que sea de responsabilidad de la empresa sociedad de capital, se inicia por la propia entidad en vía administrativa, dictando resolución ante la que cabe recurso ante la Jurisdicción Social (arts. 167.4 y 295 del TRLGSS y art. 2 apartado o) de la LRJS). Dictada la resolución firme en vía administrativa por la entidad gestora, la recaudación de la prestación se realiza por la Administración territorialmente competente de la TGSS. De haberse reconocido en sentencia firme la responsabilidad empresarial en el pago de una prestación de Seguridad Social, se ejecutará por el trámite de ejecución de sentencia al amparo de la $\operatorname{LRJSS}^{526}$.

Con la redacción del art. 2 apartado o) de la LRJS pudiera defenderse la competencia de esa jurisdicción para el ejercicio de la acción individual de responsabilidad contra el administrador social, por cuanto que extiende esa jurisdicción al conocimiento de la responsabilidad de prestaciones de Seguridad Social y desempleo, sea del empresario o de tercero el responsable de las mismas, pero cuando se habla de terceros es para aludir a los supuestos en que la responsabilidad de éstos surge en el ámbito de la relación laboral, por su carácter solidario, siempre que la solidaridad derive de la normativa reguladora del orden social por hallarnos ante supuestos de concurrencia de empresas (contratas, subcontratas, cesión ilegal de trabajadores, ETT), o ante empresas reales que ocultan su realidad bajo el ropaje de personas jurídicas para eludir la responsabilidad personal patrimonial ilimitada (levantamiento del velo). Como se indica en la Sentencia del TS, Sala Social, de 28 de febrero de 1997 -RJ Ar. 4220/1997-, debe distinguirse entre aquellas cuestiones que son prejudiciales en el proceso social, porque van a identificar como empresarios a quienes no lo son formalmente, de aquellas otras responsabilidades en las que no se trata de identificar sujetos de la relación laboral, sino de extender a otros sujetos responsabilidades impuestas en la legislación de sociedades, en cuyo caso la competencia es del orden civil, aunque se reclamen deudas por prestaciones de Seguridad Social.

\footnotetext{
${ }^{526}$ Arts. 66, 80 y 295 del TRLGSS, arts. 69 y 70 del Real Decreto 1415/204, de 11 de junio, RGRSS, y arts. 237 y siguientes de la LRJS.
} 
Es aplicable la doctrina jurisprudencial ${ }^{527}$ que atribuye al orden civil la competencia para conocer acerca de la acción individual de responsabilidad del administrador, cuando se reclamen deudas por prestaciones, al no ser aplicable la autotutela administrativa. Se deja clara la competencia del orden civil para conocer acerca de la reclamación de la responsabilidad del administrador en deudas de Seguridad Social de la sociedad de capital, según esa doctrina, por no ser esa responsabilidad una cuestión accesoria o perjudicial de la responsabilidad empresarial en prestaciones de la sociedad, ya que, para resolver la responsabilidad en prestaciones de la empresa no es preciso determinar previamente la responsabilidad del administrador.

Comoquiera que la acción individual de responsabilidad ha de ejercitarse ante la Jurisdicción Civil, ante los Juzgados de lo Mercantil, la doctrina contenida en esa jurisprudencia es de aplicación actualmente para determinar la competencia para conocer acerca del ejercicio de esa acción si el daño se ha causado en una deuda de prestaciones de Seguridad Social de la mercantil, al tener que determinarse si concurren los requisitos propios de la responsabilidad por daños de los arts. 236 a 241 bis de la LSC.

Sólo se admitió la competencia del orden social para reclamar la TGSS y el INSS deudas por prestaciones abonadas en virtud del pago anticipado de prestaciones, cuando la responsabilidad del administrador sea debida a no haber adaptado el capital social mínimo dentro del plazo legal establecido en la DT. $3^{\text {a }}$ del R.D. Legislativo 1564/1989, de 22 de diciembre (Sentencia del STS, Sala Social, de 20 de septiembre de 1999 -Rec. 1339/1998-). Precepto legal carente ya de eficacia.

\section{V.- RELACIÓN ENTRE ACCIÓN INDIVIDUAL Y RESPONSABILIDAD POR DEUDAS DEL ADMINISTRADOR POR CRISIS DISOLUTORIA.}

Vamos a examinar la relación general entre la responsabilidad por daños del administrador del art. 241 de la LSC y la responsabilidad por deudas prevista en el art. 367 de la LSC, distinguiendo según estemos ante un acreedor privado, o ante un acreedor de entidad pública de Seguridad Social, ya que en el segundo supuesto, como

527 SSTS, Sala Social, 28 de febrero de 1997 -RJ Ar. 4220/1997-; 28 de octubre de 1997 -RJ 7680/1997-; 13 de abril de 1998 -RJ 1998/4577-; 21 de julio de 1998 -RJ 6211/1998-; 9 de noviembre de 1999 -RJ 199918520-; 9 de junio de 2000 -RJ 200015109-; 8 de mayo de 2002 -RJ 200217541-. Igualmente, en Reclamaciones de deudas por la TGSS, SSTS de la Sala Contencioso-Administrativa, de 18 de junio de 2002 -Rec. Interés de Ley 3424/2001-; 15 de octubre de 2003 -RJ 200318582-; 21 de julio de 2003 -RJ 200316939-; y 31 de marzo de 2003 -RJ 200313485- 
hemos visto en el apartado IV.2 de este Capítulo, el procedimiento de reclamación de ambas responsabilidades es diferente, para la acción individual de responsabilidad ha de acudirse a la vía judicial, y para la reclamación de la responsabilidad por deudas del art. 367 de la LSC, se sigue el procedimiento administración de recaudación que examinaremos en el Capítulo VI.

Es conveniente conocer esa relación por dos razones. En primer lugar, para contrastar la diferente forma de reclamación que tienen las entidades gestoras de la Seguridad Social, si ejercitan ambas vías de reclamación, con los diferentes procedimientos que han de seguir, no coincidentes con los de los acreedores privados, especialmente para la reclamación al amparo del art. 367 de la LSC. En segundo lugar, porque los trabajadores de la sociedad de capital, como acreedores particulares, pueden reclamar al administrador social el pago de créditos laborales o de prestaciones de Seguridad Social adeudadas por la sociedad de capital, acudiendo ante los Juzgados de lo Mercantil.

\section{Relación general de ambas acciones de responsabilidad ante acreedores privados.}

La acción individual de responsabilidad del artículo 241 de la LSC es una acción por daños causados por el administrador social al acreedor, por lo que deben de concurrir todos los requisitos expuestos en los apartados anteriores, mientras que la responsabilidad de los arts. 360 y 367 de la LSC, es una responsabilidad solidaria del administrador por deudas de la sociedad de incumplirse los deberes orgánicos previstos ante la concurrencia de una causa de disolución societaria ${ }^{528}$.

Nos hallamos ante dos institutos con naturaleza y efectos jurídicos diversos. La acción individual es una modalidad específica de responsabilidad por daños y la responsabilidad solidaria por deudas impuesta al administrador es una responsabilidad ex lege por deuda ajena, una garantía por deuda ajena que se impone ante el incumplimiento de deberes disolutorios para ampliar las posibilidades de cobro del

\footnotetext{
528 Vid.: BATALLER GRAU, J.: “Disolución y Liquidación”, AA.VV. (Coord.: ROJO FERNÁNDEZRÍO, A. et altri): Comentario de la Ley de Sociedades de Capital, Tomo II, Vol. 2, Cívitas, Madrid, 2011, pp. 2572-2578; BELTRÁN SÁNCHEZ, E.: "La responsabilidad de los administradores por obligaciones sociales”, op. cit., pp. 301-444; VALPUESTA GASTAMINZA, E. M.: Comentarios a la Ley de Sociedades..., op. cit., 2018.
} 
acreedor $^{529}$. Para mayor conocimiento acerca de naturaleza jurídica nos remitimos a las reflexiones que hacemos en los Capítulos III y IV.

Los supuestos de hecho y los efectos de la responsabilidad del art. 367 de la LSC, son diferentes a los de la acción individual de responsabilidad del art. 241 de ese cuerpo legal. La acción de responsabilidad por deudas del artículo 367 de la LSC y la acción individual de responsabilidad, no sólo tienen distinta naturaleza, sino que exigen requisitos diferentes ${ }^{530}$. Mediante la acción individual de responsabilidad de los artículos 236 a 241 bis de la Ley de Sociedades de Capital, los administradores de las sociedades responden del daño directo causado a los acreedores por conducta antijurídica y culpable, mientras que en la responsabilidad por deudas sólo se exige el incumplimiento imputable de los deberes de promoción de la disolución, sin requerirse ni daño, ni culpa o dolo, ni relación de causalidad entre ese incumplimiento y el impago de la deuda (entre otras, Sentencias del TS, Sala Civil, 477/2010, de 22 de julio, 889/2011, de 19 de diciembre y 942/2011, de 29 de diciembre).

Siendo distintas la acción de responsabilidad por deudas del art. 367 de la LSC y la acción individual de responsabilidad por daños del art. 241 de la LSC, las mismas no son excluyentes ni incompatibles, admitiendo la jurisprudencia la compatibilidad en régimen de concurso ideal de ambas acciones cuando se incumplan deberes disolutorios por los administradores, porque puede surgir tanto una responsabilidad por deudas como una responsabilidad por daños, cuando la causa de disolución sea debida a la negligencia de los administradores causando una lesión directa a los acreedores ${ }^{531}$. De ejercitarse ambas acciones, pretendiéndose la misma petición de condena solidaria de los administradores respecto del pago de determinadas deudas, esta pretensión se obtiene con la estimación de una de las dos acciones, pero la estimación de ambas acciones no podría dar lugar nunca a una condena doble ante un mismo hecho, sino a una única y misma condena dineraria, por lo que, puede considerarse que las acciones se

\footnotetext{
${ }^{529}$ Sentencias del TS, Sala Civil, núm. 228/2008, de 25 de marzo; 458/2010, de 30 de junio; 680/2010, de 10 de noviembre; 225/2012, de 13 de abril; y 202/2020, de 28 de mayo -Rec. 3365/2017-.

${ }^{530}$ SSTS, Sala Civil, TS, Sala Civil, 919/2011 de 23 de diciembre -RJ 2012/1895-; 395/2012, de 18 de junio de 2012 -Rec. 1852/2009-; 733/2013, de 4 de diciembre; y 202/2020, de 28 de mayo -Rec. $3365 / 2017-$, entre otras.

${ }^{531}$ Sentencias del TS, Sala Civil, 11 de noviembre de 1991; 10 de diciembre de 1996; 11 de noviembre de 1997; 100/2003, de 12 de febrero -Rec. 1793/1997-; 540/2005, de 7 de julio -Rec. 43/1999-; 183/2005, de 20 de junio; 950/2005, de 30 noviembre -RJ 2006135-; 464/2008, de 30 de mayo -Rec. 1219/2001-; 919/2011, de 23 de diciembre -RJ 2012/189-; 733/2013, de 4 de diciembre -RJ 2014/1835-; 455/2017, de 18 julio; 202/2020, de 28 de mayo -Rec. 3365/2017-, entre otras muchas.
} 
ejercitan de forma alternativa o subsidiaria (Sentencia del TS, Sala Civil, 202/2020, de 28 de mayo -Rec. 3365/2017-).

No existe óbice jurídico alguno, para que el trabajador de la sociedad de capital acumule ambas acciones frente al administrador en defensa de su derecho de crédito laboral o de Seguridad Social, la de los artículos 241 y 367 de la LSC ${ }^{532}$. De acumularse ambas acciones, si el trabajador obtiene plena satisfacción de su pretensión con la estimación de una de las acciones interpuestas, no se precisa que el tribunal conozca o entre en el fondo de la otra acción acumulada ${ }^{533}$. Estimada una de las dos pretensiones, la de responsabilidad por deudas, si se obtiene la plena satisfacción del crédito, no cabe que deba entrase a conocer acerca de la otra acción de responsabilidad, la del art. 241 de la LSC, ya que, si por medio de ambas acciones se pretende la condena de los administradores para obtener el pago de determinados créditos contra la sociedad, esta pretensión se cumple con la estimación de una de las dos acciones, sin que la estimación de ambas acciones pueda dar lugar nunca a una doble condena. En aquellos supuestos en que se pretende la misma condena dineraria, puede considerarse que las acciones se ejercitan de forma alternativa o subsidiaria, salvo que con una de ellas se pretenda una condena de importe superior. Estimándose íntegramente las peticiones del trabajador demandante al resolverse una de las dos acciones, no incurre la sentencia en vicio de incongruencia, por no entrar a conocer del fondo de la otra acción. El art. 218.1 LEC prescribe que las sentencias decidan todos los puntos litigiosos que hayan sido objeto del debate, pero esto no exige un pronunciamiento detallado sobre cada una de las cuestiones de hecho planteadas, sino sobre los temas que constituyen el objeto del proceso (TS, Sala Civil, Sentencias 6/2011, de 10 de febrero y 606/2013, de 18 de octubre). No hay vicio de incongruencia siempre que con una de las dos acciones se obtenga plena satisfacción de la pretensión. No obstante, no debe olvidarse, que en el

\footnotetext{
532 Tribunal Supremo, Sala Civil, Sentencias 100/2003, de 12 de febrero -Rec. 1793/1997-; 540/2005, de 7 de julio -Rec. 43/1999-; 183/2005, de 20 de junio; 950/2005, de 30 noviembre -RJ 2006135-; 464/2008, de 30 de mayo -Rec. 1219/2001-; 919/2011, de 23 de diciembre -RJ 2012/189-; 733/2013, de 4 de diciembre -RJ 2014/1835-; 455/2017, de 18 julio; 202/2020, de 28 de mayo -Rec. 3365/2017-, entre otras muchas.

En la Sentencia 919/2011 de 23 de diciembre -RJ 2012/189- se indica, "nada impide el ejercicio acumulado de ambas acciones siempre que concurran los requisitos y presupuestos exigidos por las distintas normas, ya que la realidad demuestra que la pasividad de los administradores en la promoción de la disolución y liquidación, en concurrencia con otras circunstancias, puede generar "daño directo" -así las Sentencias 794/2008, de 29 de julio y 1049/2008, de 11 de noviembre, contemplan supuestos en los que daño y falta de disolución y liquidación se enlazan- y aunque el impago del crédito al acreedor no puede identificarse sin más con "daño" y, menos aún, con daño directo".

${ }^{533}$ STS, Sala Civil, 733/2013, de 4 de diciembre -RJ 2014/1835-.
} 
nuevo régimen jurídico del art. 367 de la $\mathrm{LSC}^{534}$, se impone sólo la responsabilidad solidaria del administrador por las deudas posteriores al acaecimiento de la causa de disolución, de modo que si procediere la condena del administrador también por deudas anteriores, sería preciso entrar a analizar la acción individual respecto a esas deudas anteriores. Igualmente procedería que se entrase a conocer la acción individual de responsabilidad, pese a haberse estimado la acción del art. 367 de la LSC, si mediante la acción individual se reclamase mayor indemnización por ser mayores los daños causados por la conducta antijurídica y culpable del administrador social. En esos supuestos en que la petición de condena no tenga el mismo contenido cuando se ejercitan acumuladamente las dos acciones, pese a no caber nunca una doble condena, si será necesario pronunciarse sobre la acción ejercitada de modo subsidiario, si el demandante manifiesta un claro interés en la declaración de la responsabilidad de la acción subsidiaria (Sentencia del TS, Sala Civil 202/2020, de 28 de mayo -Rec. 3365/2017-).

Cuestión diferente será determinar cuál debe ser el contenido del fallo de la sentencia cuando se plantea una sola petición y una sola causa petendi, ante el impago del crédito laboral o de Seguridad Social de la sociedad deudora por la conducta orgánica del administrador social. Caben dos hipótesis. En primer lugar, que de la demanda se deduzca claramente que se están ejercitando dos peticiones diversas con causas de pedir distintas, que sean subsumibles en los presupuestos fácticos y jurídicos de los arts. 241 y 367 de la LSC, aunque no se expliciten numéricamente esos preceptos, en cuyo supuesto puede entrarse a conocer acerca de las dos pretensiones. En segundo lugar, si de la demanda no resulta que se ejercitan claramente las dos pretensiones, sino que únicamente se está ejerciendo la acción individual de responsabilidad o sólo la responsabilidad por deudas, al ser único el petitum y una única la causa petendi, no cabría que de oficio el tribunal entrase a conocer sobre la acción no ejercitada en la demanda, ya que estaríamos ante claros vicios de incongruencia del fallo de la sentencia con el petitum y causa petendi, y con el carácter contradictorio del proceso (arts. 216 a 218 de la LEC), produciendo una clara indefensión del demandado, con vulneración del principio de Tutela Judicial Efectiva del artículo 24 de la CE (Sentencia del TS, Sala Civil, núm. 485/2012, de 18 julio -Rec. 990/2009-).

\footnotetext{
${ }^{534}$ Desde la entrada en vigor de la Ley 19/2005, de 14 de noviembre.
} 
En la Sentencia 485/2012, de 18 julio, acerca de la relación entre el principio de iura novit curia y el de congruencia de la sentencia, se declara que, en virtud de principio de conocer y de juzgar conforme a Derecho, se permite al tribunal fundar su decisión en preceptos jurídicos distintos de los invocados y aplicar la norma material que entiende adecuada para la decisión del caso, pero en virtud de las exigencias de la congruencia de la sentencia, no puede decidir qué tutela otorga al demandante de entre todas las posibles, ya que lo impide el principio de congruencia del artículo 218 de la Ley de Enjuiciamiento Civil. Por otro lado, el principio de aportación de parte que rige el proceso, no puede ser sustituido por el juzgador, para incluir hechos no incluidos en la demanda, por cuando causaría indefensión de la parte contraria. La congruencia de las resoluciones judiciales, en definitiva, impide a la sentencia apartarse de la causa de pedir sin que pueda decidir por causa diferente a aquella por la que se pide, y ello, aunque lo pedido pudiera ser procedente por la causa distinta no incluida en la demanda.

Las acciones se deben ejercitar con claridad y precisión, sin que quepa el efecto sorpresivo, ni someter a la contraparte y al tribunal al esfuerzo de averiguar el fundamento de lo que realmente se pretende en la demanda (STS, Sala Civil 491/2006, de 18 de mayo -RJ 2006, 3808-, reiterada en la 669/2011, de 4 de octubre -RJ 2011, 7388-). No cabe la acumulación tácita de una acción cuando en el petitum y causa petendi sólo se ha planteado una única pretensión sin invocarse los presupuestos de la otra acción no planteada expresamente (STS núm. 55/2008, de 8 de febrero -RJ 2008/2664-). En todo caso, la identificación de la acción ejercitada vendrá dada por los hechos alegados, el petitum y la causa petendi, ya que la demanda deberá fundamentarse jurídicamente de conformidad con el art. 399 de la LEC, por consagrase en el proceso ordinario en nuestro Derecho procesal civil la teoría de la individualización, frente a la de sustanciación que rige el juicio verbal. No puede resolverse por la acción no ejercitada, delimitada por el petitum y la causa petendi ${ }^{535}$, porque son distintos los presupuestos y requisitos de una y otra acción, por lo que no pueden confundirse ni intercambiarse aleatoriamente, siendo distinta la defensa frente a una u otra acción ${ }^{536}$. La sentencia debe respetar las peticiones y causas de pedir de los

\footnotetext{
535 SSTS, Sala Civil, núm. 157/2006, de 1 marzo -RJ 2006/929-; núm. 1013/2006, de 13 octubre -RJ 2006/6446; núm. 934/2007, de 10 septiembre -RJ 2007/4963-; núm. 411/2008, de 14 mayo -RJ 2008/3073-; y núm. 598/2010, de 14 octubre -RJ 2010/8866-, entre otras muchas.

536 SSTS, Civil, 43/2010, de 12 de febrero -Rec. 1850/2005-; 269/2007, de 8 de marzo -Rec. 5041/2000-; 1101/2007, de 26 de octubre -Rec. 4182/2000-; 499/2008, de 4 de junio -Rec. 1101/2001-; entre otras.
} 
demandantes, porque el fallo debe circunscribirse al objeto del proceso, delimitado por el petitum y la causa petendi.

Cuestión relacionada será determinar si, al haberse ejercitado sólo la acción individual de responsabilidad, y no la responsabilidad solidaria por deudas, concurriendo ambas causas, podría posteriormente en una nueva demanda exigir el trabajador acreedor la responsabilidad solidaria por deudas no ejercitada en la primera demanda, o viceversa. Para MUÑOZ PAREDES ${ }^{537}$, eso lo impediría el juego conjunto de la cosa juzgada y la preclusión de los arts. 222 y 400 de la LEC, siempre que los hechos que pudieran fundamentar ambas acciones existiese y fuesen conocidos al interponerse la primera demanda. Por el contrario, no habría cosa juzgada ni preclusión, si los hechos que amparan la posterior demanda de responsabilidad solidaria por deudas no existían ni se conocían a la fecha de la demanda anterior al amparo del art. 241 de la LSC. Esta es la interpretación realizada por el TS, Sala Civil, cuando ejercitándose en un primer proceso la acción de responsabilidad por deudas del art. 367 LSC contra los administradores, al no condenarse a éstos a responder de todas las deudas sociales el acreedor posteriormente promueve un segundo pleito ejercitando la acción individual de responsabilidad para reclamar el resto de las deudas, estimando el Tribunal Supremo, en Sentencia 5/2020, de 8 de enero -Rec. 1011/2017-, que si "la demandante en el primer pleito podía haber acumulado a la acción ex art. 367 LSC, la acción individual de responsabilidad ex art. $241 \mathrm{LSC}$, al no hacerlo, se produjo el efecto preclusivo, que provoca ahora la apreciación de la eficacia de cosa juzgada material en sentido negativo de lo resuelto en el primer pleito respecto de este segundo".

Cabría de igual modo que el trabajador de la sociedad acumulara en su demanda ante el Juzgado de lo Mercantil las tres posibles acciones para exigir la responsabilidad del administrador en defensa de su crédito de Seguridad Social o laboral dañado: la acción social de responsabilidad del art. 240 de la LSC, la acción individual de responsabilidad del art. 241 de la LSC, y la responsabilidad solidaria por deudas del art. 367 de ese cuerpo legal. En virtud del principio de congruencia de la sentencia con las pretensiones procesales ejercitadas, se han de conocer en juicio y pronunciarse en el fallo de la sentencia sobre las tres pretensiones ejercitadas, salvo que con estimación de una de ellas se obtenga plena satisfacción de las pretensiones, por lo que al tener causas de pedir distintas y ser beneficiarios directos de la pretensión sujetos distintos -la sociedad

${ }^{537}$ MUÑOZ PAREDES, A.: “Tratado Judicial de Responsabilidad...”, op. cit., pp. 485 a 489. 
en la acción social y el trabajador en la otras dos acciones-, desestimada una de las pretensiones o acciones ejercitadas no es óbice para que deban resolverse expresamente las otras acciones (Sentencia, TS, Sala Civil, 540/2005, de 7 de julio -Rec. 43/1999-), ya que pueden acumularse las tres causas de pedir, eligiendo el demandante la que considera principal. Acumulación teórica admisible en Derecho, pero que el trabajador dará prioridad a la acción de responsabilidad por deudas y a la acción individual de responsabilidad, ya que con ellas puede obtener directamente satisfacción de su crédito, por lo que la acción social se plantearía con carácter subsidiario, ya que con la acción social el patrimonio beneficiado es el de la sociedad, lo que indirectamente podría permitir obtener posteriormente el pago de la sociedad.

La acción del art. 241 de la LSC para el trabajador será una vía más dificultosa para obtener una indemnización ante una falta de pago por la sociedad de la obligación contraída, al ser mayor la carga probatoria exigida al acreedor, por lo que normalmente, de acumularse ambas, el demandante dará preferencia a la acción de responsabilidad por deudas, pudiendo en su caso, dar carácter accesorio a la acción individual de responsabilidad para las deudas anteriores a la causa de disolución.

\section{Relación entre la acción individual de responsabilidad por daños y la responsabilidad solidaria por deudas del administrador en materia de Seguridad Social.}

Examinaremos la relación entre la acción individual y la responsabilidad por deudas cuando la reclamación se realice por un organismo público de Seguridad Social.

La responsabilidad solidaria del administrador por deuda ajena de los arts. 360 y 367 de la LSC, cuando estemos ante una reclamación de deudas con la Seguridad Social de la sociedad de capital, no exige su reclamación judicial, como debe hacer todo acreedor privado, sino que esa responsabilidad solidaria se exigirá directamente al administrador social por la TGSS a través del procedimiento administrativo de recaudación de los recursos del sistema de la Seguridad Social (principio de autotutela administrativa), mediante la reclamación administrativa de deuda por derivación de responsabilidad, o por la Inspección de Trabajo y Seguridad Social mediante acta de liquidación de cuotas por derivación de responsabilidad. Actos administrativos revestidos de ejecutividad y 
ejecutoriedad, sin necesidad de tener que acudirse a la vía judicial ${ }^{538}$. Nos remitimos a los Capítulos III, IV y VI de esta investigación.

Por el contrario, la acción individual de responsabilidad contra el administrador social al amparo del art. 241 de la LSC, para reclamar deudas de Seguridad Social no podrá efectuarse directamente a los administradores mediante reclamación administrativa dentro del procedimiento de recaudación de la Seguridad Social, al no hallarnos ante una responsabilidad por deudas de las previstas en el art. 18.3 del TRLGSS. No rige para la acción individual de responsabilidad en materia de deudas de Seguridad Social el principio de autotutela administrativa, como hemos examinado en el apartado IV.2 de este Capítulo.

La acción individual de responsabilidad del art. 241 de la LSC es una responsabilidad por daños, que ha de ser declarada judicialmente, por lo que la TGSS o las entidades gestoras si reclaman la responsabilidad por cotizaciones o por prestaciones, deberán plantear la pertinente demanda ante los Juzgados de lo Mercantil ${ }^{539}$.

Siendo la reclamación de la responsabilidad solidaria del administrador en el pago de las deudas de Seguridad Social de la sociedad de capital, al amparo de los arts. 360 y 367 de la LSC, un supuesto de autotutela administrativa, contra los actos administrativos firmes dictados en vía administrativa conocerá la Jurisdicción Contencioso-Administrativa ${ }^{540}$.

Al tener cauces procedimentales distintos la reclamación de deudas de Seguridad Social, según se ejercite la acción individual de responsabilidad o se reclamen administrativamente deudas al amparo de los arts. 360 y 367 de la LSC, la acción individual de responsabilidad quedará de facto reducida a un papel residual y complementario de la derivación administrativa de responsabilidad al administrador social al amparo del art. 18.3 del TRLGSS, para las deudas que no puedan recabarse en la derivación administrativa de responsabilidad del art. 367 de la LSC (deudas

538 Arts. 38, 39, 97 a 105 y Disposición Adicional 1a. 2 apartado b) de la Ley 39/2015, de 1 de octubre, LPACAP, y arts. 18 apartados 3 y 4, 33 apartado 1.d) y 34 del TRLGSS, en relación con los arts. 12 y 22.6 de la Ley 23/2015, de 21 de julio, LOITSS, en relación con los arts. 12, 13, 62.2 y 65 apartado 1.c) del R.D. 1415/2004, de 11 de junio, del RGRSS, y arts. 29 a 36 del R.D. 928/1998, de 14 de mayo, del Reglamento sobre Procedimiento para a imposición de sanciones por infracciones del Orden Social y para los expedientes liquidatorios de cuotas de Seguridad Social -RISOS-.

539 Arts. 9.2, 86 ter, apartado 2.a) de la LOPJ. Véase el apartado IV.4 de este Capítulo.

540 Arts. 1 y 2 de la Ley 29/1998, de 13 de julio, Reguladora de la Jurisdicción ContenciosoAdministrativa, y arts. 38.4 y 129 del TRLGSS, en relación con el art. 46 del R.D.1415/2004, de 11 de junio, del RGRSS, y art. 33.3 del R.D. 928/1998, de 14 de mayo, del RISOS. 
anteriores a la causa de disolución). Por ello en la doctrina ${ }^{541}$ se mantiene que, tras la Ley 19/2005, de 14 de noviembre, que limitó la responsabilidad del art. 367 de la LSC a las deudas posteriores, asistimos a un renacimiento de la acción individual de responsabilidad para exigir esas deudas.

En todo caso, será vía preferente la derivación administrativa de responsabilidad al amparo del art. 367 de la LSC y del art. 18.3 del TRLGSS, frente al ejercicio de la acción individual, para reclamarse las deudas de Seguridad Social al administrador, por cuatro razones fundamentales. En primer lugar, porque pueden reclamarse todas las deudas de la sociedad de capital no prescritas, partiendo de la presunción "iuris tantum”, establecida en el art. 367.2 de la LSC, donde se establece que se presumen de fecha posterior a la causa legal de disolución las deudas reclamadas al administrador, con lo que hay una inversión del "onus probandi" y deberá ser éste quien acredite que la causa de disolución es de fecha posterior a alguna de las deudas reclamadas. Al respecto en el Criterio Técnico 89/2011, de la Dirección General de la Inspección de Trabajo y Seguridad Social, sobre derivación de responsabilidad a los administradores de sociedades mercantiles capitalistas en materia de deudas por cuotas de Seguridad Social, se indica en el apartado o) criterio $4^{\circ}$ que, (sic) "por tanto, puede ser objeto de derivación la totalidad de la deuda existente en todos los casos en los que los propios interesados no demuestren otra cosa, ya que sobre ellos recae la carga de la prueba, salvo que el funcionario actuante compruebe que efectivamente se trata de obligaciones que se han generado en una fecha inequívocamente anterior, supuesto en el que no cabe acudir a la presunción". En segundo lugar, porque en virtud del principio de autotutela administrativa (ejecutividad), la reclamación se efectúa directamente por vía administrativa a través del procedimiento administrativo recaudatorio, mediante acta de liquidación de cuotas por derivación extendida por la Inspección de Trabajo y Seguridad Social, o mediante reclamación de deuda por la Administración de la Tesorería General de la Seguridad Social ${ }^{542}$. En tercer lugar, porque en la propia reclamación se exige, no sólo el principal de la deuda, sino también el recargo, los intereses devengados y las costas del procedimiento administrativo ${ }^{543}$. En cuarto lugar, porque en virtud del

${ }^{541}$ ESTEBAN VELASCO, G.: “La acción individual de responsabilidad”, op. cit., p. 193, quien advierte del riesgo de buscar por esta vía la ampliación forzada de la aplicación de la acción individual de responsabilidad.

${ }^{542}$ Arts. 33.2 y 34 del Real Decreto Legislativo 8/2015, de 30 de octubre, TRLGSS, en relación con los arts. 12, 13, 62.2. y 65 del R.D. 1415/204, de 11 de junio, RGRSS.

${ }^{543}$ Arts. 33.2 y $\left.34.1 . c\right)$ del TRLGSS. 
principio de ejecutividad el pago de la deuda es exigible y debe ingresarse en vía administrativa en plazos preclusivos, aunque no sea firme en vía administrativa la derivación de responsabilidad ${ }^{544}$, porque la interposición del recurso de alzada contra la reclamación de deuda o la resolución que eleva a definitiva el acta de liquidación, no suspende el pago, salvo que se garantice con aval o se consigne su importe ${ }^{545}$.

Quedaría sólo la acción individual de responsabilidad como vía residual y complementaria para deudas anteriores a la causa de disolución, no satisfechas mediante la derivación de responsabilidad, por haber acreditado el administrador que la fecha de concurrencia de la causa disolutoria es posterior a todas o parte de las deudas reclamadas.

\section{VI.- ACUMULACIÓN DE LA ACCIÓN INDIVIDUAL FRENTE AL ADMINISTRADOR Y LA ACCIÓN CONTRA LA SOCIEDAD POR INCUMPLIMENTO DE LA OBLIGACIÓN.}

Cuando como consecuencia del incumplimiento de la obligación social se cause por el administrador social un daño directo al acreedor, por serle imputable el incumplimiento, se admite la acumulación de ambas acciones, acción de responsabilidad por incumplimiento contractual contra la sociedad y acción individual de responsabilidad contra el administrador social ${ }^{546}$. En la doctrina ${ }^{547}$ se ha venido admitiendo que el acreedor pueda acumular la acción por deudas contra la sociedad y la acción de responsabilidad por daños contra el administrador, sin que ello signifique una doble indemnización por un mismo daño. Esta acumulación de reclamaciones no significa que se perciban dos indemnizaciones por un mismo daño, sino que se facilitan dos medios de reclamación frente a sujetos distintos por una misma acción dañosa del administrador, y con fundamento en dos pretensiones distintas.

Cuestión distinta será que, ante determinados créditos, como el caso de los créditos laborales y de Seguridad Social, conozcan jurisdicciones distintas cuando se reclama la

\footnotetext{
${ }^{544}$ Arts. 33.3 y 34.3 del TRLGSS.

545 Arts. 33.3 y 34.3 del TRLGSS, en relación con los arts. 62, 64, 65 y 66 del R.D. 1415/2004, de 11 de junio, RGRSS y art. 33.3 del Real Decreto 928/1998, de 14 de mayo, RISOS.

546 Sentencias del Tribunal Supremo, Sala Civil, 409/2005, de 26 de mayo; núm. 539/2012, de 18 de septiembre; núm. 242/2014, de 23 de mayo -RJ 2014/2943-; núm. 253/2016, de 18 de abril -RJ 2016/1342; y núm. 131/2016, de 3 de marzo -RJ 2016/801, entre otras muchas.

${ }^{547}$ Entre otros: DÍAZ ECHEGARAY, J. L.: Deberes y Responsabilidades ..., op. cit., p. 363; ESTEBAN VELASCO, G.: "La acción individual de responsabilidad”, op. cit., p. 288; SÁNCHEZ CALERO, F.: Los administradores en las sociedades en las sociedades de capital, op. cit., pp. 424-425.
} 
deuda a la sociedad o al administrador mediante la acción individual de responsabilidad, en que no cabrá esa acumulación de acciones procesales.

De no ser créditos laborales o de Seguridad Social la acumulación de ambas acciones no es obligatoria sino potestativa ${ }^{548}$, ya que en nuestra jurisprudencia es pacífico considerar la acumulación de estas acciones como algo conveniente para permitirse que en un único juicio se determine la existencia de la deuda de la sociedad impagada, y la concurrencia de la responsabilidad por daños del administrador, pero no como algo obligatorio e imperativo. Se impide la acumulación de dos o más acciones cuando se excluyan mutuamente, o sean contrarias entre sí, de suerte que la elección de una impida o haga ineficaz el ejercicio de la otra; incompatibilidad que no cabe apreciar cuando se ejercita la acción de reclamación de la deuda a la sociedad y la acción de reclamación de la responsabilidad por daños del administrador (STS, Sala Civil, núm. 1014/2005, de 13 de diciembre -Rec. 1638/1999_ ${ }^{549}$ ). No es obligatoria ${ }^{550}$ la acumulación de la acción de responsabilidad contra el administrador y la acción de reclamación de cantidad contra la sociedad, porque nada impide que en el proceso de la acción individual de responsabilidad se entre a conocer de forma prejudicial acerca de la existencia de la deuda de la sociedad impagada, por ser el impago el presupuesto de la responsabilidad (STS, Sala Civil, núm. 950/2005, de 30 de noviembre -Rec. 1117/1999-).

Pudiéndose teóricamente acumular la acción contra la sociedad por incumplimiento contractual y la acción de responsabilidad frente al acreedor, surge inmediatamente el problema de cuál es el tribunal competente. Para ello debemos distinguir que sea un acreedor privado, y por otro lado una Administración de la Seguridad Social.

Si es un mero acreedor privado se plantea la cuestión de determinar el tribunal competente, ya que, para conocer la acción judicial por incumplimiento del contrato de la sociedad, son competentes los Juzgados de Primera Instancia (arts. 9.2 y 85 de la Ley Orgánica 6/1985, de 1 de julio, del Poder Judicial -LOPJ-), mientras que la acción de responsabilidad del administrador viene atribuida a los Juzgados de lo Mercantil (art. 86 ter de la LOPJ).

\footnotetext{
${ }^{548}$ MUÑOZ PAREDES, A.: Tratado judicial de la responsabilidad ..., op. cit., p. 438.

${ }^{549}$ Doctrina que según se indica en esa Resolución Judicial se ha mantenido en la misma Sala en STS de 4 de junio de 1990, 28 de junio de 1994, 19 de octubre de 1996 y 22 de mayo de 1999.

${ }^{550}$ MUÑNOZ PAREDES, A.: Tratado judicial de la responsabilidad..., op. cit., p. 439.
} 
Ante ello caben dos opciones, o bien atribuir la competencia al Juzgado de Primera Instancia, o bien atribuirla al Juzgado de lo Mercantil.

La competencia podría inicialmente atribuirse, o bien al Juzgado de Primera Instancia porque ese juzgado es competente para conocer sobre incumplimientos de los contratos de la sociedad, atrayendo la competencia para conocer la responsabilidad del administrador, o bien atribuirla al Juzgado de lo Mercantil, partiendo del principio de especialidad de estos juzgados, por lo que, en aras de la economía procesal llevaría a residenciar en los mismos las reclamaciones contra la sociedad de capital al amparo del art. 86 ter de la LOPJ $^{551}$.

Ante esa doble posibilidad, la competencia fue atribuida definitivamente al Juzgado de lo Mercantil por la jurisprudencia ${ }^{552}$, y para ello se ha considerado que la acción de responsabilidad contra el administrador es la acción principal, y que la acción de reclamación del crédito del acreedor frente a la sociedad es accesoria, por constituir un presupuesto de la primera y tratarse, por ello, de una cuestión prejudicial.

Si es un trabajador por cuenta ajena quien pretende reclamar un crédito laboral a la sociedad de capital y la responsabilidad por daños al administrador social, deberá interponer la demanda contra la sociedad ante la Jurisdicción Social ${ }^{553}$, y la demanda de

${ }^{551}$ MOYA JIMÉNEZ, A.: La responsabilidad de los administradores de empresas insolventes, editorial Bosch, $10^{\text {a }}$ edición, 2015, p. 295

552 Tribunal Supremo, Sala Civil, en Sentencias 253/2016, de 18 de abril -RJ 2016/1342-; núm. 242/2014, de 23 de mayo -RJ 2014/2943-; y Sentencia 539/2012, de 10 de septiembre.

En la Sentencia 539/2012, de 10 de septiembre, se defiende esa atribución de competencia en los siguientes términos: "Ante los juzgados de lo mercantil se ejercita la acción más específica sobre responsabilidad de los administradores, la cual tiene carácter principal respecto de la acción por incumplimiento social, que opera con carácter prejudicial respecto de la primera. Así se infiere de la aplicación analógica de las normas sobre las prejudicialidad civil, de las que se infiere que la competencia para resolver una cuestión que aparece con carácter prejudicial respecto de otra corresponde al tribunal competente para conocer de la cuestión principal. En consecuencia, ante la ausencia de una regulación legal específica, debe considerarse preferible esta solución a la que resultaría de la aplicación del principio de disposición por la parte demandante (artículo 71.2 LEC en el caso de acumulación de acciones) o mayor antigüedad del proceso (artículo 79.1 LEC, en el caso de acumulación de procesos), articuladas en consideración a la situación de órganos judiciales con competencias paralelas. (b) La finalidad que persigue la norma de atribución de competencia residual a los juzgados de lo civil -artículo 45 LEC, que consagra el principio de la vis atractiva- es la de cerrar el sistema normativo de distribución de competencias entre los distintos órganos judiciales. Este principio no puede prevalecer frente a la norma de especialización competencial de los juzgados de lo mercantil -artículo 86 ter LOPJ-, pues esta, sin alejar la materia del orden jurisdiccional civil, al que pertenecen los juzgados mercantiles, va encaminada a la necesidad de avanzar en el proceso de especialización de estos a que lleva la complejidad de la realidad social y económica de nuestro tiempo, según se declara en la E.M. de la LORC. Este principio quedaría en entredicho si aceptáramos la competencia de los Juzgados de Primera Instancia para el conocimiento de las acciones acumuladas".

553 Art. 1 apartados a), b) y o) de la LRJS. 
la acción individual de responsabilidad contra el administrador ante el Juzgado de lo Mercantil, por lo que al ser órdenes judiciales distintos no hay posibilidad procesal de acumular esas acciones. Reclamación ante órdenes jurisdiccionales distintos que va en contra de la solidaridad de la posible condena.

De igual modo, las entidades públicas de la Seguridad Social tampoco pueden acumular la reclamación de la deuda contra el administrador social al ejercitar la acción individual de responsabilidad al amparo del art. 241 de la LSC, con la reclamación de la deuda a la sociedad de capital, ya que discurren por cauces procedimentales y procesales diversos $\mathrm{y}$ ante jurisdicciones distintas.

Si se reclaman a la Sociedad de Capital deudas de cotizaciones de Seguridad Social, se inicia el procedimiento administrativo recaudatorio mediante la expedición de reclamación de deuda emitida por la TGSS, o mediante acta de liquidación de cuotas extendida por la Inspección de Trabajo y Seguridad Social ${ }^{554}$, contra cuyos actos administrativos firmes cabe recurso ante la Jurisdicción Contencioso-Administrativa ${ }^{555}$. En cambio, la acción individual de responsabilidad contra el administrador para reclamar deudas de cotizaciones Seguridad Social debe plantearse ante la Jurisdicción Civil, como hemos examinado en el apartado IV.4 de este Capítulo.

Si lo que se reclama por la Administración de la Seguridad Social son deudas por prestaciones de Seguridad Social anticipadas al trabajador, y de las que debe responder la sociedad de capital, el procedimiento administrativo se inicia mediante resolución administrativa firme de la entidad gestora (INSS/ISM), declarando la responsabilidad de la sociedad, resolución que podrá ser recurrida por la empresa ante la Jurisdicción Social $^{556}$. Una vez dictada la resolución administrativa se procede a la reclamación de la deuda a la sociedad por la TGSS a través del procedimiento administrativo de recaudación de los recursos de la Seguridad Social, tanto en vía voluntaria como en vía ejecutiva $^{557}$. No se exige en el procedimiento administrativo recaudatorio la responsabilidad empresarial en el pago de una prestación, si ha sido declarada en sentencia firme por la Jurisdicción Social, al llevarse a cabo por el trámite de ejecución

\footnotetext{
554 Arts. 33 a 36 del TRLGSS, en relación con los arts. 61 a 66 del Real Decreto 1415/2004, de 11 de junio, RGRSS, y arts. 29 a 36 Real Decreto 928/1998, de 14 de mayo.

555 Art. 3.f) de la LRJSS; arts. 1 a 3 de la Ley 29/1998, de 13 de julio, Reguladora de la Jurisdicción Contencioso-Administrativa; arts. 38.4 y 129 del TRLGSS, en relación con el art. 46 del R.D. 1415/2004, de 11 de junio, RGRSS; y art. 33.3 del R.D. 928/1998, de 14 de mayo.

556 Art. 2 apartado o), de la LRJS.

${ }^{557}$ Arts. 167.4 y 295 del TRLGSS y art. 69.3 del Real Decreto 1415/2004, de 11 de junio, RGRSS.
} 
de sentencia ${ }^{558}$. Por el contrario, la reclamación de esa deuda por prestaciones ante el administrador social, ejercitando la acción individual de responsabilidad, deberá plantearse ante la Jurisdicción Civil, como hemos señalado en el apartado IV.4 de este Capítulo.

\section{VII.- EFECTOS DE LA DECLARACIÓN DEL CONCURSO DE ACREEDORES DE LA SOCIEDAD EN LA ACCIÓN INDIVIDUAL DE RESPONSABILIDAD.}

La declaración de concurso de acreedores de la sociedad de capital no paraliza ni suspende la acción individual de responsabilidad frente al administrador (artículos 132, 136.1.2 $2^{\mathrm{a}}$ y 139.1, en relación con el art. 155 del TRLC y STS, Sala Civil, núm. 737/2014, de 22 de diciembre -Recurso 1261/2013-), y ello, porque la acción individual no va dirigida al reintegro del patrimonio de la sociedad de capital, como sucede con la acción social, sino a reparar el daño causado al acreedor por el administrador, quien no estará necesariamente en situación concursal. Durante el concurso de acreedores los trabajadores por cuenta ajena o las Administraciones de la Seguridad Social, podrán ejercitar ante el Juzgado de lo Mercantil la acción individual de responsabilidad contra el administrador social, al margen del concurso de acreedores de la sociedad deudora (STS, Sala Civil, núm. 737/2014, de 22 de diciembre -Recurso 1261/2013-). Concurso de acreedores que, en cambio, sí paraliza y suspende la reclamación de responsabilidad solidaria del administrador por las deudas sociales del art. 367 de la LSC, cuando reclame el trabajador su deuda laboral (artículos 136.1.2 ${ }^{\mathrm{a}}$ y 139.1, en relación con el art. 155 del TRLC y STS, Sala Civil, núm. 737/2014, de 22 de diciembre -Recurso 1261/2013-).

En la doctrina científica mayoritaria ${ }^{559}$ se admite la no paralización de la acción individual del acreedor contra el administrador de la sociedad de capital aunque esta se

${ }_{558}$ Arts. 2, letra o) y 237 y ss de la Ley 36/2011, de 10 de octubre, LRJS, en relación con el art. 69.4 del Real Decreto 1415/2004, de 11 de junio.

559 GARCÍA CRUCES, J. A.: "La responsabilidad concursal", en AA.VV. (Coord.: ROJO FERNÁNDEZ-RÍO, A. y BELTRÁN SÁNCHEZ, E.): La responsabilidad de los administradores de las sociedades mercantiles, 6 a edición, Tirant Lo Blanch, Valencia, 2016, pp. 429-430; ESTEBAN VELASCO, G.: "La acción individual de responsabilidad", op. cit., pp. 298 y 299; VALPUESTA GASTAMINZA, E. M.: Comentarios a la Ley de Sociedades de Capital, op. cit., p. 647; BELLO MARTÍN-CRESPO, Ma P.: "Responsabilidad civil de administradores de sociedades de capital y Ley Concursal", Estudios sobre la Ley Concursal (Libro Homenaje a Manuel Olivencia), Tomo II, editorial Marcial Pons, Madrid, 2005, pp. 1729-1730; MAS-GUINDAL GARCÍA, J.: "La responsabilidad de los administradores sociales. Una aproximación al régimen del artículo 241 de la Ley de Sociedades de Capital", en Gobierno Corporativo: la Estructura del órgano de Gobierno y la 
halle en concurso de acreedores. No paralización porque la acción individual de responsabilidad es irrelevante, no afecta al concurso, ya que el crédito satisfecho no es con cargo a la masa activa, sino con cargo al patrimonio del administrador, no siendo un crédito concursal, por lo que no tiene sentido que el concurso de la sociedad tenga que desplegar efecto alguno sobre ella ${ }^{560}$, sin que tampoco pueda defenderse que la par conditio creditorum sea el fundamento para que la responsabilidad del administrador derivada de la acción individual sólo pueda exigirse una vez cubierta la responsabilidad concursal del administrador ${ }^{561}$. Una forma de garantizar en el concurso la existencia de bienes suficientes del administrador social para hacer efectiva su eventual responsabilidad concursal del art. 456 del TRLC, sería solicitar en el proceso por la administración concursal el embargo preventivo de bienes del administrador social, medida cautelar prevista en el art. 133 del TRLCA ${ }^{562}$. Embargo preventivo que pudiera ser de aplicación tardía al exigir el actual art. 133 del TRLC, como presupuesto que, de lo actuado resultare fundada posibilidad de que puedan ser condenados los administradores en la sentencia de calificación del concurso, ya que esa convicción la obtendrá el juez una vez que éste se encuentre en fase procesal muy avanzada ${ }^{563}$.

Para otro sector doctrinal debería paralizarse el ejercicio de la acción individual durante el concurso de acreedores ${ }^{564}$.

No paralización de la acción individual que ha admitido en la Sentencia del TS, Sala Civil, núm. 737/2014 de 22 de diciembre -Recurso 1261/2013-.

Responsabilidad de los Administradores, en AA.VV. (Dir.: MARTÍNEZ-ECHEVERRÍA Y GARCÍA DE DUEÑAS, A.), edit. Thomson Reuters Aranzadi, $1^{\circ}$ edición 2015, pp. 806-807; QUIJANO GONZÁLEZ, J.: "Coordinación de acciones societarias (social, individual y por deudas) y concursales de responsabilidad", en $R D C P$, . $^{\circ}$ 22, 2015, edición digital en Smarteca, p. 7. El profesor QUIJANO GONZÁLEZ la única matización que hace sería evitar que, más que reclamar indemnización de daños, se pretenda utilizar la acción para reclamar deudas impagas en situaciones de insuficiencias patrimoniales, cuando con ello pudiéramos estar ante una "utilización desviada" de la acción.

${ }^{560}$ GARCÍA CRUCES, J. A.: "La responsabilidad concursal”, op. cit., pp. 429-430.

${ }^{561}$ ESTEBAN VELASCO, G.: "La acción individual de responsabilidad", op. cit., pp. 298 y 299.

562 VALPUESTA GASTAMINZA, E. M.: Comentarios a la Ley de Sociedades de Capital, op. cit., p. 647.

563 LÓPEZ MEDRANO, F.: "Las acciones de daños y de cobertura del pasivo en el concurso de acreedores", en Anuario de Derecho Concursal, nº 12 (2007-3), p. 40.

564 SÁNCHEZ CALERO, F.: Los administradores en las sociedades de capital, 2007, op. cit., pp. 508509; ALONSO UREBA, A.: "La responsabilidad concursal de los administradores de una sociedad de capital en situación concursal (el art. 172.3 de la Ley Concursal y sus relaciones con las acciones societarias de responsabilidad", en AA.VV.: Derecho Concursal. Estudio sistemático de la Ley 22/2003 y de la Ley 8/2003, para la Reforma Concursal, Madrid, 2003, pp. 560-562; MORALES BARCELÓ, J.: "La responsabilidad de los administradores de las sociedades mercantiles en situación de pérdidas y de insolvencia", op. cit., p. 461. 
Al no afectar la declaración del concurso a la acción individual, cuestión diversa serán los problemas resultantes de la necesaria armonización de la responsabilidad derivada de la acción individual con la responsabilidad concursal del administrador que pudiera declararse en el concurso de acreedores de la sociedad de capital, y para ello, según la doctrina mayoritaria, deberá solicitarse en el proceso concursal la medida cautelar del embargo preventivo de bienes del administrador social al amparo del art.133 del TRLC.

Al no verse afectada la acción individual de responsabilidad contra el administrador, por el hecho de hallarse la sociedad deudora en concurso de acreedores, se refuerza el protagonismo de esa acción individual para obtener la satisfacción de los créditos que no se hayan podido percibir en el concurso de la sociedad deudora. Es por ello, que los acreedores pueden ejercitar la acción individual durante la situación concursal de la sociedad de capital, o una vez finalizado el mismo, y en este segundo supuesto, porque el concurso interrumpe, en todo caso, los plazos de prescripción de la acción individual de responsabilidad contra los administradores (art. 155.3 y 4 del TRLC).

La declaración de concurso interrumpe la prescripción de la acción individual de responsabilidad, y ello pese a no verse afectado su ejercicio por la declaración del concurso (arts. 136.1.2 ${ }^{\circ}$ y 139.1 del TRLC y STS, Sala Civil, núm. 737/2014, de 22 de diciembre -RJ 2014l6885- ${ }^{565}$ ). En el art. 155.3 del TRLC, al regularse la interrupción de la prescripción se indica que, desde la declaración hasta la conclusión del concurso queda interrumpida la prescripción de las acciones contra socios y contra administradores, liquidadores y auditores de la persona jurídica deudora. Se impone la interrupción de la prescripción de todas las acciones contra los administradores en ese precepto, incluyendo a la acción individual, porque no se distingue entre las diversas acciones, sin que la interrupción esté vinculada a la suspensión de la tramitación de la acción individual por el concurso, ya que la interrupción de la prescripción de la acción tiene como justificación la conveniencia de que los terceros afectados por la sociedad, esperen a las resultas del concurso, en la medida en que podrá incidir en el daño o perjuicio susceptible de ser resarcido mediante la acción individual (STS, Sala Civil, núm. 737/2014, de 22 de diciembre -RJ 201416885-) .

565 En esa Sentencia se señala que "el hecho de que el ejercicio de esta acción individual no quede suspendido como consecuencia de la declaración de concurso no significa que no alcance a esta acción el efecto de la interrupción de la prescripción. La interrupción de la prescripción no va ligada necesariamente a la suspensión o paralización de la acción, siendo posible que estando interrumpida la prescripción pueda ejercitarse la acción". 
Interrumpida la prescripción, una vez finalizado el concurso se inicia de nuevo el cómputo del plazo de la prescripción de la acción (art. 155.4 del TRLC).

El crédito que pudiera ostentar el administrador social condenado por la acción individual al pago de la deuda de la sociedad en concurso, no sería de la misma naturaleza que el que tendría el acreedor en la masa pasiva, sino que sería un crédito subordinado $^{566}$.

Al no afectar el concurso de acreedores a la acción individual de responsabilidad contra el administrador, las entidades gestoras y de recaudación de la Seguridad Social podrán exigir esa responsabilidad al administrador fuera del concurso de acreedores, ejercitando esa acción procesal ante el Juzgado de lo Mercantil competente, con independencia de seguir esas entidades incluidas en la lista de acreedores en el concurso de la sociedad, sin que se pueda percibir un doble pago, de modo que el pago íntegro de la deuda por el administrador extingue el crédito contra la sociedad.

Cuestión diferente y que será objeto de estudio en el Capítulo IV apartado IX, es cómo afecta el concurso de acreedores a la derivación administrativa de deudas de Seguridad Social al amparo del art. 367 de la LSC y del art. 18.3 del TRLGSS, ya que como hemos indicado, el concurso sí que afecta a las acciones de reclamación al administrador de las deudas solidarias de la sociedad en concurso (arts. 136.1.2 ${ }^{\circ} \mathrm{y}$ 139.1. del TRLC). Ahora bien, repárese que suspende las acciones procesales, y la derivación de deudas al administrador no es una acción procesal, sino que es reclamación administrativa directa en virtud del principio de autotutela reconocido en el art. 18.3 del TRLGSS, por lo que en el Capítulo IV nos preguntaremos acerca de la posible paralización del procedimiento de recaudación.

${ }^{566}$ MORALES BARCELÓ, J.: "La responsabilidad de los administradores de las sociedades mercantiles en situación de pérdidas y de insolvencia”, op. cit, p. 459. 



\section{PARTE:}

\section{LA DERIVACIÓN EX LEGE DE DEUDAS DE SEGURIDAD SOCIAL DE LA SOCIEDAD DE CAPITAL AL ADMINISTRADOR SOCIAL}

\section{CAPÍTULO:}

\section{DERIVACIÓN DE RESPONSABILIDAD POR CAUSA DE DISOLUCIÓN DE PLENO DERECHO}

La responsabilidad solidaria del administrador social ante la concurrencia de una causa de disolución de pleno derecho, por quedar reducido el capital social por debajo del importe mínimo legal establecido, sin que se subsane esa anomalía dentro de un plazo máximo de un año, se recoge en el art. 360 de al LSC, siendo de aplicación a todas las sociedades de capital, y no sólo a la sociedad de responsabilidad limitada, como sucedía antes de la entrada en vigor de la LSC.

\section{I.- REGULACIÓN LEGAL Y ANTECEDENTES NORMATIVOS.}

En el art. 108 de la Ley 2/1995, de 23 de marzo, se introdujo por primera vez en nuestro Derecho la responsabilidad del administrador por deudas de la sociedad de responsabilidad limitada, cuando incumpla sus deberes legales de concurrir la causa de disolución de pleno derecho por haberse reducido el capital social por debajo del mínimo legal, cuando esa reducción fuere debida al cumplimiento de la ley.

En ese precepto se impuso una responsabilidad solidaria al administrador cuando por cumplimiento de una ley, el capital social quedase reducido por debajo del mínimo legal de 500.000 pesetas, en cuyo caso la sociedad quedaría disuelta de pleno derecho, una vez transcurriese un año desde la adopción del acuerdo de reducción sin que se hubiere inscrito en el Registro Mercantil su transformación, disolución, o el aumento del capital hasta una cantidad igual o superior a dicho mínimo legal. Transcurrido ese plazo sin haberse inscrito la transformación, la disolución de la sociedad, o el aumento de su 
II PARTE. III CAPÍTULO

capital, los administradores respondían de modo personal y solidariamente, entre sí y con la sociedad, de las deudas de la sociedad de capital.

Este tipo de responsabilidad del administrador social no se recogió para los administradores de la sociedad anónima en el Real Decreto Legislativo 1564/1989, de 22 de diciembre, que aprobó el Texto Refundido de la anterior Ley de Sociedades Anónimas.

Tras la aprobación del Real Decreto Legislativo 1/2010, de 2 de julio, el legislador procede a refundir en un único texto la regulación de las sociedades de capital, atendiendo el mandato otorgado al Gobierno en la Disposición Final $7^{\text {a }}$ de la Ley $3 / 2009$, de 3 de abril $^{567}$, sobre modificaciones estructurales de sociedades mercantiles ${ }^{568}$, introduciendo esta responsabilidad ante esa causa de disolución de pleno derecho, siendo de aplicación por primer vez a los tres tipos de sociedades de capital: anónima, de responsabilidad limitada, y sociedad comanditaria por acciones.

\section{II.- RESPONSABILIDAD DEL ADMINISTRADOR SOCIAL.}

La responsabilidad solidaria del administrador por deudas de la sociedad de capital ante la concurrencia de la causa de disolución de pleno derecho, nace cuando haya transcurrido un año desde que la Junta General adoptó el acuerdo de reducción del capital social por debajo del mínimo legal, en virtud del cumplimiento de una ley, sin haberse inscrito en el Registro Mercantil alguno de los tres actos jurídicos siguientes: a) la transformación societaria a otro tipo que permita tener ese capital social, b) la disolución de la mercantil, o c) el aumento del capital hasta alcanzar el mínimo legal.

Responsabilidad solidaria del administrador en el pago de las deudas sociales de la sociedad de capital que se recoge en el art. 360.1. b) de la LSC, precepto que procede del art. 108 de la Ley 2/1995, de 23 de marzo, que regulaba las Sociedades de Responsabilidad Limitada, que fue refundida y derogada por la LSC. Con esta regulación legal se ha extendido esta responsabilidad a todas las sociedades de capital, y deja de aplicarse sólo a la sociedades de responsabilidad limitada.

Responsabilidad por deudas del administrador social que ha venido siendo calificada como supuesto de responsabilidad ex lege por deuda ajena y no por deuda propia. Se

567 BOE 4.4.2009.

568 Art. 360.1, causa de la letra b), de la LSC. 
trata de supuestos de responsabilidad por deuda ajena ante el incumplimiento de deberes legales cuando concurra una causa de disolución de pleno derecho.

El TS, Sala de lo Civil, en Sentencia núm. 103/2015, de 10 marzo, no consideró aplicable esta causa de disolución a una cooperativa, al no establecerse esa responsabilidad del Consejo Rector, ni en la Ley Estatal de Cooperativas, ni en la Ley Autonómica.

Al ser una disolución de pleno derecho, se produce ipso iure, no precisándose acuerdo de la Junta General, cesando los administradores automáticamente en el cargo, ordenándose al registrador que lo haga constar expresamente (art. 238.2 RRM), aunque pueden ser designados liquidadores si los estatutos así lo han establecido, debiendo hacerse constar esa circunstancia en el Registro Mercantil.

Antes de analizar el contenido de esta responsabilidad, reseñemos brevemente los capitales mínimos de las sociedades de capital, así como las especialidades previstas para determinadas entidades, como las financieras y de seguros, que están sujetas a supervisión de las entidades públicas de autorización y control.

El capital mínimo legal exigido en función del tipo societario elegido será el siguiente. Para las sociedades anónimas y las sociedades comanditarias por acciones se ha fijado en 60.000 euros (arts. 3.2 y 4.3 de la LASC); y para las sociedades de responsabilidad limitada 3.000 euros (art. 4.1 de la LSC), pero con la especialidad de permitirse que se puedan constituir sociedades de responsabilidad limitada con capital inferior a los 3.000 euros sometiéndolas a un régimen específico en el art. 4 bis de la LSC. De este modo, esta causa de disolución de pleno derecho afecta a las sociedades de responsabilidad limitada constituidas inicialmente con un capital social igual o superior al mínimo legal.

En las sociedades anónimas deportivas su capital social en ningún caso podrá ser inferior al establecido para las sociedades anónimas, esto es, 60.000 euros, pudiendo ser de importe superior en los términos establecidos reglamentariamente (art. 21 de la Ley 10/1990, de 15 de octubre, del Deporte ${ }^{569}$ ). En el art. 3 del Real Decreto 1251/1999, de 16 de julio, sobre Sociedades Anónimas Deportivas ${ }^{570}$, se establecen las reglas para la determinación del capital social mínimo de los clubes que accedan a una competición profesional, que será el resultado de los dos sumatorios siguientes. Por un lado, el 25 
por 100 de la media de los gastos realizados, incluidas amortizaciones, por los clubes y sociedades anónimas deportivas que participaran en la penúltima temporada finalizada de la respectiva competición profesional; y por otro, en función de los saldos patrimoniales netos negativos que, en su caso, arroje el balance de las cuentas anuales del ejercicio anterior del club deportivo. Cuando el primer sumando sea inferior al segundo, el capital social mínimo se fijará en el duplo del segundo sumando.

La Sociedad Nueva Empresa, como modalidad específica de sociedad de responsabilidad limitada, tiene un capital mínimo legal de 3.000 euros, sin que pueda ser superior a 120.000 euros (art. 443 LSC).

Las sociedades profesionales podrán constituirse con arreglo a cualquiera de las formas societarias previstas en las leyes (art. 1.2 de la Ley 2/2007, de 15 de marzo, que regula las Sociedades Profesionales $\left.{ }^{571}\right)$. Si se constituyen como sociedades de capital, su capital social mínimo será el de la forma societaria elegida: sociedad anónima, de responsabilidad limitada o comanditaria por acciones, teniendo como especialidad que, si bien de las deudas sociales responderá la sociedad con todo su patrimonio y los socios tendrán la responsabilidad prevista para el tipo societario elegido. No obstante, de las deudas sociales que se deriven de los actos profesionales responderán solidariamente la sociedad y los profesionales, socios o no, que hayan actuado (art. 11 de la Ley 2/2007, de 15 de marzo).

La Sociedad de Garantía Recíproca, que tiene la consideración de entidad mercantil financiera (arts. 1 y 4 de la Ley 1/1994, de 11 de marzo, sobre el Régimen Jurídico de las Sociedades de Garantía Recíproca ${ }^{572}$, no de sociedad de capital, por lo que no le es aplicable esta responsabilidad del art. 360 de la LSC, al no haberse previsto expresamente la misma en esa disposición legal, no existiendo remisión expresa al art. 360 de la LSC (art. 59 de la Ley 1/1994, de 11 de marzo ${ }^{573}$ ). Su capital social mínimo

${ }^{571}$ BOE del 16.3.2007.

572 BOE del 12.3.1994.

573 "Artículo 59. Causas de disolución.

1. La sociedad de garantía Recíproca se disolverá:

a) Por acuerdo de la Junta General, convocada con los mismos requisitos exigidos para la modificación de estatutos y adoptado con la mayoría exigida por el artículo 36.3 .

b) Por cumplimiento del término fijado en los estatutos.

c) Por la conclusión de la empresa que constituya su objeto o la imposibilidad manifiesta de realizar el fin social, o por la paralización de los órganos sociales, de modo que resulte imposible su funcionamiento. 
no podrá ser inferior a 10.000.000 de euros (art. 8 de la Ley 1/1994, de 11 de marzo), siendo nula la reducción del capital por debajo de la cifra mínima legal (art. 49.3 de la Ley 1/1994, de 11 de marzo). En estas sociedades de garantía recíproca es causa de disolución legal, no de pleno derecho, la reducción del capital social desembolsado por debajo del importe mínimo fijado legalmente (art. 59 apartado 1.e) de la Ley 1/1994, de 11 de marzo). Al ser causa de Disolución Legal, en esa legislación específica se establece que será de aplicación el art. 262 apartados 2 a 5 de la LSA, esto es, los actuales artículos 365 a 367 de la LSC, por lo que ante esa causa de disolución por haberse reducido el capital social desembolsado por debajo de la cifra mínima legal, los administradores deben cumplir con dos deberes, en primer lugar, con el deber de convocar en el plazo de dos meses a la Junta General para que se adopten medidas de remoción o se acuerde la disolución, y de no adoptarse esos acuerdos o ser contrarios, el segundo deber será solicitar dentro de los dos meses siguientes la disolución judicial o el concurso. De incumplir alguno de esos dos deberes responderán solidariamente los administradores de las deudas posteriores al a concurrencia de la causa de disolución prevista en el art. 367 de la LSC.

Tienen especialidad en el capital mínimo las entidades sujetas a control administrativo de las autoridades de supervisión pública, como entidades financieras ${ }^{574}$ y de seguros ${ }^{575}$,

d) Por consecuencia de pérdidas que dejen reducido el patrimonio a una cantidad inferior a las dos terceras partes del capital social, a no ser que éste se aumente o se reduzca en la medida suficiente.

e) Por reducción del capital social desembolsado o de los Recursos propios computables por debajo de las cifras mínimas exigidas en la presente Ley.

f) Por la fusión de la sociedad con otra sociedad de garantía Recíproca o por la escisión total de la sociedad en dos o más sociedades de esa misma naturaleza.

g) Por la apertura de la fase de liquidación, cuando la sociedad se hallare declarada en concurso.

h) Por revocación del Ministerio de Economía y Hacienda de la autorización conforme a lo establecido en el artículo 12.4 de esta Ley.

i) Por cualquier otra causa establecida en los estatutos.

2. Cuando concurra alguna de las causas previstas en los apartados b), c), d), e) e i) del apartado anterior, la disolución de la sociedad requerirá acuerdo de la Junta general constituida con arreglo al artículo 36.1. Será aplicable en tales casos lo dispuesto en el artículo 262, apartados 2 a 5, de la Ley de Sociedades Anónimas.

3. En el supuesto previsto en el párrafo g) del apartado primero, la sociedad quedará automáticamente disuelta al producirse en el concurso la apertura de la fase de liquidación. El juez del concurso hará constar la disolución en la resolución de apertura y, sin nombramiento de liquidadores, se realizará la liquidación de la sociedad conforme a lo establecido en el capítulo II del título V de la Ley Concursal".

${ }^{574}$ Las Entidades de Crédito, que han de revestir la forma de sociedad anónima, tienen que tener un capital social inicial no inferior a 18 millones de euros (art. 4 del Real Decreto 84/2015, de 13 de febrero-BOE de 14.2.2015-, por el que se desarrolla la Ley 10/2014, de 26 de junio, de ordenación, supervisión y solvencia de Entidades de Crédito).

575 Que las Entidades Aseguradoras tienen capitales sociales mínimos diferentes, en función del ramo del seguro. Las sociedades anónimas y cooperativas de seguros deberán tener los siguientes capitales 
que no son objeto de análisis al estar sujetas a la intervención y control de los órganos reguladores.

La responsabilidad por deudas por esta causa de disolución de pleno derecho es exigible al administrador social de las sociedades de capital; sociedad anónima, de responsabilidad limitada y sociedad comanditaria por acciones.

Salvo para la sociedad de responsabilidad limitada en régimen de formación, regulada en el art. 4 bis, se prohíbe que se pueda constituir una sociedad de capital con un capital social inferior al mínimo legal (art. 5.1 de la LSC). Pero no sólo existe esa prohibición legal para el momento de la constitución, sino que durante toda la vida societaria ha de mantenerse ese capital mínimo legal, ya que no se podrán autorizar escrituras de modificación del capital social si éste queda por debajo del mínimo legal, salvo cuando sea consecuencia del cumplimiento de una ley (art. 5.1 de la LSC). Supuesto de reducción por debajo del mínimo legal por el cumplimiento de una ley, que será la circunstancia determinante del nacimiento de la responsabilidad solidaria del administrador social en los términos en el art. 360 de la LSC, y que pasamos a estudiar.

En el Derecho comunitario se establece igual regla de que el capital social no podrá reducirse por debajo del mínimo legal, en el art. 77 de la Directiva (UE) 2017/1132 del Parlamento Europeo y del Consejo, de 14 de junio de 2017, sobre determinados aspectos del Derecho de sociedades ${ }^{576}$, pero se autoriza a los Estados para que puedan permitir tal reducción si se ha previsto que ésta sólo surtirá efectos si se procede a un aumento del capital suscrito destinado a poner a éste a un nivel, al menos, igual al mínimo establecido (lo que en nuestro Derecho es la operación acordeón).

En la disolución de pleno derecho del art. 360 de la LSC, estamos ${ }^{577}$ (sic) "ante una reducción del capital por debajo del mínimo legal por exigencias de una ley, que es

sociales mínimos cuando pretendan operar en los ramos que a continuación se enumeran: a) 9.015.000 euros en los ramos de vida, caución, crédito, cualquiera de los que cubran el riesgo de responsabilidad civil y en la actividad exclusivamente reaseguradora. b) 2.103.000 euros en los ramos de accidentes, enfermedad, defensa jurídica, asistencia y decesos. En el caso de entidades aseguradoras que únicamente practiquen el seguro de enfermedad otorgando prestaciones de asistencia sanitaria y limiten su actividad a un ámbito territorial con menos de dos millones de habitantes, será suficiente la mitad del capital o fondo mutual previsto en el párrafo anterior. c) 3.005.000 euros, en los restantes (art. 33 de la Ley 20/2015, de 14 de julio, de ordenación, supervisión y solvencia de las Entidades Aseguradoras y Reaseguradoras, BOE del 15.7.2015).

${ }^{576}$ DOUE, serie L 30.6.2017.

${ }^{577}$ FERNÁNDEZ DÍEZ, A.: "Prescripción de la responsabilidad del administrador por deudas de Seguridad Social de la Sociedad", en Revista General de Derecho del Trabajo y de la Seguridad Social, n. ${ }^{\circ}$ 56, julio 2020, p. 433. 
supuesto distinto de la causa de disolución prevista en el art. 363.1.f) de la LSC, consistente en la reducción del capital social por debajo del mínimo legal, que no sea consecuencia del cumplimiento de una ley, en cuyo caso, la sociedad incurre en causa de disolución legal, distinta a la de pleno derecho, surgiendo los deberes disolutorios para el administrador regulados en los arts. 365 y 366 de la LSC, de cuyo incumplimiento surgirá otra responsabilidad por deudas, la contemplada en el art. 367”, que analizaremos en el Capítulo IV de esta tesis. Supuesto este, de reducción del capital por debajo del mínimo legal no exigido por la ley, que es difícil que pueda darse en la práctica por la prohibición del art. 343 de la $\mathrm{LSC}^{578}$, por lo que como señala BATALLER GRAU ${ }^{579}$, esta reducción de capital es nula y no inscribible pudiendo acontecer sólo cuando el acuerdo de reducción supere los controles notariales y registrales.

La reducción del capital legal por debajo del mínimo legal por imperativo de la ley, que puede abocar a la disolución de pleno derecho, según la doctrina ${ }^{580}$, puede ser debida a cuatro circunstancias, como reseñábamos en una publicación anterior, elaborada con motivo de la redacción de esta tesis ${ }^{581}$. En primer lugar, por amortización de acciones del socio moroso prevista en el art. 84.2 de la LSC. En segundo lugar, por la enajenación obligada de la autocartera de los arts. 139.3, 141.2 y 145.2 de la LSC. En tercer lugar, por separación o exclusión de socios establecida en el art. 358.2 de la LSC $^{582}$. En cuarto lugar, por pérdidas en la sociedad anónima que obliguen a reducir el capital social de conformidad con el art. 327 de la LSC, lo que sucede cuando las

${ }^{578}$ BROSETA PONT, M. y MARTÍNEZ SANZ, F.: Manual de Derecho Mercantil, Tecnos, $23^{\text {a }}$ edición, Vol. I, 2016, p. 578; BATALLER GRAU, J.: “Disolución y Liquidación”, op. cit., pp. 2532-2539.

579 BATALLER GRAU, J.: "Disolución y Liquidación”, op. cit, p. 2537.

${ }^{580}$ VALPUESTA GASTAMINZA, E. M.: Comentarios a la Ley de Sociedades de Capital, op. cit., pp. 933-935. BATALLER GRAU, J.: "Disolución y Liquidación”, op. cit., p. 2536; RODRÍGUEZ RUIZ DE LA VILLA, D. y HUERTA VIESCA, M. I.: La responsabilidad de los administradores por las deudas de las Sociedades de Capital (en las Leyes de Sociedades Anónimas, de Sociedades de Responsabilidad Limitada, de Sociedad Limitada Nueva Empresa, Concursal, General Tributaria $y$ de Responsabilidad Medioambiental), op. cit., pp. 225-528 y 533-534. Vid. su nota 60 sobre las distintas posturas doctrinales acerca de si se incluye la reducción del capital por causas de pérdidas agravadas que determinen la obligación de tener que reducir el capital social por debajo del mínimo legal, siendo partidarios de su inclusión, de modo que la responsabilidad del antiguo art. 108 LSRL, recogida actualmente en el art. 360 LSC, es norma especial que desplaza a la responsabilidad del art. 367 de la LSC, pero no enerva la obligación de convocar a la Junta General prevista en el art. 365 de la LSC, una vez se haya reducido el patrimonio neto, pp. 533-534.

581 FERNÁNDEZ DÍEZ, A.: "Prescripción de la responsabilidad del administrador por deudas de Seguridad Social de la sociedad", op. cit., pp. 433-434.

582 En la sociedad de responsabilidad limitada, el socio excluido, al que se le reembolsen sus participaciones sociales, responde de las deudas de la sociedad contraídas con anterioridad a la exclusión, con el importe de las participaciones sociales reembolsadas (arts. 331 y 357 LSC). 
pérdidas hayan disminuido el patrimonio neto por debajo de las dos terceras partes del capital, y haya transcurrido un año sin haberse recuperado el patrimonio neto.

La reducción por pérdidas es el único supuesto de reducción obligatoria del capital social por debajo del mínimo legal, pero esa reducción ha de ser subsanada de modo inmediato y simultáneo de conformidad con el art. 343 de la LSC, al exigirse tres requisitos para la validez de ese acuerdo de reducción. En primer lugar, que ese acuerdo de reducción vaya acompañado del acuerdo de simultánea transformación de la sociedad, o bien, que vaya acompañado del acuerdo de simultáneo aumento del capital (operación acordeón) hasta una cuantía igual o superior al mínimo legal. En segundo lugar, que en caso de operación acordeón, se requiere la efectividad del aumento del capital, ya que la eficacia del acuerdo de reducción del capital queda condicionada a la ejecución del aumento del capital. Y en tercer lugar, que para poderse inscribir el acuerdo de reducción del capital deben inscribirse simultáneamente la transformación societaria o el aumento del capital (arts. 343 a 345 LSC).

La disolución de pleno derecho opera ipso iure una vez transcurre el plazo de un año. En el art. 360 de la LSC se establece que la sociedad de capital se disolverá, lo que impone la disolución automática, sin necesidad de acuerdo de la Junta General, a diferencia de la disolución por causas legales o estatutarias, en que se precisa el acuerdo de la Junta General, o, en su defecto la resolución judicial pertinente (arts. 364 y 366 LSC).

La inscripción de la disolución de pleno derecho en el Registro Mercantil no precisa escritura pública, sino que la practicará el registrador de oficio o a instancia de cualquier interesado, mediante nota al margen de la última inscripción expresando que la sociedad ha quedado disuelta (art. 360.2 LSC y art. 238 RRM).

Para que pueda producirse la disolución ipso iuris de la sociedad, y para que posteriormente nazca la responsabilidad solidaria del administrador social en las deudas de la sociedad de capital, es preciso que concurran dos requisitos. En primer lugar, que haya transcurrido un año desde el acuerdo de reducción del capital social -factor o requisito temporal-. Y, en segundo lugar, ausencia en ese plazo de la inscripción registral de la remoción de la causa de disolución de pleno derecho -factor o requisito sustantivo formal-. Analicemos ambos elementos. 
No nace la responsabilidad por deudas del administrador social si se supera o remueve la causa disolutoria por alguna de las siguientes actuaciones jurídicas. En primer lugar, si dentro del año siguiente al acuerdo de reducción del capital social se procede a transformar la sociedad en otra que permita mantener ese capital social. En segundo lugar, si se aumenta el capital social hasta el importe mínimo legal y se inscribe en el registro. En tercer lugar, si antes del plazo del año la sociedad adopta el acuerdo de disolución (arts. 360 y 368 LSC). O, en cuarto lugar, si antes del transcurso del año la sociedad decide proceder a su fusión con otra sociedad, a la escisión total o el traspaso global del activo y pasivo a una nueva sociedad, si con ello en la nueva mercantil se mantiene el capital social mínimo legal, como se ha apuntado en la doctrina, pese a no mencionarse esta causa de remoción en el art. 360 de la LSC ${ }^{583}$. Actuaciones jurídicas que para impedir el nacimiento de la responsabilidad del administrador social precisan además que se cumpla otro requisito formal, que la escritura pública de transformación, aumento, disolución, fusión, escisión o traspaso global de activo y pasivo se inscriba en el RM antes de que se cumpla el plazo de un año desde que se adoptó el acuerdo de reducción.

Ese requisito de inscripción registral viene a ser el requisito determinante de la responsabilidad, al vincularse ésta exclusivamente al incumplimiento del deber de inscribir los acuerdos en el Registro Mercantil ${ }^{584}$.

En el cómputo del plazo del año establecido en el art. 360 de la LSC, para que nazca la responsabilidad del administrador, hemos de determinar cuál es el dies a quo y cuál es el dies ad quem.

El día de inicio o dies a quo será la fecha en que se adoptó el acuerdo de reducción del capital social, no la fecha de reducción del capital, ni tampoco la fecha del reembolso de las acciones o participaciones sociales en caso de exclusión de los socios. Con relación al reembolso de las acciones o participaciones, hemos de reseñar que, en la LSC, a diferencia de la anterior LSRL, ya no exige que el plazo del año se compute desde la fecha de reembolso de las participaciones sociales (art. 102.2 de la anterior LSRL), salvo que se estimase que se ha producido un exceso en la refundación, o vicio ultra

583 RODRÍGUEZ RUIZ DE LA VILLA, D. y HUERTA VIESCA, M. I.: La responsabilidad de los administradores por las deudas de las Sociedades de Capital (en las Leyes de Sociedades Anónimas, de Sociedades de Responsabilidad Limitada, de Sociedad Limitada Nueva Empresa, Concursal, General Tributaria y de Responsabilidad Medioambiental), op. cit., p. 530.

${ }^{584}$ BATALLER GRAU, J.: “Disolución y Liquidación”, op. cit., 2011, p. 2538. 
vires. En el art. $238.1 .3^{\circ}$ del RRM se mantiene el mismo criterio que el art. 102.2 de la anterior LSRL, por lo que deberá ser reinterpretado al amparo del nuevo régimen jurídico de la disolución de pleno derecho del art. 360 de la LSC. Actualmente, en el art. 358 de la LSC, en caso de reducción del capital social con reembolso de participaciones se remite a las disposiciones de la propia ley en materia de disolución, en este caso al art. 360 de la LSC, sin fijar especialidad alguna en el cómputo del plazo del año.

Será dies ad quem el transcurso del año desde la adopción del acuerdo de reducción del capital social por debajo del mínimo legal.

Cumplido el requisito temporal para que nazca la responsabilidad del administrador, debe igualmente concurrir un requisito sustantivo formal, que no se haya inscrito en el Registro Mercantil la escritura de aumento del capital, de transformación o de disolución, fusión o escisión o el traspaso global del activo y pasivo.

Algunos autores ${ }^{585}$, partiendo del art. 55 del RRM ${ }^{586}$, consideran como fecha de inscripción la fecha del asiento de presentación, lo que podría practicarse por razones de urgencia en cualquier registro distinto al que corresponda a la sociedad (art. 46 RRM), estimando RODRÍGUEZ RUIZ DE LA VILLA, D. y HUERTA VIESCA, M. I. ${ }^{587}$ que para los casos en los que proceda la disolución, por no haberse adoptado otros acuerdos de remoción de la causa, "sería suficiente la inscripción registral del testimonio de la sentencia firme de disolución, ante la imposibilidad de disponer en el plazo del año de la notificación de la sentencia”.

Los deberes del administrador cuyo incumplimiento generan esta responsabilidad se reconducen a los dos siguientes. En primer lugar, no haber convocado a la Junta General para que adopte alguno de los acuerdos legales que remuevan la causa de disolución o para que directamente acuerde su disolución voluntaria (arts. 360 y 368 de la LSC). En segundo lugar, que adoptado por la junta algún acuerdo social, no se haya inscrito antes del año en el RM por causa imputable al administrador social la escritura de

585 RODRÍGUEZ RUIZ DE LA VILLA, D. y HUERTA VIESCA, M. I.: La responsabilidad de los administradores por las deudas de las Sociedades de Capital (en las Leyes de Sociedades Anónimas, de Sociedades de Responsabilidad Limitada, de Sociedad Limitada Nueva Empresa, Concursal, General Tributaria y de Responsabilidad Medioambiental), op. cit., p. 530.

${ }^{586}$ En el art. 55.1 del RRM al regular la fecha de la inscripción en el Registro, establece que "se considera como fecha de la inscripción la fecha del asiento de presentación".

587 RODRÍGUEZ RUIZ DE LA VILLA, D. y HUERTA VIESCA, M .I.: La responsabilidad de los administradores por las deudas de las Sociedades de Capital (en las Leyes de Sociedades Anónimas, de Sociedades de Responsabilidad Limitada, de Sociedad Limitada Nueva Empresa, Concursal, General Tributaria y de Responsabilidad Medioambiental), op. cit., p. 529. 
transformación societaria, la de disolución, la de aumento del capital social hasta el importe mínimo legal, o, en su caso, la de fusión, escisión o traspaso global del activo y pasivo.

No nacerá la responsabilidad si la falta de aumento del capital, de disolución o transformación son imputables a la Junta General, habiendo cumplido el administrador con su primera obligación de convocar la junta, o en su caso de instar la disolución judicial $^{588}$. Sentencia de disolución que pudiera no poder ser dictada antes del año siguiente al acuerdo de reducción del capital. No obstante, si el administrador social ha solicitado antes del transcurso del año la disolución judicial, de no haber adoptado la junta alguno de los acuerdos legales, podría entenderse que al haber hecho todo lo posible para evitar la disolución de pleno derecho, debería quedar exonerado de responsabilidad por falta de imputabilidad ${ }^{589}$, aunque no se haya dictado la sentencia dentro del plazo del año.

De incumplir el administrador social esos dos deberes de promoción de la disolución de pleno derecho, responderá de modo solidario de las deudas de la sociedad de capital (art. 360.1 de la LSC). Responsabilidad solidaria de los integrantes del órgano de administración porque tiene la facultad-obligación de convocar la Junta General para que se adopten los acuerdos de remoción de la causa de disolución o las medidas alternativas legalmente procedentes (arts. 166 y 167 de la LSC), y porque, una vez adoptados esos acuerdos el administrador social es quien debe solicitar su inscripción registral (art. 233 de la LSC).

Se ha criticado en la doctrina la severidad de la responsabilidad solidaria por las deudas sociales $^{590}$, entendiendo que la disolución automática por el transcurso del año evitará

588 VALPUESTA GASTAMINZA, E. M.: Comentarios a la Ley de Sociedades de Capital, op. cit., p. 934; BELTRÁN SÁNCHEZ, E.: "La responsabilidad de los administradores por obligaciones sociales”, op. cit., p. 312; RODRÍGUEZ RUIZ DE LA VILLA, D. y HUERTA VIESCA, M. I.: La responsabilidad de los administradores por las deudas de las Sociedades de Capital (en las Leyes de Sociedades Anónimas, de Sociedades de Responsabilidad Limitada, de Sociedad Limitada Nueva Empresa, Concursal, General Tributaria y de Responsabilidad Medioambiental, op. cit., p. 530.

589 RODRÍGUEZ RUIZ DE LA VILLA, D. y HUERTA VIESCA, M. I.: La responsabilidad de los administradores por las deudas de las Sociedades de Capital (en las Leyes de Sociedades Anónimas, de Sociedades de Responsabilidad Limitada, de Sociedad Limitada Nueva Empresa, Concursal, General Tributaria y de Responsabilidad Medioambiental, op. cit., p. 534.

590 BELTRÁN SÁNCHEZ, E.: "La responsabilidad de los administradores por obligaciones sociales", op. cit., p. 312; ARANGUREN URRIZA, F. J.: La sociedad de Responsabilidad Limitada, Tomo II, Editorial Trivium, Madrid, 1998, p. 825. 
que pueda mantenerse de modo indefinido o prolongado en el tiempo la actividad de la sociedad $^{591}$.

Estamos ante una responsabilidad ex lege por deudas sociales, similar a la responsabilidad del art. 367 de la LSC, y diferente de la responsabilidad por daños de los arts. 236 a 241 de la $\operatorname{LSC}^{592}$.

En el art. 360 de la LSC se impone al administrador social una responsabilidad solidaria en las deudas sociales, sin concretar el alcance de la responsabilidad, ya que no se señala si responde de las deudas posteriores a la causa de disolución, como se hace en la responsabilidad del administrador por causa legal de disolución (art. 367 de la LSC).

Surge la duda de si responderá de todas las deudas sociales, aunque fueren de fecha anterior a la causa disolutoria ${ }^{593}$, si por el contrario responderá de las posteriores al acuerdo de reducción del capital social, o si finalmente responderá sólo de las posteriores al acaecimiento de la causa de disolución ${ }^{594}$.

La doctrina ${ }^{595}$ partidaria de que la responsabilidad sea sólo por las deudas posteriores al acaecimiento de la causa de disolución, justifica esa limitación en que nos hallamos ante responsabilidad de la misma naturaleza que la prevista en el art. 367 de la LSC, por lo que debe aplicarse analógicamente esa disposición legal "respondiendo sólo de las deudas posteriores al acaecimiento de la causa de disolución”.

No estimamos defendible la interpretación de hacer responsable al administrador social de todas las deudas sociales, incluyendo a las anteriores al acaecimiento, porque si el legislador hubiese querido imponer la responsabilidad por todas las deudas, al ser una responsabilidad más gravosa que la del art. 367 de la LSC, lo hubiere establecido

${ }^{591}$ BELTRÁN SÁNCHEZ, E.: "La responsabilidad de los administradores por obligaciones sociales", op. cit., p. 312.

592 VALPUESTA GASTAMINZA, E. M.: Comentarios a la Ley de Sociedades de Capital, op. cit., pp. 934-935.

593 RODRÍGUEZ RUIZ DE LA VILLA, D. y HUERTA VIESCA, M. I.: La responsabilidad de los administradores por las deudas de las Sociedades de Capital (en las Leyes de Sociedades Anónimas, de Sociedades de Responsabilidad Limitada, de Sociedad Limitada Nueva Empresa, Concursal, General Tributaria y de Responsabilidad Medioambiental), op. cit., p. 533, para quienes responden de las deudas posteriores al año de la adopción del acuerdo de reducción del capital, y para las anteriores, incluso para las anteriores a la fecha de entrada en vigor de la responsabilidad prevista inicialmente para las SRL en la Ley 2/1995, de 23 de marzo, siempre que la deuda no estuviere prescrita.

594 DÍAZ ECHEGARAY, J. L.: Deberes y Responsabilidades de los Administradores de Sociedades de Capital, op. cit., pp. 403-404; BATALLER GRAU, J.: “Disolución y Liquidación”, op. cit., p. 2539.

${ }^{595}$ BATALLER GRAU, J.: “Disolución y Liquidación”, op. cit., p. 2539. 
expresamente, como se hizo cuando en la responsabilidad por causa legal de disolución en la redacción inicial del art. 105.5 de la anterior LSRL, se impuso de modo expreso y taxativo una responsabilidad por todas las deudas sociales, cosa que no se hizo al regularse la responsabilidad por causa de disolución de pleno derecho del art. 108 de la LSRL, en que no se extendió la responsabilidad a todas las deudas. Así, cuando se limitó la responsabilidad por causa legal de disolución a las deudas posteriores mediante la Ley 19/2005, de 14 de noviembre, se modificó el art. 105 de la LSRL, pero no hubo necesidad de reformar el art. 108 de la LSRL, y si no se modificó este último es porque en él el legislador no contemplo en ningún momento una responsabilidad por todas las deudas, como sí hizo en el art. 105 de la LSRL ${ }^{596}$.

El administrador social no responderá de todas las deudas sociales, porque el art. 360 de la LSC ha incorporado el régimen jurídico del art. 108 de la LSRL a la nueva ley para hacer extensible esta causa de disolución a todas las sociedades, pero manteniendo el mismo ámbito material u objetivo de responsabilidad recogido en la LSRL, en la que no se impuso una responsabilidad por todas las deudas, por lo que no precisó hacerse esa limitación en la reforma del año 2005.

Partiendo de esta segunda interpretación que mantenemos, cabrían a su vez dos concepciones. En primer lugar, entender que si bien la causa de disolución opera de modo automático con el transcurso del año desde la adopción del acuerdo de reducción del capital social, y comoquiera que al concluir ese plazo se consuma la disolución de pleno derecho que estaba latente, en la medida que la disolución es imputable al administrador social por incumplir sus obligaciones orgánicas, aquél debería responder de modo retroactivo por las deudas posteriores a la adopción del acuerdo de reducción del capital, pese a no ser esa la fecha del acaecimiento de la disolución de pleno derecho. Por el contrario, podría defenderse que estando ante una responsabilidad por deuda ajena por causa imputable al administrador por incumplir éste sus deberes orgánicos, con naturaleza similar a la responsabilidad por deudas del art. 367 de la LSC, debería realizarse una interpretación sistemática de ambos preceptos, para llegar a igual conclusión acerca del contenido de las deudas objeto de responsabilidad, lo que dotaría de la mayor homogeneidad posible a ambas responsabilidades por deuda ajena ante una causa de disolución, sea por causa legal de disolución o por causa de pleno derecho, de

596 FERNÁNDEZ DÍEZ, A.: "Prescripción de la responsabilidad del administrador por deudas de Seguridad Social de la sociedad”, op. cit., p. 437. 
modo que respondería de las deudas posteriores al acaecimiento de la causa de disolución de pleno derecho. No obstante, con esta segunda opción serán menores las deudas exigibles al administrador, ya que a partir de ese momento opera la disolución ipso iuris, con lo que no podría intervenir jurídicamente en el tráfico económico.

Con la finalidad de solventar las dudas existentes y excluir expresamente la responsabilidad por todas las deudas, sería conveniente reformar el precepto legal para recoger expresamente que el administrador no responderá de todas las deudas sociales, sino que al ser una responsabilidad por causa imputable responderá "ope legis", o bien de las deudas posteriores a la adopción de acuerdo de reducción del capital social, o bien de las posteriores al acaecimiento de la causa de disolución.

El administrador social asume una responsabilidad solidaria en las deudas con respecto a la sociedad de capital, que es de carácter personal e ilimitada, respondiendo con todo su patrimonio de las deudas sociales ${ }^{597}$, y en nuestra investigación también de las deudas de Seguridad Social, sean por cotizaciones o por prestaciones de responsabilidad empresarial, con exclusión del recargo de prestaciones, salvo que se le haya impuesto expresamente en la resolución de la entidad gestora (art. 12.4 del RGRSS). Con relación a la derivación del recargo de prestaciones por incumplimientos del empresario o de otras empresas concurrentes en un mismo centro de trabajo de la normativa sobre las condiciones de seguridad y salud (art. 164 del TRLGSS, art. 24. 4 de la Ley 31/1995, de 8 de noviembre, de Prevención de Riesgos Laborales; arts. 42 y 43 del TRLET; y art. 13 de la Orden de 18.1.1996, de aplicación y desarrollo del Real Decreto 1300/1995, de 12 de julio, sobre Incapacidades Laborales de la Seguridad Social) ${ }^{598}$, nos remitimos al

597 RODRÍGUEZ RUIZ DE LA VILLA, D. y HUERTA VIESCA, M. I.: La responsabilidad de los administradores por las deudas de las Sociedades de Capital (en las Leyes de Sociedades Anónimas, de Sociedades de Responsabilidad Limitada, de Sociedad Limitada Nueva Empresa, Concursal, General Tributaria y de Responsabilidad Medioambiental), op. cit., p. 533.

${ }^{598}$ En contratas o subcontratas con prestación de servicios de varias empresas en un mismo lugar o centro de trabajo, la obligación de vigilar las condiciones de seguridad de los trabajadores de las subcontratas, no sólo compete a la empresa subcontratista, sino también a la empresa principal, procediendo la responsabilidad solidaria de ambas en el recargo de prestaciones, si la prestación causada por el trabajador de una subcontrata, se ha causado por incumplimiento la normativa de prevención de riesgos laborales por ambas empresas, aunque no sea una contrata de la propia actividad (Sentencia del TS, Sala Social, 842/2018, 18 Septiembre -Rec. 144/2017-). Para el resto de contratas de la propia actividad, declaran la responsabilidad solidaria las Sentencias de 7.10.2008 rcud. 2426/2007-; 18 enero 2010 -rcud. 3237/2007-; 20 marzo 2012 -rcud. 1470/2011-, entre otras.

Recargo de prestación que es, igualmente, susceptible de que se transmita a la empresa sucesora en la actividad (supuestos de fusión por absorción, cesión de activo y pasivo, escisión societaria, etc.), según la última jurisprudencia que, parte de la doctrina sentada en la STJUE de 5 de marzo de 2015 (Asunto C-343/13), en la que el Tribunal de Luxemburgo consideró que, en la sucesión de empresas por fusión por absorción, se transmite íntegro el activo y pasivo, donde se incluyen las sanciones 
Capítulo I, apartado III.3 y al Capítulo VI, apartados II.2.1 de esta tesis, donde se analiza cuándo es derivable en el procedimiento administrativo de recaudación el recargo por prestaciones, y la Administración de la Seguridad Social competente para la derivación de responsabilidad.

impuestas a la empresa sucedida por incumplimiento de la normativa laboral. Ante esa Sentencia del TJUE nuestro Tribunal Supremo rectificó su anterior doctrina en la que negaba la transmisión empresarial del recargo de prestaciones. Reconoce la transmisión del recargo de prestaciones las Sentencias del TS, Sala Social, de 23 de marzo de 2015 -rcud. 2057/2014-; 14 de abril de 2015 -rcud. 962/2014-; 5 de mayo de 2015 -rcud. 1075/2014-; 2 de noviembre de 2015 -rcud. 3426/2014-; 15 de enero de 2015 -rcud. 1258/2014-; 10 de diciembre de 2015 -rcud. 1012/2014-; 8 de junio de 2016 rcud. 1103/2015-, entre otras muchas. 



\section{IVo CAPÍtulo:}

\section{DERIVACIÓN DE RESPONSABILIDAD POR INCUMPLIMIENTOS DE DEBERES DISOLUTORIOS Y CONCURSALES}

\section{I.- LA RESPONSABILIDAD SOLIDARIA DEL ADMINISTRADOR POR CAUSA LEGAL DE DISOLUCIÓN.}

\section{Régimen Jurídico de la responsabilidad y sus antecedentes normativos.}

La responsabilidad solidaria ex lege del administrador social por incumplimiento de deberes disolutorios, por incumplimiento de los deberes legales ante la concurrencia de una causa legal o estatutaria de disolución, se regula en el actual art. 367 de la LSC.

Es el supuesto más representativo o paradigmático de responsabilidad solidaria ex lege por deudas de Seguridad Social de la sociedad de capital a cargo del administrador social. Esta responsabilidad se introduce por primera vez en nuestro ordenamiento jurídico, mediante la Ley 19/1989, de 25 de julio, de reforma parcial y adaptación de la legislación mercantil a las Directivas de la Comunidad Económica Europea (CEE) en materia de Sociedades ${ }^{599}$.

Según señala la doctrina ${ }^{600}$, esta responsabilidad se introdujo en nuestro Derecho interno en trasposición del art. 17 de la Segunda Directiva Comunitaria en materia de Sociedades, Directiva 77/91/CE, de 13 de diciembre de 1976, "tendente a coordinar, para hacerlas equivalentes, las garantías exigidas en los Estados Miembros a las sociedades, definidas en el párrafo segundo del artículo 58 del Tratado, con el fin de proteger los intereses de los socios y terceros, en lo relativo a la constitución de la sociedad anónima, así como al mantenimiento y modificaciones de su capital"601. Precepto que obligaba a convocar la junta de accionistas en el plazo que se estableciese

\footnotetext{
${ }^{599}$ BOE 27.7.1989.

${ }^{600}$ SÁNCHEZ CALERO, F.: Los administradores en las sociedades de capital, op. cit., p. 443; DÍAZ ECHEGARAY, J. L.: Deberes y responsabilidades de los Administradores de sociedades de Capital, op. cit, p. 373; RODRÍGUEZ RUIZ DE LA VILLA, D. y HUERTA VIESCA, M. I.: La responsabilidad de los administradores por las deudas de las Sociedades de Capital (en las Leyes de Sociedades Anónimas, de Sociedades de Responsabilidad Limitada, de Sociedad Limitada Nueva Empresa, Concursal, General Tributaria y de Responsabilidad Medioambiental), op. cit., p. 43.

${ }^{601}$ DOL núm. 26 de 31.1.1977.
} 
en el Derecho interno, en el supuesto de pérdidas graves, para determinar si procedía la disolución o la adopción de otras medidas, pero que no imponía esa responsabilidad por deudas al administrador social ${ }^{602}$.

Responsabilidad del administrador por deudas sociales del actual art. 367 de la LSC, creada ex novo por nuestro legislador mediante la Ley 19/1989, de 25 de julio, al considerar que era un instrumento eficaz para la protección de los acreedores y para eliminar del tráfico económico las sociedades incursas en causa de disolución, impidiéndose así que siguiesen operando esas sociedades sin adoptarse medidas de remoción, o para en último término lograr una ordenada liquidación societaria. Responsabilidad solidaria por deudas del administrador social que no sólo se contempla para los supuestos de pérdidas graves o cualificadas, ante cuyo acaecimiento la Directiva obligaba a convocar la junta de accionistas, sino que se extiende a todas las causas legales de disolución

Con la introducción de esta modalidad de responsabilidad ex lege del administrador social en nuestro Derecho, se ha dicho con razón ${ }^{603}$, que esta responsabilidad ha desplazado a la responsabilidad civil extracontractual del administrador social regulada en los arts. 236 a 241 de la LSC, ya que los acreedores exigirán la responsabilidad de los mismos a través de esta nueva institución, al ser una responsabilidad formal por el incumplimiento imputable de los deberes del cargo ante la concurrencia de una causa legal de disolución, responsabilidad con menor carga probatoria, al no exigir daño

602 El art. 17 de esa Directiva establecía:

"1. En caso de pérdida grave del capital suscrito, deberá convocarse junta general en un plazo fijado por las legislaciones de los Estados miembros, con el fin de examinar si procede la disolución de la sociedad o adoptar cualquier otra medida .

2. La legislación de un Estado miembro no podrá fijar en más de la mitad del capital suscrito el importe de la pérdida considerada como grave en el sentido del apartado l".

Directiva derogada, y actualmente en vigor con igual contenido el art. 58 de la Directiva 2017/1132, de 14 de junio (DO L 30.7.2017), sobre Aspectos del Derecho de Sociedades, cuyo precepto vuelve a decir:

"Artículo 58. Pérdida grave del capital suscrito:

1. En caso de pérdida grave del capital suscrito, se convocará junta general en un plazo fijado por las legislaciones de los Estados miembros, con el fin de examinar si procede la disolución de la sociedad o adoptar cualquier otra medida.

2. La legislación de un Estado miembro no podrá fijar en más de la mitad del capital suscrito el importe de la pérdida considerada como grave en el sentido del apartado l".

${ }^{603}$ QUIJANO GONZÁLEZ, J.: "La responsabilidad de los administradores por la no disolución de la sociedad y las causas de exoneración”, $R d S$, n. ${ }^{\circ} 19$, año 2002, pp. 73-85. El profesor QUIJANO GONZÁLEZ señala que esta responsabilidad se ha convertido en la vía ordinaria de reclamación del acreedor social contra el administrador social. 
directo al acreedor, ni relación de causalidad, ni culpabilidad en los términos de los arts. 236 y siguientes de la LSC, aunque sí imputabilidad.

\subsection{Régimen jurídico.}

El Régimen Jurídico de esta responsabilidad solidaria del administrador con la sociedad en el pago de las deudas de la sociedad de capital, se establece en el art. 367 de la $\mathrm{LSC}^{604}$, que se complementa con los deberes impuestos a los administradores en los arts. 364 a 366 de la LSC.

Para nuestra doctrina ${ }^{605}$ y jurisprudencia ${ }^{606}$, los presupuestos objetivos determinantes o generadores de esta responsabilidad por deudas del administrador, al amparo del art.

${ }^{604}$ Art. 367 : "Responsabilidad solidaria de los administradores.

1.- Responderán solidariamente de las obligaciones sociales posteriores al acaecimiento de la causa legal de disolución los administradores que incumplan la obligación de convocar en el plazo de dos meses la junta general para que adopte, en su caso, el acuerdo de disolución, así como los administradores que no soliciten la disolución judicial o, si procediere, el concurso de la sociedad, en el plazo de dos meses a contar desde la fecha prevista para la celebración de la junta, cuando ésta no se haya constituido, o desde el día de la junta, cuando el acuerdo hubiera sido contrario a la disolución.

2.- En estos casos las obligaciones sociales reclamadas se presumirán de fecha posterior al acaecimiento de la causa legal de disolución de la sociedad, salvo que los administradores acrediten que son de fecha anterior".

605 BELTRÁN SÁNCHEZ, E.: "La responsabilidad de los administradores por obligaciones sociales", op. cit., pp. 308 y 310; SÁNCHEZ CALERO, F.: Los administradores en las sociedades de capital, op. cit., p. 479; VALPUESTA GASTAMINZA, E. M.: Comentarios a la Ley de Sociedades de Capital, op. cit., p. 948; SANTAELLA SÁEZ, O.: "Cuestiones prácticas de la responsabilidad del administrador societario para responder de las deudas sociales”, en Diario La Ley, n 9403, de 25 de abril de 2019, edición digital

https://diariolaley.laleynext.es/Content/Documento.aspx?params=H4sIAAAAAAAEAMtMS bF1CTEAAiNLI0sLA7Wy1KLizPw8WyMDQ0sDYyNTtbz81NQQF2fb0ryU1LTMvNQUk JLMtEqX OSQyoJU25Ki01S11KT8 GwUg-LhBqSm, p. 9; BATALLER GRAU, J.: "Disolución y Liquidación”, op. cit., p. 2573; QUIJANO GONZÁLEZ, J.: "Responsabilidad de los administradores por no disolución de la sociedad (art. 262.5 TRLSA) (Sentencia de la Audiencia Provincial de Burgos de 24 de julio de 1995)", 1995, op. cit., pp. 269-270; EIZAGUIRRE BERMEJO, J.M.: "Disolución y liquidación: obligaciones", en AA.VV. (Director: SÁNCHEZ CALERO): Comentarios a la Ley de Sociedades Anónimas, Madrid. 1993, p. 82. QUIJANO GONZÁLEZ, J.: "Responsabilidad de los administradores por no disolución de la sociedad (art. 262.5 TRLSA) (Sentencia de la Audiencia Provincial de Burgos de 24 de julio de 1995)”, op. cit., pp. 274-275.

606 Por todas SSTS, Sala Civil, 420/2019, de 15 de julio; 27/2017, de 18 de enero -Rec. 1422/2014-; 246/2015, de 14 de mayo -Rec. 1121/2013-; 395/2012, de 18 de junio; 225/2012, de 13 de abril -Rec. 1018/2009-; 942/2011, de 29 de diciembre -Rec. 1725/2008-; 680/2010, de 10 noviembre. Esta responsabilidad de los administradores se vincula a cualquier causa de disolución (Sentencia del TS, Sala Civil, 246/2015, de 14 de mayo).

En la Sentencia 420/2019, de 15 de julio, se señala que "Para que los administradores sociales deban responder al amparo de lo dispuesto en el art. 367 LSC, se requieren los siguientes requisitos (Sentencias 942/2011, de 29 de diciembre, y 395/2012, de 18 de junio): 1 ) la concurrencia de alguna de las causas de disolución de la sociedad previstas en el art. 363.1 LSC; 2) la omisión por los administradores de la convocatoria de junta general para la adopción de acuerdos de disolución o de remoción de sus causas, o de la solicitud de concurso, o la disolución judicial; 3) el transcurso de dos 
367 de la LSC, son los cinco siguientes: a) concurrencia de alguna causa de disolución prevista en el art. 363 de la LSC; b) la falta de convocatoria de la Junta General en el plazo de dos meses para que adopte el acuerdo de disolución o para la remoción de la causa disolutoria, o alternativamente, de estar ante la causa de disolución por pérdidas y hallarse la sociedad en insolvencia actual, no solicitar el concurso de acreedores; c) en el caso de no haberse constituido la junta, solicitar la disolución judicial en el plazo de dos meses a contar desde la fecha prevista para la celebración de la junta, o, de proceder, solicitar el concurso; d) si se hubiese celebrado la junta, pero no se hubiera adoptado el acuerdo de disolución o el acuerdo hubiese sido contrario, solicitar la disolución judicial en el plazo de dos meses a contar desde el día de la junta, o, de proceder, el concurso; e) imputabilidad al administrador de la conducta pasiva; y f) inexistencia de causa justificadora de la omisión.

Responsabilidad del administrador social aplicable a los tres tipos de sociedades de capital: sociedad anónima, sociedad de responsabilidad limitada y sociedad comanditaria por acciones. Es igualmente aplicable a las Sociedades de Garantía Recíproca (art. 59.2 de la Ley 1/1994, de 11 de marzo, sobre el Régimen Jurídico de las Sociedades de Garantía Recíproca), ya que en el art. 59.2 se declara aplicable el art. 262 apartados 2 a 5 del Real Decreto Legislativo 1564/1989, de 22 de diciembre, antigua LSA, por lo que esa remisión se entenderá a los arts. 364 a 367 de la LSC ${ }^{607}$.

En cambio, esta responsabilidad solidaria no está prevista en la legislación estatal de cooperativas, sí que por el contrario se recoge en alguna normativa autonómica de cooperativas, que no es objeto de esta investigación.

El régimen de responsabilidad de los administradores en las sociedades de capital del art. 367 de la LSC, ha sido criticado por un sector doctrinal ${ }^{608}$, por ser excesivamente

meses desde que concurre la causa de disolución o desde la fecha de la junta contraria a la disolución; 4) la imputabilidad al administrador de la conducta pasiva; y 5) la inexistencia de causa justificadora de la omisión"

607 Las causas de disolución que motivan esa responsabilidad del administrador en la Sociedad de Garantía Recíproca son las siguientes: a) Por la conclusión de la empresa que constituya su objeto o la imposibilidad manifiesta de realizar el fin social, o por la paralización de los órganos sociales, de modo que resulte imposible su funcionamiento; b) Por consecuencia de pérdidas que dejen reducido el patrimonio a una cantidad inferior a las dos terceras partes del capital social, a no ser que este se aumente o se reduzca en la medida suficiente; c) Por reducción del capital social desembolsado o de los recursos propios computables por debajo de las cifras mínimas exigidas en la presente Ley; y d) por causas establecidas en los estatutos sociales (art. 58 de la Ley 1/1994, de 11 de marzo).

608 ALCOVER GARAU, G.: "El ámbito de responsabilidad de los administradores en los nuevos artículos 262.5 de la Ley de Sociedades Anónimas y 105.5 de la Ley de Sociedades de Responsabilidad Limitada", en $R d S$, n 1, 2006, p. 87; VICENT CHULIÁ, F.: "La responsabilidad de 
severo, abogando por su desaparición, al argumentarse que para exigir responsabilidad al administrador es suficiente la responsabilidad por daños a través de la acción individual de responsabilidad.

Será objeto de estudio únicamente la responsabilidad del administrador de las sociedades de capital, no de otras entidades mercantiles diferentes, siendo la causa objeto de especial atención la de pérdidas del patrimonio neto, al ser las que motivan o pueden generar los incumplimientos más frecuentes en materia de deudas de Seguridad Social de la sociedad de capital.

\subsection{Antecedentes normativos.}

La responsabilidad del administrador en el pago de las deudas sociales de la sociedad de capital, de incumplir los deberes disolutorios, regulada en el art. 367 de la LSC, se introduce en nuestro Derecho mediante la Ley 19/1989, de 25 de julio, que, a efectos de esta responsabilidad da nueva redacción a los arts. 150 y 152 de la Ley de Sociedades Anónimas, de 17 de julio de 1951. En el artículo 150 se regulan las causas de disolución y en el artículo 152 los deberes y las responsabilidades del administrador social.

Para conocer cuál es, y ha sido, el contenido y el alcance de la responsabilidad del administrador social por incumplir sus deberes disolutorios, recogeremos en estos antecedentes los preceptos relativos a los deberes que deben de cumplir, y los relativos a las causas de disolución que determinan el nacimiento de la responsabilidad.

Los Deberes de los administradores y el contenido de la responsabilidad solidaria, se establecen en el art. 152 de la Ley de Sociedades Anónimas, de 17 de julio de $1951^{609}$.

los administradores en el concurso", en RDCP, $\mathrm{n}^{\circ} 4,2006$, pp. 44 y ss; SÁNCHEZ CALERO, F.: Los administradores en las sociedades de capital, op. cit., p. 484.

609 “Artículo 152.

1. Transcurrido el término de duración de la sociedad, ésta se disolverá de pleno Derecho, a no ser que con anterioridad hubiese sido expresamente prorrogada e inscrita la prórroga en el Registro Mercantil.

2. Cuando concurra alguna de las causas previstas en los números $3 .^{\circ}, 4 .^{\circ}, 5 .^{\circ}$ y $7 .^{\circ}$ del apartado 1 del artículo 150, la disolución de la sociedad requerirá acuerdo de la junta general constituida con arreglo al artículo 51. Los administradores deberán convocar junta general en el plazo de dos meses, para que adopte el acuerdo de disolución. Cualquier accionista podrá requerir a los administradores para que convoquen la junta, si, a su juicio, existe causa legítima para la disolución.

3. En el caso de la que la junta solicitada no fuese convocada o no pudiese lograrse el acuerdo o éste fuese contrario a la disolución, cualquier interesado podrá solicitar la disolución judicial de la sociedad.

4. Los administradores están obligados a solicitar la disolución judicial de la sociedad cuando el acuerdo social fuese contrario a la disolución o no pudiera ser logrado. 
Se impone por primera vez la responsabilidad solidaria en las deudas de la sociedad si el administrador social incumpliere los deberes que se le imponen ante la concurrencia de una causa legal o estatutaria de disolución (art. 152.5).

En este precepto se impone una responsabilidad solidaria del administrador por incumplir los deberes disolutorios siguientes, en primer lugar, no convocar en el plazo de dos meses a la Junta General para que adopte el acuerdo de disolución, cuando concurran determinadas causas legales o estatutarias de disolución; y, en segundo lugar, de no adoptarse o no celebrarse la junta, o ser el acuerdo contrario, si incumple el deber de solicitar en el plazo de dos meses la disolución judicial.

La obligación del administrador era convocar la Junta General para que ésta adopte el acuerdo de disolución, sin que se contemple la posibilidad de que pudiera evitarse la disolución mediante la adopción de medidas de remoción de la causa, lo que será objeto de reforma posterior.

Las causas de disolución que generaban esos deberes disolutorios eran las recogidas en el art. 150.1, números 3. $.^{\circ} 4 .^{\circ}, 5^{\circ}$ y $7 .^{\circ}$ de la Ley de Sociedades Anónimas, de 17 de julio de 1951.

Las causas que desencadenaban la responsabilidad solidaria del administrador social eran las siguientes: $1^{\circ}$ conclusión de la empresa que constituya su objeto, imposibilidad manifiesta de realizar el fin social o por la paralización de los órganos sociales, de modo que resulte imposible su funcionamiento; $2^{\circ}$ pérdidas que dejen reducido el patrimonio a una cantidad inferior a la mitad del capital social, a no ser que este se aumente o se reduzca en la medida suficiente; $3^{\circ}$ reducción del capital social por debajo del mínimo legal; y $4^{\circ}$ cualquiera otra causa establecida en los estatutos sociales.

Responsabilidad por deudas por causa legal o estatutaria de disolución que podría resultar aplicable al administrador de la sociedad de responsabilidad limitada, en virtud

5. Responderán solidariamente de las obligaciones sociales los administradores que incumplan la obligación de convocar en el plazo de dos meses la junta general, para que adopte, en su caso, el acuerdo de disolución o que no soliciten la disolución judicial de la sociedad en el plazo de dos meses, a contar desde la fecha prevista para la celebración de la Junta, cuando esta no se haya constituido, o desde el día de la Junta, cuando el acuerdo hubiera sido contrario a la disolución.» 
de los artículos 11 y 30 de la Ley de 17 de julio de 1953, que regulaba la Sociedad de Responsabilidad Limitada, según redacción dadas por la Ley 19/1989, de 25 de julio ${ }^{610}$.

No se preveía la responsabilidad solidaria en las deudas por incumplirse los deberes legales de promover la que actualmente se conoce como disolución de pleno derecho, esto es, cuando se haya reducido el capital social por debajo del mínimo legal como consecuencia del cumplimiento de una ley.

En la Disposición Final Primera de la Ley 19/1989, de 25 de julio, se autorizaba al Gobierno para que en un plazo de un año procediese a aprobar mediante Real Decreto Legislativo un nuevo texto refundido de la legislación de sociedades anónimas, aclarando, regularizando y armonizando las diversas disposiciones legales, permitiéndose alterar los capítulos, las secciones de las leyes a refundir, así como fraccionar los artículos y alterar el orden de sus párrafos o apartados. Finalmente, también se autorizaba al Gobierno a aprobar un nuevo texto refundido de la legislación de las sociedades de responsabilidad limitada.

De ese mandato sólo se atiende la autorización para la aprobación del Texto Refundido de la Ley de Sociedades Anónimas, que se aprueba mediante el Real Decreto Legislativo 1564/1989, de 22 de diciembre -en adelante LSA-. Por el contrario, la habitación para la aprobación del texto refundido de las sociedades de responsabilidad limitada caducó sin haberse atendido. En ese nuevo texto refundido se derogaban las disposiciones anteriores, entre ellas, la Ley de 17 de julio de 1951 de Sociedades Anónimas y las reformas introducidas por la Ley 19/1989, de 25 de julio.

En el nuevo Texto Refundido Regulador de las Sociedades Anónimas, aprobado por el Real Decreto Legislativo 1564/1989, de 22 de diciembre, se recogía esa modalidad de responsabilidad solidaria del administrador social en las deudas de la sociedad mercantil en los mismos términos en que se había introducido por la Ley 19/1989. Regulación de responsabilidad solidaria en la sociedad anónima que podría resultar de aplicación a la sociedad limitada en virtud de los arts. 11 y 30 de la Ley de 17 de julio de 1953, durante el período anterior a la entrada en vigor de la Ley 2/1995, de 23 de marzo, reguladora de

\footnotetext{
${ }^{610}$ En el art. 11 se hacía una remisión a la legislación de sociedades anónimas al indicarse, que: "Será de aplicación a los administradores de la sociedad de responsabilidad limitada lo dispuesto para los administradores de la sociedad anónima, salvo lo establecido en esta Ley". No se preveía nada en contrario.

En el art. 30 se señalaba: "La sociedad de responsabilidad limitada se disolverá por las mismas causas y con los mismos efectos que la sociedad anónima".
} 
la Sociedad de Responsabilidad Limitada -en adelante LSRL- ${ }^{611}$, y que derogó la Ley de 1953. Con esta nueva Ley 2/1995, de 23 de marzo, ya se recoge expresamente una regulación propia sobre esta responsabilidad solidaria del administrador, sin necesidad de hacerse una remisión normativa a la legislación de las sociedades anónimas.

En la LSA se recogían los deberes disolutorios en el art. 262, y la responsabilidad solidaria del administrador en su apartado 5.

En el art. 262.5 se establecía que:

"Responderán solidariamente de las obligaciones sociales los Administradores que incumplan la obligación de convocar en el plazo de dos meses la Junta general, para que adopte, en su caso, el acuerdo de disolución o que no soliciten la disolución judicial de la Sociedad en el plazo de dos meses, a contar desde la fecha prevista para la celebración de la Junta, cuando ésta no se haya constituido, o desde el día de la Junta, cuando el acuerdo hubiera sido contrario a la disolución".

Los deberes de los administradores y el contenido de la responsabilidad tenían el mismo contenido que en anterior Ley de Sociedades Anónimas de 17 de julio de 1951, en redacción dada por la Ley 19/1989, ya que estamos ante un Texto Refundido. En el art. 262 de la LSA se establecían esos deberes y la responsabilidad del administrador ${ }^{612}$.

Las causas de disolución generadoras de la responsabilidad se recogían en el art. 260.1 de la LSA, y eran las mismas, esto es: $1^{\circ}$ conclusión de la empresa que constituya su objeto, imposibilidad manifiesta de realizar el fin social o por la paralización de los órganos sociales de modo que resulte imposible su funcionamiento; $2^{\circ}$ pérdidas que

${ }^{611}$ BOE del 24.3.1995

612 "Art. 262. Acuerdo social de disolución:

1. Cuando concurra alguna de las causas previstas en los números $3 .{ }^{\circ}, 4 .^{\circ}, 5 .^{\circ}$ y $7 .^{\circ}$ del apartado 1 del artículo 260, la disolución de la Sociedad requerirá acuerdo de la Junta General constituida con arreglo al artículo 102.

2. Los Administradores deberán convocar Junta General en el plazo de dos meses para que adopte el acuerdo de disolución. Cualquier accionista podrá requerir a los Administradores para que convoque la Junta si, a su juicio, existe causa legítima para la disolución.

3. En el caso de que la Junta solicitada no fuese convocada o no pudiese lograrse el acuerdo o éste fuese contrario a la disolución, cualquier interesado podrá solicitar la disolución judicial de la Sociedad.

4. Los Administradores están obligados a solicitar la disolución judicial de la Sociedad cuando el acuerdo social fuese contrario a la disolución o no pudiera ser logrado.

5. Responderán solidariamente de las obligaciones sociales los Administradores que incumplan la obligación de convocar en el plazo de dos meses la Junta general, para que adopte, en su caso, el acuerdo de disolución o que no soliciten la disolución judicial de la Sociedad en el plazo de dos meses, a contar desde la fecha prevista para la celebración de la Junta, cuando ésta no se haya constituido, o desde el día de la Junta, cuando el acuerdo hubiera sido contrario a la disolución". 
dejen reducido el patrimonio a una cantidad inferior a la mitad del capital social, a no ser que este se aumente o se reduzca en la medida suficiente; $3^{\circ}$ reducción del capital social por debajo del mínimo legal; y $4^{\circ}$ cualquiera otra causa establecida en los estatutos sociales.

No se preveía tampoco la responsabilidad solidaria por disolución de pleno derecho por reducción del capital por debajo del mínimo legal como consecuencia del cumplimiento de una ley, porque estamos ante un Texto Refundido.

Con la nueva $\operatorname{LSRL}^{613}$ se regula ya expresamente para ese tipo societario la responsabilidad del administrador por incumplimiento de deberes disolutorios. En el art. 105.5 se establecía:

"El incumplimiento de la obligación de convocar Junta General o de solicitar la disolución judicial determinará la responsabilidad solidaria de los administradores por todas las deudas sociales".

La gran novedad de este precepto consistía en que, ante las dudas que planteaba la redacción del art. 262.5 de la LSA, acerca del contenido o ámbito temporal de las deudas objeto de responsabilidad, ahora se quiere dejar claro por el legislador, que una vez se incumplan los deberes legales, la responsabilidad del administrador social es por todas las deudas sociales que no estén prescritas, sean éstas anteriores o posteriores al acaecimiento de la causa de disolución. Cuestión ésta que ante la severidad y rigurosidad de la opción legislativa, recibida con críticas en la doctrina e incluso en la jurisprudencia $^{614}$, va a ser objeto posteriormente de una reforma legal.

Diferencia de menor entidad es la alusión a las deudas sociales en la Ley 2/1995, frente a obligaciones sociales a que se refiere el art. 262.5 de la LSA, pero tanto en un caso como en otro, estamos ante una mera diferenciación semántica, sin ninguna incidencia

${ }^{613}$ BOE 24.03.1995.

${ }^{614}$ En la Sentencia del TS, Sala Civil, 1219/2004, de 16 de diciembre -Rec. 3375/1998-, se habla de solución indudablemente dura para los administradores, cuando con relación a las deudas objeto de responsabilidad en la sociedad anónima, se concluye "en referencia a las obligaciones sociales de las que responden los demandados, si bien en teoría puede discutirse si responden solamente de las contraídas después de la concurrencia de la causa de disolución o bien de las contraídas antes de la concurrencia de la causa y vencidas después o también de las contraídas y vencidas antes de la concurrencia de la causa, ante la falta de explicitación del artículo 262.5 de la nueva Ley, hay que llegar a la conclusión de que los demandados responden de todas las obligaciones de la sociedad, solución indudablemente dura para los administradores, pero que responde al deseo de la nueva Ley de obligar a los administradores a solicitar la disolución de aquellas sociedades anónimas cuya apariencia jurídica no corresponda a su situación real” 
en el ámbito objeto de responsabilidad, ya que se reconoce que la responsabilidad es por todas las obligaciones, no sólo contractuales, sino también de las obligaciones que nacen de la ley, de un ilícito o un cuasicontrato (Fundamento de Derecho Quinto de la Sentencia TS, Sala Civil, 1219/2004, de 16 de diciembre -Rec. 3375/1998-).

En el art. 105 de la $\operatorname{LSRL}^{615}$, se regulaban los deberes y el contenido de la responsabilidad del administrador. Se imponía a los administradores sociales el deber de convocar en el plazo de dos meses a la Junta General para que adopte el acuerdo de disolución, pudiendo ésta no sólo pronunciarse sobre la disolución, sino alternativamente acordar medidas de remoción de la causa de disolución. De no haber adoptado la junta el acuerdo de disolución sin haberse removido la causa, o de haber sido contrario a la disolución, o si no llegó a celebrarse la junta, el administrador social deberá en el plazo de dos meses siguientes solicitar la disolución judicial de la sociedad, de modo que el incumplimiento de la obligación de convocar la Junta General o de solicitar la disolución judicial determinaba la responsabilidad solidaria de los administradores por todas las deudas sociales.

Es con esta LSRL cuando se contempla ya la posibilidad de que la Junta General pueda adoptar medidas alternativas a la disolución, como es la remoción o superación de la causa de disolución para permitir la continuidad de la actividad empresarial, sin tener imperativamente que disolverse la sociedad.

Las causas de disolución que motivaban la responsabilidad se recogían en el art. 104 en las letras c) a g) del apartado 1. Eran las siguientes: $1^{\circ}$ Por la conclusión de la empresa

615 "Artículo 105. Acuerdo de disolución:

1. En los casos previstos en las letras c) a g) del apartado 1 y en el apartado 2 del artículo anterior, la disolución requerirá acuerdo de la Junta General adoptado por la mayoría a que se refiere el apartado 1 del artículo 53. Los administradores deberán convocar la Junta General en el plazo de dos meses para que adopte el acuerdo de disolución. Cualquier socio podrá solicitar de los administradores la convocatoria si, a su juicio, concurriera alguna de dichas causas de disolución.

2. La Junta General podrá adoptar el acuerdo de disolución o aquél o aquéllos que sean necesarios para la remoción de la causa.

3. Si la Junta no fuera convocada, no se celebrara, o no adoptara alguno de los acuerdos previstos en el apartado anterior, cualquier interesado podrá instar la disolución de la sociedad ante el Juez de Primera Instancia del domicilio social. La solicitud de disolución judicial deberá dirigirse contra la sociedad.

4. Los administradores están obligados a solicitar la disolución judicial de la sociedad cuando el acuerdo social fuese contrario a la disolución o no pudiera ser logrado. La solicitud habrá de formularse en el plazo de dos meses a contar desde la fecha prevista para la celebración de la Junta, cuando ésta no se haya constituido, o desde el día de la Junta, cuando el acuerdo hubiera sido contrario a la disolución o no se hubiera adoptado.

5. El incumplimiento de la obligación de convocar Junta General o de solicitar la disolución judicial determinará la responsabilidad solidaria de los administradores por todas las deudas sociales". 
que constituya su objeto, por imposibilidad manifiesta de conseguir el fin social, o por la paralización de los órganos sociales de modo que resulte imposible su funcionamiento; $2^{\circ}$ por falta de ejercicio de la actividad o actividades que constituyan el objeto social durante tres años consecutivos; $3^{\circ}$ por consecuencia de pérdidas que dejen reducido el patrimonio contable a menos de la mitad del capital social, a no ser que éste se aumente o se reduzca en la medida suficiente (se habla de patrimonio contable); $4^{\circ}$ por reducción del capital social por debajo del mínimo legal que no haya sido por mandato de una ley; y $5^{\circ}$ por cualquier otra causa establecida en los estatutos.

Se introduce por primera vez, como causa específica de la sociedad de responsabilidad limitada, la falta de ejercicio de la actividad durante tres años consecutivos, causa de disolución que no se recogía en la LSA. Otra novedad es que, por primera vez, se introduce un nuevo régimen jurídico de disolución, la disolución de pleno derecho (art. 108 LSRL), que tiene lugar cuando la reducción del capital social por debajo del mínimo legal sea consecuencia del cumplimiento de una ley, de modo que, si esa reducción no es fruto de una ley, estaremos ante una causa legal de disolución ordinaria, pero no ante una disolución de pleno derecho. Novedad que no se recoge en la LSA, donde la reducción del capital social por debajo del mínimo legal se sujeta a la disolución ordinaria, no contemplándose la disolución de pleno derecho.

La responsabilidad de los administradores por deudas sociales ante el incumplimiento de sus deberes legales, tanto en el contenido de la responsabilidad, como en las causas de disolución, ha tenido tres reformas fundamentales antes de la actual LSC. La primera fue la reforma realizada por la Ley Concursal, la segunda la efectuada por la Ley 19/2005, de 14 de noviembre, que limita la responsabilidad del administrador a las deudas posteriores a la causa de disolución, aunque recoge una presunción iuris tantum entendiendo que todas las deudas son anteriores, salvo prueba en contrario, y el tercer hito reformista de menor relevancia, tuvo lugar con la Ley 16/2007, de 4 de julio. Examinemos brevemente esas reformas para ir comprendiendo el alcance sucesivo del contenido de la responsabilidad del administrador social.

La Ley 22/2003, de 9 de julio, Ley Concursal ${ }^{616}$, modificó el contenido de los deberes y de la consiguiente responsabilidad de los administradores, tanto para las sociedades anónimas como para las de responsabilidad limitada. En materia del contenido de la

${ }^{616}$ BOE del 10.7.2003. 
responsabilidad se modifica el art. 262.5 de la LSA y el art. 105.5 de la LSRL. Se modificó el art. 262.5 de la LSA sobre los presupuestos de la responsabilidad solidaria del administrador, responsabilidad que seguiría surgiendo si se incumple alguno de los dos deberes ( $1^{\circ}$ deber: convocatoria de la Junta General, y $2^{\circ}$ deber sucesivo; solicitud judicial de la disolución), pero se reforma el contenido del segundo deber, ya que, de no celebrarse la junta, o de no haber adoptado el acuerdo pertinente, el administrador deberá solicitar la disolución judicial o el concurso de acreedores si la sociedad fuese insolvente, en casos de pérdidas cualificadas que dejasen reducido el patrimonio a la mitad del capital social. De este modo, se imponía la responsabilidad solidaria tanto por no cumplir los deberes disolutorios, como por no solicitar el concurso de acreedores de ser la sociedad insolvente como consecuencia de pérdidas cualificadas. Pero la redacción no era la misma para ambas sociedades, para la sociedad anónima, los administradores tenían el deber de convocar en el plazo de dos meses a la junta para que adoptase el acuerdo de disolución, y si ésta no adoptó ese acuerdo, si fuese contrario a la disolución o al concurso, o si no se llegó a constituirse, los administradores dentro de los dos meses siguientes a la fecha de la junta deberían solicitar la disolución judicial o el concurso, si procediere éste. En la sociedad de responsabilidad limitada, la responsabilidad se desencadenaba si no se convocaba la junta, o si no se solicitaba la disolución judicial o el concurso de proceder éste.

Quedaba redactado el art. 262.5 de la LSA del siguiente modo.

"5. Responderán solidariamente de las obligaciones sociales los administradores que incumplan la obligación de convocar en el plazo de dos meses la Junta General para que adopte, en su caso, el acuerdo de disolución, así como los administradores que no soliciten la disolución judicial o, si procediere, el concurso de la sociedad, en el plazo de dos meses a contar desde la fecha prevista para la celebración de la junta, cuando ésta no se haya constituido, o desde el día de la junta, cuando el acuerdo hubiera sido contrario a la disolución o al concurso."

El art. 105.5 LSRL, queda redactado del siguiente modo:

"5. El incumplimiento de la obligación de convocar Junta General o de solicitar la disolución judicial o, si procediera, el concurso de acreedores de la 
sociedad determinará la responsabilidad solidaria de los administradores por todas las deudas sociales."

Mediante la Ley Concursal se estableció para las sociedades anónimas y para las sociedades de responsabilidad limitada, que la declaración de concurso de acreedores no era por sí misma causa de disolución, pero que, si en el procedimiento concursal se produjera la apertura de la fase de liquidación la sociedad quedaría automáticamente disuelta (art. 260.2 LSA y art. 104.2 LSRL). Se modifica la causa de disolución por pérdidas cualificadas, para establecer que procedía la solicitud de la declaración de concurso, en lugar de la disolución, cuando por pérdidas cualificadas se redujese el patrimonio a una cantidad inferior a la mitad del capital, siempre que como consecuencia de ello la sociedad deviniese insolvente (Reforma del art. 260.1.4. ${ }^{\circ}$ de la LSA y art. 104.1. apartado e), de la LSRL). Modificación ésta importante, ya que de concurrir simultáneamente causa de disolución y de concurso, primaba el régimen jurídico concursal sobre la disolución.

Igualmente se modifican en la Ley Concursal los deberes de los administradores (art. 262, apartados 2 y 4 de la LSA y art. 105.1 de la LSRL). Modificación de los deberes que no tenía igual contenido en ambos tipos societarios. Con relación al primer deber, en las sociedades anónimas ${ }^{617}$ se establecía que los administradores deberían convocar la Junta General en el plazo de dos meses para que adoptase el acuerdo de disolución, pero se les facultaba, no se les obligaba, para que solicitasen la declaración de concurso,

617 “Artículo 262 LSA. Acuerdo social de disolución:

1. Cuando concurra alguna de las causas previstas en los números $3^{\circ}, 4^{\circ}, 5^{\circ}$ y $7^{o}$ del apartado 1 del artículo 260, la disolución de la sociedad requerirá acuerdo de la junta general constituida con arreglo al artículo 102.

2. Los administradores deberán convocar Junta General en el plazo de dos meses para que adopte el acuerdo de disolución.

Asimismo podrán solicitar la declaración de concurso por consecuencia de pérdidas que dejen reducido el patrimonio neto a una cantidad inferior a la mitad del capital social, a no ser que éste se aumente o se reduzca en la medida suficiente, siempre que la referida reducción determine la insolvencia de la sociedad, en los términos a que se refiere el artículo 2 de la Ley 22/ 2003, de 9 de julio, Concursal.

Cualquier accionista podrá requerir a los administradores para que se convoque la Junta si, a su juicio, existe causa legítima para la disolución, o para el concurso».

3. En el caso de que la junta solicitada no fuese convocada o no pudiese lograrse el acuerdo o éste fuese contrario a la disolución, cualquier interesado podrá solicitar la disolución judicial de la sociedad.

4. Los administradores están obligados a solicitar la disolución judicial de la sociedad cuando el acuerdo social fuese contrario a la disolución o no pudiera ser logrado. La solicitud habrá de formularse en el plazo de dos meses a contar desde la fecha prevista para la celebración de la junta, cuando ésta no se haya constituido, o desde el día de la junta, cuando el acuerdo hubiera sido contrario a la disolución o no se hubiera adoptado". 
si las pérdidas hubieren reducido el patrimonio a una cantidad inferior a la mitad del capital y frutos de las mismas la mercantil incurriera en insolvencia. En cambio, en las sociedades de responsabilidad limitada ${ }^{618}$ se establecía que cuando concurriese causa de disolución se requería el acuerdo de la Junta General sobre la disolución o el concurso, debiendo los administradores convocarla para que se pronunciase sobre esas dos medidas (la disolución o el concurso), pero la LSRL no se les facultaba para solicitar el concurso.

Para ambos tipos societarios, en el supuesto de que la junta no adoptase ninguno de esos acuerdos, los administradores estaban obligados en los dos meses siguientes a cumplir con el segundo deber subsidiario -solicitar la disolución judicial-, pero no se aludía a la solicitud de concurso, solicitud ésta que, pese a ese silencio, sería exigible en virtud de los establecido en el art. 5 de la Ley Concursal, ya que de ser la sociedad insolvente deberá solicitarse el concurso. Solicitud del concurso de acreedores, que, por el contrario, sí se establecía al regularse el alcance de la responsabilidad de los administradores en los arts. 262.5 de la LSA y 105.5 de la LSRL, donde para cumplir con el segundo deber se imponía a los administradores la obligación de solicitar la disolución judicial, o, de proceder, el concurso de acreedores.

Con no muy buena técnica jurídica, al regularse el alcance de los deberes del administrador, por un lado, se prevé la solicitud del concurso en el cumplimiento del primer deber, pero no se alude a la obligación de solicitar el concurso, cuando se delimita el contenido del segundo deber. Por el contrario, al regularse el régimen jurídico del alcance de la responsabilidad del administrador, dentro del primer deber, se

618 “Artículo 105 LSRL. Acuerdo de disolución:

1. En los casos previstos en los párrafos c) a g) del apartado 1 del artículo anterior, la disolución, o la solicitud de concurso, requerirá acuerdo de la Junta General adoptado por la mayoría a que se refiere el apartado 1 del artículo 53. Los administradores deberán convocar la Junta General en el plazo de dos meses para que adopte el acuerdo de disolución o inste el concurso. Cualquier socio podrá solicitar de los administradores la convocatoria si, a su juicio, concurriera alguna de dichas causas de disolución, o concurriera la insolvencia de la sociedad, en los términos a que se refiere el artículo 2 de la Ley Concursal.

2. La Junta General podrá adoptar el acuerdo de disolución o aquél o aquéllos que sean necesarios para la remoción de la causa.

3. Si la Junta no fuera convocada, no se celebrara, o no adoptara alguno de los acuerdos previstos en el apartado anterior, cualquier interesado podrá instar la disolución de la sociedad ante el Juez de Primera Instancia del domicilio social. La solicitud de disolución judicial deberá dirigirse contra la sociedad.

4. Los administradores están obligados a solicitar la disolución judicial de la sociedad cuando el acuerdo social fuese contrario a la disolución o no pudiera ser logrado. La solicitud habrá de formularse en el plazo de dos meses a contar desde la fecha prevista para la celebración de la Junta, cuando ésta no se haya constituido, o desde el día de la Junta, cuando el acuerdo hubiera sido contrario a la disolución o no se hubiera adoptado". 
establece la obligación de convocar la junta, sin referirse a la solicitud del concurso, y en el segundo deber, en cambio, sí se alude a solicitar la disolución judicial o el concurso.

Con relación a las causas de disolución se modifica la causa de pérdidas cualificadas tanto en la $\operatorname{LSA}^{619}$ como en la LSRL ${ }^{620}$, para establecer que es causa de disolución las pérdidas que dejen reducido el patrimonio a una cantidad inferior a la mitad del capital social, a no ser que éste se aumente o se reduzca en la medida suficiente, y siempre que no sea procedente solicitar la declaración de concurso conforme a lo dispuesto en la Ley Concursal. Para la SRL, se establecía igual contenido, pero se especificaba que el patrimonio era el patrimonio contable. La única modificación fue hacer referencia expresa a la ley concursal.

La Ley 19/2005, de 14 de noviembre, sobre la Sociedad Anónima Europea domiciliada en España, fue la que introdujo la última reforma acerca del contenido de la responsabilidad de los administradores, al redactar nuevamente los arts. 262.5 de la LSA y 105.5 dela LSRL, para recoger la misma redacción en ambos tipos de sociedades, donde se establecen dos aspectos novedosos de especial relevancia. Por un lado, se señala que la responsabilidad solidaria de los administradores se limitaba a las obligaciones sociales posteriores al acaecimiento de la causa legal de disolución, si incumplían sus deberes. Se limitaba así la responsabilidad a las deudas posteriores a la causa de disolución, frente a la regulación precedente que se extendía a todas las deudas sin limitación alguna según la interpretación judicial dominante. Pero, por otro lado, se establece la presunción iuris tantum al considerar de fecha posterior todas las deudas reclamadas, debiendo acreditar el administrador que son de fecha anterior, con lo que se invierte el onus probandi.

\footnotetext{
619 “Artículo 260. Causas de disolución.

(...)

$4^{\circ}$ Por consecuencia de pérdidas que dejen reducido el patrimonio neto a una cantidad inferior a la mitad del capital social, a no ser que éste se aumente o se reduzca en la medida suficiente, y siempre que no sea procedente solicitar la declaración de concurso conforme a lo dispuesto en la Ley Concursal".

e) Por consecuencia de pérdidas que dejen reducido el patrimonio contable a menos de la mitad del capital social, a no ser que éste se aumente o se reduzca en la medida suficiente, y siempre que no sea procedente solicitar la declaración de concurso conforme a lo dispuesto en la Ley Concursal. (...)".
} 
II PARTE. IV ${ }^{\circ}$ CAPÍTULO

Los artículos 265.5 de la LSA y 105.5 de la LSRL, quedaron redactados de este modo:

«5. Responderán solidariamente de las obligaciones sociales posteriores al acaecimiento de la causa legal de disolución los administradores que incumplan la obligación de convocar en el plazo de dos meses la junta general para que adopte, en su caso, el acuerdo de disolución, así como los administradores que no soliciten la disolución judicial o, si procediere, el concurso de la sociedad, en el plazo de dos meses a contar desde la fecha prevista para la celebración de la junta, cuando ésta no se haya constituido, o desde el día de la junta, cuando el acuerdo hubiera sido contrario a la disolución o al concurso. En estos casos las obligaciones sociales reclamadas se presumirán de fecha posterior al acaecimiento de la causa legal de disolución de la sociedad, salvo que los administradores acrediten que son de fecha anterior.»

Como puede apreciarse tras esas reformas legales, no tenían igual contenido los deberes establecidos en el art. 262 apartados 2 y 4 de la LSA y art. 105 apartados 1 a 4 de la LSRL, con relación al contenido de la responsabilidad del administrador del art. 262.5 de la LSA y art. 105.5 de la LSRL. Redacción legislativa dispar de deberes y contenido de la responsabilidad que se mantiene en la actual regulación de la LSC.

Tras esas dos reformas legales, el legislador no aludía en los mismos términos al cumplimiento de los dos deberes desencadenantes de la responsabilidad, ya que se hacía de modo distinto, según se esté regulando el contenido de los deberes (art. 262 apartados 1 a 4 de la LSA y art. 105 apartados 1 a 4 de la LSRL), o según se prescriba el contenido de la responsabilidad de los administradores (art. 262.5 de la LSA y art. 105.5 LSRL). Por un lado, en la regulación de los deberes del administrador, en el art. 262 apartados 2 y 4 de la LSA, se imponía a éstos el deber u obligación de convocar la junta dentro de los dos meses siguientes a la causa disolución, facultándoles para solicitar el concurso de acreedores, y, en segundo lugar, de no adoptar la junta el acuerdo, ser contrario o no haberse reunido, se les imponía la obligación de solicitar en los dos meses siguientes la disolución judicial, pero no el concurso. Por el contrario, a efectos de la responsabilidad de los administradores (art. 262.5 de la LSA y art. 105 de la LSRL), deben convocar la junta (primer deber), sin aludirse a solicitar el concurso, y si esta no se reúne o no adopta los acuerdos pertinentes, en los dos meses siguientes deben solicitar la disolución judicial o, ahora sí, el concurso, de proceder éste (segundo deber). 
Obsérvese, por otro lado, la diferente regulación y contenido de las obligaciones del administrador ante una causa de disolución y de concurso, en la sociedad anónima y en la sociedad de responsabilidad limitada, tras esa reforma legal. En la sociedad anónima, los administradores cuando concurran causa de disolución, estaban obligados a convocar la junta para que adoptase medidas correctoras de la causa o el acuerdo de disolución, pero estaban facultados para solicitar el concurso, cuando la sociedad fuese insolvente de concurrir la causa de disolución por pérdidas cualificadas (patrimonio neto por debajo de la mitad del capital). Por el contrario, en la sociedad de responsabilidad limitada deberían convocar la junta para que ésta adopte los acuerdos de disolución o para instar el concurso de ser la sociedad insolvente. En ambas sociedades, de no adoptar esos acuerdos, o no haberse reunido la junta, los administradores deberían en los dos meses siguientes solicitar la disolución judicial.

A partir de esta doble reforma legal, se produce una descoordinación de obligaciones entre esos preceptos, que se mantiene en la actual LSC, en los arts. 365 y 366 al establecerse el régimen jurídico de los deberes, y en el art. 367 al regular el contenido de la responsabilidad, ya que en el art. 367 se impone la obligación de solicitar el concurso, de ser la sociedad insolvente, en el momento de tener que cumplir el segundo deber, esto es cuando, la junta no adoptó el acuerdo pertinente, o no se celebró la misma, pero no en el momento de cumplir el primer deber (convocatoria de la junta); mientras que al regular los deberes (arts. 365 y 366 de la LSC), dentro del primer deber, los administradores sólo están obligados a convocar la junta para que ésta adopte el acuerdo de disolución, o si la sociedad fuere insolvente para que ésta inste el concurso (art. 365 LSC); mientras que dentro del segundo deber, de ser el acuerdo de la junta contrario, o no haberse celebrado, en el art. 366.2 de la LSC se obliga a los administradores a solicitar la disolución judicial, y no se alude a la solicitud de concurso.

Esta disfunción o descoordinación es prueba de una deficiente técnica legislativa, que planteará problemas interpretativos, que abordaremos en apartados posteriores de este capítulo. Por un lado, si ante la causa de pérdidas cualificadas concurriendo insolvencia, los administradores debían solicitar el concurso ante el juez de lo mercantil, o convocar la junta. Por otro lado, en el caso de ser la sociedad insolvente -concurriendo o no conjuntamente con la causa de disolución por pérdidas-, si responden solidariamente de 
las deudas sociales de no solicitar los administradores el concurso, o si la solicitud de concurso le libera de la responsabilidad solidaria del art. 367 de la LSC.

Esos antecedentes tendrán importancia para interpretar la voluntas legislatoris, especialmente a la hora de dilucidar si concurriendo simultáneamente insolvencia y pérdidas cualificadas, deben solicitar el concurso o convocar la junta, y a la hora de estimar o no aplicable la responsabilidad por deudas si no solicitan el concurso.

La tercera reforma tuvo lugar mediante la Ley 16/2007, de 4 de julio, de reforma y adaptación de la legislación mercantil en materia contable para su armonización internacional con base en la normativa de la Unión Europea ${ }^{621}$. Fue una reforma de contenido menor en la sociedad anónima, para cambiar "patrimonio" por "patrimonio neto", y "Ley concursal" por la referencia expresa a la fecha y número de la Ley Concursal. Para ello, se modifica, por un lado, el art. 260 apartado $1.4 .^{\circ}$ sobre la causa de disolución por pérdidas cualificadas y el art. 262 apartado 2 de la LSA. En la sociedad de responsabilidad limitada con igual finalidad se modifica el art. 104.1.e) de la LSRL, para referirse al "patrimonio neto", y ya no al "patrimonio contable", en la causa de disolución por pérdidas cualificadas.

En este sentido el art. 260 apartado $1.4^{\circ}$ de la LSA, se modificó para aludir al "patrimonio neto", frente a la redacción anterior que sólo hablaba de "patrimonio", y para cambiar la alusión a la Ley Concursal, por “Ley 22/2003, de 9 de julio, Concursal”. Quedó redactado tras la Ley 16/2007, como sigue:

«4. ${ }^{\circ}$ Por consecuencia de pérdidas que dejen reducido el patrimonio neto a una cantidad inferior a la mitad del capital social, a no ser que éste se aumente o se reduzca en la medida suficiente, y siempre que no sea procedente solicitar la declaración de concurso conforme a lo dispuesto en la Ley 22/2003, de 9 de julio, Concursal.»

Paralelamente se reforma el apartado 2 del artículo 262 de la LSA, para cambiar la referencia a "la Ley Concursal", por "artículo 2 de la Ley 22/2003, de 9 de julio, Concursal”, y "patrimonio" por "patrimonio neto". Quedaba ese apartado redactado así:

${ }^{621}$ BOE 5.7.2007. 
«2. Los administradores deberán convocar Junta General en el plazo de dos meses para que adopte el acuerdo de disolución.

Asimismo podrán solicitar la declaración de concurso por consecuencia de pérdidas que dejen reducido el patrimonio neto a una cantidad inferior a la mitad del capital social, a no ser que éste se aumente o se reduzca en la medida suficiente, siempre que la referida reducción determine la insolvencia de la sociedad, en los términos a que se refiere el artículo 2 de la Ley 22/2003, de 9 de julio, Concursal.

Cualquier accionista podrá requerir a los administradores para que se convoque la Junta si, a su juicio, existe causa legítima para la disolución, o para el concurso.»

La Ley 16/2007, de 4 de julio, modificaba el art. 104.1.e. de la LSRL, de la causa de disolución por pérdidas, para aludir al "patrimonio neto", quedando redactado:

«e) Por consecuencia de pérdidas que dejen reducido el patrimonio neto a una cantidad inferior a la mitad del capital social, a no ser que éste se aumente o se reduzca en la medida suficiente, y siempre que no sea procedente solicitar la declaración de concurso conforme a lo dispuesto en la Ley 22/2003, de 9 de julio, Concursal.»

Finalmente, también se redactó nuevamente el art. 142 apartado 1.a), sobre causa de disolución por pérdidas de la Sociedad Nueva Empresa, para aludir al patrimonio neto. Sociedad Nueva Empresa introducida como modalidad de Sociedad de Responsabilidad Limitada por la Ley 7/2003, de 1 de abril. Quedó redactado como sigue:

«a) Por consecuencia de pérdidas que dejen reducido el patrimonio neto a una cantidad inferior a la mitad del capital social durante al menos seis meses, a no ser que se restablezca el patrimonio neto en dicho plazo.»

La Ley 3/2009, de 3 de abril, sobre modificaciones estructurales de las Sociedades Mercantiles $^{622}$, suprimió la fusión o escisión total de la sociedad, como causa de disolución de la sociedad anónima.

${ }^{622}$ BOE del 4.4.2009. 
Con esa última reforma legal, quedaron determinadas las causas de disolución y los deberes de los administradores en las sociedades anónimas ${ }^{623}$ y sociedades de responsabilidad limitada ${ }^{624}$, a partir de cuya regulación se refundieron, armonizaron y

${ }^{623}$ Causas de disolución de la sociedad anónima. Art. 260 LSA:

"Artículo 260. Causas de disolución

1. La sociedad anónima se disolverá:

$1^{\circ}$ Por acuerdo de la junta general, adoptado con arreglo al artículo 103.

$2^{\circ}$ Por cumplimiento del término fijado en los estatutos.

$3^{\circ}$ Por la conclusión de la empresa que constituya su objeto o la imposibilidad manifiesta de realizar el fin social o por la paralización de los órganos sociales, de modo que resulte imposible su funcionamiento.

$4^{o}$ Por consecuencia de pérdidas que dejen reducido el patrimonio neto a una cantidad inferior a la mitad del capital social, a no ser que éste se aumente o se reduzca en la medida suficiente, y siempre que no sea procedente solicitar la declaración de concurso conforme a lo dispuesto en la Ley 22/2003, de 9 de julio, Concursal.

$5^{\circ}$ Por reducción del capital social por debajo del mínimo legal.

$6^{\circ}(\sin$ contenido $)$.

$7^{\circ}$ Por cualquier otra causa establecida en los estatutos.

2. La declaración de concurso no constituirá, por sí sola, causa de disolución, pero si en el procedimiento se produjera la apertura de la fase de liquidación la sociedad quedará automáticamente disuelta. En este último caso, el juez del concurso hará constar la disolución en la resolución de apertura y, sin nombramiento de liquidadores, se realizará la liquidación de la sociedad conforme a lo establecido en el Capítulo II del Título V de la Ley Concursal".

Deberes y responsabilidad del administrador en la sociedad anónima. Art. 262 LSA:

"Artículo 262. Acuerdo social de disolución:

1. Cuando concurra alguna de las causas previstas en los números $3^{\circ}, 4^{\circ}, 5^{\circ}$ y $7^{\circ}$ del apartado 1 del artículo 260, la disolución de la sociedad requerirá acuerdo de la junta general constituida con arreglo al artículo 102.

2. Los administradores deberán convocar Junta General en el plazo de dos meses para que adopte el acuerdo de disolución.

Asimismo podrán solicitar la declaración de concurso por consecuencia de pérdidas que dejen reducido el patrimonio neto a una cantidad inferior a la mitad del capital social, a no ser que éste se aumente o se reduzca en la medida suficiente, siempre que la referida reducción determine la insolvencia de la sociedad, en los términos a que se refiere el artículo 2 de la Ley 22/2003, de 9 de julio, Concursal.

Cualquier accionista podrá requerir a los administradores para que se convoque la Junta si, a su juicio, existe causa legítima para la disolución, o para el concurso».

3. En el caso de que la junta solicitada no fuese convocada o no pudiese lograrse el acuerdo o éste fuese contrario a la disolución, cualquier interesado podrá solicitar la disolución judicial de la sociedad.

4. Los administradores están obligados a solicitar la disolución judicial de la sociedad cuando el acuerdo social fuese contrario a la disolución o no pudiera ser logrado. La solicitud habrá de formularse en el plazo de dos meses a contar desde la fecha prevista para la celebración de la junta, cuando ésta no se haya constituido, o desde el día de la junta, cuando el acuerdo hubiera sido contrario a la disolución o no se hubiera adoptado.

5. Responderán solidariamente de las obligaciones sociales posteriores al acaecimiento de la causa legal de disolución los administradores que incumplan la obligación de convocar en el plazo de dos meses la junta general para que adopte, en su caso, el acuerdo de disolución, así como los administradores que no soliciten la disolución judicial o, si procediere, el concurso de la sociedad, en el plazo de dos meses a contar desde la fecha prevista para la celebración de la junta, cuando ésta no se haya constituido, o desde el día de la junta, cuando el acuerdo hubiera sido contrario a la disolución o al concurso.

En estos casos las obligaciones sociales Reclamadas se presumirán de fecha posterior al acaecimiento de la causa legal de disolución de la sociedad, salvo que los administradores acrediten que son de fecha anterior".

${ }^{624}$ Causas de disolución de la sociedad de responsabilidad limitada. Art. 104 LSRL:

"Artículo 104. Causas de disolución. 
aclararon, en un texto unificado y en un mismo régimen jurídico para las sociedades de capital. Causas de disolución que con la nueva LSC se recogen en el arts. 363 de la LSC que, en virtud del principio de armonización y regularización suprime la referencia a la

Ley 22/2003, de 9 de julio, Concursal, en la causa de disolución por pérdidas. Deberes

1. La sociedad de responsabilidad limitada se disolverá:

a) Por cumplimiento del término fijado en los estatutos, de conformidad con lo establecido en el artículo 107.

b) Por acuerdo de la Junta General adoptado con los requisitos y la mayoría establecidos para la modificación de los estatutos.

c) Por la conclusión de la empresa que constituya su objeto, la imposibilidad manifiesta de conseguir el fin social, o la paralización de los órganos sociales de modo que resulte imposible su funcionamiento.

d) Por falta de ejercicio de la actividad o actividades que constituyan el objeto social durante tres años consecutivos.

e) Por consecuencia de pérdidas que dejen reducido el patrimonio neto a una cantidad inferior a la mitad del capital social, a no ser que éste se aumente o se reduzca en la medida suficiente, y siempre que no sea procedente solicitar la declaración de concurso conforme a lo dispuesto en la Ley 22/2003, de 9 de julio, Concursal.

f) Por reducción del capital social por debajo del mínimo legal. Cuando la reducción sea consecuencia del cumplimiento de una ley se estará a lo dispuesto en el artículo 108.

g) Por cualquier otra causa establecida en los estatutos.

2. La declaración de concurso no constituirá, por sí sola, causa de disolución, pero si en el procedimiento se produjera la apertura de la fase de liquidación la sociedad quedará automáticamente disuelta. En este último caso, el juez del concurso hará constar la disolución en la resolución de apertura y, sin nombramiento de liquidadores, se realizará la liquidación de la sociedad conforme a lo establecido en el Capítulo II del Título V de la Ley Concursal”.

Deberes y responsabilidad de los administradores de la sociedad de responsabilidad limitada. Art. 105 LSRL:

"Artículo 105. Acuerdo de disolución.

1. En los casos previstos en los párrafos c) a g) del apartado 1 del artículo anterior, la disolución, o la solicitud de concurso, requerirá acuerdo de la Junta General adoptado por la mayoría a que se refiere el apartado 1 del artículo 53. Los administradores deberán convocar la Junta General en el plazo de dos meses para que adopte el acuerdo de disolución o inste el concurso. Cualquier socio podrá solicitar de los administradores la convocatoria si, a su juicio, concurriera alguna de dichas causas de disolución, o concurriera la insolvencia de la sociedad, en los términos a que se refiere el artículo 2 de la Ley Concursal.

2. La Junta General podrá adoptar el acuerdo de disolución o aquél o aquéllos que sean necesarios para la remoción de la causa.

3. Si la Junta no fuera convocada, no se celebrara, o no adoptara alguno de los acuerdos previstos en el apartado anterior, cualquier interesado podrá instar la disolución de la sociedad ante el Juez. de Primera Instancia del domicilio social. La solicitud de disolución judicial deberá dirigirse contra la sociedad.

4. Los administradores están obligados a solicitar la disolución judicial de la sociedad cuando el acuerdo social fuese contrario a la disolución o no pudiera ser logrado. La solicitud habrá de formularse en el plazo de dos meses a contar desde la fecha prevista para la celebración de la Junta, cuando ésta no se haya constituido, o desde el día de la Junta, cuando el acuerdo hubiera sido contrario a la disolución o no se hubiera adoptado.

5. Responderán solidariamente de las obligaciones sociales posteriores al acaecimiento de la causa legal de disolución los administradores que incumplan la obligación de convocar en el plazo de dos meses la junta general para que adopte, en su caso, el acuerdo de disolución, así como los administradores que no soliciten la disolución judicial o, si procediere, el concurso de la sociedad, en el plazo de dos meses a contar desde la fecha prevista para la celebración de la junta, cuando ésta no se haya constituido, o desde el día de la junta, cuando el acuerdo hubiera sido contrario a la disolución o al concurso.

En estos casos las obligaciones sociales reclamadas se presumirán de fecha posterior al acaecimiento de la causa legal de disolución de la sociedad, salvo que los administradores acrediten que son de fecha anterior". 
de los administradores que se regulan en los arts. 364 a 366 de la LSC, suprimiéndose igualmente las referencias al art. 2 de la Ley 22/2003, de 9 de julio, Concursal. Finalmente, se incorpora al art. 367 de la LSC, la responsabilidad de los administradores por el incumplimiento de los deberes legales ante la concurrencia de la causa de disolución, tal y como se recogía a partir de la reforma de la Ley 19/2005.

En la regulación de los deberes de los administradores en la LSC, al fijarse el régimen jurídico del primer deber en el art. 365 de la LSC, se realiza una refundición entre el contenido de la LSA y de la LSRL, al establecerse que los administradores deben convocar la junta, para que ésta adopte el acuerdo de disolución, o para que ésta inste la solicitud de concurso, de ser la sociedad insolvente.

Preceptos que tras su inicial regulación, sólo han tenido una reforma, al modificarse las causas de disolución mediante la Ley 25/2011, de 1 de agosto, de reforma parcial de la Ley de Sociedades de Capital y de incorporación de la Directiva 2007/36/CE, del Parlamento Europeo y del Consejo, de 11 de julio, sobre el ejercicio de determinados derechos de los accionistas de sociedades $\operatorname{cotizadas}^{625}$, para incluirse como causa de disolución de todas las sociedades de capital, la del cese en el ejercicio de la actividad o actividades que constituyan el objeto social, entendiéndose que se ha producido el cese tras un período de inactividad superior a un año. Causa esta que con anterioridad a esa reforma era propia sólo de la Sociedad de Responsabilidad Limitada, siendo el período de inactividad de tres años.

La causa de disolución de pleno derecho ha sido objeto de estudio en el capítulo anterior, al que nos remitimos.

\section{II.- FUNDAMENTO Y NATURALEZA JURÍDICA DE LA RESPONSABILIDAD POR DEUDAS.}

\section{Fundamento de la responsabilidad por deudas.}

La doctrina científica ${ }^{626}$ y la jurisprudencia ${ }^{627}$ sitúan el fundamento de esta responsabilidad en el propósito de estimular o compeler a los administradores a

\footnotetext{
${ }^{625}$ BOE del 2.8.2011.

${ }^{626}$ SÁNCHEZ CALERO, F.: Los administradores en las sociedades de capital, op. cit., p. 445; DÍAZ ECHEGARAY, J. L.: Deberes y Responsabilidades de los Administradores de Sociedades de Capital, op. cit., pp. 388-389.

${ }^{627}$ SSTS, Sala Civil, núm. 560/2013, de 7 de octubre; núm. 409/2013, de 20 de junio; núm. 458/2010, de 30 de junio; núm. 124/2010, de 12 de marzo; y núm. 228/2008, de 25 marzo. En el mismo sentido son
} 
promover la disolución de la sociedad cuando incurra en causa disolutoria, bajo la amenaza de que si no cumplen con sus deberes legales responden de las deudas posteriores a la causa de disolución, para evitar que operen en esas condiciones en el tráfico económico, con los consiguientes perjuicios para los acreedores y para la confianza en general en el tráfico económico. Estamos ante una responsabilidad cuya finalidad es proporcionar confianza al tráfico mercantil y robustecer la seguridad de las transacciones comerciales, cuando intervienen personas jurídicas mercantiles en que los socios no responden personalmente de las deudas.

Se justifica o se fundamenta esta responsabilidad del administrador ante la concurrencia de una causa de disolución, "en el riesgo que se ha generado para los acreedores posteriores que han contratado sin gozar de la garantía patrimonial suficiente por parte de la sociedad del cumplimiento de su obligación de pago" (Sentencias del TS, Sala Civil, 601/2019, de 8 de noviembre; y 22/2020, de 16 de enero -Rec. 520/2017-).

En materia de deudas de Seguridad Social esta responsabilidad por deudas permitirá extender el círculo de sujetos responsables, al incluir con carácter solidario a los administradores sociales, ya que con el incumplimiento de sus deberes legales ante la concurrencia de causas de disolución, están contribuyendo decisivamente a la generación de deudas de la sociedad de capital en los momentos previos a la liquidación y al cese de la actividad, especialmente ante la causa disolutoria de pérdidas patrimoniales cualificadas.

\section{Naturaleza jurídica de la responsabilidad por deudas.}

La responsabilidad solidaria de los administradores sociales por deudas de la sociedad de capital prevista en el art. 367 de la LSC -al igual que la del art. 360 de la LSC para la disolución de pleno derecho-, permite la derivación administrativa de responsabilidad por deudas de Seguridad Social de conformidad con el art. 18.3 del TRLGSS.

Responsabilidad por deudas del administrador social que ha venido siendo calificada como supuestos de responsabilidad ex lege por deuda ajena y no por deuda propia. Se trata de supuestos de responsabilidad ex lege por deuda ajena, que en determinados momentos se calificó de objetiva o cuasi-objetiva, ante el incumplimiento imputable del

de destacar las Sentencias 173/2011, de 17 de marzo; 407/2011, de 23 de junio; 225/2012, de 13 de abril; 360/2012, de 13 de junio; 395/2012, de 18 de junio; y 818/2012, de 11 de enero, entre otras muchas. 
administrador de unos concretos deberes legales, cuando concurra una causa de disolución, sea disolución de pleno derecho o disolución por causa legal.

La primera nota distintiva de esta responsabilidad por deudas es su carácter de solidaridad ${ }^{628}$, en una doble dirección. Por un lado, es una responsabilidad solidaria del administrador social con la sociedad por las deudas de Seguridad Social de esta. Por otro lado, es una responsabilidad solidaria de los administradores entre sí, ya que de ser $\operatorname{varios}^{629}$, responden todos ellos, salvo que no le sea imputable el incumplimiento de los deberes legales a alguno de ellos.

Estamos ante una responsabilidad solidaria del administrador con la propia sociedad deudora (art. 367 LSC), y ante una responsabilidad solidaria entre los propios administradores (art. 237 LSC). Por esa naturaleza de la responsabilidad solidaria, el acreedor $^{630}$, en virtud del ius eligendi, podrá reclamar esas deudas a todos los administradores y a la sociedad conjuntamente, o reclamar a la sociedad y alguno de los administradores, o sólo a los administradores, y en este caso, a todos o sólo a alguno de ellos, sin perjuicio de poder reclamar posteriormente en virtud del ius variandi al resto de los deudores y responsables solidarios (art. 1144 del Código Civil), ya que la reclamación contra alguno de ellos no enerva la que pudiera realizarse ante el resto, mientras la deuda no resulte íntegramente pagada (arts. 1137 a 1148 del Código Civil). Solidaridad que tiene relación entre los propios administradores, ya que, pagado el total

${ }^{628}$ QUIJANO GONZÁLEZ, J.: "Responsabilidad de los administradores por no disolución de la sociedad (art. 262.5 TRLSA) (Sentencia de la Audiencia Provincial de Burgos de 24 de julio de 1995)”, op. cit., 1995, pp. 274-275; SÁNCHEZ CALERO, F.: Los administradores en las sociedades de capital, op. cit., pp. 464-466; GARCÍA CRUCES, J. A.: Derecho de Sociedades Mercantiles, Tirant Lo Blanch, Valencia 2019, p. 505; BELTRÁN SÁNCHEZ, E.: "La responsabilidad de los administradores por obligaciones sociales", op. cit., pp. 341-342; DÍAZ ECHEGARAY, J. L.: Deberes y Responsabilidades de los Administradores de Sociedades de Capital, op. cit., pp. 391 y 406; RODRÍGUEZ RUIZ DE LA VILLA, D. y HUERTA VIESCA, M. I.: La responsabilidad de los administradores por las deudas de las Sociedades de Capital (en las Leyes de Sociedades Anónimas, de Sociedades de Responsabilidad Limitada, de Sociedad Limitada Nueva Empresa, Concursal, General Tributaria y de Responsabilidad Medioambiental), op. cit., pp. 71-87 y 533; CALBACHO LOSADA, F.: El ejercicio de las acciones de las acciones de responsabilidad contra los administradores de la sociedad anónima, op. cit., pp. 482-488.

${ }^{629}$ QUIJANO GONZÁLEZ, J.: "Responsabilidad de los administradores por no disolución de la sociedad (art. 262.5 TRLSA) (Sentencia de la Audiencia Provincial de Burgos de 24 de julio de 1995)”, op. cit., 1995, pp. 274-275.

SSTS, Sala Civil, de 583/2008, de 24 de junio -Rec. 3077/2001; 235/2007, de 8 de marzo -Rec. 2036/2000-; 794/2005, de 25 de octubre -Rec. 1218/1999-; y de 23 de febrero de 2004.

${ }^{630}$ QUIJANO GONZÁLEZ, J.: "Responsabilidad de los administradores por no disolución de la sociedad (art. 262.5 TRLSA) (sentencia de la Audiencia Provincial de Burgos de 24 de julio de 1995)”, op. cit., 1995, pp. 274-275; BELTRÁN SÁNCHEZ, E.: "La responsabilidad de los administradores por obligaciones sociales", op. cit., p. 342; BATALLER GRAU, J.: "Disolución y Liquidación”, op. cit., p. 2576. 
de la deuda por uno de ellos, se extingue la deuda ante el acreedor, con efectos para la sociedad deudora y los administradores responsables solidarios, pero determina que surja una acción de regreso del que ha satisfecho la deuda, tanto respecto a la sociedad, como respecto al resto de administradores en su parte correspondiente (art. 1145.2 del Código Civil).

Examinada desde la perspectiva del administrador o administradores es una responsabilidad personal e ilimitada ${ }^{631}$, ya que cada uno responde ante el acreedor de la totalidad de la deuda social y con todo su patrimonio, en aplicación de la regla de responsabilidad universal del art. 1911 del Código Civil, con los límites de los artículos 605 a 607 de la LEC. Es también, una responsabilidad autónoma ${ }^{632}$ con relación a otras responsabilidades del administrador, como la responsabilidad por daños, siendo compatible con la misma, de modo que son acumulables por el acreedor ${ }^{633}$, si es una acreedor privado que tiene que ejercitarlas en vía judicial.

En todo caso, para la doctrina científica estamos ante una responsabilidad distinta a la responsabilidad por daños de los arts. 236 a 241 de la LSC, porque no tiene naturaleza indemnizatoria $^{634}$. Es una responsabilidad por deudas que no exige que concurra un daño, ni que se acredite dolo o culpa en la producción del daño, ni tampoco relación de causalidad entre la conducta y el daño $0^{635}$. Al ser una responsabilidad por incumplirse

${ }^{631}$ GARCÍA CRUCES, J. A.: Derecho de Sociedades Mercantiles, op. cit., p. 505.

${ }^{632}$ GARCÍA CRUCES, J. A.: Derecho de Sociedades Mercantiles, op. cit., p. 505; DÍAZ ECHEGARAY, J. L.: Deberes y Responsabilidades de los Administradores de Sociedades de Capital, op. cit., p. 391; BATALLER GRAU, J.: “Disolución y liquidación”, op. cit., 2011, p. 2576.

633 SSTS, Sala Civil, 100/2003, de 12 de febrero -Rec. 1793/1997-; 540/2005, de 7 de julio -Rec. 43/1999-; 183/2005, de 20 de junio; 950/2005, de 30 noviembre -RJ 2006135-; 464/2008, de 30 de mayo -Rec. 1219/2001-; 455/2017, de 18 julio; 919/2011, de 23 de diciembre -RJ 2012/189-; y 733/2013, de 4 de diciembre -RJ 2014/1835-, entre otras muchas.

${ }^{634}$ QUIJANO GONZÁLEZ, J.: "Responsabilidad de los administradores por no disolución de la sociedad (art. 262.5 TRLSA) (Sentencia de la Audiencia Provincial de Burgos de 24 de julio de 1995)”, op. cit., 1995, pp. 273-274; BELTRÁN SÁNCHEZ, E.: "La responsabilidad de los administradores por obligaciones sociales”, op. cit., pp. 332-341. SÁNCHEZ CALERO, F.: Los administradores en las sociedades de capital, op. cit., p. 461.

${ }^{635}$ QUIJANO GONZÁLEZ, J.: "Responsabilidad de los administradores por no disolución de la sociedad (art. 262.5 TRLSA) (Sentencia de la Audiencia Provincial de Burgos de 24 de julio de 1995)", op. cit., 1995, pp. 278-279; SÁNCHEZ CALERO, F.: Los administradores en las sociedades de capital, op. cit., pp. 461-462; DÍAZ ECHEGARAY, J. L.: Deberes y Responsabilidades de los Administradores de Sociedades de Capital, op. cit., p. 392; BELTRÁN SÁNCHEZ, E.: "La responsabilidad de los administradores por obligaciones sociales”, op. cit., pp. 332-341; COLBACHO LOSADA, F.: El ejercicio de las acciones de responsabilidad contra los administradores de la sociedad anónima, op. cit., p. 396; ESTEBAN VELASCO, G.: “La acción individual de responsabilidad”, op. cit., pp. 290298. 
deberes legales no podrá exigirse a los administradores que prueben que no les es imputable el incumplimiento ${ }^{636}$.

Es una responsabilidad que, según la jurisprudencia ${ }^{637}$, se impone ante el incumplimiento por el administrador social de deberes legales encaminados a la disolución de la sociedad o a la remoción de la causa de disolución; y que es diferente a la responsabilidad por daños ya que no precisa la existencia de daño, porque su objeto no es la indemnización de un daño causado, ni, lógicamente, relación de causalidad entre el daño y la conducta del administrador, no exigiendo otro reproche culpabilístico que la imputabilidad de la conducta omisiva.

Con relación a la naturaleza jurídica de la responsabilidad por deudas por causa legal de disolución del art. 367 de la LSC, se ha ido perfilando de modo progresivo a lo largo del tiempo en la jurisprudencia y en la doctrina, desde que se introdujo en nuestro Derecho y hasta nuestros días. En una primera etapa, a nivel jurisprudencial ${ }^{638}$ y doctrinal ${ }^{639}$ se atribuyó a esta responsabilidad una naturaleza sancionadora, al concebirse como una especie de sanción civil, sanción civil objetiva o cuasi objetiva. En etapas posteriores, tanto la doctrina ${ }^{640}$ como la jurisprudencia ${ }^{641}$, conciben esta responsabilidad, no tanto

${ }^{636}$ BELTRÁN SÁNCHEZ, E.: "La responsabilidad de los administradores por obligaciones sociales", op. cit., p. 349; QUIJANO GONZÁLEZ, J.: "Responsabilidad de los administradores por no disolución de la sociedad (art. 262.5 TRLSA) (Sentencia de la Audiencia Provincial de Burgos de 24 de julio de 1995)", op. cit., p. 274; QUIJANO GONZÁLEZ, J.: "La responsabilidad de los administradores por la no disolución de la sociedad y las causas de exoneración”, 2002, op. cit., p. 75.

${ }^{637}$ SSTS, Sala Civil, 408/2008, de 14 de mayo -RJ 2008/3076-; 669/2008, de 3 de julio -RJ 2008/4366-; 71/2008, de 10 de julio -RJ 2008/3356-; 124/2010, de 12 de marzo; 669/2011, de 4 de octubre; 919/2011, de 23 de diciembre -RJ 2012/1895-; 371/2012, 13 de junio -Rec. 326/2010-; y 395/2012, de 18 de junio de 2012 -Rec. 1852/2009-, entre otras muchas.

${ }^{638}$ STS, Sala Civil, núm. 651/1997, de 15 de julio -Rec. 2388/1993-; de 2 de marzo de 2004; 195/2006, de 9 de marzo -Rec. 2325/1999-; 408/2008, de 14 de mayo -RJ 2008/3076-; 669/2008, de 3 de julio RJ 2008/4366-; 71 /2008, de 10 de julio -RJ 2008/3356-; 124/2010, de 12 de marzo; y 242/2011, de 4 de abril, entre otras muchas.

639 BERCOVITZ RODRÍGUEZ-CANO, A.: "Régimen general de la responsabilidad civil de los administradores de las sociedades de capital”, en AA.VV. (Coord.: GALÁN CORONA, E. y GARCÍA CRUCES, J. A.): La responsabilidad de los administradores de las sociedades de capital, Tecnos, Madrid 1999, p. 19; QUIJANO GONZÁLEZ, J.: "Responsabilidad de los administradores por no disolución de la sociedad (art. 262.5 TRLSA) (Sentencia de la Audiencia Provincial de Burgos de 24 de julio de 1995)", 1995, op. cit., pp. 273-274; QUIJANO GONZÁLEZ, J.: “La responsabilidad de los administradores por la no disolución de la sociedad y las causas de exoneración”, 2002, op. cit., pp. 73-76; QUIJANO GONZÁLEZ, J.: "Responsabilidad societaria y concursal de administradores: de nuevo sobre la coordinación y el marco de relaciones”, en RDCP, núm. 10/2009, edición digital en Smarteca, p. 22, que la califica de responsabilidad-sanción y no mera sanción, en contraposición a la responsabilidad-indemnización.

${ }^{640}$ BELTRÁN SÁNCHEZ, E.: "La responsabilidad de los administradores por obligaciones sociales", op. cit., pp. 332 у 340-341; CALBACHO LOSADA, F.: El ejercicio de las acciones de responsabilidad contra los administradores de la Sociedad Anónima, op. cit., p. 399, quien diferencia 
como una verdadera sanción civil, sino como una responsabilidad solidaria ex lege por deuda ajena en garantía del acreedor. BELTRÁN SÁNCHEZ ${ }^{642}$, por un lado defiende que, inicialmente, estamos ante una especie de sanción civil, en que no es preciso probarse la existencia de un daño, ni relación de causalidad, pero que, en último término, en la jurisprudencia se ha venido calificando como una asunción de responsabilidad ex lege, ya que a la responsabilidad de la sociedad se añade por ministerio de la ley una responsabilidad de los administradores, siendo la sociedad la única deudora, pero no la única responsable. En palabras de BELTRÁN SÁNCHEZ ${ }^{643}$, estamos ante una responsabilidad-garantía legal y no ante una responsabilidadindemnización.

En la jurisprudencia reciente se ha negado que esta responsabilidad del administrador sea una sanción civil, se niega el carácter sancionador. En la Sentencia del Tribunal Supremo número 225/2012, de 13 de abril -Rec. 1018/2009-, se señala que la responsabilidad regulada en los expresados preceptos no tiene naturaleza de "sanción" en sentido estricto, como lo prueba, por un lado, que no sólo provoca un efecto negativo para el administrador, sino también, un correlativo derecho para los acreedores y, por otro, que la norma no impide al administrador subrogarse en la posición del acreedor y repetir contra la sociedad con éxito, en el caso de que la sociedad, pese a estar incursa en causa de disolución, tenga bienes suficientes para atender su crédito. Tal responsabilidad tan solo exige la infracción imputable de los deberes disolutorios impuestos en los arts. 365 y 366 de la LSC. Igualmente se ha negado ese carácter sancionador, para no aplicar con carácter retroactivo, como debería haberse hecho de ser una verdadera sanción, la reforma efectuada por la Ley 19/2005, de 14 de noviembre, que limitó la responsabilidad del administrador a las deudas posteriores a la causa de disolución ${ }^{644}$, y para negar que la responsabilidad se extinga con la muerte del

esta responsabilidad del administrador, como una responsabilidad por deuda ajena, frente a la responsabilidad exigida mediante la acción individual de responsabilidad, que es una responsabilidad del administrador por deuda propia, por el daño que causa con su conducta al acreedor; ESTEBAN VELASCO, G.: “La acción individual de responsabilidad”, op. cit., pp. 290-298.

${ }^{641}$ Sentencias del TS, Sala Civil, núm. 228/2008, de 25 de marzo; 409/2013, de 20 de junio; 458/2010, de 30 de junio; 680/2010, de 10 de noviembre; 225/2012, de 13 de abril; 367/2014, de 10 julio; 246/2015, de 14 mayo; 246/2015, de 14 mayo; y núm. 455/2017, de 18 julio, entre otras.

${ }^{642}$ BELTRÁN SÁNCHEZ, E.: "La responsabilidad de los administradores por obligaciones sociales ”, op. cit., pp. 331-341.

${ }^{643}$ BELTRÁN SÁNCHEZ, E.: “La responsabilidad de los administradores por obligaciones sociales”, op. cit., p. 336

${ }^{644}$ SSTS, Sala Civil, 458/2010, de 30 de junio; 590/2013, de 15 de octubre -Rec. 1268/2011-; 414/2013, de 21 de junio; y 733/2013, de 4 de diciembre -Rec. 1694/2011-. 
administrador, de modo que se integra en el caudal hereditario de los herederos (STS, Sala Civil, 590/2013, de 15 de octubre -Rec. 1268/2011-).

Consideramos que nos hallamos ante una responsabilidad ex lege por deuda ajena, una garantía por deuda ajena que se impone a los administradores ante el incumplimiento imputable de deberes legales disolutorios, para ampliar las posibilidades de cobro del acreedor $^{645}$; y se calificada ex lege porque tiene su fuente - hecho determinante - en el mero reconocimiento legal. En Sentencia del TS, Sala Civil, núm. 246/2015, de 14 de mayo -Rec. 1121/2013-, se concluye que, "es una responsabilidad por deuda ajena, ex lege, que no tiene naturaleza de "sanción" o "pena civil", como señalan las SSTS 367/2014, de 10 de julio; 1063/2012, de 7 de marzo; y 13 de abril de 2012, entre otras".

Para clarificar que no estamos ante una responsabilidad de naturaleza objetiva o cuasi objetiva, como se ha indicado en la jurisprudencia inicial, ni tampoco ante una responsabilidad con naturaleza sancionadora, se ha calificado la misma en la última doctrina jurisprudencial como responsabilidad abstracta o de responsabilidad formal ex lege por deuda ajena ${ }^{646}$.

\section{III.- CAUSAS LEGALES DE DISOLUCIÓN.}

Las causas legales de disolución de la sociedad de capital que pueden determinar el nacimiento de la responsabilidad del administrador social en las deudas de Seguridad Social de la sociedad de capital, son las recogidas en el art. 363 de la LSC, precepto modificado por la Ley 25/2011, de 1 de agosto, de reforma parcial de la Ley de Sociedades de Capital y de incorporación de la Directiva 2007/36/CE, del Parlamento Europeo y del Consejo, de 11 de julio, sobre el ejercicio de determinados derechos de los accionistas de sociedades cotizadas ${ }^{647}$.

Mediante esa reforma legal se suprime el apartado 2, pasando el anterior apartado 3 a ser el nuevo apartado 2, y se redacta nuevamente el apartado 1 sobre las causas de

${ }^{645}$ SSTS, Sala Civil, núm. 228/2008, de 25 de marzo; 458/2010, de 30 de junio; 680/2010, de 10 de noviembre; 173/2011, de 17 de marzo; 407/2011, de 23 de junio; 923/2011, de 26 de noviembre; 104/2012, de 5 de marzo; 225/2012, de 13 de abril; 360/2012, de 13 de junio; 395/2012, de 18 de junio; 818/2012, de 11 de enero; 409/2013, de 20 de junio; 414/2013, de 21 de junio; 560/2013, de 7 octubre; 590/2013, de 15 de octubre; 367/2014, de 10 de julio; 246/2015, de 14 de mayo; 27/2017, de 18 de enero; 650/2017, de 29 de noviembre; y 420/2019, de 15 de julio, entre otras muchas.

${ }^{646}$ SSTS, Sala Civil, 195/2006, de 9 de marzo -Rec. 2325/1999-; 205/2008, de 1 diciembre; 124/2010, de 12 de marzo; 458/2010, de 30 de junio; 409/2013, de 20 de junio -RJ 2013/4378-; y 560/2013, de 7 de octubre.

${ }^{647}$ BOE 2.8.2011. 
disolución, para recoger como causa de disolución de todas las sociedades de capital el cese de la actividad constitutiva del objeto social, especialmente por inactividad durante un período superior a un año, que anteriormente era causa de disolución sólo de la sociedad de responsabilidad limitada (anterior art. 363.2 de la LSC), permaneciendo el resto de las causas disolutorias con igual contenido.

\section{Causas legales.}

Las causas legales de disolución han de ser constatadas y adoptadas por la Junta General, o en su defecto por resolución judicial (arts. 362 y 364 de la LSC), por lo que los administradores están obligados a convocar la junta en un plazo fatal e improrrogable. No son causas automáticas de disolución, ya que la junta podrá acordar medidas de remoción de la causa que permitan continuar la actividad social, o bien, de estimarse que no puede ser removida la causa, iniciar el proceso de disolución.

Examinemos brevemente las causas legales de disolución recogidas en el art. 363 de la LSC, ya que su conocimiento será fundamental para poder derivar la responsabilidad solidaria al administrador social. Dedicaremos un apartado propio a la causa de disolución por pérdidas cualificadas (reducción del patrimonio neto por debajo de la mitad del capital social), por ser la que motivarán la mayoría de las derivaciones de deudas de Seguridad Social.

\subsection{Cese de la actividad.}

La primera causa de disolución es el cese en el ejercicio de las actividades que constituye el objeto social, estableciéndose que se entiende producido ese cese de actividad tras un período de inactividad superior al año, computado de fecha a fecha, en un período de 12 meses o 365 días, sin identificarse con ejercicio social. Inactividad que debe ser total y continuada ${ }^{648}$, de tener una pluralidad de actividades integrantes del objeto social, por lo que de reanudarse temporalmente alguna de ellas, daría lugar a iniciar un nuevo cómputo del plazo del año ${ }^{649}$. Causa de disolución que comparte

${ }^{648}$ RODRÍGUEZ RUIZ DE LA VILLA, D. y HUERTA VIESCA, M. I.: La responsabilidad de los administradores por las deudas de las Sociedades de Capital (en las Leyes de Sociedades Anónimas, de Sociedades de Responsabilidad Limitada, de Sociedad Limitada Nueva Empresa, Concursal y General Tributaria y de Responsabilidad Medioambiental), op. cit., p. 506.

${ }^{649}$ BATALLER GRAU, J.: "Disolución y Liquidación", op. cit., p. 2555; RODRÍGUEZ RUIZ DE LA VILLA, D. y HUERTA VIESCA, M. I.: La responsabilidad de los administradores por las deudas de las Sociedades de Capital (en las Leyes de Sociedades Anónimas, de Sociedades de Responsabilidad Limitada, de Sociedad Limitada Nueva Empresa, Concursal y General Tributaria y de Responsabilidad Medioambiental), op. cit., p. 506. 
supuestos de hecho con la causa de conclusión de la empresa que constituye el objeto social, y con la causa de paralización de los órganos sociales ${ }^{650}$.

Esta causa fue introducida inicialmente para las sociedades de responsabilidad limitada en el art. 363.2 de la LSC, al ser esta ley un Texto Refundido de la LSA y de la LSRL, ya que sólo se recogía para aquel tipo societario, no para la sociedad anónima (art.104.1.d. de la LSRL), siendo el período de inactividad, no de un año, sino de tres años consecutivos. Mediante la Ley 25/2011, de 1 de agosto, se modifica la LSC, para extender esta causa de disolución a todas las sociedades de capital, dejando de ser aplicable sólo a la sociedad de responsabilidad limitada, reduciendo el período de inactividad tres a un año.

El fundamento de esta causa disolutoria es evitar la persistencia en el Registro Mercantil de sociedades que no deban continuar inscritas ante su inactividad ${ }^{651}$.

Cese en la actividad que algún sector doctrinal ${ }^{652}$ entiende en sentido fáctico más que jurídico, por lo que acontece pese a que la sociedad siga desarrollando una mínima actividad formal consistente en la elaboración de las cuentas anuales, presentación de declaraciones fiscales sin actividad, siempre y cuando haya cesado totalmente en las actividades que constituyan su objeto social. Lo relevante es la inexistencia de actividad externa de la sociedad, por lo que no enerva esta causa el hecho de celebrarse juntas de accionistas y adoptarse acuerdos, si no hay actividad ${ }^{653}$. Son indicios de que concurre esta causa el hecho objetivo de falta de depósito de las cuentas anuales, la baja en el impuesto de actividades económicas, así como la extinción de las relaciones de servicios o de suministros ${ }^{654}$.

Al hallarnos ante un hecho negativo, por la dificultad probatoria que implica para el acreedor, al amparo del art. 217.7 de la LEC, se ha defendido ${ }^{655}$ que corresponderá al

${ }^{650}$ VALPUESTA GASTAMINZA, E. M. : Comentarios a la Ley de Sociedades de Capital, op. cit., p. 937.

${ }^{651}$ GARCÍA CRUCES, J. A.: Derecho de Sociedades Mercantiles, op. cit., p. 497; BATALLER GRAU, J.: "Disolución y Liquidación", op. cit., p. 2554.

${ }^{652}$ RODRÍGUEZ RUIZ DE LA VILLA, D. y HUERTA VIESCA, M. I.: La responsabilidad de los administradores por las deudas de las Sociedades de Capital (en las Leyes de Sociedades Anónimas, de Sociedades de Responsabilidad Limitada, de Sociedad Limitada Nueva Empresa, Concursal y General Tributaria y de Responsabilidad Medioambiental), op. cit., p. 506.

${ }^{653}$ BATALLER GRAU, J.: "Disolución y Liquidación", op. cit., p. 2554.

${ }^{654}$ BATALLER GRAU, J.: "Disolución y Liquidación", op. cit., p. 2555.

${ }^{655}$ RODRÍGUEZ RUIZ DE LA VILLA, D. y HUERTA VIESCA, M. I.: La responsabilidad de los administradores por las deudas de las Sociedades de Capital (en las Leyes de Sociedades Anónimas, 
deudor por mayor facilidad probatoria acreditar que no concurre la causa de disolución por no haber cesado la sociedad en todas o alguna de sus actividades

Causa que es irrelevante a efectos de una posible derivación de responsabilidad al administrador de las deudas de Seguridad Social, porque si no hay actividad normalmente no nacerán deudas de Seguridad Social que van asociada a la prestación laboral de servicios. El cese en las actividades durante un año es causa de inicio del procedimiento administrativo para la toma de razón de la extinción por cese de actividad y baja de oficio de la inscripción de la empresa en Seguridad Social (art. 18 del RGIASS).

No obstante, si el cese de la actividad no hubiere ido acompañado de la tramitación de las bajas en Seguridad Social de los trabajadores, se habrán producido descubiertos de cotización y reclamaciones de deuda por la TGSS que pueden haber ganado firmeza siendo exigibles en vía ejecutiva a la sociedad. De existir esas deudas, constatado el hecho de la causa de disolución, podrían derivarse las mismas al administrador social si no se revisan de oficio las reclamaciones de deuda emitidas a la sociedad para su anulación, que será lo pertinente (arts. 18, 35.2.3ํ, 54 y ss del RGRSS).

El reinicio de la actividad en el decimotercer mes es en sí mismo remoción de la causa de disolución sin que llegue a nacer la responsabilidad solidaria del art. 367 de la LSC (Sentencias del TS, Sala Civil, 585/2013, de 14 de octubre -Rec. 1192/2011-; 246/2015, de 14 de mayo -RJ 310/2015-).

Como señala GARCÍA CRUCES ${ }^{656}$ esta causa no aboca indefectiblemente a la disolución, ya que la sociedad puede removerla, retomando la actividad.

\subsection{Conclusión del objeto social.}

Con conclusión del objeto social se alude a la finalización de la actividad constitutiva del objeto social. La conclusión del objeto social como causa de disolución radica en la circunstancia de que con tal hecho desaparece la razón por la que se constituyó la sociedad $^{657}$.

de Sociedades de Responsabilidad Limitada, de Sociedad Limitada Nueva Empresa, Concursal y General Tributaria y de Responsabilidad Medioambiental), op. cit., p. 508.

${ }^{656}$ GARCÍA CRUCES, J. A.: Derecho de Sociedades Mercantiles, op. cit., p. 497.

${ }^{657}$ GARCÍA CRUCES, J. A.: Derecho de Sociedades Mercantiles, op. cit., p. 498. 
Serían supuestos típicos de esta causa de disolución, empresas creadas exclusivamente para determinados eventos, como fue la celebración de los Juegos Olímpicos de Barcelona de 1992, la sociedad cuyo objeto social sea la explotación de una actividad por concesión administrativa, una vez se extinga la concesión, la sociedad cuyo objeto exclusivo sea la prestación de servicios a otra empresa, cuando finaliza el contrato ${ }^{658}, \mathrm{o}$ la sociedad con objeto exclusivo para explotar una patente o marca durante un período temporal concreto ${ }^{659}$. No debe confundirse esta causa con otra próxima, pero distinta, como es la conclusión del fin social.

La Sentencia del TS, Sala Social, 616/2017, de 12 de julio -Rec. 32/2017-, que afecta a RUMASA, consideró que concurría esta causa legal de disolución, porque la actividad que constituía su objeto social había concluido, en la medida en que habían finalizado todos los pleitos cuya gestión constituía el cometido principal de la sociedad, y ello, por haberse modificado la actividad, al quedar limitado su objeto a dos actividades básicas, la relativa al proceso de privatización, que duró hasta el año 1990, y posteriormente a la gestión de los pleitos interpuestos tras la expropiación.

Nos hallamos ante una causa de disolución de difícil constatación o acreditación ${ }^{660}$, y que puede darse tanto en sociedades con objeto de duración temporal como indefinido ${ }^{661}$.

Causa disolutoria de escasa relevancia en la derivación de deudas de Seguridad Social al administrador, ya que con el acaecimiento de la misma se cesa en la actividad, por lo que no surgirán deudas posteriores, con la excepción de que se mantenga el alta de algún empleado para las gestiones jurídicas encaminadas a la tramitación de las bajas

658 RODRÍGUEZ RUIZ DE LA VILLA, D. y HUERTA VIESCA, M. I.: La responsabilidad de los administradores por las deudas de las Sociedades de Capital (en las Leyes de Sociedades Anónimas, de Sociedades de Responsabilidad Limitada, de Sociedad Limitada Nueva Empresa, Concursal y General Tributaria y de Responsabilidad Medioambiental), op. cit., pp. 215-216.

${ }^{659}$ CALBACHO LOSADA, F.: El ejercicio de las acciones de las acciones de responsabilidad contra los administradores de la sociedad anónima, op. cit., p. 407; CARRIÓN GARCÍA DE PARADA, P.: "De la disolución y liquidación”, La sociedad de Responsabilidad Limitada, Tomo I, Colegios Notariales de España, Madrid, 1995, pp. 464-465.

${ }^{660}$ GARCÍA CRUCES, J. A.: Derecho de Sociedades Mercantiles, op. cit., p. 498; RODRÍGUEZ RUIZ DE LA VILLA, D. y HUERTA VIESCA, M. I.: La responsabilidad de los administradores por las deudas de las Sociedades de Capital (en las Leyes de Sociedades Anónimas, de Sociedades de Responsabilidad Limitada, de Sociedad Limitada Nueva Empresa, Concursal y General Tributaria y de Responsabilidad Medioambiental), op. cit., p. 215.

661 RODRÍGUEZ RUIZ DE LA VILLA, D. y HUERTA VIESCA, M. I: La responsabilidad de los administradores por las deudas de las Sociedades de Capital (en las Leyes de Sociedades Anónimas, de Sociedades de Responsabilidad Limitada, de Sociedad Limitada Nueva Empresa, Concursal y General Tributaria y de Responsabilidad Medioambiental), op. cit., pp. 215-216 
fiscales, de Seguridad Social, o preparación de las cuentas anuales, etc., en cuyo caso esas altas en Seguridad Social sólo tendría justificación por un plazo razonable y prudencial, el menor posible, para la tramitación de esas obligaciones formales.

\subsection{Imposibilidad de conseguir el fin social.}

Según el art. 363.1.c) de la LSC la imposibilidad de conseguir el fin social ha de ser manifiesta, ha de ser clara, definitiva e insuperable ${ }^{662}$, originaria o sobrevenida ${ }^{663}$. Caracteres recogidos en la jurisprudencia ${ }^{664}$, donde se ha señalado que la imposibilidad puede ser originaria o sobrevenida, pero no es causa de disolución la existencia de meras dificultades u obstáculos transitorios y vencibles en la realización del fin social, de forma que debemos hallarnos ante una falta de posibilidad clara $\mathrm{y}$, sobre todo, definitiva de la que será difícil reponerse la sociedad si no es con un grave quebranto para los accionistas.

Imposibilidad manifiesta de conseguir el fin social, que es causa próxima, pero distinta $^{665}$ a la conclusión de la empresa que constituye el objeto social. Causa que en algunos casos el supuesto de hecho será común con el de paralización de los órganos sociales $^{666}$.

Se incluirán en esta causa los supuestos en que el objeto social devenga imposible por razones técnicas o naturales ${ }^{667}$. La Sentencia del TS, Sala Civil, 760/2007, de 4 de julio Rec. 4503/2000-, subsume en esta causa la decisión de desguazar los dos únicos buques de la empresa, sin previsión de sustitución, y no en la de pérdidas cualificadas, por lo que el plazo de dos meses para que los administradores convoquen la Junta General

${ }^{662}$ RODRÍGUEZ RUIZ DE LA VILLA, D. y HUERTA VIESCA, M. I.: La responsabilidad de los administradores por las deudas de las Sociedades de Capital (en las Leyes de Sociedades Anónimas, de Sociedades de Responsabilidad Limitada, de Sociedad Limitada Nueva Empresa, Concursal y General Tributaria y de Responsabilidad Medioambiental), op. cit., p. 217; GARCÍA CRUCES, J. A.: Derecho de Sociedades Mercantiles, op. cit., p. 498; BATALLER GRAU, J.: "Disolución y Liquidación", op. cit., p. 2550; CALBACHO LOSADA, F.: El ejercicio de las acciones de las acciones de responsabilidad contra los administradores de la sociedad anónima, op. cit., p. 407; VALPUESTA GASTAMINZA, E. M.: Comentarios a la Ley de Sociedades de Capital, op. cit., p. 938.

${ }^{663}$ BATALLER GRAU, J.: "Disolución y Liquidación”, op. cit., p. 2550.

${ }^{664}$ Sentencias del TS, Sala Civil de 14 de febrero de 1945 -Aranzadi RJ 1945, 136-; de 3 de julio de 1967 -Aranzadi RJ 1967, 2939-; de 23 de marzo de 1974 -Aranzadi RJ 1974, 1057-; de 5 de junio de 1978 Aranzadi RJ 1978, 2220-; de 12 de noviembre de 1987 -Aranzadi RJ 1987, 8373-.

${ }^{665}$ BATALLER GRAU, J.: "Disolución y Liquidación”, op. cit., p. 2550.

${ }^{666}$ VALPUESTA GASTAMINZA, E. M.: Comentarios a la Ley de Sociedades de Capital, op. cit., p. 938.

${ }^{667}$ GARCÍA CRUCES, J. A.: Derecho de Sociedades Mercantiles, op. cit., p. 498; BATALLER GRAU, J.: "Disolución y Liquidación", op. cit., p. 2550. 
nace en la fecha en que se inició el expediente de paralización definitiva de los buques, que tuvo lugar en octubre de 1993, momento a partir del cual los administradores tendrían que haber advertido necesariamente la imposibilidad manifiesta de realizar el fin social, aunque el desguace efectivo se realizó en septiembre de 1994.

Es una causa con un fuerte elemento de apreciación subjetiva para los administradores y acreedores, en nuestro caso para la TGSS y OEITSS, lo que genera incertidumbre acerca de la fecha del cómputo de dos meses para la convocatoria de la junta de accionistas, y en su caso, para el nacimiento de la responsabilidad del administrador ${ }^{668}$. Se han incluido dentro de esta causa de disolución, supuestos de mayor apreciación objetiva, como la sociedad que carece de sede física o de domicilio, de personal, y con baja en el censo de obligados tributarios, la carencia de financiación esencial, la imposibilidad de conseguir personal especializado imprescindible, o los medios materiales o laborales para el funcionamiento social, así como los impedimentos técnicos o materiales que impiden alcanzar el fin social ${ }^{669}$.

En la doctrina ${ }^{670}$ hay cierto consenso en incluir en esta causa la imposibilidad de obtener beneficios y las situaciones de infracapitalización.

Se entiende por infracapitalización material la inadecuación del capital social para alcanzar el fin u objeto social, por insuficiente en relación con el montante económico que implica la actividad. Existe infracapitalización material cuando el capital social es insuficiente para el ejercicio de la empresa proyectada ${ }^{671}$. En la doctrina ${ }^{672}$, se ha citado como supuesto de infracapitalización material, la Resolución de la Dirección General de

${ }^{668}$ CALBACHO LOSADA, F.: El ejercicio de las acciones de las acciones de responsabilidad contra los administradores de la sociedad anónima, op. cit., p. 407.

669 RODRÍGUEZ RUIZ DE LA VILLA, D. y HUERTA VIESCA, M. I.: La responsabilidad de los administradores por las deudas de las Sociedades de Capital (en las Leyes de Sociedades Anónimas, de Sociedades de Responsabilidad Limitada, de Sociedad Limitada Nueva Empresa, Concursal y General Tributaria y de Responsabilidad Medioambiental), op. cit., pp. 220-224.

${ }^{670}$ BROSETA PONT, M. y MARTÍNEZ SANZ, F.: Manual de Derecho Mercantil, op. cit., p. 577; Para una relación exhaustiva de autores Vid. nota 530 de RODRÍGUEZ RUIZ DE LA VILLA, D. y HUERTA VIESCA, M. I.: La responsabilidad de los administradores por las deudas de las Sociedades de Capital (en las Leyes de Sociedades Anónimas, de Sociedades de Responsabilidad Limitada, de Sociedad Limitada Nueva Empresa, Concursal y General Tributaria $y$ de Responsabilidad Medioambiental), op. cit., pp. 217 y 510-518; GARCÍA CRUCES, J. A.: Derecho de Sociedades Mercantiles, op. cit., p. 218; BATALLER GRAU, J.: "Disolución y Liquidación", op. cit., p. 2550.

${ }^{671}$ BATALLER GRAU, J.: "Disolución y Liquidación", op. cit., p. 2551.

${ }^{672}$ RODRÍGUEZ RUIZ DE LA VILLA, D. y HUERTA VIESCA, M. I.: La responsabilidad de los administradores por las deudas de las Sociedades de Capital (en las Leyes de Sociedades Anónimas, de Sociedades de Responsabilidad Limitada, de Sociedad Limitada Nueva Empresa, Concursal y General Tributaria y de Responsabilidad Medioambiental), op. cit., p. 219, vid la nota 530 . 
Registros y el Notariado de fechas 22 y 23 de junio de 1993, que admite que se pueda denegar la inscripción registral respecto a la constitución de una sociedad de responsabilidad limitada con capital de 500.000 pesetas, que se consideró inadecuado para el objeto social tan amplio, que estaba integrado, entre otras, por las actividades de construcción, promoción inmobiliaria, instalación de tratamientos de agua, explotación de centros comerciales, residencias geriátricas, explotaciones mineras.

Por otro lado, estaríamos ante una infracapitalización nominal, cuando los socios en lugar de hacer aportaciones al capital social, para incrementar el patrimonio social, prefieren financiar a la sociedad otorgándole préstamos, para de este modo, ser a su vez acreedores de la mercantil, y en el caso de tener dificultades la empresa hallarse en igual o similar posición que el resto de los acreedores sociales. Se ha descrito esta figura por PAZ-ARES RODRÍGUEZ ${ }^{673}$, en los siguientes término, "se comienza con la fundación de una persona jurídica cuyo capital nominal es demasiado pequeño para los negocios planteados, acto seguido, el socio o grupo de socios de control, conciertan un préstamo con la sociedad y le suministran los fondos necesarios para que pueda llevar a efecto el objeto social. De este modo, los socios prestamistas se atribuyen el papel de acreedores, de manera que si los negocios fracasan tienen la posibilidad de hacer valer su derecho sobre el patrimonio de la sociedad en concurrencia con los demás acreedores". Préstamos de los socios a la sociedad que, para mayor actuación en fraude de los acreedores, pueden ir acompañados de garantías hipotecarias sobre los bienes de la sociedad.

Se ha identificado también esta causa de disolución con la imposibilidad de obtener beneficios ${ }^{674}$, cuando con carácter objetivo, total, manifiesto y definitivo no puede alcanzarse el propósito para el que se constituyó la sociedad, como es la obtención de ganancias repartibles a través del ejercicio de la actividad social, sin que la imposibilidad de obtener beneficios se confunda con el hecho de no repartir dividendos durante determinados ejercicios (Sentencia de la Audiencia Provincial de Valladolid, núm. 346/2017, de 18 octubre -JUR 2017\293845-). Siendo indiferente que esta imposibilidad de obtener beneficios sea originaria o sobrevenida (Sentencia de la

673 PAZ-ARES RODRÍGUEZ, J. C.: "Sobre la Infracapitalización de las Sociedades", en Anuario de Derecho Civil, Tomo XXXVI, Fascículo III, julio-septiembre de 1983, pp. 1618-1619.

${ }^{674}$ Sentencia de la Audiencia Provincial de Valladolid, 346/2017, de 18 octubre -JUR 2017\293845-, y Sentencia de la Sección $1^{\text {a }}$ de la Audiencia Provincial de Pontevedra, 301/2000, de 6 julio -Aranzadi AC 2000\2042-. 
Sección $1^{a}$ de la Audiencia Provincial de Pontevedra, núm. 301/2000, de 6 julio Aranzadi AC 2000\2042-).

Se ha identificado esta causa como aquélla que implica la paralización de la actividad social por una causa no susceptible de ser evitada ni subsanada y, por tanto, de carácter permanente (Sentencia de la Sección $1^{\text {a }}$ de la Audiencia Provincial de Valladolid, núm. 28/2002, de 28 enero -Aranzadi JUR 200217447-).

Son causas distintas la infracapitalización material y la despatrimonialización (Sentencia del TS, Sala civil, 226/2008, de 24 marzo). La primera acontece cuando el capital social se estima manifiestamente insuficiente para emprender y desarrollar la actividad, y la segunda, tiene lugar cuando por pérdidas el patrimonio ha quedado reducido a un importe inferior a la mitad del capital social, habiendo sido el capital suficiente con anterioridad para el desarrollo de la actividad empresarial emprendida.

Causa de disolución que suele apreciarse cuando se ha cesado en la actividad empresarial, identificándose en algunos casos su concurrencia con la paralización de los órganos sociales. En Sentencia del TS, Sala Civil, 588/1999, de 2 julio -Aranzadi RJ 1999 4900-, se reconduce a esta causa, el cese de hecho de la actividad con incumplimientos previos de obligaciones contables, fiscales y con la Seguridad Social ${ }^{675}$, con una conclusión final de haber llegado la sociedad a una situación de verdadera descapitalización. En similares términos, de cese de actividad acompañado del incumplimiento de la obligación de presentación de las cuentas en el Registro Mercantil, en la Sentencia del TS, Sala Civil, 124/2010, de 12 marzo -RJ 2010\2345-, se declara que ambas circunstancias son constitutivas de las causas de disolución de imposibilidad de conseguir el fin social o de paralización de los órganos sociales. En la Sentencia núm. 124/2010, de 12 marzo -RJ 2010/2345-, se declara acreditada la causa de imposibilidad manifiesta de realizar el fin social o la paralización de los órganos sociales, que han imposibilitado el funcionamiento de la sociedad, por el cese de la actividad de la sociedad con la falta de presentación de cuentas.

675 Constaban como hechos probados que, "la compañía fue dada de baja de la Licencia Fiscal, no satisfizo el Impuesto de Sociedades en los últimos años, no llevó contabilidad en su verdadero significado, dejó de efectuar los pagos de las cuotas de la Seguridad Social, encontrándonos ante un efectivo estado de inoperatividad total societaria y que, por consecuencia de juicio de desahucio por falta de pago, hubo de abandonar el local donde tenía su sede, sin que acreditase hubiera accedido a otro, con reflejo en el Registro Mercantil, para definitivamente dejar de ser activa a partir del mes de julio de 1989". Esos hechos, suponían para el TS, "la imposibilidad de realizar el fin social en cuanto se instauró la desaparición de hecho de la empresa, carente de domicilio social y con paralización de los órganos sociales, es decir que entró en situación de descapitalización y quiebra técnica" 
Causa ésta que puede ser origen de una derivación de responsabilidad de deudas de Seguridad Social al administrador, especialmente ante los supuestos de infracapitalización, lo que no será una tarea sencilla al ser de difícil acreditación, y que de ser una infracapitalización material podrá acudirse también a la prueba de presunciones e indicios, de modo que lleve a la convicción razonable de ser el capital social manifiestamente insuficiente para la explotación de la actividad empresarial, lo que presenta su dificultad si la sociedad cuenta con patrimonio suficiente. Causa de infracapitalización que puede ir acompañada de despatrimonialización (art. 363.1. apartado e) de la LSC), lo que permitirá fundamentar con mayor viabilidad la derivación de responsabilidad.

\subsection{Paralización de órganos sociales.}

La paralización de los órganos sociales debe ser permanente, definitiva e insuperable ${ }^{676}$. Ha de ser persistente, insuperable o muy difícil de superar ${ }^{677}$. Por el contrario, para otros autores $^{678}$, al desgajarse esta causa de otra conexa con la que iba unida en la legislación anterior, cual es la imposibilidad de alcanzar el fin social, la paralización de los órganos sociales ya no precisaría que fuese definitiva e insuperable, pudiendo ser una paralización temporal que provoque una inmediata puesta en peligro de la economía de la sociedad.

Para la Sentencia del TS, Sala Civil, 653/2014, de 26 de noviembre -Rec. 745/2013-, "la paralización de los órganos sociales para que sea causa de disolución debe ser permanente e insuperable (que "resulte imposible su funcionamiento"), no transitoria o vencible".

$\mathrm{Al}$ hablarse de órganos sociales, nuestra doctrina ${ }^{679}$ entiende que donde realmente se produce la causa de disolución, al imposibilitar la paralización el funcionamiento de la

\footnotetext{
676 BROSETA PONT, M. y MARTÍNEZ SANZ, F.: Manual de Derecho Mercantil, op. cit., p. 577; CALBACHO LOSADA, F.: El ejercicio de las acciones de responsabilidad contra los administradores de la sociedad anónima, op. cit., p. 408.

677 GARCÍA CRUCES, J. A.: Derecho de Sociedades Mercantiles, op. cit., p. 498.

${ }^{678}$ BATALLER GRAU, J.: “Disolución y Liquidación”, op. cit., p. 2552.

679 RODRÍGUEZ RUIZ DE LA VILLA, D. y HUERTA VIESCA, M. I.: La responsabilidad de los administradores por las deudas de las Sociedades de Capital (en las Leyes de Sociedades Anónimas, de Sociedades de Responsabilidad Limitada, de Sociedad Limitada Nueva Empresa, Concursal y General Tributaria y de Responsabilidad Medioambiental), op. cit., p. 255; CALBACHO LOSADA, F.: El ejercicio de las acciones de responsabilidad contra los administradores de la sociedad anónima, op. cit., pp. 408-409; BROSETA PONT, M. y MARTÍNEZ SANZ, F.: Manual de Derecho Mercantil, op. cit., p. 577; GARCÍA CRUCES, J. A.: Derecho de sociedades Mercantiles, op. cit., p. 499; BATALLER GRAU, J.: “Disolución y Liquidación”, op. cit., p. 2552.
} 
sociedad, es en la Junta General ${ }^{680}$, por bloqueo de la misma, al no conseguir constituirse por falta de quórum, o no poder adoptar acuerdos por falta de mayorías, considerando que el bloqueo en el órgano de administración siempre podría ser resuelto por la junta con el cese y nombramiento de otros administradores, salvo que el bloqueo del órgano de administración sea consecuencia del propio bloqueo de la junta, al hallarse divida al 50\%. Admitiendo la gravedad de la paralización de la junta, no por ello, la paralización del órgano de administración puede ser infravalorada, ya que, por un lado, ese bloqueo de la junta se suele producir también en el órgano de administración $^{681}$, y por otro lado, pese a poder ser sustituido por la junta, no es descartable que la sociedad con órgano de administración social paralizado pueda llegar a una situación concursal ${ }^{682}$.

En el art. 363.1.d) de la LSC se alude a paralización de los órganos sociales en plural, ello, no obstante, basta con que se paralice cualquiera de ellos para que concurra la causa, en la medida en que sea suficiente para bloquear el funcionamiento de la sociedad (Sentencia del TS, Sala Civil, 373/2010, de 15 de junio -Rec. 358/2006-).

Causa de disolución que tiene lugar en los casos de bloqueo efectivo en que, aun celebrándose formalmente reuniones del Consejo de Administración y convocándose juntas generales, no pueden lograrse acuerdos o los adoptados no se ejecutan, de modo que resulte imposible el funcionamiento de la sociedad (Sentencia del TS, Sala Civil, 989/2000, de 4 noviembre -Rec. 3083/1995-).

Cuando la paralización afecte a la junta al no poder adoptar el acuerdo de disolución, lo procedente será la solicitud judicial de disolución, bien por cualquier socio o por el

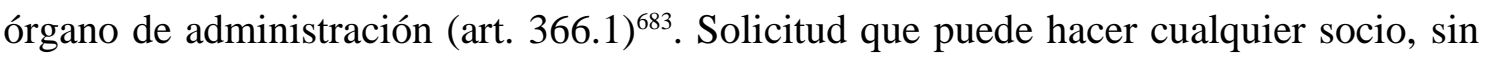
necesidad de agotar el trámite previo de la convocatoria de la junta, ya que, si la

${ }^{680}$ STS, Sala Civil, 373/2010, de 15 de junio -Rec. 358/2006-, "como el bloqueo del órgano de administración, al que corresponde permanentemente la gestión social y actuar por la sociedad en las relaciones con los terceros, podrá ser superada, normalmente, por la junta general, se entiende que, como regla, es la paralización de éste órgano la verdaderamente causante de la disolución. La paralización de la junta general puede exteriorizarse no sólo mediante una imposibilidad de ser convocada o constituida, sino, también, mediante la de adoptar acuerdos".

${ }^{681}$ VALPUESTA GASTAMINZA, E. M.: Comentarios a la Ley de Sociedades de Capital, op. cit., p. 938.

${ }^{682}$ Es de esta opinión BATALLER GRAU, J.: "Disolución y Liquidación”, op. cit., p. 2552, quien por ello estima que no debe esperarse a iniciarse la tramitación de la disolución, a los supuestos de paralización definitiva e insuperable, sino que puede iniciarse con la mera constatación del conflicto corporativo.

${ }^{683}$ BATALLER GRAU, J.: “Disolución y Liquidación”, op. cit., p. $25523{ }^{683}$; GARCÍA CRUCES, J. A.: Derecho de sociedades Mercantiles, op. cit., p. 499. 
paralización afecta a ese órgano, será un trámite ilógico y sin sentido por la propia inoperancia de la junta (Sentencia del TS, Sala Civil, 989/2000, de 4 noviembre -Rec. 3083/1995-), por la imposibilidad de adoptar ningún acuerdo (Sentencia del TS, Sala Civil, 507/2000, de 15 de mayo -Rec. 2231/1995-).

Por el contrario, no es causa de disolución por paralización de los órganos sociales, el hecho de que haya un socio que sistemáticamente impugne los acuerdos sociales, ya que de admitirse esa interpretación cualquier socio minoritario podría por su propia voluntad abocar a la disolución de una sociedad (Sentencia del TS, Sala Civil, de 185/2011, de 28 de marzo -Rec. 333/2007-).

La paralización de los órganos sociales normalmente se producirá en las sociedades cerradas y con un número de socios pequeño, con división en dos bloques enfrentados ${ }^{684}$.

Estamos ante una causa de disolución que suele darse en pequeñas sociedades con socios enfrentados con controles paritarios del capital social, y/o en sociedades familiares constituidas al cincuenta por ciento por los dos cónyuges, con ruptura enfrentada del vínculo matrimonial, que llevan a la sociedad a una situación de bloqueo orgánico, que suele ir acompañada con gran frecuencia de incumplimientos de obligaciones con la Seguridad Social, por lo que a través de la actuación inspectora deberán iniciarse las actuaciones administrativas de derivación de responsabilidad una vez se constate esa paralización y el incumplimiento de los deberes de los administradores sociales.

\subsection{Reducción del capital social por debajo del mínimo legal.}

Esta causa opera cuando la reducción del capital social por debajo del mínimo legal no sea consecuencia del cumplimiento de una ley, ya que, si fuese obligatorio por disposición legal, estaríamos ante la causa de disolución de pleno derecho del art. 360 de la LSC.

Causa ésta de imposible acaecimiento, ya que en el art. 343 de la LSC, sólo se permite la reducción por debajo del mínimo legal, cuando simultáneamente se adopta y ejecuta

\footnotetext{
${ }^{684}$ SSTS, Sala Civil, 770/1995, de 25 de julio -RJ 1995\6201-; 441/2006, de 11 mayo -RJ 200613953-; 347/2000, de 7 de abril -Rec. 2066/1995-; 797/2002, de 20 de julio -Rec. 680/1997-; 441/2006, de 11 de mayo -Rec. 2875/1999-; 15 de junio de 2010 -Rec. 358/2006-; 229/2011, de 11 de abril -Rec. 2289/2007-; 653/2014, de 26 de noviembre -Rec. 745/2013-.
} 
el acuerdo de aumento del capital hasta o por encima del mínimo legal, de modo que la eficacia y la inscripción del acuerdo de reducción se condiciona a la ejecución e inscripción del aumento del capital. Por ello, la doctrina ${ }^{685}$ entiende que es difícil imaginar que esta causa pueda darse en la práctica, ya que sería un acuerdo nulo, quedando reducida a los supuestos de laboratorio de haberse superado el control notarial y registral ${ }^{686}$.

\subsection{Otras causas.}

Finalmente, otras causas menos relevantes, y con escasa incidencia en la posible derivación de responsabilidad de deudas de Seguridad Social, serán las prevista en el art. 363.1 apartados g) y h) de la LSC y en el art. 363.2 para las sociedades comanditaria por acciones.

En el art. 363.1. g) de la LSC se establece como causa legal de disolución cuando el valor de las participaciones sin voto y de las acciones sin voto exceden de la mitad del capital social desembolsado y no se restablezca la proporción en el plazo de dos años.

Las sociedades anónimas y las sociedades de responsabilidad limitada pueden tener acciones o participaciones sociales sin derecho a voto, siempre y cuando no excedan de la mitad del capital social (art. 98 LSC). De este modo, si en el curso de la vida societaria se excediese ese porcentaje, de no reducirse esas acciones o participaciones por debajo de la mitad del capital social en el plazo de dos años, nace la obligación de los administradores de convocar la Junta General dentro de los dos meses siguientes al cumplimiento de ese plazo, ya que, de otro modo, incurren en responsabilidad solidaria por deudas de Seguridad Social generadas a partir del acaecimiento de la causa de disolución.

Las acciones o participaciones sin derecho a voto podrán superar la mitad del capital social, fundamentalmente en dos situaciones. En primer lugar, porque se haya tenido que reducir el capital social por pérdidas, lo que resulta obligatorio en la sociedad anónima cuando las pérdidas reducen el patrimonio a las dos terceras partes del capital social (art. 327 LSC), habiendo transcurrido un año sin haberse superado ese desequilibrio. En esos casos de reducción del capital social por pérdidas, las acciones o

${ }^{685}$ BROSETA PONT, M. y MARTÍNEZ SANZ, F.: Manual de Derecho Mercantil, op. cit., p. 578; GARCÍA CRUCES, J. A.: Derecho de Sociedades Mercantiles, op. cit. p. 499; BATALLER GRAU, J.: "Disolución y Liquidación", op. cit., p. 2558.

${ }^{686}$ BATALLER GRAU, J.: “Disolución y Liquidación”, op. cit., p. 2558. 
las participaciones sin voto tienen el privilegio de no verse afectadas, y sólo excepcionalmente se verán afectadas por la reducción si las pérdidas superan el importe de las acciones o participaciones con voto (art. 100 LSC). Es por ello que, cuando la sociedad tenga ese tipo de participaciones o acciones, la Inspección de Trabajo y Seguridad Social habrá de examinar todas las reducciones de capital social para detectar si las acciones o participaciones sin derecho a voto han superado en algún momento la mitad del capital social, por ser un posible supuesto de derivación de deudas al administrador social. En segundo lugar, otra circunstancia que puede dar lugar a que se rompa ese equilibrio, será la exclusión o separación de un socio con participaciones sociales con derecho a voto, que hayan abocado a la amortización de esas participaciones, especialmente cuando las participaciones sin derecho a voto están próximas a la mitad del capital (art. 358 LSC).

La comprobación de esta causa no será fácil para la TGSS, teniendo mayor facilidad para constatar su concurrencia la Inspección de Trabajo y Seguridad Social, la que en el curso de actuaciones inspectoras ante la empresa podrá comprobar si ha habido amortización de acciones o participaciones con derecho a voto, especialmente cuando representen un porcentaje importante y hubiere habido reducciones de capital que hayan motivado la pérdida del equilibrio prescrito en el art. 98 de la LSC.

Servirán como medio de constatación las escrituras públicas en que consta la composición del capital, las de reducciones o aumentos del capital, las de exclusión o separación de socios (que deben ser objeto de inscripción en el Registro Mercantil -arts. 165, 200, 201 y 208 RRM-), siendo muy importante la consulta del índice único notarial, y de los datos registrales, así como el examen del libro registro de socios de la sociedad de responsabilidad limitada (arts. 104 y 105 LSC), o el libro registro de acciones nominativas (art. 116 LSC), con las sucesivas transmisiones patrimoniales, el libro de actas de los órganos sociales, y en todo caso, requiriendo a la sociedad la relación actualizada de socios y socios sin derecho a voto.

La última causa de disolución será cualquier otra prevista en los estatutos sociales, por lo que deberán consultarse los mismos cuando la mercantil sea deudora con la Seguridad Social, por si hubiere alguna causa específica que motivase la disolución de la sociedad, y por ello, el nacimiento de una eventual responsabilidad de los administradores sociales. Estas causas estatutarias de conformidad con el art. 28 de la LSC no podrán ser contrarias a los principios configurados del tipo de sociedad de 
capital $^{687}$, ni podrán servir para aminorar los requisitos establecidos legalmente sobre las causas legales de disolución, por ser éstos mínimos y obligatorios, pudiendo agravar los requisitos legales, pero no suavizarlos ${ }^{688}$.

No es argumento para excluir esta causa de disolución como determinante de la responsabilidad por deudas del administrador social, el hecho de que en el art. 367 de la LSC se aluda a que la responsabilidad nace cuando concurra causa legal de disolución. La referencia sólo a la causa legal de disolución en una interpretación literal y superficial del precepto podría llevarnos a concluir que se ha querido excluir de la responsabilidad la causa estatutaria de disolución prevista en el art. 363.1. h) de la LSC. Por el contrario, todas las causas legales de disolución del art. 363.1 de la LSC, incluida la estatutaria, serán causas desencadenantes de la responsabilidad solidaria del administrador del art. 367 de la LSC.

Esta última es la interpretación mantenida en la doctrina, en la jurisprudencia, y en la propia legislación.

Para la doctrina mayoritaria ${ }^{689}$ esta responsabilidad del art. 367 LSC nace ante la concurrencia de cualquiera de las causas del art. 363 de la LSC, incluida la estatutaria .

Para la jurisprudencia ${ }^{690}$ la responsabilidad del administrador se desencadena cuando incumpla sus deberes ante la concurrencia de las causas de disolución recogidas en el actual art. 363 de la LSC, incluidas las estatutarias del art. 363.1. h) -causa recogida anteriormente en el art. 260 apartado 7 de la LSA y en el art. 104.1.g) de la LSRL -.

En la Sentencia del TS, Sala civil, 733/2013, de 4 diciembre -Rec. 1694/2011-, se señala que "como hemos recordado en otras ocasiones (Sentencia 585/2013, de 14 de octubre Rec. 1192/2011-), es preciso que, mientras los administradores demandados estaban en el ejercicio de su cargo, la sociedad hubiera incurrido en alguna de las causas de

687 VALPUESTA GASTAMINZA, E. M.: Comentarios a la Ley de Sociedades de Capital, op. cit., p. 941.

${ }^{688}$ GARCÍA-PITA Y LASTRES, J. L.: "La disolución de las Sociedad Anónima: Aspectos Generales", en Cuadernos de Derecho y Comercio, número 6, diciembre de 1989, pp. 154-157.

689 BATALLER GRAU, J.: "Disolución y Liquidación", op. cit., p. 2573; VALPUESTA GASTAMINZA, E. M.: Comentarios a la Ley de Sociedades de Capital, op. cit., p. 948; BELTRÁN SÁNCHEZ, E.: "La responsabilidad de los administradores por obligaciones sociales", op. cit., pp. 308-311; SÁNCHEZ CALERO, F.: Los administradores en las sociedades de capital, op. cit., p. 449.

${ }^{690}$ SSTS, Sala Civil, 680/2010, de 10 noviembre -Rec. 791/2007-; 942/2011, de 29 de diciembre; 395/2012, de 18 de junio; 585/2013, de 14 de octubre; 733/2013, de 4 diciembre -Rec. 1694/2011-; 246/2015, de 14 de mayo -Rec. 1121/2013-; y 420/2019, de 15 de julio -Rec. 3654/2016-. De igual modo, STS, Sala Contencioso-Administrativa, 874/2019, de 24 de junio. 
disolución contenidas en los núm. $3^{\circ}, 4^{\circ}, 5^{\circ}$ y $7^{\circ}$ del apartado 1 del art. 260 TRLSA (en la actualidad las causas de disolución se regulan en el art. 363 LSC)". Dejando claro que las causas son todas las recogidas en el art. 363 de la LSC, y entre ellas la prevista en los estatutos del art. 363.1.h) de esa disposición legal. En la Sentencia del TS, Sala Civil, 246/2015, de 14 de mayo -Rec. 1121/2013-, se indica que "aunque esta responsabilidad de los administradores se vincule a cualquier causa de disolución, su importancia se manifiesta singularmente en los supuestos de pérdidas que dejen reducido el patrimonio neto a una cantidad inferior a la mitad del capital social (...)".

Claramente, mencionando a todas las causas de disolución del art. 363.1 de la LSC, como causas legales de disolución, con inclusión de las previstas en los estatutos sociales, pueden citarse las Sentencias del TS, Sala Civil, núm. 942/2011, de 29 de diciembre; 395/2012, de 18 de junio; y 420/2019, de 15 de julio -Rec. 3654/2016-, entre otras, donde se señala que el primer presupuesto para que se desencadene la responsabilidad por deudas del art. 367 LSC, es "la concurrencia de alguna de las causas de disolución de la sociedad previstas en el art. 363.1 de la LSC".

Finalmente, en Sentencia del TS, Sala Contencioso-Administrativa, 874/2019, de 24 de junio -Rec. 2765/2018-, abordando la derivación de responsabilidad de deudas de Seguridad Social de la sociedad de capital al administrador social, al amparo del art. 367 LSC y art. 18 TRLGSS, señala expresamente que "el análisis del referido artículo 367 del TRLSC permite concluir que para que los administradores puedan y deban responder por deudas de la sociedad es preciso que concurran los siguientes requisitos: a) la existencia de alguna de las causas de disolución previstas en el artículo 363 del mismo Texto Refundido (...)”. Con lo que se incluyen todas las reguladas en el art. 363.1 de la LSC, entre ellas a las estatutarias.

Por si todo lo anterior no fuere suficiente para mantener que se incluyen las causas de disolución estatutarias, en el art. 40.12 del Real Decreto Ley 8/2020, de 17 de marzo, de medidas urgentes extraordinarias para hacer frente al impacto económico y social del COVID-19691, se establece que "si la causa legal o estatutaria de disolución hubiera acaecido durante la vigencia del estado de alarma, los administradores no responderán de las deudas sociales contraídas en ese periodo", donde queda claro que la responsabilidad excluida excepcionalmente por la crisis sanitaria y el estado de alarma

${ }^{691}$ BOE del 18.3.2020. 
vigente del 14.3.2020 al 20.6.2020, es por causas legales y estatutarias de disolución, de modo que fuera del estado de alarma se responde por ambas causas de disolución.

No sigue esta doctrina mayoritaria la Guía Operativa de actuación en materia de derivación de responsabilidad a los administradores de sociedades mercantiles capitalistas en materia de deudas de Seguridad Social ${ }^{692}$, dictada por la Dirección General de la Inspección de Trabajo y Seguridad Social, de septiembre de 2017, que excluye expresamente la causa estatutaria de la responsabilidad del art. 367 de la LSC (página 18).

Reseñar, por último, que en las sociedades comanditarias por acciones es causa de disolución el fallecimiento, el cese, la incapacidad o la apertura de la fase de liquidación en el concurso de acreedores que afecte a todos los socios colectivos, salvo que, en el plazo de seis meses y mediante modificación de los estatutos sociales se incorpore algún socio colectivo o se acuerde la transformación a otro tipo societario (art. 363.2 LSC). Causa de disolución porque el socio colectivo es de existencia obligada, y porque responde de modo personal de las deudas sociales (art. 1.4 LSC).

\section{Especial referencia a la disolución por pérdidas cualificadas.}

\subsection{Régimen jurídico y finalidad de la causa de disolución.}

Causa prevista en el art. 363. 1. e) de la LSC, en el que se establece como causa legal de disolución las "pérdidas que dejen reducido el patrimonio neto a una cantidad inferior a la mitad del capital social, a no ser que éste se aumente o se reduzca en la medida suficiente, y siempre que no sea procedente solicitar la declaración de concurso".

Esta causa de disolución por despatrimonialización de la sociedad, no debe confundirse con otra causa de disolución, cual es la infracapitalización material cuando la cifra de capital se estima notoriamente insuficiente para la consecución de su fin social o la consecución de su objeto social.

La causa de disolución por pérdidas que para la Sociedad Nueva Empresa se regula con alcance distinto en el art. 453 de la LSC, donde se establece que estas sociedades se disolverán por las causas establecidas en esa Ley para la sociedad de responsabilidad limitada (causas del art. 363 de la LSC), lo que es consecuencia de ser una modalidad específica de sociedad de responsabilidad limitada. Ahora bien, en la Sociedad Nueva

${ }^{692}$ LA LEY 193/2017. 
Empresa, esta causa tiene un régimen jurídico propio y específico, ya que acaece cuando las pérdidas dejen reducido el patrimonio neto a una cantidad inferior a la mitad del capital social durante al menos seis meses, a no ser que se restablezca el patrimonio neto en dicho plazo. Aquí se fija un plazo de mantenimiento de las pérdidas de seis meses para que concurra la causa de disolución, con lo que no nacerán los deberes desencadenantes de la responsabilidad de los administradores hasta que transcurran esos seis meses durante los que el patrimonio neto quedó reducido a la mitad del capital social.

Causa de disolución que tiene también su especialidad en la Sociedad de Garantía Recíproca, en cuyo art. 59.1 apartado de la Ley 1/1994, de 11 de marzo, se configura en los siguientes términos, “d) Por consecuencia de pérdidas que dejen reducido el patrimonio a una cantidad inferior a las dos terceras partes del capital social, a no ser que éste se aumente o se reduzca en la medida suficiente". Es una regulación más estricta al fijar la reducción del patrimonio en importe inferior al régimen jurídico general del art. 363 de la LSC.

El régimen jurídico de la disolución de la sociedad de capital municipal por pérdidas se establece en el art. 103 del Real Decreto Legislativo 781/1986, de 18 de abril, por el que se aprueba el Texto Refundido de las disposiciones legales vigentes en materia de Régimen Local ${ }^{693}$, en cuyo precepto, cuando las pérdidas excedan de la mitad del capital social será obligatoria la disolución de la Sociedad, y la Corporación Municipal resolverá sobre la continuidad y forma de prestación del servicio. En ese precepto se impone como obligatoria la disolución por pérdidas cualificadas, sin preverse la posible adopción de medidas de remoción de la causa, no obstante lo cual, ha sido reinterpretado por nuestra jurisprudencia a la luz de la regulación de las sociedades de capital, para concluir que no debe imponerse la disolución obligatoria de la sociedad de capital municipal, sino que, en función del principio de continuidad de la empresa, la Corporación Municipal puede adoptar medidas de remoción como el aumento del capital de la sociedad municipal, que fue lo que se debatió en la Sentencia del TS, Sala Civil, número 272/2007, de 9 de marzo -Rec. 2226/2000-.

${ }^{693}$ BOE del 22.4.1986. 
Un sector doctrinal califica a esta causa con los adjetivos de pérdidas cualificadas ${ }^{694}$, o pérdidas graves ${ }^{695}$, pérdidas significativas ${ }^{696}$ y que para algunos autores es la única causa para la que tienen sentido que se imponga la responsabilidad solidaria de los administradores en el pago de las deudas de la sociedad ${ }^{697}$. Extensión de responsabilidad por deudas a los administradores para todas las causas legales de disolución del art. 367 de la LSC, que no venía exigida por el Derecho comunitario ${ }^{698}$.

Causa de disolución que es en parte transposición del art. 17 de la segunda Directiva 77/91/CEE del Consejo, de 13 de diciembre de 1976, Directiva sustituida actualmente por la Directiva (UE) 2017/1132 del Parlamento Europeo y del Consejo, de 14 de junio de 2017, sobre determinados aspectos del Derecho de sociedades ${ }^{699}$, en cuyo artículo 58 se vuelve a recoger de modo idéntico su contenido.

Para nuestra doctrina ${ }^{700}$, la finalidad de esta causa de disolución es mantener el equilibrio entre patrimonio neto y capital social, como medio de garantía de los acreedores, al no responder los socios de las deudas sociales en la sociedad de capital.

Como se señala en nuestra jurisprudencia ${ }^{701}$, esta causa de disolución es una medida de protección de la integridad del capital social a fin de evitar una desproporción entre éste y el patrimonio, que perjudique la garantía frente a los acreedores, siendo indiferente

${ }^{694}$ ESTEBAN VELASCO, G.: “Algunas reflexiones sobre la Responsabilidad de los Administradores frente a los Socios y los Terceros: Acción individual y acción por no Promoción o Remoción de la disolución”, op. cit., 1995, pp. 68-69; BATALLER GRAU, J.: “Disolución y Liquidación”, op. cit., p. 2555.

695 SÁNCHEZ CALERO, F.: Los administradores en las sociedades de capital, 2007, op. cit., p. 450.

${ }^{696}$ DÍAZ ECHEGARAY, J. L.: Deberes y responsabilidades de los Administradores de sociedades de Capital, op. cit., pp. 381-382.

${ }^{697}$ DÍAZ ECHEGARAY, J. L.: Deberes y responsabilidades de los Administradores de sociedades de Capital, op. cit., p. 381, autor que critica que esa responsabilidad se extienda a todas las causas de disolución; Igual crítica realiza SÁNCHEZ CALERO, F.: Los administradores en las sociedades de capital, 2007, op. cit., p. 449.

698 SÁNCHEZ CALERO, F.: Los administradores en las sociedades de capital, 2007, op. cit., p. 449; DÍAZ ECHEGARAY, J. L.: Deberes y responsabilidades de los Administradores de Sociedades de Capital, op. cit., p. 374

${ }^{699}$ DOUE, serie L 169 de 30.6.2017.

700 BELTRÁN SÁNCHEZ, E.: "La responsabilidad de los administradores por obligaciones sociales", op. cit., p. 313; BATALLER GRAU, J.: "Disolución y Liquidación", op. cit., p. 2555; MOYA BALLESTER, J.: La responsabilidad de los administradores de sociedades en situaciones de crisis, op. cit., 2010, p. 88; MOYA BALLESTER, J.: La responsabilidad de los administradores de sociedades en situaciones de crisis, op. cit., pp. 89-90; MACHADO PLAZAS, J.: Pérdida del capital social y responsabilidad de los administradores por deudas sociales, op. cit., pp. 181-186; MOYA JIMÉNEZ, A.: La responsabilidad de los administradores de empresas insolventes, op. cit., pp. 88 y 467-474; SÁNCHEZ CALERO, F.: Los administradores en las sociedades de capital,2007, op. cit., p. 445.

${ }^{701}$ Sentencias del TS, Sala Civil, 560/2013, de 7 de octubre; 328/2011, de 19 de mayo -Rec. 1691/2007-; 458/2010, de 30 de junio. 
cuál sea la cifra del capital, el motivo de las pérdidas, o si existen o no posibilidades de recuperación. Cuando la sociedad incurre en pérdidas cualificadas constitutivas de la causa legal de disolución, el ordenamiento jurídico impone a los administradores la obligación de, o bien promover la liquidación para reorientar el objeto social al reparto del haber existente entre los socios, después de pagar las deudas sociales; o alternativamente instar la adopción de acuerdos dirigidos a remover la causa de disolución, para reconstruir el patrimonio social.

Cuando habiendo pérdidas que reduzcan el patrimonio neto a una cantidad inferior a la mitad del capital social, concurra insolvencia de la sociedad, se deberá solicitar por los administradores el concurso de acreedores en lugar de promoverse la disolución (arts. 2 y 5 del TRLC, en relación con los arts. 363.1.e) y 364 a 367 LSC), porque la causa de disolución cede y deja paso a la solicitud de medidas concursales ${ }^{702}$, al ser una de las finalidades de la causa de disolución evitar la insolvencia, de modo que de no ser ya posible prima la solicitud del concurso (Sentencia del TS, Sala Civil, 937/2004, de 5 octubre -Rec. 2607/1998-).

Esta es la causa legal de disolución más importante ${ }^{703}$ y de mayor incidencia ${ }^{704}$ en la actividad económica de las sociedades de capital. Será la causa que originará la mayoría de los procedimientos administrativos de derivación de la responsabilidad solidaria de los administradores sociales por deudas de Seguridad Social de la sociedad de capital. En palabras del Tribunal Supremo, esta es la causa de disolución generadora de responsabilidad del administrador que se manifiesta como más relevante de las previstas en el art. 363 de la LSC (Sentencia del TS, Sala Civil, 246/2015, de 14 de mayo).

Esta causa de disolución tampoco será una fase posterior y necesaria de una previa y obligatoria reducción del capital social por pérdidas del artículo 327 de la LSC. La sociedad anónima puede incurrir en esta causa de disolución sin tenerse que haber visto

\footnotetext{
702 BELTRÁN SÁNCHEZ, E.: "La responsabilidad de los administradores por obligaciones sociales”, op. cit., p. 310.

${ }^{703}$ BATALLER GRAU, J.: "Disolución y Liquidación”, op. cit., p. 2555; RODRÍGUEZ RUIZ DE LA VILLA, D. y HUERTA VIESCA, M. I.: La responsabilidad de los administradores por las deudas de las Sociedades de Capital (en las Leyes de Sociedades Anónimas, de Sociedades de Responsabilidad Limitada, de Sociedad Limitada Nueva Empresa, Concursal y General Tributaria y de Responsabilidad Medioambiental), op. cit., p. 225.

704 VALPUESTA GASTAMINZA, E. M.: Comentarios a la Ley de Sociedades de Capital, op. cit., p. 939.
} 
previamente obligada a reducir el capital social por pérdidas ${ }^{705}$. Esta causa de disolución, no es un fase o estadio posterior a la reducción obligatoria del capital por pérdidas, sino que puede surgir antes de tenerse que adoptar ésta.

Esta responsabilidad por pérdidas cualificadas, tiene dos funciones, una preconcursal ${ }^{706}$ y otra paraconcursal ${ }^{707}$. Función preconcursal para impedir que, de existir pérdidas graves de capital, la sociedad pueda continuar en el tráfico económico sin adoptar medidas que puedan abocarla inexorablemente a la insolvencia. Se pretende evitar que la sociedad con pérdidas acabe en insolvencia, por ser ésta una situación de mayor gravedad y con mayores perjuicios para los acreedores que la causa de disolución por pérdidas cualificadas. Función paraconcursal, ya que, en esos casos de pérdidas graves, los acreedores prefieren reclamar la responsabilidad solidaria a los administradores para obtener el pago íntegro de la deuda social directamente de éstos, en lugar de instar el concurso de la sociedad para no verse sometidos en tal caso a la pars conditio creditorum. Función paraconcursal que deja de cumplir esta causa con la Ley Concursal $^{708}$, ya que la acción procesal de responsabilidad solidaria del art. 367 de la LSC queda suspendida tras la declaración del concurso de la sociedad de capital (arts. 136.1.2. ${ }^{\circ}$ y 139.1 del TRLC). Por el contrario, esta función paraconcursal continúa en materia de derivación de responsabilidad de deudas de Seguridad Social, ya que no se suspende el procedimiento administrativo de recaudación cuando se declare el concurso de acreedores de la sociedad de capital (para un mayor estudio de la derivación de deudas al administrador social de la sociedad en concurso, véase el apartado IX de este capítulo).

705 MOYA BALLESTER, J.: La responsabilidad de los administradores de sociedades en situaciones de crisis, op. cit., 2010, p. 93; Cuando las pérdidas reducen el patrimonio por debajo de las dos terceras partes del capital social, estaremos ante la compensación obligatoria de las mismas mediante la reducción del capital social, en palabras de MACHADO PLAZAS, J.: Pérdida del capital social y responsabilidad de los administradores por deudas sociales, op. cit., p. 189.

${ }^{706}$ BELTRÁN SÁNCHEZ, E.: "La responsabilidad de los administradores por obligaciones sociales", op. cit., pp. 310-311; MOYA BALLESTER, J.: La responsabilidad de los administradores de sociedades en situaciones de crisis, op. cit., pp. 466-467; MACHADO PLAZAS, J.: Pérdida del capital social y responsabilidad de los administradores por deudas sociales, op. cit., p. 185.

Declaran esa función preconcursal, entre otras, las Sentencias del TS, Sala Civil, 826/2011, de 23 de noviembre y 395/2012, de 18 de junio.

707 BELTRÁN SÁNCHEZ, E.: "La responsabilidad de los administradores por obligaciones sociales", op. cit., pp. 310-311; MOYA BALLESTER, J.: La responsabilidad de los administradores de sociedades en situaciones de crisis, op. cit., pp. 466-467.

${ }^{708}$ BELTRÁN SÁNCHEZ, E.: "La responsabilidad de los administradores por obligaciones sociales”, op. cit., pp. 309-311. 


\subsection{Relación entre el patrimonio neto y el capital social.}

En esta causa de disolución es irrelevante la cuantía del capital social, sea el mínimo legal u otro superior ${ }^{709}$, lo relevante es la proporción entre éste y el patrimonio neto.

Para acreditar la concurrencia de esta causa de disolución, habrá de relacionarse el capital social y del patrimonio neto. Ambos datos se recogen en la contabilidad. El capital social está integrado por las aportaciones de bienes o derechos patrimoniales susceptibles de valoración económico realizadas por los socios (arts. 1.2, 4, 58 y ss de la LSC). Capital social que se refleja en el Balance dentro del pasivo y patrimonio neto, cuentas 100, 101 y 102. El otro elemento a relacionar con el capital social es el patrimonio neto, que en el balance se refleja en la parte de patrimonio neto y pasivo, por contraposición al activo.

Para determinar la cuantía de las pérdidas, así como para conocer qué integra el patrimonio neto, habrá de partirse de la normativa contable ${ }^{710}$ recogida en el Código de Comercio y en el Real Decreto 1514/2007, de 16 de noviembre, por el que se aprueba el Plan General de Contabilidad ${ }^{711}$.

Las cuentas anuales comprenderán el balance, la cuenta de pérdidas y ganancias, un estado que refleje los cambios en el patrimonio neto del ejercicio, un estado de flujos de efectivo y la memoria. Estos documentos forman una unidad. El estado de cambios en el patrimonio neto y el estado de flujos de efectivo no serán obligatorios cuando así lo establezca una disposición legal (art. 34.1 del Código de Comercio).

En el balance figurarán de forma separada el activo, el pasivo y el patrimonio neto, diferenciándose en el patrimonio neto, al menos, los fondos propios de las restantes partidas que lo integran (art. 35.1 del Código de Comercio, y Real Decreto 1514/2007, de 16 de noviembre).

El patrimonio neto se define en el art 36.1. letra c) del Código de Comercio, donde se establece que,

"El patrimonio neto es la parte residual de los activos de la empresa, una vez. deducidos todos sus pasivos. Incluye las aportaciones realizadas por los socios, ya

\footnotetext{
${ }^{709}$ MOYA BALLESTER, J.: La responsabilidad de los administradores de sociedades en situaciones de crisis, editorial La Ley, Madrid, 2010, p. 92.

${ }^{710}$ Sentencia del TS, Sala Civil, 215/2020, de 1 de junio -Rec. 2849/2017-.

${ }^{711}$ BOE 20.11.2007.
} 
II ${ }^{a}$ PARTE. IV ${ }^{\circ}$ CAPÍTULO

sea en el momento de su constitución o en otros posteriores, que no tengan la consideración de pasivos, así como los resultados acumulados u otras variaciones que le afecten".

Ahora bien, seguidamente ese precepto en su apartado segundo nos aclara que, "a los efectos de la distribución de beneficios, de la reducción obligatoria de capital social y de la disolución obligatoria por pérdidas, se considerará patrimonio neto el importe que se califique como tal conforme a los criterios para confeccionar las cuentas anuales, incrementado en el importe del capital social suscrito no exigido, así como en el importe del nominal y de las primas de emisión o asunción del capital social suscrito que esté registrado contablemente como pasivo. También a los citados efectos, los ajustes por cambios de valor originados en operaciones de cobertura de flujos de efectivo pendientes de imputar a la cuenta de pérdidas y ganancias no se considerarán patrimonio neto".

Por otro lado, a efectos de esta causa de disolución integran también el patrimonio neto los préstamos participativos (Sentencias del TS, Sala Civil, 696/2016, de 24 de noviembre -Rec. 871/2014- y 215/2020, de 1 de junio -Rec. 2849/2017-), ya que en la Disposición Adicional Tercera de la Ley 16/2007, de 4 de julio ${ }^{712}$, se modifica la letra d) del artículo 20 del Real Decreto Ley 7/1996, de 7 de junio, sobre Medidas urgentes de carácter fiscal y de fomento y liberalización de la actividad económica ${ }^{713}$, para establecer que:

«d) Los préstamos participativos se considerarán patrimonio neto a los efectos de reducción de capital y liquidación de sociedades previstas en la legislación mercantil.»

Recogiendo las referidas previsiones legales en la Resolución de 5 de marzo de 2019, del Instituto de Contabilidad y Auditoría, de Cuentas -por la que se desarrollan los criterios de presentación de los instrumentos financieros y otros aspectos contables relacionados con la regulación mercantil de las sociedades de capital- ${ }^{714}$, en su artículo 3 se señala:

\footnotetext{
${ }^{712}$ BOE del 05.7.2007.

${ }^{713}$ BOE del 08.6.1996.

${ }^{714}$ BOE del 11.3.2019.
} 
“1. Patrimonio neto: constituye la parte residual de los activos de la empresa, una vez deducidos todos sus pasivos. Incluye las aportaciones realizadas, ya sea en el momento de la constitución de la sociedad o en otros posteriores, por sus socios o propietarios, que no tengan la consideración de pasivos, así como los resultados acumulados u otras variaciones que le afecten. Se entiende por resultados acumulados u otras variaciones que le afecten, los ingresos y gastos del ejercicio y de los ejercicios anteriores que no se hayan distribuido.

A los efectos de decidir si procede la distribución de beneficios, o determinar si concurre la causa de reducción obligatoria de capital social o de disolución obligatoria por pérdidas de acuerdo con lo dispuesto en el Texto Refundido de la Ley de Sociedades de Capital, se considerará patrimonio neto el importe que se califique como tal conforme a los criterios para confeccionar las cuentas anuales, incrementado en el importe del capital social suscrito no exigido, así como en el importe del nominal y de las primas de emisión o asunción del capital social suscrito que esté registrado contablemente como pasivo. También a los citados efectos, los ajustes por cambios de valor originados en operaciones de cobertura de flujos de efectivo pendientes de imputar a la cuenta de pérdidas y ganancias no se considerarán patrimonio neto.

Los préstamos participativos se presentan en el pasivo del balance si cumplen la definición de pasivo incluida en el apartado 3 de este artículo, pero se considerarán patrimonio neto a los efectos de determinar si concurren las causas de reducción obligatoria de capital social o de disolución obligatoria por pérdidas reguladas en el Texto Refundido de la Ley de Sociedades de Capital”.

Elemento importante a examinar, a efectos de la causa de disolución por pérdidas ${ }^{715}$, será el estado de cambios en el patrimonio neto del ejercicio, porque este documento contable tiene dos partes (art. 35.3 del Código de Comercio). La primera reflejará exclusivamente los ingresos y gastos generados por la actividad de la empresa durante el ejercicio, distinguiendo entre los reconocidos en la cuenta de pérdidas y ganancias y los registrados directamente en el patrimonio neto. La segunda contendrá todos los movimientos habidos en el patrimonio neto, incluidos los procedentes de transacciones realizadas con los socios o propietarios de la empresa cuando actúen como tales.

${ }^{715}$ BATALLER GRAU, J.: "Disolución y Liquidación”, op. cit., p. 2556 
También se informará de los ajustes al patrimonio neto debidos a cambios en criterios contables y correcciones de errores.

Del art. 36 del Código de Comercio, del Real Decreto 1514/2007, de 16 de noviembre, y de la Resolución, de 5 de marzo de 2019, resultará ${ }^{716}$ que, a efectos de esta causa de disolución por pérdidas, el concepto de patrimonio neto incluye: el patrimonio neto contable que figura en las cuentas (donde se distingue entre los fondos propios y el resto de partidas que lo integran), incrementado en el importe del capital social suscrito no exigido, así como en el importe del nominal y de las primas de emisión o asunción del capital social suscrito que esté registrado contablemente como pasivo, los importes de los préstamos participativos computados en el pasivo, y el importe positivo o negativo de las pérdidas por deterioro derivadas del Inmovilizado, de las Inversiones Inmobiliarias y de las Existencias. Las pérdidas derivadas del deterioro del Inmovilizado, de las Inversiones Inmobiliarias y de las Existencias no se computaron en el período de crisis económica, desde el ejercicio económico de 2008 al 31.12.2014 ${ }^{717}$.

A efectos de la determinación del patrimonio neto, los elementos del pasivo no pueden sumarse a la cifra del patrimonio neto, porque "patrimonio neto" y "pasivo" son masas patrimoniales diferentes, ya que "el primero, integrado por capital, reservas y resultado del ejercicio, constituyen fuentes de financiación propias de la sociedad, externas en unos casos (capital) e internas en otros (reservas, resultado ejercicio). Refleja el valor de los bienes y derechos aportados por los socios a la compañía, y el "pasivo" está integrado por obligaciones de pago a terceros y, como tales, sus elementos constituyen fuentes de financiación ajena de la sociedad. Ambas masas patrimoniales constituyen conjuntamente la estructura financiera de la sociedad cuyo valor monetario conjunto se corresponde con el valor de la masa patrimonial que integra el activo (estructura económica de la empresa) -con arreglo a la ecuación Activo $=$ Patrimonio neto + Pasivo-. Lo que vale tanto como decir que el "patrimonio neto" tiene un valor monetario equivalente a la diferencia entre el valor del activo y el valor del pasivo. Dicho en otros términos, el patrimonio neto constituye la parte residual de los activos de la empresa,

${ }^{716}$ BELTRÁN SÁNCHEZ, E.: “La responsabilidad de los administradores por obligaciones sociales”, op. cit., p. 313.

${ }^{717}$ Disposición Adicional Única del Real Decreto Ley 10/2008, de 12 de diciembre, con vigencia desde el ejercicio contable de 2008 hasta el cerrado el 31.12.2014, ya que esa disposición fue prorrogada sucesivamente por las siguientes disposiciones: Real Decreto Ley 5/2010, de 31 de marzo, el Real Decreto-Ley 3/2013, de 22 de febrero, y el Real Decreto-Ley 4/2014, de 7 de marzo, convalidado este por la Ley 14/2014, de 30 de septiembre. 
una vez deducidos todos sus pasivos. En términos de legalidad contable, el patrimonio neto constituye el valor o "riqueza" de los propietarios de la sociedad, es decir, la parte que correspondería a los socios una vez realizados los activos y liquidados los pasivos de la empresa" (Sentencia del TS, Sala Civil, 215/2020, de 1 de junio -Rec. 2849/2017). Puntualizar, que de conformidad con el Real Decreto 1514/2007, de 16 de noviembre, el patrimonio neto contable del modelo de balance de las cuentas anuales, del que se parte para determinar el patrimonio neto a efectos de esta causa de disolución, comprende:

- Con signo positivo: el capital escriturado, las primas de emisión, las reservas, los resultados de ejercicios anteriores, las aportaciones de los socios que no tengan la consideración de pasivo, el beneficio del ejercicio, otros instrumentos del patrimonio neto, y las subvenciones, donaciones y legados.

- Con signo negativo: los dividendos pasivos, las acciones y participaciones propias, los resultados negativos de ejercicios anteriores, las pérdidas del ejercicio y los dividendos a cuenta entregados.

- Finalmente forman parte del patrimonio neto contable, con signo positivo o negativo, los ajustes por cambio de valor (ajustes éstos que como hemos señalado, no se computa en el patrimonio neto a efectos de la causa de disolución -art. 36 del Código de Comercio-).

Reseñar que en alguna sentencia se alude de modo simplificado a fondos propios negativos (STS, Sala Civil, núm. 100/2012, de 7 marzo -Rec. 674/2009-), recurso a los fondos propios que no siempre será suficiente, debiéndose tener en cuenta el concepto del patrimonio neto a efectos de disolución reseñado, aunque una parte esencial de éste lo integren los fondos propios. Por el contrario, en la Sentencia del TS, Sala civil, 760/2007, de 4 de julio -Rec. 4503/2000-, se señala que "como viene declarando la jurisprudencia de esta Sala, para apreciar el desequilibrio patrimonial que obliga a los administradores a promover la disolución de la compañía debe tomarse en cuenta el patrimonio neto (activo menos pasivo) y compararlo con el capital social (el nominal o estatutario), sin sumar este a la diferencia positiva a favor del activo (Sentencia de 20 de febrero de 2004, en Recurso $n^{\circ} 1065 / 98$ ), ya que el desequilibrio patrimonial atendible es el que se da entre el capital social y el patrimonio neto, constituido éste por el activo real o suma de derechos, excluidas las deudas (Sentencia de 20 de octubre de 2003, en Recurso no 4465/97)". 
Las pérdidas han de deducirse de la contabilidad de la empresa, sin que el incumplimiento de la obligación legal de formular o depositar las cuentas constituya causa legal de disolución ${ }^{718}$, ni implique de modo inmediato la responsabilidad solidaria por deudas del administrador social. Lo que sucede es que la falta de presentación o depósito de las cuentas anuales provocará una inversión de la carga probatoria, por facilidad probatoria, de modo que será el administrador el que deberá acreditar la ausencia de concurrencia de la causa de disolución ${ }^{719}$, porque es de mala fe y al mismo tiempo irracional pretender que del incumplimiento de una obligación derive un beneficio para el incumplidor, en cuanto deja sin prueba a la contraparte de datos objetivos muy importantes (Sentencia TS, Sala Civil, 937/2004, de 5 de octubre -Rec. 2607/1998-).

Documentación contable que podrá ser requerida a la empresa por la Inspección de Trabajo y Seguridad Social, por estar facultada para recabar de la empresa todo tipo de documentación con trascendencia en la comprobación del cumplimiento de obligaciones con la Seguridad Social, sean libros, registros, programas informáticos, archivos en soporte magnético y contabilidad (art. 13.3.c) de la Ley 23/2015, de 21 de julio, Ordenadora del sistema de Inspección de Trabajo y Seguridad Social -LOITSS- ${ }^{720}$ ). Contabilidad que igualmente podrá solicitar la TGSS en ejercicio de su función recaudadora (art. 40.1 del TRLGSS).

De no llevarse la contabilidad surgirá el problema de poder acreditar las pérdidas cualificadas por la Inspección de Trabajo y Seguridad Social y la TGSS, en cuyo caso, la falta de contabilidad será un indicio que, conjuntamente con otros hechos como el incumplimiento generalizado de obligaciones con la Seguridad Social, el cese de actividad, el cierre de hecho de la empresa, o importe de la deuda de cuantía igual al importe del capital social, etc., permitirán iniciar el procedimiento administrativo de derivación de responsabilidad de las deudas al administrador, correspondiendo la carga

\footnotetext{
${ }^{718}$ Según la STS, Sala Civil, 202/2020, de 28 de mayo -Rec. 3365/2017-, "la falta de formulación de las cuentas anuales, aprobación y depósito en el Registro Mercantil privan a los terceros del conocimiento de la situación patrimonial y contable de la compañía, y que ello puede ser apreciado como un indicio que pudiera generar dudas sobre la existencia de pérdidas o de falta de actividad de la sociedad. Pero por sí sólo, como sostienen incluso las sentencias de las Audiencias que se adscriben a la reseñada tesis, no constituye una prueba directa de la concurrencia de la situación de pérdidas".

${ }^{719}$ SSTS, Sala Civil, 937/2004, de 5 de octubre; 505/2014, de 8 de octubre -Rec. 237/2013-; y 202/2020, de 28 de mayo -Rec. 3365/2017-

${ }^{720}$ BOE del 22.7.2015.
} 
probatoria de acreditar que no concurre la causa de disolución a éste o a la sociedad, por facilidad probatoria.

El importe de la deuda en relación con la cifra del capital social no es causa de disolución por pérdidas (STS, Sala Civil, en Sentencia 540/2004, de 17 de junio -Rec. 2329/1998-), ya que la despatrimonialización no resulta de la comparar el importe de la deuda y el capital social, sino de comparar éste con el patrimonio neto. Sólo excepcionalmente, y ante esas situaciones de empresas desaparecidas sin depósito de cuentas en el Registro Mercantil, en alguna doctrina judicial de los Tribunales Superiores de Justicia ${ }^{721}$, en la derivación administrativa de responsabilidad se ha partido del importe de las deudas con la Seguridad Social a efectos de determinar la concurrencia de la causa legal de disolución, por estimarse que las deudas con la Seguridad Social son un elemento indiciario de hallarnos ante la causa de disolución por pérdidas cualificadas ${ }^{722}$. Es un mero indicio, porque una sociedad puede tener una elevada deuda, que puede ser superior a su capital social, sin que por ello estemos ante esta causa de disolución, al poder tener un patrimonio neto sólido ${ }^{723}$. Las deudas serán también indicio de la causa de disolución, cuando la sociedad sigue con su actividad sin haber presentado las cuentas anuales en el Registro Mercantil durante varios ejercicios económicos, desatendiendo de modo generalizado el pago de sus cotizaciones sociales, especialmente cuando no han sido hallados bienes para el pago de las mismas.

En ausencia de contabilidad, se ha admitido como elemento probatorio indiciario de la causa de disolución por pérdidas, la declaración anual del impuesto de sociedades, si de ella resulta que el patrimonio neto es inferior al 50\% del capital social (Sentencia del TSJ Madrid, Sala Contencioso-Administrativa $n^{\circ}$ 168/2012, de 4 de mayo -Rec. 339/2011-).

721 Sentencia del TSJ Madrid, Sala Contencioso-Administrativa $n^{\circ}$ 168/2012, de 4 de mayo -Rec. 339/2011; Sentencia del TSJ Valencia, Sala Contencioso-Administrativa no 648/2018, de 3 de julio Rec. 689/2015-; Sentencia del TSJ del País Vasco, Sala Contencioso-Administrativa no 305/2016, de 28 de junio -Rec. 734/2015-; y Sentencia, TSJ Castilla La Mancha nº 233/2019, de 22 julio -Aranzadi 20191290270-, entre otras.

722 NICOLÁS BERNAD, J. A.: "Acciones por subrogación del FOGASA en supuestos de despatrimonialización empresarial", en Revista General de Derecho del Trabajo y Seguridad Social, número 48, 2018, pp. 61-63, para quien, ante esos supuestos, si la deuda es superior a la mitad del capital social, cabe presumir que concurre la causa de disolución, desplazándose la carga de la prueba de que no concurre la mima, a la sociedad y a los administradores.

723 NICOLÁS BERNAD, J. A.: "Acciones por subrogación del FOGASA en supuestos de despatrimonialización empresarial”, 2018, op. cit., p. 37. 
En la Guía Operativa de actuación en materia de derivación de responsabilidad a los administradores de sociedades mercantiles capitalistas en materia de deudas de Seguridad Social, de septiembre de 2017, de la Dirección General de la Inspección de Trabajo y Seguridad Social, y en el Criterio Técnico 89/2011, de la Dirección General de la Inspección de Trabajo y Seguridad Social, se señala que, cuando no se disponga de documentación contable (por no haber sido localizada la empresa o los administradores, por incomparecencia de éstos o por falta de depósito de las cuentas en el Registro), deberá acreditarse la insuficiencia patrimonial por vías indirectas, como podría ser, haber sido declarado el crédito incobrable por la TGSS, o constar la causa de disolución en declaración judicial, teniéndose presente que los conceptos de pérdidas e importe de la deuda no son identificables, el montante de la deuda, y en concreto de la deuda de Seguridad Social, podrán tomarse como un indicio de insuficiencia patrimonial para la derivación de la responsabilidad al administrador social, sin perjuicio de que la empresa acredite que no se encuentra en causa de disolución.

\subsection{Efectos de la crisis sanitaria del Covid-19 en la causa de disolución.}

Esta causa de disolución por pérdidas cualificadas no ha sido de aplicación en el ejercicio económico del 2020 (art. 13 de la Ley 3/2020, de 18 de septiembre, de medidas procesales y organizativas para hacer frente al Covid-19 en el ámbito de la Administración de Justicia ${ }^{724}$ ), por los efectos de la crisis sanitaria del Covid-19. Se ha establecido una suspensión o exceptuación de esta causa de disolución para el ejercicio económico de 2020, excluyéndose la responsabilidad por deudas de Seguridad Social tanto si resulta de las cuentas anuales del ejercicio como de un balance trimestral de comprobación de ese ejercicio (art. 13 de la Ley 3/2020, de 18 de septiembre, en relación con el art. 40.12 del Real Decreto-Ley 8/2020, de 17 de marzo). Artículo 13 de la Ley 3/2020 que se complementa con la norma que excluye la responsabilidad del

${ }^{724}$ BOE del 19.9.2020. En el artículo 13 se establece:

"Artículo 13. Suspensión de la causa de disolución por pérdidas.

1. A los solos efectos de determinar la concurrencia de la causa de disolución prevista en el artículo 363.1.e) del texto refundido de la Ley de Sociedades de Capital, aprobado por el Real Decreto Legislativo 1/2010, de 2 de julio, no se tomarán en consideración las pérdidas del ejercicio 2020. Si en el resultado del ejercicio 2021 se apreciaran pérdidas que dejen reducido el patrimonio neto a una cantidad inferior a la mitad del capital social, deberá convocarse por los administradores o podrá solicitarse por cualquier socio en el plazo de dos meses a contar desde el cierre del ejercicio conforme al artículo 365 de la citada Ley, la celebración de junta general para proceder a la disolución de la sociedad, a no ser que se aumente o reduzca el capital en la medida suficiente.

2. Lo dispuesto en el apartado anterior se entiende sin perjuicio del deber de solicitar la declaración de concurso de acuerdo con lo establecido en la presente Ley". 
administrador por las deudas del período del primer estado de alarma, del 14.3.2020 al 20.6.2020 (art. 40.12 del Real Decreto-Ley 8/2020, de 17 de marzo). Precepto legal que es aplicable a la SLNE, aunque se aluda sólo en el mismo al art. 363 apartado 1. e) de la LSC y no al art. 453 de la LSC, por ser un olvido legislativo, existiendo la misma ratio legis.

Del referido art. 13 de la Ley 3/2020, surge la duda de si se excluyen también las pérdidas que resulten de los balances trimestrales del 2021, ya que de conformidad con el art. 13.1. in fine de la Ley 3/2020, "Si en el resultado del ejercicio 2021 se apreciaran pérdidas que dejen reducido el patrimonio neto a una cantidad inferior a la mitad del capital social, deberá convocarse por los administradores o podrá solicitarse por cualquier socio en el plazo de dos meses a contar desde el cierre del ejercicio conforme al artículo 365 de la citada Ley, la celebración de Junta General para proceder a la disolución de la sociedad, a no ser que se aumente o reduzca el capital en la medida suficiente".

Ante ese precepto caben dos interpretaciones. En virtud de una primera ${ }^{725}$, puede entenderse que la causa se ha suspendido hasta el 2022, de modo que para el 2021 las pérdidas deben resultar sólo de las cuentas anuales, con lo que no operaría la causa en caso de resultar de balances trimestrales del 2021, como se ha hecho con el concurso de acreedores en el art. 6 de esa disposición legal, al no tener obligación el deudor de solicitar el concurso antes del 31.12.2021 -según redacción dada a ese precepto mediante el Real Decreto en la Ley 5/2021, de 12 de marzo, de medidas extraordinarias

725 Son partidarios de entender que la causa se ha suspendido hasta 2022: ALCOVER GARAU, G.: “Aproximación al Régimen Jurídico de los artículos 8 a 18 del Capítulo II (medidas concursales y societarias) del Real Decreto Ley 16/2020, de 28 de abril, de medidas procesales y organizativas para hacer frente al Covid-19 en el ámbito de la Administración de Justicia”, en Diario La Ley, № 9634, Tribuna, 18 de mayo de 2020, edición digital, p. 13 de 13, para quien la redacción es confusa y (sic) "caben tres posibilidades: (i) que sean exclusivamente las pérdidas de 2021 las que provoquen la disminución que da lugar a la necesidad de la Junta General de Socios, lo que sería absurdo si hubiera perdidas de los años anteriores al año 2020; (ii) que sean las pérdidas del año 2021 y las de los años anteriores al año 2020 las que cuenten, pero así la norma sería inútil, ya que es obvio que en tal caso se debería convocar la Junta General de Socios del artículo 364 de la Ley de Sociedades de Capital; y (iii) que en 2022 contasen las pérdidas del 2020, de forma que así la norma tendría sentido, pero se contradeciría con la del apartado primero, que tiene un alcance general. No obstante, todo ello, parece que lo más seguro sería decantarse por esta última opción": SALINAS ADELANTADO, C.: "El nuevo escenario preconcursal y concursal después del RDL 16/2020 y el TRLC: ¿Realmente hay que esperar a 2021 para tomar decisiones?”, en Diario La Ley, № 9652, Tribuna, 12 de junio de 2020, edición digital, p. 3 de 10, al señalar que "elimina la obligación de disolución por las pérdidas generadas en 2020 y pospone la posibilidad de la disolución por pérdidas generadas en el ejercicio 2021 a principios de 2022 (art. 18 RDL 16/2020)"; ESTEVE-SEGARRA, A.: "Responsabilidad de los administradores y directivos de la empresa por deudas laborales y de Seguridad Social por la crisis económica del coronavirus", en $R d S$, núm. 90, 2020, p. 79, al indicar que se suspende la causa de disolución por pérdidas hasta el 2022. 
de apoyo a la solvencia empresarial en respuesta a la pandemia de la Covid-19 ${ }^{726}$. Debería darse igual tratamiento al concurso y a la disolución por pérdidas, permitiendo que a lo largo del año 2021 las empresas puedan recuperar su patrimonio enjugando las pérdidas en las que han incurrido por causas exógenas, en buena medida como consecuencia de las limitaciones o cierres temporales de actividades ordenados por las autoridades sanitarias. En virtud de una segunda interpretación literal y sistemática de la redacción inicial de la Ley 3/2020 727 , se entendió que la única especialidad del art. 13.1 in fine, era fijar un plazo específico y distinto para convocar la Junta General para promover la disolución dentro de los dos meses siguientes al cierre del ejercicio, pero no excluir las pérdidas de los balances trimestrales, ya que, por otro lado, de haberse querido excluir la causa disolutoria de los balances trimestrales se hubiese establecido expresamente como se hizo en la redacción inicial del artículo 6 con el concurso de acreedores, excluido hasta el 14.3.2021. No era muy coherente en la redacción inicial de los artículo 6 y 13 de esa Ley, no estar obligados a promover la disolución o la remoción de la causa -medida preconcursal-, y en cambio tener que solicitar el concurso a partir del 14.3.2021. Interpretación que se veía reforzada acudiendo a la voluntas legislatoris al indicarse en la exposición de motivos de la Ley 3/2020 que la finalidad de esa medida es permitir ( $\mathrm{sic}$ ) "a las empresas ganar tiempo para poder reestructurar su deuda, conseguir liquidez y compensar pérdidas, ya sea por la recuperación de su actividad ordinaria o por el acceso al crédito o a las ayudas públicas. De esta forma, se prevé que a los efectos de la causa legal de disolución por pérdidas no se computen las del presente ejercicio", esto es, en la exposición de motivos sólo contempla las del 2020, pero no dice que no computen las del 2021.

\footnotetext{
${ }^{726}$ BOE del 13.3.2021

${ }^{727}$ QUIJANO GONZÁLEZ, J.: "Los órganos societarios y el Estado de Alarma”, Diario la Ley, № 9675 , Sección Tribuna, 16 de julio de 2020, edición digital,

https://diariolaley.laleynext.es/Content/Documento.aspx?params, p. 25 de 31, para quien, (sic) "ahora no se trata de no computar determinadas pérdidas, sino de no tomar en consideración las pérdidas de un ejercicio en su conjunto; y sólo de un ejercicio, el corriente de 2020, pues la propia norma aclara que, si en el resultado del ejercicio de 2021 se aprecian pérdidas cualificadas, la obligación de convocar junta para disolver o adoptar solución alternativa suficiente vuelve a aplicarse en sus propios términos"; RUIZ GONZÁLEZ, M. A.: "Análisis del Real Decreto-Ley 16/2020, de 28 de abril, de medidas procesales y organizativas para hacer frente al Covid-19 en el ámbito de la Administración de Justicia", Diario La Ley, No 9640, Tribuna, 26 de mayo de 2020, edición digital, p. 7 de 7, que establece "a este respecto, aunque con una redacción ciertamente confusa, no parece que dicha suspensión haya de entenderse hasta la finalización del ejercicio 2021, sino que, a partir del ejercicio 2020, una vez constatada la causa de disolución por pérdidas, habrá de procederse a la misma, lo que entra en coherencia con el último apartado, que no exonera de la obligación de solicitud de la declaración de concurso.
} 
Tras la reforma de la Ley 3/2020 por el Real Decreto-Ley 5/2021, en virtud de una interpretación literal y sistemática de los arts. 6 y 13 de la Ley 3/2020, y pese a no haberse modificado el art. 13 de la Ley 3/2020, estimamos que deberá darse igual tratamiento a la causa de disolución por pérdidas y al concurso, para evitar que se vean abocadas a la disolución empresas que sean viables económicamente al finalizar el ejercicio 2021, porque la exoneración del deber de solicitar el deudor el concurso antes del 31.12.2021 tiene igual finalidad en la disolución por pérdidas cualificadas, que estas resulten solo del balance al cierre del ejercicio 2021, para permitir a la empresa poder superar la causa compensando pérdidas a lo largo del año 2021, por entender que estas se han generado, en buena medida, por causas exógenas a la sociedad como consecuencia de los estados de alarma del 2020 y 2021, por lo que sería razonable que se excluyesen las pérdidas del 2021 que resultasen de un balance trimestral, debiendo manifestarse en las cuentas de cierre del ejercicio, motivo por el que debe convocarse cuanto antes a la Junta General, dentro de los dos meses siguientes al 31 de diciembre. Ante esa dualidad interpretativa, e inclinándonos por la primera interpretación, con la finalidad de dar certeza a los administradores y a las sociedades, deberá ser objeto de reforma también el art. 13 de la Ley 3/2020 para exceptuar expresamente las pérdidas de los balances trimestrales del enero a septiembre de 2021, para no abocar a muchas empresas a la disolución y a la destrucción de empleo, siendo conscientes que podrá tener paralelamente como efecto fáctico negativo poder permitir la continuidad en el año 2021 de empresas zombis insalvables. Al no haberse clarificado esta cuestión, se va a generar mucha incertidumbre en los administradores sociales, los cuales, ad cautelam, y ante la eventualidad de poder incurrir en responsabilidad, serán proclives a cumplir con los deberes de promover la disolución de la sociedad si la causa se manifiesta en los balances trimestrales.

\section{IV.- PRESUPUESTOS OBJETIVOS DE RESPONSABILIDAD. DEBERES INCUMPLIDOS.}

Ante la concurrencia de una causa legal de disolución de la sociedad de capital, para que nazca la responsabilidad solidaria de los administradores por las deudas de la sociedad deberán incumplir cualquiera de las dos obligaciones o deberes legales establecidos en 
los arts. 365 a 367 LSC $^{728}$, que operan como los presupuestos objetivos de la responsabilidad.

Los presupuestos objetivos o materiales que desencadenan esta responsabilidad por deudas de los administradores, al amparo del art. 367 de la LSC, serán los siguientes ${ }^{729}$. En primer lugar, que acaezca la causa de disolución y conozcan su acaecimiento. En segundo lugar, si incumplen la obligación de convocar la Junta General en el plazo máximo de dos meses, computados desde que acaece la causa o en su defecto desde que conocieron o debieron conocer su acaecimiento, para que la misma adopte el acuerdo de disolución o medidas alternativas que permitan remover la causa de disolución; o cuando siendo la sociedad insolvente no solicitasen el concurso de acreedores, pudiendo en caso de insolvencia inminente convocar la junta para que ésta decida las medidas a adoptar. En tercer lugar, cuando ante el acuerdo contrario a la disolución, o ante el acuerdo no adoptado, sin haberse removido la causa, si incumplen la obligación de solicitar la disolución judicial dentro de los dos meses siguientes a la fecha de la celebración de la junta o a la fecha prevista para la celebración de la junta si ésta no se constituyó; o bien si no solicitan en ese plazo de dos meses el concurso de acreedores de ser la sociedad insolvente.

Los deberes determinantes de la derivación administrativa de responsabilidad al administrador desaparecen si en el plazo concedido para convocar la junta o solicitar la disolución judicial o el concurso de acreedores, cesa la causa de disolución. En cambio,

728 CALBACHO LOSADA, F.: El ejercicio de las acciones de responsabilidad contra los administradores de la sociedad anónima, op. cit., pp. 412-470; SÁNCHEZ CALERO, F.: Los administradores en las sociedades de capital, op. cit., pp. 445-485; RODRÍGUEZ RUIZ DE LA VILLA, D. y HUERTA VIESCA, M. I.: La responsabilidad de los administradores por las deudas de las Sociedades de Capital (en las Leyes de Sociedades Anónimas, de Sociedades de Responsabilidad Limitada, de Sociedad Limitada Nueva Empresa, Concursal, General Tributaria $y$ de Responsabilidad Medioambiental), op. cit. pp. 212-340; MOYA BALLESTER, J.: La responsabilidad de los administradores de sociedades en situaciones de crisis, op. cit., pp. 247 y ss; BATALLER GRAU, J.: “Disolución y Liquidación”, op. cit. pp. 2560-2578; BELTRÁN SÁNCHEZ, E.: "La responsabilidad de los administradores por obligaciones sociales", op. cit., pp. 311-330; VALPUESTA GASTAMINZA, E. M.: Comentarios a la Ley de Sociedades de Capital, op. cit., pp. 942-961; ESTEBAN VELASCO, G.: "Algunas reflexiones sobre la Responsabilidad de los Administradores frente a los Socios y los Terceros: Acción individual y acción por no Promoción o Remoción de la disolución”, op. cit., pp. 68-73; QUIJANO GONZÁLEZ, J.: "Responsabilidad de los administradores por no disolución de la sociedad (art. 262.5 TRLSA) (Sentencia de la Audiencia Provincial de Burgos de 24 de julio de 1995)", op. cit., pp. 269-273.

${ }^{729}$ Por todas SSTS, Sala Civil, 458/2010, de 30 de junio; 680/2010, de 10 noviembre; 173/2011, de 17 de marzo -Rec. 1408/2007-; 942/2011, de 29 de diciembre; 395/2012, de 18 de junio; 225/2012, de 13 de abril -Rec. 1018/2009-; 560/2013, de 7 de octubre; 585/2013, de 14 de octubre; 27/2017, de 18 de enero -Rec. 1422/2014-; y 420/2019, de 15 de julio, entre otras.

En igual sentido, STS, Sala Contencioso Administrativo 875/2019, de 24 de junio -Rec. 2902/2018-, sobre derivación de deudas de Seguridad Social de la sociedad de capital al administrador social. 
si la causa se remueve después de finalizar los dos periodos, o los administradores cumplen con retraso con los deberes legales, éstos responderán de las deudas anteriores al cumplimiento tardío o anteriores a la fecha de la remoción de la causa, pero no así de las posteriores a ese momento (Sentencia del TS, Sala Civil, 328/2011, de 19 de mayo).

Será objeto de análisis, si en los dos deberes referidos se incluye la solicitud del concurso de acreedores o de medidas preconcursales, y, por lo tanto, si quedarían liberados de responsabilidad los administradores que soliciten el concurso en lugar de convocar la junta cuando concurren simultáneamente las dos causas, disolución e insolvencia.

Concurriendo el presupuesto objetivo para que proceda la derivación administrativa de responsabilidad, debe concurrir también el presupuesto subjetivo de imputabilidad de la responsabilidad, que será objeto de análisis en el apartado VI.

Analicemos los presupuestos objetivos determinantes de esa responsabilidad.

\section{Acaecimiento y conocimiento de la causa de disolución.}

La responsabilidad de los administradores por las deudas de la sociedad nace cuando concurra la causa legal de disolución, computándose el plazo para el cumplimiento del primer deber de convocar la Junta General, desde que "conocieron o pudieron conocer", desde que "debieron conocer" el acaecimiento de la misma o desde el momento en que "no podían ignorar la grave situación de la sociedad", en virtud de la diligencia de un ordenado empresario $^{730}$ (art. 225 de la LSC).

El momento del acaecimiento de la causa de disolución, y en su caso, de su conocimiento por el administrador, a efectos de determinar el dies a quo para el cumplimiento del primer deber de convocar la Junta General, es una cuestión de hecho, que, de debatirse, habrá de acreditarse por medios probatorios válidos en Derecho (Sentencia del TS, Sala Civil, 328/2011, de 19 de mayo).

Corresponde en principio al acreedor ${ }^{731}$ acreditar la concurrencia de la causa de disolución y que el administrador social ha incumplido alguno de los dos deberes

${ }^{730}$ STS, Sala Civil, 977/2000, de 30 de octubre; 776/2001, de 20 de julio; 766/2002, de 18 de julio; 1219/2004, de 16 de diciembre; 195/2006, de 9 de marzo; 760/2007, de 4 de julio; 873/2007, de 16 de julio; 986/2008, de 23 de octubre; 460/2010, de 14 de julio; 791/2010, de 10 de noviembre; 173/2011, de 17 de marzo; 328/2011, de 19 de mayo; y 100/2012, de 7 de marzo -Rec. 674/2009-.

731 BELTRÁN SÁNCHEZ, E.: "La responsabilidad de los administradores por obligaciones sociales", op. cit., p. 312; VALPUESTA GASTAMINZA, E. M.: Comentarios a la Ley de Sociedades de 
legales; pero debido a la presunción del art. 367 de la LSC de presumirse de fecha posterior todas las obligaciones reclamadas, ello puede abocar a que sea el administrador social quien deba acreditar que no concurría la causa de disolución en la fecha de devengo de la obligación. La desaparición o el cierre de hecho de la empresa no exime a los administradores de cumplir con los deberes legales impuestos en los arts. 365 a 367 de la LSC (Sentencia del TS, Sala Civil, 409/2008, de 14 de mayo -Rec. 251/2001-), y el cierre de hecho acompañado de la falta de presentación de cuentas, son elementos suficientes de acreditación de las causas de disolución de imposibilidad manifiesta de realizar el fin social o la paralización de sus órganos sociales que imposibilitan su funcionamiento (Sentencia del TS, Sala Civil, 124/2010, de 12 de marzo -Rec. 1435/2005-).

En la doctrina científica ${ }^{732}$ se ha alegado que la presunción del art. 367 de la LSC de ser las deudas posteriores a la causa de disolución, debería entenderse como una presunción de acaecimiento de la causa de disolución a la fecha de la obligación reclamada, al no ser fácil determinar por el acreedor el momento del acaecimiento de la causa de disolución, siendo la deuda de fácil determinación objetiva. De este modo, no correspondería al acreedor probar el acaecimiento de la causa de disolución, o la fecha en que los administradores conocieron o debieron conocer la misma, sino que la presunción operaría en el sentido de entender que la causa de disolución ya concurría en la fecha de la obligación reclamada, debiendo los administradores desvirtuar la presunción probando que la causa no concurría en la fecha de la obligación, o que no la conocían, ni podían conocerla.

Esta es la interpretación de la STS, Sala Civil, 458/2010, de 30 de junio, al señalar que, "sin perjuicio de prueba en contrario, se presume que en el momento de nacer la obligación cuyo cumplimiento se reclama la sociedad ya estaba incursa en causa de disolución”.

Capital, op. cit., p. 950; DÍAZ ECHEGARAY, J. L: Deberes y responsabilidades de los Administradores de Sociedades de Capital, op. cit., p. 400.

Y SSTS, Sala Civil, 492/2006, de 23 de mayo; 138/2007, de 20 de febrero; y 152/2007, de 21 de febrero.

732 BELTRÁN SÁNCHEZ, E.: “La responsabilidad de los administradores por obligaciones sociales", op. cit., p. 343. 
La TGSS o el OEITSS en la derivación administrativa de responsabilidad de las deudas de Seguridad Social deberán acreditar la causa y su acaecimiento ${ }^{733}$, de disponer de prueba directa. De no disponerse de pruebas directa, deberá alegarse la concurrencia de la causa partiendo de la prueba de indicios, estimándose de fecha anterior a la obligación reclamada, correspondiendo al administrador social por facilidad probatoria del art. 217.7 de la LEC, la prueba de acreditar la no concurrencia de la causa o ser de fecha posterior a la deuda reclamada, o bien, que siendo de fecha anterior, no pudieron ni debieron conocerla con anterioridad a la deuda en atención a las exigencias del deber de diligencia. Esta inversión de la carga de la prueba al administrador, cobra su pleno sentido y justificación, en aquellos supuestos de cierre de hecho de la empresa sin ordenada liquidación, y sin haber cumplido con sus obligaciones contables, ya que, en tales circunstancias no puede exigirse al acreedor de la deuda de Seguridad Social la prueba directa, especialmente del montante de las pérdidas, de ser esa la causa disolutoria (Sentencia del TS, Sala Civil, 937/2004, de 5 de octubre).

\subsection{Acaecimiento de las diversas causas de disolución.}

El acaecimiento y conocimiento de la causa de disolución, dependerá de la concreta causa.

Con relación a la causa de disolución de cese de las actividades integrantes del objeto social (art. 363.1.a) de la LSC), o la de conclusión de la empresa que constituye el objeto social (art. 363.1.b) de la LSC), serán los administradores los primeros en conocer el cese de actividades que constituyen el objeto social, en cuanto encargados de la dirección y gestión societaria, por lo que no podrán alegar desconocimiento, con lo que nace desde el día en que la sociedad cesó en sus actividades con carácter definitivo. En favor de los acreedores, y en nuestro caso de la TGSS o del OEITSS, se establece una presunción, de modo que una vez hayan transcurrido doce meses de inactividad se entiende ope legis producida la causa (art. 363.1.a) de la LSC), siendo dies a quo el cierre, vaya o no acompañado de las bajas de los trabajadores en Seguridad Social y de la baja de la empresa en censo de obligados tributarios. Causas de cese y conclusión de la empresa que constituye el objeto social, que, en sí mismas, no deberán generar deudas de Seguridad Social posteriores, y si se ha cesado en la actividad, no habrá

\footnotetext{
${ }^{733}$ Criterio Técnico 89/2011 de la Dirección General de la Inspección de Trabajo y Seguridad Social, y en
} la Guía Operativa de septiembre de 2017. 
prestaciones laborales de servicios de las que puedan surgir deudas por cotizaciones o por prestaciones.

Más problemático será determinar por la TGSS o por la Inspección de Trabajo y Seguridad Social, el momento en que acaece la causa de la imposibilidad manifiesta de conseguir el fin social (art. 363.1.c) de la LSC), de la que sí pueden surgir deudas de Seguridad Social al continuarse la actividad laboral. Causa que presenta una evidente dificultad probatoria, siendo de difícil apreciación por los acreedores, por lo que, a falta de prueba directa habrá de acudirse a las pruebas de indicios, como pudieran ser, el cierre de hecho, la desaparición del domicilio, carecer de trabajadores reales, pese a no haber solicitado las bajas de los empleados en Seguridad Social, etc. En esta causa serían encuadrables los supuestos aludidos de infracapitalización material o nominal de la sociedad, con la dificultad de acreditarse que el capital social es manifiestamente insuficiente para el fin social, para lo que servirá de indicio el examen de la contabilidad, comprobando si la empresa está suficientemente financiada, y esa financiación puede abocarla a incurrir en la causa de disolución por pérdidas cualificadas.

La causa de disolución por paralización de los órganos sociales (art. 363.1.d) de la LSC), precisa que sea una paralización definitiva y no transitoria, siendo difícil concretar en qué momento se produce la paralización, ya que no se determinan cuántas juntas de accionistas han de haberse convocado sin llegarse a reunir, o cuántas han de celebrarse sin llegar a adoptar acuerdos ${ }^{734}$. En todo caso, por la TGSS o por el OEITSS, se entenderá producida la misma, cuando fruto del bloqueo manifiesto de los órganos sociales, no se ha convocado o reunido, o no se ha adoptado acuerdo social alguno en la junta ordinaria a celebrar dentro de los seis primeros meses del año para aprobar la gestión y cuentas anuales, o no se celebran o adoptan acuerdos en juntas obligatorias como las previstas en el art. 171 de la LSC para la sustitución de los administradores en caso de cese. Si la paralización es del órgano de administración, se entenderá producida si no se adoptan decisiones básicas sobre funcionamiento de la sociedad como empresa, por no ejecutarse los cometidos de dirección o gestión, que en el ámbito laboral se traduce en el ejercicio de los poderes disciplinarios y de dirección u organización de la

734 RODRÍGUEZ RUIZ DE LA VILLA, D. y HUERTA VIESCA, M. I.: La responsabilidad de los administradores por las deudas de las Sociedades de Capital (en las Leyes de Sociedades Anónimas, de Sociedades de Responsabilidad Limitada, de Sociedad Limitada Nueva Empresa, Concursal, General Tributaria y de Responsabilidad Medioambiental), op. cit., p. 255. 
relación laboral, que se constata objetivamente por la imposibilidad de concertar contratos de trabajo, de adoptar medidas de dirección, organización, suspensión, extinción o modificación de las relaciones laborales, fruto del bloqueo del órgano de administración, lo que les impide cumplir las obligaciones legales ante las Administraciones Públicas, especialmente ante la Seguridad Social y la Agencia Tributaria.

La causa de disolución de exceder las acciones o participaciones sin voto de la mitad del capital social (art. 363.1.g) de la LSC), será fácil de comprobar a través de las escrituras públicas y de la inscripción registral en que conste la reducción de capital que ha motivado ese desequilibrio, naciendo la causa generadora de la responsabilidad una vez hayan transcurrido dos años sin haberse restablecido el equilibrio. Aquí existe mayor certeza para que la TGSS o el OEITSS acrediten el acaecimiento y conocimiento por los administradores de esta causa disolutoria, al estar ante hechos objetivos que deben elevarse a escritura pública e inscribirse en el Registro Mercantil, con lo que es obligatoria la consulta registral y el índice único notarial.

La causa de reducción del capital social por debajo del mínimo legal que no sea fruto del cumplimiento de una ley (art. 363.1.f) de la LSC), como hemos reseñado, es de difícil aplicación en la práctica, ya que sería un acuerdo nulo, por ir en contra los arts. 4 y 343 de la LSC, de modo que tendría lugar si ese acuerdo superase los filtros notariales y registrales, en cuyo caso, el acaecimiento sería constatable a través de la escritura que documenta la reducción del capital social o de las actas de las juntas en que se adoptó el $\operatorname{acuerdo}^{735}$.

\subsection{Acaecimiento de las pérdidas cualificadas.}

Debemos determinar cuándo concurre la causa de disolución por pérdidas cualificadas (art. 363.1.e) de la LSC), cuándo se entiende que es conocida o debió ser conocida por los administradores, si las pérdidas han de constar en las cuentas anuales que cierran el ejercicio económico, o si, por el contrario, pueden producirse o derivarse de los balances de comprobación o en cualquier otro momento del año.

${ }^{735}$ BATALLER GRAU, J.: “Disolución y Liquidación”, op. cit., p. 2558. 
En la doctrina científica se han mantenido esas dos opciones. Para un sector, las pérdidas cualificadas habrán de constar en la cuentas anuales ${ }^{736}$, no siendo suficiente que consten en los balances trimestrales de comprobación. Para esta interpretación doctrinal se parte de tres argumentos. Un primer argumento conceptual, en virtud del cual se entiende que las pérdidas son las del ejercicio económico, las que se reflejan en las cuentas anuales. Un segundo argumento, es que con el recurso a las cuentas anuales se evita que una situación de pérdidas transitorias de un trimestre aboque a la sociedad a la disolución, pudiendo en trimestres sucesivos obtenerse elevados beneficios, con lo que se causaría un daño más grave que el que se pretende evitar. Y mediante un último argumento, se señala que en interpretación sistemática esa es la solución que se impone para la reducción obligatoria del capital cuando las pérdidas reducen el patrimonio neto de la sociedad anónima por debajo de los dos tercios del capital social, exigiéndose que transcurra un ejercicio social sin haberse recuperado, por lo que se estaría contemplando las cuentas formuladas al finalizar el ejercicio social.

Una de las críticas ${ }^{737}$ que se ha realizado a esta interpretación, es que, tras la reforma de la Ley 19/2005, de 14 de noviembre, que limitó la responsabilidad del administrador a las deudas posteriores al acaecimiento de la causa de disolución, conllevaría que una sociedad con pérdidas cualificadas siguiese operando en el mercando con conocimiento por los administradores de que probablemente acabe en situación de insolvencia, contrayendo nuevas deudas que difícilmente se podrán pagar, sin que se asuma responsabilidad por esas obligaciones contraídas en el período anterior a la formulación de las cuentas anuales.

Para otro sector doctrinal ${ }^{738}$, las pérdidas pueden deducirse de un balance de comprobación, de otro documento contable provisional, o en cualquier momento en el

${ }^{736}$ ROJO FERNÁNDEZ-RÍO, A.: "Los deberes legales de los administradores en orden a la disolución de la sociedad de capital como consecuencia de pérdidas”, en Derecho de Sociedades, Estudio en Homenaje a Sánchez Calero, Vol. II. Madrid, 2002, pp. 1462 y ss; SÁNCHEZ CALERO, F.: Los administradores en las sociedades de capital, op. cit., pp 455-457; DÍAZ ECHEGARAY, J. L.: Deberes y responsabilidades de los Administradores de sociedades de Capital, op. cit., pp. 364-386; GIRÓN TENA, J.: Derecho de sociedades Anónimas, Valladolid, 1952. El profesor Rojo señala que el plazo para convocar los administradores la Junta General, debe computarse desde el momento que se formulen las cuentas, y de no elaborarse las mismas, se tomará como dies a quo aquél en que finalice el plazo para su formulación.

${ }^{737}$ MOYA BALLESTER, J.: La responsabilidad de los administradores de sociedades en situaciones de crisis, op. cit., pp. 109-110.

738 BELTRÁN SÁNCHEZ, E.: "La responsabilidad de los administradores por obligaciones sociales", op. cit., p. 315; BATALLER GRAU, J.: “Disolución y Liquidación”, op. cit., p. 2556; ESTEBAN VELASCO, G.: “Algunas reflexiones sobre la Responsabilidad de los Administradores frente a los 
ejercicio social, sin necesidad de esperarse a la formulación de las cuentas anuales. Se defiende que las pérdidas deben apreciarse en el momento en que surjan, sin esperarse a la formulación de las cuentas anuales, partiendo básicamente de dos argumentos. En primer lugar, de una interpretación teleológica de la institución de la disolución por pérdidas cualificadas, por tener la misma una función preventiva o preconcursal, siendo su finalidad evitar que acaben en situación de insolvencia esas sociedades, con el consiguiente daño que ello supondría para los acreedores y el tráfico económico en general, finalidad que se vería seriamente amenazada si hubiera que esperar a la formulación de las cuentas anuales. En segundo lugar, se ha afirmado en virtud de un argumento sistemático que no se precisa que las pérdidas consten en el balance anual, porque incluso para la reducción obligatoria del capital en la sociedad anónima, cuando las pérdidas reduzcan el patrimonio neto por debajo de los dos tercios de la cifra del capital social, habiendo transcurrido un ejercicio social sin recuperarse el patrimonio (art. 327 de la LSC), sólo se exige que esas pérdidas consten en un balance elaborado dentro de los seis meses anteriores al acuerdo de reducción del capital, sin exigirse que sea una balance anual.

Este sector doctrinal ${ }^{739}$, con esa interpretación se decanta por una mayor protección del acreedor y por resaltar el carácter preventivo de la disposición legal que impone la responsabilidad al administrador social. No exigen que las pérdidas deban reflejarse en las cuentas anuales ya que pueden ser tan manifiestas que los administradores no pueden desconocerlas, sin esperar a finalizar el ejercicio económico ${ }^{740}$. Lo verdaderamente relevante es que las pérdidas existan y sean o deban ser conocidas por los administradores, y no tanto su reflejo formal en las cuentas anuales o en los balances

Socios y los Terceros: Acción individual y acción por no Promoción o Remoción de la disolución", op. cit., p. 69; QUIJANO GONZÁLEZ, J.: "La responsabilidad de los administradores por no disolución de la sociedad (art. 262.5 TRLSA) (Sentencia de la Audiencia Provincial de Burgos de 24 de julio de 1995)", 1995, op. cit., p. 270; MACHADO PLAZAS, J.: Pérdida del capital social y responsabilidad de los administradores por deudas sociales, op. cit., pp. 201-212 y 206-211; RODRÍGUEZ ARTIGAS, F. y MARÍN DE LA BÁRCENA GARCIMARTÍN, F.: "Algunas cuestiones sobre la responsabilidad de los administradores de la Sociedad a por no promoción de la disolución en caso de pérdidas (art. 265.2 LSA). STS 16 de diciembre de 2004 ”, en $R d S, \mathrm{n}^{\circ} 24,2005$, pp. 298-302; CERDÁ ALBERO, F.: Administradores, insolvencia y disolución por pérdidas, Tirant Lo Blanch, Valencia, 2000, pp. 108-111.

${ }^{739}$ MOYA BALLESTER, J.: La responsabilidad de los administradores de sociedades en situaciones de crisis, op. cit., pp. 104-105.

${ }^{740}$ BELTRÁN SÂNCHEZ, E.: "La responsabilidad de los administradores por obligaciones sociales", op. cit., p. 315. 
trimestrales, porque el desequilibrio patrimonial puede aparecer en cualquier momento del ejercicio económico ${ }^{741}$.

Con esta segunda interpretación se reforzará el cumplimiento de los deberes de diligencia, con un conocimiento diario y actualizado de la situación patrimonial de la sociedad por los administradores, especialmente a la altura de nuestros días en que la llevanza de la contabilidad se realiza con la utilización de la información contable informatizada, mediante información financiera digital ${ }^{742}$, con conocimiento inmediato de la posible situación de pérdidas patrimoniales.

Esta segunda interpretación doctrinal es la que sigue nuestra jurisprudencia ${ }^{743}$, para la cual, las pérdidas cualificadas pueden resultar en cualquier momento del ejercicio, de un balance de comprobación trimestral, sin tenerse que esperar a las cuentas anuales, y sea cual sea la fuente de conocimiento. E incluso, cuando sean de tal entidad las pérdidas que no pueden ser desconocidas por los administradores.

En la Sentencia del TS, Sala Civil, 328/2011, de 19 de mayo, exponiendo y contrastando los argumentos esgrimidos por las dos interpretaciones doctrinales, considera mejor fundados los sentados por los partidarios de la constatar las pérdidas en cualquier momento del año, sirviendo un balance trimestral. Sólo excepcionalmente acoge obiter dicta el criterio de la formulación de las cuentas anuales la Sentencia del TS, Sala Civil, 110/2004, de 23 de febrero, que como nos recuerda la Sentencia 328/2011, de 19 de mayo, "sin embargo, al final no se pronunció sobre el problema" del momento en que se entienden producidas las pérdidas.

Al poderse derivar las pérdidas tanto de las cuentas anuales como de un balance trimestral de comprobación, en la derivación administrativa de responsabilidad de deudas de Seguridad Social al administrador social, se debe explicitar la fecha en que el

${ }^{741}$ QUIJANO GONZÁLEZ, J.: "Responsabilidad de los administradores por no disolución de la sociedad (art. 262.5 TRLSA) (Sentencia de la Audiencia Provincial de Burgos de 24 de julio de 1995)”, op. cit., p. 270; BATALLER GRAU, J.: "Disolución y Liquidación", op. cit., p. 2556.

742 RODRÍGUEZ RUIZ DE LA VILLA, D. y HUERTA VIESCA, M. I.: La responsabilidad de los administradores por las deudas de las Sociedades de Capital (en las Leyes de Sociedades Anónimas, de Sociedades de Responsabilidad Limitada, de Sociedad Limitada Nueva Empresa, Concursa, General Tributaria y de Responsabilidad Medioambiental), op. cit., p. 235.

${ }^{743}$ Sentencias del TS, Sala Civil, 977/2000, de 30 de octubre; 776/2001, de 20 de julio; 766/2002, de 18 de julio -Rec. 328/1997-; 1219/2004, de 16 de diciembre; 760/2007, de 4 de julio; 873/2007, de 16 de julio; 986/2008, de 23 de octubre; 460/2010, de 14 de julio; 328/2011, de 19 de mayo; 173/2011, de 17 de marzo; y 100/2012, de 7 marzo. 
administrador social conoció o debió conocer, porque no pudo ignorar, que había pérdidas que reducían el patrimonio neto a la mitad del capital social.

Fecha que, cuando menos, será, en el caso de las cuentas anuales, el 31 de marzo del año siguiente, fecha límite para la formulación de las cuentas anuales (arts. 26 y 253 de la LSC), con la excepción relativa al año 2020 en que el plazo de tres meses para formular las cuentas del ejercicio 2019 se computa a partir del 1 de junio de 2020, por lo que debieron formularse antes del 31.8.2020, como consecuencia de la declaración del estado de alarma por la crisis sanitaria de la Covid-19 (art. 40.3 del Real Decreto-Ley 8/2020, de 17 de marzo, de medidas urgentes extraordinarias para hacer frente al impacto económico y social del Covid-19744).

En el caso de desprenderse de un balance trimestral de comprobación, la fecha en que se conocieron o debieron ser conocidas las pérdidas será el último día del trimestre, que es cuando debe cerrarse el balance (art. 28 del Código de Comercio). Pese a que estos balances trimestrales no tienen fijado un plazo máximo desde el cierre del trimestre para su formulación, a diferencia de lo que ocurre con las cuentas anuales, debemos entender que los administradores sociales han conocido las pérdidas al momento del cierre trimestral, ya que, en todo caso, la sociedad debe llevar el libro diario de contabilidad en el que se han de anotar todas las operaciones, sin que puedan realizarse anotaciones por períodos superiores al trimestre (art. 28 del Código de Comercio), por lo que la Inspección de Trabajo y Seguridad Social partirá de esa fecha de cierre del trimestre para acreditar que el administrador ha debido conocer la situación de las pérdidas patrimoniales, a efectos de la derivación administrativa de responsabilidad. De ahí la importancia de que la Inspección de Trabajo y Seguridad Social requiera en sus

\footnotetext{
${ }^{744}$ Artículo 40.3. "La obligación de formular las cuentas anuales, ordinarias o abreviadas, individuales o consolidadas, en el plazo de tres meses a contar desde el cierre del ejercicio social que incumbe al órgano de gobierno o administración de una persona jurídica y, cuando fuere legalmente exigible, el informe de gestión y demás documentos exigibles según la legislación de sociedades, queda suspendida hasta el 1 de junio de 2020, reanudándose de nuevo por otros tres meses a contar desde esa fecha. No obstante lo anterior, será válida la formulación de las cuentas que realice el órgano de gobierno o administración de una persona jurídica durante el estado de alarma pudiendo igualmente realizar su verificación contable dentro del plazo legalmente previsto o acogiéndose a la prórroga prevista en el apartado siguiente" (Art. 40.3 del Real Decreto-Ley 8/2020, de 17 de marzo, de medidas urgentes extraordinarias para hacer frente al impacto económico y social del Covid-19 -BOE del 18 de marzo-, según redacción dada por el Real Decreto-Ley 19/2020, de 26 de mayo, por el que se adoptan medidas complementarias en materia agraria, científica, económica, de empleo y Seguridad Social y tributarias para paliar los efectos del Covid-19 -BOE del 27 de mayo-; en relación con el Real Decreto 463/2020, de 14 de marzo, por el que se declara el Estado de Alarma para la gestión de la situación de crisis sanitaria ocasionada por el Covid-19 -BOE del 14 de marzo-).
} 
actuaciones la aportación de los balances trimestrales de comprobación, sin esperar a la aprobación y depósito de las cuentas anuales.

Para la derivación administrativa de responsabilidad al administrador de las deudas de Seguridad Social por la Inspección de Trabajo y Seguridad Social o la Tesorería General de la Seguridad Social, deberán tenerse en cuenta dos momentos temporales. El primer momento cronológico será la fecha en que los administradores conocieron o debieron de conocer las pérdidas -fecha límite del 31 de marzo del año siguiente, para las cuentas de ejercicio sociales naturales, o el 31.8.2020 para las cuentas del 2019-, o el último día natural del trimestre en los balances de comprobación. El segundo momento temporal será comprobar si dentro de los dos meses siguientes a esas fechas, los administradores han convocado la Junta General para que ésta promoviese la disolución de la sociedad. De no haber convocado la Junta General nacerá la responsabilidad en deudas de Seguridad Social.

\section{Deber de convocar la Junta o solicitar el concurso.}

\subsection{Convocatoria de la Junta General.}

El alcance y contenido del primer deber de los administradores consistente en la convocatoria de la Junta General para procurar la disolución o para alternativamente adoptar una acuerdo que remueva efectivamente la causa de disolución, se recoge en la jurisprudencia ${ }^{745}$ al establecerse que, concurriendo causa de disolución, el ordenamiento jurídico impone a los administradores sociales una serie de deberes para proceder a: 1) Promover la liquidación de la sociedad por el procedimiento societario, reorientando el objeto social al reparto entre los socios del haber existente después de pagar las deudas sociales; o 2) Promover la adopción de acuerdos dirigidos a remover la causa de disolución.

QUIJANO ${ }^{746}$ considera que el legislador parece buscar una especie de "disolución a toda costa", ya que ante la concurrencia de una causa de disolución se han configurado una serie de obligaciones con un exceso de rigidez, desencadenándose una responsabilidad por no procurarse la disolución societaria.

${ }^{745}$ SSTS, Sala Civil, 458/2010, de 30 de junio; 173/2011, de 17 de marzo; y 225/2012, de 13 de abril.

${ }^{746}$ QUIJANO GONZÁLEZ, J.: "Responsabilidad de los administradores por no disolución de la sociedad (art. 262.5 TRLSA) (Sentencia de la Audiencia Provincial de Burgos de 24 de julio de 1995)”, op. cit., p. 272. 
El primer deber que se impone a los administradores cuando concurra una causa legal de disolución prevista en el art. 363.1 de la LSC, es convocar a la Junta General de accionistas en el plazo de dos meses (arts. 365.1 y 367 de la LSC), a computar desde la concurrencia $^{747}$ de la causa, lo que implica conocer con precisión el momento de su acaecimiento, lo que no será fácil ${ }^{748}$. En la jurisprudencia y en la doctrina se considera que concurre la causa de disolución desde que los administradores conocieron o debieron conocer la misma ${ }^{749}$, o desde que no pudieron desconocer o ignorar la concurrencia de la causa de disolución ${ }^{750}$.

El día inicial del cómputo de los dos meses para la convocatoria de la Junta de la sociedad es aquel en que los administradores efectivamente conocieron la concurrencia de causa de disolución, o en que debieron conocer porque no podían ignorar su acaecimiento de haber ajustado su comportamiento al de un ordenado empresario, entre cuyos deberes figura el de informarse diligentemente sobre la marcha de la sociedad, a tenor de lo dispuesto hoy en el artículo 225.2 de la Ley de Sociedades de Capital.

Se impone la obligación de convocar la Junta General, porque la disolución de la sociedad ha de ser adoptada por la misma (Sentencia del Tribunal Supremo, Sala Civil, 1219/2004, de 16 de diciembre).

La Junta General ha de ser convocada dentro del plazo de dos meses siguientes a la concurrencia o conocimiento de la causa de disolución ${ }^{751}$. Plazo de dos meses que ha

747 BELTRÁN SÁNCHEZ, E.: "La responsabilidad de los administradores por obligaciones sociales", op. cit., p. 311; QUIJANO GONZÁLEZ, J.: "Responsabilidad de los administradores por no disolución de la sociedad (art. 262.5 TRLSA) (Sentencia de la Audiencia Provincial de Burgos de 24 de julio de 1995)", op. cit., p. 271.

${ }^{748}$ QUIJANO GONZÁLEZ, J.: "Responsabilidad de los administradores por no disolución de la sociedad (art. 262.5 TRLSA) (Sentencia de la Audiencia Provincial de Burgos de 24 de julio de 1995)", op. cit., p. 271; ESTEBAN VELASCO, G.: "Algunas reflexiones sobre la Responsabilidad de los Administradores frente a los Socios y los Terceros: Acción individual y acción por no Promoción o Remoción de la disolución”, op. cit., pp. 68-69; BATALLER GRAU, J.: “Disolución y Liquidación”, op. cit., p. 2564.

${ }^{749}$ SSTS, Sala Civil, 1219/2004, de 16 de diciembre; 986/2008, de 23 de octubre; 760/2007, de 4 de julio; 460/2010, de 14 de julio; y 286/2011, de 23 de noviembre -Rec. 90/2008-.

En la doctrina científica: QUIJANO GONZÁLEZ, J.: "Responsabilidad de los administradores por no disolución de la sociedad (art. 262.5 TRLSA) (Sentencia de la Audiencia Provincial de Burgos de 24 de julio de 1995)", op. cit., p. 271; BELTRÁN SÁNCHEZ, E.: "La responsabilidad de los administradores por obligaciones sociales”, op. cit., p. 315.

${ }^{750}$ STS, Sala Civil, 766/2002, de 18 de julio; 760/2007, de 4 de julio; y 460/2010, de 14 de julio. En la doctrina científica: BELTRÁN SÁNCHEZ, E.: "La responsabilidad de los administradores por obligaciones sociales”, op. cit., p. 315; VALPUESTA GASTAMINZA, E. M.: Comentarios a la Ley de Sociedades de Capital, op. cit., p. 951.

${ }^{751}$ QUIJANO GONZÁLEZ, J.: "Responsabilidad de los administradores por no disolución de la sociedad (art. 262.5 TRLSA) (Sentencia de la Audiencia Provincial de Burgos de 24 de julio de 1995)”, op. cit., p. 271; BELTRÁN SÁNCHEZ, E.: “La responsabilidad de los administradores por obligaciones 
sido calificado como un plazo fatal ${ }^{752}$, de modo que si no se convoca a la junta en ese plazo nace la responsabilidad solidaria de los administradores en el pago de las obligaciones sociales posteriores al acaecimiento de la causa de disolución ${ }^{753}$. Sólo excepcionalmente, en Sentencia del TS, Sala Civil, 110/2004, de 23 de febrero -Rec. 1041/1998-, se exoneró a los administradores de responsabilidad, si el plazo de dos meses se incumplió en unos pocos días, ya que conocidas las pérdidas cualificadas en las cuentas formuladas el 31 de marzo, los administradores convocaron la Junta General el 14 de junio, para que se celebrase el 1 de julio. Sentencia no seguida posteriormente, y que fue objeto de crítica por la doctrina ${ }^{754}$.

El plazo de dos meses para convocar la Junta General durante la vigencia del estado de alarma en el año 2020 por la crisis sanitaria de la Covid-19, se vio afectado ya que, si antes de la declaración del estado de alarma, y durante la vigencia del mismo, concurriere causa legal o estatutaria de disolución de la sociedad, el plazo legal para convocar los administradores la Junta General quedó suspendido durante la vigencia del primer estado de alarma -del 14.3.2020 al 20.6.2020- (art. 40.11 del Real Decreto-Ley 8/2020, de 17 de marzo ${ }^{755}$ ). Suspensión que implica que se reanudó su computo a partir del 21.6.2020, siempre y cuando el plazo de dos meses no hubiere transcurrido íntegramente a fecha de la declaración del estado de alarma, ya que en ese caso se habría consolidado el incumplimiento ${ }^{756}$.

Cuando la causa de disolución sea por pérdidas que reduzcan el patrimonio neto a menos de la mitad del capital social (art. 363.1.e) de la LSC), el cómputo del dies a quo

sociales”, op. cit., p. 326; MOYA BALLESTER, J.: La responsabilidad de los administradores de sociedades en situaciones de crisis, op. cit., p. 248; BATALLER GRAU, J.: "Disolución y Liquidación", op. cit., p. 2564; CALBACHO LOSADA, F.: El ejercicio de las acciones de responsabilidad contra los administradores de la sociedad anónima, op. cit., pp. 418-419; RODRÍGUEZ RUIZ DE LA VILLA, D. y HUERTA VIESCA, M. I.: La responsabilidad de los administradores por las deudas de las Sociedades de Capital (en las Leyes de Sociedades Anónimas, de Sociedades de Responsabilidad Limitada, de Sociedad Limitada Nueva Empresa, Concursal, General Tributaria y de Responsabilidad Medioambiental), op. cit., pp. 270 y ss.

${ }^{752}$ SÁNCHEZ CALERO, F.: Los administradores en las sociedades de capital, op. cit., p. 447.

753 SSTS, Sala Civil, en las Sentencias 1219/2004, de 16 de diciembre; 760/2007, de 4 de julio; y 460/2010, de 14 de julio.

754 BELTRÁN SÁNCHEZ, E.: "La responsabilidad de los administradores por obligaciones sociales", op. cit., p. 326. MOYA BALLESTER, J.: La responsabilidad de los administradores de sociedades en situaciones de crisis, op. cit., p. 248.

755 Art. 40.11 "En caso de que, antes de la declaración del estado de alarma y durante la vigencia de ese estado, concurra causa legal o estatutaria de disolución de la sociedad, el plazo legal para la convocatoria por el órgano de administración de la junta general de socios a fin de que adopte el acuerdo de disolución de la sociedad o los acuerdos que tengan por objeto enervar la causa, se suspende hasta que finalice dicho estado de alarma".

${ }^{756}$ QUIJANO GONZÁLEZ, J.: "Los órganos societarios y el Estado de Alarma”, op. cit., pp. 23 de 31. 
del plazo de dos meses para convocar la Junta General estará en función de la fecha en que los administradores han conocido, o debieron de conocer, porque no podían ignorar, que existían las pérdidas cualificadas. Este conocimiento será, en el caso de las cuentas anuales, cuando menos el 31 de marzo del año siguiente, fecha límite para la formulación de las cuentas anuales (arts. 26 y 253 de la LSC), y en el caso de resultar de un balance trimestral, el día siguiente al cierre del trimestre, por lo que deben convocar la junta antes de que expire el plazo de dos meses siguientes a esas fechas (art. 365 de la LSC en relación con el art. 28 del Código de Comercio).

De resultar las pérdidas de las cuentas anuales, el plazo para convocar la junta finalizará el 31 de mayo del año siguiente al cierre del ejercicio social, con la excepción de las cuentas del año 2019 por el estado de alarma por la Covid-19757, en que el plazo de dos meses para convocar la junta se computará desde que finalizó, el 31.8.2020, el plazo de tres meses para formular las cuentas del 2019, con lo que el plazo para convocar la junta finaliza el 31.10.2020. De resultar las pérdidas del ejercicio 2021, la convocatoria de la Junta General debe tener lugar dentro de los dos meses siguientes al cierre del ejercicio social, esto es antes del 28.2.2022 (interpretación literal del art. 13 de la Ley 3/2020, de 18 de septiembre), con lo que el legislador está obligando, no sólo a formular las cuentas anuales antes de los tres meses siguientes al cierre del ejercicio, excepcionando para ese ejercicio el plazo de tres meses del art. 253 de la LSC, sino también obligando a convocar la junta dentro de los dos meses siguientes al cierre del ejercicio, estableciendo una regla especial del día final o dies ad quem del plazo para convocar, lo que es criticable por no distinguirse con claridad ambas obligaciones, y sus plazos respectivos. Finalmente, téngase en cuenta que la causa de pérdidas cualificadas no operó en el ejercicio económico de 2020 (art. 13 de la Ley 3/2020, de 18 de septiembre).

El deber de los administradores es convocar la Junta General dentro del plazo de los dos meses siguientes a la concurrencia de la causa, o a su conocimiento, pero no se

\footnotetext{
757 Ya que según el art. 40.3 del Real Decreto-Ley 8/2020, de 17 de marzo," La obligación de formular las cuentas anuales, ordinarias o abreviadas, individuales o consolidadas, en el plazo de tres meses a contar desde el cierre del ejercicio social que incumbe al órgano de gobierno o administración de una persona jurídica y, cuando fuere legalmente exigible, el informe de gestión y demás documentos exigibles según la legislación de sociedades, queda suspendida hasta el 1 de junio de 2020, reanudándose de nuevo por otros tres meses a contar desde esa fecha. No obstante lo anterior, será válida la formulación de las cuentas que realice el órgano de gobierno o administración de una persona jurídica durante el estado de alarma pudiendo igualmente realizar su verificación contable dentro del plazo legalmente previsto o acogiéndose a la prórroga prevista en el apartado siguiente".
} 
establece ninguna previsión específica para la fecha de la celebración de la Junta General $^{758}$. Es un plazo de dos meses para convocar la junta, con lo que los administradores cumplen si la convocan el último día del plazo $^{759}$. No se está exigiendo que la Junta General se celebre dentro de los dos meses siguientes al acaecimiento de la causa, sino que sea convocada dentro de los dos meses siguientes a la concurrencia de esa causa legal de disolución, pudiéndose celebrar la junta más allá de los dos meses de la concurrencia de la causa de disolución ${ }^{760}$.

Como especialidad excepcional, hemos de reseñara que como consecuencia de la declaración, el 14 de marzo de 2020, del estado de alarma por la crisis sanitaria de la Covid-19761, "si la convocatoria de la junta general se hubiera publicado antes de la declaración de ese estado de alarma, para reunirse la junta durante la vigencia del mismo, el órgano de administración podrá modificar el lugar y la hora previstos para celebración de la junta o revocar el acuerdo de convocatoria. En caso de revocación del acuerdo de convocatoria, el órgano de administración deberá proceder a nueva convocatoria dentro del mes siguiente a la fecha en que finalizó el estado de alarma"

${ }^{758}$ QUIJANO GONZÁLEZ, J.: "Responsabilidad de los administradores por no disolución de la sociedad (art. 262.5 TRLSA) (sentencia de la Audiencia Provincial de Burgos de 24 de julio de 1995)”, op. cit., p. 271; MACHADO PLAZAS, J.: Pérdida del capital social y responsabilidad de los administradores por deudas sociales", op. cit., pp. 241-242; MOYA BALLESTER, J.: La responsabilidad de los administradores de sociedades en situaciones de crisis, op. cit., p. 248; CERDÁ ALBERO, F.: Administradores, insolvencia y disolución por pérdidas, op. cit., p. 112; RODRÍGUEZ RUIZ DE LA VILLA, D. y HUERTA VIESCA, M. I.: La responsabilidad de los administradores por las deudas de las Sociedades de Capital (en las Leyes de Sociedades Anónimas, de Sociedades de Responsabilidad Limitada, de Sociedad Limitada Nueva Empresa, Concursal, General Tributaria $y$ de Responsabilidad Medioambiental), op. cit., p. 311.

759 RODRÍGUEZ RUIZ DE LA VILLA, D. y HUERTA VIESCA, M. I.: La responsabilidad de los administradores por las deudas de las Sociedades de Capital (en las Leyes de Sociedades Anónimas, de Sociedades de Responsabilidad Limitada, de Sociedad Limitada Nueva Empresa, Concursal, General Tributaria y de Responsabilidad Medioambiental), op. cit., p. 311.

${ }^{760}$ QUIJANO GONZÁLEZ, J.: "Responsabilidad de los administradores por no disolución de la sociedad (art. 262.5 TRLSA) (Sentencia de la Audiencia Provincial de Burgos de 24 de julio de 1995)", op. cit., p. 271; MOYA BALLESTER, J.: La responsabilidad de los administradores de sociedades en situaciones de crisis, op. cit., pp. 248-249; VICENT CHULIÁ, F.: "La Responsabilidad de los administradores en sociedades no operativas", Derecho de los negocios, Año no 4, № 28, 1993, p. 7; VICENT CHULIÁ, F.: "Compendio Crítico del Derecho Mercantil”, op. cit., p. 902; ROJO FERNÁNDEZ-RÍO, A.: "Los deberes legales de los administradores en orden a la disolución de la sociedad de capital como consecuencia de pérdidas", op. cit., p. 1471; CERDÁ ALBERO, F.: Administradores, insolvencia y disolución por pérdidas, op. cit., p. 112; MACHADO PLAZAS, J.: Pérdida del capital social y responsabilidad de los administradores por deudas sociales, op. cit., p. 242.

${ }^{761}$ Mediante el Real Decreto 463/2020, de 14 de marzo. 
(art. 40.6 del Real Decreto-Ley 8/2020, de 17 de marzo). Estado de alarma que estuvo vigente en el período del 14.3.2020 al 20.6.2020 ambos inclusive ${ }^{762}$.

Si en la convocatoria de la junta no se fijó la fecha para reunirse en segunda convocatoria, celebrada sin adoptarse el acuerdo o sin removerse la causa, los administradores deberán dentro de los dos meses siguientes solicitar la disolución judicial $^{763}$, ya que no les exoneraría de responsabilidad la nueva convocatoria que hiciesen transcurridos los dos meses desde la causa de disolución.

A efectos de la responsabilidad solidaria de los administradores por las deudas de Seguridad Social de la sociedad, no sirve cualquier convocatoria de la junta, sino que ésta ha de ser convocada para tratar sobre el acaecimiento de la causa de disolución, y, en su caso, si la sociedad se disuelve o si se remueve la causa, de modo que se desencadena la responsabilidad solidaria de los administradores si las juntas convocadas "manifiestamente incumplen los presupuestos legales para su existencia y eficacia", por tener otras finalidades distintas (Sentencia del TS, Sala Civil, 416/2006, de 28 de abril Rec. 4187/2000-), como expedientes de regulación de empleo y cesión global de activos y pasivos, sin haberse removido la causa en el plazo los dos meses desde su acaecimiento (Sentencia del TS, Sala Civil, 27/2017, de 18 de enero).

En cuanto a las formalidades ${ }^{764}$ de la convocatoria deberán respetarse las exigidas para la junta en el art. 173 LSC, así como las exigidas para adoptar posibles medidas de remoción de la causa.

En la convocatoria debe constar en el orden del día que se va a tratar la disolución de la sociedad por concurrir causa legal, pudiendo especificarse o no la concreta causa de disolución ${ }^{765}$. Según doctrina registral, es suficiente que en el orden del día de la

\footnotetext{
${ }^{762}$ Estado de alarma que se declaró mediante el Real Decreto 463/2020, de 14 de marzo -BOE del 14- y cuya última prórroga finalizó a las 00:00 horas del 21 de junio de 2020 según Real Decreto 555/2020, de 5 de junio -BOE del 6 de junio-.

763 CALBACHO LOSADA, F.: El ejercicio de las acciones de responsabilidad contra los administradores de la sociedad anónima, op. cit., pp. 423-424

764 CALBACHO LOSADA, F.: El ejercicio de las acciones de responsabilidad contra los administradores de la sociedad anónima, op. cit., pp. 419-420; RODRÍGUEZ RUIZ DE LA VILLA, D. y HUERTA VIESCA, M. I.: La responsabilidad de los administradores por las deudas de las Sociedades de Capital (en las Leyes de Sociedades Anónimas, de Sociedades de Responsabilidad Limitada, de Sociedad Limitada Nueva Empresa, Concursal, General Tributaria $y$ de Responsabilidad Medioambiental), op. cit., p. 311; MOYA BALLESTER, J.: La responsabilidad de los administradores de sociedades en situaciones de crisis, op. cit., pp. 249-250.

765 CALBACHO LOSADA, F.: El ejercicio de las acciones de responsabilidad contra los administradores de la sociedad anónima, op. cit., p. 420, quien cita la RDGRN de 21 de junio de 1995 y la Sentencia del Tribunal Supremo de 18 de marzo de 1970; MOYA BALLESTER, J.: La
} 
convocatoria se incluya la propuesta de "disolución", como tema a tratar, sin que deba concretarse qué causa es la concurrente (RDGRN, de 21 de junio de 1995).

La junta convocada no puede tener cualquier orden del día, sino que debe estar convocada para constatar la causa y para adoptar las medidas legales pertinentes de disolución o remoción de la causa (Sentencia del TS, Sala Civil, 416/2006, de 28 de abril -Rec. 4187/2000-). La convocatoria de la junta debe ser para que adopte el acuerdo de disolución ${ }^{766}$, pudiendo facultativamente incluirse en el orden del día la adopción de medidas de remoción, ya que de no preverse el acuerdo de disolución, los administradores no se exonerarían de responsabilidad por incumplimiento del primer deber $^{767}$. De recogerse en el orden de día una concreta causa de disolución, no podrá acordarse posteriormente en la junta la disolución por causa diversa (Sentencia del TS, Sala Civil, 521/2010, de 23 de julio -Rec. 1633/2006-).

La convocatoria de la junta podrá incluir en el orden del día no sólo la propuesta de disolución de la sociedad, sino que, si lo pretendido es la remoción de la causa, deberá hacerse constar en el orden del día la propuesta de remoción ${ }^{768}$ (modificación de los estatutos, fusión, escisión, cesión global de activos y pasivos, aumento, reducción del

responsabilidad de los administradores de sociedades en situaciones de crisis, op. cit., pp. 249 y 255; VALPUESTA GASTAMINZA, E. M.: Comentarios a la Ley de Sociedades de Capital, op. cit., p. 945; Discrepan y defienden que ha de recogerse la causa en el orden del día, para así permitir que los socios puedan tomar la decisión con información y conocimiento suficiente de la situación societaria, RODRÍGUEZ RUIZ DE LA VILLA, D. y HUERTA VIESCA, M. I.: La responsabilidad de los administradores por las deudas de las Sociedades de Capital (en las Leyes de Sociedades Anónimas, de Sociedades de Responsabilidad Limitada, de Sociedad Limitada Nueva Empresa, Concursal, General Tributaria y de Responsabilidad Medioambiental), op. cit., pp. 313-314; Critican la falta de mención de la concreta causa de disolución, recogida en la RDGRN de 21 de junio de 1995, MACHADO PLAZAS, J.: Pérdida del capital social y responsabilidad de los administradores por deudas sociales, op. cit., pp. 240, quien no comparte el criterio de la RDGRN de 21.6.1995, por considerar que el Derecho de información del accionista tiene un contenido material, que incluye tener la información suficiente antes de acudir a la junta para poder ejercer el Derecho de voto; y QUIJANO GONZÁLEZ, J.: "La responsabilidad de los administradores por la no disolución de la sociedad y las causas de exoneración", op. cit., p. 75.

766 QUIJANO GONZÁLEZ, J.: "Responsabilidad de los administradores por no disolución de la sociedad (art. 262.5 TRLSA) (Sentencia de la Audiencia Provincial de Burgos de 24 de julio de 1995)", op. cit., p. 271; QUIJANO GONZÁLEZ, J.: "La responsabilidad de los administradores por la no disolución de la sociedad y las causas de exoneración”, 2002, op. cit., p. 75.

767 SSTS, Sala Civil, 1219/2004, de 16 de diciembre; 977/2000, de 30 de octubre; 588/2013, de 14 de octubre; 733/2013, de 4 de diciembre; y 27/2017, de 18 de enero.

768 QUIJANO GONZÁLEZ, J.: "La responsabilidad de los administradores por la no disolución de la sociedad y las causas de exoneración", 2002, op. cit., p. 75; RODRÍGUEZ RUIZ DE LA VILLA, D. y HUERTA VIESCA, M. I.: La responsabilidad de los administradores por las deudas de las Sociedades de Capital (en las Leyes de Sociedades Anónimas, de Sociedades de Responsabilidad Limitada, de Sociedad Limitada Nueva Empresa, Concursal, General Tributaria $y$ de Responsabilidad Medioambiental), op. cit., p. 318; CALBACHO LOSADA, F.: El ejercicio de las acciones de responsabilidad contra los administradores de la sociedad anónima, op. cit., p. 421. 
capital, etc.). De incluir medidas alternativas de remoción (art. 365.2 LSC), como modificación de estatutos sociales, aumento, reducción del capital, fusión, modificación societaria etc., la junta debe constituirse con requisitos de quórum de asistencia, y adoptar los acuerdos con las mayorías exigidos para esas medidas alternativas en los arts. 194 y 199 de la LSC $^{769}$.

La Junta General convocada por los administradores puede ser tanto una junta ordinaria como una extraordinaria ${ }^{770}$ (art. 163 de la LSC), aunque al tenerse que convocar dentro de los dos meses siguientes al acaecimiento de la causa de disolución, lo normal es que sea a través de una junta extraordinaria ${ }^{771}$, ya que la ordinaria se ha de celebrar dentro de los seis meses siguientes al cierre del ejercicio social (art. 164 LSC), y la causa de disolución pudo acaecer dentro del propio ejercicio. Puede ser igualmente una Junta Universal si asisten todos los socios y deciden por unanimidad su celebración (art. 178 LSC), en cuyo caso, si tiene lugar dentro de los dos meses siguientes al acaecimiento de la causa de disolución, y se pronuncian acerca del acuerdo de disolución de la sociedad, cesaría el primer deber de los administradores para convocar la junta ${ }^{772}$, ya que la finalidad ha sido cumplida al haberse pronunciado ésta sobre la concurrencia de la causa de disolución. Cuestión distinta será si el acuerdo de la Junta Universal fuese contrario a la disolución, en cuyo caso, de persistir la causa de disolución, surgiría el segundo deber de los administradores de solicitar la disolución judicial. De convocarse la Junta General para constatar la causa y disolver la sociedad, el quórum de asistencia y las mayorías exigidas serán las ordinarias y no las reforzadas previstas para la modificación de estatutos o para acuerdos como la transformación, fusión etc. (arts. 193, 198, 201 y 364 LSC).

769 CALBACHO LOSADA, F.: El ejercicio de las acciones de responsabilidad contra los administradores de la sociedad anónima, op. cit., pp. 421-425. Igual conclusión en sentencia del TS, Sala Civil, 76/2008, de 5 de febrero.

${ }^{770}$ QUIJANO GONZÁLEZ, J.: "Responsabilidad de los administradores por no disolución de la sociedad (art. 262.5 TRLSA) (Sentencia de la Audiencia Provincial de Burgos de 24 de julio de 1995)”, op. cit., p. 271; MACHADO PLAZAS, J.: Pérdida del capital social y responsabilidad de los administradores por deudas sociales, op. cit., p. 238; CALBACHO LOSADA, F.: El ejercicio de las acciones de responsabilidad contra los administradores de la sociedad anónima, op. cit., p. 420; MOYA BALLESTER, J.: La responsabilidad de los administradores de sociedades en situaciones de crisis, op. cit., p. 250.

${ }^{771}$ MOYA BALLESTER, J.: La responsabilidad de los administradores de sociedades en situaciones de crisis, op. cit., p. 249.

772 QUIJANO GONZÁLEZ, J.: "Responsabilidad de los administradores por no disolución de la sociedad (art. 262.5 TRLSA) (Sentencia de la Audiencia Provincial de Burgos de 24 de julio de 1995)", op. cit., p. 271; SEQUEIRA MARTÍN, A.: "De la Disolución y Liquidación”, en AA.VV. (Coord.: ARROYO MARTÍNEZ, I. y EMBID IRUJO, J. M.): Comentarios a la Ley de Sociedades Anónimas, Tecnos, Madrid, 2001, p. 2498. 
La Junta General deberá adoptar el acuerdo de disolución, ya que es una acuerdo obligatorio $^{773}$, o alguno de los acuerdos alternativos que remuevan la causa, pudiéndose impugnar cualquier otro acuerdo que adopte la junta por ser contrario a la ley ${ }^{774}$.

El deber de convocar la Junta General es un deber orgánico (arts. 166 y ss de la LSC), que compete al órgano ${ }^{775}$ y no individualmente a sus miembros. La junta ha de ser convocada por acuerdo de la mayoría absoluta de los miembros concurrentes del Consejo de Administración (art. 248 LSC), por algún administrador solidario (arts. 210.1 y 233.2.b) LSC), o conjuntamente por los administradores mancomunados (arts. 210.1 y 233.2.c) de la LSC) ${ }^{776}$. Habiendo delegación de facultades, por existir Consejeros Delegados o una Comisión Ejecutiva ${ }^{777}$, la delegación no libera al consejo del deber ante la falta de convocatoria del órgano delegado.

773 CALBACHO LOSADA, F.: El ejercicio de las acciones de responsabilidad contra los administradores de la sociedad anónima, op. cit., pp. 429-430.

${ }^{774}$ MOYA BALLESTER, J.: La responsabilidad de los administradores de sociedades en situaciones de crisis, op. cit., p. 254; Por el contrario CALBACHO LOSADA, F.: El ejercicio de las acciones de responsabilidad contra los administradores de la sociedad anónima, op. cit., p. 422, defiende que la adopción de medidas de remoción de la causa, como pudieran ser el acuerdo de aumento o reducción del capital social, no anula el acuerdo de la junta aunque no estuviere en el orden del día.

775 MACHADO PLAZAS, J.: Pérdida del capital social y responsabilidad de los administradores por deudas sociales, op. cit., p. 237; CALBACHO LOSADA, F.: El ejercicio de las acciones de responsabilidad contra los administradores de la sociedad anónima, op. cit., pp. 419-420; QUIJANO GONZÁLEZ, J.: "Responsabilidad de los administradores por no disolución de la sociedad (art. 262.5 TRLSA) (Sentencia de la Audiencia Provincial de Burgos de 24 de julio de 1995)”, op. cit., pp. 272273, para quien ante administradores mancomunados, si uno propone al resto la convocatoria y no se lleva a cabo para el proponente ha de entenderse que se exonera de la responsabilidad del incumplimiento de este deber, así como del deber subsidiario si solicita la disolución judicial, y en caso de administradores solidarios, la petición de alguno libera al resto; QUIJANO GONZÁLEZ, J.: "La responsabilidad de los administradores por la no disolución de la sociedad y las causas de exoneración", 2002, op. cit., pp. 82-83; MOYA BALLESTER, J.: La responsabilidad de los administradores de sociedades en situaciones de crisis, op. cit., p. 248; RODRÍGUEZ RUIZ DE LA VILLA, D. y HUERTA VIESCA, M. I.: La responsabilidad de los administradores por las deudas de las Sociedades de Capital (en las Leyes de Sociedades Anónimas, de Sociedades de Responsabilidad Limitada, de Sociedad Limitada Nueva Empresa, Concursal, General Tributaria $y$ de Responsabilidad Medioambiental), op. cit., p. 313; BELTRÁN SÁNCHEZ, E.: "La responsabilidad de los administradores por obligaciones sociales”, op. cit., pp. 326-327; VAlPUESTA GASTAMINZA, E. M.: Comentarios a la Ley de Sociedades de Capital, op. cit., p. 944.

${ }^{776}$ En la administración debemos distinguir entre el ámbito de representación y el ámbito de gestión, ubicándose en el ámbito interno de gestión los requisitos exigidos para la válida convocatoria de la Junta General, de modo de hallarnos ante una administración mancomunada debe realizarse la convocatoria conjuntamente por todos los administradores, pero si no la han convocado todos los administradores mancomunados, pero asisten todos ellos a la junta, sin que ninguno de los que no participaron en la convocatoria objeten ese defecto formal, se considera que asienten en la celebración de la junta, con lo que se subsanaría el defecto inicial, según se ha establecido en la STS, Sala Civil, 424/ 2019, de 16 de julio.

777 QUIJANO GONZÁLEZ, J.: “Responsabilidad de los administradores por no disolución de la sociedad (art. 262.5 TRLSA) (Sentencia de la Audiencia Provincial de Burgos de 24 de julio de 1995)”, op. cit., p. 272. 
Siendo el cumplimiento del primer deber, la convocatoria de la junta, un deber orgánico, no obstante QUIJANO ${ }^{778}$ defiende que si el Consejo de Administración no convoca a la junta, cualquier administrador que hubiere propuesto la convocatoria, que hubiere votado a favor, y que haga constar en acta su voluntad de convocar, así como su oposición al acuerdo contrario, al hacer lo exigible debería quedar exonerado de responsabilidad, pudiendo quedar exonerado también el que desconociese la concurrencia de la causa de disolución en el plazo de los dos meses, y ese desconocimiento no sea por negligencia, sino por causa inimputable, como sería ocultamiento de la información ${ }^{779}$.

Se ha planteado en la doctrina si ante el cese de la mayoría de los miembros del Consejo de Administración, o de los administradores mancomunados, podrían el resto convocar la Junta General con la finalidad de proveer la cobertura de los mismos, incluyendo también en el orden del día la adopción del acuerdo de disolución. Un sector doctrinal, pese a que en el art. 171 de la LSC establece que en estos casos la convocatoria será para cubrir las vacantes, no obstante, al existir un deber legal que debe cumplirse en un plazo perentorio, el consejo deficitario tendría competencia para añadir la disolución en el orden de día de la convocatoria, conjuntamente con la cobertura de vacantes del órgano de administración ${ }^{780}$. Ante el cese de administradores antes de agotarse el plazo para convocar la junta o para cumplir con el segundo deber de solicitud de disolución judicial, otro sector doctrinal ${ }^{781}$, entiende que si existiendo la causa no han cumplido los cesados o dimitidos con esos deberes incurren en responsabilidad.

De ser un Consejo de Administración y haber cesado la mayoría de los consejeros, los restantes podrán convocar la junta, y pese a que en el art. 171 de la LSC permite la

778 QUIJANO GONZÁLEZ, J.: "Responsabilidad de los administradores por no disolución de la sociedad (art. 262.5 TRLSA) (Sentencia de la Audiencia Provincial de Burgos de 24 de julio de 1995)”, op. cit., pp. 272-273; CALBACHO LOSADA, F.: El ejercicio de las acciones de responsabilidad contra los administradores de la sociedad anónima, op. cit., p. 436.

779 QUIJANO GONZÁLEZ, J.: "La responsabilidad de los administradores por la no disolución de la sociedad y las causas de exoneración", 2002, op. cit., p. 83.

${ }^{780}$ BELTRÁN SÁNCHEZ, E.: "La responsabilidad de los administradores por obligaciones sociales", op. cit., p. 327; ROJO FERNÁNDEZ-RÍO, A.: "Los deberes legales de los administradores en orden a la disolución de la sociedad de capital como consecuencia de pérdidas", op. cit., p. 1471; MACHADO PLAZAS, J.: Pérdida del capital social y responsabilidad de los administradores por deudas sociales, op. cit., pp. 341-342. Para este autor, cuando consecuencia de las renuncias el cargo quede inoperante, los administradores renunciantes deberán convocar a la junta con inclusión dentro del orden del día, cuando menos de tres cuestiones, en primer lugar, la designación de nuevos administradores, en segundo lugar, la constatación de la concurrencia de la causa de disolución, y en tercer lugar, la adopción del acuerdo de disolución o alternativamente de remoción de la causa.

${ }^{781}$ MACHADO PLAZAS, J.: Pérdida del capital social y responsabilidad de los administradores por deudas sociales, op. cit., p. 341. 
convocatoria con el único objeto de cubrir las vacantes, debería exonerar de responsabilidad si los administradores incluyesen en el orden del día también la adopción del acuerdo de disolución o medidas alternativas subsidiarias, y no obligarles a solicitar directamente la disolución judicial, ya que en esa situación extraordinaria debe prevalecer el derecho de la sociedad a decidir previamente acerca de su continuidad.

En la doctrina jurisprudencial se admite que, si con motivo de la renuncia al cargo, no quedasen otros administradores o a los restantes les resultare imposible cumplir con su obligación de promover la disolución, el administrador o los administradores renunciantes deberán convocar la Junta General para cubrir la vacante e incluir otros asuntos en el orden del día que permita que la sociedad pueda seguir funcionando, como la constatación de la causas de disolución por la junta, ya que el deber de diligencia impide que se paralicen los órganos sociales, debiendo atender en el interregno la gestión y la representación de la sociedad ${ }^{782}$.

Cualquier socio podrá requerir a los administradores para que convoquen la junta para adoptar el acuerdo de disolución, sin precisarse ser titular del porcentaje mínimo de capital social previsto para instar convocatorias de la junta del art. 168 de la LSC (art. 365.1 LSC $)^{783}$. Con el requerimiento de cualquier socio a los administradores, no nace un nuevo plazo de dos meses para la convocatoria, sino que para eximirse de responsabilidad deben convocar dentro de los dos meses desde que concurre la causa de disolución ${ }^{784}$.

Los administradores cumplen con haber convocado la junta para que ésta constate y adopte en su caso el acuerdo de disolución o cualquier otro acuerdo que remueva la causa (art. 365 LSC). Acuerdo de disolución que debe constar en escritura pública e

782 SSTS, Sala Civil, 771/2007, de 5 de julio -Rec. 3063/2000-; 228/2008, de 25 de marzo -Rec. 219/2001-; 667/2009, de 23 de octubre -Rec. 199/2005-; 784/2010, de 9 de diciembre -Rec. 902/2007; SSTS, Sala Contencioso-Administrativa, 18 de octubre de 2010 -Rec. 2733/2006-;y 18 de noviembre de 2013 -Rec. 4486/2012-, entre otras.

${ }^{783}$ MACHADO PLAZAS, J.: Pérdida del capital social y responsabilidad de los administradores por deudas sociales, op. cit., p. 243; CALBACHO LOSADA, F.: El ejercicio de las acciones de responsabilidad contra los administradores de la sociedad anónima, op. cit., p. 426; MOYA BALLESTER, J.: La responsabilidad de los administradores de sociedades en situaciones de crisis, op. cit., p. 251; BATALLER GRAU, J.: "Disolución y Liquidación”, op. cit., p. 2569; VALPUESTA GASTAMINZA, E. M.: Comentarios a la Ley de Sociedades de Capital, op. cit., p. 944.

784 RODRÍGUEZ RUIZ DE LA VILLA, D. y HUERTA VIESCA, M. I.: La responsabilidad de los administradores por las deudas de las Sociedades de Capital (en las Leyes de Sociedades Anónimas, de Sociedades de Responsabilidad Limitada, de Sociedad Limitada Nueva Empresa, Concursal, General Tributaria y de Responsabilidad Medioambiental), op. cit., p. 269. 
inscribirse la misma obligatoriamente en el Registro Mercantil (arts. 19 y 22.2 del Código de Comercio, art. 369 de la LSC y arts. 94.1.7., 95 y 239 del Real Decreto 1784/1996, de 19 de julio, que aprueba el Reglamento del Registro Mercantil -RRM-). En la inscripción de la disolución se harán constar, además de la causa que la determina, el cese de los administradores y las personas encargadas de la liquidación (art. 240 del RRM). Practicada la inscripción, el registrador mercantil remitirá, por vía telemática, la misma al BORM para su publicación (art. 369 LSC).

No tiene efectos en esta responsabilidad del administrador, si cumplido con el deber de convocar la junta, posteriormente no se solicita la inscripción de la escritura de disolución en el Registro Mercantil ${ }^{785}$, ya que estaremos ante el incumplimiento de otro deber que podrá generar la responsabilidad por daños del art. 236 LSC.

Una cosa es que la falta de inscripción de la disolución en el Registro Mercantil no tenga efectos en la responsabilidad del administrador, si realmente ha cumplido con la obligación de convocar la Junta General, al no ser un requisito exigido en el art. 367 de la LSC, y otra cosa distinta será que la falta de inscripción de la escritura de disolución pueda ser un indicio, salvo prueba en contrario, de no haberse cumplido con el deber de convocatoria. En este orden de ideas, para la reclamación de la responsabilidad solidaria al administrador en las deudas laborales de la sociedad de capital, exigida al administrador social en caso de pérdidas cualificadas al amparo del art. 367 de la LSC, se ha defendido ${ }^{786}$ que para acreditar que se cumplió con el deber de convocar la junta, no cabría oponer al FOGASA el libro de actas de la Junta ${ }^{787}$, porque al ser un documento privado podrá confeccionarse en cualquier momento, exigiendo a esos efectos que conste inscrito el acuerdo en el Registro, en virtud de la falta de efectos externos de la carencia de inscripción. Téngase en cuenta que la fecha del acta de la junta pudiera no ser prueba suficiente, al ser documento privado en que su fecha no tiene efectos ante terceros sino en la fecha de su inscripción (art. 1227 del Código Civil).

785 RODRÍGUEZ RUIZ DE LA VILLA, D. y HUERTA VIESCA, M. I.: La responsabilidad de los administradores por las deudas de las Sociedades de Capital (en las Leyes de Sociedades Anónimas, de Sociedades de Responsabilidad Limitada, de Sociedad Limitada Nueva Empresa, Concursal, General Tributaria y de Responsabilidad Medioambiental), op. cit., p. 320.

786 NICOLÁS BERNAD, J. A.: “Acciones por subrogación del FOGASA en supuestos de despatrimonialización empresarial”, 2018, op. cit., pp. 68-69.

${ }^{787}$ De conformidad con el art. 202 de la LSC, todo acuerdo de la Junta General deberá constar en el libro de actas de la junta, siendo aprobada el acta por la propia junta al final de la reunión, y en su defecto, por el presidente y dos interventores, dentro de los quince días siguientes. 
En la derivación administrativa de las deudas de Seguridad Social al administrador, deberá hacerse constar que se ha incumplido con la obligación de convocar la Junta General dentro del plazo legal de los dos meses siguientes al acaecimiento de la causa de disolución. Al ser difícilmente exigible la prueba de un hecho negativo, será suficiente la alegación del incumplimiento conjuntamente con la mención de haberse solicitado y obtenido una certificación registral en la que no conste la celebración de ninguna junta en que se hubiere adoptado el acuerdo de disolución ${ }^{788}$, recayendo en el administrador la prueba de haberse celebrado. Servirán también como prueba indiciaria adicional, si no constase tampoco la convocatoria publicada en la página web de la sociedad, en el BORM o en un diario de la localidad, o por otros medios admitidos en los estatutos sociales (art. 173 de la LSC), ni en los libros registros de actas de la Junta y del Consejo de Administración (arts. 202 y 250 de la LSC).

Cesa el deber de convocar la Junta General, si dentro del plazo de dos meses que tienen los administradores para convocarla, cesa la causa de disolución (Sentencia del TS, Sala Civil, 328/2011, de 19 de mayo). Igualmente cesa dicha convocatoria si por mandato judicial se ha convocado la junta dentro de ese plazo, a instancias de la minoría, incluyendo en el orden del día la adopción del acuerdo de disolución ${ }^{789}$.

La falta de acuerdo de disolución o de adopción de medidas de remoción de la causa de disolución, supone que se abre el pazo para que los administradores cumplan con el segundo deber, la solicitud de disolución judicial.

\subsection{Solicitud del concurso de acreedores}

Cuando concurran de modo simultáneo la insolvencia empresarial y una causa de disolución por pérdidas cualificadas, se plantea la cuestión de determinar con qué obligación han de cumplir los administradores a efectos de liberarse de la responsabilidad por deudas prevista en el art. 367 de la LSC, si deben convocar la Junta General, como se establece en el arts. 365 y 367 de la LSC, o, si por el contrario, deberían solicitar el concurso de acreedores, como se prescribe en los arts. 2, 3 y 5 del TRLC.

788 RODRÍGUEZ RUIZ DE LA VILLA, D. y HUERTA VIESCA, M.I.: La responsabilidad de los administradores por las deudas de las Sociedades de Capital (en las Leyes de Sociedades Anónimas, de Sociedades de Responsabilidad Limitada, de Sociedad Limitada Nueva Empresa, Concursal, General Tributaria y de Responsabilidad Medioambiental), op. cit., p. 311.

${ }^{789}$ MOYA BALLESTER, J.: La responsabilidad de los administradores de sociedades en situaciones de crisis, op. cit., pp. 250 y 257; BELTRÁN SÁNCHEZ, E.: "La responsabilidad de los administradores por obligaciones sociales", op. cit., p. 326. 
La declaración del concurso de acreedores no constituye en sí misma causa de disolución de la sociedad (art. 361.1 de la LSC), pero si dentro del proceso concursal se abriese la fase de liquidación, se produciría entonces la disolución de la sociedad.

No puede identificarse la insolvencia -que es presupuesto del concurso de acreedores de conformidad con el art. 2.1. del TRLC-, con la causa de disolución por pérdidas cualificadas, ya que son situaciones jurídicas diversas, aunque puedan concurrir en algunos casos de modo simultáneo ${ }^{790}$. De este modo, puede existir causa de disolución por pérdidas cualificadas sin que la sociedad se halle en situación de insolvencia, en causa de concurso de acreedores, cuando ante un desbalance patrimonial se sigue cumpliendo de modo regular con las obligaciones sociales; y viceversa, puede la sociedad hallarse en situación de insolvencia sin tener pérdidas cualificadas (Sentencia del TS, Sala Civil, 590/2013, de 15 de octubre -Rec. 1268/2011-), sin que su patrimonio se hubiere reducido a la mitad de capital social, como sería el supuesto de falta definitiva de liquidez ${ }^{791}$ contando con un patrimonio igual o superior al capital, pero siendo el mismo de difícil realización ${ }^{792}$.

${ }^{790}$ En la Sentencia del TS, Sala Civil, 590/2013, de 15 octubre, se señala al respecto que, "el estado de insolvencia no constituye, por sí, una causa legal que haga surgir el deber de los administradores de promover la disolución de la sociedad. No cabe confundir, como parece que hacen la demanda y la sentencia recurrida, entre estado de insolvencia y la situación de pérdidas que reducen el patrimonio neto de la sociedad por debajo de la mitad del capital social, que, como veremos a continuación, sí constituye causa de disolución. Aunque es frecuente que ambas situaciones se solapen, puede ocurrir que exista causa de disolución por pérdidas patrimoniales que reduzcan el patrimonio de la sociedad a menos de la mitad del capital social, y no por ello la sociedad esté incursa en causa de concurso. En estos supuestos opera con normalidad el deber de promover la disolución conforme a lo prescrito, antes en los arts. 262 TRLSA y 105 LSRL, y ahora en el art. 365 LSC. Y a la inversa, es posible que el estado de insolvencia acaezca sin que exista causa legal de disolución, lo que impone la obligación de instar el concurso, cuya apertura no supone por sí sola la disolución de la sociedad, sin perjuicio de que pueda ser declarada durante su tramitación por la junta de socios y siempre por efecto legal derivado de la apertura de la fase de liquidación (art. 145.3 de la Ley Concursal). De ahí que la imprecisión apreciada por la sentencia de apelación debería haber conducido a confirmar la desestimación de la acción de responsabilidad por falta de justificación de los requisitos legales, y al no hacerlo, la Audiencia infringió los preceptos mencionados". Doctrina a la que se remite la Sentencia del TS, Sala Contencioso-Administrativa, 874/2019, de 24 de junio.

${ }^{791}$ MOYA BALLESTER, J.: La responsabilidad de los administradores de sociedades en situaciones de crisis, op. cit., pp. 122-126.

${ }^{792}$ Según Sentencia del TS, Sala Civil, 122/2014, de 1 de abril -Rec. 541/2012- "No puede confundirse la situación de insolvencia que define el artículo 2.2. de la Ley Concursal cuando afirma que «se encuentra en estado de insolvencia el deudor que no puede cumplir regularmente sus obligaciones exigibles», con la situación de pérdidas agravadas, incluso de fondos propios negativos, que determinan el deber de los administradores de realizar las actuaciones que las leyes societarias les imponen encaminadas a la disolución de la sociedad y, que, en caso de incumplimiento de tales deberes, dan lugar por esa sola razón a su responsabilidad con arreglo a la legislación societaria. En la Ley Concursal la insolvencia no se identifica con el desbalance o las pérdidas agravadas. Cabe que el patrimonio contable sea inferior a la mitad del capital social, incluso que el activo sea inferior al pasivo y, sin embargo, el deudor pueda cumplir regularmente con sus obligaciones, pues obtenga financiación. Y, al contrario, el activo puede ser superior al pasivo pero que la deudora carezca de 
Concurriendo una situación de pérdidas cualificadas -causa de disolución-, sin ir acompañada de insolvencia, los administradores habrán de convocar en el plazo de dos meses la Junta General al amparo del art. 365 LSC, y, por el contrario, de concurrir pérdidas cualificadas acompañada de insolvencia -que es causa de concurso de acreedores-, surge la duda de qué obligación deben cumplir los administradores para liberarse de la responsabilidad por deudas, si solicitar el concurso dentro de los dos meses siguientes como se establece en los artículos 2, 3 y 5.1. del TRLC, o convocar la junta para que sea ésta la que decida si debe solicitarse el concurso, como parece imponerse en el art. 365.1 de la LSC.

Para determinar con qué obligación han de cumplir los administradores, nuestra doctrina $^{793}$ distingue en función de que la sociedad se hallare en insolvencia actual o inminente. Se define la situación de insolvencia actual como aquella situación en que el deudor no puede cumplir regularmente con sus obligaciones exigibles (art. 2.3 del TRLC y Sentencia del TS, Sala Civil, 590/2013, de 15 de octubre). En cambio, la insolvencia será inminente, cuando no acaecida, se prevé por la sociedad su próxima concurrencia, cuando prevea que no podrá en un futuro inmediato cumplir de modo regular y puntual con sus obligaciones (art. 2.3 del TRLC).

En la insolvencia inminente no se obliga a la sociedad y a los administradores sociales a solicitar el concurso, sino que se les faculta ${ }^{794}$ para que se anticipen a los acontecimientos y puedan con carácter potestativo solicitar el concurso, eso es lo que se viene a indicar en la propia exposición de motivos de la anterior Ley Concursal de 2003, donde se señala expresamente que "el deudor tiene la obligación de solicitar la

liquidez (por ejemplo, por ser el activo ser liquidable a muy largo plazo y no obtener financiación) lo que determinaría la imposibilidad de cumplimiento regular de las obligaciones en un determinado momento y, consecuentemente, la insolvencia actual. Por consiguiente, aunque con frecuencia se solapen, insolvencia y desbalance patrimonial no son equivalentes, y lo determinante para apreciar si ha concurrido el supuesto de hecho del art. 165.1 de la Ley Concursal es la insolvencia, no el desbalance o la concurrencia de la causa legal de disolución por pérdidas agravadas".

793 QUIJANO GONZÁLEZ, J.: "Capital social y pérdidas cualificadas: Deberes y responsabilidades de los administradores", en $R D C P, \mathrm{~N}^{\circ}$ 31, julio 2019, edición digital en Smarteca, pp. 2 y ss; MOYA BALLESTER, J.: La responsabilidad de los administradores de sociedades en situaciones de crisis, op. cit., pp. 395-406; MARÍN DE LA BÁRCENA GARCIMARTÍN, F.: La acción individual de responsabilidad de los administradores de las sociedades de capital (art. 135 LSA), 2005, op. cit., p. 359 , y en "Deberes y responsabilidad de los administradores ante la insolvencia de las Sociedades de Capital", 2005, op. cit., edición digital, pp. 21 y 22; PULGAR EZQUERRA, J.: "El presupuesto objetivo de apertura del concurso de acreedores", op. cit., pp. 87 y 96; VALPUESTA GASTAMINZA, E. M.: Comentarios a la Ley de Sociedades de Capital, op. cit., p. 947.

794 QUIJANO GONZÁLEZ, J.: "Capital social y pérdidas cualificadas: Deberes y responsabilidades de los administradores", 2019, op. cit., pp. 10-11; MOYA BALLESTER, J.: La responsabilidad de los administradores de sociedades en situaciones de crisis, op. cit., pp. 357-358. 
declaración de concurso cuando conozca o debiera conocer su estado de insolvencia, pero tiene la facultad de anticiparse a éste".

Cuando las pérdidas cualificadas vayan acompañadas de insolvencia inminente, los administradores estarán facultados para solicitar el concurso ${ }^{795}$ o para convocar la junta para que sea ésta quien decida acordar medidas adecuadas para la superación de la causa de disolución y de una próxima insolvencia, o, en su defecto, de no poderse superar la insolvencia, para instar a los administradores a solicitar el concurso, en cuyo caso, los administradores deberían solicitar el concurso de acreedores. Pero si, ante la insolvencia inminente, el administrador solicita en plazo el concurso, esta solicitud y la posterior declaración de concurso desplaza a la obligación de convocar la Junta General para que acuerde la disolución, por lo que no se incurriría en responsabilidad por deudas del art. 367 LSC $^{796}$. Si el concurso solicitado por los administradores sociales no fuere declarado judicialmente, o fuere posteriormente revocada la declaración, renacería la obligación de promover la disolución de la sociedad ${ }^{797}$.

Al facultarse a los administradores a solicitar el concurso o convocar la junta ante la insolvencia inminente ${ }^{798}$, cobra sentido que en el art. 365.1 de la LSC se establezca que los administradores deban convocar la Junta General, para que sea ésta quien aprecie si pueden adoptarse medidas que eviten la próxima insolvencia, o si por el contrario, de no encontrarse otra salida, insten a los administradores a solicitar directamente el concurso de acreedores, bien por seguir siendo inminente la insolvencia, o por apreciarse que puede ser ya actual la insolvencia, en cuyo caso, los administradores ya estarían obligados a solicitar el concurso de acreedores (arts. 2, 3 y 5 del TRLC).

795 QUIJANO GONZÁLEZ, J.: “Capital social y pérdidas cualificadas: Deberes y responsabilidades de los administradores”, 2019, op. cit., pp. 10-13.

796 QUIJANO GONZÁLEZ, J.: “Capital social y pérdidas cualificadas: Deberes y responsabilidades de los administradores”, 2019, op. cit., pp. 10-11.

797 QUIJANO GONZÁLEZ, J.: “Capital social y pérdidas cualificadas: Deberes y responsabilidades de los administradores”, 2019, op. cit., pp. 10-11 y 19-21.

798 QUIJANO GONZÁLEZ, J.: “Capital social y pérdidas cualificadas: Deberes y responsabilidades de los administradores”, 2019, op. cit., pp. 5-6 y 10-11; MOYA BALLESTER, J.: La responsabilidad de los administradores de sociedades en situaciones de crisis, op. cit., pp. 161 y 356-358; Matiza esa interpretación BATALLER GRAU, J.: “Disolución y Liquidación”, op. cit., pp. 2565 y 2573, quien no distinguía entre ambas situaciones de insolvencia, al considerar que concurriendo pérdidas cualificadas e insolvencia, el legislador permite que los administradores decidan entre convocar la Junta General, para que ésta determine si procede la disolución o si por ser la sociedad insolvente debe solicitarse el concurso, o solicitar directamente el concurso, pero que si se frustra la junta, serán ellos los que deberán solicitar directamente el concurso de acreedores. 
Por el contrario, concurriendo pérdidas cualificadas e insolvencia actual ${ }^{799}$, prima la obligación de solicitar el concurso y no el deber de convocar la junta (arts. 2, 3 y 5.1 del TRLC). Solicitud del concurso que exonera a los administradores de la responsabilidad del art. 367 de la LSC $^{800}$. En esta situación de insolvencia actual, los administradores están obligados ${ }^{801}$ a solicitar el concurso de acreedores en el plazo de dos meses desde que conocieron o debieron conocer la insolvencia (arts. 3 y 5.1 del TRLC).

De todo lo anterior ha de concluirse que, de concurrir pérdidas cualificadas acompañada de insolvencia -que es causa de concurso de acreedores-, cesa la obligación de convocar la Junta de accionistas y prevalece la normativa concursal que obliga a los administradores a solicitar el concurso de acreedores, dentro del plazo de dos meses siguientes al conocimiento de la insolvencia (art. 2, 3 y 5.1 del TRLC, en interpretación sistemática con los arts. 365 y 367 de la LSC, y Sentencias del TS, Sala Civil, 590/2013, de 15 de octubre; 560/2013, de 7 de octubre; 458/2010, de 30 de junio). En la jurisprudencia de la Sala Contencioso-Administrativa ${ }^{802}$, y con motivo de la derivación

799 QUIJANO GONZÁLEZ, J.: "Capital social y pérdidas cualificadas: Deberes y responsabilidades de los administradores", 2019, op. cit., pp. 2-13; MOYA BALLESTER, J.: La responsabilidad de los administradores de sociedades en situaciones de crisis, op. cit., pp. 395-406; BELTRÁN SÁNCHEZ, E.: "La responsabilidad de los administradores por obligaciones sociales", op. cit., pp. 318-321 y 328329; MARÍN DE LA BÁRCENA GARCIMARTÍN, F.: La acción individual de responsabilidad de los administradores de las sociedades de capital (art. 135 LSA), 2005, op. cit., p. 359, y en "Deberes y responsabilidad de los administradores ante la insolvencia de las Sociedades de Capital", 2005, op. cit., edición digital, pp. 21 y 22; VALPUESTA GASTAMINZA, E. M.: Comentarios a la Ley de Sociedades de Capital, op. cit., p. 947; DÍAZ ECHEGARAY, J. L: Deberes y responsabilidades de los Administradores de sociedades de Capital, op. cit., pp. 382 y 414; PULGAR EZQUERRA, J.: "El presupuesto objetivo de apertura del concurso de acreedores", op. cit., pp. 87 y 96.

800 QUIJANO GONZÁLEZ, J.: "Capital social y pérdidas cualificadas: Deberes y responsabilidades de los administradores", 2019, op. cit., pp. 10-13 y 19-21; BELTRÁN SÁNCHEZ, E.: "La responsabilidad de los administradores por obligaciones sociales", op. cit., pp. 328-329; DÍAZ ECHEGARAY, J. L: Deberes y responsabilidades de los Administradores de sociedades de Capital, op. cit., pp. 412-414.

${ }^{801}$ QUIJANO GONZÁLEZ, J.: "Capital social y pérdidas cualificadas: Deberes y responsabilidades de los administradores", 2019, op. cit., pp. 2-13; SÁNCHEZ-CALERO GUILARTE, J.: "Deber de solicitar la declaración de concurso (Artículo 5)", en AA.VV. (Dir.: SÁNCHEZ-CALERO GUILARTE, J. y GUILARTE GUTIÉRREZ, V.): Comentarios a la Legislación Concursal, Tomo I, Lex Nova, Valladolid, 2004, p. 202; Vid.: MOYA BALLESTER, J.: La responsabilidad de los administradores de sociedades en situaciones de crisis, op. cit., pp. 357-358; QUIJANO GONZÁLEZ, J.: "Capital social y pérdidas cualificadas: Deberes y responsabilidades de los administradores", 2019, op. cit., pp. 10-13 y 19-21.

${ }^{802}$ Sentencias del TS, Sala Contencioso-Administrativa, 874/2019, de 24 de junio; 875/2019, de 24 de junio; 897/2019, de 25 de junio; 915/2019, de 26 de junio; 338/2020, de 6 de marzo -Rec. 7827/2018-; 1346/2020, de 19 octubre de 2020 -Rec. 7410/2018-; 1411/2020, de 27 de octubre de 2020 -Rec. 3759/2018-; 1713/2020, de 14 diciembre -Rec. 1987/2019-; 117/2021, de 1 de febrero -Rec. 6149/2019-; 120/2021, de 2 de febrero -Rec. 4284/2019-. En todas esas Sentencias el interés de casacional del recurso para la fijación de jurisprudencia, era determinar si, para la derivación de deudas de Seguridad Social al amparo del art. 367 LSC, cuando concurra insolvencia, debe concurrir también causa de disolución por pérdidas cualificadas. 
de deudas de Seguridad Social de la sociedad de capital al administrador social, en virtud del art. 367 LSC y art. 18.3 TRLGSS, no se planteó la distinción entre insolvencia actual e inminente, ni tampoco si procede convocarse la junta o instar directamente el concurso.

Con relación a la obligación de solicitar el concurso de acreedores, de modo excepcional y como consecuencia de la crisis sanitaria por la Covid-19, la sociedad de capital que se encuentre en estado de insolvencia durante los años 2020 y 2021, no tendrá la obligación de solicitar la declaración de concurso de acreedores antes del 31.12.2021 (art. 6 de la Ley 3/2020, de 18 de septiembre). Igualmente y de modo correlativo, no hay obligación de promover la disolución cuando las pérdidas cualificadas determinantes de la causa de disolución sean del año 2020, como consecuencia de la crisis sanitaria de la Covid-19 (art. 13 de la Ley 3/2020, de 18 de septiembre).

El deber de los administradores de solicitar el concurso de acreedores ante el Juez de lo Mercantil, en el caso de que concurra insolvencia, es un deber orgánico ${ }^{803}$, que compete al órgano y no a los administradores individualmente. El art. 365 de la LSC no cambia la competencia para la solicitud del concurso de acreedores prevista en el TRLC -Ley especial de preferente aplicación al respecto-, que corresponde al administrador social $^{804}$.

Finalmente, declarado el concurso concurriendo pérdidas cualificadas e insolvencia, durante la vigencia del convenio acordado con los acreedores, cesa igualmente la obligación de los administradores de instar la disolución (STS, Sala Civil, 590/2013, de 15 de octubre $\left.{ }^{805}\right)$.

${ }^{803}$ BELTRÁN SÁNCHEZ, E.: "La responsabilidad de los administradores por obligaciones sociales", op. cit., p. 329.

${ }^{804}$ QUIJANO GONZÁLEZ, J.: "Capital social y pérdidas cualificadas: Deberes y responsabilidades de los administradores", 2019, op. cit., pp. 5-6; MOYA BALLESTER, J.: La responsabilidad de los administradores de sociedades en situaciones de crisis, op. cit., pp. 395-406; BELTRÁN SÁNCHEZ, E.: "La responsabilidad de los administradores por obligaciones sociales", op. cit., pp. 318-321 y 328329; SÁNCHEZ CALERO, F.: Los administradores en las sociedades de capital, op. cit., p. 494.

${ }^{805}$ Esa Sentencia señala, "tampoco durante la fase de cumplimiento del convenio puede surgir el deber de promover la disolución y la consiguiente responsabilidad por no hacerlo dentro del plazo legal. Lo impide, no la vigencia de los efectos de la declaración de concurso, que cesan conforme al art. 133.2 LC , sino la propia normativa societaria (en nuestro caso, los arts. 260.1.4. ${ }^{\circ}, 262.2$ y 5 TRLSA ), que establece el concurso de acreedores como un límite al deber de los administradores de promover la disolución, bajo la lógica de que la situación de concurso de la compañía se rige por una normativa propia, que expresamente prevé la disolución de la compañía, como consecuencia necesaria a la apertura de la fase de liquidación (art. 145.3. LC), y que, en caso de aprobación de convenio, impone 


\subsubsection{Solicitud de medidas preconcursales.}

Si la solicitud del concurso de acreedores exime de la responsabilidad solidaria del administrador social prevista en el art. 367 de la LSC, cuando concurra causa de disolución por pérdidas cualificadas y causa de insolvencia, debemos preguntarnos si se exoneraría también de esa responsabilidad, si en vez de solicitar el concurso de acreedores solicita alguna de las medidas preconcursales del arts. 583 y siguientes del TRLC.

Las medidas preconcursales o previas a la solicitud judicial del concurso se regulan en el libro segundo del TRLC (arts. 583 a 693 del TRLC). Medidas o institutos preconcursales que se articularán a través de acuerdos de refinanciación, acuerdos extrajudiciales de pagos, o propuestas anticipadas de convenio, y que impide que los acreedores puedan solicitar el concurso durante un plazo de tres meses (art. 588 del TRLC). Estas medidas preconcursales fueron introducidas por la Ley 38/2011, de 10 de octubre, que reformó la anterior Ley Concursal ${ }^{806}$, y que tienen como finalidad ofrecer a las empresas una solución ágil y económica a sus crisis, según nos indica su exposición de motivos.

El inicio de negociaciones para alcanzar alguna de las tres medidas preconcursales, podrá comunicarse al juez competente del concurso, tanto ante una insolvencia actual como ante una insolvencia inminente (arts. 583 apartados 1 y 2, 597 y 631 del TRLC), pero en caso de insolvencia actual esa comunicación se deberá hacer antes del plazo de los dos meses que tiene el administrador para solicitar la declaración del concurso (art. 584 en relación con el art. 5 del TRLC).

Antes del transcurso del plazo de los dos meses para solicitar el concurso de acreedores, se podrá proceder a comunicar al juez competente del concurso la apertura de negociaciones para una propuesta anticipada de convenio, para un acuerdo de refinanciación, o para un acuerdo extrajudicial de pago (arts. 583 y 584 del TRLC). Realizada la comunicación, hasta que no transcurran tres meses no podrán presentarse solicitudes de declaración judicial de concurso de acreedores, por lo que se dispone de un período de tres meses para intentar llegar a alguno de esos tres tipos de acuerdos que

al deudor el deber de instar la liquidación cuando, durante la vigencia del convenio, conozca la imposibilidad de cumplir los pagos comprometidos y las obligaciones contraídas con posterioridad a su aprobación (art. 142.2. LC)". Las referencias a los arts. 260.1.4. ${ }^{\circ}, 262.2$ y 5 TRLSA, han de entenderse realizadas a los arts. 363.1.e) y arts. 365.1 y 367 de la LSC.

${ }^{806}$ BOE del 11.10.2011. 
eviten el concurso de acreedores (arts. 588, 594 y 595 del TRLC). De no haberse conseguido acordar ninguna de esas medidas que eviten el concurso, el administrador social deberá solicitar el concurso de acreedores dentro del mes hábil siguiente de hallarse en insolvencia actual (art. 595 del TRLC), salvo que hubiere solicitado esas medidas preconcursales antes del 31 de diciembre de 2020 o en el año 2021, en cuyo caso, no hay obligación de solicitar el concurso antes del 31.12.2021 (art. 6 apartados 1 y 3 de la Ley $3 / 2020$, de 18 de septiembre).

Realizada esa comunicación de inicio de negociaciones en plazo, los administradores no estarían obligados a solicitar el concurso de acreedores (art. 595 del TRLC a contrario sensu), ya que con la apertura de negociaciones se pretende evitar el mismo, y ello pese a no señalarse expresamente en el actual TRLC que la comunicación de apertura de negociaciones exonera del deber de solicitar el concurso, a diferencia de la anterior LC en que se prescribía expresamente en el art. 5 bis. 2 que la comunicación en plazo del inicio de negociaciones impedía que el deudor tuviese el deber de solicitar el concurso ante la insolvencia actual. A esa conclusión debemos seguir llegando en aplicación de los arts. 584, 594 y 595 del TRLC, interpretados a la luz del anterior art. 5.2 de la LC de 2003, al ser el régimen jurídico de la disposición legal refundida el que ha de ser preservado en el nuevo TRLC para seguir teniendo éste fuerza de Ley.

Medidas preconcursales que, al ser previas al concurso y al primar la legislación concursal sobre la societaria, evitan que durante su negociación puedan derivarse las deudas de Seguridad Social al administrador social, pese a no aludirse a las mismas en los arts. 365 a 367 de la LSC, ya que estos preceptos son anteriores a la Ley 38/2011, de 10 de octubre, que introdujeron aquellas medidas, por lo que esos preceptos de la LSC deben reinterpretarse para incluirlas.

Se dispone de un período de tres meses para entablar negociaciones y llegar a alguno de aquellos acuerdos con los acreedores. De no alcanzarse ningún acuerdo con los acreedores dentro de este plazo, y persistir la insolvencia, el administrador social deberá solicitar el concurso dentro del mes siguiente (art. 595 del TRLC), pero si ante la falta de acuerdos continuase la causa de disolución sin insolvencia, el administrador deberá convocar la Junta General dentro de los dos meses siguientes al vencimiento del plazo de los tres meses que había para acordar las medidas preconcursales, al reabrirse de 
nuevo el plazo para promover la disolución ${ }^{807}$, plazo que quedó suspendido durante los tres meses, partiendo de una interpretación sistemática de los arts. 583, 588 y 594 del TRLC, en relación con los arts. 365 a 367 de la LSC.

Para el profesor QUIJANO ${ }^{808}$, de concurrir pérdidas cualificadas con una posible insolvencia inminente, al no ser obligatoria la solicitud de concurso ni de medidas preconcursales, la apertura de negociaciones no puede tener la misma relevancia que ante una insolvencia actual, por lo que seguiría vivo el deber de procurar la disolución, salvo que en los plazos establecidos para la negociación de esas medidas preconcursales, las pérdidas hayan dejado de ser cualificadas o se hayan adoptado acuerdos alternativos a la disolución.

Ahora bien, si la normativa concursal es preferente a la societaria ante una insolvencia actual o inminente, una vez efectuada la comunicación judicial de esas medidas, debería cesar la obligación de convocar la junta, a resultas de la negociación en plazo de las medias preconcursales, ya que se admite la solicitud de esas medidas tanto ante una insolvencia actual como inminente (arts. 583 y ss del TRLC).

Para la Dirección General de la Inspección de Trabajo y Seguridad Social, en la Guía Operativa de actuación en materia de derivación de responsabilidad a los administradores de sociedades mercantiles capitalistas en materia de Seguridad Social, de septiembre de 2017, en la página 25, dentro de las obligaciones del administrador social de los arts. 365 y 366 de la LSC, se incluye, en primer lugar, la convocatoria de la junta para adoptar el acuerdo de disolución, de concurrir únicamente causa de disolución, y en caso de que concurra causa de disolución y concurso, el deber de instar el concurso, así como la solicitud de las medidas preconcursales.

Estas medidas preconcursales operarían como obligación alternativa a la convocatoria de la junta para acordar la disolución, y como medida previa a la solicitud del concurso, de hallarnos ante una sociedad insolvente actual con causa de disolución por pérdidas. Medidas preconcursales que se pretenden reforzar en la Directiva (UE) 2019/1023 del Parlamento Europeo y del Consejo, de 20 de junio de 2019, sobre marcos de reestructuración preventiva, exoneración de deudas e inhabilitaciones, y sobre medidas

\footnotetext{
${ }^{807}$ QUIJANO GONZÁLEZ, J.: “Capital social y pérdidas cualificadas: Deberes y responsabilidades de los administradores”, 2019, op. cit., pp. 6, 11 y 12.

${ }^{808}$ QUIJANO GONZÁLEZ, J.: "Capital social y pérdidas cualificadas: Deberes y responsabilidades de los administradores”, 2019, op. cit., p. 12.
} 
para aumentar la eficiencia de los procedimientos de reestructuración, insolvencia y exoneración de deudas y por la que se modifica la Directiva (UE) 2017/1132 (Directiva sobre reestructuración e insolvencia) ${ }^{809}$, donde se prevén medidas de potenciación de soluciones preconcursales o de reestructuración preventiva de la empresa, para evitar el concurso, posibilitándose que se pueda acordar la suspensión de las ejecuciones singulares (art. 6 de la Directiva), para favorecer las negociaciones de un plan de reestructuración preventiva, señalando que los Estados miembros "velarán por que la suspensión pueda abarcar todas las categorías de créditos, incluidos los créditos garantizados y los preferentes" (art. 6.2 de la Directiva), e imponiendo a los administradores ante la insolvencia inminente la obligación de tener en cuenta los intereses de los acreedores, tomar medidas para evitar la insolvencia, y evitar una conducta dolosa o gravemente negligente que ponga en peligro la viabilidad de la empresa (art. 19).

\section{Deber de solicitar la disolución judicial o el concurso.}

\subsection{Solicitud de la disolución judicial.}

Cumplido el primer deber por los administradores, cuando la Junta General convocada no se reúna, o reunida no adopta ningún acuerdo de disolución o de remoción de la causa, sin haberse superado la misma, los administradores sociales como órgano están obligados a solicitar la disolución judicial de la sociedad (arts. 366 y 367 de la LSC), o de ser la sociedad insolvente el concurso de acreedores (art. 367 LSC y arts. 2 a 5 del TRLC), ya que, de no hacerlo dentro de los dos meses siguientes a la fecha de la reunión de la Junta General, o a la fecha prevista para la reunión de no haber tenido lugar ésta, los administradores responderían de modo solidario con la sociedad de capital de todas las deudas de Seguridad Social posteriores al acaecimiento de la causa de disolución (art. 367 LSC y STS, Sala Civil, 27/2017, de 18 de enero y 585/2013, de 14 de octubre, entre otras muchas).

Es una norma de cierre ${ }^{810}$ que obliga a los administradores a solicitar la disolución judicial de la sociedad para evitar que continúen en el tráfico económico las sociedades incursas en causa de disolución.

\footnotetext{
${ }^{809}$ DOUE, serie L del 26.6.2019.

${ }^{810}$ MOYA BALLESTER, J.: La responsabilidad de los administradores de sociedades en situaciones de crisis, op. cit., p. 276.
} 
El plazo de dos meses que tienen los administradores es un plazo para cumplir con este deber subsidiario, de cuyo incumplimiento se derivará el nacimiento de la responsabilidad solidaria por deudas, pero no es un plazo de prescripción o de caducidad para instar la disolución judicial, por lo que se puede presentar la demanda una vez transcurran esos dos meses, lo que tendrá efectos en la responsabilidad del administrador ${ }^{811}$.

Los plazos procesales, y entre ellos éste, quedaron suspendidos durante el período del 14.3.2020 al 3.6.2020, como consecuencia del estado de alarma por la crisis sanitaria de la Covid-19 (Disposición Adicional 2a del Real Decreto 463/2020, de 14 de marzo ${ }^{812}$ ), y cuyo cómputo se reinició de nuevo desde el principio a partir del 4.6.2020 (art. 2 del Real Decreto-Ley 16/2020, de 28 de abril ${ }^{813}$, y art. 8 del Real Decreto 537/2020, de 22 de mayo $^{814}$ ), con lo que desde ese 4 de junio 2020 se inició nuevamente el cómputo de nuevo del plazo de dos meses para solicitar la disolución judicial. No obstante, como medida excepcional y como consecuencia de la crisis sanitaria por la Covid-19, no hubo obligación de promover la disolución de la sociedad cuando las pérdidas determinantes de la causa de disolución fuesen del año 2020 (art. 13 de la Ley 3/2020, de 18 de septiembre).

Es este segundo deber, un deber subsidiario ${ }^{815}$ del primer deber de convocatoria de la Junta General, por lo que se ha defendido que este deber surge cuando se haya convocado la junta por los administradores ${ }^{816}$, en definitiva, cuando previamente se ha cumplido con el primer deber. En el art. 366 de la LSC se obliga a los administradores a

811 BATALLER GRAU, J.: “Disolución y Liquidación”, op. cit., p. 2571.

812 "Disposición Adicional Segunda. Suspensión de plazos procesales.

1. Se suspenden términos y se suspenden e interrumpen los plazos previstos en las leyes procesales para todos los órdenes jurisdiccionales. El cómputo de los plazos se reanudará en el momento en que pierda vigencia el presente Real Decreto o, en su caso, las prórrogas del mismo". La reanudación del cómputo de los plazos, fue derogada tácitamente por el nuevo cómputo integro de los plazos desde que se levantó la suspensión (art. 2 del Real Decreto-Ley 16/2020, de 28 de abril).

${ }^{813}$ BOE del 29.4.2020.

${ }^{814}$ BOE del 23.5.2020.

815 MACHADO PLAZAS, J.: Pérdida del capital social y responsabilidad de los administradores por deudas sociales, op. cit., p. 281; ROJO FERNÁNDEZ-RÍO, A.: "Los deberes legales de los administradores en orden a la disolución de la sociedad de capital como consecuencia de pérdidas", op. cit., p. 1471; BELTRÁN SÁNCHEZ, E.: "La responsabilidad de los administradores por obligaciones sociales", op. cit., p. 327; MOYA BALLESTER, J.: La responsabilidad de los administradores de sociedades en situaciones de crisis, op. cit., p. 279; CERDÁ ALBERO, F.: Administradores, insolvencia y disolución por pérdidas, op. cit., p. 107.

${ }^{816}$ QUIJANO GONZÁLEZ, J.: "Responsabilidad de los administradores por no disolución de la sociedad (art. 262.5 TRLSA) (Sentencia de la Audiencia Provincial de Burgos de 24 de julio de 1995)", op. cit., p. 271; VALPUESTA GASTAMINZA, E. M.: Comentarios a la Ley de Sociedades de Capital, op. cit., p. 946; MOYA BALLESTER, J.: La responsabilidad de los administradores de sociedades en situaciones de crisis, op. cit., pp. 279-280. 
solicitar la disolución judicial, cuando "el acuerdo social fuese contrario a la disolución o no pudiera ser logrado", lo que implica que para cumplir con el segundo deber, han debido cumplir con el primer deber de convocar la junta ${ }^{817}$. Para acreditar que se ha cumplido con el primer deber, con la solicitud judicial se ha de acompañar la convocatoria de la junta ${ }^{818}$.

Por el carácter subsidiario, de no haber cumplido con el primer deber, si los administradores solicitan posteriormente la disolución judicial, no estarían cumpliendo con el deber de promover la disolución, sino que lo harían como cualquier interesado ${ }^{819}$.

Será dies a quo para cumplir este deber, la fecha de la reunión, en primera y/o segunda convocatoria, o la fecha prevista para la reunión, de no haberse celebrado.

La solicitud de disolución judicial, para un sector doctrinal es un deber orgánico, del órgano de administración ${ }^{820}$, con independencia de que ante la falta de solicitud del órgano, o por acuerdo contrario del mismo, cualquier administrador a título individual pueda solicitar la disolución judicial, al tener la condición de interesado (art. 366 de la LSC), lo que tendrá efectos en su exoneración de responsabilidad ${ }^{821}$. Por el contrario, otro sector doctrinal, considera que ese segundo deber no es orgánico, sino que es una

817 VALPUESTA GASTAMINZA, E. M.: Comentarios a la Ley de Sociedades de Capital, op. cit., p. 946.

818 VAlPUESTA GASTAMINZA, E. M.: Comentarios a la Ley de Sociedades de Capital, op. cit., p. 946.

${ }^{819}$ MOYA BALLESTER, J.: La responsabilidad de los administradores de sociedades en situaciones de crisis, op. cit., pp. 279-280.

${ }^{820}$ EIZAGUIRRE BERMEJO, J. M.: “Disolución y liquidación”, op. cit., p. 78; MACHADO PLAZAS, J.: Pérdida del capital social y responsabilidad de los administradores por deudas sociales, op. cit., pp. 294-295; QUIJANO GONZÁLEZ, J.: "La responsabilidad de los administradores por la no disolución de la sociedad y las causas de exoneración”, 2002, op. cit., p. 84; MOYA BALLESTER, J.: La responsabilidad de los administradores de sociedades en situaciones de crisis, op. cit., p. 281; BELTRÁN SÁNCHEZ, E.: "La responsabilidad de los administradores por obligaciones sociales", op. cit., p. 328; VALPUESTA GASTAMINZA, E. M.: Comentarios a la Ley de Sociedades de Capital, op. cit., p. 946.

${ }^{821}$ QUIJANO GONZÁLEZ, J.: “La responsabilidad de los administradores por la no disolución de la sociedad y las causas de exoneración”, 2002, op. cit., p. 84, quien asume la competencia orgánica para este segundo deber, pero admitiendo que cada miembro del órgano de administración pueda instar ante el órgano la disolución, y en defecto de acuerdo o de ser éste contrario, ya como interesado, podrá solicitar directamente la misma; MACHADO PLAZAS, J.: Pérdida del capital social y responsabilidad de los administradores por deudas sociales, op. cit., pp. 294-295, para quien en cuanto interesado, más que obligado estaría el administrador a título individual facultado para solicitar la disolución judicial, y en esa medida exonerado de responsabilidad; BELTRÁN SÁNCHEZ, E.: "La responsabilidad de los administradores por obligaciones sociales", op. cit., p. 328; MOYA BALLESTER, J.: La responsabilidad de los administradores de sociedades en situaciones de crisis, op. cit., p. 282; VALPUESTA GASTAMINZA, E. M.: Comentarios a la Ley de Sociedades de Capital, op. cit., p. 946. 
obligación de carácter individual que puede cumplir cualquier administrador a título individual $^{822}$.

Un sector doctrinal minoritario ha defendido que no podrían acogerse a este segundo deber los administradores que deliberadamente convoquen con irregularidades la junta en cumplimiento del primer deber ${ }^{823}$.

Para que surja este segundo deber se precisa la concurrencia de dos presupuestos ${ }^{824}$. El primero, es que la Junta General convocada al efecto por los administradores no se hubiera constituido, o que constituida, no hubiera adoptado el acuerdo de disolución, o que el acuerdo fuere contrario a la disolución. El segundo presupuesto es que subsista la causa de disolución sin haberse removido la misma dentro del plazo de los dos meses que tienen los administradores para la formulación de la solicitud judicial, ya que si en el plazo de los dos meses cesa la causa, se extingue la obligación ${ }^{825}$. Cesa, por otro lado, la obligación de solicitar la disolución judicial si la sociedad incurriese en ese plazo de dos meses en causa de concurso de acreedores, en cuyo caso, los administradores deberán solicitar el concurso, como veremos más adelante (art. 367 de la LSC y arts. 2, 3 y 5 del TRLC).

El primer presupuesto es que la junta no se hubiere reunido, o que reunida no adoptase el acuerdo de disolución, o hubiere votado en contra de la disolución. Comoquiera que en nuestro Derecho no pueden impugnarse acuerdos negativos (Sentencia del TS, Sala

822 CALBACHO LOSADA, F.: El ejercicio de las acciones de responsabilidad contra los administradores de la sociedad anónima, op. cit., p. 436, para este autor estamos ante una obligación de carácter individual que no precisa ser adoptada orgánicamente, frente a lo exigido para el primer deber; ESTEBAN VELASCO, G.: "Algunas reflexiones sobre la Responsabilidad de los Administradores frente a los Socios y los Terceros: Acción individual y acción por no Promoción o Remoción de la disolución”, op. cit., p. 70, para quien la solicitud de disolución judicial hecha por un administrador o por cualquier interesado exonera de responsabilidad al resto de administradores siempre que no hubieren incurrido en infracción del primer deber de convocatoria de la junta; QUIJANO GONZÁLEZ, J.: "Responsabilidad de los administradores por no disolución de la sociedad (art. 262.5 TRLSA) (Sentencia de la Audiencia Provincial de Burgos de 24 de julio de 1995)", 1995, op. cit., p. 272; CERDÁ ALBERO, F.: Administradores, insolvencia y disolución por pérdidas, op. cit., pp. 112-113; SÁNCHEZ CALERO, F.: Los administradores en las sociedades de capital, op. cit. p. 449; DÍAZ ECHEGARAY, J. L.: Deberes y responsabilidades de los Administradores de Sociedades de Capital, op. cit., p. 403.

${ }^{823}$ RODRÍGUEZ RUIZ DE LA VILLA, D. y HUERTA VIESCA, M. I.: La responsabilidad de los administradores por las deudas de las Sociedades de Capital (en las Leyes de Sociedades Anónimas, de Sociedades de Responsabilidad Limitada, de Sociedad Limitada Nueva Empresa, Concursal, General Tributaria y de Responsabilidad Medioambiental), op. cit., p. 327; En contra CALBACHO LOSADA, F.: El ejercicio de las acciones de responsabilidad contra los administradores de la sociedad anónima, op. cit., p. 437.

${ }^{824}$ BELTRÁN SÁNCHEZ, E.: "La responsabilidad de los administradores por obligaciones sociales", op. cit., pp. 322-323.

${ }^{825}$ BELTRÁN SÁNCHEZ, E.: “La responsabilidad de los administradores por obligaciones sociales”, op. cit., p. 327. 
Civil, 286/2015, de 2 de junio), si la junta no adopta ningún acuerdo, los administradores deben solicitar la disolución judicial para exonerarse de la responsabilidad del art. 367 de la LSC ${ }^{826}$.

De haberse recurrido judicialmente el acuerdo de la junta contrario a la disolución por terceros interesados (accionistas o acreedores), consideramos con un sector de la doctrina $^{827}$, que ello no exime a los administradores de tener que cumplir con el deber subsidiario de solicitar la disolución judicial. Por el contrario, otro sector ${ }^{828}$ estima que la impugnación judicial del acuerdo contrario a la disolución, dentro de los dos meses siguientes a su adopción, y hasta que se dicte sentencia firme, haría cesar la obligación de los administradores de solicitar la disolución judicial, naciendo ese deber una vez en sentencia se declarase que concurría causa de disolución, en cuyo caso, se computaría el plazo de dos meses para el cumplimiento de este deber desde la sentencia firme que apreciase que sí hubo causa de disolución, obviamente si continuase existiendo la causa. Otra interpretación doctrinal ${ }^{829}$, distingue en función del motivo por el que la resolución judicial declara la nulidad del acuerdo de disolución de la junta, si es por defectos de forma o por no apreciar la concurrencia de causa, de modo que si fuese por no apreciar que concurre la causa de disolución no estarían los administradores obligados a solicitar la disolución, mientras que si se anula el acuerdo de la junta por defectos de forma o por vulneración de derechos de los socios, sin entrar en el fondo, deben los administradores solicitar la disolución.

No se exime el administrador de cumplir con este deber por el hecho de haberse impugnado el acuerdo contrario de la junta, ya que estamos ante un deber imperativo de los administradores, sólo condicionado a que haya desaparecido la causa de disolución (Sentencias del TS, Sala Civil, 328/2011, de 19 de mayo; 585/2013 de 14 de octubre; 27/2017, de 18 de enero). Así nuestra jurisprudencia es clara al señalar que concurriendo causa legal de disolución, "los concretos deberes que los arts. 365 y 366 LSC imponían a los administradores eran: i) en primer lugar, convocar la Junta general

${ }^{826}$ BELTRÁN SÁNCHEZ, E.: "La responsabilidad de los administradores por obligaciones sociales”, op. cit., p. 327.

827 CALBACHO LOSADA, F.: El ejercicio de las acciones de responsabilidad contra los administradores de la sociedad anónima, op. cit., p. 438.

828 RODRÍGUEZ RUIZ DE LA VILLA, D. y HUERTA VIESCA, M. I.: La responsabilidad de los administradores por las deudas de las Sociedades de Capital (en las Leyes de Sociedades Anónimas, de Sociedades de Responsabilidad Limitada, de Sociedad Limitada Nueva Empresa, Concursal, General Tributaria y de Responsabilidad Medioambiental), op. cit., p. 338.

${ }^{829}$ ROJO FERNÁNDEZ-RÍO, A.: "Los deberes legales de los administradores en orden a la disolución de la sociedad de capital como consecuencia de pérdidas", op. cit., p. 1469. 
en el plazo de dos meses para que adopte el acuerdo de disolución; ii) en el caso en que no se hubiera podido constituir la junta, solicitar la disolución judicial en el plazo de dos meses a contar desde la fecha prevista para la celebración de la junta; y iii) si se hubiese celebrado la junta, pero no se hubiera adoptado el acuerdo de disolución o el acuerdo hubiese sido contrario, solicitar la disolución judicial en el plazo de dos meses a contar desde el día de la junta" (Sentencias del TS, Sala Civil, 585/2013, de 14 de octubre y 27/2017, de 18 de enero).

El segundo presupuesto es que siga existiendo la causa de disolución, por lo que, si dentro del plazo de los dos meses que tienen los administradores para solicitar la disolución judicial, cesa la causa de disolución, cesa la obligación de solicitar la disolución judicial (Sentencia del TS, Sala Civil, 328/2011, de 19 de mayo) ${ }^{830}$.

De no haber cesado la causa de disolución dentro del plazo de los dos meses que tienen los administradores sociales para el cumplimiento del segundo deber, éstos deben solicitar la disolución judicial de la sociedad, ya que en otro caso, incurren en responsabilidad solidaria de las deudas de Seguridad Social (art. 367 LSC), sin que la adopción de otras medidas distintas como un expediente de regulación de empleo que acabó con la extinción de todas las relaciones laborales, y la posterior venta de activos y pasivos de la compañía, "justificasen la omisión del deber de instar la disolución de la sociedad", ya que ese ERE no sólo era compatible con la disolución de la compañía, sino que además conducían a ella (Sentencia del TS, Sala Civil, 27/2017, de 18 de enero).

Si la disolución judicial la solicitan terceros interesado antes de expirar el plazo que tienen los administradores para cumplir este segundo deber, se ha estimado por un sector doctrinal ${ }^{831}$ que cesa la obligación de éstos de cumplir con este deber, si bien, deberían manifestar su aquiescencia a la solicitud, siendo lo más prudente personarse en

${ }^{830}$ Los deberes que surgen de la concurrencia de la causa desaparecen si, en el plazo concedido cesa la causa, ya desaparezca dentro del plazo de dos meses para convocar la junta, o dentro del plazo de dos meses para instar la disolución judicial, ya que, si la causa se remueve después de finalizar esos dos periodos, los administradores responderán de las deudas anteriores, pero no así de las posteriores a ese momento (Sentencia del TS, Sala Civil, 328/2011, de 19 de mayo).

831 CALBACHO LOSADA, F.: El ejercicio de las acciones de responsabilidad contra los administradores de la sociedad anónima, op. cit., p. 442; ESTEBAN VELASCO, G.: "Algunas reflexiones sobre la Responsabilidad de los Administradores frente a los Socios y los Terceros: Acción individual y acción por no Promoción o Remoción de la disolución”, op. cit., p. 70. 
intervención adhesiva en el proceso ${ }^{832}$. Para nuestra jurisprudencia cesa la obligación de los administradores de solicitar la disolución judicial si dentro del plazo de los dos meses se ha solicitado la disolución judicial por cualquier interesado (Sentencias del TS, Sala Civil, 981/2002, de 24 de octubre -Rec. 1030/1997- y 1080/2003, de 17 noviembre -Rec. 144/1998-- ${ }^{833}$. De este modo, por algún sector doctrinal ${ }^{834}$ se estima que el cumplimiento de este deber por los administradores, lo es en defecto de solicitud judicial por cualquier interesado dentro de ese plazo, o si el interesado desiste de su demanda.

Existirá igual deber de solicitar la disolución judicial, si habiendo acordado la junta la disolución, posteriormente, y sin haber desaparecido la causa, se revoca el acuerdo ${ }^{835}$.

Si la junta adoptó medidas alternativas a la disolución, como el aumento del capital, se precisa que éste sea efectivo ${ }^{836}$, de modo que de no alcanzarse, nace la obligación de los administradores de solicitar la disolución judicial ${ }^{837}$.

No tiene efectos en esta responsabilidad del administrador, si cumplido con el deber de solicitar la disolución judicial, posteriormente no se solicita la inscripción de la

832 CALBACHO LOSADA, F.: El ejercicio de las acciones de responsabilidad contra los administradores de la sociedad anónima, op. cit., p. 442.

${ }^{833}$ En la Sentencia del TS, Sala Civil, 981/2002, de 24 de octubre, se señala al respecto que, "no es aceptable la interpretación literal, rígida e inflexible del art. 262.5 LSA de modo que baste simplemente la no convocatoria de la junta de accionistas, o que no se solicite la disolución judicial, todo ello dentro de los plazos señalados en la citada norma para hacerlo, para que se declare la responsabilidad solidaria de los Administradores por las deudas sociales. Ha de tenerse en cuenta que el art. 262.3 LSA permite a cualquier interesado solicitar la disolución judicial de la sociedad cuanto la junta no fuese convocada o no pudiese lograrse el acuerdo o éste fuese contrario a la disolución. Por tanto, puede darse el hecho de que en el plazo de dos meses del art. 262.5 LSA los administradores no cumplan su obligación, pero haya solicitado la disolución cualquier interesado. No es razonable que, pese a cumplirse la finalidad de la Ley, los administradores sean responsables solidarios. En suma, pues, el art. 262.5 ha de conjugarse con el apartado 3 anterior y analizar si en el plazo de dos meses se ha pedido, aunque sea por un interesado, la disolución judicial de la sociedad, que es lo que quiere el legislador".

834 RODRÍGUEZ RUIZ DE LA VILLA, D. y HUERTA VIESCA, M. I.: La responsabilidad de los administradores por las deudas de las Sociedades de Capital (en las Leyes de Sociedades Anónimas, de Sociedades de Responsabilidad Limitada, de Sociedad Limitada Nueva Empresa, Concursal, General Tributaria y de Responsabilidad Medioambiental), op. cit., p. 326.

${ }^{835}$ CALBACHO LOSADA, F.: El ejercicio de las acciones de responsabilidad contra los administradores de la sociedad anónima, op. cit., p. 438.

${ }^{836}$ Sentencias del TS, Sala Civil, núm. 110/2004, de 23 de febrero; núm. 460/2010, de 14 de julio; y núm. 328/2011, de 19 de mayo.

837 CALBACHO LOSADA, F.: El ejercicio de las acciones de responsabilidad contra los administradores de la sociedad anónima, op. cit., pp. 431-432. 
disolución en el Registro Mercantil, o la anotación preventiva de la demanda ${ }^{838}$, otra cuestión es que ello pueda generar la responsabilidad por daños de los art. 236 LSC.

Con la solicitud de disolución judicial de la sociedad por los administradores se cierra la posibilidad de incurrir los mismos en responsabilidad ${ }^{839}$. Lo mismo cabe señalar con la solicitud de concurso de hallarse la sociedad en insolvencia, como veremos seguidamente.

Finalmente, señalar que la solicitud de disolución judicial se ha de tramitar por los cauces procesales de la jurisdicción voluntaria (arts. 125 a 128 de la Ley 15/2015, de 2 de julio, de Jurisdicción Voluntaria -en adelante LJV-840).

La competencia para conocer de la disolución judicial de una sociedad corresponderá al Juzgado de lo Mercantil de su domicilio social. Están legitimados para instar la disolución judicial de la sociedad los administradores, los socios y cualquier interesado, siendo preceptiva la intervención de Abogado y Procurador (art. 121 de la LJV).

El Juez resolverá el expediente por medio de auto en el plazo de cinco días a contar desde la terminación de la comparecencia. En el supuesto de que el Juez declare disuelta la sociedad, el auto incluirá la designación de las personas que vayan a desempeñar el cargo de liquidadores, y un testimonio del mismo se remitirá al Registro Mercantil que corresponda para su inscripción (art. 128 LJV).

\subsection{Solicitud del concurso de acreedores y medidas preconcursales.}

Cuando la causa de disolución por pérdidas cualificadas concurra conjuntamente con una situación de insolvencia de la sociedad, al primar el Derecho concursal sobre el Derecho societario, cesa el deber de solicitar la disolución judicial e impera el deber de los administradores de solicitar el concurso de acreedores ante el Juzgado de lo Mercantil ${ }^{841}$, dentro de los dos meses siguientes a la fecha de celebración de la Junta General o de la fecha prevista para la celebración de la junta (arts. 2, 3, 5 y 44 del

838 RODRÍGUEZ RUIZ DE LA VILLA, D. y HUERTA VIESCA, M. I.: La responsabilidad de los administradores por las deudas de las Sociedades de Capital (en las Leyes de Sociedades Anónimas, de Sociedades de Responsabilidad Limitada, de Sociedad Limitada Nueva Empresa, Concursal, General Tributaria y de Responsabilidad Medioambiental), op. cit., p. 330; CALBACHO LOSADA, F.: El ejercicio de las acciones de responsabilidad contra los administradores de la sociedad anónima, op. cit., p. 438.

839 CALBACHO LOSADA, F.: El ejercicio de las acciones de responsabilidad contra los administradores de la sociedad anónima, op. cit., p. 438.

${ }^{840}$ BOE del 03.07.2015.

${ }^{841}$ BELTRÁN SÁNCHEZ, E., "La responsabilidad de los administradores por obligaciones sociales", op. cit., pp. 322-323. 
TRLC, en relación con los arts. 363, 1, e) y 367 de la LSC; y STS, Sala Civil, 590/2013, de 15 de octubre; 560/2013, de 7 de octubre; y 458/2010, de 30 de junio).

Esta es la solución legal expresamente establecida en el art. 367 de la LSC, donde se prescribe que responderán solidariamente de las deudas sociales, los administradores que, en el plazo de dos meses siguientes a la celebración de la Junta General sin acuerdo de disolución, o desde la fecha prevista para la junta que no llegó a celebrarse, no solicitasen la disolución judicial o, si procediese, el concurso de la sociedad. Esta es la interpretación de la doctrina mayoritaria ${ }^{842}$.

A esto no se opone la doctrina jurisprudencial sentada por el TS, Sala ContenciosoAdministrativa $^{843}$, de que para que sea aplicable la responsabilidad solidaria del art. 367 LSC, debe concurrir inexorablemente causa de disolución por pérdidas, concurriendo también causa de concurso, ya que, con esta doctrina, lo que se pretende dilucidar y lo que fue el objeto de fijación de doctrina, era, si de concurrir causa de concurso debía concurrir también causa de disolución, para que procediese la derivación administrativa de responsabilidad, siendo su respuesta afirmativa. Al respecto, en esa sentencia se señala que "la cuestión que reviste interés objetivo para la formación de jurisprudencia es la siguiente: determinar si para acordar la Administración de la Seguridad Social la derivación de responsabilidad solidaria del administrador de una sociedad de capital, resulta necesario no sólo constatar una situación fáctica que habla a favor de la insolvencia de la sociedad y verificar que dicho administrador no ha cumplido los deberes legales a que se refiere el artículo 367.1 de la Ley de Sociedades de Capital (RD Legislativo 1/2010), sino también y además, justificar la efectiva existencia de una causa legal de disolución de la sociedad", siendo su respuesta que deben concurrir las dos situaciones, ya que, en todo caso, se precisa causa de disolución.

${ }^{842}$ QUIJANO GONZÁLEZ, J.: "Capital social y pérdidas cualificadas: Deberes y responsabilidades de los administradores”, 2019, op. cit., pp. 2-13; MOYA BALLESTER, J.: La responsabilidad de los administradores de sociedades en situaciones de crisis, op. cit., pp. 394 y ss; BELTRÁN SÁNCHEZ, E.: "La responsabilidad de los administradores por obligaciones sociales", op. cit., pp. 322-323; DÍAZ ECHEGARAY, J. L.: Deberes y responsabilidades de los Administradores de sociedades de Capital, op. cit., p. 382.

${ }^{843}$ Sentencias del TS, Sala Contencioso-Administrativo, 874/2019, de 24 de junio; 875/2019, de 24 de junio; 897/2019, de 25 de junio; 915/2019, de 26 de junio; 338/2020, de 6 de marzo -Rec. 7827/2018;1346/2020, de 19 octubre de 2020 -Rec. 7410/2018-; 1411/2020, de 27 de octubre de 2020 -Rec. 3759/2018-; 1654/2020, de 3 de diciembre de 2020 -Rec. 730/2019-; 1713/2020, de 14 diciembre Rec. 1987/2019-; 83/2021, de 27 de enero -Rec. 2046/2019-; 117/2021, de 1 de febrero -Rec. 6149/2019-.; 120/2021, de 2 de febrero -Rec. 4284/2019-. 
Durante la vigencia del estado de alarma del 14.3.2020 al 20.6.2020 por la crisis sanitaria de la Covid-19, se suspendieron los plazos y términos procesales (Disposición Adicional $2^{\text {a }}$ del Real Decreto 463/2020, de 14 de marzo), plazos procesales que volvieron a computarse desde su inicio de nuevo a partir del 4 de junio de 2020 (art. 2 del Real Decreto-Ley 16/2020, de 28 de abril y art. 8 del Real Decreto 537/2020, de 22 de mayo).

Debido a esa crisis sanitaria por la Covid-19, hasta el 31.12.2021 no hubo obligación de solicitar el concurso de acreedores (art. 6 de la Ley 3/2020, de 18 de septiembre), ni obligación de promover la disolución cuando las pérdidas determinantes de la causa de disolución sean del año 2020 o resulten de los balances trimestrales del 2021 (arts. 6 y 13 de la Ley 3/2020, de 18 de septiembre, en interpretación sistemática).

Dentro del cumplimiento de este deber de solicitud de concurso ha de incluirse, por tener el mismo efecto en la responsabilidad por deudas, la comunicación de inicio de negociaciones para adoptar medidas preconcursales dirigida al Juez competente para conocer del concurso (art. 583 y siguientes del TRLC).

Nos remitimos a lo reseñado al respecto en el anterior apartado IV.2.2.1 de este capítulo acerca de los efectos en la responsabilidad de los administradores prevista en el art. 367 de la LSC, cuando se solicitan las medidas preconcursales, concluyendo que, si como consecuencia de los acuerdos con los acreedores se superase la insolvencia y la causa de disolución por pérdidas, no existiría obligación ni de solicitar el concurso ni de promoverse la disolución de la $\operatorname{sociedad}^{844}$, por lo que no llegaría a nacer la responsabilidad por deudas del art. 367 LSC. Por el contrario, si fruto del acuerdo se superase la insolvencia pero continuasen las pérdidas cualificadas, renacería el deber de los administradores de solicitar la disolución judicial de la mercantil, de procurar la disolución de la sociedad ${ }^{845}$.

\section{Medidas alternativas. Remoción de la causa de disolución.}

La posibilidad jurídica de poder adoptarse medidas de remoción de la causa, se prevé en el art. 365.2 de la LSC, donde al regular el deber de los administradores de convocar la Junta General, dentro del plazo de los dos meses siguientes al acaecimiento o

${ }^{844}$ QUIJANO GONZÁLEZ, J.: "Capital social y pérdidas cualificadas: Deberes y responsabilidades de los administradores”, 2019, op. cit., pp. 11-12.

${ }^{845}$ QUIJANO GONZÁLEZ, J.: "Capital social y pérdidas cualificadas: Deberes y responsabilidades de los administradores", 2019, op. cit., pp. 11-12. 
conocimiento de la causa de disolución, para la adopción del acuerdo de disolución (art. 365.1 LSC), se prescribe que la “junta general podrá adoptar el acuerdo de disolución o, si constare en el orden del día, aquél o aquéllos necesarios para la remoción de la causa".

\subsection{Adopción por la Junta y su plazo de ejecución.}

La obligación de los administradores constitutiva del primer deber es convocar en el plazo de dos meses la junta para que ésta constate y acuerde la disolución o medidas alternativas de remoción de la causa que eviten la disolución, cuestiones que deberán recogerse en el orden del día de la convocatoria (art. 365.2 LSC). Para la válida adopción de medidas alternativas éstas deberán constar en el orden del día de la convocatoria, conjuntamente con la adopción del acuerdo de disolución, para que, en caso de no adoptarse ninguna medida alternativa, la junta se pronuncie sobre la concurrencia de la causa de disolución ${ }^{846}$, porque en el art. 365.1 LSC se obliga a convocarla para que adopte el acuerdo de disolución ${ }^{847}$, si concurre la causa, y se faculta en el art. 365.2 de la LSC para que pueda acordar medidas alternativas de remoción de la causa.

El plazo de dos meses desde el acaecimiento de la causa de disolución es para convocar la junta (art. 365 LSC), sin que, cuando se pretendan adoptar medidas alternativas, pueda efectuarse una convocatoria de la junta fuera del plazo legal de dos $\operatorname{meses}^{848}$, y sin

${ }^{846}$ MOYA BALLESTER, J.: La responsabilidad de los administradores de sociedades en situaciones de crisis, op. cit., pp. 255 y 262. Este autor afirma que los administradores están obligados a convocar la junta para que adopte el acuerdo de disolución, no para que adopte un acuerdo de remoción, de modo que si no consta la disolución en el orden del día, aunque sea con carácter subsidiario, no están cumpliendo con el primer deber establecido en el art. 365 LSC.

${ }^{847}$ Es doctrina jurisprudencial que el deber primario de los administradores es convocar la junta para disolver (SSTS, Sala Civil, 1219/2004, de 16 de diciembre; 313/2006, de 3 de abril; 977/2000, de 30 de octubre -Rec. 3341/1995-; 585/2013, de 14 de octubre; 733/2013, de 4 de diciembre; 27/2017, de 18 de enero).

848 SSTS, Sala Civil, núm. 27/2017, de 18 de enero; 733/2013, de 4 de diciembre; 585/2013, de 14 de octubre; 100/2012, de 7 de marzo; y núm. 1219/2004, de 16 de diciembre.

Sentencias del TS, Sala Civil, núm. 733/2013, de 4 de diciembre y 27/2017, de 18 de enero. En esas sentencias se condena a los administradores a responder de las deudas sociales por haber incumplido el deber de convocar la Junta General dentro de los dos meses siguientes a la causa disolutoria, sin haberse superado la misma, al haberse limitado aquéllos a adoptar determinadas medidas, como actuaciones tendentes a minorar las deudas (en el caso de la primera Sentencia), o medidas de regulación de empleo y de venta de activos (en el caso de la segunda Sentencia), sin que con ello se superase la causa de disolución, por lo que pasados dos meses desde el acaecimiento de la causa, se declara la responsabilidad solidaria de aquéllos. En igual doctrina en la Sentencia 1219/2004, de 16 de diciembre, donde se afirma, "se impone a los administradores el deber de convocar la junta para acordar la disolución de la sociedad, dentro del plazo de dos meses desde que concurra la causa de disolución. La Ley, asimismo, prevé una posibilidad de remoción de la causa de disolución, pero si tal causa no ha sido removida antes del plazo bimensual, concurre el hecho generador de la 
que las medidas de remoción deban ejecutarse o acordarse dentro de los dos meses siguientes al acaecimiento de la causa de disolución, ya que el plazo de dos meses es para convocar.

Nuestra jurisprudencia ha dejado meridianamente claro que, el plazo de dos meses para convocar la junta es plenamente aplicable cuando se pretenden acordar medidas de remoción de la causa de disolución por pérdidas, ya que, de convocarse la junta fuera de ese plazo sin que se hubiere removido o superado la causa disolutoria, los administradores incurren en responsabilidad por las deudas sociales ${ }^{849}$.

No debe confundirse el hecho de que la causa de disolución se remueva o se supere dentro del plazo de dos meses que tienen los administradores para convocar la junta o solicitar la disolución judicial -lo que implicaría que se extinguen esos deberes de los administradores- ${ }^{850}$, con que el acuerdo de remoción deba ser adoptado o ejecutado dentro de los dos meses siguientes al acaecimiento de la causa de disolución.

Las medidas alternativas encaminadas a remover la causa de disolución son facultativas no obligatorias, pudiendo ser incluidas en el orden del día, pero lo que sí es obligatorio

responsabilidad". En esa Sentencia se condena a los administradores a responder de las deudas sociales, porque no convocaron la junta dentro de los dos meses siguientes a la causa de disolución por pérdidas, por no cumplir con el deber de convocar en plazo la junta, habiéndose convocado sólo una junta para acordar una reducción del capital social, sin que constase la existencia de causa de disolución, ni la adopción del pertinente acuerdo en el orden del día, y sin haberse removido la causa dentro de los dos meses siguientes a su acaecimiento. No se impone, de este modo, la obligación de que de adoptarse por la junta una medida de remoción que enerve la causa de disolución, se deba ejecutar dentro de los dos meses siguientes a su acaecimiento.

${ }^{849}$ Sentencia del TS, Sala Civil, 977/2000, de 30 de octubre; 1219/2004, de 16 de diciembre; 313/2006, de 3 de abril -Rec. 2702/1999-; 286/2011, de 23 de noviembre; 100/2012, de 7 de marzo; 585/2013, de 14 de octubre; 733/2013, de 4 de diciembre; 27/2017, de 18 de enero. En la Sentencia TS, Sala Civil, 328/2011, de 19 de mayo, se exoneró a los administradores de responsabilidad, porque dentro del plazo de los dos meses adoptaron medidas encaminadas al reflotamiento de la sociedad dedicada a la actividad del ramo de seguros, como fue la presentación de un plan de viabilidad o reorganización ante la Generalitat, que, si no se llevó a efecto, fue por la intervención de la sociedad por la autoridad administrativa competente (Generalitat de Cataluña).

${ }^{850}$ BELTRÁN SÁNCHEZ, E.: "La responsabilidad de los administradores por obligaciones sociales", op. cit., p. 323; MOYA BALLESTER, J.: La responsabilidad de los administradores de sociedades en situaciones de crisis, op. cit., pp. 273-275; SÁNCHEZ CALERO, F.: Los administradores en las sociedades de capital, op. cit., p. 454. DÍAZ ECHEGARAY, J. L.: Deberes y responsabilidades de los Administradores de sociedades de Capital, op. cit., p. 416.

Se extinguirá el deber de convocar a la junta en el plazo de dos meses, o el deber subsidiario de solicitar la disolución judicial, sin antes del vencimiento de esos respectivos plazos, se remueva o desaparece la causa de disolución, no naciendo la responsabilidad solidaria del administrador. Se extingue el deber de los administradores por desaparecer el presupuesto fáctico normativo, por cesar la causa de disolución antes del transcurso del plazo para dar cumplimiento al primer deber, o, en su caso, antes de que concluya el plazo para el cumplimiento del segundo deber.

Para SÁNCHEZ CALERO, en estos supuestos, más que extinción de deber de convocar la junta, estaremos ante el hecho de que el presupuesto para que surja la responsabilidad por deudas de los administradores no llega a nacer. Vid. su nota 56 en SÁNCHEZ CALERO, F.: Los administradores en las sociedades de capital, op. cit., p. 454. 
es incluir en el orden del día la constatación de la causa y la adopción del acuerdo de disolución.

La medida de remoción alternativa a la disolución que adopte la junta ha de ser válida, ya que de ser un acuerdo nulo de la junta nacería a partir de ese momento la obligación de los administradores de cumplir con el deber subsidiario de solicitar la disolución judicial $^{851}$.

De adoptarse un acuerdo de remoción por la Junta General, éste debe ser realmente ejecutado, no siendo suficiente la mera adopción del mismo, debiendo ser efectivo para remover la causa de disolución ${ }^{852}$, ya que, de no ser así, no puede evitar la sociedad estar incursa en causa de disolución ${ }^{853}$.

No se establece ningún plazo para la ejecución de las medidas alternativas de remoción que puede adoptar la Junta General, que dependerá del tipo de medida pretendida ${ }^{854}$, ya que, si es aumento, reducción del capital, modificación de estatutos sociales, etc., se exige la observancia de unos trámites legales preceptivos (Sentencia del TS, Sala Civil, 76/2008, de 5 de febrero), con lo que de acordarse y no llegar a ejecutarse, nos podremos encontrar con el problema de dilucidar si los administradores deben solicitar la disolución judicial, y desde cuándo computa el plazo de dos meses, si desde la fecha de la celebración de la junta, por entenderse que no se ha logrado o adoptado el acuerdo de disolución, o desde la fecha en que la medida de remoción no se llevó a cabo.

851 RODRÍGUEZ RUIZ DE LA VILLA, D. y HUERTA VIESCA, M. I.: La responsabilidad de los administradores por las deudas de las Sociedades de Capital (en las Leyes de Sociedades Anónimas, de Sociedades de Responsabilidad Limitada, de Sociedad Limitada Nueva Empresa, Concursal, General Tributaria y de Responsabilidad Medioambiental), op. cit., p. 272, quien cita la Sentencia del TS, Sala Civil, 507/2000, de 15 de mayo de 2000 -Rec. 2231/1995-, que aprecia la concurrencia de causa de disolución por pérdidas, cuando el acuerdo de reducción y ampliación del capital para enervar la causa de disolución, no se adoptó válidamente en la Junta General, por no haberse cumplido el quórum estatutario agravado exigido para la válida constitución de la misma.

${ }^{852}$ Sentencias del TS, Sala Civil, núm. 110/2004, de 23 de febrero; núm. 460/2010, de 14 de julio; y núm. 328/2011, de 19 de mayo.

${ }^{853}$ Sentencias del TS, Sala Civil, núm. 110/2004, de 23 de febrero; núm. 460/2010, de 14 de julio; y núm. 328/2011, de 19 de mayo. En la Sentencia del TS, Sala Civil, 328/2011, de 19 de mayo, con relación a la medida alternativa del aumento o reducción del capital social para superar la causa de disolución por pérdidas cualificadas, insiste en dejar claro que "la Ley prevé que la causa de disolución se elimine mediante aumento o disminución del capital social. Pero la virtualidad de la medida depende de la operación de aumento o disminución y no solo del acuerdo que se adopta en junta", para sintetizar con la afirmación de que "el acuerdo es condición necesaria, pero no suficiente: se requiere su ejecución para que el capital efectivamente aumente o disminuya".

854 CALBACHO LOSADA, F.: El ejercicio de las acciones de responsabilidad contra los administradores de la sociedad anónima, op. cit., p. 435, alude a la obligación de los administradores de procurar que los acuerdos alternativos de remoción se adopten dentro de un plazo razonable, debiendo solicitar los mismos la disolución judicial, desde el momento que consideren que la demora perjudica a los acreedores sociales. 
En este caso, cabría preguntarse si los administradores deberían cumplir con el segundo deber de solicitar la disolución judicial, y, por otro lado, cuál es el dies a quo del cumplimiento de este deber, si la fecha de la junta o la fecha en que se comprueba que no se hizo efectivo el aumento del capital.

Con relación a esta cuestión, señalar que en el art. 366.2 de la LSC se impone ese segundo deber, cuando "el acuerdo de la junta fuere contrario a la disolución o no pudiera ser logrado", para seguidamente señalar que el dies a quo del plazo de dos meses para el cumplimiento del segundo deber -solicitud de disolución judicial-, se computa desde la fecha de la junta "cuando el acuerdo hubiera sido contrario a la disolución o no se hubiere adoptado". Por otro lado, en el art. 367 de la LSC, a la hora de declarar la responsabilidad solidaria de los administradores, con relación al incumplimiento del segundo deber, se señala que, responden de las deudas sociales los administradores "que no solicitan la disolución judicial, o de proceder el concurso de acreedores, en el plazo de dos meses a contar (..) desde el día de la junta, cuando el acuerdo hubiere sido contario a la disolución". En esos preceptos se habla de "acuerdos contrarios a la disolución" y de "acuerdos de disolución no logrados o no adoptados", dentro del presupuesto fáctico generador del segundo deber y del cómputo del plazo.

¿Estamos ante un acuerdo de disolución no logrado, o no adoptado? Ha de darse una respuesta positiva como se puede desprender de la doctrina mantenida en la jurisprudencia ${ }^{855}$, porque, o bien el acuerdo de disolución no fue logrado, pese a ser incluido en el orden del día, o bien fue contrario a la disolución, ya que, en todo caso, debe de constar en el orden del día de la convocatoria para que se entienda cumplido correctamente el primer deber. Los administradores deberían por ello cumplir con el segundo deber de solicitar la disolución judicial, al no haber adoptado la junta el

${ }^{855}$ STS, Sala Civil, 977/2000, de 30 de octubre; 1219/2004, de 16 de diciembre; 313/2006, de 3 de abril Rec. 2702/1999-; 286/2011, de 23 de noviembre; 100/2012, de 7 de marzo; 585/2013, de 14 de octubre; 733/2013, de 4 de diciembre; y 27/2017, de 18 de enero. Esta es la doctrina recogida en la Sentencia del TS, Sala Civil, 313/2006, de 3 de abril -Rec. 2702/1999-, cuando se aprecia la responsabilidad del administrador cuando la convocatoria de la junta no se produjo dentro del plazo de dos meses, y no se incluyó en el orden del día el acuerdo de disolución, sino sólo una operación acordeón, que no se llevó a buen término, señalando "no es menos cierto que la convocatoria no se hizo dentro de los dos meses, ni en ella se contemplaba el acuerdo de disolución, ni cabe alegar desconocimiento de la situación en que se encontraba la sociedad (lo pone de manifiesto la misma propuesta de "operación acordeón") ni, finalmente, puede excusar el hecho de que la propuesta no pudiera llevarse a efecto por falta de requisitos formales o el que por tal motivo se volviera a convocar casi ocho meses después nueva Junta General Extraordinaria, cuando los administradores deben solicitar la liquidación judicial en el plazo de dos meses cuando el acuerdo social fuere contrario a la disolución o "no pudiere ser logrado". La cursiva es nuestra. 
acuerdo de disolución, o al haber sido contrario, o al no haberse logrado, por haber adoptado sólo un acuerdo de remoción que no fue efectivo dentro de los dos meses siguientes a su adopción.

Ahora, bien desde una interpretación teleológica, y considerando que la disolución estaría condicionada y subordinada a que la medida de remoción no se hiciese efectiva, ya que al ser facultativa su finalidad es obtener la remoción de la causa de disolución, y con ello permitir la continuidad de la empresa y del empleo, en la medida en que no resultasen perjudicados los acreedores, podría defenderse que de adoptarse medidas alternativas, como la ampliación, reducción de capital o reintegración del patrimonio por los socios, etc., sería razonable esperar a que concluyese la ejecución de esas medidas, ya que en la tramitación legal de la ampliación del capital en sociedades de cierta entidad, implicará que el período de suscripción se extienda durante un plazo superior a los dos meses siguientes a la celebración de la junta. En esos supuestos, de haberse adoptados medidas alternativas, siempre que éstas fuesen suficientes, adecuadas y objetivamente realizables en función de la situación de la empresa, una vez que haya finalizado el plazo para su ejecución sin haberse hecho efectivas, los administradores si hubiesen cumplido con su primer deber, deberían proceder a solicitar la disolución judicial (cumplimiento del segundo deber subsidiario), dentro del plazo de dos meses desde que finalizó el establecido legalmente o por la junta para la remoción de la causa $^{856}$. Postura ésta que con la doctrina de nuestra jurisprudencia no es actualmente defendible, por lo que debería realizarse la pertinente reforma legislativa.

Con relación al dies a quo del plazo, en interpretación literal de los arts. 366.2 y 367 de la LSC y según la actual doctrina jurisprudencial, el plazo de dos meses de este segundo deber, se computaría desde la fecha de celebración de la junta, en la medida en que al haber acordado sólo una medida de remoción que no se ha llevado a efecto, estaríamos ante un acuerdo de disolución no logrado, no adoptado, o, en su caso, contrario a su adopción. Por ello, y para evitar la inseguridad jurídica sobre el nacimiento de la responsabilidad del administrador, es conveniente y necesario, como mantiene el

856 CALBACHO LOSADA, F.: El ejercicio de las acciones de responsabilidad contra los administradores de la sociedad anónima, op. cit., pp. 431-432. Entiende este autor, que sería contrario a la finalidad de la norma, que si la junta opta por una medida de remoción, deba proponer simultáneamente la disolución, ya que ambas medidas son incompatibles, y una, la remoción, pretende evitar la otra, la disolución, debiendo quedar ésta en suspenso hasta que la junta decida sobre la medida alternativa, sin que la Ley imponga que se deba adoptar el acuerdo en el plazo de dos meses. 
profesor BELTRÁN ${ }^{857}$, que se adopte el acuerdo de disolución bajo condición suspensiva cuando se acuerden medidas de remoción, en aras de la seguridad jurídica acerca del cumplimiento de los deberes de los administradores.

De todo lo anterior, resultaría que, de acordarse medidas de remoción y no ser efectivas éstas dentro de los dos meses siguientes al acuerdo de la junta, deberían los administradores solicitar la disolución judicial.

Si los administradores no cumplen con sus dos deberes y posteriormente a esos incumplimientos se removiere la causa de disolución, aquéllos serían responsables solidarios de las deudas de Seguridad Social de la sociedad devengadas durante el período en que la empresa estuvo incursa en causa de disolución, esto es, desde el acaecimiento de la causa hasta que la misma se removió ${ }^{858}$. Responsabilidad que alcanza a todos los que han sido administradores incumplidores durante el tiempo que en que concurrió la causa de disolución, en el supuesto de cese y nombramiento de distintos administradores ${ }^{859}$.

\subsection{Determinación de las medidas de remoción.}

Aludiremos para concluir a las medidas alternativas susceptibles de superar la causa de disolución. Medidas que serán distintas en función de la concreta causa concurrente, dedicando atención preferente a las que tiendan a superar la causa de disolución por pérdidas, por ser esta causa la de mayor concurrencia en la derivación de deudas de Seguridad Social.

Hemos de empezar señalando que no cualquier medida alternativa a la disolución que pueda adoptarse exonera de la responsabilidad. Han de ser medidas idóneas para remover la concreta causa de disolución, no sirviendo aquellas medidas que no logren su remoción, como la minoración de deudas o adopción de un ERE si no permiten superar la causa disolutoria (Sentencias del TS, Sala Civil, núm. 733/2013, de 4 de diciembre; 27/2017, de 18 de enero).

${ }^{857}$ BELTRÁN SÁNCHEZ, E.: "La responsabilidad de los administradores por obligaciones sociales”, op. cit., p. 326.

${ }^{858}$ Sentencias del TS, Sala Civil, 977/2000, de 30 de octubre; 1219/2004, de 16 de diciembre; 585/2013, de 14 de octubre; y 733/2013, de 4 de diciembre.

859 RODRÍGUEZ RUIZ DE LA VILLA, D. y HUERTA VIESCA, M. I.: La responsabilidad de los administradores por las deudas de las Sociedades de Capital (en las Leyes de Sociedades Anónimas, de Sociedades de Responsabilidad Limitada, de Sociedad Limitada Nueva Empresa, Concursal, General Tributaria y de Responsabilidad Medioambiental), op. cit., p. 309. 
Nuestra jurisprudencia interpreta muy restrictivamente la exoneración o moderación de responsabilidad por adopción de medidas alternativas, si no remueven la causa, frente la jurisprudencia elaborada antes de la Ley 19/2005, de 14 de noviembre, en que los administradores respondían de todas las deudas sociales, fueren anteriores o posteriores $^{860}$.

Las medidas de remoción idóneas normalmente serán de carácter jurídico ${ }^{861}$ para la mayoría de las causas de disolución previstas en el art. 363 de la LSC. Podrán ser causas de remoción las siguientes medidas jurídicas: a) la modificación de los estatutos, para ampliar o cambiar el objeto social, ante la causa de cese de la actividad o de conclusión del objeto social, o de imposibilidad de conseguir el fin social; b) recapitalización para superar la causa de imposibilidad de conseguir el fin social; c) la transformación del tipo societario, la fusión, la escisión, o la cesión global del activo o pasivo, para superar causas de disolución como reducción del capital por debajo del mínimo legal, la de pérdidas cualificadas, la imposibilidad de conseguir el fin social, o la causa consistente en que las acciones o participaciones sociales sin derecho a voto superen la mitad del capital social desembolsado.

Hay otras causas de difícil remoción como sería la paralización absoluta de los dos órganos sociales, de la Junta General y del órgano de administración, en cuyo supuesto

${ }^{860}$ En Sentencia del TS, Sala Civil, núm. 27/2017, de 18 de enero, se señala al respecto, "lo que cuestiona el recurso es si cabe amortiguar el rigor de esta responsabilidad cuando consta que los administradores no promovieron la disolución, pero llevaron a cabo actuaciones tendentes a paliar la crisis económica de la compañía. Propiamente, la ley no establece la ausencia de esta actuación como un requisito negativo para que proceda la responsabilidad del art. 367 LSC. Cuestión distinta es que la jurisprudencia haya tenido en cuenta, en algún caso, la existencia de alguna causa que justificaba el incumplimiento de los deberes de promover la disolución. Esta jurisprudencia que aflora con la Sentencia de Pleno de 28 de abril de 2006, trataba de mitigar el rigor de la norma en su redacción anterior a la Ley 19/2005 (en que se respondía solidariamente de todas las deudas sociales anteriores y posteriores), en algunos casos en que concurrían circunstancias que justificaban que no se imputara esa responsabilidad a los administradores cuando habían desarrollado una actuación significativa para evitar el daño. Esta doctrina fue reiterada en las Sentencias posteriores de 20 de noviembre de 2008, 1 de junio de 2009 y 12 de febrero de 2010” (...), para seguidamente, concluir, "con la regulación actual del art. 367 LSC, que reduce la responsabilidad respecto de las deudas posteriores a la aparición de la causa de disolución, son muy excepcionales las causas que pudieran justificar el incumplimiento del deber legal de promover la disolución. Debe ser algo que ponga en evidencia que, en esas condiciones, a los administradores dejaba de serles exigible el deber de instar la disolución".

${ }^{861}$ BELTRÁN SÁNCHEZ, E.: "La responsabilidad de los administradores por obligaciones sociales", op. cit., p. 324; MACHADO PLAZAS, J.: Pérdida del capital social y responsabilidad de los administradores por deudas sociales, op. cit., pp. 250-251; RODRÍGUEZ RUIZ DE LA VILLA, D. y HUERTA VIESCA, M. I.: La responsabilidad de los administradores por las deudas de las Sociedades de Capital (en las Leyes de Sociedades Anónimas, de Sociedades de Responsabilidad Limitada, de Sociedad Limitada Nueva Empresa, Concursal, General Tributaria y de Responsabilidad Medioambiental), op. cit., pp. 271 a 191; MOYA BALLESTER, J.: La responsabilidad de los administradores de sociedades en situaciones de crisis, op. cit., pp. 254-273. 
se podría acudir a vías de solución extrajudicial previstas en los estatutos, como sumisión a un arbitraje que permita adoptar acuerdos ante el bloqueo de los órganos sociales. En caso de paralización de la junta no cabe exigir que, para que cualquier interesado solicite la disolución judicial al amparo del art. 366.1 de la LSC, previamente se tenga que convocar la Junta General por los administradores, o que preceda una previa convocatoria judicial de la junta, porque en esos casos no tiene sentido el previo intento de convocatoria que a nada habría conducido, precisamente por la propia inoperancia de la junta o del órgano de administración (Sentencia del TS, Sala Civil, núm. 989/2000, de 4 de noviembre -Rec. 3083/1995-).

Nos vamos a detener en el análisis de las medidas de remoción de la causa de pérdidas cualificadas, al ser la causa más relevante.

Para la remoción de esta causa no se requiere que se alcance el equilibrio entre patrimonio neto y capital social, sino que es suficiente con que el patrimonio neto quede por encima de la mitad del capital social ${ }^{862}$.

En el art. 363.1. e) de la LSC se contemplarían medidas de remoción de la causa de disolución por pérdidas, como el aumento o la reducción del capital social en la medida suficiente para que el patrimonio neto sea superior a la mitad de ese capital, sin exigirse que se restablezca el pleno equilibrio entre ambos.

Para nuestra jurisprudencia ${ }^{863}$ cuando la sociedad incurre en pérdidas cualificadas constitutivas de la causa legal de disolución, nuestro ordenamiento jurídico impone a los administradores la obligación de, o bien promover la liquidación reorientando el objeto social al reparto del haber existente entre los socios, después de pagar las deudas sociales; o alternativamente promover la adopción de acuerdos dirigidos a remover la causa de disolución, para reconstruir el patrimonio social, que podrán consistir, en aumento del capital, reducir el capital social, o en una operación conjunta de aumento y reducción del capital, para poder restablecer el equilibrio entre la cifra de capital y el

862 RODRÍGUEZ RUIZ DE LA VILLA, D. y HUERTA VIESCA, M. I.: La responsabilidad de los administradores por las deudas de las Sociedades de Capital (en las Leyes de Sociedades Anónimas, de Sociedades de Responsabilidad Limitada, de Sociedad Limitada Nueva Empresa, Concursal, General Tributaria y de Responsabilidad Medioambiental), op. cit., p. 289; BELTRÁN SÁNCHEZ, E.: "La responsabilidad de los administradores por obligaciones sociales", op. cit., p. 325; MOYA BALLESTER, J.: La responsabilidad de los administradores de sociedades en situaciones de crisis, op. cit., p. 263.

863 SSTS, Sala Civil, 458/2010, de 30 de junio; 173/2011, de 17 de marzo; 225/2012, de 13 de abril; y 560/2013, de 7 de octubre. 
patrimonio, o en una reintegración del patrimonio, que es la medida más eficiente, pese a no mencionarse expresamente como medida alternativa.

En esa jurisprudencia se habla de medidas de reconstrucción del patrimonio social, que podrá realizarse mediante diversas vías, jurídicas o económicas.

Pese a aludirse en el art. 363.1. e) de la LSC, de modo expreso sólo a dos medidas, aumento y reducción del capital social, no estamos ante una lista cerrada ${ }^{864}$, de modo que puede enervarse esta causa de disolución por causas económicas o por causas jurídicas ${ }^{865}$.

Entre las causas económicas la doctrina ${ }^{866}$ cita la obtención de beneficios, siempre que eleven el patrimonio neto por encima de la mitad del capital social.

Se producirá la superación jurídica ${ }^{867}$ de la causa de disolución, cuando se adopten y ejecuten algunas de las siguientes medidas:

a) El aumento de capital mediante nuevas aportaciones sociales. El aumento del capital ha de ser efectivo, ha de ejecutarse para que se remueva la causa, no siendo suficiente el mero acuerdo de aumento del capital ${ }^{868}$. En la medida en que la ejecución del acuerdo de aumento del capital puede extenderse por un período superior al plazo de dos meses que tienen los administradores para convocar la Junta General, se defiende en un sector doctrinal ${ }^{869}$ que, de adoptarse ese tipo de acuerdos de remoción, se debe adoptar bajo condición suspensiva el acuerdo de disolución, facultando a los administradores sociales para que en caso de fracaso de ese aumento, o de retraso de más de dos meses para su ejecución, puedan considerar

${ }^{864}$ MOYA BALLESTER, J.: La responsabilidad de los administradores de sociedades en situaciones de crisis, op. cit., p. 255.

${ }^{865}$ BELTRÁN SÁNCHEZ, E.: "La responsabilidad de los administradores por obligaciones sociales", op. cit., p. 324.

866 BELTRÁN SÁNCHEZ, E.: "La responsabilidad de los administradores por obligaciones sociales", op. cit., p. 324.

${ }^{867}$ BELTRÁN SÁNCHEZ, E.: "La responsabilidad de los administradores por obligaciones sociales”, op. cit., p. 324; MACHADO PLAZAS, J.: Pérdida del capital social y responsabilidad de los administradores por deudas sociales, op. cit., pp. 250-251; RODRÍGUEZ RUIZ DE LA VILLA, D. y HUERTA VIESCA, M. I.: La responsabilidad de los administradores por las deudas de las Sociedades de Capital (en las Leyes de Sociedades Anónimas, de Sociedades de Responsabilidad Limitada, de Sociedad Limitada Nueva Empresa, Concursal, General Tributaria y de Responsabilidad Medioambiental), op. cit., pp. 271 a 191; MOYA BALLESTER, J.: La responsabilidad de los administradores de sociedades en situaciones de crisis, op. cit., pp. 254-273.

${ }^{868}$ Sentencias del TS, Sala Civil, núm. 110/2004, de 23 de febrero; núm. 460/2010, de 14 de julio; y núm. 328/2011, de 19 de mayo, entre otras.

${ }^{869}$ BELTRÁN SÁNCHEZ, E.: “La responsabilidad de los administradores por obligaciones sociales”, op. cit., pp. 325-326. 
cumplida la condición, y por lo tanto, disuelta la sociedad. Para otros autores ${ }^{870}$, ante el fracaso del aumento previsto del capital, nacería el segundo deber de los administradores de solicitar la disolución judicial (postura ésta que, como hemos reseñado más arriba, no es la que se desprende de la jurisprudencia). Aumento del capital que ha de ser efectivo dentro de los dos meses siguientes a la fecha de celebración de la junta que lo haya acordado, si no hubo acuerdo sobre la disolución, o si no fue logrado, ya que de otro modo, los administradores deberán solicitar la disolución judicial (arts. 366 y 367 LSC). Un medio rápido de lograr la efectividad sería acudir al capital autorizado en la sociedad anónima, de modo que los estatutos sociales autorizasen a los administradores sociales para que, sin necesidad de convocar la junta, puedan ellos acordar el aumento del capital social en cuantía suficiente, siempre que ese aumento no sea superior al 50\%, y pueda lograrse dentro del plazo de los dos meses. El aumento del capital para superar las pérdidas patrimoniales podrá realizarse con nuevas aportaciones dinerarias o no dinerarias, así como mediante la compensación de créditos (arts. 295 y 301 de la LSC). No será posible el aumento del capital mediante el aumento del valor nominal de las acciones o participaciones con cargo a reservas, porque la causa de disolución es debida a las pérdidas que obligan a allegar nuevos recursos por la ausencia de beneficios o de reservas suficientes (arts. 273, 295.2 y 303 LSC) ${ }^{871}$. Acerca de la necesidad de la inscripción en el Registro Mercantil del aumento del capital para que se enerve la causa de disolución, estimamos con un primer sector doctrinal que no es necesario, al no ser esa inscripción constitutiva del aumento, ya que el patrimonio neto se incrementa realmente aunque no se haya inscrito ${ }^{872}$, mientras que para otro sector, sí sería necesaria la inscripción ${ }^{873}$.

b) La reducción del capital minorando el valor de las acciones y/o de las participaciones sociales, ya que no cabe el reembolso de acciones o participaciones, ni la

870 CALBACHO LOSADA, F.: El ejercicio de las acciones de responsabilidad contra los administradores de la sociedad anónima, op. cit., p. 431.

${ }^{871}$ MOYA BALLESTER, J.: La responsabilidad de los administradores de sociedades en situaciones de crisis, op. cit., p. 262.

872 BELTRÁN SÁNCHEZ, E.: “La responsabilidad de los administradores por obligaciones sociales”, op. cit., p. 326.

873 RODRÍGUEZ RUIZ DE LA VILLA, D. y HUERTA VIESCA, M. I.: La responsabilidad de los administradores por las deudas de las Sociedades de Capital (en las Leyes de Sociedades Anónimas, de Sociedades de Responsabilidad Limitada, de Sociedad Limitada Nueva Empresa, Concursal, General Tributaria y de Responsabilidad Medioambiental), op. cit., p. 276, quien cita la STS, Sala Civil, de 3 de abril de 1998. 
condonación de dividendos pasivos de las acciones suscritas y no desembolsadas (arts. 317 y 321 LSC). Esta modalidad de reducción del capital social tiene como finalidad restablecer el equilibrio entre patrimonio neto y capital social (art. 317.1 LSC), debiendo afectar por igual a todas las acciones o participaciones sociales, eso sí, respetando los privilegios que a esos efectos estuvieren establecidos (arts. $317 \mathrm{y}$ 320 LSC). Reducción que no tiene que ser por el total de las pérdidas, sino, como señala el art. 363.1.e) de la LSC, en la medida suficiente para que cese la causa de disolución, para que el patrimonio neto quede por encima de la mitad del capital, pudiendo llegar la reducción hasta la totalidad de las pérdidas para equilibrar capital y patrimonio neto, sin ser ello obligatorio ${ }^{874}$. Para algunos autores ${ }^{875}$ si la reducción fuere de importe superior al total de las pérdidas, en la medida en que se superen éstas, tendría el carácter de reducción parcialmente voluntaria del capital, con lo que los acreedores tendrían el derecho de oposición. Recordemos que, en las reducciones obligatorias del capital encaminadas a restablecer, en todo o en parte, el equilibrio entre patrimonio y capital social queda excluido el derecho de oposición de los acreedores sociales (art. 335.a) de la LSC). El acuerdo de reducción de capital social de la sociedad anónima debe publicarse en el BORME y en la página web de la sociedad, o de no tener, en un periódico de gran circulación en la provincia del domicilio social (art. 319 LSC), sin que sea obligatorio para la superación de la causa de disolución su inscripción en el Registro Mercanti1 ${ }^{876}$.

c) La llamada operación acordeón (reducción y aumento simultáneo del capital), prevista en los arts. 343 a 345 de la LSC, en medida suficiente para superar esa proporción mínima entre patrimonio neto y capital. Reducción que podrá llegar a cero o en cuantía superior a cero, que, en todo caso, debe ir simultáneamente acompañada del correspondiente aumento del capital (arts. 343 y 344 LSC). No sólo el aumento y la reducción del capital deben ser acuerdos simultáneos de la Junta General, sino que la eficacia de la reducción del capital queda condicionada a la ejecución del aumento del capital social (art. 344 LSC), no admitiéndose la

${ }^{874}$ MACHADO PLAZAS, J.: Pérdida del capital social y responsabilidad de los administradores por deudas sociales, op. cit., p. 258; MOYA BALLESTER, J.: La responsabilidad de los administradores de sociedades en situaciones de crisis, op. cit., p. 257; BELTRÁN SÁNCHEZ, E.: "La responsabilidad de los administradores por obligaciones sociales", op. cit., p. 325.

875 MUÑOZ MARTíN, N.: "Pérdidas de la Sociedad de Responsabilidad Limitada", en Estudios de Derecho Mercantil, Homenaje al profesor Justino F. Duque, Valladolid, 1998, p. 517.

${ }^{876}$ BELTRÁN SÁNCHEZ, E.: "La responsabilidad de los administradores por obligaciones sociales", op. cit., p. 326; MOYA BALLESTER, J.: La responsabilidad de los administradores de sociedades en situaciones de crisis, op. cit., p. 260. 
inscripción de la reducción del capital, si no va acompañada de la inscripción de la ejecución del aumento del capital social (art. 345 LSC).

d) La transformación en otro tipo societario que no exigiese esa proporción mínima entre capital y patrimonio (sociedad colectiva, sociedad comanditaria). El régimen jurídico de las transformaciones societarias se recoge en los arts. 3 a 20 de la Ley 3/2009, de 3 de abril, sobre modificaciones estructurales de las sociedades mercantiles ${ }^{877}$.

e) Mediante una fusión ${ }^{878}$ o escisión, en la medida en que con ello la nueva entidad quede con un patrimonio neto superior al $50 \%$ del capital social. El régimen jurídico de las fusiones y escisiones se recogen respectivamente, en los arts. 21 a 67 y 68 a 80 de la Ley 3/2009, de 3 de abril.

f) Algún autor menciona como medida de remoción de esta causa, para las sociedades anónimas cotizadas, la emisión de acciones rescatables ${ }^{879}$.

g) Otra medida jurídica de remoción serían los préstamos participativos, que pasan a integrar el patrimonio neto a efectos de la disolución ${ }^{880}$. Préstamos participativos que se recogen con signo positivo en el balance. La disposición adicional tercera de la Ley 16/2007, de 4 de julio, modifica la letra d) del artículo 20 del Real Decreto-Ley 7/1996, de 7 de junio, sobre Medidas urgentes de carácter fiscal y de fomento y liberalización de la actividad económica, para establecer que: «d) Los préstamos participativos se considerarán patrimonio neto a los efectos de reducción de capital y liquidación de sociedades previstas en la legislación mercantil.». En cambio, no sería medida alternativa válida de remoción de la causa, la realización de préstamos a la sociedad por los socios, ya que no incrementan el patrimonio neto, entrañando

${ }^{877}$ BOE del 4.4.2009.

${ }^{878}$ MOYA BALLESTER, J.: La responsabilidad de los administradores de sociedades en situaciones de crisis, op. cit., p. 256.

879 RODRÍGUEZ RUIZ DE LA VILLA, D. y HUERTA VIESCA, M. I.: La responsabilidad de los administradores por las deudas de las Sociedades de Capital (en las Leyes de Sociedades Anónimas, de Sociedades de Responsabilidad Limitada, de Sociedad Limitada Nueva Empresa, Concursal, General Tributaria y de Responsabilidad Medioambiental), op. cit., p. 287. Para estos dos autores al ser fondos propios con vocación de financiación a medio y largo plazo, permitirían incrementar el patrimonio neto para superar las pérdidas cualificadas, de modo que pueden sacar a la sociedad de la disolución durante el período en que las acciones no son rescatables.

880 RODRÍGUEZ RUIZ DE LA VILLA, D. y HUERTA VIESCA, M. I.: La responsabilidad de los administradores por las deudas de las Sociedades de Capital (en las Leyes de Sociedades Anónimas, de Sociedades de Responsabilidad Limitada, de Sociedad Limitada Nueva Empresa, Concursal, General Tributaria y de Responsabilidad Medioambiental), op. cit., p. 287. 
nueva deuda social, salvo que el importe de esos préstamos se aporten sin contraprestación a la sociedad como medio reintegración del patrimonio ${ }^{881}$.

h) Una última medida de remoción sería la reintegración del patrimonio social mediante aportaciones que realicen los socios, aportaciones que no se pueden imponer a los mismos, exigiendo el acuerdo de todos los interesados, por lo que, o bien participan voluntariamente todos los socios, o bien las realizan alguno de ellos con la anuencia del resto, con imputación de esas aportaciones a todas las acciones o a parte de ellas $^{882}$. Reintegración del patrimonio que será voluntaria para los socios, y que no exige la adopción del acuerdo en la Junta General, ya que no cabe obligar a los socios a realizar aportaciones obligatorias que no integren el capital social (arts. 89 y 291 LSC). Admite que un medio de remoción es la reintegración del patrimonio mediante aportaciones de los socios que estén voluntariamente dispuesto a ello, en Sentencia del TS, Civil, 76/2008, de 5 de febrero -Rec. 5783/2000-. Reintegración del patrimonio social que, pese a no contemplarse expresamente como medida alternativa, es la vía más eficiente para incrementar el patrimonio social, mucho más idónea que el aumento del capital social.

\section{Cumplimiento tardío de los deberes generadores de responsabilidad.}

El cumplimiento tardío es el cumplimiento fuera de plazo de los deberes impuestos en los arts. 365.1 y 366.2 de la LSC, bien sea del primer deber de convocar la junta, o bien sea del deber subsidiario de solicitar la disolución judicia ${ }^{1883}$. Sólo cabe el cumplimiento tardío de la convocatoria de la junta, si previamente no se hubiere solicitado la disolución judicial por algún interesado (art. 366.1 de la LSC).

881 RODRÍGUEZ RUIZ DE LA VILLA, D. y HUERTA VIESCA, M. I.: La responsabilidad de los administradores por las deudas de las Sociedades de Capital (en las Leyes de Sociedades Anónimas, de Sociedades de Responsabilidad Limitada, de Sociedad Limitada Nueva Empresa, Concursal, General Tributaria y de Responsabilidad Medioambiental), op. cit., p. 289. Para estos autores sería distinto que esos préstamos los pidiesen los socios, y con los mismos, realizasen aportaciones de ese dinero a la sociedad como medio de reintegración del patrimonio.

${ }^{882}$ SÁNCHEZ CALERO, F.: Los administradores en las sociedades de capital, op. cit., p. 454; MOYA BALLESTER, J.: La responsabilidad de los administradores de sociedades en situaciones de crisis, op. cit., p. 256; RODRÍGUEZ RUIZ DE LA VILLA, D. y HUERTA VIESCA, M. I.: La responsabilidad de los administradores por las deudas de las Sociedades de Capital (en las Leyes de Sociedades Anónimas, de Sociedades de Responsabilidad Limitada, de Sociedad Limitada Nueva Empresa, Concursal, General Tributaria y de Responsabilidad Medioambiental), op. cit., p. 276.

${ }^{883}$ MACHADO PLAZAS, J.: Pérdida del capital social y responsabilidad de los administradores por deudas sociales, op. cit., pp. 346-347; BELTRÁN SÁNCHEZ, E.: "La responsabilidad de los administradores por obligaciones sociales", op. cit., p. 329; DÍAZ ECHEGARAY, J. L.: Deberes y responsabilidades de los Administradores de Sociedades de Capital, op. cit., pp. 414-416. 
El plazo de dos meses para convocar la Junta General o para solicitar la disolución judicial, no es un plazo esencial absoluto ${ }^{884}$ y preclusivo que impida un posterior cumplimiento. Cabe un cumplimiento posterior al transcurso de esos plazos, especialmente ante la eventualidad de estar ante un plazo que pude ser insuficiente ${ }^{885}$ para cumplir con los deberes impuestos a los administradores, de modo que se adopte el acuerdo de disolución y se proceda a la liquidación societaria fuera de los plazos legales prescritos. Otra cosa serán los efectos que ese cumplimiento tardío puede tener, si es que los tiene, en la responsabilidad de los administradores sociales.

La posibilidad o viabilidad jurídica de producirse un cumplimiento tardío se contempla en las Sentencias del TS, Sala Civil, 560/2013, de 7 de octubre, y 458/2010, de 30 de junio, al señalarse que "la ley impone a los administradores la responsabilidad solidaria por las deudas sociales, dentro de ciertos límites, en caso de incumplimiento o de cumplimiento tardío del deber de promover la disolución". En esas sentencias se declaran dos cosas, por un lado, que puede haber un cumplimiento tardío, y, por otro lado, que ese cumplimiento tardío genera responsabilidad por deudas, que no enerva la derivación de la responsabilidad por deudas, pero no se entró a debatir acerca de si la responsabilidad era por deudas anteriores o posteriores al posible cumplimiento tardío, ya que, en primer lugar, se trataba de deudas anteriores, y en segundo lugar, se dilucidaba el incumplimiento del deber de procurar la disolución en plazo de adoptarse y ejecutarse medidas distintas al acuerdo de disolución.

Dentro de nuestra doctrina se han perfilado varias líneas interpretativas acerca de los efectos del cumplimiento tardío.

Para un primer sector doctrinal mayoritario ${ }^{886}$, los administradores sólo responderían de las obligaciones sociales posteriores al acaecimiento de la causa de disolución y

884 CALBACHO LOSADA, F.: El ejercicio de las acciones de responsabilidad contra los administradores de la sociedad anónima, op. cit., p. 465.

885 MACHADO PLAZAS, J.: Pérdida del capital social y responsabilidad de los administradores por deudas sociales, op. cit., p. 347.

${ }^{886}$ QUIJANO GONZÁLEZ, J.: "Responsabilidad de los administradores por no disolución de la sociedad (art. 262.5 TRLSA) (Sentencia de la Audiencia Provincial de Burgos de 24 de julio de 1995)", op. cit. 1995, p. 273; ESTEBAN VELASCO, G.: "Algunas reflexiones sobre la Responsabilidad de los Administradores frente a los Socios y los Terceros: Acción individual y acción por no Promoción o Remoción de la disolución”, op. cit., p. 70; MACHADO PLAZAS, J.: Pérdida del capital social y responsabilidad de los administradores por deudas sociales, op. cit., p. 348; DÍAZ ECHEGARAY, J. L.: Deberes y responsabilidades de los Administradores de sociedades de Capital, op. cit., pp. 414416; BELTRÁN SÁNCHEZ, E.: "La responsabilidad de los administradores por obligaciones sociales", op. cit., pp. 329-330. 
anteriores al cumplimiento tardío, por lo que, quedarían eximidos de responder de las deudas sociales posteriores al cumplimiento tardío. A efectos de responsabilidad, dentro de este primer sector, se han distinguido tres momentos temporales en las obligaciones sociales, a) obligaciones anteriores a la causa de disolución, de las que no responden los administradores, b) obligaciones sociales posteriores a la causa de disolución y anteriores al cumplimiento tardío de los deberes, de las que responden solidariamente los administradores sociales, y c) obligaciones sociales posteriores al cumplimiento tardío de las que no responden los administradores ${ }^{887}$. Postura doctrinal que se cohonesta mejor con la finalidad y la naturaleza de esta responsabilidad ex lege por deudas ajenas.

Para un segundo sector ${ }^{888}$, el cumplimiento tardío exime de responsabilidad al administrador social con relación a los acreedores que no hubieren reclamado la responsabilidad solidaria con anterioridad a ese cumplimiento tardío, de modo que sólo responderían los administradores si al momento de la reclamación de la responsabilidad no hubieren cumplido aún con alguno de sus deberes.

Para una tercera interpretación ${ }^{889}$, el cumplimiento tardío no enervaría la responsabilidad, por lo que no produce efecto alguno.

Finalmente, algún autor ha defendido que el cumplimiento tardío puede exonerar o enervar la responsabilidad solidaria de los administradores por deudas posteriores al cumplimiento, en función de si con el cumplimiento tardío se causa o no daño o perjuicio al derecho de crédito social, especialmente en los supuestos en que la situación abocase en insolvencia, debiendo examinarse si con el cumplimiento extemporáneo los acreedores resultaron o no perjudicados en sus créditos, ya que si no son perjudicados, al poder cobrar los mismos de la sociedad, los administradores no responderían solidariamente con la sociedad, respondiendo en otro caso, incluso de las deudas posteriores al cumplimiento si como consecuencia de ese cumplimiento tardío no pudieran cobrar de la mercantil ${ }^{890}$.

\footnotetext{
${ }^{887}$ BATALLER GRAU, J.: “Disolución y Liquidación”, op. cit., p. 2574.

${ }^{888}$ ROJO FERNÁNDEZ-RÍO, A.: "Los deberes legales de los administradores en orden a la disolución de la sociedad de capital como consecuencia de pérdidas", op. cit., pp. 1477-1478.

${ }^{889}$ CERDÁ ALBERO, F.: Administradores, insolvencia y disolución por pérdidas, op. cit., p. 107.

890 CALBACHO LOSADA, F.: El ejercicio de las acciones de responsabilidad contra los administradores de la sociedad anónima, op. cit., p. 468.
} 
El cumplimiento tardío según nuestra jurisprudencia ${ }^{891}$ no tendría efectos para alzar la responsabilidad del administrador cumplidor extemporáneo.

En la Sentencia del TS, Sala Civil, 1219/2004, de 16 de diciembre, aludiendo al carácter fatal del plazo de dos meses, y a que el cumplimiento tardío no tiene efectos para liberar a los administradores de la responsabilidad solidaria por las deudas sociales contraídas hasta ese cumplimiento, se argumenta que, "el texto legal no ofrece duda: se impone un plazo inexorable de dos meses a los administradores de las sociedades anónimas para convocar la Junta de accionistas para que en su caso acordar la disolución o las medidas sustitutivas adecuadas. Si fuese la voluntad del legislador el establecer una excepción o cesación de responsabilidad por un cumplimiento tardío, tal cosa sería lógicamente incompatible con el establecimiento de un término fatal, cual es el de dos meses, para convocar la junta. En efecto, si la responsabilidad se alzase en el momento del cumplimiento tardío ello supondría que los administradores en cualquier momento (transcurridos meses o años), cumplido que fuera su deber se liberarían de la responsabilidad que la norma les atribuye y carecería de sentido alguno el plazo bimensual que tan claramente ha establecido la Ley".

En la Sentencia del TS, Sala Civil, 195/2006 de 9 marzo -Rec. 2325/1999- se señala que, "ha declarado esta Sala que el cumplimiento tardío por los administradores de los deberes previstos en el art. 262.5 LSA no les exime de una responsabilidad ya contraída en cuanto ésta parte del conocimiento adquirido o debido adquirir por él (SSTS 30-102000 en recurso núm. 3341/95 [RJ 2000, 9909], 16-12-04 en recurso núm. 3375/98 [RJ 2004, 8215] y 27-10-98 en recurso núm. 1638/94 [RJ 1998,8256]), y menos aún cuando las cuentas del ejercicio no se presentaron hasta un año y medio después del nombramiento del administrador". De esta Sentencia podremos extraer dos ideas o conclusiones con la expresión de "no les exime de una responsabilidad ya contraída", ante un eventual cumplimiento tardío. Por un lado, que un cumplimiento tardío no alza la responsabilidad ya asumida o contraída a esa fecha, se refiere expresamente a la contraída a la fecha del eventual cumplimiento tardío, sin que con ello se deba incluir una posible responsabilidad por deudas nacidas a partir de ese momento. Por otro lado, y, en segundo lugar, esta Sentencia tampoco excluye expresamente, porque no entra en su análisis, la exoneración para deudas posteriores a un posible cumplimiento tardío, ya

${ }^{891}$ Sentencias del TS, Sala Civil, 1219/2004 de 16 diciembre; 195/2006, de 9 marzo; 328/2011, de 19 de mayo; 560/2013, de 7 de octubre; y 458/2010, de 30 de junio. 
que de los hechos probados constaba que no ha habido cumplimiento tardío, sino reclamación de responsabilidad por incumplimiento del primer deber, por lo que se declara la responsabilidad solidaria por deudas contraídas con anterioridad a la reclamación de esa responsabilidad.

En la Sentencia del TS, Sala Civil, 416/2006, de 28 de abril -Rec. 4187/2000- se alude a que las “juntas extemporáneas celebradas no pueden enervar la acción entablada, por no probadas y por extemporáneas" y más adelante se indica que "el acuerdo adoptado en todo caso era intempestivo, pues había transcurrido holgadamente el plazo legal en que ha de producirse para enervar la responsabilidad de los administradores". En esta Sentencia se declara que el cumplimiento tardío no enerva la responsabilidad.

En la Sentencia del TS, Sala Civil, 173/2011, de 17 de marzo -Rec. 1408/2007-, ante la alegación formulada en el recurso de que la convocatoria de la Junta General con posterioridad al transcurso del plazo legal determinaba la extinción de la responsabilidad que a dicha fecha no se hubiera exigido, se declara que, "una vez que los administradores ya han incurrido en responsabilidad por tolerar el funcionamiento de la sociedad incursa en causa de disolución sin adoptar las medidas alternativamente previstas dentro del plazo señalado, la reacción tardía no opera a modo de excusa absolutoria como causa de exención de la responsabilidad". En esta Sentencia, descartándose la aplicación de una de las posiciones doctrinales arriba reseñada (la mantenida por el Profesor ROJO FERNÁNDEZ-RÍO), claramente se proclama que el cumplimiento tardío no es excusa absolutoria de la responsabilidad contraída, condenándose a los administradores de modo solidario al pago de deudas que eran anteriores a la junta extemporánea.

En esas cuatro sentencias, no fue objeto de debate y de ratio decidendi, si los administradores responden de las deudas posteriores al cumplimiento tardío, ya que se declaró la responsabilidad por deudas anteriores a un eventual cumplimiento tardío. Se afirma que el cumplimiento tardío no enerva o exime de una responsabilidad ya contraída, o que no es absolutoria de la responsabilidad, que era precisamente por deudas anteriores al cumplimiento tardío.

En la Sentencia del TS, Sala Civil, 585/2013, de 14 de octubre, con motivo de la remoción o superación de la causa de disolución, señala que, "la remoción de la causa de disolución no extinguió la posible responsabilidad en que hubiera podido incurrir el 
administrador durante el tiempo en que incumplió el deber de promover la disolución, respecto de los créditos existentes entonces, pero sí evita que a partir del momento en que cesa la causa de disolución puedan surgir nuevas responsabilidades derivadas de aquel incumplimiento. Esto es, los acreedores de las deudas sociales surgidas después de que la compañía hubiera superado la causa de disolución, carecen de legitimación para reclamar la condena solidaria del administrador basada en un incumplimiento anterior". Doctrina cuyo sentido último, de exoneración de responsabilidad, podría tener similar razón jurídica para aplicarse las deudas posteriores al cumplimiento tardío del deber de los administradores de promover la disolución.

Concluimos partiendo de todas esas sentencias que el cumplimiento tardío exonera de responsabilidad por las deudas posteriores al mismo, no de las anteriores, ya que, si la imposición de la responsabilidad es por no cumplir en plazo con los deberes de promoción de la disolución, no sería razonable conferir igual alcance a la responsabilidad del administrador que no cumple que al que cumple con retraso. MACHADO PLAZAS ${ }^{892}$, acoge el criterio de que el cumplimiento tardío ha de tener efectos para eximir de las deudas posteriores al cumplimiento del deber, porque estamos ante una responsabilidad por incumplimiento de una obligación, y no ante una responsabilidad por daños.

\section{La falta de solicitud de concurso como presupuesto de la responsabilidad.}

Deberemos determinar si concurriendo causa de concurso de acreedores, sin existir la causa de disolución por pérdidas, podría derivarse la responsabilidad solidaria al administrador social al amparo del art. 367 de la LSC y art. 18.3 TRLGSS, como sería el impago de cotizaciones durante tres o más meses anteriores a la derivación de administrativa de la deuda (arts. 2 y $4.5^{\circ}$ del TRLC). Debemos preguntarnos, en definitiva, si sería aplicable la responsabilidad solidaria del art. 367 de la LSC, o si ésta sólo sería aplicable cuando la causa de insolvencia concurra conjuntamente con la causa de disolución por pérdidas cualificadas.

Con respecto esta cuestión, se habían mantenido dos interpretaciones en la Sala Contencioso-Administrativa de los Tribunales Superiores de Justicia. Para una primera interpretación judicial, se negaba la aplicabilidad de la responsabilidad solidaria del art.

${ }^{892}$ MACHADO PLAZAS, J.: Pérdida del capital social y responsabilidad de los administradores por deudas sociales, op. cit., pp. 347-348. 
367 de la LSC ante el incumplimiento de deberes concursales si la causa concursal no iba acompañada de causa de disolución por pérdidas ${ }^{893}$. Para una segunda línea interpretativa, se consideraba aplicable la responsabilidad solidaria de concurrir causa de insolvencia, aunque no vaya acompañada de causa de disolución por pérdidas ${ }^{894}$.

Ante esa dualidad interpretativa, esta cuestión ha sido finalmente resuelta por el Tribunal Supremo ${ }^{895}$, que ha fijado como doctrina, que la derivación de responsabilidad en deudas de Seguridad Social procede cuando la causa de insolvencia, de concurso, vaya acompañada de la causa de disolución por pérdidas cualificadas, de modo que no cabría exigir esa responsabilidad solidaria al administrador social si no hay causa de disolución, pese a concurrir causa de insolvencia. Para esa jurisprudencia de la Sala Contencioso-Administrativa, la situación de insolvencia no es presupuesto de la responsabilidad solidaria del art. 367 LSC, ya que el presupuesto de la misma es la concurrencia de una causa de disolución. De existir sólo causa de insolvencia -causa concursal-, sin ir acompañada de causa de disolución de pérdidas cualificadas, no es de aplicación la responsabilidad solidaria del art. 367 LSC si el administrador social no solicita el concurso dentro de los dos meses siguientes a la insolvencia.

Esta doctrina jurisprudencial exige que debe concurrir causa de disolución por pérdidas cualificadas conjuntamente con la insolvencia, porque el primer presupuesto de la responsabilidad solidaria de los administradores es "claramente la concurrencia de una causa de disolución", de modo que la alusión a las "obligaciones sociales posteriores al acaecimiento de la causa legal de disolución" del art. 367 de la LSC, no sólo es para determinar un mero límite temporal del alcance de la responsabilidad, sino para fijar un verdadero requisito de nacimiento de la responsabilidad, debiendo concurrir

${ }^{893}$ Sentencia de 20 de enero de 2017 de la Sala de lo Contencioso-Administrativo del Tribunal Superior de Justicia de Canarias, de Sta. Cruz de Tenerife, dictada en el Recurso de apelación núm. 139/2016, entre otras.

${ }^{894}$ Sentencias de la Sala de lo Contencioso-Administrativo del Tribunal Superior de Justicia de La Rioja de 3 de marzo de 2016, Recurso no 79/2015, de fecha 14 de marzo de 2017 -Rec. 195/2015-; de 19 de julio de 2018 -Rec.128/2017-; de13 de septiembre de 2018 -Rec.127/2017-; Sentencia de la Sala de lo Contencioso-Administrativo del Tribunal Superior de Justicia de les Illes Balears, de fecha 22 de septiembre de 2015; y la Sentencia de la Sala del mismo orden jurisdiccional del Tribunal Superior de Justicia del País Vasco de 28 de junio de 2016 -Recurso n 734/2015-, entre otras.

895 SSTS, Sala Contencioso-Administrativa, 874/2019, de 24 de junio -Rec. 2765/2018-; 875/2019, de 24 de junio; 897/2019, de 25 de junio; 915/2019, de 26 de junio; 338/2020, de 6 de marzo -Rec. 7827/2018-; 1346/2020, de 19 de octubre; 1411/2020, de 27 de octubre; 1654/2020, de 3 de diciembre -Rec. 730/2019-; 1713/2020, de 14 diciembre -Rec. 1987/2019-; 83/2021, de 27 de enero -Rec. 2046/2019-; 117/2021, de 1 de febrero -Rec. 6149/2019-; 120/2021, de 2 de febrero -Rec. 4284/2019-. 
necesariamente la causa de disolución, la que debe acreditar la Administración de la Seguridad Social o la Inspección de Trabajo y Seguridad Social.

En esa interpretación jurisprudencial de la Sala Contenciosa se invoca, y se sigue, la doctrina administrativa recogida en el Criterio Técnico 89/2011 de la Dirección General de la Inspección de Trabajo y Seguridad Social.

De concurrir sólo insolvencia sin causa de disolución, podría declarase en la sentencia de calificación del concurso la responsabilidad concursal del administrador social para cubrir el déficit patrimonial. Responsabilidad concursal que es distinta a la responsabilidad por deudas, al ser de carácter indemnizatorio y no derivable en el procedimiento administrativo de recaudación.

Ante esta doctrina, siendo situación más grave la insolvencia que la causa de disolución por pérdidas, para evitar llegar a situaciones de insolvencia, con el consiguiente perjuicio para los acreedores, y entre ellos a las entidades gestoras de la Seguridad Social, sería conveniente de lege ferenda, recoger expresamente la responsabilidad del administrador, cuando ante la situación de insolvencia de la sociedad, no cumpla en el plazo legal de dos meses con la obligación de solicitar el concurso de acreedores o medidas preconcursales, de modo que pueda ser exigible en vía administrativa la responsabilidad solidaria de las deudas sociales posteriores al acaecimiento de la causa de insolvencia, por ser insuficiente una eventual responsabilidad concursal para responder de las dudas de Seguridad Social. Es insuficiente la responsabilidad concursal, en primer lugar, porque no tiene el mismo alcance y contenido que la responsabilidad por deudas, ya que no tiene como finalidad hacer responsable al administrador social de las deudas sociales posteriores a la insolvencia (impago de tres mensualidades de cotizaciones), sino que esa responsabilidad sólo se limita a cubrir el déficit patrimonial que resulte de la masa activa del concurso, y, en segundo lugar, porque esa responsabilidad no va asociada al mero incumplimiento de la obligación, sino que exige la concurrencia de circunstancias más gravosas, que el concurso se califique como culpable, y que los administradores como personas responsables de esa calificación hayan generado o agravado la insolvencia. De extenderse esa responsabilidad solidaria al incumplimiento de la obligación de solicitar tempestivamente el concurso de acreedores, el legislador obligaría a los administradores a cumplir diligentemente con la obligación de solicitar en plazo el concurso, en aras de la adecuada protección de los acreedores. 
Señalar finalmente, que cuando se halle en concurso una empresa perteneciente a un grupo societario, pese a la competencia exclusiva del juez del concurso, esa circunstancia no es óbice alguno para que la TGSS dicte el acuerdo o resolución de derivación de responsabilidad por deudas de Seguridad Social de las empresas del grupo, ya que en el acuerdo de derivación se identifica a los sujetos responsables, siempre que no se exija el pago de la deuda a alguna de las empresas concursadas, al ser cuestiones diversas el acuerdo de derivación en que se identifica a los posibles responsables, y la reclamación de la deuda, afectando la competencia exclusiva del concurso sólo el acto de reclamación de la deuda, pero no al merco acuerdo de derivación en que se identifican a los sujetos responsables ${ }^{896}$.

\section{V.- ÁMBITO OBJETIVO DE RESPONSABILIDAD. DEUDAS DE SEGURIDAD SOCIAL ANTERIORES Y POSTERIORES.}

La responsabilidad por deudas de Seguridad Social de los administradores por incumplir los deberes de ordenada disolución, será por todas las deudas de la sociedad de capital nacidas con posterioridad al acaecimiento de la causa legal de disolución (art. 367 de la LSC), siempre que no sean anteriores al nombramiento y aceptación del cargo, de acceder al mismo habiéndose incumplidos los deberes de promoción de la disolución de los administradores anteriores (Sentencias del TS, Sala Civil, 601/2019, de 8 de noviembre -Rec. 596/2017-), y sin que se extienda la responsabilidad a las deudas posteriores al cese en el cargo (Sentencias del TS, Sala Civil, 731/2013, de 2 de diciembre -Rec. 1444/2011-; y 601/2019, de 8 de noviembre -Rec. 596/2017-).

Al presumirse de fecha posterior todas las reclamadas, podrá derivarse la responsabilidad por las deudas pendientes, incumbiendo la carga de la prueba al administrador para acreditar que son de fecha anterior (art. 367.2 de la LSC).

Como excepción a esa regla general de responder de las deudas posteriores al acaecimiento de la causa de disolución, si la causa legal o estatutaria de disolución hubiera tenido lugar durante la vigencia del estado de alarma por la crisis sanitaria de la

896 SSTS, Sala Contencioso-Administrativa, 1661/2018, de 22 de noviembre -Rec. 2507/2016-; y 1008/2019, de 8 de julio -Rec. 220/2017-, que se separan expresamente de la interpretación contraria que se mantuvo en la Sentencia 1098/2017, de 20 de junio -Rec. 2765/2016-.

En esa jurisprudencia se sienta como doctrina de interés casacional, que "la Tesorería General de la Seguridad Social puede declarar mediante el correspondiente acuerdo de derivación la responsabilidad solidaria, por deudas que afecten a sociedades concursadas, a una sociedad integrante del mismo grupo, pero no sometida a concurso, sin necesidad de acudir al juez que está tramitando el procedimiento concursal". 
Covid-19, los administradores no responderán de las deudas sociales contraídas durante ese periodo, esto es, de las deudas sociales generadas en el período del 14.3.2020 al 20.6.2020 ambos inclusive (art. 40.12 y Disposición Final 10. ${ }^{a}$ del Real Decreto-Ley 8/2020, de 17 de marzo ${ }^{897}$, en relación con el Real Decreto 463/2020, de 14 de marzo ${ }^{898}$, y Real Decreto 555/2020, de 5 de junio $^{899}$, por el que se prorroga el Estado de Alarma declarado por el Real Decreto 463/2020, de 14 de marzo). Precepto que no es de aplicación durante el segundo estado de alarma declarado por el R.D. 926/2020, de 25 de octubre, con vigencia del 25.10.2020 al 8.5.2021 ${ }^{900}$, ya que la eficacia de ese precepto finalizó con el primer estado de alarma (Disposición Final 10a del Real Decreto-Ley 8/2020).

Del tenor literal del artículo 40.12 del Real Decreto-Ley 8/2020, de 17 de marzo, resulta una exoneración de responsabilidad de los administradores por las deudas sociales generadas durante el estado de alarma, si la causa de disolución ha acaecido durante el mismo, configurándose ese estado de alarma como un período neutro a efectos de determinar el alcance material de la responsabilidad por deudas de los administradores al amparo del art. 367 de la LSC, opción legislativa que critica QUIJANO ${ }^{901}$, estimando que hubiere sido más correcto que, al haberse suspendido el plazo para convocar la junta durante el estado de alarma, y haberse reanudado su cómputo a la finalización del mismo, si los administradores incumplen el deber, deberían responder de las deudas posteriores al acaecimiento de la causa de disolución, ya que de otro modo, sería "un estímulo, casi una coartada o patente de corso, para contraer con descuido obligaciones por cuenta de la sociedad justamente en una situación tan delicada como lo es el estado de alarma".

Causa de disolución por pérdidas cualificadas que no opera, que se ha dejado en suspenso, para el ejercicio económico de 2020 (art. 13 de la Ley 3/2020, de 18 de septiembre) por la crisis sanitaria de la Covid-19, lo que nos lleva a concluir que no cabría responder de las deudas sociales generadas por esta causa en el año 2020 si la causa de disolución por pérdidas fuese de ese ejercicio, para intentar mantener y

897 Art. 40.12 "Si la causa legal o estatutaria de disolución hubiera acaecido durante la vigencia del estado de alarma, los administradores no responderán de las deudas sociales contraídas en ese periodo".

${ }^{898}$ Real Decreto 463/2020, de 14 de marzo, por el que se declara el Estado de Alarma para la gestión de la situación de crisis sanitaria ocasionada por el Covid-19 -BOE del 14.3.2020-.

${ }^{899}$ BOE del 6.6.2020, que aprobó la última prórroga del Estado de Alarma.

${ }^{900}$ Real Decreto 956/2020, de 3 de noviembre -BOE del 4.11.2020-, que prorroga el Estado de Alarma.

${ }^{901}$ QUIJANO GONZÁLEZ, J.: “Los órganos societarios y el Estado de Alarma”, 2020, op. cit., p. 24. 
conservar el mayor número de empresas, sin que se vean abocadas a la disolución, ante el daño económico que se ha generado de modo excepcional en ese ejercicio económico, y que consideramos que tampoco operaría si las pérdidas cualificadas surgiese de balances de comprobación de los tres primeros trimestres del año 2021 (art. 13 de la Ley 3/2020, de 18 de septiembre -nos remitimos al apartado III.2 de este Capítulo-).

Responden de las deudas u obligaciones legales ${ }^{902}$-que son las que nos interesan en nuestra tesis-, incluyéndose las obligaciones con la Seguridad Social de la sociedad de capital $^{903}$, sean deudas por cotizaciones o por prestaciones de responsabilidad empresarial, nacidas con posterioridad a la concurrencia de una causa legal de disolución, habiendo incumplido los deberes de los arts. 365 y 366 de la LSC (art. 367 de la LSC y art. 18.3 del TRLGSS).

Los administradores responden de las obligaciones sociales, y al emplear el término de obligaciones se incluyen las que nazcan de la Ley (455/2017, de 18 de julio -Rec. 1589/2014- ${ }^{904}$ ), incluso de un ilícito civil (Sentencia del TS, Sala Civil, no 1219/2004 de 16 diciembre -Rec. 3375/1998-).

Responsabilidad que se extiende sólo a las deudas posteriores al acaecimiento de la causa de disolución, tras la reforma legal introducida con la Ley 19/2005, de 14 de noviembre, sobre la sociedad anónima europea domiciliada en España ${ }^{905}$, ya que antes de esa reforma, la responsabilidad abarcaba tanto a las deudas sociales posteriores como a las anteriores a la causa de disolución .

Para determinar la legislación aplicable sobre responsabilidad de los administradores, cuando se produce una modificación de su régimen jurídico, como el alcance de las deudas objeto de la responsabilidad del administrador, habrá de estarse a la vigente en la fecha en que nace la responsabilidad, a la legislación vigente a la fecha en que se

\footnotetext{
902 SÁNCHEZ CALERO, F.: Los administradores en las sociedades de capital, op. cit., p. 463; DÍAZ ECHEGARAY, J. L: Deberes y responsabilidades de los Administradores de sociedades de Capital, op. cit., p. 408; BELTRÁN SÁNCHEZ, E.: "La responsabilidad de los administradores por obligaciones sociales", op. cit., p. 343.

${ }^{903}$ En igual sentido, MERCADER UGUINA, J. R. y SUÁREZ CORUJO, B.: "La responsabilidad laboral y de Seguridad Social de los Administradores Sociales", op. cit., p. 563.

904 En Sentencia del TS, Sala Civil, 455/2017, de 18 de julio -Rec. 1589/2014- se indica que no sólo deudas comerciales, sino que incluye toda clase de deudas de la sociedad, entre ellas a las derivadas de la relación laboral (salarios, indemnizaciones, cotizaciones, etc.). En esa Sentencia se reclamaban indemnizaciones por despido no percibidas de la empresa ni del FOGASA.

${ }^{905}$ BOE del 15.11.2005, con vigencia desde el 16 de noviembre de 2005.
} 
incurre por el administrador en responsabilidad por incumplir los deberes de promover la disolución (tempus regit actum), por no tener carácter retroactivo las reformas de la normativa de la responsabilidad de los administradores ${ }^{906}$.

La cuestión que debemos abordar es si responde de todas las deudas posteriores a la causa de disolución, o si, por el contrario, cuando accede al cargo una vez se han incumplido los deberes por los anteriores administradores, responderá de las deudas posteriores a la concurrencia de la causa, aunque sean anteriores a su nombramiento, o si, por el contrario, solo responderá de las posteriores al nombramiento.

En la Sentencia del TS, Sala Civil, 601/2019, de 8 de noviembre -Rec. 596/2017-, se opta por la segunda interpretación, ya que se declara que el nuevo administrador sólo responde de las deudas posteriores al nombramiento, cuando la causa de disolución es anterior, si él no cumple con las obligaciones de promover la disolución desde su nombramiento, en un nuevo plazo de dos meses que, para él, se computa desde que asumió el cargo. El Tribunal Supremo alude a las obligaciones posteriores al nombramiento, pero de conformidad con el art. 214.3 de la LSC, deberá entenderse que debería responder de las deudas posteriores a la aceptación del cargo, a la asunción de las funciones del mismo, ya que el nombramiento surte efectos desde la aceptación del cargo $^{907}$.

A partir de esta Sentencia del TS, Sala Civil, 601/2019, de 8 de noviembre -Rec. 596/2017-, la obligación de responder de las deudas posteriores a la causa de disolución (art. 367 de la LSC), se ha de matizar, en el sentido de que han de ser, en todo caso, posteriores a la fecha de asunción del cargo, en el supuesto de nuevos administradores que aceptan el cargo una vez se encuentre la sociedad en causa de disolución. Una interpretación que es claramente restrictiva de la redacción literal del art. 367 de la LSC.

Con esta nueva doctrina jurisprudencial los nuevos administradores sólo responderían de las obligaciones posteriores a asumir el cargo, pero no de las anteriores que sean

906 SSTS, Sala Civil, 458/2010, de 30 junio -Rec. 1337/2006-; 680/2010, de 10 noviembre -Rec. 791/2007-; 826/2011, de 23 de noviembre; 923/2011, de 26 de noviembre; 225/2012, de 13 de abril; 367/2014, de 10 julio -Rec. 1858/2012-; y 456/2015, de 4 de septiembre -Rec. 2414/2013-.

No se ha aplicado retroactivamente, por no ser de naturaleza sancionadora.

${ }^{907}$ RODRÍGUEZ RUIZ DE LA VILLA, D. y HUERTA VIESCA, M. I.: "La responsabilidad por deudas de los nuevos administradores sociales de la sociedad de capital en causa legal de disolución", Diario La Ley, n..$^{\circ}$ 9556, Sección Tribuna, 20 de enero de 2020, edición digital, https://diariolaley.laleynext.es/Content/Documento.aspx?params=H4sIAAAAAAAEAFXMsQqEMB CE4acx9WYVxCKVeYT0x-mOsAhZ8aLg2xubA6f4qFTkRAT1bXUMvXuxP5Ty4HJD549uWyCFMdwZMGiGfJcdLmizenaEMp-wGE, pp. 7-8. 
posteriores a la causa de disolución. De éstas sólo responderían los anteriores administradores incumplidores.

Limitación de deudas objeto de su responsabilidad que no defendemos, por dos razones. En primer lugar, porque esa limitación no está establecida normativamente, ya que en el art. 367 de la LSC, ante el incumplimiento de los deberes de promover la disolución o solicitar el concurso, se impone una responsabilidad por todas las deudas posteriores a la concurrencia de la causa de disolución, sin otra matización, y donde la ley no distingue no debemos distinguir, partiendo de la inveterada regla jurídica "ubi lex non distinguet nec nos ditinguere debemus". En segundo lugar, porque de facto se reduce el ámbito de las deudas y de los sujetos responsables, con claro perjuicio a los acreedores, cuando la finalidad o naturaleza de esta responsabilidad es ser una garantía por deuda ajena en beneficio de los acreedores.

Se estarán restringiendo las garantías de los acreedores y el círculo de posibles sujetos garantes de las deudas, por dos razones fundamentales. En primer lugar, porque con la doctrina sentada por el TS en la Sentencia 601/2019, de 8 de noviembre, de limitar la responsabilidad a las deudas posteriores al nombramiento, se está restringiendo el ámbito de los sujetos responsables de las deudas que pudieran nacer en el período comprendido entre el cese efectivo de un administrador y el nombramiento de otro que lo sustituya, en los supuestos de administración pluripersonal cuyo cese no afecte al funcionamiento del órgano de administración. Se estarían excluyendo posibles sujetos responsables de deudas de un determinado período, el que va entre el cese efectivo de un administrador y el nombramiento de otro posterior que lo sustituya, cuando ese nombramiento se produzca transcurrido un período superior al previsto legalmente para que opere la caducidad del cargo de la persona que ha cesado (art. 222 de la LSC), cuando no se nombre al nuevo integrante del órgano en la primera Junta General, o una vez que transcurra el plazo para convocar la junta que apruebe las cuentas anuales. En esos casos en que pueda seguir funcionando el órgano de administración, pero que no se sustituya en plazo a uno de sus miembros, para las deudas sociales nacidas entre la fecha del cese y el nombramiento, el acreedor dispondrá de un garante menos para exigir el pago solidario de la deuda, cuando al nuevo integrante del órgano de administración también le es imputable el incumplimiento, que no se olvide es el presupuesto de la responsabilidad solidaria. Incluso, podrán sucederse distintos administradores, que pudieran no llegar a ser responsables de las deudas, como podría 
acaecer cuando los nuevos administradores nombrados cesan, a su vez, antes de los dos meses de haber aceptado el cargo ${ }^{908}$. Pero, en segundo lugar, se reducen las garantías de los acreedores, porque con esa limitación de responsabilidad a las deudas posteriores al nombramiento-aceptación del cargo, el nuevo administrador estará especialmente interesado en cumplir las obligaciones posteriores al acceso al cargo, y no tanto las anteriores, con claro perjuicio para los acreedores anteriores -circunstancia que reseñan también algunos autores ${ }^{909}$.

Con anterioridad, aunque no se abordó directamente esta cuestión, encontramos una sentencia del Tribunal Supremo en la que obiter dicta, se aludía a deudas posteriores a la causa de disolución y anteriores a su nombramiento, aunque no fue objeto de la ratio decidendi si los administradores respondían de deudas anteriores a la asunción del cargo, apreciándose esa conclusión de modo indirecto (Sentencia del TS, Sala Civil, 826/2011, de 23 de noviembre -Rec. 1753/2007-910). Podríamos citar las Sentencias del T.S., Sala Civil, 733/2014, de 4 de diciembre -Rec. 1694/2011-; y 195/2006, de 9 de marzo -Rec. 2325/1999-; y 497/2006, de 26 de mayo -Rec. 4020/1999-, como argumentos adicionales para sostener que deberían responder de las deudas posteriores a la causa de disolución aunque fuesen anteriores al nombramiento, ya que se condenó a los nuevos administradores por las deudas anteriores al mismo si la causa de disolución era anterior, y, una vez accedieron al cargo, no cumplieron con los deberes de promover la disolución.

Por otro lado, el límite temporal máximo de responsabilidad de las deudas objeto de responsabilidad, serán las deudas generadas hasta la fecha del cumplimiento tardío de los deberes de promoción de la disolución por el administrador ${ }^{911}$, o, en su caso, por las deudas generadas hasta la remoción de la causa de disolución (Sentencia del TS, Sala

\footnotetext{
908 RODRÍGUEZ RUIZ DE LA VILLA, D. y HUERTA VIESCA, M. I.: "La responsabilidad por deudas de los nuevos administradores sociales de la sociedad de capital en causa legal de disolución”, 2020, op. cit., edición digital, p. 5.

${ }^{909}$ RODRÍGUEZ RUIZ DE LA VILLA, D. y HUERTA VIESCA, M. I.: "La responsabilidad por deudas de los nuevos administradores sociales de la sociedad de capital en causa legal de disolución”, 2020, op. cit., edición digital, pp. 7-8.

${ }^{910}$ En esa Sentencia 826/2011, de 23 de noviembre, ante el recurso de dos administradores condenados a responder de deudas laborales de un período anterior al nombramiento y posteriores a la causa de disolución, analizando el contenido del art. 262.5 de la LSA y actual art. 367 de la LSC, señala que "pese a que su literalidad no exime a los administradores que incumplen del deber de promover la disolución del pago de deudas generadas en fechas en las que no administraban la sociedad incursa en causa legal de disolución". La cursiva es nuestra, donde puede verse que se admite una responsabilidad por deudas anteriores a ocuparse el cargo de administrador.

${ }^{911}$ Sobre cumplimiento tardío, véase el apartado IV.5 de este Capítulo.
} 
Civil, 585/2013, de 14 de octubre -Rec. 1192/2011-912), o finalmente, hasta las deudas nacidas antes de su cese efectivo en el cargo, porque no responden de las deudas contraídas por la sociedad con posteriores al cese (Sentencia TS, Sala Civil, 585/2013, de 14 de octubre $)^{913}$.

En la consulta de la DGITSS de 19 de agosto de 2013, sobre derivación de responsabilidad a los administradores sociales ${ }^{914}$, se dice que el nuevo administrador nombrado cuando ya había acaecida la causa de disolución, debe cumplir con los deberes de promover la disolución a partir del nombramiento, y si no lo hace responde de todas las deudas posteriores a la causa de disolución, aunque sean anteriores las deudas a su nombramiento, y cesa la responsabilidad por las deudas posteriores a su cese $^{915}$.

Para la doctrina del Tribunal Supremo (Sentencias de la Sala Civil, n ${ }^{\circ}$ 144/2017, de 1 de marzo -Rec. 2198/2014-, con cita en las Sentencias 246/2015, de 14 de mayo y 456/2015, de 4 de septiembre), la responsabilidad de los administradores por las deudas sociales nace cuando concurre una causa de disolución, y no cuando nace la deuda, aunque tal deuda origine posteriormente la causa de disolución por pérdidas, por lo que, el administrador contra el que se dirige la derivación administrativa de responsabilidad no puede ser el que ostentaba el cargo cuando se produjo la deuda, sino el que lo ostentaba cuando se produjo la causa de disolución y no cumplió los deberes de promover la disolución.

La derivación administrativa de responsabilidad de deudas de Seguridad Social de la sociedad de capital al administrador, únicamente puede exigirse a partir de junio de 2004 (fecha de entrada en vigor de la reclamación de deuda por derivación y del acta de

${ }^{912}$ En esa Sentencia se indica que "La remoción de la causa de disolución de la compañía no extinguió la posible responsabilidad en que hubiera podido incurrir el administrador durante el tiempo en que incumplió el deber de promover la disolución, respecto de los créditos existentes entonces, pero sí evita que a partir del momento en que cesa la causa de disolución puedan surgir nuevas responsabilidades derivadas de aquel incumplimiento".

${ }^{913}$ En igual sentido SSTS, Sala Civil, 731/2013, de 2 de diciembre -Rec. 1444/2011-; y 601/2019, de 8 de noviembre -Rec. 596/2017-, entre otras muchas.

${ }^{914}$ Referencia La Ley 2492/2013.

915 En esa Consulta se argumenta en sus dos últimos apartados del siguiente modo: "5. El nuevo administrador, que teóricamente asume dicho cargo cuando ya la sociedad está incursa en causa de disolución, no se podrá considerar responsable sino hasta que no se hayan cumplido los plazos a que se refiere el artículo 367.1 TRLSC. En este tiempo, el nuevo administrador debe evaluar la situación contable de la sociedad para actuar en consecuencia. Pero si no lo hace así y permite, con su inacción, que la sociedad siga actuando, una vez ha tenido ocasión para constatar la existencia de una causa de disolución, contribuyendo con ello al deterioro del crédito de los acreedores, debe responder según la Ley, de todas las deudas sociales. 
liquidación de cuotas por derivación de responsabilidad según Disposición Final $2^{\mathrm{a}}$ de la Ley 52/2003, de 10 de diciembre), para las deudas nacidas desde el 1 de enero de 2004, fecha de entrada en vigor del art. 15.3 de la anterior LGSS, actual art. 18.3 del TRLGSS, por el principio de irretroactividad de los procedimientos administrativos y de las disposiciones normativas (D.T. $3^{\text {a }}$ de la LPACAP, Sentencia del TS, Sala Contencioso-Administrativa, de 31 de marzo de 2010 -Rec. 340/2008- ${ }^{916}$, y Consulta de la TGSS 16/2009, de 31 de mayo, sobre responsabilidad solidaria de los administradores sociales por los hechos anteriores a la Ley 52/2003 ${ }^{917}$ ). Para un mayor análisis véase el Capítulo VI apartado I.3.1, al que nos remitimos.

La responsabilidad solidaria del administrador por las deudas de Seguridad Social al amparo del art. 367 de la LSC, será por las deudas posteriores al acaecimiento de la causa de disolución, presumiéndose de fecha posterior todas las reclamadas, salvo prueba en contrario del administrador social (art. 367.2 de la LSC). En virtud de esa presunción legal, según el Criterio Técnico 89/2011, de la DGITSS, “puede ser objeto de derivación la totalidad de la deuda existente en todos los casos en los que los propios interesados no demuestren otra cosa, ya que sobre ellos recae la carga de la prueba, salvo que el funcionario actuante compruebe que efectivamente se trata de obligaciones que se han generado en una fecha inequívocamente anterior, supuesto en el que no cabe acudir a la presunción”.

Las deudas de Seguridad Social que se devenguen o nazcan a partir del día siguiente al acaecimiento de la causa legal de disolución, serían susceptibles de ser derivables a los administradores sociales, una vez que quede acreditado el incumplimiento de los deberes legales de promover la disolución o de solicitar el concurso de acreedores.

En la derivación administrativa de responsabilidad se precisa acreditar la concurrencia de la causa de disolución -que marca el inicio temporal de las obligaciones objeto de

\footnotetext{
${ }^{916}$ Esa Sentencia niega la aplicación retroactiva de la derivación administrativa de responsabilidad, si se pretende iniciar para exigir deudas anteriores a enero de 2004, fecha ésta en que entra en vigor la competencia de la TGSS y de la ITSS, para declarar en vía administrativa la responsabilidad solidaria en el pago de deudas de Seguridad Social, argumentando que, "tiene razón la Sala de instancia en cuanto que la reforma llevada a cabo por la Ley 52/2003 carece de eficacia retroactiva, al no haber establecido la norma nada al respecto y ser la irretroactividad un principio general de nuestro ordenamiento, salvo, claro está, respecto de una regulación más favorable de una norma sancionadora, situación aquí ausente. En consecuencia, no prospera el recurso".

${ }^{917}$ En esa Consulta se concluye que "que no procede la aplicación de la retroactividad de la citada Ley 52/03 para exigir responsabilidad a los Administradores sociales por hechos anteriores a su entrada en vigor".
} 
responsabilidad- y el incumplimiento de los deberes de los administradores de promover la disolución o solicitar el concurso.

El acaecimiento de la causa de disolución nos servirá para determinar el dies a quo de las deudas exigibles al administrador social, las deudas iniciales por las que asumirá la responsabilidad. Para determinar esas deudas debemos distinguir entre el devengo y la exigibilidad de la deuda, ya que en toda obligación han de distinguirse entre la realización del hecho que genera la deuda, el nacimiento de la deuda, y el momento temporal en que esa deuda puede ser exigida, la exigibilidad de la deuda.

Es jurisprudencia ${ }^{918}$ reiterada que es la fecha de nacimiento de la deuda y no su exigibilidad la que determina si la deuda de Seguridad Social es posterior al acaecimiento de la causa de disolución. En las Sentencias 151/2016, de 10 de marzo Rec. 2421/2013- y 225/2019, de 10 de abril -Rec. 4146/2016- se señala que lo relevante para decidir si la obligación es anterior o posterior sería la fecha de nacimiento o devengo de la obligación, no su exigibilidad ni la fecha de la Sentencia que la declara. En la Sentencia del TS, Sala Civil, 585/2013, de 14 de octubre -Rec. 11912/2011-, con relación a una póliza de crédito bancario, se señala que la deuda nace en la fecha del otorgamiento de la póliza del préstamo, fecha a la que debe estarse a la hora de determinar si la deuda es anterior o posterior a la causa de disolución. Criterio de estimar que la deuda es anterior o posterior, en función de la fecha del nacimiento de la obligación, y no de la fecha del pago, que se reitera en la Sentencia del TS, Sala Civil, 22/2020, de 16 de enero -Rec. 1520/2017-, que, para un aval, estimó que ha de estarse a la fecha de formalización del aval, y no a la fecha en que el avalista pagó al acreedor por impago del deudor.

El art. 367 LSC no establece una regla especial sobre la determinación del momento en que nace la obligación, de modo que resultan aplicables las reglas generales del Derecho de obligaciones, y en materia de deudas de Seguridad Social, la normativa de Seguridad Social sobre el nacimiento de esas deudas. En obligaciones de tracto sucesivo, ha de estarse, no a la fecha de la formalización del contrato o relación jurídica, sino a la fecha de devengo de cada una de las obligaciones que vayan surgiendo en el decurso de la

\footnotetext{
918 SSTS, Sala Civil, 585/2013, de 14 de octubre -Rec. 1192/2011-; 151/2016, de 10 de marzo -Rec. 2421/2013-; 246/2015, de 14 de mayo -Rec.1121/2013-; 144/2017, de 1 de marzo -Rec. 2198/2014-; 225/2019, de 10 de abril -Rec. 4146/2016-; y 22/2020, de 16 de enero -Rec. 1520/2017-.
} 
relación jurídica ${ }^{919}$. En las deudas puras pero con pago aplazado, deberá estarse a la fecha de nacimiento de la deuda, y no a la fecha en que se ingresa la deuda aplazada ${ }^{920}$. En obligaciones de restitución o resolutorias la obligación a efectos de estimarse si es anterior o posterior, no nace con la formalización de la relación jurídica, sino cuando se cumple la condición resolutoria que obliga a restituir o devolver la prestación ${ }^{921}$.

Estas reglas acerca del nacimiento de las obligaciones, sean obligaciones de tracto sucesivo o tracto único, obligaciones de restitución, u obligaciones con pago aplazado, son aplicables a las deudas de Seguridad Social.

Serán deudas de tracto sucesivo, cuya fecha de nacimiento es la de su devengo, las deudas por cuotas de Seguridad Social que se devengan por meses vencidos, y determinadas deudas por prestaciones de pago periódico, como una incapacidad temporal, riesgo por lactancia, embarazo, etc., para las mensualidades devengadas de fecha posterior al hecho causante de la prestación, aunque el hecho causante hubiere sido de fecha anterior. Doctrina no aplicable para prestaciones cuyo capital coste debe ingresar la empresa declarada responsable en la TGSS (pensiones por Incapacidad Permanente, Jubilación, Muerte-Supervivencia), para las que, al ser de tracto único, ha de estarse a la fecha del hecho causante.

En la derivación administrativa de deudas de Seguridad Social, según la Consulta DGITSS, de fecha 5 de agosto de 2014, sobre derivaciones de responsabilidad ${ }^{922}$, para determinar qué deudas por cotizaciones pueden derivarse, habrá de estarse a la fecha del devengo de la deuda, a la fecha en que nace la obligación, y no a la fecha de su ingreso, no a la fecha en que es exigible la deuda. Distinción importante entre devengo y exigibilidad de la deuda, ya que, las deudas por cuotas se devengan por meses naturales vencidos (art. 16 del RGCSS) -tomándose las retribuciones del mes, con inclusión de la

919 SSTS, Sala Civil, de 145/2012, de 21 de marzo -Rec. 272/2009-; 161/2012, de 21 de marzo -Rec. 473/2009-; 505/2013, de 24 de julio -Rec. 2178/2011-; 62/2019, de 31 de enero -Rec. 1932/2016-; 225/2019, de 10 de abril -Rec. 4146/2016-; y 215/2020, de 1 de junio -Rec. 2849/2017-.

${ }^{920}$ SSTS, Sala Civil, 716/2018, de 19 de diciembre -Rec. 3648/2015-; 585/2013, de 14 de octubre -Rec. 11912/2011-; 22/2020, de 16 de enero -Rec. 1520/2017-; 151/2016, de 10 de marzo -Rec. 2421/2013-; 246/2015, de 14 de mayo -Rec.1121/2013-; y 144/2017, de 1 de marzo -Rec. 2198/2014-.

921 STS, Sala Civil, 151/2016, de 10 de marzo -Rec. 2421/2013-; 505/2014, de 8 de octubre -Rec. 237/2013-.

En la Sentencia 151/2016, se indica "En el caso de una obligación restitutoria derivada del ejercicio de una facultad resolutoria, tal obligación no nace cuando se celebra el negocio que se pretende resolver, por más que tenga una relación directa con el mismo, sino del acaecimiento del hecho resolutorio y del ejercicio por el interesado de la facultad resolutoria derivada del mismo. Es ese el momento temporal que debe tomarse en consideración para determinar si la obligación es o no posterior al acaecimiento de la causa legal de disolución".

${ }^{922}$ Referencia La Ley 1935/2014. 
prorrata de pagas de vencimiento superior al mes-, mientras que, el plazo reglamentario de ingreso de las cuotas mensuales, o fecha de ingreso, será el mes siguiente a su devengo (art. 56 del RGRSS).

En la Consulta de 5 de agosto de 2014 se argumenta que la forma correcta de reclamar la responsabilidad solidaria del administrador, ante una causa de disolución por pérdidas resultante de las cuentas anuales cerradas al 31 de diciembre, sería, "derivar todas las obligaciones de Seguridad Social cuyo nacimiento se haya producido posteriormente a la causa legal de disolución (diciembre), entendiéndose el mes de nacimiento de dicha obligación aquel al que se refieren las cuotas a liquidar, independientemente de la fecha de pago de las mismas". De este modo, se argumenta que, "cuando se entiende probada la existencia de causa legal de disolución el 31 de diciembre (si se toman las Cuentas Anuales de cierre de ejercicio económico coincidente con el natural), parece obvio que las obligaciones sociales que pudieran ser derivadas a los administradores sociales, son las posteriores al 31 de diciembre, es decir, las nacidas a partir del 1 de enero del año siguiente".

Con este criterio administrativo del OEITSS, ante una causa de disolución por pérdidas que resultan de las cuentas anuales, al acaecer la causa de disolución el 31 de diciembre, las deudas de Seguridad Social objeto de la derivación serán las cuotas devengadas o que nazcan a partir de enero del año siguiente, cuotas de enero cuyo plazo reglamentario de ingreso será dentro del mes de febrero (mes siguiente al devengo), por lo que no podrán derivarse las cuotas del mes de diciembre del año en que acaece la causa de disolución, aunque su plazo reglamentario de ingreso sea el 31 de enero. De igual modo, si las pérdidas resultan de un balance trimestral de comprobación, se podrán derivar las deudas por cotizaciones correspondientes al mes siguiente al trimestre cerrado (esto es, si constan pérdidas en el balance del primer trimestre, se podrán derivar las cuotas de Seguridad Social a partir del mes de abril, pero no las cuotas de marzo que se ingresan y son exigibles el 31 de abril).

No obstante esta regla general, de hallarnos ante una causa de disolución de pérdidas cualificadas con patrimonio neto negativo resultante de las cuentas anuales cerradas al finalizar el ejercicio, y de no acreditar el administrador social la fecha, mes o trimestre en que ha acecido la causa de disolución por pérdidas (de no aportarse los balances trimestrales requeridos en las labores de comprobación inspectora), en virtud de la presunción de ser deudas posteriores todas las reclamadas (art. 367 de la LSC), éste 
debe responder de las obligaciones nacidas a lo largo del ejercicio económico y no sólo de las posteriores a la finalización de ese ejercicio (Sentencia del TS, Sala Civil, 212/2020, de 29 de mayo -Rec. 4544/2017-923).

La TGSS en su Guía operativa de enero de 2015 y en deudas por cotizaciones, en un supuesto atiende al criterio del devengo y en otro al de su exigibilidad, al indicar que cuando se hayan cumplido en plazo reglamentario por la empresa las obligaciones previstas en el art. 29 del TRLGSS, esto es, la trasmisión de datos para la práctica de oficio de la liquidación (sistema de liquidación directa), la fecha del devengo de las cuotas ha de tomarse como fecha de la obligación anterior o posterior, a efectos del art. 367 de la LSC. Pero, por el contrario, si la empresa no ha cumplido con las obligaciones del art. 29 del TRLGSS, será la fecha de la reclamación de deuda la que ha de tomarse a efectos de considerar la obligación anterior o posterior a la causa de disolución. Criterio éste que no se comparte por varias razones. En primer lugar, porque la deuda por cuotas nace con su devengo, no en la fecha en que se liquide, determine o ingrese, no nace cuando se reclame por la TGSS. Las deudas por cuotas se devengan por meses vencidos, aunque no se hayan reclamado por la TGSS cuotas devengadas. No debe confundirse la determinación y exigibilidad administrativa de la deuda, con el devengo o nacimiento de la misma, ya que el hecho de no determinarse su importe por la TGSS hasta fecha posterior a su devengo, no convierte a la deuda en deuda posterior al devengo. En segundo lugar, porque al estar a la exigibilidad de la deuda en ese segundo supuesto, se estarán reclamando por la TGSS deudas anteriores por el mero hecho de no haber cumplido la empresa otra obligación, cual es no haber transmitido en plazo los datos de cotización, falta de transmisión que no es constitutiva del nacimiento de la deuda.

En la relación laboral van surgiendo diversas obligaciones, unas de tracto sucesivo y otras de tracto único, entre éstas, las indemnizaciones por extinción de la relación laboral que, ante un despido improcedente, a efectos de si son anteriores o posteriores a

923 En esta Sentencia la causa de las perdidas cualificadas resultaba de las cuentas cerradas al 31 de diciembre de 2008 y la deuda nació en julio de 2008, estimándose que, salvo prueba en contrario del administrador, al ser el patrimonio neto negativo de $-65.802,38 €-$, la causa de disolución tuvo que ser anterior al 31 de diciembre, por lo que la deuda es posterior, ya que "procede presumir que la obligación social, que conocemos surgió el 31 de julio de 2008, fue posterior a la causa de disolución". 
la causa de disolución, en Sentencia del TS, Sala civil, 455/2017, de 18 de julio $^{924}$, se establece que la obligación de indemnizar nace cuando la empresa opta por la indemnización. Los créditos indemnizatorios por extinción de la relación laboral, cuando son declarados en sentencia firme por ser materialmente imposible la readmisión por cierre de empresa, o en auto de ejecución de sentencia, de no proceder la readmisión, esas indemnizaciones nacen con la sentencia firme o auto de ejecución de sentencia, siendo esa la fecha a que debe estarse para determinar si son anteriores o posteriores a la causa legal de disolución (Sentencia del TS, Sala Civil, 420/2019, de 15 de $_{\text {julio }}{ }^{925}$ ). Si partimos de la doctrina de estas sentencias, naciendo las obligaciones vinculadas a la extinción del contrato en la fecha de opción empresarial por la readmisión en caso de despido improcedente, o en la fecha de la sentencia o auto que declara nulo el despido o improcedente con imposible readmisión (empresa desparecida), trasladados sus efectos a la cotización de los salarios de tramitación, cabría señalar que para determinar si son deudas anteriores o posteriores a la causa de disolución en un despido improcedente hemos de estar a la fecha en que se han declarado, a la fecha del auto o sentencia que declarada el derecho a su percepción ante una imposible readmisión (empresa desaparecida) o a la fecha de la opción empresarial

924 En la Sentencia del TS, Sala civil, 455/2017, de 18 de julio -Rec. 1589/2014-, la demanda la interponen unos trabajadores, fundada tanto en la responsabilidad por daño y por deudas (artículos 241 y 367 LSC), solicitaban la condena solidaria de los demandados al pago de 133.831,14 €, cantidad que había quedado por cobrar de sus indemnizaciones laborales, tras el pago parcial efectuado por el Fondo de Garantía Salarial. En el procedimiento, se constató la existencia de pérdidas en los años 2008 a 2010, que dejaban reducido el patrimonio de la sociedad en una cifra muy inferior a la cifra del capital social. Trabajadores que fueron despedidos el 30.12.2009. La Sentencia, examinando si la indemnización por despido es posterior a la causa de disolución señala, "con relación al nacimiento de la obligación, hay que precisar que el concreto Derecho de crédito a la indemnización por despido no nace con el contrato de trabajo. La contraprestación a la prestación de los servicios laborales es el salario (art. 26 del Estatuto de los Trabajadores), mientras que la indemnización por despido nace una vez que el mismo es declarado judicialmente improcedente y la empresa opta por la no readmisión (art. 56 del Estatuto de los Trabajadores). En el caso de autos, el nacimiento de la obligación indemnizatoria tuvo lugar cuando la sociedad estaba ya en causa legal de disolución".

925 En Sentencia del TS, Sala Civil, 420/2019, de 15 de julio, se señala que, "En primer lugar, discute la parte recurrente que las deudas sociales fueran posteriores a la fecha en que concurría la causa de disolución. Según la documentación obrante en las actuaciones, la causa de disolución por pérdidas cualificadas existía y era conocida por el administrador, como mínimo, desde la fecha del balance de situación presentado en el ERE (30 de abril de 2013). A su vez, las deudas sociales consistentes en los créditos de las trabajadoras no se concretaron hasta que el juzgado de lo social transformó la condena a su readmisión en una indemnización sustitutoria, lo que tuvo lugar mediante sendos Autos de 11 de abril de 2014. Como recuerda la Sentencia de esta Sala 473/2016, de 13 de julio, la jurisprudencia de la Sala de lo Social del Tribunal Supremo ha declarado que la sentencia del juzgado de lo social que acuerda la extinción del contrato de trabajo por incumplimientos graves del empleador reviste carácter constitutivo. Por tal razón, tanto la extinción de la relación laboral como el nacimiento del crédito indemnizatorio correspondiente operan con carácter ex nunc desde la sentencia firme que lo acuerda (Sentencias de la Sala de lo Social del Tribunal Supremo 1497/1990, de 21 de diciembre, 22 de junio de 2011, 20 de julio de 2012 y 285/2016, de 13 de abril, y las en ellas citadas)". 
por la readmisión, y no a la fecha de los meses a que se refieren las cotizaciones de los diversos meses correspondientes a los salarios de tramitación.

A efectos de las deudas de Seguridad Social, y de todo lo anterior, resultan las siguientes conclusiones:

- El carácter anterior o posterior a la causa de disolución de la deuda de Seguridad Social viene determinado por el momento en que la deuda queda realizada o devengada, y no por la fecha de su pago o por la fecha de su reclamación, que en el caso de las obligaciones de tracto sucesivo o de vencimiento periódico, será la fecha de devengo de cada mensualidad ${ }^{926}$.

- En el caso de deudas por cuotas, será la fecha del mes al que corresponden las cotizaciones, la fecha del devengo, por ser obligaciones de tracto sucesivo, de devengo periódico, excepto las cuotas por salarios de tramitación en el despido improcedente que nacen en la fecha del auto o sentencia que declara el derecho a su percepción en caso de imposible readmisión -empresa desaparecida-, o en la fecha de la opción empresarial por la readmisión.

- En el caso de prestaciones de Seguridad Social, la deuda u obligación de la entidad gestora, y en su caso de la empresa declarada responsable, nace cuando acaece el hecho causante de una prestación, con independencia de que se solicite fuera del plazo reglamentario, en cuyo caso, sus efectos se retrotraen tres meses desde la solicitud (art. 53 del TRLGSS). Para determinar si esas deudas por prestaciones son anteriores o posteriores a la concurrencia de una causa de disolución, se ha de estar a la fecha del hecho causante de la prestación, cuando sea una obligación de tracto único, como sucede con las prestaciones de pago único -incluidas las indemnizaciones del trabajador derivadas de una accidente de trabajo o enfermedad profesional, en que a esos efectos ha de estarse a la fecha del accidente del que surge el derecho a la indemnización ${ }^{927}$ - o con las prestaciones cuyo importe ha de ser

926 SSTS, Sala Civil, de 225/2019, de 10 de abril -Rec. 4146/2016-; 145/2012, de 21 de marzo -Rec. 272/2009-; 161/2012, de 21 de marzo -Rec. 473/2009-; 505/2013, de 24 de julio; 62/2019, de 31 de enero -Rec. 1932/2016-; y 215/2020, de 1 de junio -Rec. 2849/2017-.

927 Sentencia del TS, Sala Civil, 193/2020, de 25 de mayo -Rec. 2077/2017-, se señala "En nuestro caso, en la instancia se ha declarado que la sociedad X, se hallaba incursa en causal legal de disolución en el año 2008, sin que su administrador hubiera cumplido los reseñados deberes legales de disolución. Conforme al art. 367 LSC, el administrador deviene responsable solidario de todas las deudas sociales posteriores a la aparición de la causa de disolución. La deuda social es el crédito que un trabajador de la sociedad, Luis Miguel, tiene reconocido por un juzgado de lo social, que condenó a la sociedad a indemnizar a este trabajador los daños y perjuicios sufridos por un accidente laboral. La Sentencia del juzgado de lo social que condena a la sociedad al pago de este crédito es del día 13 de julio de 2011, 
capitalizado de una vez por la empresa en la TGSS (normalmente pensiones de incapacidad permanente, muerte y supervivencia o jubilación). En cambio, para las prestaciones periódicas de devengo mensual, obligación de tracto sucesivo (incapacidad temporal, de riesgo por embarazo, de riesgo por lactancia, prestación por nacimiento o cuidado de hijo, etc.), ha de estarse a la fecha de devengo de las mensualidades respectivas, para determinar si la obligación es anterior o posterior a la causa de disolución, aunque el hecho causante haya sido anterior.

- En caso de responsabilidad por colaboración de la empresa en la percepción indebida de prestaciones (art. 55. 2 del TRLGSS), la deuda por el reintegro de la prestación indebidamente percibida nace desde que se ha producido el hecho determinante de la percepción indebida, que puede ser de fecha distinta al hecho causante de la prestación, como sería compatibilizar indebidamente una prestación nacida anteriormente con el trabajo por cuenta ajena, ya que en las deudas nacidas de una obligación restitutoria, la fecha de la deuda no es la del hecho causante de la prestación, sino la fecha del hecho causante de la restitución o reintegro de la obligación (Sentencia del TS, Sala Civil, 151/2016, de 10 de marzo y 505/2014 de 8 octubre -237/2013-).

- En el caso de deudas por cuotas de Seguridad Social aplazadas, que correspondan a períodos anteriores a la fecha de concurrencia de la causa de disolución, si la empresa no cumple las condiciones del aplazamiento, y tienen que ser reclamadas

esto es, posterior a la aparición de la causa de disolución. Pero el accidente laboral que ocasionó los daños objeto de indemnización acaeció el día 25 de octubre de 2006, esto es, con anterioridad a que la sociedad incurriera en causa de disolución. Como hemos hecho en otras ocasiones, hemos de analizar cuándo nace la deuda social, en atención a su naturaleza. De acuerdo con la jurisprudencia de la sala, las obligaciones de indemnización de daños y perjuicios ocasionados por un siniestro, en este caso un accidente laboral, nacen con el siniestro, sin perjuicio de que el nacimiento de la acción para su reclamación pueda demorarse a un momento posterior en el que pueda conocerse ya el alcance del perjuicio sufrido. Así lo recordaba la Sentencia 116/2015, de 3 de marzo, cuando razonaba: "el Derecho a la indemnización nace con el siniestro, y la sentencia que finalmente fija el "quantum" tiene naturaleza declarativa, no constitutiva, es decir, no crea un Derecho "ex novo" sino que se limita a determinar la cuantía de la indemnización por el Derecho que asiste al asegurado desde que se produce el siniestro cuyo riesgo es objeto de cobertura".

Y la Sentencia de pleno 736/2016, de 21 de diciembre, que unificó las soluciones adoptadas por la jurisdicción social (Vid.: Sentencia de la Sala $4^{\mathrm{a}} \mathrm{TS}$, de 18 de febrero de 2016) y la Civil, en relación con la invalidez ocasionada por un accidente y su cobertura por un seguro, reiteró que la fecha relevante era la del accidente y no la de la declaración de incapacidad. El daño y perjuicio se origina con el accidente y es consecuencia inherente al mismo, sin que el siniestro pueda confundirse con la declaración formal de sus consecuencias. La fecha del accidente sirve para fijar el régimen legal aplicable a todos los efectos, incluidos los intereses. En cualquier caso, la sentencia judicial que declara la obligación de indemnizar y condena a su pago no tiene carácter constitutivo, sino declarativo, aunque sea una declaración de condena. De tal forma que no puede concluirse, como pretende el Recurrente, que la obligación de indemnizar haya nacido con la sentencia, sino que nace con la causación del daño o perjuicio. 
por la TGSS con posterioridad a la causa de disolución, lo fundamental no será la fecha de su reclamación, sino si la deuda es de un período anterior o posterior a la causa de disolución ${ }^{928}$.

Con relación a los intereses de demora, en la STS, Sala Civil, núm. 151/2016, de 10 de marzo -Rec. $2421 / 2013-{ }^{929}$, se parte del carácter accesorio respecto a la deuda de la que trae causa para determinar si es anterior o posterior, con independencia de que pudieran seguir devengándose nuevos intereses de demora tras la causa de disolución. En las deudas de Seguridad Social los intereses de demora nacen una vez finaliza el plazo reglamentario de ingreso de la deuda (art. 84.2 letra e) del RGRSS). Doctrina que es intrascendente en la responsabilidad solidaria en las deudas ya que el administrador social responde de la deuda, de los recargos, intereses y costas (arts. 33.2 y 34.1 apartado c) del TRLGSS).

En el procedimiento administrativo de derivación de la responsabilidad solidaria al administrador de las deudas de Seguridad Social de capital, podrán reclamarse a éste, al amparo del art. 367 de la LSC y art. 18.3 del TRLGSS, el importe principal de la deuda con los recargos, intereses de demora y las costas del procedimiento administrativo devengadas (arts. 33.2 y 34.1.c) del TRLGSS y art. 13.3 del RGRSS ${ }^{930}$ ).

${ }^{928}$ SSTS, Sala Civil, 716/2018, de 19 de diciembre -Rec. 3648/2015- ; 585/2013, de 14 de octubre -Rec. 11912/2011-; 151/2016, de 10 de marzo -Rec. 2421/2013-; 246/2015, de 14 de mayo -Rec.1121/2013; 144/2017, de 1 de marzo -Rec. 2198/2014-; y 22/2020, de 16 de enero -Rec. 1520/2017-.

${ }^{929}$ Con relación al pago de intereses y su carácter accesorio de la obligación principal de la que trae causa, señala "tal obligación nació cuando $\mathrm{X}$, se constituyó en mora, al ser requerida de pago en octubre de 27 de octubre de 2008, esto es, antes del acaecimiento de la causa legal de disolución, sin perjuicio de que tales intereses se siguieran devengando con posterioridad a dicho momento y su adeudo fuera declarado en una sentencia también de fecha posterior, por cuanto que, de no concurrir la nota de acusada accesoriedad a que se ha hecho referencia, lo relevante para decidir si la obligación es anterior o posterior sería la fecha de nacimiento de la obligación, no su completo devengo o exigibilidad ni la fecha de la sentencia que la declara" (...), continuando que "hemos venido entendiendo que no debe estarse al momento en el que la obligación es exigible o al momento en el que se devenga o se declara, sino que es preciso remontarse al momento en el que la obligación se contrae o del que trae causa, lo que resulta de particular trascendencia en el caso de obligaciones pecuniarias que traen causa de otras de carácter distinto. El momento relevante es el primero, esto es, el correspondiente al momento en el que la sociedad asumió la obligación de la que trae causa la posteriormente declarada".

930 Art. 13.3. "Salvo que la responsabilidad solidaria se halle limitada por ley, la reclamación de deuda por derivación comprenderá el principal de la deuda y los recargos e intereses que se hubieran devengado al momento de su emisión, en el procedimiento recaudatorio seguido contra el primer responsable solidario a quien se hubiera reclamado, o que hubiera cumplido dentro de plazo las obligaciones en materia de liquidación de cuotas. Incluirá, asimismo, las costas que se hubieran generado para el cobro de la deuda. Desde la reclamación de deuda o el acta de liquidación por derivación serán exigibles a todos los responsables solidarios el principal, los recargos e intereses que deban exigirse a ese primer responsable, y todas las costas que se generen para el cobro de la deuda". 
Señalar para finalizar que, para evitar que el coste de la reclamación de una deuda de escasa cuantía sea superior a los costes de su reclamación administrativa, se establecen unas cuantías mínimas precisas para que se reclamen las deudas de Seguridad Social. Ese importe mínimo se ha fijado en el 3\% del IPREM mensual vigente en el momento de la respectiva liquidación, salvo en los casos de responsabilidad por sucesión mortis causa en los que dicha cuantía se fija en el 20\% del IPREM mensual (arts. 7 y 10 de la Orden TAS/1562/2005, de 25 de mayo, que establece las normas para la aplicación y desarrollo del Reglamento General de Recaudación de la Seguridad Social ${ }^{931}$ ). Para esas deudas, no podrá emitirse, ni notificarse la reclamación de deuda o el acta de liquidación correspondiente.

Cuando el importe a reclamar por prestaciones no exceda de esos importes, las entidades gestoras y colaboradoras en la gestión no remitirán a la TGSS las resoluciones definitivas en vía administrativa en las que se declare la procedencia de reintegros de prestaciones por importes inferiores (art. 11 de la Orden TAS/1562/2005, de 25 de mayo).

No obstante lo anterior, se permite la acumulación de deudas de un mismo deudor, en una única reclamación, para alcanzar esos importes y poder iniciar el procedimiento administrativo recaudatorio (art. 13 de la Orden TAS/1562/2005, de 25 de mayo).

\section{VI.- ÁMBITO SUBJETIVO DE LA RESPONSABILIDAD.}

\section{Administradores responsables. Delimitación de los sujetos responsables.}

Incurren en responsabilidad solidaria en el pago de las deudas de Seguridad Social de la sociedad de capital, los administradores que incumplan los deberes de promover la disolución de la sociedad cuando concurra causa de disolución (art. 367 de la LSC y art. 18.3 del TRLGSS). Estamos ante una responsabilidad personal ${ }^{932}$ de todas las personas que integran el órgano de administración, cualquiera que sea la forma en que se haya organizado la administración, siempre que les sea imputable el incumplimiento de los deberes de promover la ordenada disolución de la entidad mercantil.

\footnotetext{
931 BOE del 11 de junio de 2005.

932 SÁNCHEZ CALERO, F.: Los administradores en las sociedades de capital, op. cit., p. 458; BELTRÁN SÁNCHEZ, E.: "La responsabilidad de los administradores por obligaciones sociales", op. cit., p. 347.
} 
El régimen jurídico de la administración de las sociedades mercantiles, se regula en el Título VI de la LSC (arts. 209 a 252).

Sea cual sea la forma de organización de la administración, son responsables de las deudas de Seguridad Social, al amparo del art. 367 de la LSC, todos los administradores que ostenten el cargo cuando se produjo el incumplimiento de los deberes legales de promover la disolución o de solicitar el concurso de acreedores, o dicho en otro sentido, los que ocupen el cargo a la fecha de vencimiento de los plazos para el cumplimiento de los dos deberes de ordenada disolución, bien sea el deber de convocar la Junta General, o bien sea el deber de solicitar la disolución judicial, o, de proceder, el concurso de acreedores (arts. 365 y 366 de la LSC) ${ }^{933}$. Los responsables son todos los administradores, se hayan constituido bajo la forma de administradores solidarios, mancomunados, o de Consejo de Administración, en este último supuesto responden todos los que lo integren. De haberse nombrado Consejeros Delegados o una Comisión Ejecutiva, nombramiento que recaerá entre miembros integrantes del consejo, (art. 249 de la LSC), no quedan exonerados de la responsabilidad del art. 367 de la LSC el resto de los miembros del Consejo de Administración ${ }^{934}$. Responsabilidad por deudas que no alcanza a los administradores suplentes ${ }^{935}$.

933 MACHADO PLAZAS, J.: Pérdida del capital social y responsabilidad de los administradores por deudas sociales, op. cit., p. 341, para quien la responsabilidad alcanza a los administradores que estuvieren en el ejercicio del cargo durante la vigencia del plazo de dos meses para cumplir con los deberes legales; DÍAZ ECHEGARAY, J. L.: Deberes y responsabilidades de los Administradores de sociedades de Capital, op. cit., p. 404; MOYA BALLESTER, J.: La responsabilidad de los administradores de sociedades en situaciones de crisis, op. cit., pp. 486-487, para quien la responsabilidad alcanza a los administradores que estuvieren en el ejercicio del cargo cuando se incumplieron los deberes legales; BELTRÁN SÁNCHEZ, E.: "La responsabilidad de los administradores por obligaciones sociales", op. cit., p. 347, quien señala que la responsabilidad se extiende a quienes integraban el órgano de administración, el día del vencimiento del plazo para el cumplimiento de los correspondientes deberes legales, cualquiera que sea la forma de organizarse la administración.

934 Sentencias del TS, Sala Civil 647/2006 de 23 junio -Rec. 4192/1999-; 205/2008, de 1 de diciembre Rec. 80/2001-; 460/2010, de 14 de julio -Rec. 945/2006-; y 826/2011 de 23 noviembre -Rec. 1753/2007-, entre otras. En la Sentencia 205/2008, de 1 de diciembre -Rec. 80/2001-, se señala que "procede, en suma, apreciar la responsabilidad de los administradores, para la que resulta indiferente que determinadas funciones del Consejo de Administración hayan sido delegadas en concretos miembros del mismo. El art. 133 LSA se refiere como titulares de la responsabilidad que en él se establece a los «administradores» (o «miembros del órgano de administración»: art. 133.3 LSA ). Esta cualidad la ostentan los nombrados como tales por la Junta General (art. 123 LSA). En consecuencia, los legitimados desde el punto de vista de la exigencia de responsabilidad son quienes ostentan esta condición, independientemente de que determinadas facultades del consejo de administración hayan sido delegadas en consejeros concretos, puesto que éstos actúan por mandato de los administradores o como gestores de éstos, y sólo cabe eximir a aquellos de responsabilidad en el caso de que, como prescribe el artículo 133.3 LSA, prueben que, no habiendo intervenido en la adopción y ejecución del acuerdo lesivo, desconocían su existencia o, conociéndola, hicieron todo lo conveniente para evitar el 
Al ser una responsabilidad de las personas integrantes del órgano, su identidad deberá recogerse en el acto jurídico de la derivación administrativa de responsabilidad, pudiendo la ITSS o la TGSS acceder a esa información a través del Registro Mercantil, ya que es objeto de inscripción registral el nombramiento y los ceses de los administradores de las sociedades de capital, constando las fechas de vigencia del cargo, las dimisiones, revocaciones y la caducidad del cargo (arts. 94.1.4 ${ }^{\circ}, 138,143,144,145$, $147,148,175.1 .5^{\circ}, 191$ y 192 del RRM), con independencia de poder requerir esos datos directamente a la sociedad de capital.

Siendo el administrador social responsable de las deudas sociales, en caso de concurso de acreedores de aquél, el crédito que resulta de la derivación de deudas por responsabilidad al amparo del art. 367 LSC, tendrá la condición de crédito contra la masa del administrador siempre que el hecho determinante de la responsabilidad y el crédito resultante corresponda a un período comprendido entre la declaración y la conclusión del concurso (art. 242.13 del TRLC y Sentencia del Tribunal Supremo, Sala Civil, 650/2017, de 29 de noviembre -Rec. 1418/2015).

Esta responsabilidad por deudas del administrador social no es aplicable a los liquidadores, ya que no tienen jurídicamente la condición de administradores sociales, con independencia de que pueda nombrase liquidador al administrador (art. 376 LSC), en cuyo caso se nova su condición jurídica de administrador a liquidador. No es aplicable la responsabilidad solidaria al liquidador, básicamente por dos razones que señala BELTRÁN ${ }^{936}$. En primer lugar, porque los liquidadores no son administradores arts. 374 y 375 LSC-, y en segundo lugar, porque los liquidadores no pueden incumplir el deber de promover la disolución, no pudiendo ser sancionados por el incumplimiento de un deber que no tienen legalmente atribuido.

daño o, al menos, se opusieron expresamente a aquél". Las referencias a los arts. 133 debe entenderse a 236 de la LSC y las del art. 123 al art. 214 de la LSC.

935 QUIJANO GONZÁLEZ, J.: "Principales aspectos del estatuto jurídico de los administradores: nombramiento, duración, retribución, conflicto de intereses separación; los suplentes", 1994, op. cit., p. 675; CALBACHO LOSADA, F.: El ejercicio de las acciones de responsabilidad contra los administradores de la sociedad anónima, op. cit., p. 503; RODRÍGUEZ RUIZ DE LA VILLA, D. y HUERTA VIESCA, M. I.: La responsabilidad de los administradores por las deudas de las Sociedades de Capital (en las Leyes de Sociedades Anónimas, de Sociedades de Responsabilidad Limitada, de Sociedad Limitada Nueva Empresa, Concursal, General Tributaria y de Responsabilidad Medioambiental), op. cit., p. 54.

936 BELTRÁN SÁNCHEZ, E.: "La responsabilidad de los administradores por obligaciones sociales”, op. cit., p. 350. 
Lo anterior, no obsta a que se aplique al administrador posteriormente nombrado liquidador, la responsabilidad solidaria, si cuando ostentó la condición de administrador incumplió sus deberes, ya que su responsabilidad nacería de su anterior condición de administrador.

Analicemos brevemente siete supuestos de administradores y figuras conexas que pueden plantear dudas acerca de si están sujetos a la responsabilidad por deudas de Seguridad Social al amparo de los art. 367 de la LSC y art. 18.3 del TRLGSS. Nos referimos a los administradores de hecho, a la persona física designada como representante de la persona jurídica nombrada administradora de una sociedad de capital, al personal de alta dirección, a los apoderados, al administrador social fallecido, al administrador de la sociedad dominante y al consejero empleado público de la sociedad de capital estatal. Figuras cuyo régimen jurídico general se analiza con mayor profundidad en el Capítulo segundo, apartado II. 4, al que nos remitimos.

\subsection{Administrador de hecho.}

Responden solidariamente de las deudas de Seguridad Social, no sólo los administradores de derecho, sino también los administradores de hecho, los que realmente desempeñan de modo continuado y sin título jurídico la administración, sea directamente, o sea indirectamente por ejercer una influencia decisiva en el administrador de derecho.

Se define en nuestro ordenamiento al administrador de hecho como "la persona que en la realidad del tráfico desempeñe sin título, con un título nulo o extinguido, o con otro título, las funciones propias de administrador, como, en su caso, aquella bajo cuyas instrucciones actúen los administradores de la sociedad" (art. 236.3 de la LSC).

Dentro de esa amplia definición legal, el administrador de hecho podrá reconducirse a dos grandes subespecies en la responsabilidad por deudas, el administrador oculto y el administrador notorio. A efectos de un mayor conocimiento de esta figura nos remitimos al Capítulo II, apartado II, 4.1.1 de esta tesis.

Para nuestra jurisprudencia ${ }^{937}$ los rasgos esenciales de la figura del administrador de hecho, serían, en primer lugar, el ejercicio efectivo de las funciones propias del órgano de administración, sea de modo directo en caso del notorio, o de modo indirecto en caso

${ }^{937}$ En la Sentencia 224/2016, de 8 de abril -Rec. 2535/2013-; 421/2015, de 22 de julio -Rec. 1701/2013-; 721/2012, de 4 de diciembre -Rec. 1139/2010-. 
del oculto -la funcionalidad-, en segundo lugar, que el ejercicio de las funciones sea continuado o permanente, no puntual o esporádico (habitualidad), y en tercer lugar, que esas funciones se desempeñen de modo independiente o autónomo sin subordinación a un tercero (autonomía).

Pese a esa omisión o falta de referencia expresa al administrador de hecho en la regulación de la responsabilidad por deudas de los administradores sociales (art. 367 de la LSC), nuestra jurisprudencia ${ }^{938}$ los ha incluido expresamente dentro del ámbito subjetivo de esta responsabilidad por deudas.

La Sentencia del TS, Sala Civil, 455/2017 de 18 julio -Rec. 1589/2014-, justifica esa extensión de la responsabilidad por deudas a los administradores de hecho señalando expresamente que, "esta sala ya se ha pronunciado sobre la cuestión debatida, en el sentido de hacer extensiva la responsabilidad de los administradores a los administradores de hecho, cuando en su actuación intervengan con las mismas facultades y atribuciones que los de derecho". Al intervenir con las mismas facultades y atribuciones que el administrador de derecho, pretendiendo con ello eludirse la responsabilidad por deudas del administrador, nombrándose a un administrador formal, meramente aparente, estamos ante un típico supuesto de fraude de ley, por lo que ha de aplicarse la norma jurídica tratada de eludir, cual es la responsabilidad solidaria del administrador real prevista en el art. 367 de la LSC, sin que sea óbice la alegación de carecer legalmente de competencias para convocar la Junta General, ya que siendo realmente el administrador efectivo, nada le impediría participar de facto, de modo directo -administrador de hecho notorio-, o de modo indirecto -administrador de hecho oculto, instruyendo al administrador formal-, en las convocatorias de la Junta General y en la fijación del orden del día, por lo que, al asumir de hecho los mismos deberes, debe asumir jurídicamente las mismas responsabilidades ${ }^{939}$.

\footnotetext{
938 Sentencias del TS, Sala Civil, 501/2007, de 7 mayo -Rec. 2225/2000-; 228/2008, de 25 marzo -Rec. 219/2001-; 240/2009, de 14 de abril, -Rec. 1504/2004-; 721/2012, de 4 de diciembre -Rec. 1139/2010; 421/2015, de 22 de julio -Rec. 1701/2013-; 224/2016, de 8 de abril -Rec. 2535/2013-; y 455/2017 de 18 julio -Rec. 1589/2014-.

939 HERNANDO CEBRIÁ, L.: “¿Sociedad dominante administradora de hecho? Más allá del velo corporativo", op. cit., p. 10, para quien "se ha de distinguir, por lo tanto, entre aquellos administradores de hecho con posición de dominio o con influencia dominante, por quedar el administrador de Derecho subordinado a ellos, no ya sólo en cuanto a aspectos materiales de gestión empresarial, sino también a aspectos propios de la organización social, de aquellos otros supuestos en los que los administradores intraneus gocen de cierta autonomía”.
} 
En la doctrina científica, ya antes de esta reiterada jurisprudencia admitiendo la responsabilidad del administrador de hecho en la responsabilidad por deudas, un sector mayoritario ${ }^{940}$ defendía su aplicación, frente a un sector minoritario que se mostraba en contra $^{941}$.

En la Guía operativa de la DGITSS de septiembre de 2017 sobre actuación en materia de derivación de responsabilidad a los administradores de sociedades mercantiles capitalistas en materia de deudas de Seguridad Social, se señala que "siempre que podamos demostrar su existencia, cabe la posibilidad de derivarle a él la deuda por aplicación de lo dispuesto en el art. 367 de la LSC, (aunque tengamos que partir de un concepto creado para la responsabilidad general del art. 236 LSC), por cuanto en el art. 367 LSC en el que se establece la responsabilidad solidaria, se refiere a los administradores sin más precisión, lo que admitiría la derivación”.

\subsection{Administrador persona jurídica.}

La sociedad de capital puede nombrar como administradores, no sólo a personas físicas, sino también a personas jurídicas (art. 212.1 LSC). De nombrarse administrador a una persona jurídica, es obligatorio que ésta designe a una sola persona física para el ejercicio permanente de las funciones propias del cargo (art. 212 bis de la LSC).

Al tener la persona jurídica administradora que designar a una persona física, que es la que ejercerá las funciones permanentes del cargo de administrador, debemos plantearnos si esa persona física responde también de modo solidario ante terceros de las deudas de la sociedad de capital al amparo del art. 367 de la LSC.

En el apartado 5 al art. 236 de la LSC se establece que "la persona física designada para el ejercicio permanente de las funciones propias del cargo de administrador

${ }^{940}$ ROJO FERNÁNDEZ-RÍO, A.: "Los deberes legales de los administradores en orden a la disolución de la sociedad de capital como consecuencia de pérdidas", op. cit., p. 1440; BELTRÁN SÁNCHEZ, E.: "La responsabilidad de los administradores por obligaciones sociales", op. cit., pp. 347-348, para quien no sería razonable que el administrador de hecho no asumiese este tipo de responsabilidad por deudas, sin que sea razón suficiente que no se le puede sancionar por no tener competencia para convocar la junta, ya que, al ser el administrador real y efectivo, participará activamente en la decisión de cumplir e incumplir el mandato legal; MARTíNEZ SANZ, F. y BARTLE AGUSTÍN, M.: "Los administradores responsables", op. cit., p. 86; VALPUESTA GASTAMINZA, E. M.: Comentarios a la Ley de Sociedades de Capital, op. cit., p. 952; HERNANDO CEBRIÁ, L.: "¿Sociedad dominante administradora de hecho? Más allá del velo corporativo", op. cit., p. 10.

${ }^{941}$ SÁNCHEZ CALERO, F.: Los administradores en las sociedades de capital, op. cit., p. 458, para quien no puede extenderse al administrador de hecho, la responsabilidad que legalmente sólo se prevé para la responsabilidad por daños, en virtud de una interpretación restrictiva de ese régimen general de la responsabilidad, teniendo en cuenta que el administrador de hecho no puede convocar la Junta General. 
persona jurídica deberá reunir los requisitos legales establecidos para los administradores, estará sometida a los mismos deberes y responderá solidariamente con la persona jurídica administrador". Con la introducción de este nuevo precepto, mediante la Ley 31/2014, de 3 de diciembre, con vigencia desde el 24.12.2014, se extiende el régimen de responsabilidad de los administradores a las personas asimiladas al administrador.

A partir de la introducción de este precepto, responden solidariamente de las deudas de sociedad de capital al amparo del art. 367 de la LSC, tanto la persona jurídica administradora como la persona física designada para el ejercicio permanente de las funciones del cargo ${ }^{942}$. Responsabilidad que estimamos de aplicación por las siguientes razones. En primer lugar, porque la persona física designada para ejercer las funciones del cargo de administrador persona jurídica, debe reunir los requisitos legales establecidos para los administradores, y, lo que es más importante, está sometido a los mismos deberes que éstos, entre ellos los deberes de lealtad, diligencia ${ }^{943}$, y todos los inherentes al cargo, con lo que no podrá alegar que no tiene la potestad de promover jurídicamente la disolución, para convocar la Junta General o solicitar la disolución judicial, obligación que deberá asumir, incluso, de recibir instrucciones contrarias de la persona jurídica administradora. Si tiene esas potestades, no queda exento de responsabilidad si no ha promovido la disolución o solicitado el concurso por haber seguido las instrucciones de la persona jurídica administradora. Las facultades de promover la disolución o de solicitar el concurso, corresponden materialmente al representante del administrador persona jurídica, ya que es el representante el facultado para cumplir con los deberes del art. $365 \mathrm{LSC}^{944}$. En segundo lugar, porque no sólo tiene reconocidos los mismos deberes, sino que no existe disposición legal que le impida ejercer los deberes de promover la disolución, convocar la Junta General, a

${ }^{942}$ MARTÍNEZ SANZ, F. y BARTLE AGUSTÍN, M.: "Los administradores responsables”, op. cit., p. 95; Vid.: BRENES CORTÉS, J.: "Responsabilidad del representante persona física del administrador persona jurídica y su posible configuración como administrador de hecho", op. cit., 2018.

943 MARTÍNEZ SANZ, F. y BARTLE AGUSTÍN, M.: "Los administradores responsables”, op. cit., p. 95; GRIMALDOS GARCÍA, M. I.: "Presupuestos y extensión subjetiva de la responsabilidad. Solidaridad: artículos 236 y 237. Otras acciones por infracción del deber de lealtad: artículos 227.2 y 232", op. cit., p. 327.

944 DEL VAL TALENS, P.: El administrador persona jurídica en las sociedades de capital, op. cit., pp. 368-369. Para esta autora, el representante persona física está facultado para cumplir con los deberes de promover la disolución y el concurso, sin que le exonere no haber recibido instrucciones de la persona jurídica, y paralelamente, la persona jurídica debe, como administrador, estar al tanto de la marcha de la sociedad administrada para dar instrucciones al representante para que éste ejercite los deberes de disolución. 
diferencia de los supuestos de representación voluntaria u otorgamiento de poderes a terceros. En tercer lugar, porque en ese precepto se impone la responsabilidad solidaria ante terceros de la persona física y de la persona jurídica administradora, responsabilidad solidaria que no sólo es aplicable a la responsabilidad por daños, sino también a la responsabilidad por deudas del art. 367 de la LSC, porque en el art. 236.5 de la LSC no se regulan sólo aspectos relativos a la responsabilidad, sino que se recoge el régimen jurídico general de la persona jurídica administradora, por lo que se ha criticado la inclusión de este precepto en el art. 236 de la LSC, cuando debía haberse incluido dentro del art. 212 bis de la LSC ${ }^{945}$.

La persona jurídica administradora y la persona física designada, responden solidariamente de las deudas de Seguridad Social de la sociedad de capital al amparo de lo previsto en el art. 367 de la LSC, bien sea la persona jurídica administrador único de la sociedad de capital, o bien sea administrador conjuntamente con otras personas, en cuyo supuestos esa persona jurídica, en su condición de administrador, y la persona designada, responden con el resto de los administradores, solidariamente entre ellos (solidaridad interna de los administradores), pero también con la sociedad (solidaridad pasiva externa).

Del incumplimiento de los deberes legales de promover la disolución de la sociedad, que constituyen el presupuesto de la responsabilidad solidaria del art. 367 de la LSC, responderán solidariamente de las deudas de Seguridad Social posteriores a la causa de disolución, la persona jurídica administradora y la persona física representante, porque ante los acreedores constituyen un todo unitario a efectos de responsabilidad, el administrador persona jurídica y su representante persona física. Para DEL VAL TALENS $^{946}$, el carácter material de las obligaciones del art. 365 LSC, no excluye la responsabilidad de ninguno de los dos, del administrador persona jurídica y del representante, añadiendo nosotros que, aunque debe ejercitarlas materialmente el representante, a ambos le son exigibles e imputables jurídicamente su incumplimiento. Para que opere la exención de responsabilidad del art. 237 LSC ante los acreedores, será preciso que exista causa de exoneración en la persona física y en la persona jurídica administradora, en ambos de modo conjunto, ya que, si el incumplimiento es imputable

\footnotetext{
945 BRENES CORTÉS, J.: "Responsabilidad del representante persona física del administrador persona jurídica y su posible configuración como administrador de hecho", op. cit. Véase su nota 34.

946 DEL VAL TALENS, P.: El administrador persona jurídica en las sociedades de capital, op. cit., p. 369.
} 
a uno de ellos, ambos responden de modo solidario ante los acreedores, sin perjuicio de que posteriormente quien haya pagado la deuda de la sociedad repita frente al otro, si el incumplimiento fuere imputable a uno sólo de ellos, como sería el supuesto de que el representante persona física haya ocultado información al representante persona jurídica, de modo que ésta desconociese la concurrencia de causa de disolución, lo que impidió conocer la necesidad de promover la disolución ${ }^{947}$.

Con anterioridad a la incorporación de ese apartado 5 del art. 236 LSC, un sector doctrinal $^{948}$ defendía que la persona jurídica administradora era la única responsable de las deudas sociales de la sociedad de capital del art. 367 de la LSC, pero no la persona física designada, sin perjuicio de la posterior reclamación que la persona jurídica administradora pudiera realizar ante la persona física representante, de incumplir su instrucciones, pero sin que los terceros tuvieren acción para reclamar la responsabilidad solidaria a esa persona física. Todo ello, salvo que ese tercero fuese realmente un administrador de hecho, siendo la persona jurídica un mero testaferro, en cuyo caso se aplicaba el régimen jurídico del administrador de hecho. Por el contrario, otro sector ${ }^{949}$, ya defendía la extensión de responsabilidad solidaria a la persona jurídica administradora y a la persona física.

Según la Guía operativa de actuación en materia de derivación de responsabilidad a los administradores de sociedades mercantiles capitalistas en materia de deudas de Seguridad Social, de la DGITSS, de septiembre de 2017, en su página 14 se señala que "No es posible derivar directamente la deuda a la persona física-administradora de la sociedad administradora. Ahora bien, una vez declarada la derivación de responsabilidad a la persona jurídica por la vía del artículo 367 LSC, teniendo en cuenta que el artículo 18.3 LGSS exige que la responsabilidad solidaria se determine en aplicación de cualquier norma con rango de Ley que se refiera o no excluya

947 BRENES CORTÉS, J.: "Responsabilidad del representante persona física del administrador persona jurídica y su posible configuración como administrador de hecho", versión digital, op. cit., p. 15.

948 CALBACHO LOSADA, F.: El ejercicio de las acciones de responsabilidad contra los administradores de la sociedad anónima, op. cit., pp. 545-546; RODRÍGUEZ RUIZ DE LA VILLA, D. y HUERTA VIESCA, M. I.: La responsabilidad de los administradores por las deudas de las Sociedades de Capital (en las Leyes de Sociedades Anónimas, de Sociedades de Responsabilidad Limitada, de Sociedad Limitada Nueva Empresa, Concursal, General Tributaria y de Responsabilidad Medioambiental), op. cit., pp. 60-63.

949 QUIJANO GONZÁLEZ, J.: La responsabilidad civil de los administradores de la Sociedad Anónima, aspectos sustantivos, 1985, op. cit., pp. 347-350 y 372, señalando expresamente como propuesta en las conclusiones (p. 372) que, "en el supuesto de administradores representantes de personas jurídicas, sean o no ellas mismas administradoras, la responsabilidad del representante debe extenderse, por vía de solidaridad, a la persona jurídica cuyo interés se actúa en el órgano social". 
expresamente las obligaciones de Seguridad Social, entendemos que será posible derivar la deuda a la persona física-administradora de la sociedad administradora, (que es quien en realidad ha debido cumplir con las obligaciones establecidas en los artículos 365 y 366 LSC en el plazo de dos meses desde que tuvo conocimiento de la existencia de causa de disolución, y cuyo incumplimiento determina el nacimiento de la responsabilidad solidaria de la persona jurídica administradora) partiendo de la previsión recogida en el artículo 236.5 LSC, que establece que, la persona física designada para el ejercicio permanente de las funciones propias del cargo de administrador persona jurídica deberá reunir los requisitos legales establecidos para los administradores, estará sometida a los mismos deberes y responderá solidariamente con la persona jurídica administrador".

Llega a exigir la responsabilidad solidaria por un camino más tortuoso, cuando resulta directamente impuesta en el art. 236.5 de la LSC, por no reparar esa Guía en que la persona física representante está sometida al régimen jurídico del administrador, con los mismos deberes y responsabilidades, y entre aquéllos el de promover la disolución, por lo que le es imputable la falta de convocatoria de la Junta General o de la solicitud de la disolución judicial, pudiéndose derivar directamente la responsabilidad de las deudas de la sociedad administrada a la persona jurídica administradora y a la persona física designada, conjuntamente con el resto de los administradores de hallarnos ante un administración pluripersonal.

Para la derivación administrativa de responsabilidad se ha de determinar la identificación de la persona jurídica administradora y de la persona física designada como representante, pudiendo obtenerse esa información del Registro Mercantil, donde debe inscribirse la condición de administrador de la persona jurídica, haciendo constar su identidad o razón social (art. 215 de la LSC y arts. 138 y 141 del RRM), e inscribirse la identidad de la persona física designada para ejercer las funciones (art. 143 RRM). La identidad del representante designado debe inscribirse al mismo tiempo que el nombramiento de la persona jurídica administradora en la hoja de la sociedad administrada.

Para un estudio más amplio sobre el contenido y alcance de la solidaridad, interna entre los administradores, y externa ante los acreedores, en el caso del administrador persona jurídica, nos remitimos al Capítulo segundo apartado IV. 4.1.2. 


\subsection{Personal de alta dirección y gerentes.}

Al no ser jurídicamente administradores, ya que no tienen una relación de integración orgánica con la sociedad, sino que el vínculo con ésta es constitutivo de una relación laboral del personal de alta dirección ${ }^{950}$, los gerentes o ese personal de alta dirección ${ }^{951}$ no responderán de las deudas de la sociedad por causa de disolución (arts. 360 y 367 de la LSC).

Lo anterior, pese a que tras la reforma del art. 236 de la LSC, por la Ley 31/2014, de 3 de diciembre ${ }^{952}$, se hubiese ampliado el ámbito subjetivo de la responsabilidad por daños del administrador social, introduciéndose un nuevo apartado 4, donde se incluyen, dentro de las personas sujetas a la responsabilidad por daños de los administradores, al personal que tenga atribuidas las facultades de la más alta dirección, cuando existiendo Consejo de Administración, no exista delegación permanente de facultades por el consejo, por ser ese personal de alta dirección quien asume poderes generales inherentes a la titularidad jurídica de la empresa, salvo los que sean indelegables por el Consejo de Administración, debiendo seguir las instrucciones y recomendaciones del órgano de administración. Rasgos funcionales de ejercer poderes inherentes a la titularidad de la empresa bajo las instrucciones del órgano de administración que definen la condición laboral del personal de alta dirección (art. 1 del Resal Decreto 1382/1985, de 1 de agosto, que regula la relación laboral especial del personal de alta dirección).

En la medida en que los preceptos del ámbito subjetivo de la responsabilidad por daños del art. 236 de la LSC, se han ido extendiendo por la jurisprudencia a la responsabilidad

\footnotetext{
${ }^{950}$ Real Decreto 1382/1985, de 1 de agosto, por el que se regula la relación laboral de carácter especial del personal de alta dirección -BOE del 12 de agosto-. En cuyo art. 1.2 se establece que, "Se considera personal de alta dirección a aquellos trabajadores que ejercitan poderes inherentes a la titularidad jurídica de la Empresa, y relativos a los objetivos generales de la misma, con autonomía y plena responsabilidad sólo limitadas por los criterios e instrucciones directas emanadas de la persona o de los órganos superiores de gobierno y administración de la Entidad que respectivamente ocupe aquella titularidad".

${ }^{951}$ MACHADO PLAZAS, J.: Pérdida del capital social y responsabilidad de los administradores por deudas sociales, op. cit., p. 341; BELTRÁN SÁNCHEZ, E.: "La responsabilidad de los administradores por obligaciones sociales”, op. cit., pp. 350-351; RODRÍGUEZ RUIZ DE LA VILLA, D. y HUERTA VIESCA, M. I.: La responsabilidad de los administradores por las deudas de las Sociedades de Capital (en las Leyes de Sociedades Anónimas, de Sociedades de Responsabilidad Limitada, de Sociedad Limitada Nueva Empresa, Concursal, General Tributaria y de Responsabilidad Medioambiental), op. cit. pp. 63-71; MARTÍNEZ SANZ, F. y BARTLE AGUSTÍN, M.: "Los administradores responsables", op. cit., p. 92; GRIMALDOS GARCÍA, M. I.: "Presupuestos y extensión subjetiva de la responsabilidad. Solidaridad: artículos 236 y 237. Otras acciones por infracción del deber de lealtad: artículos 227.2 y 232”, op. cit., pp. 317-318.

${ }^{952}$ BOE del 4.12.2014.
} 
por deudas del art. 367 de la LSC, cuando las personas asimiladas intervienen con las mismas facultades y atribuciones que los administradores (Sentencia del TS, Sala Civil, 455/2017, de 18 julio -Rec. 1589/2014-), bien pudiera pensarse que ante esa nueva regulación legal que hace responsable a ese personal de alta dirección de la responsabilidad por daños, por aplicación analógica se podría defender la extensión a la responsabilidad por deudas del art. 367 de la LSC, para el personal alta dirección cuando exista Consejo de Administración sin delegación permanente de facultades en consejeros delegados.

No sería jurídicamente aplicable al personal de alta dirección la responsabilidad por deudas del art. 367 de la LSC, no sólo por una interpretación estricta y restrictiva de ese precepto, sino principalmente, porque con la responsabilidad por deudas se sanciona al administrador que ha incumplido los deberes legales de promover la disolución, como convocar la Junta General, y al personal de alta dirección o gerentes no se les puede delegar por el Consejo de Administración la competencia de convocatoria de la Junta General y de la fijación de su orden del día (art. 249 bis apartado j) de la LSC) ${ }^{953}$, al ser indelegables (art. 249 bis apartado j) de la LSC), de modo que si no tiene competencia para convocar la Junta General, y ese es el presupuesto del incumplimiento del primer deber desencadenante de la responsabilidad por deudas, difícilmente es defendible su aplicación a quien no se le puede imputar el incumplimiento de un deber legal. Por otro lado, no puede olvidarse que hay sentencias que, ante el carácter cuasi-sancionador de la responsabilidad por deudas, han negado su aplicación a los representantes voluntarios de la sociedad ${ }^{954}$.

Cuestión distinta sería si ese personal de alta dirección fuese un verdadero administrador de hecho, en cuyo caso, de probarse tal condición, sí resultaría responsable solidario de las deudas de Seguridad Social al amparo del art. 367 de la LSC, pero por su condición de administrador de hecho ${ }^{955}$.

953 Criterio mantenido por la Jurisprudencia en SSTS, Sala Civil, 760/2002, de 16 de julio -Rec. 304/1997-; y 222/2004, de 22 de marzo -Rec. 1556/1998-, entre otras, con carácter general para los representantes voluntarios del órgano de administración.

954 SSTS, Sala Civil, 760/2002, de 16 de julio -Rec. 304/1997-; 222/2004 de 22 de marzo -Rec. 1556/1998-; y 261/2007, de 14 de marzo -Rec. 262/2000-, entre otras.

${ }^{955}$ Sentencias del TS, Sala Civil, 222/2004, de 22 de marzo -Rec. 1556/1998-; 261/2007, de 14 de marzo -Rec. 262/2000-; 501/2007, de 7 de mayo -Rec. 2225/2000-; y 240/2009, de 14 de abril, -Rec. $1504 / 2004-$, entre otras. 


\subsection{Apoderados generales y otros representantes voluntarios.}

Al no tener los apoderados ${ }^{956}$ la condición de administradores, tampoco serán responsables de las deudas de Seguridad Social, por muy amplios que sean sus poderes. La responsabilidad por deudas del art. 367 de la LSC se impone a los administradores, entre los que no podrán incluirse a los apoderados, incluso aunque tengan un poder general, ya que la condición de administradores o de miembros del órgano de administración sólo la ostentan los nombrados como tales por la Junta General (art. 214 LSC).

No serán sujetos responsables de las deudas del art. 367 de la LSC, porque por muy amplios que fuesen sus poderes no tienen la potestad de convocar la Junta General, al ser una atribución indelegable del órgano de administración (art. 249 bis apartado j) de la LSC), y si no tienen competencia para cumplir con el primer deber de promover la disolución (art. 365 de la LSC), no podrá exigirse la responsabilidad por deudas.

Si no concurre la circunstancia de ser el apoderado un administrador de hecho, no será responsable de las deudas sociales, por amplias que pudieran ser las facultades conferidas al mismo, porque si actúa como auténtico mandatario ${ }^{957}$ siguiendo las instrucciones de los administradores legalmente designados, no puede ser calificado como administrador de hecho. Sólo en el caso de que el apoderado sea realmente un administrador de hecho, incurre en responsabilidad por deudas del art. 367 de la LSC, no por su condición de apoderado, sino por su condición de administrador de hecho ${ }^{958}$.

${ }^{956}$ MACHADO PLAZAS, J.: Pérdida del capital social y responsabilidad de los administradores por deudas sociales, op. cit., p. 341; BELTRÁN SÁNCHEZ, E.: "La responsabilidad de los administradores por obligaciones sociales", op. cit., pp. 350-351; RODRÍGUEZ RUIZ DE LA VILLA, D. y HUERTA VIESCA, M. I.: La responsabilidad de los administradores por las deudas de las Sociedades de Capital (en las Leyes de Sociedades Anónimas, de Sociedades de Responsabilidad Limitada, de Sociedad Limitada Nueva Empresa, Concursal, General Tributaria y de Responsabilidad Medioambiental), op. cit. pp. 63-71; MARTÍNEZ SANZ, F. y BARTLE AGUSTÍN, M.: "Los administradores responsables", op. cit., p. 92; GRIMALDOS GARCÍA, M. I.: "Presupuestos y extensión subjetiva de la responsabilidad. Solidaridad: artículos 236 y 237. Otras acciones por infracción del deber de lealtad: artículos 227.2 y 232”, op. cit., pp. 317-318.

957 Sentencias del TS, Sala Civil, de 26 de mayo de 1998 -RJ 1998/4004-; 7 de junio de 1999 -RJ 1999/4730-; 30 de julio de 2001 -RJ 2001/6632-; 760/2002, de 16 de julio -Rec. 304/1997-; 222/2004, de 22 de marzo -Rec. 1556/1998-; 261/2007, de 14 de marzo -Rec. 262/2000-; 501/2007, de 7 de mayo -Rec. 2225/2000-; y 240/2009, de 14 de abril, -Rec. 1504/2004-.

958 Sentencias del TS, Sala Civil, de 26 de mayo de 1998 -RJ 1998/4004-; 7 de junio de 1999 -RJ 1999/4730-; 30 de julio de 2001 -RJ 2001/6632-; 760/2002, de 16 de julio -Rec. 304/1997-; 222/2004, de 22 de marzo -Rec. 1556/1998-; 261/2007, de 14 de marzo -Rec. 262/2000-; 501/2007, de 7 de mayo -Rec. 2225/2000-; 55/2008, de 8 de febrero -Rec. 5168/2000-; y 240/2009, de 14 de abril, -Rec. 1504/2004-, entre otras. 
La condición de administrador de hecho, en principio, no abarca a los apoderados siempre que actúen regularmente por mandato de los administradores o como gestoresfactores de éstos, pues la característica del administrador de hecho no es la realización material de determinadas funciones, sino la actuación en la condición de administrador sin observar las formalidades esenciales que la ley o los estatutos exigen para adquirir tal condición (Sentencia del TS, Sala Civil, 240/2009, de 14 de abril, -Rec. 1504/2004-). No obstante, ha de tenerse en cuenta que la figura del administrador de hecho de las sociedades se presenta a veces como una mera actuación de simples apoderadosgestores, aunque carezcan de poderes, y para destruir esa condición formal con la finalidad de acreditar ser verdaderos administradores de hecho, deberá llevarse a cabo una prueba suficiente, directa o indiciaria, que acredite que ostentan y actúan con la condición de administradores de hecho, lo que resultará más fácil cuando la sociedad carezca de un efectivo administrador legalmente nombrado, ya que no resulta posible la existencia de una sociedad que opere sin los órganos sociales previstos con carácter imperativo en la ley (Sentencia del TS, Sala Civil, 222/2004, de 22 de marzo -Rec. $1556 / 1998-)$

\subsection{Administrador fallecido.}

Si la persona física que ha ostentado el cargo de administrador social hubiere incumplido las obligaciones de procurar la disolución ante la concurrencia de una causa legal de disolución, el hecho de su fallecimiento posterior, que extingue la personalidad civil (art. 32 del Código Civil), no significa que no pueda hacerse efectiva esa responsabilidad por deudas del art. 367 de la LSC del administrador fallecido, porque al hallarnos ante una responsabilidad patrimonial transmisible ${ }^{959}$, tras su fallecimiento esa deuda sí que se podrá reclamar a la herencia yacente o a los herederos ${ }^{960}$ que hayan aceptado la herencia, sin perjuicio de que pueda operar la aceptación a beneficio de inventario, en cuyo supuesto, se responde con el importe de los bienes recibidos (art. 1023.1. ${ }^{\circ}$ del Código Civil).

959 CALBACHO LOSADA, F.: El ejercicio de las acciones de responsabilidad contra los administradores de la sociedad anónima, op. cit., pp. 566-567; RODRÍGUEZ RUIZ DE LA VILLA, D. y HUERTA VIESCA, M. I.: La responsabilidad de los administradores por las deudas de las Sociedades de Capital (en las Leyes de Sociedades Anónimas, de Sociedades de Responsabilidad Limitada, de Sociedad Limitada Nueva Empresa, Concursal, General Tributaria y de Responsabilidad Medioambiental), op. cit., p. 53.

960 SSTS, Sala Civil, núm. 590/2013, de 15 de octubre -Rec. 1268/2011-. 
Esta transmisión a la herencia yacente y a los herederos de la responsabilidad por deudas contraída por el administrador fallecido, se admitió por el Tribunal Supremo, Sala Civil, en la Sentencia núm. 590/2013, de 15 de octubre -Rec. 1268/2011-, partiendo de dos argumentos esenciales. En primer lugar, porque la responsabilidad de los administradores de una sociedad de capital derivada del incumplimiento del deber de promover la disolución no tiene naturaleza sancionadora ${ }^{961}$, por lo que no puede aplicarse el régimen legal sancionador propio de la responsabilidad penal. Si no es una sanción, no procede la aplicación de las garantías constitucionales propias de las normas penales, aunque esta responsabilidad por deudas del art. 367 de la LSC tenga una finalidad disuasoria de determinados comportamientos, como ocurre con las sanciones penales (STC 164/1995, de 13 de noviembre). En segundo lugar, porque en estos supuestos, el crédito reclamado deriva del ejercicio de una acción de responsabilidad civil, que no se extingue por la muerte del obligado responsable, sino que es susceptible de sucesión y, por ello, podría formar parte del caudal hereditario. La muerte extingue la responsabilidad penal, pero no las obligaciones de responsabilidad civil, sea cual fuera la fuente de la que nazcan. Nos encontraríamos ante una responsabilidad solidaria del administrador fallecido con la sociedad (art. 18.3 del TRLGSS y art. 367 de la LSC), y ante una responsabilidad mortis causa de los herederos en la deuda del fallecido (arts. 18.3 y 142.1 del TRLGSS y arts. 13 y 15 del RGRSS). Dos responsabilidades con título jurídico propio, pudiendo procederse a la derivación en un mismo acto, o en dos actos sucesivos. Será en un mismo acto si cuando se deriva la deuda a los administradores sociales, ya había fallecido con anterioridad uno de los administradores responsables, constando fehacientemente ese hecho y la identidad de los herederos, en cuyo caso, los herederos o la herencia yacente ocuparán la posición del fallecido en virtud de la nueva y compatible responsabilidad mortis causa. Será una derivación en dos actos distintos y sucesivos, si el fallecimiento del administrador tiene lugar después de dictarse el acto administrativo de derivación de su responsabilidad sin haberse efectuado el pago de la deuda, en cuyo caso, deberá promoverse una nueva y posterior derivación administrativa de la deuda al amparo del art. 15 del RGRSS.

961 SSTS, Sala Civil, 458/2010, de 30 de junio; 557/2010, de 27 de septiembre -Rec. 2194/2006-; 923/2011, de 26 de noviembre -Rec. 1769/2008-; 104/2012, de 5 de marzo -Rec. 411/2009-; 225/2012, de 13 de abril -Rec. 1018/2009- ; 818/2012, de 11 de enero -Rec. 2236/2010-; y 414/2013, de 21 de junio -Rec. 809/2011-. 


\subsection{Administrador de la sociedad dominante $y$ responsabilidades del grupo societario.}

En el tráfico jurídico es muy frecuente la presencia de grupos de sociedades que se hallan bajo una misma dirección unitaria. Grupo societario admitido en el ordenamiento jurídico, y que tiene como función esencial maximizar todos los recursos para obtener la consecución del objeto social del grupo, así como los objetos sociales o actividades de las sociedades integrantes del grupo. Grupos que podrán tener una estructura jerárquica o una estructura de coordinación u horizontal.

Para un mayor conocimiento de la condición de administrador de hecho de la sociedad dominante o de sus administradores, con relación a las sociedades filiales, nos remitimos al Capítulo Segundo, apartado II.4.1.4.

Como señala VICENT CHULIÁ ${ }^{962}$, el grupo de sociedades es perfectamente lícito en nuestro ordenamiento, salvo en los supuestos de grupos fraudulentos en los que existe comunicación de responsabilidades entre las sociedades del grupo, salvo que sea un grupo patológico.

Los grupos societarios no han sido objeto de una regulación general de su régimen jurídico, encontrando una definición legislativa general de los mismos en el art. 42.1 del Código de Comercio, al regular la contabilidad y la consolidación de las cuentas en los grupos societarios. En ese precepto se define al grupo de sociedades, cuando una sociedad dominante ejerce el control sobre otras u otras sociedades dependientes.

En la LSC no existe una regulación del régimen general de responsabilidad de los grupos de sociedades, ni una definición de los mismos, remitiéndose al Código de Comercio, ya que en el art. 18 de la LSC, se establece que, "a los efectos de esta ley se considerará que existe grupo de sociedades cuando concurra alguno de los casos establecidos en el artículo 42 del Código de comercio, y será sociedad dominante la que ostente o pueda ostentar, directa o indirectamente, el control de otra u otras".

Tampoco encontramos una definición legal del grupo en la normativa laboral general, por lo que debe acudirse al art. 42 del Código de Comercio, sin que ello sea óbice para que sea contemplado en varias disposiciones de esta rama social del Derecho. Sólo excepcionalmente encontramos una definición del grupo societario en alguna

\footnotetext{
962 VICENT CHULIÁ, F., “Grupos de sociedades y conflictos de intereses”, op. cit., edición digital, pp. 1
} y 3 . 
disposición normativa del Derecho del Trabajo, como ocurre en la normativa relativa a la consulta y participación de los representantes de los trabajadores en empresas o sociedades de dimensión comunitaria, como el art. 4 de la Ley 10/1997, de 24 de abril, sobre derechos de información y consulta de los trabajadores en las empresas y grupos de empresas de dimensión comunitaria ${ }^{963}$, precepto al que se remite el art. 2 apartado d) de la Ley 31/2006, de 18 de octubre, sobre implicación de los trabajadores en las sociedades anónimas y cooperativas europeas ${ }^{964}$, que recogen una definición similar a la del art. 42 del Código de Comercio.

En el grupo de sociedades puede existir una dirección unitaria en la estrategia y en políticas del grupo, en la programación de los objetivos generales de las sociedades del grupo. Esa dirección unitaria no determina necesariamente la existencia de una responsabilidad solidaria de las sociedades del grupo, por la personalidad jurídica independiente de cada sociedad del grupo, disponiendo cada una de su propio patrimonio. La dirección unitaria no conlleva la responsabilidad solidaria de las empresas integrantes del grupo por el mero hecho de tener administradores o accionistas

${ }^{963}$ BOE del 25.4.1997. En el artículo 4 de esa Ley se define en los siguientes términos a la empresa que ejerce el control.

"Artículo 4. Definición de «empresa que ejerce el control». 1. A efectos de la presente Ley se considerará «empresa que ejerce el control» a aquella que pueda ejercer una influencia dominante sobre otra, que se denominará «empresa controlada», por motivos de propiedad, participación financiera, estatutos sociales u otros. 2. Se presumirá, salvo prueba en contrario, que una empresa puede ejercer una influencia dominante sobre otra cuando dicha empresa, directa o indirectamente: a) Posea la mayoría del capital suscrito de la empresa. b) Posea la mayoría de los Derechos de voto correspondientes a las acciones emitidas por la empresa. c) Tenga la facultad de nombrar a la mayoría de los miembros del órgano de administración, de dirección o de control de la empresa. Cuando dos o más empresas de un grupo cumplan uno o varios de los requisitos anteriores, tendrá la consideración de «empresa que ejerce el control» aquella que reúna el señalado en la letra c) o, en su defecto, el de la letra b), salvo que se pruebe que otra empresa puede ejercer una influencia dominante. 3. A efectos de lo dispuesto en el apartado anterior, los Derechos de voto y de nombramiento que ostente la empresa que ejerce el control incluirán los de cualquier otra empresa controlada y los de toda persona u órgano que actúe en nombre propio pero por cuenta de la empresa que ejerce el control o de cualquier otra empresa controlada. 4. No obstante lo dispuesto en los apartados anteriores: a) No se considerará que una empresa ejerce el control respecto de otra de la que posea participaciones cuando se trate de una de las sociedades contempladas en el artículo 3 , apartado 5, letras a) o c), del reglamento (CE) núm. 139/2004 del Consejo, de 20 de enero de 2004, sobre control de las concentraciones entre empresas. b) No se presumirá que existe influencia dominante únicamente por el hecho de que un mandatario ejerza sus funciones en virtud de la legislación de un Estado miembro, relativa a la liquidación, la quiebra, la insolvencia, la suspensión de pagos, el concurso de acreedores u otro procedimiento análogo. 5. La legislación aplicable a fin de determinar si una empresa es una «empresa que ejerce el control» será la legislación del Estado miembro por la que se rija dicha empresa.

Cuando la legislación por la que se rige la empresa no sea la de un Estado miembro, la legislación aplicable será la del Estado miembro en el que esté establecido su representante o, a falta de tal representante, la del Estado miembro en que esté situada la dirección central de la empresa del grupo que emplee al mayor número de trabajadores".

${ }^{964}$ BOE del 19.10.2006. 
comunes $^{965}$, de tener una dirección comercial común ${ }^{966}$, o, por la circunstancia de estar las sociedades participadas entre si $^{967}$. Esas meras circunstancias no son suficientes para derivar la responsabilidad solidaria en deudas de Seguridad Social a todas las empresas del grupo ${ }^{968}$. Sólo podrá apreciarse responsabilidad si hubiere un uso abusivo de la dirección en perjuicio de terceros (v. gr.: los trabajadores, etc.).

Con carácter general en el grupo de sociedades cada sociedad integrante tiene su propia personalidad jurídica y asume sus propias responsabilidades por los incumplimientos de sus obligaciones, por lo que, en principio, cada sociedad de capital integrante de un grupo responde de sus propias deudas de Seguridad Social, y la responsabilidad del administrador social es exigible con relación al incumplimiento de sus obligaciones respecto de la sociedad de la que es administrador, pero no responde del incumplimiento de las obligaciones de los administradores de las otras sociedades del grupo.

No existe comunicación de responsabilidades ni entre sociedades ni entre administradores de las distintas sociedades del grupo, salvo en dos situaciones. En primer lugar, habrá comunicación de responsabilidad solidaria entre todas las sociedades integrantes de un grupo, cuando pueda calificarse a éste como empresa grupo a efectos laborales o grupo patológico ${ }^{969}$, en cuyo caso en aplicación del art. 18.4 del TRLGSS podrá derivarse al resto la responsabilidad solidaria por deudas de cotización de cualquiera de las integrantes del grupo. En segundo lugar, existirá

${ }^{965}$ SSTS, Sala Social, de 21 de diciembre de 2000 -Rec. 4383/1999-, y 26 de diciembre de 2001 -Rec. 139/2001-.

${ }^{966}$ SSTS, Sala Social, de 30 de abril de 1999 -Rec. 4003/1998-.

${ }^{967}$ SSTS, Sala Social, de 20 de enero de 2003 -Rec. 1524/2002-, y 3 de noviembre de 2005 -Rec. 3400 /2004-.

${ }^{968}$ SSTS, Sala Contencioso-Administrativa, 1661/2018, de 22 de noviembre -Rec. 2507/2016-.

${ }^{969}$ Sobre los grupos de empresa véase, MOLINA NAVARRETE, C.: Persona jurídica y disciplina de los grupos de empresa, Edit. Publicaciones del Real Colegio de España, Bolonia, 1995; CRUZ VILLALÓN, J.: "Notas acerca del régimen contractual en los grupos de empresa", en Temas Laborales, 1996, $\mathrm{n}^{\circ}$ 38; MONEREO PÉREZ, J. L.: Teoría jurídica de los grupos de empresas y Derecho del trabajo, Editorial Comares, 1997; PÉREZ DE LOS COBOS ORIHUEL, F.: "Filialización. Grupos de empresa", en Descentralización productiva y nuevas formas organizativas del trabajo, X Congreso Nacional de Derecho del Trabajo y de la Seguridad Social, Ministerio de Trabajo y Asuntos Sociales, Madrid, 2000; BAZ RODRÍGUEZ, J.: Las relaciones de trabajo en la empresa de grupo, Editorial Comares, Granada, 2002; MONTOYA MELGAR, A.: "El poder de dirección del empresario en las estructuras empresariales complejas", en Revista del Ministerio de Trabajo y Asuntos Sociales, $\mathrm{N}^{\circ}$ 48, 2004; SEMPERE NAVARRO, A. V. y ARETA MARTÍNEZ, M.: "El Derecho del Trabajo y los Grupos de Empresas: inventario", en Revista del Ministerio de Trabajo y Asuntos Sociales, $\mathrm{N}^{\circ}$ 48, 2004; JIMÉNEZ ROJAS, F.: La relación individual de trabajo en los grupos de empresa, Editum, Murcia, 2014; MOLINS GARCÍA-ATANCE, J.: "El grupo de empresas con efectos laborales", en Trabajo y Derecho, La Ley, $\mathrm{N}^{\circ}$ 4, abril 2015, edición digital; CRUZ VILLALÓN, J. y DOMÍNGUEZ MORALES, A.: "El Empresario", en Revista Española de Derecho del Trabajo, núm. 215, 2018, Thomson Reuters, 2018. 
comunicación de responsabilidades, cuando pueda atribuirse la condición de administrador de hecho de alguna filial a los administradores de la sociedad matriz o a la propia sociedad dominante del grupo, en cuyo caso ese administrador de hecho de la filial respondería de las obligaciones que la legislación establece para los administradores de derecho de la filial.

Para que pueda apreciarse la responsabilidad solidaria de las sociedades de un grupo, en la empresa grupo laboral o grupo patológico, es preciso que concurran varios requisitos. Para que pueda aplicarse la responsabilidad solidaria de las distintas sociedades del grupo, nuestra jurisprudencia social y Contencioso-Administrativa exige la concurrencia de varios requisitos: a) funcionamiento unitario, con prestaciones laborales indiferenciadas; b) la confusión patrimonial; c) la unidad de caja; d) la utilización fraudulenta de la personalidad jurídica, con creación de la empresa "aparente"; y e) el uso abusivo -anormal- de la dirección unitaria, con perjuicio para los derechos de los trabajadores. Circunstancias que han recibido una previa matización o precisión en la jurisprudencia, para evitar una extensión de la responsabilidad solidaria indebida. La extensión de la responsabilidad de las empresas del grupo no exige que concurran acumulativamente todas esas circunstancias, entre otras cosas, porque en un entramado de empresas, la intensidad o la posición en relación de aquéllas con los trabajadores o con el grupo no es la misma ${ }^{970}$.

Para evitar una extensión de la responsabilidad solidaria indebida se han delimitado esos requisitos en la jurisprudencia ${ }^{971}$. La confusión patrimonial no es identificable con el capital social, ya que el control del capital no implica confusión de patrimonios, y sin que se estime concurrente por la mera utilización de infraestructuras comunes. La caja única hace referencia a lo que en doctrina se ha calificado como "promiscuidad en la gestión económica" y que alude a la situación de "permeabilidad operativa y contable", que no es identificable con las novedosas situaciones de «cash pooling» entre empresas del mismo grupo, en las que la unidad de caja es meramente contable y no va acompañada de confusión patrimonial alguna, por tratarse de una gestión centralizada de la tesorería. Con el requisito de "creación de empresa aparente" -íntimamente unido a la confusión patrimonial y de plantillas- se alude a la utilización fraudulenta de la personalidad jurídica, que es la que consiente la aplicación de la doctrina del

\footnotetext{
${ }^{970}$ SSTS, Sala Social, de 20 de marzo de 2013 -Rec. 81/2012- y 27 de mayo de 2013 -Rec. 78/2012-,
} entre otras.

${ }^{971}$ Por todas STS, Sala Social, de 27 de mayo de 2013 -Rec. 78/2012-. 
"levantamiento del velo". Finalmente, se aclara que la legítima dirección unitaria puede ser objeto de abusivo ejercicio -determinante de solidaridad- cuando se ejerce anormalmente y causa perjuicio a los trabajadores, como en los supuestos de actuaciones en exclusivo beneficio del grupo o de la empresa dominante.

En el grupo de empresas a efectos laborales el levantamiento del velo permite descubrir al grupo como verdadero empresario unitario ${ }^{972}$. Se podrá derivar la responsabilidad solidaria a las empresas del grupo, al ser el verdadero empresario ${ }^{973}$.

Derivación de responsabilidad solidaria a las sociedades integrantes de la empresa grupo, que, a efectos de cotización a la Seguridad Social, se ha reconocido en reiterada jurisprudencia de la Sala Contencioso-Administrativa del Tribunal Supremo ${ }^{974}$, en

972 MOLINS GARCÍA-ATANCE, J.: "El grupo de empresas con efectos laborales", en Trabajo y Derecho, La Ley, No 4, abril 2015, edición digital, p. 6.

973 En este sentido, ÁlVAREZ ROYO-VILLANOVA, S.: "La necesaria revisión de la doctrina del levantamiento del velo", en AA.VV. (Dir.: MARTÍNEZ-ECHEVERRÍA Y GARCÍA DE DUEÑAS, A.): Gobierno Corporativo: la Estructura del órgano de Gobierno y la Responsabilidad de los Administradores, Aranzadi Thomson Reuters, $1^{\mathrm{a}}$ edición, 2015, p. 841.

${ }^{974}$ STS, Sala Contencioso-Administrativa, 1661/2018, de 22 de noviembre -Rec. 2507/2016-; 1673/2016, de 8 de julio -Rec. 3831/2014-; 1292/2016, de 2 de junio -Rec. 2890/2014-.

En la Sentencia del TS, Sala Contencioso-Administrativa, 1292/2916, de 2 de junio -Rec. 2890/2014-, se señala "Por su parte, el art. 15 de la LGSS , al que remite el art. 104 de la misma, establece en su redacción por Ley 52/2003, en vigor desde el 1 de enero de 2004, una pluralidad de supuestos de responsabilidad solidaria. Además del previsto en su apartado 3, responsabilidad por aplicación de supuestos previstos en cualquier norma con rango de ley, entre los que tendría cabida el art. 44 del ET, se introdujo también en la Ley 52/2003 el apartado 4 que dispone: «4. En caso de que la responsabilidad por la obligación de cotizar corresponda al empresario, podrá dirigirse el procedimiento recaudatorio que se establece en esta Ley y su normativa de desarrollo contra quien efectivamente reciba la prestación de servicios de los trabajadores que emplee, aunque formalmente no figure como empresario en los contratos de trabajo, en los registros públicos o en los archivos de las entidades gestoras y servicios comunes». Por consiguiente, tras la reforma del art. 15 de la LGSS por la Ley 52/2003, que introdujo los nuevos apartados 3 y 4 , ya es posible, sin ninguna duda, fundar la responsabilidad solidaria en la existencia de un grupo de empresas, con la única condición de que éste exista realmente y pueda afirmarse que es éste, el grupo de empresas, el empresario real, sin necesidad de sobreponer o mezclar la regulación legal de la sucesión de empresas con la doctrina jurisprudencial del grupo de empresas. Para declarar la responsabilidad con esta base, lo relevante no es tanto el elemento de fraude a los Derechos de los trabajadores que la actora dice inexistente, sino si es posible alcanzar la conclusión de que el empresario real que recibe la prestación laboral, y por ende es responsable de la obligación de cotizar, es el grupo de empresas y, por tanto, todas ellas han de responder del pago de la obligación, aunque no sean la empresa formalmente empleadora. Para establecer esta conclusión hay que acudir a la realidad económica, organizativa y patrimonial subyacente, más allá del papel que juegue cada una de las empresas en el conjunto del grupo", y para la calificación del grupo, acude a los rasgos identificativos sentados en por la Sala Social, indicando en el Fundamento de Derecho Quinto, "Por consiguiente, en el estado actual de la jurisprudencia, la presencia de los "elementos adicionales" a los que la Sala de instancia se refiere resulta esencial para entender que concurre una unidad empresarial a efectos laborales en los grupos de empresa. Y esos componentes adicionales, a tenor de aquella doctrina, serían actualmente los siguientes: 1. El funcionamiento unitario de las organizaciones de trabajo de las empresas del grupo, manifestado en la prestación indistinta de trabajo -simultánea o sucesivamente- en favor de varias de las empresas del grupo; 2. La confusión patrimonial; 3. La unidad de caja; 4. La utilización fraudulenta de la personalidad jurídica, con creación de la empresa «aparente»; y 5. El uso abusivo -anormal- de la dirección unitaria, con perjuicio para los Derechos de los trabajadores". 
aplicación del art. 18.4 del TRLGSS, reconociéndose que, para declarar la responsabilidad solidaria, lo relevante no es el hecho de que deba concurrir el elemento de fraude a los derechos de los trabajadores, sino si es posible concluir que el empresario real que recibe la prestación laboral, y por ende responsable de la obligación de cotizar, es el grupo de empresas. Si el grupo es el empresario real, las sociedades que lo integran han de responder del pago de la obligación de cotizar a la Seguridad Social, y, para llegar a identificar a la empresa grupo hay que acudir a la realidad económica, organizativa y patrimonial de las sociedades, más allá del papel que juegue cada una de ellas en el conjunto del grupo.

En la empresa grupo no estaremos ante una derivación de responsabilidad al amparo del art. 18.3 del TRLGSS. La responsabilidad solidaria en la empresa grupo no tienen como fundamento jurídico el art. 18.3 del TRLGSS, ya que no exige que concurran hechos susceptibles de ser subsumidos en normas jurídicas ajenas, sino que esta responsabilidad viene impuesta en la propia norma de Seguridad Social (art. 18.4 del TRLGSS), al ser el propio grupo el empresario real entendido como entidad sin personalidad jurídica (art. 1.2. del TRLET ${ }^{975}$ ).

Por otro lado, en Sentencia del TS, Sala Contencioso-Administrativa, 1661/2018, de 22 de noviembre -Rec. 2507/2016-, recogiendo doctrina de la Sala Social, que cita, señala, que, "para extender la responsabilidad no basta la concurrencia de que dos o más empresas pertenezcan al mismo grupo, para derivar de ello, sin más, una responsabilidad solidaria, sino que es necesaria la concurrencia de otros elementos adicionales, como la confusión de plantillas; la confusión de patrimonios sociales; la apariencia externa de unidad empresarial y la dirección unitaria de varias entidades empresariales; por consiguiente, los componentes del grupo tienen, en principio un ámbito de responsabilidad propio, como personas jurídicas independientes que son. En síntesis, la unidad real del grupo como ente empresarial único requiere: unidad de actividades; trasvase de fondos y cesiones inmobiliarias; movilidad de los trabajadores en el seno del grupo; estrategia unificadora y prestaciones laborales indiferenciadas, es decir, que los trabajadores realicen su prestación de modo simultáneo e indiferenciado en varias sociedades del grupo" (...), "Es doctrina jurisprudencial reiterada de esta Sala de lo Social del Tribunal Supremo que el grupo de empresas a efectos laborales no es un concepto de extensión equivalente al grupo de sociedades del Derecho Mercantil. El reconocimiento del grupo de empresas en el ordenamiento laboral, cuyos efectos se manifiestan sobre todo en la comunicación de responsabilidades entre las empresas del grupo, exige la presencia de una serie de factores atinentes a la organización de trabajo; y estos factores, sistematizados en la sentencia de 3 de mayo de 1990 y en otras varias posteriores como la de 29 de mayo de 1995, la de 26 de enero de 1998 y la de 26 de diciembre de 2001, configuran un campo de aplicación normalmente más restringido que el del grupo de sociedades. En concreto, estos factores específicos del grupo de empresas en el ordenamiento laboral consisten en la existencia de un funcionamiento integrado de la organización de trabajo, o en la prestación de trabajo indistinta o común a las empresas del grupo, o en la búsqueda artificiosa de dispersión o elusión de responsabilidades laborales".

${ }^{975}$ En la STS, Sala Tercera, de 1673/2016, de 8 de julio -Rec. 3831/2014- en su Fundamento de Derecho Octavo, señala que "tras la reforma del artículo 15 de la LGSS por la Ley 52/2003, que introdujo los nuevos apartados 3 y 4, ya es posible, sin ninguna duda, fundar la responsabilidad solidaria en la existencia de un grupo de empresas, con la única condición de que éste exista realmente y pueda afirmarse que es éste, el grupo de empresas, el empresario real, sin necesidad de sobreponer o mezclar la regulación legal de la sucesión de empresas con la doctrina jurisprudencial del grupo de empresas. 
Por otro lado, pese a no haberse regulado expresamente la responsabilidad por deudas de los administradores de la sociedad dominante, el ejercicio de la dirección unitaria sobre la sociedad dominada podría determinar la declaración de la responsabilidad solidaria de la sociedad dominante o de sus administradores, acudiendo a la figura del administrador de hecho, en los supuestos en que se pueda atribuir esa condición a los administradores de la sociedad matriz o a la propia sociedad dominante ${ }^{976}$. Podrá atribuirse la condición de administrador de hecho de la sociedad dominada, además de a los administradores de derecho de la sociedad matriz, también a la propia sociedad dominante $^{977}$, y/o al socio con control mayoritario ${ }^{978}$, si son éstos los que actúan como verdaderos administradores de hecho, como pudiera suceder cuando las instrucciones al administrador de derecho de la filial procedan directamente de la Junta General de la matriz, o de quien ostenta el control mayoritario del capital ${ }^{979}$.

Condición de administrador de hecho de la sociedad filial o dependiente que podrá tener el administrador de derecho de la sociedad matriz o dominante, bien por actuar como

Para declarar la responsabilidad con esta base, lo relevante no es tanto el elemento de fraude a los Derechos de los trabajadores, sino si es posible alcanzar la conclusión de que el empresario real que recibe la prestación laboral, y por ende es responsable de la obligación de cotizar, es el grupo de empresas y, por tanto, todas ellas han de responder del pago de la obligación, aunque no sean la empresa formalmente empleadora. Para establecer esta conclusión hay que acudir a la realidad económica, organizativa y patrimonial subyacente, más allá del papel que juegue cada una de las empresas en el conjunto del grupo".

976 DÍAZ ECHEGARAY, J. L: Deberes y responsabilidades de los Administradores de sociedades de Capital, 2006, op. cit. pp. 293-301; SÁNCHEZ CALERO, F.: Los administradores en las sociedades de capital, 2007, op. cit. pp. 361-363; VICENT CHULIÁ, F.: "Grupos de sociedades y conflictos de intereses", op. cit., edición digital, p. 3, que en los grupos patrológicos apunta la posible condición de administrador de hecho de la sociedad dominante; MARTÍNEZ SANZ, F. y BARTLE AGUSTÍN, M.: “Los administradores responsables”, 2016, op. cit., pp. 87-90; HERNANDO CEBRIÁ, L.: “¿Sociedad dominante administradora de hecho? Más allá del velo corporativo", op. cit., pp. 25-31; MARTÍNEZGIRÓN MACHUCA, P.: "Algunas reflexiones sobre la responsabilidad de los administradores en los grupos de sociedades tras la Sentencia del Tribunal Supremo de 11 de diciembre de 2015", op. cit., pp. 161-178, para quien podrá atribuirse en los grupos de sociedades la condición de administrador de hecho a la sociedad dominante y a sus administradores; MORENO SERRANO, E.: "La responsabilidad de la sociedad matriz como administrador de hecho", 2018, op. cit., pp. 259-264.

977 SÁNCHEZ CALERO, F.: Los administradores en las sociedades de capital, op. cit., p. 362-363; HERNANDO CEBRIÁ, L.: “SSociedad dominante administradora de hecho? Más allá del velo corporativo”, op. cit., pp. 25-26; MARTÍNEZ-GIRÓN MACHUCA, P.: “Algunas reflexiones sobre la responsabilidad de los administradores en los grupos de sociedades tras la sentencia del Tribunal Supremo de 11 de diciembre de 2015", op. cit., pp. 161-178; MORENO SERRANO, E.: “ $L a$ responsabilidad de la sociedad matriz como administrador de hecho”, 2018, op. cit., p. 264.

978 HERNANDO CEBRIÁ, L.: “¿Sociedad dominante administradora de hecho? Más allá del velo corporativo”, op. cit., pp. 25-26.

979 HERNANDO CEBRIÁ, L.: “SSociedad dominante administradora de hecho? Más allá del velo corporativo", op. cit., pp. 25-26, quien señala que "cuando las instrucciones provengan de la Junta General de la sociedad, como órgano soberano, se puede atribuir a ésta la condición de administradora de hecho", y paralelamente, que, "cuando la actuación del administrador de Derecho de la matriz que actúe, a su vez, como administrador oculto en la filial, provenga de las instrucciones recibidas desde el socio mayoritario de la misma, a él será también trasladable, eadem ratio, la aplicación de la doctrina del administrador de hecho" (sic). 
administrador notorio o como administrador oculto de seguir el administrador de la filial de modo continuado las directrices que le imparte habitual y permanentemente el administrador de la sociedad matriz (art. 236.3 de la LSC).

De hallarnos ante la primera modalidad de administrador de hecho notorio, y probarse que los administradores de la sociedad dominante son quienes realmente ejercen las funciones de administración y gestión en la sociedad dominada, partiendo de la doctrina jurisprudencial $^{980}$ del administrador de hecho notorio, los administradores de la sociedad dominante ostentarán la condición de administradores de hecho de sociedad dominada, cuando concurran tres condiciones. En primer lugar, cuando desarrollen una actividad de gestión sobre materias propias del administrador de la sociedad dominada, entre ellas, convocar las juntas. En segundo lugar, cuando la actividad de gestión en la sociedad filial se realice de forma permanente, habitual y continuada, esto es, cuando el ejercicio de la gestión tenga intensidad cualitativa y cuantitativa. Y, en tercer lugar, cuando esa actividad gestora se preste de forma independiente, con poder autónomo de decisión, imponiéndose a la sociedad dominada.

Mayor dificultad probatoria encontraremos para calificar a la sociedad matriz o al administrador de ésta, como administrador de hecho oculto, que es aquél que, sin ejercer materialmente las funciones de administración, es quien decide en último término los actos constitutivos de la administración de la filial, al impartir instrucciones continuadas, habituales y permanentes sobre la gestión y administración de la sociedad dominada, no teniendo autonomía ni independencia los administradores de la filial. En este supuesto podríamos hallarnos ante el administrador oculto del art. 236.3 de la LSC, condición que recaería en los administradores de la sociedad dominante o en la sociedad dominante ${ }^{981}$.

${ }^{980}$ En la Sentencia del TS, Sala Civil, 224/2016, de 8 de abril -Rec. 2535/2013-, sobre el concepto y rasgos definitorios del administrador de hecho, señala, "la noción de administrador de hecho presupone un elemento negativo (carecer de la designación formal de administrador, con independencia de que lo hubiera sido antes, o de que lo fuera después), y se configura en torno a tres elementos caracterizadores: i) debe desarrollar una actividad de gestión sobre materias propias del administrador de la sociedad; ii) esta actividad tiene que haberse realizado de forma sistemática y continuada, esto es, el ejercicio de la gestión ha de tener una intensidad cualitativa y cuantitativa; y iii) se ha de prestar de forma independiente, con poder autónomo de decisión, y con respaldo de la sociedad".

${ }^{981}$ MORENO SERRANO, E.: "La responsabilidad de la sociedad matriz como administrador de hecho", op. cit., p. 261, para quien, "habría administración de hecho por parte de la sociedad dominante cuando se supera la actividad de gestión, planificación y control de la política del grupo, para llegar a suplantar la voluntad de los administradores de las filiales de manera continuada mediante 
Constatado el incumplimiento de los deberes de promoverse la disolución o de solicitar el concurso de la sociedad filial, si podemos atribuir a los administradores de la sociedad dominante la condición de administrador de hecho, sea notorio u oculto, de la sociedad dominada, partiendo de la doctrina jurisprudencial establecida sobre la concurrencia de los requisitos propios de esta figura, cabría la derivación administrativa de la responsabilidad solidaria de las deudas de Seguridad Social de la sociedad dominada, a los administradores de ésta, y a los administradores de la sociedad dominante, en su condición de administradores de hecho de la filial; e incluso, en supuestos muy excepcionales, a la propia sociedad matriz, de probarse que es ésta la administradora de hecho. Decimos muy excepcionalmente a la sociedad dominante, porque ésta tendrá su propio órgano de administración que será quien ejerza normalmente como administrador de hecho de la filial, por el propio reparto de funciones orgánicas en las sociedades de capital, de modo que para atribuir esa condición a la propia matriz o al socio de la matriz con control mayoritario, se exigiría un mayor esfuerzo probatorio para acreditar que son éstos los que asumen la función de administradores de hecho de la filial.

Si el administrador social de la sociedad dominada ha de tener autonomía de decisión para cumplir con sus deberes legales, por no estar sujeto a una obediencia debida a la matriz, al no ser el interés del grupo absoluto y superior al interés de la sociedad administrada $^{982}$, sin que en ningún caso pueda poner en riesgo la continuidad y solvencia de la sociedad dominada ${ }^{983}$, la circunstancia de haber seguido las instrucciones permanentes de la sociedad matriz no les exonera de responsabilidad. No es causa eximente del incumplimiento de los deberes legales de ordenada disolución de los arts. 364 a 367 de la LSC, el hecho de haberse visto obligados los administradores de la sociedad filial a seguir las instrucciones de los administradores de la sociedad matriz. Se ha defendido por la doctrina ${ }^{984}$ la aplicación analógica del art. 236.2 LSC,

instrucciones permanentes, reiteradas, y con conocimiento y consentimiento de la filial, ya que de este modo se podría imputar los actos del administrador de hecho a la propia sociedad" (sic).

982 STS, Sala Civil, 695/2015, de 11 de diciembre -Rec. 2141/2013-; 45/2019, de 23 de enero -Rec. 243/2016-.

983 MARTÍNEZ-GIRÓN MACHUCA, P.: “Algunas reflexiones sobre la responsabilidad de los administradores en los grupos de sociedades tras la Sentencia del Tribunal Supremo de 11 de diciembre de 2015”, op. cit., pp. 174-178.

${ }^{984}$ DÍAZ ECHEGARAY, J. L.: Deberes y responsabilidades de los Administradores de Sociedades de Capital, 2006, op. cit., pp. 300-301, quien estima que la relación del grupo no modifica las obligaciones de los administradores de la sociedad dominada, quienes deben cumplir sus funciones con la diligencia propia del cargo; SÁNCHEZ CALERO admitiendo la aplicación analógica del actual 
que establece que no se exonera de responsabilidad el administrador por la circunstancia de haber incumplido un deber legal siguiendo instrucciones de la Junta General, de modo que por analogía, tener que seguir los administradores de la sociedad filial las instrucciones de la sociedad matriz, no es causa eximente del incumplimiento de los deberes de promover disolución.

No es causa eximente porque en la jurisprudencia de la Sala Civil del Tribunal Supremo $^{985}$, el administrador de la sociedad filial tiene un ámbito de responsabilidad que no desaparece por el hecho de la integración en un grupo societario, pues tal integración no deroga sus obligaciones de gestión ordenada, representación leal, fidelidad al interés de la sociedad, lealtad y secreto que le incumben como tal administrador social, y que vienen referidos a la sociedad de la que es administrador, no al grupo societario ni a otras sociedades integradas en el grupo.

Acreditada la condición de administrador de hecho de la propia sociedad matriz o del administrador de la sociedad dominante, procedería la derivación de responsabilidad al amparo del art. 18.3 del TRLGSS. No acreditándose que la sociedad matriz sea administradora de hecho, podría exigirse la responsabilidad a la sociedad dominante por las deudas de Seguridad Social de la sociedad dominada, por otras vías jurídicas, como sería en los supuestos de descapitalización fraudulenta de la sociedad dominada por la dominante, o abuso de la personalidad jurídica en perjuicio de los créditos de Seguridad Social, acudiendo a la doctrina jurisprudencial del levantamiento del velo, en cuyo caso la derivación de responsabilidad sería al amparo del art. 18.4 del TRLGSS.

\subsection{Consejero empleado público de la sociedad de capital estatal.}

El régimen jurídico de responsabilidad de los consejeros empleados públicos de la sociedad mercantil de capital estatal se regula en el art. 115 de la LRJSP ${ }^{986}$.

art. 237 LSC, no obstante, estima que, si el administrador de la sociedad dominada, actuó siguiendo instrucciones de la sociedad matriz, al ser el acto dañoso imputable a la sociedad dominante, la responsabilidad debe recaer sobre ella, Vid.: SÁNCHEZ CALERO, F.: Los administradores en las sociedades de capital, 2007, op. cit., pp. 360-361.

985 Sentencias del TS, Sala Civil, 693/2017, de 20 diciembre -Rec. 2469/2015-, y 695/2015, de 11 de diciembre -Rec. 2141/2013-.

986 "Artículo 115. Régimen de responsabilidad aplicable a los miembros de los consejos de administración de las sociedades mercantiles estatales designados por la Administración General del Estado.

1. La responsabilidad que le corresponda al empleado público como miembro del consejo de administración será directamente asumida por la Administración General del Estado que lo designó. 
En virtud de este precepto, en las sociedades mercantiles estatales, cuando el órgano de administración adopta la forma de Consejo de Administración, y el cargo de consejero designado por la Administración General del Estado lo asuma un empleado público, es la Administración la que asume directamente la responsabilidad ante terceros, sin perjuicio de que ésta pueda exigir la responsabilidad del empleado público al amparo del art. 115.2 de la LRJSP, cuando el daño en los bienes o derechos de la Administración, por asumir ésta directamente la responsabilidad, se hubiera causado concurriendo dolo, culpa o negligencia graves del empleado público consejero.

En el art. 115.1 de la LRJSP se establece que "la responsabilidad que le corresponda al empleado público como miembro del consejo de administración será directamente asumida por la Administración General del Estado que lo designó". Estamos ante una exoneración de responsabilidad del consejero empleado público, con el subsiguiente traslado de la misma a la Administración General del Estado, a través del Ministerio del que dependa la sociedad de capital.

Exoneración del consejero empleado público que en iguales términos se prevé en el art. 2.13 Real Decreto-Ley 25/2020, de 3 de julio, de medidas urgentes para apoyar la reactivación económica y el empleo ${ }^{987}$. En esta Disposición Legal se crea el Fondo de apoyo a la solvencia de empresas estratégicas, fondo carente de personalidad jurídica y adscrito a la Administración General del Estado a través del Ministerio de Hacienda. Fondo que podrá entrar en el capital social de empresas estratégicas como medida temporal de apoyo a la solvencia de las mismas. Si al formar parte del capital de esas empresas, la Administración del Estado, a través del Fondo, designa como consejeros del órgano de administración en la empresa participada a empleados públicos, ese

2. La Administración General del Estado podrá exigir de oficio al empleado público que designó como miembro del consejo de administración la responsabilidad en que hubiera incurrido por los daños y perjuicios causados en sus bienes o Derechos cuando hubiera concurrido dolo, o culpa o negligencia grave, conforme a lo previsto en las leyes administrativas en materia de responsabilidad patrimonial".

987 BOE del 6.7.2020.

Artículo 2 apartado 13 "La responsabilidad que en los casos previstos en las leyes le pudiera corresponder, en su caso, al empleado público como miembro de los consejos de administración de las empresas objeto de participación en su capital social, será directamente asumida por la Administración. El Consejo Gestor podrá exigir de oficio al empleado público la responsabilidad en que hubiera incurrido por los daños y perjuicios causados en sus bienes o Derechos cuando hubiera concurrido dolo, o culpa o negligencia grave, conforme a lo previsto en las leyes administrativas en materia de responsabilidad patrimonial".

Igual exoneración del consejero empleado público prevista en el art. 17.11 del Real Decreto-Ley $5 / 2021$, de 12 de marzo, de medidas extraordinarias de apoyo a la solvencia empresarial en respuesta a la pandemia de la Covid-19 (BOE 13.3.2021), para los consejeros empleados públicos designados en nombre de la Administración. 
consejero queda exento de responsabilidad prevista en la legislación societaria o concursal por asumirla directamente la Administración General del Estado, sin perjuicio de que la Administración a través del Fondo se resarza del daño causado a la misma exigiendo la responsabilidad del consejero empleado público. En esta disposición se exonera de responsabilidad al consejero empleado público, sin que estemos necesariamente ante una sociedad mercantil estatal, sino que nos hallamos ante una sociedad privada en que la Administración entra temporalmente en su capital para mantener y potenciar su viabilidad empresarial.

Exención de responsabilidad del consejero empleado público prevista en el art. 115.1 de la LRJSP que nos plantea como primera cuestión dilucidar si se incluye la responsabilidad por deudas del art. 367 de la LSC.

En virtud de una primera interpretación que defiende HERNÁNDEZ SAINZ ${ }^{988}$, la exoneración de responsabilidad del consejero empleado público sería sólo de la responsabilidad por daños de los arts. 236 a 241 bis de la LSC (acción social e individual de responsabilidad), debiendo incluirse igualmente en la exoneración la responsabilidad concursal para la cobertura del déficit patrimonial del actual art. 456 del TRLC, por entender que en ese precepto se establece una exoneración de la responsabilidad civil de naturaleza indemnizatoria y culpabilística, abogando por una interpretación sistemática de los párrafos 1 y 2 del art. 115 de la LRJSP, de modo que si en el párrafo segundo de ese precepto se establece que "la Administración podrá exigir de oficio al empleado público que designó como miembro del consejo de administración la responsabilidad en que hubiera incurrido por los daños y perjuicios causados en sus bienes o derechos cuando hubiera concurrido dolo, o culpa o negligencia graves, conforme a lo previsto en las leyes administrativas en materia de responsabilidad patrimonial", es porque la responsabilidad que asume la Administración al amparo del art. 115.1 de la LRJSP es una responsabilidad civil indemnizatoria, en la que se incluye tanto la responsabilidad del art. 236 de la LSC, como la responsabilidad del art. 456 del TRLC, de modo que deberá excluirse la responsabilidad por deudas del art. 367 de la LSC, responsabilidad por deudas que asumiría el consejero empleado público en los mismos términos que el resto de consejeros. Al interpretar sistemáticamente los dos párrafos del art. 115 de la LRJSP,

988 HERNÁNDEZ SAINZ, E. : "El nuevo régimen de responsabilidad de los consejeros de sociedades mercantiles estatales: ¿hacia la irresponsabilidad por la gestión de sociedades públicas?”, op. cit., edición digital, pp. 30 y ss. 
para esta autora, el legislador en ese precepto está contemplando sólo los supuestos de la responsabilidad por daños o responsabilidad civil indemnizatoria, que es la que asume la Administración en el funcionamiento normal o anormal de los servicios públicos, y que sería la que posteriormente permitiría recabar internamente la responsabilidad al empleado público, para resarcirse de la indemnización abonada al tercero perjudicado, ya que la responsabilidad del consejero empleado público se exige conforme a lo previsto en las leyes administrativas en materia de responsabilidad patrimonial, al amparo del art. 36 de la LRJSP.

Para una segunda interpretación por la que nos inclinamos, de una lectura literal, sistemática y teleológica del art. 115.1 de la LRJSP, ha de concluirse que, al referirse a la responsabilidad del consejero, sin mayor restricción, condicionamiento o limitación, se incluirían las tres responsabilidades previstas en la legislación societaria y concursal: la responsabilidad por daños del art. 236 de la LSC, la responsabilidad concursal para la cobertura del déficit patrimonial y la responsabilidad por deudas del art. 367 de la LSC.

- En primer lugar, porque en virtud de una interpretación literal del apartado 1, ha de concluirse que se refiere a todas las responsabilidades de naturaleza civil en que pueden incurrir los administradores al amparo de la legislación de sociedades o concursal, ya que "donde la ley no distingue no debemos distinguir". En el precepto se establece claramente que "la responsabilidad que le corresponda al empleado público como miembro del consejo de administración será directamente asumida por la Administración General del Estado que lo designó”. Más clara no puede ser la redacción de este precepto, nos encontramos ante una disposición que está fijando el régimen jurídico general de responsabilidad de un concreto miembro del órgano del Consejo de Administración en atención a su condición de empleado público, para sustraerlo de la legislación societaria o concursal, y atribuir directamente su responsabilidad a la Administración. Régimen jurídico de responsabilidad del consejero empleado público tanto ante terceros como ante la propia sociedad. Ese régimen jurídico general de responsabilidad del consejero empleado público no se ha limitado a la responsabilidad por daños del art. 236 de la LSC, como se ha hecho en otras disposiciones cuando el legislador lo ha querido (art. 116.6 de la LRJSP y art. 179 LPAP). Esta interpretación resulta avalada igualmente por la propia rúbrica o título del artículo 115 de la LRJSP, que es encabezado por el rótulo "régimen de responsabilidad aplicable a los miembros de los consejos de administración de las 
sociedades mercantiles estatales designados por la Administración General del Estado". Nos encontramos en definitiva ante el establecimiento del régimen jurídico general de responsabilidad del consejero empleado público aplicable en los supuestos de responsabilidad del administrador contemplados en la legislación de sociedades y concursal, por lo que deberá de incluirse la responsabilidad por deudas del art. 367 de la LSC.

- En segundo lugar, porque en virtud de una interpretación sistemática con el art. 116.6 de la LRJSP y el art. 179 de la LPAP, cuando el legislador ha querido limitar la responsabilidad del administrador de la sociedad mercantil estatal a un supuesto concreto de responsabilidad civil patrimonial, lo ha hecho de modo expreso, como sucede en esos preceptos en que se exonera a los administradores de las sociedades mercantiles estatales de capital íntegramente público de la responsabilidad por daños del art. 236 de la LSC, y sólo de esa modalidad de responsabilidad, porque en esas sociedades la condición de administrador la puede ostentar cualquier persona, por no estar contemplando la condición de empleado público de ese cargo.

- En tercer lugar, partiendo de una interpretación teleológica del precepto, con la exoneración directa de responsabilidad del consejero empleado público y la correlativa atribución directa de su responsabilidad a la Administración General del Estado, la finalidad pretendida por el legislador es sustraer a ese empleado público del régimen jurídico de responsabilidad civil de los administradores, para que siga sujeto al régimen de responsabilidad de todo empleado público, por haber sido designado consejero en su calidad de empleado público y en representación de la Administración. Este régimen jurídico de responsabilidad, en definitiva, es una garantía para el empleado público de no ver modificado su régimen de responsabilidad civil al haber sido designado consejero por la Administración y actuando en su condición de empleado público, y es igualmente una mayor garantía para los terceros acreedores sociales afectados por la actuación orgánica del consejero, que tienen la garantía de poder cobrar sus créditos de la Administración, y que por lo tanto, se cohonesta mejor con la naturaleza de la responsabilidad ex lege por deuda ajena del art. 367 de la LSC, que se establece en garantía de los acreedores.

- En cuarto lugar, no cabe argumentar que si en el párrafo segundo del art. 115 de la LRJSP se permite a la Administración recabar el daño que se le causa por el consejero empleado público en sus bienes o derechos, cuando ha habido en la 
conducta de éste dolo, culpa o negligencia grave, es porque se está regulando sólo la responsabilidad por daños en su párrafo primero. El art. 115.2 de la LRJSP se establece que "la Administración General del Estado podrá exigir de oficio al empleado público que designó como miembro del consejo de administración la responsabilidad en que hubiera incurrido por los daños y perjuicios causados en sus bienes o derechos cuando hubiera concurrido dolo, o culpa o negligencia grave, conforme a lo previsto en las leyes administrativas en materia de responsabilidad patrimonial". En este apartado segundo no se está delimitando el presupuesto jurídico de la responsabilidad o el ámbito objetivo de responsabilidad asumida por la Administración en virtud del apartado 1, y de la que se exonera ex lege ante terceros al empleado público, porque ambos apartados regulan aspectos distintos. Este apartado segundo lo que está haciendo es algo más simple, habilitar a la Administración para exigir al empleado público la responsabilidad por el daño patrimonial que ha sufrido ella en sus bienes al tener que responder ante terceros de la actuación orgánica del consejero, pero sólo cuando haya habido una conducta dolosa, culposa o negligente graves, que son los elementos subjetivos determinantes de la responsabilidad patrimonial de los empleados públicos en el art. 36.2 de la LRJSP, precisamente por seguir éstos sometidos al régimen jurídico de responsabilidad administrativa y no al régimen jurídico de responsabilidad de la legislación de sociedades; y sin que ello implique que deba haber en todo caso una responsabilidad por daños causados a terceros, sino que la Administración puede verse obligada a asumir una responsabilidad por deudas o por daños, sin que hubiere ni dolo, ni culpa grave del consejero empleado público. Responsabilidad que se tramita por el procedimiento del art. 36 de la LRJSP y de la LPACAP (con las especialidades de los arts. 91 y 92 de la LPACAP). Estamos sólo ante una remisión a la legislación administrativa para la exigencia de responsabilidad del empleado público, a efectos de establecer el procedimiento de resarcimiento, y contemplándose las mismas causas subjetivas de imputación de responsabilidad: dolo, culpa o negligencias graves.

En el art. 115.2 de la LRJSP no se habla de daños causados a un tercero, sino de los daños causados a los bienes de la Administración, y ese daño se causa tanto haya asumido la Administración una responsabilidad por deudas como una responsabilidad por daños en virtud de conducta orgánica del consejero empleado 
público. Responsabilidad que exige la Administración al empleado público consejero conforme a lo previsto en las leyes administrativas en materia de responsabilidad patrimonial.

Tan es así que en el art. 2.13 del Real Decreto-Ley 25/2020, de 3 de julio, se permite a la Administración del Estado, a través del "Consejo Rector del Fondo de apoyo a la solvencia de empresas estratégicas", exigir al empleado público consejero la compensación del perjuicio que sufre aquélla al tener que asumir ope legis la responsabilidad del consejero empleado público de una empresa privada, sin que en esa sociedad mercantil privada sea de aplicación el régimen jurídico de responsabilidad patrimonial de la Administración, por lo que no puede ligarse inextricablemente o limitarse la responsabilidad impuesta legalmente a la Administración, en este precepto ni en el art. 115.1 de la LRJSP, a los supuestos de hecho de la responsabilidad patrimonial por daños de la Administración. El presupuesto jurídico para reclamar al consejero empleado público la responsabilidad en el art. 2.13 del Real Decreto-Ley 25/2020, es consecuencia de haberla asumido directamente y ope legis la Administración, igual presupuesto que el previsto en el art. 115.2 de la LRJSP. En ese art. 2.13. se establece expresamente que " $L a$ responsabilidad que en los casos previstos en las leyes le pudiera corresponder, en su caso, al empleado público como miembro de los consejos de administración de las empresas objeto de participación en su capital social, será directamente asumida por la Administración. El Consejo Gestor podrá exigir de oficio al empleado público la responsabilidad en que hubiera incurrido por los daños y perjuicios causados en sus bienes o derechos cuando hubiera concurrido dolo, o culpa o negligencia grave, conforme a lo previsto en las leyes administrativas en materia de responsabilidad patrimonial'. En ese precepto se permite a la Administración exigir al empleado público la pertinente responsabilidad administrativa por haber tenido que asumir ante terceros la responsabilidad societaria, sin que haya una responsabilidad patrimonial de la Administración, ya que estamos ante una empresa privada que no es una sociedad estatal.

- En quinto lugar, si la finalidad del régimen jurídico del art. 115 de la LRJSP es someter al empleado público designado por la Administración del Estado miembro del órgano de administración, al régimen disciplinario y de responsabilidad propio del Derecho administrativo, sustrayéndolo del régimen de responsabilidad del 
administrador, no se entendería muy bien el motivo de limitarse la exclusión de la responsabilidad del art. 115 de la LRJSP, sólo a la responsabilidad por daños, sin incluirse también la responsabilidad por deudas del art. 367 de la LSC.

En virtud de esta interpretación que mantenemos, cuando el consejero de la sociedad mercantil de capital estatal sea un empelado público designado por la Administración General del Estado, ese consejero no asume ante terceros ninguna responsabilidad civil patrimonial, sea consecuencia de una responsabilidad por daños o por deudas prevista en la legislación de sociedades, sino que la responsabilidad es asumida ex lege directamente por la Administración, por regularse en el art. 115 de la LRJSP el régimen jurídico general de exoneración de responsabilidad mercantil del consejero empleado público, por primar la condición de relación de servicios con la Administración, a diferencia de lo que ocurre en el art. 116.6 de la LRJSP, en que se regula sólo la exoneración de una modalidad concreta de responsabilidad, no de toda responsabilidad, cual es la responsabilidad por daños, pero únicamente cuando se hayan seguido instrucciones de la Administración. Con esta interpretación, en una sociedad estatal de capital en que el único socio sea la Administración General de Estado, si el cargo de consejero lo ocupa un empleado público designado por su condición de tal, se aplicaría el art. 115.1 y no el art. 116.6 de la LRJSP, de modo que el consejero empleado público no asumiría ante terceros ninguna responsabilidad, haya o no seguido las instrucciones de la Administración (art. 115.1 de la LRJSP), asumiéndola, en todo caso, la propia Administración, sin perjuicio de que ésta pueda exigir posteriormente la responsabilidad del empleado público al amparo del art. 115.2 de la LRJSP, cuando como consecuencia de la conducta dolosa o por culpa grave, ese empleado público haya causado una daño en los bienes o derechos de la Administración sin haber seguido las instrucciones impartidas, daño que se causa porque la Administración tiene que asumir ope legis directamente la responsabilidad por daños o por deudas.

En virtud de esta interpretación, con la redacción del art. 115.1 de la LRJSP estaríamos consiguientemente ante un supuesto específico de responsabilidad patrimonial de la Administración ante terceros, por exoneración de la responsabilidad del consejero, sin condicionarse jurídicamente a la producción de un daño extracontractual a terceros, siendo la razón de ser de esta disposición sustraer al empleado público del régimen de responsabilidad personal patrimonial que la LSC impone a los administradores, para seguir sometiéndolo al régimen de responsabilidad propio de los empleados públicos. 
El art. 115 de la LRJSP, según HERNÁNDEZ SAINZ989 (sic) “configura un anómalo supuesto de responsabilidad de la Administración en la que ésta responde conforme a parámetros privados, en concreto, conforme a los parámetros de la responsabilidad de los administradores de sociedades mercantiles, pero quedando sometida la acción para la exigencia de responsabilidad a las reglas procedimentales administrativas y siendo resueltas las controversias en última instancia por la jurisdicción contenciosoadministrativa". En definitiva, la exigencia de la responsabilidad deberá instrumentalizarse jurídicamente a través del cauce procedimental de la responsabilidad patrimonial de la Administración del Estado, por el procedimiento administrativo de los arts. 32 y siguientes de la LRJSP, ya que en esos preceptos se regula la responsabilidad patrimonial de la Administración por los daños causados a los particulares, seas personas físicas o jurídicas.

A efectos de exigir la responsabilidad solidaria por deudas de Seguridad Social a la Administración General del Estado, al Misterio tutelante de la sociedad mercantil estatal, en cuanto responsable solidario que ocupa el lugar del consejero empleado público, será de aplicación la derivación administrativa de responsabilidad por deudas (art. 18.3 del TRLGSS en relación con el art. 367 de la LSC), como en cualquier otro supuesto de responsabilidad derivada exigible a la Administración (como contratassubcontratas, sucesión de empresa, cesión ilegal de mano de obra, etc.), sin que deba exigirse por la vía de la responsabilidad patrimonial de la Administración del art. 32 de la LRJSP.

Se siga una u otra interpretación, en el art. 115 de la LRJSP se establece una exoneración de responsabilidad del empleado público consejero de cualquier tipo de sociedad mercantil de capital estatal, sea anónima o de responsabilidad limitada, cuando concurran las siguientes circunstancias, que para un mayor análisis nos remitimos al Capítulo II apartado II.4.1.5 de esta tesis:

- En primer lugar, esta exoneración de responsabilidad acontece cuando estemos ante sociedades de capital en que la Administración del Estado posea, directa o indirectamente, una participación social superior al 50\% del capital social, o en las

\footnotetext{
989 HERNÁNDEZ SAINZ, E.: "El nuevo régimen de responsabilidad de los consejeros de sociedades mercantiles estatales: ¿hacia la irresponsabilidad por la gestión de sociedades públicas?”, op. cit., edición digital, pp. 30 y 31.
} 
que, sin ostentar la mayoría del capital, posea el control societario en los términos del art. 42 del Código de Comercio (art. 111 de la LRJSP y art. 166.1. c) de la LPAP).

- En segundo lugar, cuando el órgano de administración adopte la forma de Consejo de Administración. Es criticable por no tener razón fundada esta limitación a una concreta forma de organización del órgano de administración.

- En tercer lugar, que el consejero designado por la Administración del Estado sea un empleado público, con lo que no habría exoneración si para ese cargo se designa a una persona que no tenga la condición de empleado público. Ostentan la condición de empleados públicos las personas reseñadas en los arts. 1, 2, 3 y 8 del Real Decreto Legislativo 5/2015, de 30 de octubre, por el que se aprueba el Texto Refundido de la Ley del Estatuto Básico del Empleado Público ${ }^{990}$. Al no tener la condición de empleado público el alto cargo que no sea empleado público, quedaría a excluido de esta regulación según sostiene HERNÁNDEZ SAINZ ${ }^{991}$.

- En cuarto lugar, que el consejero sea designado por la Administración General del Estado, lo que incluye a los consejeros nombrados por la Administración del Estado de ser la sociedad mercantil pública de único socio, o cuando siendo una sociedad mixta, el consejero sea designado por esa Administración estatal por el sistema de representación proporcional o por el sistema de cooptación.

- En quinto lugar, que es suficiente con que la sociedad mercantil tenga la condición de sociedad estatal, sin exigirse que ostente la Administración la totalidad de capital social (a diferencia de la exención de responsabilidad prevista en el art. 179 de la LPAP), por lo que se incluyen a las sociedades mixtas, con lo que hay una diversidad de regímenes de responsabilidad aplicables a los administradores.

En principio, esta exoneración ante terceros de responsabilidad del empleado público nombrado por la Administración miembro del Consejo de Administración, del art. 115 de la LRJSP, sólo es de aplicación directa a las sociedades mercantiles estatales, y no a

${ }^{990}$ BOE del 31.10.2015.

Tienen la condición de empleados públicos: los funcionarios de carrera, los funcionarios interinos, el personal laboral y el personal eventual al servicio de cualquiera de las Administraciones públicas siguientes: a) La Administración General del Estado; b) Las Administraciones de las comunidades autónomas y de las ciudades de Ceuta y Melilla; c) Las Administraciones de las entidades locales; d) Los organismos públicos, agencias y demás entidades de Derecho público con personalidad jurídica propia, vinculadas o dependientes de cualquiera de las Administraciones Públicas; e) Las Universidades Públicas.

${ }^{991}$ HERNÁNDEZ SAINZ, E.: "El nuevo régimen de responsabilidad de los consejeros de sociedades mercantiles estatales: ¿hacia la irresponsabilidad por la gestión de sociedades públicas?”, op. cit., edición digital, p. 26. 
las Administraciones Autonómicas o Locales, ya que las disposiciones del Capítulo V del Título II, -los arts. 111 a 117- de la LRJSP, no tienen la condición de legislación básica (Disposición Final 14 apartado 2. c) de la LRJSP).

Al sustraer al consejero empleado público del régimen de responsabilidad previsto en la LSC, se crea un trato diverso entre los integrantes del Consejo de Administración en las sociedades mercantiles estatales mixtas, razón por la cual, un sector de la doctrina científica $^{992}$ aboga por la derogación de este art. 115 de la LRJSP.

Al responder no el consejero empleado público sino la Administración General del Estado que lo designó, ésta responderá solidariamente con el resto de los consejeros de la sociedad de capital, en los términos establecidos en los arts. 237, 360 y 367 de la LSC, y contra esos responsables solidarios podrá derivarse la responsabilidad por deudas con la Seguridad Social por el procedimiento administrativo de derivación de responsabilidad, con independencia de que al ser responsable una Administración Pública, o ser la sociedad de capital estatal parte del sector público institucional ${ }^{993}$, la TGSS tendrá también abierta la vía de la deducción de las cantidades que, con cargo a los Presupuestos Generales del Estado, deban transferirse a la Administración responsable o a la sociedad de capital pública deudora, de conformidad con lo previsto en los arts. 39 y 40 del RGRSS.

\section{Solidaridad de la responsabilidad.}

La responsabilidad del administrador social en las deudas de la Seguridad Social de la sociedad de capital (art. 367 LSC y art. 18.3 TRLGSS), es una responsabilidad solidaria en un doble sentido. Por un lado, y en el plano externo ante los acreedores, los administradores sociales responden solidariamente con la sociedad de las deudas de ésta, y por otro lado, en el plano interno, los administradores responden de modo

\footnotetext{
992 NAVARRO FRÍAS, I.: "Sociedades públicas: Derecho mercantil vs Derecho administrativo. En particular, deberes y responsabilidad de los administradores de sociedades públicas estatales", op. cit., p. 30.

${ }_{993}$ Art. 2.2. b) de la LRJSP, art. 2.2 de la LPACAP, y 2.2. c) de la LGP.
} 
solidario entre sí $1^{994}$. "Es una responsabilidad solidaria entre los administradores y de éstos con la sociedad"995.

En la doctrina científica ${ }^{996}$ se señala que el administrador es garante solidario de una deuda ajena ante el incumplimiento de sus obligaciones, siendo la sociedad de capital la única deudora, pero ya no la única responsable de las deudas sociales, ya que devienen también responsables de esas deudas, pese a no ser deudores, los administradores sociales. Con la imposición ex lege de la responsabilidad solidaria del administrador en las deudas de la sociedad de capital, "se está añadiendo, en garantía de los acreedores, al patrimonio de la sociedad de capital el patrimonio personal de los administradores" 997 .

Estamos ante una responsabilidad ex lege por deuda ajena y no por deuda propia, consecuencia del incumplimiento imputable de los deberes legales del administrador de promover la disolución ante la concurrencia de una cusa legal de disolución de la sociedad de capital.

Esta responsabilidad solidaria de los administradores es una responsabilidad solidaria de primer grado ${ }^{998}$, ya que no tienen carácter subsidiario respecto a la responsabilidad de único deudor, de la sociedad de capital, de modo que no obliga a reclamar primero contra en patrimonio de la sociedad, y sólo en defecto de éste reclamar al responsable subsidiario. Es una responsabilidad solidaria de primer grado en que la TGSS o la ITSS, una vez declare la responsabilidad solidaria mediante la derivación administrativa de la deuda, podrá reclamar directamente el importe de la deuda de Seguridad Social de la mercantil al administrador social -sin tener que reclamar primero a la sociedad-, o

${ }^{994}$ ESTEBAN VELASCO, G.: "Algunas reflexiones sobre la Responsabilidad de los Administradores frente a los Socios y los Terceros: Acción individual y acción por no Promoción o Remoción de la disolución", op. cit., p. 75.

995 QUIJANO GONZÁLEZ, J.: "Responsabilidad de los administradores por no disolución de la sociedad (art. 262.5 TRLSA) (Sentencia de la Audiencia Provincial de Burgos de 24 de julio de 1995)”, op. cit., p. 275.

${ }^{996}$ QUIJANO GONZÁLEZ, J.: "Responsabilidad de los administradores por no disolución de la sociedad (art. 262.5 TRLSA) (Sentencia de la Audiencia Provincial de Burgos de 24 de julio de 1995)”, op. cit., pp. 274-275; ESTEBAN VELASCO, G.: "Algunas reflexiones sobre la Responsabilidad de los Administradores frente a los Socios y los Terceros: Acción individual y acción por no Promoción o Remoción de la disolución”, op. cit., pp. 72 y 74-75; MACHADO PLAZAS, J.: Pérdida del capital social y responsabilidad de los administradores por deudas sociales, op. cit., pp. 352-353; ROJO FERNÁNDEZ-RÍO, A.: "Los deberes legales de los administradores en orden a la disolución de la sociedad de capital como consecuencia de pérdidas", op. cit., p. 1440; BELTRÁN SÁNCHEZ, E.: "La responsabilidad de los administradores por obligaciones sociales", op. cit., p. 331.

997 MACHADO PLAZAS, J.: Pérdida del capital social y responsabilidad de los administradores por deudas sociales, op. cit., pp. 352-353

998 MACHADO PLAZAS, J.: Pérdida del capital social y responsabilidad de los administradores por deudas sociales, op. cit., pp. 354-355. 
reclamar de modo simultáneo la responsabilidad al administrador o administradores, de ser varios, así como a la propia sociedad.

La nota distintiva de esta responsabilidad del administrador en las deudas de Seguridad Social de la sociedad de capital, es la de su carácter de solidaridad ${ }^{999}$. Solidaridad que tiene dos vertientes o planos, externo e interno ${ }^{1000}$. Es una "solidaridad pasiva externa legal" "1001, en virtud de la cual, el acreedor podrá reclamar el importe total de la deuda, a su elección, contra la sociedad de capital y/o contra los administradores responsables solidarios, y en este caso contra todos ellos o contra alguno, debiendo asumir ante el acreedor cada uno de ellos el total de la deuda, y sin que el acreedor esté obligado a reclamar contra todos a la vez ${ }^{1002}$. Por otro lado, es una responsabilidad solidaria de los administradores entre sí -relación interna o solidaridad interna entre los administradores ${ }^{1003}$-, ya que de ser varios ${ }^{1004}$, responden todos ellos, salvo que no le sea

999 QUIJANO GONZÁLEZ, J.: "Responsabilidad de los administradores por no disolución de la sociedad (art. 262.5 TRLSA) (Sentencia de la Audiencia Provincial de Burgos de 24 de julio de 1995)", op. cit., 1995, pp. 274-275; ESTEBAN VELASCO, G.: "Algunas reflexiones sobre la Responsabilidad de los Administradores frente a los Socios y los Terceros: Acción individual y acción por no Promoción o Remoción de la disolución”, op. cit., p. 75; SÁNCHEZ CALERO, F.: Los administradores en las sociedades de capital, op. cit., pp. 464-466; GARCÍA CRUCES, J. A.: Derecho de Sociedades Mercantiles, op. cit., p. 505; BELTRÁN SÁNCHEZ, E.: "La responsabilidad de los administradores por obligaciones sociales”, op. cit., pp. 341-342; DÍAZ ECHEGARAY, J. L.: Deberes y Responsabilidades de los Administradores de Sociedades de Capital, op. cit., pp. 391 y 406; RODRÍGUEZ RUIZ DE LA VILLA, D. y HUERTA VIESCA, M. I.: La responsabilidad de los administradores por las deudas de las Sociedades de Capital (en las Leyes de Sociedades Anónimas, de Sociedades de Responsabilidad Limitada, de Sociedad Limitada Nueva Empresa, Concursal, General Tributaria y de Responsabilidad Medioambiental), op. cit., pp. 71-87 y 533; CALBACHO LOSADA, F.: El ejercicio de las acciones de las acciones de responsabilidad contra los administradores de la sociedad anónima, op. cit., pp. 482-488.

1000 Sentencias del TS, Sala Civil, de 583/2008, de 24 de junio -Rec. 3077/2001-; 235/2007, de 8 de marzo -Rec. 2036/2000-; 794/2005, de 25 de octubre -Rec. 1218/1999-; 458/2010, de 30 de junio Rec. 1337/2006-; 110/2004, de 23 de febrero -Rec. 1041/1998-, entre otras.

1001 MACHADO PLAZAS, J.: Pérdida del capital social y responsabilidad de los administradores por deudas sociales, op. cit., pp. 360-364; SÁNCHEZ CALERO, F.: Los administradores en las sociedades de capital, op. cit., p. 340; DÍAZ ECHEGARAY, J. L.: Deberes y responsabilidades de los Administradores de sociedades de Capital, op. cit., p. 268.

1002 QUIJANO GONZÁLEZ, J.: "Responsabilidad de los administradores por no disolución de la sociedad (art. 262.5 TRLSA) (Sentencia de la Audiencia Provincial de Burgos de 24 de julio de 1995)", op. cit., 1995, pp. 274-275; ESTEBAN VELASCO, G.: "Algunas reflexiones sobre la Responsabilidad de los Administradores frente a los Socios y los Terceros: Acción individual y acción por no Promoción o Remoción de la disolución”, op. cit. p. 75; MACHADO PLAZAS, J.: Pérdida del capital social y responsabilidad de los administradores por deudas sociales, op. cit., p. 356, para quien la solidaridad pasiva no es un litisconsorcio pasivo necesario; SÁNCHEZ CALERO, F.: Los administradores en las sociedades de capital, op. cit., p. 340; DÍAZ ECHEGARAY, J. L: Deberes y responsabilidades de los Administradores de sociedades de Capital, op. cit., p. 268.

1003 MACHADO PLAZAS, J.: Pérdida del capital social y responsabilidad de los administradores por deudas sociales, op. cit., pp. 364-365; SÁNCHEZ CALERO, F.: Los administradores en las sociedades de capital, op. cit., p. 340; DÍAZ ECHEGARAY, J. L.: Deberes y responsabilidades de los Administradores de Sociedades de Capital, op. cit., p.268.

1004 QUIJANO GONZÁLEZ, J.: "Responsabilidad de los administradores por no disolución de la sociedad (art. 262.5 TRLSA) (Sentencia de la Audiencia Provincial de Burgos de 24 de julio de 
imputable el incumplimiento de los deberes legales a alguno de ellos, y ello con independencia de la forma de organización del órgano de administración, de modo que una cuestión será la posible existencia de varios administradores mancomunados, y otra cosa es que éstos respondan, no mancomunadamente, sino de modo solidario de la totalidad de las deudas de la sociedad ${ }^{1005}$.

Por esa naturaleza de la responsabilidad solidaria el acreedor ${ }^{1006}$, en primer lugar, en virtud del ius eligendi podrá exigir el pago de esas deudas a todos los administradores y a la sociedad conjuntamente, o reclamar a la sociedad y alguno de los administradores, o sólo a los administradores, y en este caso, a todos, o sólo a alguno de ellos, sin perjuicio de poder reclamar posteriormente en virtud del ius variandi al resto de los deudores y responsables solidarios (art. 1144 del Código Civil), ya que la reclamación contra alguno de ellos no enerva la que pudiera realizarse ante el resto, mientras la deuda no resulte íntegramente pagada (arts. 1137 a 1148 del Código Civil). Si la deuda la paga la sociedad de capital, se extingue la misma cesando la responsabilidad de los administradores, ya que son meros garantes solidarios, pero no son deudores, por lo que aquélla no tiene acción de regreso ante los administradores ${ }^{1007}$. En segundo lugar, la solidaridad tiene relación entre los propios administradores, ya que, pagado el total de la deuda por uno de ellos, se extingue la deuda ante el acreedor, con efectos para la sociedad deudora y los administradores responsables solidarios, pero determina que surja una acción de regreso del que ha satisfecho la deuda, tanto respecto a la sociedad como respecto al resto de administradores en su parte correspondiente (art. 1145.2 del

1995)", op. cit., 1995, pp. 274-275; MACHADO PLAZAS, J.: Pérdida del capital social y responsabilidad de los administradores por deudas sociales, op. cit., pp. 356 y 366-367.

1005 CALBACHO LOSADA, F.: El ejercicio de las acciones de responsabilidad contra los administradores de la sociedad anónima, op. cit., p. 499.

1006 QUIJANO GONZÁLEZ, J.: "Responsabilidad de los administradores por no disolución de la sociedad (art. 262.5 TRLSA) (Sentencia de la Audiencia Provincial de Burgos de 24 de julio de 1995)", op. cit., 1995, pp. 274-275; MACHADO PLAZAS, J.: Pérdida del capital social y responsabilidad de los administradores por deudas sociales, op. cit., pp. 351-364; SÁNCHEZ CALERO, F.: Los administradores en las sociedades de capital, op. cit., p. 340; BELTRÁN SÁNCHEZ, E.: "La responsabilidad de los administradores por obligaciones sociales", op. cit., p. 342; BATALLER GRAU, J.: "Disolución y Liquidación", op. cit., p. 2576.

1007 QUIJANO GONZÁLEZ, J.: "Responsabilidad de los administradores por no disolución de la sociedad (art. 262.5 TRLSA) (Sentencia de la Audiencia Provincial de Burgos de 24 de julio de 1995)", op. cit., 1995, p. 275; ESTEBAN VELASCO, G.: "Algunas reflexiones sobre la Responsabilidad de los Administradores frente a los Socios y los Terceros: Acción individual y acción por no Promoción o Remoción de la disolución”, op. cit., p. 75. 
Código Civil, Sentencia del TS, Sala Civil, 458/2010, de 30 de junio -Rec. $1337 / 2006)^{1008}$.

Al ser una responsabilidad solidaria, en la derivación administrativa de responsabilidad se ha de hacer constar quiénes son los administradores responsables solidarios, sin que se tenga que exigir el pago por la TGSS a todos ellos al mismo tiempo y en el mismo acto, ya que declarar quiénes son responsables solidarios es, simplemente, el presupuesto necesario para exigir posteriormente el pago a cualquiera de ellos (STS, Sala Contencioso-Administrativa, núm. 1661/2018, de 22 de noviembre -Rec. 2507/2016-).

Examinada desde la perspectiva del administrador o administradores, es una responsabilidad personal e ilimitada ${ }^{1009}$, ya que de ser persona física cada uno responde ante el acreedor de la totalidad de la deuda social y con todo su patrimonio, en aplicación de la regla de responsabilidad universal del art. 1911 del Código Civil, sin perjuicio del límite de bienes inembargables de los arts. 605 a 607 de la LEC; y de ser el administrador una persona jurídica responderá con su patrimonio social.

Finalmente, al ser una responsabilidad solidaria la que asume el administrador social, como una especie de co-garante legal de la sociedad, podrá oponer el administrador social a la TGSS o al OEITSS, las mismas excepciones que podría oponer la sociedad de capital respecto a las deudas de Seguridad Social que no sean excepciones meramente personales (arts. 1148 y 1845 del Código Civil) ${ }^{1010}$, pudiendo cuestionar no sólo la improcedencia del acto de derivación sino también la improcedencia de la deuda de Seguridad Social reclamada y su importe, ya que el responsable solidario podrá

1008 QUIJANO GONZÁLEZ, J.: "Responsabilidad de los administradores por no disolución de la sociedad (art. 262.5 TRLSA) (Sentencia de la Audiencia Provincial de Burgos de 24 de julio de 1995)", op. cit., 1995, pp. 274-275; ESTEBAN VELASCO, G.: “Algunas reflexiones sobre la Responsabilidad de los Administradores frente a los Socios y los Terceros: Acción individual y acción por no Promoción o Remoción de la disolución”, op. cit., p. 75; MACHADO PLAZAS, J.: Pérdida del capital social y responsabilidad de los administradores por deudas sociales, op. cit., pp. 351-364; SÁNCHEZ CALERO, F.: Los administradores en las sociedades de capital, op. cit., p. 340; BELTRÁN SÁNCHEZ, E.: "La responsabilidad de los administradores por obligaciones sociales", op. cit., p. 342, quien habla de comunidad de intereses entre los administradores en el pago de la deuda.

1009 GARCÍA CRUCES, J. A.: Derecho de Sociedades Mercantiles, op. cit., p. 505.

1010 MACHADO PLAZAS, J.: Pérdida del capital social y responsabilidad de los administradores por deudas sociales, op. cit., p. 367.

En el art 1845 del Código Civil, se establece:

"Artículo 1845.

En el caso del artículo anterior podrán los cofiadores oponer al que pagó las mismas excepciones que habrían correspondido al deudor principal contra el acreedor y que no fueren puramente personales del mismo deudor". 
oponer al acreedor todas las excepciones que se deriven de la obligación reclamada y las excepciones personales que el responsable tenga contra él.

\section{Nacimiento, duración y extinción de la responsabilidad.}

La responsabilidad solidaria de los administradores en las deudas de Seguridad Social de la sociedad de capital, al amparo del art. 367 LSC y art. 18.3 TRLGSS, nacerá si durante la vigencia del cargo incumplen los deberes de promover la disolución establecidos en los arts. 365 y 366 de la LSC.

\subsection{Nombramiento, aceptación e inscripción registral.}

Para que el administrador sea responsable solidario de las deudas de Seguridad Social por causa de disolución, la primera condición será que esté en el ejercicio del cargo en la fecha en que debería cumplir con los deberes legales de promover la disolución, lo que implica que haya sido nombrado administrador por la Junta General y haya aceptado el cargo, sin que la inscripción en el Registro Mercantil -RM- del nombramiento sea constitutiva ${ }^{1011}$, sin que tenga efectos en la validez del nombramiento (art. 214 de la LSC y art. 9.1 del RRM ${ }^{1012}$ ).

El nombramiento surte efectos desde la aceptación, no desde el nombramiento (art. 214.3 de la LSC), sin que la fecha de la aceptación pueda ser anterior al nombramiento (art. 141 RRM), pero sí posterior. Aceptación que podrá ser expresa o tácita, resultando ésta de actos concluyentes de ejercicio de funciones propias del cargo ${ }^{1013}$. Una vez acepte el cargo, deberá inscribirse en el RM el nombramiento y la aceptación (art. 215 LSC, arts. $94.1 .4^{\circ}$ y 138 a 143 del RRM), a medida que se vaya produciendo la aceptación y dentro del plazo de los diez días siguientes a ésta (art. 215 LSC y art. 141 del RRM).

En la inscripción del nombramiento se deberá hacer constar la identidad de los nombrados, la fecha del nombramiento, el plazo de vigencia del cargo, y en su caso, de

1011 CALBACHO LOSADA, F.: El ejercicio de las acciones de responsabilidad contra los administradores de la sociedad anónima, op. cit., p. 509.

${ }^{1012}$ En el art 9 se recoge el principio de publicidad del registro, en función del cual, los actos sujetos a inscripción sólo surtirán efecto ante terceros de buena fe, desde la publicación de la inscripción.

"Artículo 9. Oponibilidad.1. Los actos sujetos a inscripción sólo serán oponibles a terceros de buena fe desde su publicación en el «Boletín Oficial del Registro Mercantil». Quedan a salvo los efectos propios de la inscripción".

1013 CALBACHO LOSADA, F.: El ejercicio de las acciones de responsabilidad contra los administradores de la sociedad anónima, op. cit., p. 508; DÍAZ ECHEGARAY, J. L.: Deberes y responsabilidades de los Administradores de sociedades de Capital, op. cit., p. 404. 
ser un Consejo de Administración el cargo para el que hubiese sido nombrado (art. 138 del RRM).

Con carácter excepcional, durante la vigencia del estado de alarma por la crisis sanitaria de la Covid-19 (14.3.2020 al 20.6.2020) se suspendieron los plazos para la presentación de asientos en el RM (art. 42 del Real Decreto Ley 8/2020, de 17 de marzo ${ }^{1014}$, en relación con el Real Decreto 463/2020, de 14 de marzo; y con el Real Decreto $555 / 2020$, de 5 de junio ${ }^{1015}$, por el que se prorrogó ese Estado de Alarma). Plazos que se alzaron con efectos del 10 de junio de 2020 (Disposición Adicional Cuarta del Real Decreto-Ley 21/2020, de 9 de junio, de medidas urgentes de prevención, contención y coordinación para hacer frente a la crisis sanitaria ocasionada por el Covid-19 ${ }^{1016}$ ).

Será sujeto responsable de las deudas de Seguridad Social, si una vez aceptado el cargo, acaeciese una causa de disolución y no cumpliese en el plazo de dos meses con los deberes de promover a disolución. Será responsable de las deudas sociales, incluso si tras la aceptación del cargo, habiendo acaecido una causa de disolución con anterioridad, e incumplidos los deberes por los anteriores administradores, no procede a cumplir con los deberes de promover la disolución en el plazo de dos meses desde la aceptación de cargo ${ }^{1017}$.

La responsabilidad del administrador nacerá tras la aceptación del cargo, si incumple los deberes de promover la disolución o de solicitar el concurso de acreedores, con independencia de que ese nombramiento no hubiera accedido al RM, porque la inscripción del nombramiento de administrador no es constitutiva, pero su ausencia sí tendrá efectos ante terceros en función del principio de publicidad material registral, tanto en su aspecto positivo (principio de legitimación registral), ya que su contenido se

1014 “Artículo 42. Suspensión del plazo de caducidad de los asientos del registro durante la vigencia del real decreto de declaración del estado de alarma. Durante la vigencia del estado de alarma y, en su caso, las prórrogas del mismo que pudieran acordarse, se adoptarán las siguientes medidas: Primera. Se suspende el plazo de caducidad de los asientos de presentación, de las anotaciones preventivas, de las menciones, de las notas marginales y de cualesquiera otros asientos registrales susceptibles de cancelación por el transcurso del tiempo. Segunda. El cómputo de los plazos se reanudará al día siguiente de la finalización del estado de alarma o de su prórroga en su caso".

1015 BOE del 6.6.2020, en cuyo artículo 2 del Real Decreto 555/2020, de 5 de junio, se declaró la última prórroga del Estado de Alarma, la que finalizó a las 00 horas del 21 de junio de 2020.

1016 BOE del 10.6.2020.

1017 SSTS, Sala Civil, 195/2006, de 9 marzo; 497/2006, de 26 de mayo -Rec. 4020/1999-; 826/2011, de 23 de noviembre -Rec. 1753/2007-; 460/2010, de 14 de julio -Rec. 945/2006-; y 601/2019, de 8 de noviembre -Rec. 596/2017-, entre otras.

RODRÍGUEZ RUIZ DE LA VILLA, D. y HUERTA VIESCA, M. I.: "La responsabilidad por deudas de los nuevos administradores sociales de la sociedad de capital en causa legal de disolución”, 2020, op. cit., edición digital, p. 3. 
presume exacto y válido produciendo sus efectos mientras no se inscriba la declaración judicial de su inexactitud o nulidad (art. 7 del RRM), como en su dimensión negativa (principio de oponibilidad), en virtud del cual los actos sujetos a inscripción sólo serán oponibles a terceros de buena fe desde su publicación en el Boletín Oficial del referido Registro (art. 9.1 RRM). Principio de publicidad material del registro que admite prueba en contrario, por lo que, en principio la derivación administrativa de deuda de Seguridad Social procedería frente a quien conste como administrador en el RM en el momento de haberse consumado el incumplimiento de los deberes de promover la disolución, correspondiendo la carga de la prueba encaminada a destruir la presunción registral al inscrito. Algún autor ${ }^{1018}$ defiende que debería constar no sólo la aceptación sino la firma del aceptante, para no verse obligado un inscrito indebidamente que no haya sido nunca administrador, tener que probar un hecho negativo, no haber sido nombrado ni haber aceptado el cargo. Paralelamente, y, al contrario, esa inscripción registral no impide que en la derivación administrativa de responsabilidad pueda acreditarse, a través de la actuación inspectora que, en esa fecha, pese a la falta de inscripción, la condición jurídica de administradores de derecho corresponde a otras personas, por haber sido nombradas por la Junta General, haber aceptado el cargo, y ejercerlo, pese a la falta de inscripción registral, al no ser ésta constitutiva.

\subsection{Cese y caducidad del cargo. Efectos de la inscripción registral.}

Con carácter general, la responsabilidad por deudas de Seguridad Social afecta a los administradores que ocupen el cargo el día del vencimiento de los plazos para cumplir con los dos deberes de promover la disolución ${ }^{1019}$, durante la vigencia del plazo de los dos meses que tienen para cumplir con sus deberes de promover la ordenada disolución de la sociedad ${ }^{1020}$, o que ocupasen el cargo cuando se han incumplido los deberes legales de promover la disolución ${ }^{1021}$.

De este modo, deberemos estar a la fecha del cese del cargo, para determinar si en la misma se habían ya incumplido los deberes de promover la disolución de la sociedad, a

\footnotetext{
1018 PRADES CUTILLAS, D.: La responsabilidad del administrador en las sociedades de capital en la jurisprudencia del Tribunal Supremo”, op. cit., edición digital, pp. 226-227.

1019 BELTRÁN SÁNCHEZ, E., "La responsabilidad de los administradores por obligaciones sociales", op. cit., p. 347.

${ }^{1020}$ MACHADO PLAZAS, J.: Pérdida del capital social y responsabilidad de los administradores por deudas sociales, op. cit., p. 341.

${ }^{1021}$ MOYA BALLESTER, J.: La responsabilidad de los administradores de sociedades en situaciones de crisis, op. cit., p. 487.
} 
efectos de derivar al administrador la responsabilidad por las deudas de Seguridad Social.

Se utiliza el término de cese en sentido amplio para aludir a la expiración del cargo.

Cese en el cargo del administrador que podrá tener lugar por dimisión o renuncia a instancias del propio administrador, por destitución de la Junta General, y por caducidad del cargo o expiración del tiempo convenido (Sentencia del TS, Sala Civil, 386/2000, de 13 abril -Rec. 2143/1995-).

La dimisión ${ }^{1022}$ del cargo por el propio administrador dimisionario se formalizará por escrito, debiéndose notificar fehacientemente a la sociedad (art. 147.1.1 ${ }^{\circ} \mathrm{RRM}$ ), sin que tenga efectos ante terceros de constar en documento privado según VILLAR EZCURRA $^{1023}$. Para su inscripción en el RM no se exige escritura pública, sirviendo el escrito de renuncia otorgado por el administrador y notificado fehacientemente a la sociedad, o la certificación del acta de la Junta General o del Consejo de Administración, con las firmas legitimadas notarialmente, (art. 147.1. $1^{\circ}$ y $2^{\circ}$ del RRM). Al ser una declaración recepticia de voluntad precisa sólo que se comunique fehacientemente a la sociedad, sin ser necesario que la mercantil acepte la misma (Sentencia TS, Sala Civil, 667/2009, de 23 de octubre -Rec. 199/2005-). Dimisión que ha de inscribirse en el RM debiendo constar en la inscripción la fecha en que se produjo (art. 147.1.2 $2^{\circ} \mathrm{RRM}$ ). Si la renuncia se efectúa en acta notarial ha de tenerse por cierta y tendrá efectos desde la fecha en que se produce, con independencia de que haya accedido al registro extemporáneamente ${ }^{1024}$.

1022 "Artículo 147. Dimisión y cese de administradores. Administradores suplentes.

1. $1 .{ }^{\circ}$ La inscripción de la dimisión de los administradores se practicará mediante escrito de renuncia al cargo otorgado por el administrador y notificado fehacientemente a la sociedad, o en virtud de certificación del acta de la Junta general o del Consejo de administración, con las firmas legitimadas notarialmente, en la que conste la presentación de dicha renuncia. $2 .^{\circ}$ En el documento en virtud del cual se practique la inscripción de la dimisión del administrador deberá constar la fecha en que ésta se haya producido.3..$^{\circ}$ La inscripción del cese de los administradores por fallecimiento o por declaración judicial de fallecimiento, se practicará a instancia de la sociedad o de cualquier interesado en virtud de certificación del Registro Civil."

${ }^{1023}$ VILLAR EZCURRA, M.: "La responsabilidad tributaria", op. cit., p. 625.

${ }^{1024}$ SSTS, Sala Civil, 417/2006, de 28 de abril -Rec. 3287/1999-; y 341/2007, de 22 de marzo -Rec. 3447/2000-.

En la Sentencia 417/2006, de 28 de abril, al respecto se argumenta que, "la renuncia efectuada por la recurrida en acta notarial de 11 de enero de 1995, ha de tenerse por eficaz para poner fin al periodo que cabría computar para exigir su responsabilidad, no obstante haberse inscrito en el Registro Mercantil el 24 de marzo siguiente, pues, aun cuando no quepa oponer el cese a terceros de buena fe, por razón de tratarse de un acto sujeto a inscripción (artículos 21.1 y 22.2 CCom. y arts. 4, 9, 94.1. $4^{\circ}$ y 147.1 RRM), ni cabe aceptar una exoneración por el mero hecho de la renuncia cuando ya la sociedad se halla incursa en causa de disolución, es claro que la renuncia impide una actuación eficaz 
Deberá en la derivación administrativa de responsabilidad recabarse información registral acerca de la fecha del cese, dato que debe constar en su inscripción (art. 147. $2^{\circ}$ del RRM), teniendo en cuenta que la falta de inscripción obliga al dimisionario y a la sociedad a acreditar que el cese ha tenido lugar y su fecha, por no ser oponibles a terceros los actos no inscritos.

No debemos confundir el hecho de que nazca la responsabilidad del administrador por haber incumplido con anterioridad a su cese las obligaciones de promover la disolución o solicitar el concurso de acreedores, con las deudas objeto de su responsabilidad, ya que una vez haya cesado de modo efectivo en el cargo deja de responder por las deudas posteriores a su cese (Sentencias del TS. Sala Civil, 731/2013, de 2 de diciembre -Rec. 1444/2011-; y 601/2019, de 8 de noviembre -Rec. 596/2017-) ${ }^{1025}$.

La destitución de los administradores por la Junta General se prevé en el art. 223 LSC, ya que, si la junta los nombra es igualmente libre para destituirlos, de modo que podrá separarlos del cargo en cualquier momento, aunque la separación no constase en el orden del día de la reunión. Destitución o separación que ha de inscribirse en el Registro Mercantil (art. 148 RRM) ${ }^{1026}$.

Los administradores podrán igualmente ser separados del cargo si la Junta General hubiere transigido o adoptado el acuerdo de promover el ejercicio de la acción social de responsabilidad (art. 238.2 LSC), o si se declara mediante resolución judicial firme (art. 148 RRM).

Con relación a la caducidad del cargo por finalización del plazo de vigencia, o lo que es lo mismo, por la llegada del dies ad quem del plazo de vigencia del cargo, señalar dos

desde la fecha en que se produce, que en este caso ha de tenerse por cierta, y que, dadas las específicas circunstancias del caso, ya destacadas, hace irrelevante que el momento de la inscripción se haya dilatado poco más de dos meses".

En la Sentencia 341/2007, de 22 de marzo -Rec. 3447/2000-, se insiste que "la cuestión planteada en el motivo ha sido abordada por la Sentencia de Pleno de 28 de abril de 2006, que fijó en la fecha de la renuncia por acta notarial el momento eficaz para poner fin al periodo que cabría computar para exigir responsabilidad, ya que la renuncia impide una actuación eficaz desde la fecha en que se produce, que en este caso ha de tenerse por cierta".

1025 Según estas sentencias, el administrador que ha dejado de cumplir con los reseñados deberes legales de promover la disolución responde solidariamente del pago de las deudas sociales surgidas con posterioridad a la aparición de la causa de disolución, pero no de las posteriores a su cese.

1026“Artículo 148. Separación de administradores. La inscripción de la separación de los administradores se practicará, según su causa, en virtud de los documentos siguientes: a) Si la separación hubiera sido acordada por la Junta General o se produjera como consecuencia del acuerdo de promover o de transigir la acción social de responsabilidad, mediante cualquiera de los documentos a que se refiere el artículo 142. b) Si la separación hubiese sido acordada por resolución judicial firme, mediante testimonio de la misma." 
cuestiones. En primer lugar, que el plazo de vigencia del cargo es distinto según estemos ante una sociedad anónima o sociedad de responsabilidad limitada. En la sociedad anónima la duración del cargo la establecen los estatutos sociales, sin que pueda exceder de seis años, aunque cabe que sea reelegido una o varias veces por iguales períodos de duración máxima (art. 221.2 LSC). Por el contrario, los administradores de las sociedades de responsabilidad limitada son elegidos por tiempo indefinido, salvo que los estatutos hubieren fijado un plazo máximo, en cuyo caso podrían ser reelegidos una o más veces por períodos de igual duración (art. 221.1 LSC). En segundo lugar, reseñar que la caducidad no opera de modo automático a la fecha de expiración de la duración del cargo, sino que el cargo del administrador caduca cuando vencido el período de vigencia se haya celebrado la Junta General que haya nombrado al nuevo administrador, o, en su defecto, cuando haya transcurrido el plazo para la celebración de la junta que ha de aprobar las cuentas anuales (art. 222 LSC), que como sabemos, ésta ha de ser convocada dentro de los primeros seis meses siguientes a la finalización del ejercicio social (art. 164 LSC), todo ello, para evitar la paralización del órgano de administración.

La caducidad del cargo no determina la pérdida automática de la condición de administrador a los efectos de apreciarse la concurrencia de esta responsabilidad (Sentencia del TS, Sala Contencioso-Administrativa, de 18 de noviembre de 2013 -Rec. 4486/2012-). Durante ese período transitorio se continúa teniendo la condición de administrador social (art. 222 LSC). En Sentencia del TS, Sala Civil, 951/2007, de 25 de septiembre -Rec. 4052/2000-, se alude al período de extensión de la responsabilidad del administrador que incluye desde el vencimiento del término de duración del cargo hasta la fecha de celebración de la junta que procedió al nombramiento de los nuevos administradores, señalando que "los recurrentes habían cesado como administradores, no solamente porque su nombramiento había caducado de acuerdo con el artículo 126 LSA, sino también porque ni siquiera podía considerárseles como tales a los efectos de continuar provisionalmente la gestión de la sociedad en tanto se produjera la sustitución del órgano de administración, ya que cuando los contratos fueron perfeccionados se había celebrado ya una junta extraordinaria que había procedido al nombramiento de un nuevo administrador único”. En la Sentencia del TS, Sala Civil, 228/2008, de 25 de marzo -Rec. 219/2001-, se extiende el período que genera el nacimiento de la responsabilidad por incumplimiento de los deberes disolutorios desde el vencimiento 
del término de vigencia del cargo hasta la fecha en que debió celebrarse la Junta General para la aprobación de las cuentas -30 de junio del año siguiente-.

Tras la expiración del término de vigencia del cargo, el administrador afectado se entiende "ope legis" que continúa transitoriamente en el cargo, y con mayor fundamento si no hubiere otro administrador titular o suplente, para evitar la paralización del órgano social, y si continúa en el cargo sigue estando sujeto a la responsabilidad legal impuesta al administrador, de modo que ésta no cesa en la fecha de la llegada del término. En la Sentencia del TS, Sala Civil, 667/2009, de 23 de octubre -Rec. 199/2005-, se concluye que, tanto la renuncia -declaración unilateral notificada fehacientemente a la sociedad (arts. 147 RRM y 1732 CC)-, como la caducidad por transcurso del plazo de duración correspondiente, producen la extinción del cargo de administrador social, pero si no hay otro administrador titular o suplente, el administrador renunciante o cesante está obligado a convocar la junta para cubrir la vacante y atender, en el interregno, a las necesidades de la gestión y representación. Se ha de entender que subsiste transitoriamente su cargo y como consecuencia su responsabilidad, para evitar el daño que a la sociedad pueda producir la paralización del órgano de administración y por exigirlo así el deber de diligencia. En esta sentencia, y con la finalidad de evitar la paralización del órgano social y debido a las exigencias del deber de diligencia, se estima que se continúa con la condición de administrador hasta la sustitución del mismo, no sólo en el caso de caducidad, sino también en los casos de dimisión o cese, si no hay otros administradores titulares o suplentes, ya que es contrario a dicho deber dejar a la sociedad sin órgano de administración.

Igual interpretación se mantiene en materia de derivación administrativa de responsabilidad a los administradores. En Sentencia del TS, Sala ContenciosoAdministrativa, de 18 de noviembre de 2013 -Rec. 4486/2012-, se considera que se mantiene la condición de administrador pese a haber transcurrido su plazo máximo, al no haberse nombrado nuevo administrador ni haber transcurrido el plazo para la convocatoria de la junta que ha de aprobar las cuentas del ejercicio social anterior, por lo que durante ese período no estaría exento de responsabilidad si no ha cumplido con sus deberes legales, porque "la caducidad de su nombramiento no exime al administrador de seguir desempeñando sus funciones hasta la designación de quien vaya a sucederle". En términos similares, en la Sentencia TS, Sala ContenciosoAdministrativa, 18 de octubre de 2010 -Rec. 2733/2006-, se declara que, "La seguridad 
en el tráfico mercantil justifica que el mero hecho de la caducidad del nombramiento por el transcurso del tiempo previsto para el mandato no implique automáticamente la pérdida de la condición de administrador, quedando quien la ostente obligado a adoptar las medidas oportunas para que se nombre a otro, en caso de que no desee continuar, o para que se revoque su nombramiento". En esta Sentencia, no sólo en caso de vencimiento del plazo del cargo, sino para supuestos de dimisión o renuncia del cargo, el administrador cesante habrá de realizar los actos encaminados a nombramiento de nuevo administrador, convocando la pertinente Junta General, para evitar la paralización del órgano de administración.

Paralelamente en la jurisprudencia se admite la validez de la Junta General convocada por los administradores con cargos caducados o tras su dimisión, con la finalidad de evitar la paralización de los órganos sociales y de que incurra en causa de disolución (Sentencias del TS, Sala Civil, 771/2007, de 5 de julio -Rec. 3063/2000-; y 784/2010, de 9 diciembre -Rec. 903/2007- ${ }^{1027}$ ).

Como ha señalado la jurisprudencia, al hablar del cese de los administradores deben diferenciarse sus efectos materiales, esto es, período que se computa de ejercicio del cargo, período en el que como administrador está obligado a cumplir con sus deberes, entre ellos promover la disolución; y sus efectos adjetivos, esto es la eficacia ante terceros del cese en el caso de su falta de inscripción en el RM, y que tendrá importancia a efectos del cómputo del plazo de prescripción de la responsabilidad. En la Sentencia del TS, Sala Civil, 1145/2008, de 27 de noviembre -Rec. 1050/2003-, se señala que la noción material de cese se refiere al tiempo en que se mantiene la

1027 En el Fundamento de Derecho Quinto de la Sentencia 784/2010, de 9 de diciembre, acerca de la validez de la Junta General convocada por órgano de administración con cargo caducado, se señala " No obstante, como excepción, en aras al principio de conservación de la empresa y estabilidad de la sociedad y de los mercados, a fin de evitar la paralización de los órganos sociales, y, a la postre, la incursión en causa de disolución, en los supuestos de acefalía funcional del órgano de administración, razones pragmáticas ya tenidas en cuenta en la Sentencia 771/2007, de 5 de julio (RJ 2007, 3875), que se refiere a que "la nulidad pretendida introduciría una perturbación en la situación jurídica de la sociedad", imponen Reconocer a quienes de hecho administran con el cargo caducado facultades para convocar junta dirigida a regularizar los órganos de la sociedad (...) Además, cualquiera de los administradores que permanezcan en el ejercicio del cargo podrá convocar la junta general con ese único objeto (...). El nombramiento de los administradores caducará cuando, vencido el plazo, se haya celebrado la Junta General siguiente o hubiese transcurrido el término legal para la celebración de la Junta que deba resolver sobre la aprobación de cuentas del ejercicio anterior, tenida en cuenta como límite, entre otras, en la resolución de la Dirección General de los Registros y del Notariado de 30 octubre 2009. Partiendo de la anterior premisa, el hecho de que la convocatoria efectuada por los administradores con cargo caducado comprendiese, además del dirigido a la regularización del órgano de administración, otros extremos, en modo alguno determina la nulidad radical e indiscriminada de toda la convocatoria, ni supone un obstáculo para la validez de los actos dirigidos a aquel fin". 
responsabilidad del administrador, al período de ejercicio del cargo, al lapso temporal en el que deben de estar comprendidas las acciones u omisiones determinantes de responsabilidad; período que finaliza en la fecha del cese real y efectivo sin incluirse el período de falta de inscripción del cese en el RM, porque esa falta de inscripción no puede dar lugar a que se extienda o prolongue la responsabilidad más allá del cese efectivo. La falta de inscripción no conlleva la ampliación del período temporal en el que deben de estar comprendidas las acciones $u$ omisiones determinantes de responsabilidad, al no tener la inscripción del cese carácter constitutivo ${ }^{1028}$. Cuestión distinta serán los efectos procesales o adjetivos del cese no inscrito, para el cómputo del plazo de prescripción de la responsabilidad del administrador, que conforme al art. 949 del Código de Comercio es un plazo de 4 años a computar desde la fecha del cese, de modo que de no haberse inscrito al tercero de buena fe no le sería oponible esa falta de inscripción, iniciándose el cómputo del plazo de prescripción desde la fecha de inscripción ${ }^{1029}$. Partiendo de esos efectos adjetivos de la falta de inscripción del cese,

${ }^{1028}$ En igual sentido, Sentencias del TS, Sala Civil, 664/2006, de 26 junio -Rec. 4434/1999-; 497/2006, de 26 mayo -Rec. 4020/1999-; 417/2006, de 28 de abril -Rec. 3287/1999-; 103/2007, de 7 febrero -Rec. 362/2000-;760/2007, de 4 de julio -Rec. 4503/2000-; 208/2009, de 1 de abril -Rec. 2198/2003-; 951/2007, de 25 de septiembre -Rec. 4052/2000-; 669/2008, de 3 de julio -Rec. 4186/2001-; 123/2010, de 11 de marzo -Rec. 1239/2005-; y 328/2011, de 19 de mayo -Rec. 1691/2007-, entre otras muchas.

En la Sentencia del TS, Sala Civil, 951/2007, de 25 de septiembre -Rec. 4052/2000-, se indica "Esta Sala tiene declarado en recientes resoluciones que la falta de inscripción del cese de los administradores en el Registro Mercantil no puede por sí misma ser determinante de la prolongación de su responsabilidad más allá de su cese efectivo, dado que éste impide un ejercicio eficaz de las funciones de administración desde la fecha en que se produce, la inscripción carece de carácter constitutivo y la imposibilidad de oponer a terceros los efectos del cese del administrador cuando no ha sido inscrito (principio llamado a garantizar frente a terceros la efectividad de las obligaciones contraídas por los administradores aparentes en nombre de la sociedad) no es suficiente para la integración de los elementos determinantes de la existencia de responsabilidad de los mismos (SSTS de 23 de diciembre de 2002, Recurso ${ }^{\circ}$ 1698/97; 24 de diciembre de 2002, Recurso ${ }^{\circ}$ 1753/97; 16 de julio de 2004, Recurso $\mathrm{n}^{\circ}$ 2566/98; 28 de mayo de 2005, Recurso $\mathrm{n}^{\circ}$ 4720/98; 28 de abril de 2006, Recurso n. ${ }^{\circ} 3287 / 1999 ; 26$ de mayo de 2006, Recurso n. ${ }^{\circ} 3788 / 1999 ; 7$ de febrero de 2007, Recurso ${ }^{\circ}$ 362/2000; 22 de marzo de 2007, Recurso n. ${ }^{\circ} 3447 / 2000$; y 4 de julio 2007, Recurso n. ${ }^{\circ} 4503 / 2000$ )".

${ }^{1029}$ En la Sentencia del TS, Sala Civil, 1145/2008, de 27 de noviembre -Rec. 1050/2003-, se señala que "Mas distinto es el efecto que debe atribuirse a la falta de inscripción en el Registro Mercantil del cese del administrador de cara a efectuar el cómputo del plazo de prescripción de la acción tendente a exigir su responsabilidad. Como enseñan las citadas Sentencias de 26 de junio de 2006 y de 3 de julio de 2008, debe entenderse que, si no consta el conocimiento por parte del afectado del momento en que se produjo el cese efectivo por parte del administrador, o no se acredita de otro modo su mala fe, el cómputo del plazo de cuatro años que comporta la extinción por prescripción de la acción no puede iniciarse sino desde el momento de la inscripción, dado que sólo a partir de entonces puede oponerse al tercero de buena fe el hecho del cese y, en consecuencia, a partir de ese momento el legitimado para ejercitar la acción no puede negar su desconocimiento".

En igual sentido Sentencias del TS, Sala Civil, 664/2006, de 26 junio -Rec. 4434/1999-; 208/2009, de 1 de abril -Rec. 2198/2003-; Sentencias de 13 de abril de 2000 -RJ 2000/1829-; 2 de abril de 2002 -RJ 2002/2666-; 416/2005, de 28 de mayo -Rec. 4720/1998-; 497/2006, de 26 de mayo -Rec. 4020/1999-; 951/2007, de 25 septiembre -Rec. 4052/2000-; 669/2008, de 3 de julio -Rec. 4186/2001-; 123/2010, de 11 de marzo -Rec. 1239/2005-, entre otras. 
para los acreedores de buena fe que no tuvieren conocimiento del mismo, el plazo de prescripción para exigir la responsabilidad del administrador se computa desde la inscripción registral. Si el cese del administrador no inscrito en el RM le constase a la TGSS por cualquier otro medio, habría que estar a la fecha en que tuvo conocimiento, así en la Sentencia del TS, Sala Contencioso-Administrativa, 551/2019, de 24 de abril Rec. 157/2017-, se señala "no se ha acreditado la existencia de otros hechos que de forma simultánea pudiesen acreditar que la acreedora [la TGSS] podría conocer el cambio en los órganos de gestión de la sociedad ".

Cuando el cese efectivo del administrador es anterior a que acaezca la causa de disolución, al no podérsele exigir el cumplimiento de los deberes legales de promover la disolución o de solicitar el concurso, el administrador no incurre en la responsabilidad por las deudas de la sociedad de capital recogida en el art. 367 de la $\operatorname{LSC}^{1030}$.

No responden de las deudas de Seguridad Social al amparo del art. 367 de la LSC, los administradores que hayan perdido jurídicamente esa condición con anterioridad al acaecimiento de la causa legal de disolución, bien sea porque hayan dimitido voluntariamente, o bien por haber sido cesados por la Junta General, y ello con independencia de que el cese se haya inscrito o no en el RM, ya que no podría imputarse el incumplimiento a quien jurídicamente no puede cumplir con el deber ${ }^{1031}$, todo ello, claro está, siempre que a partir de ese momento no fuere un verdadero administrador de hecho, ya que en este supuesto si le sería exigible la responsabilidad por deudas. Es por ello relevante la fecha en que tiene efectos el cese, sea renuncia, dimisión o destitución, de modo que podrá tenerse por cierta $^{1032}$ si consta en las actas del Consejo de Administración o de la Junta General, en acta notarial, y especialmente en el RM, teniendo en cuenta que esa inscripción no es constitutiva.

${ }^{1030}$ SSTS, Sala Civil, 556/2003, de 5 de junio -Rec. 3162/1997-; 497/2006, de 26 mayo -Rec. 4020/1999; 951/2007, de 25 de septiembre -Rec. 4052/2000-; 1145/2008, de 27 de noviembre -Rec. 1050/2003-; 328/2011, de 19 de mayo -Rec. 1691/2007-; 731/2013, de 2 de diciembre -Rec. 1444/2011-; y 601/2019, de 8 de noviembre -Rec. 596/2017-, entre otras muchas.

1031 BELTRÁN SÁNCHEZ, E.: "La responsabilidad de los administradores por obligaciones sociales", op. cit., pp. 347-349; MOYA BALLESTER, J.: La responsabilidad de los administradores de sociedades en situaciones de crisis, op. cit., p. 488; SÁNCHEZ CALERO, F.: Los administradores en las sociedades de capital, op. cit., p. 459; DÍAZ ECHEGARAY, J. L.: Deberes y responsabilidades de los Administradores de sociedades de Capital, op. cit., p. 404; CALBACHO LOSADA, F.: El ejercicio de las acciones de responsabilidad contra los administradores de la sociedad anónima, op. cit., pp. 518-521.

1032 SÁNCHEZ CALERO, F.: Los administradores en las sociedades de capital, op. cit., p. 460. 
Por el contrario, si el cese o la pérdida de vigencia del cargo es posterior al acaecimiento de la causa de disolución, habremos de distinguir, a su vez, si ese cese es anterior o posterior a que expire el plazo de dos meses para cumplir con alguno de los deberes legales de promover la disolución de la sociedad. Hemos de determinar si para incurrir en responsabilidad es suficiente con que el cese se produzca una vez concurra la causa de disolución, aunque no hayan transcurrido los dos meses para cumplir con los deberes legales de promover la disolución, o si, por el contrario, para incurrir en responsabilidad el cese ha de ser posterior, no sólo a la causa de disolución sino también al transcurso del plazo de los dos meses para cumplir con esos deberes.

Para la jurisprudencia ${ }^{1033}$ no plantea dudas la responsabilidad del administrador social cuando el cese es posterior al incumplimiento de alguno de los deberes de promover la disolución, cuando el cese tiene lugar una vez hayan transcurrido dos meses desde la causa de disolución sin haber cumplido con los deberes de promover la disolución, porque el incumplimiento se consumó durante el ejercicio del cargo.

Con relación al cese posterior a la causa de disolución y anterior al transcurso del plazo de los dos meses para cumplir con los deberes de promover la disolución, conviene aludir a la interpretación defendida en la doctrina y la jurisprudencia.

El sector mayoritario de la doctrina opta por exigir la responsabilidad a los administradores que están ocupando el cargo a la fecha del vencimiento de los plazos para cumplir con los deberes de promover la disolución ${ }^{1034}$. Para otro sector doctrinal ${ }^{1035}$ incurren en la responsabilidad solidaria todos los administradores que han ocupado el cargo durante el período a que se extiende el incumplimiento, de modo que el cese después del acaecimiento de la causa sin cumplir con los deberes, no exonera al administrador, cualquiera que sea la causa, incluido la destitución por la junta o la dimisión. Ni la renuncia voluntaria, ni el cese acordado por la junta, ni la caducidad del

1033 Sentencias del TS, Sala Civil, 497/2006, de 26 mayo -Rec. 4020/1999-; 341/2007, de 22 de marzo Rec. 3447/2000-; 760/2007, de 4 de julio -Rec. 4503/2000-; 951/2007, de 25 de septiembre -Rec. 4052/2000-; 228/2008, de 25 de marzo -Rec. 219/2001-; 338/2009, de 29 de mayo -Rec. 2106/2004-, entre otras. Según la Sentencia del TS 760/2007, de 4 de julio -Rec. 4503/2000-, el administrador responde si cesó en el cargo antes de formularse las cuentas, pero varios meses después de advertir o haber debido advertir, la causa de disolución por pérdidas.

1034 BELTRÁN SÁNCHEZ, E.: "La responsabilidad de los administradores por obligaciones sociales", op. cit., pp. 347-348; DÍAZ ECHEGARAY, J. L.: Deberes y responsabilidades de los Administradores de sociedades de Capital, op. cit., p. 404; ESTEBAN VELASCO, G.: “Algunas reflexiones sobre la Responsabilidad de los Administradores frente a los Socios y los Terceros: Acción individual y acción por no Promoción o Remoción de la disolución”, op. cit., p. 74.

1035 CALBACHO LOSADA, F.: El ejercicio de las acciones de responsabilidad contra los administradores de la sociedad anónima, op. cit., p. 415. 
cargo, si han incumplido los deberes legales les exonera de responsabilidad, ni siquiera cuando caduque el cargo antes de transcurrir los dos meses sin haber cumplido con sus deberes $^{1036}$.

En la jurisprudencia encontramos igualmente pronunciamientos en favor y en contra de la imputación de la responsabilidad.

Por un lado, hay resoluciones que vienen a excluir la responsabilidad cuando el cese es posterior a la causa de disolución, pero anterior a que transcurran los plazos para cumplir con alguno de los deberes de promoción de la disolución ${ }^{1037}$. En la Sentencia del TS, Sala Civil, 103/2007, de 7 de febrero -Rec. 362/2000-, se confirma la sentencia de apelación que exoneraba de responsabilidad al administrador con cese en el cargo anterior al vencimiento del plazo de los dos meses para cumplir con el deber de promover la disolución, señalando el Tribunal Supremo que, "los administradores cesaron en su cargo en la Junta General Extraordinaria y Universal celebrada el día 19 de julio de 1995, poco más de un mes después de ser decretado el archivo del expediente de suspensión de pagos, por no haberse alcanzado el quórum preciso para la aprobación del convenio, hecho y momento que determina el surgimiento de la obligación de los administradores de promover la disolución de la sociedad caso de concurrir los presupuestos para ello, y desde el que debe computarse el plazo de dos meses dentro del cual debe cumplirse dicha obligación", y añade "ante todo debe retenerse que la sentencia recurrida, además de poner el acento en el cese de los administradores sociales, apenas un mes después del archivo del expediente de suspensión de pagos, circunstancia que conduce a la exoneración de la responsabilidad que les reclama el demandante".

De modo no tan claro, podría citarse la Sentencia del TS, Sala Civil, 313/2006, de 3 de abril -Rec. 2702/1999-, que rechaza el petitum del administrador recurrente de no ser responsable por haber cesado antes de consumarse el incumplimiento, y que fue condenado en apelación, señalando, “pues la Sentencia recurrida (Fundamento Jurídico Tercero) afirma que el ahora recurrente no ha probado su cese como miembro del Consejo de Administración de "X, S.A." con anterioridad al plazo fijado para cumplir

1036 CALBACHO LOSADA, F.: El ejercicio de las acciones de responsabilidad contra los administradores de la sociedad anónima, op. cit., pp. 415-416.

1037 SSTS, Sala Civil, 103/2007, de 7 de febrero -Rec. 362/2000-; 313/2006, de 3 de abril -Rec. 2702/1999-; y 417/2006, de 28 de abril -Rec. 3287/1999-. 
las obligaciones por cuya omisión se acciona, aunque cesara como Vicepresidente y Consejero Delegado y fuera despedido del cargo retribuido de Director General".

Aunque parece inclinarse por exigir la responsabilidad cuando el cese o dimisión es posterior a la causa de disolución y anterior al vencimiento del plazo de dos meses para promover la disolución, la Sentencia del TS, Sala Civil, 417/2006, de 28 de abril -Rec. 3287/1999-, cuando obiter dicta afirma, que "lo que suscita la cuestión relativa a la posición de los administradores que presentan la dimisión dentro del período en que deberían realizar la promoción de la liquidación en los términos que la Ley exige, en lo que habría que señalar que si es cierto que la renuncia no exonera por sí misma de la responsabilidad que impone el artículo 262.5 LSA cuando se produce después de haber incurrido la sociedad en causa de disolución, que ha debido ya conocer o que de hecho ha conocido el administrador dimisionario, y sin que se haya realizado por el administrador la actuación que legalmente se le impone", Finalmente acaba concluyendo que, "ni cabe aceptar una exoneración por el mero hecho de la renuncia cuando ya la sociedad se halla incursa en causa de disolución, es claro que la renuncia impide una actuación eficaz desde la fecha en que se produce, que en este caso ha de tenerse por cierta” ${ }^{1038}$. En esta Sentencia, por un lado, se señala que la renuncia no exonera de responsabilidad si es posterior a la causa de disolución, pero, por otro lado, finalmente admite que la renuncia impide al renunciante ejercer los cometidos del cargo, con lo que, le exonera de responsabilidad. En esa resolución judicial se exonera

${ }^{1038}$ La Sentencia del TS, Sala Civil, 417/2006, de 28 de abril -Rec. 3287/1999-, señala “ lo que suscita la cuestión relativa a la posición de los administradores que presentan la dimisión dentro del período en que deberían realizar la promoción de la liquidación en los términos que la Ley exige, en lo que habría que señalar que si es cierto que la renuncia no exonera por sí misma de la responsabilidad que impone el artículo 262.5 LSA cuando se produce después de haber incurrido la sociedad en causa de disolución, que ha debido ya conocer o que de hecho ha conocido el administrador dimisionario, y sin que se haya realizado por el administrador la actuación que legalmente se le impone, $\mathrm{Y}$ en este sentido, la renuncia efectuada por la recurrida, en acta notarial de 11 de enero de 1995, ha de tenerse por eficaz para poner fin al periodo que cabría computar para exigir su responsabilidad, no obstante haberse inscrito en el Registro Mercantil en 24 de marzo siguiente, pues, aún cuando no quepa oponer el cese a terceros de buena fe, por razón de tratarse de un acto sujeto a inscripción (artículos 21.1 y 22.2 CCom., y arts. 4, 9, 94.4 y 147.1 RRM), ni cabe aceptar una exoneración por el mero hecho de la renuncia cuando ya la sociedad se halla incursa en causa de disolución, es claro que la renuncia impide una actuación eficaz desde la fecha en que se produce, que en este caso ha de tenerse por cierta, y que, dadas las específicas circunstancias del caso, ya destacadas, hace irrelevante que el momento de la inscripción se haya dilatado poco más de dos meses. La oponibilidad a terceros de los actos sujetos a inscripción y no inscritos, por otra parte, se presenta, en punto al cese de los administradores (artículos 21.1 CCom. y 9 RRM), como un problema de eficacia respecto de la sociedad de actuaciones o gestiones realizadas por los administradores no inscritos o que permanecen inscritos después de su cese, cuestión distinta de la que aquí se está contemplando sobre todo cuando, como ocurre en el caso, la permanencia de la inscripción registral del administrador que ya ha cesado no ha sido determinante ni influyente en la relación entre la sociedad y el acreedor que reclama”. 
de responsabilidad a la administradora, porque en el breve período de tiempo en que desempeñó el cargo, de octubre 1994 a enero 1995, no llegó a poder conocer la situación económica en que se hallaba la sociedad ${ }^{1039}$.

Por el contrario, encontramos otras resoluciones judiciales que no liberan de responsabilidad si el cese fuese posterior a la causa de disolución pero anterior al vencimiento del plazo de los dos meses para cumplir con el primer deber de promover la disolución ${ }^{1040}$.

No se exonera de responsabilidad al administrador que conociendo la concurrencia de la causa de disolución por pérdidas a través del informe de auditoría, anunció su renuncia al cargo en prensa, cuando el órgano de administración había convocado a la junta no para acordar la disolución o medidas de remoción, sino para aprobar las cuentas anuales, por estimarse que la renuncia era una actitud pasiva que no le exime de responsabilidad una vez concurre la causa de disolución (Sentencia del Tribunal Supremo, Sala Civil, 1092/1999, de 22 de diciembre -Rec. 2659/1995-). Es de reseñarse esta doctrina, porque la mera renuncia al cargo, cuando se tiene conocimiento de la causa de disolución no exonera de responsabilidad, en cuanto no conlleva actos encaminados a evitar el incumplimiento.

Igualmente, la Sentencia del TS, Sala Civil, 228/2008, de 25 de marzo -Rec. 219/2001-, con relación a la caducidad del cargo y ante el incumplimiento de las obligaciones de promover la disolución durante el período comprendido entre la fecha de vencimiento del período de vigencia del cargo y la fecha en que debió celebrarse la Junta General que ha de aprobar las cuentas del ejercicio anterior, se declara que el administrador no

1039 Textualmente señala, "Fue nombrada administradora en 17 de octubre de 1994. Realizó una serie de gestiones y actuaciones para averiguar la real situación económica de la sociedad que, poco después, conducida por el otro administrador, codemandado en rebeldía y condenado por la sentencia, despidió a sus trabajadores y fue sustituida en su actividad por otras empresas (noviembre de 1994). No pudo obtener ni información satisfactoria, ni una auditoría de cuentas, ni la rendición de cuentas que solicitó. Renunció por escritura pública de 11 de enero de 1995, que se inscribió en 24 de marzo siguiente, pero que la impedía actuar desde la renuncia misma. La Sala de instancia, valorando prudentemente la posición y la actuación de tal administradora, que desconocía la verdadera situación, que no ha tomado ninguna decisión que genere o incremente el daño, y que sólo ha podido actuar respecto de una situación generada con mucha anterioridad y que alcanzaba el grado de "caótica" entre el 17 de octubre y el 11 de enero siguiente (menos de tres meses), decide que no cabe establecer su responsabilidad. Y esa decisión, tanto si se considera la acción entablada en base al artículo 262.5 LSA desde la perspectiva de la responsabilidad civil cuanto desde la idea de "sanción", ha de ser sostenida".

1040 SSTS, Sala Civil, 228/2008, de 25 de marzo -Rec. 219/2001-; 1092/1999, de 22 de diciembre -Rec. 2659/1995-; SSTS, Sala Contencioso-Administrativa de 18 de noviembre de 2013 -Rec. 4486/2012- y de 18 de octubre de 2010 -Rec. 2733/2006-. 
se exime de responsabilidad porque no puede abandonarse la administración social, al señalar, "no cabe desconocer la exigencia, reiterada tanto por la doctrina de la DGRN, como por la jurisprudencial, de realizar los actos necesarios para regularizar los órganos de la sociedad y acomodarlos a la legalidad estricta, pues otra conducta supone un abandono irresponsable, que no puede excusar de las consecuencias perjudiciales para terceros, tanto más cuando no se trató de procurar las inscripción en el Registro Mercantil del cese en el cargo", señalando posteriormente, "ya que abandonar la administración sin procurar la debida cumplimentación del órgano social carece de la más mínima justificación”. En la misma línea, la Sentencia del T.S., Sala Civil, 951/2007, de 25 de septiembre -Rec. 4052/2000-, para los supuestos de renuncia o caducidad del cargo una vez ha acaecido la causa de disolución, por cuanto no puede abandonarse el cargo sin haber promovido la disolución de la sociedad, especialmente si no quedasen administradores que pudiesen cumplir con esa obligación.

El profesor BELTRÁN ${ }^{1041}$, ante la dimisión del administrador concurriendo una causa legal de disolución que le obligaría a promover la disolución, señala que, (sic) "los administradores han de ser sancionados si se limitan a presentar la dimisión sin convocar simultáneamente la junta, o en su caso, solicitar la disolución judicial, o el concurso", porque pese al cese deben cumplir con sus deberes legales. Interpretación a la que nos adherimos

La dimisión dentro del plazo para cumplir con la obligación no sería excusable, entendiendo que incurrirá en responsabilidad el administrador que, ante la concurrencia de una causa de disolución abandona irresponsablemente el cargo sin promover o instar ante el resto de los administradores la adopción del acuerdo de convocatoria de la Junta General para que ésta apruebe la disolución o medidas de remoción, o si, el cese o dimisión no va acompañado de actos para designar un nuevo administrador que permita cumplir con la obligación legal ${ }^{1042}$. Si como consecuencia de esa dimisión, el órgano de

1041 BELTRÁN SÁNCHEZ, E.: "La responsabilidad de los administradores por obligaciones sociales", op. cit., p. 349.

${ }^{1042}$ La jurisprudencia admite la validez de la Junta General realizada por los administradores con cargos caducados, o tras su dimisión, con la finalidad de evitar la paralización de los órganos sociales y de que incurra en causa de disolución (Sentencias del TS, Sala Civil, 771/2007, de 5 de julio -Rec. 3063/2000-, y 784/2010, de 9 diciembre -Rec. 903/2007-).

No se olvide, por otro lado, que para evitar la paralización del órgano de administración, tras el vencimiento del plazo de vigencia del cargo, de conformidad con el art. 222 LSC, no se entiende producida la caducidad del mismo hasta que se celebre una nueva junta que elija al nuevo administrador, o en su defecto, hasta que transcurra el plazo para convocatoria de la junta que ha de aprobar las cuentas anuales. 
administración finalmente no cumple con la obligación de promover en plazo la disolución, el dimisionario incurre con el resto de administradores en responsabilidad, porque no puede abandonarse irresponsablemente el cargo sin regularizar la situación de la sociedad, o sin contribuir al ordinario funcionamiento del órgano de administración, al ser la dimisión una conducta pasiva irresponsable con la que se pretende inhibirse de la marcha de la sociedad, conducta que no es excusable (Sentencias del Tribunal Supremo, Sala Civil, 228/2008, de 25 de marzo -Rec. 219/2001- y 1092/1999, de 22 de diciembre -Rec. 2659/1995-). No incurriría en responsabilidad el dimisionario, si el resto de administradores hubiere podido cumplir en plazo con el deber de promover la disolución, pero si finalmente el resto de administradores no cumplen, el incumplimiento debe afectar también al dimisionario.

Para la doctrina mayoritaria ${ }^{1043}$, la dimisión en bloque de todos o la mayoría de los miembros del Consejo de Administración, o de los administradores mancomunados en número que hiciere inoperante el órgano de administración, una vez acaecida la causa de disolución y antes de cumplirse el plazo legal para promover la disolución, los administradores incurrirían en responsabilidad si se limitan a presentar su dimisión sin convocar la junta o sin solicitar la disolución judicial o el concurso de acreedores, pero por el contrario, si son cesados por la Junta General antes del vencimiento del plazo para cumplir con sus deberes legales, quedarán exonerados de responsabilidad.

En la doctrinal administrativa de la DGRN, la renuncia de la totalidad de los administradores o de un número que hiciese inoperante la convocatoria de la junta tendrá consecuencias jurídicas, ya que en los casos de dimisión de la totalidad o de un

1043 CALBACHO LOSADA, F.: El ejercicio de las acciones de responsabilidad contra los administradores de la sociedad anónima, op. cit., p. 520, pero si el cese no afecta a todos los administradores, si el cese no afecta al funcionamiento del órgano de administración, ese cese no podría condicionarse al nombramiento de un sustituto; MOYA BALLESTER, J.: La responsabilidad de los administradores de sociedades en situaciones de crisis, op. cit., pp. 487-488, estima que, si la junta destituye al administrador antes de agotarse el plazo para cumplir con el deber legal, no se podría argumentar que el cesado ha incumplido el deber, porque el incumplimiento se produciría con el vencimiento del plazo; BELTRÁN SÁNCHEZ, E.: "La responsabilidad de los administradores por obligaciones sociales", op. cit., p. 349; MACHADO PLAZAS, J.: Pérdida del capital social y responsabilidad de los administradores por deudas sociales, op. cit., pp. 341-342, para quien, en los casos de dimisión en bloque de la totalidad de los miembros del órgano de administración, se estima que no quedarían exonerados de la responsabilidad por deudas, por el mero hecho de la dimisión, una vez que conocen la concurrencia de la causa de disolución, si simultáneamente no convocan la Junta General, o, en su caso, no solicitan la disolución judicial, ya que, cuando consecuencia de las renuncias, el cargo de administrador quede inoperante, los administradores renunciantes deberán convocar a la junta con inclusión dentro del orden del día, cuando menos de tres cuestiones, en primer lugar, la designación de nuevos administradores, en segundo lugar, la constatación de la concurrencia de la causa de disolución, y en tercer lugar, la adopción del acuerdo de disolución o alternativamente de remoción de la causa. 
número suficiente para hacer inoperante el órgano de administración, los cesantes deben continuar al frente de la gestión hasta que se nombren nuevos administradores. En esta línea de pensamiento en su Resoluciones de 24 de marzo de 1994, citando otras anteriores, señala, "es doctrina de este centro directivo [Resoluciones de 26 y 27 mayo 1992 (RJ $1992 \backslash 5260$ y RJ 1992 L5261) y Resoluciones de 8 y 9 junio 1993 (RJ 1993\5415 y RJ 1993 5416)], y en ella se apoya la nota recurrida, que sin prejuzgar la facultad que, corresponde a los Administradores de desvincularse unilateralmente del cargo que les ha sido conferido y han aceptado, por más que la sociedad pretenda oponerse a ello [artículos 1732 del Código Civil y 141 de la Ley Sociedades Anónimas (RCL 1989\2737 y RCL 1990\206)], no cabe desconocer que el mínimo deber de diligencia exigible en el ejercicio de ese cargo cuando como consecuencia de su renuncia quede el mismo totalmente vacante o, sin que ello llegue a producirse, devenga inoperante -renuncia de un Administrador mancomunado o un número de Administradores que impida la válida constitución del Consejo de Administraciónobliga a los renunciantes, pese a su decisión, a continuar al frente de la gestión hasta que la sociedad haya podido adoptar las medidas necesarias para proveer a dicha situación (artículos 127 de la Ley de Sociedades Anónimas y 1737 del Código Civil)”. Partiendo de esta interpretación, en Sentencia de la Audiencia Provincial de Barcelona, de 8 julio 1999 -RJ 1999/7039-, se declara la responsabilidad por deudas del administrador social dimisionario al estimarse que "la dimisión no podía producir los efectos pretendidos por el renunciante hasta que la sociedad lo hubiera sustituido por otro administrador o, al menos, podido adoptar las medidas necesarias para proveer a dicha situación RDGRN de 26 de mayo de 1992 (RJ 1992L5260), 8 de junio de 1993 (RJ 1993\5415), 24 de marzo de 1994 (RJ 1994\2029), y 22 de junio de 1994 (RJ 1994\4919)”.

Finalmente señalar que, en los supuestos continuar los administradores en el ejercicio de las funciones tras la efectividad jurídica de la caducidad del cargo, en nuestra jurisprudencia $^{1044}$ se ha declarado la responsabilidad en calidad de administrador de hecho. En la Sentencia del TS, Sala Civil, 123/2010, de 11 de marzo -Rec. 1239/2005-, se señala con relación a la continuidad en el ejercicio de las funciones de administrador tras la caducidad del cargo, en cuanto administrador de hecho: "continuidad en el ejercicio de sus funciones como administradores de hecho. Esta Sala se ha pronunciado

${ }^{1044}$ Sentencias del TS, Sala Civil, 228/2008, de 25 de marzo -Rec. 219/2001-; 240/2009, de 14 de abril Rec. 1504/2004-; 123/2010, de 11 de marzo -Rec. 1239/2005-, entre otras. 
en el sentido de que el cese del nombramiento por caducidad del administrador no constituye requisito suficiente para entender producido el cese del mismo si se prueba que existió una continuidad en el ejercicio de sus funciones como administrador de hecho, permaneciendo en sus funciones de administración y representación orgánica de la sociedad (STS de 23-09-2008, RC 2803/2003), y ha considerado que se da esa continuidad si existe un proceso abierto en el que es parte la sociedad (STS de 14 de abril de 2009, RC 1504/2004)".

De este modo, si no consta inscrito el cese en el Registro Mercantil, pero de las actuaciones inspectoras se constatase fehacientemente el cese material o efectivo de los administradores con efectos anteriores a la concurrencia de la causa de disolución, los administradores cesados no deberían ser incluidos en la derivación administrativa de responsabilidad por deudas de Seguridad Social al amparo del art. 9.1 del RRM. Pero, por el contrario, si no constase inscrito el cese y la sociedad no acredita fehacientemente éste o que la fecha de sus efectos es anterior a la causa de disolución, deberían ser incluidos en el acuerdo administrativo de derivación de responsabilidad o en el acta de liquidación de cuotas por derivación de responsabilidad, ya que en esos casos la carga de la prueba del cese y sus efectos corresponde a la sociedad y a los administradores. En todo caso, si se prueba que pese al cese en el cargo continúan en el ejercicio de sus funciones, serán declarados responsables en su calidad de administradores de hecho.

\subsection{Efectos de la sucesión de administradores en la responsabilidad por deudas.}

Si como consecuencia del cese o dimisión de los administradores ya había acaecido una causa de disolución, los nuevos administradores nombrados con posterioridad tienen la obligación de promover la disolución o solicitar el concurso ${ }^{1045}$ si no quieren incurrir en responsabilidad $^{1046}$.

Con relación al plazo de dos meses para el cumplimiento de la obligación de promover la disolución o solicitar el concurso de acreedores, en el supuesto de nombrarse nuevos administradores con posterioridad a la concurrencia de la causa de disolución, habiendo transcurrido el plazo legal de dos meses desde el acaecimiento de la causa disolutoria, ese plazo para que los nuevos administradores cumplan con sus deberes se computará

\footnotetext{
1045 Sentencias del TS, Sala Civil, 540/2005, de 7 de julio -Rec. 43/1999-; 195/2006, de 9 de marzo -Rec. 2325/1999-; 497/2006, de 26 de mayo -Rec. 4020/1999-; y 601/2019, de 8 de noviembre -Rec. 596/2017-.

1046 BELTRÁN SÁNCHEZ, E.: "La responsabilidad de los administradores por obligaciones sociales”, op. cit., p. 349.
} 
desde la fecha en que asumen el cargo, y no desde la causa de disolución ${ }^{1047}$. El dies a quo para los nuevos administradores se computa desde la asunción del cargo. Con toda claridad declara la Sentencia del TS, Sala Civil, 601/2019, de 8 de noviembre -Rec. 596/2017- que, concurriendo causa de disolución antes del nombramiento del nuevo administrador, habiendo incumplido los anteriores los deberes de promover la disolución o solicitar el concurso de acreedores, "en caso de cambio de administrador, desde que asume la administración, para él nace un nuevo plazo de dos meses para promover la disolución".

En la Sentencia 733/2013, de 4 de diciembre -Rec. 1694/2011-, con relación a un administrador nombrado con posterioridad a la causa de disolución, sin haberse removido ésta, y habiendo transcurrido el plazo de dos meses desde el acaecimiento de la misma, la responsabilidad para los nuevos administradores nace "dos meses después de que asumieran el cargo"; argumentándose, "es claro que, bajo el régimen legal aplicable, la deuda social con los dos demandantes resulta exigible al amparo del art. 262.5 TRLSA a todos los administradores demandados y condenados, porque en todos los casos existía cuando cada uno de ellos incumplió el deber de instar la disolución. En el caso de Aureliano, lógicamente, la responsabilidad surgió dos meses después de que asumiera el cargo, el 20 de noviembre de 2003. También hay que desestimar el motivo quinto del recurso del Sr. Juan porque, en su caso el deber de promover la disolución surge tras la asunción del cargo de administrador (21 de junio de 2002), pues ya entonces estaba la sociedad en causa legal de disolución, y mientras ostentó el cargo e incumplió este deber nació la deuda social a cuyo pago solidario se le condena en virtud del art. 262.5 TRLSA, en concreto, con el contrato de préstamo de 30 de julio de 2002". Las cursivas son nuestras.

En la Sentencia del TS, Sala Civil, 195/2006, de 9 marzo -Rec. 2325/1999-, ante una sociedad inactiva desde junio de 1993, nombrado un nuevo administrador con posterioridad a la causa de disolución, sin cumplir con sus deberes de promover la disolución dentro de los dos meses siguientes al nombramiento, se señala "porque si bien es cierto que este recurrente fue nombrado administrador de la sociedad deudora con posterioridad al nacimiento de la deuda, no lo es menos que la sentencia recurrida declara probado que a partir de junio de 1993 la sociedad ya estaba inactiva y su

${ }^{1047}$ Sentencia del TS, Sala Civil, 195/2006, de 9 de marzo -Rec. 2325/1999-; 497/2006, de 26 de mayo Rec. 4020/1999-; 540/2005, de 7 julio; 733/2013, de 4 de diciembre; 601/2019, de 8 de noviembre Rec. 596/2017-. 
situación era de descontrol financiero, contable y administrativo, por lo que, como razona esa misma sentencia, este recurrente tenía que haber promovido la ordenada liquidación de la sociedad a partir del 28 de enero de 1994, fecha de la Junta que adoptó el acuerdo de nombrarle y en la que ya se reflejó ese absoluto descontrol de la sociedad, habiendo declarado esta Sala que el cumplimiento tardío por los administradores de los deberes previstos en el art. 262.5 LSA (RCL 1989, 2737 y RCL 1990, 206) no les exime de una responsabilidad ya contraída en cuanto ésta parte del conocimiento adquirido o debido adquirir por él (SSTS 30-10-00 en Recurso núm. 3341/95 [RJ 2000, 9909], 16-12-04 en Recurso núm. 3375/98 [RJ 2004, 8215] y 27-1098 en Recurso núm. 1638/94 [RJ 1998, 8256]), y menos aún cuando, siempre según la sentencia recurrida, las cuentas del ejercicio 1993 no se presentaron hasta después de dirigida la reclamación contra los administradores mediante demanda presentada el 13 de junio de 1995, es decir, un año y medio después del nombramiento de este recurrente como administrador". La cursiva es nuestra.

En la Sentencia del TS, Sala Social, 497/2006, de 26 de mayo -Rec. 4020/1999-, se condena al nuevo administrador, porque tras su nombramiento, y habiendo acaecido la causa de disolución con anterioridad sin promoverse la disolución, él tampoco cumplió con su deber a partir del nombramiento.

Por si existían dudas, claramente se afirma que nace un nuevo plazo de dos meses a computar desde la asunción del cargo, en la Sentencia del TS, Sala Civil, 601/2019, de 8 de noviembre -Rec. 596/2017-. En esta Sentencia se señala que, si en la fecha del nombramiento del nuevo administrador, ya había transcurrido el plazo de dos meses desde que concurrió la causa de disolución, sin que los anteriores administradores hubieren cumplido las obligaciones de promover la disolución o solicitar el concurso de acreedores, (sic) "en caso de cambio de administrador, desde que asume la administración, para él nace un nuevo plazo de dos meses para promover la disolución".

Frente a esta reiterada y clara línea jurisprudencial, no puede tomarse como ejemplo de resolución judicial que mantiene solución distinta, la Sentencia del TS, Sala Civil, 460/2010, de 14 de julio -Rec. 945/2006-, cuando, en el Fundamento de Derecho Undécimo, se señala que, "aunque el catorce de noviembre de dos mil dos se acordó en Junta General ampliar el capital, el doce de mayo de dos mil tres venció el plazo establecido para hacerla efectiva con los correspondientes negocios de suscripción, sin que se hubiera logrado restablecer la proporción entre patrimonio y capital que hiciera 
improcedente la disolución por la Causa Cuarta del artículo 260 del Texto Refundido de la Ley de Sociedades Anónimas -Real Decreto Legislativo 1564/1989, de 22 de diciembre-. Con lo que el plazo bimensual comenzó de nuevo a correr, ahora también en perjuicio de los nuevos consejeros". La cursiva es nuestra. Con esa afirmación, lo que se hace es recordar que, una vez accedan nuevos administradores al cargo, si la sociedad continúa en causa de disolución, y no se ha cumplido por los anteriores administradores con el primer deber, para los nuevos consejeros se computará el plazo de dos meses para convocar la junta desde que asumen el cargo.

La Consulta de 19 de agosto de 2013 de la Dirección General de la Inspección de Trabajo y Seguridad Social, sobre derivación de responsabilidad a los administradores ${ }^{1048}$ señala que, "el nuevo administrador, que teóricamente asume dicho cargo cuando ya la sociedad está incursa en causa de disolución, no se podrá considerar responsable sino hasta que no se hayan cumplido los plazos a que se refiere el artículo 367.1 TRLSC. En este tiempo, el nuevo administrador debe evaluar la situación contable de la sociedad para actuar en consecuencia. Pero si no lo hace así y permite, con su inacción, que la sociedad siga actuando, una vez ha tenido ocasión para constatar la existencia de una causa de disolución, contribuyendo con ello al deterioro del crédito de los acreedores, debe responder según la Ley, de todas las deudas sociales. La cita de la Sentencia del Tribunal Superior de Justicia de Andalucía de Sevilla, Sala de lo Contencioso-Administrativo, de 20 de abril de 2012, que recoge el jefe de la Inspección Provincial en su escrito ilustra claramente la finalidad de la norma. Señala primero que no puede entenderse cómo nadie se presta a figurar en un Consejo de Administración de una sociedad sin cerciorarse previamente de su situación contable. Para luego concluir que la responsabilidad alcanza a quienes generaron inicialmente la situación, más igualmente a quienes la aceptan, la hacen suya sin óbice alguno y continúan gestionado el discurrir de la empresa en la misma actitud de incumplimiento".

No defendió esta interpretación un sector doctrinal ${ }^{1049}$, ya que con anterioridad a esta doctrina jurisprudencial entendió que, en caso de nombrarse nuevos administradores una vez acaecida la causa de disolución, los nuevos administradores deberían cumplir con los deberes legales, y el pazo de dos meses, en su caso, para convocar o solicitar la disolución judicial no nace ex novo, no se computaría desde el nombramiento, sino que

${ }^{1048}$ Referencia La Ley 2492/2013.

1049 CALBACHO LOSADA, F.: El ejercicio de las acciones de responsabilidad contra los administradores de la sociedad anónima, op. cit., p. 418. 
se computa desde el acaecimiento de la causa para el primer deber de convocar la junta, o desde la fecha de la junta para el segundo deber de pedir la disolución judicial. Es por ello, que CALBACHO LOSADA, estimaba que si cuando han sido nombrados ya han transcurrido los plazos legales deberían cumplir sus dos deberes de modo inmediato ${ }^{1050}$. En esos supuestos los nuevos administradores podrían quedar exonerados de responsabilidad si acreditan que la información recibida al acceder al cargo era incorrecta, o que se les ocultó la verdadera situación en que se hallaba la sociedad ${ }^{1051}$.

A partir de la Sentencia del TS, Sala Civil, 601/2019, de 8 de noviembre -Rec. 596/2017-, los nuevos administradores responden de las deudas posteriores "al nombramiento", y que en interpretación sistemática con el art. 214.3 de la LSC, ha de entenderse posteriores a la aceptación del $\operatorname{cargo}^{1052}$, una vez incumplan los deberes legales de promover la disolución o solicitar el concurso, si la causa de disolución hubiere acaecido con anterioridad a su nombramiento (Sentencia del TS, Sala Civil, 601/2019, de 8 de noviembre -Rec. 596/2017-), siempre que no se hubiere removido la causa de disolución dentro de los dos meses siguientes a asumir el cargo. Podríamos asistir a nombramientos sucesivos de administradores, por cese de los anteriores antes de que transcurran los dos meses desde la aceptación de sus cargos, en cuyo caso, según RODRÍGUEZ RUIZ DE VILLA y HUERTA VIESCA ${ }^{1053}$, los acreedores sociales podrían ver "cómo se suceden ante sus ojos diversas personas físicas y/o jurídicas administradoras sociales de sociedades de capital incursas en causa legal de disolución, que no lleguen a incorporarse al elenco de legitimados pasivos para sufrir los efectos de la acción de responsabilidad por deudas", porque, para que la responsabilidad por deudas se consume se precisa que continúen en el cargo una vez transcurran los dos meses desde la aceptación del mismo, concluyendo críticamente estos autores, que, "los garantes solidarios adicionales lo serán, pues, sólo los que superen, al menos, la barrera fatídica de los dos meses desde su aceptación del cargo haciendo oídos sordos al art. 367.1 LSC", porque en ese precepto se alude a las obligaciones sociales posteriores al

1050 CALBACHO LOSADA, F.: El ejercicio de las acciones de responsabilidad contra los administradores de la sociedad anónima, op. cit., p. 418.

1051 CALBACHO LOSADA, F.: El ejercicio de las acciones de responsabilidad contra los administradores de la sociedad anónima, op. cit., p. 418.

1052 RODRÍGUEZ RUIZ DE LA VILLA, D. y HUERTA VIESCA, M. I.: "La responsabilidad por deudas de los nuevos administradores sociales de la sociedad de capital en causa legal de disolución”, 2020, edición digital, op. cit., p. 7.

1053 RODRÍGUEZ RUIZ DE VILLA, D. y HUERTA VIESCA, M. I.: "La responsabilidad por deudas de los nuevos administradores sociales de la sociedad de capital en causa legal de disolución”, 2020, edición digital, op. cit., p. 5. 
acaecimiento de la causa de disolución, no de las posteriores al nombramiento o aceptación del cargo. A partir de esta Sentencia del TS, Sala Civil, 601/2019, de 8 de noviembre -Rec. 596/2017-, al requisito de responder de las deudas posteriores a la causa de disolución, se ha de matizar, siempre que sean posteriores a la fecha de asunción del cargo en el supuesto de nuevos administradores que aceptan el cargo una vez se encontrase la sociedad en causa de disolución.

Partiendo de la Sentencia de la Sala $1^{\text {a }}$ del Tribunal Supremo 314/2006, de 23 de marzo -Rec. 2643/1999-, que exoneró de responsabilidad a la nueva administradora que ocupó el cargo durante tres meses, sin haber podido comprobar la situación real de la sociedad, pese a sus esfuerzos por acceder a esa información, RODRÍGUEZ RUIZ DE VILLA y HUERTA VIESCA ${ }^{1054}$, defendieron que, en aplicación de esa nueva doctrina del Tribunal Supremo, "el nuevo administrador social no será responsable ex artículo 367 LSC, aunque hayan transcurrido los plazos que allí se contemplan, si prueba haber hecho los esfuerzos oportunos para tratar de llegar a conocer la situación real de la sociedad sin haberlo conseguido, siendo tales actuaciones: el requerimiento informativo al resto de administradores y al personal de la misma, así como el haber encargado la práctica de una auditoría interna”.

\section{Exoneración de responsabilidad. Imputabilidad del administrador.}

La responsabilidad por deudas impuesta legalmente a los administradores, por el incumplimiento de los deberes de promover la disolución, recae sobre todos los integrantes del órgano de administración, porque, ab initio estamos, según la doctrina científica $^{1055}$, "ante una presunción colectiva de responsabilidad de todos sus integrantes", cualquiera que haya sido la forma de organización de ese órgano gestor de la sociedad. Debido a esa presunción colectiva de responsabilidad, si hay incumplimiento de los deberes de promover la disolución, tal incumplimiento es predicable de todos los miembros integrantes del órgano de administración, y como

${ }^{1054}$ RODRÍGUEZ RUIZ DE VILLA, D. y HUERTA VIESCA, M. I.: "La responsabilidad por deudas de los nuevos administradores sociales de la sociedad de capital en causa legal de disolución”, 2020, edición digital, op. cit., p. 9.

1055 MACHADO PLAZAS, J.: Pérdida del capital social y responsabilidad de los administradores por deudas sociales, op. cit., pp. 432-433; SÁNCHEZ CALERO, F.: Los administradores en las sociedades de capital, op. cit., p. 339; QUIJANO GONZÁLEZ, J.: "La responsabilidad de los administradores por la no disolución de la sociedad y las causas de exoneración”, 2002, op. cit., p. 81. 
señala QUIJANO ${ }^{1056}$, tal circunstancia no precisa prueba del acreedor social, quien sólo debe acreditar la causa de disolución y la no convocatoria en plazo de la Junta General.

La razón de ser de esta presunción colectiva de responsabilidad, es porque estamos ante una obligación del órgano, siendo imputable en principio el incumplimiento a todos sus integrantes, para no exigirse que sea el acreedor quien deba acreditar la imputación de todos los miembros del órgano, ya que, como señala SÁNCHEZ CALERO ${ }^{1057}$ los acreedores podrán llegar a saber quiénes lo integran acudiendo al Registro Mercantil, a la contabilidad anual u otros medios, pero, en cambio, les resultará más difícil saber quiénes de sus integrantes participaron en la reunión del órgano de administración. Fruto de esa presunción colectiva de responsabilidad se invierte la carga de la prueba, al ser cada miembro del órgano quien podrá salvar su responsabilidad si prueba que concurre en él una causa de exoneración. Responsabilidad colectiva que es fruto de la colegialidad del órgano ${ }^{1058}$.

Presunción de responsabilidad colectiva que resulta del art. 237 de la LSC $^{1059}$, donde se establece, por un lado, la presunción iuris tantum de culpabilidad colectiva de los administradores, pero, por otro lado, se prevé que cada miembro integrante del órgano pueda ser exonerado de responsabilidad si prueba su falta de imputabilidad. La responsabilidad colectiva de los administradores implica la existencia de pluralidad de integrantes del cargo, con lo que queda excluida cuando estemos ante un administrador único ${ }^{1060}$. Precepto que es aplicable en todos los supuestos de pluralidad de administradores $^{1061}$, especialmente para el Consejo de Administración, pero también para la administración mancomunada, aunque según SÁNCHEZ CALERO, no para los administradores solidarios que actúan individualmente.

\footnotetext{
1056 QUIJANO GONZÁLEZ, J.: "La responsabilidad de los administradores por la no disolución de la sociedad y las causas de exoneración", 2002, op. cit., p. 81.

${ }^{1057}$ SÁNCHEZ CALERO, F.: Los administradores en las sociedades de capital, op. cit., p. 339.

${ }^{1058}$ QUIJANO GONZÁLEZ, J.: La responsabilidad civil de los administradores de la Sociedad Anónima, aspectos sustantivos", 1985, op. cit., pp. 265-266.

1059 "Artículo 237. Carácter solidario de la responsabilidad. Todos los miembros del órgano de administración que hubiera adoptado el acuerdo o realizado el acto lesivo responderán solidariamente, salvo los que prueben que, no habiendo intervenido en su adopción y ejecución, desconocían su existencia o, conociéndola, hicieron todo lo conveniente para evitar el daño o, al menos, se opusieron expresamente a aquél".

${ }^{1060}$ SÁNCHEZ CALERO, F.: Los administradores en las sociedades de capital, op. cit., pp. 336-338 y 341.

${ }^{1061}$ SÁNCHEZ CALERO, F.: Los administradores en las sociedades de capital, op. cit., pp. 336-338 y 441.
} 
Esta exclusión de la solidaridad en la responsabilidad entendemos que podría ser aplicable a los administradores solidarios en la responsabilidad por daños, ya que ésta le es atribuible al que ha actuado y causado el daño, pero en el caso de la responsabilidad por deudas, de hallarnos ante administradores solidarios, cada uno de ellos individualmente considerado, puede cumplir con los deberes legales de promover la disolución, sin precisar el concurso del resto, de modo que si ninguno de ellos ha cumplido con la obligación, esa omisión afecta a la falta de cumplimiento, con lo que todos ellos resultarán responsables, operando plenamente la presunción de responsabilidad colectiva del art. 237 de la LSC, a salvo de la eventual aplicación de la posible concurrencia de alguna causa de exoneración.

En art. 237 de la LSC está incluido dentro de la responsabilidad por daños del administrador, para las acciones individuales y sociales de responsabilidad. En cambio, en la responsabilidad por deudas del art. 367 LSC, no se recoge expresamente una disposición de igual contenido, ya que sólo se alude a los administradores que incumplan los deberes de promover la disolución, o de solicitar el concurso, a la hora de hacerles responsables solidarios con la sociedad de capital de las deudas de la mercantil, pero sin preverse ninguna presunción de solidaridad en caso de pluralidad de administradores. No obstante, se ha admitido en la doctrina mayoritaria ${ }^{1062}$ y en la jurisprudencia ${ }^{1063}$, la aplicación analógica del art. 237 LSC a la responsabilidad por deudas del art. 367 de la LSC, por lo que será de aplicación, tanto la presunción de culpabilidad colectiva, como las causas de exención o exoneración de responsabilidad de ese precepto legal.

1062 QUIJANO GONZÁLEZ, J.: "Responsabilidad de los administradores por no disolución de la sociedad (art. 262.5 TRLSA) (Sentencia de la Audiencia Provincial de Burgos de 24 de julio de 1995)", op. cit., p. 275; QUIJANO GONZÁLEZ, J.: "La responsabilidad de los administradores por la no disolución de la sociedad y las causas de exoneración”, 2002, op. cit., pp. 81-82; MACHADO PLAZAS, J.: Pérdida del capital social y responsabilidad de los administradores por deudas sociales, op. cit., pp. 432-433; CALBACHO LOSADA, F.: El ejercicio de las acciones de responsabilidad contra los administradores de la sociedad anónima, op. cit., p. 481; DÍAZ ECHEGARAY, J. L.: Deberes y responsabilidades de los Administradores de sociedades de Capital, op. cit., p. 407; MOYA BALLESTER, J. : La responsabilidad de los administradores de sociedades en situaciones de crisis, op. cit., pp. 497-501; BELTRÁN SÁNCHEZ, E.: "La responsabilidad de los administradores por obligaciones sociales", op. cit., p. 349.

1063 Se exige la concurrencia de imputabilidad al administrador del incumplimiento de sus deberes, de su conducta pasiva, y la consiguiente inexistencia de causa justificadora de la omisión (Sentencias TS, Sala Civil, 942/2011, de 29 de diciembre; 27/2017, 18 de enero; 560/2013, de 7 de octubre; 585/2013, de 14 de octubre; 680/2010 de 10 noviembre; 458/2010, de 30 de junio; 173/2011, de 17 de marzo; y 942/2011, de 29 de diciembre; 225/2012, de 13 de abril; 395/2012, de 18 de junio; y 420/2019, de 15 de julio, entre otras muchas. Doctrina de la Sala Civil, que hace suya la Sala ContenciosoAdministrativa en la derivación de deudas de Seguridad Social al administrador social, recientemente en la Sentencia 875/2019, de 24 de junio -Rec. 2902/2018-. 
Las causas de exoneración habrán de ser acreditadas por los administradores que pretendan ser excluidos de la responsabilidad, con lo que la carga de la prueba de esas circunstancias exonerantes, como toda excepción procesal, recae sobre el administrador ${ }^{1064}$. Ese sistema de presunción de responsabilidad solidaria colectiva de los administradores, en la medida en que es una presunción de incumplimiento de los deberes de promover la disolución por parte de los integrantes del órgano, podrá ser destruida por el administrador social a título individual, acreditando que el incumplimiento no le es imputable, por existir causas que puedan exonerarle de responsabilidad ${ }^{1065}$. Como señala QUIJANO1066 “el inicial automatismo de esta responsabilidad debe quedar compensado con la posibilidad de que cualquier administrador pruebe que no le es imputable el incumplimiento", o en palabras de ESTEBAN VELASCO 1067, “los administradores podrán exonerarse probando que no les es imputable culpa alguna, teniendo en cuenta la estructura del órgano y las circunstancias del caso". BELTRÁN ${ }^{1068}$, en similares términos, dirá que al hallarnos "ante una sanción por incumplimiento de unos deberes legales específicos, hace que no puedan ser sancionados aquellos administradores que prueben que no les es imputable el incumplimiento".

En función de la responsabilidad colectiva de los administradores, y según la forma de organización del órgano, según QUIJANO ${ }^{1069}$, “de hallarnos ante un administrador

1064 QUIJANO GONZÁLEZ, J.: "Responsabilidad de los administradores por no disolución de la sociedad (art. 262.5 TRLSA) (Sentencia de la Audiencia Provincial de Burgos de 24 de julio de 1995)", op. cit., p. 275; QUIJANO GONZÁLEZ, J.: "La responsabilidad de los administradores por la no disolución de la sociedad y las causas de exoneración”, 2002, op. cit., p. 81; DÍAZ ECHEGARAY, J. L.: Deberes y responsabilidades de los Administradores de sociedades de Capital, op. cit., p. 407; BELTRÁN SÁNCHEZ, E.: "La responsabilidad de los administradores por obligaciones sociales", op. cit., p. 349.

1065 BELTRÁN SÁNCHEZ, E.: "La responsabilidad de los administradores por obligaciones sociales", op. cit., p. 349; ESTEBAN VELASCO, G.: “Algunas reflexiones sobre la Responsabilidad de los Administradores frente a los Socios y los Terceros: Acción individual y acción por no Promoción o Remoción de la disolución”, op. cit., p. 72; QUIJANO GONZÁLEZ, J.: "Responsabilidad de los administradores por no disolución de la sociedad (art. 262.5 TRLSA) (Sentencia de la Audiencia Provincial de Burgos de 24 de julio de 1995)", op. cit., p. 275.

1066 QUIJANO GONZÁLEZ, J.: "Responsabilidad de los administradores por no disolución de la sociedad (art. 262.5 TRLSA) (Sentencia de la Audiencia Provincial de Burgos de 24 de julio de 1995)", op. cit., p. 275.

1067 ESTEBAN VELASCO, G.: “Algunas reflexiones sobre la Responsabilidad de los Administradores frente a los Socios y los Terceros: Acción individual y acción por no Promoción o Remoción de la disolución”, op. cit., p. 72.

1068 BELTRÁN SÁNCHEZ, E., "La responsabilidad de los administradores por obligaciones sociales", op. cit., p. 349.

1069 QUIJANO GONZÁLEZ, J.: "Responsabilidad de los administradores por no disolución de la sociedad (art. 262.5 TRLSA) (Sentencia de la Audiencia Provincial de Burgos de 24 de julio de 1995)", op. cit., p. 272. 
único, éste es el que debe cumplir con los deberes de promover la disolución, y por lo tanto él será el responsable; si fueren varios los administradores, de tener la condición de administradores solidarios, cada uno asume las obligaciones de promover la disolución de modo que, si uno cumple, el cumplimiento tiene efecto en los demás; si la administración fuere mancomunada, los deberes deben ser cumplidos de modo conjunto, especialmente el deber de convocar la junta, pero que si uno propone convocar la junta, sin contar con el acuerdo de los demás, el primero debería quedar exento de responsabilidad, al hacer todo lo posible por cumplir el primer deber, lo mismo sería aplicable para el segundo deber; en caso de ser un Consejo de Administración, la decisión ha de ser colegiada, por mayoría, de modo que si el acuerdo de convocar la Junta General no tuviere el apoyo de la mayoría, los que hayan propuesto la convocatoria, pese a quedar en minoría en la votación, haciendo constar en acta su voluntad de convocar y su oposición al acuerdo contrario, al haber hecho todo lo posible deben quedar exonerados de responsabilidad".

Con relación al cumplimiento del deber de convocar la junta, en caso de ser administradores mancomunados, se ha admitido excepcionalmente que puedan convocarla, no por todos, sino por algunos, siempre que el resto acuda posteriormente a la Junta General y no haga objeción o reparo del defecto de convocatoria, entendiéndose que de ese modo asiente a la misma y se subsana el defecto de origen (Sentencia del TS, Sala Civil, de núm. 424/2019, de 16 de julio -Rec. 3784/2016-).

Ante la aplicación analógica del art. 237 de la LSC, deberá sustituirse las referencias al daño, por las referencias al incumplimiento de la obligación de promover la disolución o el concurso, lo que nos lleva a examinar si esas causas de exoneración mantienen su coherencia, o si producen distorsiones ${ }^{1070}$. Para QUIJANO ${ }^{1071}$, no se aprecia incongruencia en la aplicación de esas causas de exoneración a la responsabilidad por deudas, ya que, si un administrador prueba que no intervino en la adopción del acuerdo de no cumplir con el deber de promover la disolución, y que desconocía sin culpa la concurrencia de la causa de disolución, o que conociéndola, hizo todo lo posible para cumplir con esos deberes, o que se opuso expresamente a la decisión del órgano de incumplir, al acreditar su falta de imputabilidad, quedaría exento de responsabilidad.

1070 QUIJANO GONZÁLEZ, J.: "La responsabilidad de los administradores por la no disolución de la sociedad y las causas de exoneración", 2002, op. cit., p. 82.

1071 QUIJANO GONZÁLEZ, J.: "La responsabilidad de los administradores por la no disolución de la sociedad y las causas de exoneración”, 2002, op. cit., p. 82. 
En virtud de esa aplicación analógica del art. 237 de la LSC, BELTRÁN ${ }^{1072}$, señala que (sic) "quedan exentos de responsabilidad quienes hicieren todo lo conveniente para evitar el incumplimiento de los deberes impuestos para propiciar la disolución o el concurso y quienes se opusiesen expresamente al acuerdo del órgano de no convocar la junta para la disolución o de no solicitar la disolución judicial o el concurso".

Ante la presunción de culpabilidad colectiva, resulta fundamental analizar brevemente la exoneración de responsabilidad del administrador. Las causas de exoneración del art. 237 de la LSC, en su aplicación analógica a la responsabilidad por deudas del art. 367 de la LSC, serían reconducibles a cuatro. En primer lugar, que haya desconocimiento de la convocatoria del órgano de administración que adoptó el acuerdo contrario a la disolución. En segundo lugar, que exista desconocimiento de la concurrencia de la causa de disolución. En tercer lugar, que de conocerse la causa y reunirse el órgano para adoptar una decisión, haber hecho todo lo necesario para que el órgano de administración acordase convocar la Junta General -cumplimiento del primer deber-, o pedir la disolución judicial -cumplimiento del segundo deber de los administradores-. En cuarto lugar, que de haber adoptado el órgano de administración un acuerdo contrario a promover la disolución o a solicitar el concurso, se hubieren opuesto expresamente a ese acuerdo dejando constancia al efecto. Son de difícil acreditación las causas primera y segunda de exoneración, desconocer la convocatoria o desconocer la causa de disolución, por el deber de diligencia que tiene todo administrador, ya que como señala SÁNCHEZ CALERO, la mera ausencia o la no asistencia a la reunión no es causa suficiente, ya que como administrador debe procurar su asistencia ${ }^{1073}$.

El problema será delimitar cómo operan esas causas de exoneración cuando el órgano de administración es mancomunado o un Consejo de Administración, ya que cuando el órgano es unipersonal, no plantearía mayores problemas, siendo el administrador el que debe acreditar la causa de exoneración, siendo de difícil apreciación, ya que el deber de diligencia hace muy difícil la prueba de desconocer la concurrencia de la causa de disolución, y por otro lado, el incumplimiento del deber sólo depende de su propia conducta, no de terceros. Según QUIJANO ${ }^{1074}$, en caso de administrador único, o

1072 BELTRÁN SÁNCHEZ, E.: "La responsabilidad de los administradores por obligaciones sociales", op. cit., p. 349.

${ }^{1073}$ SÁNCHEZ CALERO, E.: "La responsabilidad de los administradores por obligaciones sociales", op. cit., p. 344.

1074 QUIJANO GONZÁLEZ, J.: "La responsabilidad de los administradores por la no disolución de la sociedad y las causas de exoneración", 2002, op. cit., p. 81. 
administradores solidarios, la acreditación de la causa de exoneración será más dificultosa, que no imposible, debido al carácter individual de la obligación incumplida.

Con relación a la causa de exoneración de desconocer el acuerdo contrario a la disolución, o de desconocer la causa de disolución, QUIJANO ${ }^{1075}$ defiende que, siendo orgánico el cumplimiento del primer deber, consistente en acordar en el consejo la convocatoria de la junta, (sic) "si constando la causa de disolución, el órgano de administración convoca una Junta General que no incluya en el orden del día la disolución y medidas alternativas, la exoneración podrá afectar a los administradores, que no habiendo intervenido en la convocatoria de esa junta, desconozcan la existencia de la causa de disolución y de la convocatoria del órgano de administración, pero siempre que el desconocimiento no tenga su origen en la dejación o desinformación negligente, ya que el deber de diligencia incluye acceder a la información, lo que implica el conocimiento de las decisiones del consejo, sin descartarse el ocultamiento de la información, de modo que pudiera transcurrir el plazo para convocar la junta, sin llegar a conocer un miembro del órgano de administración ausente, la concurrencia de la causa de disolución”. En igual sentido, MOYA BALLESTER ${ }^{1076}$, para quien la causa de exoneración de desconocer la convocatoria del consejo para acordar la concurrencia o desconocer la causa de disolución, en el caso de disolución por pérdidas, es de difícil acreditación por el administrador, por su deber de diligencia, que implica estar al corriente de toda la información, así como acerca de la situación económica de la sociedad.

MACHADO PLAZAS ${ }^{1077}$, admitiendo la aplicabilidad analógica del precepto legal, estima que no puede aplicarse el mismo en su integridad, especialmente la causa eximente de no haber promovido la disolución por desconocer la causa de disolución por pérdidas, por la imposibilidad de alegar el administrador que desconocía la misma debido al deber de diligencia al que está sujeto ${ }^{1078}$, que le obliga a conocer en todo momento la situación patrimonial y financiera de la sociedad.

1075 QUIJANO GONZÁLEZ, J.: "La responsabilidad de los administradores por la no disolución de la sociedad y las causas de exoneración", 2002, op. cit., p. 83.

1076 MOYA BALLESTER, J. : La responsabilidad de los administradores de sociedades en situaciones de crisis, op. cit., p. 499.

1077 MACHADO PLAZAS, J.: Pérdida del capital social y responsabilidad de los administradores por deudas sociales, op. cit., p. 433.

${ }^{1078}$ En igual sentido, postulando que la causa de exoneración de desconocer la causa de disolución, en el caso de disolución por pérdidas, es de difícil acreditación por el administrador, por su deber de diligencia, que implica estar al corriente acerca de la situación económica de la sociedad, MOYA 
Con relación a la causa de exoneración de haber hecho todo lo posible por evitar que el órgano de administración adoptase el acuerdo contrario a la convocatoria de la junta o a la solicitud de la disolución judicial, habrán de valorarse las circunstancias concurrentes que alegue el administrador que pretenda ser exonerado. QUIJANO ${ }^{1079}$ defiende que si el Consejo de Administración no convoca a la junta, cualquier administrador que hubiere propuesto la convocatoria, que hubiere votado a favor, y que haga constar en acta su voluntad de convocar, así como su oposición al acuerdo contrario, al hacer lo exigible, deberían quedar exonerados.

Para QUIJANO, una posible vía de exoneración podría ser la impugnación del acuerdo del órgano de administración en que se acordó no convocar o convocar para finalidad distinta a promover la disolución, sin que con ello se concluya que la impugnación sea exigible en todo caso para la exoneración, porque no es la única vía de exoneración, criticando al respecto la doctrina sentada en la Sentencia del Tribunal Supremo, Sala Civil, 1092/1999, de 22 de diciembre -Rec. 2659/1995- ${ }^{1080}$.

MACHADO PLAZAS ${ }^{1081}$, admite finalmente que, (sic) "los administradores pueden exonerarse cuando demuestren que frente al acuerdo contrario a la disolución o inexistente de la junta, y frente al acuerdo contrario al cumplimiento de la convocatoria de la junta, o en su caso, de la petición imperativa de disolución del órgano de administración, han solicitado la disolución judicial de la sociedad como cualquier interesado. Las mismas consecuencias jurídicas ha de tener la petición individual de disolución judicial cuando no exista actividad alguna del órgano de administración”.

Con relación al segundo deber de solicitar la disolución judicial, MOYA BALLESTER $^{1082}$, interpretando la causa exonerante del art. 237 LSC, de haber hecho

BALLESTER, J.: La responsabilidad de los administradores de sociedades en situaciones de crisis, op. cit., p. 499.

1079 QUIJANO GONZÁLEZ, J.: "La responsabilidad de los administradores por no disolución de la sociedad y las causas de exoneración”, op. cit., p. 83; CALBACHO LOSADA, F.: El ejercicio de las acciones de responsabilidad contra los administradores de la sociedad anónima, op. cit., p. 436.

${ }^{1080}$ En esa Sentencia se señala que, "la negativa de un miembro del consejo a firmar el informe de gestión y las cuentas anuales, y el posterior anuncio en prensa de su renuncia, no le exoneraba de responsabilidad, ya que no impugnó el acuerdo de convocatoria de la Junta General en los términos en que se hacía", porque la convocatoria debería ser para acordar la disolución o medidas de remoción, "adoptando una postura meramente pasiva de inhibirse de la marcha de la sociedad mediante esa inoperante renuncia a su cargo".

1081 MACHADO PLAZAS, J.: Pérdida del capital social y responsabilidad de los administradores por deudas sociales, op. cit., pp. 433-434.

1082 MOYA BALLESTER, J. : La responsabilidad de los administradores de sociedades en situaciones de crisis, op. cit., p. 500. 
todo lo posible para evitar el daño -en este caso, para promover la disolución-, considera que para exonerarse de esta responsabilidad, (sic) "deberá solicitar el administrador la disolución judicial, cuando el órgano de administración hubiere previamente cumplido con el primer deber de convocar la junta, y el acuerdo del consejo sobre la petición de disolución judicial fuese contrario o no pudiera ser logrado, en cuyo caso, esa petición de disolución judicial libera al administrador solicitante y a los que hubieren votado en el órgano de administración a favor de la solicitud de disolución judicial. De no haberse pronunciado el consejo de administración sobre el deber de solicitud judicial de disolución, la solicitud de disolución judicial hecha por un administrador, exoneraría de responsabilidad al resto, siempre que se hubiese cumplido con el primer deber. Finalmente, si el consejo de administración no cumplió con el primer deber de convocar la junta, el administrador solicitante sólo se exoneraría de esta responsabilidad, si previamente solicitó de modo formal del consejo de administración la convocatoria de la junta general"'.

Para QUIJANO ${ }^{1083}$ el órgano es sujeto obligado a solicitar la disolución judicial, sin perjuicio de poderse solicitar por cualquiera de sus miembros, en su calidad de interesados, lo que tendrá efectos en la exoneración de responsabilidad del solicitante individual, y recogiendo el criterio de GARCÍA CRUCES, nos dirá que, en caso de un Consejo de Administración, el consejero individual, (sic) "deberá instar un acuerdo colegiado, como primera medida, para que sea el órgano administrativo el que cumpla la obligación legal dentro del plazo, y con tal comportamiento el administrador en cuestión estará en condiciones de quedar exento de responsabilidad por no serle imputable el incumplimiento, estando además, como interesado facultado para solicitar la disolución judicial, con lo que decae la concurrencia de los presupuestos para exigirle la responsabilidad"1084.

En nuestra jurisprudencia se han analizado las causas de exoneración del actual art. 237 de la LSC, mereciendo mención las Sentencias del TS, Sala civil, sobre exoneración de responsabilidad a los administradores que "hicieron todo lo posible para evitar el incumplimiento" (1092/1999, de 22 de diciembre -Rec. 2659/1995-; 313/2006, de 3 de abril -Rec. 2702/1999-).

1083 QUIJANO GONZÁLEZ, J.: "La responsabilidad de los administradores por la no disolución de la sociedad y las causas de exoneración”, 2002, op. cit., p. 84.

1084 QUIJANO GONZÁLEZ, J.: "La responsabilidad de los administradores por la no disolución de la sociedad y las causas de exoneración”, 2002, op. cit., p. 84. 
En la Sentencia del Tribunal Supremo, Sala Civil, 1092/1999, de 22 de diciembre -Rec. 2659/1995- ${ }^{1085}$, no se exonera de responsabilidad al administrador que, en reunión del Consejo de Administración se acordó convocar la Junta General de accionistas para aprobar las cuentas anuales, pero no para acordar la disolución o medidas de remoción, pese a tener conocimiento a través del informe de auditoría, de que la sociedad estaba en causa de disolución por pérdidas, estimando el TS que no era causa de exoneración de responsabilidad el hecho de no haber firmado las cuentas, limitándose a adoptar una actitud pasiva, anunciando en prensa la renuncia al cargo, pero sin haber impugnado el acuerdo del órgano de administración. Es de reseñarse esta doctrina, porque la mera renuncia al cargo cuando se tiene conocimiento de la causa de disolución, no exonera de responsabilidad, en cuanto no conlleva actos encaminados a evitar el incumplimiento, de hacer todo lo posible para evitar el mismo, implicando todo lo contrario, un abandono irresponsable del cargo, cuando lo que se espera del administrador es una actitud proactiva para procurar que la Junta General pueda adoptar el acuerdo de disolución, y de no ser posible, en último lugar, solicitar a título individual la disolución judicial, como administrador con interés directo y sujeto legitimado.

En la Sentencia del TS, Sala Civil, 313/2006, de 3 de abril -Rec. 2702/1999-, interpretando las causas de exoneración del actual art. 237 LSC, de “desconocer el acuerdo del consejo de administración de no convocar la junta", o "de conocerlo, haber hecho todo lo posible para que la convocatoria se llevase a término", establece que el administrador sólo puede exonerarse si asume y cumple la carga de probar que no intervino ni conocía el acuerdo contrario del órgano colegiado, o de conocerlo, que hizo todo lo conveniente para evitarlo, lo que vendría a significar que, dada su condición de administrador colectivo, carente de la facultad de convocar por sí mismo la junta, debió solicitar la disolución judicial de la sociedad, directamente o instando al órgano colegiado de administración para que acuerde la disolución judicial.

Como sentencia que exonera a la nueva administradora que ocupó el cargo durante tres meses, entre el 17 de octubre y el 11 de enero siguiente, fecha esta en que dimite, porque no llegó a tener conocimiento de la real situación económica, sin haber llegado a

1085 En esa Sentencia se señala que, "la negativa de un miembro del consejo a firmar el informe de gestión y las cuentas anuales, y el posterior anuncio en prensa de su renuncia, no le exoneraba de responsabilidad, ya que no impugnó el acuerdo de convocatoria de la Junta General en los términos en que se hacía", porque la convocatoria debería ser para acordar la disolución o medidas de remoción, "adoptando una postura meramente pasiva de inhibirse de la marcha de la sociedad mediante esa inoperante renuncia a su cargo". 
conocer realmente las pérdidas que arrastraba la sociedad desde 1989, reseñamos la Sentencia del TS, Sala Civil, 417/2006, de 28 de abril -Rec. 3287/1999-, que justifica la exoneración porque el cumplimiento de las obligaciones legales o estatutarias no puede exigirse razonablemente a quien no ejerció de hecho ninguna facultad de control, disposición, representación y dirección de la sociedad, ni tuvo realmente tiempo material para tener pleno conocimiento de la situación económica de la sociedad y de promover la disolución de la misma en el plazo de dos meses, porque la nueva administradora vivía en otra ciudad, habiendo heredado acciones de la compañía de su padre y adquirido otras de sus hermanos coherederos, y durante el período en que estuvo en el cargo realizó una serie de gestiones y actuaciones para averiguar la real situación económica de la sociedad no obteniendo información satisfactoria, ni una auditoría de cuentas, ni la rendición de cuentas que solicitó. Sorprende la exoneración, ya que no es razón la circunstancia de no haber ejercido realmente el cargo de administradora, ya que durante los tres meses ocupó el mismo, no constando haber otro administrador de hecho oculto o notorio -al respecto, reseñar que, la administradora alegó que durante los tres meses que ocupó el cargo, fue mera administradora formal, que no se ejecutaron acuerdos, y que no llegó a realizar tarea alguna de dirección, gestión ni administración de la empresa-. La única relevancia que puede tener la sentencia, es para reseñar que es causa de exoneración la circunstancia de no llegar a conocer el administrador la real situación económica de la sociedad, pese a haber adoptado todas las medidas encaminadas a ese fin, discrepando de la calificación de ser mera administradora formal, ya que, si no era verdadera administradora, la exención debería haber sido por ese motivo y no por no poder conocer la causa de disolución.

No es causa de exoneración de la responsabilidad por deudas del art. 367 LSC, el hecho de haberse delegado facultades del Consejo de Administración en consejeros delgados, o comisiones ejecutivas, ya que los delegantes no quedan exentos, pesa a descentralizar determinadas funciones, ya que como sabemos la facultad de convocar la Junta General es indelegable (art. 249 bis, apartado j) de la LSC).

Han de tenerse en cuenta tres aspectos esenciales para la exoneración. En primer lugar, que no exonera de responsabilidad la mera circunstancia de haberse otorgado poderes generales, ya que el administrador social, pese a los poderes conferidos, es el sujeto responsable al no perder su condición de administrador, correspondiéndole a él el ejercicio de las facultades y deberes del cargo de administrado, y entre ellas, la 
convocatoria de la junta ${ }^{1086}$. En segundo lugar, que tampoco exonera de la responsabilidad ya contraída, el fallecimiento del administrador, ya que la deuda por responsabilidad se trasmite a la herencia yacente y herederos que acepten la herencia (Sentencia del TS, Sala Civil, 590/2013, de 15 de octubre -Rec. 1268/2011-). Y en tercer lugar, no se minora ni se exonera de responsabilidad el administrador que en lugar de promover la disolución, adoptó otras medidas legales sin remover la causa disolutoria, como concluir un expediente de regulación de empleo (ERE), que acabó con la extinción de todas las relaciones laborales, y la posterior venta de activos y pasivos de la compañía, circunstancias que, como señala la Sentencia del TS, Sala Civil, 27/2017, de 18 de enero, no justificaban la omisión del deber de instar la disolución de la sociedad, y por lo tanto no eximían de responsabilidad, ya que esas medidas no sólo eran compatibles con la disolución de la compañía, sino que además conducían a ella, con el agravante de que la extinción de las relaciones laborales mediante el ERE, y la venta de activos y pasivos, suponían de facto el cese por parte de la sociedad de su actividad empresarial, lo que ahondaba más en la necesidad de su disolución.

Concluimos señalando que será difícil que el administrador pueda acreditar que no conocía, ni la concurrencia de la causa de disolución, ni el acuerdo contrario o la falta de acuerdo del órgano de administración de promover la disolución, porque las exigencias del deber de diligencia les obliga a estar informado sobra la marcha y funcionamiento orgánico de la sociedad. Por otro lado, la causa de exoneración de haber hecho todo lo posible para cumplir con los deberes de promover la disolución, o de haberse opuesto al acuerdo contrario del órgano de administración, no debería limitarse a haber votado a favor de promover la disolución en la reunión del consejo, o en reunión conjunta de los administradores mancomunados, sino que, haciendo constar expresamente su postura favorable a convocar la junta, se precisaría que posteriormente se adoptase una actitud proactiva encaminada a solicitar la disolución judicial (Sentencias del TS, Sala Civil, 1092/1999, de 22 de diciembre -Rec. 2659/1995-; 313/2006, de 3 de abril -Rec. 2702/1999-), no siendo suficiente haber impugnado el acuerdo del consejo contrario a la promoción de la disolución.

1086 Sentencias del TS, Sala Civil, de 26 de mayo de 1998 -RJ 1998/4004-; 7 de junio de 1999 -RJ 1999/4730-; 30 de julio de 2001 -RJ 2001/6632-; 760/2002, de 16 de julio -Rec. 304/1997-; 222/2004, de 22 de marzo -Rec. 1556/1998-; 261/2007, de 14 de marzo -Rec. 262/2000-; 501/2007, de 7 de mayo -Rec. 2225/2000-; 240/2009, de 14 de abril -Rec. 1504/2004-; 721/2012, de 4 de diciembre Rec. 1139/2010-; y 420/2019, de 15 de julio -Rec. 3654/2016-. 


\section{5.- La buena fe en la moderación o exención de responsabilidad del administrador en la responsabilidad solidaria por deudas del art. 367 de la LSC.}

Con relación a la causa de disolución por pérdidas, debemos aludir brevemente, acerca del hecho de si tiene relevancia para moderar la responsabilidad del administrador la circunstancia de conocer el acreedor social la difícil situación económica de la empresa en el momento de contraer la obligación social. Alusión breve, porque si pudiera tener importancia en los supuestos de acreedores privados, carece de relevancia para el cumplimiento de obligaciones de Seguridad Social, como son el pago de cotizaciones sociales o de prestaciones de responsabilidad empresarial, porque la deficitaria situación económica no es causa de moderación o exención de responsabilidad, ni para la empresa directamente responsable, ni por consiguiente para los sujetos responsables solidarios.

En ningún precepto regulador de la responsabilidad por daños de los arts. 236 a 241 de la LSC, o de la responsabilidad por deudas del art. 367 del mismo cuerpo legal, se hace mención expresa a esa circunstancia, de modo especial no se alude a que sea causa de exoneración o de moderación de la responsabilidad del administrador. Ahora bien, pudiera ser un factor importante el principio jurídico general de que los derechos han de ejercitarse de buena fe. Principio jurídico aplicable en las relaciones jurídicas en todas las ramas del Derecho, como se establece en el art. 7.1 del Código Civil. Ante ello, debemos clarificar si ese principio de ejercicio de buena fe de los derechos puede servir al administrador social para quedar exonerado, en todo o en parte, de responsabilidad de probar que, cuando se concierta la obligación social por la mercantil, el acreedor tenía un conocimiento suficientemente claro de la grave situación de crisis patrimonial de la sociedad de capital, de modo que racionalmente cabría concluirse que el crédito devendría incobrable.

En nuestra jurisprudencia podemos observar dos etapas distintas, en una primera, se ha dado relevancia para la minoración de responsabilidad del administrador, frente a una última etapa, en que el conocimiento de la difícil situación económica ha dejado de tener importancia en la responsabilidad por deudas del art. 367 de la LSC.

\subsection{Primera etapa jurisprudencial.}

En una primera etapa, el conocimiento por el acreedor social de la grave situación económica de la sociedad de capital, en las causas de disolución por pérdidas, ha llevado a nuestros tribunales a moderar, y en ciertos casos, a eximir de responsabilidad 
al administrador social, en función de las exigencias del principio de buena fe que debe acompañar al ejercicio de los derechos ${ }^{1087}$.

En esta primera jurisprudencia el conocimiento por el acreedor social, al momento de contratar con la sociedad, acerca de la infracapitalización, infrapatrimonialización o de la mala situación económica y financiera en que se hallaba la sociedad deudora, no les autoriza para dirigirse luego contra sus administradores reclamando la responsabilidad solidaria del art. 367 de la LSC, por impedirlo las exigencias del principio de buena fe en el ejercicio de los derechos.

\subsection{Segunda etapa jurisprudencial.}

En una segunda etapa se declara tajantemente que el conocimiento por el acreedor de la mala situación económica de la sociedad deudora no exonera de responsabilidad al administrador $^{1088}$.

Las recientes Sentencia del Tribunal Supremo, Sala Civil, 207/2018, de 11 de abril Rec. 2647/2015- y 420/2019, de 15 de julio -Rec. 3654/2016-, aclaran las dudas que pudieran persistir dejando claro que el mero conocimiento de la situación de crisis económica o de insolvencia de la sociedad por parte del acreedor al tiempo de generarse su crédito, no le priva de legitimación para ejercitar la acción de responsabilidad.

Con estas sentencias el conocimiento de la grave situación económica ya no es causa que exima de responsabilidad al administrador, y los supuestos de exoneración de responsabilidad de los administradores han de ser anecdóticos y limitados a supuestos objetivamente excepcionales.

${ }^{1087}$ En materia de responsabilidad por deudas del art. 367 de la LSC, podemos reseñar las Sentencias del TS, Sala Civil, núm. 776/2001, de 20 de julio -Rec. 1663/1996-; núm. 942/2003, de 16 de octubre Rec. 4040/1997-; núm. 118/2006, de 16 de febrero -Rec. 2285/1999-; núm. 1195/2006, de 22 de noviembre -Rec. 4564/1999-; núm. 61/2007, de 31 de enero -Rec. 2442/2000-; núm. 408/2008, de 14 de mayo -Rec. 187/2001-; y núm. 298/2009 de 14 de mayo -Rec. 1926/2004-.

Para la acción individual de responsabilidad, entre otras, las Sentencias del TS, Sala Civil, de 3 de julio de 1998 -Rec. 981/1994-; núm. 109/2000, de 16 de febrero de 2000 -Rec. 1449/95-; 1311/2002, de 30 de diciembre de 2002 -Rec. 1701/1997-; y 100/2003, de 12 de febrero de 2003 -Rec. 1793/1997-.

1088 Doctrina que se inicia con la Sentencia del TS, Sala Civil núm. 733/2013, de 4 de diciembre, confirmándose con las posteriores SSTS, 207/2018, de 11 de abril -Rec. 2647/2015-, y 420/2019, de 15 de julio -Rec. 3654/2016-. En la Sentencia 420/2019 se declara la responsabilidad solidaria del administrador en las deudas laborales de la sociedad con sus trabajadores, sin que la circunstancia de conocer los trabajadores la difícil situación de la empresa, sea óbice para declarar la responsabilidad del administrador. 
No nos extendemos más sobre esta cuestión, porque el cumplimiento de obligaciones con la Seguridad Social no es causa de exoneración de responsabilidad, ni para la sociedad de capital deudora, ni para los administradores sociales cuando resulten responsables solidarios, al hallarnos ante obligaciones de Derecho público, sobre la que no cabe la transacción ni arbitraje (art. 27 TRLGSS), ya que, ante situaciones de dificultades económicas, se prevén institutos jurídicos como el aplazamiento en el pago de deudas de Seguridad Social (art. 23 del TRLGSS), por lo que en materia de derivación de deudas de Seguridad Social al administrador social, no cabe la moderación de la responsabilidad por el hecho de que al nacer o ser exigible la deuda se conociese por las entidades gestoras la deficitaria situación económica de la sociedad de capital, ya que son deudas públicas, que son exigibles ope legis, en virtud de una norma legal imperativa, con independencia de la situación económica del deudor, ya que la obligación de cotizar nace del hecho objetivo de la existencia de prestaciones laborales por cuenta ajena, sin que la mala situación económica sea causa de fuerza mayor (STS, Sala Social 402/2020, de 22 de mayo -Rec. 3/2019-), y la deuda del pago de prestaciones de responsabilidad empresarial del incumplimiento de las obligaciones legales de la empresa en materia de afiliación, altas y cotizaciones por sus trabajadores a la Seguridad Social.

\section{VII.- ÁMBITO TEMPORAL DE LA RESPONSABILIDAD $Y$ SU PRESCRIPCIÓN.}

Los administradores sociales responden de las deudas de Seguridad Social de la sociedad de capital de haber incumplido los deberes de promover la disolución o el concurso, ante la concurrencia de causa legal de disolución.

Para la viabilidad de la reclamación de la responsabilidad por deudas del administrador social, habrán de tenerse en cuenta dos plazos de prescripción, por un lado, el plazo de prescripción de la deuda de la sociedad de capital, y por otro lado, el plazo de prescripción de la responsabilidad del administrador, ya que un responsable solidario no puede tener peor condición que el deudor principal en materia de prescripción de la deuda $^{1089}$.

1089 BELTRÁN SÁNCHEZ, E.: "La responsabilidad de los administradores por obligaciones sociales", op. cit., pp. 351-352. 
Para la derivación administrativa de la responsabilidad solidaria al administrador social, es preciso, en primer lugar, que no haya prescrito la deuda de la sociedad, y en segundo lugar, que no haya prescrito la acción de la derivación de la responsabilidad del administrador, lo que exige que la derivación de responsabilidad se ejercite durante el período de tiempo válido.

Nos corresponde analizar la prescripción de la responsabilidad por deudas del administrador, el período temporal en que podrá exigirse la responsabilidad solidaria al administrador. Nos remitimos a una anterior publicación en que se abordó con mayor amplitud esta prescripción ${ }^{1090}$.

En primer lugar, hemos de reseñar que, a diferencia de los acreedores particulares en que la carga de la prueba acerca de la prescripción de la deuda y de la responsabilidad corresponde a la sociedad y/o al administrador social ${ }^{1091}$, en las deudas con la Seguridad Social la prescripción se aprecia de oficio (art. 42.4 del RGRSS).

En segundo lugar, la determinación del ámbito temporal de la responsabilidad del administrador, del plazo de prescripción de esta responsabilidad, se reduce a dilucidar si debe aplicarse el régimen jurídico del art. 949 del Código de Comercio ${ }^{1092}$, o el nuevo art. 241 bis de la LSC $^{1093}$. Si debe seguirse aplicando el art. 949 del Código de Comercio, como se vino defendiendo mayoritariamente por la doctrina científica y la jurisprudencia hasta la introducción del nuevo art. 241 bis de la LSC, o si por el contrario, tras la incorporación de este precepto debe aplicarse el mismo tanto a la responsabilidad por daños como a la responsabilidad por deudas, de modo que ambas responsabilidades tengan un régimen unitario y homogéneo en materia de prescripción.

1090 Para un conocimiento más exhaustivo del plazo de prescripción de la acción de Reclamación o derivación administrativa de la responsabilidad del administrador social, así como sobre la prescripción de las deudas de Seguridad Social, nos remitimos a nuestro estudio, FERNÁNDEZ DÍEZ, A.: "Prescripción de la responsabilidad del administrador por deudas de Seguridad Social de la sociedad", op. cit., 2020, pp. 430 a 488.

${ }^{1091}$ Sentencia del TS, Sala Civil, 227/2006, de 9 de marzo -Rec. 2418/1999-, que señala, "corresponde a quien alega la prescripción la prueba del "dies a quo", de manera que la falta de concreción y la indeterminación del día inicial, o las dudas que sobre el particular puedan surgir no deben resolverse en principio en contra de la parte a cuyo favor juega el Derecho reclamado (Sentencias de 10 de marzo de 1989 y de 3 de diciembre de 1993)".

1092 Art. 949 del Código de Comercio "La acción contra los socios gerentes y administradores de las compañías o sociedades terminará a los cuatro años, a contar desde que por cualquier motivo cesaren en el ejercicio de la administración".

${ }^{1093}$ Introducido por el art. Único 22 de la Ley 31/2014, de 3 de diciembre, por la que se modifica la Ley de Sociedades de Capital para la mejora del gobierno corporativo -BOE del 4 de diciembre de 3014-. 
Surgen dudas acerca de la aplicación del nuevo art. 241 bis de la LSC, porque este precepto se incluye dentro de la regulación de la responsabilidad por daños de los administradores en el Capítulo V "Responsabilidad de los administradores" del Título VI "La administración de la sociedad”, y la responsabilidad por deudas del art. 367 de la LSC, se regula dentro del Título X “Disolución y liquidación”, Capítulo I “Disolución”.

Ambos preceptos establecen un mismo período de prescripción, cuatro años, pero difieren en la fijación del dies a quo, ya que en el art. 949 del Código de Comercio, el día inicial del cómputo del plazo de prescripción se sitúa en la fecha del cese del administrador, y en el art. 241 bis de la LSC el cómputo del pazo de prescripción se inicia en la fecha en que la acción haya podido ejercitarse (actio nata).

No tenemos aún jurisprudencia unificada sobre qué precepto legal es de aplicación a la responsabilidad por deudas de los arts. 360, 367 y concordantes de la LSC. Discrepancia que se mantiene en la doctrina científica y en la doctrina judicial menor.

Mientras no sea objeto de unificación la doctrina discrepante de los Tribunales y Audiencias Provinciales acerca de esta prescripción, hasta la fecha, en la jurisprudencia actual $^{1094}$ se ha aplicado a esta responsabilidad por deudas el régimen jurídico del art. 949 del Código de Comercio, el plazo de prescripción de cuatro años a computar desde la fecha de cese del administrador, salvo que el cese no haya accedido al RM, en cuyo supuesto, para los acreedores de buena fe ese plazo no se inicia sino desde la fecha de la inscripción registral, salvo que el acreedor conociere el hecho del cese del administrador social, en cuyo caso se computa desde ese conocimiento. Hasta la entrada en vigor del art. 241 bis de la LSC se aplicaba en la jurisprudencia a la responsabilidad por deudas y por daños el mismo precepto, el art. 949 del Código de Comercio.

No se ha pronunciado expresamente aún el Tribunal Supremo acerca de qué precepto de los dos será aplicable actualmente, ya que en la reciente Sentencia de la Sala civil, 14/2018, de 12 de enero -Rec. 751/2015-, posterior a la entrada en vigor del art. 241 bis

\footnotetext{
${ }^{1094}$ Sentencias del TS, Sala Civil, de 20 de julio de 2001 -Rec. 1495/1996-; 1 marzo de 2004; 26 de mayo de 2004; 5 de octubre de 2004; 25 de marzo de 2005; 15 de junio de 2005; 22 de diciembre de 2005; 6 de marzo de 2006; 227/2006, de 9 de marzo -Rec. 2418/1999-; 30 de enero de 2007; 21 de febrero de 2007; 30 de abril de 2008 -Rec. 3355/2000-; 3 de julio de 2008 -Rec. 4186/2001-; 10 de julio de 2008 -Rec. 4059/2001-; 12 de marzo de 2010 -Rec. 1435/2005-; 15 de abril de 2010 -Rec. 470/2006-; 11 de noviembre de 2010 -Rec. 1927/2006-; y 23 de noviembre de 2010 -Rec 1151/2007-. Jurisprudencia esta recogida en la Sentencia del TS, Sala Civil, 242/2011, de 4 de abril -Rec. 1820/2006-. En igual sentido, Sentencias 328/2011, de 19 de mayo -Rec. 1691/2007- y 826/2011, de 23 de noviembre Rec. 1753/2007-.
} 
de la LSC, los hechos analizados eran de fecha anterior, sin ser objeto de debate ni de la ratio decidendi esta cuestión al haberse ejercitado una acción social de responsabilidad. Pese a ello, en varias sentencias de la Audiencias Provinciales que se decantan por aplicar el art. 949 del Código de Comercio, invocan, a nuestro entender erróneamente, la Sentencia del TS, Sala Civil, 14/2018, de 12 de enero -Rec. 751/2015-.

La principal dificultad para la aplicación del nuevo art. 241 bis de la LSC a la responsabilidad por deudas de los arts. 360 y 367 de la LSC, viene dada por haberse incluido aquél precepto dentro de la responsabilidad por daños, en la acción social e individual de responsabilidad, y por otro lado, porque en el art. 241 bis de la LSC, al fijarse el plazo de prescripción de cuatro años desde que la acción puede ejercitarse, se alude única y exclusivamente a la acción social e individual de responsabilidad, ya que se señala expresamente que "la acción de responsabilidad contra los administradores, sea social o individual, prescribirá a los cuatro años a contar desde el día en que hubiera podido ejercitarse", se habla expresamente sólo de la acción social o individual, y no de la responsabilidad en general del administrador, teniendo en cambio el art. 241 bis como rótulo "prescripción de las acciones de responsabilidad", rotulo genérico omnicomprensivo con vocación de extenderse a todo tipo de responsabilidades y no sólo a la responsabilidad por daños.

A partir del nuevo art. 241 bis de la LSC, en la doctrina científica y en la doctrina judicial menor, se han adoptado dos interpretaciones acerca del dies a quo del plazo de prescripción de la responsabilidad por deudas del administrador, una favorable a seguir aplicándose el art. 949 del Código de Comercio y otra partidaria de aplicar el nuevo art. 241 bis de la LSC.

Un primer sector doctrinal estima que el art. 241 bis de la LSC se aplicaría exclusivamente a la acción social e individual de responsabilidad, pero no a la acción de responsabilidad por deudas ${ }^{1095}$. Un segundo sector ${ }^{1096}$ considera por el contrario que el

1095 MUÑOZ PAREDES, A.: Tratado judicial de la responsabilidad de los administradores. La responsabilidad societaria, 1995, op. cit., pp. 653-654; SALDAÑA VILLOLDO, B.: "Nuevos problemas de la responsabilidad de los administradores: la acción social y la responsabilidad por deudas tras la Ley 31/2004", op. cit., pp. 147 a 165; MUÑOZ PAREDES, A.: La responsabilidad de los administradores societarios, 2018, op. cit., p. 44.

1096 MASSAGUER FUENTES, J.: Artículo 241 bis. Prescripción de las acciones de responsabilidad, en AA.VV. (Coord.: JUSTE MENCÍA, J.): Comentario de la reforma del régimen de sociedades de capital en materia de gobierno corporativo (Ley 31/2014), Thomson Reuters, Navarra 2015, p. 482; CABANAS TREJO, R.: "Sobre el nuevo sistema de cómputo de las acciones de responsabilidad contra los administradores", Diario La Ley, abril de 2015, n 8513, pp. 5-6. 
art. 241 bis de la LSC es de aplicación también a la responsabilidad por deudas del art. 367 de la LSC.

En la doctrina judicial de las Audiencias Provinciales se vienen manteniendo igualmente ambas interpretaciones, sin haber unanimidad de criterio.

Un primer grupo de resoluciones judiciales se decanta por aplicar el art. 241 bis de la LSC a la responsabilidad por deudas del administrador del art. 367 de la LSC $^{1097}$, partiendo de dos argumentos esenciales. En primer lugar, por ser la LSC ley especial frente al Código de Comercio, por lo que debe aplicarse aquélla de modo preferente, y, en segundo lugar, porque estamos ante una acción de responsabilidad por el incumplimiento de los administradores de unas obligaciones impuestas en la propia LSC -arts. 365, 366 y 367-, y no en el Código de Comercio.

De aplicarse el art. 241 bis de la LSC, el dies a quo se computará desde que el acreedor o titular de la acción "disponga de los elementos fácticos y jurídicos idóneos para fundar una situación de aptitud plena para litigar"-actio nata- (Sentencias 1049/2008, de 11 de noviembre -Rec. 974/2004- y 261/2007, de 14 de marzo -Rec. 262/2000-).

Como señalábamos en otro lugar, ${ }^{1098}$ el dies a quo se computará (sic) "desde que la acción pueda ejercitarse, que será a partir del momento en que se han incumplido los deberes de promoverse la disolución o el concurso, que es cuando nace la responsabilidad del administrador, o desde que el acreedor tiene conocimiento del incumplimiento, o en palabras del art. 1968. $2^{\circ}$ del Código Civil, "desde que lo supo el agraviado". Son cuestiones distintas el dies a quo del plazo de prescripción de la responsabilidad -desde el incumplimiento de la obligación de promover la disolución o su conocimiento por el acreedor-, y el dies a quo para determinar el ámbito objetivo de las deudas sujetas a la responsabilidad -las deudas posteriores al acaecimiento de la causa de disolución-“.

El plazo de prescripción en la actio nata del art. 241 bis de la LSC se computaría desde que la acción puede ejercitarse, desde que los administradores incumplieron los deberes de promoción de la disolución o de adopción de medidas alternativa, o desde que el

${ }^{1097}$ Sentencias de la Audiencia Provincial de Barcelona n ${ }^{\circ}$ 335/2018, de 17 de mayo -Rec. 465/2017- y 251/2017, de 15 de junio -Rec. 23/2016-; Sentencia de la Audiencia Provincial de Valencia no 297 /2018, de 18 de abril -Rec. 426/2018-; Sentencia de la Audiencia Provincial de Salamanca ${ }^{\circ}$ 332/2018, de 17 de julio -Rec. 203/2018-.

1098 FERNÁNDEZ DÍEZ, A.: "Prescripción de la responsabilidad del administrador por deudas de Seguridad Social de la sociedad", op. cit., 2020, pp. 452 a 454. 
acreedor conoció esa circunstancia, o bien, desde que dispone de todos los elementos fácticos y jurídicos para entablar la acción (Sentencia del TS, Sala Civil, 1014/2005, de 13 de diciembre -Rec. 1638/1999-). Tener todos los datos fácticos y jurídicos que permitan el ejercicio de la acción, implica ${ }^{1099}$ conocer la identidad de la persona responsable, de modo que si se conoce la deuda, pero se desconoce la identidad del sujeto responsable, hasta que no se tenga conocimiento de esa identidad no se podrá iniciar el cómputo del plazo de prescripción de la acción.

Si la deuda de la sociedad no es pacífica, por ser el crédito del acreedor litigioso, el plazo de prescripción de la responsabilidad nacería a partir de la sentencia firme que reconoce la deuda y/o el crédito (Sentencia del TS, Sala Civil, 1049/2008, de 11 de noviembre -Rec. 974/2004- ${ }^{1100}$ ).

Finalmente, para otro grupo de sentencias de la doctrina judicial menor, se considera que debe seguir aplicándose el art. 949 del Código de Comercio a la responsabilidad por deudas ${ }^{1101}$, en primer lugar, porque partiendo de una interpretación literal, el legislador ha incluido de modo expreso y limitativo sólo a la acción social e individual de responsabilidad en el régimen jurídico de la prescripción del art. 241 bis de la LSC, sin incluirse la acción de responsabilidad por deudas, pudiendo hacerlo, y en segundo lugar, porque el art. 949 del Código de Comercio continúa en vigor, al no haber sido derogado al introducirse el nuevo art. 241 bis de la LSC.

De resultar de aplicación el art. 949 del Código de Comercio -interpretación que mantenemos-, el dies a quo del plazo de cuatro años de prescripción de la responsabilidad nacería con el cese en el cargo, salvo que no se hubiere inscrito en el

1099 Sentencia del TS, Sala Civil, 350/2020, de 24 de junio -Rec. 4442/2017-, que cita a las Sentencias de esa misma Sala, 25/2015, de 2 de febrero, y 725/2014, de 18 de diciembre.

${ }^{1100}$ En la Sentencia 1049/2008, de 11 de noviembre, se señala "Como se recuerda en la Sentencia de esta Sala de 14 de marzo de 2007 (...). En la citada Sentencia de la Sala se consideró que la acción no pudo ejercitarse antes, como mínimo, del momento en que las deudas de la sociedad fueron declaradas mediante sentencia firme $y$, en su ejecución, se procedió infructuosamente al embargo de bienes de la sociedad administrada por los demandados, así como que su ejercicio estaba subordinado no solamente al conocimiento de la inviabilidad económica de la empresa, sino también, como mínimo, a la constancia de la insolvencia de la sociedad como factor demostrativo de la imposibilidad de hacer efectivos los créditos contra ella".

${ }^{1101}$ Sentencia de la Audiencia Provincial de Valladolid no 314/2016, de 11 de noviembre -Rec. 352/2016-; Sentencia de la Audiencia Provincial de Alicante $n^{\circ}$ 190/2019 de 20 febrero -Rec. 611/2018-; Sentencias de la Audiencia Provincial de Pontevedra $n^{\circ}$ 164/2017, de 6 de abril -Rec. 82/2017- y 162/2016, de 31 de marzo -Rec. 50/2016-; Sentencia de la Audiencia Provincial de la Coruña $n^{\circ}$ 142/2019, de 10 abril -Rec. 53/2019-. 
Registro Mercantil, en cuyo caso, para los acreedores de buena fe nace a partir de la inscripción registral ${ }^{1102}$.

Que el plazo de prescripción de la responsabilidad no se inicie en la fecha de cese, cuando éste no haya accedido al registro mercantil, sino en la fecha de su posterior inscripción, no significa que se extienda la responsabilidad del administrador social a los incumplimientos posteriores al cese real y efectivo. En la jurisprudencia se distingue, a efectos de esta responsabilidad, entre los efectos materiales del cese, en virtud de los cuales se responde sólo por los incumplimientos habidos durante el desempeño del cargo, y los efectos adjetivos del mismo, esto es, que el inicio del plazo de prescripción de la responsabilidad no nacerá para los terceros de buena fe mientras no conste inscrito el cese en el RM, porque sólo a partir de la inscripción registral puede oponerse ese hecho al tercero de buena fe (artículos 21.1 y 22 del Código de Comercio y art. 9 del RRM), salvo que se acredite que el acreedor conocía el cese, en cuyo caso el plazo de prescripción se computaría desde la fecha de ese conocimiento (Sentencia del TS, Sala Contencioso-Administrativa, 551/2019, de 24 de abril-Rec. 157/2017- ${ }^{1103}$ ).

1102 Sentencias del TS, Sala Civil, 669/2008, de 3 de julio; 240/2009, de 14 de abril; 402/2009, de 12 de junio -Rec. 2352/2004-; 415/2009, de 18 de junio -Rec. 2760/2004-; 206/2010, de 15 de abril -Rec. 470/2006-; 123/2010, 11 de marzo -Rec. 1239/2005-; 291/2010, de 18 de mayo -Rec. 738/2006-; 96/2011, de 15 de febrero -Rec. 1963/2007-; 184/2011, de 21 de marzo -Rec. 1456/2007-; 328/2011, de 19 de mayo -Rec. 1691/2007-; 389/2016, de 8 de junio -Rec. 79/2014-; 14/2018, de 12 de enero Rec. 751/2015.

Según esta doctrina del TS, al interpretar el art. 949 Código de Comercio, se ha declarado que la falta de inscripción del cese de los administradores en el Registro Mercantil no comporta por sí misma, en lo sustantivo, que el administrador cesado siga siendo responsable frente a terceros de deudas posteriores al cese, ya que debe distinguirse los efectos materiales y adjetivos de la inscripción, al no ser constitutiva. El administrador no responde de las deudas posteriores al cese efectivo, o de los incumplimientos de los deberes de disolución posteriores al cese, pero en cambio, en virtud de los efectos adjetivos, la falta de inscripción del cese impide que se inicia el dies a quo del plazo de prescripción de la responsabilidad, para los acreedores de buena fe, porque, pese a no ser constitutiva, la inscripción es obligatoria (arts. 22.2 Código de Comercio y 94.1 RRM); y mientras no se realice, no es oponible frente a terceros (arts. 21.1 y .4 Código de Comercio y 9.1 RRM). Por esta razón, los efectos de la publicidad material negativa implican que, si no consta el conocimiento por parte del afectado del momento en que se produjo el cese efectivo del administrador, o no se acredita de otro modo su mala fe, el cómputo del plazo de cuatro años que comporta la extinción por prescripción de la acción no puede iniciarse sino desde el momento de la inscripción, dado que sólo a partir de entonces puede oponerse al tercero de buena fe el hecho del cese y, en consecuencia, a partir de ese momento el legitimado para ejercitar la acción no puede negar su desconocimiento (SSTS 669/2008, de 3 de julio; 240/2009, de 14 de abril; 123/2010, de 11 de marzo; 96/2011, de 15 de febrero; y $184 / 2011$ de 21 de marzo).

${ }^{1103}$ En la Sentencia del TS, Sala Contencioso-Administrativa, 551/2019, de 24 de abril -Rec. 157/2017-, se señala que "la Sentencia impugnada -como la de contraste centra lo litigioso en la eficacia de la inscripción registral frente a terceros -en este caso la TGSS como acreedora- y de ahí a una cuestión de prueba: si a la vista del material probatorio existente, la TGSS pudo conocer quién era el administrador, lo que lleva a la valoración de las pruebas obrantes en autos". Si el cese le constase a la TGSS o a la ITSS, pese a la falta de inscripción registral del mismo, el plazo de prescripción para la derivación de la responsabilidad administrativa, nacería desde que constase ese hecho a esas entidades 
El dies a quo del plazo de prescripción de la responsabilidad del art. 949 del Código de Comercio se computará desde la inscripción en el Registro Mercantil, no desde la fecha del asiento de presentación en el Registro de la escritura (Sentencia TS, Sala Civil, 389/2016, de 8 de junio -Rec. 79/2014-), porque la fecha del asiento se toma en cuenta a efectos de la prioridad para acceder al registro, pero no para que se pueda oponer a terceros.

De ser varios los administradores, la fecha del cese a efectos del cómputo del plazo de prescripción, será respectivamente la fecha del cesado cada uno de ellos, sin tenerse que esperar a que cese el último de los que ocupaban el cargo (Sentencia del TS, Sala civil, 14/2018, de 12 de enero -Rec. 751/2015-).

De optarse por la aplicación del art. 949 del Código de Comercio, la acción no prescribe mientras continúe en el cargo el administrador, aunque hayan pasado más de cuatro años desde que nació la responsabilidad del administrador social, claro está, siempre que la deuda no hubiese prescrito. Interpretación ésta que resulta más ventajosa para los intereses de la Administración de la Seguridad Social, ya que permitirá un mayor período temporal para la reclamación de la responsabilidad solidaria del administrador, básicamente por dos razones. En primer lugar, porque se interrumpe el plazo de prescripción de las deudas de Seguridad Social por su reclamación a la sociedad de capital, y esa interrupción de la prescripción afecta a los responsables solidarios, a los administradores (art. 43.3 RGRSS), y, en segundo lugar, porque interrumpida la prescripción de la deuda, mientras el administrador continúe en el cargo no se inicia el plazo de prescripción de la derivación administrativa de la responsabilidad

Somos partidarios de seguir aplicando el art. 949 del Código de Comercio a la responsabilidad por deudas del art. 367 de la LSC, mientras no exista jurisprudencia unificada al respecto ${ }^{1104}$, al ofrecer mayores garantías al acreedor para el ejercicio de la acción, lo que se cohonesta mejor con la naturaleza de esta responsabilidad, que es una responsabilidad por deuda ajena en garantía de los acreedores de la sociedad.

En la Guía operativa de actuación en materia de derivación de responsabilidad a los administradores de sociedades mercantiles capitalistas en materia de deudas de

públicas, como puede ser a través de la declaración fiscal del impuesto de sociedades u otros documentos o pruebas practicadas en vía administrativa o judicial.

1104 FERNÁNDEZ DÍEZ, A.: "Prescripción de la responsabilidad del administrador por deudas de Seguridad Social de la sociedad”, op. cit., 2020, p. 451. 
Seguridad Social, de la Dirección General de la Inspección de Trabajo y Seguridad Social, de septiembre de 2017, se declara que para la derivación de responsabilidad al administrador al amparo del art. 367 de la LSC, es de aplicación el art. 949 del Código de Comercio, y no el art. 241 bis de la LSC.

La prescripción de la acción para derivar la responsabilidad del administrador y la prescripción de la deuda de Seguridad Social ante la sociedad y el administrador social, tienen igual duración temporal, 4 años, pero es distinto el dies a quo, en las deudas por cuotas se computa desde que finalizó el plazo reglamentario de ingreso, y en la acción para reclamar la responsabilidad solidaria del administrador se computará desde el cese en el cargo.

El plazo de prescripción de la acción para reclamar la derivación administrativa de la responsabilidad del administrador social en las deudas de Seguridad Social, se interrumpe por la declaración del concurso de la sociedad de capital ${ }^{1105}$. En la Sentencia del TS, Sala Contencioso-Administrativa 1400/2020, de 26 de octubre 2020 -Rec. $5951 / 2018-^{-1106}$, con fundamento en el art. 155 del TRLC, se señala que el proceso concursal de la sociedad interrumpe la prescripción de la derivación administrativa para reclamar la TGSS al administrador social la responsabilidad solidaria en deudas de Seguridad Social de la sociedad anteriores al concurso, prevista en el art. 367 de la LSC,

${ }^{1105}$ Art. 155 del TRLC y Sentencia del TS, Sala Contencioso-Administrativa 1400/2020, de 26 de octubre 2020 -Rec. 5951/2018-.

${ }^{1106}$ En esa Sentencia indicaba "que la cuestión en la que se entiende que existe interés casacional objetivo para la formación de jurisprudencia es si, es aplicable a los procedimientos regulados en el artículo 13 del Reglamento General de Recaudación de la Seguridad Social, de derivación de responsabilidad solidaria a los administradores sociales, la interrupción de la prescripción recogida en el artículo 60 de Ley Concursal, o bien solo es aplicable la interrupción de la prescripción regulada en el artículo 21 del Real Decreto 1/1994, de 20 de junio, por el que aprueba el Texto Refundido de la Ley General de la Seguridad Social (actual artículo 24 del Real Decreto Legislativo 8/2015, de 30 de octubre, por el que se aprueba el Texto Refundido de la Ley General de la Seguridad Social), y la de los artículos 42.1 y 43 del Reglamento General de Recaudación de la Seguridad Social". La referencia al art. 60 de la Ley Concursal debe entenderse al art. 155 del TRLC.

Se resuelve el recurso fijándose domo doctrina de interés casacional que, "ante el impago de cotizaciones generadoras de un Derecho de crédito a favor de la TGSS, sujeto con carácter general a las reglas sobre prescripción de la LGSS y del RGRSS, la TGSS puede proceder a la derivación de responsabilidad solidaria de los administradores; ahora bien, si la mercantil deudora es declarada en concurso son aplicables las especialidades de la Ley Concursal, de forma que la TGSS puede estar a las resultas del concurso, luego tratándose de créditos concursales queda interrumpida la prescripción de la acción frente a los administradores conforme al artículo 60 de la Ley Concursal". La cursiva es nuestra. Actual art. 155.3 del TRLC.

Interrupción de la prescripción ante los acreedores privados para reclamar la responsabilidad por daños del administrador que se Reconoció en Sentencia del TS, Sala Civil, 737/2014, de 22 de diciembre -Rec. 1261/2013-, pese a no suspenderse durante el concurso de la sociedad la acción individual de responsabilidad. 
de no haberse derivado la responsabilidad durante el proceso concursal y haber optado la TGSS por esperar a la resultas de ese proceso concursal ${ }^{1107}$.

En el art. 155 apartados 1 y 3 del TRLC se declara expresamente que, desde la declaración del concurso de la sociedad hasta su conclusión, se interrumpe la prescripción de las deudas de la mercantil (apartado 1), así como la acción para reclamar la responsabilidad contra los administradores (apartado 3). Pero esa interrupción de la prescripción no tiene efecto ante los deudores solidarios, los fiadores y los avalistas (art. 155.2 del TRLC), separándose así este precepto concursal de la regla general de interrupción de la prescripción en obligaciones solidarias del art. 1974 del Código Civil -para los obligados solidarios-, y en parte del art. 1975 del Código Civil para los fiadores o avalistas -garantes de deuda ajena-, ya que en ese precepto la reclamación judicial sí interrumpe la prescripción para fiadores y avalistas, pero no la reclamación extrajudicial o el reconocimiento de deuda.

Del art. 155 del TRLC y de esa Sentencia del TS núm. 1400/2020, de 26 de octubre 2020, se concluye que el concurso de acreedores de la sociedad determina que se interrumpa ope legis la prescripción de la deuda y de la acción de responsabilidad contra los administradores (art. 155 del TRLS), plazos de prescripción que comienzan a correr de nuevo desde su inicio a la finalización del concurso de acreedores (art. 155.4 del TRLC). En cambio, si la mercantil no ha estado en concurso de acreedores, se aplican los plazos de prescripción de la deuda de los arts. 24 del TRLGSS y 43 del RGRSS ${ }^{1108}$,

${ }^{1107}$ Antes de esta Sentencia, defendíamos que, si la declaración del concurso de la sociedad interrumpía la prescripción de la acción de responsabilidad por deudas y de la acción individual de responsabilidad contra los administradores sociales (art. 155.3 del TRLC), sin que esa declaración concursal suspenda el ejercicio de la acción individual de responsabilidad del art. 241 de la LSC, aunque sí interrumpe la prescripción de la acción individual de responsabilidad (Sentencia del TS, Sala Civil, 737/2014, de 22 de diciembre -Rec. 1261/2013-), a igual conclusión habría de llegarse para la derivación administrativa de responsabilidad, esto es, que la declaración de concurso de la sociedad interrumpe el plazo de prescripción de la derivación de administrativa de responsabilidad, pese a no suspenderse la actuación administrativa de derivación de responsabilidad, Vid.: FERNÁNDEZ DÍEZ, A.: "Prescripción de la responsabilidad del administrador por deudas de Seguridad Social de la sociedad", op. cit., 2020, pp. 463-464.

${ }^{1108}$ Se trataba de una derivación administrativa de la TGSS iniciada el 11 de abril de 2016, consecuencia de un informe de la ITSS de 11 de julio de 2011, siendo declarada en concurso la sociedad el 19 de septiembre de 2011, proceso concursal que concluye con la liquidación de 3 de febrero de 2013, estimando no prescrita ni la acción de derivación ni la deuda por aplicación del art. 155 del TRLC. La sociedad estaba en causa de disolución por pérdidas al finalizar el ejercicio económico de 2009, teniendo descubiertos de cuotas desde abril de 2009. Las deudas de Seguridad Social de enero de 2010 a febrero de 2012, en abril de 2016 estarían prescritas en aplicación del art. 24 del TRLGSS y arts. 42 y 43 del TRLGSS, sólo si se habían reclamado con anterioridad a abril de 2016 a la sociedad, se interrumpirá la prescripción de la deuda ante ella y los administradores (art. 43 del RGRSS). En cambio, consecuencia de la declaración del concurso de acreedores, en aplicación del art. 155 del TRLC, ese concurso declarado el 19 de septiembre de 2011, interrumpió “ope legis" la prescripción 
lo que determina que si no se reclaman las cuotas devengadas dentro de los 4 años siguientes a la finalización del plazo reglamentario de ingreso, prescribirán ante la sociedad y ante el administrador social.

Interrupción de la prescripción de la acción para derivar la responsabilidad al administrador durante el concurso que había admitido la doctrina judicial menor ${ }^{1109}$.

Por la aplicación de ese precepto de la Ley Concursal el TS en esa sentencia considera que no había prescrito ni la deuda de Seguridad Social (art. 155.1 del TRLC) ni la acción de responsabilidad (art. 155.3 del TRLC).

Hemos de reseñar para concluir, que, excepcionalmente durante el estado de alarma por la crisis sanitaria de la Covid-19 -del 14.3.2020 al 3.6.2020-, el plazo de prescripción de la acción para la derivación administrativa de la responsabilidad al administrador social se suspendió, reanudándose su cómputo a partir del 4.6.2020 ${ }^{1110}$. En ese Decreto del estado de alarma se alude a la suspensión de los plazos de caducidad y prescripción (Disposición Adicional $4^{\text {a }}$ del Real Decreto 463/2020, de 14 de marzo), aunque la prescripción se interrumpe y la caducidad se suspende, pero por mandato legal expreso es uno de los posibles supuestos de suspensión del cómputo del plazo de prescripción, con lo que este período es un paréntesis en el cómputo de los plazos prescriptivos. Suspensión de los plazos para reclamar la responsabilidad por la Inspección de Trabajo y Seguridad Social que se reconoce expresamente en la Disposición Adicional $2^{\mathrm{a}}$ del Real Decreto-Ley 15/2020, de 21 de abril, de medidas urgentes complementarias para apoyar la economía y el empleo ${ }^{1111}$ ). Téngase en cuenta que, si bien la suspensión de la

de la deuda (art. 155.1 del TRLCC) y de la acción contra el administrador (art. 155.3), plazos de prescripción de 4 años de la deuda y de la acción de derivación que comenzaron a computarse de nuevo desde su inicio, el 3 de febrero de 2013, fecha de finalización del concurso (art. 155.4 del TRLC), lo que permitió reclamar en abril de 2016 deudas anteriores a febrero de 2012.

1109 Sentencias del TSJ de La Rioja, Sala Contencioso-Administrativa, 192/2019, de 13 de junio Aranzadi 2019/217184-; 400/2018, de 31 de diciembre -Aranzadi 2018/1623-; 161/2018, de 14 de mayo -Rec. 125/2017-; y 8/2018 de 17 enero -Aranzadi 2018/89933-; Sentencia del TSJ del País Vasco, Sala Contencioso-Administrativa, 303/2017, de 14 de junio -Rec. 829/2016-; Sentencia del TSJ de Andalucía, sede de Sevilla, Sala Contencioso-Administrativa, de 8 de junio de 2017 -Rec. 552/2016-, entre otras.

${ }^{1110}$ Disposición Adicional $4^{a}$ del Real Decreto 463/2020, de 14 de marzo, por el que se declara el Estado de Alarma para la gestión de la situación de crisis sanitaria ocasionada por el Covid-19 - BOE del 14.3.2020-; en relación con el art. 10 y Disposición Derogatoria del Real Decreto 537/2020, de 22 de mayo, por el que se prorroga el Estado de Alarma declarado -BOE del 23.5.2020-:

"Artículo 10. Plazos de prescripción y caducidad de Derechos y acciones suspendidos en virtud del Real Decreto 463/2020, de 14 de marzo.

Con efectos desde el 4 de junio de 2020, se alzará la suspensión de los plazos de prescripción y caducidad de Derechos y acciones".

${ }^{1111}$ BOE del 22.4.2020. Se establece en sus apartados 2 y 3 : 
prescripción no está contemplada expresamente en nuestra legislación, tampoco está excluida, señalando el Tribunal Supremo, Sala civil, en Sentencia de 12 de junio de 1997 -Rec. 2121/1993-, en su Fundamento de Derecho Tercero que "la suspensión de la prescripción paraliza ésta, no corre el tiempo para la misma, pero no inutiliza el ya transcurrido y así, cuando desaparece la causa de suspensión, se reanuda el cómputo de prescripción. Pero el Código civil no la admite y han desaparecido antiguos supuestos en que se daba. Tan sólo existe cuando alguna específica y excepcional norma la ha establecido". La cursiva es nuestra.

\section{VIII.- SUBSISTENCIA DE LAS DEUDAS DE SEGURIDAD SOCIAL DE LA SOCIEDAD DISUELTA, LIQUIDADA Y EXTINGUIDA. SUJETOS RESPONSABLES.}

\section{Responsabilidad del liquidador $y$ de los socios de la sociedad disuelta $y$ extinguida.}

La disolución de la sociedad de capital abre el período de liquidación, conservando su personalidad jurídica durante la fase liquidataria, hasta la conclusión de todas las operaciones materiales de liquidación, hasta la extinción de todas las relaciones de la sociedad con los socios y con los acreedores (internas y externas). Concluidas esas operaciones e inscrita la escritura pública de extinción, se cancelarán los asientos registrales de la sociedad en el Registro Mercantil (arts. 371 y 396 de la LSC). En el momento en que se cancelen los asientos registrales de la sociedad queda extinguida su personalidad jurídica, aunque como veremos, no impedirá que posteriormente pueda ser demandada. GARCÍA CRUCES ${ }^{112}$ sitúa la extinción de la sociedad una vez concluyan las operaciones materiales de liquidación, siendo la cancelación registral una operación formal o mecánica que da publicidad legal a la extinción. Otros autores ${ }^{1113}$ sitúan la

“2. Durante el periodo de vigencia del estado de alarma, declarado por el Real Decreto 463/2020, de 14 de marzo y sus posibles prórrogas, quedan suspendidos los plazos de prescripción de las acciones para exigir responsabilidades en lo que se refiere al cumplimiento de la normativa de orden social y de Seguridad Social.

3. Todos los plazos relativos a los procedimientos regulados en el Reglamento general sobre procedimientos para la imposición de sanciones por infracciones de orden social y para los expedientes liquidatorios de cuotas de la Seguridad Social, aprobado por Real Decreto 928/1998, de 14 de mayo, están afectados por la suspensión de plazos administrativos prevista en la Disposición Adicional Tercera del Real Decreto 463/2020, de 14 de marzo".

1112 GARCÍA-CRUCES, J. A.: Derecho de Sociedades Mercantiles, op. cit., p. 516.

1113 PIÑOLETA ALONSO, L. M.: "La extinción de la sociedad", en AA.VV. (Coord.: ROJO FERNÁNDEZ-RÍO, A. et altri): Comentario de la Ley de Sociedades de Capital, Tomo II, Civitas Thomson Reuters, 2011, p. 2705. 
extinción en el otorgamiento de la escritura de extinción y en la inscripción, y no en la conclusión de las operaciones de liquidación y el reparto del haber social.

La liquidación es tanto un estado, como un procedimiento, ya que todas las actividades van dirigidas, no a la consecución del objeto social, sino a la liquidación societaria, a la realización de bienes, derechos de la sociedad, cobrando los créditos y pagando las deudas sociales, para finalmente con el sobrante pagar la cuota de liquidación de los socios, y proceder a otorgar la escritura pública de extinción de la sociedad. Hay un sector doctrinal ${ }^{1114}$ que entiende que con la liquidación se modifica el fin social, ya que no será la obtención de beneficios mediante el desarrollo de la actividad económica, sino la realización de operaciones liquidatarias para concluir en la extinción, y se realiza el objeto social en la medida en que es necesario para la extinción de la sociedad. Para otro sector doctrinal ${ }^{1115}$, la liquidación no supone en modo alguno, ni una modificación del objeto social, ni la sustitución del fin social, ya que la fase de liquidación no implica necesariamente el cese de la actividad empresarial, y la modificación del fin social significaría contar con el consentimiento de todos los socios, lo que no se requiere para el acuerdo de disolución, lo que acaece para este sector doctrinal es que el fin y objeto social quedan matizados ya que la actividad social va encaminada también a conseguir la extinción.

Con la apertura del período de liquidación cesan en sus funciones los administradores sociales y son sustituidos por los liquidadores, pudiendo, no obstante, recaer este cargo en los administradores (art. 376 de la LSC). De nombrarse liquidadores a los administradores sociales, se produce una novación de competencias, ya que cesan en el ejercicio de los cometidos legales de los administradores, para asumir las competencias propias del cargo de los liquidadores.

Abierta la liquidación, los liquidadores en el plazo de tres meses deben elaborar el inventario y el balance de situación inicial referido al día de la disolución (art. 383 de la LSC).

Durante el período de liquidación los liquidadores deben proceder a la realización de bienes y derechos, cobrando los créditos de la sociedad y pagando las deudas sociales,

\footnotetext{
${ }^{1114}$ BELTRÁN SÁNCHEZ, E.: "La liquidación", Comentario a los arts. 371 a 394, en AA.VV. (Coord.: ROJO FERNÁNDEZ-RÍO, A. et altri): Comentario de la Ley de Sociedades de Capital, Thomson Reuters, 2011, pp. 2596-2597.

${ }^{1115}$ GARCÍA CRUCES, J. A.: Derecho de Sociedades Mercantiles, op. cit., p. 491.
} 
de modo que mientras no se abonen las deudas, o en su defecto, se consigne en la entidad financiera el importe de las mismas en favor de los acreedores, no podrá abonarse a los socios la cuota de liquidación (arts. 384, 385, 387, 391 y 394 LSC).

Será en este momento cuando se procederá a la extinción de las relaciones laborales, de no haberse producido con anterioridad, al amparo del procedimiento del despido colectivo, siendo la causa de resolución de las relaciones laborales la extinción de la personalidad jurídica de la sociedad de capital ${ }^{1116}$. Estamos en presencia de una causa extintiva eficaz por si misma -la extinción o desaparición de la persona jurídica contratante-, si bien para hacerla efectiva debe seguirse el correspondiente procedimiento de despido colectivo. Para los supuesto de concurrencia de alguna de las causas legales de disolución previstas en el art. 363 de la LSC, la extinción de las relaciones laborales tendrá lugar al amparo del artículo $49.1 \mathrm{~g}$ ) del TRLET, precepto que se remite al 51 de dicho texto legal, remisión que lo es a los meros efectos procedimentales, pero no a efectos causales, puesto que la causa de este supuesto extintivo sería autónoma de las establecidas en el artículo 51.1 del TRLET ${ }^{1117}$. En la Sentencia del TS, Sala Social, 616/2017, de 12 de julio -Rec. 32/2017-, se indica que la extinción de los contratos de los trabajadores de la empresa en liquidación y el abono de las correspondientes indemnizaciones y conceptos salariales que pudieran generarse, constituyen operaciones intrínsecas a la fase de liquidación de la sociedad que, necesariamente, deberán ser llevadas a cabo por los liquidadores (sic) "en el momento que estimen más oportuno para la mayor satisfacción de los intereses derivados de las operaciones liquidatarias". El momento de proceder a la extinción corresponde a los liquidadores, sin que se exija esperarse al final de las operaciones liquidatarias.

Realizadas esas operaciones de pago de las deudas y realización de los bienes y derechos de la mercantil, los liquidadores someterán a aprobación de la Junta General de socios el balance final, el informe completo de las operaciones liquidatarias realizadas y el proyecto de división del activo sobrante entre los socios.

Si durante la fase de liquidación no se pudieren atender todas las deudas, por ser menor el activo, la sociedad pese a hallarse en liquidación, entrará obligatoriamente en

\footnotetext{
1116 Art. 49.1.g) último inciso del TRLET y art. 30 del Real Decreto 1483/2012, de 29 de octubre, que aprueba el Reglamento sobre los procedimientos de despidos colectivos.

1117 STS, Sala Social, de 12 de julio de 2017 -Rec. 32/2017-; 3 de diciembre de 2014 -Rec. 201/2013-; 26 de junio de 2014 -Rec. 219/2013-; de 17 de febrero de 2014 -Rec. 142/2013-; y 23 de septiembre de 2014 -Rec. 309/2013-.
} 
situación concursal, debiendo los liquidadores solicitar el concurso de acreedores (art. 3.1 y 5 del TRLC), con lo que éstos cesarán en sus cargos siendo sustituidos por la administración concursal, y la liquidación se llevará a cabo por vía judicial dentro del proceso concursal ante el Juez de lo Mercantil competente.

Pagadas todas las deudas sociales, o consignados sus importes, una vez que la Junta General de socios apruebe el balance final con la propuesta de reparto de la cuota de liquidación de los socios, sin haberse impugnado judicialmente en el plazo de dos meses el acuerdo adoptado en la junta, o si impugnado se dicta sentencia firme confirmando los acuerdos, se procede al pago de la cuota de liquidación de los socios.

La cuota de liquidación deberá entregarse en dinero, salvo que los socios por unanimidad acordasen la entrega de bienes en especie, a todos o alguno de ellos, y salvo que en los estatutos sociales se reconociese el derecho de algún socio a recibir como cuota de liquidación bienes en especie que hubiere aportado u otros bienes. En todo caso, de recibirse como cuota de liquidación bienes in natura, el art. 247.3 del Reglamento del Registro Mercantil exige que en la escritura pública de extinción de la sociedad se describan los bienes entregados, con sus datos registrales, y el valor de los mismos, lo cual implica describir suficientemente los bienes adjudicados, sin que sirvan referencias genéricas como entrega de inmovilizado material o inversiones financieras a corto (Resolución de la Dirección General del Registro y Notariado de 3 de mayo de 2017). De entregarse bienes en especie debe constar su valor por tener que traducirse a dinero el importe de la cuota de liquidación. Determinado su valor dinerario, caben dos posibilidades $^{1118}$, que sea superior o inferior a la cuota de liquidación. De ser superior, para recibir ese bien como cuota de liquidación deberá satisfacer en metálico en favor del resto de los socios el superior valor. De ser el valor inferior, conjuntamente con el bien deberá recibir la diferencia en metálico

El balance final y la relación nominal de socios con sus respectivas cuotas de liquidación, son documentos que habrán de acompañarse obligatoriamente a la escritura pública de extinción de la sociedad para su inscripción en el Registro Mercantil (art. 395.2 de la LSC). En la escritura pública de extinción de la sociedad los liquidadores habrán de manifestar que han procedido al pago de los acreedores, o en su defecto, a la consignación bancaria de sus créditos, y que se ha satisfecho la cuota de liquidación de

${ }^{1118}$ GARCÍA CRUCES, J. A.: Derecho de Sociedades Mercantiles, op. cit., p. 512. 
los socios (art. 395.1 de la LSC). Finalmente, en la inscripción registral se transcribirá el balance final, la identidad de los socios y el valor de la cuota de liquidación que ha correspondido a cada uno de ellos (art. 396.2 de la LSC). De aparecer posteriormente activo sobrevenido, bienes o derechos, el liquidador deberá proceder a entregar a los socios su respectiva cuota adicional (art. 398 LSC), otorgando ante notario la correspondiente escritura pública para hacer constar esa cuota adicional e inscribirla en el Registro Mercantil, debiendo el registrador anotar ese valor de cuota adicional de cada socio (art. 248 RRM). Esta publicidad registral de la cuota de liquidación, y en su caso de las cuotas adicionales por activos sobrevenidos, permitirá a los acreedores poder exigir la responsabilidad solidaria de los $\operatorname{socios}^{1119}$.

Esos datos registrales serán fundamentales para que la TGSS o la Inspección de Trabajo y Seguridad Social, puedan conocer quiénes son los socios y cuál ha sido la cuota de liquidación de cada uno de ellos, con la finalidad de exigir a los mismos la responsabilidad solidaria en el pago de las deudas de la Seguridad Social que se hallaren pendientes tras la finalización de la liquidación y la extinción de la sociedad. Responsabilidad solidaria establecida en el art. 142.1 último párrafo del TRLGSS, en cuyo precepto se establece que, en caso de que el empresario deudor sea una sociedad disuelta y liquidada, sus obligaciones de cotización a la Seguridad Social pendientes se transmitirán a los socios o partícipes en el capital social, quienes responderán personalmente hasta el límite del valor de la cuota de liquidación de cada uno de ellos. Responsabilidad que, en caso de activos sobrevenidos, se ampliará hasta los nuevos importes de las cuotas adicionales de liquidación correspondientes a esos activos sobrevenidos (art. 398 LSC). Importes de cuotas de liquidación que constarán en el registro, pero que, si otros acreedores hubieren anteriormente exigido esa responsabilidad a los socios, por otras deudas sobrevenidas, ese pago no accede al Registro Mercantil, con lo que nos podríamos encontrar con una información que no sería correcta, señalando PILOÑETA $\mathrm{ALONSO}^{1120}$, que al no poder el registrador anotar el pago hecho con las cuotas de liquidación, únicamente mediante resolución judicial podría recogerse registralmente esa circunstancia, al amparo del art. 20 del Código de Comercio.

\footnotetext{
1119 PIÑOLETA ALONSO, L. M.: “Activo y pasivo sobrevenido", Comentario a arts. 398 a 400, en AA.VV. (Coord.: ROJO FERNÁNDEZ-RÍO et altri.): Comentario de la Ley de Sociedades de Capital, Tomo II, Civitas Thomson Reuters, 2011, p. 2734.

${ }^{1120}$ PIÑOLETA ALONSO, L. M.: “Activo y pasivo sobrevenido”, op. cit., p. 2742.
} 
En el art. 142 del TRLGSS se habla sólo de deudas de cotización, pero no de deudas que tuviera o se manifestasen después de la liquidación en materia de prestaciones de Seguridad Social, por lo que ese precepto no podría invocarse para reclamar en vía administrativa la responsabilidad solidaria de los socios, con el límite de la cuota de liquidación de cada uno, con relación a las deudas de la sociedad en materia de prestaciones de Seguridad Social, ya que, cuando se habla de otros posibles sujetos terceros a los que se puede extender la responsabilidad en el pago de prestaciones de responsabilidad de la empresa, en el art. 168 del TRLGSS no se contempla a los socios tras la liquidación y extinción societaria, como sí se ha hecho expresamente en el art. 142 del TRLGSS. Vacío normativo que no nos impedirá defender la derivación administrativa a los socios reclamando las deudas por prestaciones, por lo que a continuación pasamos a señalar.

La responsabilidad solidaria por cotizaciones del art. 142.1 del TRLGSS, es una concreción en materia de deudas de cotización a la Seguridad Social de la responsabilidad solidaria impuesta con carácter general a los socios para todo tipo de deudas sobrevenidas en el art. 399 de la LSC, en cuyo precepto se establece que los socios responden de modo solidario de las deudas sociales no satisfechas, y hasta el límite de lo que hubieran recibido cada uno de ellos como cuota de liquidación, incluyendo en su caso, la cuota adicional de liquidación ante activos sobrevenidos o conocidos tras la liquidación (art. 398 LSC). Es una responsabilidad personal, solidaria y automática o directa de los socios, que se fundamenta en el hecho de ser éstos los causahabientes de la sociedad cancelada ${ }^{121}$. Es una responsabilidad limitada, no ilimitada, al tener como límite máximo exigible la cuota o cuotas adicionales de liquidación, lo que es consecuencia del carácter limitado de la responsabilidad de los socios de la sociedad capitalista al importe del capital suscrito, y en este caso de la cuota de liquidación recibida ${ }^{1122}$.

En virtud de este precepto, al declararse expresamente mediante una norma con rango legal la responsabilidad solidaria del socio, será de aplicación el art. 18.3 del TRLGSS, en el que se permite exigir en vía administrativa la responsabilidad solidaria de terceros, en este caso de los socios, para la reclamación no sólo de deudas de cotización, sino también para exigir el pago de los demás recursos de la Seguridad Social, cuando

${ }^{1121}$ PIÑOLETA ALONSO, L. M.: “Activo y pasivo sobrevenido”, op. cit., pp. 2738-2740 y 2743.

1122 PIÑOLETA ALONSO, L. M.: “Activo y pasivo sobrevenido”, op. cit., pp. 2741-2742. 
ocurran hechos, omisiones, negocios o actos jurídicos que impongan esa responsabilidad a terceros en virtud de norma legal que no haya excluido la responsabilidad por deudas de Seguridad Social.

Estamos ante una norma legal, el art. 399 de la LSC, que imponen una responsabilidad solidaria ex lege a los socios para el pago de las deudas que sobrevengan tras la liquidación, sin excluirse deudas por prestaciones de Seguridad Social, por lo que, al amparo de los arts. 18.3 del TRLGSS y 1444 del Código Civil, podrá la TGSS ${ }^{1123}$ exigir a los socios solidariamente el importe de las deudas por prestaciones que fueren de responsabilidad de la empresa sociedad de capital, respondiendo cada uno de ellos hasta el límite de sus respectivas cuotas de liquidación, una vez que la responsabilidad de la sociedad de capital en el pago de las prestaciones se haya declarado en resolución administrativa firme por la entidad gestora (INSS, ISM, SEPE). Ello es posible por cuanto que las prestaciones de Seguridad Social de responsabilidad empresarial son un recurso económico de la Seguridad Social ${ }^{1124}$.

Tanto estemos ante deudas por cotizaciones como ante deudas por prestaciones, podrá exigirse su pago a los socios a través del procedimiento administrativo recaudatorio de los recursos de la Seguridad Social, mediante reclamación de deuda expedida por la TGSS. Ahora bien, nos surge una nueva cuestión, ¿cómo es posible que hayan quedado deudas pendientes, si no puede procederse a repartir la cuota de liquidación, ni inscribirse la extinción de la sociedad, sin que los liquidadores hayan abonado todas las deudas, como se exige en los arts. 391, 394 y 395 de la LSC?

Ante esa pregunta caben dos hipótesis. En primer lugar, que las deudas existiesen antes de la conclusión de la liquidación y de la inscripción en el Registro Mercantil de la escritura de extinción de la personalidad jurídica de la sociedad, en cuyo caso, caben a su vez dos posibilidades, que los liquidadores las conociesen o no las conociesen. Si no las conocieron, no tendrían responsabilidad por las mismas, pero si los liquidadores las conocían, incurrirán en responsabilidad ante los acreedores ${ }^{1125}$, pero es una responsabilidad por daños, no solidaria ex lege, equivalente a la de los administradores de los arts. 236 y siguientes de la LSC, ejercitable en vía judicial. Responsabilidad por daños prevista en el art. 397 de la LSC, donde se establece que los liquidadores serán

${ }^{1123}$ Arts. 2.1.d), 12, 13 y 69 del Real Decreto 1415/2004, de 11 de junio, RGRSS ${ }^{1124}$ Art. 2.1.d) del Real Decreto 1415/2004, de 11 de junio.

${ }^{1125}$ PIÑOLETA ALONSO, L. M.: “Activo y pasivo sobrevenido”, op. cit., pp. 2738-2740 y 2743. 
responsables ante los socios y los acreedores de cualquier perjuicio que les hubieren causado con dolo o culpa en el desempeño del cargo. Responsabilidad por daños que no puede exigirse en vía administrativa por la TGSS, sino que habrá de ejercitarse en vía judicial $^{1126}$. Ahora bien, esa responsabilidad por daños, no excluye la responsabilidad por deudas de los socios, por lo que la TGSS podrá seguir derivando la deuda a los socios con el límite de las cuotas de liquidación de los mismo, y éstos podrán posteriormente reclamar la responsabilidad de los liquidadores. Por el importe de la deuda no obtenida de los socios con la derivación administrativa de deuda, podrá la TGSS ejercitar la acción judicial de responsabilidad por daños ante los liquidadores, cuando incurran en esa responsabilidad, ya que en la responsabilidad por daños debe repararse íntegramente el daño causado.

La segunda hipótesis será que siendo anteriores las deudas, como es obvio, porque corresponderán a un período de vida laboral de la sociedad, se hubieren conocido tras la liquidación y extinción de la mercantil. En este caso no nace responsabilidad de los liquidadores, siendo los socios con sus cuotas de liquidación los únicos responsables. Deudas del período de actividad conocidas posteriormente, porque se declarasen en resolución judicial del orden social una vez se haya extinguido la sociedad, o porque se afloren con posterioridad mediante actuación de la Inspección de Trabajo y Seguridad Social. Estaríamos ante deudas nuevas de la sociedad del período de actividad y que no estén prescritas.

La derivación administrativa de responsabilidad ante los socios podrá realizarse mediante acta de liquidación de cuotas por derivación extendida por la Inspección de Trabajo y Seguridad Social, de ser deudas por cotizaciones originadas por falta de alta y afiliación a la Seguridad Social de trabajadores, por diferencias de cotización que no resulten directamente de la facturación de la liquidación en el sistema de liquidación directa (incluidas bonificaciones o reducciones de cuotas fraudulentas), o por aplicación indebida de bonificaciones en la cotización a la Seguridad Social prevista para las acciones de formación profesional para el empleo. De ser otras deudas de cotización distintas a las anteriores, la ITSS podrá emitir informe a la TGSS para que sea ésta la que inicie el procedimiento administrativo de derivación de responsabilidad, derivación de responsabilidad que también será competencia de la TGSS cuando se trate de deudas

${ }^{1126}$ NICOLÁS BERNAD, J. A.: "La responsabilidad de los administradores sociales ante la Inspección de Trabajo”, op. cit., pp. 75, 76 y 90, abogaba por la procedencia de extender acta de liquidación cuando incurra el liquidador social en la responsabilidad por daños al acreedor Seguridad Social. 
por prestaciones de responsabilidad empresarial ${ }^{1127}$, como veremos con carácter general en el apartado II.2 del Capítulo VI de esta investigación. Tanto la reclamación de deuda de la TGSS como el acta de liquidación de la ITSS, podrán emitirse contra todos los socios conjuntamente hasta el importe de sus cuotas de liquidación societarias, o contra alguno de ellos, al ser todos responsables solidarios, de modo que el procedimiento seguido contra alguno de los responsables solidarios, no suspende ni impide que pueda seguirse contra el resto (art. 13 del RGRSS).

Conviene tener en cuenta que de haberse entregado como cuota de liquidación bienes y no dinero, al tener que estar aquéllos valorados en dinero (deuda de suma ${ }^{1128}$ ), es esa suma dineraria la que podrá derivarse al socio, ya que el bien puede tener un valor diferente al estimado inicialmente en la cuota de liquidación, cuando se reclame al socio la deuda de Seguridad Social.

La responsabilidad del art. 142.1 del TRLGSS y la del art. 399 de la LSC, es una responsabilidad solidaria ex lege de los socios, que no podrá ser exigible a la mercantil al estar ya extinguida. En este sentido MARTÍN JIMÉNEZ y MATEOS BEATO ${ }^{1129}$, defienden que es una responsabilidad solidaria entre los socios, pero subsidiaria de los mismos respecto a la sociedad. Alusión informal y no técnico-jurídica de subsidiariedad puntualizamos, en el sentido de que no podrá obtenerse ya materialmente el pago de la deuda de la sociedad, al carecer de activos, pero sin que estemos ante una responsabilidad subsidiaria "stricto sensu", por cuanto que no hay obligación jurídica de obtener una previa resolución judicial o administrativa que declare la insolvencia de la mercantil. Es una responsabilidad solidaria y directa de los socios, sin ser exigible una previa excusión de bienes de la mercantil, al haberse extinguido y liquidado, lo que no obsta a que se pueda demandar a la sociedad.

Como medida de lege ferenda proponemos recoger expresamente en el art. 168 del TRLGSS, que en los supuestos de sociedad disuelta los socios responden con la cuota de liquidación de las deudas por prestaciones, y no sólo de las deudas por cotizaciones como se establece en el art. 142.1 del TRLGSS.

\footnotetext{
1127 Arts. 33 y 34 TRLGSS, y arts. 62, 65, 69 y 70 del RGRSS.

1128 VALPUESTA GASTAMINZA, E. M.: Comentarios a la Ley de Sociedades de capital, op. cit., p. 1025.

${ }^{1129}$ MARTÍN JIMÉNEZ, R. y MATEOS BEATO, A.: La responsabilidad de empresas y administradores con la Seguridad Social, op. cit., p. 160.
} 
Deberá establecerse igualmente que los liquidadores y administradores concursales, responderán de modo solidario de las deudas de Seguridad Social conocidas en el procedimiento liquidatorio, cuando consecuencia del incumplimiento de sus obligaciones no se hubiesen satisfecho aquéllas, en todo o en parte.

\section{Responsabilidad en la sociedad extinguida. Sentencia del TS 324/2017, de 24 de mayo.}

Si la escritura de extinción y la cancelación de los asientos registrales extinguen la sociedad (arts. 395 y 396 de la LSC), pudiera pensarse que a partir de ese momento la sociedad carecería de personalidad jurídica y no podría ser demanda para exigirle el cumplimiento de las obligaciones sobrevenidas con posterioridad a su extinción, ya que para ello se prevé la responsabilidad de los socios con sus cuotas de liquidación (art. 399 de la LSC).

Sobre esta trascendental cuestión se ha pronunciado el TS, Sala Civil, en Sentencia de 324/2017, de 24 mayo -Rec. 197/2015-, que partiendo de las Sentencias 979/2011, de 27 de diciembre, y 220/2013, de 20 de marzo, y de resoluciones de la DGRN, afirma que la sociedad extinguida, cuando sobrevienen deudas con posterioridad a la extinción de su personalidad jurídica tras la finalización del procedimiento de disolución y liquidación, puede ser demanda, y en su caso, condenada, al mantener latente su personalidad jurídica mientras no se hayan satisfecho todas las operaciones liquidatarias que pueden surgir ante un eventual pasivo o activo sobrevenido, porque la personalidad jurídica de las sociedades mercantiles no concluye con la formalización de las operaciones liquidatarias, o con la cancelación de los asientos registrales. En esa sentencia se confirma la dictada en instancia en la que se condenó a una sociedad disuelta y extinguida, que había tenido como actividad la promoción de viviendas, a la realización de las obras de reparación de los defectos constructivos, o bien a abonar su importe, una vez se manifiestan los defectos de construcción tras la cancelación de los asientos registrales por liquidación ${ }^{1130}$.

${ }^{1130}$ En esta Sentencia se concluye, "Es cierto que la actual Ley de Sociedades de Capital, en su art. 399, prevé la responsabilidad solidaria de los antiguos socios respecto de las deudas sociales no satisfechas hasta el límite de sus respectivas cuotas de liquidación, en caso de pasivos sobrevenidos. En muchos casos, para hacer efectiva esta responsabilidad, no será necesario dirigirse contra la sociedad. Pero reclamaciones como la presente, sin perjuicio de que acaben dirigiéndose frente a los socios para hacer efectiva responsabilidad solidaria hasta el límite de sus respectivas cuotas de liquidación, pueden requerir de un reconocimiento judicial del crédito, para lo cual resulte conveniente dirigir la demanda frente a la sociedad. En estos supuestos, en que la reclamación se basa en que el crédito reclamado debería haber formado parte de la liquidación, y que por lo tanto la practicada no es 
Es por esa personalidad latente para concluir operaciones de activo o pasivo sobrevenido, que GARCÍA CRUCES ${ }^{1131}$ considera que no se extingue la personalidad jurídica de la sociedad hasta que no concluyan todas las operaciones de liquidación, hasta que no se extingan las relaciones de la sociedad con los socios o con los acreedores, por lo que conserva una personalidad latente tras la inscripción registral de la escritura de extinción y la cancelación de sus asientos.

Con esta Sentencia se permite reclamar a la sociedad extinguida, que estará representada por el liquidador, aunque sus efectos prácticos serán de difícil ejecución, ya que carece de patrimonio y bienes para poder hacer efectiva su responsabilidad por una deuda sobrevenida, salvo activos sobrevenidos, siendo en último término los socios los que deberán responder de la deuda social. En esa Sentencia se afirma que tiene capacidad para ser demandada la sociedad extinguida, y para reclamarle judicialmente el crédito, especialmente en casos como el debatido en la instancia, vicios de construcción, en que la exigibilidad del crédito puede requerir un reconocimiento judicial para el que resulta conveniente reconocer legitimación pasiva a la sociedad.

De este modo, partiendo de la doctrina de esta Sentencia, nada obsta a que la reclamación administrativa de la deuda sobrevenida se exija de modo solidario a los socios, que responden con el importe de sus cuotas de liquidación y a la sociedad extinguida, que continúa teniendo una personalidad latente para la realización de esas operaciones liquidatarias por pasivo sobrevenido, la que intervendrá en el procedimiento administrativo a través del liquidador. Sociedad que no dispondrá de bienes con que hacer efectiva la deuda, con lo que en última instancia serán los socios

definitiva, no sólo no debemos negar la posibilidad de que pueda dirigirse la reclamación frente a la sociedad sino que, además, no debemos exigir la previa anulación de la cancelación y la reapertura formal de la liquidación. De este modo, no debe privarse a los acreedores de la posibilidad de dirigirse directamente contra la sociedad, bajo la representación de su liquidador, para reclamar judicialmente el crédito, sobre todo cuando, en atención a la naturaleza del crédito, se precisa su previa declaración. Dicho de otro modo, a estos meros efectos de completar las operaciones de liquidación, está latente la personalidad de la sociedad, quien tendrá capacidad para ser parte como demandada, y podrá estar representada por la liquidadora, en cuanto que la reclamación guarda relación con labores de liquidación que se advierte están pendientes. Además, el art. 400 LSC atribuye esta representación a los (antiguos) liquidadores para la formalización de actos jurídicos en nombre de la sociedad, tras su cancelación. De ahí que ratifiquemos la posición contenida en las Sentencias de esta Sala de 979/2011, de 27 de diciembre, y 220/2013, de 20 de marzo, y entendamos que la sociedad demandada gozaba de capacidad para ser parte en este concreto pleito, en el que se reclama la reparación del perjuicio sufrido por un cumplimiento defectuoso de las obligaciones contractuales asumidas por la sociedad frente a la demandante".

${ }^{1131}$ GARCÍA CRUCES, J. A.: Derecho de Sociedades Mercantiles, op. cit., p. 516. 
quienes asumirán la deuda, ya que, en caso de iniciarse el procedimiento ejecutivo administrativo, serán los únicos con posibilidad de ser ejecutados en sus bienes.

Pudiendo ser objeto de notificación o citación en el procedimiento administrativo, especialmente a los efectos del reconocimiento de la deuda, las actuaciones se realizarán con el liquidador, en cuanto sujeto legitimado y con capacidad legal para representar a la sociedad (arts. 375 y 379 de la LSC).

\section{IX.- EFECTOS DE LA DECLARACIÓN DEL CONCURSO DE ACREEDORES DE LA SOCIEDAD EN LA RESPONSABILIDAD DEL ADMINISTRADOR.}

En los arts. 136.1.2 ${ }^{\circ}$ y 139.1 del TRLC ${ }^{1132}$ se establece que los jueces de lo mercantil no admitirán a trámite, desde la declaración del concurso hasta su conclusión, las demandas que se presenten en las que se ejerciten acciones de reclamación de obligaciones sociales contra los administradores de las sociedades concursadas, por haber incumplido éstos los deberes impuestos en caso de concurrencia de causa de disolución, y de haberse admitido, se ordenará el archivo de las actuaciones (art. 136.1.2 $2^{\circ}$ del TRLC). Pero no sólo se declara la inadmisión de nuevas demandas, sino, que, desde la declaración del concurso hasta su finalización quedarán en suspenso los procedimientos que pudieran haberse iniciado antes de la declaración, en los que se hubieren ejercitado acciones de reclamación de la responsabilidad a los administradores por deudas sociales por incumplimiento de los deberes en caso de concurrir causa de disolución (art. 139.1 del TRLC). Paralización que no afecta al ejercicio de la acción individual de responsabilidad, si el acreedor social quiere recabar el crédito del administrador, ni a la acción social de responsabilidad (arts. 132.1, 139.1.2 ${ }^{\circ}$ y 139.1 del TRLC, y Sentencia el TS, Sala Civil, 737/2014, de 22 de diciembre -Rec. 1261/2013-).

La declaración del concurso de acreedores de la sociedad tiene los siguientes efectos en la responsabilidad de los administradores. Con relación a la acción social de responsabilidad, la declaración de concurso no conlleva la suspensión del ejercicio de la acción y la paralización de los procedimientos en los que ya se hubiera ejercitado, sino que los efectos legales de la declaración de concurso se limitan a tres: en primer lugar, atribuir en exclusividad a la administración concursal la legitimación activa para el ejercicio de la acción social de responsabilidad (art. 132 del TRLC); en segundo lugar,

1132 Preceptos que recogen el contenido de los arts. 50.2 y 51 bis de la anterior LC de 2003, según redacción dada por la Ley 38/2011, de 10 de octubre, de reforma de la Ley 22/2003, de 9 de julio, Concursal-BOE del 11.10.2011-. 
en atribuir la competencia judicial para conocer de la acción social de responsabilidad al juez del concurso (art. 52, $7^{\mathrm{a}}$ del TRLC); y en tercero lugar, que los juicios en los que se hubieren ejercitado estas acciones antes del concurso que estuvieren en primera instancia y no haya finalizado el acto del juicio o la vista, se acumulan de oficio al concurso (art. 138 TRLC). Con relación a las acciones de reclamación de la responsabilidad solidaria de los administradores por deudas sociales de la sociedad de capital concursada en caso de concurrencia de causa de disolución (art. 367 LSC), la declaración de concurso conlleva la suspensión del ejercicio de las acciones procesales (Sentencia 737/2014, de 22 de diciembre -Rec. 1261/2013-), ya que los jueces de lo mercantil no deberán admitir a trámite las demandas en que se ejerciten estas acciones (art. 136.1.2 ${ }^{\circ}$ del TRLC), y los procedimientos pendientes se suspenderán (art. 139.1 del TRLC).

Declarado el concurso, y hasta que finalice el proceso concursal, no cabe reclamar judicialmente la responsabilidad solidaria al administrador por las deudas sociales, prevista en el art. 367 de la LSC. Con esta medida se pretende que, en los supuestos de la responsabilidad solidaria por deudas del administrador social (art. 367 de la LSC), las deudas de la sociedad de capital se sometan a la par condictio creditorum, de modo que se satisfagan de la propia masa activa del concurso, y sólo una vez finalizado éste, de no haberse cobrado en todo o en parte, se puedan reclamar a los administradores. Todo con la finalidad de primar el proceso concursal, y evitar en último término que resultasen favorecidos aquellos acreedores que hubieren sido más diligentes en la reclamación a los administradores fuera del concurso, pudiendo perjudicar al resto de los acreedores, a la par conditio creditorum, ante una eventual condena a los administradores a responder dentro del concurso del déficit de la liquidación de la sociedad, por declarase su responsabilidad concursal.

En la doctrina se ha criticado esta solución legislativa de impedir el ejercicio de las acciones de reclamación de la responsabilidad solidaria de deudas de la sociedad en concurso a los administradores, proponiendo la adopción de otras medidas de coordinación para evitar el posible perjuicio que se pudiera causar al resto de acreedores de la sociedad concursada, ante una eventual condena al administrador social a responder del déficit patrimonial tras la liquidación. GARCÍA CRUCES ${ }^{1133}$ estima que podría mantenerse abierta la posible reclamación de responsabilidad a los 
administradores del art. 367 de la LS, pese a encontrarse en concurso la sociedad, proponiendo que el acreedor que ejercitase esa reclamación deba comunicar previamente a la administración concursal su pretensión, para en su caso, la administración concursal poder valorar la importancia que esa reclamación pudiera tener en el patrimonio del administrador, y poder proponer el embargo preventivo de bienes previsto en el art. 133 del TRLC, admitido para los supuestos de que exista fundada posibilidad de ser condenados esos administradores a responder del déficit patrimonial resultante de la liquidación. Para GARCÍA CRUCES ${ }^{1134}$, incluso la reclamación de la responsabilidad solidaria al administrador de las deudas de la sociedad en concurso, pudiera tener efecto positivo en el resto de acreedores en el concurso de la sociedad, ya que, por un lado, los acreedores que obtuvieren el pago ya no integrarían la masa pasiva, con lo que ésta se distribuiría entre menos acreedores, y por otro lado, el crédito por subrogación que tendría el administrador ante la sociedad para resarcirse del pago sería un crédito subordinado, con lo que tendrían prelación para obtener el pago el resto de los créditos, fueren ordinarios o privilegiados. Pero tendría esa propuesta el inconveniente de que normalmente se tendrán datos objetivos sobre la futura declaración de concurso culpable y sobre la declaración de ser el administrador persona afectada por la calificación de concurso culpable, cuando el proceso concursal esté muy avanzado, lo que impediría que el embargo preventivo se solicite cuando se comunique el ejercicio de las acciones del art. 367 de la LSC.

Para el profesor QUIJANO ${ }^{1135}$, la suspensión de la reclamación judicial de la responsabilidad solidaria del administrador social por las deudas de la sociedad, cuando ésta se halla en situación concursal, es una medida razonable, reseñando sólo un posible efecto negativo, que tendría lugar cuando la responsabilidad surgiese por no haber solicitado el concurso existiendo conjuntamente causa de disolución, en cuyo supuesto, se pudo haber declarado la responsabilidad concursal, y reclamarse luego la responsabilidad por deudas ante una misma conducta, "lo que podría chocar de alguna manera con el principio non bis in ídem".

Que no se pueda reclamar judicialmente esta responsabilidad durante la pendencia del proceso concursal contra la sociedad, no significa que la declaración de concurso de

\footnotetext{
${ }^{1134}$ GARCÍA CRUCES, J. A.: "La responsabilidad concursal”, 2016, op. cit., pp. 441-442.

1135 QUIJANO GONZÁLEZ, J.: "Coordinación de acciones societarias (social, individual y por deudas) y concursales de responsabilidad”, 2015, op. cit., p. 8.
} 
acreedores exima de esta posible responsabilidad en que los administradores hubieran podido incurrir, ya que podrá ser exigida una vez finalice el concurso de acreedores ${ }^{1136}$.

En los arts. 136.1.2 $2^{\circ}$ y 139.1 del TRLC se alude a que no se admitirán demandas en que se ejercite la acción de reclamación de la responsabilidad solidaria del administrador social por deudas de la sociedad, o que se suspenderán los procesos en curso, pero no señala que esa declaración de concurso impida el ejercicio de la derivación administrativa de responsabilidad para exigir al administrador la responsabilidad solidaria por las deudas de la sociedad. Ante la redacción de esos preceptos, surge de modo inmediato la duda de si esa imposibilidad de reclamarse judicialmente la responsabilidad del administrador tras la declaración de concurso de la sociedad, y hasta su finalización, afecta o no a la derivación de responsabilidad al administrador de las deudas de Seguridad Social de la sociedad de capital durante el concurso de la mercantil (art. 367 de la LSC y art. 18.3 del TRLGSS).

Si partimos de una interpretación literal de esos preceptos y del principio de legalidad de las potestades y competencias administrativas, la respuesta será negativa, ya que esos preceptos no impiden el ejercicio de la derivación administrativa de responsabilidad del administrador social por deudas de Seguridad Social de la sociedad de capital durante la tramitación del concurso de acreedores de la mercantil. En primer lugar, porque en los arts. 136.1.2 $2^{\circ}$ y 139.1 del TRLC, sólo se suspende e impide el ejercicio de las acciones judiciales de reclamación de responsabilidad ante los juzgados mercantiles, pero no la reclamación de responsabilidad en virtud del principio de autotutela de la Administración, quien tiene atribuida y reconocida legalmente la competencia para reclamar la responsabilidad del administrador en el procedimiento administrativo recaudatorio (arts. 18.3, 33.2 y 34.1.a) del TRLGSS), con lo que no estamos ante un mero olvido del legislador, sino ante una opción legislativa. El legislador ha excluido sólo el ejercicio de las acciones judiciales de reclamación de la responsabilidad del

1136 Como señala la Sentencia del TS, Sala Civil, 590/2013, de 15 octubre 2013 -Rec. 1268/2011- "en supuestos en que concurra la causa $4^{\mathrm{a}}$ del art. 260.1 TRLSA [actual núm. 363.1.d) LSC], pérdidas que hayan reducido el patrimonio neto por debajo de la mitad del capital social, cesa el deber de instar la disolución si, por concurrir además el estado de insolvencia de la compañía conforme al art. 2.2 LC (cuando "no puede cumplir regularmente sus obligaciones exigibles"), se solicita y es declarado el concurso de acreedores de la sociedad. Así se desprende de una interpretación del citado art. 260.1.4 TRLSA, en relación con los apartados 2 y 5 del art. 262 TRLSA. Lo anterior no significa que la declaración de concurso de acreedores exima de la posible responsabilidad ex art. 262.5 TRLSA, en que los administradores hubieran podido incurrir antes del concurso, sin perjuicio de que, tras la reforma introducida por la Ley 38/2011, de 10 de octubre, la declaración de concurso suspenda el ejercicio de esta acción de responsabilidad (art. 50.2 LC) y, si se lo hubiera sido y estuviera en tramitación, se paralizará el procedimiento (art. 51.1.bis LC)". 
administrador, pero no el ejercicio de potestades administrativas, ya que no ha afectado o alterado esa competencia, y para que una potestad administrativa puede ser alterada o suspendida precisa una disposición legal que la establezca expresamente en virtud del principio de legalidad de la actuación administrativa (como resulta de los arts. 9.3 y 103 de la CE, arts. 34, 38, 39.1 y 98 de la LPACAP y arts. 3 y 8 de la LRJSP). Limitación de una potestad administrativa que, si no ha sido declarada legalmente, no cabe sostener su aplicación al procedimiento administrativo en virtud de una aplicación analógica, o en virtud de una interpretación teleológica de los arts. 136.1.2 $2^{\circ}$ y 139.1 del TRLC. Ya en la doctrina administrativista, GARCÍA DE ENTERRÍA ${ }^{1137}$ había establecido que, en virtud del principio de legalidad de las potestades administrativas, se precisa su atribución legal de modo expreso y específico, y una vez atribuidas son inalienables, intransmisibles e irrenunciables. En virtud del principio de legalidad la Administración ejerce unas competencias que tiene reconocidas para el cumplimiento de sus fines institucionales, ejercicio siempre sometido a la Ley y al Derecho (Sentencia del TS, Sala de Conflictos de Jurisdicción, 2/2018, de 21 de marzo -Rec. 1/2018-). En segundo lugar, prueba de que no estamos ante un olvido del legislador, es que, en otros supuestos, cuando ha querido, sí ha contemplado la existencia de ejercicio de la autotutela administrativa o de las potestades administrativas si pueden afectar al patrimonio del deudor, de la sociedad de capital, al obligar a los jueces del orden contencioso-administrativo para que emplacen a la administración concursal para que pueda comparecer en los procesos que se sigan ante la jurisdicción contenciosoadministrativa, para que puedan defender la masa activa (art. 136.3 del TRLC), por lo que, si ha previsto los efectos del ejercicio de potestades administrativas durante el concurso para la sociedad, y no ha dicho nada con relación a la reclamación de deudas contra el administrador, es porque no ha querido impedir la derivación de la deuda en vía administrativa. En tercer lugar, porque la prohibición de ejercitar la acción judicial civil del art. 367 de la LC, no siempre va a impedir que durante el concurso de la sociedad se reclame la responsabilidad por deudas de la sociedad en que el administrador haya podido incurrir, al igual que sucede cuando sea avalista de una deuda social, donde el acreedor podría reclamar el pago al administrador social avalista, y ello es así porque ese derecho no se ve afectado (arts. 136, 138, 139 y 155.2 del TRLC), y con mayor fundamento, si la competencia administrativa no ha sido afectada,

${ }^{1137}$ GARCÍA DE ENTERRÍA, E.: Curso de Derecho Administrativo, Volumen I, Cívitas, $2^{\circ}$ edición, y $2^{\mathrm{a}}$ reimpresión, Madrid, 1978, pp. 259 y 262-267. 
no existe razón jurídica que impida a la Administración ejercitar las competencias que tiene legalmente atribuidas en virtud del principio de legalidad administrativa. Finalmente, porque como veremos, esta ha sido la respuesta del TS, en la Sala de Conflictos de Competencia.

MARTÍNEZ LUCAS ${ }^{1138}$ estima que la declaración de concurso no impedirá la declaración de responsabilidad solidaria de sus administradores societarios citando la STS, Sala Civil, 30 octubre 2000 -Rec. 3341/1995-. Sentencia que no aborda expresamente si el concurso de acreedores paraliza la derivación administrativa de la responsabilidad.

No suspendiéndose la derivación administrativa de responsabilidad solidaria del administrador social en las deudas de Seguridad Social de la sociedad, por la declaración de concurso de la mercantil, esa derivación de deuda, según ESTEBAN MONASTERIO"1139 (sic) "debe ser ejercitada con prudencia y cautela y con estricta observancia de los presupuestos habilitados legalmente, que no es ni más ni menos que el mandato constitucional dirigido a los poderes públicos de actuar con sometimiento pleno a la Ley y al Derecho (art. 103.1 CE), esto es, al principio de legalidad”.

Paralización o suspensión de acción judicial de reclamación de la responsabilidad prevista en la ley concursal, que no es de aplicación a la derivación administrativa de deuda al administrador social de la sociedad en concurso de acreedores, según ha señalado el Tribunal Supremo, Sala de Conflictos de Competencia, en Auto 39/2013, de 19 de diciembre de 2013 -Rec. 35/2013-1140, que resolvió un conflicto negativo de competencia planteado entre dos Juzgados de Lugo, el Juzgado ContenciosoAdministrativo $\mathrm{n}^{\mathrm{o}} 1$ y el Mercantil $\mathrm{n}^{\circ} 2$, en favor del primero. Conflicto entre esos órdenes jurisdiccionales que se había planteado con motivo de la demanda formulada por el administrador de la sociedad concursada, contra el acuerdo de la Dirección

1138 MARTÍNEZ LUCAS, J. A.: “Responsabilidad de los administradores por cuotas de la Seguridad Social”, Actualidad Laboral n 1, 2005, edición digital, https://laleydigital-laleynext-es.ponton.uva.es/Content/Documento.aspx?params, p. 4.

${ }^{1139}$ ESTEBAN MONASTERIO, I.: "Responsabilidad de los administradores sociales por deuda pública”, Revista Aranzadi Doctrinal, núm. 2/2020 parte Jurisprudencia, edición digital, https://insignis-aranzadidigital-es.ponton.uva.es/maf/app/document, p. 8.

1140 Se señala que, "en la Ley Concursal no hay norma alguna que impida, como consecuencia de la declaración de concurso de la sociedad, la derivación de responsabilidad al administrador, en este caso la acordada por la Tesorería General de la Seguridad Social, en un procedimiento administrativo, al amparo del art. 15.3 de la Ley General de la Seguridad Social, en relación con el art. 13 del Reglamento General de Recaudación de la Seguridad Social. Ni tampoco atribuye al juez del concurso competencia respecto del control judicial de este acto administrativo". 
Provincial de Lugo de la TGSS por el que se le declara responsable solidario de los descubiertos en cotizaciones de la sociedad que estaba en concurso de acreedores. En ese Auto se señala que la derivación administrativa de deudas de Seguridad Social al administrador, no se ve afectada por el concurso de acreedores de la sociedad. Llega a esa conclusión tras señalar que los únicos efectos que ha previsto la Ley Concursal, son, por un lado, atribuir al juez del concurso el conocimiento de la acción social de responsabilidad contra el administrador, y por otro lado, impedir el ejercicio de las acciones civiles de reclamación de deudas de la sociedad al administrador durante el concurso de la mercantil, suspendiendo los procesos en tramitación, pero sin que el concurso afecte a la acción individual y a la derivación administrativa de deudas con la Seguridad Social de la sociedad al administrador.

La STS, Sala Contencioso-Administrativa, núm. 1400/2020, de 26 de octubre -Rec. 5951/2018-, no se pronunció sobre la paralización de la derivación administrativa de responsabilidad al administrador durante el proceso concursal, al no ser objeto de fijación de doctrina, siendo objeto de interés casacional determinar si, cuando la sociedad está en concurso de acreedores, "es aplicable a los procedimientos de derivación de responsabilidad solidaria a los administradores sociales, la interrupción de la prescripción recogida en el artículo 155 del TRLC, o la interrupción de la prescripción regulada en los artículos 24 del TRLGSS y, 42.1 y 43 del RGRSS”. Esa Sentencia fija como doctrina de interés casacional, que, "ante el impago de cotizaciones generadoras de un derecho de crédito a favor de la TGSS, sujeto con carácter general a las reglas sobre prescripción de la LGSS y del RGRSS, la TGSS puede proceder a la derivación de responsabilidad solidaria de los administradores; ahora bien, si la mercantil deudora es declarada en concurso son aplicables las especialidades de la Ley Concursal, de forma que la TGSS puede estar a las resultas del concurso, luego tratándose de créditos concursales queda interrumpida la prescripción de la acción frente a los administradores conforme al artículo 60 de la Ley Concursal" (actual art. 155.3 del TRLC). La cursiva es nuestra. Se señala que "la TGSS puede estar", no que "debe estar a las resultas del concurso", lo que implícitamente estaría admitiendo la derivación durante el proceso concursal, pese a no haber sido esta cuestión objeto de fijación de doctrina.

Igual doctrina se ha mantenido para la derivación de deudas tributarias al administrador social de una sociedad mercantil en concurso de acreedores, estimando que la 
Administración puede derivar la responsabilidad al administrador, ya que esa potestad administrativa no está afectando a la competencia exclusiva y excluyente del juez del concurso para conocer acerca de todas las cuestiones derivadas del proceso concursal, ya que la derivación de deuda se efectúa a un tercero, al administrador social, por lo que no se está incidiendo en el patrimonio de la sociedad, ni se afecta la par conditio creditorum $^{1141}$.

En todo caso, durante el proceso concursal se interrumpe la prescripción de las acciones contra los administradores (art. 155.3 del TRLC), de modo que, si la TGSS decide no derivar la responsabilidad al administrador durante ese proceso concursal, se interrumpe la prescripción, tanto de la deuda de Seguridad Social como de la acción de derivación la responsabilidad solidaria por deudas contra el administrador social del art. 367 de la LSC (STS, Sala Contencioso-Administrativa, núm. 1400/2020, de 26 de octubre -Rec. $5951 / 2018-)$.

En igual sentido se han pronunciado varios Tribunales Superiores de Justicia ${ }^{1142}$, al estimar que el concurso de la sociedad de capital no paraliza la derivación administrativa de responsabilidad al administrador social al amparo del art. 367 de la LSC. Recogemos como representativas, brevemente a tres de esas resoluciones:

- En Sentencia del TSJ de Castila y León con sede en Valladolid, Sala ContenciosoAdministrativa, núm. 859/2018, de 27 de septiembre -Rec. 902/2016-, partiendo de los arts. 18.3.3 y 33.2 del TRLGSS, y del Auto referido del TS, señala que "a la vista de esta normativa resulta claro que se ha otorgado a la Tesorería General de la

${ }^{1141}$ Según la Sentencia del TS, Sala de Conflictos, 2/2018, de 21 de marzo -Rec. 1/2018-, "La derivación de responsabilidad no se dirige contra el concursado, sino contra terceros (en este caso, el administrador concursal, aunque no necesariamente siempre así) que, por incurrir en alguno de los presupuestos contemplados en los arts. 41 y siguientes LGT, se hacen solidaria o subsidiariamente responsables de la deuda tributaria. En consecuencia, la derivación de responsabilidad acordada por la AEAT no supone ninguna injerencia en el patrimonio del deudor ni ataca la par condictio creditorum. Al no existir específica atribución competencial a favor de los Juzgados de lo Mercantil para conocer de tales acciones individuales de responsabilidad, la competencia para declarar la responsabilidad tributaria ha de corresponder a la AEAT, sin perjuicio de su posible revisión en vía administrativa ante los Tribunales Económico Administrativos y, en vía jurisdiccional, ante la Jurisdicción ContenciosoAdministrativa”. En igual sentido en STS, Conflictos de Jurisdicción, núm. 3/2013, de 9 de abril -Rec. 1/2013-; SSTS, Sala Contencioso-Administrativa, núm. 1141/2017, de 27 de junio -Recurso de Casación no 433/2016-, con núm. 1421/2016, de 15 de junio -Recurso de Casación n 1916/2015-.

1142 Sentencias del TSJ de La Rioja, Sala Contencioso-Administrativa, núm. 192/2019, de 13 de junio Aranzadi 2019/217184-; 400/2018, de 31 de diciembre -Aranzadi 2018/1623-; 161/2018, de 14 de mayo -Rec. 125/2017-; y 8/2018, de 17 enero -Aranzadi 2018/89933-; Sentencia del TSJ del País Vasco, Sala Contencioso-Administrativa, núm. 303/2017, de 14 de junio -Rec. 829/2016-; Sentencia del TSJ de Andalucía, sede de Sevilla, Sala Contencioso-Administrativa, de 8 de junio de 2017 -Rec. 552/2016-, entre otras. 
Seguridad Social la facultad de autotutela en vía administrativa para la declaración de la responsabilidad solidaria que aquí nos ocupa, sin perjuicio, obviamente, de su ulterior control jurisdiccional, y que debemos considerar que esta competencia no es a la que se refiere la ley concursal con relación a las acciones de responsabilidad que puedan dirigirse contra los administradores sociales y con independencia de la responsabilidad que pueda corresponderles a los administradores por aplicación de la legislación concursal, en concreto su artículo 146".

- En Sentencia del TSJ Castilla y León, con sede en Burgos, Sala ContenciosoAdministrativa, núm. 172/2017, de 15 septiembre -Rec. 43/2016 y acumulado 51/2016-, establece que el concurso de acreedores de la sociedad, no impide la derivación de responsabilidad al administrador social por la TGSS, al señalar que, "en la Ley Concursal no hay norma alguna que impida, como consecuencia de la declaración de concurso de la sociedad, la derivación de responsabilidad al administrador, en este caso la acordada por la Tesorería General de la Seguridad Social, en un procedimiento administrativo, al amparo del art. 15.3 de la Ley General de la Seguridad Social, en relación con el art. 13 del Reglamento General de Recaudación de la Seguridad Social. Ni tampoco atribuye al juez del concurso competencia respecto del control judicial de este acto administrativo."

- La Sentencia del TSJ de Andalucía con sede en Sevilla, Sala Contencioso-

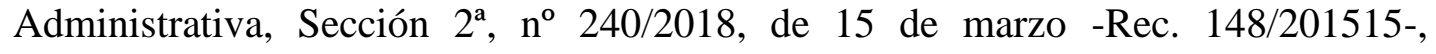
señalando que, "son compatibles el procedimiento ante la TGSS de declaración de responsabilidad de los Administradores sociales y el de concurso seguido ante el Juzgado de lo Mercantil. El art. 8.7 de la Ley Concursal modificado por Ley 38/11, de 10 de octubre, invocado se refería a las acciones tendentes a exigir responsabilidad civil por los perjuicios causados al concursado y no a la responsabilidad cuasi-objetiva de los administradores societarios por las deudas sociales derivadas del incumplimiento de sus deberes de promover la disolución social. Se invoca la Sentencia de esta Sala de fecha 26 de mayo de 2011 y STSJ de Cantabria de 21 de mayo de 2013. Las previsiones de la Ley 38/2011 no se refiere a la autotutela de la Seguridad Social sino a la acción de los particulares (ante el orden civil)".

- Sentencia del TSJ de Galicia con sede en A Coruña, Sala ContenciosoAdministrativa, 150/2016, de 6 de abril -Rec. 15083/2015- , que señala, "existen, pues, normas dirigidas a coordinar el ejercicio y el mantenimiento de las acciones de 
responsabilidad contra administradores después de la declaración de concurso pero ello se limita a la acción social de responsabilidad -que se atribuye al Juez Mercantil- y a la acción de responsabilidad por deudas sociales -que se paraliza o evita durante el concurso-, sin incluir, sin embargo, la acción individual de responsabilidad y mucho menos los procedimientos de derivación de responsabilidad por deudas con la Seguridad Social. En todo caso, la cuestión ha sido resuelta en sentido contrario al planteamiento del actor por la Sala Especial de Conflictos de Competencias el Tribunal Supremo, en Auto de 19 de diciembre de 2013 (Rec. 35/2013)”.

Esta es la doctrina administrativa de la DGITSS, quien en Consulta de fecha 21 de octubre de $2014^{1143}$, señala que la tramitación del concurso de acreedores de la sociedad de capital, no paraliza o suspende el procedimiento administrativo de derivación de responsabilidad de deudas de la sociedad al administrador, argumentando al respecto lo siguiente, "En todo caso, y a salvo de que la jurisprudencia del Tribunal Supremo pueda establecer lo contrario, en base a criterios de interpretación finalista o teleológica, esta Dirección General considera ajustado a Derecho el criterio contenido en la Sentencia del Juzgado de lo Contencioso-Administrativo núm. 8 de Valencia, de 10 de junio de 2014, que se adjunta a su consulta, según el cual la regulación vigente en materia de Seguridad Social no se vería afectada por las modificaciones introducidas en el procedimiento concursal por la Ley 38/2011. En efecto, estando al tenor literal de la norma, que debe en principio interpretarse en sus propios términos, tales modificaciones afectan estrictamente a las demandas presentadas ante los órganos judiciales para el ejercicio de acciones de reclamación de obligaciones sociales contra los administradores societarios, supuesto plenamente diferente a la posibilidad legalmente prevista de que la Tesorería General de la Seguridad Social declare la responsabilidad solidaria de los citados administradores en el pago de las deudas a la Seguridad Social en los supuestos contemplados en el art. 367 LSC. Este criterio es el que, de forma indirecta, se ha mantenido en un reciente Auto de 19 de diciembre de 2013 del Tribunal Supremo (Sala Especial de Conflictos de Competencia), que resuelve el conflicto de competencias planteado entre un Juzgado de lo Contencioso-Administrativo y un Juzgado de lo Mercantil de Lugo, al negar ambos su competencia para juzgar la demanda interpuesta contra una resolución de derivación de responsabilidad dictada por la Dirección

\footnotetext{
${ }^{1143}$ Referencia La Ley 2499/2014.
} 
Provincial de la TGSS de Lugo. Pese a tratarse de una resolución dictada con posterioridad a la entrada en vigor de la Ley 38/2011”.

En igual sentido, de estimar que el concurso de acreedores de la sociedad de capital no paraliza la derivación administrativa de responsabilidad al administrador social, la Consulta de la Subdirección General de Ordenación e Impugnaciones de la TGSS de 12 de marzo de 2007 (exp. 1646/2006), que citan MERCADER UGUINA y SUÁREZ CORUJO. ${ }^{1144}$

Al no paralizarse la derivación administrativa de responsabilidad del administrador social, cuando concurra causa de disolución conjuntamente con causa de concurso de acreedores, puede dar lugar a que se obtenga el pago de la deuda de la Seguridad Social de la sociedad de capital en vía administrativa con cargo a la responsabilidad solidaria de los administradores. De ser así, y ante la eventualidad de que en el proceso concursal se declare la responsabilidad de los administradores, en caso de concurso calificado como culpable, y se les condene a responder del déficit patrimonial de la liquidación, con la finalidad de evitar que se reclame una doble responsabilidad para percibir una misma deuda, como medida de lege ferenda debería establecerse la obligación de la TGSS de comunicar al juez del concurso el inicio del procedimiento administrativo de derivación, para que pueda ser tenido en cuenta si se ha obtenido el pago de la deuda de los administradores, ya que la TGSS está dentro de la masa pasiva del concurso, y deberá conocerse si la deuda ha sido satisfecha por el administrador, para, por un lado, excluirse de la masa pasiva, ya que es regla general que obtenido el pago del avalista o deudor solidario de la sociedad concursada, ese pago debe ser tenido en cuenta en la formación de la lista de acreedores, al subrogarse el avalista o responsable solidario en la posición que ocupaba el titular del crédito, que en caso de ser administrador, su crédito será siempre subordinado (arts. 263, 264, 281 y 283 del TRLC), y por otro lado, para que, una vez declarada la responsabilidad concursal del administrador, se pueda tener en cuenta el resultado de la derivación administrativa de la deuda. Obligación de comunicar la derivación administrativa de responsabilidad, que sería distinta de la previsión de la Ley Concursal de que los jueces o tribunales contenciosoadministrativos deban emplazar a la administración concursal cuando se ejerciten

${ }^{1144}$ MERCADER UGUINA, J. R. y SUÁREZ CORUJO, B.: “La responsabilidad laboral y de Seguridad Social de los Administradores Sociales", op. cit., p. 583. 
acciones con trascendencia en el patrimonio de la sociedad concursada (art. 136.3 del TRLC).

Señalar finalmente que, pese a ser una situación distinta a la abordada, incluso de hallarse la sociedad de capital en concurso, no es óbice para que en vía administrativa pueda declarase su responsabilidad solidaria por deudas de sociedades integrantes de un mismo grupo empresarial si no se reclama la deuda en vía administrativa a esa sociedad, ya que son dos momentos o situaciones jurídicas distintas, aunque relacionadas, por un lado, el acuerdo o resolución administrativa de la derivación de responsabilidad a los distintos sujetos responsables, que deben identificarse en el acuerdo de derivación, y la reclamación efectiva de la deuda a todos o a alguno de ellos, pudiéndose reclamar la deuda en vía administrativa a los sujetos responsables que no se hallen en concurso de acreedores. Si la reclamación de la deuda por responsabilidad solidaria fuese a la empresa en concurso, entonces sí que se estaría afectando la competencia exclusiva y excluyente del juez del concurso, por lo que no podría reclamarse en vía administrativa, pero la jurisdicción del juez del concurso no se ve afectada por el acuerdo de derivación en que se identifican a los sujetos responsables, y los presupuestos jurídicos de la derivación ${ }^{1145}$. Según la Sentencia del TS, número 1182/2019, de 16 de septiembre Rec. 9/2017-, no estamos ante supuestos de ejecución frente a los bienes y derechos de contenido patrimonial del concursado, ni de acciones de reclamación de deudas sociales interpuestas contra los socios subsidiariamente responsables de los créditos de la sociedad deudora, supuestos en los que entraría en juego la jurisdicción exclusiva y excluyente del juez del concurso a tenor del artículo 52. $6^{\mathrm{a}}$ y $.7^{\mathrm{a}}$ del TRLC. Estamos ante un procedimiento administrativo de derivación de responsabilidad solidaria por deudas a la Seguridad Social con fundamento en la existencia de un grupo empresarial, del que forma parte una empresa en concurso de acreedores, sin que la TGSS haya iniciado procedimiento de cobro frente a mercantiles concursadas. Concluye esa sentencia señalando como doctrina de interés casacional que, "la Tesorería General de la Seguridad Social puede declarar mediante el correspondiente acuerdo de derivación la responsabilidad solidaria, por deudas que afecten a sociedades concursadas, a una

1145 Sentencias del TS, Sala Contencioso-Administrativa, $\mathrm{n}^{\circ}$ 1661/2018, de 22 de noviembre -Rec. 2507/2016-; no 1008/2019, de 8 de julio -Rec. 220/2017-; y n 1182/2019, de 16 de septiembre -Rec. 9/2017-, que se separan expresamente de la interpretación contraria que se mantuvo en la Sentencia $\mathrm{n}^{\circ}$ 1098/2017, de 20 de junio -Rec. 2765/2016-. 
sociedad integrante del mismo grupo, pero no sometida a concurso, sin necesidad de acudir al juez que está tramitando el procedimiento concursal”.

Concurriendo causa de disolución por pérdidas cualificadas y causa de concurso de la sociedad de capital, si los administradores no solicitan el concurso en el plazo de dos meses, responden de las deudas de Seguridad Social posteriores a la causa de disolución, por lo que, por la TGSS o la ITSS se podrá proceder a derivar la responsabilidad administrativa en el administrador social para exigir la responsabilidad solidaria en el pago de las deudas de Seguridad Social de la sociedad de capital. Derivación administrativa de responsabilidad que no se paraliza o suspende por el hecho de ser declarada la sociedad de capital en concurso de acreedores. 


\section{Vo CAPÍtulo:}

\section{OTROS SUPUESTOS DE DERIVACIÓN DE RESPONSABILIDAD AL ADMINISTRADOR DE DEUDAS DE LA SOCIEDAD DE CAPITAL}

\section{I.- RESPONSABILIDAD EN LA SOCIEDAD EN FASE DE CONSTITUCIÓN.}

\section{Régimen jurídico de la responsabilidad.}

Las sociedades de capital pueden constituirse de modo simultáneo o mediante fundación sucesiva, acudiendo a la suscripción pública del capital social. La fundación sucesiva sólo es aplicable a la sociedad anónima (arts. 41 y siguientes de la LSC). Cuando la sociedad anónima se constituye mediante fundación sucesiva no resulta de aplicación el régimen jurídico de responsabilidad que vamos a estudiar, ya que según GARCÍA CRUCES ${ }^{1146}$, durante el período de suscripción pública de las acciones anteriores a la inscripción registral, se realizan las operaciones necesarias para lograr la constitución de la sociedad encaminadas al otorgamiento de las escrituras públicas y a su inscripción, no pudiendo realizar operaciones ad extra ante terceros, no puede desarrollar la actividad constitutiva del objeto social, razón por la que las aportaciones realizadas por los socios son indisponibles hasta que la sociedad no se inscriba, salvo para destinarse a gastos imprescindibles para la inscripción: de notaría, registro y fiscales (art. 45 LSC). No cabe destinar ese patrimonio a ninguna actividad distinta. La sociedad en formación sólo cabe en la fundación simultánea ${ }^{1147}$, no en la fundación sucesiva de la sociedad anónima.

Cuando la constitución de la sociedad de capital no es por formación sucesiva, sino que se constituye en un único acto mediante escritura pública por los fundadores (fundación simultánea), se prevén una serie de responsabilidades para las sociedades que se hallen en fase de formación o constitución (arts. 36 a 38 de la LSC), por cuanto que cabe la posibilidad de que, aún no inscritas en el Registro Mercantil, empiecen a desarrollar la actividad constitutiva de su objeto social, generándose obligaciones y deudas de

${ }^{1146}$ GARCÍA CRUCES, J. A.: Derecho de Sociedades Mercantiles, Tirant Lo Blanch, 2a edición, 2019, p. 126.

${ }^{1147}$ FERNÁNDEZ DE LA GÁNDARA, L.: "Derecho de Sociedades”, Tirant Biblioteca Virtual, edición electrónica, 2010, Vol. I, p. 371. 
Seguridad Social, con lo que al no tener aún la plena personalidad jurídica habrá que determinar quién o quiénes son los sujetos responsables de cumplir las obligaciones de Seguridad Social durante ese proceso de formación societaria.

Antes de su inscripción, según FERNÁNDEZ DE LA GÁNDARA ${ }^{1148}$, la sociedad de capital en formación, con carácter transitorio, es un sujeto del tráfico jurídico, titular pleno de la actividad desarrollada y, en determinadas condiciones, responsable de las obligaciones contraídas frente a terceros, por tener ya un patrimonio propio pese a no haber adquirido la plena personalidad jurídica.

Toda sociedad en formación tiene cierta capacidad de obrar y cierta personalidad jurídica, aunque no haya alcanzado la personalidad correspondiente al tipo societario elegido, la que se adquiere con la inscripción en el Registro Mercantil de las escrituras de constitución (art. 33 LSC). Tienen cierta personalidad por cuanto que en la LSC se reconocen ciertas facultades de actuación en el tráfico jurídico. La sociedad en formación tiene cierta personalidad jurídica, aunque no sea aún una verdadera sociedad de capital, de modo que cuando en el art. 33 de la LSC se señala que si con la inscripción la sociedad adquiere la personalidad jurídica que le corresponde al tipo societario elegido, es porque antes de la inscripción ya tenía algún tipo de personalidad, que existe una personalidad jurídica única con diversas graduaciones de la personalidad, o con diversos grados de personalidad ${ }^{1149}$. Estamos ante una entidad provisional durante el período previo a su inscripción registral, siendo un centro de imputación de relaciones jurídicas ${ }^{150}$. Si finalmente no llega a inscribirse en el registro la sociedad, dejaremos de estar ante una sociedad en formación para pasar a hallarnos ante una sociedad irregular, con un régimen jurídico distinto.

La fecha de inicio del período de formación societaria en la doctrina puede entenderse de modo diferente ${ }^{1151}$, o bien situar el dies a quo o momento inicial, en el otorgamiento de la escritura pública de constitución, con lo que el período de formación iría desde el

1148 FERNÁNDEZ DE LA GÁNDARA, L.: “Derecho de Sociedades”, edición electrónica, op. cit., p. 370.

1149 VALPUESTA GASTAMINZA, E. M.: Comentarios a la Ley de Sociedades de Capital, Editorial, Bosch, $3^{\text {a }}$ edición, 2018, pp. 144 y 148-149.

${ }^{1150}$ VALPUESTA GASTAMINZA, E. M.: Comentarios a la Ley de Sociedades de Capital, op. cit., p. 144.

${ }^{1151}$ VALPUESTA GASTAMINZA, E. M.: Comentarios a la Ley de Sociedades de Capital, op. cit., p. 144. Cita en favor de la primera interpretación la Sentencia del TS, Sala Civil, núm. 323/2001, de 28 de marzo, y en favor de la segunda la Sentencia del mismo Tribunal y Sala de 24 de noviembre de 2010. 
otorgamiento de la escritura hasta la inscripción de la misma en el Registro Mercantil, o bien por el contrario, según otra concepción más amplia, ese período se extendería también al período anterior al otorgamiento de la escritura, desde que conste el acuerdo de los fundadores de constituir la sociedad -que podría ser anterior al otorgamiento de las escrituras- hasta la inscripción registral, de modo que la fase de constitución no nacería estrictamente con el otorgamiento de la escritura púbica, sino desde el momento en que se haya acordado constituir la sociedad.

La primera concepción la defiende la doctrina mayoritaria ${ }^{1152}$, para quienes la sociedad en formación nace una vez se ha otorgado la escritura por los socios, no antes, que es cuando se perfecciona el negocio jurídico societario, cuando existe una voluntad de cerrar el proceso de fundación con la posterior inscripción de la escritura en el Registro Mercantil.

En la Sentencia del TS, Sala Civil, 323/2001, de 28 de marzo -Rec. 872/1996-, se parte de la concepción de que la sociedad en formación nace con la escritura pública de constitución, señalando que "en la creación de sociedades mercantiles cabe de este modo señalar varias etapas: a) Una primera de preconstitución o presociedad; b) Una segunda de sociedad en formación (artículo 15 de la Ley de Sociedades Anónimas); y c) Una tercera, que corresponde a sociedad debidamente constituida e inscrita (artículo 7 de la Ley de Sociedades Anónimas)”. En la segunda etapa sitúa la escritura pública de constitución.

Por el contrario, para la Sentencia del TS, Sala Civil, 740/2010, de 24 noviembre -Rec. $876 / 2007-{ }^{1153}$, la sociedad en formación se inicia antes del otorgamiento de la escritura si hay constancia y conocimiento por terceros de la voluntad de constituir la sociedad.

1152 Vid.: GARCÍA CRUCES, J. A.: Derecho de Sociedades Mercantiles, op. cit., pp. 128-129; BROSETA PONT, M. y MARTÍNEZ SANZ, F.: Manual de Derecho Mercantil, Tecnos, $23^{a}$ edición, Vol. I, 2016, p. 384; FERNÁNDEZ DE LA GÁNDARA, L.: “Derecho de Sociedades”, edición electrónica, op. cit., pp. 371-372.

1153 Se señala sobre la personalidad jurídica de las sociedades no formalizadas, lo siguiente: "Nuestro sistema, reconoce a los particulares potestad para la creación de sociedades civiles que gozan de personalidad jurídica como efecto de la eficacia organizativa de la voluntad contractual de los socios de constituir una sociedad. Para que la sociedad pueda oponerse frente a terceros, además, debe exteriorizar su existencia aunque no se expliciten los pactos sociales, lo que acontece en supuestos como el presente en el que los socios contratan en nombre de la sociedad, de tal forma que el tercero es conocedor de que la relación obligatoria se entabla con el ente personificado. (...) Con la inscripción la sociedad adquirirá la personalidad jurídica que corresponda al tipo social elegido. Ello no supone la imposibilidad de que se suscriban contratos en nombre de futuras sociedades de responsabilidad limitada después de haberse otorgado escritura de constitución aun no inscrita, proyectándose sus efectos, según los casos, a la sociedad en fase de constitución, a los socios, a los 
Igualmente se ha reconocido cierta personalidad a la sociedad en formación por la Dirección General de Registros y el Notariado. La RDGRN de 22 de noviembre de 2000 -Aranzadi RJ 2000\5835- se pronuncia acerca de la denegación registral en el Registro de la Propiedad de la inscripción de la compraventa de un inmueble por una sociedad que, constituida en escritura pública no se hallaba inscrita en el Registro Mercantil, considerando el registrador de la propiedad que al carecer de personalidad jurídica la compra del inmueble no puede acceder al registro. En la resolución del recurso gubernativo se accede a la inscripción registral de la compraventa en favor de todos los socios constituyentes ${ }^{1154}$.

administradores, a quienes contrataron en nombre de esta, y, en ocasiones, tanto a la sociedad como a socios y gestores (...) hoy artículos 36 y siguientes de la Ley de Sociedades de Capital. Ahora bien, aunque como sostiene la Sentencia 957/2001 de 19 octubre, la inscripción de la escritura fundacional en el Registro Mercantil tiene la condición de requisito constitutivo, y en tanto no se cumpla la Sociedad carece de personalidad a determinados efectos, la personalidad jurídica, como instrumento eficaz para la organización de las empresas y creación de un centro de imputación de relaciones jurídicas útil en el tráfico jurídico, no queda limitada a los supuestos en los que se ha otorgado escritura pública -momento a partir del cual entra en juego la previsión contenida en el artículo 15 de la Ley de Sociedades Anónimas, como se deduce de la interpretación sistemática de este precepto en relación con el artículo 14 de la Ley de Sociedades de Responsabilidad Limitada, y hoy del artículo 33 en relación con el 24 del Texto Refundido de la Ley de Sociedades de Capital-, de tal forma que del contrato, incluso aformal, cabe derivar cierto grado de personalidad". La cursiva es nuestra.

Esa Sentencia de 24 de noviembre de 2010 cita otras sentencias para defender cierta personalidad a la sociedad en fase de constitución, incluso con anterioridad al otorgamiento de la escritura (STS, Sala Civil, de 1 de octubre de 1986 -RJ 1986/5230-; de 20 de febrero de 1988 -RJ 1988/1073-; 1004/1992, de 13 de noviembre -RJ 1992/9402-; 611/1996, de 17 de julio -RJ 1996/ 5724-; 743/2009, de 13 de noviembre).

${ }^{1154}$ En esa Resolución se indica, "Es indudable que el nacimiento de una sociedad limitada con el régimen jurídico específico definido en la legislación respectiva, no se produce hasta la inscripción del negocio fundacional en el Registro Mercantil, y en consecuencia, no puede pretenderse la inscripción de los bienes ahora cuestionados a favor de dicha sociedad limitada que aparece como comprador en el negocio calificado (cfr. artículo 383 Reglamento Hipotecario). Lo anterior, sin embargo, no puede llevar a desconocer los efectos jurídicos que el negocio de constitución de una sociedad produce desde el momento mismo de su celebración y, en consecuencia, en la medida en que aquellos efectos tengan sustantividad jurídico-real inmobiliaria, no podrá negarse su puntual y fiel reflejo registral (cfr. artículos 1 y 2 Ley Hipotecaria), en términos que no ofrezcan duda de la verdadera situación jurídica que se encuentran los bienes en cuestión. En efecto, otorgada la escritura pública de formalización del contrato constitutivo de la sociedad (cfr. artículo 1462 Código Civil), los bienes puestos en común salen del patrimonio personal de los aportantes para integrarse en una nueva masa patrimonial, la definición de cuyo régimen se halla en situación jurídica de provisionalidad, pues, en su día -al tiempo de la inscripción en el Registro Mercantil- se le aplicará íntegramente el legal del tipo alegado (la sociedad limitada), que entre tanto ésta goza ya de autonomía (cfr.: artículos 2 del Código de Comercio, art. 1699 en relación con el art. 1679 Código Civil, arts. 15.2 y 16.1 de la Ley de Sociedades Anónimas y art. 11.3 de la Ley de Sociedades de Responsabilidad Limitada), con un ámbito específico de responsabilidad (obligaciones derivadas de las actuaciones previstas en el artículo 15.2 Ley de Sociedades Anónimas, obligaciones inherentes a la propiedad de los bienes aportados, etc.), un régimen de gestión determinado (unanimidad, sin perjuicio de las facultades concretas que unánimemente y para el tiempo intermedio hayan sido conferidas bien a los futuros gestores de la sociedad pretendida, bien a mandatarios determinados), y con específicas previsiones liquidatorios si no se ultimase el proceso de nacimiento de la sociedad legalmente tipificada y que los otorgantes persiguen con el negocio celebrado (cfr. artículo 16.1 de la Ley de Sociedades Anónimas). Durante la pendencia de la inscripción de la escritura de constitución en el Registro Mercantil, la 
De igual modo en la Resolución de la Dirección General de Registros y del Notariado de 14 de febrero de 2001 (RJ 2002, 2154), sostiene que "de ciertos preceptos legales de reciente promulgación resulta que las sociedades mercantiles en formación e irregulares gozan de personalidad jurídica -o, al menos, de cierta personalidad-, suficiente para adquirir y poseer bienes de todas clases, así como contraer obligaciones y ejercitar acciones. La inscripción en el Registro Mercantil sólo es necesaria para que las sociedades de capital adquieran «su» especial personalidad jurídica [artículos 7.1, párrafo primero, apartados i) y f) de la Ley de Sociedades Anónimas y 11.1. i) y f) de la Ley de Sociedades de Responsabilidad Limitada] que añade la limitación de responsabilidad de los socios; y para excluir la responsabilidad solidaria de los administradores [junto a la de la propia sociedad], conforme al artículo 120 del Código de Comercio".

Se parte de una concepción amplia o estricta del período de sociedad en formación, en todo caso, debe constar la voluntad de constituir la sociedad, haberse nombrado a las personas encargas inicialmente de la administración o gestión, y haberse realizado las aportaciones que integran el capital social, en definitiva, haberse constituido un patrimonio social, ya que en los arts. 37 y 38 de la LSC, se alude a ese patrimonio como centro de imputación de relaciones jurídicas, sujeto con cierta responsabilidad como veremos.

Se reconoce cierta personalidad jurídica a la formación de una masa patrimonial por los socios, patrimonio que ya es algo distinto jurídicamente al patrimonio de los socios, adquiriendo entidad propia durante el período previo a la inscripción registral. El Tribunal Supremo ${ }^{1155}$, ya con la legislación de sociedades mercantiles anterior a la LSC,

titularidad de los bienes aportados -o la de los que en desenvolvimiento de actuaciones previstas en el artículo 15.2 de la Ley de Sociedades Anónimas, hayan sustituido a aquellos o incrementado esa masa patrimonial- no es ya una titularidad individual de los respectivos socios aportantes, sino una titularidad común a todos ellos en la situación jurídica de provisionalidad definida anteriormente y, por consecuencia, ningún obstáculo debe haber para reflejar en el Registro de la Propiedad tal modificación jurídico-real inmobiliaria, practicando la respectiva inscripción a favor de todos los constituyentes".

${ }^{1155}$ Sentencia del TS, Sala Civil, 1113/1998, de 27 de noviembre -Rec. 3350/1995-. En igual sentido la Sentencia 567/1995, de 8 de junio -Rec. 531/1992-, donde con relación a la legislación de la anterior LSA, y sobre la sociedad en formación, señalaba que "no se puede hablar en estos casos de una situación de semi-personalidad jurídica, sino más bien de personalidad controlada o condicionada a los supuestos que se dejan dichos y que no ha sido aún resuelta legalmente en forma decidida, pues el artículo 7 de la derogada Ley de Sociedades Anónimas, de aplicación a los hechos, supedita la validez de estos contratos a la aceptación ratificadora de la sociedad en el plazo de tres meses, precepto que en su rigor ha de ser objeto de interpretación flexible, adecuada a la realidad de los tiempos y dinamismo del tráfico mercantil, para no marginar frontalmente a las sociedades en formación válidamente 
ha venido declarando que, "no se puede desconocer la eficacia de las escrituras públicas de formación de sociedades, durante el período anterior a su inscripción en el Registro Mercantil, por ostentar dicho documento público plenos efectos internos entre los socios (artículos 1256 y 1257 del C.Civil) y junto a estos -ad intra-, no cabe tampoco desconocer los efectos -ad extra-, respecto a terceros que contraten con la sociedad teniéndola como tal, al conocer y admitir su existencia de hecho y jurídica y cuya personalidad resulta controlada o condicionada (Sentencia de 8 de junio de 1995)".

Teniendo ese patrimonio entidad propia en la fase de constitución societaria, cabrá derivación o exigir al mismo la responsabilidad por deudas de Seguridad Social generadas, y, en su caso a los sujetos a los que la LSC atribuya responsabilidad.

Examinemos la responsabilidad durante el período de la sociedad en formación, esto es, hasta la inscripción en el Registro Mercantil.

En los arts. 36 a 38 de la LSC se regula el régimen de responsabilidades por los actos y contratos anteriores a la inscripción de las escrituras en el Registro Mercantil, que es cuando la sociedad adquiere la personalidad jurídica plena del tipo societario elegido.

La primera regla general de responsabilidad se establece en el art. 36 de la LSC, regla que pese a su aparente sencillez, presenta problemas de aplicación ${ }^{1156}$, y muchas excepciones, como veremos. En virtud de esa regla general, "por los actos y contratos celebrados en nombre de la sociedad antes de su inscripción en el Registro Mercantil, responden solidariamente quienes los hubieren celebrado, a no ser que su eficacia hubiese quedado condicionada a la inscripción y, en su caso, a la posterior aceptación o asunción por la sociedad". De este modo si su eficacia no está condicionada a la inscripción y a la aceptación posterior de la sociedad, de esos actos responden los administradores y apoderados que los hayan concertado en nombre de la sociedad, pero no la sociedad en formación.

constituidas y que operan en el mercado en periodo anterior a su constatación registral, y así esta Sala ha tenido ocasión de tener en cuenta (Sentencia de 16 de julio de 1992), como también para admitir la ratificación tácita. Tanto el artículo $15.2^{\circ}$ de la vigente Ley de Sociedades Anónimas de 22 de diciembre de 1989, como el 11 de la reciente Ley de Sociedades de Responsabilidad Limitada, de 23 de marzo de 1995, autorizan negocios a las sociedades en formación, de los que responderá la propia sociedad con el patrimonio formado por las aportaciones de los socios.

${ }^{1156}$ GARCÍA CRUCES, J. A.: Derecho de Sociedades Mercantiles, op. cit., p. 128. 
Para FERNÁNDEZ DE LA GÁNDARA ${ }^{1157}$, en el artículo 36 LSC se establece una responsabilidad solidaria de los intervinientes, la que, "sólo quedaría excepcionada por el juego de una condición suspensiva: no incurrirán en responsabilidad cuando la eficacia de los actos y contratos celebrados se hubiere condicionado a la inscripción y, en su caso, posterior asunción de los mismos por parte de la sociedad”.

Se habla de responsabilidad de actos y contratos, sin exclusiones, exigiéndose sólo que se realicen en nombre de la sociedad ${ }^{1158}$, pudiendo ser contratos y actos de desarrollo de la actividad empresarial constitutiva del objeto social, en cuyo caso nacerán obligaciones y deudas de Seguridad Social, aunque salvo pacto en contrario esa actividad será desarrollada por el administrador social en la fase de constitución por estar autorizado para la ejecución del objeto social (art. 37.3 de la LSC).

Se contempla la responsabilidad de quien haya celebrado los actos o contratos, siendo indiferente si es administrador, apoderado o socio ${ }^{1159}$. Las personas que pueden celebrar esos actos y contratos jurídicos serán, o bien los administradores que son los representantes orgánicos de la sociedad, y en la escritura pública de constitución han de identificarse las personas que se encargan inicialmente de la administración y representación societaria (art. 22.1.e LSC), o bien representantes voluntarios (apoderados) $)^{1160}$. Esos actos y contratos, que pueden estar o no comprendidos dentro del objeto social, habrán de ser celebrados por quienes tienen el poder de representación, por los administradores -posición orgánica-, o por apoderados -relación contractual-, y que en virtud de tales títulos pueden obligar a la sociedad en cuyo nombre actúan ${ }^{1161}$.

Por estos actos y contratos responde sólo el administrador o el apoderado, o en palabras de algún autor ${ }^{1162}$ el gestor actuante que ha realizado los actos y contratos. Repárese en que no hay una responsabilidad solidaria del administrador o gestor actuante con la sociedad en formación, sino una imputación única de responsabilidad del actuante, si es una única persona, o de ser varias, existirá un imputación de responsabilidad solidaria para los actuantes, lo que tendrá efectos de cara a determinar si estamos ante una

\footnotetext{
${ }^{1157}$ FERNÁNDEZ DE LA GÁNDARA, L.: Derecho de Sociedades, edición electrónica, op. cit., p. 371. ${ }^{1158}$ GARCÍA CRUCES, J. A.: Derecho de Sociedades Mercantiles, op. cit., p. 128.

1159 VALPUESTA GASTAMINZA, E. M.: Comentarios a la Ley de Sociedades de Capital, op. cit., p. 150.

${ }^{1160}$ GARCÍA CRUCES, J. A.: Derecho de Sociedades Mercantiles, op. cit., p. 128.

${ }^{1161}$ FERNÁNDEZ DE LA GÁNDARA, L.: Derecho de Sociedades, edición electrónica, op. cit., p. 371.

1162 VALPUESTA GASTAMINZA, E. M.: Comentarios a la Ley de Sociedades de Capital, op. cit., pp. 150-154.
} 
derivación de deudas de Seguridad Social, o más propiamente ante la imputación de la deuda al único sujeto responsable, que puede estar formado por una o varias personas de haber sido varios actuantes o intervinientes.

Esta responsabilidad del gestor actuante por los actos del período previo a la adquisición de la personalidad jurídica plena, siempre que no sean aceptados posteriormente por la sociedad, se reconoce expresamente en el art. 7 de la Directiva 2017/1132, de 14 de junio DOUE, serie L 30.6.2017) sobre Aspectos del Derecho de Sociedades.

Ahora bien, esa regla general tiene una primera excepción. En virtud del art. 37.1 de la LSC, si el gestor o apoderado ha sido designado específicamente por todos los socios para la realización de esos actos y contratos, durante el período de formación responderá el patrimonio social que tuviere la sociedad, que normalmente será el formado por los socios, y de ser insuficiente responden los socios por la parte del capital no desembolsado (art. 37 apartados 1 y 2 LSC) ${ }^{1163}$. Hay autores que consideran que responde también solidariamente el gestor o apoderado ${ }^{1164}$. El mandato ha de ser otorgado por todos los socios (unanimidad), y específico, lo que implica que no sea un apoderamiento general, con vigencia limitada al período previo a la inscripción registral ${ }^{1165}$. Si el gestor o apoderado fue nombrado por todos los socios para realizar esos actos, tras la inscripción en el Registro de las escrituras dentro del plazo del año siguiente a su otorgamiento, será la sociedad la única responsable de esos actos y contratos, cesando la responsabilidad del gestor, administrador o apoderado (arts. 36, 37.1 y 38 apartados 1 y 2 LSC).

Si el gestor o apoderado no fue nombrado por todos los socios para realizar los actos y contratos del período de formación societaria, responde el gestor o apoderado y no el patrimonio social de la sociedad en formación (arts. 36 y 37 de la LSC). Si la sociedad se inscribe antes del año siguiente al otorgamiento de la escritura, aceptando dentro de los tres meses siguientes a la inscripción esos actos y contratos formalizados por el gestor o apoderado, responde la sociedad cesando la responsabilidad del gestor o apoderado actuante (arts. 37.1 y 38 apartados 1 y 2 de la LSC). Pero hasta que no se inscriba la sociedad y acepte los contratos, se mantiene la responsabilidad del gestor o

${ }^{1163}$ GARCÍA CRUCES, J. A.: Derecho de Sociedades Mercantiles, op. cit., p. 131, quien considera que la responsabilidad del socio por el capital no desembolsado es subsidiaria.

${ }^{1164}$ Para VALPUESTA GASTAMINZA, E. M.: Comentarios a la Ley de Sociedades de Capital, op. cit., pp. 152-153, responde no sólo el patrimonio social sino también el gestor por ser de aplicación los arts. 37 y 36 de la LSC.

${ }^{1165}$ GARCÍA CRUCES, J. A.: Derecho de Sociedades Mercantiles, op. cit., pp. 130-131. 
apoderado. La sociedad podrá aceptar los actos celebrados a nombre de la misma dentro de los tres meses siguientes a la inscripción en el Registro Mercantil (art. 38.1 de la LSC). VALPUESTA GASTAMINZA ${ }^{1166}$, admite que se puedan aceptar los contratos por la sociedad pasado el plazo de tres meses desde la inscripción, considerando en ese caso que el tercero contratante podría no sentirse vinculo por la ratificación extemporánea de modo, que, a su elección, podría reclamar al gestor el cumplimiento del contrato. Aceptación del contrato que será por el órgano competente, el administrador si son actos constitutivos del objeto social, o de la Junta General en otro caso $^{1167}$. Aceptación que podrá ser expresa o tácita, ya que nuestra jurisprudencia ha admitido la asunción tácita en algunas situaciones. En la STS, Sala Civil, núm. 740/2010, de 14 de noviembre -Rec. 876/2007-, admite la ratificación tácita recogiendo doctrina precedente ${ }^{1168}$ sobre la misma, al señalar: "La ratificación puede producirse de forma expresa o tácita, afirmando la Sentencia 67/2005, de 4 febrero, que respecto a la ratificación tácita la expresión más elemental de ésta es el aprovechamiento de los efectos de lo convenido en el contrato, lo que tiene una peculiar aplicación en el caso de las sociedades en las que más que de representadas procede hablar de órganos y más que de ratificación de los actos de quien han actuado como órgano, sin serlo (porque todavía no existe la persona jurídica) de aceptación por la sociedad".

En segundo lugar, otra excepción a la regla general de responsabilidad del gestor del art. 36 de la LSC, son los actos realizados por el administrador social dentro de las facultades que le confieren las escrituras para la fase anterior a la inscripción (art. 37.1 de la LSC). Salvo que la escritura disponga otra cosa, para FERNÁNDEZ DE LA GÁNDARA $^{1169}$, el poder de representación de los administradores no quedaría circunscrito al objeto social, sino a las específicas facultades conferidas en la escritura de constitución para la fase de formación societaria. Habrá de estarse a las escrituras

\footnotetext{
1166 VAlPUESTA GASTAMINZA, E. M.: Comentarios a la Ley de Sociedades de Capital, op. cit., p. 153.

1167 VALPUESTA GASTAMINZA, E. M.: Comentarios a la Ley de Sociedades de Capital, op. cit., pp. 150-153; Discrepan al considerar que la competencia es de la Junta General, GARCÍA CRUCES, J. A.: Derecho de sociedades Mercantiles, op. cit., pp. 131-132, que considera que los debe aceptar la Junta General, ya que normalmente los actos habrán sido realizados por los administradores; y FERNÁNDEZ DE LA GÁNDARA, L.: Derecho de Sociedades, edición electrónica, op. cit., p. 374, quien en este punto sigue ALONSO UREBA, A.

1168 En igual sentido las Sentencias del TS, Sala Civil, 567/1995, de 8 de junio -Rec. 531/1992-; 1113/1998; de 27 de noviembre -Rec. 3350/1995-; y 674/2007, de 14 junio _Rec. 1959/2000-, entre otras.

${ }^{1169}$ FERNÁNDEZ DE LA GÁNDARA, L.: Derecho de Sociedades, edición electrónica, op. cit., p. 373.
} 
para comprobar para qué actos está autorizado el administrador social en la fase previa a la inscripción de la sociedad.

En todo caso, se entiende ope legis, y esta es una nueva excepción a la regla del art. 36 de la LSC, que, salvo pacto en contrario en las escrituras o en los estatutos, el administrador está facultado para realizar todos los actos constitutivos del objeto social, si las operaciones sociales se inician con el otorgamiento de las escrituras (art. 37 apartado 3, en relación con el art. 24 de la LSC). En virtud de esos preceptos, si la fecha del inicio de las operaciones sociales coincide con la fecha del otorgamiento de las escrituras, se entiende que los administradores están facultados para el pleno desarrollo del objeto social y para realizar todos los actos y contratos, salvo que conste otra cosa en los estatutos o en las propias escrituras. Hasta que se inscriba la sociedad, de esos actos y contratos responde el patrimonio que tuviere la sociedad en formación que estará integrado por las aportaciones de los socios, más ingresos obtenidos de la explotación del objeto social, deducidos los gastos realizados, y de no ser suficiente ese patrimonio, subsidiariamente responden los socios por la parte del capital suscrito y no desembolsado (art. 37 apartados 1 y 2 de la LSC) ${ }^{1170}$, para VALPUESTA GASTAMINZA ${ }^{1171}$, también respondería solidariamente el administrador, ya que juega la regla general de responsabilidad del art. 36 de la LSC, esto es, la responsabilidad del que ha realizado los contratos, y porque además esa responsabilidad del gestor administrador cesa con la inscripción (art. 38.2. LSC). Una vez inscrita la sociedad en plazo legal (antes del año), cesa automáticamente la responsabilidad del patrimonio formado y de los socios, siendo responsable únicamente la sociedad (art. 38 apartados 1. y 2. LSC). Si el administrador no estuviese autorizado para realizar los actos constitutivos del objeto social, durante la fase de constitución social no respondería la sociedad con el patrimonio que tuviere, sino que sería una responsabilidad personal del mismo, al no regir la regla del art. 37, sino la regla del art. 36 de la LSC.

Con relación a las deudas del período de formación para los actos que estuviere autorizado el administrador, nos inclinamos por la primera interpretación, la que entiende que por esos actos y contratos del administrador responde la sociedad en formación con el patrimonio que tuviere, y los socios por el importe del capital no desembolsado (art. 37 de la LSC), pero no el administrador social, por tres razones. En

${ }^{1170}$ GARCÍA CRUCES, J. A.: Derecho de Sociedades Mercantiles, op. cit., p. 131.

${ }^{1171}$ VALPUESTA GASTAMINZA, E. M.: Comentarios a la Ley de Sociedades de Capital, op. cit., pp. 152 a 154. 
primer lugar, porque la regla de responsabilidad del art. 36 de la LSC se limita a los actos y contratos no incluidos en el art. 37 de la LSC, siendo la responsabilidad del art. 37 una excepción a la regla general de responsabilidad del art. 36, no un supuesto acumulativo de responsabilidades. En segundo lugar, porque los actos y contratos del art. 37 de la LSC son actos que vinculan a la sociedad en formación con su patrimonio, de modo que con la inscripción registral de las escrituras se consolida ipso iure esa vinculación jurídica, ya que la sociedad queda obligada ope legis por esos actos y contratos con la inscripción de las escrituras (art. 38.1 LSC), mientras que para que venga obligada por los del art. 36 de la LSC, se precisa su aceptación dentro de los tres meses siguientes a la inscripción (art. 38.1 LSC). En tercer lugar, porque cuando el art. 38.2 de la LSC habla del cese de responsabilidad del administrador, lo es para los actos y contratos que no sean subsumibles en el art. 37 de la LSC, como sucedería cuando en las escrituras o en los estatutos no se autoriza al administrador a realizar actos constitutivos del objeto social en la fase de constitución, ya que en ese supuesto respondería él personalmente (art. 36 LSC).

Se está reconociendo cierta personalidad a la sociedad en formación, ya que salvo pacto en contrario en las escrituras o en los estatutos sociales, el administrador está facultado para realizar toda clase de contratos para desarrollar el objeto social, entre ellos los laborales, y para cumplir con las obligaciones de Seguridad Social derivadas de los mismos (art. 37.3 LSC). Se está reconociendo la posibilidad de que, antes de completarse la plena personalidad jurídica con la inscripción, la sociedad lleve a cabo "actuaciones sociales externas, con vistas a la realización del objeto social, que entran en la competencia propia de los administradores" $" 1172$.

Al permitirse al administrador social realizar la actividad constitutiva del objeto social, para lo que se reconoce la responsabilidad del patrimonio social, se está admitiendo la existencia jurídica de la sociedad durante el proceso previo a su inscripción registral ${ }^{1173}$.

Si la sociedad puede iniciar su actividad económica, el administrador está autorizado para solicitar válidamente la inscripción de la sociedad en formación en Seguridad Social y para solicitar el alta en Seguridad Social de los trabajadores a nombre de la sociedad en formación. Al poderse iniciar la actividad sin necesitarse la previa inscripción de la escritura en el Registro Mercantil, tampoco será necesaria su 
aportación para la inscripción en Seguridad Social de la sociedad. El requisito de aportación de la certificación de la inscripción en el Registro Mercantil para la inscripción de la sociedad en Seguridad Social, impuesto en el art. 10 del RGIASS, debe interpretarse de conformidad con los arts. 24 y 37.3 de la LSC. Cuestión distinta será, que para cesen las responsabilidades del período de formación, deba aportarse en la Seguridad Social la certificación de la inscripción en el Registro Mercantil, ya que a partir de ese momento cesan retroactivamente las responsabilidades del administrador, en su caso, y del patrimonio formado por los socios, porque los arts. 38.1 y 39 de la LSC señalan que con la inscripción en el Registro Mercantil antes de que transcurra el año desde la escritura, la sociedad queda obligada por los actos y contratos formalizados en el período de formación, cesando la responsabilidad del administrador.

Una regla de cierre de las anteriores responsabilidades es que una vez inscrita la sociedad en el Registro Mercantil, cesa la responsabilidad de los gestores por los actos del art. 36 LSC, siempre y cuando la sociedad haya aceptado, dentro de los tres meses siguientes a la inscripción en el Registro Mercantil, esos actos y contratos formalizados ${ }^{1174}$. Aceptación de los actos o contratos que podrá ser expresa o tácita ${ }^{1175}$. La falta de aceptación por la sociedad de los actos del gestor del art. 36 de la LSC, invalida el contrato frente a la misma, que por esta causa no responde de los actos o contratos formalizados, ni de sus consecuencias, quedando imputadas las obligaciones que pudieran derivarse del mismo hacia el gestor o los gestores que hubiesen contratado con el tercero (Fundamento de Derecho Segundo de la Sentencia del TS, Sala de lo Civil, de 9 de septiembre de 1991 -Rec. 1837/1989- ${ }^{1176}$ ).

Cesa automáticamente la responsabilidad de los administradores, apoderados y de los socios con la inscripción registral de la sociedad -si la inscripción se produce dentro del plazo máximo de doce meses desde el otorgamiento de las escrituras-, de los actos de

${ }^{1174}$ Según el TS (Sala de lo Civil), cabe la aceptación fuera del plazo de tres meses si así lo admite el acreedor, al señalarse en la Sentencia, de 23 mayo de 1995 -Rec- 789/1992-, que en su Fundamento de Derecho Tercero, se indica que, se "subordina la validez del contrato concluido en nombre de la sociedad antes de su inscripción en el Registro Mercantil a este requisito y a la aceptación por la Sociedad dentro del plazo de tres meses, pero no es menos cierto que no impide una aceptación (en rigor, ratificación) pasado dicho plazo si así lo admite la otra parte (...)».

1175 En igual sentido las Sentencias del TS, Sala Civil, 567/1995, de 8 de junio -Rec. 531/1992-; 14 de junio de 2007; 674/2007, de 14 junio -Aranzadi RJ 3652/2007-; 740/2010, de 24 de noviembre, entre otras.

${ }^{1176}$ En igual sentido, entre otras, Sentencias del TS, Sala Civil, de 9 octubre 1990 -Aranzadi RJ 7590/1990-; de 4 enero 1989 -Aranzadi RJ 93/1989-; 6 de julio de 1977 -RJ 3262/1977-; 4 de enero de 1989 -RJ 93/1989-; y 31 de enero de 1990 -RJ 110/1990-. 
los que eran responsables en el periodo de formación los apoderados, gestores o administradores previstos en el art. 37, ya que tras la inscripción responde de esos actos la sociedad de capital (art. 38 apartados 1 y 2 de la LSC). Los actos del art. 37, son los siguientes, los indispensables para la inscripción de la sociedad, los realizados por los administradores dentro de las facultades que les confiere las escrituras para la fase de formación, y los actos realizados por tercera persona en virtud de mandato específico de todos los socios.

Si el patrimonio social tras la inscripción, deducidos los gastos indispensables para la práctica de la misma, fuese inferior al capital social, los socios están obligados a cubrir la diferencia, ya que no puede constituirse la sociedad con capital inferior al mínimo legal (arts. 4 y 38.3 de la LSC). Es la llamada responsabilidad diferencial. Responsabilidad que sólo puede reclamar la sociedad, pero no los acreedores, quienes tendrían sólo una legitimación subsidiaria para exigir a los socios esas aportaciones suplementarias al patrimonio social, en virtud de la acción subrogatoria del art. 1111 del Código Civil ${ }^{1177}$. Para FERNÁNDEZ DE LA GÁNDARA ${ }^{1178}$, esta responsabilidad de los socios no podrían exigirla los acreedores, ya que "los terceros no tienen acción directa frente a los socios sino frente a la sociedad, que a su vez ostentaría un derecho de crédito frente a los socios por el montante de las aportaciones complementarias adeudadas en proporción al capital suscrito por cada uno de ellos”.

Si la sociedad en formación no se llega a inscribir en el Registro Mercantil dentro del año siguiente a la constitución, estamos ante una sociedad irregular, aplicándose las reglas previstas para esa situación.

Un supuesto distinto es el previsto en el art. 4 bis de la $\operatorname{LSC}^{1179}$, que regula las sociedades de responsabilidad limitada en régimen de formación sucesiva. Ese precepto permite constituir una sociedad de responsabilidad limitada con un capital social inferior al mínimo legal de 3.000 euros, sociedad que se habrá inscrito en el Registro Mercantil teniendo plena personalidad jurídica (art. 33 LSC). No nos encontramos ante una sociedad en formación, sino ante una sociedad íntegramente constituida, con plena capacidad y personalidad jurídica. Por el contrario, en la sociedad en formación no estamos ante una sociedad íntegramente constituida, ya que no ha llegado a adquirir su

${ }^{1177}$ GARCÍA CRUCES, J. A.: Derecho de Sociedades Mercantiles, op. cit., p. 133.

${ }^{1178}$ FERNÁNDEZ DE LA GÁNDARA, L.: Derecho de Sociedades, edición electrónica, op. cit., p. 373.

1179 Precepto introducido por la Ley 14/2013, de 27 de septiembre, de apoyo a los emprendedores y su internacionalización. 
plena personalidad jurídica. Teniendo plena personalidad jurídica la sociedad responde ante terceros con su patrimonio social, por lo que las deudas de Seguridad Social son exigibles sólo a la sociedad. Ello, no obstante, se imponen una serie de especialidades en su régimen jurídico. Entre ellas, la establecida en el art. 4 bis, apartado 2 de la LSC, en virtud de la cual, hasta que la sociedad no alcance el capital mínimo legal de 3.000 euros, en caso de tener que disolverse, si el patrimonio social existente en ese momento fuere insuficiente para el pago de las obligaciones o deudas sociales, responden de modo solidario los socios y los administradores para desembolsar el importe necesario para completar el capital mínimo legal de 3.000 euros. No es una responsabilidad por deudas, sino una responsabilidad para desembolsar el importe íntegro del capital social mínimo legal, que se hará efectiva por el liquidador en el proceso de liquidación, por lo que no es supuesto de derivación de responsabilidad en el procedimiento de recaudación de Seguridad Social, es un supuesto próximo a la responsabilidad del socio ante el liquidador para, en el período de liquidación, ingresar en el patrimonio social el importe de las acciones sociales pendientes de desembolsar (art. 385.2 de la LSC). No se olvide que el período de liquidación tiene como finalidad cobrar los créditos sociales, realizar bienes y derechos para pagar las deudas sociales, no pudiendo hasta que se hayan pagado éstas, o consignado su importe, repartir a los socios la cuota de liquidación (arts. 384, 385, 387, 391 y 394 LSC), y que si no se pueden pagar todas las deudas el liquidador debe solicitar el concurso de acreedores. Si eso es aplicable a los socios, al imponer el art. 4 bis una responsabilidad solidaria al administrador con los socios para el desembolso del capital social mínimo, cabría pensar que podría derivarse la deuda al administrador, lo que no estimamos procedente por ser una responsabilidad para completar el capital social en el período de liquidación, no para pagar deudas a terceros.

\section{Derivación administrativa de responsabilidad.}

En primer lugar, vamos a analizar la responsabilidad en las deudas de Seguridad Social del gestor, apoderado o persona actuante al amparo del art. 36 de la LSC, cuando no ha sido nombrado por todos los socios para realizar esos contratos en el período de formación, y cuando la eficacia de esos actos no quedó condicionada a la inscripción de la sociedad y a su posterior aceptación.

Regirá el mismo régimen de responsabilidad cuando el administrador no estuviere autorizado para realizar la actividad social durante el período de formación (art. 37 LSC a contrario sensu), para iniciar el objeto social y la actividad laboral, si en los 
estatutos sociales o en las escrituras no se haya autorizado el inicio de la actividad hasta que la sociedad no se haya inscrito en el Registro (art. 24 LSC).

Si la sociedad acepta estos contratos dentro de los tres meses siguientes a la inscripción en el Registro Mercantil, cesa la responsabilidad de la persona actuante y asume la responsabilidad la sociedad, con lo que ya no cabría exigir el pago de las deudas de Seguridad Social al gestor actuante o administrador no autorizado (art. 38.1 LSC).

Hasta la inscripción y aceptación de esos actos y contratos responde la persona actuante, por lo que, prima facie, las deudas de Seguridad Social serían exigibles al mismo, pero teniendo en cuenta que de aceptar la sociedad esos contratos una vez inscrita, responde la misma y cesa la responsabilidad del gestor, esto plantea un problema de coordinación de la reclamación al gestor-administrador o la sociedad, en función del tiempo que se tarde en inscribirse la sociedad en el Registro Mercantil.

Según Criterio Técnico 21/1999, de la DGITSS, en los supuestos en que la legislación mercantil establece una responsabilidad solidaria del administrador social o gestor por las deudas de la sociedad en formación del período anterior a la inscripción en el Registro Mercantil de la sociedad, la ITSS podrá proceder a la derivación administrativa de deudas, mediante la extensión de un acta de liquidación. Criterio Técnico declarado vigente por el Criterio Técnico de revisión y vigencia de criterios técnicos de fecha de 26.2.2013, que ha de ser reinterpretado a la luz del actual Criterio Técnico 89/2011, ya que fue redactado cuando no se había regulado legalmente la competencia para derivar deudas de Seguridad Social -que tuvo efecto para reclamarse deudas desde el 1.1.2004 como veremos en el Capítulo VI-, competencia prevista actualmente en el art. 18.3 del TRLGSS.

Ahora bien, si una vez inscritas las escrituras públicas de constitución en el Registro Mercantil, la sociedad no acepta los contratos formalizados (arts. 36 y 37 LSC), de haber iniciado el administrador no autorizado o el gestor a nombre de la sociedad en formación la actividad laboral con trabajadores por cuenta ajena, sin haber sido designado el tercero gestor expresamente para ello por todos los socios, en este caso, las deudas de Seguridad Social sólo podrán ser exigida al gestor material o al administrador no autorizado, a quien ha realizado y organizado la actividad laboral (contratando trabajadores por cuenta de la futura sociedad), ya que responderá él personalmente, no 
respondiendo el patrimonio social en formación (arts. 36, 37 a contrario sensu y 38.1 y .2 de la LSC).

La persona física o jurídica actuante -sea gestor, apoderado, o el administrador social que no estuviese autorizado para realizar esos actos en las escrituras o en los estatutos-, sería el verdadero responsable directo de las deudas de Seguridad Social, una vez inscrita la sociedad si no acepta esos contratos.

Si se inició la actividad laboral con trabajadores y la sociedad tras la inscripción continúa con las relaciones laborales, a partir de los tres meses siguientes a esa inscripción, estaríamos ante una aceptación tácita de esos contratos de trabajo, y consiguientemente, estaría aceptando todos sus efectos jurídicos, entre ellos, la consolidación de las altas de los trabajadores y las obligaciones pertinentes, especialmente en materia de deudas por cotizaciones a la Seguridad Social que se hubieren devengado desde el inicio de la actividad laboral, con lo que cesan las responsabilidades de las personas del período de formación.

Si dentro de los tres meses la sociedad no asume la continuidad de las relaciones laborales, y no acepta ninguno de esos actos realizados por el administrador no autorizado o por el gestor, sin que éste estuviere autorizado para concertar esos actos o contratos, responde el administrador o el gestor actuante como único sujeto responsable. Otra cuestión sería determinar si en ese caso responde también la sociedad y la masa patrimonial que tuviere la sociedad. Entendemos que no por dos razones. En primer lugar, porque para que cese la responsabilidad del gestor actuante o administrador no autorizado, es preciso que la sociedad se haya inscrito y acepte los contratos celebrados (art. 38.1 de la LSC). Y, en segundo lugar, porque los actos y contratos por los que responde el patrimonio formado en la etapa de constitución societaria son sólo y exclusivamente los del art. 37 de la LSC, es decir: $1^{\circ}$ los realizados por los administradores dentro de las facultades que le otorgue la escritura para esta fase de constitución, incluyendo todos los actos y contratos propios del objeto social, salvo que constase previsión en contra en las escrituras o en los estatutos sociales; $2^{\circ} \operatorname{los}$ actos imprescindibles para la inscripción (que no sería el caso); y $3^{\circ}$ los actos realizados en virtud de un mandato específico conferido por todos los socios.

Si la persona actuante interviene en nombre de la sociedad sin mandato específico de todos los socios, y de ser el administrador sin estar autorizado para realizar esos actos y 
contratos porque en las escrituras o en los estatutos se ha excluido expresamente que se pudieran iniciar operaciones constitutivas del objeto y de la actividad social durante el período comprendido entre la constitución de la sociedad en escritura pública y su inscripción en el Registro Mercantil, la responsabilidad será únicamente del gestor, apoderado o administrador.

A efectos de deudas de Seguridad Social se pudo haber solicitado la inscripción en Seguridad Social de la sociedad en formación, ya que de conformidad con el art. 24 de la LSC, las operaciones constitutivas del objeto social se inician en la fecha del otorgamiento de las escrituras, salvo disposición en contrario de los estatutos. Es por ello que ya no sería necesaria aportar la certificación registral para la inscripción en Seguridad Social, pese a lo establecido en el art. 11.2.2. ${ }^{\circ}$ del Real Decreto 84/1996, de 26 de enero -RGIASS-, otra cosa es que deba aportarse con posterioridad para acreditar la adquisición de la plena personalidad jurídica y consolidar la inscripción a nombre de la persona jurídica constituida. De haberse solicitado la inscripción en Seguridad Social de la sociedad en formación, y una vez la mercantil se inscriba en el Registro Mercantil sin aceptar esos contratos, la inscripción en Seguridad Social formalizada por el gestor o apoderado no tendría efectos jurídicos a nombre de la sociedad, ya que no sería ésta la responsable de esos contratos de trabajo (arts. 36, 37 y 38.1 LSC).

En ese caso, el responsable de los actos de encuadramiento y de ingresar las deudas de Seguridad Social devengadas -cotizaciones o prestaciones-, sería del gestor, apoderado o administrador no autorizado (art. 36 de la LSC), por ser el verdadero empresario, y no la sociedad, con lo que más que ante una derivación de deuda nos encontraremos ante la imputación de responsabilidad al verdadero sujeto responsable, a quien ha organizado la actividad laboral, a quien tiene la condición de empresario en Seguridad Social (art. 1 del TRLET y arts. 18.4 y 138.3 del TRLGSS). En puridad, no sería un supuesto de derivación de responsabilidad solidaria a un tercero conjuntamente con el empresario responsable directo (sociedad en formación), sino que estaremos ante la determinación o imputación de la deuda al único sujeto responsable, que puede ser unipersonal o pluripersonal, persona física, jurídica, o entes sin personalidad jurídica (art. 1.2 del TRLET). 
Al tener que determinarse al verdadero sujeto responsable o empleador, la TGSS ${ }^{1180}$ deberá promover la revisión de oficio de la inscripción de la empresa y de las altas en Seguridad Social de los trabajadores para la sociedad, que podrá hacer a iniciativa de la actuación de la ITSS, para imputar la responsabilidad de esos actos y de las deudas correspondientes al gestor, apoderado o administrador no autorizado actuante.

Nos hallamos ante la responsabilidad únicamente de la persona actuante, que obligará a revisar de oficio la previa resolución del alta en Seguridad Social de los trabajadores y la inscripción de la empresa al amparo de los arts. 54 a 56 del RGIASS ${ }^{1181}$, revisión que sólo podría hacerse en vía administrativa cuando, en caso de estar ante actos declarativos de derechos, esa revisión sea debida a omisiones o inexactitudes en las declaraciones al formalizarse los actos objeto de revisión, ya que de no estar ante omisiones o inexactitudes habría de acudirse ante la jurisdicción para la revisión de los actos declarativos de derechos ${ }^{1182}$.

${ }^{1180}$ Art. 54 a 57 del RGIASS y Sentencias del TS, Sala Contencioso-Administrativa, de 8 de julio de 2014 -Rec. 3416/2012-; 2213/2016, de 11 de octubre -Rec. 673/2015-; y 74/2019, de 29 de enero -Rec. 2972/2016-.

1181 "Artículo 55. Facultades de revisión: límites. Rectificación de errores. 1. Cuando la inscripción, protección de las contingencias de accidentes de trabajo y enfermedades profesionales, tarifación, cobertura de la prestación por incapacidad temporal, afiliación, altas, bajas y variaciones obrantes en los sistemas de documentación de la Tesorería General de la Seguridad Social no sean conformes con lo establecido en las leyes, en este Reglamento y demás disposiciones complementarias, si así resultare del ejercicio de sus facultades de control o por cualquier otra circunstancia, dicha Tesorería General podrá adoptar las medidas y realizar los actos necesarios para su adecuación a las normas establecidas, incluida la revisión de oficio de sus propios actos en la forma y con el alcance previstos en este artículo y los siguientes. 2. Las facultades de la Tesorería General de la Seguridad Social para revisar, de oficio o a instancia de parte, sus propios actos de inscripción, formalización de la protección frente a riesgos profesionales, cobertura de la prestación económica por incapacidad temporal, tarifación, afiliación, altas, bajas y variaciones de datos no podrán afectar a los actos declarativos de Derechos, en perjuicio de los beneficiarios de los mismos, salvo que se trate de revisión motivada por la constatación de omisiones o inexactitudes en las solicitudes y demás declaraciones del beneficiario.3. La Tesorería General de la Seguridad Social podrá rectificar, en cualquier momento, los errores materiales o de hecho y los aritméticos de los actos regulados en este Reglamento".

1182 Sentencias del TS, Sala Contencioso-Administrativa, de 8 de julio de 2014 -Rec. 3416/2012-; 2213/2016, de 11 de octubre -Rec. 673/2015-; y 74/2019, de 29 de enero -Rec. 2972/2016-. De conformidad con esas sentencias del TS, para los actos declarativos de Derechos, como ocurre cuando se deja sin efecto un alta en un Régimen de Seguridad Social por haberse simulado una relación laboral inexistente, o se procede a un cambio de encuadramiento -del Régimen del Mar al Régimen General de la Seguridad Social, o del Régimen General al Régimen especial de Trabajadores Autónomos-, o anular un alta en el Sistema Especial de Trabajadores Agrarios por cuenta propia, al reconocer cada uno de esos regímenes ventajas para los trabajadores, no puede la TGSS revisar de oficio esos actos declarativos, sino que en virtud de lo prescrito en el art. 55 del RGAISS y art. 146 LRJS, debe presentar demanda judicial de oficio de revisión de sus actos declarativos de Derecho, ya que en otro caso la resolución administrativa de revisión es nula de pleno Derecho. Sólo puede revisarse en vía administrativa esos actos declarativos de Derecho, cuando se trata de rectificar errores materiales, o que el alta indebida haya sido debida a inexactitudes en las declaraciones presentadas en la solicitud inicial. 
De tener la inscripción de empresa, las altas y bajas en Seguridad Social la condición de actos declarativos de derechos, la TGSS podría revisar en vía administrativa esos actos, procediendo a inscribir como empresa al gestor o administrador no autorizado y a tramitar las altas de oficio de los trabajadores para el nuevo sujeto responsable, si con la inscripción de la sociedad y las altas de los trabajadores se facilitaron datos inexactos, se ocultaron datos con relevancia jurídica o finalmente si con posterioridad constasen hechos nuevos -como sería el supuesto examinado- (artículos 146 de la LRJS y 55 del RGIASS). En esos supuestos, sería competencia de la ITSS solicitar al gestor o administrador, mediante requerimiento de cuotas o acta de liquidación, las cotizaciones en Seguridad Social devengadas por los trabajadores, al ser un supuesto de falta de cotización por faltas de alta en Seguridad Social (art 34.1.a) del TRLGSS). Una vez ingresadas esas cotizaciones, fruto del requerimiento o del acta de liquidación, las altas de oficio retrotraen sus efectos a la fecha de inicio de la prestación laboral (art. 35.1.2. ${ }^{\circ}$ del RGIASS).

Se ha admitido que las altas en Seguridad Social y los cambios de encuadramiento son actos declarativos de derechos en la reciente jurisprudencia ${ }^{1183}$. Para la nueva doctrina jurisprudencial, a la hora de determinar cuál es el procedimiento (administrativo o jurisdiccional) a seguir para la revisión de esos actos administrativos, lo decisivo es si se trata de un acto declarativo de derechos o no, y la respuesta depende "del contenido de cada concreto acto administrativo $\mathrm{y}$, en particular, de que efectivamente amplíe el

${ }^{1183}$ En los Fundamentos de Derecho $4^{\circ}$ de la Sentencia 74/2019, de 19 de enero, reproduciendo la doctrina sentada en las Sentencias de 8 de julio de 2014 -Rec. 3416/2012-; 2213/2016, de 11 de octubre -Rec. 673/2015-, se ha afirmado que, "La Administración sostuvo que los actos de encuadramiento no son actos declarativos de Derechos, sino actos instrumentales constitutivos de una relación jurídica, en el desenvolvimiento de la cual se adquirirán Derechos y obligaciones por las partes de la misma, de lo que dedujo la procedencia del procedimiento de revisión de oficio regulado en el artículo 56 del Reglamento de Inscripción, Afiliación, Altas y Bajas. Frente a tal planteamiento la jurisprudencia que se está glosando sostiene respecto de los llamados actos de "encuadramiento" que al margen de cómo los órganos jurisdiccionales del orden social interpreten y apliquen la legislación sobre Seguridad Social, en este orden contencioso-administrativo hay que estar indefectiblemente al significado que los conceptos tienen en el Derecho Administrativo en el que la noción de "acto declarativo de Derechos" o, en una terminología más moderna, su perfecto equivalente de "actos favorables" tienen un significado muy preciso y profundamente arraigado. Un acto declarativo de Derechos o acto favorable es todo aquel acto administrativo -cualquiera que sea su naturaleza a otros efectos- del que su destinatario obtiene Derechos, facultades u otras situaciones jurídicas ventajosas. Todo acto de la Seguridad Social o es declarativo de Derechos o no lo es: tertium non datur. Que determinados actos de la Seguridad Social deban ser caracterizados como "actos de encuadramiento", teniendo una naturaleza constitutiva, seguramente será relevante en determinados supuestos; pero, a la hora de determinar cuál es el procedimiento (administrativo o jurisdiccional) a seguir para su revisión, lo decisivo en el orden contencioso-administrativo es si se trata de un acto declarativo de Derechos o no". Y concluye esta jurisprudencia que, "ni que decir tiene que la respuesta a este interrogante depende del contenido de cada concreto acto administrativo y, en particular, de que efectivamente amplíe el patrimonio o la esfera jurídica de su destinatario". 
patrimonio o la esfera jurídica de su destinatario". Para esta doctrina jurisprudencial, los actos de encuadramiento son actos declarativos de derecho, no meros actos instrumentales de los que podrán posteriormente surgir derechos, porque el encuadramiento en uno u otro régimen de Seguridad Social no otorga a los incluidos en ellos los mismos derechos (para las situaciones de revisión por cambios de encuadramiento), y por otro lado, porque la mera anulación de una situación de alta en Seguridad Social priva de los derechos contemplados en el régimen correspondiente de la Seguridad Social. Es por ello que no pueden revisar de oficio en vía administrativa los actos de encuadramiento, o dejarse sin efecto altas en el sistema de Seguridad Social, sino que ha de acudirse a la revisión en vía judicial por aplicación del art. 146 de la LRJS $^{1184}$, salvo que existan omisiones, inexactitudes o hechos nuevos (la Sala Contencioso-Administrativa aplica un precepto de la Jurisdicción Social, y remite a la revisión ante la Jurisdicción Social, cuando los actos de encuadramientos, altas, bajas en Seguridad Social, son impugnables ante la Jurisdicción Contencioso-Administrativa, de conformidad con el art. 3.f) de la LRJS, art. 63 del RGIASS y arts. 1 y 2 de la Ley 29/1998, de 13 de julio, Reguladora de la Jurisdicción Contencioso-Administrativa, LJCA- ${ }^{1185}$ ).

Para esa jurisprudencia, "cuando se produce la revisión de estos actos de afiliación y alta, se está afectando a un acto, ciertamente previo a una eventual prestación, que por

${ }^{1184}$ Por el contrario, el TS, Sala Social, en Sentencia de 22 de mayo de 2020 -rcud. 54/2018-, declara que la TGSS pueda revisar de oficio en vía administrativa la inscripción de la empresa y las altas en Seguridad Social, anulándolas, cuando se ejerza una actividad ilegal o para la que se exija una preceptiva autorización administrativa careciendo la empresa de la misma, citando Sentencias anteriores de esa misma Sala de fechas 22 mayo de 2001 -rcud. 4093/2000-; 29 octubre 2001 -rcud. 146/2001-; 13 mayo 2002 -rcud. 2568/2001-; 16 de octubre de 2012 -rcud. 4343/2010-; y 17 octubre 2012 -rcud. 4339/2010-, en función de su actividad de control de ajuste de los actos de encuadramiento a la legalidad.

De igual modo se declaró por la misma Sala Social del TS, que las variaciones por la TGSS de las altas en Seguridad Social en función de sus competencias de control de la legalidad, son actos instrumentales y no actos declarativos de Derechos (Sentencias de 19 de marzo de 2001 -rcud. 3095/2000-; 16 de junio de 2003 -rcud. 2835/2001-; 18 de noviembre de 2004 (R. 5193/2003); 3 de diciembre de 2004 (R. 6052/2003); 25 de enero de 2005 -rcud. 5515/2003-); 30 de septiembre de 2005 -rcud. 3824/2004-; y 22 de noviembre de 2006 -rcud. 2792/2001-), al considerar que modificar de oficio un alta del RGSS a otro régimen distinto no es un acto declarativo de Derechos, sino que no son actos consecuencia inmediata del acto administrativo de control, al señalar que "es evidente que estos actos declarativos de Derecho, a que se contrae la excepción, no pueden referirse a las consecuencias legales inherentes a tales variaciones, que no son actos sino consecuencia inmediata del acto administrativo. De otra manera quedaría sin efectividad la afirmación que realiza el precepto de poder practicarse de oficio tales cambios".

No obstante, señalar que prima la jurisprudencia de la Sala funcionalmente competente para conocer de los actos administrativos sobre encuadramientos, altas, bajas en Seguridad Social, correspondiendo esa competencia a la Sala Contencioso-Administrativa.

${ }^{1185}$ BOE del 14.07.1998. 
sí constituye un título jurídico para alcanzar otros derechos, y desde luego, ya de por sí otorga unos efectos favorables para la persona afectada, máxime en este caso donde no se trata de un simple acto de cambio de encuadramiento, sino que se produce la revisión de un acto de afiliación y alta en el Sistema Especial de Seguridad Social de trabajadores por cuenta propia agrarios, de manera que la trabajadora por cuenta propia deja de estar protegida por el sistema de Seguridad Social (...)"1186.

Actos declarativos de derechos en Seguridad Social no serían sólo los que declaren el derecho a una prestación cuando acaezca el hecho causante, sino que para HERRERA CUEVAS $^{1187}$ pueden tener esa consideración los actos de encuadramiento en Seguridad Social. Señala que los actos de encuadramiento son actos de gravamen en orden a la obligación de cotización, y declarativos de derechos en cuanto conllevan la inclusión en el sistema protegible de la Seguridad Social, de modo que la revisión del acto de encuadramiento, de las altas en Seguridad Social, pueden no lesionar un derecho declarado a una prestación, pero sin embargo, sí "lesionará el derecho a la condición preexistente de asegurado". Para este autor, citando la STS 24 de marzo de 1995 (sic) "el acto de encuadramiento no es un acuse de recibo de la declaración de voluntad del administrado, sino un acto administrativo de constitución de una relación jurídica que supone para el administrado, junto con una serie de obligaciones, un derecho subjetivo público actual”.

En cambio, para DESDENTADO BONETE ${ }^{1188}$, los actos de encuadramiento no serían constitutivos, carácter que se aprecia con más intensidad en materia de relación jurídica de cotización, ya que, aunque falte la resolución administrativa de reconocimiento de la situación de alta en Seguridad Social, ello no exime de la obligación de cotizar a la empresa, ya que ésta nace por la prestación material de servicios laborales. Según

${ }^{1186}$ Fundamento de Derecho Octavo de la Sentencia 74/2019, de 29 de diciembre, recogiendo la doctrina de las Sentencias de 8 de julio de 2014 -Rec. 3416/2012-; y 2213/2016, de 11 de octubre -Rec. 673/2015-.

1187 HERRERA CUEVAS, E. J.: "La autotutela administrativa respecto de los actos de encuadramiento", Actualidad Laboral, Sección Doctrina, 1999, Ref. XII, pág. 189, Tomo 1, La Ley, edición digital, es.ponton.uva.es/Content/Documento.aspx?params, pp. 8-9.

https://laleydigital-laleynext-

1188 DESDENTADO BONETE, A.: "Responsabilidades por el incumplimiento de las obligaciones en materia de actos de encuadramiento en la Seguridad Social”, op. cit., edición digital, pp. 4-7 y 14 de 24 , al señalar que "los actos de encuadramiento carecen de eficacia constitutiva sobre las relaciones de cotización y protección. Son obligaciones administrativas de información, que producen actos administrativos de constancia o aceptación, y su incumplimiento se configura como una infracción sancionable administrativamente. Esta conclusión es bastante clara con respecto a la relación de cotización”, y que en materia de acción protectora plantea mayores problemas. 
MERCADER UGUINA ${ }^{1189}$, "ha sido criterio comúnmente aceptado que los actos de afiliación, altas y bajas en Seguridad Social, no son actos declarativos de derechos sino, en todo caso, actos administrativos que generan expectativas de derechos, en particular las prestaciones", y que "por ser actos instrumentales han quedado excluidos del ámbito de aplicación del art. 146 de la LRJS”.

Partiendo de esa jurisprudencia, hemos de precisar dos cuestiones, por un lado, que al estar ante un hecho nuevo que no constaba en el momento de practicarse la inscripción inicial de la empresa y de las altas iniciales de los trabajadores, puede caber la revisión de oficio en vía administrativa de la inscripción y de las altas, aunque éstos sean considerados actos declarativos de derechos (arts. 55.2 y 56.1 del RGIASS). En segundo lugar, que, con esas variaciones, la TGSS estaría modificando actos administrativos para ajustarlos a la legalidad vigente ante el conocimiento de hechos nuevos, ejercitando sus competencias de control y de ajuste o acomodo a la legalidad (arts. 54 y 55 del RGIASS).

En el supuesto de imputación de responsabilidad al gestor como auténtico empleador y único sujeto responsable, ante la concurrencia de un hecho nuevo -que la sociedad en formación no ha aceptado los contratos de trabajo tras su inscripción en el Registro Mercantil-, no estamos anulando las altas en Seguridad Social de los trabajadores para excluirlos del sistema, ni efectuando cambios de encuadramiento entre regímenes o sistemas especiales de Seguridad Social distintos, que eran los actos que motivaron esa nueva jurisprudencia de la Sala Contencioso-Administrativa, por lo que no se verán afectados los derechos de los trabajadores que continúan incluidos en el mismo régimen de la Seguridad Social, y en su caso en el mismo sistema especial ${ }^{1190}$. Repárese que

${ }^{1189}$ MERCADER UGUINA, J. R.: Los Procedimientos Administrativos en materia de Seguridad Social, Aranzadi Thomson Reuters, 2017, p. 278.

${ }^{1190}$ En las Sentencias del TS, Sala Contencioso-Administrativa, de 8 de julio de 2014 -Rec. 3416/2012-; 2213/2016, de 11 de octubre -Rec. 673/2015-; y 74/2019, de 29 de enero -Rec. 2972/2016-, se indica que, frente al argumento de la Seguridad Social, de que sólo se exceptuaba de revisión los actos cuando afecten a prestaciones a los beneficiarios de la Seguridad Social en perjuicio de los mismos partiendo de la diferencia entre actos de afiliación y alta, y reconocimiento de prestación, al amparo de los arts. 6 , 7 y 9 del Real Decreto 84/1996,el Tribunal Supremo en esas Sentencias, señala que "es que precisamente el contenido de dichos preceptos abona la tesis sostenida en la sentencia recurrida y en la jurisprudencia en la que se sustenta", pues el art. 7.1 del RD 84/1996 atribuye al acto de alta el reconocimiento "a la persona, que inicia una actividad [...] su condición de comprendida en el campo de aplicación del Régimen de la Seguridad Social [...] con los Derechos y obligaciones correspondientes", con lo que queda reafirmado el carácter dual del acto de alta, que no por implicar obligaciones, deja de tener un contenido favorable para el afiliado en situación de alta. Y es que, como dice el art. 6.2 del RD 84/1996, "la afiliación al sistema de la Seguridad Social, por sí sola o en unión de otros requisitos o presupuestos, constituirá título jurídico para la adquisición de Derechos y el 
según esas sentencias para determinar si el acto es o no declarativo de derechos "la respuesta a este interrogante depende del contenido de cada concreto acto administrativo y, en particular, de que efectivamente amplíe el patrimonio o la esfera jurídica de su destinatario”. Sólo cabría plantearse si se estarían afectando los derechos o la esfera jurídica de los trabajadores si no se reconocen efectos retroactivos a las nuevas altas en Seguridad Social, cuando se tramiten las bajas en la sociedad en formación y simultáneamente las altas para el gestor. En el art. 60.2 del RGIASS, se otorga a la TGSS amplio margen de maniobra al determinar los efectos de los cambios de encuadramiento, por lo que con carácter general la TGSS procede a tramitar las nuevas altas y las bajas indebidas con carácter simultáneo para no causar perjuicio a los trabajadores ${ }^{1191}$, de modo que serían válidas las altas y cotizaciones efectuadas con

nacimiento de obligaciones y condicionará la aplicación de las normas que regulan dicho sistema". Por su parte, el art. 9 del RD 1984/1996 dispone, en concordancia con el anterior que "siempre que se hayan cumplido los requisitos generales y específicos establecidos, la afiliación al sistema de la Seguridad Social y el alta en el Régimen correspondiente producirán los Derechos y obligaciones que, para dichas situaciones, se establecen en la Ley General de la Seguridad Social y en las normas reguladoras de los distintos Regímenes de la misma, así como en el presente Reglamento y en las demás disposiciones complementarias. Por tanto, cuando se produce la revisión de estos actos de afiliación y alta, se está afectando a un acto, ciertamente previo a una eventual prestación, pero que por sí constituye un título jurídico para alcanzar otros Derechos, y desde luego, ya de por sí otorga unos efectos favorables para la persona afectada, máxime en este caso donde no se trata de un simple acto de cambio de encuadramiento, sino que se produce la revisión de un acto de afiliación y alta en el Sistema Especial de Seguridad Social de trabajadores por cuenta propia agrarios, de manera que la trabajadora por cuenta propia deja de estar protegida por el sistema de Seguridad Social por virtud de este sistema especial (S.E.T.A.) (Fundamento de Derecho Octavo de la Sentencia 74/2019, de 29 de diciembre, recogiendo la doctrina de las Sentencias de 8 de julio de 2014 -Rec. 3416/2012-; y 2213/2016, de 11 de octubre -Rec. 673/2015-).

${ }^{1191}$ En ese sentido la Consulta de 26 de octubre de 2010 de la Dirección General de la ITSS sobre "Encuadramiento. Efectos de las altas indebidas y criterio desigual aplicado, con base en una interpretación restrictiva del artículo 60 del RD 84/1996, de 26 de enero". Ref. La Ley 2800/2010, publicada en el Foro del Conocimiento de la ITSS, consulta que Recoge el criterio de la Subdirección General de Ordenación e Impugnaciones de la TGSS.

En esa consulta se señala "Para el supuesto de hecho en el que no haya existido una actuación de la Inspección, el criterio impartido con carácter general, y sin perjuicio de atender a las circunstancias concretas que concurran en cada caso, es que en aquellos supuestos en que se aprecie un encuadramiento indebido en un Régimen del sistema de Seguridad Social, pero debido en otro Régimen, sin que tal hecho constituya una infracción manifiesta del ordenamiento jurídico, dada la ausencia de un expediente sancionador, y sin que la Inspección de Trabajo y Seguridad Social haya procedido a la incoación de la correspondiente acta de liquidación, no se considera necesario ni conveniente retrotraer la baja en el Régimen de encuadramiento indebido al momento del alta inicial, ni, tampoco, coherente retrotraer hasta dicho momento los efectos del alta en el Régimen debido, al no existir constancia de una actuación fraudulenta u omisiva que determine una conducta infractora que diera lugar a aplicar efectos retroactivos, ya que si la Tesorería General tuviera indicios de una conducta de este carácter lo pondría en conocimiento de la Inspección de Trabajo y Seguridad Social a los efectos procedentes, criterio, además, acorde con la doctrina sentada en las Sentencias del Tribunal Supremo de 4 de junio de 1996, y otras posteriores, como la de 25 de julio de 2001 o, la de 10 de junio de 2003, dictada en Recurso de Casación en Interés de Ley, donde al Alto Tribunal declara que el alta en el Régimen Especial de Trabajadores Autónomo, y correlativa baja en el Régimen General, practicada de oficio por la Tesorería General de la Seguridad Social a los socios y administradores de sociedades mercantiles, no tiene efectos retroactivos". 
anterioridad a la resolución de cambio de encuadramiento, salvo que concurran hechos fraudulentos o incumplimientos flagrantes del ordenamiento.

En nuestro supuesto, estaremos ante nuevas altas de los trabajadores para un sujeto responsable distinto, sin cambio de régimen de Seguridad Social, y por un hecho nuevo que podría permitir la modificación de oficio por la TGSS de las anteriores altas de los trabajadores y la inscripción de la empresa en Seguridad Social, aunque sean actos declarativos de derechos ${ }^{1192}$, al tener la potestad de corregir los datos inexactos. Nos encontramos ante la baja en un código de cuenta de la sociedad en formación y el alta en otro a nombre del administrador social, que tiene su fundamento en una disposición legal, en el arts. 36 y 38 de la LSC, en relación con el art. 1.2 del TRLET, arts. 18.4, 136 y ss del TRLGSS, que obliga a tramitar las altas en Seguridad Social a nombre del gestor o administrador social no autorizado en cuanto verdadero empresario. La actuación administrativa para comprobar la adecuación de las altas, bajas e inscripción de empresas a la legalidad vigentes, ante hechos nuevos que no pudieron tenerse en cuenta en el momento de los actos iniciales objeto de revisión, tiene cobertura jurídica en las facultades de control del cumplimiento de la legalidad que tienen atribuidas tanto la ITSS (arts. 12.1.c) y 22 apartados 6 y 7 de la LOITSS) como la TGSS (art. 54, 55 apartados 1 y 2 , y 56.1 del RGIASS ${ }^{1193}$ ).

Con independencia del debate de poder o no practicarse la revisión de oficio por la TGSS de la inscripción o las altas en Seguridad Social, cuando la ITSS extienda un acta de liquidación o requerimiento de ingreso de cuotas por faltas de alta para el verdadero empresario, una vez se ingresen las cuotas reclamadas, las altas en Seguridad Social retrotraen sus efectos al inicio del período objeto de liquidación (art. 35.1.2. ${ }^{\circ}$ del RGIASS), con lo que no se ve afectada la esfera jurídica de los trabajadores, no se

${ }^{1192}$ Revisión de inexactitudes constadas de hechos nuevos (arts. 55.2 y 56 del RGIASS).

Son ejemplos de esa facultad de Revisión de Oficio en vía administrativa, por conocerse hechos nuevos no tenidos en cuenta en el acto inicial, las SSTS, Sala Contencioso-Administrativa, 2023/2017, de 19 de diciembre de 2017 -Rec. 3052/2015-; 1384/2019, de 16 de octubre de 2019 -Rec. 2064/2017, por ejemplo, con relación a la potestad de la TGSS para modificar una baja reconocida como voluntaria inicialmente, cuando con posterioridad constan hechos nuevos de los que resulta su naturaleza, sin necesidad de tener que acudir previamente al proceso de oficio ante la jurisdicción competente, ya que "los artículos 54 y 55 del Reglamento General sobre inscripción de empresas y afiliación, altas, bajas y variaciones de datos de trabajadores en la Seguridad Social, otorga la potestad para "comprobar en todo momento la exactitud de los datos obrantes en sus sistemas de documentación" (artículo 54.2), respecto de las materias a que se refiere dicho reglamento".

${ }^{1193}$ En esos preceptos del RGIASS se otorga a la TGSS la competencia para adecuar las inscripciones, altas, bajas en Seguridad Social a la legalidad vigente, cuando como consecuencia de su actividad de control constate esa inadecuación con hechos nuevos. 
afectan actos declarativos de derechos al tener que modificar la TGSS las altas iniciales. En los supuestos de falta de alta de los trabajadores en Seguridad Social por ser el empresario real distinto del empresario formal, la ITSS tiene competencia para extender el acta de liquidación por falta de alta (art. 34 apartado 1.a) del TRLGSS) sin que jurídicamente se tenga que revisarse previamente de oficio por la TGSS el alta para la empresa ${ }^{1194}$.

Finalmente señalar que cabría otra posibilidad para exigir el pago al gestoradministrador social responsable no autorizado, cual sería estimar que estamos ante un supuesto legal de responsabilidad solidaria recogido en el art. 18.4 del TRLGSS ${ }^{1195}$ en relación con el art. 12.3 del RGRSS y arts. 36 y 38.2 de la LSC, donde se prevé la reclamación solidaria de las cotizaciones a quien realmente reciba la prestación laboral de servicios, al estimarse en la jurisprudencia ${ }^{1196}$ que el art. 18.4 del TRLGSS es el fundamento para la responsabilidad solidaria del empresario real, en aquellos supuestos en que formalmente consten terceros como empresario en los registros de la TGSS, como sucede con la empresa grupo a efectos laborales. De este modo, si no se ha iniciado la reclamación de cotizaciones ante la sociedad en formación, podrá dirigirse directamente la reclamación contra el gestor administrador no autorizado, con lo que deberán tramitarse las altas en Seguridad Social para esta nueva empresa, y las correlativas bajas en la sociedad en formación. Si por el contrario, ya se hubiere iniciado el procedimiento de reclamación de deudas ante la sociedad en formación, procedería la reclamación de las cuotas al gestor administrador no autorizado mediante la reclamación de deuda por derivación o acta de liquidación de cuotas de derivación de responsabilidad (art. 12.3 del RGRSS).

${ }^{1194}$ VINUESA ALADRO, A.: "La Inspección de Trabajo y Seguridad Social: Ley 42/1997, de 14 de noviembre", Actualidad Laboral, Sección Doctrina, 1998, Ref. XII, p. 157, tomo 1, editorial La Ley, Ref. La Ley 2547/2001, edición digital,

https://laleydigital-laleynext-es.ponton.uva.es/Content/Documento.aspx?params, $\quad$ p. 20, quien comentando la anterior LOITSS ya señalaba que "la novedad de la LOITSS estriba en reconocer expresamente la facultad de la ITSS para iniciar procedimientos de encuadramiento sin que por ello se paralice la actividad liquidataria", tal y como actualmente se recoge en el art. 22.7 de la LOITSS de 2015.

${ }^{1195}$ Art. 18.4 "En caso de que la responsabilidad por la obligación de cotizar corresponda al empresario, podrá dirigirse el procedimiento recaudatorio que se establece en esta Ley y en su normativa de desarrollo contra quien efectivamente reciba la prestación de servicios de los trabajadores que emplee, aunque formalmente no figure como empresario en los contratos de trabajo, en los registros públicos o en los archivos de las entidades gestoras y servicios comunes".

1196 SSTS, Sala Contencioso-Administrativa, 1661/2018, de 22 de noviembre -Rec. 2507/2016-; 1673/2016, de 8 de julio -Rec. 3831/2014- ; 1292/2016, de 2 de junio de 2016 -Rec. 2890/2014-; y 8 de julio de 2016 -Rec. 3831/2014-. 
Estimamos que lo correcto es extender acta de liquidación a nombre del administrador, con nuevas propuestas de altas de los trabajadores para la empresa del gestor administrador no autorizado, ya que la sociedad en formación no sería sujeto responsable de las cuotas del período de formación, con lo que no estamos en puridad ante un supuesto de responsabilidad solidaria de un tercero en deudas de la sociedad en formación, sino ante deudas propias.

Con relación a las deudas por prestaciones, revisada de oficio la inscripción de la empresa y las altas en Seguridad Social, podrían reclamarse las deudas por prestaciones al gestor o administrador no autorizado mediante reclamación de deuda de la TGSS, si constase declarada en resolución administrativa firme de la entidad gestora la responsabilidad empresarial en el pago de las prestaciones del gestor o administrador empresario real (art. 69 del Real Decreto 1415/2004, de 11 de junio, RGRSS). En su defecto, podría derivarse la responsabilidad a los gestores actuantes al amparo del art. 18.3 del TRLGSS en relación con los arts. 36 y 38 de la LSC, al imponerse legalmente una responsabilidad solidaria de los mismos en el art. 36 de la LSC, aunque estimamos más adecuado imputar directamente por la entidad gestora al gestor actuante la responsabilidad en su condición de empresario real.

Finalmente, la responsabilidad por las deudas de Seguridad Social del período de formación para los supuestos del art. 37 de la LSC, será de la sociedad en formación con su patrimonio, y, en su caso, responderán también los socios por el importe del capital social no desembolsado. Hasta que se inscriba la sociedad, responde el patrimonio que tuviere la sociedad en formación que estará integrado por las aportaciones de los socios, más los ingresos obtenidos de la explotación del objeto social, deducidos los gastos realizados, y de no ser suficiente ese patrimonio, subsidiariamente responden los socios por la parte del capital suscrito y no desembolsado (art. 37 apartados 1 y 2 de la LSC) ${ }^{1197}$. Como hemos señalado, para algunos autores, interpretación que no compartimos, responde también solidariamente el gestor, administrador o apoderado ${ }^{1198}$. Responsabilidad que cesará con la inscripción de la sociedad en el Registro Mercantil (art. 38 de la LSC).

${ }^{1197}$ GARCÍA CRUCES, J. A.: Derecho de Sociedades Mercantiles, op. cit., p. 131.

${ }_{1198}$ Para VALPUESTA GASTAMINZA, E. M.: Comentarios a la Ley de Sociedades, op. cit., pp. 152153 , serían también responsables los gestores, administradores y apoderados. 
Si el patrimonio social tras la inscripción, deducidos los gastos indispensables para la práctica de la misma, fuese inferior al capital social, los socios están obligados a cubrir la diferencia, ya que no puede constituirse la sociedad con capital inferior al mínimo legal (arts. 4 y 38.3 de la LSC). Es la llamada responsabilidad diferencial. Responsabilidad que para algún autor ${ }^{1199}$, sólo puede reclamar la sociedad, pero no los acreedores, quienes tendrían sólo una legitimación subsidiaria para exigir a los socios esas aportaciones suplementarias al patrimonio social, en virtud de la acción subrogatoria del art. 1111 del Código Civil.

Los actos por los que responde el patrimonio de la sociedad en formación, y en su caso, los socios por el importe de los dividendos pasivos, son los tres siguientes: $1^{\circ}$ los actos y contratos indispensables para la inscripción de la sociedad; $2^{\circ}$ los actos realizados en virtud de mandato específico de todos los socios; y $3^{\circ}$ los realizados por los administradores dentro de las facultades que les confieren las escrituras, incluido el ejercicio de las operaciones sociales y el ejercicio de la actividad laboral, ya que salvo pacto en contrario de los estatutos o de las escrituras, se entiende que los administradores están autorizados legalmente para iniciar los actos constitutivos del objeto social, una vez esas operaciones se inicien con el otorgamiento de las escrituras.

Si se generasen deudas de Seguridad Social en este periodo de formación en esos tres tipos de actos, especialmente cuando se ha iniciado la actividad laboral en fase de formación, el sujeto responsable sería la sociedad en formación, respondiendo los socios con el importe del capital no desembolsado. Responsabilidad de los socios que se ha calificada de subsidiaria ${ }^{1200}$, y que para algunos autores ${ }^{1201}$, se extiende también a los gestores actuantes o a los administradores.

Por la interpretación que mantenemos, durante el período de formación hasta la inscripción registral, por esos actos y por las deudas de Seguridad Social correspondientes, responde la sociedad en formación con el patrimonio social, y los socios hasta el límite de lo que se obligaron a aportar (art. 37.3 LSC). Responsabilidad por esas deudas de Seguridad Social que cesa cuando se inscriba la sociedad en el Registro Mercantil, en cuyo caso, sólo responderá ésta, lo que nos obligará a esperar al transcurso del plazo máximo para inscribir la sociedad, ya que, de no realizarse, la

${ }^{1199}$ GARCÍA CRUCES, J. A.: Derecho de Sociedades Mercantiles, op. cit., p. 133.

${ }^{1200}$ GARCÍA CRUCES, J. A.: Derecho de Sociedades Mercantiles, op. cit., p. 131.

1201 VALPUESTA GASTAMINZA, E. M.: Comentarios a la Ley de Sociedades, op. cit., pp 152-153, considera que serían también responsables los gestores, administradores y apoderados. 
sociedad deviene en irregular, pudiéndose aplicar a partir de ese momento las responsabilidades por deudas de Seguridad Social previstas para la situación de sociedad irregular, que abordaremos más adelante (arts. 38, apartados 1 y 2 y 39 de la LSC).

Si la sociedad no llega a inscribirse durante el período de formación, durante el año siguiente al otorgamiento de la escritura de constitución, de las deudas anteriores a la calificación de la sociedad como irregular, siempre que no constase claramente la voluntad de no inscribirse, deberán responder solidariamente los gestoresadministradores actuantes, el patrimonio social formado y los socios por la parte del capital social no desembolsado (arts. 36, 37 y 38 de la LSC), ya que la responsabilidad de todos cesa con la inscripción registral, no en otro caso (arts. 37 y 38, apartados 1 y 2 LSC), pudiéndose derivar la responsabilidad por deudas de Seguridad Social a todos ellos (art. 18.3 del TRLGSS).

\section{Antecedentes normativos de la responsabilidad.}

La responsabilidad del administrador por las deudas en la fase de constitución de la sociedad anónima se contempló inicialmente con regulación muy parca en el art. 7 de la Ley de 17 de julio de 1951, Reguladora de la Sociedad Anónima.

En ese art. 7 se establecía "La validez de los contratos concluidos en nombre de la sociedad antes de su inscripción en el Registro Mercantil, quedará subordinada a este requisito y a la aceptación por la sociedad dentro del plazo de tres meses. En su defecto, los gestores serán responsables solidariamente frente a las personas con las que hubieren contratado en nombre de la sociedad. Los gestores podrán realizar antes de la inscripción los actos necesarios para la constitución de la sociedad, siendo de cuenta de ella los gastos que por esta causa se originen".

Se partía de la inexistencia de personalidad jurídica de la sociedad mientras no se inscribiese en el Registro Mercantil, por lo que no resultaba vinculada por los actos y contratos previos. De esos actos y contratos, excepcionales, sólo eran responsables quienes los hubieren celebrado, y sólo cesaba esa responsabilidad una vez la sociedad se inscribiese en el Registro Mercantil y los aceptase dentro de los tres meses siguientes. De este modo, se parte de que la sociedad no tiene ningún tipo de personalidad ni patrimonio hasta la inscripción, por lo que responden sólo los gestores en la etapa de constitución. 
En parecidos términos se regulaba la sociedad de responsabilidad limitada en el art. 6 de la Ley de 17 de julio de 1953, donde se establecía: "La validez de los contratos concluidos en nombre de la Sociedad antes de su inscripción en el Registro Mercantil, quedará subordinada a este requisito y a la aceptación por la Sociedad dentro del plazo de tres meses. En su defecto, los gestores serán responsables solidariamente frente a las personas con las que hubieran contratado en nombre da la Sociedad. Los gestores podrán realizar, antes de la inscripción, los actos necesarios para la constitución de la Sociedad, siendo de cuenta de ella los gastos que por esta causa se originen".

Posteriormente mediante la Ley 19/1989, de 25 de julio, de reforma parcial y adaptación de la Legislación Mercantil a las Directivas de la Comunidad Económica Europea (CEE) en materia de Sociedades ${ }^{1202}$, se da nueva redacción al art. 13 de la LSA, de 17 de julio de 1951, donde se establecía el Régimen Jurídico de la Sociedad Anónima en formación. En ese precepto se establecía:

"1. Por los actos y contratos celebrados en nombre de la sociedad antes de su inscripción en el Registro Mercantil, responderán solidariamente quienes los hubieren celebrado, a no ser que su eficacia hubiese quedado condicionada a la inscripción y, en su caso, posterior asunción de los mismos por parte de la sociedad.

2. Por los actos y contratos indispensables para la inscripción de la sociedad, por los realizados por los administradores dentro de las facultades que les confiere el contrato para la fase anterior a la inscripción y por los estipulados en virtud de mandato específico por las personas a tal fin designadas por todos los socios responderá la sociedad en formación con el patrimonio formado por las aportaciones de los socios. Los socios responderán personalmente hasta el límite de lo que se hubiesen obligado a aportar.

3. Una vez inscrita la sociedad quedará obligada por los actos y contratos a que se refiere el apartado anterior. También quedará obligada la sociedad por aquellos actos que aceptase dentro del plazo de tres meses desde su inscripción. En ambos supuestos cesará la responsabilidad solidaria de socios, administradores y representantes a que se refieren los apartados anteriores. En el caso de que el valor del patrimonio social, sumado el importe de los gastos indispensables para la

${ }^{1202}$ BOE del 267.7.1989 
II ${ }^{a}$ PARTE. Vº CAPÍTULO

inscripción de la sociedad, fuese inferior a la cifra del capital, los socios estarán obligados a cubrir la diferencia".

Es una responsabilidad muy similar a la actual, donde ya se contempla una cierta personalidad de la sociedad en formación, respondiendo con su patrimonio por tres tipos de actos, siendo el resto de responsabilidad de quien los haya celebrado, salvo que tras la inscripción la sociedad los acepte en el plazo de tres meses. En cambio, no contemplaba la autorización del administrador para realizar las operaciones sociales y consiguientemente para obligar a la sociedad en formación.

Esta responsabilidad resultaba de aplicación a la sociedad de responsabilidad limitada, en función de la cláusula de remisión del art. 6 de la Ley de 17 de julio de 1953, Reguladora de la Sociedad de Responsabilidad Limitada, según redacción dada por la Ley 19/1989, de 25 de julio, al Régimen Jurídico de la Sociedad Anónima en formación.

Responsabilidad que pasará al nuevo Texto Refundido de la LSA aprobado por el Real Decreto Legislativo 1564/1989, de 22 de diciembre, donde en su art. 15 sobre la sociedad en formación se indica:

“Art. 15. Sociedad en formación.

1. Por los actos y contratos celebrados en nombre de la Sociedad antes de su inscripción en el Registro Mercantil, responderán solidariamente quienes los hubieren celebrado, a no ser que su eficacia hubiese quedado condicionada a la inscripción y, en su caso, posterior asunción de los mismos por parte de la Sociedad.

2. Por los actos y contratos indispensables para la inscripción de la Sociedad, por los realizados por los Administradores dentro de las facultades que les confiere la escritura para la fase anterior a la inscripción y por los estipulados en virtud de mandato especifico por las personas a tal fin designadas por todos los socios, responderá la Sociedad en formación con el patrimonio formado por las aportaciones de los socios. Los socios responderán personalmente hasta el límite de lo que se hubiesen obligado a aportar.

3. Una vez inscrita, la Sociedad quedará obligada por los actos y contratos a que se refiere el apartado anterior. También quedará obligada la Sociedad por aquellos 
actos que acepte dentro del plazo de tres meses desde su inscripción. En ambos supuestos cesará la responsabilidad solidaria de socios, Administradores y representantes a que se refieren los apartados anteriores.

4. En el caso de que el valor del patrimonio social, sumado el importe de los gastos indispensables para la inscripción de la Sociedad, fuese inferior a la cifra del capital, los socios estarán obligados a cubrir la diferencia."

Responsabilidad por deudas del administrador que se establece para las sociedades anónimas, y que, como hemos indicado, sería de aplicación indirecta a los administradores de la sociedad de responsabilidad limitada, en función de la técnica de remisión a la regulación de la sociedad anónima establecida en el nuevo art. 11 de la Ley de 17 de julio de 1953, Reguladora del Régimen Jurídico de las Sociedades de Responsabilidad Limitada, redactado por la Ley 19/1989.

El apartado 2 del art. 15 del Real Decreto Legislativo 1564/1989, de 22 de diciembre, se modifica por la Ley 56/2007, de 28 de diciembre, de Medidas de Impulso de la Sociedad de la Información ${ }^{1203}$, quedando redactado:

"No obstante, si la fecha de comienzo de las operaciones sociales coincide con la de otorgamiento de la escritura fundacional, y salvo que los estatutos sociales o la escritura dispongan otra cosa, se entenderá que los administradores ya quedan facultados para el pleno desarrollo del objeto social y para realizar toda clase de actos y contratos, de los que responderán la sociedad en formación y los socios en los términos que se han indicado."

Con esa redacción se autoriza al administrador social a realizar los actos y contratos propios del objeto social. Curiosamente este apartado 2 se modifica nuevamente por la Ley $3 / 2009$, de 3 de abril, de modificaciones estructurales de las sociedades mercantiles ${ }^{1204}$, por haberse omitido en la reforma anterior de 2007, la redacción inicial, que ahora se vuelve a introducir como primer párrafo de ese apartado $2^{\circ}$. De este modo al apartado 2 se le da la siguiente redacción:

${ }^{1203}$ BOE 29.12.2007.

${ }^{1204}$ BOE 04.04.2009. 
«2. Por los actos y contratos indispensables para la inscripción de la sociedad, por los realizados por los administradores dentro de las facultades que les confiere la escritura para la fase anterior a la inscripción y por los estipulados en virtud de mandato específico por las personas a tal fin designadas por todos los socios, responderá la sociedad en formación con el patrimonio formado por las aportaciones de los socios. Los socios responderán personalmente hasta el límite de lo que se hubiesen obligado a aportar.

No obstante, si la fecha de comienzo de las operaciones sociales coincide con la de otorgamiento de la escritura fundacional, y salvo que los estatutos sociales o la escritura dispongan otra cosa, se entenderá que los administradores ya quedan facultados para el pleno desarrollo del objeto social y para realizar toda clase de actos y contratos, de los que responderán la sociedad en formación y los socios en los términos que se han indicado.»

Con esta nueva redacción se recoge el actual régimen jurídico de la sociedad en formación que se refunde en los actuales arts. 36 a 38 de la LSC.

Con la nueva Ley 2/1995, de 23 de marzo, que regulaba las Sociedades de Responsabilidad Limitada, se establecía en el art. 11.3 una remisión en esta materia al Texto Refundido de la Ley de Sociedades Anónimas de 1989.

\section{II.- RESPONSABILIDAD EN LA SOCIEDAD IRREGULAR.}

\section{Régimen jurídico de la responsabilidad.}

El factor determinante para que una sociedad mercantil se califique como sociedad irregular es la ausencia de inscripción registral ${ }^{1205}$. La irregularidad de la sociedad se manifiesta de dos formas ${ }^{1206}$, una vez transcurra un año desde el otorgamiento de la escritura sin que se haya solicitado su inscripción (criterio objetivo) o, cuando quede constatada la voluntad de los socios de no inscribir la sociedad (criterio subjetivo).

Para FERNÁNDEZ DE LA GÁNDARA ${ }^{1207}$ la sociedad irregular no inscrita existe jurídicamente, "puede actuar como tal en el tráfico, tiene capacidad de obrar y un

\footnotetext{
${ }^{1205}$ FERNÁNDEZ DE LA GÁNDARA, L.: Derecho de Sociedades, edición electrónica, op. cit., p. 65.

1206 FERNÁNDEZ DE LA GÁNDARA, L.: Derecho de Sociedades, edición electrónica, 2010, Vol. I, pp. 63, 378 y ss.

${ }^{1207}$ FERNÁNDEZ DE LA GÁNDARA, L.: Derecho de Sociedades, edición electrónica, 2010, Vol. I, p. 381.
} 
patrimonio separado, elementos que presuponen a su vez, como lo hace el artículo 39.2 LSC, denominación social, domicilio y nacionalidad". Como señala este autor ${ }^{1208}$, a la sociedad irregular se le atribuye una "relativa personificación", no sólo porque en el art. 39 de la LSC, se define esta sociedad y se establecen las responsabilidades ante terceros, sino por la previsión establecida en el artículo 322.3 del Real Decreto 1784/1996, de 19 de julio, que aprueba el Reglamento del Registro Mercantil -en adelante RRM ${ }^{1209}{ }_{-}$, según la cual, si no estuviera inscrita en el Registro Mercantil la sociedad mercantil que hubiera sido declarada en concurso de acreedores, se procederá a su inscripción.

No es un hecho infrecuente la existencia de sociedades que desarrollan su objeto social sin que se hayan inscrito en el Registro Mercantil, bien porque los socios acuerdan no inscribir la sociedad, o bien porque pretendiendo su inscripción, por las razones que fueren, no lo han conseguido, sin que haya supuesto ello un obstáculo para que los socios continúen con la actividad iniciada, siendo en palabras de FERNÁNDEZ DE LA GÁNDARA ${ }^{1210}$ un problema endémico, de palpitante vigencia y actualidad.

Caben dos formas de concebir la sociedad irregular ${ }^{1211}$. Para una primera concepción, sería aquella sociedad que, naciendo como sociedad en formación, al haberse otorgado escritura pública, deviene irregular una vez quede constancia de la voluntad de los socios de no inscribirla en el Registro Mercantil. Una vez que se tenga esa constancia deviene en sociedad irregular. Para una segunda concepción, es una sociedad que ante terceros actúa como sociedad de capital sin voluntad de inscribirse desde el inicio, por lo que desde el inicio sería irregular y no en formación.

Ante esas dos concepciones, VALPUESTA GASTAMINZA ${ }^{1212}$ considera que el legislador en la LSC se ha inclinado por la primera opción, por dos motivos. En primer lugar, porque al armonizar el Texto Refundido de 2010 en la LSC, al establecerse su

\footnotetext{
${ }^{1208}$ FERNÁNDEZ DE LA GÁNDARA, L.: Derecho de Sociedades, edición electrónica, 2010, Vol. I, p. 380. sido declarada en concurso de acreedores, se procederá a su inscripción. En el caso de que faltara la escritura de constitución, la inscripción se practicará en virtud de un mandamiento judicial, que deberá contener, al menos, la denominación y el domicilio de la sociedad y la identidad de los socios de los que el juez tenga constancia".

${ }^{1210}$ FERNÁNDEZ DE LA GÁNDARA, L.: Derecho de Sociedades, edición electrónica, 2010, Vol. I, p. 380.

${ }^{1211}$ VALPUESTA GASTAMINZA, E. M.: Comentarios a la Ley de Sociedades de Capital, op. cit., pp. 156-157.

1212 VALPUESTA GASTAMINZA, E. M.: Comentarios a la Ley de Sociedades de Capital, op. cit., p. 157.
} 
Régimen Jurídico, la rúbrica de la Sección $3^{\mathrm{a}}$ del Capítulo III es "sociedad devenida irregular”, mientras que en el anterior art. 16 de la LSA de 1989, la rúbrica utilizada era la de "sociedad irregular". En segundo lugar, porque en el art. 39.1 de la LSC se indica "si la sociedad en formación hubiere iniciado", frente al texto original de la LSA que señalaba "si la sociedad hubiere iniciado", lo que denota que la sociedad irregular deviene tras la sociedad en formación, no naciendo irregular desde su inicio.

Para la doctrina mayoritaria la sociedad irregular es una sociedad en formación que no llega a inscribirse en el Registro Mercantil, ya que exige el otorgamiento de la escritura de constitución ${ }^{1213}$. Irregularidad que se constatará a través de dos circunstancias. En primer lugar, cuando quede constancia de la falta de voluntad de los fundadores de inscribir a la sociedad en el Registro Mercantil, cuestión que no es de fácil prueba ${ }^{1214}$. En segundo lugar, por el transcurso de un año desde el otorgamiento de la escritura sin inscripción registral. Plazo preclusivo de un año, que "va a fijar con precisión y seguridad, el momento en que la sociedad irregular nace y queda sujeta al régimen jurídico de la sociedad irregular" ${ }^{215}$.

Al haberse optado legislativamente por la primera construcción dogmática, entendiéndose que la sociedad deviene irregular, que no nace irregular, se le aplican las normas en materia de responsabilidad establecidas para la sociedad en formación, durante esa situación, y cuando quede constancia de la voluntad de no inscribirse en el Registro la sociedad, y en todo caso, si ha transcurrido más de un año desde el otorgamiento de las escrituras sin haber sido inscrita en el Registro Mercantil, para las deudas contraídas ${ }^{1216}$ se aplican las normas de la sociedad colectiva si realiza una actividad mercantil, o de la sociedad civil si no desarrolla una actividad mercantil (art. 39 de la LSC).

1213 GARCÍA CRUCES, J. A.: Derecho de Sociedades Mercantiles, Tirant Lo Blanch, $2^{\text {a }}$ edición, Valencia, 2019, p. 135; FERNÁNDEZ DE LA GÁNDARA, L.: Derecho de Sociedades, edición electrónica, op. cit., pp. 380-381, para quien la falta de otorgamiento de escritura es incompatible con la figura de la sociedad irregular, para él, "el legislador cuenta en todo caso con el otorgamiento de la escritura pública como presupuesto del tipo, ya que aquella no es una simple vía de acceso al Registro Mercantil sino un elemento esencial de carácter constitutivo: sin ella no hay sencillamente sociedad. O con otras palabras dicho: la irregularidad se anuda exclusivamente al incumplimiento de la formalidad de la inscripción registral y nunca a la falta del acto constitutivo y de la escritura”.

1214 BROSETA PONT, M. y MARTÍNEZ SANZ, F.: Manual de Derecho Mercantil, op. cit. p. 385; FERNÁNDEZ DE LA GÁNDARA, L.: Derecho de Sociedades, edición electrónica, op. cit., p. 65.

1215 FERNÁNDEZ DE LA GÁNDARA, L.: Derecho de Sociedades, edición electrónica, op. cit., p. 382.

1216 JIMÉNEZ SÁNCHEZ, G. J.: Lecciones de Derecho Mercantil, op. cit., pp. 176-177; BROSETA PONT, M. y MARTÍNEZ SANZ, F.: Manual de Derecho Mercantil, p. 385; GARCÍA CRUCES, J. A.: Derecho de Sociedades Mercantiles, p. 136. 
Para las sociedades irregulares se aplicarán las normas de responsabilidad de las sociedades colectivas de tener actividad mercantil, o las normas de la sociedad civil, de no tener una actividad mercantil. El TS, Sala de lo Civil, en la Sentencia del 1280/2006, de 19 de diciembre -Rec. 342/2000-, señala que, "el artículo 16.2 LSA dispone que en tales circunstancias (esto es, verificada la voluntad de no inscribir la sociedad o transcurrido un año desde el otorgamiento de la escritura), si la sociedad ha iniciado o continúa sus operaciones, se aplicarán las normas de la sociedad colectiva o, en su caso, las de la sociedad civil. Esta remisión no puede conducir al reconocimiento de la personalidad jurídica en la sociedad (...), sino al régimen de responsabilidad de los socios por las deudas sociales, que en el caso de desarrollo de actividades mercantiles será el previsto para las sociedades colectivas, lo que la Sala da por supuesto y los recurrentes no combaten por la vía pertinente (error de derecho en la apreciación de la prueba, error notorio, arbitrariedad o irracionabilidad, de acuerdo con las Doctrina del Tribunal Constitucional). Es ello coherente con la doctrina de esta Sala, en cuanto ha señalado que la sociedad irregular con actividad mercantil ha de regirse por las normas de la sociedad colectiva respecto de terceros y por sus pactos entre los socios (Sentencias de 21 de abril de 1987, 20 de febrero de 1988, 16 de marzo de 1989, etc.) y en cuanto ha enfatizado que el carácter irregular de la sociedad no puede ser invocado por los socios para impedir el cumplimiento de las obligaciones contraídas (Sentencias de 17 de septiembre de 1984, 13 de marzo de 1989). En similares términos, se concluye en la Sentencia del TS núm. 474/2002, Sala Civil, de 20 de mayo -Rec. 3787/1996-, al señalarse que las sociedades irregulares mercantiles se rigen por las normas de la sociedad colectiva, por los pactos de las partes (...)”.

Para FERNÁNDEZ DE LA GÁNDARA la sociedad irregular tiene su propio régimen jurídico, que opera como ley especial -el art. 39 de la LSC-, frente a la regulación establecida en los artículos 36 a 38 LSC para la sociedad en formación ${ }^{1217}$.

Si la sociedad de capital irregular precisa otorgamiento de escritura pública, porque deviene irregular al no inscribirse en el Registro Mercantil, para la fase de sociedad en

1217 FERNÁNDEZ DE LA GÁNDARA, L.: Derecho de Sociedades, edición electrónica, op. cit., p. 381, señalando que "basta con que se den los presupuestos del artículo 39.1 LSC para que estas figuras se sustraigan a las reglas de la sociedad en formación y queden sometidas al régimen especial previsto para las sociedades que, habiendo ya cubierto el aspecto negocial de su constitución, se hallan pendientes de completar el proceso con la inscripción, que determinará la adquisición de la personalidad jurídica”. 
formación, en materia de deudas de Seguridad Social se aplica las normas de responsabilidad analizadas en el apartado anterior, a las que nos remitimos.

Por el contrario, para las deudas de Seguridad Social posteriores a devenir irregular, esto es, para las posteriores al momento en que se tenga constancia de la inexistencia de voluntad de inscribirse a la sociedad -cuestión no fácil de probar, que nada impediría que pudiera coincidir con el otorgamiento de la escritura, si constase esa voluntad de modo fehaciente-, y para las deudas de Seguridad Social nacidas a partir del año desde el otorgamiento de las escrituras sin haberse inscrito en el registro, se aplican las normas de la sociedad colectiva, si se desarrolla actividad mercantil, o de la sociedad civil, de no desarrollarse una actividad mercantil.

Para diferenciar la sociedad civil de la mercantil, y determinar si se aplican las normas de la sociedad colectiva o de la sociedad civil, según la doctrina ${ }^{1218}$ una sociedad será mercantil, y no civil, no tanto porque haya adoptado una de las formas societarias del Código de Comercio (art. 116 del Código de Comercio), sino porque ejerza una actividad mercantil (arts. 1, 117 y 124 del Código de Comercio), ya que las sociedades civiles pueden adoptar las formas previstas en el Código de Comercio (art. 1670 del Código Civil). Rige el criterio de la actividad desarrollada, como elemento diferenciador entre sociedad civil y mercantil.

La sociedad civil no exige escritura pública para tener personalidad jurídica, salvo cuando se aporten bienes inmuebles o derechos reales (art. 1667 del Código Civil). La forma en la constitución del contrato de sociedad civil no es ad solemnitatem $^{1219}$ (artículo 1667). La sociedad civil tendrá personalidad jurídica siempre que los pactos por los que se rija no se mantengan secretos entre los socios, siempre que sean conocidos por terceros (sociedad externa), siempre que no sea una sociedad interna (art. 1669 del Código Civil). La sociedad interna se caracteriza frente a la sociedad externa por la existencia de una voluntad de no participar en el tráfico jurídico excluyendo con

1218 GARRIGUES, J.: Curso de Derecho Mercantil, Tomo I, 1976, p. 311; BROSETA PONS, M.: Manual de Derecho Mercantil, Tecnos 1981, op. cit. p. 158; JIMÉNEZ SÁNCHEZ, G. J.: Lecciones de Derecho Mercantil, 1992, op. cit., p. 153; BROSETA PONT, M. y MARTÍNEZ SANZ, F.: Manual de Derecho Mercantil, p. 385; FERNÁNDEZ DE LA GÁNDARA, L.: Derecho de Sociedades, edición electrónica, op., cit, 2010, p. 41; VALPUESTA GASTAMINZA, E. M.: Comentarios a la Ley de Sociedades de Capital, op. cit., p. 156; GARCÍA CRUCES, J. A.: Derecho de Sociedades Mercantiles, p. 136.

${ }^{1219}$ FERNÁNDEZ DE LA GÁNDARA, L.: Derecho de Sociedades, edición electrónica, 2010, op. cit., pp. 61-62. 
ello la nota de personalidad jurídica ${ }^{1220}$. Sociedad interna que se rige por los preceptos de la comunidad de bienes (art. 1669 del Código Civil).

La sociedad civil tendrá personalidad jurídica cuando se manifieste externamente ante terceros como tal sociedad. En el Registro Mercantil sólo es obligatoria la inscripción de la sociedad mercantil, pero no las sociedades civiles (art. 81 del RRM). Mediante Real Decreto 1867/1998, de 4 de septiembre, se introdujo un párrafo $3^{\circ}$ en el art. 81 del RRM, para establecer que podrían también inscribirse las sociedades civiles, cualquiera que fuere su objeto, aunque no tuvieren forma mercantil. Apartado que fue anulado por el TS, en Sentencia de la Sala Contencioso Administrativa, de fecha de 24 de febrero de 2000 -BOE 24.4.2000, Rec. 526/1998-, por lo que actualmente no pueden ser inscritas las sociedades civiles.

Si la sociedad irregular es sociedad mercantil, a partir del momento en que sobrevenga la condición de irregular, esto es, desde que se tenga constancia de la voluntad de no inscribirse la sociedad, o desde que haya pasado un año desde el otorgamiento de la escritura sin haberse inscrito, se aplican las normas de la sociedad colectiva, y responderán de las deudas de Seguridad Social los socios ${ }^{1221}$ de modo personal e ilimitado, con todo su patrimonio (art. 1911 del Código Civil), y solidariamente entre ellos, pero subsidiariamente respecto a la sociedad (arts. 127, 128 y 237 del Código de Comercio). De ser sociedad civil ${ }^{1222}$, por no realizar actividad mercantil, se aplican las nomas de la sociedad civil, en virtud de las cuales responde la sociedad con su patrimonio, y de modo subsidiario los socios en proporción a sus aportaciones. Los socios en la sociedad civil no responden entre ellos de modo solidario, sino mancomunadamente y cada uno en función de su aportación a la sociedad, estamos ante una responsabilidad mancomunada pero subsidiaria, pues solo se procederá contra el patrimonio de los socios cuando no se haya podido obtener el pago del patrimonio de la sociedad (arts. 1689 y 1698 del Código Civil, RDGRN, Resol. 13-2-2013 ${ }^{1223}$ ).

${ }^{1220}$ FERNÁNDEZ DE LA GÁNDARA, L.: Derecho de Sociedades, edición electrónica, 2010, op. cit., p. 49.

${ }^{1221}$ GARRIGUES, J.: Curso de Derecho Mercantil, op. cit., pp. 373-375; BROSETA PONT, M.: Manual de Derecho Mercantil, op. cit., p. 182; JIMÉNEZ SÁNCHEZ, G. J.: Lecciones de Derecho Mercantil, op. cit., p. 162; BROSETA PONT, M. y MARTÍNEZ SANZ, F.: Manual de Derecho Mercantil, p. 385; GARCÍA CRUCES, J. A.: Derecho de Sociedades Mercantiles, p. 66.

1222 DÍEZ-PICAZO Y PONCE DE LEÓN, L. y GULLÓN BALLESTEROS, A.: Sistema de Derecho Civil, Tecnos, 1979, p. 512.

${ }^{1223}$ En la RDGRN 13-02-2013 -BOE de 11 marzo 2013-, se señala que "los socios de una sociedad civil son responsables del resultado de la gestión social y descartada su solidaridad con respecto a la 
Esta aplicación de las reglas de las sociedades colectivas o civiles en materia de responsabilidad por las deudas, no implica que la sociedad se transforme ope legis en esa clase de sociedad, ya que no estamos ante una transformación legal de la sociedad $^{1224}$. La aplicación de las normas de la sociedad colectiva en la responsabilidad por deudas adquiere su pleno sentido por ser el régimen jurídico que ofrece mayores garantías para los terceros, cumpliendo así la sociedad colectiva la función de "sociedad general del tráfico" $" 1225$.

El problema será determinar si la persona que interviene como administrador en la sociedad no siendo socio, si respondería de las deudas sociales, ya que tanto en la sociedad colectiva como en la sociedad civil sólo pueden ser administradores los socios (art. 1692 a 1695 del Código Civil).

Para responder a esta cuestión cabrían dos interpretaciones. En virtud de una primera no sería de aplicación al administrador esa responsabilidad por dos razones. En primer lugar, porque estamos ante una norma con cierto carácter de sanción, por lo que no cabe una aplicación analógica in malam partem. En segundo lugar, porque cabría entender que la remisión del art. 39 de la LSC a las normas de la sociedad colectiva y civil, lo es para determinar, tanto quiénes son los sujetos responsables, como cuál es la naturaleza de responsabilidad, de modo que, si en la colectiva y la civil sólo responden los socios,

sociedad, se deberá considerar que su responsabilidad frente a terceros será mancomunada, esto es, que responden de las deudas sociales en la medida de su participación social, es decir, con todos sus bienes de acuerdo con el art. 1911 del Código Civil, pero sólo después de haberse hecho excusión del fondo social".

1224 GARCÍA CRUCES, J. A.: Derecho de Sociedades Mercantiles, p. 137. Para FERNÁNDEZ DE LA GÁNDARA, L.: Derecho de Sociedades, edición electrónica, 2010, op. cit., en la pp. 65-66, indica que "acreditada la existencia de la irregularidad, las mayores dificultades vienen planteadas por el proceso de regularización de la sociedad y el mecanismo de conversión. En caso de practicarse la inscripción de la anónima irregular en el Registro, ello no supone su transformación (en sociedad colectiva) o en sociedad civil, ni un acuerdo de transformación social, ni siquiera un acuerdo social de inscripción; se trata de un simple acto de gestión. Dicho en otras palabras el sometimiento ex lege de la sociedad anónima irregular a las normas de la sociedad colectiva, no lleva aparejada la transformación, es decir, el cambio de forma". Pero al analizar la sociedad anónima irregular, nos dirá en la p. 382, que "El artículo 39.2 LSC establece que si la sociedad ha iniciado o continua sus operaciones, se aplicarán las normas de la sociedad colectiva o, en su caso, las de la sociedad civil. Se introduce por esta vía un mecanismo de aplicación subsidiaria - ya que sólo juega en el caso de que los socios no se decidan a instar la resolución y convengan permanecer en sociedad sin someterse al trámite de la inscripción - destinado a subsumir de forma automática e indubitada la anónima irregular dentro del régimen de la colectiva o, en su caso, de la sociedad civil. Una vez se ha abandonado el propósito de inscribir y, por ende, de constituir una sociedad anónima, la conversión automática en uno de estos dos tipos societarios se hace depender únicamente de la actuación en sociedad y de su exteriorización. La sociedad deja de ser una anónima espúrea para convertirse, en sentido técnico de verdadera transformación, en una figura duradera sujeta, por razón del objeto, al régimen de la sociedad civil o de la sociedad colectiva".

1225 BROSETA PONT, M. y MARTÍNEZ SANZ, F.: Manual de Derecho Mercantil, p. 385. 
ya que no cabe que la administración se desarrolle por personas que no sean socios, ha de entenderse que responden sólo los socios y no el administrador que no es socio.

Para una segunda interpretación, por la que optamos, no sólo responden los socios, sino también el administrador de no ser socio, y ello por cinco motivos. En primer lugar, porque como se ha indicado con motivo de la naturaleza de la responsabilidad del actual art. 367 de la LSC, y a efectos de determinar si sería de aplicación retroactiva la reforma de la responsabilidad más beneficiosa establecida mediante la Ley 19/2005 de 14 de noviembre, en la jurisprudencia ${ }^{1226}$ se ha negado la aplicación retroactiva, por no ser de naturaleza sancionadora esa responsabilidad. En segundo lugar, porque la remisión que hace el art. 39 de la LSC a la sociedad colectiva o civil, es para determinar la naturaleza de la responsabilidad, no para la delimitación de los sujetos responsable. En tercer lugar, han de incluirse entre los sujetos responsables a los administradores de no ser socio, ya que antes de ser irregular, al haberse constituido la sociedad como sociedad de capital, podía esa sociedad ser administrada por un tercero no socio (art. 212.2 de la LSC), y no tendría mucho sentido excluirlo cuando es el responsable, como los socios, de solicitar la inscripción registral (arts. 31 y 32 de la LSC). En cuarto lugar, porque cabría alegar la aplicación supletoria del art. 120 del Código de Comercio, que, para los supuestos de sociedad mercantil irregular, se impone a los administradores encargados de la gestión social la responsabilidad solidaria ante terceros en el pago de las deudas sociales, si incumplen la obligación de constituir la sociedad mediante escritura pública e inscribirla en el Registro Mercantil. En quinto y último lugar, porque el administrador sin aportación de capital, en las sociedades personalistas tendrá, en todo caso, la consideración de socio industrial (art. 116 del Código de Comercio), y como tal socio, en las relaciones externas, responde de las deudas sociales como cualquier otro socio colectivo que aporte capital. La doctrina científica ${ }^{1227}$ incluye en la responsabilidad por deudas de la sociedad colectiva al socio industrial, porque la exoneración del mismo para asumir las pérdidas no tiene efectos externos ante los acreedores, por lo que ante éstos responde como el resto de los socios colectivos, con la matización de que, al no participar en las pérdidas, puede exigir todo lo pagado al resto de los socios. Con igual o más razón deberán responder los administradores que no eran socios durante la etapa de

\footnotetext{
${ }^{1226}$ Sentencias del TS, Sala Civil, núm. 246/2015, de 14 de mayo -Rec. 1121/2013-; 367/2014, de 10 de julio; 100/2012, de 7 de marzo -Rec. 674/2009-; y 225/2012, de 13 de abril, entre otras.

${ }^{1227}$ BROSETA PONT, M. y MARTÍNEZ SANZ, F.: Manual de Derecho Mercantil, op. cit., pp. 333-334; GARCÍA CRUCES, J. A.: Derecho de Sociedades Mercantiles, op. cit., pp. 68-69.
} 
la sociedad en formación, una vez deviene la irregularidad. Responsabilidad similar a la que tendría el socio comanditario que asuma la administración, o que incluya su nombre como socio colectivo en la razón social sin serlo (art. 147 del Código de Comercio). Nada obsta, para que el administrador no socio reclame en vía de regreso todo lo pagado a los socios colectivos, como ocurre con el socio industrial. Interpretación que realizamos salvo mejor doctrina.

Si la sociedad irregular se inscribiese en el Registro Mercantil con posterioridad al transcurso del año del otorgamiento de la escritura, durante el período en que haya sido irregular no cesa la responsabilidad de los socios y administradores (art. 39.2 en relación con el art. 38.2 de la LSC), de modo que de las deudas sociales del período de la irregularidad éstos siguen respondiendo de modo personal y solidariamente, pero con carácter subsidiario respecto al patrimonio formado en la misma ${ }^{1228}$.

La posterior inscripción en el Registro Mercantil de la sociedad de capital, no supone que se produzca una modificación societaria, se trata de un simple acto de gestión ${ }^{1229}$.

\section{Derivación administrativa de responsabilidad.}

De todas las deudas de Seguridad Social de la sociedad irregular es responsable la sociedad irregular con su patrimonio, siendo responsables subsidiarios los socios, quienes responden de modo personal e ilimitado de las deudas, y entre sí de modo solidario, de ser una sociedad con actividad mercantil. Si no tuviere la sociedad actividad mercantil, los socios responden subsidiariamente con la sociedad, de modo personal cada uno con su patrimonio, sin responsabilidad solidaria entre ellos, sino mancomunadamente en proporción a sus aportaciones al capital social.

$\mathrm{Al}$ responder los socios de modo subsidiario respecto a la sociedad, pero entre ellos de modo solidario, personal e ilimitado (sociedades colectivas), o mancomunadamente en proporción a su aportación social, pero cada uno con todo su patrimonio (sociedad sin actividad mercantil), cuando se extienda acta de liquidación de cuotas o se dicte resolución de derivación de responsabilidad por la TGSS, con la consiguiente reclamación de deuda de derivación, no se iniciará la recaudación ante los socios hasta que no conste la insolvencia de la sociedad, bien conste ésta en cualquier procedimiento

\footnotetext{
1228 Art. 39 de la LSC y artículos 127 y 237 del Código de Comercio.

${ }^{1229}$ FERNÁNDEZ DE LA GÁNDARA, L.: Derecho de Sociedades, edición electrónica, 2010, op. cit., p. 66.
} 
administrativo recaudatorio, en resolución judicial, o si se ha abierto la fase de liquidación de la sociedad concursada (art. 14 del RGRSS).

El procedimiento administrativo de derivación de deudas de cotización, difiere en función de que se reclame la responsabilidad por acta de liquidación de derivación extendida por la Inspección de Trabajo y Seguridad Social ${ }^{1230}$, cuando sean deudas por cotizaciones, o se reclame por la TGSS.

La reclamación de responsabilidad solidaria a los socios de las deudas por cotizaciones podría exigirse mediante acta de liquidación por derivación extendida por la ITSS, o mediante reclamación de deuda de la TGSS. Tras la reforma de la Ley General de Seguridad Social, mediante la Ley 34/2014, de 26 de diciembre, de medidas en materia de liquidación e ingreso de cuotas de la Seguridad Social ${ }^{1231}$, la ITSS puede proceder directamente a derivar la responsabilidad mediante acta de liquidación por derivación, o emitir un informe recogiendo los hechos y fundamentos jurídicos de la responsabilidad para que la TGSS proceda a la derivación de la responsabilidad (arts. 33 y 34 del TRLGSS, en relación con los arts. 13, 62 y 65 del RGRSS).

Ahora bien, si la ITSS tuviere que extender un acta de liquidación por falta de alta en Seguridad Social de trabajadores, por diferencias de cotización, o por bonificaciones indebidas, de ser deudas de un período de responsabilidad de los socios por irregularidad de la sociedad, en el acta de liquidación extendida se podrá declarar la responsabilidad subsidiaria de los socios sin tenerse que extender otra específica de derivación de responsabilidad (art. 34 TRLGSS, art. 65 del RGRSS, arts. 32 a 34 del RISOS, Criterios Técnicos de la DGITSS números 29/2000 ${ }^{1232}$ y 31/2000, de 18 de mayo ${ }^{1233}$ ), aunque no podrá ser exigida la deuda a los responsables subsidiarios hasta que conste la declaración de insolvencia de la sociedad irregular, lo que puede dar lugar

\footnotetext{
1230 Admite la derivación mediante acta de liquidación de cuotas NICOLÁS BERNAD, J. A.: "La responsabilidad de los administradores sociales ante la Inspección de Trabajo”, op. cit., p. 78.

${ }^{1231}$ BOE del 27.12.2014. Disposición Legal que reformó el art. 30 del TRLGSS de 1994, que pasó al actual art. 33 del vigente TRLGSS.

1232 Referencia La Ley 2878/2009.

1233 Referencia La Ley 283/2000.

En el Criterio Técnico 31/2000, se indica con relación a la responsabilidad subsidiaria en las contratas que "la exigencia de la responsabilidad subsidiaria requiere la declaración de insolvencia del empresario contratista o subcontratista (arts. 127.1 LGSS (La Ley 2305/1994) y 12.1 RGR), ello sin perjuicio de extender también acta de liquidación al responsable solidario o subsidiario concurrentemente a la extendida al deudor originario (art. 14 RPS). La jurisprudencia en sus pronunciamientos lo vienen entendiendo así, TCT, Sentencias 14.6.83, -Ar. 5664-; 25.10.83, -Ar. 8819-; 14.10.88, -Ar. 6559-; 10.5.89, -Ar. 3625-; y 8.2.89, -Ar. 1580-".
} 
a disfunciones, como veremos en el Capítulo VI al analizar la responsabilidad subsidiaria.

MARTÍN JIMÉNEZ y MATEOS BEATO consideran que el acta de liquidación de derivación de responsabilidad, procederá ante deudas de Seguridad Social que sean competencia de la Inspección ${ }^{1234}$, esto es, deudas por cotizaciones derivadas de faltas de afiliación o alta en Seguridad Social de los trabajadores, o por diferencias de cotización que no resulten directamente de las liquidaciones, incluidas las bonificaciones indebidas del subsistema de formación para el empleo (art. 34.1 TRLGSS). Esa limitación de los supuestos de derivación administrativa de responsabilidad de la ITSS no resulta de la legislación vigente, ya que el acta por derivación no se limita legalmente y no se condiciona a que tenga como causa el resto de supuestos de actas de liquidación, como veremos en el Capítulo VI.

Existe compatibilidad y concurrencia de competencias entre la TGSS y la ITSS para derivar la responsabilidad de deudas por cuotas, en los arts. 33 y 34 del TRLGSS. Con esta nueva distribución de competencias deja de ser de aplicación literal el Criterio Técnico 29/2000 de la DGITSS, que debe ser reinterpretado con la nueva regulación de los arts. 33 y 34 del TRLGSS, lo mismo que se ha de reinterpretar en esos términos el Criterio Técnico 38/2003 de la DGITSS.

El acta de liquidación de cuotas se emitirá directamente a la sociedad que es el deudor principal, haciéndose constar en la misma el sujeto responsable subsidiario -los socios y los administradores-. El procedimiento administrativo se seguirá contra la sociedad hasta la recaudación de su importe en vía voluntaria o ejecutiva, notificándose a todos los responsables, incluidos los subsidiarios, los que podrán efectuar alegaciones (art. 33.1 del Real Decreto 928/1998, de 14 de mayo).

1234 MARTÍN JIMÉNEZ, R. y MATEOS BEATO, A.: La Responsabilidad de Empresas y Administradores con la Seguridad Social, Thomson Reuters, 2009, p. 271. Según el Criterio Técnico 29/2000, la competencia para la derivación de responsabilidad, entre la TGSS y la ITSS, vendrá dada, en función de que la circunstancia que motive la derivación de la responsabilidad le conste o no a la TGSS por los datos obrantes en la misma. De constarle esos datos objetivos y subjetivos, puede ésta iniciar el procedimiento. Si no le constan y se descubren en actuación de la ITSS, sería ésta la competente para extender el acta de liquidación por derivación, salvo que haya sido actuación inspectora a instancias de la propia TGSS, en cuyo caso procede informe a la misma. En todo caso, cuando la inspección extienda acta de liquidación y concurran supuestos de responsabilidad solidaria o subsidiaria lo hará constar en el acta, con indicación de los sujetos responsables. Criterio Técnico declarado vigente por el Criterio Técnico 93/2013, pero que debe ser reinterpretado tras la Ley 34/2014, de 26 de diciembre (BOE del 27), con lo que actualmente, la ITSS puede emitir informe a la TGSS para que sea ésta quien inicie la derivación de responsabilidad, sin tener que extender obligatoriamente acta de liquidación por derivación. 
En el acta de liquidación dirigida contra los socios y administradores habrá de constar $^{1235}$ : el carácter subsidiario de la responsabilidad, así como la causa y fundamento jurídico de esa responsabilidad -en este caso, tendrá como fundamento el art. 18.3 del TRLGSS, en relación con el art. 39 de la LSC y artículos 127 y 237 del Código de Comercio, o los arts. 1689 y 1698 del Código Civil-, número de los trabajadores afectados, período reclamado, con el importe total de la deuda, excluidos los recargos, intereses y costas. En el texto del acta de liquidación constarán los hechos determinantes de la deuda, y los fundamentos jurídicos de la misma y demás datos esenciales recogidos en el art. 32 del Real Decreto 928/1998, de 14 de mayo, debiendo hacerse mención a que la deuda sólo será exigible una vez conste la insolvencia de la sociedad irregular. Según el Criterio Técnico 31/2000 de la Dirección General de la ITSS $^{1236}$, el acta de liquidación "ha de contener los hechos y los fundamentos jurídicos que amparen la extensión de responsabilidad, de forma que pruebe la responsabilidad correspondiente que se imputa; ha de tener en cuenta, además de la general, la prescripción específica de responsabilidad en los supuestos que se aplicable; (...) la identidad de los trabajadores a los que alcanza el ámbito de la extensión de la deuda, y que justifica la cuantía que se imputa al correspondiente responsable por derivación". Téngase en cuenta que en el art. 32.1.d) del Real Decreto 928/1998, de 14 de mayo, exige sólo que conste el número de trabajadores afectados.

Aunque en el art. 33 del Real Decreto 928/1998, se impone la obligación de notificar el acta de liquidación por la Inspección a todos los sujetos responsables, sean solidarios o subsidiarios, para que puedan formular alegaciones, de ser un acta con responsables subsidiarios, el procedimiento recaudatorio continúa con relación al deudor principal, hasta que se dicte resolución elevando a definitiva la liquidación, en cuyo caso, el deudor principal, no el responsable subsidiario, debe ingresar el importe de la deuda dentro del mes siguiente a la notificación de esa resolución, salvo que garantice o consigne su importe (art. 34, apartados 2 y 3 del TRLGSS). La resolución elevándose a definitiva ha de notificarse dentro de los seis meses siguientes a la fecha del acta de liquidación, ya que en otro caso caduca el procedimiento, el dies ad quem es la fecha de la notificación de la resolución, no la de la fecha de la resolución del acta (frente al

\footnotetext{
1235 Art. 32 apartados 1, b y d del Real Decreto 928/1998, de 14 de mayo.

${ }^{1236}$ Relativos a derivación de la responsabilidad del sujeto responsable principal del pago de cuotas a la Seguridad Social y a otros -Ref. La Ley 283/2000-
} 
tenor literal, a la fecha de la actuación inspectora, del art. 33 del Real Decreto 928/1998, de 14 de mayo, y según interpretación del TS, Contencioso-Administrativa, de fechas de 23 de febrero de 2010 -Rec. 243/2008- y 7 de febrero de 2014 -Rec. 4607/2012-, ésta dictada en Recurso de Casación en Interés de Ley). Resolución elevando a definitiva la derivación de responsabilidad que debe declarar la procedencia o improcedencia de la responsabilidad subsidiaria, aunque la deuda no sea exigible a los responsables subsidiarios si no consta la previa declaración de insolvencia del deudor principal, habiéndose interrumpido la prescripción de la acción de derivación con la extensión del acta de liquidación.

Sólo una vez conste la insolvencia de la sociedad, se iniciará el procedimiento recaudatorio en vía voluntaria ante los socios responsables subsidiarios, ya que sólo pueden tramitarse en el mismo procedimiento liquidatorio y recaudatorio las actas de liquidación con responsables solidarios, no las actas con responsables subsidiarios (art. 33.1 del Real Decreto 928/1998, de 14 de mayo).

Declarada la insolvencia de la sociedad, bien conste la misma en un procedimiento administrativo o judicial, o bien se hubiese abierto la fase de liquidación en el concurso de acreedores de la sociedad (art. 14.3 del RGRSS), se inicia el procedimiento recaudatorio por la TGSS del acta de liquidación ante los socios responsables subsidiarios. Esto porque en el art. 12.5 del RGRSS se establece que el procedimiento recaudatorio seguido para las reclamaciones de deuda por derivación de la TGSS, es el que ha de seguirse para la reclamación de la deuda del acta de liquidación de cuotas por derivación. Procedimiento de derivación por la TGSS que pasamos a exponer.

El procedimiento de derivación de responsabilidad por la TGSS de iniciará una vez conste la insolvencia de la sociedad irregular (art. 14.3 del RGRSS). Antes de extender la reclamación de deuda por derivación, debe notificarse a los sujetos responsables subsidiarios el acuerdo de inicio del procedimiento de derivación, dándoles un plazo de 15 días para alegaciones. Efectuada las alegaciones por la TGSS se dictará la resolución administrativa de derivación de responsabilidad a la que se acompaña la reclamación de deuda por el importe total de la deuda. Resolución que ha de dictarse en el plazo máximo de seis meses desde el día siguiente al que se notificó el acuerdo de inicio del expediente, ya que, en otro caso, caduca el procedimiento administrativo recaudatorio (art. 14.1 del RGRSS). Dictada la resolución y la reclamación de deuda por la TGSS se exigirá el pago de las cotizaciones a los socios y administradores. En la reclamación de 
deuda a los responsables subsidiarios, al ser una reclamación en vía voluntaria, sólo se incluirá el importe del principal de la deuda, pero no los recargos, los intereses y las costas de la reclamación emitida a la sociedad responsable directa y principal del pago (arts. 33.2.b), en relación con el 34.1.c) del TRLGSS y art. 14.2 del RGRSS).

La reclamación de deuda por cotizaciones se tendrá que ingresar en los plazos siguientes, a) las notificadas entre el 1 y 15 de cada mes, desde la notificación hasta el 5 del mes siguiente o inmediato hábil posterior, y b) las notificadas entre el día 16 y el último día de mes, entre la fecha de notificación y el día 20 del mes siguiente o día hábil posterior (art. 30.3 del TRLGSS y art. 64 RGRSS).

De reclamarse a los socios deudas por prestaciones, la competencia es de la TGSS, y no del OEITSS. Para iniciar el procedimiento debe haberse dictado previamente resolución administrativa firme por la entidad gestora de la prestación (INSS, ISM, SEPE) declarando la responsabilidad empresarial, y, en su caso, las responsabilidades empresariales solidarias o subsidiarias que pudieran existir (arts. 1.d) y 69 del RGRSS). El plazo reglamentario del pago de la reclamación de deuda será desde la fecha de notificación de la reclamación hasta el último día hábil del mes siguiente a la notificación (art. 70.1 RGRSS). Transcurridos esos períodos reglamentarios de pago se inicia la reclamación en vía ejecutiva, emitiendo la TGSS la providencia de apremio.

Si la sociedad no ha ingresado la deuda por prestaciones, una vez conste declarada su insolvencia, podrá exigirse la responsabilidad subsidiaria a los socios de la sociedad irregular, procediendo la TGSS a iniciar el procedimiento administrativo de derivación de responsabilidad ante los socios (arts. 1.1.d), 12, 13, 69 y 70 del RGRSS).

\section{Antecedentes normativos de la responsabilidad.}

La regulación de la sociedad irregular tiene lugar mediante la Ley 19/1989, de 25 de julio, de reforma parcial y adaptación de la legislación mercantil a las Directivas de la Comunidad Económica Europea (CEE) en materia de Sociedades ${ }^{1237}$, que reforma la LSA de 1951 y la LSRL de 1953.

En la Ley de Sociedades Anónimas se introduce su régimen jurídico en el art. 14, donde se estableció que, "Verificada la voluntad de no inscribir la sociedad y, en cualquier caso, transcurrido un año desde el otorgamiento de la escritura sin que se haya

${ }^{1237}$ BOE del 27.7.1989 
solicitado su inscripción, cualquier socio podrá instar la disolución de la sociedad en formación y exigir, previa liquidación del patrimonio común, la restitución de sus aportaciones. En tales circunstancias, si la sociedad ha iniciado o continúa sus operaciones se aplicarán las normas de la sociedad colectiva o, en su caso, las de la sociedad civil. El apartado tercero del artículo anterior no será aplicable a la posterior inscripción de la sociedad.

Con anterioridad a esta Ley 19/1989, en nuestro Derecho de sociedades no se regulaba la sociedad irregular, así GARRIGUES ${ }^{1238}$, afirmaba que la sociedad anónima no inscrita, no está constituida legalmente y no existe a ningún efecto, ni interno ni externo El régimen jurídico era el mismo que el actual.

La Ley 2/1995, de 24 de marzo, de Sociedades de Responsabilidad Limitada, se remitía a la normativa de la S.A. en materia de sociedad en formación y sociedad irregular (art. 11.3).

\section{III.- RESPONSABILIDAD EN LA SOCIEDAD UNIPERSONAL SOBREVENIDA.}

\section{Régimen jurídico de la responsabilidad.}

La sociedad de capital unipersonal se regula en el Capítulo III del Título I, arts. 12 a 17 de la LSC, teniendo esta condición toda sociedad anónima o limitada que, o bien se ha constituido por un único socio (unipersonal de origen), o bien constituida por varios socios, posteriormente uno de ellos deviene en titular de todo el capital social (unipersonal sobrevenida), computándose como propiedad del único socio las participaciones sociales o acciones que pertenezcan a la sociedad (art. 12 LSC).

La regulación de los arts. 12 a 17 de la LSC incorpora a nuestro Derecho la previsión que sobre esta materia contenía la $12^{\mathrm{a}}$ Directiva de Sociedades, de 21 de diciembre de 1989 (Directiva 89/667/CEE), que ha sido derogada por la actual Directiva 2009/102/CE del Parlamento Europeo y del Consejo, de 16 de septiembre de 2009, en materia de Derecho de sociedades, relativa a las sociedades de responsabilidad limitada de socio único ${ }^{1239}$, donde se regulan las dos modalidades de sociedades anónimas y de responsabilidad limitadas unipersonales, las constituidas inicialmente por un único

${ }^{1238}$ GARRIGUES, J.: Curso de Derecho Mercantil, op. cit., Tomo I, 1976, p. 435.

${ }^{1239}$ DOUE, Serie L de 1.10.2009. 
socio y las que han adquirido con posterioridad la condición de unipersonal al asumir una persona todo el capital social. Régimen jurídico de la sociedad unipersonal que se aplica a la sociedad anónima unipersonal siempre que se prevea su existencia en el ordenamiento interno del Estado miembro de la UE (arts. 2 y 6 de la Directiva).

La unipersonalidad está sujeta a unas exigencias de publicidad para evitar abusos, estableciéndose un régimen obligatorio de publicidad registral y de publicidad de los contratos estipulados entre la sociedad unipersonal y el único el socio. Con relación a la publicidad registral, y para la sociedad unipersonal sobrevenida, la declaración de haber adquirido el único socio la totalidad de capital social se hará constar en escritura pública que se inscribirá en el Registro Mercantil. En la inscripción registral debe recogerse la identidad del único socio (art. 13 de la LSC).

El legislador parece mostrar en la regulación de la sociedad unipersonal, una valoración negativa, que se explicaría por un cierto prejuicio sobre la capacidad financiera y patrimonial de esa sociedad de capital ${ }^{1240}$.

La especialidad de la sociedad unipersonal en materia de responsabilidad ${ }^{1241}$, consiste en atribuir responsabilidad solidaria, personal e limitada en las deudas sociales al único socio, cuando sobrevenida la unipersonalidad con posterioridad a la constitución, hayan transcurrido seis meses desde que se adquirió esa condición sin inscribirse en el Registro Mercantil la escritura en que conste la unipersonalidad (art. 14.1 de la LSC). La unipersonalidad sobrevenida somete al socio único a una responsabilidad ilimitada por las deudas sociales. Es una responsabilidad solidaria del socio con la sociedad por las deudas sociales, por lo que los acreedores sociales podrán dirigirse directamente contra el socio único, sin necesidad de hacer previa excusión del patrimonio social ${ }^{1242}$.

Para las situaciones en que se pretenda que el socio evite las consecuencias del régimen de unipersonalidad sobrevenida, no adquiriendo íntegro el capital para dejar en manos de un tercero, normalmente un testaferro, un mínimo porcentaje del capital (por ejemplo, adquisición del 99,99 por ciento del capital), cabe la posibilidad de acreditar

\footnotetext{
${ }^{1240}$ GARCÍA CRUCES, J.A.: Derecho de Sociedades Mercantiles, op. cit., p. 550.

${ }^{1241}$ GARCÍA CRUCES, J.A.: Derecho de Sociedades Mercantiles, op. cit., p. 551; BROSETA PONT, M. y MARTÍNEZ SANZ, F.: Manual de Derecho Mercantil, op. cit., p. 660; FERNÁNDEZ DE LA GÁNDARA, L.: Derecho de Sociedades, edición electrónica, 2010, op. cit., p. 309.

1242 FERNÁNDEZ DE LA GÁNDARA, L.: Derecho de Sociedades, edición electrónica, 2010, op. cit., p. 309.
} 
que realmente es una sociedad unipersonal acudiendo al fraude de ley (art. 6.4 del Código Civil), a través dela doctrina del levantamiento del velo ${ }^{1243}$.

La responsabilidad solidaria del único socio por las deudas sociales se extiende a todo el período de unipersonalidad (art. 14 de la LSC), desde que el socio adquiere todo el capital social hasta la inscripción extemporánea en el Registro Mercantil de la escritura pública en la que conste el carácter unipersonal. A partir de esa inscripción intempestiva cesa la responsabilidad por las deudas, pero sólo por las posteriores a la inscripción en el Registro Mercantil del carácter unipersonal (art. 14.2 LSC), respondiendo a partir de ese momento de las deudas la sociedad ${ }^{1244}$.

La responsabilidad del socio único no cesa por el hecho de que la situación de unipersonalidad sea inscriba extemporáneamente en el Registro Mercantil, ya que el único efecto de esa inscripción será que el socio deja de responder de las deudas posteriores a la inscripción, sin que cese o se extinga la responsabilidad ya contraída por las deudas anteriores a esa inscripción ${ }^{1245}$.

Cumplido el presupuesto de que no se haya inscrito en el Registro Mercantil la condición de unipersonalidad, por haber transcurrido seis meses desde que el socio adquiere todo el capital social, nace responsabilidad del mismo. Responsabilidad que se mantiene hasta que se proceda a inscribir esa circunstancia en el Registro Mercantil (Sentencia del TS, Sala civil, número 499/2016, de 19 julio -Rec. 449/2014-). Es una responsabilidad objetiva y automática por el incumplimiento de la obligación de inscribir la unipersonalidad.

En la responsabilidad del socio en la sociedad unipersonal sobrevenida, prima el carácter sancionador $^{1246}$, por haberse ocultado a los acreedores la condición de sociedad

1243 BROSETA PONT, M. y MARTÍNEZ SANZ, F.: Manual de Derecho Mercantil, op. cit., p. 660; FERNÁNDEZ DE LA GÁNDARA, L.: Derecho de Sociedades, edición electrónica, 2010, op. cit., p. 309.

${ }^{1244}$ GARCÍA CRUCES, J. A.: Derecho de Sociedades Mercantiles, op. cit., p. 551

1245 FERNÁNDEZ DE LA GÁNDARA, L.: Derecho de Sociedades, edición electrónica, 2010, op. cit., p. 309.

${ }^{1246}$ DÍAZ ECHEGARAY, J. L.: Deberes y Responsabilidades de los Administradores de Sociedades de Capital, op. cit., pp. 391-392; FERNÁNDEZ DE LA GÁNDARA, L.: Derecho de Sociedades, edición electrónica, 2010, op. cit., p. 309. 
unipersonal, razón por la que se hace responder al socio de las deudas sociales de modo personal e ilimitado ${ }^{1247}$.

Esta responsabilidad del único socio es una especialidad del nuestro Derecho interno de sociedades, ya que no encuentra parangón en otros países europeos, y para algún autor $^{1248}$ hubiere sido preferible haber optado por el cierre registral de la sociedad irregular sobrevenida, antes que por ese régimen especial de responsabilidad.

Sobre el carácter solidario de la responsabilidad del único socio, la STS, Sala Civil, 499/2016, de 19 julio -Rec. 449/2014-, establece que es una "responsabilidad personal, ilimitada y solidaria sobre las deudas sociales del socio único. El socio único no deviene obligado solidario sino responsable solidario: responde del incumplimiento de la deudora, que es la sociedad, sin perjuicio de que por su carácter solidario, tras dicho incumplimiento, los acreedores pueden dirigir su reclamación indistintamente frente a la sociedad y frente al socio único, sin que en este último caso se exija la previa excusión de los bienes y derechos de la sociedad". Aplicado a las deudas de Seguridad Social, una vez la empresa no haya ingresado las deudas por el transcurso del plazo reglamentario de ingreso, podrá exigirse la responsabilidad solidaria al único socio.

\section{Derivación administrativa de responsabilidad.}

Al ser responsable solidario el único socio de las deudas de la sociedad unipersonal, una vez haya adquirido ese carácter la sociedad, al no haberse inscrito la unipersonalidad en los seis meses siguientes en el Registro Mercantil, si la sociedad no ha ingresado en plazo reglamentario la deuda de Seguridad Social, podrá derivarse la responsabilidad solidaria al único socio. Responsabilidad solidaria que se extiende a todas las deudas generadas en todo el período de la unipersonalidad, cesando la misma una vez se inscriba extemporáneamente en el registro la escritura en que conste el carácter unipersonal.

Las deudas por cuotas recogidas en las actas de liquidación de cuotas extendidas por la Inspección de Trabajo y Seguridad Social, así como las deudas por cuotas de las reclamaciones de deuda expedidas por la TGSS, serán exigibles solidariamente a la

\footnotetext{
${ }^{1247}$ DÍAZ ECHEGARAY, J. L.: Deberes y Responsabilidades de los Administradores de Sociedades de Capital, op. cit., pp. 391-392.

${ }^{1248}$ BROSETA PONT, M. y MARTÍNEZ SANZ, F.: Manual de Derecho Mercantil, op. cit., p. 660.
} 
sociedad y al socio ${ }^{1249}$, respondiendo ambos del importe del principal, de los recargos, de los intereses y de las costas del procedimiento recaudatorio ${ }^{1250}$.

Derivación administrativa de deudas por cuotas de Seguridad Social que se estima pertinente su reclamación por la ITSS, según Criterio Técnico 21/1999, de la DGITSS, para los supuestos de sociedad unipersonal sobrevenida. Criterio Técnico declarado vigente por el Criterio Técnico de revisión y vigencia de criterios técnicos de fecha de 26.2.2013, reinterpretado a la luz del actual Criterio Técnico 89/2011.

La derivación administrativa de deudas por cuotas podría iniciarse una vez ha transcurrido el plazo reglamentario de ingreso de las cotizaciones -mes siguiente a la fecha de devengo de las cuotas del mes correspondiente-, sin que la empresa hubiere efectuado su ingreso. A partir de ese momento, tanto la TGSS, mediante acuerdo de derivación y reclamación de deuda por derivación, como la ITSS, mediante acta de liquidación de cuotas por derivación de responsabilidad, podrían derivar la deuda al sujeto responsable, al único socio. El único socio responde del principal de la deuda por cuotas, así como de los recargos, de los intereses y de las costas del procedimiento recaudatorio $^{1251}$.

De ser deudas por prestaciones de la sociedad de capital, una vez se declare la responsabilidad empresarial de la sociedad en resolución administrativa firme de la entidad gestora, la TGSS reclamará su importe a la mercantil, emitiendo la reclamación de deuda para que la sociedad proceda a ingresar su importe dentro del mes siguiente a la notificación, y ante la falta de pago se inicia el procedimiento ejecutivo contra la sociedad (arts. 69 y 70 del Real Decreto 1415/2004, de 11 de junio, RGRSS).

De constar la situación de sociedad unipersonal sobrevenida, la TGSS podría derivar la deuda por prestaciones de responsabilidad empresarial al socio mediante el procedimiento de derivación dictando la pertinente resolución administrativa. Dictada esa resolución se procede a reclamar el pago emitiéndose la pertinente reclamación de deuda por la TGSS (art. 13 del RGRSS), reclamación de deuda que puede expedirse conjuntamente con la resolución administrativa de derivación de responsabilidad o

${ }^{1249}$ NICOLÁS BERNAD, J. A.: "La responsabilidad de los administradores sociales ante la Inspección de Trabajo", op. cit., pp. 76-77.

1250 Arts. 33 y 34 del TRLGSS, arts. 12, 13 y 62 a 66 del RGRSS, y arts. 33 a 36 del Real Decreto 928/1998, de 14 de mayo.

1251 Arts. 33 y 34 del TRLGSS, arts. 12, 13 y 62 a 66 del RGRSS, y arts. 33 a 36 del Real Decreto 928/1998, de 14 de mayo. 
posteriormente, siempre que se haga dentro del plazo máximo de seis meses a computar desde la fecha del acuerdo de inicio del procedimiento administrativo de derivación (art. 13 RGRSS).

\section{Antecedentes normativos de la responsabilidad.}

El antecedente de esta figura lo encontramos en el art. 129 de la Ley 2/1995 de 23 de marzo, reguladora de la Sociedad de Responsabilidad Limitada, donde se indicaba:

"Transcurridos seis meses desde la adquisición por la sociedad del carácter unipersonal sin que esta circunstancia se hubiere inscrito en el Registro Mercantil, el socio único responderá personal, ilimitada y solidariamente de las deudas sociales contraídas durante el período de unipersonalidad. Inscrita la unipersonalidad, el socio único no responderá de las deudas contraídas con posterioridad".

Para la Sociedad Anónima, la Ley 2/1995, introducía en el Real Decreto Legislativo 1564/1989, de 22 de diciembre, un nuevo Capítulo que, con el número XI y bajo el título «De la sociedad anónima unipersonal», se integraba por el artículo 311, que se remitía al régimen de la sociedad limitada unipersonal, al tener el régimen jurídico más consolidado y mejor estructurado, por lo que era aplicable el art. 129 de la Ley 2/1995. $\mathrm{El}$ art. 311 quedaba redactado del siguiente modo:

«Artículo 311. Sociedad anónima unipersonal.

Será de aplicación a la sociedad anónima unipersonal lo dispuesto en el capítulo XI de la Ley de Sociedades de Responsabilidad Limitada.»

Éste era uno de los pocos supuestos en que la norma reguladora de las sociedades anónimas se remitía a la normativa de sociedades de responsabilidad limitada.

\section{IV.- RESPONSABILIDAD EN LAS TRANSFORMACIONES SOCIETARIAS.}

En este apartado examinaremos los supuestos de responsabilidad de los socios, que se extenderá al administrador social sólo si ostentase esa condición de accionista de la mercantil. Responsabilidad de los socios prevista legalmente con motivo de las diversas transformaciones societarias cuando esté afectada una sociedad mercantil. 


\section{Transformaciones societarias.}

En los arts. 4 y 7 de la Ley 3/2009, de 3 de abril, sobre modificaciones estructurales de las sociedades mercantiles ${ }^{1252}$, se regulan las modalidades o supuestos de transformación societaria de mayor interés para esta investigación, ya que prescindimos de la transformación de una sociedad anónima en anónima europea.

Una sociedad de capital se puede transformar en sociedad colectiva o comanditaria simple, o agrupación de interés económico, y viceversa ${ }^{1253}$. Igualmente, una sociedad de capital puede transformarse en sociedad civil o en cooperativa, y viceversa ${ }^{1254}$.

“Artículo 4. Supuestos de posible transformación.

1. Una sociedad mercantil inscrita podrá transformarse en cualquier otro tipo de sociedad mercantil.

2. Una sociedad mercantil inscrita, así como una agrupación europea de interés económico, podrán transformarse en agrupación de interés económico. Igualmente una agrupación de interés económico podrá transformarse en cualquier tipo de sociedad mercantil y en agrupación europea de interés económico.

3. Una sociedad civil podrá transformarse en cualquier tipo de sociedad mercantil.

4. Una sociedad anónima podrá transformarse en sociedad anónima europea. Igualmente una sociedad anónima europea podrá transformarse en sociedad anónima.

5. Una sociedad cooperativa podrá transformarse en sociedad mercantil, y una sociedad mercantil inscrita en sociedad cooperativa.

6. Una sociedad cooperativa podrá transformarse en sociedad cooperativa europea y una sociedad cooperativa europea podrá transformarse en sociedad cooperativa".

“Artículo 7. Transformación de sociedad cooperativa.

${ }^{1252}$ BOE del 4.4.2009.

${ }^{1253}$ Art. 4 de la Ley 3/2009, de 3 de abril.

${ }^{1254}$ Art. 4 de la Ley 3/2009, de 3 de abril. 
1. La transformación de una sociedad cooperativa en otro tipo social o de éste en aquélla, se regirá en lo referente a los requisitos y efectos de la transformación de la sociedad cooperativa por la legislación que le sea aplicable.

2. La transformación de sociedades cooperativas en sociedades cooperativas europeas y viceversa se regirá por lo dispuesto en el Reglamento (CE) número 1435/2003 y por las normas que lo desarrollan”.

Debemos previamente conocer cómo responden los socios de las deudas sociales en los diversos tipos de sociedades, ya que las conversiones societarias tienen trascendencia en materia de responsabilidad.

En las sociedades de capital los socios no responden de las deudas sociales, sólo responden de desembolsar el capital suscrito, salvo en las sociedades comanditarias por acciones en que el socio colectivo sí responde de las deudas sociales (art. 1 apartados 2 a 4 de la LSC). No tienen especialidades en materia de responsabilidad de los socios la sociedad anónima europea ${ }^{1255}$, la Sociedad Limitada Nueva Empresa, o las sociedades laborales y participadas ${ }^{1256}$.

Con relación a las sociedades profesionales, que podrán adoptar cualquiera de las formas admitidas en el Derecho de sociedades, la responsabilidad de los socios se rige por la forma societaria elegida, con la especialidad de que de las deudas sociales que se deriven de los actos profesionales responderán solidariamente la sociedad y los profesionales, sean socios o no, que hayan actuado, siéndoles de aplicación las reglas generales sobre la responsabilidad contractual o extracontractual que corresponda (art. 11 de la Ley 2/2007, de 15 de marzo, de Sociedades Profesionales ${ }^{1257}$ ).

En las sociedades colectivas y comanditarias simples, existen los llamados socios colectivos a los que corresponde la gestión social o administración, quienes responden de las deudas sociales de modo subsidiario con respecto a la sociedad, pero entre ellos de modo solidario, personal e ilimitado con su patrimonio por las deudas de Seguridad Social (arts. 127, 148 y 237 del Código de Comercio). Es una responsabilidad solidaria entre los socios colectivos, pero subsidiaria respecto a la sociedad, ya que según el art. 237 del Código de Comercio antes de ir contra ellos debe haberse hecho excusión de los

\footnotetext{
${ }^{1255}$ Regulada por el Título XIII, arts. 455 a 494 de la LSC, y por el Reglamento (CE) 2157/2001 del Consejo, de 8 de octubre (DO L 294, de 10.11.2001).

${ }^{1256}$ Reguladas por la Ley 44/2015, de 14 de octubre (BOE del 15).

${ }^{1257}$ BOE 16.3.2007.
} 
bienes del patrimonio societario ${ }^{1258}$. Igual responsabilidad personal, ilimitada y solidaria entre ellos, tendrán los socios comanditarios de la sociedad comanditaria simple que hayan incluido su nombre en la razón social, o se hayan implicado en la gestión de la compañía (arts. 147 y 148 del Código de Comercio), responsabilidad que es subsidiaria respecto a la sociedad comanditaria (art. 237 del Código de Comercio). Finalmente, los socios comanditarios responden ante terceros con relación a los bienes que se obligaron a aportar al patrimonio social (art .148 del Código de Comercio).

Por otro lado, la sociedad civil que tiene personalidad jurídica siempre que los pactos sociales no se mantengan ocultos ante terceros (art. 1669 del Código Civil), de sus deudas sociales responde la sociedad con su patrimonio, siempre que quien gestione lo hagan en nombre de la sociedad y estando autorizado. No responden los socios de modo solidario de las deudas sociales (arts. 1689 y 1698 del Código Civil). Los socios responden de modo subsidiario, si no hubiere bienes en el patrimonio social para el gago de las deudas, y en proporción a sus cuotas ${ }^{1259}$, pero no solidariamente entre ellos ${ }^{1260}$.

En la Agrupación de Interés Económico (AIE) regulada por la Ley 12/1991, de 29 de abril $^{1261}$, en el art. 5 se establece que los socios responderán personal y solidariamente entre sí por las deudas de la agrupación, pero de modo subsidiario con relación a ésta. Debemos recordar que la AIE tiene personalidad jurídica propia y carácter mercantil, y se regirán por lo dispuesto en esa ley y, supletoriamente, por las normas de la sociedad colectiva que resulten compatibles con su específica naturaleza (art. 1 de la Ley 12/1991). Estamos ante una responsabilidad personal y solidaria por las deudas sociales, aunque subsidiaria respecto a la agrupación, como en la sociedad colectiva, por lo que digamos para las transformaciones en sociedades colectivas les será de aplicación a la AIE. Es importante recordar que la Agrupación de Interés Económico sólo podrá constituirse por personas físicas o jurídicas que desempeñen actividades empresariales, agrícolas o artesanales, por entidades no lucrativas dedicadas a la investigación y por quienes ejerzan profesiones liberales (art. 4 de la Ley 12/1991, de 29 de abril).

1258 GARRIGUES, J.: Curso de Derecho Mercantil, 1976, pp. 374 y 386 a 389; BROSETA PONT, M.: Manual de Derecho Mercantil, op. cit., p. 182; JIMÉNEZ SÁNCHEZ, G. J.: Lecciones de Derecho Mercantil, Tecnos, 1992, pp. 162 y 165-166; BROSETA PONT, M. y MARTÍNEZ SANZ, F.: Manual de Derecho Mercantil, Tecnos, 23ª edición, Vol. I, 2016, pp. 332-333.

1259 Arts. 1689 y 1698 del Código Civil.

${ }^{1260}$ DÍEZ-PICAZO Y PONCE DE LEÓN, L. y GULLÓN BALLESTEROS, A.: Sistema de Derecho Civil, Tecnos, 1979, p. 512.

${ }^{1261}$ BOE 30.4.1991. 
Con relación a las cooperativas de ámbito estatal señalar que, con carácter general, los socios no responden de las deudas sociales, sino que su responsabilidad se limita a realizar la aportación comprometida al capital social. No obstante, de haber causado baja y con relación a las deudas contraídas con anterioridad a su baja en la cooperativa, responde con el importe recibido de la aportación reembolsada al capital social si fuere preciso para pagar esas deudas (art. 15 apartados 3 y 4 de la Ley 27/1999, de 16 de julio que regula las Cooperativas). Por lo demás, no tiene efectos sustanciales en la responsabilidad en las transformaciones societarias, siendo supuesto similar al de las anónimas y de responsabilidad limitada, con la especialidad aludida en caso de baja del socio cooperativista, por lo que le es de aplicación lo que se diga para las sociedades de capital.

Estas transformaciones societarias tienen efectos en la responsabilidad de los socios, ya que, si los socios de las cooperativas y de las sociedades de capital no responden de las deudas sociales, salvo el socio colectivo de la sociedad comanditaria por acciones (art. 1 apartados 2 a 4 de la LSC), en cambio en las sociedades mercantiles personalistas (como las sociedades colectivas y comanditarias simples) y en las sociedades civiles, los socios colectivos sí responden de las deudas sociales.

Examinemos cómo opera la responsabilidad de los socios ante ciertas transformaciones societarias.

El art. 21 de la Ley 3/2009, de 3 de abril, regula los efectos en la responsabilidad de los socios, estableciendo:

“Artículo 21. Responsabilidad de los socios por las deudas sociales.

1. Los socios que en virtud de la transformación asuman responsabilidad personal e ilimitada por las deudas sociales responderán en la misma forma de las deudas anteriores a la transformación.

2. Salvo que los acreedores sociales hayan consentido expresamente la transformación, subsistirá la responsabilidad de los socios que respondían personalmente de las deudas de la sociedad transformada por las deudas sociales contraídas con anterioridad a la transformación de la sociedad. Esta responsabilidad prescribirá a los cinco años a contar desde la publicación de la transformación en el «Boletín Oficial del Registro Mercantil». 
Analizaremos las responsabilidades de los socios por dos tipos de transformaciones. En primer lugar, por las transformaciones de las sociedades con responsabilidad limitada de los socios en las deudas sociales, en otras sociedades en que los socios responden de modo ilimitado. En segundo lugar, la transformación de sociedades con responsabilidad personal e ilimitada en las deudas sociales, en sociedades con responsabilidad limitada de los socios.

\subsection{Transformación de sociedades con responsabilidad limitada en sociedades de responsabilidad ilimitada.}

Si una sociedad de capital o cooperativa, en que no responden los socios de las deudas sociales, se transforma en sociedad civil, los socios pasan a responder de todas las deudas de Seguridad Social, de las anteriores y posteriores a la transformación, de modo subsidiario con la sociedad, pero a nivel personal de modo ilimitado con su patrimonio (art. 1911 del Código Civil), y en proporción a la participación en las pérdidas y ganancias de cada uno de ellos en la nueva sociedad, ya que no responden solidariamente entre sí (art. 21 de la Ley 3/2009, de 3 de abril).

Si una sociedad de capital (sociedad anónima, de responsabilidad limitada o comanditaria por acciones), en que los socios no responden de las deudas sociales, se transforma en sociedad colectiva o comanditaria simple, los nuevos socios colectivos de esas nuevas sociedades pasan a responder de modo personal e ilimitado, y solidariamente entre ellos de las deudas de Seguridad Social, pero de modo subsidiario respeto a la sociedad. Responsabilidad que se extiende a todas las deudas, a las anteriores y a las posteriores a la transformación (art. 21 de la Ley 3/2009, de 3 de abril). Lo mismo si se transforma una sociedad de capital o cooperativa en AIE, en que los socios pasan a responder de modo solidario, pero subsidiariamente con la Agrupación de las deudas sociales anteriores o posteriores a la transformación.

\subsection{Transformación de sociedades con responsabilidad ilimitada en sociedades de responsabilidad limitada.}

Si una sociedad colectiva o comanditaria simple se transforma en sociedad de capital, a partir de la transformación los socios dejan de responder de modo personal de las deudas sociales anteriores, entre ellas de las de Seguridad Social, si los acreedores han consentido en esa transformación. Si los acreedores no han consentido en la transformación societaria, lo que sería el caso de la Seguridad Social de existir deudas, 
los socios colectivos seguirán respondiendo de las deudas de la sociedad colectiva o comanditaria anteriores a la transformación, de modo personal y solidario entre ellos, y subsidiariamente respecto a la sociedad (art. 21 de la Ley 3/2009, de 3 de abril), durante un período de cinco años a computar desde la publicación en el BORME de la transformación. La misma responsabilidad si la AIE se convierte en sociedad de capital.

Igualmente, si una sociedad civil se transforma en sociedad de capital o cooperativa estatal, a partir de la transformación, los socios dejan de responder de modo personal de las deudas sociales anteriores, si los acreedores han consentido en esa transformación. Si los acreedores no han prestado su consentimiento, respecto de los mismos, los socios seguirán respondiendo de las deudas de la sociedad anteriores a la transformación, de modo personal y en proporción a su cuota de participación, pero de modo subsidiario respecto a la sociedad, durante un período de cinco años a computar desde la publicación en el BORME de la transformación (art. 21 de la Ley 3/2009, de 3 de abril).

\section{Derivación administrativa de responsabilidad.}

Cuando proceda la responsabilidad subsidiara de los socios respecto a la sociedad, pero ilimitada, personal y solidaria de los socios entre sí, una vez conste la insolvencia de la sociedad deudora principal, podrá iniciarse el procedimiento administrativo de derivación de responsabilidad ante los socios que sigan respondiendo de ese modo por las deudas sociedad como consecuencia de la transformación societaria.

Procedimiento de derivación que se iniciará normalmente por la TGSS, pero que puede ser iniciado también por acta de liquidación por derivación de la ITSS cuando sean deudas por cotizaciones a la Seguridad Social. Derivación administrativa de deudas por cuotas de Seguridad Social que se estima pertinente su reclamación por la ITSS, según Criterio Técnico 21/1999, de la DGITSS, para los supuestos de responsabilidad de los socios en los supuestos de transformaciones societarias, en que se impone en la legislación mercantil una responsabilidad personal, solidaria o subsidiaria por las deudas de la sociedad. Criterio Técnico declarado vigente por el Criterio Técnico de revisión y vigencia de criterios técnicos de fecha de 26.2.2013, reinterpretado a la luz del actual Criterio Técnico 89/2011.

Cuando sean deudas por prestaciones de responsabilidad empresarial la competencia para la derivación administrativa de la deuda al administrador social será de la TGSS (al respecto nos remitimos al apartado II del Capítulo VI). 
A efectos del procedimiento de derivación nos remitimos al apartado II.3 de este capítulo, por ser de aplicación lo reseñado en la sociedad irregular en que los socios responden también de modo subsidiario con la sociedad, y de forma personal, ilimitada y solidaria entre ellos.

\section{V.- RESPONSABILIDAD DEL ADMINISTRADOR SOCIAL POR LEVANTAMIENTO DEL VELO SOCIETARIO.}

Un supuesto de posible responsabilidad del administrador social, será la responsabilidad ante el uso fraudulento de la personalidad jurídica de la sociedad de capital.

Responsabilidad que recaerá en el administrador, no por su condición de tal, sino ante todo por su condición de socio-administrador cuando pueda ser calificado como empresario real, o por su condición de administrador de la sociedad dominante en las sociedades integrantes de un grupo.

Otras responsabilidades conexas en los grupos societarios, serán las responsabilidades de las mercantiles en la empresa grupo o en los grupos patológicos, que pudieran acabar afectando al administrador de una sociedad dominante si se calificase como administrador de hecho o derecho de las sociedades dominadas (véase el capítulo cuarto apartado sexto sobre responsabilidad del administrador de la sociedad dominante y las responsabilidades del grupo societario).

Sujeto de la relación jurídico laboral es el empresario, persona física, jurídica, o entidad sin personalidad jurídica, que reciba la prestación de servicios de los trabajadores por cuenta ajena, la organice y la remunere (art. 1.1 del TRET).

Cuando sea una sociedad de capital la que ha concertado las relaciones laborales, dirige y obtiene la utilidad laboral de la prestación de servicios, ostentará la condición de empresario en la relación laboral, y consiguientemente, será el sujeto de la relación de Seguridad Social que nace del contrato de trabajo. La sociedad de capital será quien asume, en su condición de empresario, las obligaciones con la Seguridad Social, sean obligaciones instrumentales de afiliación, altas, bajas de trabajadores, de cotización, recaudación, o, en su caso, derivadas de la responsabilidad en prestaciones.

Sociedad de capital que al tener personalidad jurídica propia y patrimonio propio, diferenciada de la personalidad y del patrimonio de sus socios, responde con su patrimonio, no respondiendo los socios y los administradores de las deudas de 
Seguridad Social, salvo en los supuestos previstos legalmente, por atribuirse responsabilidad solidaria o subsidiaria a los socios o a los administradores sociales (arts. 1, 4, 33, 30, 36 a 40, 52, 57, 73, 74, 77, 236, 241, 360, 367 y concordantes de la LSC).

\section{Levantamiento del velo societario.}

Si bien la condición de empresario la asume la sociedad de capital, para evitar supuestos de fraude a los trabajadores y a la Seguridad Social, con carácter excepcional, se permite desconocer la condición formal de empleador de la sociedad, en virtud de la doctrina judicial del levantamiento del velo, en dos supuestos ${ }^{1262}$. En primer lugar, cuando, estemos ante la "empresa grupo" y los "grupos de empresas patológicos", en que, al concurrir una serie de circunstancias, determinan la comunicación de responsabilidades entre las sociedades integrantes del grupo, la responsabilidad solidaria de las sociedades del grupo. Y, en segundo lugar, cuando se utiliza el ropaje de la personalidad jurídica de la sociedad de capital, en la que los socios no responden de las deudas sociales, para eludir la responsabilidad personal ilimitada del socio de control, lo que acaecerá en la mayoría de los supuestos en que socio-administrador único sea quien ejerza realmente la actividad empresarial, cuando sea el verdadero empleador.

Doctrina de levantamiento del velo de origen jurisprudencial que se inicia con la Sentencia del TS, Sala Civil, de 28 de mayo de 1984 (n. ${ }^{\circ} 330$, Ponente Carlos de la Vega Benayas), donde ya se señalaba que, "la más autorizada doctrina, en el conflicto entre seguridad jurídica y justicia, valores hoy consagrados en la Constitución (artículos $1^{\circ} .1$ y $\left.9^{\circ} .3\right)$, se ha decidido prudencialmente, y según casos y circunstancias, por aplicar

1262 JIMÉNEZ SÁNCHEZ, J. J.: “Algunas reflexiones, desde el punto de vista del Derecho del Trabajo, acerca de las acciones de responsabilidad frente a los administradores de las sociedades mercantiles; las cuestiones competencial material y procedimental”, Actualidad Laboral, núm. 40, 1996, pp. 765766; CAVAS MARTÍNEZ, F.: "Jurisdicción competente para determinar la responsabilidad solidaria de los administradores sociales por débitos laborales y de Seguridad Social”, en Revista Doctrinal Aranzadi Social, Vol. II, párrafo. 30, 1998, edición digital, pp. 1-2; ÁLVAREZ ROYOVILLANOVA, S.: "La necesaria revisión de la doctrina del levantamiento del velo", en AA.VV. (Dir.: MARTÍNEZ-ECHEVERRÍA Y GARCÍA DE DUEÑAS, A.): Gobierno Corporativo: la Estructura del órgano de Gobierno y la Responsabilidad de los Administradores, 2015, p. 846; CRUZ VILLALÓN, J. y DOMÍNGUEZ MORALES, A.: "El Empresario", 2018, op. cit., p. 1, quienes señalan que ante la ausencia de "regulación completa de los grupos empresariales ha motivado que sea la jurisprudencia la que defina algunos de los aspectos más importantes que quedan sin precisar por la norma, especialmente en materia de determinación de la persona del empleador y de responsabilidades económicas cuando el grupo no tiene la condición de empleado".

Sobre levantamiento del velo, Vid. también: AA.VV. (Coord.: BAYLOS GRAU, A. y COLLADO GARCÍA, L.): Grupos de empresas y Derecho del Trabajo, Madrid, Editorial Trotta, 1994. 
por vía de equidad y acogimiento del principio de la buena fe (artículo $7^{\circ} .1$ del Código Civil ), la tesis y práctica de penetrar en el substratum personal de las entidades o sociedades, a las que la ley confiere personalidad jurídica propia, con el fin de evitar que al socaire de esa ficción o forma legal (de respeto obligado, por supuesto) se puedan perjudicar ya intereses privados o públicos o bien ser utilizada como camino del fraude (artículo $6^{\circ} .4$ del Código Civil), admitiéndose la posibilidad de que los jueces puedan penetrar (levantar el velo jurídico) en el interior de esas personas cuando sea preciso para evitar el abuso de esa independencia (artículo $7^{\circ} .2$ del Código Civil) en daño ajeno o de los derechos de los demás (artículo 10 de la Constitución española) o contra el interés de los socios, es decir, de un mal uso de su personalidad, en un ejercicio antisocial de su derecho".

La doctrina del levantamiento del velo se ha elaborado como señala CAVAS MARTÍNEZ ${ }^{1263}$, "normalmente con la finalidad de identificar al empresario real en aquellos supuestos en que la personalidad jurídica de la sociedad, su autonomía patrimonial y la limitación de la responsabilidad de los socios, se utiliza abusivamente para privar de efectividad a los derechos de los trabajadores. Pero también se ha utilizado el levantamiento del velo para declarar la responsabilidad solidaria de las empresas que forman parte de un grupo considerado como conjunto económico único, para lo cual es preciso examinar las relaciones existentes entre las sociedades agrupadas, así como para calificar la relación de los socios que prestan servicios para la sociedad, al objeto de determinar si existe o no concurrencia de relaciones laboral y societaria".

La doctrina del levantamiento del velo es, "un instrumento jurídico que se pone al servicio de una persona, física o jurídica, para hacer efectiva una legitimación pasiva distinta de la que resulta de la relación contractual o extracontractual, mantenida con una determinada entidad o sociedad a la que la ley confiere personalidad jurídica propia, convirtiendo a los que serían terceros -los socios o la sociedad- en parte responsable a partir de una aplicación, ponderada y restrictiva de la misma, que permita constatar una situación de abuso de la personalidad jurídica societaria perjudicial a los intereses públicos o privados, que causa daño ajeno, burla los derechos de los demás o se utiliza como un medio o instrumento defraudatorio, o con un fin fraudulento y que se produce,

${ }^{1263}$ CAVAS MARTÍNEZ, F.: "La responsabilidad patrimonial de los socios y administradores sociales en el ámbito laboral”, en Revista Doctrinal Aranzadi Social, núm. 9/2002, edición digital, p. 5. 
entre otros supuestos, cuando se trata de eludir responsabilidades personales, y entre ellas el pago de deudas (STS 29 de junio de 2006, y las que en ella se citan). Como dice la Sentencia de 28 de enero de 2005, supone, en definitiva, un procedimiento para descubrir, y reprimir en su caso, el dolo o abuso cometido con apoyo en la autonomía jurídica de una sociedad, sancionando a quienes la manejan, con lo que se busca poner coto al fraude o al abuso" ${ }^{1264}$.

Levantar el velo de una persona jurídica consiste en hacer abstracción de su personalidad, o de alguno de sus atributos en determinadas circunstancias (Sentencia del TS, Sala Social, de 26 de diciembre de 2001 -rcud. 139/2001-). El origen de esta teoría se atribuye a los tribunales anglosajones (incluidos los norteamericanos, donde se habla de penetración del velo: "piercing the veil"), y equivale a una reacción o modalización del principio de separación de patrimonios, que es consecuencia de la constitución de una persona jurídica distinta a la de los socios. Con esta doctrina se produce de facto una derogación de las reglas de la persona moral o jurídica, para desconocer los principios de la persona jurídica, cuando esos principios han sido desconocidos por los propios socios de la entidad mercantil.

Con la doctrina del levantamiento del velo se pretende que prime la justicia material, y no se utilicen instituciones jurídicas como la sociedad de capital, desvirtuando su esencia, para perjudicar derechos o intereses de las personas que se relacionan con la sociedad, como sus trabajadores o las instituciones públicas de Seguridad Social. Doctrina de la teoría del levantamiento del velo, que tiene como soporte o fundamento

1264 Según Sentencias del Tribunal Supremo, Sala Civil, 201/2008, de 28 de febrero -Rec. 5713/2000-, con cita de la Sentencia de esa Sala de 19 de septiembre de 2007.

En la STS, Sala Civil, núm. 457/2008, de 30 de mayo -Rec. 1040/2001-, se establece que para una correcta aplicación de la técnica del levantamiento del velo es preciso que se acredite la concurrencia de dos premisas: a) la primera es que exista un mal uso (abuso) de la personalidad de la sociedad; b) la segunda consiste en que se haya producido un daño o un perjuicio para un tercero. Como consecuencia de ello, la persona o personas que "instrumentan" la sociedad causante del daño deben responder, sin que se puedan amparar en la responsabilidad limitada de la misma. No es suficiente la existencia de una conducta antijurídica de la sociedad, sino que además es preciso que la misma se utilice abusivamente para causar el perjuicio al tercero.

Sobre la doctrina del levantamiento del velo societario véanse las STS, Sala Civil, 28 de mayo de 1984 -RJ 1984, 2800-; 20 de junio de 1991 -RJ 1991, 4526-; 16 de marzo de 1992 -RJ 1992, 2189-; 201/2008, de 28 de febrero -Rec. 5713/2000-; 630/2010, de 14 de octubre -Rec. 2253/2006-; 326/2013, de 16 de mayo -Rec. 1892/2010-; 127/2015, de 17 de marzo -Rec. 767/2013-; y Sentencias TS, Sala Social, 20 de junio de 2018 -Rec. 168/2017-, entre otras muchas. 
la prohibición del fraude de ley (art. 6.4 del Código Civil ${ }^{1265}$ ) y del abuso de derecho (art. 7.2 del Código Civil ${ }^{1266}$ ).

La doctrina del levantamiento del velo ha sido fruto de la labor creativa jurisprudencial, para la superación del ropaje formal de la personalidad jurídica de la sociedad mercantil, para extender el ámbito de los sujetos responsable de la obligación de cotizar a la Seguridad Social, a otros sujetos o personas físicas o jurídicas relacionadas con aquélla en determinadas situaciones. ${ }^{1267}$

Siendo la doctrina del levantamiento del velo un medio para combatir el uso fraudulento de la limitación de la responsabilidad, al ser principio general del Derecho que el fraude no se presume, sino que ha de ser acreditado por quien lo alegue, se precisa que se pruebe debidamente que, por la forma de operar la sociedad, el ropaje societario se utiliza para eludirse la aplicación de la responsabilidad personal del socio de control.

${ }^{1265}$ Art. 6.4 "Los actos realizados al amparo del texto de una norma que persigan un resultado prohibido por el ordenamiento jurídico, o contrario a él, se considerarán ejecutados en fraude de ley y no impedirán la debida aplicación de la norma que se hubiere tratado de eludir".

${ }^{1266}$ Art. 7.2 "La Ley no ampara el abuso del Derecho o el ejercicio antisocial del mismo. Todo acto u omisión que por la intención de su autor, por su objeto o por las circunstancias en que se realice sobrepase manifiestamente los límites normales del ejercicio de un Derecho, con daño para tercero, dará lugar a la correspondiente indemnización y a la adopción de las medidas judiciales o administrativas que impidan la persistencia en el abuso".

${ }^{1267}$ En Sentencia del TS, Sala Social, de 25 de mayo de 2000 -Rec. 895/1999-, en el Fundamento de Derecho Segundo, se señala que, "Levantar el velo de una persona jurídica consiste en hacer abstracción de su personalidad, o de alguno de sus atributos, en hipótesis determinadas. El origen de la teoría se atribuye a los tribunales anglosajones, y equivale a una reacción o modalización del principio de separación de patrimonios, fruto de la constitución de la persona jurídica, originariamente construido por el Derecho alemán. Las fuentes de esta teoría son jurisprudenciales, no legales, porque el fenómeno equivale a una derogación judicial de las reglas de la persona moral o jurídica: el levantamiento del velo tiene lugar siempre con ocasión de un litigio donde el juez estima que los principios de la persona jurídica han sido en realidad desconocidos por los propios socios o componentes de la entidad. Doctrina y jurisprudencia admiten que la regla debe ser el respeto de la personalidad moral; pero acto seguido admiten la necesidad ocasional de levantar el velo, porque lo impone "la realidad de la vida y el poder de los hechos" o "la preeminencia de las realidades económicas sobre las formas jurídicas"; hasta se apela al interés público y a la equidad. De ahí que haya sido preciso construir un inventario de las situaciones que caracterizadamente autorizan el levantamiento, destacando entre ellas la confusión de patrimonios, la infracapitalización, el fraude, la persona jurídica ficticia y la conclusión de contratos entre la persona física y su sociedad".

Mediante la técnica de «levantamiento del velo», según Sentencia del TS, Sala Civil, de 12 noviembre 1991 -Aranzadi 1991/8234-, “y ante el conflicto entre Seguridad Jurídica y Justicia, valores consagrados hoy en la Constitución (arts. 1.1 y 9.3), se ha decidido prudencialmente y según los casos y circunstancias, por aplicar partiendo de la equidad y acogimiento del principio de la buena fe (artículo 7.1 del Código Civil) la práctica de penetrar en el substratum personal de las entidades o sociedades, a las que la Ley confiere personalidad jurídica propia, con el fin de evitar que al socaire de esa ficción de forma legal (de respeto obligado, por supuesto) se puedan perjudicar ya intereses privados o públicos como camino del fraude (art. 6.4 del Código Civil) admitiéndose la posibilidad de que los jueces puedan penetrar (levantamiento del velo jurídico) en el interior de esas personas cuando sea preciso para evitar el abuso de esa independencia (art. 7.2 del Código Civil), en daño ajeno o de los Derechos de los demás (art. 10 de la Constitución)". 
Toda sociedad de capital tiene su patrimonio y personalidad jurídica propia, que son independientes de la personalidad y patrimonio de sus socios. Personalidad de la entidad mercantil que no puede desconocerse, que está protegida por el Derecho, razón por la cual, el desconocimiento de la personalidad jurídica societaria debe ser excepcional, el último recurso, si no queremos arrumbar una institución fundamental en el tráfico jurídico, como es la sociedad mercantil en general. Aplicación excepcional y ponderada del levantamiento del velo, que ya se anunciaba la Sentencia del TS, Sala Civil, de 28 de mayo de 1984, al dejar claro que levantar el velo "no significa que haya de soslayarse o dejarse de lado la personalidad del ente gestor constituido en sociedad anónima sujeta al Derecho privado", sino que es instrumento para combatir la utilización fraudulenta de la institución societaria. La circunstancia de que la sociedad tenga una única persona con control del capital social, no puede ser motivo suficiente para desconocer la personalidad y existencia independiente de la sociedad. Esta técnica del levantamiento del velo societario, en cuanto es un medio para combatir el fraude, de reaccionar ante el uso torticero de la limitación de la responsabilidad que es consustancial a las sociedades de capital, exige que se acrediten suficientemente los elementos constitutivos del fraude.

Con esta doctrina del levantamiento de velo, y partiendo de la necesidad de respetar con carácter general la personalidad de la sociedad, de modo excepcional se admite en determinadas circunstancias, la necesidad de levantar el velo, porque lo impone "la realidad de la vida y el poder de los hechos o la preeminencia de las realidades económicas sobre las formas jurídicas; y hasta se apela al interés público y a la equidad" (Sentencia del TS, Sala Social, de 25 de mayo de 2000 -Rec. 895/1999-).

Para que pueda desconocerse la personalidad societaria del único socio de control de la sociedad de capital, han de concurrir otras circunstancias que denoten un ánimo de fraude a sus acreedores, entre ellos a sus trabajadores, y por ende a la Seguridad Social, como entidad acreedora de las obligaciones empresariales derivadas de las relaciones laborales.

Con esta doctrina del levantamiento del velo se prescinde del mero ropaje formal societario, para penetrar en el verdadero substrato personal, tratando de imputar la responsabilidad a la persona física que realmente organice y dirija la actividad laboral, y consiguientemente quien debe asumir la responsabilidad por obligaciones con la 
Seguridad Social. Se trata de identificar"1268 "los reales intereses que subyacen en el interior de la sociedad, para evitar sociedades o empresas ficticias, insolventes, cuyo único fin es eludir la responsabilidad personal de sus miembros, para que no se perjudiquen otros intereses dignos de protección, públicos o privados, al amparo de esta ficción o apariencia legal".

El efecto de esta doctrina del levantamiento del velo es extender la responsabilidad a personas distintas a la propia persona jurídica societaria, para evitar eludirse la responsabilidad de otros sujetos o entidades que son los realmente responsables (los socios). Pero no tiene como finalidad esta doctrina dejar sin efecto jurídico a la sociedad, ya que, al extenderse el círculo de sujetos responsables, no se está declarando la nulidad de la sociedad. En este sentido DE ÁNGEL YÁGÜEZ ${ }^{1269}$, concluye que las sentencias que levantan el velo societario no declaran la nulidad de la sociedad, por lo que siguen operando en el tráfico jurídico.

Dentro de la doctrina de levantamiento del velo societario, es objeto de análisis el supuesto de sociedad con socio de control que ejerce la actividad sirviéndose del ropaje societario para eludir la responsabilidad patrimonial personal ilimitada (de ser persona física), que puede reunir también la condición de administrador social, o administrador de la sociedad dominante si las sociedades dominadas son sociedades ficticias sin actividad real, despatrimonializadas, sirviendo de mero centro de imputación de deudas.

Nos interesa la figura del administrador-socio de control, la responsabilidad imputable al socio por la teoría del levantamiento del velo, en cuanto sujeto que debe ser calificado como el verdadero empleador, que utiliza el ropaje societario para diluir su responsabilidad, ya que la responsabilidad del administrador de la sociedad dominante fue abordada en el capítulo cuarto, dentro del ámbito subjetivo, al estudiar la responsabilidad de ese administrador, al que nos remitimos.

\section{2.- Responsabilidad del socio de control-administrador.}

El supuesto de responsabilidad por uso fraudulento de la personalidad jurídica de la sociedad de capital, tiene lugar cuando el administrador-socio con control mayoritario o

\footnotetext{
${ }^{1268}$ CAVAS MARTÍNEZ, F.: "Jurisdicción competente para determinar la responsabilidad solidaria de los administradores sociales por débitos laborales y de Seguridad Social”, en Revista Doctrinal Aranzadi Social, Vol. II párrafo. 30, 1998, edición digital, pp. 1-2 .

1269 DE ÁNGEL YÁGÜEZ, R.: La doctrina del levantamiento del velo de la persona jurídica en la jurisprudencia, Civitas, 6 edición, 2013, p. 122.
} 
exclusivo de la sociedad de capital (normalmente en las sociedades de escasa entidad patrimonial y societaria, en que suele aunarse la doble condición de socio dominante y administrador), ejerce realmente la actividad empresarial a título personal, pero bajo el ropaje formal de la personalidad jurídica de la sociedad, con la finalidad de eludir fraudulentamente ante los acreedores la responsabilidad personal patrimonial ilimitada. Será a través de la teoría del levantamiento del velo ${ }^{1270}$ como podremos penetrar en el sustrato material real de la sociedad para desconocer y superar su constitución formal aparente.

La finalidad de la doctrina de levantamiento del velo es identificar al verdadero empresario responsable de las obligaciones derivadas de la relación laboral, penetrar en el sustrato societario cuando se constituye y actúa fraudulentamente la sociedad, con la pretensión de eludir la responsabilidad patrimonial que correspondería a la persona que realmente ejerce la actividad empresarial. Para evitar esas actuaciones fraudulentas se ha elaborado la doctrina jurisprudencial del "levantamiento del velo de la sociedad".

Para evitar un uso abusivo de la personalidad jurídica de las sociedades mercantiles, según HERNANDO CEBRIÁ 1271, “mediante la doctrina del levantamiento del velo se penetra en el sustrato personal de las sociedades mercantiles, con la finalidad de hacer responsable al sujeto que ejerciendo la actividad de modo personal, especialmente cuando el socio único con control total de la entidad, y administrador, se sirve del ropaje de la personalidad jurídica propia de la sociedad para eludir de modo fraudulento la responsabilidad patrimonial personal ilimitada del art. 1911 del Código Civil, y en el orden social, para evitar ostentar la condición de empresarial y sujeto obligado y responsable personalmente de ingresar las cotizaciones de Seguridad Social”.

La doctrina del levantamiento del velo, se ha elaborado como señala CAVAS MARTÍNEZ ${ }^{1272}$, "normalmente, con la finalidad de identificar al empresario real en aquellos supuestos en que la personalidad jurídica de la sociedad, su autonomía patrimonial y la limitación de la responsabilidad de los socios se utiliza abusivamente para privar de efectividad a los derechos de los trabajadores".

1270 STS, Sala Civil, 30 de diciembre de 2015 -Rec. 2002/2013-; 127/2015, de 17 de marzo de 2013 -Rec. 767/2013-; 14 de octubre de 2010 -Rec. 2253/2006-; 28 de febrero de 2008; 19 de septiembre de 2007; y STS, Sala Social, 20 de junio de 2018 -Rec. 168/17-, entre otras.

1271 HERNANDO CEBRIÁ, L.: “¿Sociedad dominante administradora de hecho? Más allá del velo corporativo", 2011, op. cit., versión electrónica, p. 27.

1272 CAVAS MARTÍNEZ, F.: "La responsabilidad patrimonial de los socios y administradores sociales en el ámbito laboral”, en Revista Doctrinal Aranzadi Social, núm. 9/2002, edición digital, p. 5. 
Con la doctrina del levantamiento del velo se permite desconocer la personalidad jurídica de una sociedad, para penetrar en el fondo o sustrato de la entidad, y atribuir la responsabilidad a la persona o entidad que realmente ejerza una actividad, sirviéndose torticeramente del ropaje de la limitación de la responsabilidad que acompaña a la sociedad de capital, siendo una consecuencia de la aplicación de la prohibición del fraude de ley y del abuso de derecho (arts. 6.3 y 7.2 del Código Civil). La teoría del levantamiento del velo supone, en definitiva, un procedimiento para descubrir y reprimir el abuso cometido al servirse torticeramente de la autonomía jurídica formal, de la personalidad jurídica diferenciada de una sociedad, sancionando a quienes la utilizan fraudulentamente en daño de terceros acreedores

Como señala CAVAS MARTÍNEZ1273 “en ocasiones, la constitución de la sociedad (a menudo, unipersonal, familiar) no es más que un subterfugio, una operación de ingeniería jurídica con la que se busca eludir la responsabilidad personal del empresario real y desviar dicha responsabilidad al patrimonio social, cuando éste existe, porque no es infrecuente que estas sociedades se constituyan con un capital social mínimo, o hayan sido sobrevenidamente descapitalizadas, siendo vaciadas de patrimonio y de actividad no obstante lo cual se las mantiene como sociedades ficticias".

En la jurisprudencia social ${ }^{1274}$, en virtud de la técnica del levantamiento del velo, "se penetra en la realidad subyacente de la sociedad mercantil para evitar que a través de la misma pueda realizarse una actuación fraudulenta en perjuicio de terceros. Partiendo de este criterio realista, de primacía de realidad, de la determinación de la responsabilidad del verdadero empresario ha sido aplicado por la Sala de lo Social, en diversas ocasiones, apreciando la responsabilidad directa del empresario oculto en supuestas sociedades aparentes como muestran, entre otras, las Sentencias de 29 de marzo de 1985 (RJ 1985\1451), 9 de junio de 1987 (RJ 1987\4316) y 12 de diciembre de 1988 (RJ 198819592)".

La doctrina del levantamiento del velo, en cuanto manifestación del principio de prohibición del fraude de ley, para imputar la responsabilidad a quien realmente ejerce la actividad empresarial, sirviéndose del ropaje de la sociedad, tendrá carácter

${ }^{1273}$ CAVAS MARTÍNEZ, F.: "La responsabilidad patrimonial de los socios y administradores sociales en el ámbito laboral”, 2002, op. cit., p. 4.

${ }^{1274}$ Sentencia del TS, Sala Social, de 27 de marzo de 1989 -Aranzadi 1989/2416-, que Recoge la doctrina de la Sentencia del TS, Sala Civil, de 28 de mayo de 1984 -Aranzadi RJ 1984/2800-. 
excepcional, y exigirá un especial esfuerzo probatorio por quien lo invoque, principalmente por dos razones. En primer lugar, porque nuestro ordenamiento permite la creación de sociedades unipersonales (arts. 12 a 17 de la LSC), sin que su composición familiar societaria sea impedimento jurídico alguno para su lícita existencia, de modo que esas meras circunstancias no podrán conducirnos a declarar la responsabilidad patrimonial de los socios. En segundo lugar, que al ser la doctrina del levantamiento del velo una manifestación de la doctrina de la prohibición del fraude de ley, el fraude no se presume, sino que exige prueba del mismo, lo que significa que, salvo prueba suficiente en contrario, habrá de reconocerse la personalidad societaria, la responsabilidad patrimonial de la sociedad, respondiendo sólo los socios de la obligación de aportar el capital suscrito, sin responder de las deudas sociales (art. 1 de la LSC). Si se pretende que sea imputable la responsabilidad a los socios, por ser la sociedad un mero ropaje jurídico para eludir la aplicación de la responsabilidad personal patrimonial ilimitada de las personas que realmente ejercen la actividad empresarial, habrán de acreditarse los hechos objetivos que permitan llegar a esa conclusión, correspondiendo esa prueba a la Inspección de Trabajo y Seguridad Social, quien a través de los Inspectores y Subinspectores podrán comprobar, en actuaciones directas ante la empresa, la realidad material del ejercicio empresarial, al estar facultados para visitar los centros de trabajo, recabar información ante el empresario y los trabajadores, así como requerir la aportación de todo tipo de documentación, sea laboral, fiscal, mercantil, etc., con trascendencia en el cumplimiento de las obligaciones empresariales del orden social (art. 13, apartados 1 y 3 de la LOITSS).

Para esa labor tendente a acreditar los hechos objetivos que permitan concluir que estamos ante el ejercicio de la actividad empresarial por el socio o los socios, deberá partirse de la jurisprudencia y la doctrina judicial, donde se han ido perfilando los elementos probatorios necesarios o suficientes para la aplicación solvente de la doctrinal del levantamiento del velo, en cuanto vía excepcional de desconocimiento de la personalidad societaria.

Tanto en la doctrina científica, como en la jurisprudencia, se parte siempre de la regla general de que debe respetarse la personalidad moral o jurídica de la sociedad; y sólo, como técnica jurídica excepcional, se admite la necesidad ocasional de levantar el velo, cuando lo imponga "la realidad de la vida y el poder de los hechos", o "la preeminencia de las realidades económicas sobre las formas jurídicas", para imputar la condición de 
empresario real al socio o los socios, de ahí que haya sido necesario construir un inventario de situaciones que autorizan el levantamiento o desconocimiento de la personalidad societaria, destacando entre ellas, la confusión de patrimonios, la infracapitalización, el fraude, la persona jurídica ficticia y la conclusión de contratos entre la persona física y su sociedad ${ }^{1275}$.

En la Sentencia del TS, Sala Social, 850/2017, de 31 de octubre -Rec. 115/2017- ${ }^{1276}$, se señala sobre grupo empresarial a efectos laborales, y en lo que aquí nos interesa, con relación al funcionamiento unitario que, "en los supuestos de prestación de trabajo indistinta o conjunta para dos o más entidades societarias de un grupo nos encontramos, ante una única relación de trabajo cuyo titular es el grupo en su condición de sujeto real y efectivo de la explotación unitaria por cuenta de la que prestan servicios los trabajadores; situaciones integrables en el art. 1.2. ET, que califica como empresarios a las personas físicas y jurídicas y también a las comunidades de bienes que reciban la prestación de servicios de los trabajadores". Principio general que es de aplicación al ejercicio de la actividad individual o plural por los socios (empleador plural), y no sólo a los grupos societarios.

El control del capital por la sociedad dominante o por el único o mayoritario socio, no implica que concurra, en todo caso, el elemento indiciario de la confusión patrimonial, para pretender derivar la responsabilidad al socio del control, ya que, el simple dato de participación económica, por llamativo que pueda parecer, incluso con el control de la totalidad del capital social, si no existen elementos adicionales que prueben una condición de empresario real oculto, carece de relevancia ya que, esa participación económica tiene expreso reconocimiento legal en las sociedades unipersonales, no siendo factor determinante de la extensión de la responsabilidad solidaria, sin que nos permita atribuir la condición de empresario al sujeto con control societario ${ }^{1277}$. No debe confundirse la confusión de patrimonio, con que el capital social esté en manos de un único socio.

En las sociedades de capital rige el principio de que los socios no responden

${ }^{1275}$ Sentencias del TS, Sala Social, de 26 de diciembre de 2001 -rcud. 139/2001- y 9 de julio de 2001 -RJ 2001/10019-.

${ }^{1276}$ En igual sentido, Sentencias del TS, Sala Social, 20 de junio de 2018 -rcud. 168/2017-; 20 de octubre de 2015 -Rec. 172/2014-; 31 de octubre de 2017 -Rec. 115/2017-; y 10 de noviembre de 2017 -rcud. 3049/2015-, entre otras muchas.

1277 Sentencias del TS, Sala General de lo Social (Pleno), de 25 de septiembre de 2013 -Aranzadi 2014/1204, Recurso de casación 3/2013-; y de 27 de mayo de 2013 -Rec. 78/2012-. 
personalmente de las deudas sociales, principio aplicable igualmente en el caso de concentración de todas las acciones en una sola persona. La Jurisprudencia, fiel a este principio básico del régimen jurídico de las sociedades, ha mantenido ininterrumpidamente como regla general la doctrina de la no exigencia de responsabilidad a las personas físicas accionistas mayoritarias de una sociedad, inclusive cuando fueran administradores o consejeros de la empresa, salvo que quedara demostrada la existencia de fraude de Ley en la utilización de la forma societaria, en cuyo caso ha procedido a "levantar el velo de la personalidad societaria" y a "penetrar en el sustrato personal de la persona jurídica (Sentencia del TSJ Andalucía/Málaga, Sala Social, 653/2019 de 10 abril -Aranzadi 2019/1697-). Existirá ese fraude de ley, según esa Sentencia, cuando "la sociedad no es más que una apariencia formal, que encubre una actuación individual o plural de naturaleza no societaria, cuyas responsabilidades se tratan de eludir acudiendo a la creación de lo que no es más que una ficción, amparándose para ello en normas que persiguen un fin diferente y que se utilizan de manera fraudulenta para obtener un propósito que, en cuanto civilmente ilícito, no puede ser jurídicamente protegido. Es indiscutible que esta situación puede perseguirse ya desde la constitución de la sociedad o lograrse a lo largo de la vida de la misma, pero siempre se encarna a través de una voluntad precisa y consciente de crear o mantener como sociedad lo que en realidad no lo es, y con la finalidad de desligar patrimonios privados de una responsabilidad personal que trata de eludirse, trasladándola a una persona jurídica cuya existencia, por su irrealidad, no puede ser mantenida en Derecho".

Cuando la sociedad que formalmente ejerce la actividad empresarial, no cumple con unas mínimas obligaciones que permitan reconocerla como tal en el tráfico jurídico, como sociedad real, al carecer de contabilidad, no haber celebrado ninguna reunión de sus órganos societarios, se ha levantado el velo, imputándose la condición de empresario al socio o los socios. En la Sentencia del TS, Sala Social, de 29 de marzo de 1985 -Aranzadi 1985/1451-, constaba que: “el demandado Sr. P, con la colaboración de su esposa, constituyó formalmente una Sociedad Anónima, de existencia sólo aparente y de la que ni se llevó contabilidad, ni se celebraron juntas de accionistas, para enmascarar una actuación empresarial plenamente individual". Partiendo de que la sociedad no ha operado como tal, siendo un mero ropaje formal para eludir las responsabilidades de las personas físicas, verdaderos titulares de la actividad, concluye 
que, "no puede invocarse la infracción del artículo 1.2 del Estatuto de los Trabajadores, pues concurre en ellos la calidad que niegan tener de empresarios, como personas físicas que reciben la prestación de servicios de los trabajadores, ni tampoco en interpretación errónea del artículo 1902 del Código Civil, ni de los artículos 1, 79 y 80 de la Ley de Sociedades Anónimas, pues lo que se sostiene en la sentencia es que no se puede eludir la responsabilidad patrimonial genérica, que proclama dicho Código, mediante la creación de una Sociedad puramente aparente en cuanto nunca ha funcionado como tal".

En la Sentencia del TS, Sala Social, de 9 junio 1987 -ECLI:ES:TS:1987:12092, Aranzadi 1987/4316-, se levantó el velo de una mercantil, por cuanto que el anterior empresario individual, que venía ejerciendo la actividad empresarial como persona física, procedió con posterioridad a constituir una sociedad titulada con su propio nombre y apellidos, a la que incorporó a su esposa y a su hija, a los solos efectos de lograr la pluralidad de fundadores precisa para su constitución; pero el capital social de dicha sociedad nunca fue aportado, ni la misma funcionó nunca como tal persona jurídica real; sin que la empresa en su funcionando hubiere experimentado en ningún momento modificación alguna; continuando el anterior empresario individual como la única persona que dirigía la actividad, incluso después de haber sido declarado en situación de incapacidad permanente absoluta por la entidad gestora de la Seguridad Social. En esta sentencia ante el despido de los trabajadores, se condena al anterior empresario que constituyó la sociedad, porque continuó siendo el verdadero empresario real, siendo la sociedad constituida meramente un ropaje formal sin contenido real, y exonera de responsabilidad a los otros socios de su núcleo familiar, ya que, como meros socios aparentes no han tenido la condición de empleadores.

Pese a la forma societaria se consideró empresario a los socios y administradores de una sociedad de capital, miembros de una misma familia, por ejercer realmente la actividad empresarial a título personal, pero sirviéndose del ropaje de una sociedad mercantil, y partiendo de los artículos 6 y 7 del Código Civil se les declara responsables solidarios de las relaciones laborales, en cuanto empresa familiar de titularidad compartida, por ejercerse la actividad a título individual o personal por el administrador social (Sentencia del TS, Sala Social, de 26 febrero 1990 -ECLI:ES:TS:1990:17276, Aranzadi $\left.1990 / 1232-{ }^{1278}\right)$.

${ }^{1278}$ En esa Sentencia se concluye que, "aplicando tales principios básicos del ordenamiento jurídico al caso que hoy ocupa la atención enjuiciadora de la Sala no puede, ciertamente, ignorarse que, conforme 
Al haber confusión de patrimonios entre las sociedades y los socios administradores, siendo todos ellos los que han recibido la utilidad patrimonial de la prestación laboral de servicios, se ha declarado la responsabilidad solidaria de las sociedades y de los socios administradores, al apreciarse la condición de coempresarios, en Sentencia del TS, Sala Social, 9 julio 2001 -rcud. 4378/1999_- 279

Se declaró que la condición real de empresario era atribuible a los socios, cuando habiéndose constituido la sociedad en escritura pública, no llegó a inscribirse en el Registro Mercantil, y ello no obstante, lleva a cabo su actividad concertando como tal sociedad contratos de trabajo, levantándose el velo societario en la Sentencia del TSJ Cataluña, Sala Social, 7805/1999, de 3 noviembre -Aranzadi 1999/4664-, porque con "tal proceder no sólo se abusa de la personalidad confundiendo la esfera societaria y la individual, sino que se utiliza la fórmula y denominación de sociedad anónima con sólo cobertura aparente y sin existencia jurídica real con fines contrarios a los previstos por el ordenamiento, lo que implica y lleva aparejada la responsabilidad de las consecuencias de su actuación solidariamente a los integrantes de tal entelequia fraudulenta".

En Sentencia del TSJ de Canarias/Tenerife, Sala Social, 714/2016, de 4 octubre -JUR 2017/221958- ${ }^{1280}$, se levantó el velo societarios de varias sociedades, con un mismo

al firme relato histórico de la sentencia impugnada, la fórmula societaria que se adoptó para la configuración de la titularidad empresarial a la que vinieron prestando servicios los trabajadores demandantes comportó un evidente ropaje jurídico que encubrió una realidad empresarial distinta, protagonizada por las tres personas físicas, ahora recurrentes (...), cuando queda acreditado según el incombatido relato fáctico probado de la sentencia recurrida, que la fórmula societaria, pese a su aparente formalidad jurídica, encubrió una real titularidad empresarial de carácter familiar que se desenvolvió en función de los intereses individuales de las personas unidas por el vínculo parental, es obvio, que no cabe reconocer virtualidad a aquella mera apariencia jurídica, reveladora de un manifiesto fraude legal y perturbadora de los legítimos intereses de tercero, cuya buena fe resulta claramente conculcada (...), al darse una situación de manifiesta irregularidad material en la configuración del expresado ente social, cuya existencia sólo vino a encubrir la realidad de una empresa familiar directamente regida por el expresado recurrente, obviamente, no cabe esgrimir con éxito aquella condición de mero gestor de la persona jurídica para eludir las responsabilidades inherentes al efectivo y real desempeño, a nivel individual, de una compartida titularidad empresarial.

1279 En esa Sentencia se señala, "es claro, y ya se ha razonado el fundamento de la Sentencia de suplicación para aplicar un criterio de responsabilidad solidaria, porque todos los demandados han venido beneficiándose de la actividad profesional del demandante, aunque, como narra el hecho probado primero él haya venido prestando sus servicios «para las empresas Cepilux fabricación, SA y Carboline Ibérica, SA», puesto que la confusión de actividades, propiedades, patrimonios, la dirección desarrollada por las mismas personas físicas etc. han llevado a la conclusión de la unidad de empresa y de responsabilidad solidaria, sin que el recurrente sea capaz de destruir dicha convicción".

${ }^{1280}$ En esa Sentencia se señala "la Sentencia de instancia no condenó al recurrente en base a culpa o negligencia en el desempeño de la administración social, sino, como se reconoce por el propio recurrente, por aplicación de la doctrina del levantamiento del velo. De manera que mal puede entenderse que en la sentencia de instancia se haya resuelto sobre una cuestión para la que la 
administrador social, que procedió a despatrimonializar la sociedad en que prestaba servicios el trabajador demandante, sin haber presentado en el Registro Mercantil las cuentas ninguna de las sociedades, teniendo todas ellas el mismo domicilio, declarándose que el verdadero empresario era el administrador social en aplicación de la doctrina del levantamiento del velo. La condena del administrador no fue por responsabilidad patrimonial en el ejercicio del cargo (art. 241 de la LSC), cuestión sobre la que Jurisdicción Social carece de competencia, como bien se indica en esa resolución judicial, sino por levantamiento del velo.

Estaremos ante indicios de una sociedad ficticia, donde la condición de empresario debería ser atribuida a las personas que dirijan y reciban la utilidad patrimonial de las prestaciones laborales de los trabajadores, sea el socio y/o el administrador social, cuando concurran incumplimiento de unas mínimas obligaciones formales que permitan reconocer hallarnos ante una verdadera sociedad de capital, como pueden ser a título enunciativo las siguientes. En primer lugar, cuando no conste tener o mantener la sociedad el capital aportado, pese a haberse declarado y justificado ante el notario en el momento de su constitución (art. 62 LSC), si ha sido posteriormente distraído. En segundo lugar, cuando no conste que se hayan celebrado reuniones de los órganos de gobierno y administración -reuniones del órgano de administración o de la junta de accionistas, especialmente las obligatorias, como la aprobación de las cuentas anuales (arts. 160 a 164, 253 y 272 de la LSC)-. En tercer lugar, cuando no se lleva libro alguno de la sociedad, como el libro de actas de la Junta (art. 202 LSC), libro de actas del Consejo de Administración (art. 250 LSC), el libro registro de socios (art. 104 LSC). En cuarto lugar, cuando no se formulan las cuentas anuales, ni se depositan en el Registro Mercantil. En quinto lugar, cuando los medios patrimoniales necesarios para la actividad -sean inmuebles, bienes muebles, marcas, patentes, etc.- no sean de la

jurisdicción social es incompetente (como es, en efecto, la acción de responsabilidad patrimonial de los administradores sociales prevista en el artículo 241 de la Ley de Sociedades de Capital (...) La condena solidaria del recurrente se basó por la juzgadora en la aplicación de la doctrina del levantamiento del velo, por considerar, a la vista de la prueba practicada, que el verdadero empleador era en todo momento D. Cecilio y que las sociedades mercantiles eran solo aparentes. Y la jurisdicción social sí que es competente para resolver sobre este levantamiento del velo, pues al fin y al cabo no es una cuestión separada y autónoma de la relación laboral (como es la responsabilidad patrimonial de administradores), sino que implica indagar y resolver sobre quien es el verdadero empleador en el contrato de trabajo. Que la juzgadora haya aplicado de oficio la doctrina del levantamiento del velo no es en sí irregular por cuanto se trata de una manifestación del principio quot iura novit curia, a partir de los concretos hechos aportados el procedimiento por las partes, el juzgador puede aplicar el Derecho que considere correcto, sin sujetarse a la concreta fundamentación jurídica usada por las partes". 
sociedad, sino del tercero que se sirve del ropaje societario. En sexto lugar, cuando constan ingresos y pagos de la actividad en cuentas bancarias de titularidad individual y no societaria, o en cuentas bancarias societarias pero cuyos fondos posteriormente acaban en cuentas individuales del socio.

Si se cumpliesen por la sociedad esas mínimas obligaciones formales que permitan reconocer operativamente a una sociedad en el ejercicio de su objeto social, para que pudiera tener éxito el levantamiento del velo, atribuyendo la responsabilidad a la persona que se sirviese del ropaje societario para desarrollar la actividad, deberá acreditarse, bien mediante prueba directa, que será normalmente de difícil aportación, y especialmente a través de la prueba de indicios, que pese a realizarse formalmente esos actos a nombre de la sociedad, quien realmente ejerce la actividad es el tercero, por ser el titular real de los medios patrimoniales, de la organización empresarial, y, quien, es en último término, el beneficiario de la utilidad patrimonial de las relaciones laborales.

En los supuestos de levantamiento del velo procederá la derivación de la responsabilidad, al amparo del art. 18.4 del TRLGSS, a las personas que realmente ejercen la actividad empresarial, sirviéndose fraudulentamente del ropaje societario, por cuanto en ese precepto se permite exigir la responsabilidad en las deudas de Seguridad Social a la persona que realmente dirige la prestación laboral y recibe la utilidad patrimonial de los servicios laborales. Estamos ante una responsabilidad de quien realmente tiene el control y obtiene la utilidad de las relaciones laborales, que no necesariamente será el administrador social, aunque en sociedades de escaso capital y familiares, suelen confluir en una misma persona la condición de socio y administrador. Derivación de responsabilidad al socio o administrador que realmente ejerce la actividad empresarial, en virtud de la doctrina del levantamiento del velo, admitida en Consulta de la DGITSS de 21 de enero de $2011^{1281}$.

Sería ese socio único o socio de control que se sirve fraudulentamente del ropaje de la personalidad jurídica de la sociedad de capital, el responsable de las obligaciones con la Seguridad Social que resulten de las prestaciones laborales de servicios desarrolladas formalmente para la sociedad unipersonal ${ }^{1282}$

\footnotetext{
${ }^{1281}$ Referencia la Ley 72/2011.

1282 Situación distinta sería cuando el socio único utiliza la sociedad, no para encubrir relaciones laborales de sus trabajadores, sino para prestar servicios formalmente bajo la cobertura de un contrato civil o mercantil con otra empresa, cuando la prestación de servicios de socio único en el ámbito de esa otra
} 
Ante la insuficiencia del art. 18.4 del TRLGSS, que limita la responsabilidad sólo a deudas por cotizaciones, como medida de lege ferenda, proponemos que debe extenderse la responsabilidad del empresario real también a las deudas por prestaciones de responsabilidad empresarial, para que en el art. 168 del TRLGSS, o bien se reproduzca igual precepto para las deudas por prestaciones, o bien, lo que estimamos mejor técnicamente, se haga una remisión expresa en materia de responsabilidad en prestaciones al art. 18.4 del TRLGSS.

\section{VI.- RESPONSABILIDAD CONCURSAL NO DERIVABLE DEL ADMINISTRADOR SOCIAL DE LA SOCIEDAD EN CONCURSO DE ACREEDORES.}

La responsabilidad concursal del administrador social se regula en el art. 456 del TRLC $^{1283}$, que al ser un Texto Refundido, recoge la redacción dada mediante el Real Decreto-Ley 4/2014, de 7 de marzo, por el que se adoptan medidas urgentes en materia de refinanciación y reestructuración de deuda empresarial ${ }^{1284}$

Este nuevo régimen de responsabilidad concursal se aplica a las secciones de calificación que se hayan abierto estando en vigor la reforma legal del año 2014, pero

empresa reúna los requisitos de una relación laboral: prestación personal de servicios, dependiente, retribuida y por cuenta ajena. En este caso la sociedad unipersonal se utiliza para ocultar una relación laboral. Al respecto véase, SELMA PENALVA, A.: "La relación laboral encubierta. La "sociedad unipersonal" como forma de simulación", Revista española de Derecho del Trabajo, núm. 143, 2009, editorial Cívitas.

1283 "Artículo 456. Condena a la cobertura del déficit.

1. Cuando la sección de calificación hubiera sido formada o reabierta como consecuencia de la apertura de la fase de liquidación, el juez, en la sentencia de calificación, podrá condenar, con o sin solidaridad, a la cobertura, total o parcial, del déficit a todos o a algunos de los administradores, liquidadores, de Derecho o de hecho, o directores generales de la persona jurídica concursada que hubieran sido declarados personas afectadas por la calificación en la medida que la conducta de estas personas que haya determinado la calificación del concurso como culpable hubiera generado o agravado la insolvencia.

2. Se considera que existe déficit cuando el valor de los bienes y Derechos de la masa activa según el inventario de la administración concursal sea inferior a la suma de los importes de los créditos reconocidos en la lista de acreedores.

3. En caso de pluralidad de condenados a la cobertura del déficit, la sentencia deberá individualizar la cantidad a satisfacer por cada uno de ellos, de acuerdo con la participación en los hechos que hubieran determinado la calificación del concurso.

4. En caso de reapertura de la sección sexta por incumplimiento del convenio, si el concurso hubiera sido ya calificado como culpable, el juez para fijar la condena a la cobertura, total o parcial, del déficit, atenderá tanto a los hechos declarados probados en la sentencia de calificación como a los determinantes de la reapertura".

Real Decreto-Ley convertido posteriormente en la Ley 17/2014, de 30 de septiembre, por la que se adoptan medidas urgentes en materia de refinanciación y reestructuración de deuda empresarial" (BOE del 1 de octubre), que añadieron al art. 172 bis apartado 1 de la anterior Ley Concursal de 2003 el inciso final siguiente "en la medida que la conducta que ha determinado la calificación culpable haya generado o agravado la insolvencia".

${ }^{1284}$ BOE del 8.3.2014. 
no de modo retroactivo a las secciones abiertas con anterioridad, en las que regirá el régimen general de derecho transitorio conforme al cual las normas no tienen eficacia retroactiva, al declararse su irretroactividad en la jurisprudencia ${ }^{1285}$.

Podrán estar sujetos a responsabilidad concursal los administradores o liquidadores, de derecho o de hecho, así como los directores generales que ocupen esos cargos en la fecha de declaración del concurso, o que los hayan ocupado dentro de los dos años anteriores a la fecha de la declaración concursal (arts. 442, 455.2. $1^{\circ}$, y 456 del TRLC).

Responsabilidad concursal cuya consecuencia será la condena por el Juez del concurso en la sentencia de calificación a los sujetos responsable, entre ellos, a los administradores, para que cubran, en todo o en parte, el déficit patrimonial de la sociedad con la finalidad de ingresar esos importes en la masa activa de concurso, pero no para pagar directamente a los acreedores ${ }^{1286}$.

Para que pueda condenarse a la cobertura del déficit concursal a los administradores, los sujetos legitimados deberán solicitarlo expresamente, aunque no se exige que adopte la forma de una demanda, pero tampoco se prohíbe, debiendo constar expresamente la pretensión de condena a la cobertura del déficit concursal, sin que se exija la mención expresa del precepto normativo que la fundamenta ${ }^{1287}$.

1285 Sentencias del TS, Sala Civil 772/2014, de 12 de enero -Rec. 473/2013-; 421/2015, de 22 de julio Rec. 1701/2013-; 203/2017, de 29 de marzo -Rec. 1579/2014-; y 279/2019, de 22 de mayo -Rec. 1073/2016-.

${ }^{1286}$ QUIJANO GONZÁLEZ, J.: "Responsabilidad societaria y concursal de administradores: de nuevo sobre la coordinación y el marco de relaciones”, en RDCP, núm. 10/2009, versión electrónica, pp. 1314. En ese sentido la Sentencia del TS, Sala Civil, 213/2020, de 29 de mayo -Rec. 1700/2017-.

${ }^{1287}$ En las Sentencias del TS, Sala Civil, 203/2016, de 1 de abril -Rec. 2616/2013-; 256/2020 de 5 junio Rec. 3001/2017-; y 258/2020 de 5 junio -Rec. 3653/2017-, se señala, "La Ley no sujeta el informe de la administración concursal, ni el dictamen del ministerio fiscal, a una formalidad específica. Pero como deben contener una solicitud concreta y las razones que justifican esta petición, que lógicamente se fundarán en una relación de hechos y en su valoración jurídica, la forma es equivalente a la demanda. Deben contener una propuesta clara de resolución (art. 169.1 LC), lo que permite relacionar estos escritos de alegaciones con la sentencia de calificación, pues ha de pedirse, en primer lugar, una calificación fortuita o culpable, y, en este segundo caso, lo que pretenden que recoja la sentencia de calificación culpable del concurso, conforme a los pronunciamiento previstos en el art. 172 (tras la Ley 38/2011, también el art. 172 bis LC): personas afectadas por la calificación culpable y, en su caso, los cómplices; tiempo de inhabilitación; pérdida de Derechos en el concurso, obligación de restituir lo indebidamente percibido, indemnización de daños y perjuicios ocasionados por las conductas que motivan la calificación culpable, y la posible condena a los administradores (o liquidadores) para indemnizar el importe total o parcial de los créditos no satisfechos con la liquidación (actualmente, cobertura del déficit concursal). "Tanto el petitum como la causa petendi, conformada por los hechos y las razones jurídicas que justifican la concurrencia de la(s) causa(s) de calificación culpable y el resto de los pronunciamientos consiguientes, deben quedar claros en el informe y el dictamen que interesan la calificación culpable, pues con arreglo a ello se emplaza a la concursada y a las personas respecto de las que se pide sean declaradas afectadas por la calificación o cómplices, para que puedan comparecer y oponerse. Obviamente, estos "demandados" deberán 
Con relación al contenido material de la responsabilidad concursal, surge la duda acerca de qué debe entenderse por ese déficit objeto de responsabilidad, ya que en el art. 456 del TRLC no se aclara qué debe entenderse por déficit, si sería el que resulte con la realización de los activos patrimoniales del concursado para pagar todos los créditos; o, el que había al tiempo de la declaración de concurso, que ha de constar en los documentos que acompañan al informe de la administración concursal (el inventario del activo y la lista de acreedores). En las Sentencias del TS, Sala Civil, 213/2019, de 29 de mayo -Rec. 1700/2017-, 214/2020, de 29 de mayo -Rec. 1706/2017- acerca de qué debe entenderse por cobertura del déficit se señala que, "es lógico que los administradores responsables de la conducta que generó la insolvencia, mediante una conducta realizada con dolo o culpa grave, respondan de sus consecuencias, representadas por el déficit entendido como pasivo (contra la masa y concursal) que no pueda llegar a satisfacerse con el activo realizado, y que lo sea en la medida en que el tribunal de instancia haya justificado que contribuyeron a esa generación o agravación de la insolvencia”. La cursiva es nuestra.

Se declarará esa responsabilidad concursal, sólo cuando concurran estas cinco circunstancias: a) que el concurso se haya calificado culpable ${ }^{1288}$, b) que la sección de

contestar en función de la concreta calificación postulada y de las razones que la justificaban, de las que forman parte los hechos que las sustentan en la práctica, y no podrán ser juzgados por causas y hechos no alegados en el informe de la administración concursal o en el dictamen del ministerio fiscal. De tal forma que, a la vista del informe y el dictamen, con sus respectivos escritos de oposición se conforma el objeto litigioso, que, como ocurre en un juicio declarativo, impide que pueda ser juzgado algo distinto, a riesgo de incurrir en incongruencia la Sentencia".

1288 De conformidad con el art. 442 del TRLC el concurso se calificará como culpable cuando en la generación o agravación del estado de insolvencia hubiera mediado dolo o culpa grave de los administradores o liquidadores, de hecho y de Derecho, o directores generales; dolo o culpa que ha de acreditarse. En todo caso, según el art. 443 del TRLC se declarará culpable : a) cuando el deudor se hubiera alzado con la totalidad o parte de sus bienes en perjuicio de sus acreedores o hubiera realizado cualquier acto que retrase, dificulte o impida la eficacia de un embargo en cualquier clase de ejecución iniciada o de previsible iniciación; b) cuando durante los dos años anteriores a la fecha de la declaración de concurso hubieran salido fraudulentamente del patrimonio del deudor bienes o Derechos; c) cuando antes de la fecha de declaración del concurso el deudor hubiese realizado cualquier acto jurídico dirigido a simular una situación patrimonial ficticia; d) cuando el deudor hubiera cometido inexactitud grave en cualquiera de los documentos acompañados a la solicitud de declaración de concurso o presentados durante la tramitación del procedimiento, o hubiera acompañado o presentado documentos falsos; e) cuando el deudor legalmente obligado a la llevanza de contabilidad hubiera incumplido sustancialmente esta obligación, llevara doble contabilidad o hubiera cometido en la que llevara irregularidad relevante para la comprensión de su situación patrimonial o financiera; y f) cuando la apertura de la liquidación haya sido acordada de oficio por incumplimiento del convenio debido a causa imputable al concursado.

Se presume iuris tantum, culpable el concurso, según el art. 444 del TRLC, cuando el deudor o, en su caso, sus representantes legales, administradores o liquidadores: $1 .^{\circ}$ Hubieran incumplido el deber de solicitar la declaración del concurso; $2{ }^{\circ}$ Hubieran incumplido el deber de colaboración con el juez del concurso y la administración concursal, no les hubieran facilitado la información necesaria o conveniente para el interés del concurso, o no hubiesen asistido, por sí o por medio de apoderado, a la 
calificación se haya abierto como consecuencia de la apertura de la fase de liquidación ${ }^{1289}$; c) que las personas responsables hayan sido declaradas personas afectadas por la calificación del concurso culpable; d) que la conducta de esas personas, que ha llevado a calificar como culpable el concurso, haya generado o agravado la insolvencia, y e), finalmente, que la condena estará en función del grado de participación del administrador en la generación o agravación de la insolvencia.

Esta responsabilidad concursal requiere una conducta reprochable del administrador, imputable a título de dolo o culpa, y que la misma haya generado o agravado la insolvencia de la sociedad, sin exigirse que esa conducta sea la causa exclusiva de la generación o agravación de la insolvencia, por cuanto es preciso que contribuya a esas finalidades -relación de causalidad- ${ }^{1290}$. Lo que caracteriza la conducta del administrador prevista en el art. 442 del TRLC, que determina la calificación del concurso de la sociedad como culpable, es que en la generación o agravación del estado de insolvencia haya mediado dolo o culpa grave del administrador, siendo una norma que tiende a proteger los intereses de los acreedores, que son los perjudicados con esa conducta de los administradores, y no tanto de proteger los intereses de la sociedad, por lo que no es necesario que la conducta del administrador social sea contraria al mejor interés de la sociedad para que el concurso pueda calificarse como culpable (Sentencia del TS, Sala Civil, 693/2017, de 20 de diciembre -Rec. 2469/2015-). Con esa calificación de culpabilidad del concurso, por conducta antijurídica de los administradores, prima la defensa del interés de los acreedores, en la medida en que las normas del concurso culpable son normas de protección a los acreedores, más que de la sociedad $^{1291}$.

junta de acreedores, siempre que su participación hubiera sido determinante para la adopción del convenio; $3 .^{\circ} \mathrm{Si}$, en alguno de los tres últimos ejercicios anteriores a la declaración de concurso, el deudor obligado legalmente a la llevanza de contabilidad no hubiera formulado las cuentas anuales, no las hubiera sometido a auditoría, debiendo hacerlo, o, una vez aprobadas, no las hubiera depositado en el Registro mercantil o en el registro correspondiente.

1289 Sentencia del TS, Sala Civil, 108/2015, de 11 marzo -Rec. 1020/2013-, la declaración de responsabilidad concursal del administrador, sólo procede en caso de apertura de la fase de liquidación o bien en caso de reapertura de la Sección por incumplimiento del convenio, estimando que no procede su declaración, si la sección de calificación no se formó por la apertura de la fase de liquidación al haberse llegado a una solución de convenio.

1290 QUIJANO GONZÁLEZ, J.: "Responsabilidad societaria y concursal de administradores: de nuevo sobre la coordinación y el marco de relaciones”, en RDCP, núm. 10/2009, versión electrónica, p. 14.

1291 QUIJANO GONZÁLEZ, J.: "Los deberes de los administradores sociales y la calificación del concurso (Comentario de la sentencia del Tribunal Supremo, S. 1a, de 20 de diciembre de 2017)", en Anuario de Derecho Concursal, n 44/2018, Comentarios de jurisprudencia, edición digital, p. 10. 
En los supuestos del art. 443 del TRLC, para considerar culpable el concurso no se precisa probar el dolo o la culpa, ni acreditar que con esos incumplimientos se ha generado o agravado la insolvencia, ya que se establece una presunción iuris et de iure de concurso culpable, en función de la gravedad objetiva de los propios incumplimientos (como sucede con el supuesto del art. $443.5^{\circ}$ del TRLC de incumplir sustancialmente la obligación de llevanza de la contabilidad, llevar doble contabilidad o cometer irregularidades relevantes que impidan la comprensión de su situación patrimonial o financiera etc.).

En los incumplimientos de ese precepto, que determinan la calificación ope legis de concurso culpable, para realizar esa calificación no se exige que los mismos hayan agravado o generado la insolvencia, de modo que ante ese tipo de incumplimientos, como llevar una doble contabilidad, irregularidades muy relevantes en la contabilidad que impidan conocer la situación patrimonial o financiera, etc., aunque no generen o agraven la insolvencia, determinan la calificación del concurso como culpable; o en palabras del $\mathrm{TS}^{1292}$, la concurrencia de incumplimientos o hechos del art. $443.5^{\circ}$ del TRLC (art. 164.2.1 ${ }^{\circ}$ de la LC anterior) "conlleva en todo caso la calificación culpable del concurso. Es cierto que para esta calificación culpable resulta irrelevante la valoración jurídica de si la irregularidad contable contribuyó a generar o agravar".

Otra cosa será que, para posteriormente declararse la responsabilidad concursal del administrador, esa irregularidad imputable al mismo, sí que ha de tener relevancia en la generación o agravación de la insolvencia ${ }^{1293}$, ya que, "la mera calificación culpable del concurso no debe determinar la condena a cubrir el déficit concursal, sino que es preciso que concurra alguna razón adicional relacionada con lo que es objeto de condena"1294; razón o justificación adicional que según QUIJANO ${ }^{1295}$ se relaciona con la declaración de persona afectada por el concurso culpable, al serle imputable la generación o agravación de la insolvencia y también se tendrá en cuenta para la individualización de la condena. $\mathrm{O}$ en otros términos, no es suficiente que el concurso haya sido calificado como culpable, sino que para declararse esa responsabilidad se precisa valorar,

\footnotetext{
${ }^{1292}$ Sentencias del TS, Sala Civil, 279/2019, de 22 de mayo -Rec. 1073/2016-; y 213/2020, de 29 de mayo -Rec. 1700/2017-.

${ }^{1293}$ Sentencia del TS, Sala Civil, 279/2019, de 22 de mayo -Rec. 1073/2016-.

1294 Sentencias del TS, Sala Civil, 421/2015, de 22 de julio -Rec. 1701/2013- y 693/2017, de 20 de diciembre -Rec. 2469/2015-.

1295 QUIJANO GONZÁLEZ, J.: "Los deberes de los administradores sociales y la calificación del concurso (Comentario de la Sentencia del Tribunal Supremo, S. 1a, de 20 de diciembre de 2017)", op. cit., p. 10.
} 
conforme a criterios normativos, los distintos elementos subjetivos y objetivos del comportamiento del administrador, por no ser un régimen automático de responsabilidad $^{1296}$.

En palabras del TS, Sala Civil, en sus Sentencias, 213/2020, de 29 de mayo -Rec. 1700/2017-, 214/2020, de 29 de mayo -Rec. 1706/2017-, “la justificación o ratio iuris de esta responsabilidad por déficit radica en la contribución a la generación o agravación de la insolvencia, que es la que provocó la apertura del concurso y, en caso de liquidación, la consecuencia final de que no se puedan pagar todos los créditos. Bajo esta lógica resarcitoria, tiene sentido que el déficit, en cuanto impide puedan ser pagados todos los créditos, sea el resultado de la insolvencia. Y quienes hayan contribuido a la generación o a la agravación de la insolvencia, con una conducta que ha justificado la calificación culpable del concurso, responden de la satisfacción de este perjuicio, mediante la cobertura total o parcial del déficit, en función de su contribución".

Ante la concurrencia de una causa de concurso culpable como eran las irregularidades muy relevantes en la contabilidad, al contabilizarse créditos irreales, porque se habían incluido en el balance del ejercicio 2012 unos créditos por "deudores varios" por un importe de 1.606.000 euros, que en el balance de situación del año siguiente (2013) quedaron reducidos a 440.000 euros, sin que conste justificación de estos créditos, el TS, Sala Civil, en Sentencia, 279/2019, de 22 de mayo -Rec. 1073/2016-, señala que, "la justificación de la condena a la cobertura del déficit radica en la incidencia que la conducta o conductas que hubieran merecido la calificación culpable del concurso han tenido en la generación o agravación de la insolvencia".

Para que las irregularidades contables puedan justificar la calificación culpable es necesario no sólo que se haya contravenido la normativa contable, sino además que tengan entidad suficiente, que sea relevante para la comprensión de la situación patrimonial o financiera de la entidad concursada, lo que se ha estimado concurrente cuando en la contabilidad se han omitido las deudas con Hacienda de dos años

\footnotetext{
${ }^{1296}$ Sentencia del TS, Sala de lo Civil, 772/2014, de 12 enero -Rec. 473/2013-.
} 
consecutivos por un importe considerable (Sentencia del TS, Sala Civil, 258/2020, de 5 junio -Rec. 3653/2017- ${ }^{1297}$ )

Cuando la conducta del concurso culpable sea incumplimiento sustancial de la obligación de llevanza de la contabilidad o la comisión de irregularidades relevantes para la comprensión de la situación financiera de la empresa (art. $443.5^{\circ}$ del TRLC), con presunción iuris et de iure, no cabe que esa irregularidad contable se vuelva a considerar como otra causa distinta de concurso culpable, al amparo del art. $443.4^{\circ}$ del TRLC, consistente en inexactitudes graves en los documentos acompañados a la solicitud de declaración de concurso, si estimamos que los documentos inexactos aportados eran la contabilidad irregular, ya que ya fue apreciada al amparo del art. $443.5^{\circ}$ del TRLC, y son conductas que tienen el mismo reproche de desvalor jurídico $^{1298}$.

La falta de aportación de documentación contable en la solicitud de concurso, podrá subsumirse en la causa del art. $443.4^{\circ}$ del TRLC, o del art. $443.5^{\circ}$ del TRLC, pero al encerrar el mismo desvalor, el concurso podría calificarse de culpable por cualquier de ellas, pero no por las dos al mismo tiempo. En cambio, sí se admite que puedan tomarse

1297 En la esa Sentencia $258 / 2020$ de 5 junio, se afirma, "la falta de contabilización de deudas correspondientes al Impuesto de Sociedades de los ejercicios 2003 y 2004 de la mercantil Meflur S.L. (de la que la concursada es su sucesora) por un importe total de 2.307.049,25 euros, constituye una irregularidad contable. Como muy bien argumenta la Audiencia en su Sentencia, no podía pretenderse compensar esta obligación con un supuesto crédito frente a la AEAT por devolución de IVA de junio y julio de 2004, porque esta pretensión había sido rechazada por la Agencia Tributaria y esta decisión había sido luego ratificada por el Tribunal Económico Administrativo Central y por la Sala de lo Contencioso-Administrativo del TSJ de Aragón en los años 2007 y 2008. La irregularidad contable es clara. Para que pueda justificar la calificación culpable, es necesario que la irregularidad sea relevante para la comprensión de su situación patrimonial o financiera. Y esta relevancia viene determinada por el importe total de la obligación no contabilizada, que asciende a 2.307.049,25 euros. Es una cantidad que tiene una entidad suficiente como para distorsionar la imagen de solvencia de la concursada".

${ }^{1298}$ En relación con la apreciación de la causa de culpabilidad del art. $443.4^{\circ}$ del TRLC (art. 164.2.2 de la anterior LC) de inexactitudes graves en los documentos acompañados a la solicitud del concurso, el TS, Sala Civil, en su Sentencia 650/2016, de 3 de noviembre -Rec. 725/2014-, advirtió que "Para su consideración como causa de culpabilidad diferenciada de otras previstas en la Ley Concursal es necesario que tal inexactitud no haya sido ya objeto de valoración por aplicación de un precepto preferente que contemple el mismo desvalor, como ocurre cuando la inexactitud en las cuentas anuales acompañadas a la solicitud de concurso ha sido considerada como irregularidad contable relevante para la comprensión de su situación patrimonial o financiera y ha determinado la aplicación de la específica causa de culpabilidad del art. 164.2.1 de la Ley Concursal".

Partiendo de esa doctrina, en Sentencia del TS, Sala Civil, 670/2019, de 16 de diciembre -Rec. 178/2017- se ratifica que, la no aportación de las cuentas anuales o de determinados documentos contables, no puede integrar, como distintas, dos causas de culpabilidad del concurso, la prevista en el art. $443.5^{\circ}$ del TRLC (incumplimiento sustancial de la obligación de llevar contabilidad, llevar doble contabilidad o haber cometido irregularidad relevante para la comprensión de su situación patrimonial o financiera en la contabilidad que llevara), y la prevista en el art. $443.4^{\circ}$ del TRLC (inexactitud grave en cualquiera de los documentos acompañados a la solicitud de declaración de concurso o presentados durante la tramitación del procedimiento), cuando el desvalor de la conducta es el mismo. 
dos causas de calificación de concurso culpable, de apartados distintos del art. 443 del TRLC, aunque una conlleva o subsuma la otra, cuando comporten distintos reproches o desvalor $^{1299}$.

En los supuestos de concurso culpable del art. 444 del TRLC, nos hallamos ante incumplimientos en los que se presume iuris tantum la culpabilidad de las conductas, pero al estar ante una presunción iuris tantum, cabe la prueba en contrario ${ }^{1300}$. Dentro de estos incumplimientos se considera el concurso culpable, con presunción iuris tantum si, en alguno de los tres ejercicios anteriores a la declaración del concurso, no se hubiese solicitado el concurso, no se hubiesen formulado las cuentas, no se hubiesen sometido a auditoria, o bien, no se depositaron las mismas en el Registro Mercantil.

En todo caso, para la declaración judicial de la responsabilidad concursal, sean supuestos del art. 443 o del art. 444 del TRLC, debe existir la relación causal entre la conducta constitutiva de concurso culpable, atribuible al administrador social -aunque éste sea consecuencia de una presunción iuris et de iure del art. 443 del TRLC, o iuris tantum del art. 444 del TRLC- y la agravación o generación de la insolvencia, ya que se precisa que esos hechos o conductas hayan contribuido a generar o agravar la insolvencia ${ }^{1301}$. De este modo, "no cabe condenar a los administradores o liquidadores, de derecho o de hecho, apoderados generales a la cobertura total o parcial del déficit, si con su conducta (la que ha merecido la calificación culpable y su declaración de persona

\footnotetext{
1299 Son conductas con reproche distinto, que pueden tomarse como diferentes, para la calificación del concurso culpable, la irregularidad contable de no incluir un bien en el inventario, y el consiguiente alzamiento o desaparición del bien o activo. La Sentencia del TS, Sala Civil, 670/2019, de 16 de diciembre -Rec. 178/2017- señalará "así, la omisión de ese activo en el inventario, en caso de merecer esta inexactitud la consideración de grave, podría justificar la calificación culpable al amparo del art. 164.2. $2^{\circ} \mathrm{LC}$; y, si se constata que ese activo salió del patrimonio del deudor sin justificación o causa alguna, cabría también calificar culpable el concurso al amparo del art. 164.2.4 ${ }^{\circ}$ LC. En este ejemplo, el desvalor no es el mismo: en un caso se sanciona el suministro de información, en este caso contable, inexacta al solicitar el concurso; y en otro se sanciona el alzamiento o la desaparición de unos bienes o activos de la concursada. Tendría sentido que se calificara culpable el concurso al amparo de ambas causas porque, además de que el desvalor es distinto en cada caso, las consecuencias de la calificación pueden variar: en caso de apreciarse el alzamiento de bienes, podría haber una condena a su restitución (art. 172.2.3 ${ }^{\circ} \mathrm{LC}$ ), lo que no ocurriría si sólo se calificara el concurso culpable por inexactitudes graves en la documentación aportada con la solicitud de concurso". Las referencias a los arts. 164.2.2 $2^{\circ}$ y $164.2 .4^{\circ}$ de la LC, deben entenderse a los arts. $443.4^{\circ}$ y $443.1^{\circ}$ del TRLC, respectivamente.

${ }^{1300}$ Sentencia del TS, Sala de lo Civil, 327/2015 de 1 junio -Rec. 1449/2013-, la presunción iuris tantum, de concurso culpable, por no haberlo solicitado el deudor, invierte la carga de la prueba, de modo que pueda acreditarse "que dicho incumplimiento no agravó la insolvencia del deudor".

1301 Sentencias del TS, Sala Civil 772/2014, de 12 de enero -Rec. 473/2013-; 421/2015, de 22 de julio Rec. 1701/2013-; 693/2017, de 20 de diciembre -Rec. 2469/2015-; y 279/2019, de 22 de mayo -Rec. 1073/2016-.
} 
afectada por la calificación) no han contribuido a la generación o a la agravación de la insolvencia"1302.

De este modo, son dos valoraciones jurídicas distintas, una cosa es la calificación del concurso como culpable, que es un presupuesto de la responsabilidad concursal, y otra la condena de responsabilidad concursal, y para ésta se precisa que la persona afectada por la calificación de ese concurso como culpable haya contribuido con su conducta a generar o agravar la insolvencia.

En caso de ser varios los responsables, la sentencia deberá individualizar la cantidad a satisfacer por cada uno de ellos, de acuerdo con su respectiva participación en los hechos que hubieran determinado la calificación del concurso. El montante o importe de esta condena estará en función de la incidencia que la conducta del administrador social haya tenido en la generación o en la agravación de la insolvencia ${ }^{1303}$.

En conclusión, en virtud de la responsabilidad concursal se condenará a los administradores de derecho o de hecho, si con su conducta -la que ha merecido la calificación de culpable y su declaración de persona afectada por la calificación-, han contribuido a la generación o a la agravación de la insolvencia; y, por otra parte, el importe de esa condena estará en función de la incidencia que su conducta haya tenido en la generación o agravación de la insolvencia (art. 456.3 del TRLC). Condena que podrá declararse o no con el carácter de solidaridad (art. 456.1 del TRLC), pero de ser con carácter solidario, en la relación entre los condenados rige el principio de que cada uno debe responder de la cuota individual determinada en la sentencia, en función del grado de participación, con lo que podría en acción de regreso exigir el pago al resto de responsables solidarios.

Todas las cantidades que se obtengan con la ejecución de la sentencia de calificación se integrarán en la masa activa del concurso para su posterior pago a los acreedores (art. 461.2 del TRLC), no se integran directamente en el patrimonio de los acreedores (Sentencia del TS, Sala Civil, 213/2020, de 29 de mayo -Rec. 1700/2017-).

La legitimación para solicitar la ejecución de la condena corresponde a la administración concursal, otorgándose legitimación subsidiaria a los acreedores que

${ }^{1302}$ Sentencia del TS, Sala Civil, 279/2019, de 22 de mayo -Rec. 1073/2016-; 213/2020, de 29 de mayo Rec. 1700/2017-.

${ }^{1303}$ Sentencias del TS, Sala Civil, 279/2019, de 22 de mayo -Rec. 1073/2016-; 213/2020, de 29 de mayo Rec. 1700/2017- 
hubiesen requerido por escrito a la administración concursal para que solicite la ejecución, si ésta no la recaba dentro del mes siguiente (art. 461.1 del TRLC). Es legitimación para solicitar la ejecución, no para la solicitud de la declaración de la responsabilidad, ya que ésta se hará de oficio por el juez del concurso en la sentencia que califique el concurso (art. 455 del TRLC).

En función de esa legitimación subsidiaria del art. 461.1 del TRLC, la TGSS podrá promoverla si forma parte de la masa pasiva del concurso, ya que ha de ser llamado al proceso de existir deudas con la Seguridad Social (arts. 252 y 253 del TRLC).

En todo caso, para finalizar, señalar que no estamos ante una responsabilidad ex lege por deudas, sino que es una responsabilidad de naturaleza indemnizatoria ${ }^{1304}$, que no es sancionadora $^{1305}$, que sólo puede imponerse en sentencia dentro del proceso concursal,

${ }^{1304}$ QUIJANO GONZÁLEZ, J.: "Responsabilidad societaria y concursal de administradores: de nuevo sobre la coordinación y el marco de relaciones", en $R D C P$, núm. 10/2009, versión electrónica, p. 15.

${ }^{1305}$ Partiendo de la actual redacción del art. 456 del TRLC, que Recoge el anterior art. 172 bis de la LC, según redacción dada por el Real Decreto-Ley 4/2014, de 7 de marzo, en la Sentencia del TS, Sala Civil 772/2014, de 12 de enero -Rec. 473/2013- acerca de la naturaleza esta responsabilidad concursal, se señala que, "como ya declararon las Sentencias núm. 56/2011, de 23 de febrero (RJ 2011, 2475), y 669/2012, de 14 de noviembre (RJ 2013, 1614), la norma que regula la responsabilidad concursal no es una norma sancionadora (...). No establece una sanción sino un régimen agravado de responsabilidad civil, cuya función no es penalizar al administrador o liquidador sino proteger los intereses de los acreedores sociales.(...) La naturaleza del régimen de responsabilidad concursal establecido en el art. 172.3 de la Ley Concursal había sido fijada por una serie de sentencias de esta Sala de un modo razonablemente uniforme, de modo que, afirmaba esta jurisprudencia, no podía considerarse como una responsabilidad de naturaleza resarcitoria sino como un régimen agravado de responsabilidad civil por el que, concurriendo determinados requisitos, el coste del daño derivado de la insolvencia podía hacerse Recaer, en todo o en parte, en el administrador o liquidador social al que son imputables determinadas conductas antijurídicas, y no en los acreedores sociales, y en la que no se exigía la concurrencia de una relación de causalidad entre la conducta del administrador o liquidador determinante de la calificación del concurso como culpable y el déficit concursal del que se hacía responsable a dicho administrador o liquidador (o, por decirlo en otras palabras, no era necesario otro enlace causal distinto del que resulta "ex lege" de la calificación del concurso como culpable según el régimen de los arts. 164 y 165 de la Ley Concursal y la imputación de las conductas determinantes de tal calificación a determinados administradores o liquidadores de la persona jurídica concursada), y que había sido encuadrada en alguna de las sentencias de esta Sala entre los mecanismos que modulaban la heteropersonalidad de las sociedades respecto de sus administradores en la exigencia de responsabilidad por sus acreedores. Existiendo esta jurisprudencia razonablemente uniforme (a lo que no obsta la existencia de una cierta evolución y la introducción de algunos matices por una u otra sentencia), la introducción de tal inciso en esa reforma legal no puede considerarse como una aclaración o interpretación de la normativa preexistente, sino como la decisión del legislador de modificar el criterio determinante de la responsabilidad concursal e introducir un régimen de responsabilidad de naturaleza resarcitoria, en cuanto que podrá hacerse responsable al administrador, liquidador o apoderado general de la persona jurídica (y, en determinadas circunstancias, a los socios) de la cobertura total o parcial del déficit concursal « en la medida que la conducta que ha determinado la calificación culpable haya generado o agravado la insolvencia $»$. La cursiva es nuestra.

En igual sentido la Sentencias del TS, 421/2015, de 22 de julio -Rec. 1701/2013- ; 279/2019, de 22 de mayo -Rec. 1073/2016-; 213/2020, de 29 de mayo -Rec. 1700/2017-. 
por lo que no podrá ser objeto del procedimiento administrativo de recaudación a través de la derivación de responsabilidad.

Responsabilidad distinta a la de los administradores afectados por la calificación del concurso, será la responsabilidad por daños de los administradores concursales, si por actos u omisiones generan daño a los acreedores, de cuya acción resarcitoria conocerá el juez que está o ha conocido el proceso concursal, en juicio declarativo (arts. 94 a 99 del TRLC), de donde resulta otra posible acción procesal de la TGSS, para reclamar los daños a los créditos de la Seguridad Social generados en el concurso de acreedores.

\section{VII.- LA INSUFICIENTE REGULACIÓN DE LA RESPONSABILIDAD DEL ADMINISTRADOR SOCIAL EN LAS DEUDAS DE SEGURIDAD SOCIAL DE LA SOCIEDAD DE CAPITAL.}

Al no haberse previsto expresamente en la legislación de Seguridad Social la responsabilidad del administrador social en el pago de obligaciones de la sociedad de capital, ni la responsabilidad de las empresas integrantes de determinados grupos de sociedades en el cumplimiento de las obligaciones de Seguridad Social, a diferencia de lo que se ha establecido en otros ordenamientos encaminados a la recaudación de recursos públicos como el Derecho tributario, abogamos por la necesidad de que se establezca un régimen jurídico propio y específico de la responsabilidad de los administradores sociales en las deudas u obligaciones de Seguridad Social de las sociedades de capital ante incumplimientos imputables de la disposiciones del orden social, así como explicitar el régimen jurídico de las entidades integrantes de la empresa grupo o grupos patológicos.

Régimen jurídico propio, específico y articulado de la responsabilidad de los administradores en deudas de Seguridad Social de la sociedad de capital, por conducta imputable de los mismos, que no será obstáculo para que siga manteniéndose en vigor el art. 18.3 del TRLGSS, que operaría como disposición de cierre de otros posibles supuestos generales de responsabilidad, como norma en blanco de determinación de otros supuestos de responsabilidad por remisión a disposiciones legales de otros órdenes jurídicos. Régimen jurídico de responsabilidad del administrador en el pago de deudas u obligaciones de Seguridad Social de la sociedad de capital, que encuentra su fundamento o justificación al ser los administradores quienes, en último término, con su actuación orgánica serán los responsables de cumplir o hacer cumplir las obligaciones 
de la sociedad de capital con la Seguridad Social. Abogamos, en definitiva, por la necesidad de determinar la responsabilidad de los administradores ante el incumplimiento imputable a los mismos, por conducta activa o pasiva, de las obligaciones de Seguridad Social de la sociedad de capital.

En ese régimen jurídico de responsabilidad de los administradores, distinguiremos entre dos grandes supuestos, por un lado la responsabilidad del administrador por incumplimiento imputable de las obligaciones con la Seguridad Social de la sociedad de capital, y por otro lado, la responsabilidad del administrador por incumplimientos de obligaciones orgánicas establecidas en la legislación mercantil con relevancia en deudas de Seguridad Social, para explicitar de modo expreso en una disposición legal de Seguridad Social esa responsabilidad por deudas del administrador, determinando los supuestos principales y de mayor relevancia de la responsabilidad, con la introducción de algunas correcciones y nuevas propuestas para garantizar los derechos de la Administración de Seguridad Social en la reclamación de esas deudas.

Igualmente, partiendo de la licitud de los grupos de sociedades donde cada entidad conserva su patrimonio y personalidad jurídica propia, respondiendo cada una de las sociedades de sus propias obligaciones con la Seguridad Social, no obstante, deberá regularse de modo expreso en la legislación de la Seguridad Social la responsabilidad de las empresas integrantes de la empresa grupo y de los grupos patológicos, para incorporar al ordenamiento jurídico la actual doctrina jurisprudencial sobre la responsabilidad solidaria de las sociedades integrantes, ante la insuficiencia del actual art. 18.4 del TRLGSS que no permite la reclamación de deudas por prestaciones de responsabilidad empresarial. Regulación específica de la responsabilidad en los grupos de empresa, que no será óbice para que se mantenga en vigor el régimen jurídico general del art. 18.4 del TRLGSS de responsabilidad del empresario real en aplicación de la doctrina del levantamiento del velo.

\section{Régimen jurídico de responsabilidad de los administradores por incumplimientos de disposiciones de Seguridad Social.}

El régimen jurídico específico de responsabilidad del administrador social deberá determinar el ámbito subjetivo, los presupuestos normativos determinantes de la responsabilidad -los hechos determinantes de la responsabilidad-, el ámbito objetivo o 
material de responsabilidad -deudas de Seguridad Social de la sociedad de capital objeto de responsabilidad-, así como el ámbito temporal de la responsabilidad.

En la configuración del régimen jurídico de responsabilidad del administrador social en las deudas de Seguridad Social de la sociedad de capital podría tenderse a una aproximación al régimen de responsabilidad tributaria establecido en los arts. 42, 43 y 182 de la LGT.

La regla general de esta responsabilidad sería la responsabilidad subsidiaria de los administradores en el pago de las deudas de Seguridad Social de la sociedad de capital por conducta imputable por acción u omisión. Responderá de modo subsidiario el administrador social cuando el incumplimiento de las obligaciones de Seguridad Social de la sociedad de capital le fuere imputable, bien por no haber realizado los actos necesarios que fuesen de su incumbencia para que la sociedad cumpliese con sus obligaciones, bien por haber consentido el incumplimiento de quienes de ellos dependan, o bien por haber adoptado acuerdos que posibilitasen las infracciones.

Ámbito subjetivo de responsabilidad. Serán sujetos responsables los administradores de hecho o de derecho, sean personas físicas o jurídicas.

Este régimen jurídico de responsabilidad de los administradores en las deudas de Seguridad Social de la sociedad de capital, sería un régimen basado en la culpa, no objetivo. Responsabilidad fundada en la culpa que no es óbice para que, como ocurre en la responsabilidad indemnizatoria por daños, se invierta el onus probandi de modo que deba acreditar el administrador que el incumplimiento no le es imputable, como sucede cuando pretenda exonerarse acreditando haber realizado los actos necesarios para cumplir la sociedad con las obligaciones legales de Seguridad Social. Inversión del onus probandi que se admite también en el recargo de prestaciones, que según la jurisprudencia tiene naturaleza híbrida con elementos sancionadores, indemnizatoriosprestacionales, preventivos ${ }^{1306}$. No se olvide que la presunción de inocencia no es aplicable en el procedimiento de liquidación y recaudación de los recursos económicos

${ }^{1306}$ En la Sentencia del TS, Sala Social, de 28 de febrero de 2019 -Rcud. 508/2017-, partiendo de la naturaleza sancionadora del recargo, señala que la carga de la prueba, conforme al art. 217 de la Ley de Enjuiciamiento Civil, recae en el empresario quien deba probar que obró con la diligencia debida, con la diligencia que le era exigible, siendo él quien debe acreditar que concurra causa de exoneración por ser un supuesto de caso fortuito o de fuerza mayor, la situación de necesidad la causante del accidente. Acerca de esta Sentencia Vid.: MÉNDEZ SEBASTIÁN, P.: "La cuadratura del círculo procesal de las responsabilidades por accidente de trabajo. En particular, la vinculación entre las decisiones judiciales sobre Recargo, sanción e Indemnización por daños", op. cit. 
de la Seguridad Social, ni en la derivación administrativa de responsabilidad, al no tener naturaleza sancionadora (STS, Sala Contencioso-administrativa de 20 de abril de 1992 ponente: Conde Martín de Hijas, Vicente). Presunción de inocencia que es plenamente aplicable al procedimiento administrativo sancionador en el orden social ${ }^{1307}$.

Responsabilidad de los integrantes del órgano de administración que se configurará como una presunción de culpa colectiva similar a la prevista en el art. 237 de la LSC, de modo que sea cada integrante del órgano quien deba acreditar que el incumplimiento no le es imputable por haber hecho lo necesario para cumplir con las obligaciones o evitar el incumplimiento. De ser persona jurídica el órgano de administración, responderán de modo solidario la persona jurídica y la persona física designada.

Habrá de excluirse la responsabilidad del empleado público designado en virtud de esa condición por la Administración Pública para ocupar el cargo del órgano de administración de una sociedad de capital o mercantil de carácter público, en cuyo supuesto, la responsabilidad se le imputará a la Administración de la que dependa la sociedad mercantil, sin perjuicio de poder reclamar la Administración Pública la responsabilidad del empleado público. Con ello, se solventan las dudas que en deudas de Seguridad Social pudieran surgir de los actuales arts. 115 y 116 LRJSP.

El ámbito material u objetivo de la responsabilidad serán las deudas de Seguridad Social no prescritas de la sociedad de capital, sean deudas por cuotas de Seguridad Social y de recaudación conjunta o por prestaciones de responsabilidad empresarial,

${ }^{1307}$ En virtud del principio de inocencia aplicable con ciertos matices al procedimiento administrativo sancionador (STC 76/90, de 26 abril, entre otras), no puede exigirse que sea el infractor quien acredite su inocencia, lo que no es óbice para que pueda probar que la infracción no le es imputable por concurrir causa de exoneración de responsabilidad como por ser un supuesto de fuerza mayor, porque en toda infracción administrativa ha de haber dolo o culpa del infractor (art. 28 de la LRJSP), sin que a ello se oponga la presunción de certeza de los hechos comprobados por los Inspectores o Subinspectores, que es cuestión diversa. El elemento subjetivo del injusto, dolo o culpa, debe concurrir en la infracción administrativa, pese a no aludirse expresamente al mismo en el TRLISOS, sin que ello implique que estemos ante un régimen de responsabilidad objetiva o si culpa, ya que el procedimiento sancionador ha de respetar la presunción de inocencia. RODRÍGUEZ-SAÑUDO GUTIÉRREZ, F.: "Garantías jurídicas para el empresario ante la actuación sancionadora de la Inspección de Trabajo", Actualidad Laboral, n 6, Sección Estudios, quincena del 16 al 31 marzo 2007, p. 684, Tomo 1, Editorial La Ley, Ref., La Ley 1015/2007, edición digital,

https://laleydigital-laleynext-es.ponton.uva.es/Content/Documento.aspx?params, p. 6, para quien, pese a no hacerse alusión al dolo o la culpa en el TRLISOS, "de ello no puede concluirse, sin embargo, que la norma laboral haya establecido un sistema de responsabilidad objetiva, en el que baste la comprobación del acto ilícito para que se produzca la infracción, sin dolo o culpa por parte del sujeto que lo realiza. Hace ya tiempo que doctrina y jurisprudencia, en general y no referido en especial al ámbito de lo social, han Rechazado esta posibilidad, que se niega tenga cabida en el ordenamiento español”. En igual sentido STS, Sala Social de 28 de febrero de 2019 -Rcud. 508/2017-.

Principio de presunción de inocencia no aplicable al procedimiento liquidatorio y recaudatorio de Seguridad Social. 
incluyendo el recargo de prestaciones, siempre que la deuda tenga su origen en el incumplimiento imputable de los administradores de las obligaciones con la Seguridad Social de la sociedad de capital, y en el caso del recargo de prestaciones si el incumplimiento de las obligaciones de prevención de riesgos laborales sean imputable a los administradores ${ }^{1308}$. Responsabilidad subsidiaria que incluirá las deudas de Seguridad Social, sin incluir la responsabilidad en las sanciones administrativas, pudiéndose extender en un futuro la responsabilidad a éstas como se hace en el Derecho tributario, lo que exigirá que una disposición con rango de ley imponga expresamente esa responsabilidad en la sanción, para cumplirse con las exigencias de los principios de legalidad y de personalidad de la sanción.

Regla general de responsabilidad subsidiaria en las deudas de la sociedad que no será óbice para, en su caso, apreciar la responsabilidad solidaria en aplicación del art. 18.4 del TRLGSS, si se acredita que el administrador social es el empresario real, y no la sociedad de capital (doctrina del levantamiento del velo).

Como excepción a la responsabilidad general subsidiaria en deudas del administrador, éste no responderá de la falta de ingreso de las cuotas devengadas en la empresa si la sociedad de capital ha cumplido en plazo reglamentario con la obligación de comunicación de datos a la TGSS para la facturación mensual de la liquidación de cuotas (art. 29 del TRLGSS, deuda consecuencia de la infracción tipificada en el art. 22.3 del TRLISOS), salvo que la falta de ingreso sea debida a una actuación fraudulenta del administrador o salvo que se hubieren atendido otras deudas temporalmente concurrentes o de vencimiento posterior, que en conjunto sean de importe similar y de menor prelación o preferencia de conformidad con el art. 25 del TRLGSS y la Ley Concursal.

Responderá igualmente el administrador social de modo subsidiario con la sociedad de capital de la devolución de prestaciones indebidamente percibidas por el trabajador,

\footnotetext{
1308 Responsabilidad que legalmente se admite pueda imponerse a sujeto distinto del empresario del trabajador, cuando haya imputabilidad del incumplimiento de las disposiciones legales de prevención de riesgos laborales, como ocurre en los trabajos en misión en la empresa usuaria, en la descentralización productiva, incluso aunque no haya propia actividad, etc. (art. 24 apartados 3 y 4 de la LPRL, art. 42.3 del TRLISOS, y art. 16.2 de la LETT y SSTS, Sala Social, 5 mayo 1999 -Rec. 3656/1997-; 14 mayo 2008 -Rec. 4016/2006-; 7 octubre 2008 -Rec. 2426/2007-; 18 enero 2010 -Rec. 3237/2007-; 20 marzo 2012 -Rec. 1470/2011-; 18 de septiembre de 2018 -Rec. 144/2017-, en ésta última se extiende la responsabilidad solidaria a empresas sin que concurra la propia actividad).
} 
cuando por acción u omisión haya contribuido a esa percepción, en los supuestos de responsabilidad de subsidiaria de la empresa establecida en el art. 55.2 del TRLGSS.

Responsabilidad subsidiaria del administrador que será aplicable igualmente, cuando en las contratas, cesión ilegal de mano de obra, se haya apreciado responsabilidad solidaria de la sociedad en el pago de obligaciones por cotizaciones o por prestaciones de la empresa contratista-subcontratista o de la cedente de mano de obra, en aplicación de los arts. 42 y 43 del TRLET, y art. 141.1, en relación con el art. 168 apartados 1 y 2 del TRLGSS. De apreciarse responsabilidad subsidiaria de la sociedad en contratas o subcontratas por deudas anteriores a la contrata, responderá el administrador de igual modo con la sociedad de capital. Responsabilidades que serán aplicables si el incumplimiento de las obligaciones determinantes de la responsabilidad de la sociedad de capital garante es imputable al administrador social.

La responsabilidad será solidaria para responder de deudas por cotizaciones, cuando los administradores hayan sido los causantes o los colaboradores activos en la generación de la deuda, en los cinco supuestos siguientes: a) deudas por cotizaciones del período de falta de inscripción, afiliación, alta en Seguridad Social de los trabajadores; b) comunicación de datos falsos que ocasionen diferencias de cotización por deducciones, compensaciones, reducciones, bonificaciones o incentivos fraudulentos; c) no ingresar, en la forma y plazos reglamentarios, las cuotas de Seguridad Social y las de recaudación conjunta cuando no se han cumplido dentro de plazo las obligaciones de comunicación de datos a la Tesorería General de la Seguridad Social para poderse emitir la liquidación por el sistema de liquidación directa; d) falseamiento de documentos o la simulación de la ejecución de la acción formativa, incluida la teleformación, para la obtención o disfrute indebido de bonificaciones en materia de formación profesional para el empleo, responsabilidad solidaria que se extenderá a la entidad de formación y a los administradores sociales de ésta si han sido los causantes o los colaboradores necesarios; e) retener indebidamente, no ingresándola dentro de plazo, la parte de cuota de Seguridad Social descontada a sus trabajadores o efectuar descuentos superiores a los legalmente establecidos, no ingresándolos en el plazo reglamentario. De no acreditarse haber sido los administradores los causantes o colaboradores necesarios, regirá la responsabilidad subsidiaria general para el pago de esas deudas.

Ámbito temporal de la responsabilidad. Dentro de esta ámbito habrá de distinguirse entre deudas por cotizaciones y deudas por prestaciones. 
Deudas por cotizaciones. El plazo de prescripción de la acción para derivar la responsabilidad al administrador social de las deudas por cotizaciones a la Seguridad Social por incumplimientos imputables será de cuatro años, que en el caso de la responsabilidad solidaria será dies a quo de inicio del plazo de prescripción desde que finalizó el plazo reglamentario de ingreso de las cuotas de Seguridad Social y otras de recaudación conjunta. En caso de la responsabilidad subsidiaria el plazo de prescripción para declarar la responsabilidad y exigir el pago de la deuda al responsable será de 4 años, que se deberá computará desde la declaración de la insolvencia de la sociedad y del resto de responsables solidarios.

Deudas por prestaciones. El plazo de prescripción para declarar la entidad gestora la responsabilidad derivada subsidiaria del administrador social en las deudas por prestaciones será el mismo plazo establecido para el reconocimiento de la prestación de Seguridad Social, a computar desde el acaecimiento del hecho causante. En cambio, el plazo de prescripción para exigir la TGSS al administrador social el pago de la deuda subsidiaria de la prestación, mediante reclamación de deuda, será de cuatro años desde la declaración de la insolvencia de la sociedad y del resto de los responsables solidarios. Nos encontraremos ante dos procedimientos administrativos distintos, el primero es la declaración de responsabilidad subsidiaria por la entidad gestora, y el segundo es el procedimiento recaudatorio de la TGSS ante el responsable directo -la empresa- y ante el responsable subsidiario -el administrador social-, que en el caso del administrador ese procedimiento recaudatorio no se iniciará hasta que conste la insolvencia de la sociedad y otros responsables solidarios.

Competencia para la derivación de responsabilidad. Ha de distinguirse igualmente entre deudas por cotizaciones o por prestaciones, y entre una responsabilidad solidaria o subsidiaria.

La competencia para declarar la responsabilidad solidaria del administrador en el pago de deudas por cotizaciones, dentro del procedimiento de liquidación y recaudación de Seguridad Social, corresponderá a la TGSS, mediante la emisión de la resolución de derivación de responsabilidad y la reclamación de deuda, previa adopción del acuerdo de inicio, y a la ITSS mediante acta de liquidación en los términos establecidos en el art. 33 y 34 del TRLGSS. La declaración y reclamación de la responsabilidad subsidiaria en deudas por cotizaciones será competencia de la TGSS, debiendo la ITSS emitir el pertinente informe de constatar los hechos determinantes de la responsabilidad 
subsidiaria. Los administradores tendrán derecho al trámite de audiencia previa, a presentar alegaciones con carácter previo a dictarse la resolución administrativa de declaración de la responsabilidad derivada, así como a interponer recursos administrativos o judiciales frente a la misma. Los actos administrativos de derivación de la responsabilidad serán recurribles ante la Jurisdicción Contencioso-Administrativa, una vez firmes en vía administrativa.

Por el contrario, cuando nos encontremos ante una responsabilidad imputable del administrador social por el incumplimiento de disposiciones propias y específicas de Seguridad Social, la competencia para la declaración de la responsabilidad subsidiaria de aquél en las deudas por prestaciones, será de la entidad gestora, y no de la TGSS, por ser un acto de gestión de prestaciones, y no un acto de gestión recaudatoria de una deuda preexistente, al tenerse que aplicar la legislación de Seguridad Social reguladora de la responsabilidad en las prestaciones, al haber nacido la responsabilidad por incumplimientos imputables del administrador de las obligaciones de Seguridad Social. Resolución de la entidad gestora que será recurrible ante la Jurisdicción Social (art. 2 apartado o, de la LRJS). Una vez firme en vía administrativa la resolución de la entidad gestora, ésta lo comunicará a la TGSS, para que por ese Servicio Común inicie el procedimiento administrativo de recaudación de la deuda por prestaciones ante la sociedad de capital. En cambio, el procedimiento recaudatorio de la responsabilidad subsidiaria del administrador social, emitiendo la TGSS la reclamación de la deuda, no podrá iniciarse hasta que no se haya declarado la insolvencia de la sociedad u otros responsables solidarios.

Finalmente, deberá preverse en la legislación de Seguridad Social que, en el supuesto de sociedad disuelta, los socios responden con la cuota de liquidación de las deudas por prestaciones, y no sólo de las deudas por cotizaciones como se establece en el art. 142.1 del TRLGSS, para dejar constancia expresa de esa responsabilidad y solventarse las dudas que al respecto pudiera existir, aunque estimamos que actualmente podría ser exigida al amparo del art. 18.3 del TRLGSS en relación con el art. 399 de la LSC.

Del mismo modo, ante la insuficiencia del art. 18.4 del TRLGSS, que limita la responsabilidad sólo a deudas por cotizaciones, debería modificarse ese precepto para extender la responsabilidad solidaria al empresario real, tanto de las deudas por cotizaciones como por prestaciones de responsabilidad empresarial, bien se reproduzca igual precepto en el art. 168 del TRLGSS para recoger la responsabilidad en 
prestaciones, o bien se haga una remisión en el art. 168 al art. 142.1, último párrafo del TRLGSS.

\section{Régimen jurídico de responsabilidad de los administradores por incumplimiento de los deberes orgánicos de la legislación de sociedades.}

Conviene que en la legislación de Seguridad Social, y con independencia del actual art. 18.3 del TRLGSS, se determinen los supuestos principales de responsabilidad del administrador social en deudas por incumplimientos de deberes orgánicos establecidos en la legislación mercantil.

- En primer lugar, deberá declarase que el administrador social responderá de las deudas de Seguridad Social de la sociedad de capital, sean deudas por cotizaciones o por prestaciones de responsabilidad empresarial, en todos los supuestos en que en la legislación mercantil y de sociedades se declare la responsabilidad del administrador en las deudas de la sociedad, siempre que no se hayan excluido a las deudas de Seguridad Social. Con esta previsión quedan incluidos todos los supuestos actuales de responsabilidad ex lege del administrador en deuda ajena de la sociedad (arts. 360, 367, 14, 36 a 39 de la LSC y concordantes).

Igualmente, de modo paralelo, como propuesta de lege ferenda debería establecerse en la legislación de sociedades que, en la responsabilidad por causa de disolución, sea por causa legal o disolución de pleno derecho, la responsabilidad se extenderá a las deudas posteriores al acaecimiento de la causa de disolución, con el mismo alcance para los nuevos administradores si tras la aceptación del cargo no cumplen en plazo, a computar desde la fecha de acceso al cargo, con los deberes de promover la disolución.

Responsabilidad que cesará con el cumplimiento tardío y con el cese efectivo en el cargo para las deudas posteriores a esos hechos.

- En segundo lugar, debería declararse la responsabilidad solidaria del administrador social en las deudas por cotizaciones o por prestaciones de responsabilidad empresarial, si incumple las obligaciones de solicitar en plazo el concurso o medidas preconcursales, de hallarse la sociedad en causa de insolvencia, responsabilidad solidaria que ha de extenderse a las deudas posteriores a la concurrencia de la insolvencia con el mismo régimen jurídico que la responsabilidad por causa de 
disolución. Responsabilidad que podría igualmente recogerse en la legislación concursal para su aplicabilidad general, lo que actuaría como medio indirecto para instarles a cumplir con sus obligaciones y evitar perjuicios mayores a los acreedores. Derivación de responsabilidad admitida en algunas sentencias de los TSJ y que se ha visto revisada a partir de la nueva jurisprudencia dictada en unificación de doctrina en el año 2019 por la Sala Tercera del TS.

La actual regulación impidiendo al responsabilidad por deudas si no se solicita el concurso y no concurre causa de disolución, no se cohonesta con el principio general de derecho de que quien puede los más puede lo menos, ya que si responde de las deudas sociales quien no ha promovido la disolución o medidas de remoción, que es una situación preconcursal, no es lógico que incumplimientos de mayor gravedad para el tráfico jurídico y económico, por sus efectos más nocivos para el mercado, como no solicitar el concurso, conlleve menores consecuencias jurídicas en la responsabilidad del administrador, ya que la responsabilidad concursal, independientemente de no ser una responsabilidad ex lege en deudas, exige mayores requisitos para su apreciación, debe ser declarada dentro del proceso concursal, y su contenido es menor, ya que es para cubrir el déficit de la liquidación societaria.

Se configura una responsabilidad ex lege por deudas de Seguridad Social distinta a la responsabilidad concursal para cubrir el déficit patrimonial, por cuanto que ésta, en primer lugar, no tiene el mismo contenido, ya que no tiene como finalidad hacer responsable al administrador social de las deudas sociales posteriores a la insolvencia, sino que esa responsabilidad sólo se limita a cubrir el déficit patrimonial que resulte del concurso, y, en segundo lugar, porque esa responsabilidad no va asociada al mero incumplimiento de una obligación legal, sino que exige la concurrencia de circunstancias más gravosas, como es la acreditación de hallarnos ante un concurso culpable, y que el incumplimiento del administrador ha generado o agravado la insolvencia de la sociedad.

Con esta nueva responsabilidad ex lege se obligaría a los administradores a cumplir diligentemente con la obligación de solicitar en plazo el concurso, en aras de la adecuada protección de los acreedores, sin los daños que su omisión o retraso puede conllevar para éstos. Responsabilidad que permitiría reclamar las deudas al 
administrador fuera del concurso, aunque deberá comunicarse al juez del concurso para evitar un pago duplicado, y excluirse de la masa pasiva del concurso.

- En tercer lugar, debería igualmente establecerse expresamente que la derivación administrativa de la responsabilidad solidaria del administrador de incumplir los deberes de promover la disolución o solicitar el concurso de acreedores, no se verá afectada por la eventual declaración de concurso de acreedores de la sociedad de capital, como está actualmente reconocido en la doctrina judicial. Paralelamente, debería establecerse también la obligación de la TGSS de comunicar al juez del concurso el inicio del procedimiento administrativo de derivación, para que pueda tenerse en cuenta el resultado de la derivación administrativa de la deuda en la masa pasiva y en su caso en la responsabilidad concursal.

- En cuarto lugar, debería declararse expresamente la responsabilidad solidaria de los administradores en todas las deudas de Seguridad Social no prescritas que quedasen pendientes de la sociedad en los supuestos de cierre de hecho sin ordenada liquidación. Responsabilidad distinta y específica a la prevista en el art. 367 de la LSC, ya que, ante el cierre de hecho, el administrador respondería de todas las deudas pendientes de Seguridad Social, aunque pudieran ser de un período anterior a una teórica concurrencia de una causa de disolución, todo ello, para instarles a cumplir con los deberes de ordenada disolución, aunque sea extemporáneamente, por ser el cierre de hecho un claro incumplimiento de los deberes inherentes al cargo, especialmente cuando se dejan elevadas deudas de Seguridad Social.

- En quinto lugar, debería establecerse que los liquidadores y administradores concursales, responderán de modo solidario de las deudas de Seguridad Social conocidas en el procedimiento liquidatorio, cuando consecuencia del incumplimiento de sus obligaciones, no se hubiesen satisfecho aquéllas, en todo o en parte.

La responsabilidad del administrador social, de la administración concursal y de los liquidadores, en todos esos supuestos de responsabilidad ex lege por incumplimiento de las obligaciones establecidas en la legislación societaria y concursal, prescribirá a los cuatro años de conformidad con el art. 949 del Código de Comercio, siempre que no haya prescrito la deuda objeto de responsabilidad solidaria.

Al ser una responsabilidad general ex lege en deudas por incumplimientos de la legislación mercantil, la competencia para declarar y exigir la responsabilidad derivada 
del administrador social, será de la TGSS o de la ITSS, cuando sean deudas por cotizaciones, en función de la distribución de competencias establecidas en los arts. 33 y 34 del TRLGSS. De hallarnos ante una deuda por prestaciones de la sociedad de capital, declarada mediante resolución firme de la entidad gestora, al estar ya ante una deuda nacida, determinada y líquida, la reclamación de la responsabilidad derivada al administrador en estos supuestos será competencia de la TGSS, por ser un puro acto de gestión recaudatoria y no un acto de gestión de prestaciones, al no ser una responsabilidad exigible en aplicación de las disposiciones de Seguridad Social reguladora de la responsabilidad en prestaciones.

Sin perjuicio de las anteriores responsabilidades, deberá mantenerse en vigor el art. 18.3 del TRLGSS para otros supuestos legales de responsabilidad solidaria o subsidiaria que se pudieran imponer en disposiciones legales de otros órdenes normativos a terceros que puedan resultar responsables y que no tengan la condición de administradores sociales de las sociedades de capital, así como para las nuevas responsabilidades de los administradores sociales que pudieran establecerse en la legislación mercantil.

\section{3.- Régimen de responsabilidad en los grupos de sociedades: empresa grupo y grupo patológico.}

Se debería recoger expresamente en el Derecho de Seguridad Social, la responsabilidad solidaria en las deudas de Seguridad Social, sean deudas por cotizaciones o por prestaciones de responsabilidad empresarial, en los supuestos de empresa grupo y grupos patológicos, cuando concurra alguna de las siguientes circunstancias: a) funcionamiento unitario de las organizaciones de trabajo de las empresas del grupo, manifestado en la prestación indistinta de trabajo -simultánea o sucesivamente- en favor de varias de las empresas del grupo; b) La confusión patrimonial; c) unidad de caja; d) utilización fraudulenta de la personalidad jurídica, con creación de la empresa «aparente»; y e) uso abusivo -anormal- de la dirección unitaria, con perjuicio para los derechos e intereses de la Seguridad Social.

La competencia para declarar la responsabilidad en deudas por cotizaciones será de la TGSS y de la ITSS. Cuando sean deudas por prestaciones en aplicación de la legislación de Seguridad Social sobre responsabilidad en prestaciones, la competencia para declarar la responsabilidad será de la entidad gestora, la que comunicará a la TGSS la resolución 
II PARTE. Vº CAPÍTULO

administrativa firme de declaración de la responsabilidad, para que ésta inicie el procedimiento administrativo recaudatorio emitiendo la reclamación de deuda 
VI CAPÍtULO:

\section{PROCEDIMIENTO ADMINISTRATIVO DE DERIVACIÓN DE DEUDAS DE SEGURIDAD SOCIAL AL ADMINISTRADOR SOCIAL}

\section{I.- DERIVACIÓN ADMINISTRATIVA DE LA RESPONSABILIDAD AL ADMINISTRADOR SOCIAL.}

\section{La declaración y la derivación administrativa de responsabilidad. Autotutela administrativa.}

\subsection{Declaración y derivación administrativa de responsabilidad.}

En los apartados 3 y 4 del artículo 18 del TRLGSS se regula la "derivación administrativa de responsabilidad" a terceras personas llamadas responsables $\operatorname{conexos}^{1309}$, que será el presupuesto normativo que nos va a permitir la derivación de responsabilidad al administrador social de las deudas de Seguridad Social de la sociedad de capital, cuyo régimen jurídico analizaremos en el posterior apartado, y que es una variante o una especie del género "declaración administrativa de responsabilidad".

Mediante la derivación administrativa de responsabilidad se exige a un tercero, dentro del procedimiento de recaudación, el pago de deudas ajenas de Seguridad Social, en nuestro caso, al administrador social las deudas de la sociedad de capital. La nota esencial de la derivación de responsabilidad, sea solidaria o subsidiaria, es ser un instrumento que permite a Administración exigir a un tercero dentro del procedimiento recaudatorio el pago de deudas que no le son propias ${ }^{1310}$.

Declaraciones y derivaciones de responsabilidad que se emiten por la Administración de la Seguridad Social, sin tener que acudir a reclamar la responsabilidad de los terceros ante los tribunales.

${ }^{1309}$ ALMANSA PASTOR, J. M.: Derecho de la Seguridad Social, op. cit., p. 283; MANRIQUE LÓPEZ, F.: Manual de Derecho de la Seguridad Social, op. cit., p. 324; BLASCO LAHOZ, J. F. y LÓPEZ GANDÍA, J.: Curso de Seguridad Social, Tirant Lo Blanch, $12^{\mathrm{a}}$ edición, 2020, edición digital, https://biblioteca-tirantcom.ponton.uva.es/cloudLibrary/ebook/show/9788491693185\#ulNotainformativaTitle, pp. 178-179.

${ }^{1310}$ CUYÁS PRAT, D, y FAVÀ FERRÉ, I.: "Derivaciones de responsabilidad de deudas tributarias: cuestiones de actualidad", Actualidad Jurídica Aranzadi, núm. 958/2020 parte Artículo, Editorial Aranzadi, S.A.U., Cizur Menor. 2020, edición digital, p. 1. 
Con la derivación administrativa de responsabilidad se alude a la responsabilidad en deuda ajena y con la declaración administrativa de responsabilidad se alude a la responsabilidad en deuda propia, como sucede cuando la entidad gestora declara la responsabilidad de la empresa empleadora en las prestaciones de sus trabajadores (art. 367 de la LSC).

Derivación de responsabilidad que en deudas por cotizaciones podrá realizar tanto la TGSS como la ITSS dentro del procedimiento de recaudación ${ }^{1311}$.

Aunque no distingue terminológicamente entre declaración y derivación administrativa de responsabilidad, al aplicar el término genérico de declaración administrativa de responsabilidad a los supuestos de derivación administrativa de responsabilidad, GARCÍA FERNÁNDEZ ${ }^{1312}$ señala no obstante, (sic) "que lo analizado en los apartados anteriores nos debe permitir distinguir las declaraciones administrativas de responsabilidad por deudas de los supuestos de declaraciones administrativas de responsabilidad con señalamiento de varios deudores, con carácter de subsidiarios o solidarios entre ellos", poniendo el ejemplo de la resolución del INSS en que declara la responsabilidad de la empresa contratista o subcontratista y de la empresa principal en una contrata, indicando que es una declaración administrativa de responsabilidad, pero no una declaración administrativa de responsabilidad por deudas en sentido estricto, al no producirse dentro del procedimiento recaudatorio.

Defendemos el término de derivación administrativa de responsabilidad, que es el empleado por el legislador, para los supuestos en que se efectúa una reclamación de deudas por responsabilidad derivada o conexa, sea con carácter solidario o subsidiario, a un tercero distinto del sujeto responsable principal. Denominación que delimita correctamente el contenido de esta modalidad o supuesto de declaración de responsabilidad dentro del procedimiento recaudatorio. El legislador en el art. 34 apartado 1.c del TRLGSS, emplea la expresión de acta de liquidación de cuotas por

1311 PÉREZ CAPITÁN, L.: "Una aproximación al estudio de la responsabilidad derivada en materia de cotización a la Seguridad Social”, Revista Doctrinal Aranzadi Social, Vol. V, editorial Aranzadi, BIB 199811190, edición digital https://insignis-aranzadidigital-es.ponton.uva.es/maf/app/document?srguid, pp. 65-66 de 69. Para quien la reclamación de deuda o el acta de liquidación son los únicos instrumentos a través de los cuales la Administración puede exigir la denominada responsabilidad derivada por cuotas de Seguridad Social.

1312 GARCÍA FERNÁNDEZ, E.: Las declaraciones administrativas de responsabilidad. Derivación de deudas tributarias y de Seguridad Social, editorial Bosch, 2005, p. 72. 
derivación, y en el art. 13.4 del RGRSS, para la reclamación de la derivación de la deuda que emite la TGSS, se refiere a "la reclamación de deuda por derivación".

La doctrina ${ }^{1313}$ acuñó ya desde sus inicios la denominación de "responsabilidad derivada" para aludir a la extensión de responsabilidad a sujetos distintos al sujeto responsable directo, a los "responsables conexos"1314.

Derivación administrativa de responsabilidad que es la denominación empleada en la doctrina administrativa de la TGSS y la ITSS, tanto en Consultas, Circulares, o Criterios Técnicos ${ }^{1315}$.

El término de derivación administrativa de responsabilidad en las deudas delimita y define con más precisión el contenido del acto de reclamación de la responsabilidad solidaria o subsidiaria a un tercero, ya que estamos ante una reclamación derivada de una deuda a persona o entidad distinta del sujeto responsable principal, por lo que, estamos adicionando nuevos responsables con relación a una deuda de Seguridad Social, que en su nacimiento sólo tenía a un único sujeto responsable, la empresa sociedad de capital.

La derivación administrativa de responsabilidad al hacer responder a un tercero de la obligación que legalmente asume ante la Administración el sujeto responsable directo o principal, tiene dos efectos sustanciales ${ }^{1316}$. En primer lugar, amplía el círculo de sujetos ante los que la Administración puede exigir el cumplimiento de la obligación (función de garantía en el pago de la deuda), y, en segundo lugar, y en esa medida, el nuevo

1313 ALARCÓn CARACUEL, M. R. y GONZÁLEZ ORTEGA, S.: Compendio de Seguridad Social, Tecnos, Madrid, 1991, p. 128.

1314 ALMANSA PASTOR, J. M.: Derecho de la Seguridad Social, op. cit., p. 283; MANRIQUE LÓPEZ, F.: Manual de Derecho de la Seguridad Social, op. cit., p. 324; BLASCO LAHOZ, J. F. y LÓPEZ GANDÍA, J.: Curso de Seguridad Social, op. cit., edición digital, pp.178-179.

1315 Por todos, el vigente Criterio Técnico núm. 89/2011, de 6 de junio de 2011, de la DGITSS, sobre derivación de responsabilidad a los administradores de sociedades mercantiles capitalistas en materia de deudas por cuotas de Seguridad Social. El Criterio Técnico 21/1999, de 9 de julio de 1999, de la DGITSS, Interpretativo sobre derivación de responsabilidad a los Administradores de Sociedades Mercantiles Capitalistas. Criterio Técnico núm. 29/2000, de la DGITSS, para determinados supuestos de la acción inspectora en materia de Seguridad Social, que en su apartado cuarto estable criterios sobre la derivación administrativa de deudas. Criterio Técnico núm. 31/2000, de 18 de mayo de 2000, de la DGITSS, relativo a derivación de la responsabilidad del sujeto responsable principal del pago de cuotas a la Seguridad Social y a otros. Criterio Técnico 38/2003, de la DGITSS, de 9 de diciembre de 2003, sobre resultados liquidatorios en el marco de la colaboración inspectora con la Administración de la Seguridad Social, que sienta pautas sobre los informes de derivación de responsabilidad de la ITSS.

1316 GARCÍA FERNÁNDEZ, E.: Las declaraciones administrativas de responsabilidad. Derivación de deudas tributarias y de Seguridad Social, op. cit., p. 34. 
sujeto responsable tendrá un interés directo en que el responsable principal cumpla con su obligación (función preventiva).

La derivación de responsabilidad, como señala en el ámbito tributario ZABALA RODRÍGUEZ-FORNOS ${ }^{1317}$, pretende exigir a "deudores supletorios" la responsabilidad en el pago de una deuda, cuya vinculación con la obligación principal queda determinada por la concurrencia acumulativa de dos presupuestos: el nacimiento de la deuda, que hace surgir la relación entre el sujeto pasivo y la Administración, y, de otra parte, la producción del presupuesto determinante de la responsabilidad legalmente previsto, que genera, a su vez, la conexión entre el responsable conexo y la Administración. En similares términos caracteriza la derivación de responsabilidad, VILLAR EZCURRA ${ }^{1318}$, al señalar que para su operatividad deben concurrir dos presupuestos, en primer lugar, un presupuesto material, como es el impago de la deuda por el deudor principal, y un presupuesto formal o procedimental, que es el acto que dicta la Administración declarando la derivación de responsabilidad a un tercero, determinando el alcance y la extensión de la obligación de pago.

La derivación de responsabilidad en las deudas de Seguridad Social se ha caracterizado por algún autor ${ }^{1319}$ como un supuesto de extensión del ámbito subjetivo de los sujetos responsables, siendo sus notas esenciales, en primer lugar, su naturaleza incidental, en segundo lugar, su operatividad en el ámbito subjetivo (incremento del número de reclamados) y en tercer lugar, su adscripción a un procedimiento especial (el de reclamación de deudas de la Seguridad Social).

La derivación administrativa de responsabilidad es un acto declarativo de la responsabilidad solidaria o subsidiaria de un tercero en el pago de una deuda ya existente, no crea ex novo una deuda, no es un acto constitutivo de una nueva deuda, autónoma o independiente ${ }^{1320}$, sino que su finalidad es reforzar o garantizar la deuda

${ }^{1317}$ ZABALA RODRÍGUEZ-FORNOS, A.: "Responsabilidad tributaria y responsables del tributo", en "Comentarios a la Ley General Tributaria", coordinado por HERRERO DE EGAÑA Y ESPINOSA DE LOS MONTEROS, J. M., Ed. Thomson-Aranzadi, $1^{a}$ Edición, 2008, pp. 333 y ss.

${ }^{1318}$ VILLAR EZCURRA, M.: "La responsabilidad tributaria", op. cit., p. 593.

${ }^{1319}$ LLUIS Y NAVAS, J.: "La extensión de reclamación de deudas a la Seguridad Social", Actualidad Laboral, № 15, Sección Estudios, Quincena del 1 al 14 septiembre 2006, p. 1794, Tomo 2, Editorial La Ley, Ref. 2250/2006, edición digital, https://laleydigital-laleynext-es.ponton.uva.es/Content/Documento.aspx?params, p. 1.

1320 STS, Sala Civil, 316/2020, de 17 de junio -Rec. 4270/2017-. 
con un patrimonio adicional ${ }^{1321}$. La derivación de responsabilidad tiene una función garantizadora de la recaudación de una deuda preexistente, por lo que el sujeto responsable solidario o subsidiario no sustituye al sujeto pasivo principal, sino que se sitúa junto a él como garante del crédito adeudado, siendo esa derivación administrativa una lex specialis del régimen de responsabilidad por deuda ajena del art. 367 de la LSC, no teniendo naturaleza sancionadora ${ }^{1322}$. De poderse derivar la responsabilidad en sanciones impuestas a la sociedad de capital, sólo en ese supuesto serían de aplicación con peculiaridades los principios inspiradores del orden penal en cuanto manifestación del ius puniendi del Estado, uno de cuyos principios es la personalidad de la sanción ${ }^{1323}$. La derivación de responsabilidad y los sujetos responsables conexos han de recogerse en disposición con rango legal, al exigirlo así las garantías inherentes a la reserva de ley, como ha establecido claramente la jurisprudencia en materia tributaria (arts. 31 y 133.1 de la Constitución) ${ }^{1324}$, tanto en su dimensión formal (rango de la norma que prevé la derivación de responsabilidad), como en la material (predeterminación normativa de la conducta que determina la derivación), y en la procedimental, al tenerse que ejercer la potestad en el marco procedimental diseñado por el legislador (Sentencia del TS, Sala Contencioso-Administrativa 1421/2016, de 15 de junio -Rec. 1916/2015-). Derivación

1321 SSTS, Sala Civil, 315/2020, de 17 de junio -Rec. 4186/2017- y 316/2020, de 17 de junio -Rec. 4270/2017-

1322 SSTS, Sala Contencioso-Administrativa 1033/2019, de 10 de julio -Rec. 4540/2017-; y 88/2017, de 24 de enero -Rec. 3034/2015-; así como Sentencias del TS, Sala Civil, 316/2020, de 17 de junio -Rec. 4270/2017-; y 315/2020, de 17 de junio -Rec. 4186/2017-.

1323 SSTS, Sala Contencioso-Administrativa, de 8 de noviembre de 2010 -Rec. 4941/2007-; 6 de julio de 2015 -Rec. 3418/2013-; 1421/2016, de 15 de junio -Rec. 1916/2015-.

${ }^{1324}$ En la doctrina se ha calificado la cotización a la Seguridad Social de carácter esencialmente tributario (BORRAJO DACRUZ, E.: «El contenido de la relación jurídica de seguro social», Revista de Derecho Mercantil, núm. 76, abril-junio 1960, pp. 301 a 342, y núm. 77, julio-septiembre 1960, pp. 57 a 116; MANRIQUE LÓPEZ, F.: Manual de Derecho de la Seguridad Social, Universidad de Deusto, 1984, Bilbao, p. 322, quien fundamenta la reserva de ley en arts. 31.1 y 133.1 de la CE), como exacción parafiscal (ALMANSA PASTOR, J. M.: Derecho de la Seguridad Social, op. cit., p. 286.); SÁNCHEZ-BARRIGA PEÑAS, R.: "Reserva de Ley y cotización a la Seguridad Social (Especial referencia a la cotización adicional por horas extraordinarias)", Relaciones Laborales, Sección Comentarios de jurisprudencia, 1992, p. 460, T. 1, ed. La Ley, Ref. La Ley 905/2001, edición digital https://laleydigital-laleynext-es.ponton.uva.es/Content/Documento.aspx?params, p. 4, de naturaleza tributaria sujeta a la reserva de ley en la determinación de sus elementos esenciales como los siguientes: "presupuesto de hecho o hecho imponible que origina la cotización, los sujetos pasivos que han de soportarla, base y tipo que la cuantifican, así como las exenciones, bonificaciones, condonaciones o cualquiera otra excepción a la cuantía normal"; para MONEREO PÉREZ et altri en AA.VV. (MONEREO PÉREZ, J. L. et altri): Manual de Seguridad Social, op. cit., 2020, p. 157, es una prestación patrimonial pública que debe llamarse por su nombre cuota de Seguridad Social.

En la jurisprudencia se ha declarado que a la cotización es de aplicación la reserva de ley, aunque por su condición no de tributo, sino de prestación patrimonial de carácter público del art. 31.3 de la CE (SSTS, Sala Contencioso-Administrativa, de 27 de marzo de 1991-Rec. 1.014/1990-; 7 de marzo de 1997 -Rec. 8204/1990-; de 3 de diciembre de 1999 -Rec. 1543/1994-, y STS, Sala de Conflictos, de 9 de mayo de 1995 -Rec. 17/1991-, que revisa la Sentencia de 27 de marzo de 1991, puntualizando la Sentencia de la sala de conflictos que estará sometida a reserva de ley relativa, no absoluta. 
de responsabilidad en materia de Seguridad Social, que al tener la cotización naturaleza de prestación patrimonial de carácter público, estará sujeta a una reserva de ley relativa, en la que se permite una mayor colaboración del reglamento con la ley, determinando la ley los sujetos responsables y hechos determinantes de responsabilidad, y remitiendo al reglamento la regulación detallada del procedimiento de derivación con respeto a las disposiciones legales básicas del procedimiento administrativo común, regulación recogida en el RGRSS y en el $\operatorname{RISOS}^{1325}$, teniendo en cuenta que la regulación general del procedimiento administrativo está sujeto a una reserva de ley propia ${ }^{1326}$ (art. 105 apartado c) de la $\mathrm{CE}$, con respecto al derecho de audiencia del interesado).

Ni la declaración administrativa de responsabilidad, ni la derivación administrativa de responsabilidad, deben identificarse o confundirse con la sanción administrativa, con el ejercicio de la potestad sancionadora de la Administración ${ }^{1327}$. No tienen la misma

${ }^{1325}$ En la Sentencia del TS, Sala 3 , de 3 de diciembre de 1999 -Rec. 1543/1994- se señala: "habida cuenta de la mencionada naturaleza de prestaciones patrimoniales públicas que tienen las aportaciones o cotizaciones de los sujetos obligados al sistema de la Seguridad Social, la reserva de ley que para ellas existe tan sólo deriva del artículo 31.3 CE en cuanto dispone que sólo "con arreglo a la ley" pueden establecerse. En definitiva, esta locución no tiene el mismo alcance y eficacia jurídica que las utilizadas en el artículo $133 \mathrm{CE}$ al regular la potestad tributaria ("mediante ley" o "en virtud de ley") para establecer la reserva de ley en relación con los elementos esenciales de los tributos y los beneficios fiscales. Ahora bien, conforme a la doctrina del Tribunal Constitucional establecida en la citada Sentencia 185/1995, de 14 de diciembre, la reserva de ley en materia de prestaciones patrimoniales de carácter público puede concretarse en los siguientes puntos: A) Se trata de una reserva de ley de carácter relativo, en la que aunque los criterios o principios que han de regir la materia deben contenerse en una ley, resulta admisible la colaboración del reglamento, y el alcance de tal colaboración está en función de la diversa naturaleza de la prestación patrimonial. En ello coincide la invocada Sentencia de la Sala del artículo 61 LOPJ, de 9 de mayo de 1995, cuando llega a las siguientes dos conclusiones (F.J. $8^{\circ}$ ): $1^{\circ}$ ) que no cabe una identificación con los tributos, pues aparte de su naturaleza, las instituciones jurídicas se califican por el régimen jurídico aplicable, y el previsto para aquellos por la Ley General Tributaria y demás normas concordantes difiere del establecido para las aportaciones al sistema de la Seguridad Social; y $2^{\circ}$ ) en el ámbito de estas cotizaciones son válidas las remisiones normativas contenidas en la norma legal reguladora de la materia, por lo que en este caso no incurrirían en tacha de inconstitucionalidad sobrevenida las habilitaciones a la potestad reglamentaria contenidas en diversos preceptos de la Ley General de la Seguridad Social, Texto Refundido de 30 de mayo de 1974, tales como los artículos 71 y 73.2 del mismo. B) La creación de la clase de prestación de que se trata ha de estar prevista en la ley; es necesario, por tanto una interpositio legislatoris para su establecimiento sin que sea suficiente para ello una mera norma reglamentaria. C) (...) la reserva establecida en el artículo 31.3 CE no excluye la posibilidad de que la ley pueda contener remisiones a normas infraordenadas, siempre que tales remisiones no provoquen, por su indeterminación, una degradación de la reserva formulada por la Constitución en favor del legislador (STC 17/1987). También en este punto coincide la doctrina de la reiterada Sentencia de 9 de mayo de 1992, cuando señala que el establecimiento de una cotización adicional sobre las percepciones se enmarca en el ámbito de la reserva de ley material predicable ex artículo $31.3 \mathrm{CE}$, ya que las prestaciones patrimoniales públicas incluyen el deber de cotizar, así como los elementos configuradores de la aportación; y no se extiende, en cambio, la exigencia del rango normativo de ley a otros elementos de la regulación de la Seguridad Social".

1326 SSTC 55/2018, de 24 de mayo -Fundamento de Derecho 6-; 110/2018, de 17 de octubre Fundamento de Derecho $4^{\circ}$-; 18/1981, de 8 junio -Fundamento de Derecho $5^{\circ}$-, entre otras muchas.

${ }^{1327}$ GARCÍA FERNÁNDEZ, E.: Las declaraciones administrativas de responsabilidad. Derivación de deudas tributarias y de Seguridad Social, op. cit., pp. 16-19. 
naturaleza ni el mismo régimen jurídico, pese a pertenecer al género de actos de gravamen.

Habrá derivación de deuda a un tercero sin que éste sea responsable de una infracción administrativa del orden social, como sucede en la derivación de deudas al administrador social en que éste responde de las deudas de Seguridad Social de la sociedad de capital, sin que sea sujeto pasivo de una infracción del orden social, o, como acontece cuando hay una sucesión de empresa en que el nuevo empresario responde de las deudas de Seguridad Social del empresario anterior, sin que exista ningún ilícito administrativo tipificado en la Ley de Infracciones y Sanciones en el Orden Social en que haya incurrido la nueva empleadora. Y al contrario, una misma conducta puede ser objeto en un mismo sujeto de una sanción administrativa y de una responsabilidad en el pago de la deuda de Seguridad Social (ejemplo la falta de cotización a la Seguridad Social de la empresa), ya que al no tener la reclamación de deuda naturaleza sancionadora, cabe la imposición de una sanción y la reclamación simultánea del pago de la deuda de la Seguridad Social a la empresa, por ser compatibles la sanción y el cumplimiento de la obligación, sin conculcarse el principio non bis in ídem.

La infracción y sanción administrativa están sujetas al principio de tipicidad legal de la infracción y la sanción (art. 25 de la Constitución, y arts. 25 y 27 de la LPACAP), y el acto de declaración o derivación de responsabilidad, como todo acto jurídico, está sometido al ordenamiento jurídico en general, con respeto a la reserva de ley en la determinación de los sujetos pasivos de una deuda patrimonial tributaria o social (art. 31. 3 de la Constitución).

Diferenciación que se aprecia con nitidez en la ejecutividad del acto administrativo de reclamación, ya que la derivación de responsabilidad es inmediatamente ejecutable, aunque no sea firme en vía administrativa, al tener que abonar el sujeto responsable la deuda reclamada, sin que el recurso administrativo paralice su cobro, salvo otorgamiento de garantía suficiente. En cambio, la sanción administrativa sólo podrá ser exigida cuando haya ganado firmeza en vía administrativa (arts. 33.5 y 34.3 del TRLGSS, art. 98 apartado 1. b) de la LPACAP, y art. 21.1, 24 y 25 del RISOS). 


\subsection{Autotutela administrativa.}

En virtud de la autotutela, según GARCÍA DE ENTERRÍA ${ }^{1328}$, la Administración está capacitada como sujeto de derecho para tutelar por sí misma sus propias situaciones jurídicas, incluso sus pretensiones innovativas del statu quo sin necesidad de recabar la tutela judicial.

Las declaraciones y derivaciones administrativas de responsabilidad, ponen de manifiesto la "situación de superioridad en que las normas de Derecho han colocado a las Administraciones Públicas respecto a la posición que se predica de los particulares"1329. Declaraciones y derivaciones administrativas de responsabilidad que tienen la condición jurídica de actos o resoluciones administrativas dictadas por el órgano administrativo competente ajustándose a los requisitos y al procedimiento establecido, con sujeción plena al ordenamiento jurídico y sirviendo con objetividad la finalidad propia del acto (art. 34 de la LPACAP).

Mediante la derivación administrativa de responsabilidad contemplada en los apartados 3 y 4 del artículo 18 del TRLGSS, nos hallamos ante una manifestación del principio de "autotutela administrativa"1330, y más concretamente, ante una manifestación de la llamada "autotutela agresiva"1331, en virtud del cual la Administración de la Seguridad Social podrá, en primer lugar, declarar la responsabilidad solidaria o subsidiaria del administrador social para exigir el pago de las deudas de Seguridad Social de la sociedad de capital, y, en segundo lugar, proceder contra el patrimonio de ese sujeto responsable conexo.

\footnotetext{
${ }^{1328}$ GARCÍA DE ENTERRÍA, E.: Curso de Derecho Administrativo, Volumen I, Cívitas, $2^{\circ}$ edición, y $2^{\mathrm{a}}$ reimpresión, Madrid, 1978, p. 311.

${ }^{1329}$ GARCÍA FERNÁNDEZ, E.: Las declaraciones administrativas de responsabilidad. Derivación de deudas tributarias y de Seguridad Social, op. cit., p. 20, quien cita a Eduardo García de Enterría y a Tomás Ramón Fernández.

1330 MARTÍN JIMÉNEZ, R. y MATEOS BEATO, A.: La responsabilidad de empresas y Administradores con la Seguridad Social, op. cit., p. 201; MERCADER UGUINA, J. R. y SUÁREZ CORUJO, B.: "La responsabilidad laboral y de Seguridad Social de los Administradores Sociales", op. cit., pp. 574-578; GARCÍA FERNÁNDEZ, E.: Las declaraciones administrativas de responsabilidad. Derivación de deudas tributarias y de Seguridad Social, op. cit., pp. 13 a 28; GARCÍA DE ENTERRÍA, E.: Curso de Derecho Administrativo, Volumen I, Cívitas, $2^{\circ}$ edición, y $2^{\mathrm{a}}$ reimpresión, Madrid, 1978, p. 314.

${ }^{1331}$ MERCADER UGUINA, J. R. y SUÁREZ CORUJO, B.: "La responsabilidad laboral y de Seguridad Social de los Administradores Sociales", op. cit., p. 575; GARCÍA FERNÁNDEZ, E.: Las declaraciones administrativas de responsabilidad. Derivación de deudas tributarias y de Seguridad Social, op. cit., pp. 25 y ss.
} 
En virtud del privilegio de la autotutela, la TGSS con respecto a las deudas de Seguridad Social, está autorizada para que declarar la responsabilidad solidaria de los administradores conforme a los artículos 363 a 367 de la Ley de Sociedades de Capital y artículos 12.2 y 13 del RGRSS, en relación con el artículo 18 del TRLGSS ${ }^{1332}$.

La derivación administrativa de responsabilidad faculta al órgano competente de la Administración para identificar a los distintos sujetos responsables, y exigirles el pago de la obligación, tanto en vía voluntaria, dentro del procedimiento de recaudación de los recursos de la Seguridad Social (autotutela declarativa o ejecutividad del acto ${ }^{1333}$ ), como en vía ejecutiva, procediendo contra el patrimonio del sujeto responsable (autotutela ejecutiva o ejecutoriedad del acto administrativo ${ }^{1334}$ ).

Autotutela administrativa de la Administración de la Seguridad Social, que, en sus dos manifestaciones de autotuela declarativa (ejecutividad) y ejecutiva (ejecutoriedad), viene recogida, respectivamente, en los arts. 38 y 39 de la LPACAP (presunción de validez y carácter ejecutivo de los actos administrativos) y en los arts. 97 a 101 de la LPACAP (ejecución forzosa de los actos administrativos).

La autotutela declarativa de la Seguridad Social se recoge en los arts. 21, 33 y 34 del TRLGSS, en relación con el art. 7 del RGRSS, en cuyo precepto, bajo el rótulo de "presunción de legalidad", se establece que, "los actos de la Tesorería General de la Seguridad Social para la determinación y recaudación de la deuda con la Seguridad Social gozan de presunción de legalidad y son inmediatamente ejecutivos". La autotutela ejecutiva se incorpora al art. 38 del TRLGSS, siendo desarrollada procedimentalmente en el título tercero del RGRSS.

El privilegio de autotutela atribuido a la Administración Pública no es contrario a la Constitución, sino que tiene su fundamento en la competencia constitucional de las Administraciones Públicas para la defensa de los intereses generales, con sometimiento a la Ley y al Derecho ${ }^{1335}$. Privilegios de ejecutividad y ejecutoriedad de los actos administrativos que no son incompatibles con el art. 24.1 de la Constitución, ya que

\footnotetext{
1332 STS, Sala Contencioso-Administrativa, 1400/2020, de 26 de octubre -Rec. 5951/2018-.

1333 GARCÍA DE ENTERRÍA, E.: Curso de Derecho Administrativo, op. cit., Volumen I, 1978, pp. 315 317.

${ }^{1334}$ GARCÍA DE ENTERRÍA, E.: Curso de Derecho Administrativo, op. cit., Volumen I, 1978, pp. 317 318.

${ }^{1335}$ Art. 103.1 de la Constitución y Sentencias del TC 22/1984, de 17 de febrero -Aranzadi RTC 1984/22; 148/1993 de 29 abril -Aranzadi RTC 1993/148-; y 78/1996 de 20 mayo -RTC 1996/78-, entre otras.
} 
cabe el control pleno de los actos administrativos ante la Jurisdicción ContenciosoAdministrativa $^{1336}$.

En función del principio de ejecutividad los actos de la Administración se presumen válidos y producen efectos desde la fecha en que se dicten, salvo aquellos actos que afecten a los derechos e intereses de los interesados en el procedimiento administrativo, en cuyo caso, su eficacia queda demorada a la fecha de la recepción de la notificación ${ }^{1337}$.

Por otro lado, en virtud del principio de ejecutoriedad la Administración podrá exigir el cumplimiento de la obligación mediante la ejecución forzosa sobre el patrimonio del sujeto responsable ${ }^{1338}$. Ejecución forzosa cuyo límite es el respeto de los derechos fundamentales del administrado (Fundamento de Derecho Cuarto de la Sentencia del TC 22/1984, de 17 de febrero). Con vocación de formar doctrina general el TS, Sala Contencioso-Administrativa, en Sentencia 586/2020, de 28 de mayo -Rec. 5751/2017-, ha señalado que la Administración -era la Administración Tributaria-, no puede dictar una providencia de apremio si está aún pendiente de resolverse de modo expreso un recurso potestativo de reposición, aunque no se hubiere pedido la suspensión cautelar del acto, porque la Administración no puede entender que existe ya la resolución presunta del recurso (desestimatoria por silencio), por haber expirado el plazo para resolver, ya que está obligada a dictar resolución expresa en todo caso, al ser el silencio negativo una ficción jurídica, un "no acto", con lo que se está denunciando el abuso del silencio para la ejecutoriedad del acto administrativo.

En definitiva, la autotutela administrativa es una técnica de gestión administrativa eficaz de los servicios públicos, y en nuestro caso, una técnica de gestión para logar la mejor defensa de los intereses públicos de la Seguridad Social, cuyo objetivo es el

1336 SSTC 22/1984, de 17 de febrero -BOE 9.3.1984-; 66/1984, de 6 junio -BOE. 19.6.1984-; 148/1993, de 29 abril -BOE 28.5.1993-; 78/1996, de 20 mayo -BOE 21.6.1996-; y 121/2010, de 29 noviembre BOE 5.1.2011-, entre otras muchas.

${ }^{1337}$ Arts. 39 y ss de la LPACAP y Sentencia del TC 22/1984, de 17 de febrero -Aranzadi RTC 1984/22-. En el Fundamento de Derecho Cuarto de esta Sentencia, con relación a la ejecutividad del acto, se declara que, "una vez admitida la conformidad con la Constitución de la potestad administrativa de autotutela, en virtud de la cual se permite que la Administración emane actos declaratorios de la existencia y límites de sus propios derechos con eficacia ejecutiva inmediata".

1338 Arts. 97 y ss de la LPACAP y SSTC 22/1984, de 17 de febrero -RTC 1984/22- y 119/1991, de 3 junio -BOE 8.7.1991-, entre otras. En el Fundamento de Derecho Cuarto de la STC 22/1984, se refiere a la ejecutoriedad del acto, al indicar que, "la Administración, a través de sus órganos competentes, procede a la ejecución forzosa de actos administrativos". 
mantenimiento de un régimen público de Seguridad Social, con fundamento último en el principio constitucional de eficacia en la actuación administrativa ${ }^{1339}$.

En virtud de la autotutela administrativa, la TGSS y la ITSS pueden declarar la responsabilidad derivada de los administradores sociales en el pago de las deudas de Seguridad Social de la sociedad de capital, mediante actos administrativos, sin necesidad de tener que acudir ante los tribunales para que se les reconozca previamente el derecho. Pero no sólo pueden declarar la responsabilidad, sino que, ante la falta de pago de la deuda derivada en el plazo reglamentario establecido, puede la TGSS proceder en vía ejecutiva contra el patrimonio de los administradores dentro del procedimiento de recaudación de los recursos de la Seguridad Social.

\section{Régimen jurídico de la derivación administrativa de responsabilidad al administrador social.}

El Fundamento Jurídico de la derivación administrativa de la responsabilidad solidaria o subsidiaria del administrador social en las deudas de Seguridad Social de la sociedad de capital dentro del procedimiento administrativo de recaudación, en aplicación de la responsabilidad impuesta a los mismos por el incumplimiento de sus obligaciones orgánicas previstas en la legislación mercantil, lo encontramos en el art. 18.3, en relación con los arts. 33.2 y 34 apartado 1. c) del TRLGSS.

En virtud de la autotutela administrativa, tanto la TGSS como la ITSS, tienen plena capacidad para derivar la responsabilidad por deudas de la sociedad de capital al

1339 Según Sentencia TSJ Extremadura, Sala Contencioso-Administrativa, 59/2000, de 25 de enero -Rec. 1998/1996-, "La declaración de responsabilidad solidaria de los administradores de una sociedad anónima, que es de lo que ahora se trata, es un acto sujeto al Derecho Administrativo y no al Derecho Privado, protegido, pues, por el privilegio de autotutela declarativa (...). La autotutela declarativa y el principio de ejecutividad significan la obligatoriedad del acto administrativo para su destinatario. A lo que debemos añadir que el principio constitucional de eficacia (artículo 103 C.E.) ampara que el Legislador ordinario conceda a las Administraciones Públicas el privilegio de la autotutela -por todas, Sentencia del Tribunal Constitucional número 22/84, de 17 de febrero, Fundamento Jurídico Cuarto-. En consecuencia, la autotutela declarativa no es sino una técnica de gestión administrativa eficaz de los servicios públicos. Su generalidad requiere que toda exclusión se contemple en norma especial, lo que no es el caso. En el supuesto sometido a la deliberación de la Sala, la Tesorería General de la Seguridad Social, al dictar el acto administrativo recurrido, se limita a declarar la consecuencia normativamente prevista en el artículo 262.5, por no haber convocado los administradores Junta General en el plazo de dos meses. Pues bien, la gestión recaudatoria de los recursos del régimen público de Seguridad Social corresponde a la Tesorería General de la Seguridad Social, de modo que cuando la Subdirección Provincial de Recaudación Ejecutiva declara en el caso la responsabilidad solidaria de los administradores de la sociedad y la Dirección Provincial confirma dicha declaración no se está sino ante actos administrativos dictados en el marco de la gestión de un servicio público por lo que, en definitiva, la potestad de autotutela declarativa resulta incuestionable (artículo 41 de la Constitución Española, en relación con los artículos 1, 18 y concordantes del Real Decreto Legislativo 1/1994, de 20 de Junio )". 
administrador dentro del procedimiento administrativo de recaudación, sin necesidad de recabar la tutela ante la Jurisdicción Civil, fundándose exclusivamente en aplicación de normas mercantiles ${ }^{1340}$.

Esta derivación administrativa de responsabilidad dentro del procedimiento administrativo de recaudación de la Seguridad Social, por remisión a otros sectores normativos que impongan una responsabilidad solidaria o subsidiaria, fue introducida en nuestro Derecho de Seguridad Social mediante la Ley 52/2003, de 10 de diciembre, de disposiciones específicas en materia de Seguridad Social ${ }^{1341}$, que modificó y redactó los artículos 15 apartados 3 y 4, 30, 31 y 104.1 del Real Decreto Legislativo 1/1994, de 20 de junio, que aprobó el anterior Texto Refundido de la Ley General de la Seguridad Social ${ }^{1342}$, preceptos incorporados a los actuales arts. 18 apartados 3 y 4, 33, 34 y 142.1 del TRLGSS.

La derivación administrativa de responsabilidad por deudas de Seguridad Social de la sociedad de capital, de posible aplicación al administrador social y al socioadministrador con control societario, tiene su fundamento jurídico en dos preceptos legales del TRLGSS. En primer lugar, en el art. 18.3 del TRLGSS para la derivación de deudas de Seguridad Social de la sociedad de capital al administrador social por incumplimiento de sus deberes orgánicos, cuando la responsabilidad por deudas se imponga en la legislación mercantil, fundamentalmente en la LSC. En segundo lugar, en el art. 18.4 del TRLGSS para el socio-administrador con control societario, al facultarse a la Administración para dirigir la reclamación de deudas por cotizaciones, no tanto contra el empresario formal, sino contra el verdadero empresario, contra el empresario real que efectivamente reciba la prestación de servicios laborales, la organice, la dirija, y la retribuya, aunque en los registros de la Seguridad Social conste otro sujeto como empresario.

Si en el artículo 18.3 del TRLGSS nos hallamos ante un supuesto de derivación de la deuda a sujetos distintos del responsable principal, sin que éste deje de ostentar jurídicamente la condición de responsable principal, por ser el empresario a efectos laborales y de Seguridad Social; en cambio, en el art. 18.4 del TRLGSS, podremos decir

\footnotetext{
${ }^{1340}$ MERCADER UGUINA, J. R. y SUÁREZ CORUJO, B.: "La responsabilidad laboral y de Seguridad Social de los Administradores Sociales", op. cit., p. 575.

${ }^{1341}$ (BOE del 11 de diciembre), con entrada en vigor desde el 1.1.2004, excepto la redacción de los arts. 30 y 31 de la anterior Ley General de la Seguridad Social, que entraron en vigor el 1.6.2004. Los artículos 30 y 31 , son los actuales artículos 33 y 34 del TRLGSS.

${ }^{1342}$ BOE del 29.6.1994.
} 
que estamos dirigiendo la reclamación de la deuda al verdadero sujeto principal, por ser quien realmente debió asumir la deuda en cuanto empresario. De igual modo, al amparo del artículo 18.4 del TRLGSS y de conformidad con el art. 12.3 del RGRSS, se podrá exigir la deuda acudiendo a la vía de la responsabilidad solidaria, sin tener que anular o dejar sin efecto la reclamación de la deuda emitida con anterioridad al deudor formal, cuando previamente se haya reclamado la deuda a éste.

Preceptos que se complementan con los arts. 33.2 y 34 apartado 1.c) del TRLGSS, que regulan los dos actos administrativos o institutos jurídicos instrumentales para la derivación administrativa de responsabilidad: la reclamación de deuda por derivación y el acta de liquidación de cuotas por derivación de responsabilidad.

Analicemos brevemente ambos supuestos generales de reclamación de deudas de Seguridad Social, que podrán servirnos de fundamento jurídico para reclamar la responsabilidad del administrador social o de los socios en las deudas de Seguridad Social de la sociedad de capital. Por un lado, la derivación administrativa de responsabilidad del art. 18.3 del TRLGSS, y por otro, la reclamación de la deuda a quien queda atribuirse a efectos laborales la condición de empresario real del art. 18.4 del TRLGSS.

En el art. 18.3 del TRLGSS, se establece que , "son responsables del cumplimiento de la obligación de cotizar y del pago de los demás recursos de la Seguridad Social las personas físicas o jurídicas o entidades sin personalidad a las que las normas reguladoras de cada régimen y recurso impongan directamente la obligación de su ingreso y, además, los que resulten responsables solidarios, subsidiarios o sucesores mortis causa de aquellos, por concurrir hechos, omisiones, negocios o actos jurídicos que determinen esas responsabilidades, en aplicación de cualquier norma con rango de ley que se refiera o no excluya expresamente las obligaciones de Seguridad Social, o de pactos o convenios no contrarios a las leyes. Dicha responsabilidad solidaria, subsidiaria o mortis causa se declarará y exigirá mediante el procedimiento recaudatorio establecido en esta ley y en su normativa de desarrollo".

En virtud de este precepto se podrá declarar la responsabilidad solidaria o subsidiaria a personas o entidades distintas del sujeto responsable directo de una deuda de Seguridad Social, cuando una disposición con rango de ley imponga la responsabilidad por deudas, sin haberse excluido en esa responsabilidad a las deudas de Seguridad Social. 
Responsabilidad que podrá ser declarada por la Administración de la Seguridad Social dentro del procedimiento administrativo de recaudación ${ }^{1343}$. Precepto que permitirá reclamar la responsabilidad solidaria o subsidiaria al administrador social en deudas de Seguridad Social de la sociedad de capital.

Con la reforma normativa emprendida con la Ley 52/2003, de 10 de diciembre, el legislador pretendería, dos cosas. En primer lugar, reaccionar ante la jurisprudencia que se había dictado por el Tribunal Supremo acerca de la incompetencia de la Administración de la Seguridad Social para derivar a terceros sujetos la responsabilidad por deudas en el procedimiento administrativo de recaudación, cuando esa responsabilidad por deudas tuviere como fundamento una norma de orden jurídico distinto al ordenamiento Laboral y de Seguridad Social, por tener que aplicarse disposiciones civiles o mercantiles, en cuyo caso, la Administración no podía declarar la derivación de responsabilidad en el procedimiento administrativo, sino que tendría que reclamarla ante la jurisdicción competente ${ }^{1344}$. En segundo lugar, el legislador pretende igualmente clarificar y elevar a rango legal la insuficiente regulación reglamentaria sobre la derivación administrativa de responsabilidad por deudas de Seguridad Social, que se contemplaba de modo insuficiente y sin rango normativo adecuado en el reglamento de recaudación de la Seguridad Social anterior (art. 10 del Real Decreto 1637/1995, de 6 de octubre, que aprobó en anterior Reglamento General de Recaudación de los recursos del Sistema de la Seguridad Social ${ }^{1345}$ ).

A partir de la Ley 52/2003, de 10 de diciembre, la Administración de la Seguridad Social asumirá la competencia para declarar la responsabilidad solidaria, subsidiaria o

1343 Vid.: GALA DURÁN, C.: La responsabilidad laboral y de seguridad social de los administradores de las sociedades mercantiles, op. cit., p. 190; MARTÍN JIMÉNEZ, R. y MATEOS BEATO, A.: La responsabilidad de empresas y Administradores con la Seguridad Social, op. cit., pp. 201 y siguientes.

1344 Así en el Criterio Técnico 38/2000, de la DGITSS, de 9 de diciembre de 2003, sobre resultados liquidatorios en el marco de la colaboración inspectora con la Administración de la Seguridad Social, ya recogía que en una reforma legal en tramitación iba a permitir la derivación administrativa de responsabilidad, señalando "significar que en los momentos presentes las Cortes Generales han culminado la tramitación de un proyecto legislativo sobre disposiciones específicas en materia de Seguridad Social, que supone para los supuestos de responsabilidad solidaria y subsidiaria de administradores, el que sea posible que la declaración de tal responsabilidad sea efectuada por la Administración, sin tener que acudir como parte al procedimiento ante la Jurisdicción Civil. A partir de la promulgación de esa Ley, la Tesorería General y la Inspección de Trabajo y Seguridad Social, en sus respectivos ámbitos marcados por los artículos 30 y 31 del TRLGSS, podrán producir los actos administrativos que les corresponden, con arreglo al procedimiento administrativo que les es propio, y con revisión posterior ante la Jurisdicción Contencioso-Administrativa, lo que supondrá una extensión de los ámbitos que son susceptibles de la actuación de la Inspección de Trabajo y Seguridad Social".

${ }^{1345}$ BOE del 24.10.1995. Derogado por el actual RGRSS. 
"mortis causa", dentro del procedimiento administrativo de recaudación, de personas o entidades distintas al responsable directo de la deuda (sociedad de capital), no sólo cuando esa responsabilidad se imponga en disposiciones laborales o de Seguridad Social, sino también, y esto es la gran novedad legislativa de la reforma, cuando esa responsabilidad venga impuesta en una norma con rango de ley de cualquier rama o sector del ordenamiento jurídico, por concurrir hechos, omisiones, actos jurídicos, que determinen el nacimiento de esa responsabilidad, siempre que en la declaración legal de extensión de la responsabilidad no se hayan excluido expresamente las deudas de Seguridad Social.

Nos hallamos ante un precepto de declaración de responsabilidad por remisión legal. Las notas definitorias de la derivación administrativa de la responsabilidad establecida en el art. 18.3 del TRLGSS, serán las siguientes:

- En primer lugar, que exista una norma con rango de ley que haya establecido una responsabilidad por deudas de un tercero, sea ese responsable persona física o jurídica. A nuestros efectos, que exista una disposición legal que haya impuesto una responsabilidad por deudas del administrador social en las deudas de la sociedad de capital. Esta condición la tiene la $\operatorname{LSC}^{1346}$.

- En segundo lugar, que la disposición legal que imponga esa responsabilidad por deudas al tercero podrá ser de cualquier orden o sector normativo, ya que en el art. 18.3 del TRLGSS no se impone ninguna limitación al respecto. Disposición legal que imponga la responsabilidad de cualquier orden normativo que se reitera en los arts. 33.2 y 34.1.c) del TRLGSS, al regular los actos administrativos de la derivación de responsabilidad. Partiendo de esa remisión general a las distintas ramas del ordenamiento jurídico, en el art. 12. 2 del RGRSS se señala que esas disposiciones legales podrán ser "normas específicas de Seguridad Social, laborales, civiles, administrativas o mercantiles". Remisión a las normas mercantiles que permitirá en el procedimiento administrativo de recaudación declarar la responsabilidad del administrador social en las deudas de la Seguridad Social de la sociedad de capital, cuando esa legislación les imponga una responsabilidad por deudas, sea una responsabilidad solidaria o subsidiaria, sin haberse excluido expresamente a las deudas u obligaciones con la Seguridad Social.

${ }^{1346}$ MERCADER UGUINA, J. R. y SUÁREZ CORUJO, B.: "La responsabilidad laboral y de Seguridad Social de los Administradores Sociales", op. cit., p. 577. 
Con la regulación de los arts. 18.3, 33.2 y 34.1.c) del TRLGSS se podrá derivar la responsabilidad por deudas al administrador social prevista en los arts. 36 a 40, 360 y 367 de la LSC. Por el contrario, no cabrá la derivación de responsabilidad al amparo de ese precepto para exigir en el procedimiento administrativo de recaudación la responsabilidad por daños del administrador social, regulada en los arts. 236 a 241 de la LSC, ya que en estos preceptos se regula la responsabilidad extracontractual por daños, correspondiendo a los órganos jurisdiccionales su declaración al conocer la demanda en que se ejercite la acción individual de responsabilidad, porque no estamos ante un supuesto de imposición legal de una responsabilidad solidaria o subsidiaria por deudas del administrador social, sino ante una responsabilidad por daños que ha de ser apreciada y declarada judicialmente ${ }^{1347}$.

- En tercer lugar, impuesta legalmente la responsabilidad solidaria o subsidiaria del administrador social en las deudas de la sociedad de capital en la legislación mercantil, esa responsabilidad del administrador se extiende ipso iure a las deudas de Seguridad Social, salvo exclusión expresa, ya que, en ese precepto se exige para que proceda la responsabilidad por deudas de Seguridad Social, que la ley que imponga esa responsabilidad "se refiera o no excluya expresamente las obligaciones de Seguridad Social". Requisito de no exclusión de la responsabilidad en las deudas de Seguridad Social que cumple la $\operatorname{LSC}^{1348}$. No exclusión de la responsabilidad por deudas de Seguridad Social de la ley que impone la responsabilidad, que se reitera en los art. 33.2 y 34 apartado 1. c) del TRLGSS, al regular los dos actos de derivación administrativa de responsabilidad (reclamación de deuda y acta de liquidación por derivación). Dicho de otro modo, la responsabilidad se extiende a las deudas de Seguridad Social cuando hayan sido expresamente incluidas, o cuando sin haberse incluido, el legislador no las haya excluido de modo expreso. La regla general resultante será que se responde de las deudas de Seguridad Social, salvo exclusión

1347 Vid.: MARTÍN JIMÉNEZ, R. y MATEOS BEATO, A.: La responsabilidad de empresas y Administradores con la Seguridad Social, op. cit., p. 213; MERCADER UGUINA, J. R. y SUÁREZ CORUJO, B.: "La responsabilidad laboral y de Seguridad Social de los Administradores Sociales", op. cit., p. 579; por el contrario, consideró que sí podría reclamar la Administración de la Seguridad Social, en el procedimiento administrativo de recaudación, la responsabilidad por daños de la acción individual de responsabilidad, GALA DURÁN. Vid. GALA DURÁN, C.: La responsabilidad laboral y de seguridad social de los administradores de las sociedades mercantiles, op. cit., pp. 191-198; NICOLÁS BERNAD, J. A.: "La responsabilidad de los administradores sociales ante la Inspección de Trabajo", op. cit., pp. 79 y ss.

1348 MERCADER UGUINA, J. R. y SUÁREZ CORUJO, B.: "La responsabilidad laboral y de Seguridad Social de los Administradores Sociales”, op. cit., p. 577. 
expresa. La ausencia de exclusión expresa opera como regla general de inclusión. Estamos ante una disposición con vocación omnicomprensiva, totalizadora de los supuestos de responsabilidad establecidos legalmente, que serían de aplicación salvo exclusión expresa.

- En cuarto lugar, que la responsabilidad resulte "de concurrir hechos, omisiones, negocios o actos jurídicos" que determinen esa responsabilidad solidaria o subsidiaria, impuesta en norma con rango de ley, lo que exige que en la derivación de responsabilidad al administrador social éste incurra en las omisiones $\mathrm{u}$ acciones determinantes de la responsabilidad por deudas impuesta en la legislación de sociedades. Fundamentalmente, que incurra en las acciones y omisiones en el proceso de constitución societaria de los arts. 36 a 40 de la LSC, o, que incurra en las omisiones de los deberes que tienen legalmente establecidos ante la concurrencia de una causa de disolución de la sociedad (arts. 360 y 367 de la LSC). Responsabilidad solidaria o subsidiaria, ante esos hechos $\mathrm{u}$ omisiones, que se ha impuesto expresamente al administrador por la legislación de sociedades ${ }^{1349}$.

- En quinto lugar, que esta responsabilidad podrá declararse y exigirse en el procedimiento administrativo de recaudación ${ }^{1350}$. Esta es la otra gran aportación de la reforma, ya que con anterioridad a la misma la jurisprudencia ${ }^{1351}$ había excluido la derivación administrativa de la responsabilidad, obligando a la Administración de la Seguridad Social a reclamar la responsabilidad del administrador social ante la Jurisdicción Civil si se trataba de aplicar un precepto civil o mercantil en la apreciación de la responsabilidad derivada. SÁNCHEZ-BUSTAMANTE Y DE LA

1349 MARTÍN JIMÉNEZ, R. y MATEOS BEATO, A.: La responsabilidad de empresas y Administradores con la Seguridad Social, op. cit., p. 213.

${ }^{1350}$ MERCADER UGUINA, J. R. y SUÁREZ CORUJO, B.: "La responsabilidad laboral y de Seguridad Social de los Administradores Sociales", op. cit., pp. 575 y 577.

1351 SSTS, Sala Contencioso-Administrativa, 18 de junio de 2002 -Rec. interés de ley 3424/2001-; 18 de marzo de 2003 -Rec. 35/2002-; 31 de marzo de 2003 -Rec. 11159/1998-; 21 de julio de 2003 -Rec. 88/2002-; 15 de octubre de 2003 -Rec. 95/2002-; 18 de mayo de 2004 -Rec. 73/2002-; 22 de junio de 2004 -Rec. 9/2003-; 15 de septiembre de 2004 -Rec. 122/2003-; y Sala de Conflictos de Competencias del TS, Auto 4/1996, de 8 de marzo -Rec. 7/1995-, que venían declarando de modo reiterado, que la competencia para apreciar si concurrían los presupuestos legales de la responsabilidad por deudas del administrador social de la legislación de sociedades, correspondía a la Jurisdicción Civil, sin que cupiese la autotutela administrativa por la Administración de la Seguridad Social. En igual sentido, declarando la competencia de la Jurisdicción Civil, Sentencias del TS, Sala Social, Sentencias de 21 de julio de 1998 -Aranzadi RJ 1998/6211-, y siguiendo esa doctrina, se formó reiterada jurisprudencia de la Sala Social del TS, que recogemos en el Capítulo II apartado IV.4, al que nos remitimos, con una salvedad, la responsabilidad del administrador por no haber inscrito en plazo legal el RM la escritura elevando el capital social a los nuevos importes fijados en las anteriores LSA y LSRL, cuya competencia se atribuyó a la Jurisdicción Social en las reclamaciones de los trabajadores. 
HERRÁN ${ }^{1352}$, con motivo de la Sentencia del TS, Sala Contencioso-Administrativa, 18 de junio de 2002 -Rec. 3424/2001-, ya estimaba inadecuado que la TGSS tuviese que acudir ante los tribunales del orden civil para reclamar la responsabilidad solidaria del administrador en las deudas de Seguridad Social en los supuestos de responsabilidad solidaria previstos en la legislación de sociedad, por entender que la TGSS en la declaración de responsabilidad de los administradores realiza un acto de gestión recaudatoria, que como tal podía emitir dentro del procedimiento recaudatorio.

Nos encontramos ante un precepto, el art. 18.3 del TRLGSS, en virtud del cual, la causa legal de responsabilidad en deudas de Seguridad Social se halla en preceptos normativos de órdenes jurídicos distintos al Derecho de la Seguridad Social. Precepto que opera como norma de remisión en blanco de responsabilidad, esto es, cuando una ley declare la responsabilidad del administrador en el pago de las deudas de la sociedad, sea responsabilidad solidaria o subsidiaria, salvo exclusión expresa, pasará a ser un supuesto normativo de determinación de la responsabilidad legal del administrador en las deudas de Seguridad Social de la sociedad de capital. En este sentido, la responsabilidad solidaria o subsidiaria del administrador tendrá como habilitante una ley de Seguridad Social, en la que podrá localizarse la causa expresa o fuente próxima de la responsabilidad por deudas de Seguridad Social, siendo su causa o fuente remota la legislación de sociedades. Con esta reforma se pretende que en el ordenamiento de Seguridad Social exista "causa legal"1353 para atribuir al administrador la responsabilidad impuesta en otra rama del Derecho, ya que hasta la Ley 52/2003, de 10 de diciembre, los supuestos de derivación de responsabilidad en deudas de Seguridad Social se recogían en la Ley General de la Seguridad Social, en los arts. 104.1 y 127 apartados 1 y 2 del Real Decreto Legislativo 1/1994, de 20 de junio ${ }^{1354}$.

La responsabilidad del administrador social en deudas de la sociedad de capital impuesta en el Derecho de sociedades en virtud de este precepto, será una responsabilidad en las deudas de Seguridad Social, no sólo de deudas de cotización de

1352 SÁNCHEZ-BUSTAMANTE Y DE LA HERRÁN, J. M.: "Declaración de responsabilidad de los administradores societarios por la Tesorería General de la Seguridad Social: una competencia por resolver", Diario La Ley, $\mathrm{N}^{\circ}$ 5896, 19 de noviembre de 2003, editorial La Ley, edición digital, https://laleydigital-laleynext-es.ponton.uva.es/Content/Documento.aspx?param, pp. 10-11, La Ley $1714 / 2003$.

1353 MARTÍN JIMÉNEZ, R. y MATEOS BEATO, A.: La responsabilidad de empresas y Administradores con la Seguridad Social, op. cit., p. 212.

${ }^{1354}$ Actuales arts. 142.1 y 168 del TRLGSS y arts. 42 a 44 del TRLET. 
la sociedad de capital, sino también de las deudas de la sociedad de capital por otros recursos económicos de Seguridad social, fundamentalmente deudas por prestaciones de responsabilidad de la sociedad de capital ${ }^{1355}$-como se examinó en el Capítulo I apartado III de esta investigación-.

Esta responsabilidad del administrador en las deudas de la sociedad de capital fundamentalmente vendrá impuesta en los supuestos fácticos recogidos en los arts. 14, 36 a 40, 360 y 367 de la LSC, que han sido objeto de estudio en los capítulos anteriores, y que, en unos casos, la mayoría, será una responsabilidad solidaria (arts. 14, 36 a 38, 360 y 367 de la LSC), y en otros, los menos, será una responsabilidad subsidiaria (art. 39 LSC, en la sociedad irregular).

No teniendo la derivación administrativa de responsabilidad naturaleza de sanción, el crédito de la Administración consecuencia del acto de derivación no tendrá la condición de crédito subordinado de conformidad con el art. 281.1.4 ${ }^{\circ}$ del TRLC, en los supuestos de concurso de acreedores del administrador social (Sentencias del TS, Sala Civil, 316/2020, de 17 de junio -Rec. 4270/2017- y 315/2020, de 17 de junio -Rec. 4186/2017-).

La declaración de la responsabilidad solidaria o subsidiaria del administrador en las deudas de la sociedad de capital, al amparo de la responsabilidad impuesta en la legislación de sociedades, exige que por la TGSS o la ITSS se acrediten los hechos constitutivos del presupuesto normativo de la ley de sociedades determinantes de la responsabilidad, así como sus fundamentos jurídicos, identificando a los sujetos responsables, no siendo suficiente con la mera cita del art. 18.3 del TRLGSS y del concreto precepto de la Ley de Sociedades. Deberán de acreditarse los incumplimientos de las obligaciones del administrador, los hechos u omisiones que esa legislación exige para la imposición de la responsabilidad. En palabras del RGRSS "los hechos y fundamentos de derecho en que se funda la responsabilidad" (art. 13.4 del RGRSS). Los hechos y las infracciones legales determinantes de la responsabilidad; o en palabras del RISOS, "los hechos comprobados por el funcionario actuante como motivadores de la liquidación y los elementos de convicción de que ha dispuesto en la labor inspectora,

${ }^{1355}$ MERCADER UGUINA, J. R. y SUÁREZ CORUJO, B.: "La responsabilidad laboral y de Seguridad Social de los Administradores Sociales”, op. cit., p. 563; GALA DURÁN, C.: La responsabilidad laboral y de Seguridad Social de los administradores de las sociedades mercantiles, op. cit., pp. 175177; MARTÍN JIMÉNEZ, R. y MATEOS BEATO, A.: La responsabilidad de empresas y Administradores con la Seguridad Social, op. cit., pp. 201 y ss. 
describiendo con la suficiente precisión tales hechos y los medios utilizados para su esclarecimiento; y las disposiciones infringidas con expresión del precepto o preceptos vulnerados" (art. 32 apartado 1.c) del RISOS). En los supuestos que se compruebe la existencia de presunto responsable solidario o subsidiario, se hará constar tal circunstancia, así como el motivo de su presunta responsabilidad (art. 32.1.b) in fine del RISOS).

Un segundo supuesto legal de derivación administrativa de responsabilidad por deudas de cotizaciones a la Seguridad Social y de cuotas de recaudación conjunta, se establece en el art. 18.4 del TRLGSS, precepto que permite dirigir la reclamación administrativa de las deudas por cotizaciones, contra "quien efectivamente reciba la prestación de servicios de los trabajadores que emplee, aunque formalmente no figure como empresario en los contratos de trabajo, en los registros públicos o en los archivos de las entidades gestoras y servicios comunes". Precepto que es una incorporación legal expresa de la doctrina jurisprudencial del levantamiento del velo. Disposición legal que permitirá a la TGSS y a la ITSS exigir la deuda por cuotas de Seguridad Social al socioadministrador cuando pueda ser calificado como empresario real, en los supuestos de abuso de la personalidad jurídica de la sociedad, por haber acudido fraudulentamente al ropaje societario para eludir su responsabilidad personal ilimitada.

Precepto desarrollado en el art. 12.3 del RGRSS, en el que se establece que, "en caso de que la responsabilidad por la obligación de cotizar corresponda al empresario podrá dirigirse el procedimiento recaudatorio contra quien efectivamente reciba la prestación de servicios de los trabajadores que emplee, aunque formalmente no figure como empresario en los contratos de trabajo, en los registros públicos o en los archivos de las entidades gestoras y servicios comunes. Si el procedimiento recaudatorio se hubiera dirigido ya contra quien figurase como empresario, las nuevas actuaciones contra el empresario efectivo se seguirán conforme a lo establecido en el artículo siguiente, a no ser que se aprecien otras circunstancias que determinen la concurrencia de responsabilidad subsidiaria".

Con este último inciso del art. 12.3 del RGRSS, no previsto en la ley, al remitirse al artículo 13 del RGRSS que regula la responsabilidad solidaria, se está calificando esta responsabilidad con el carácter de solidaria cuando se hubiere efectuado previamente la reclamación al deudor principal, con el claro propósito -en caso de levantamiento del velo por no ser el empresario formal un verdadero empresario- de no cuestionar la 
validez de la reclamación emitida a éste, ya que si no es el verdadero empresario, en puridad él no sería el sujeto obligado a cotizar, lo que podría implicar también la necesidad de revisar la inscripción del mismo en la Seguridad Social, y abocaría a un procedimiento administrativo más largo y complejo no siempre revisable en vía administrativa (art. 147 LRJS), siendo más operativo en consecuencia dirigir la reclamación con el carácter de solidaridad al empresario real, que no exige necesariamente la previa revisión del encuadramiento del empresario formal, mediante la emisión de una reclamación de deuda por derivación o acta de liquidación por derivación. Critican MARTÍN JIMÉNEZ y MATEOS BEATO ${ }^{1356}$ la inclusión de este precepto dentro de la regulación común de la derivación de responsabilidad por ley ajena a la Seguridad Social prevista en el art. 18.3 del TRLGSS, por entender que estamos ante una reclamación de la deuda por cuotas al empresario real, y en aplicación de la normativa laboral y de Seguridad Social, siendo un supuesto de responsabilidad solidaria.

Carácter solidario de la responsabilidad que se nos muestra claramente cuando nos hallemos ante la empresa grupo, en que, pese a no desconocerse la personalidad jurídica de las diversas sociedades, se considera empresa a efectos laborales a todas ellas de modo solidario, partiendo del concepto amplio de empresario del art. 1.2 del TRLET, en cuanto entidad sin personalidad jurídica que recibe la prestación laboral de servicios.

El art. 18.4 del TRLGSS servirá de título jurídico para derivar la responsabilidad en el pago de deudas por cuotas de Seguridad Social a la persona o entidad jurídica que, sin ostentar formalmente la condición de empresario en los registros públicos de la Seguridad Social, ni en los contratos de trabajo formalizados, sea quien real y efectivamente reciba la prestación de servicios de los trabajadores. Al amparo de este precepto legal, la derivación administrativa de responsabilidad tendrá lugar, fundamentalmente, en cuatro supuestos. En primer lugar, en la empresa grupo y en el grupo patológico ${ }^{1357}$. En segundo lugar, en virtud de la doctrina del levantamiento del

\footnotetext{
1356 MARTÍN JIMÉNEZ, R. y MATEOS BEATO, A.: La responsabilidad de empresas y Administradores con la Seguridad Social, op. cit., p. 240.

1357 TSJ Extremadura, Sala Contencioso-Administrativa, Sentencias 261/2019, de 15 julio -Aranzadi JUR 2019/248986-; 99/2019, de 28 marzo -Aranzadi JUR 2019/132609-; 93/2019, de 21 marzo -Aranzadi JUR 2019/121209-; y 240/2018, de 31 mayo -Aranzadi JUR 2018/209716-, señala, "nos encontramos en presencia de un grupo empresarial, ya que a tal conclusión conduce que las sociedades tienen el número y en personas los mismos administradores, los cuales sirven para subrogar en parte respecto de otros arrendatarios anteriores y sucesivos en los mismos locales con trabajadores que prestan los servicios de manera sucesiva o simultánea en las empresas, todas ellas con el mismo domicilio, su
} 
velo societario, para imputar la responsabilidad al administrador social o socio de control, de estimarse que es el verdadero empresario, que hemos analizado en el capítulo V. En tercer lugar, en los supuestos de cesión de mano de obra, cuando la empresa prestamista de mano de obra sea un mero intermediario en suministro de trabajadores, no siendo una empresa real; o en los supuestos de cesión de trabajadores entre empresas reales. En cuarto lugar, se podrán incluir los supuestos de empresario cotitular o empleador plural, que en el ámbito de las Administraciones Públicas ostentan la sociedad pública que gestiona un servicio y la Administración de la que depende o tiene el control económico, o entre la Administración Autonómica y local, en ambos casos cuando exista un "poder directivo general", que es el que se ejerce en supuestos de pluralidad empresarial al que se refiere el artículo 1.2 del Estatuto de los Trabajadores, pese a no ser calificada la prestación de servicios de cesión ilegal (Sentencias del TS, Sala Social, de 14 de mayo 2014 -rcud. 1467/2013-1358, y 4 de febrero 2015 -rcud. 96/2014- ${ }^{1359}$ ).

gran mayoría el teléfono o email, circunstancias todas ellas que considera la Sala son determinantes para determinar que, no solo por el ejercicio análogo o idéntico de la actividad comercial o de las relaciones económicas entre ellas obedecen a un mismo grupo empresarial como estrategia empresarial de división de responsabilidades a través de la división de la persona jurídica para fraccionar responsabilidades o hacer ilusorios algunos derechos provenientes de concurso en algunos casos, lo que a juicio de la Sala determina que, efectivamente, se produzca el fenómeno a que se hace referencia en los preceptos citados en relación al artículo 18.4 del Texto Refundido de la Seguridad Social de 2015, en relación con el artículo 6.4 del Código Civil (LEG 1889, 27) señalado y 12.2 del Reglamento General de Recaudación de la Seguridad Social de 2004 (RCL 2004, 1453, 2019). Es decir, que al margen de las formalidades y realidades aparentes, lo que de hecho sucede en el caso que nos ocupa, realidad a la que ha de aplicarse el Derecho al margen de artificiosidades es que para el ejercicio empresarial en la misma rama de negocio, con empresarios jurídicos de prácticamente idéntica denominación han troceado la empresa y empresario real, con división aparente y ficticia de la personalidad, lo que determina las consecuencias legales impuestas y citadas, y que nos conducen a desestimar el recurso interpuesto".

${ }^{1358}$ En esa Sentencia, se señala respecto a la condición de empresario plural que, "la negación de la existencia de cesión ilegal del art. 43 ET no impide afirmar la existencia de una posición empresarial plural (ex art. 1.2 ET ) (...), la construcción de un sistema de coordinación, como el que vincula a las codemandadas, deviene en la asunción de una postura empresarial común, tal y como queda plasmada en los múltiples elementos que se extraen del relato de hechos probados de la sentencia, al que antes hemos aludido. Si bien la utilización de la encomienda de gestión a la empresa pública justifica un cambio de la identidad del empresario, ello no comporta la desaparición de la Consejería en su papel de empleadora, sino la modificación de ese sujeto de la relación que ya no recae sobre una sola entidad, sino que pasa a ser plural".

${ }^{1359}$ En esta Sentencia se aprecia la condición de empresario plural entre la Comunidad Autónoma y una entidad local, por ser aquélla la que subvenciona los costes salariales y de Seguridad Social, ha aportado los medios de gestión necesarios, tales como el sistema informático, la dirección y ejecución de programas, supervisando, detectando la necesidades e identificando los beneficiarios de loa servicios, considerando que, pese a no ser una auténtica cesión ilegal, si es un supuesto de empresario plural, porque, "aun cuando la demandante no recibiera órdenes directas de la Consejería, en cuanto a horarios, jornada, organización interna del trabajo, vacaciones, etc., que son las manifestaciones típicas en una empresa del poder de dirección y organización empresarial que lleva a cabo sobre sus 
Ese precepto permite expresamente sólo la reclamación de deudas por cuotas, sin aludirse a deudas de otros recursos económicos de la Seguridad Social, lo que no se cohonesta con la naturaleza de esta responsabilidad, que tiene su fundamento en exigir la deuda al verdadero sujeto responsable, al verdadero empresario, y no al empresario formal o aparente. Si el deudor formal ha generado una deuda por prestaciones, ésta debería ser exigible con igual fundamento al empresario real, por imponerlo así el principio de prohibición del fraude de ley y la primacía de la realidad jurídica (art. 6.4 del Código Civil, en relación con los arts. 1 y 43 del TRLET).

Derivación de responsabilidad para el pago de deudas por cotizaciones a la Seguridad Social en los grupos de empresa reconocida por la jurisprudencia, sin que impida esa declaración de responsabilidad derivada la circunstancia de estar alguna de las empresas del grupo en concurso de acreedores, mientras no se reclame a ésta la deuda, citando como preceptos que amparan la misma los actuales arts. 18.3 y 33.2 del TRLGSS ${ }^{1360}$.

La responsabilidad solidaria en el pago de cotizaciones en los grupos de empresas sería reconducible, en buena técnica jurídica, al art. 18.4 del TRLGSS, y no al art. 18.3 del TRLGSS como señalan esas sentencias. En el art. 18.4 del TRLGSS se imputa la responsabilidad a quien pueda ser considerado empleador a efectos laborales, condición atribuida a efectos de la responsabilidad por cotizaciones a la empresa grupo o al grupo patológico. En cambio, en el art. 18.3 del TRLGSS se permite la derivación de responsabilidad solidaria cuando ésta venga establecida en una norma con rango de ley, y en la derivación a la empresa grupo o grupos patológicos la responsabilidad no viene impuesta expresamente en una norma con rango de ley, sino que resulta de la determinación de la condición de empresario real responsable, prescindiendo del empresario formal.

En las Sentencias del TS, Sala Contencioso-Administrativa, 1661/2018, de 22 noviembre -Rec. 2507/2016-; 1008/2019, de 8 de julio -Rec. 220/2017-; 1181/2019, de 16 septiembre -Rec. 22/2016-; se señala que, “en efecto, sabemos que los artículos 15 , 30 y 104 del Real Decreto Legislativo 1/1994, facultan a la Tesorería General de la Seguridad Social para, en caso de impago, dirigirse contra el empresario responsable y contra los responsables solidarios. Solidaridad establecida por esta misma disposición

trabajadores, sí que ha ejercido la Consejería lo que podríamos denominar como "poder directivo general".

1360 SSTS, Sala Contencioso-Administrativa, 1661/2018, de 22 noviembre -Rec. 2507/2016-; 1008/2019, de 8 de julio -Rec. 220/2017-; y 1181/2019, de 16 septiembre -Rec. 22/2016-. 
con fuerza de Ley". La alusión a la solidaridad impuesta por la misma disposición de Seguridad Social con fuerza de ley, con relación a los grupos de empresas, hemos de puntualizar que la responsabilidad en la empresa grupo o grupo patológico no tiene como fundamento el art. 18.3 del TRLGSS, ya que este precepto contempla la derivación por responsabilidad solidaria cuando ésta venga impuesta por norma legal, sea en disposición legal de Seguridad Social o de otro orden normativo, y en ninguna disposición legal de Seguridad Social -a diferencia de otros supuestos como son las contratas, cesión legal, o sucesión de empresa-, se establece una responsabilidad solidaria en los grupos de empresa, ni incluso en la legislación mercantil se impone esa responsabilidad solidaria en los grupos de empresa.

El carácter solidario de la responsabilidad en los grupos se ha venido declarando por la jurisprudencia partiendo de la doctrina del levantamiento del velo, de la determinación del empresario a efectos laborales, que es lo que se recoge en el actual art. 18.4 del TRLGSS. En esta dirección se pronuncia el TS, Sala Contencioso-Administrativa en Sentencias 1292/2016 de 2 junio -Rec. 2890/2014- y 1673/2016, de 8 julio -Rec. 3831/2014-, donde la responsabilidad de los grupos de empresa se localiza en el art. 18.4 del TRLGSS, al indicar, "por su parte, el art. 15 de la LGSS, al que remite el art. 104 de la misma, establece en su redacción por Ley 52 / 2003, en vigor desde el 1 de enero de 2004, una pluralidad de supuestos de responsabilidad solidaria. Además del previsto en su apartado 3, responsabilidad por aplicación de supuestos previstos en cualquier norma con rango de ley, entre los que tendría cabida el art. 44 del ET, se introdujo también en la Ley 52/2003, el apartado 4 que dispone: «4. En caso de que la responsabilidad por la obligación de cotizar corresponda al empresario, podrá dirigirse el procedimiento recaudatorio que se establece en esta Ley y su normativa de desarrollo contra quien efectivamente reciba la prestación de servicios de los trabajadores que emplee, aunque formalmente no figure como empresario en los contratos de trabajo, en los registros públicos o en los archivos de las entidades gestoras y servicios comunes». Por consiguiente, tras la reforma del art. 15 de la LGSS por la Ley 52/2003, que introdujo los nuevos apartados 3 y 4 , ya es posible, sin ninguna duda, fundar la responsabilidad solidaria en la existencia de un grupo de empresas, con la única condición de que éste exista realmente y pueda afirmarse que es éste, el grupo de empresas, el empresario real, sin necesidad de sobreponer o mezclar la regulación legal 
de la sucesión de empresas con la doctrina jurisprudencial del grupo de empresas". Doctrina judicial ésta que estimamos más correcta y que defendemos.

El único precepto que permite la reclamación derivada de deudas por cotizaciones en la empresa grupo sería el art. 18.4 del TRLGSS, en relación con el art. 1.2 del TRLET, y no tanto el art. 18.3 del TRLGSS. Artículo 18.4 del TRLGSS que permite reclamar la deuda por cuotas al empresario real sin cuestionar la reclamación que haya podido emitirse con anterioridad al empresario formal. Ese precepto lo que está contemplando, en definitiva, es una reclamación de la deuda por cuotas al empresario que realmente percibe y hace suya la prestación laboral. Ante la insuficiencia del precepto y como propuesta de lege ferenda hemos abogado en esta tesis por su reforma para que se incluya también la responsabilidad en el pago de prestaciones de responsabilidad empresarial.

En los grupos de empresa, cuando se reclame la responsabilidad solidaria a las sociedades integrantes de la empresa grupo o del grupo patológico, en puridad, no cabría hablar de una responsabilidad por deudas del administrador social, porque los responsables son las entidades mercantiles, salvo que se califique como administrador de hecho o de derecho de las filiales a la sociedad matriz o a su administrador.

Derivación administrativa de responsabilidad dentro del procedimiento administrativo de recaudación, por la TGSS y por la ITSS, al amparo de los apartados 3 y 4 del art. 18 del TRLGSS, que se ha reconocido, tras la entrada en vigor de la Ley 52/2003, de 10 de diciembre, de modo reiterado por el $\mathrm{TS}^{1361}$.

A efectos de este trabajo, nos interesa fundamentalmente la eventual declaración de responsabilidad del administrador-socio de control, para partiendo de la doctrina del levantamiento del velo societario, y del art. 18.4 del TRLGSS, reclamarle las cotizaciones, cuando pueda ser calificado como el empresario real, por haberse servido del ropaje de la personalidad jurídica societaria para eludir la aplicación de la responsabilidad patrimonial personal ilimitada del art. 1911 del Código Civil. En la derivación de responsabilidad por levantamiento del velo, estaremos ante una responsabilidad de quien realmente ejerza, dirija y retribuya la relación laboral, que no

1361 Por todas, y como más recientes, SSTS, Sala Contencioso-Administrativo, 1661/2018, de 22 noviembre -Rec. 2507/2016-; 1181/2019, de 16 septiembre -Rec. 22/2016-; 1182/2019, de 16 septiembre -Rec. 9/2017-; 1008/2019, de 8 julio -Rec. 220/2017-; 1807/2017, de 23 noviembre -Rec. 2012/2015-; 619/2017, de 5 abril -Rec. 1594/2015-; 509/2017, de 23 marzo -Rec. 1486/2015-; 1673/2016, de 8 julio -Rec. 3831/2014-; y 1292/2016, de 2 junio -Rec. 2890/2014-. 
necesariamente concurrirá en la persona del administrador social, aunque en sociedades de escaso capital y familiares, suelen confluir ambas condiciones.

\section{Antecedentes normativos.}

La derivación administrativa de responsabilidad al administrador social dentro del procedimiento administrativo de recaudación, fue introducida en nuestro Derecho de Seguridad Social mediante la Ley 52/2003, de 10 de diciembre, de disposiciones específicas en materia de Seguridad Social ${ }^{1362}$.

En el artículo 12. uno ${ }^{1363}$ de la Ley 52/2003, de 10 de diciembre, se introdujeron los nuevos apartados 3 y 4 del artículo 15 del anterior Texto Refundido de la Ley General de la Seguridad Social -Real Decreto Legislativo 1/1994, de 20 de junio ${ }^{1364}$. En el art. 12. dos ${ }^{1365}$ se da nueva redacción al art. 104.1, del Real Decreto Legislativo 1/1994, de

1362 (BOE del 11 de diciembre), con entrada en vigor desde el 1.1.2004, excepto la redacción de los arts. 30 y 31 de la anterior Ley General de la Seguridad Social, actuales artículos 33 y 34 del TRLGSS, que entraron en vigor el 1.6.2004.

1363 “Artículo 12. Responsabilidad por cotizaciones y otros recursos. Uno. Se adicionan dos nuevos apartados 3 y 4, al artículo 15 del Texto Refundido de la Ley General de la Seguridad Social, aprobado por el Real Decreto Legislativo 1/1994, de 20 de junio (RCL 1994, 1825), en los siguientes términos:

«3. Son responsables del cumplimiento de la obligación de cotizar y del pago de los demás recursos de la Seguridad Social las personas físicas o jurídicas o entidades sin personalidad a las que las normas reguladoras de cada régimen y recurso impongan directamente la obligación de su ingreso y, además, los que resulten responsables solidarios, subsidiarios o sucesores "mortis causa" de aquéllos, por concurrir hechos, omisiones, negocios o actos jurídicos que determinen esas responsabilidades, en aplicación de cualquier norma con rango de ley que se refiera o no excluya expresamente a las obligaciones de Seguridad Social, o de pactos o convenios no contrarios a las leyes. Dicha responsabilidad solidaria, subsidiaria, o "mortis causa" se declarará y exigirá mediante el procedimiento recaudatorio establecido en esta Ley y su normativa de desarrollo.

4. En caso de que la responsabilidad por la obligación de cotizar corresponda al empresario, podrá dirigirse el procedimiento recaudatorio que se establece en esta Ley y su normativa de desarrollo contra quien efectivamente reciba la prestación de servicios de los trabajadores que emplee, aunque formalmente no figure como empresario en los contratos de trabajo, en los registros públicos o en los archivos de las entidades gestoras y servicios comunes".

${ }^{1364}$ BOE del 29.6.1994.

1365 Dos. Se modifica el apartado 1 del artículo 104 del Texto Refundido de la Ley General de la Seguridad Social, aprobado por el Real Decreto Legislativo 1/1994, de 20 de junio, en los siguientes términos:

«1. El empresario es sujeto responsable del cumplimiento de la obligación de cotización e ingresará las aportaciones propias y las de sus trabajadores, en su totalidad.

Responderán, asimismo, solidaria, subsidiariamente o "mortis causa" las personas o entidades sin personalidad a que se refieren los artículos 15 y 127.1 y 2 de esta Ley.

La responsabilidad solidaria por sucesión en la titularidad de la explotación, industria o negocio que se establece en el citado artículo 127 se extiende a la totalidad de las deudas generadas con anterioridad al hecho de la sucesión. Se entenderá que existe dicha sucesión aun cuando sea una sociedad laboral la que continúe la explotación, industria o negocio, esté o no constituida por trabajadores que prestaran servicios por cuenta del empresario anterior.

En caso de que el empresario sea una sociedad o entidad disuelta y liquidada, sus obligaciones de cotización a la Seguridad Social pendientes se transmitirán a los socios o partícipes en el capital, 
20 de junio, y en el artículo 5 apartados seis ${ }^{1366}$ y siete $^{1367}$ se da nueva redacción a los arts. 30 y 31 de la anterior Ley General de la Seguridad Social, para regular la

que responderán de ellas solidariamente y hasta el límite del valor de la cuota de liquidación que se les hubiere adjudicado".

1366 “Artículo 5. Recaudación en período voluntario y en vía ejecutiva. Se da nueva redacción al artículo 25, al apartado 1 del artículo 26 y a los artículos 27, 28, 29, 30, 31, 32, 33 y 34 del Texto Refundido de la Ley General de la Seguridad Social, aprobado por el Real Decreto Legislativo 1/1994, de 20 de junio (RCL 1994, 1825), en los siguientes términos:

Seis. «Artículo 30. Reclamaciones de deudas.

1. Transcurrido el plazo reglamentario sin ingreso de las cuotas debidas, la Tesorería General de la Seguridad Social reclamará su importe al sujeto responsable incrementado con el recargo que proceda, conforme a lo dispuesto en el artículo 27 de esta Ley, en los siguientes supuestos:

a) Falta de cotización respecto de trabajadores dados de alta, cuando no se hubiesen presentado los documentos de cotización en plazo reglamentario o cuando, habiéndose presentado, contengan errores aritméticos o de cálculo que resulten directamente de tales documentos. Si estas circunstancias fuesen comprobadas por la Inspección de Trabajo y Seguridad Social, lo comunicará a la Tesorería General de la Seguridad Social con la propuesta de liquidación que proceda.

b) Falta de cotización en relación con trabajadores dados de alta que no consten en los documentos de cotización presentados en plazo reglamentario, respecto de los que se considerará que no han sido presentados dichos documentos.

c) Diferencias de importe entre las cuotas ingresadas y las que legalmente corresponda liquidar, debidas a errores aritméticos o de cálculo que resulten directamente de los documentos de cotización presentados.

d) Deudas por cuotas cuya liquidación no corresponda a la Inspección de Trabajo y Seguridad Social.

2. Procederá también reclamación de deuda cuando, en atención a los datos obrantes en la Tesorería General de la Seguridad Social y por aplicación de cualquier norma con rango de ley que no excluya la responsabilidad por deudas de Seguridad Social, deba exigirse el pago de dichas deudas:

a) A los responsables solidarios, en cuyo caso la reclamación comprenderá el principal de la deuda a que se extienda la responsabilidad solidaria, los recargos, intereses y costas devengados hasta el momento en que se emita dicha reclamación.

b) Al responsable subsidiario, por no haber ingresado éste el principal adeudado por el deudor inicial en el plazo reglamentario señalado en la comunicación que, en este caso, se libre a tal efecto.

c) A quien haya asumido la responsabilidad por causa de la muerte del deudor originario, en cuyo caso, la reclamación comprenderá el principal de la deuda, los recargos, intereses y costas devengados hasta que se emita.

3. (...)

4. (...)

5. (...)".

En caso de resolución desestimatoria del recurso, transcurrido el plazo de 15 días desde su notificación sin pago de la deuda, se iniciará el procedimiento de apremio mediante la expedición de la providencia de apremio o el procedimiento de deducción, según proceda».

1367 Siete. «Artículo 31. Actas de liquidación de cuotas.

1. Procederá la formulación de actas de liquidación en las deudas por cuotas originadas por: (...), c) Por derivación de la responsabilidad del sujeto obligado al pago, cualquiera que sea su causa y régimen de la Seguridad Social aplicable, y en base a cualquier norma con rango de ley que no excluya la responsabilidad por deudas de Seguridad Social. En los casos de responsabilidad solidaria legalmente previstos, la Inspección podrá extender acta a todos los sujetos responsables o a alguno de ellos, en cuyo caso el acta de liquidación comprenderá el principal de la deuda a que se extienda la responsabilidad solidaria, los recargos, intereses y costas devengadas hasta la fecha en que se extienda el acta.

En los casos a los que se refieren los párrafos anteriores a), b) y c), la Inspección de Trabajo y Seguridad Social podrá formular requerimientos a los sujetos obligados al pago de cuotas adeudadas por cualquier causa, previo reconocimiento de la deuda por aquéllos ante el funcionario actuante. En este caso, el ingreso de la deuda por cuotas contenida en el 
reclamación de deuda por derivación y el acta de liquidación de cuotas por derivación de responsabilidad. Preceptos incorporados a los actuales apartados 3 y 4 del artículo 18 y a los artículos 33, 34 y 142.1 del TRLGSS.

En la Disposición Final Segunda de la Ley 52/2003, acerca de la entrada en vigor de la misma se establecía que "la presente Ley entrará en vigor el día primero del mes siguiente al de su publicación en el Boletín Oficial del Estado, salvo lo establecido en sus artículos 3, 4, y 5, que entrarán en vigor el día primero del sexto mes siguiente al de dicha publicación". Esto es, el art. 15 apartados 3 y 4, y el art. 104.1 de la anterior Ley General de la Seguridad Social entraron en vigor el 1 de enero de 2004, pero en cambio, los artículos 30 y 31 de la Ley General de la Seguridad Social, que regulaban la reclamación de deuda por derivación por responsabilidad emitida por la TGSS y el acta de liquidación de cuotas por derivación a extender por la ITSS, cuando la responsabilidad solidaria o subsidiaria estuviere recogida en norma con rango de ley de cualquier orden normativo que no excluyese las deudas de Seguridad Social, entraron en vigor el 1 de junio de 2004.

Con anterioridad a la Ley 52/2003, de 10 de diciembre, en las leyes reguladoras de la Ley General de la Seguridad Social y en los Reglamentos de Recaudación de la Seguridad Social, solamente se hacía referencia a los responsables solidarios o subsidiarios del pago de las obligaciones de Seguridad Social, para circunscribirlos a quienes lo fueren de conformidad con la propia normativa reguladora de los diversos recursos de la Seguridad Social, sin que se incluyesen, por remisión, supuestos de responsabilidad establecidos en otros órdenes o sectores normativos. Esa era la regulación de los responsables solidarios y subsidiarios de los Reglamentos Generales de Recaudación de los Recursos del Sistema de la Seguridad Social, aprobados por el Real Decreto 716/1986, de 7 de marzo ${ }^{1368}$ y por el Real Decreto $1517 / 1991$, de 11 de

requerimiento será hecho efectivo hasta el último día del mes siguiente al de su notificación. En caso de incumplimiento del requerimiento se procederá a extender acta de liquidación y de infracción por impago de cuotas.

Las actas de liquidación de cuotas se extenderán por la Inspección de Trabajo y Seguridad Social, notificándose en todos los casos a través de los órganos de dicha Inspección que, asimismo, notificarán las actas de infracción practicadas por los mismos hechos, en la forma que reglamentariamente se establezca.

2. (...)

3. (...).

4. (...). “

1368 BOE del 16.4.1986, con vigencia del 17.4.1986 al 25.10.1991, se regulaba en los arts. 10 y 11 , respetivamente, los responsables solidarios o subsidiarios, para referirse exclusivamente a quienes ostenten esa condición en la normativa reguladora de la Seguridad Social. 
octubre $^{1369}$. En esos reglamentos la responsabilidad solidaria y subsidiaria sólo era la establecida por las normas reguladoras de los diferentes recursos del Sistema de la Seguridad Social, sin referencia a ninguna disposición de otros sectores normativos, salvo en lo relativo a la remisión al Estatuto de los Trabajadores en la responsabilidad en contratas, subcontratas, cesión temporal de trabajadores y sucesión de empresa, que se recogía en los Textos Refundidos de las anteriores Leyes Generales de la Seguridad Social. En definitiva, eran supuestos de responsabilidad en deudas de Seguridad Social previstos expresamente en la normativa laboral y de Seguridad Social.

Estas dos últimas disposiciones se dictaron durante la vigencia de los anteriores Textos Refundidos de la Ley General de la Seguridad Social, aprobados por el Decreto 2065/1974, de 30 de mayo ${ }^{1370}$, con vigencia del 23.7.1974 a 31.8.1994, y por el Real Decreto Legislativo 1/1994, de 20 de junio ${ }^{1371}$, con vigencia del 1.9.1994 a 1.1.2016, en los que, dentro de los responsables solidarios o subsidiarios, sólo se regulaba la responsabilidad de la empresa, y las responsabilidades solidarias o subsidiarias de las empresas en las contratas, subcontratas, cesión temporal de mano de obra, y en sucesión mortis causa (arts. 15, 17, 68 y 97 apartados 1 y 2 del Real Decreto 2065/1974, de 30 de

“Art. 10.1 La responsabilidad solidaria en el pago de deudas a la Seguridad Social deriva del hecho de estar incurso el responsable en los supuestos en que, por normas reguladoras de los diferentes recursos del sistema de la Seguridad Social, se imponga expresamente tal responsabilidad. Esta responsabilidad podrá hacerse efectiva en cualquier momento del procedimiento recaudatorio, sin más requisitos que la previa reclamación de la deuda en la forma y por la cuantía que proceda".

"Art. 11.1 La responsabilidad subsidiaria se origina como consecuencia de estar incurso el responsable en los supuestos general o especialmente previstos, a tal efecto, por las normas vigentes".

1369 BOE 25.10.1991, con vigencia del 26.10.1991 hasta el 12.11.1995, los responsables solidarios (art. 10), y los subsidiarios (art. 11), serían quienes lo fueren de conformidad con la normativa de los diversos recursos económicos de la Seguridad Social, sin que se incluyen supuestos de responsabilidad establecidos en otros ordenes normativos distintos.

“Art. 10. Responsables solidarios. 1. La responsabilidad solidaria en el pago de las deudas a la Seguridad Social deriva del hecho de estar incurso el responsable en los supuestos en que, por las normas reguladoras de los diferentes recursos del Sistema de la Seguridad Social, se imponga expresamente tal responsabilidad. Esta responsabilidad podrá hacerse efectiva en cualquier momento del procedimiento recaudatorio, sin más requisito que la previa reclamación de la deuda en la forma y por la cuantía que proceda salvo, en las deudas por cuotas, a los solidarios que hubieran presentado los documentos de cotización en plazo reglamentario, a los que se exigirá su responsabilidad en iguales términos que a los demás responsables del cumplimiento de la obligación de cotizar que hubieran presentado en plazo dichos documentos".

En el art. 11.1 "La responsabilidad subsidiaria en el pago de las deudas con la Seguridad Social se origina como consecuencia de estar incurso el responsable en los supuestos general o específicamente previstos, a tal efecto, por las normas vigentes".

1370 BOE del 20.7.1974 y 22.7.1974.

${ }^{1371}$ BOE del 29.06.1994. 
enero; y arts. 15, 104 y 127 apartados 1 y 2 del Real Decreto Legislativo 1/1994, de 20 de junio).

Antes de la reforma del Real Decreto Legislativo 1/1994, de 20 de junio, por la Ley 52/2003, de 10 de diciembre, en el Real Decreto 1637/1995, de 6 de octubre ${ }^{1372}$, se contempló, novedosamente y por primera vez, la responsabilidad solidaria o subsidiaria, si la misma estuviere establecida en cualquier disposición normativa, sin mayores concreciones, sin aludirse al rango ni al sector jurídico de la misma.

En el artículo 10 de ese Real Decreto 1637/1995, de 6 de octubre, se regulaba expresamente la responsabilidad solidaria en los supuestos de sucesión empresarial, contratas, subcontratas y cesión temporal de mano de obra, así como la responsabilidad de entidades depositarias de bienes embargados que colaborasen o consintiesen el levantamiento del embargo (apartados 1 a 4); para en su apartado 5 recoger una cláusula de cierre sobre la responsabilidad solidaria del siguiente contenido, "se originará asimismo responsabilidad solidaria en el pago de las deudas con la Seguridad Social en el caso de aval, fianza u otra garantía personal prestada con carácter solidario en favor de la Tesorería General de la Seguridad Social y, en general, por el hecho de estar incurso el responsable en los demás supuestos en los que, por pacto o por norma, se imponga expresamente tal tipo de responsabilidad". Se contemplaba la responsabilidad solidaria impuesta en cualquier norma jurídica, sin ninguna limitación de rango ni de sector normativo, con lo que esa regulación reglamentaria podía estar incurriendo en un posible vicio ultra vires, si se pretendiese a su amparo imponer una responsabilidad no prevista expresamente en la normativa legal laboral o de Seguridad Social.

Ese reglamento añadía este nuevo supuesto de responsabilidad, junto a los tradicionales supuestos de responsabilidad solidaria previstos en la Ley de la Seguridad Social para las contratas, la cesión temporal de mano de obra, y la sucesión de empresa. Responsabilidad solidaria que se declaraba por la TGSS en el procedimiento administrativo de recaudación (art. 11 del Real Decreto 1637/1995) ${ }^{1373}$, y por la ITSS mediante acta de liquidación.

\footnotetext{
${ }^{1372}$ BOE del 24.10.1995, que aprobó un nuevo Reglamento de Recaudación de los Recursos del Sistema de la Seguridad Social, con vigencia 13.11.1995 hasta 25.6.2004.

1373 “Artículo 11. Responsables solidarios: aspectos procedimentales.
} 
Sobre el contenido de la responsabilidad, en el artículo 10.6 de ese Real Decreto 1637/1995, de 6 de octubre, se establecía que, "la responsabilidad solidaria alcanzará tanto a la deuda como, en su caso, a los recargos, intereses y a las costas del procedimiento de apremio impagados, con aplicación de los límites que para las garantías solidarias prestadas resulten de su constitución".

La reclamación de la responsabilidad solidaria se realizaba por la TGSS mediante la reclamación de deuda, y por la ITSS, mediante el acta de liquidación de cuotas, reguladas en los arts. 30 y 31 del Real Decreto 1/1994, de 20 de junio, y en los arts. 80 a 86 del Real Decreto 1637/1995, así como en los arts. 32 a 36 del Real Decreto 628/1998, de 14 de mayo -RISOS-.

En el art. 80 apartado e) del Real Decreto 1637/1995 ${ }^{1374}$ al regular la reclamación de deuda por derivación de responsabilidad por la TGSS, establecía que, “e) en los supuestos en que, por derivación de responsabilidad en el pago de cuotas debida a cualquier título, se impute la responsabilidad solidaria o subsidiaria en el

1. La responsabilidad solidaria podrá hacerse efectiva en cualquier momento del procedimiento recaudatorio conforme a las reglas establecidas en el presente artículo y, en su caso, en el artículo 115 de este Reglamento y en las disposiciones que los desarrollen:

a) Tanto si la deuda se encuentra en período voluntario de recaudación como en vía ejecutiva será necesaria la previa reclamación administrativa para el pago de la misma en la forma que para las reclamaciones de deuda se establece en este Reglamento y para las actas de liquidación en el Reglamento General sobre procedimientos para la imposición de sanciones por infracciones de orden social y para los expedientes liquidatorios de cuotas de la Seguridad Social, aprobado por el Real Decreto 928/1998, de 14 de mayo.

Cuando la responsabilidad solidaria hubiere sido declarada y notificada al responsable solidario en cualquier momento anterior a la reclamación administrativa de la deuda, ésta podrá dirigirse a todos los deudores solidarios o algunos de ellos mediante reclamación de deuda o acta de liquidación, según proceda.

Si la responsabilidad solidaria no hubiere sido declarada y notificada con anterioridad a la reclamación administrativa de la deuda a alguno de los deudores que se consideran solidarios, en el mismo acto administrativo se declarará la responsabilidad solidaria y se reclamará el pago a todos o a cualquiera de los deudores así declarados.

b) Las reclamaciones de deuda y las actas de liquidación en los supuestos a que se refiere el apartado precedente, expresarán necesariamente, bien el acto administrativo anterior si existiere o en otro caso los hechos y los preceptos o fundamentos de derecho de los que derive la responsabilidad solidaria de los sujetos obligados. En ambos casos, se notificarán a éstos con expresión de los elementos esenciales de la liquidación de la deuda y de la declaración de la responsabilidad solidaria y el alcance sustantivo de la misma, así como la forma y plazos en que debe ser satisfecha la deuda, que serán los establecidos en este Reglamento para los ingresos en período voluntario o, su caso, en vía ejecutiva, indicándose además el recurso procedente, el órgano ante el que ha de presentarse y plazo para interponerlo.

2. En los supuestos de aval, fianza u otra garantía personal prestada con carácter solidario, el procedimiento para la exigencia de esta responsabilidad será el regulado en el artículo 115 de este Reglamento".

Redacción dada al apartado 11.a) por el Real Decreto 2032/1998, de 25 de septiembre (BOE 13.10.1998).

1374 Apartado e), según la redacción introducida por Real Decreto 2032/1998, de 25 de septiembre -BOE del 13.10.1998-, y con vigencia desde el 14.10.1998. 
cumplimiento de la obligación de cotizar, siempre que, por los datos obrantes en la Tesorería General de la Seguridad Social, pueda determinarse el sujeto responsable, la cuantía de la deuda y los trabajadores afectados".

Ese precepto reglamentario se debía interpretar partiendo de la nueva redacción del art. 30 apartado 1.e) del Real Decreto Legislativo 1/1994,de 20 de junio, de la anterior Ley General de la Seguridad Social, introducida por la Ley 66/1997, de 30 de diciembre, de medidas fiscales, administrativas y del orden social ${ }^{1375}$, en virtud del cual, y con vigencia desde el 1 de enero de 1998 al 31 de mayo de 2004, se preveía la reclamación de deuda por la TGSS, "por derivación de responsabilidad en el pago de cuotas debida a cualquier título, cuando de los datos obrantes en la Tesorería General de la Seguridad Social pueda determinarse el sujeto responsable, la cuantía de la deuda y los trabajadores afectados". Se hablaba responsabilidad atribuible por cualquier título jurídico, pero no que la responsabilidad se contemplase en norma jurídica distinta del orden social, por lo que el art. 10.5 del Real Decreto 1637/1995, de 6 de octubre, difícilmente podría tener cobertura en el art. 30 de la Ley General de la Seguridad Social.

Del juego conjunto del nuevo art. 30 apartado 1. e) de la Ley General de la Seguridad Social, con vigencia desde el 1 de enero de 1998, y los arts. 10.5 y 80 apartado e) del Reglamento de Recaudación, se abría la puerta para reclamar la responsabilidad solidaria del administrador social, partiendo de la legislación de sociedades en la que se establecía una responsabilidad por deudas de éste, ya que se imponía la responsabilidad solidaria cuando viniese impuesta por cualquier título, previsión que, en interpretación sistemática con el art. 10.5 del Reglamento, de estar incurso el responsable en los demás supuestos en los que, por norma, se imponga expresamente tal tipo de responsabilidad, permitía acudir a la TGSS a disposiciones normativas mercantiles. La única dificultad para la TGSS era el requisito impuesto legalmente de que los hechos determinantes de la misma le habrían de constar por los datos obrantes en ese Servicio Común, con lo que hacía muy difícil su aplicación, ya que los posibles hechos determinantes de la responsabilidad por deudas del administrador no serán datos que consten en la TGSS, sólo podría conocerlos previa actuación de la ITSS.

${ }^{1375}$ BOE del 31.12.1997. 
Disposiciones normativas, especialmente el Reglamento de Recaudación, que permitieron a la TGSS derivar la deuda del sujeto obligado principal (la sociedad), al responsable solidario (al administrador social).

El acta de liquidación de cuotas por derivación se recogía en el art. 31 apartado 1.c) del Real Decreto 928/1998, de 14 de mayo -RISOS-, al señalarse que, "procederá la extensión de actas de liquidación en las deudas por cuotas originadas por: c) por derivación de la responsabilidad del sujeto obligado al pago, cualquiera que sea su causa y Régimen de la Seguridad Social aplicable". No aludía a que se pudiera declarar la responsabilidad en virtud de cualquier norma y de cualquier sector normativo, porque se partía de la responsabilidad impuesta en la normativa de Seguridad Social.

Ese precepto del RISOS recogía la nueva modalidad de acta de liquidación por derivación de responsabilidad, introducida en el art. 31.1. c) de la Ley General de la Seguridad Social por la Ley 66/1997, de 30 de diciembre, de medidas fiscales, administrativas y del orden social, con vigencia desde el 1 de enero de 1998, donde se establecía que, procedía el acta de liquidación de cuotas, "por derivación de la responsabilidad del sujeto obligado al pago, cualquiera que sea su causa y Régimen de la Seguridad Social aplicable. En los supuestos de responsabilidad solidaria, la Inspección podrá extender acta a todos los sujetos responsables o a alguno de ellos".

Precepto legal que refería el acta de liquidación por derivación de responsabilidad, cualquiera que fuere la causa y el Régimen de Seguridad Social, pero no habilitaba para acudir a disposiciones legislativas distintas del orden social, como la legislación mercantil.

La habilitación de una norma de Seguridad Social con rango de ley para acudir a disposiciones normativas de sectores distintos al social, se establece por primera vez con la Ley 52/2003, de 10 de diciembre, al dar nueva redacción al art. 30 de la Ley General de la Seguridad Social para permitir la reclamación de la responsabilidad derivada por la TGSS acudiendo a disposiciones ajenas a la Seguridad Social, y al art. 31 para el acta de liquidación añadiendo "y en base a cualquier norma con rango de ley que no excluya la responsabilidad por deudas de Seguridad Social". Remisión a normas con rango de ley de cualquier sector normativo, para la responsabilidad solidaria, subsidiaria o mortis causa, que se introducía con carácter general en el art. 15.3 de esa Ley General de la Seguridad Social. 
A partir del 1.6.2004, fecha de entrada en vigor de la reforma de los arts. 30 y 31 de la Ley General de la Seguridad Social, según redacción dada por la Ley 52/2003, de 10 de diciembre, esos preceptos quedaron con el siguiente contenido:

Art. 30.2 "Procederá también reclamación de deuda cuando, en atención a los datos obrantes en la Tesorería General de la Seguridad Social y por aplicación de cualquier norma con rango de ley que no excluya la responsabilidad por deudas de Seguridad Social, deba exigirse el pago de dichas deudas:

a) A los responsables solidarios, en cuyo caso la reclamación comprenderá el principal de la deuda a que se extienda la responsabilidad solidaria, los recargos, intereses y costas devengados hasta el momento en que se emita dicha reclamación.

b) Al responsable subsidiario, por no haber ingresado éste el principal adeudado por el deudor inicial en el plazo reglamentario señalado en la comunicación que, en este caso, se libre a tal efecto.

c) A quien haya asumido la responsabilidad por causa de la muerte del deudor originario, en cuyo caso, la reclamación comprenderá el principal de la deuda, los recargos, intereses y costas devengados hasta que se emita".

Art. 31.1. c) "1. Procederá la formulación de actas de liquidación en las deudas por cuotas originadas por (...): c) Por derivación de la responsabilidad del sujeto obligado al pago, cualquiera que sea su causa y régimen de la Seguridad Social aplicable, y en base a cualquier norma con rango de ley que no excluya la responsabilidad por deudas de Seguridad Social. En los casos de responsabilidad solidaria legalmente previstos, la Inspección podrá extender acta a todos los sujetos responsables o a alguno de ellos, en cuyo caso el acta de liquidación comprenderá el principal de la deuda a que se extienda la responsabilidad solidaria, los recargos, intereses y costas devengadas hasta la fecha en que se extienda el acta".

Paralelamente, en la regulación de los responsables subsidiarios, en el artículo 12. 3 de ese Real Decreto 1637/1995, se establecía que "existirá, en general, responsabilidad subsidiaria en el pago de las deudas con la Seguridad Social en los demás supuestos en que, por pacto o por norma, se prevea, general o específicamente, tal tipo de responsabilidad". Se introducía, de este modo, también una nueva responsabilidad 
subsidiaria cuando en cualquier norma se impusiere la misma, sin concretar el rango y el sector normativo, con lo que permitía acudir a cualquier disposición. En el aparado 5, b) se indicaba que para reclamar la responsabilidad subsidiaria, era preciso que, “ $b$ ) que exista acto administrativo, simultáneo o subsiguiente, de derivación de la responsabilidad. Este acto, que deberá ser dictado por el órgano competente para reclamar administrativamente el pago de la deuda, expresará los elementos esenciales de la liquidación, así como acuerdo motivado declarando la responsabilidad subsidiaria y la cantidad a que ésta alcance y que, como consecuencia del mismo, el declarado responsable subsidiario pasará a ocupar la posición del primer obligado".

Responsabilidad subsidiaria que de conformidad con el art. 12.4 de ese Real Decreto se limitaba al importe de la deuda liquidada y notificada al deudor principal en período voluntario, sin incluir recargos, ni las sanciones pecuniarias impuestas al deudor principal, salvo cuando resultase de la participación del responsable subsidiario en la infracción de normas de Seguridad Social.

Como consecuencia de esa regulación legal y reglamentaria vigente con anterioridad a la Ley 52/2003, de 10 de diciembre, principalmente la TGSS, y en menor medida la ITSS, dictaron actos administrativos de derivación de la responsabilidad solidaria de las deudas de la sociedad de capital al administrador social, acudiendo a los supuestos de la legislación mercantil, fundamentalmente al art. 262.5 de la LSA y al art. 105.5 de la LSRL, en que se imponía una responsabilidad solidaria del administrador en las deudas de la sociedad cuando incumpliera sus deberes legales ante la concurrencia de una causa legal de disolución. Recurso a la legislación mercantil para derivar la responsabilidad al administrador social, pese a no existir una disposición legal de Seguridad Social que contemplase expresamente esa responsabilidad.

Recurridas esas derivaciones administrativas de responsabilidad de deudas al administrador social, dictadas dentro del procedimiento administrativo de recaudación, los Tribunales Superiores de Justicia adoptaron resoluciones judiciales contradictorias, unas admitiendo la competencia de la TGSS para dictar en el procedimiento administrativo de recaudación actos de derivación de responsabilidad al administrador, y otras negando esa competencia, declarando que la TGSS debería reclamar la declaración de esa responsabilidad ante el orden jurisdiccional civil, para que sea éste quien declare si concurren los presupuestos normativos determinantes de la responsabilidad del administrador, ya que debe aplicarse una norma mercantil 
competencia de ese orden jurisdiccional, no pudiendo ser declarada en virtud del principio de autotutela administrativa por ese Servicio Común de la Seguridad Social.

Esa discrepancia interpretativa de los Tribunales Superiores de Justicia se resolvió de modo definitivo en jurisprudencia muy reiterada ${ }^{1376}$, con una primera sentencia del TS, Sala Contencioso Administrativo, de 18 de junio de 2002 -Rec. 3424/2001-, en la que se asumía la doctrina fijada anteriormente por la Sala de Conflictos de Competencias del TS, quien, en Auto 4/1996, de 8 de marzo -Rec. 7/1995-, había declarado que la competencia para apreciar si concurrían los presupuestos legales de la responsabilidad por deudas del administrador social, previstos en la legislación de sociedades, correspondía a la Jurisdicción Civil, no pudiendo hacer esa declaración de responsabilidad la Administración de la Seguridad Social en el procedimiento administrativo de recaudación, ya que deberían examinarse los posibles incumplimientos de las obligaciones establecidas en esa legislación mercantil, sobre cuya aplicación no tiene competencia la Administración de la Seguridad Social. Doctrina atribuyendo la competencia a esa Jurisdicción Civil, que había sentado igualmente el TS, Sala Social, en numerosa jurisprudencia ${ }^{1377}$, salvo para la responsabilidad por deudas del administrador por incumplir el plazo legal para elevar la sociedad el capital social a los nuevos importes de diez millones de pesetas, en la sociedad anónima anteriores (LSA), o a quinientas mil pesetas en la sociedad de responsabilidad limitada (LSRL), en que se declaró la competencia de la Jurisdicción Social para conocer las demandas de los trabajadores ${ }^{1378}$.

En la doctrina ${ }^{1379}$ se defendió antes de la Ley 52/2003, de 10 de diciembre, la competencia para derivar la responsabilidad en el procedimiento administrativo, sin

1376 SSTS, Sala Contencioso-Administrativo, de 18 de junio de 2002 -RJ Aranzadi 2002/8616-; 18 de marzo de 2003 -RJ 2003/3145-; 31 de marzo de 2003 -RJ 2003/3485-; 21 de julio de 2003 -RJ 2003/6939-; 15 de octubre de 2003 -RJ 203/8582-; 18 de mayo de 2004 -RJ 2004/4411-; 22 de junio de 2004 -RJ 2004/4813-; y 15 de septiembre de 2004 -RJ RJ 2004/7302-.

1377 Entre otras, en SSTS, Sala Social, de 28 de febrero de 1997 -RJ Aranzadi 4220/1997-; 28 de octubre de 1997 -RJ 7680/1997-; 13 de abril de 1998 -RJ 1998/4577-; 21 de julio de 1998 -RJ 6211/1998-; 9 de noviembre de 1999 -RJ 1999\8520; 9 de junio de 2000 -RJ 2000\5109-; y 8 de mayo de 2002 -RJ 2002\7541-

1378 SSTS, Sala 4ª , de 28 de octubre de 1997 -RJ Aranzadi 7680/1997-; 31 de diciembre de 1997 -Rec. 1858/1997-; 31 de marzo de 1999 -Rec. 3073/1998-; 20 de septiembre de 1999 -Rec. 1339/1998-; 12 de abril de 2000 -rcud. 4605/1998-.

${ }^{1379}$ NICOLÁS BERNAD, J. A.: "La responsabilidad de los administradores sociales ante la Inspección de Trabajo", op. cit. pp. 98-99, quien consideraba que la ITSS estaba facultada para declarar la responsabilidad solidaria del administrador en deudas de la sociedad por incumplimiento sus mercantiles si producen un perjuicio a la Seguridad Social, invocando para ello el art. 7.4 de la 
necesidad de acudirse a los tribunales del orden civil. NICOLÁS BERNAD ${ }^{1380}$, una vez el Tribunal Supremo, en la Sentencia de 18 de junio de 2002, rechazó la derivación administrativa de responsabilidad en el procedimiento recaudatorio para reclamar la responsabilidad solidaria del administrador en aplicación de disposiciones legales mercantiles, seguía defendiendo, no obstante, la derivación en los cinco supuestos siguientes (sic): "a) incumplimientos de la normativa laboral que tengan conexión directa con la falta de pago de las obligaciones sociales; b) transgresiones de la Disposición Transitoria $3^{\text {a }}$, Disposición Transitoria $6^{\text {a }} .2$ de la LSA y artículo 129 de la LRSL (supuestos difíciles de producirse, en la práctica; c) la responsabilidad solidaria del socio único en la sociedad unipersonal sobrevenida de los artículos 311 LSA y 129 LSRL; d) la responsabilidad de los socios colectivos y comanditarios en el supuesto de que estas sociedades colectivas y comanditarias se transformen en anónimas, por las deudas sociales anteriores a la transformación, salvo que los acreedores consientan expresamente la transformación (art. 232 LSA); e) Supuestos en los que proceda el levantamiento del velo societario".

Al negarse por el TS la competencia para derivar la responsabilidad del administrador social en el procedimiento administrativo de recaudación, y en ausencia de previsión legal expresa, mediante la Ley 52/203, de 10 de diciembre, el legislador reconoce y atribuye expresamente la competencia para declarar y exigir, dentro del procedimiento administrativo de recaudación de los recursos de la Seguridad Social, la responsabilidad por deudas previstas en disposiciones legales de otros sectores del ordenamiento jurídico.

Mediante esa Ley 52/2003, de 10 de diciembre se solventa el problema de la inexistencia de la previa habilitación legal para derivar la responsabilidad dentro del procedimiento administrativo de recaudación, añadiendo los apartados 3 y 4 al art. 15 Real Decreto Legislativo 1/1994, de 20 de junio, anterior Texto Refundido de la Ley

anterior Ley 42/1997, actual art. 22.5 de la LOITSS de 2015, los arts. 10 y 12 del RGRSS y los arts. 29.2, 32. b y 33.1 del RISOS.

1380 NICOLÁS BERNAD, J. A.: “Un obstáculo para la derivación administrativa de responsabilidad por deudas sociales a entes societario por incumplimiento de la normativa mercantil", Boletín Aranzadi Laboral, núm. 4/2003, parte Boletín, editorial Aranzadi, S.A.U., Cizur Menor. 2003, edición digital, https://insignis-aranzadidigital-es.ponton.uva.es/maf/app/document?srguid, pp. 8-9. 
General de la Seguridad Social -en adelante LGSS- $^{1381}$, y redactando nuevamente los arts. 30, 31 y 104.1 del Real Decreto Legislativo 1/1994, de 20 de junio -LGSS- ${ }^{1382}$.

\subsection{Irretroactividad de la reforma de la Ley 52/2003, de 10 de diciembre.}

A partir de la Ley 52/2003, de 10 de diciembre, se permite la derivación de responsabilidad al administrador social de las deudas de Seguridad Social de la sociedad de capital dentro del procedimiento recaudatorio por la TGSS y por la ITSS, partiendo de la legislación de sociedades, surgiendo la duda acerca de si la nueva ley debía ser aplicada retroactivamente o no. Duda que conllevaba responder a su vez dos cuestiones, en primer lugar, desde cuándo puede derivarse la responsabilidad al administrador social en el procedimiento administrativo de recaudación, y en segundo lugar, qué deudas serían derivables, todas las no prescritas o sólo las deudas posteriores a la entrada en vigor de la Ley 52/2003.

Con relación a esta cuestión sobre la aplicación retroactiva o no de la Ley 52/2003, de 10 de diciembre, hemos de recordar que el art. 15 apartados 3 y 4, contiene esencialmente normas sustantivas. Así, en el apartado 3 se establecía la responsabilidad solidaria o subsidiaria en deudas de Seguridad Social cuando en una disposición con rango de ley venga establecida esa responsabilidad, sin que se haya excluido expresamente la responsabilidad por deudas de Seguridad Social. Ahora bien, en el último inciso del apartado 3 de ese artículo 15, se señalaba que esa responsabilidad sería declarada y exigida en el procedimiento administrativo de recaudación de la Seguridad Social, inciso este último de carácter procedimental, ya que remitía la declaración de responsabilidad al procedimiento administrativo, sin tener que acudirse a la vía judicial civil.

Planteada la duda acerca de la aplicación retroactiva de la reforma de la Ley 52/2003, para algunas sentencias de los Tribunales Superiores de Justicia, se entendía que la reforma lo que hizo fue atribuir la competencia para declarar y exigir la responsabilidad del administrador social dentro del procedimiento administrativo de recaudación, sin tener que acudir ante los tribunales de la Jurisdicción Civil, ya que la responsabilidad de éste ya existía con anterioridad, estribando la diferencia en que antes la TGSS no podía declararla en vía administrativa, sino que, como cualquier otro acreedor, debería acudir

${ }^{1381}$ Los apartados 3 y 4, que pasarán a ser los apartados 3 y 4 del art. 18 del TRLGSS.

${ }^{1382}$ Que se incorporan a los arts. 33, 34 y 142.1 del TRLGSS. 
ejercitando su derecho ante los tribunales, con lo que, a partir de la entrada en vigor de la reforma, en el propio procedimiento administrativo de recaudación se podrían derivar al administrador las deudas de la sociedad anteriores a enero de $2004^{1383}$.

La Sentencia del TSJ de Castilla y León/Burgos, Sala Contencioso-Administrativa, 413/2006, de 27 julio -JUR 2006/224671-, en la que se impugnaba la derivación de responsabilidad de la TGSS emitida tras la entrada en vigor de la Ley 52/2003, reclamando al administrador social las deudas de la sociedad de capital del periodo de mayo de 1999 a septiembre de 2003, reconoce la competencia de la TGSS para derivar la deuda, y señalaba "la Sala entiende que estas últimas disposiciones, legal y reglamentaria, han otorgado a la Tesorería General de la Seguridad Social la facultad de autotutela en vía administrativa para la declaración de la responsabilidad solidaria que aquí nos ocupa, ya que lo determinante no es la fecha en la que se ha generado la deuda, sino la fecha en la que se verificó tal derivación de responsabilidad, en el presente caso el 23 de febrero de dos mil cinco, cuando ya se encontraba en vigor dicha reforma", la cursiva es nuestra. Permitía derivar la responsabilidad por deudas anteriores a enero de 2004, a la entrada en vigor de la Ley 52/2003, mediante actos de derivación administrativa, siempre que éstos fuesen posteriores a la entrada en vigor de la reforma.

En la Sentencia del TSJ de Castilla La Mancha, Sala Contencioso-Administrativa, número 86/2007, de 28 mayo -JUR 2007/295092-, se argumentaba, "el art. 12 uno de la Ley 52/2003 de 10 diciembre (...) adiciona dos nuevos apartados 3 y 4, al art. 15 del Texto Refundido de la Ley General de la Seguridad Social, aprobado por el Real Decreto Legislativo 1/1994, de 20 de junio (...), consecuentemente con esta nueva redacción, se aprueba como norma de desarrollo el Real Decreto 1415/2004, de 11 de junio (...), de lo expuesto la conclusión no puede ser otra que reconocer la efectiva competencia administrativa para que en el seno del procedimiento recaudador efectuar la declaración necesaria para, con observancia de las normas sustantivas que sean aplicables, extender la responsabilidad por incumplimiento de la obligación de cotizar a los administradores de las sociedades. Esta conclusión (...), es la que resulta del propio

1383 Sentencias de las Salas de lo Contencioso-Administrativo del TSJ de Castilla y León-Burgos, de 27 de julio de 2006 -JUR 2006/224671-; del TSJ de Castilla-La Mancha, de 28 de mayo de 2007 -JUR 2007/295092-; y 7 de marzo de 2011 -JUR 2011/169277-; y dos Sentencias del TSJ de AndalucíaSevilla, de fecha de 11 de octubre 2007 -JUR 2008/58767- y -JUR 2008/58915-; Sentencia del TSJ Murcia, Sala Contencioso-Administrativa, 193/2011, de 4 marzo -JUR 2011/180601-. 
estado normativo anterior a la reforma. De manera que, si bien antes de la modificación se establecieron las bases para negar la competencia, con la reforma (...) no puede sino concluirse la clara voluntad del legislador de establecer esa competencia de la Administración en el seno del procedimiento de recaudación. Y es en este sentido en el que los órganos judiciales se están pronunciando, siempre y cuando, claro está, no se trate de resoluciones administrativas dictadas antes de la entrada en vigor de la reforma en fecha 1 de enero de 2004 de acuerdo con la Disposición Final Segunda de la Ley de Reforma", la cursiva es nuestra.

Esta Sentencia, admite la validez de la resolución administrativa de derivación de la responsabilidad siempre que fuesen emitidas con posterioridad a la entrada en vigor de la reforma, que sitúa en el 1.1.2004, con independencia de cuál fuese la fecha de las deudas reclamadas, cuando en enero de 2004 entra en vigor el art. 15.3 de la LGSS anterior, pero no el art. 30 de la LGSS, redactado por la Ley 52/2003, que regulaba la reclamación de deuda por derivación, que entró en vigor el 1.6.2004. Por otro lado, el nuevo Reglamento de Recaudación de la Seguridad Social, aprobado por el Real Decreto 1415/2004, de 11 de junio -RGRSS-, había entrado en vigor el 26 de junio de 2004, en cuyo art. 62.2, reguló por primera vez, en disposición reglamentaria en desarrollo del art. 30.2 de la LGSS, la reclamación de deuda por derivación de la TGSS cuando la ley de cualquier orden normativo que imponga una responsabilidad solidaria o subsidiaria no haya excluido las deudas de Seguridad Social.

Ante esa Sentencia, precisamos, que de enero a mayo de 2004, la TGSS no tendría reconocida la competencia para extender la reclamación de deuda por derivación al administrador social, porque no había entrado en vigor el art. 30 de la LGSS según redacción dada por la Ley 52/2003, ni en el Reglamento General de Recaudación aprobado por el R.D. 1415/2004, de 11 de junio, que permitían extender el acto administrativo de derivación de responsabilidad cuando ésta viniese impuesta en una disposición legal de cualquier orden normativo. Téngase en cuenta que el nuevo supuesto sustantivo de responsabilidad derivada impuesto en normativa ajena a la Seguridad Social contemplado en el artículo 15.3 de la Ley General de la Seguridad Social, de conformidad con lo establecido en su último inciso, (sic) "se declarará y exigirá mediante el procedimiento administrativo recaudatorio establecido en esta ley y en su normativa de desarrollo", y ni en esa ley ni en el Reglamento de recaudación vigente se había regulado o autorizado aún, la expedición de la reclamación de deuda o 
del acta de liquidación por derivación en los supuestos de responsabilidades impuestas en disposiciones legales ajenas a la Seguridad Social.

En la Sentencia del TSJ Andalucía/Sevilla, Sala Contencioso-Administrativa, de 11 octubre 2007 -JUR 2008/58915-, ante una derivación administrativa de responsabilidad de la TGSS de fecha 13.12.2004, tras la entrada en vigor de la reforma y del nuevo RGRSS, en que se derivaba al administrador la deuda de los periodos desde julio de 1994 hasta marzo de 1997, señala "queda, por tanto, claro que desde la entrada en vigor de la normativa que comentamos, la TGSS ostenta competencia para valorar y acreditar que la sociedad ha llegado a alguno de los supuestos que define el artículo 104 de la Ley de Sociedades de Responsabilidad Limitada, y que el Administrador, teniendo obligación de interesar su disolución o la convocatoria, no lo ha hecho, de suerte que conforme al artículo 105 de la Ley 2/1995 incurre en responsabilidad solidaria, una vez comprobada, desde luego, la existencia de una deuda que por su cuantía ha dejado reducido el patrimonio contable de la sociedad a menos de la mitad del capital social, y que respecto de la misma se siguió el correspondiente expediente de apremio, extremos estos que en el supuesto de autos ni siquiera los discute el actor. Por lo demás, habiéndose dictado la resolución que declaraba responsable solidario al recurrente cuando ya estaba en vigor el artículo 15.3 de la Ley General de la Seguridad Social y el artículo 12 del RD 1415/2004, y que las sentencias que invoca se refieren a la normativa anterior, respecto de la cual la jurisprudencia había sentado que la TGSS no era competente para la valoración de las circunstancias y causas que concurrían y para la aplicación de las normas mercantiles, la alegación ha de rechazarse”. Se admite la validez de la derivación administrativa de responsabilidad por ser emitida tras la entrada en vigor de la reforma legal, pero por unas deudas anteriores a enero de 2004. En igual sentido la Sentencia del TSJ Andalucía/Sevilla, misma Sala, de 11 octubre 2007 -JUR 2008/58767-.

En cambio, para otra interpretación que compartimos, la irretroactividad de la reforma supone que la derivación administrativa de responsabilidad debe emitirse a partir de la entrada en vigor de la reforma de la Ley 52/2003, y sólo para reclamar deudas posteriores a la reforma, no las deudas anteriores. En esta línea se sitúa la Sentencia del TSJ Andalucía, Sevilla, Sala Contencioso-Administrativa, de 6 mayo 2008 -JUR 2008/317791-. Se impugnaba una derivación administrativa de responsabilidad de fecha 18.12.2006, en que se reclamaban al administrador las deudas de la sociedad de los 
siguientes períodos, enero a diciembre de 2002, enero a septiembre de 2003, noviembre y diciembre de 2003, enero de 2004, y de agosto a diciembre de 2004. Según esta Sentencia, “el legislador (...) promulgó la Ley 52/2003, cuyo artículo 5 da nueva redacción el art. 30 del Real Decreto Legislativo 1/1994. Mas ha de convenirse que dicha norma, de carácter sustantivo, no procedimental, en tanto que atribuye facultades nuevas a un órgano Administrativo, al no establecerse nada al respecto, conforme al carácter general de irretroactividad de las normas, no posee carácter retroactivo, por lo que no es posible aplicar a situaciones nacidas bajo la vigencia del texto anterior, lo cierto es que se trata de hechos acaecidos parcialmente vigente la antigua regulación, que la regla general, art. 2.3 del $\mathrm{CC}$ es la irretroactividad de las leyes, y a falta de regulación expresa en cuanto a la retroactividad de la norma, es de aplicación al caso lo establecido en las Disposiciones Transitorias Primera y Cuarta del Código Civil, por lo que tanto los derechos del actor, nacidos por hechos acaecidos durante la vigencia de la regulación antigua, como la acción de la Administración, en igual sentido, se rigen por la normativa antigua, que ya hemos visto recibió el tratamiento jurisprudencial comentado. Por tanto, sólo podía la Administración declarar dicha responsabilidad a partir de enero de 2004, no respecto de períodos anteriores, tal y como acontece en el caso que nos ocupa, que declara dicha responsabilidad por débitos para con la Seguridad Social desde enero de 2002 en los períodos vistos".

Recurrida esta última Sentencia del TSJ de Andalucía por la TGSS ante el Tribunal Supremo, éste en Sentencia de la Sala Contencioso-Administrativa, de 31 marzo 2010, Rec. 340/2008, RJ 2010/2760-, estima ajustada a derecho la sentencia de instancia, considerando en su Fundamento de Derecho Séptimo, que "Tiene razón la Sala de instancia en cuanto que la reforma llevada a cabo por la Ley 52/2003 carece de eficacia retroactiva, al no haber establecido la norma nada al respecto y ser la irretroactividad un principio general de nuestro ordenamiento, salvo, claro está, respecto de una regulación más favorable de una norma sancionadora, situación aquí ausente. En consecuencia, no prospera el recurso". Doctrina de irretroactividad que se reitera en la Sentencia del TS, Sala Contencioso-Administrativa, de 30 septiembre 2013 -RJ 2013/6367-.

Con ello se admite que la derivación administrativa de deuda podrá emitirse, tras la reforma de la Ley 52/2003, por deudas posteriores a la entrada en vigor de esa reforma, no por las anteriores al año 2004. Ahora bien, nosotros puntualizamos, que la competencia administrativa para que la TGSS reclame la derivación administrativa de 
responsabilidad, no tuvo lugar el 1.1.2004, sino en junio de 2004, que es cuando entró en vigor el art. 30.2 de la Ley General de la Seguridad Social, según redacción dada por la Ley 52/2003, aunque el art. 15.3 de la Ley General de la Seguridad Social, en vigor desde el 1.1.2004, ya preveía la responsabilidad por deudas cuando ésta venga impuesta por una ley que no excluya expresamente las deudas de Seguridad Social.

Lo anterior significa que la responsabilidad del administrador en deudas de Seguridad Social de la sociedad de capital establecida en normas mercantiles, desde el 1.1.2004 ya era una responsabilidad en deudas de Seguridad Social por venir recogida expresamente en una norma de esta rama del orden social (art 15.3 de la anterior LGSS). Ahora bien, ese precepto concluía indicando que esa responsabilidad "se declarará y exigirá en el procedimiento recaudatorio establecido en esta ley y en su normativa de desarrollo", y el art. 30.2 de la LGSS, que regulaba la reclamación de deuda por derivación cuando la responsabilidad venga impuesta en normas ajenas a la Seguridad Social, no entró en vigor el 1 de enero de 2004, sino en junio de 2004. Por otro lado, el nuevo y actual RGRSS, en cuyo art. 62 se regulaba la reclamación de deuda por derivación por la TGSS, al amparo de cualquiera disposición legal que no excluya la responsabilidad por deudas de Seguridad Social, entró en vigor el 26.6.2004.

Obsérvese que, para reclamar la responsabilidad derivada en el procedimiento de recaudación de la Seguridad Social partiendo de un supuesto legal sustantivo de responsabilidad en deudas establecido en norma ajena a la de Seguridad Social, como es la mercantil, la TGSS debía emitir la reclamación de deuda por derivación, y la ITSS el acta de liquidación por derivación, pero tanto una, como otra, recogidas en el art. 30 y 31 de la anterior Ley General de la Seguridad Social, entraron en vigor el 1.6.2004, con lo que, según la Disposición Transitoria $1^{\text {a }}$ del nuevo RGRSS de 2004, los procedimientos de gestión recaudatoria de cuotas iniciados antes del 1 de junio de 2004, se regirán por la normativa anterior hasta la emisión de la providencia de apremio, regulándose por el nuevo procedimiento todos los iniciados tras la entrada en vigor del nuevo RGRSS, lo que es una especificación del principio general de que la norma adjetiva aplicable en un procedimiento administrativo será la norma vigente en la fecha de inicio del mismo (D.T. $2^{\mathrm{a}}$ de la LPACAP).

Si esto es así, procedería la reclamación de la derivación de responsabilidad desde junio de 2004 , y por deudas de enero de 2004 , o posteriores. 
Criterio de no aplicar retroactivamente la responsabilidad por deudas del administrador que ya declaró el TS, Sala Civil, en Sentencia 651/1997, de 15 julio -Rec. 2388/1993-, con relación a hechos anteriores a la introducción legal de esta responsabilidad en 1989, partiendo de la Disposición Adicional Tercera del Código Civil, que ordena la exclusión total de la retroactividad de las normas sancionadoras con penalidad civil o privación de derechos, en relación con el artículo 4.2 del Código Civil y con el artículo 9.3 de la Constitución Española ${ }^{1384}$.

Doctrina jurisprudencial de irretroactividad que, se recoge nuevamente, cuando ha de determinarse la legislación aplicable sobre responsabilidad de los administradores, al modificarse el alcance temporal de las deudas por la Ley 19/2005, a las deudas posteriores al acaecimiento de la causa de disolución, donde se declaró que cuando se produce una modificación de su régimen jurídico, ha de estarse a la regulación vigente en la fecha en que nace la responsabilidad de los administradores, por exigirlo los principios de irretroactividad de las disposiciones normativas y de seguridad jurídica, salvo previsión en contrario, (Sentencias TS, Sala Civil, 456/2015, de 4 de septiembre Rec. 2414/2013-1385; y 942/2011, de 29 de diciembre -RJ 2012/171-1386), lo que en definitiva es aplicación del axioma "tempus regit actum".

Sentado lo anterior, la única interpretación posible nos permitiría concluir que, pese a que la competencia de la TGSS para declarar en vía administrativa la responsabilidad del administrador social tiene lugar a partir de junio 2004, ello no obstante, podrían reclamarse las deudas desde enero de 2004, porque la responsabilidad del

${ }^{1384}$ En esa Sentencia se concluye que "Por demás, el artículo 4.2 del Código Civil impide la aplicación extensiva de las leyes penales, las excepcionales y las de ámbito temporal, y con arreglo al mismo, dada la inexistencia de cualquier norma transitoria en el Texto Refundido favorecedora de la aplicación del repetido artículo 262.5 a supuestos acaecidos antes de su entrada en vigor, ha de rechazarse la tesis del recurrente".

${ }^{1385}$ La Sentencia del TS, Sala Civil, 456/2015, de 4 de septiembre -Rec. 2414/2013-, señala sobre la legislación aplicable, tras la modificación del régimen jurídico de la responsabilidad por deudas, efectuada con la Ley 19/2005, de 14 de noviembre, que ello, "exige el conocimiento previo de la norma que va a aplicarse a las situaciones y relaciones jurídicas, de acuerdo con el viejo axioma tempus regit actum. La Ley 19/2005, de 14 de noviembre, sobre Sociedades Anónimas Europeas domiciliadas en España, al no disponer la retroactividad de las modificaciones de la normativa reguladora de la responsabilidad de los administradores societarios, no puede aplicarse con carácter retroactivo $\mathrm{y}$, en consecuencia, hay que estar al texto vigente en el momento en el que se desarrollaron los hechos generadores de la misma (entre las más recientes, Sentencias 826/2011, de 23 de noviembre; 923/2011, de 26 de noviembre; y 225/2012, de 13 de abril)".

${ }^{1386}$ La Sentencia señala que, "a las responsabilidades nacidas con anterioridad a la entrada en vigor de la reforma del 2005 les es aplicable el texto de la norma entonces en vigor, en este sentido, entre las más recientes, las Sentencias 557/2010, de 27 de septiembre -RJ 2010/7140-; 680/2010, de 10 de noviembre -RJ 2011/1304-; y 242/2011, de 4 abril -RJ 2011/3438-". 
administrador por deudas de Seguridad Social ya existía desde enero de 2004, como responsabilidad sustantiva impuesta por una disposición legal de Seguridad Social (art. 15.3 de la LGSS). Si desde enero de 2004 la responsabilidad del administrador en deudas de la sociedad, es ya una responsabilidad recogida en una ley de Seguridad Social, la TGSS podría a partir de junio de 2004, antes no, derivar la responsabilidad en el procedimiento administrativo de recaudación, pero eso sí, incluyendo ya las deudas desde enero de 2004, porque de esas deudas ya respondía el administrador social según legislación sustantiva de Seguridad Social (art. 15.3 de la anterior LGSS).

Ante la Sentencia del TS de 31 de marzo de 2010, la TGSS cambió su doctrina administrativa para establecer en Consulta 16/2009, de 31 de mayo ${ }^{1387}$, que "no procede la aplicación de la retroactividad de la citada Ley 52/03 para exigir responsabilidad a los Administradores sociales por hechos anteriores a su entrada en vigor".

\section{II.- COMPETENCIA PARA DERIVAR LA RESPONSABILIDAD DEL}

\section{ADMINISTRADOR EN EL PROCEDIMIENTO ADMINISTRATIVO DE RECAUDACIÓN.}

La derivación administrativa de responsabilidad prevista en el art. 18.3 del TRLGSS, permite reclamar la responsabilidad del administrador en las deudas de Seguridad Social de la sociedad de capital, dentro del procedimiento administrativo de recaudación de la Seguridad Social, sin tener que recurrir ante la Jurisdicción Civil, partiendo de las disposiciones de la Ley de Sociedades de Capital que impongan una responsabilidad del administrador en las deudas de la sociedad.

1387 Consulta TGSS, 16/2009, 31-5-2009: Responsabilidad Solidaria de los Administradores Sociales por los hechos anteriores a la Ley 52/2003. En esa Consulta se indicaba que, "El criterio que se ha venido manteniendo por esta Subdirección General ampliamente divulgado entre las Direcciones Provinciales, sobre la aplicación temporal de las modificaciones que introdujo la Ley 52/2003 en los artículos 5 y 30 de la Ley General de Seguridad Social, ha sido el siguiente: la potestad de la Tesorería General de la Seguridad Social una vez que entró en vigor la reforma operada por la Ley 52/2003, de 10 de diciembre, en los artículos 15 y 30 de la Ley General de la Seguridad Social para declarar la responsabilidad solidaria de los administradores de las sociedades alcanza a todos los supuestos que se examinen, aunque en el momento de producirse los hechos que han generado tal responsabilidad no estuviera en vigor la nueva regulación, ya que se trata de una norma procedimental que viene a clarificar la competencia para declarar la responsabilidad por deudas de la Seguridad Social, basada en incumplimientos de la legislación mercantil.

Este criterio que venía siendo avalado por distintos pronunciamientos de los Tribunales Superiores de Justicia, se ha visto superado por la reciente Sentencia del Tribunal Supremo, de fecha 31 de marzo de 2010, por la que se viene a declarar que no procede la aplicación de la retroactividad de la citada Ley 52/03 para exigir responsabilidad a los Administradores sociales por hechos anteriores a su entrada en vigor". 
La LSC, cumple los dos requisitos establecidos en el art. 18.3 del TRLGSS, ya que, en primer lugar, estamos ante una disposición con rango de ley, que impone una responsabilidad por deudas de la sociedad de capital, y, en segundo lugar, que en esa imposición de responsabilidad en las deudas no se excluyen expresamente las deudas de Seguridad Social ${ }^{1388}$.

En definitiva, procede la derivación de responsabilidad en todos aquellos supuestos normativos en que la legislación mercantil imponga una responsabilidad ex lege en el pago de las deudas de la sociedad de capital. Los principales supuestos de derivación de responsabilidad al administrador social al amparo de esa disposición legal, serán los siguientes. En primer lugar, la responsabilidad ex lege del administrador social por concurrir causa de disolución -disolución de pleno derecho o disolución por causa legal de los arts. 360 y 367 de la LSC-. En segundo lugar, la responsabilidad ex lege en la sociedad en formación (arts. 36 a 38 de la LSC), en la sociedad irregular (art. 39 de la LSC), en la sociedad unipersonal sobrevenida para el socio único-administrador (art. 14 de la LSC), y en las transformaciones societarias (art. 21 de la Ley 3/2009, de 3 de abril, de modificaciones estructurales de las sociedades mercantiles), ya que el resto de supuestos son de menor entidad. En tercer lugar, la responsabilidad de la sociedad matriz o del administrador de la sociedad dominante en los grupos de sociedades, cuando la sociedad matriz o el administrador de la dominante sean calificados como administradores de hecho o de derecho de las sociedades dominadas, al ser de aplicación el régimen de responsabilidad previsto legalmente para los administradores sociales, en cuyo supuesto la derivación de responsabilidad tendrá como fundamento el art. 18.3 del TRLGSS, pese a estar ante un grupo de sociedades.

En la reclamación de la responsabilidad por deudas de la sociedad de capital al administrador social en el procedimiento administrativo de recaudación, en los supuestos legales en que aquéllos responden de las deudas de la sociedad de capital, deberemos distinguir, la derivación de responsabilidad de deudas por cotizaciones y la derivación de responsabilidad por prestaciones, ya que el procedimiento y los sujetos legitimados para dictar los actos administrativos no serán exactamente los mismos.

Analicemos ambas competencias administrativas.

${ }^{1388}$ En igual sentido MERCADER UGUINA, J. R. y SUÁREZ CORUJO, B.: "La responsabilidad laboral y de Seguridad Social de los Administradores Sociales”, op. cit., p. 577. 


\section{Derivación de deudas por cuotas al administrador social.}

- En primer lugar, en virtud del art. 18.3 del TRLGSS se podrá derivar la deuda por cotizaciones a la Seguridad Social de la sociedad de capital, "a quienes resulten responsables solidarios o subsidiarios, por concurrir hechos, omisiones, negocios o actos jurídicos que determinen esas responsabilidades, en aplicación de cualquier norma con rango de ley que se refiera o no excluya expresamente las obligaciones de Seguridad Social”.

En el procedimiento administrativo de derivación de responsabilidad, al amparo del art. 18.3 del TRLGSS, podrán reclamarse al administrador social las deudas por cotizaciones de la sociedad de capital, en aquellos supuestos en que la legislación de sociedades les atribuye una responsabilidad solidaria o subsidiaria.

La competencia para reclamar las deudas por cotizaciones corresponderá a la TGSS y a la ITSS (arts. 33 y 34 del TRLGSS), teniendo ambos organismos igualmente la competencia para derivar la responsabilidad de esas deudas ante el administrador social, en los términos que indicaremos en el siguiente sub-apartado, de concurrir los presupuestos legales de la responsabilidad ex lege de la deuda (33.2 y 34 apartado 1.c) del TRLGSS).

- En segundo lugar, en virtud del art. 18.4 del TRLGSS se podrá derivar la responsabilidad en el pago de deudas por cuotas de Seguridad Social a la persona o entidad jurídica que, sin ostentar formalmente la condición de empresario en los registros públicos de las entidades gestoras o servicios comunes de la Seguridad Social, sea quien real y efectivamente reciba la prestación de servicios de los trabajadores. En definitiva, al amparo de este precepto legal, la derivación administrativa de responsabilidad tendrá lugar cuando, en virtud de la doctrina del levantamiento del velo societario, pueda imputarse la responsabilidad al administrador social o socio de control de estimarse que es el verdadero empresario. Mediante la doctrina del levantamiento del velo societario, se reclamarán las cotizaciones al socio o administrador social cuando puedan ser calificados como el empresario real, por haberse servido del ropaje de la personalidad jurídica societaria para eludir la aplicación de la responsabilidad patrimonial personal ilimitada del art. 1911 del Código Civil, de ser personas físicas, o a la persona jurídica de ser ésta el administrador social y verdadero empresario. En la derivación de responsabilidad por 
levantamiento del velo, estaremos ante una responsabilidad de quien realmente ejerza, dirija y retribuya la relación laboral, que no necesariamente concurrirá en la persona del administrador social, aunque en sociedades de escaso capital y familiares suelen confluir ambas condiciones.

La derivación de responsabilidad al amparo del art. 18.4 del TRLGSS, a la persona física que se sirve fraudulentamente del ropaje de una sociedad de capital para eludir su responsabilidad personal como verdadero empresario, sólo está prevista legalmente para la reclamación de deudas por cotizaciones y cuotas de recaudación conjunta. La reclamación de esta responsabilidad corresponde a la TGSS y a la ITSS (art. 33.2 y 34 apartado 1.c) del TRLGSS).

La derivación administrativa de responsabilidad por el cauce procedimental del art. 18.3 del TRLGSS, se utilizará para reclamar la responsabilidad ex lege del administrador cualquiera que sea la dimensión de la sociedad, sea en entidades mercantiles grandes, medianas o pequeñas, con independencia de ser el administrador una figura con mayores o menores perfiles de profesionalización, y con independencia de ser el órgano de administración unipersonal o pluripersonal, constituido por personas físicas o jurídicas. Lo mismo sucede con la derivación de responsabilidad a través de la doctrina del levantamiento del velo societario, que podrá tener lugar en una sociedad de pequeño tamaño, y/o de carácter familiar, para imputar la responsabilidad al socio de control, como en sociedades con un mayor volumen de capitalización, en que podrá declararse la responsabilidad en la empresa grupo o en los grupos patológicos, y en aquellas sociedades que, en fraude de los acreedores, descapitalizan las sociedades del grupo con mayor volumen de trabajadores, en beneficio de otras sociedades con menor carga salarial ${ }^{1389}$.

Ambas modalidades de derivación administrativa de responsabilidad tienen como nota común que permitirán reclamar la responsabilidad solidaria o subsidiaria, por la TGSS o por la ITSS, dentro del procedimiento administrativo de recaudación de los recursos económicos de la Seguridad Social, sin necesidad de tener que obtener previamente ante los Juzgados mercantiles la declaración de la responsabilidad del administrador social.

${ }^{1389}$ GALA DURÁN, C.: La responsabilidad laboral y de seguridad social de los administradores de las sociedades mercantiles, op. cit., p. 22, señala que en las pequeñas sociedades será más frecuente acudir a la doctrina del levantamiento del velo, y en las sociedades medianas y grandes, al recurrir a administradores profesionales, será más frecuente la reclamación de la responsabilidad del administrador social. 
El régimen jurídico legal de la derivación administrativa de deudas de Seguridad Social por responsabilidad solidaria o subsidiaria, se establece en los arts. 18 apartados 3 y 4 , 33.2, 34 apartado 1.c) y 142 del TRLGSS, en cuyos preceptos se atribuye la competencia a la TGSS para reclamar deudas por cuotas de Seguridad Social por derivación de responsabilidad, y a la ITSS para reclamar deudas por cotizaciones mediante la extensión del acta de liquidación de cuotas por derivación de responsabilidad, además de las actas de liquidación por falta de alta en Seguridad Social, por diferencias de cotización o bonificaciones indebidas (art. 34 apartado 1 letras a), b) y d) del TRLGSS), en las que se podrá apreciar también la responsabilidad derivada del administrador social.

El procedimiento administrativo de derivación de responsabilidad solidaria o subsidiaria se regula en los arts. 12, 13, 62.2, 65 apartado 1.c) y 69 del RGRSS, así como por el art. 32.1 del RISOS.

En el art. 12 del RGRSS se enumeran las disposiciones con rango de ley que pueden imponer esa responsabilidad solidaria o subsidiaria de terceros, al indicarse que podrán ser normas de Seguridad Social, laborales, civiles, administrativas o mercantiles. Enumeración que delimita los sectores normativos a los que podrá acudirse para determinar la responsabilidad solidaria o subsidiaria, por ser los órdenes normativos en que podrá establecerse la responsabilidad de terceros ajenos al deudor principal, y que en el supuesto de los administradores sociales ese orden normativo será el mercantil. No se ha incluido al Derecho penal, por su carácter punitivo, ni al Derecho tributario en el que se establece un régimen específico de responsabilidad de los administradores en las deudas tributarias, que de haberse previsto como normativa aplicable en el art. 12 del RGRSS, hubiere extendido considerablemente los supuestos de responsabilidad del administrador social en deudas de Seguridad Social. Finalmente, no se alude al Derecho procesal, porque al ser un derecho adjetivo, no es un orden normativo de posible determinación de supuestos de responsabilidades ex lege en deuda ajena.

Los principales supuestos de responsabilidad solidaria o subsidiaria del administrador social en las deudas de Seguridad Social de la sociedad de capital, en virtud de los cuales podrá derivarse a aquél la deuda a través del procedimiento administrativo de recaudación, los encontraremos en el Derecho de Seguridad Social y del Derecho Mercantil, y dentro de éste, básicamente en el Derecho de Sociedades, de modo 
principal en la LSC (arts. 360 y 367 LSC, como más relevantes, y en menor medidas arts. 14 y 36 a 40 LSC).

Adelantamos que, como podrá observarse a lo largo de nuestro estudio, tienen mayor relevancia, cuantitativa y cualitativa, los supuestos de responsabilidad solidaria de los administradores en las deudas de Seguridad Social, frente a los supuestos de responsabilidad subsidiaria.

\subsection{Distribución de competencias entre la TGSS y la ITSS.}

La competencia para la derivación de la responsabilidad al administrador social en las deudas por cotizaciones, se reconoce tanto a la TGSS como a la ITSS en los arts. $33.2 \mathrm{y}$ 34 del TRLGSS.

Teniendo ab initio ambos organismos públicos competencia para la derivación administrativa de responsabilidad, pudiendo iniciar el procedimiento tanto la TGSS como la ITSS, esa dualidad de entidades públicas competentes determinará la aplicación de distintas reglas procedimentales, con garantías que en algunos casos serán coincidentes o similares, pero en otros presentará ciertas peculiaridades. En palabras del Criterio Técnico 38/2003 de la DGITSS, "la utilización de una u otra vía en función de los supuestos concurrentes, motivará posteriormente la aplicación de distintas reglas procedimentales, con diferente grado de garantías para los presuntos responsables, en atención a que corresponda aplicar el procedimiento del Reglamento aprobado por el Real Decreto 928/1998 o el del Reglamento General de Recaudación -RGRSS ${ }^{1390 \_” . ~ N o ~}$ obstante, cuando la derivación de responsabilidad la efectúe la ITSS mediante acta de liquidación, siendo de aplicación el RISOS, en el art. 12.5 del RGRSS se señala que, "sin perjuicio de las especialidades contenidas en la normativa específica reguladora de las actuaciones de la Inspección de Trabajo y Seguridad Social, lo previsto en este reglamento para el procedimiento recaudatorio seguido en relación con reclamaciones de deuda por derivación de responsabilidad solidaria, subsidiaria o mortis causa, será de aplicación al que se siga en virtud de actas de liquidación emitidas por derivación de responsabilidad".

En la redacción anterior a la actualmente vigente, la distribución de competencias entre la TGSS y la ITSS venía determinada en función de que los datos determinantes de la

${ }^{1390}$ Criterio Técnico 38/2003, de 9 de diciembre de 2003, sobre resultados liquidatorios en el marco de la colaboración inspectora con la Administración de la Seguridad Social, -Ref. La Ley 8080/2003-. 
derivación de la responsabilidad obrasen o no en Tesorería General de la Seguridad Social. En definitiva, en función de que los hechos determinantes de la responsabilidad le constasen o no a la TGSS.

Como hemos reseñado en el apartado anterior, la competencia de la TGSS para reclamar la responsabilidad solidaria o subsidiaria de un tercero, en nuestro caso del administrador social de la sociedad de capital, se reconoció mediante la Ley 52/2003, 10 diciembre, al dar nueva redacción a los preceptos legales que regulaban los institutos o instrumentos jurídicos para la derivación de responsabilidad, por un lado, la reclamación de deuda por derivación de responsabilidad de la TGSS en el art. 30.2 $2^{1391}$ de la anterior LGSS de 1994, y por otro lado, el acta de liquidación de cuotas por derivación de responsabilidad en el art. 31 apartado 1.c) ${ }^{1392}$ del mismo texto legal.

${ }^{1391}$ En el art. 5 apartado seis de la Ley 52/2003, se da nueva redacción al art. 30 de la anterior Ley General de la Seguridad Social (Real Decreto Legislativo 1/1994, de 20 de junio), cuyo precepto estableció:

“2. Procederá también reclamación de deuda cuando, en atención a los datos obrantes en la Tesorería General de la Seguridad Social y por aplicación de cualquier norma con rango de ley que no excluya la responsabilidad por deudas de Seguridad Social, deba exigirse el pago de dichas deudas:

a) A los responsables solidarios, en cuyo caso la reclamación comprenderá el principal de la deuda a que se extienda la responsabilidad solidaria, los recargos, intereses y costas devengados hasta el momento en que se emita dicha reclamación.

b) Al responsable subsidiario, por no haber ingresado éste el principal adeudado por el deudor inicial en el plazo reglamentario señalado en la comunicación que, en este caso, se libre a tal efecto.

c) A quien haya asumido la responsabilidad por causa de la muerte del deudor originario, en cuyo caso, la reclamación comprenderá el principal de la deuda, los recargos, intereses y costas devengados hasta que se emita".

${ }^{1392}$ La Ley 52/2003, de 10 de diciembre, en su artículo 5, siete, da nueva redacción al artículo 31 de la Ley General de la Seguridad Social de 1994, estableciendo la competencia de la ITSS en los siguientes términos:

«Artículo 31. Actas de liquidación de cuotas.

1. Procederá la formulación de actas de liquidación en las deudas por cuotas originadas por:

a) (...).

b) (...).

c) Por derivación de la responsabilidad del sujeto obligado al pago, cualquiera que sea su causa y régimen de la Seguridad Social aplicable, y en base a cualquier norma con rango de ley que no excluya la responsabilidad por deudas de Seguridad Social. En los casos de responsabilidad solidaria legalmente previstos, la Inspección podrá extender acta a todos los sujetos responsables o a alguno de ellos, en cuyo caso el acta de liquidación comprenderá el principal de la deuda a que se extienda la responsabilidad solidaria, los recargos, intereses y costas devengadas hasta la fecha en que se extienda el acta.

En los casos a los que se refieren los párrafos anteriores a), b) y c), la Inspección de Trabajo y Seguridad Social podrá formular requerimientos a los sujetos obligados al pago de cuotas adeudadas por cualquier causa, previo reconocimiento de la deuda por aquéllos ante el funcionario actuante. En este caso, el ingreso de la deuda por cuotas contenida en el requerimiento será hecho efectivo hasta el último día del mes siguiente al de su notificación. En caso de incumplimiento del requerimiento se procederá a extender acta de liquidación y de infracción por impago de cuotas

Las actas de liquidación de cuotas se extenderán por la Inspección de Trabajo y Seguridad Social, notificándose en todos los casos a través de los órganos de dicha Inspección que, asimismo, 
La distribución de competencias entre esos dos organismos administrativos, que resultaba de esos preceptos, conllevaba la plena competencia de la ITSS para la derivación de responsabilidad de las deudas por cotizaciones, ya que no tenía condicionamiento o limitación legal ante la concurrencia de un supuesto legal de responsabilidad por deudas, por entender el legislador que, normalmente, los supuestos de hechos determinantes de la derivación de responsabilidad, los hechos constitutivos de una responsabilidad solidaria o subsidiaria, no le constarán a la Administración de la Seguridad Social, sino que serán descubiertos tras una previa labor de investigación o inspección ante la empresa o el sujeto responsables. Esto es así, porque en la apreciación o constatación de la responsabilidad del administrador social en deudas de la sociedad de capital, deberá acreditarse si concurre la causa mercantil determinante de la responsabilidad (si hay causa de disolución), y si se han incumplido los deberes de los administradores, lo que conlleva la necesidad de efectuar una labor investigadora en la sociedad de capital, analizando todo tipo de documentación con transcendencia; y la competencia para efectuar visitas a los centros de trabajo y/o recabar todo tipo de pruebas, corresponde a la ITSS (arts. 13, 14 y 19 de la LOITSS).

Los hechos determinantes de la responsabilidad derivada, normalmente serán desconocidos para la TGSS, tanto estemos ante una responsabilidad solidaria o subsidiaria impuesta en la propia legislación de Seguridad Social, -especialmente en supuestos de cesión temporal de mano de obra, sucesión de empresa no transparente, descentralización productiva no comunicada a la Seguridad Social, etc.-, como, particularmente, cuando la responsabilidad del tercero venga impuesta en disposiciones legales distintas del orden social, como sucede con la responsabilidad por deudas del administrador social establecida en la Ley de Sociedades de Capital.

De la redacción de esos preceptos de la Ley General de la Seguridad Social de 1994, la TGSS sólo podría derivar la responsabilidad al administrador social mediante la reclamación de deuda por derivación, si la responsabilidad solidaria o subsidiaria de éste constase de los “datos obrantes en la Tesorería General de la Seguridad Social", cuando fuese conocida por ese Servicio Común. Pero, como hemos indicado, los hechos desencadenantes de la responsabilidad del administrador, en los supuestos establecidos en la legislación de sociedades, no constarán en los registros o bases de datos de la

notificarán las actas de infracción practicadas por los mismos hechos, en la forma que reglamentariamente se establezca". 
TGSS, normalmente no serán conocidos por esa entidad. Ello hacía prácticamente inoperantes e impracticables las derivaciones de responsabilidad por la TGSS, y, especialmente, en los supuestos de responsabilidad del administrador ante el incumplimiento de sus obligaciones del cargo; cuando es el organismo que tiene asignada la función de gestión recaudadora.

El requisito de que el sujeto responsable pudiera ser determinado por la TGSS directamente en función de los datos obrantes en ese Servicio Común de la Seguridad Social, ya se exigía con anterioridad a la Ley 52/2003, en el art. 30 apartado 1.e) de la Ley General de la Seguridad Social de 1994, según redacción dada por el art. 34.1, dos, de la Ley 66/1997, de 30 de diciembre, de Medidas Fiscales, Administrativas y del Orden Social ${ }^{1393}$.

Delimitación de competencia entre la ITSS y la TGSS, en función de que los datos determinantes de la responsabilidad y los sujetos responsables fuesen conocidos o no por la TGSS, que se admitía expresamente en el Criterio Técnico 29/2000, de la Dirección General de la Inspección de Trabajo y Seguridad Social ${ }^{1394}$.

Ese Criterio Técnico admitía la plena competencia de la ITSS para la derivación de responsabilidad mediante acta de liquidación, sin limitarla a los otros tres supuestos en

${ }^{1393}$ BOE del 31.12.1997.

En la redacción del art. 30 de la anterior LGSS, dada por la Ley 66/1997, se establecía que, "1. Vencido el plazo reglamentario sin ingreso de las cuotas debidas, la Tesorería General de la Seguridad Social reclamará al sujeto responsable el importe de dichas cuotas, incrementando su importe con los recargos que procedan conforme a lo dispuesto en el número 1 del artículo 27 de la presente Ley, en los siguientes supuestos (...), Por derivación de responsabilidad en el pago de cuotas debida a cualquier título, cuando de los datos obrantes en la Tesorería General de la Seguridad Social pueda determinarse el sujeto responsable, la cuantía de la deuda y los trabajadores afectados la ley". La cursiva es nuestra.

1394 Ref. La Ley 2878/2009.

En ese criterio técnico se señalaba:

"Parece patente que, del contexto general en que se producen los referidos artículos 30 y 31 , el deslinde de los cometidos en la materia que corresponden a la Tesorería General y a la Inspección, respectivamente, vienen a descansar en la concurrencia o no de ocultación al Servicio Común -y, por tanto, de su desconocimiento- sobre las situaciones efectivas que pueden dar lugar a la tan referida extensión de responsabilidad. Dicho principio de deslinde de cometidos parece confirmado por el contenido del artículo 30.1.e) que, literalmente, hace referencia a que la Tesorería General disponga de los antecedentes precisos e indispensables (pueda determinar el sujeto, la cuantía y los trabajadores afectados) para que la misma pueda emitir la correspondiente reclamación de duda a quien resulte responsable por extensión, en los términos legales. Ello viene a suponer que en los demás supuestos, cuando resulte imprescindible la comprobación de situaciones por parte de la Inspección, a su propia iniciativa o no, procede la emisión de acta de liquidación de derivación de responsabilidad cualquiera que sea su causa y régimen de Seguridad Social aplicable, art. 30.1.c). La cuestión no deja de ofrecer importancia, en la medida que se determina el órgano competente para formular la correspondiente reclamación de cuotas, y se ejerce la opción por uno de los dos tipos de procedimientos liquidatorios existentes, que ofrecen diferentes niveles de garantías jurídicas de defensa para los presuntos deudores afectados y pueden tener distintos efectos iniciales para su ejecución forzosa". La cursiva es nuestra. 
que procede un acta de liquidación, esto es, sin limitarla sólo a los supuestos de falta de afiliación o alta en Seguridad Social de los trabajadores (art. 34.1.a), del actual TRLGSS), a deudas por diferencias de cotización que no resulten de los documentos de cotización, (art. 34.1.b), del TRLGSS) o a las deudas por bonificaciones indebidas (art. 33.1 apartados b) y d), del TRLGSS). Paralelamente, se reconoce que la competencia de la TGSS para iniciar el procedimiento administrativo de derivación de responsabilidad se reducía a aquellos supuestos en que a ese Servicio Común le consten los hechos determinantes de la responsabilidad, que, en el caso de la responsabilidad del administrador social en las deudas de la sociedad, será prácticamente inexistente, salvo que existiese ya una previa derivación administrativa de responsabilidad por acta de Inspección.

Ese Criterio Técnico 29/2000 ${ }^{1395}$, establecía como regla general la procedencia siempre del acta de liquidación por derivación de la ITSS, reduciéndose la emisión de un mero informe a la TGSS, sin extensión del acta de liquidación, para que sea la Tesorería quien inicie la derivación administrativa de responsabilidad, a tres supuestos. En primer lugar, cuando la TGSS disponga de datos determinantes de la responsabilidad y conozca los sujetos responsables, incluyendo los supuestos en que, disponiendo de los datos

1395 En ese Criterio Técnico, se establecían las siguientes pautas de actuación de la ITSS, en materia de derivación de responsabilidad: 1) Cuando, como consecuencia de actuaciones de la Inspección, proceda la práctica de acta de liquidación al sujeto responsable, habiéndose comprobado en dicha actuación la existencia de otros sujetos sobre los que derivar la responsabilidad de aquél, a éstos también se le practicará y notificará el acta con expresión de la causa de su responsabilidad en la deuda y clase de la misma, en los términos de los artículos 31.2, 32.1.b) y 33.1 del RISOS (art. 31.1.c) TRLGSS). 2) Si, como consecuencia exclusiva de actuaciones de la Inspección, ésta comprobase la concurrencia de situaciones de derivación de responsabilidad por cuotas impagadas su forma natural de reclamación de la responsabilidad solidaria (art. 10.5 RGR) viene a ser la constituida por el instrumento de acta de liquidación y su procedimiento administrativo subsiguiente (art. 31.1.c) TRLGSS). 3) En los supuestos de solicitud de actuación inspectora por parte de la Tesorería General de la Seguridad Social, en la que no haya aportación de datos o antecedentes, o cuando los que dicho Servicio disponga o los aporte para las comprobaciones sean meramente indiciarios o insuficientes al objeto de poder determinar los elementos básicos de la responsabilidad por derivación y, consecuentemente, resulte determinante al respecto el resultado de las actuaciones inspectoras, procederá la práctica del acta de liquidación que corresponda (art. 31.1.c) TRLGSS). 4) Si, por el contrario, la Tesorería General dispusiera de antecedentes suficientemente definitorios de la concurrencia de derivación de responsabilidad, con lo que la actuación inspectora tenga por objeto su confirmación, ampliación o complemento, el resultado de la actuación inspectora se reflejará en el correspondiente informe dirigido al citado Servicio Común, para que por éste se proceda a la correspondiente reclamación de cuotas y procedimiento subsiguiente (art. 30.1.e) TRI.GSS). 5) De la misma forma, informe a la Tesorería General con el resultado de las actuaciones, se procederá cuando el conjunto de la acción administrativa tenga su origen o afecte directamente a procedimientos de derivación de responsabilidad ya iniciados por dicha Tesorería, en cualquier caso, y por razones de coherencia, procediendo en tales supuestos la fórmula del referido informe (art. 30.1.e) TRLGSS). 6) También procederá informar cuando, a propia iniciativa la Inspección compruebe la concurrencia de responsabilidad subsidiaria de un tercero, habida cuenta que la exigencia de responsabilidad derivada a dicho tercero subsidiario viene condicionada por decisiones a adoptar respecto al sujeto responsable". 
básicos o esenciales, precisa que sean complementados, ampliados o ratificados por comprobaciones de la ITSS. Supuesto que será muy excepcional en materia de derivación de deudas al administrador social. En segundo lugar, cuando la ITSS comprobase en sus actuaciones supuestos de derivación de responsabilidad, y previamente la TGSS ya hubiere iniciado el procedimiento administrativo de derivación. En tercer lugar, cuando los hechos determinantes de la responsabilidad sean constitutivos de una responsabilidad subsidiaria, porque, al precisarse la previa declaración de insolvencia del deudor principal, no podrá exigirse el pago de las cuotas al responsable subsidiario, sino que el procedimiento de exacción deberá seguirse sólo ante el responsable principal, la sociedad de capital, y únicamente cuando ésta no haya pagado la deuda habiéndose declarado su insolvencia, se podría iniciar el procedimiento de recaudación ante el responsable subsidiario, quien dispondrá de su propio plazo voluntario de ingreso para abonar el principal de la deuda, salvo, claro está, que no atendiese el pago en su período de ingreso voluntario, en que se abrirá el procedimiento de apremio contra el mismo. En ese supuesto de responsabilidad subsidiaria debería emitirse informe a la TGSS, para que sea ésta la que controle y lleve a cabo la reclamación de la deuda.

Para este criterio técnico, al ser presupuesto de la responsabilidad subsidiaria la previa declaración de insolvencia del deudor principal, no resultaría pertinente declarar esa responsabilidad mediante acta de liquidación. Se está asumiendo, en cierto modo, la regulación tributaria de responsabilidad subsidiaria, ya que en el art. 176 de la LGT se establece que la derivación de responsabilidad subsidiaria se emitirá una vez se haya declarado fallido al deudor principal, y que el plazo de prescripción para exigir el pago de la deuda al responsable subsidiario se computa desde la declaración de fallido del deudor principal (art. 67 de la LGT), ya que de no establecerse esta regla especial puede prescribir la acción de derivación de responsabilidad ante el responsable subsidiario.

De proceder el informe de la ITSS a la TGSS, ese Criterio Técnico establecía como contenido mínimo del mismo que, "éste hará consignar las actuaciones comprobatorias efectuadas, los hechos comprobados y su calificación jurídica, la determinación de los puntos cuestionados por la solicitud de informe, los demás elementos que convengan al caso, la definición del sujeto o sujetos que resulten responsables, y la determinación de la deuda que proceda se les impute o de las bases suficientes para su cálculo". 
Delimitación de competencias entre actuación de la ITSS por acta de liquidación o mediante informe a la TGSS, que al apreciarse disfuncionalidades en el desarrollo de la colaboración entre la Inspección de Trabajo y Seguridad Social y la Tesorería General de la Seguridad Social, obligó a una reforma legal, debido a que la ITSS procedía en su práctica administrativa a emitir informe a la TGSS, sin apenas extender actas de liquidación por derivación de responsabilidad, por dos razones esenciales. En primer lugar, porque el mayor volumen de las derivaciones de responsabilidad era de deudas por cuotas cuya reclamación ante el deudor principal era competencia de la TGSS, como son los descubiertos totales de cotización por trabajadores dados de alta en Seguridad Social, y en segundo lugar, porque la ITSS no disponía aún de una herramienta informática a nivel nacional para la extensión de actas de liquidación de derivación de responsabilidad, que permitiese un cálculo mecanizado de la liquidación de la deuda, la que se empezó a implantar en parte con la aplicación "Integra" a partir del año 2006. Con la finalidad de realizar ciertos ajustes, se procedió a emitirse un nuevo Criterio Técnico por la DGITSS, el Criterio 38/2003 $3^{1396}$, que se dictó en momentos previos a la aprobación de la Ley 52/2003, y conociendo su tramitación

${ }^{1396}$ Criterio Técnico núm. 38/2003 de 9 de diciembre de 2003, Sobre resultados liquidatorios en el marco de la colaboración inspectora con la Administración de la Seguridad Social, Ref. La Ley 808/2003. En el se establecieron las siguientes pautas de actuación de la ITSS, determinándose cuándo debería emitirse informe. Al respecto se indicaba:

"Como criterios indicativos en la materia, cabe señalar que el informe de la Inspección de Trabajo y Seguridad Social a la Tesorería General, procedería cuando concurriesen las circunstancias siguientes:

a) Que el informe tenga como finalidad completar, confirmar o asegurar la exactitud de los datos de que disponga dicho Servicio Común, en orden al sujeto responsable, a la cuantía de la deuda derivada, y a los trabajadores afectados por la misma, a efectos de que el organismo recaudador pueda decidir sobre la procedencia o no de formular la correspondiente reclamación de deuda por derivación de responsabilidad.

b) Que la Tesorería General haya solicitado previamente la pertinente actuación inspectora a tales efectos, puesto que es quien conoce los datos de que dispone al respecto, así como los supuestos de derivación sobre los que en cada momento proyecta actuar.

c) Que el informe de la Inspección contenga el resultado de las comprobaciones a que se refiere el apartado a) precedente, que permita a la Tesorería General producir la reclamación de deuda al responsable derivado que resulte, así como la sustanciación con garantías de acierto del subsiguiente procedimiento.

d) Cuando, en el curso de las actuaciones inspectoras, se constate por la Inspección que la Tesorería General había ya iniciado actuaciones para esclarecer la eventual responsabilidad derivada al mismo sujeto, también procedería la emisión de informe siempre que responda a las características antes apuntadas.

En los demás supuestos de derivación de responsabilidad comprobados por la Inspección de Trabajo y Seguridad Social, en principio, corresponde la práctica de acta de liquidación o la formulación de requerimiento de pago, en los términos establecidos en los artículos 29 y ss. del Reglamento General aprobado por el Real Decreto 928/1998." Se concluía en ese Criterio Técnico que, "los informes de DERES que la Inspección remita a la Tesorería General respondan a los criterios expuestos y, en definitiva, que faciliten o permitan a la Tesorería General formular reclamaciones de deudas por derivación de responsabilidad, con los datos y elementos de valoración que avalen su procedencia en el curso del posterior expediente administrativo". 
parlamentaria, con el que se optaba por una interpretación de la legislación proinforme, para en la medida de lo posible, procurar que la actuación de la ITSS se recondujese vía informe, cuando estaba clara la regulación legal, de que la derivación por la TGSS procedía sólo cuando ésta conociese por sus propios datos el hecho determinante de la responsabilidad. Criterio Técnico que, de facto, procedió a modificar la distribución de competencias, para que la TGSS pudiese emitir la reclamación de deuda por derivación cuando le consten los hechos determinantes de la responsabilidad, bien directamente o bien como consecuencia de un informe de la ITSS.

Para evitar problemas de legalidad en las derivaciones de responsabilidad, al ser la TGSS quien de facto emitía las derivaciones administrativas de responsabilidad, se procede a modificar la distribución de competencias mediante la Ley 34/2014, de 26 de diciembre, de medidas en materia de liquidación e ingreso de cuotas de la Seguridad Social ${ }^{1397}$, en cuyo artículo $1.6^{1398}$ se redacta nuevamente el art. 30.2 del Real Decreto Legislativo 1/1994, de 20 de junio.

A partir de esa reforma normativa, la ITSS tendrá fundamento legal para proceder directamente a derivar la responsabilidad mediante acta de liquidación por derivación, o para emitir un informe a la TGSS recogiendo los hechos y fundamentos jurídicos de la responsabilidad para que sea ésta quien inicie el procedimiento administrativo de derivación de la responsabilidad (arts. 33 y 34 del TRLGSS, en relación con los arts. 13, 62 y 65 del RGRSS). En aras de una mayor eficiencia y coordinación de ambos organismos, el legislador ha permitido que la TGSS inicie la derivación administrativa de responsabilidad, tanto en los supuestos en que disponga de los datos determinantes de la responsabilidad, como cuando acceda a su conocimiento en virtud de una actuación inspectora previa, lo que ha tenido como efecto que el medio ordinario de

\footnotetext{
${ }^{1397}$ BOE del 27.12.2014, con vigencia desde el 28.12.2014

${ }^{1398} \mathrm{El}$ art. 30.2, quedaba redactado del siguiente modo:

“2. Procederá también reclamación de deuda cuando, en atención a los datos obrantes en la Tesorería General de la Seguridad Social o comunicados por la Inspección de Trabajo y Seguridad Social, y por aplicación de cualquier norma con rango de ley que no excluya la responsabilidad por deudas de Seguridad Social, deba exigirse el pago de dichas deudas:

a) A los responsables solidarios, en cuyo caso la reclamación comprenderá el principal de la deuda a que se extienda la responsabilidad solidaria, los recargos, intereses y costas devengados hasta el momento en que se emita dicha reclamación.

b) A los responsables subsidiarios, en cuyo caso y salvo que su responsabilidad se halle limitada por ley, la reclamación comprenderá el principal de la deuda exigible al deudor inicial en el momento de su emisión, excluidos recargos, intereses y costas.

c) A quien haya asumido la responsabilidad por causa de la muerte del deudor originario, en cuyo caso la reclamación comprenderá el principal de la deuda, los recargos, intereses y costas devengados hasta que se emita".
} 
finalización de las actuaciones de la ITSS será la emisión de un informe a la TGSS, para que sea ésta quien inicie el procedimiento administrativo de la derivación de responsabilidad.

Esta es una forma más eficiente de coordinación de competencias entre ambos organismos, de modo que la regla general operativa de funcionamiento es la emisión de un informe por la ITSS, para que la TGSS inicie el procedimiento de derivación de la responsabilidad, especialmente en los supuestos en que la TGSS tiene la competencia para reclamar la deuda a la sociedad de capital en los supuestos del art. 33.1 del TRLGSS -en primer lugar, ante descubiertos totales de cotización, por todos o algunos de los trabajadores que se hallen en alta en Seguridad Social, en segundo lugar, deudas por diferencias de cotización que resulten de los datos obrantes en la TGSS, y en tercer lugar, para las deudas por cuotas cuya competencia no sea de la ITSS-. En esos supuestos es la propia TGSS quien realiza toda la gestión recaudatoria ante la sociedad de capital, y quien podrá derivar la responsabilidad al administrador social, al conocer en todo momento el estado de pago de la deuda por la sociedad de capital.

Reclamación de la derivación de responsabilidad por la TGSS que normalmente vendrá precedida de un informe previo de la ITSS, por ser esa Inspección quien podrá acceder a los medios probatorios de los hechos determinantes de la responsabilidad. Al respecto señalan MERCADER UGUINA y SUÁREZ CORUJO ${ }^{1399}$, que la TGSS se basará en un informe que constate la situación económica de la empresa, y en los casos que fuere necesario podrán acompañar un informe del Servicio Jurídico de la Administración de la Seguridad Social.

Que esta distribución operativa de cometidos sea más eficiente, no debe llevarnos a concluir que la ITSS sólo tenga competencia para emitir el informe de derivación, ya que, tiene plena competencia legal para extender actas de liquidación de cuotas por derivación de responsabilidad (art 34 apartado 1.c) del TRLGSS), e incluso para requerir el pago de las cuotas por derivación (art. 34 apartado 1 del TRLGSS). Tampoco deberá llevarnos a concluir que el acta de liquidación por derivación deba limitarse a los supuestos en que proceda la reclamación de cuotas mediante acta de liquidación al deudor principal -a la sociedad de capital-, es decir, que tuviese que limitarse el acta de derivación sólo a deudas por faltas de alta, por diferencias de cotización o por

${ }^{1399}$ MERCADER UGUINA, J. R. y SUÁREZ CORUJO, B.: "La responsabilidad laboral y de Seguridad Social de los Administradores Sociales”, op. cit., p. 583. 
bonificaciones indebidas de cotizaciones por acciones formativas del subsistema de formación profesional para el empleo (art. 34 apartados 1. a), b), y d) del TRLGSS), ya que en el art 34 apartado 1. c) del TRLGSS, se admite expresamente la procedencia del acta de liquidación "por derivación de la responsabilidad del sujeto obligado al pago, cualquiera que sea su causa y régimen de Seguridad Social aplicable”, sin condicionar o limitar su pertinencia a que sean deudas por faltas de alta, por diferencias de cotización o por bonificaciones indebidas, y "donde la ley no distingue nosotros no debemos distinguir". No obstante, cuando se extiendan actas de liquidación por falta de alta, por diferencias de cotización o por bonificaciones indebidas (art. 34 apartado 1 letras a), b), y d) del TRLGSS), cuando exista responsabilidad solidaria del administrador, y sea conocida, ha de ser declarada en el acta de liquidación de cuotas expedida a la sociedad de capital. MERCADER UGUINA y SUÁREZ CORUJO ${ }^{1400}$ señalan en esta misma dirección que el acta de liquidación por derivación no está relacionada con el tipo de descubierto de cotización.

Mantuvieron en su día la limitación de competencias de la ITSS, MARTÍN JIMÉNEZ y MATEOS BEATO ${ }^{1401}$, para quienes, pese a la regulación legal anterior a la Ley 34/2014, de 26 de diciembre, la ITSS sólo tenía competencia para derivar la responsabilidad en los supuestos en que cupiese acta de liquidación ante la empresa deudora principal, esto es, ante deudas por faltas de alta de los trabajadores, diferencias de cotización o bonificaciones indebidas (anterior art. 31.1 apartados a), b), y d), del Texto Refundido de 1994, actual art. 34.1 apartados a), b), y d), del TRLGSS).

Iba más lejos en esta línea interpretativa GARCÍA FERNÁNDEZ ${ }^{1402}$ quien, señalaba que, la competencia para la declaración administrativa de responsabilidad correspondía siempre la TGSS, y no a la ITSS, limitándose ésta a reclamar las cuotas de Seguridad Social mediante acta de liquidación por derivación, señalando expresamente que, "si bien la competencia de la Tesorería General de la Seguridad Social, lo es para declarar la responsabilidad y definir con ello una nueva obligación, la competencia de la Inspección de Trabajo y Seguridad Social se reduce a la reclamación administrativa de la deuda por medio del instrumento que le es característico, esto es, por medio de acta

${ }^{1400}$ MERCADER UGUINA, J. R. y SUÁREZ CORUJO, B.: "La responsabilidad laboral y de Seguridad Social de los Administradores Sociales", op. cit., p. 581.

1401 MARTÍN JIMÉNEZ, R. y MATEOS BEATO, A.: La responsabilidad de empresas y Administradores con la Seguridad Social, op. cit., p. 271.

1402 GARCÍA FERNÁNDEZ, E.: Las declaraciones administrativas de responsabilidad. Derivación de deudas tributarias y de Seguridad Social, op. cit., pp. 148-149. 
de liquidación", concluyendo que, producida la declaración administrativa de responsabilidad por la TGSS, a la ITSS le corresponde "la reclamación por medio de acta de liquidación a los declarados responsables por la Tesorería de aquellas deudas que originariamente fueron reclamadas por medio de dicho instrumento, esto es, la determinadas por faltas de afiliación o de alta y por diferencias de cotización de trabajadores dados de alta", en este caso, si las diferencias no resultaban de los documentos de cotización. Según este autor, la ITSS no podría declarar la responsabilidad derivada, sino que ésta era competencia de la TGSS, para posteriormente poder aquélla extender el acta de liquidación ante la concurrencia de alguno de los tres supuestos normativos referidos.

Interpretaciones éstas de la limitación de competencia de la ITSS que no resultan de la redacción legal anterior, ni de la vigente del TRLGSS. Cuestión distinta, es que sea más operativo y eficiente que la derivación de la deuda la realice preferentemente la TGSS, especialmente en los supuestos en que ésta tiene la competencia para reclamar el pago de la deuda al responsable directo, a la sociedad de capital. Una cosa es la operatividad, coordinación y eficiencia en la gestión material de recaudación, y otra muy distinta es la distribución legal de competencias, por lo que nada obsta a que la ITSS pueda extender un acta de liquidación por derivación de responsabilidad en los supuestos en que la TGSS haya previamente reclamado sólo a la sociedad de capital las deudas por descubiertos totales de cotización al amparo del art. 33.1 del TRLGSS.

Con la actual delimitación legal de competencias en la derivación de responsabilidad de deudas por cotizaciones, se deja libertad de actuación a la Inspección para que sea ella quien, o bien extienda el acta de liquidación por derivación de responsabilidad, o bien emita informa a la TGSS, que será la vía más operativa para los supuestos de responsabilidad subsidiaria y en la responsabilidad solidaria cuando la reclamación de la deuda a la sociedad de capital se hace mediante reclamación de deuda de la TGSS. Con esta nueva distribución de competencias dejan de ser de aplicación literal los Criterios Técnicos 29/2000 y 38/2003, de la DGITSS, que deben ser reinterpretados con la nueva regulación de los arts. 33 y 34 del TRLGSS.

Se emita informe a la TGSS o se extienda acta de liquidación por derivación de responsabilidad, según el Criterio Técnico 31/2000, de 18 de mayo de 2000, de la DGITSS, relativo a derivación de la responsabilidad del sujeto responsable principal del 
pago de cuotas a la Seguridad Social y a otros ${ }^{1403}$, será necesario que las actuaciones de la Inspección recojan "los hechos y los fundamentos jurídicos que amparen la extensión de responsabilidad, de forma que pruebe la responsabilidad correspondiente que se imputa; ha de tener en cuenta, además de la general, la prescripción específica de responsabilidad en los supuestos que se aplicable (...)". Concretándose algo más el contenido de los informes, en el Criterio Técnico 29/2000, se indicaba que deberán "consignar las actuaciones comprobatorias efectuadas, los hechos comprobados y su calificación jurídica, la determinación de los puntos cuestionados por la solicitud de informe, los demás elementos que convengan al caso, la definición del sujeto o sujetos que resulten responsables, y la determinación de la deuda que proceda se les impute o de las bases suficientes para su cálculo".

Aunque el informe emitido por la ITSS sea una de las fuentes más relevante para que la TGSS conozca los la concurrencia de supuestos fácticos de derivación de responsabilidad de las deudas de la sociedades de capital a sus administradores sociales, no obstante esa Tesorería podrá obtener igualmente información de datos disponibles en las entidades financieras, Administraciones, y demás entidades u organismos de Derecho público cuando los datos sean relevantes o tengan trascendencia en el ejercicio de la función de liquidación, recaudación de cuotas de Seguridad Social o de lucha contra el fraude (art. 40 apartados 1 y 2 del TRLGSS ${ }^{1404}$ ). Consecuencia de esa potestad de poder requerir información, datos, antecedes, justificantes o documentación a las empresas y entidades, cabe citar al respecto por su relevancia para recabar información pública acerca de las sociedades de capital, la Resolución, de 9 de junio de 2020, de la Secretaría General Técnica de la Seguridad Social, por la que se publica el Convenio entre la Tesorería General de la Seguridad Social y el Consejo General del Notariado, en materia de intercambio de información ${ }^{1405}$, en virtud del cual la TGSS tendrá acceso al índice único notarial informatizado.

Con la nueva redacción de los apartados 1 y 2 del art. 40 del TRLGSS, se ha dado un paso más en favor de las competencias de la TGSS para la derivación administrativa de responsabilidad al administrador social, al no depender ya su actuación, en todo caso, de una previo informe de la ITSS aportándole los datos determinantes de la derivación de

\footnotetext{
1403 Ref. La Ley 283/2000.

${ }^{1404}$ Apartados introducidos por el Real Decreto-Ley 2/2021, de 26 de enero, de refuerzo y consolidación de medidas sociales en Defensa del Empleo -BOE del 27.1.2021-.

1405 BOE del 20.7.2020.
} 
responsabilidad, ya que ahora podrá requerir directamente a la empresa la aportación de datos con trascendencia "en el ámbito de la liquidación, control de la cotización y de recaudación de los recursos de la Seguridad Social y demás conceptos de recaudación conjunta", con lo que de facto se está reconociendo una potestad de requerimiento de documentación para efectuar una laborar de control, investigación, inspección, solapándose con la inveterada competencia de la ITSS, de fiscalización, investigación y comprobación del cumplimiento por las empresas de sus obligaciones del orden social.

\section{Derivación de deudas por prestaciones al administrador social.}

La reclamación de la deuda de Seguridad Social por prestaciones de responsabilidad empresarial, exige que previamente se haya dictado por la entidad gestora (INSS, ISM, SEPE) la resolución administrativa firme declarando la responsabilidad empresarial de la sociedad de capital por incumplimiento de sus obligaciones con la Seguridad Social (falta de afiliación, de alta en Seguridad Social, falta de cotización, prestaciones de contingencias profesionales causadas por incumplimientos de prevención de riesgos laborales, ausencia de reconocimientos médicos obligatorios o desconocimiento de órdenes de paralización de trabajos -arts. 167.4, 242, 244, 294 y 295 del TRLGSS, y arts. 1 apartado d), y 69 y siguientes del RGRSS-).

En esos supuestos en que la prestación es de responsabilidad de la empresa, de la sociedad de capital como empleadora del trabajador, se precisa la resolución de la entidad gestora declarando la responsabilidad de la sociedad, por ser una responsabilidad expresamente prevista en la normativa de Seguridad Social por incumplimiento de obligaciones establecidas en esa legislación social. Lo mismo ocurre cuando la responsabilidad no es de la empresa empleadora del trabajador, sino de otra empresa, en aquellos supuestos en que la responsabilidad viene impuesta con el carácter solidario o subsidiario por la normativa de Seguridad Social, como sucede en las contratas, cesión temporal de mano de obra, sucesión de empresa, o en responsabilidad de un tercero en los gastos sanitarios cuando la prestación del trabajador se cause concurriendo responsabilidad civil o criminal de ese tercero ajeno a la empresa (art. 168 del TRLGSS). En todos estos supuestos la entidad gestora está imputando una responsabilidad en prestaciones a las empresas, o a terceros civilmente responsables, en aplicación de disposiciones propias de Seguridad Social que regulan la responsabilidad en prestaciones. 
Todos esos supuestos de responsabilidad en prestaciones previstos en la legislación de Seguridad Social precisan una resolución administrativa firme de la entidad gestora declarando la responsabilidad de esos distintos sujetos, previo trámite de audiencia a las empresas responsables ${ }^{1406}$, resolución que es recurrible ante el orden jurisdiccional social, tras haberse agotado la vía administrativa previa (arts. 2 letra o), y 69 a 73 de la LRJS). Hemos de señalar que no existe un procedimiento administrativo específico y general para la declaración de la responsabilidad empresarial, como se prevé en el art. 167.2 del TRLGSS, siendo de aplicación el art. 96.1 del Decreto 907/1966, de 21 de abril, que aprueba el Texto Articulado de la Ley 193/1963, de 28 de diciembre, sobre Bases de la Seguridad Social, que exige la audiencia previa de la empresa para la declaración de responsabilidad empresarial ${ }^{1407}$.

Al ser una resolución de la entidad gestora de las prestaciones la que debe declarar la responsabilidad de la empresa empleadora, de otras empresas, o de terceros (supuesto, por ejemplo, de tercero responsable civil o criminal), en aplicación de la normativa de Seguridad Social reguladora de las prestaciones, la LRJS atribuye la competencia a los juzgados del orden jurisdiccional social para conocer acerca de "la imputación de responsabilidad a empresarios o terceros respecto de las prestaciones de Seguridad Social en los casos legalmente establecidos" (art. 2 apartado o), de la LRJS) ${ }^{1408}$.

\footnotetext{
${ }^{1406}$ Trámite de audiencia que a efectos de prestaciones de incapacidad permanente se está establecido con carácter general en los arts. 11 y 12 de la Orden de 18 de enero de 1996 -BOE del 26.1.196-, que desarrolla el Real Decreto 1300/1995, de 21 de julio, sobre incapacidades laborales del sistema de Seguridad Social, y que resulta del art. 82 de la LPACAP. Y para las prestaciones por desempleo en el art. 32 del Real Decreto 625/10985, de 2 de abril -BOE del 7.5.1985-. Trámite de audiencia previsto en el art. 96.1 del Decreto 907/1966, de 21 de abril, que aprueba el Texto Articulado Primero de la Ley 193/1963, de 28 de diciembre, sobre Bases de la Seguridad Social -BOE del 22.4.1966-.

1407 GALA DURÁN, C.: La responsabilidad empresarial por incumplimiento de las obligaciones de afiliación, alta y cotización a la Seguridad Social, 197, op. cit., p. 192.

En el art. 96.1 de ese Decreto se establece que "1. Cuando la Entidad Gestora deniegue su responsabilidad por una o varias prestaciones, en aplicación del artículo 94, lo hará en resolución fundada, oído el empresario o empresarios afectados siempre que sea posible. Cuando se trate de prestaciones por invalidez, cualquiera que sea su causa, la determinación de la responsabilidad por las prestaciones, y su imputación, corresponderá a las Comisiones Técnicas Calificadoras, de conformidad y con los efectos dispuestos en el artículo 144.". Las Comisiones Técnicas Calificadoras fueron suprimidas por la Disposición Final Primera del Real Decreto Ley 36/1978, de 16 de noviembre -BOE del 18.11.1978-, siendo sustituidas por los Equipos de Valoración de Incapacidades -EVI-.

${ }^{1408}$ Legitimación activa de la empresa para acudir al Juzgado de lo Social que ya se ha admitido con anterioridad a la LRJS en Sentencia del TS, Sala Social, de 4 de abril de 2011 -rcud. 556/2010-, como nos recuerda MOLINA NAVARRETE. Vid.: MOLINA NAVARRETE, C.: "Capítulo 3. Especialidades procesales en materia de prestaciones de la Seguridad Social y acumulación de acciones en procesos sobre Contingencias Profesionales", en AA.VV. (DE LA PUEBLA PINILLA, A. et altri): Análisis de la nueva Ley Reguladora de la Jurisdicción Social, $1^{a}$ edición, Tirant Lo Blanch, 2014, p. 124.
} 
La declaración de responsabilidad empresarial en prestaciones se emite por la entidad gestora dentro de su función de gestión de prestaciones, declarando el derecho a percibir una prestación, así como determinando quién es el sujeto o sujetos responsables del pago de la prestación en aplicación de la normativa de Seguridad Social (arts. 45, 66 apartado 1. a) y 167.4 del TRLGSS), función de gestión de prestaciones que es distinta a la función liquidadora y recaudadora de deudas de la Seguridad Social atribuida a la TGSS (art. 21 del TRLGSS), en cuya gestión recaudadora se incluye la derivación de responsabilidad a terceros de deudas previamente declaradas, al amparo del art. 18.3 del TRLGSS.

Dictada la resolución administrativa de la entidad gestora de la prestación, la función encaminada a hacer efectivo el pago de esa deuda de prestaciones de la sociedad de capital es una labor de gestión recaudadora, ya que no tiene como cometido la imputación del sujeto responsable según la normativa de prestaciones de Seguridad Social, sino que nos encontramos ante el "ejercicio de una actividad administrativa conducente a la realización de los créditos y derechos de la Seguridad Social" (art. 1.1 del RGRSS). Función de gestión recaudadora de deudas por prestaciones incluida dentro del procedimiento administrativo de recaudación, cuya competencia tiene en exclusividad la TGSS (art. 21 TRLGSS y art. 2 del RGRSS).

Ante esa resolución de la entidad gestora de imputación de responsabilidad por incumplimientos de la normativa de Seguridad Social en materia de prestaciones, la TGSS fijará el capital coste de la prestación en que se cifra la responsabilidad empresarial y exigirá su pago a la sociedad de capital, emitiendo la pertinente reclamación de deuda que notificará a la sociedad, quien deberá efectuar el ingreso de la deuda dentro del plazo reglamentario que finaliza el último día hábil del mes siguiente la notificación. Transcurrido el pazo reglamentario sin haberse atendido el pago, y una vez sea firme en vía administrativa la reclamación de deuda emitida, se inicia el procedimiento de ejecución dictándose la providencia de apremio ${ }^{1409}$. Actos de gestión recaudatoria que una vez firmes en vía administrativa, son impugnables ante la Jurisdicción Contencioso-Administrativa (art. 3 letra f) de la LRJS y arts. 1 y 2 de la

1409 Arts. 69 y 70 del RGRSS. Para prestaciones de desempleo, la reclamación de la deuda en vía voluntaria ante la empresa responsable, la inicia la entidad gestora de desempleo -SEPE-, y de no atender el pago la empresa, la recaudación ejecutiva se realizará por la TGSS (art. 295 TRLGSS). 
LJCA) ${ }^{1410}$. Si la responsabilidad empresarial en el pago de la prestación no se estableció en resolución de la entidad gestora, sino en sentencia de un órgano jurisdiccional social, su ejecución se llevará a efecto por los trámites de ejecución de la sentencia ${ }^{1411}$.

Una vez declarada la responsabilidad empresarial nace una deuda de prestaciones de la que es responsable la sociedad de capital en cuanto empresa empleadora. Las deudas por prestaciones de responsabilidad empresarial de la sociedad de capital, al ser un recurso económico de la Seguridad Social, podrán ser objeto de derivación de responsabilidad al administrador social en el procedimiento administrativo de recaudación, ya que en el art. 18.3 del TRLGSS se establece que son responsables de la obligación de cotizar y de pagar los demás recursos de la Seguridad Social, tanto el responsable directo (sociedad de capital), como quienes resulten responsables solidarios o subsidiarios por concurrir hechos u omisiones determinantes de esa responsabilidad al amparo de una disposición legal que no haya excluido expresamente la responsabilidad por deudas de Seguridad Social ${ }^{1412}$.

Ante esa posible derivación de responsabilidad al administrador social al amparo del art. 18.3 del TRLGSS, en relación con los arts. 360 y 367 de la LSC, la cuestión fundamental será determinar si, una vez declarada esa responsabilidad de la sociedad de capital en el pago de una prestación de Seguridad Social, esa deuda por prestaciones de la sociedad sería objeto de reclamación mediante derivación de responsabilidad al

1410 Desde las SSTS, Sala Contencioso-Administrativa, de 31 de enero de 2000 -Rec. 6603/1997 y 4886/1997-; y de 1 de febrero de 2000 -Rec. 1311/1998 y 1369/1998-, se ha distinguido, entre impugnación de la resolución de la entidad gestora que declara la responsabilidad empresarial en el pago de una prestación, que es impugnable ante la Jurisdicción Social, y el acto posterior de gestión recaudatoria de la TGSS, reclamando el pago del capital coste, que es recurrible en vía ContenciosoAdministrativa. Existe una dualidad competencial entre la Jurisdicción Social y la ContenciosoAdministrativa, correspondiendo a la primera la facultad exclusiva de pronunciarse sobre la declaración de responsabilidad empresarial, y a la segunda todo lo relativo al ejercicio de la actividad administrativa conducente a la realización de los créditos y derechos de la Seguridad Social, que incluye todo los relativo a los actos de liquidación y recaudación, de modo que cabe impugnar en esta segunda vía la cuantificación material del capital fijado partiendo, no obstante, de las bases establecidas por el INSS (Sentencias de esa Sala del TS 31 de enero de 2000 -Rec. 6603/1997 y 4886/1997-; 1 de febrero de 2000 -Rec. 1311/1998 y 1369/1998-; 22 de marzo de 2002 -Rec. 9037/1996-; 12 de marzo del 2001; 25 de septiembre del 2002; y 18 de marzo del 2003 -Rec. 1128/1998-).

${ }^{1411}$ Arts. 2 letra o), 237, 288, y 294 a 296 de la LRJS, en relación con el art. 69.4 del RGRSS, y Sentencia del TS, Sala de Conflictos de Jurisdicción, 1/2019, de 29 abril -Rec. 1/2019-.

${ }^{1412}$ En este sentido véase: GALA DURÁN, C.: La responsabilidad laboral y de Seguridad Social de los administradores de las sociedades mercantiles, op. cit., pp. 15 a 17, 130-132 y 175, 190 a 198 y ss; MARTÍN JIMÉNEZ, R. y MATEOS BEATO, A.: La responsabilidad de empresas y Administradores con la Seguridad Social, op. cit., pp. 207-209 y 279-300; GARCÍA FERNÁNDEZ, E.: Las declaraciones administrativas de responsabilidad. Derivación de deudas tributarias y de Seguridad Social, op. cit., pp. 154-158. 
administrador por la TGSS, o si se precisaría que la declaración de derivación de responsabilidad al administrador la emitiese previamente la entidad gestora de las prestaciones (INSS, ISM, SEPE). En definitiva, ha de determinarse si la derivación de deuda al administrador en el procedimiento de recaudación, corresponde a la TGSS o a la entidad gestora de la prestación. Ante esto cabrían dos interpretaciones:

- En virtud de una primera, se puede entender que la derivación de responsabilidad debería hacerla la entidad gestora, limitándose la TGSS a emitir posteriormente la reclamación de deuda para exigir el pago de la prestación al administrador. Serían partidarios de esta interpretación MARTÍN JIMÉNEZ y MATEOS BEATO ${ }^{1413}$. Estos autores, partiendo de los arts. 12.4 y 69.3 del RGRSS, señalan que (sic) "de acuerdo con lo expuesto, hay una actuación previa del INSS como entidad gestora, que debe efectuar no sólo la declaración de la responsabilidad directa del empresario infractor basada en las normas establecidas en el ámbito de la Seguridad Social, sino la responsabilidad derivada a posibles responsables solidarios o subsidiarios determinados en la propia normativa de Seguridad Social, como los administradores societarios, que resulten de la aplicación de cualquier otro ordenamiento jurídico (laboral, civil, administrativo, o mercantil artículo 12 Real Decreto 1415/2004)”. Estos autores señalan más adelante, con relación a la derivación a un tercero distinto de la empresa responsable directa, que ${ }^{1414}$ (sic) "la circunstancia normal es que la responsabilidad derivada sobre la prestación se enmarque en fase procedimental distinta a la de la responsabilidad directa, y una vez se haya intentado a través del procedimiento recaudatorio por la Tesorería General sin resultados, el cobro de la capitalización de la prestación ante el sujeto responsable directo. Por ello es adecuado considerar un segundo momento o fase dedicado a la exigencia a un tercero de la responsabilidad derivada, fase en la que debería repetirse el procedimiento anterior, dictándose una nueva Resolución de la Entidad Gestora competente en la que se declare expresamente la derivación de responsabilidad".

- En virtud de una segunda interpretación, que defendemos, cabe entender que cuando el legislador establece la competencia de la entidad gestora de la prestación para declarar la responsabilidad en el pago de una prestación (arts. 167.4 y 168 del

1413 MARTÍN JIMÉNEZ, R. y MATEOS BEATO, A.: La responsabilidad de empresas y Administradores con la Seguridad Social, op. cit., pp. 208-209.

1414 MARTÍN JIMÉNEZ, R. y MATEOS BEATO, A.: La responsabilidad de empresas y Administradores con la Seguridad Social, op. cit., p. 283. 
TRLGSS), se está refiriendo a aquellos supuestos en que es preciso imputar la responsabilidad a la empresa, a otras empresas o a un tercero civil responsable, en aplicación de la propia normativa reguladora de las prestaciones de Seguridad Social, como ocurre en la responsabilidad empresarial por falta de alta y cotización a la Seguridad Social (art. 167 del TRLGSS), en la responsabilidad de otras empresas en contratas, cesión temporal de mano de obra, sucesión empresarial, o en la responsabilidad de tercero civil o criminalmente responsable en cuanto a las prestaciones sanitarias (art. 168 del TRLGSS), o en la responsabilidad de la empresa usuaria en prestaciones de empleados de una empresa de trabajo temporal (art. 16 LETT). Cometidos que se integran dentro de la función de gestión de prestaciones, que conlleva analizar si se han cumplido los requisitos legales para que surja la responsabilidad de la entidad gestora o colaboradora, así como, en su caso, de ser una responsabilidad que no han de asumir estas entidades, quiénes son los sujetos responsables en aplicación de la normativa reguladora de las prestaciones.

Pero una vez se ha imputado la responsabilidad a la sociedad de capital por la entidad gestora competente (INSS y ISM), en aplicación de la legislación de prestaciones, nace una deuda de Seguridad Social cuya gestión recaudadora en el procedimiento administrativo corresponde exclusivamente a la TGSS (art. 2 del RGRSS). Y dentro de esa gestión recaudatoria habrá de incluirse la derivación administrativa de la deuda por prestaciones, en aplicación del art. 18.3 del TRLGSS, en cuanto estamos ante una deuda de Seguridad Social ya nacida. En ese precepto legal se declara que, "son responsables de cumplir la obligación de cotizar y del pago de los demás recursos de la Seguridad Social", no sólo el responsable directo, sino también quienes "resulten responsables solidarios, subsidiarios o mortis causa de aquéllos, por concurrir hechos, omisiones, negocios o actos jurídicos que determinen esas responsabilidades, en aplicación de normas con rango de ley que se refieran o no excluyan expresamente a las obligaciones de Seguridad Social". Concluyendo de modo taxativo ese precepto, que "dicha declaración de responsabilidad solidaria, subsidiaria o mortis causa se declarará y se exigirá mediante el procedimiento recaudatorio establecido en esta Ley y en su normativa de desarrollo". Obsérvese que la derivación no sólo es de cuotas sino también de otros recursos de Seguridad Social, de otras deudas distintas a las cuotas que pueda tener una empresa, entre las que se han de incluir las deudas por prestaciones de responsabilidad empresarial (art. 1 apartados d), y m), del RGRSS), y que la derivación 
de responsabilidad se declara y exige en el procedimiento recaudatorio (art. 18.3 in fine) -función de gestión recaudatoria-, no en el procedimiento de gestión de prestaciones-. En el art. 18.3 del TRLGSS está regulando la función de la gestión recaudadora de deudas de Seguridad Social, que incluye tanto la gestión recaudadora dirigida ante el responsable directo de la deuda, como ante otros sujetos responsables solidarios o subsidiarios, mediante la derivación administrativa de la responsabilidad en el pago de una deuda, cometidos que se llevan a cabo dentro del procedimiento recaudatorio (art. 18.3 in fine del TRLGSS).

Al estar derivando una deuda por prestaciones de la sociedad al administrador, en cuanto responsable ex lege de deudas de la sociedad (arts. 18. 3 TRLGSS, y arts. $360 \mathrm{y}$ 367 de la LSC), en aplicación del art. 18.3 del TRLGSS, estamos ante una actividad encaminada a la realización de ese derecho de crédito (art. 1, primer inciso del RGRSS), ante un acto de gestión recaudatoria de una deuda, cuya competencia es de la TGSS (art. 2 del RGRSS), no de la entidad gestora de la prestación, porque no estamos determinando el sujeto responsable de una prestación en aplicación de las disposiciones reguladoras de la normativa de prestaciones de Seguridad Social, no estamos imputando la responsabilidad aplicando la legislación de prestaciones -lo que es función de gestión de prestaciones-, sino que nos hallamos ante una mera labor de gestión recaudatoria, exigiendo el pago de una deuda preexistente al administrador social, en cuanto garante o responsable "ex lege" de una deuda de la sociedad de capital. Acto administrativo que es impugnable ante la Jurisdicción Contencioso-Administrativa (arts. 1 a 3 de la Ley 29/1998, de 13 de julio, Reguladora de la Jurisdicción Contencioso-Administrativa, y art. 3 apartado f), de la LRJS), mientras que el acto administrativo de la entidad gestora de imputación de responsabilidad en el pago de la prestación a la sociedad de capital en aplicación de la normativa reguladora de las prestaciones de Seguridad Social, al ser un acto de gestión de prestaciones, es impugnable ante la Jurisdicción Social (art. 1 apartado o), de la LRJS) ${ }^{1415}$.

Para atribuir la competencia a la TGSS en la derivación de responsabilidad del administrador social en deudas de prestaciones de la sociedad de capital, es fundamental

1415 Distinción entre actos de gestión de prestaciones y de gestión recaudatoria que son competencia respectivamente de la entidad gestora y de la TGSS, e impugnables sus resoluciones ante el orden social y contencioso-administrativo, respectivamente que señala SÁNCHEZ PUERTA D. A.: Jurisdicción y Seguridad Social. La competencia jurisdiccional en materia de Seguridad Social, ediciones Laborum, 2020, pp. 43-58. 
distinguir entre la función de gestión recaudadora y la función de gestión de prestaciones $^{1416}$. La competencia de gestión recaudadora de deudas por prestaciones es exclusiva de la TGSS, en virtud de la cual podría derivar una deuda de Seguridad Social previamente existente a un tercero responsable al amparo de disposiciones del Derecho de sociedades, en nuestro caso, al administrador social. La función de gestión de una prestación es competencia del INSS/ISM/SEPE, que comprende la competencia para la declaración de la responsabilidad empresarial en prestaciones por incumplimientos de la legislación de Seguridad Social (arts. 167 y 295 del TRLGSS), así como la declaración de responsabilidad solidaria o subsidiaria en las prestaciones de terceros $\mathrm{u}$ otras empresas, en aplicación de la legislación de Seguridad Social, en supuestos de sucesión de empresa, cesión de trabajadores, o descentralización productiva (art. 168 del TRLGSS). Diferencias de funciones que se ha establecido con toda nitidez por la doctrina jurisprudencial desde los años noventa del siglo pasado, y que se mantiene actualmente, ya que de la impugnación de esos actos conocen jurisdicciones distintas.

Interpretando los arts. 2 apartado o) y 3. f) de la LRJS, el TS, Sala Especial, en Auto 2/2015, de 10 de febrero -rcud. 33/2014- se señala que, “corresponde al orden social las cuestiones litigiosas en materia de prestaciones de Seguridad Social y al orden contencioso-administrativo, los litigios sobre actos de encuadramiento y gestión recaudatoria", señalando que el acto de "gestión recaudatoria" viene limitado tan sólo a aquellos que persigan el cobro de los recursos o que se refieran al ejercicio de la actividad administrativa conducente a la realización de los créditos y derechos de la Seguridad Social", frente a reclamaciones que aunque tengan como petitum cuestiones de cotización a la Seguridad Social por la empresa, el litigio se enmarca dentro de una

1416 Como se señala en Auto 4/2019, de 19 de febrero de 2019 -Rec. 18/2018- del TS, Sala Especial, con relación a la delimitación entre actos de gestión recaudatorio y actos de gestión de prestaciones, el acto de gestión recaudatoria "viene limitado tan sólo a aquellos que persigan el cobro de los recursos o que se refieran al ejercicio de la actividad administrativa conducente a la realización de los créditos y derechos de la Seguridad Social", que serían competencia de la Jurisdicción ContenciosoAdministrativa, mientras que serían competencia de la Jurisdicción Social los actos de gestión de prestaciones, al indicar que "deben comprenderse en ese ámbito competencial cuantas cuestiones se puedan plantear y tengan incidencia directa sobre el derecho al percibo de prestaciones de Seguridad Social (STS 10-7-2012, -rcud. 2828/2001-, con cita de la STS 10-7-2001 -rcud. 1801/2000-, y las que en ella se indican)".

En Auto del TS, Sala Especial, n. ${ }^{\circ}$ 13/2020, de 15 de junio -Rec. 21/2019-, se señala que "Con palabras del Auto de 10 febrero 2015, el concepto de gestión recaudatoria viene limitado tan sólo a aquellos que persigan el cobro de los recursos o que se refieran al ejercicio de la actividad administrativa conducente a la realización de los créditos y derechos de la Seguridad Social”. 
pretensión de reconocimiento de prestaciones. En igual sentido el TS, Sala Especial, de Auto 13/2020, de 15 de junio -Rec. 21/2019-.

La TGSS está realizando una mera labor de gestión recaudatoria al derivar la responsabilidad del administrador al amparo del art. 18.3 del TRLGSS. En desarrollo de ese precepto legal, en el art. 12.2 del RGRSS se establece que, "cuando en aplicación de normas (...) mercantiles, los órganos de gestión de recaudación aprecien la concurrencia de un responsable solidario, subsidiario o mortis causa respecto de quien hasta ese momento figurase como responsable, declararán dicha responsabilidad y exigirán el pago mediante el procedimiento recaudatorio establecido en este reglamento". Obsérvese, en primer lugar, que se atribuye la competencia para derivar la responsabilidad al órgano de gestión de la recaudación, y, en segundo lugar, que se habla de un responsable solidario, subsidiario o mortis causa en una deuda previa, que es algo distinto a ser responsable solidario, subsidiario o mortis causa de una prestación en aplicación de la normativa reguladora de prestaciones. Derivar una deuda ya nacida y liquidada a un responsable solidario, es acto de gestión recaudatoria, pero declarar la responsabilidad solidaria, subsidiaria o mortis causa de una prestación en aplicación de la normativa reguladora de prestaciones, es un acto de gestión de prestaciones competencia de la entidad gestora.

A esto no cabe alegar en contra el art. 2 apartado o) de la LRJS, ya que cuando en ese precepto se atribuye al orden social la competencia para conocer de la imputación de la responsabilidad en prestaciones del empresario o de terceros en los casos establecidos legalmente, es para la responsabilidad en prestaciones de conformidad con la normativa de Seguridad Social, pero no para atribuir la competencia en la derivación de responsabilidad en el pago de una deuda cuando la responsabilidad en deudas se establezca en ramas jurídicas distintas a la Seguridad Social, como la impuesta en el Derecho de sociedades. En el art. 18.3 del TRLGSS se alude en general a "cualquier norma con rango de ley", redacción amplia para no limitarla a la rama social del Derecho, frente a la redacción de la LRJS que alude a establecida legalmente, y debemos entender esa "legalidad" como la legalidad de Seguridad Social, y más concretamente como la legislación de Seguridad Social reguladora de la responsabilidad en prestaciones.

La doctrina científica ha interpretado ese artículo 2 letra o) de la LRJS, en esa dirección, considerando que cuando se atribuye al orden social la competencia para conocer de la 
imputación de responsabilidad en los casos legalmente establecidos, es para los supuestos de responsabilidad en prestaciones según la normativa reguladora de las prestaciones, esto es, en los supuestos previstos en los arts. 167, 168, 242 y 243 del TRLGSS. CASAS BAAMONDE ${ }^{1417}$ señala que en el art. 2. o) LRJS se incluyen expresamente (sic) "los litigios sobre la imputación de responsabilidades a empresarios o terceros respecto de las prestaciones de Seguridad Social en los casos legalmente establecidos (arts. 126 y 127 LGSS y arts. 94 a 96 LSS de 1966)". En igual sentido SÁNCHEZ PUERTA ${ }^{1418}$, señala al analizar el art. 2 letra o) de la LRJS que en ese precepto se regula "el régimen jurídico de la responsabilidad en materia de prestaciones que comprende el conjunto de reglas a través de las que se determina el sujeto obligado al pago de la prestación causada", siendo los preceptos reguladores los arts. 45, 167, 168, 242 y 243 del TRLGSS, así como los arts. 42 a 44 del TRLET. MONTOYA MELGAR $^{1419}$, señala que con en ese precepto de la ley procesal la atribución de competencia "se refiere fundamentalmente a las responsabilidades empresariales reguladas en los arts. 126 y 127 de la LGSS, y faltando todavía su desarrollo reglamentario, en los arts. 94 a 96 de la LSS de1966" -las referencias a los arts. 126 y 127 deben entenderse actualmente a los arts. 167 y 168 del TRLGSS-.

En el art. 69.3 párrafo segundo del RGRSS, se señala que si bien la responsabilidad de la sociedad de capital como empresario en el pago de la prestación, ha de ser declarada en resolución administrativa firme, se permite que en esa resolución se "declare la responsabilidad solidaria, subsidiaria o mortis causa en orden a las prestaciones de las que sean responsables las empresas por prestaciones a su cargo".

Ese art. 69.3 párrafo segundo del RGRSS no puede ser argumento en favor de la competencia de la entidad gestora de prestaciones para derivar la responsabilidad al administrador, porque en ese precepto no se contempla la derivación de responsabilidad al amparo del art. 18.3 del TRLGSS y de los arts. 360 y 367 de la LSC, sino la declaración de responsabilidad de las empresas $\mathrm{u}$ otros sujetos responsables en aplicación de la normativa de Seguridad Social reguladora de prestaciones (arts. 167,

1417 CASAS BAAMONDE, M. E.: "Jurisdicción y competencia del orden social", AA.VV. (Dir.: NOGUEIRA GUASTAVINO, M. y GARCÍA BECEDAS, G.): Lecciones de Jurisdicción Social, Tirant Lo Blanch, edición digital, https://biblioteca-tirant-com.ponton.uva.es, p. 62.

1418 SÁNCHEZ PUERTA, D. A.: Jurisdicción y Seguridad Social. La competencia jurisdiccional en materia de Seguridad Social, op. cit., p. 232.

1419 MONTOYA MELGAR, A.: "Capítulo I. De la Jurisdicción", en AA.VV. (Coord.: SEMPERE NAVARRO, A. V.) : Comentarios a la Ley de la Jurisdicción Social, Thomson Reuters, $3^{a}$ edición, marzo 2013, p. 89. 
168, 242 y 244 del TRLGSS). Al exigir el art. 69.3 del RGRSS que conste la responsabilidad solidaria o subsidiaria de las empresas, se está refiriendo a las posibles responsabilidades en las prestaciones de las empresas, en supuestos previstos en la normativa laboral y de Seguridad Social, en los que se imponen responsabilidades solidarias, subsidiarias o mortis causa de las empresas, como sucederá en supuestos de contratas, subcontratas, cesión de mano de obra, sucesión de empresas, trabajador en misión de empresas de trabajo temporal (arts. 167 y 168 TRLGSS y arts. 42 a 44 del TRLET), cometidos propios de la función de gestión de prestaciones que son competencia de la entidad gestora de la prestación.

En virtud del art. 69.3 del RGRSS la entidad gestora es la única competente para declarar la responsabilidad solidaria de otras empresas en aplicación de la responsabilidad en prestaciones de Seguridad Social (arts. 164, 168 y 242 a 244 del RTRLGSS, en relación con los arts. 42 a 44 del TRLET, art. 16 LETT, etc.), resolución que será revisable ante el orden jurisdiccional social (art. 2 apartado o de la LRJS). En esos supuestos de empresas responsables solidarias, declarada la responsabilidad solidaria de las empresas por la entidad gestora, la función de la TGSS se limitaría a reclamar la deuda a las mismas en aplicación de los arts. 69 y 70 del RGRSS, emitiendo la reclamación de deuda para que se ingrese el principal de la deuda con los intereses de capitalización, en su caso, dentro del plazo del reglamentario -mes siguiente a la notificación de la reclamación-, no siguiéndose el procedimiento de derivación de responsabilidad del art. 13 del RGRSS (Oficios de 18.11.2014 y 22.1.2018 de la Subdirección General de Procedimientos Ejecutivos y Especiales de Recaudación, que incorpora el criterio de la Subdirección General de Ordenación e Impugnaciones) ${ }^{1420}$.

Pero ese art. 69.3 del RGRSS no es de aplicación a la derivación de responsabilidad al administrador social en el pago de una deuda previa de prestaciones de la sociedad de capital, ya que en virtud del art. 18.3 del TRLGSS y art. 12.2 del RGRSS, la TGSS está

${ }^{1420}$ Según esos Oficios de 18.11.2014 y 22.1.2018 -Ref. 2013/0015- de la Subdirección General de Procedimientos Ejecutivos y Especiales de Recaudación, si por la TGSS se emite reclamación deuda a una de las empresa responsables y no a todas ellas, si ésta no atiende el pago en plazo reglamentario, y con posterioridad debe emitirse la reclamación de deuda a las otras empresas responsables solidarias, entiende la Subdirección General de Ordenaciones e Impugnaciones de la Seguridad Social -SGOI-, que esas nuevas reclamaciones de deuda deben incluir, no sólo el principal de la deuda con los intereses de capitalización, en su caso -que es lo que debió ingresar la empresa reclamada en el plazo de reglamentario de ingreso -, sino también el recargo de mora, los intereses y costas devengados con motivo de la anterior reclamación y que constarán en el momento de emitirse las otras reclamaciones de deudas a las restantes empresas responsables solidarias. 
derivando una deuda cuya gestión recaudatoria tiene atribuida, y no está declarando la responsabilidad del administrador en el pago de una prestación aplicando la normativa reguladora de prestaciones. El art. 69.3 del RGRSS, en definitiva, está contemplando los supuestos de extensión o imputación de responsabilidad a las empresas u otros sujetos en las prestaciones en virtud de norma laboral y de Seguridad Social.

Por todo lo anterior, concluimos que la derivación de deudas de prestaciones de la sociedad de capital al administrador al amparo del art. 18.3 del TRLGSS y del art. 12 del RGRSS, es competencia de la TGSS, en los supuestos de responsabilidad solidarias de los arts. 360 y 367 de la LSC, básicamente por tres razones:

- En primer lugar, porque la derivación de deudas por prestaciones dentro del procedimiento administrativo de recaudación al amparo del art. 18.3 del TRLGSS, es una mera actividad de gestión recaudatoria, y no es imputación de responsabilidad en las prestaciones en aplicación de la normativa de Seguridad Social (arts. 167, 168, 242 y 245 del TRLGSS), lo que sería propio de la labor de gestión de prestaciones. Siendo un acto de gestión recaudatoria, es competencia del órgano recaudador derivar la responsabilidad dentro del procedimiento recaudatorio a un tercero (art. 12.2 del RGRSS).

- En segundo lugar, porque en ningún precepto regulador de la derivación administrativa de deudas por prestaciones dentro del procedimiento administrativo de recaudación, se atribuye la competencia para la derivación de responsabilidad de una prestación a la entidad gestora de la prestación, a diferencia de lo que pudiera resultar de una interpretación literal del art. 12.4 del RGRSS, en el que se establece, "salvo que las normas legales de aplicación a los concretos supuestos de responsabilidad establezcan otra cosa, no podrán exigirse por responsabilidad solidaria, subsidiaria o mortis causa, las sanciones pecuniarias ni los recargos sobre prestaciones económicas debidas a accidentes de trabajo y enfermedades profesionales causados por falta de medidas de seguridad e higiene en el trabajo salvo, respecto de estos últimos, que exista declaración de responsabilidad de la entidad gestora competente". En virtud de este precepto, interpretado literalmente, para derivar las deudas por recargo de prestaciones por la TGSS, sería necesaria la previa declaración de responsabilidad de la entidad gestora, sin incluirse la derivación de responsabilidad de otras deudas por prestaciones (acerca de la 
derivación del recargo de prestaciones véase el siguiente apartado II. 2.1). La exclusión de la derivación de sanciones tiene su fundamento en el principio de personalidad de la sanción administrativa, de que sólo puede reclamarse el importe de una sanción a aquellos sujetos a los que legalmente se les impone la responsabilidad por una infracción administrativa (art. 28 de la Ley 40/2015, de 1 de octubre).

- En tercer lugar, un último argumento indirecto en favor de la competencia de la TGSS para derivar al administrador social deudas por prestaciones de la sociedad de capital, dentro del procedimiento recaudatorio, sería que, según la doctrina judicial menor, siguiendo la reiterada jurisprudencia del TS, la Jurisdicción Social no tiene competencia para conocer acerca de la responsabilidad del administrador social en las deudas de la sociedad en aplicación de la legislación de sociedades (arts. 360 y 367 de la LSC). El que no tenga competencia la Jurisdicción Social para conocer acerca de la derivación de responsabilidad del administrador en deudas de la sociedad de capital al amparo del art. 18.3 del TRLGSS y arts. 360 y 367 de la LSC, nos está señalando que no tendrá competencia porque no estamos ante una función de gestión de prestaciones de Seguridad Social, que sería competencia de la entidad gestora de las prestaciones y revisable ante la Jurisdicción Social (art. 2 apartado o, de la LRJS); sino que estamos ante una función de gestión recaudatoria, de derivación de una deuda de prestaciones dentro del proceso de recaudación de los recursos económicos de la Seguridad Social, que es competencia de la TGSS, y revisable ante la Jurisdicción Contencioso-Administrativa (art. 3, f), de la LRJS). En la Sentencia del TSJ Cataluña, Sala Social, de 11 de febrero de 2011 -Aranzadi 2011/1416-, se declara que la competencia para derivar una deuda por prestaciones, en concreto el recargo de prestaciones, al ser acto de gestión recaudatoria, es competencia de la TGSS. En la reclamación de deudas laborales y con motivo de la extinción de la relación laboral por incumplimientos empresariales graves, en Sentencia del TSJ Canarias/Tenerife, Sala Social, 714/2016, de 4 octubre -JUR 2017/221958- ${ }^{1421}$, se declaró la responsabilidad del administrador social acudiendo a

${ }^{1421}$ En esa Sentencia se señala "la Sentencia de instancia no condenó al recurrente en base a culpa o negligencia en el desempeño de la administración social, sino, como se reconoce por el propio recurrente, por aplicación de la doctrina del levantamiento del velo. De manera que mal puede entenderse que en la Sentencia de instancia se haya resuelto sobre una cuestión para la que la Jurisdicción Social es incompetente (como es, en efecto, la acción de responsabilidad patrimonial de los administradores sociales prevista en el artículo 241 de la Ley de Sociedades de Capital)”. 
la doctrina del levantamiento del velo societarios, ya que no cabe apreciar la responsabilidad del administrador en ese orden jurisdiccional acudiendo a la responsabilidad por deudas o por daños de la LSC. Igualmente, en Sentencia del TSJ Comunidad Valenciana, Sala Social, 2084/2014 de 23 septiembre -JUR 2015/30501-, se declara la incompetencia para declarar la responsabilidad del administrador en deudas del orden social en aplicación de la legislación de sociedades. De igual modo, en la reclamación de responsabilidad en prestaciones, se ha declarado la incompetencia de la Jurisdicción Social para declarar la responsabilidad del administrador social en prestaciones de responsabilidad de la sociedad de capital (TSJ de Andalucía/Sevilla, Sala Social, en Sentencia 852/2018, de 8 marzo -JUR 2018/154472- ${ }^{1422}$ ).

${ }^{1422}$ En el Fundamento de Derecho Segundo se señala "la posterior resolución de la Entidad Gestora que imputa por derivación la responsabilidad al ahora demandante, parte de que en su condición de administrador solidario incumplió su obligación de convocatoria de Junta General para proceder a la liquidación de la sociedad en el plazo de dos meses desde que se originó la situación de situarse el patrimonio contable de la empresa en menos de la mitad de la cifra del capital social, que ascendía a $3000 €$. Alega el recurrente que su primera noticia de la situación deudora de la sociedad la tuvo el 174-2007, cuando por la Tesorería General de la Seguridad Social le fue notificado un escrito declarándolo responsable de la deuda por derivación. Debe señalarse con carácter previo que aun cuando la cuestión relativa a la incompetencia jurisdiccional de este Orden especializado no ha sido invocada por el recurrente, tratándose de una materia de orden público procesal, la Sala debe conocer de la misma de oficio. Así, como declaró esta Sala en Sentencia de 20-4-2017: "La Sala debe coincidir con el Magistrado de instancia en la incompetencia de la Jurisdicción Social para examinar la reclamación formulada contra el administrador societario, por ser doctrina reiterada del Tribunal Supremo, contenida, entre otras, en las Sentencias de 28 de febrero; 28 de octubre -RJ 1997, 7680-; 31 de diciembre de 1997 -RJ 1997, 9644-; 13 de abril -RJ 1998, 4577-; 21 de julio de 1998 -RJ 1998, 6211-; 9 de noviembre de 1999 -RJ 1999, 8520-; 17 de enero -RJ 2000, 918-; 9 de junio de 2000 -RJ 2000, 5109-; y 8 mayo 2002 -RJ 2002\7541-, que "la Jurisdicción Social es incompetente para conocer las pretensiones relativas a la responsabilidad de los administradores societarios fundada en la omisión o incumplimiento de los deberes societarios a que se refieren los artículos 133.1 y 265.5 del Texto Refundido de la Ley de Sociedades Anónimas (-RCL 1989, 2737- y -RCL 1990, 206-), (-RCL 1989, 2737- y -RCL 1990, 206-), aprobado por Real Decreto Legislativo 1564/1989, de 22 de diciembre, remitiendo el conocimiento y decisión al Orden Jurisdiccional Civil, con la salvedad del incumplimiento por los administradores de lo establecido en la Disposición Transitoria Tercera de dicha norma legal, sobre el incremento del capital social a diez millones de pesetas, para cuya decisión es competente la Jurisdicción del Orden Social. Y dicha doctrina remite a la Jurisdicción Civil, porque -como se razona en dichas sentencias a cuyos extensos argumentos se hace expresa remisión-, las posibles responsabilidades, aún solidarias en su caso, son posteriores en su declaración y constatación a lo que conforma el contenido típico del litigio laboral entre empleador societario y empleado del mismo, no constituyendo, por ello, el conocimiento de dichas pretensiones por incumplimiento de las obligaciones del cargo, en el proceso laboral, una cuestión prejudicial de la que pueda conocer conforme al artículo 10 de la Ley Orgánica del Poder Judicial... y, en consecuencia, al no tratarse de una reclamación incluible en el supuesto de excepción de la Disposición Transitoria Tercera de dicha Ley de Sociedades Anónimas, ha de estimarse correcto, de acuerdo con dicha doctrina jurisprudencial referenciada, el pronunciamiento de la Sentencia de instancia al declarar la incompetencia de la Jurisdicción del Orden Social para conocer las pretensiones deducidas contra la parte recurrente de este recurso...". Conforme a esta doctrina, siendo esta jurisdicción incompetente para conocer de la responsabilidad del administrador societario recurrente, ni para condenarle, ni para absolverle, es decir, no cabe pronunciamiento alguno dejando imprejuzgada la reclamación contra él efectuada, es por lo que hemos de desestimar el recurso de suplicación interpuesto y confirmar la sentencia de 
Interpretación que adopta GARCÍA FERNÁNDEZ ${ }^{1423}$, para quien las prestaciones de responsabilidad empresarial impuestas en resolución de la entidad gestora a la sociedad, puede ser objeto de una subsiguiente declaración administrativa de responsabilidad por la TGSS, al señalar ya que "en el momento en que se proceda a su recaudación efectiva merecen aquellas la consideración genérica de recursos necesarios para la financiación de la Seguridad Social”, añadiendo (sic) "así, puede suceder, por ejemplo, que una determinada sociedad de responsabilidad limitada sea declarada por el INSS o por el ISM responsable del pago de una prestación a un trabajador y que, con posterioridad, sus administradores incurran en responsabilidad por las deudas sociales, lo que puede dar lugar a una declaración administrativa de responsabilidad realizada por la Tesorería General de la Seguridad Social”.

Por el contrario, dentro de la función de gestión de prestaciones de la entidad gestora, en aplicación del art. 167 del TRLGSS, sí se incluirá la competencia para imputar la responsabilidad al administrador social de una prestación, cuando en aplicación de la doctrina del levantamiento del velo estime que éste es el verdadero empresario ${ }^{1424}$. Competencia de determinación del verdadero empresario, mediante el levantamiento del velo societario o la figura de empresario plural, que podrá realizar la entidad gestora en ejercicio de su competencia de gestión de prestaciones, incluida la responsabilidad en el recargo de prestaciones, que se ha reconocido por la doctrina judicial menor ${ }^{1425}$.

instancia. "Como ya adelantamos en párrafos anteriores de este Fundamento Jurídico, tratándose de una materia de competencia, la Sala se ve obligada a su examen, aun cuando sea de oficio, y así concluimos que no podemos conocer de la cuestión ahora suscitada por el recurrente, relativa a la imposición de responsabilidad al administrador societario por omisión de incumplimiento de los deberes societarios a que se refieren los artículos 133.1 y 265.5 del Texto Refundido de la Ley de Sociedades Anónimas". La cursiva es nuestra.

1423 GARCÍA FERNÁNDEZ, E.: Las declaraciones administrativas de responsabilidad. Derivación de deudas tributarias y de Seguridad Social, op. cit., p. 158.

1424 Sentencia del TSJ de Cataluña, Sala Social, 4628/2019, de 4 octubre -JUR 2019/337023-; Sentencia TSJ Castilla y León, sede Burgos, Sala Social, 394/2013, de 23 julio -Aranzadi 2013/2103-; Sentencia del TSJ Canarias/Tenerife, Sala Social, 714/2016, de 4 octubre -JUR 2017/221958-, entre otras muchas.

${ }^{1425}$ Sentencia del TSJ de Cataluña, Sala Social, 4628/2019, de 4 octubre -JUR 2019/337023; en Sentencia del TSJ Castilla y León, sede Burgos, Sala Social, 394/2013, de 23 julio -Aranzadi 2013/2103-; Sentencia del TSJ Canarias/Tenerife, Sala Social, 714/2016, de 4 octubre -JUR 2017/221958-, entre otras. En la Sentencia del TSJ Canarias/Tenerife, Sala Social, 714/2016, de 4 octubre, se señala "la Sentencia de instancia no condenó al recurrente en base a culpa o negligencia en el desempeño de la administración social, sino, como se reconoce por el propio recurrente, por aplicación de la doctrina del levantamiento del velo. De manera que mal puede entenderse que en la sentencia de instancia se haya resuelto sobre una cuestión para la que la jurisdicción social es incompetente (como es, en efecto, la acción de responsabilidad patrimonial de los administradores sociales prevista en el artículo 241 de la Ley de Sociedades de Capital”. 
En la Sentencia del TSJ de Cataluña, Sala Social, 4628/2019, de 4 octubre -JUR 2019/337023-, se admite la competencia de la entidad gestora para declarar la responsabilidad del administrador cuando quepa atribuirle la condición de empresario en virtud de la doctrina del levantamiento del velo (acto de gestión de prestaciones). Igualmente, en la Sentencia del TSJ Castilla y León, sede Burgos, Sala Social, 394/2013, de 23 julio -Aranzadi 2013/2103-, se admite la competencia de la Jurisdicción Social, y, por ende, de la entidad gestora de la prestación, para determinar si los administradores son los verdaderos empresarios y, por lo tanto, si deberían ser los responsables del recargo de prestaciones que se había impuesto previamente a la sociedad de capital en la que ostentaban el cargo.

\subsection{La derivación del recargo de prestaciones.}

El recargo de la prestación es de responsabilidad de la empresa incumplidora de las disposiciones normativas de prevención de riesgos laborales, cuando ese incumplimiento hubiere sido la causa de la generación de una prestación por contingencias profesionales (art. 164 del TRLGSS). No obstante, podrá concurrir también responsabilidades de otras empresas en los supuestos de descentralización productiva, cesión ilegal de mano de obra, trabajadores en misión de una empresa de trabajo temporal, y de sucesión en actividad empresarial (arts. 42 y 43 del TRLET, art. 16 de la LETT, art. 168 del TRLGSS y art. 42.3 de la Ley 31/1995, de 8 de noviembre, de Prevención de Riesgos Laborales -LPRL- ${ }^{1426}$ ).

Se podrá declarar la responsabilidad de la empresa principal y subcontratista, incluso en contratas distintas a la propia actividad de la principal, si los incumplimientos son imputables a ambas. Incluso responderá la empresa causante del daño, cuando en el lugar de trabajo concurran varias empresas, aunque no sea la empleadora del trabajador, siempre que el hecho causante de la prestación le sea imputable por incumplimiento de la normativa de prevención de riesgos laborales ${ }^{1427}$.

Recargo de prestación que es susceptible de que se transmita a la empresa sucesora en la actividad (supuestos de fusión por absorción, cesión de activo y pasivo, escisión

\footnotetext{
${ }^{1426}$ BOE del 10.11.1995.

1427 SSTS, Sala Social, de 18 de septiembre de 2018 -rcud. 144/2017-, en que no concurría propia actividad, y para el resto de contratas, Sentencias de 7 de octubre de 2008 -rcud. 2426/2007; 18 enero 2010 -rcud. 3237/2007-; y 20 marzo 2012 -rcud. 1470/2011-, entre otras.
} 
societaria, etc.), según la última jurisprudencia ${ }^{1428}$ que parte de la doctrina sentada en la STJUE de 5 de marzo de 2015 (Asunto C-343/13) ${ }^{1429}$, en la que el Tribunal de Luxemburgo consideró que en la sucesión de empresas por fusión por absorción, se transmite íntegro el activo y pasivo, donde se incluyen las sanciones impuestas a la empresa sucedida por incumplimiento de la normativa laboral. Ante esa Sentencia del TJUE, nuestro Tribunal Supremo rectificó su anterior doctrina en la que negaba la transmisión empresarial del recargo de prestaciones.

En la reciente jurisprudencia, y a los efectos de la sucesión en la responsabilidad en materia de prestaciones de Seguridad Social, en el recargo de prestaciones prima la faceta indemnizatoria prestacional sobre la sancionadora o preventivo-punitiva. Responsabilidad en el recargo de prestaciones de la nueva empresa entrante, no sólo para el reconocido e impuesto administrativamente antes de la sucesión, sino también para el reconocido y declarado con posterioridad, cuando ante una enfermedad profesional de evolución lenta (silicosis, asbestosis), se ha contraído ésta durante la exposición al riesgo en la empresa anterior, manifestándose posteriormente ${ }^{1430}$.

Recargo de prestaciones impuesto por la entidad gestora a la sociedad de capital, y cuya gestión recaudatoria se atribuye a la TGSS dentro del procedimiento administrativo de recaudación (arts. 2 y 75 del RGRSS).

El trabajador o sus causahabientes podrán reclamar el recargo de prestaciones no sólo a la empresa, sino también al administrador social a través de la acción de responsabilidad solidaria en deudas de los arts. 360 y 367 de la LSC, o mediante la acción individual de responsabilidad (art. 241 de la LSC), de concurrir los presupuestos y requisitos de esa responsabilidad por daños.

Para que pueda responder en el procedimiento administrativo de recaudación del recargo de prestaciones otra persona, entidad o empresa responsable solidaria o subsidiariamente, deberá constar esa declaración de responsabilidad de modo expreso

\footnotetext{
1428 SSTS, Sala Social, de 23 de marzo de 2015 -rcud. 2057/2014-; 14 de abril de 2015 -rcud. 962/2014-; 5 de mayo de 2015 -rcud. 1075/2014-; 2 de noviembre de 2015 -rcud. 3426/2014-; 15 de diciembre de 2015 -rcud. 1258/2014-; 10 de diciembre de 2015 -rcud. 1012/2014-; y 8 de junio de 2016 -rcud. $1103 / 2015-$, entre otras muchas.

${ }^{1429}$ Procedimiento prejudicial a instancias de un órgano judicial portugués sobre la interpretación de la Directiva 78/855 CEE, actualmente derogada y sustituida por la Directiva 2011/35/UE.

1430 SSTS, Sala Social, de 8 de junio de 2016 -rcud. 1103/2015-; 14 de septiembre de 2016 -rcud. 90/2015-; y 20 de abril de 2017 -rcud. 1826/2015-.
} 
en la resolución de la entidad gestora de prestaciones (ISM y el INSS) que haya reconocido el derecho al recargo de prestaciones (art. 12.4, 69 y 75 del RGRSS).

Se plantea la duda acerca de si el recargo de prestaciones podría ser exigible al administrador social por la TGSS mediante la derivación administrativa de responsabilidad, ya que en el art. 12.4 del RGRSS se establece que, "salvo que las normas legales de aplicación a los concretos supuestos de responsabilidad establezcan otra cosa, no podrán exigirse por responsabilidad solidaria, subsidiaria o mortis causa, las sanciones pecuniarias ni los recargos sobre prestaciones económicas debidas a accidentes de trabajo y enfermedades profesionales causados por falta de medidas de seguridad e higiene en el trabajo salvo, respecto de estos últimos, que exista declaración de responsabilidad de la entidad gestora competente”.

En virtud de una primera interpretación literal del precepto ${ }^{1431}$, se concluiría que no será derivable al administrador social por la TGSS el recargo de prestaciones en el procedimiento administrativo recaudatorio, salvo que la responsabilidad solidaria del administrador constase en la resolución administrativa del INSS/ISM, sea en la que declara la responsabilidad de la empresa en el recargo de prestaciones, o en otra posterior ampliadora de la responsabilidad al administrador social (art. 12.4 del RGRSS). En virtud de ese precepto, para que pueda ser exigido el recargo de prestaciones en aplicación de una responsabilidad derivada, solidaria o subsidiaria, en el procedimiento administrativo de recaudación de los recursos de la Seguridad, sería preciso que se haya declarado esa responsabilidad por la entidad gestora ${ }^{1432}$.

Esta es la interpretación literal que prevalece actualmente en la derivación del recargo de prestaciones, por lo que para que la TGSS pueda reclamar esa deuda del recargo al administrador social, sería preciso que previamente se declare la responsabilidad de éste por la entidad gestora de prestaciones, porque la responsabilidad en el recargo es exclusiva de la empresa incumplidora sin que quepa su aseguramiento ni su transmisión por pacto o contrato (art. 164.2 del TRLGSS). De la actual regulación, en interpretación literal del art. 12.4 del RGRSS se concluye que la TGSS no estaría derivando por acto

${ }^{1431}$ GALA DURÁN, C.: La responsabilidad laboral y de seguridad social de los administradores de las sociedades mercantiles, op. cit., p. 198; MARTÍN JIMÉNEZ, R. y MATEOS BEATO, A.: La responsabilidad de empresas y Administradores con la Seguridad Social, Editorial Aranzadi Thomson Reuters, 2009, pp. 208-209.

${ }^{1432}$ LLOMPART BENNÀSSAR, M.: “ La responsabilidad en el ámbito laboral y de Seguridad Social”, op. cit., edición digital, pp. 18 de 44. 
propio la deuda de la sociedad de capital al administrador, sino que estaría procediendo a recaudar una deuda que con el carácter solidario se ha impuesto a la sociedad y al administrador social por la entidad gestora.

Competencia para derivación del recargo de prestaciones al administrador social en aplicación de la responsabilidad ex lege en las deudas del administrador social, que se ha reconocido a la entidad gestora de prestaciones -al INSS-, en la Sentencia del TSJ de Castilla y León, con sede en Burgos, Sala Social, 120/2014, de 5 marzo -Rec. 83/2014-. Ante la declaración previa de responsabilidad de la sociedad de capital en el recargo de prestaciones, al concurrir causa de disolución por pérdidas cualificadas incumpliéndose los deberes de promoción de la disolución por los administradores, se admite la competencia de la entidad gestora para la derivación de responsabilidad al administrador social, reproduciendo argumentos recogidos en otra sentencia de esa sala -Rec. 41/2014-, en que se declaraba la responsabilidad del administrador social por deudas en aplicación de la disposición transitoria tercera de la LSA de 1989, que establecía la responsabilidad de los administradores en las deudas de Seguridad Social si incumplieron la obligación de elevar en el plazo legal fijado el importe del capital social a los nuevos importes mínimos legales.

Ahora bien, la mayoría de los supuestos en que se ha admitido en la doctrina judicial la competencia de la entidad gestora para declarar la responsabilidad del administrador social en el recargo de prestaciones, ha sido en aplicación de la legislación de Seguridad Social en materia de responsabilidad en el recargo (acto de gestión de prestaciones), en aquellos casos en que pudiera imputársele a él el incumplimiento de la normativa de prevención de riesgos laborales, y eso sucede fundamentalmente en los supuestos de levantamiento del velo, por estimarse ser el empleador real, o en los supuestos de apreciarse la condición de empresario plural.

En este sentido en la Sentencia del TSJ de Cataluña, Sala Social, 4628/2019, de 4 octubre -Rec. 2811/2019-, al respecto señala, con remisión a la Sentencia que cita del TSJ de Baleares, de 16 de marzo de 2017, reitera la Sala de Andalucía/Málaga (en su pronunciamiento de 23 de enero de 2019) que, "la mera condición de administrador social de la empresa demandada no es una condición suficiente para derivar(lo) responsabilidad..., a modo de responsabilidad añadida a la responsabilidad de la sociedad mercantil, sobre la que (hubiera) recaído responsabilidad por incumplimiento de las obligaciones del contrato de trabajo celebrado en relación al accidente de trabajo 
sufrido por el trabajador... al no constar probado que aquél "tuviera la condición de empresa en la realidad del tráfico empresarial... de tal manera que aun en el supuesto de que existieran datos indicativos de culpa en el empleador no podrían éstos servir para trasladar al administrador social la responsabilidad del accidente de trabajo pues no todo incumplimiento en materia de prevención de los accidentes de trabajo que conduzca a una responsabilidad concreta de la empresa como sociedad mercantil puede conllevar la responsabilidad del administrador social; no pudiendo aceptarse que como en toda sociedad mercantil existe una persona física, automáticamente sea reprochada la responsabilidad a su administrador social, por las omisiones culposas detectadas a la sociedad mercantil.... Criterio que mantiene el posterior pronunciamiento del mismo Tribunal, de 19 de abril de 2019, al considerar insuficientes los datos fácticos existentes en los hechos probados de la sentencia para levantar el velo de la personalidad societaria ... a los efectos de establecer la responsabilidad del (administrador) demandado en el recargo de las prestaciones económicas en caso de accidente de trabajo...; lo que se manifiesta en armonía con lo sustentado por esta Sala de lo Social en su Sentencia, de 12 de febrero de 2013, al considerar que no existe base alguna para condenar también al administrador de la empresa que como persona física no ha tenido participación en los hechos". En definitiva, se está argumentando que para que la entidad gestora de la prestación declare la responsabilidad del administrador, es preciso que, de alguna forma, le sea imputable el incumplimiento de la normativa de prevención, como sería el caso de ser el verdadero empresario en virtud de la doctrinal del levantamiento del velo.

Igualmente, en la Sentencia del TSJ Castilla y León, sede Burgos, Sala Social, 394/2013 de 23 julio -Rec. 362/2013-, se admite la competencia de la Jurisdicción Social, y, por ende, de la entidad gestora de la prestación para determinar si los administradores son los verdaderos empresarios, y, por lo tanto, si deberían ser los responsables del recargo de prestaciones que se había impuesto previamente a la sociedad de capital en la que ostentaban el cargo.

En similares términos, en la Sentencia del TSJ Canarias/Tenerife, Sala Social, 714/2016, de 4 octubre -Rec. 171/2016-, se señala "la sentencia de instancia no condenó al recurrente en base a culpa o negligencia en el desempeño de la administración social, sino, como se reconoce por el propio recurrente, por aplicación de la doctrina del levantamiento del velo. De manera que mal puede entenderse que en la sentencia de instancia se haya resuelto sobre una cuestión para la que la jurisdicción social es 
incompetente (como es, en efecto, la acción de responsabilidad patrimonial de los administradores sociales prevista en el artículo 241 de la Ley de Sociedades de Capital".

En definitiva, se admite la competencia de la entidad gestora de prestaciones para declarar, derivar o ampliar la responsabilidad en el recargo de prestaciones a otras empresas o a terceros, como el administrador-empresario, cuando la declaración de responsabilidad se haga en aplicación de la propia normativa reguladora de la responsabilidad de prestaciones (acto de gestión de prestaciones). Así, citando los arts. 12.4 y 69.3 del RGRSS, en la Sentencia del TSJ de Castilla y León, con sede en Burgos, Sala Contencioso-Administrativa, $\mathrm{n}^{\mathrm{o}}$ 135/2018, de 25 mayo -Aranzadi JUR 2018/208554-, ante la petición dirigida por el trabajador beneficiario del recargo a la TGSS, para que se dirigiese la reclamación a otra empresa del mismo grupo empresarial, pretendiéndose que se ampliase la declaración previa de responsabilidad del recargo impuesta por el INSS, se establece que esa reclamación de ampliación de responsabilidad en el recargo de prestaciones a otra empresa del grupo, "resulta de lo dispuesto en el art. 123.1 del TRLGSS, en el que se establece que dicha responsabilidad recae sobre el empresario infractor, o en su caso, como resulta de lo dispuesto en los arts. 12.4 y 69.3 del Reglamento General de Recaudación de la Seguridad Social, también puede recaer en otras empresas respecto de las que también haya existido una declaración de responsabilidad realizada por la entidad gestora competente". La cursiva es nuestra. Esta Sentencia está señalando que la competencia para declarar o ampliar la responsabilidad en el recargo de prestaciones a otras empresas, en virtud del art. 164 del TRLGSS, es de la entidad gestora.

Para esta primera interpretación, el recargo de prestaciones sólo podría derivarse y exigirse a un tercero distinto de la empresa responsable empleadora, si consta la declaración previa de responsabilidad o ampliación-derivación de responsabilidad de la entidad gestora (INSS o del ISM), que normalmente será de otras empresas en aplicación de la normativa laboral y de Seguridad Social, por supuestos de descentralización productiva, cesión de trabajadores, sucesión de empresa, grupos de empresa $^{1433}$ o por levantamiento del velo societario para identificar al verdadero

${ }^{1433}$ Como para la descentralización productiva se reconoce esa responsabilidad en STS, Sala Social, de 18 de septiembre de 2018, aunque no haya propia actividad, y en SSTS de 7 de octubre de 2008 -rcud. 2426/2007-; 18 enero 2010 -rcud. 3237/2007-; 20 marzo 2012 -rcud. 1470/2011-, entre otras. En la Sentencia del TSJ Castilla y León/Burgos, Sala Social, 521/2019, de 24 julio -Aranzadi 2019/2006-, se reconoció la competencia de la entidad gestora -INSS- para dictar nueva resolución ampliando una resolución anterior de responsabilidad, para extenderla a una sociedad del grupo empresarial. 
empleador de imponerse al administrador social (acto de gestión de prestaciones). Pero, igualmente, en virtud del mandato expreso del art. 12.4 del RGRSS, interpretado literalmente, también sería competencia de la entidad gestora de la prestación, y no de la TGSS, derivar o declarar la responsabilidad solidaria del administrador social para el pago de la deuda del recargo de prestaciones impuesta a la sociedad de capital, en los supuestos de responsabilidad ex lege en las deudas de ésta al amparo del art. 18.3 del TRLGSS y de los arts. 360 y 367 de la LSC (lo que en puridad no sería un acto de gestión de prestaciones).

Declarada la responsabilidad solidaria de varias empresas por la entidad gestora, la TGSS procederá posteriormente a reclamar la deuda a las empresas responsables solidarias, siguiendo el procedimiento recaudatorio del art. 75 del RGSS, sin iniciar el procedimiento administrativo de derivación de responsabilidad del art. 13 del RGRSS (Oficios de 18.11.2014 y 22.1.2018 de la Subdirección General de Procedimientos Ejecutivos y Especiales de Recaudación, que incorpora el criterio de la Subdirección General de Ordenación e Impugnaciones ${ }^{1434}$. Lo mismo ocurrirá para derivar la responsabilidad al administrador, de ser competente la entidad gestora para declarar la responsabilidad solidaria, limitándose la TGSS a emitir la reclamación de deuda de conformidad con el art. 75 del RGRSS, sin iniciar el procedimiento de derivación del art. 13 del RGRSS.

Cabría hacer otra interpretación aún más restrictiva del art. 12.4 del RGRSS, y sería considerar que si sólo puede declararse la responsabilidad solidaria, subsidiaria o mortis causa en el recargo de prestaciones por la entidad gestora, es porque esa responsabilidad se está declarando en el ejercicio de su función de gestión de prestaciones, que es revisable ante los órganos jurisdiccionales del orden social (art. 2 apartado o) de la LJRS). Esto es, ante la declaración de la responsabilidad solidaria o subsidiaria en el recargo en aplicación de las disposiciones reguladoras de la responsabilidad en

\footnotetext{
${ }^{1434}$ Según esos Oficios de 18.11.2014 y 22.1.2018 -Ref. 2013/0015- de la Subdirección General de Procedimientos Ejecutivos y Especiales de Recaudación, si por la TGSS se emite reclamación deuda a una de las empresa responsables y no a todas ellas, si ésta no atiende el pago en plazo reglamentario, y con posterioridad debe emitirse la reclamación de deuda a las otras empresas responsables solidarias, entiende la Subdirección General de Ordenaciones e Impugnaciones de la Seguridad Social -SGOI-, que esas nuevas reclamaciones de deuda deben incluir, no sólo el principal de la deuda con los intereses de capitalización, en su caso -que es lo que debió ingresar la empresa reclamada en el plazo de reglamentario de ingreso -, sino también el recargo de mora, los intereses y costas devengados con motivo de la anterior reclamación y que constarán en el momento de emitirse las otras reclamaciones de deudas a las restantes empresas responsables solidarias.
} 
prestaciones (arts. 164 y 168 del TRLGSS), que serían los supuestos de responsabilidad de otras empresas o sujetos en la descentralización productiva, cesión de mano de obra, trabajadores en misión en empresas usuarias etc., que son los supuestos en que el orden jurisdiccional social tiene competencia para revisar los actos de la entidad gestora de prestaciones, al establecerse en el art. 2 apartado o de la LRJS que es competencia de ese orden conocer sobre la imputación de responsabilidades a empresas o terceros en prestaciones de Seguridad Social, obviamente porque se está ejerciendo funciones de gestión de prestaciones, imputando la responsabilidad en aplicación de la normativa reguladora de la responsabilidad en prestaciones. Pero no cuando estemos ante una responsabilidad ex lege en deuda ajena impuesta a los administradores por incumplimientos de las obligaciones orgánicas establecidas en la legislación de sociedades, porque en ese supuesto la entidad gestora no estaría declarando la responsabilidad solidaria en aplicación del régimen jurídico de responsabilidad en prestaciones establecido en el TRLGSS.

Con esta segunda interpretación restrictiva, cuando el art. 12.4 del RGRSS establece que el recargo de prestaciones no podrá ser exigido por responsabilidad solidaria, subsidiaria o mortis causa, salvo que se haya impuesto en virtud de resolución de la entidad gestora de prestaciones, se estarían contemplando los supuestos del art. 75 del RGRSS $^{1435}$, en relación con el art. 164 del TRLGSS, para la responsabilidad del

1435 “Artículo 75. Recargos sobre prestaciones.

1. Las resoluciones de la entidad gestora de la Seguridad Social en las que se declare la procedencia de recargos sobre las prestaciones económicas debidas a accidentes de trabajo y enfermedades profesionales originados por falta de medidas de seguridad e higiene en el trabajo, así como los responsables de dichos recargos, conforme a lo previsto en el artículo 123 del Texto Refundido de la Ley General de la Seguridad Social, una vez sean firmes en vía administrativa se comunicarán a la Tesorería General de la Seguridad Social, con indicación expresa del momento en que se hubiera realizado su notificación, para la recaudación por ésta del importe de tales recargos, sin perjuicio de las devoluciones que, en su caso, procedan, si se redujeran o anularan en vía judicial los derechos reconocidos en dichas resoluciones administrativas. También procederá el reintegro, total o parcial, de la parte no consumida de los recargos en los supuestos y con el alcance a que se refiere el artículo 71.2 de este Reglamento.

El importe de dichos reintegros o devoluciones se imputará con cargo al presupuesto de la Tesorería General de la Seguridad Social.

2. A estos efectos, la Tesorería General de la Seguridad Social, en el supuesto de que los recargos recaigan sobre pensiones, determinará el importe del capital coste de aquéllos, procediendo a su recaudación junto a los intereses de capitalización que procedan hasta la fecha de su ingreso. En el caso de recargos sobre otras prestaciones, la Tesorería General de la Seguridad Social recaudará directamente el importe de dichos recargos.

3. El plazo reglamentario de ingreso de dichos recargos se iniciará el día siguiente al de la notificación por la Tesorería General de la Seguridad Social de la reclamación de deuda del capital coste, incluidos los intereses de capitalización que procedan, o del importe correspondiente a otras prestaciones y finalizará el último día hábil del mes siguiente al de su notificación. 
recargo, pero en ambos casos, sólo cuando la responsabilidad de esas terceras empresas o personas se declare por la entidad gestora en aplicación de la normativa reguladora de las prestaciones (acto de gestión de prestaciones). En ese sentido en el art. 75 del RGSS se alude a " las resoluciones de la entidad gestora de la Seguridad Social en las que se declare la procedencia de recargos sobre las prestaciones económicas debidas a accidentes de trabajo y enfermedades profesionales originados por falta de medidas de seguridad e higiene en el trabajo, así como los responsables de dichos recargos, conforme a lo previsto en el artículo 123 del Texto Refundido de la Ley General de la Seguridad Social" -actual art. 164 del TRLGSS-. Esto es, ante la declaración de otros sujetos responsables solidarios en aplicación del art. 164 del TRLGSS, en aplicación de la normativa reguladora del recargo de prestaciones, pero no de la responsabilidad ex lege por deuda ajena del art. 367 de la LSC. Interpretación avalada por el art. 69.3 párrafo segundo del RGRSS, en que se atribuye a la entidad gestora la declaración de "la responsabilidad solidaria, subsidiaria o mortis causa en orden a las prestaciones de las que sean responsables las empresas por prestaciones a su cargo".

En definitiva, en ese artículo 12.4 del RGRSS, en relación con el art. 75 del RGRSS, se estaría contemplando la responsabilidad directa o la responsabilidad solidaria, subsidiaria, o mortis causa de otras empresas no empleadoras del trabajador afectado, o de terceros, en aquellos supuestos en que la normativa reguladora del recargo de prestaciones establece una responsabilidad solidaria ${ }^{1436}$ de empresas -como sucede en la descentralización productiva, cesión de mano de obra, sucesión de empresa, trabajadores en misión en la empresa usuaria-. Responsabilidad de las empresas que debe ser declarada por la entidad gestora de las prestaciones (arts. 164, 167, 242 y 245 del TRLGSS).

Partiendo de esa segunda interpretación, cabría defender, incluso una tercera opción interpretativa, de modo que, si la entidad gestora sólo puede declarar la responsabilidad solidaria o subsidiaria en el recargo cuando esté ejercicio su función de gestión de

Los intereses de capitalización que se devenguen desde el día en que se expida la correspondiente reclamación del importe de la deuda hasta el de su pago serán liquidados y adicionados por el sujeto responsable de éste.

4. Las Sentencias que condenen al pago de recargos sobre prestaciones de la Seguridad Social se ejecutarán a través de los trámites establecidos en el Texto Refundido de la Ley de Procedimiento Laboral, previa fijación por la Tesorería General de la Seguridad Social del capital coste correspondiente, en caso de tratarse de pensiones".

${ }^{1436}$ Como para la descentralización productiva se reconoce esa responsabilidad en SSTS, Sala Social, de 18 de septiembre de 2018, aunque no haya propia actividad, y Sentencias, de 7 de octubre de 2008 rcud. 2426/2007-; 18 enero 2010, -rcud. 3237/2007-; y 20 marzo 2012, -rcud. 1470/2011-, entre otras. 
prestaciones, del recargo de prestaciones, al declarar los sujetos responsables del incumplimiento de la normativa de prevención de riesgos laborales causante de la prestación, revisable ante los órganos del orden jurisdiccional social, no estaría excluyendo que la derivación de la deuda del recargo de la sociedad de capital, una vez haya nacido, pueda ser realizada por la TGSS en los supuestos de responsabilidad ex lege en deuda ajena prevista en el art. 18.3 del TRLGSS, en relación con los artículos 360 y 367 de la LSC, derivación que se efectúa dentro del procedimiento de gestión recaudadora, y el titular de la gestión recaudatoria es ese Servicio Común, no la entidad gestora. Si se atribuye sólo a la entidad gestora la derivación del recargo en ejercicio de su función de prestaciones, es porque no se ha querido excluir la derivación a la TGSS en ejercicio de su función de gestión recaudatoria en los supuestos de responsabilidad en deuda ajena.

Esta es la doctrina que se vendría a sostener en la Sentencia del TSJ de Cataluña/Barcelona, Sala Social, núm. 1123/2011, de 11 de febrero -Rec. 6702/2009-, que partiendo de la distinción entre actos de gestión de prestaciones y actos de gestión recaudatoria, atribuye la competencia de los actos de gestión de prestaciones a la entidad gestora para declarar la responsabilidad del recargo aplicando la normativa reguladora de la responsabilidad en materia de prestaciones de Seguridad Social, como sucede cuando se atribuye al administrador social la condición de empresario por la doctrina del levantamiento del velo, o por prohibición de la doctrina del fraude de ley o abuso de derecho. Por el contrario, sería gestión recaudatoria competencia de la TGSS, cuando la derivación de la deuda se efectúa al administrador social, no por ser el empresario responsable, sino en aplicación de la responsabilidad ex lege, como sucede en los hechos enjuiciados en la sentencia, en que se derivaba la deuda por la concurrencia de causa de disolución por pérdidas cualificadas sin haberse promovido por el administrador social la disolución societaria ${ }^{1437}$.

${ }^{1437}$ En el Fundamento de Derecho Segundo se argumenta del siguiente modo, "Si la declaración de extensión de responsabilidad de la Sra. Rosaura respecto de la ya establecida para la empresa Dequitec, S.A., constituye un mero acto recaudatorio de la Seguridad Social que se produce al amparo de lo establecido en los artículos 104.1 y 127.2 de la Ley General de la Seguridad Social y en el artículo 13 del Real Decreto 1415/2004, de 11 de junio, por el que se aprueba el Reglamento de General de Recaudación de la Seguridad Social, lo que parece desprenderse del Informe emitido por la Inspección de Trabajo y Seguridad Social de fecha 12 de junio de 2008, que ha sido hecho enteramente suyo por la Resolución del INSS combatida en el presente procedimiento de fecha 8 de agosto de 2008, entonces estaría claro que se trata de un acto recaudatorio que debía haber sido acordado directamente por la Tesorería General de la Seguridad Social mediante una reclamación de deuda por derivación, acto administrativo no recurrible ante el Orden Jurisdiccional Social de acuerdo 
Partiendo de esa diferenciación de esos dos actos de gestión, en esa Sentencia del TSJ de Cataluña se concluye que la derivación administrativa del recargo de prestaciones por causa de pérdidas cualificadas es competencia de la TGSS, señalando que, "en definitiva, planteadas así las cosas, esta Sala entiende que la derivación de responsabilidad de la Sra. Rosaura únicamente cabe por vía administrativa, mediante resolución acordada por la TGSS en aplicación de los artículos 104.1 y 127.2 de la LGSS y 13 del Reglamento General de Recaudación y no por tratarse de la empresaria infractora (...)". Sentencia del TSJ de Cataluña que anuló la resolución del INSS que había declarado la responsabilidad solidaria de la administradora social por incumplir sus deberes ante la concurrencia de causa de disolución, estableciendo en su fallo (sic) "que estimando en parte el recurso de suplicación interpuesto por doña Rosaura contra la Sentencia dictada por el Juzgado de lo Social no 11 de los de Barcelona, en fecha 9 de junio de 2009, recaída en los Autos 97/09, seguidos en virtud de demanda formulada por la recurrente contra el Instituto Nacional de la Seguridad Social, la Tesorería General de la Seguridad Social, el trabajador don E., la empresa DEQUITEC, S.A., y el administrador judicial don D., en impugnación de la Resolución del INSS de fecha 8 de agosto de 2008, debemos revocar y revocamos la Sentencia recurrida, anulando dicha Resolución, sin perjuicio de que por vía administrativa se siga el correspondiente procedimiento recaudatorio por derivación de responsabilidad en aplicación de los artículos 104 y 127 de la Ley General de la Seguridad Social y 13 del Reglamento de Recaudación General de Recaudación".

Ante estas tres posibles interpretaciones, estando de acuerdo en que la responsabilidad solidaria pueda extenderse al administrador social, no consideramos plenamente

con lo establecido, por exclusión, en el artículo 3.1.b) de la Ley de Procedimiento Laboral, habiendo resultado totalmente inútil la resolución del INSS reseñada y todo este procedimiento, ya que la responsabilidad de la Sra. Rosaura y el aseguramiento al Sr. Esteban de los derechos al cobro del recargo de prestaciones del $40 \%$ ya estaba garantizado por esa vía, que parece ser que también se ha desplegado paralelamente según se desprende del contenido del Recurso de Súplica articulado por la Sra. Rosaura resuelto por Auto firme de esta Sala de fecha 10 de febrero de 2010. En definitiva, en este caso procedería la declaración de incompetencia de este Orden Jurisdiccional Social con anulación de todo lo actuado. 2) Por el contrario, la cuestión debatida podría ser enfocada de distinta manera si se entendiera que no se está ante la impugnación de una reclamación de derivación de responsabilidad efectuada por la TGSS, sino ante una Resolución del INSS en materia de recargo de prestaciones del artículo 123 de la Ley General de la Seguridad Social, en cuyo caso tanto por la materia como por el órgano que resuelve es clara que la competencia revisoria judicial es de este Orden Jurisdiccional Social en aplicación del artículo 2.b) de la Ley de Procedimiento Laboral, tal como lo sería una controversia en materia de jubilación promovida por falta de alta y cotización del empresario, cuestión que se ventila en la Jurisdicción Social con independencia de que las cuotas adeudadas se reclamen en vía administrativa y se puedan discutir posteriormente en la ContenciosoAdministrativa". 
satisfactorias ninguna de ellas. En primer lugar, porque estando de acuerdo en el fondo con la primera interpretación, que se pueda derivar la responsabilidad del recargo, establecer que la derivación de la responsabilidad al administrador social al amparo de la responsabilidad ex lege en deuda ajena del art. 367 de la LSC, se tenga que declarar por la entidad gestora, es asignarle un cometido que no es propio de un acto de gestión de prestaciones del recargo -insuficiencia de la primera interpretación-. Por otro lado, con la segunda interpretación, si al amparo del art. 12.4 del RGRSS se concluye que sólo puede la entidad gestora declarar la responsabilidad de terceros en aplicación de la normativa de Seguridad Social reguladora de la responsabilidad en el recargo, estamos excluyendo la derivación del recargo al administrador social. Y, en tercer lugar, la tercera interpretación, siendo loable su finalidad, no encuentra acogida en la redacción literal del art. 12.4 del RGSS, sino todo lo contrario.

Ante estas posibles interpretaciones y con la finalidad de que la responsabilidad derivada sea declarada por la entidad competente según la naturaleza de la función ejercitada, función de gestión de prestaciones de la entidad gestora o función de gestión de recaudadora de la TGSS; y considerando que debe ser la TGSS y no la entidad gestora la competente para derivar una deuda en los supuestos de responsabilidad ex lege en deuda ajena, por ser un acto propio de gestión recaudatoria revisable ante los órganos del orden jurisdiccional contencioso-administrativo, al amparo de la doctrina jurisprudencial ${ }^{1438}$ que prima el carácter indemnizatorio-prestacional del recargo frente al carácter sancionador-preventivo ${ }^{1439}$, realizamos la siguiente propuesta de lege ferenda.

Para clarificar definitivamente la competencia administrativa, debería reformarse el art. 12.4 del RGRSS, para permitir expresamente la derivación administrativa por la TGSS de la deuda del recargo al administrador social dentro del procedimiento administrativo de recaudación, en los supuestos en que éste responda ex lege de las deudas de la sociedad de capital, al no existir actualmente una jurisprudencia del Tribunal Supremo que avale con carácter general la derivación de la deuda en el procedimiento de recaudación por la TGSS sin necesidad de una previa resolución expresa de la entidad

${ }^{1438}$ SSTS, Sala Social, de 23 de marzo de 2015 -rcud. 2057/2014; de 14 de abril de 2015 -rcud. 962/2014; 5 de mayo de 2015 -rcud. 1075/2014-; 2 de noviembre de 2015 -rcud. 3426/2014-; 15 de diciembre de 2015 -rcud. 1258/2014-; 10 de diciembre de 2015 -rcud. 1012/2014-; 8 de junio de 2016 -rcud. 1103/2015-; y 21 de diciembre de 2016 -rcud. 3373/2015-.

${ }^{1439}$ Acerca de la naturaleza del recargo de prestaciones véase el apartado III.3 del capítulo primero de esta tesis. 
gestora imponiendo la responsabilidad solidaria (excepción hecha de los supuestos de sucesión de empresa). Téngase en cuenta que en el art. 18.3 último inciso del TRLGSS se establece que la declaración de la responsabilidad solidaria o subsidiaria en deuda ajena se declara y se exige en el procedimiento recaudatorio, y quien es sujeto activo del procedimiento recaudatorio es la TGSS, no la entidad gestora (art. 21 TRLSS y art. 2 del RGRSS).

Con esta propuesta la entidad gestora podría seguir declarando la responsabilidad solidaria en el recargo cuando se impute la responsabilidad en prestaciones aplicando la normativa de Seguridad Social de responsabilidad en prestaciones, pero si se pretende derivar, en virtud de la responsabilidad ex lege del administrador social, una deuda del recargo de prestaciones de la sociedad previamente declarada por la entidad gestora, la competencia deberá ser de la TGSS. Propuesta que iría en consonancia con las últimas concepciones del recargo de prestaciones, en las que se estima que priman más sus aspectos indemnizatorios prestacionales, con lo que no estaríamos infringiendo el principio de personalidad de las sanciones, que es lo que impide la derivación a terceros de las sanciones, al no tener el recargo pura y exclusiva naturaleza sancionadora, sino que tiene naturaleza híbrida al incorporar aspectos preventivos, indemnizatorios prestacionales, y sancionadores. Todo ello en garantía del trabajador beneficiario del recargo, ya que en definitiva para el beneficiario ese recargo es parte de la prestación reconocida.

No será obstáculo a esa derivación de deuda la prohibición de transmisión del recargo del art. 164.2 del TRLGSS, ya que la prohibición de transmisión contemplada en el precepto es por pacto o contrato, no por disposición legal. No obstante, sería conveniente modificar igualmente el art. 164.2 del TRGLSS, para reconocer expresamente que la responsabilidad es trasladable en los supuestos de responsabilidad ex lege en deuda ajena.

Esta propuesta de lege ferenda, podrá encontrar apoyo en la nueva doctrina jurisprudencial $^{1440}$ que admite la sucesión empresarial en las deudas del recargo de

${ }^{1440}$ En la Sentencia del 23.3.2015, el TS partiendo del art. 127.2 de la anterior Ley General de la Seguridad Social -actual art. 168.2 del TRLGSS-, que alude a que el nuevo empresario responde de las prestaciones causadas antes de la sucesión, entiende que el término de prestaciones causadas ha de entender en sentido finalista y no literal, especialmente en prestaciones de derivadas de enfermedad profesional, en que el devenir de la misma es lento y no súbito, por lo que pudo haberse iniciado su incoación durante la prestación de servicios en la anterior empresa, concluyendo que con la expresión de prestación causada "ha de comprender los recargos de prestaciones que ya se hubiesen reconocido 
prestaciones. Con la admisión de la transmisión del recargo en la sucesión de empresa, se está reconociendo que esa deuda se asume por la nueva empresa en virtud de una responsabilidad solidaria en las deudas impuesta legalmente, pero no porque se haya declarado su responsabilidad en el incumplimiento de la normativa de prevención de riesgos laborales. Se asume la responsabilidad en una deuda previa de Seguridad Social por el hecho de la subrogación empresarial. Y si ello es posible en la sucesión de empresa, porque por mandato legal se asumen las deudas de Seguridad Social del anterior empresario, lo mismo podría ocurrir en los demás supuestos en que en virtud de una disposición legal se imponga una responsabilidad solidaria en el pago de deudas u obligaciones ajenas preexistentes, como resultaría del art. 18.3 del TRLGSS, en relación con los arts. 360 y 367 de la LSC, sin necesidad de que la responsabilidad solidaria se haya declarado por la entidad gestora de las prestaciones.

Con esta propuesta de lege ferenda sería posible la derivación por la TGSS del recargo de prestaciones a los administradores sociales, en aplicación de los art. 18.3 del TRLGSS y art. 12.2 del RGRSS, una vez se ha declarado por la entidad gestora en resolución administrativa la responsabilidad en el recargo de la sociedad de capital, porque estaremos ya ante una deuda de Seguridad Social, ante obligaciones pendientes con la Seguridad Social de la sociedad, y como tal deuda u obligación podrá ser derivada dentro del procedimiento administrativo de recaudación al administrador social por el Servicio Común, ejerciendo su función de gestión recaudadora (art. 18.3 del TRLGSS y arts. $12.2,68,70$ y 75 del RGRSS $)^{1441}$.

Téngase en cuenta que en desarrollo del art. 18.3 del TRLGSS, en el art. 12.2 del RGRSS, se establece que "cuando en aplicación de normas (...) mercantiles, los órganos de gestión de recaudación aprecien la concurrencia de un responsable solidario, subsidiario o mortis causa respecto de quien hasta ese momento figurase

antes de la sucesión [algo obvio], sino que igualmente ha de alcanzar a los que -por estar en curso de generación el daño atribuible a la infracción de la medida de seguridad- se hallasen «in fieri» a la fecha de cambio empresarial".

${ }^{1441}$ Como se señala en Auto 4/2019, de 19 de febrero de 2019 -Rec. 18/2018- del TS, Sala Especial, con relación a la delimitación entre actos de gestión recaudatorio y actos de gestión de prestaciones, el acto de gestión recaudatoria "viene limitado tan sólo a aquellos que persigan el cobro de los recursos o que se refieran al ejercicio de la actividad administrativa conducente a la realización de los créditos y derechos de la Seguridad Social", que serían competencia de la Jurisdicción ContenciosoAdministrativa, mientras que serían competencia de la Jurisdicción Social, los actos de gestión de prestaciones, al indicar que "deben comprenderse en ese ámbito competencial cuantas cuestiones se puedan plantear y tengan incidencia directa sobre el derecho al percibo de prestaciones de Seguridad Social (STS, de 10 de julio de 2012, -rcud. 2828/2011-, con cita de la STS, de 10 de julio de 2001, rcud. 1801/2000-, y las que en ella se indican)". 
como responsable, declararán dicha responsabilidad y exigirán el pago mediante el procedimiento recaudatorio establecido en este reglamento". Se está contemplando la responsabilidad solidaria, subsidiaria o mortis causa en una deuda previa, que es algo distinto a ser responsable solidario, subsidiario o mortis causa de una prestación, o del recargo en aplicación de la normativa reguladora de prestaciones (arts. 164 y 167.4 del TRLGSS). En el primer supuesto, derivar la deuda nacida y liquidada a un responsable solidario, es acto de gestión recaudatoria; en el segundo, declarar la responsabilidad solidaria, subsidiaria o mortis causa de una prestación o del recargo en aplicación de la normativa reguladora de la responsabilidad en prestaciones, es un acto de gestión de prestaciones competencia de la entidad gestora.

\section{III.- ASPECTOS COMUNES ESENCIALES DEL PROCEDIMIENTO ADMINISTRATIVO DE DERIVACIÓN DE RESPONSABILIDAD.}

\section{Normativa reguladora del procedimiento administrativo de derivación de responsabilidad.}

La derivación administrativa de responsabilidad de las deudas de Seguridad Social de la sociedad de capital al administrador social, por incumplimiento de las obligaciones generadoras de la responsabilidad solidaria o subsidiaria prevista en la legislación del Derecho de sociedades, se declara dentro del procedimiento administrativo de liquidación y recaudación de los recursos del sistema de la Seguridad Social.

La derivación de responsabilidad en materia de Seguridad Social, al tener la cotización naturaleza de prestación patrimonial de carácter público, estará sujeta a una reserva de ley relativa, no plena como en materia tributaria (art. 133.1 de la CE), con una mayor colaboración reglamentaria, determinando la ley los sujetos responsables y hechos determinantes de responsabilidad, y remitiendo al reglamento la regulación detallada del procedimiento de derivación, teniendo en cuenta que la regulación general del procedimiento administrativo está sujeto a una reserva de ley propia ${ }^{1442}$ (art. 105 apartado c), de la CE, con respeto al derecho de audiencia del interesado).

La derivación administrativa de responsabilidad se produce en el seno de un procedimiento administrativo especial, regulado por su normativa propia.

\footnotetext{
1442 SSTC 55/2018, de 24 de mayo de 2018 -Fundamento de Derecho 6º-; 110/2018, de 17 de octubre de 2018 -Fundamento de Derecho $4^{\circ}$-; y 18/1981, de 8 junio -Fundamento de Derecho $5^{\circ}$-, entre otras muchas.
} 
Procedimiento administrativo especial que forma parte del procedimiento de recaudación de los recursos de la Seguridad Social, con regulaciones específicas, en función del órgano o autoridad administrativa competente -TGSS o ITSS-.

De conformidad con la Disposición Adicional, Primera apartado 2, letra b), de la LPACAP ${ }^{1443}$, constituye un procedimiento administrativo especial el relativo "las actuaciones y procedimientos de gestión, inspección, liquidación, recaudación, impugnación y revisión en materia de Seguridad Social y Desempleo". Procedimiento que se regirá por su normativa específica y supletoriamente por la LPACAP (Disposición Adicional Primera, apartado 2 de la LPACAP y Disposición Adicional 10a apartado 2, letra b) del Real Decreto 203/2021, de 30 marzo, por el que se aprueba el Reglamento de actuación y funcionamiento del sector público por medios electrónicos ${ }^{1444}$ ). Por mandato expreso de la LPACAP ésta se convierte en norma supletoria de primer grado ${ }^{1445}$ con respecto a la regulación específica en materia de liquidación, recaudación e inspección de Seguridad Social.

Procedimiento administrativo especial regulado dentro del procedimiento de liquidación y recaudación de los recursos de la Seguridad Social en el art. 18 apartados 3 y 4, en relación con los arts. 21, 33.2 y 34 apartado 1.c) del TRLGSS. Disposición legal desarrollada por el Reglamento General de Recaudación de la Seguridad Social -arts. 12 a 15, 62 a 65, 69, 70, 75, 80, 81, 84 y siguientes-, y por la Orden TAS/1562/2005, de 25 de mayo, que desarrolla ese Reglamento de Recaudación ${ }^{1446}$.

Este procedimiento especial, cuando lo inicie la ITSS se regirá por la LOITSS y por el RISOS, siendo también de aplicación supletoria la LPACAP (Disposición Adicional

\footnotetext{
1443 “Disposición adicional primera. Especialidades por razón de materia.

1. Los procedimientos administrativos regulados en leyes especiales por razón de la materia que no exijan alguno de los trámites previstos en esta Ley o regulen trámites adicionales o distintos se regirán, respecto a éstos, por lo dispuesto en dichas leyes especiales.

2. Las siguientes actuaciones y procedimientos se regirán por su normativa específica y supletoriamente por lo dispuesto en esta Ley:

a) (...).

b) Las actuaciones y procedimientos de gestión, inspección, liquidación, recaudación, impugnación y revisión en materia de Seguridad Social y Desempleo.

c) (...).

d) (...).",

${ }^{1444}$ BOE, 31.3.2021.

1445 MERCADER UGUINA, J. R.: Los Procedimientos Administrativos en materia de Seguridad Social, op. cit., pp. 160-161.

1446 BOE del 01.06.2005.
} 
Primera apartado 2, letra b), de la Ley 39/2015, de 1 de octubre, y art. 29.2 del $\left.\operatorname{RISOS}^{1447}\right)$.

Para la TGSS se aplica igualmente, con carácter supletorio de segundo grado ${ }^{1448}$, el Real Decreto 939/2005, de 29 de julio, que aprueba el Reglamento General de Recaudación del Estado ${ }^{1449}$ (Disposición Final Primera del RGRSS), que dedica su Título IV (arts. 124 a 127) al procedimiento de derivación de responsabilidad en el ámbito tributario, disposiciones éstas que no serán de aplicación al tener su régimen jurídico en el RGRSS, pudiendo únicamente planteársela posible aplicación el art. 124 apartados 5 y 6, sobre los efectos de la declaración de insolvencia del deudor y los responsables solidarios en la derivación de la deuda al responsable subsidiario.

Como señala GARCÍA FERNÁNDEZ ${ }^{1450}$, la aplicación del Reglamento General de Recaudación del Estado será menor que la aplicación supletoria de la LPACAP, ya que la aplicación de ese Reglamento de Recaudación de Estado "no resulta homogénea con la del Reglamento de Recaudación de la Seguridad Social”.

La aplicación supletoria de primer grado de la LPACAP resultará, bien de una remisión expresa de algunos preceptos del procedimiento administrativo especial, como acontece en materia de cómputo de los plazos (art. 7 del RGRSS y art. 22 del RISOS), sobre la práctica de notificaciones (art. 8 del RGRSS y art. 22 del RISOS), acerca de las medidas cautelares en el procedimiento sancionador iniciado por la ITSS con acta de infracción (art. 14.2 del RISOS), en el período de prueba en procedimiento iniciado mediante acta de la ITSS (arts. 18.3 y 18 bis.3 del RISOS), en el plazo máximo de duración del procedimiento iniciado por la ITSS (art. 20.3 del RISOS), en los recursos administrativos (art. 46 del RGRSS, arts. 23, 33.3 y Disposición Transitoria Única del RISOS), y en la revisión de oficio (art. 47 del RGRSS y art. 33.4 del RISOS); o bien, en cuanto norma legal supletoria de integración de lagunas del procedimiento, en ausencia

1447 En ese precepto se establece que, "el procedimiento administrativo para la práctica de actas de liquidación y demás documentos liquidatorios de cuotas a la Seguridad Social y conceptos de ingreso conjunto, se ajustará a las disposiciones del presente capítulo y, subsidiariamente, a lo dispuesto en la Ley 30/1992, de 26 de noviembre, de Régimen Jurídico de las Administraciones Públicas y del Procedimiento Administrativo Común. Serán sujetos responsables quienes así resulten por aplicación de las normas reguladoras del Sistema de Seguridad Social". La Ley 30/1992, ha sido derogada por la ley 39/2015, de 1 de octubre -LPACAP-.

1448 MERCADER UGUINA, J. R.: Los Procedimientos Administrativos en materia de Seguridad Social, op. cit., pp. 164-166.

${ }^{1449}$ BOE del 02.09.2005.

${ }^{1450}$ GARCÍA FERNÁNDEZ, E.: Las declaraciones administrativas de responsabilidad. Derivación de deudas tributarias y de Seguridad Social, op. cit., p. 114. 
de regulación expresa (Disposición Adicional Primera 2.b) de la LPACAP y art. 29.2 del RISOS).

\section{Procedimiento de oficio.}

El procedimiento administrativo de derivación de responsabilidad al administrador de las deudas de Seguridad Social de la sociedad de capital, es un procedimiento que se inicia de oficio, bien por la TGSS o la ITSS de ser deudas por cotizaciones, o bien por la TGSS de estar ante deudas por prestaciones de responsabilidad de la sociedad de capital, una vez se haya dictado resolución administrativa firme de la entidad gestora de la prestación imponiendo o declarando la responsabilidad de la sociedad de capital, con la salvedad que haremos en el recargo de prestaciones.

Condición de procedimiento de oficio que cuando lo inicie la TGSS, resulta de los arts. 6 y 12 a 14 del RGRSS, impulsándose de oficio en todos sus trámites y sólo se suspenderá en los términos establecidos en los artículos 129 y siguientes de la Ley 29/1998, de 13 de julio, Reguladora de la Jurisdicción Contencioso-Administrativa LJCA- $^{1451}$, y en aquellos otros casos en que así se establezca en ese reglamento, o por mandato legal ${ }^{1452}$.

El procedimiento de liquidación de cuotas de Seguridad Social de competencia de la ITSS se inicia igualmente de oficio mediante acta de liquidación (art. 34 del TRLGSS, art. 52.1.a) del TRLISOS, art. 22.6 de la LOITSS, arts. 1.2, 29 y ss del RISOS y art. 65 del RGRSS). En el art. 1.2 del RISOS se establece que tanto el procedimiento sancionador como el liquidatorio se iniciarán siempre de oficio mediante la extensión de acta de la Inspección de Trabajo y Seguridad Social.

Como todo procedimiento de oficio, se iniciará por acuerdo del órgano competente, bien por la TGSS o por la ITSS, sea por iniciativa propia del órgano, por orden superior, a petición razonada de otros órganos (como puede ser el INSS/ISM, SEPE, en caso de prestaciones), o por denuncia (art. 58 de la LPACAP, art. 20.3 de la LOITSS y art. 9 del RISOS).

Cuando la actuación destinada a la comprobación de los hechos determinantes de la responsabilidad del administrador se inicie por la ITSS, debe distinguirse la fase previa de comprobación (arts. 20 y 21 de la LOITSS), y el inicio del procedimiento

${ }^{1451}$ BOE 14.7.1998.

${ }^{1452}$ Artículo 6.3 del RGRSS. 
administrativo de derivación de responsabilidad mediante acta de liquidación de cuotas por derivación. Procedimiento administrativo de derivación de responsabilidad que se inicia de oficio con la extensión del acta de liquidación, acta que podrá ir o no precedida de un requerimiento de pago de la deuda por derivación (art. 34 .1 del TRLSS, arts. 29 a 36 del RISOS y art. 66 del RGRSS).

La forma de iniciarse la actuación previa de comprobación de la ITSS, de conformidad con el art. 20 de la LOITSS y con el art. 9 del RISOS, podrá tener lugar:

a) Por orden superior de la autoridad competente, tanto de la Administración General del Estado como Autonómica, a través del titular de la Dirección Especial, Dirección Territorial, Jefatura de Inspección Provincial o, en su caso, Unidad especializada.

b) Por orden de servicio del titular de la Dirección Especial, de la Dirección Territorial, de las Jefaturas de la Inspección Provincial, de sus Unidades especializadas, o del Inspector encargado del equipo, en aplicación de los planes, programas y directrices sobre actuación de la Inspección de Trabajo y Seguridad Social.

c) Por petición de cualquier órgano jurisdiccional cuando determine su objeto, amplitud $\mathrm{y}$ finalidad.

d) Por petición concreta de los organismos de la Seguridad Social, que colaborarán con la Inspección de Trabajo y Seguridad Social, o a solicitud de otra Administración pública.

e) Por propia iniciativa del Inspector de Trabajo y Seguridad Social teniendo en cuenta criterios de eficacia y oportunidad según lo determinado en las disposiciones vigentes.

f) Por denuncia de hechos presuntamente constitutivos de infracción en el orden social.

La denuncia es pública, por lo que cualquier persona podrá poner en conocimiento de la TGSS o de la ITSS los hechos constitutivos de una posible derivación de responsabilidad de deudas de la sociedad de capital al administrador social (art. 62.1 de la LPACAP y art. 20.4 de la LOITSS). La denuncia es una forma de colaboración social voluntaria en defensa del interés general ${ }^{1453}$. Mediante la denuncia, según MERCADER

1453 CUADRADO RODRÍGUEZ, J. I. :La denuncia en el Derecho Tributario, Marcial Pons, Madrid, 1995, pp. 46-47. 
UGUINA y SÁNCHEZ GRANDE ${ }^{1454}$, se podrán comunicar hechos que posiblemente puedan ser relevantes a efectos de una posible derivación de responsabilidad, (sic) "sin que obligue a iniciar por sí misma el procedimiento inspector de comprobación, sino que, a la vista de ella, la Inspección procederá a la investigación y comprobación si apreciara indicios suficientes, archivándola en otro caso, sin tener efectos vinculantes en el inicio del procedimiento liquidatorio. Se trata, en suma, de informaciones sobre las que, una vez examinadas las circunstancias concurrentes -contenido, verosimilitud o gravedad- y siempre de acuerdo con las limitaciones de medios y prioridades de la Inspección, producirán como efecto la puesta en marcha de los mecanismos inspectores. Con todo, la denuncia no genera efecto vinculante alguno de cara a la iniciación del procedimiento sancionador, entrando dentro de las facultades de la Inspección de Trabajo y Seguridad Social determinar ese inicio, precedida o no por la realización de actividades investigadoras".

La forma ordinaria de inicio de la actividad inspectora previa de comprobación de posibles supuestos de derivaciones de responsabilidad, será a instancias de la TGSS o de la entidad gestora de una prestación (ISM, INSS, SEPE), o por actuación programada de la propia jefatura de la Inspección, siendo más infrecuente el inicio por denuncia.

No siendo la denuncia la forma más habitual de inicio, en cambio, sí es una peculiaridad propia de todo procedimiento administrativo de oficio (art. 62.2 de la LPACAP), por lo que aludiremos brevemente a este modo de inicio de la actuación previa de comprobación, especialmente por la ITSS, que puede culminar con un posterior apertura de un procedimiento administrativo, bien con la extensión de un acta de liquidación por la ITSS, o bien mediante el acuerdo de inicio de la TGSS si la actuación previa finalizó con informe dirigido a ese Servicio Común de la Seguridad Social.

Denuncia que podrá presentarse por medios telemáticos en la sede electrónica de la Administración, o de modo presencial. Si es de modo presencial podrá hacerse: a) en

${ }^{1454}$ MERCADER UGUINA, J. R. y SÁNCHEZ GRANDE, A.: "La Ley Ordenadora de la Inspección de Trabajo y Seguridad Social (Consideraciones en torno a la Ley 42/1997, de 14 de noviembre)", Relaciones Laborales, n. ${ }^{\circ}$ 3, Sección Legislación, Quincena del 1 al 15 febrero 1998, p. 865, Tomo 1, editorial La Ley, Ref. La Ley 6481/2002, edición digital https://laleydigital-laleynextes.ponton.uva.es/Content/Documento.aspx?params, pp. 17-18; En iguales términos, MERCADER UGUINA, J. R. y TOLOSA TRIBIÑO, C.: "Notas al Reglamento de ordenación y funcionamiento de la Inspección de Trabajo y Seguridad Social", Relaciones Laborales, n. ${ }^{\circ}$ 13, Sección Legislación, Quincena del 1 al 15 julio 2000, p. 1043, Tomo 2, Editorial La Ley, Ref. 6467/2002, edición digital https://laleydigital-laleynext-es.ponton.uva.es/Content/Documento.aspx?params, p. 5. 
cualquiera de los registros administrativos electrónicos ${ }^{1455}$, sean de la propia

Administración competente, así como en los registros electrónicos de los demás órganos

de la Administración de Estado, de las Comunidades Autónomas o de las

Administraciones Locales; b) en las representaciones diplomáticas u oficinas consulares

en el exterior; c) en las oficinas de asistencia en materia de registros; y d) finalmente, por correo postal dirigida a la Administración competente (ITSS, TGSS) ${ }^{1456}$.

Es requisito de toda denuncia que conste la identidad de la persona que la presente (art. 62.2 de la LPACAP, art. 20.5 de la LOITSS, y art. 9 del RISOS), por lo que la forma de

1455 La fecha límite para que sean obligatorios y operativos los registros electrónicos en las Administraciones Públicas, será el 2 de abril de 2021, según la Disposición Final 9a del Real DecretoLey 28/2020, de 22 de septiembre, sobre el trabajo a distancia -BOE del 23.9.2020-, que redacta nuevamente la Disposición Final $7^{\mathrm{a}}$ de la LPACAP.

${ }^{1456}$ En el art. 14 de la Ley 43/2010, de 30 de diciembre, del Servicio Postal Universal, de los derechos de los usuarios y del mercado postal -BOE del 31.12.2010-; y en el art. 31 del Real Decreto 1829/1999, de 3 de diciembre, por el que se aprueba el Reglamento por el que se regula la Prestación de los Servicios Postales, en desarrollo de lo establecido en la Ley 24/1998, de 13 de julio, del Servicio Postal Universal y de Liberalización de los Servicios Postales -BOE del 31.12.1999-, se prevé que puedan presentarse escritos de denuncia dirigidos a la Administración en las oficinas de correos.

En el artículo14 de la Ley se establece,

"Artículo 14. Derecho de presentación de escritos dirigidos a las Administraciones Públicas.

Los usuarios tendrán derecho a presentar solicitudes, escritos y comunicaciones dirigidas a las Administraciones Públicas, en los términos y a los efectos previstos en el artículo 38.4.c) de la Ley 30/1992, de 26 de noviembre, de Régimen Jurídico de las Administraciones Públicas y del Procedimiento Administrativo Común, únicamente a través de las oficinas del operador designado para la prestación del servicio postal universal, que deberá recibirlos y dirigirlos al destinatario con carácter preferente y acreditar, a solicitud del interesado, tanto su presentación en las citadas oficinas como su entrega en destino, con expresa mención de la fecha y hora en que se produzcan ambos eventos. Esta presentación surtirá los mismos efectos que en el registro del órgano administrativo al que se dirijan. Los usuarios también tendrán derecho a presentar solicitudes, escritos y comunicaciones dirigidas a las Administraciones Públicas a través de operadores postales distintos al operador designado para prestar el servicio postal universal en los términos que establece el artículo 38.4.e) de la Ley 30/1992, de 26 de noviembre, de Régimen Jurídico de las Administraciones Públicas y del Procedimiento Administrativo Común".

En el art 31 del Reglamento de señala:

"Artículo 31. Admisión de solicitudes, escritos y comunicaciones que los ciudadanos o entidades dirijan a los órganos de las Administraciones Públicas.

Las solicitudes, escritos y comunicaciones que los ciudadanos o entidades dirijan a los órganos de las Administraciones Públicas, a través del operador al que se le ha encomendado la prestación del servicio postal universal, se presentarán en sobre abierto, con objeto de que en la cabecera de la primera hoja del documento que se quiera enviar, se hagan constar, con claridad, el nombre de la oficina y la fecha, el lugar, la hora y minuto de su admisión. Estas circunstancias deberán figurar en el resguardo justificativo de su admisión. El remitente también podrá exigir que se hagan constar las circunstancias del envío, previa comparación de su identidad con el original, en la primera página de la copia, fotocopia u otro tipo de reproducción del documento principal que se quiera enviar, que deberá aportarse como forma de recibo que acredite la presentación de aquél ante el órgano administrativo competente.

Practicadas las diligencias indicadas, el propio remitente cerrará el sobre, y el empleado formalizará y entregará el resguardo de admisión, cuya matriz archivará en la oficina.

Los envíos aceptados por el operador al que se encomienda la prestación del servicio postal universal, siguiendo las formalidades previstas en este artículo, se considerarán debidamente presentados, a los efectos previstos en el artículo 38 de la Ley 30/1992, de 26 de noviembre, de Régimen Jurídico de las Administraciones Públicas y del Procedimiento Administrativo Común, y en su normativa de desarrollo". 
identificación cuando se presente la misma en la sede electrónica de la Administración, será mediante la firma electrónica reconocida, sea mediante del DNIe (Documento Nacional de Identidad electrónico), o mediante firma electrónica avanzada basada en un certificado electrónico reconocido por la plataforma @firma, (arts. 10 y 11 de la LPACAP). La denuncia dirigida a la ITSS podrá presentarse en la sede electrónica del Ministerio al que se halle adscrito el OEITSS.

No es medio de comunicación o presentación de una denuncia el correo electrónico, ya que éste no permite a la Administración identificar fehacientemente al denunciante (Instrucción N $\mathrm{N}^{\mathrm{0}}$ 6/2010 de la DGITSS, relativa al modelo de contestación para los supuestos de presentación de denuncias por correo electrónico y designación de responsables de trámites telemáticos, y Consulta de la DGITSS, de fecha 5 de octubre de $\left.2015^{1457}\right)$.

En la Nota Informativa de la DGITSS de 20 de enero de $2016^{1458}$, se señala que, "en ningún caso se prevé como vía de comunicación electrónica el correo particular o corporativo en su caso, puesto que dicho instrumento no garantiza la identificación fidedigna del remitente ni del destinatario (para eso es necesario la intervención de la firma electrónica o de cualquier otro medio de identificación admitido, ello de conformidad con lo previsto en el artículo art. 13.2 Ley 11/2007 sin que asegure, la integridad del mensaje, ni la fecha y hora de su transmisión y recepción)".

Con la finalidad de comprobarse la identidad del denunciante, en la Instrucción 2/2010, de la DGITSS ${ }^{1459}$, se indica que, "si el documento que llega se recibe vía correo ordinario, y el remitente es un particular deberá encontrarse adjunta una fotocopia compulsada del DNI. En aquellos supuestos en que no haya sido remitida, será requerida al remitente. Si el documento es presentado de forma presencial en el Registro presencial de la Inspección, será en ese momento en el que se solicitará el DNI al interesado para la comprobación de la identidad. En el caso de que se presente por persona diferente del denunciante deberá realizarse mediante aportación de

\footnotetext{
${ }^{1457}$ Consulta, de 5 de octubre de 2015, sobre si las denuncias presentadas por terceros cuyos derechos no puedan ser afectados por el resultado de la investigación inspectora deben ser contestados o no, y si en este caso, debe advertirse la ausencia de contestación -Ref.: La Ley 3165/2015-.

1458 Nota Informativa sobre contestación a dirigir a los remitentes de solicitudes relacionadas con actuación inspectora vía correo electrónico particular o corporativo -Ref.: La Ley 3/2016-.

1459 Por la que se aprueban los procedimientos de la Inspección de Trabajo y Seguridad Social relacionados con el registro y la tramitación de solicitudes, la resolución sin generación de órdenes de servicio, las notificaciones y el archivo.
} 
representación o mandato (simple), aportando la copia o exhibiendo el DNI y debidamente firmado. Deberá incluirse en el expediente el mandato o representación”.

No obstante, y a título meramente informativo, en el control del cumplimiento del Derecho de la Unión Europea, se pretende dotar a la denuncia de un papel más relevante tras la nueva Directiva (UE) 2019/1937, del Parlamento Europeo y del Consejo, de 23 de octubre de 2019, relativa a la protección de las personas que informen sobre infracciones del Derecho de la Unión, donde se reduce el formalismo de la misma admitiéndose que pueda ser verbal o escrita, sin los requisitos de identificación fehaciente que se exigen en el procedimiento administrativo interno, y especialmente en el sancionador y liquidatorio de Seguridad Social.

Pese a no ser jurídicamente una denuncia, ya que no consta fehacientemente la identidad de la persona, hemos de reseñar, que, a través del llamado "buzón del fraude" de la página web del Ministerio al que esté adscrito el OEITSS, se pondrán poner en conocimiento de la ITSS posibles incumplimientos de la normativa de Seguridad Social, sin que esa comunicación confiera la condición de denunciante, y sin que obligue al inicio de ningún procedimiento de oficio, sirviendo eso sí, en su caso, para poder programar actuaciones inspectoras cuando los hechos comunicados se puedan estimar relevantes. Nos hallamos ante un cauce de comunicación ciudadana de posibles irregularidades en el cumplimiento de las obligaciones de Seguridad Social, que no obligan al inicio de actuaciones inspectoras, operando como un mero cauce de suministro de información a las jefaturas, que podrán ser tenida o no en consideración a efectos de la programación de actuaciones inspectoras, pudiendo decidir su tramitación o su archivo sin más trámites. El informante de los hechos no tiene ni tan siquiera la condición jurídica de denunciante.

El denunciante no tiene la consideración de interesado en el procedimiento administrativo, por lo que tendrá sólo el derecho a ser informado acerca del estado de tramitación de la denuncia (art. 62.5 LPACAP, art. 20.4 de la LOITSS ${ }^{1460}$, y art. 9.3 del RISOS), pero no sobre el resultado o contenido de la actuación inspectora.

1460 Artículo 20 (...).

4. La acción de denuncia del incumplimiento de la legislación de orden social es pública. El denunciante no podrá alegar la consideración de interesado a ningún efecto en la fase de investigación, si bien tendrá derecho a ser informado del estado de tramitación de su denuncia, así como de los hechos que se hayan constatado y de las medidas adoptadas al respecto 
De tener el denunciante la condición de interesado en el procedimiento de derivación de responsabilidad, al afectar a sus derechos o intereses legítimos, tendrá derecho a conocer los hechos comprobados, los hechos determinantes de la responsabilidad y medidas adoptadas -responsabilidad declarada, identidad del responsable, naturaleza solidaria o subsidiaria de la responsabilidad, deudas objeto de responsabilidad que le afecten- (arts. 40.1 y 53.1.a) de la LPACAP, art. 20.4 de la LOITSS y art. 9.3 del RISOS).

Se tiene la condición de interesado cuando se sea titular de un derecho individual o interés legítimo digno de tutela en el procedimiento. "Existe interés legítimo cuando haya relación material entre el sujeto y el objeto del procedimiento, que equivale a una titularidad potencial de una posición de ventaja o de una utilidad jurídica por parte de quien presenta la denuncia y que se materializaría de prosperar ésta. El interés legítimo se concreta en la obtención de cualquier beneficio concreto o la eliminación de un perjuicio derivados del resultado del procedimiento" (Sentencia del TS, Sala Contencioso-Administrativa 263/2018, de 20 de febrero -Rec. 3257/2016- ${ }^{1461}$ ). Si el denunciante fuere un trabajador cuyos derechos de Seguridad Social pudieran verse afectados por la derivación administrativa de responsabilidad, adquirirá la condición de interesado (art. 33.1 del RISOS).

únicamente cuando el resultado de la investigación afecte a sus derechos individuales o colectivos reconocidos por la normativa correspondiente al ámbito de la función inspectora.

Los representantes unitarios o sindicales de los trabajadores tendrán derecho a ser informados del estado de tramitación de las denuncias presentadas por los mismos en el ámbito de su representación, así como de los hechos que se hayan constatado y de las medidas adoptadas al respecto.

En el supuesto de que la denuncia diera lugar al inicio de un procedimiento sancionador, el denunciante podrá tener, en su caso, la condición de interesado, en los términos y con los requisitos establecidos en el artículo 31 de la Ley 30/1992, de 26 de noviembre, de Régimen Jurídico de las Administraciones Públicas y del Procedimiento Administrativo Común. En el mismo supuesto, se reconoce expresamente la condición de interesados en el procedimiento a los representantes de las organizaciones sindicales o representantes de los trabajadores, en su condición de titulares de los intereses legítimos que derivan de su representación.

5. No se tramitarán las denuncias anónimas ni las que tengan defectos o insuficiencias de identificación que no hayan sido subsanadas en el plazo establecido para ello, sin perjuicio de lo señalado en el apartado 3. Tampoco se dará curso a aquellas cuyo objeto coincida con asuntos de los que esté conociendo un órgano jurisdiccional cuyo pronunciamiento pueda condicionar el resultado de la actuación inspectora, ni las que manifiestamente carezcan de fundamento".

${ }^{1461}$ En igual sentido SSTS, misma Sala, 12 de diciembre de 2012 -Rec. 887/2011-; de 5 de diciembre de 2012 -Rec. 3/2012 -; de 1 y 1 de octubre de 2012 -Rec. 310/2012; 342/2012 y 882/2011-; y de 31 de enero de 2012 -Rec. 252/2011-. 
En Consulta de la Dirección General de la Inspección de Trabajo y Seguridad Social DGITSS, de fecha 5 de octubre de 2015 ${ }^{1462}$, -actual Dirección del OEITSS-, interpretando el alcance del art. 20.4 de la LOITSS, acerca de contenido de la información que puede facilitarse al denunciante, en función de que tenga o no la condición de interesado, se concluye que, "con la nueva regulación se limita la contestación por escrito en los términos previstos en la nueva ley a los siguientes denunciantes: a) A aquellos sujetos titulares de derechos individuales y colectivos reconocidos por la normativa correspondiente al ámbito de la función inspectora, que puedan verse afectados como resultado de la actuación de investigación. b) Representantes unitarios o sindicales de los trabajadores, respecto del estado de las denuncias presentadas por los mismos en el ámbito de su representación. Al hacer referencia el artículo 20.4 al término representantes unitarios o sindicales de los trabajadores, se incluye también a los delegados sindicales de las secciones sindicales de los sindicatos, y no sólo a la representación unitaria (comité de empresa y delegados de personal)".

\section{Carácter contradictorio del procedimiento. Comunicación de inicio y audiencia al administrador social.}

El procedimiento para la derivación administrativa de responsabilidad al administrador social de las deudas de Seguridad Social de la sociedad de capital, ante los supuestos normativos en los que en la legislación de sociedades se impone una responsabilidad solidaria o subsidiaria del administrador -fundamentalmente ante la concurrencia de una causa legal de disolución de los arts. 360 y 367 de la LSC-, como todo procedimiento, se integra de cuatro fases: a) Inicio del procedimiento, b) ordenación, c) instrucción, y d) finalización o resolución.

El carácter contradictorio del procedimiento administrativo de derivación de responsabilidad, se aprecia en el acuerdo de inicio del procedimiento de derivación de responsabilidad de la TGSS, que debe notificarse al interesado, al administrador social, dándole un plazo de 15 días para que presente alegaciones, documentos y los justificantes que en su defensa estime pertinentes (art. 13.4 primer párrafo del RGRSS), sin que pueda dictarse la resolución administrativa de derivación ni la reclamación de

\footnotetext{
1462 Sobre si las denuncias presentadas por terceros cuyos derechos no puedan ser afectados por el resultado de la investigación inspectora deben ser contestados o no y si en este caso debe advertirse la ausencia de contestación -Ref.: La Ley 3165/2015-.
} 
deuda de derivación sin haberse abierto el trámite de audiencia. Plazo de alegaciones de quince días del art. 13.4 del RGRSS, que es de aplicación directa en virtud de lo prescrito en la Disposición Adicional $1^{\mathrm{a}}$ de la LPACAP, y no el plazo de diez a quince días fijado con carácter general para todo procedimiento administrativo en el art. 82.2 de la LPACAP, siendo el plazo de quince días del RGRSS más beneficioso para el administrador social, pese a lo cual MERCADER UGUINA y SUÁREZ CORUJO ${ }^{1463}$ estiman que el trámite de audiencia podrá ser de entre diez y quince días, citando el art. 84 de la Ley 30/1992 -actual art. 82.2 LPACAP-. Como señala MARTÍNEZ LUCAS ${ }^{1464}$ "se establece un trámite de audiencia previa a la emisión de la reclamación de deuda a quien pudiera ser responsable para con posterioridad expedirse la reclamación de deuda que debe contener siempre la expresión de los hechos y fundamentos de Derecho".

Carácter contradictorio que se aprecia igualmente en la derivación de responsabilidad de la deuda tributaria. En el art. 41.5 de la Ley 58/2003, de 17 de diciembre, que aprueba la Ley General Tributaria ${ }^{1465}$, se establece, que "salvo que una norma con rango de Ley disponga otra cosa, la derivación de la acción administrativa para exigir el pago de la deuda tributaria a los responsables requerirá un acto administrativo en el que, previa audiencia al interesado, se declare la responsabilidad y se determine su alcance y extensión, de conformidad con lo previsto en los artículos 174 a 176 de esta Ley. Con anterioridad a esta declaración, la Administración competente podrá adoptar medidas cautelares del artículo 81 de esta Ley y realizar actuaciones de investigación con las facultades previstas en los artículos 142 y 162 de esta Ley" ${ }^{\prime 466}$.

${ }^{1463}$ MERCADER UGUINA, J. R. y SUÁREZ CORUJO, B.: "La responsabilidad laboral y de Seguridad Social de los Administradores Sociales", p. 583.

${ }^{1464}$ MARTÍNEZ LUCAS, J. A.: "Análisis del nuevo Reglamento General de Recaudación de la Seguridad Social: el Real Decreto 1415/2004, de 11 de junio", Actualidad Laboral, No 21, Sección Estudios, Quincena del 1 al 15 dic. 2004, p. 2541, Tomo 2, Editorial La Ley, Ref. La Ley 2444/2004, edición digital https://laleydigital-laleynext-es.ponton.uva.es/Content/Documento.aspx?params, p. 5.

${ }^{1465}$ BOE del 18.12.2003.

${ }^{1466}$ En los apartados 3 y 4 del art. 174 de la LGT, se establece,

"3. El trámite de audiencia previo a los responsables no excluirá el derecho que también les asiste a formular con anterioridad a dicho trámite las alegaciones que estimen pertinentes y a aportar la documentación que consideren necesaria.

4. El acto de declaración de responsabilidad será notificado a los responsables. El acto de notificación tendrá el siguiente contenido:

a) Texto íntegro del acuerdo de declaración de responsabilidad, con indicación del presupuesto de hecho habilitante y las liquidaciones a las que alcanza dicho presupuesto.

b) Medios de impugnación que pueden ser ejercitados contra dicho acto, órgano ante el que hubieran de presentarse y plazo para interponerlos.

c) Lugar, plazo y forma en que deba ser satisfecho el importe exigido al responsable". 
Excepcionalmente, se admite que no deba emitirse el acuerdo de inicio por la TGSS, y que, por lo tanto, no se dé audiencia al administrador, cuando la reclamación de deuda por derivación de responsabilidad de la TGSS tenga como causa otra previa reclamación de deuda por derivación emitida al mismos sujeto responsable y siempre que esté basada en los mismos hechos y fundamentos de derecho (art. 13.4 último párrafo del RGRSS), ya que ese trámite contradictorio habrá tenido lugar con carácter previo a la emisión de la anterior reclamación de deuda por derivación y mediante la resolución de la declaración de responsabilidad derivada. En ese caso, se emite directamente la reclamación de deuda por derivación de responsabilidad, pero debe hacerse mención expresa de no ser necesario el acuerdo de inicio y el trámite de alegaciones. Precepto que ha de ser objeto de interpretación restrictiva, de modo que hemos de estar ante idénticos hechos y fundamentos jurídicos, de tal forma que, si la responsabilidad tuviere como justificación hechos distintos no contrastados en la reclamación anterior, o nuevos fundamentos jurídicos, será necesario el acuerdo de inicio y el trámite de alegaciones previas. De esta regulación que excepciona el trámite de audiencia, cuando se base en los mismos hechos y fundamentos de derecho de otra derivación anterior, nos permite determinar indirectamente y por interpretación sistemática, el contenido mínimo de todo acuerdo de inicio de la TGSS cuando deba dar trámite de audiencia al administrador social.

El acuerdo de inicio del procedimiento de la TGSS, salvo con la excepción referida, es requisito para la valida emisión de la resolución que ponga fin al procedimiento administrativo de derivación de responsabilidad. Una vez cumplimentado correctamente ese trámite, podrá la TGSS emitir la resolución administrativa de derivación de responsabilidad de las deudas al administrador social, que irá acompañada de la reclamación de deuda por derivación de responsabilidad (art. 13.4 del RGRSS), frente a las que cabrá interponer los pertinentes recursos en vía administrativa (art. 46 del RGRSS).

Cuando la actuación encaminada a la derivación de responsabilidad la inicie la ITSS, por ser deudas de cuotas a la Seguridad Social y cuotas de recaudación conjunta, el procedimiento administrativo, en sentido estricto, se inicia con el acta de liquidación de cuotas por derivación de responsabilidad (art. 52.1.a) del TRLISOS, art. 34 del TRLGSS, art 65.1.c) del RGRSS y arts. 29 y ss del RISOS). 
Antes de la extensión del acta de liquidación o de la formalización de un requerimiento de pago, está la fase de las actuaciones previas de comprobación (art. 55 de la LPACAP, art. 21 de la LOITSS y art. 8 del RISOS). La actividad previa de investigación que, aunque no es propiamente un procedimiento administrativo ${ }^{1467}$, ni tampoco un acto de trámite susceptible de recursos administrativos, sí tiene efectos similares a la fase de instrucción de un procedimiento, ya que opera la caducidad de la actividad previa si se excede la duración máxima prevista legalmente. No obstante, salvo en el supuesto de caducidad, la actuación que ponga fin a la fase de investigación, cuando no se extienda acta de liquidación, no es objeto de recurso administrativo ${ }^{1468}$.

Fase de comprobación de los hechos que no tendrá necesariamente carácter contradictorio $^{1469}$, de modo que su ausencia no vicia la actuación inspectora, pudiendo tener, eso sí, efectos en la validez del acta de liquidación, no tanto por esa ausencia, sino por no recoger las pruebas que acrediten los supuestos que justifican la extensión del acta de liquidación por derivación de responsabilidad.

Tras la fase previa de comprobación se podrá iniciar el procedimiento administrativo de derivación de responsabilidad, con la extensión del acta de liquidación de cuotas por derivación, que no es una resolución administrativo definitiva, sino una liquidación o derivación de responsabilidad provisional, dándose trámite de audiencia al interesado (art. 33 apartados 1 y 2 del RISOS), quien podrá presentar alegaciones en el plazo de quince días siguientes a la fecha de la notificación del acta (carácter contradictorio del procedimiento). Si se formulasen alegaciones, podrá solicitarse informe ampliatorio al Inspector o Subinspector actuante, y se dará vista y audiencia nuevamente a los responsables, por plazo de diez días, para que puedan alegar y probar nuevamente lo

${ }^{1467}$ DURÉNDEZ SÁEZ, I.: "Modificaciones recientes que afectan a la Inspección de Trabajo y Seguridad Social y al Procedimiento administrativo sancionador del orden social”, Revista española de Derecho del Trabajo, núm. 151/2011, parte Estudios, Editorial Civitas, Pamplona. 2011, BIB 2011\1083, edición digital https://insignis-aranzadidigital-es.ponton.uva.es/maf/app/document?srguid, p. 11 de 19, quien que "las actividades previas, sin formar parte del procedimiento entendido en sentido estricto, constituyen un antecedente obligado del mismo".

${ }^{1468}$ Dictamen de la Abogacía General del Estado, de fecha 18 de julio de 1994, "con ocasión del recurso de reposición interpuesto ante la negativa de la Inspección de Trabajo y Seguridad Social a facilitar copia de la denuncia al denunciado" -Ref.: La Ley 1937/2009-.

1469 PÁRAMO MONTERO, P.: "Prueba e instrucción de las actas de la Inspección de Trabajo y Seguridad Social", Diario La Ley, Sección Doctrina, 1998, Ref. D-208, Tomo 4, Editorial La Ley Ref. 11702/2001, edición digital,

https://laleydigital-laleynext-es.ponton.uva.es/Content/Documento.aspx?params, p. 2, quien señala que, que la actividad de comprobación previa no es genuinamente alegatoria ni de contradicción, porque "la actividad de investigación e inspección ciertamente no puede ser sometida en todos sus pasos a los rigores de contradicción. Las pruebas obtenidas antes del acta de inspección son validadas posteriormente en la fase propiamente de instrucción administrativa y resolución". 
que estime conveniente ante el contenido del informe ampliatorio. Acta de liquidación por derivación de responsabilidad que ante hechos determinantes de una responsabilidad solidaria, se recogerán en un mismo expediente liquidatorio (art. 33.1 del RISOS).

\section{Medidas cautelares en el procedimiento de derivación de responsabilidad.}

La adopción de medidas cautelares se contempla con carácter general en todo procedimiento administrativo en el art. 56 de la LPACAP, con la finalidad de asegurar la viabilidad o ejecución de la resolución que ponga fin al procedimiento. Medidas cautelares que se rigen por los principios de proporcionalidad, efectividad y la menor onerosidad posible (art. 56.1 de la LPACAP).

Las medidas cautelares en la derivación administrativa de responsabilidad tendrán como fundamento o finalidad evitar que al tenerse que comunicar el inicio del procedimiento al responsable, y tramitarse un procedimiento con determinada duración en el tiempo, éste pueda poner en peligro el resultado de la propia derivación de responsabilidad ${ }^{1470}$.

Las medidas cautelares que en cualquier momento del procedimiento de recaudación puede adoptar la TGSS, pero no la ITSS (art. 37.1 del TRLGSS y art. 54.1 del RGRSS), se recogen en el art. 37 del TRLGSS y en el art. 54 del RGRSS. En esos preceptos se establece el carácter provisional de esas medidas, y se exige para su adopción la necesidad de acreditar la existencia de indicios racionales de que, de no acordarse, el cobro de la deuda se vería frustrado o gravemente dificultado (art. 37.1 del TRLGSS y art. 54.1 del RGRSS).

Esas medidas cautelares en el procedimiento administrativo de derivación de responsabilidad, deben ser proporcionales al daño que se pretende evitar, por lo que no podrán exceder del importe total de la deuda derivada, con inclusión del recargo, intereses y costas, sin que puedan ocasionar perjuicios de imposible o difícil reparación (art. 37.1 del TRLGSS y art. 54.2 del RGRSS). Los gastos ocasionados en la adopción de las mismas tendrán la consideración de costas del procedimiento administrativo de apremio (art. 54.7 del RGRSS).

Al tener como fundamento asegurar la recaudación del débito, habrán de levantarse de oficio en los siguientes supuestos. En primer lugar, si desaparecen las circunstancias que justificaron su adopción. En segundo lugar, si se sustituyen por otras garantías

${ }^{1470}$ GARCÍA FERNÁNDEZ, E.: Las declaraciones administrativas de responsabilidad. Derivación de deudas tributarias y de Seguridad Social, op. cit., p. 117. 
propuestas por el responsable que la TGSS estime suficientes. Y, en tercer lugar, en todo caso, si transcurre el plazo de seis meses desde su adopción sin que se hayan convertido en definitivas dentro del procedimiento administrativo de apremio (art. 37.4 del TRLGSS y art. 54.6 del RGRSS), teniendo en cuenta que en el procedimiento recaudatorio se convertirán en definitivas cuando se dicte la providencia de apremio sin haberse cobrado la deuda (art. 54.5 del RGRSS).

No obstante, cuando se haya extendido acta de liquidación de cuotas por la ITSS elevada a definitiva, o la reclamación administrativa de la deuda, las medidas cautelares podrán adoptarse sin más trámite y practicarse por las unidades de recaudación ejecutiva de la Seguridad Social (art. 54.4 del RGRSS).

Las medidas cautelares que pueden adoptarse en el procedimiento de derivación serán: a) la retención del pago de devoluciones por ingresos indebidos, o por cualquier otro pago que deba realizar la TGSS al sujeto responsable, en la cuantía estrictamente necesaria para asegurar la responsabilidad derivada; b) el embargo preventivo de bienes o derechos, que se asegurarán mediante anotación en los registros públicos o con el depósito de los bienes muebles embargados; c) cualquier otra medida cautelar legalmente prevista (art. 37.2 TRLGSS y art. 54.3 RGRSS).

Esas medidas cautelares son aplicables no sólo a la sociedad de capital responsable directa de la deuda, sino también a los responsables solidarios, sin que se excluyan a los responsables subsidiarios, pese a no poderles exigir la deuda mientras no conste la declaración de insolvencia de la sociedad de capital, una vez se haya emitido el acto administrativo de derivación de responsabilidad, ya que, según MARTÍNEZ LUCAS ${ }^{1471}$ el art. 37.3 del TRLGSS autoriza a la TGSS a adoptar la medida cautelar cuando la deuda con la Seguridad Social no se encuentre liquidada «pero se haya devengado y haya transcurrido el plazo reglamentario para su pago», lo que presupone la existencia de una resolución administrativa que establezca la derivación de la responsabilidad, con lo que se impide que el eventual responsable subsidiario distraiga los bienes antes de reclamarle la deuda. Estimamos que al responsable subsidiario no se le podrán imponer las medidas cautelares, mientras no sea sujeto declarado responsable, condición a la que acceden tras la insolvencia de la empresa (art. 14.1 del RISOS). El artículo 37.3 del

${ }^{1471}$ MARTÍNEZ LUCAS, J. A.: "Las medidas cautelares para asegurar el cobro de las deudas con la Seguridad Social", Actualidad Laboral, Sección Doctrina, 1999, p. 263, Tomo 1, Editorial La Ley, Ref. La Ley 2570/2001, edición digital, https://laleydigital-laleynext-es.ponton.uva.es/Content/Documento.aspx?params, p. 3. 
TRLGSS será de aplicación a la empresa y a los responsables solidarios, quienes están obligados al pago transcurrido el plazo reglamentario de ingreso de la deuda.

Dentro de esas otras medidas previstas legalmente, el legislador menciona "el embargo preventivo de dinero y mercancías en cuantía suficiente para asegurar el pago de la deuda con la Seguridad Social que corresponda exigir por actividades y trabajos lucrativos ejercidos sin establecimiento, cuando los trabajadores no hayan sido afiliados o, en su caso, no hayan sido dados de alta en la Seguridad Social" y la "intervención de los ingresos de los espectáculos públicos de las empresas cuyos trabajadores no hayan sido afiliados ni dados de alta o por los que no hubiesen efectuado sus cotizaciones a la Seguridad Social" (art. 37.5 del TRLGSS). Ambos casos, tanto el embargo de dinero o de mercancías como la intervención de los ingresos de los espectáculos públicos, están pensados para la empresa deudora que ejerza, o una actividad sin establecimiento o una actividad de espectáculos públicos, no siendo aplicables al administrador social. Supuestos previstos en ese precepto legal que generarán deudas por faltas de alta en Seguridad Social de los trabajadores, que serán reclamadas a las empresas responsables por la ITSS mediante acta de liquidación, sin conferirse a esa Inspección la competencia para adoptar estas medidas cautelares, con los inconvenientes de que si se acuerdan por la TGSS dentro del procedimiento de recaudación del acta, se corre el riesgo de llegarse tarde.

MARTINEZ LUCAS ${ }^{1472}$, ha criticado que no se haya atribuido también a la Inspección la competencia para poder decretar esas medidas cautelares, por lo que (sic) "se cercenan las posibilidades de asegurar el cobro de las deudas con la Seguridad Social cuando se levanten actas de liquidación por la Inspección.”

La ITSS pueda adoptar medidas cautelares antes de iniciar el procedimiento administrativo por acta de liquidación, distintas de las anteriormente referidas, no dirigidas a asegurar el cobro de una eventual liquidación de cuotas, sino asegurar las pruebas que pudieran ser sustraídas o manipuladas. Los funcionarios de la Inspección están facultados para adoptar las medidas cautelares que estimen oportunas para garantizar que las eventuales pruebas del incumplimiento de obligaciones con la Seguridad Social no sufran alteraciones, medidas que han de ser proporcionales a esa finalidad, no debiendo causar perjuicios de difícil o imposible reparación, ni vulnerar

${ }^{1472}$ MARTÍNEZ LUCAS, J. A.: "Las medidas cautelares para asegurar el cobro de las deudas con la Seguridad Social", op. cit., pp. 2-3. 
derechos. Medidas cautelares que irán encaminadas a "evitar la destrucción, desaparición o alteración de la documentación probatoria del incumplimiento de las obligaciones determinantes de la responsabilidad de la sociedad de capital y/o del administrador social", como serían retención de libros oficiales, registros informáticos, declaraciones oficiales, etc. (art. 13 apartado 3.c) y apartado 4 de la LOITSS, en relación con arts. $7.1 .7^{\circ}$ y 19 del ROFITSS ${ }^{1473}$ ). Estas medidas cautelares se notificarán al sujeto responsable, bien mediante la diligencia que ha de extenderse de cada actuación inspectora, o bien mediante comunicación expresa dirigida al mismo.

Al no haberse reconocido legalmente la potestad de la ITSS para proponer la inmediata adopción de medidas cautelares destinadas a asegurar el resultado de la liquidación de cuotas y de las responsabilidades solidarias, especialmente cuando sea la ITSS quien desarrolle las actuaciones comprobatorias de los hechos determinantes de la derivación de responsabilidad ante la empresa y los administradores sociales, como propuesta de lege ferenda abogamos para que se reconozca de modo expreso la competencia de la ITSS para proponer la adopción de medidas cautelares en el informe de derivación emitido a la TGSS o en el acta de liquidación con derivación de responsabilidad, siempre que existan indicios racionales de que de no adoptarse dichas medidas se pudiera eludir la responsabilidad derivada. Medidas cautelares como proponer embargos preventivos, retención de devolución de ingresos indebidos, etc., que han de ser proporcionadas siempre que no causen perjuicios de imposible o difícil reparación. La propuesta de adopción de esas medidas habrán de justificarse y motivarse suficientemente por la ITSS, que ordenará y ejecutará la TGSS. De proponerse su mantenimiento en el acta de liquidación, la resolución que eleve a definitiva la misma podrá decretar su levantamiento o su mantenimiento hasta que se ingrese la deuda dentro del plazo reglamentario de ingreso o se garantice el pago mediante aval o con otra garantía suficiente.

1473 "Artículo 19. Adopción de medidas cautelares.

1. La Inspección de Trabajo y Seguridad Social podrá, de acuerdo con el artículo 5 de la Ley ordenadora, adoptar las medidas que juzgue adecuadas para impedir que se le oculten o desaparezcan pruebas materiales, se destruyan o alteren los libros, documentos, material informatizado y demás antecedentes sujetos a examen, a cuyo efecto, dicha Inspección podrá recabar de las autoridades competentes y de sus agentes el auxilio y colaboración precisos.

2. La Inspección de Trabajo y Seguridad Social reflejará las medidas cautelares adoptadas, con reseña de los materiales a que afecte, en diligencia en el Libro de Visitas o, en su defecto, por otro medio escrito y fehaciente notificado al interesado". 


\section{Motivos de oposición del administrador social a la derivación administrativa de responsabilidad.}

Cuando se derive la responsabilidad al administrador social de deudas de Seguridad Social, cabe que nos preguntemos si éste sólo puede cuestionar la procedencia de la derivación administrativa de responsabilidad, o si puede también impugnar o cuestionar la procedencia de la propia deuda de la sociedad de capital.

Con carácter general el administrador social, en cuanto sujeto responsable, puede impugnar tanto la procedencia jurídica de la derivación administrativa de responsabilidad, como la procedencia de la deuda de Seguridad Social. Teniendo mayor fundamento en la responsabilidad solidaria al podérsele exigir la deuda simultáneamente, previamente o posteriormente a la sociedad de capital.

El administrador social tendrá derecho a impugnar la validez de las liquidaciones exigidas, y no sólo la validez de la propia derivación administrativa de la responsabilidad, sin que el haber sido administrador de la sociedad suponga ninguna restricción o limitación de derecho a la impugnación de la deuda derivada, como se ha declarado en las derivaciones de responsabilidad en deudas tributarias al administrador $^{1474}$.

Se admite una oposición plena del administrador social, tanto para impugnar el acto administrativo de derivación, como para impugnar la deuda, ya que como se indica en la Sentencia del TS, Sala Contencioso-Administrativa, 1542/2019, de 7 de noviembre Rec. 4234/2017- ${ }^{1475}$, sobre la derivación de responsabilidad tributaria al administrador social, partiendo del art. 174.5 de la LGT ${ }^{1476}$, “el responsable puede combatir tanto el

1474 SSTC 39/2010, de 19 de julio; 140/2010, de 21 de diciembre; y en Sentencias del TS, Sala Contencioso-Administrativa 656/2020, de 3 junio -Rec. 5020/2017-; 539/2018, de 3 de abril -Rec. 427/2017-; 1542/2019, de 7 de noviembre -Rec. 4234/2017-, entre otras, dictadas en materia de derivación de responsabilidad tributaria.

1475 En igual Sentido SSTS, Sala Contencioso-Administrativa, 282/2018, de 21 de febrero -Rec. 17/2017-; 218/2019, de 21 febrero de 2019 -Rec. 3780/2017-; y 656/2020 de 3 junio -Rec. 5020/2017-, en derivación de deudas tributarias al administrador social.

${ }^{1476}$ Artículo 174. 5. "En el recurso o reclamación contra el acuerdo de derivación de responsabilidad podrá impugnarse el presupuesto de hecho habilitante y las liquidaciones a las que alcanza dicho presupuesto, sin que como consecuencia de la resolución de estos recursos o reclamaciones puedan revisarse las liquidaciones que hubieran adquirido firmeza para otros obligados tributarios, sino únicamente el importe de la obligación del responsable que haya interpuesto el recurso o la reclamación.

No obstante, en los supuestos previstos en el apartado 2 del artículo 42 de esta Ley no podrán impugnarse las liquidaciones a las que alcanza dicho presupuesto, sino el alcance global de la responsabilidad. Asimismo, en los supuestos previstos en el citado apartado no resultará de 
acto de derivación como la propia liquidación en que tiene su origen, porque la derivación es un procedimiento autónomo al que le resultan de aplicación las normas comunes y en el que el trámite de audiencia (referido en los apartados tercero y cuarto del propio precepto) es esencial y, obviamente, no excluye la potestad de alegar y aportar cualesquiera medios de prueba admitidos en Derecho. No hay, en definitiva, una extensión de los efectos de los recursos o de las reclamaciones entre el responsable derivado y el deudor principal, pues el procedimiento de derivación de responsabilidad es autónomo respecto del seguido frente al deudor principal”. Concluye, esa Sentencia que, "el alcance y contenido de la impugnación (que son, como se ha dicho, plenos y se extienden a los acuerdos dictados respecto del deudor principal) no quedan exceptuados, limitados o restringidos por la circunstancia de que la persona declarada responsable fuera administradora de la entidad a la que se giraron las liquidaciones (...). Abona esta tesis (excluyente de la imposición de limitaciones impugnatorias al responsable por su condición de administrador) no solo la dicción literal del precepto que nos ocupa (que no distingue en absoluto al respecto), sino la propia naturaleza jurídica del expediente de derivación de responsabilidad que constituye, como ya dijimos, un procedimiento autónomo del seguido con el deudor principal, al que no le son trasladables sin más los efectos de éste y cuyo resultado, desde luego, no puede ser calificado como un acto consentido y firme para un responsable que ha deducido contra los acuerdos correspondientes el recurso o reclamación legalmente procedentes".

Al ser el procedimiento de derivación de responsabilidad autónomo respecto del seguido frente al deudor principal, no hay una extensión de los efectos de los recursos o de las reclamaciones entre el responsable derivado y el deudor principal, ya que si la reclamación de deuda al deudor principal devino firme, por ejemplo por falta de impugnación, ello no impide al administrador social impugnar su derivación de responsabilidad, cuestionando tanto la procedencia jurídica de la misma como el importe de la deuda, de modo que puede revisarse y determinarse que el importe de la deuda sea otro, pese a haber devenido firme la reclamación efectuada al deudor principal (Sentencias del TS, Sala Contencioso-Administrativa 656/2020, de 3 junio Rec. 5020/2017-; 539/2018, de 3 de abril -Rec. 427/2017-). Nada obsta, en la responsabilidad derivada para que pueda anularse la resolución de derivación de

aplicación lo dispuesto en el artículo 212.3 de esta Ley, tanto si el origen del importe derivado procede de deudas como de sanciones tributarias". 
responsabilidad, o fijarse un importe inferior de la deuda derivada como consecuencia de la impugnación de la derivación por el administrador social, y ello aunque el importe de la deuda del deudor principal haya devenido firme, al no haberse acreditado por éste ser de importe inferior dentro de su procedimiento administrativo de reclamación de la deuda (Sentencia del TS, Sala Contencioso-Administrativa, 656/2020, de 3 junio -Rec. 5020/2017-, como se ha declarado en la derivación de responsabilidad derivada en materia tributaria).

Doctrina jurisprudencial que es de aplicación a la derivación de responsabilidad de las deudas de Seguridad Social de la sociedad de capital al administrador social, pese a no tener el TRLGSS un precepto legal expreso acerca del contenido del derecho de oposición del administrador, en que se contemple la posibilidad de impugnarse el acto de derivación y la deuda objeto de la responsabilidad, a diferencia del Derecho Tributario (art. 174.5 LGT), al ser esa la consecuencia natural del derecho constitucional de tutela judicial efectiva, de modo que no puedan limitarse las posibilidades de defensa e impugnación del sujeto responsable de la deuda derivada.

Motivos de oposición que tienen como fundamento el derecho constitucional a la tutela judicial efectiva, recogido en el art. 24 de la Constitución. En la Sentencia del TC 39/2010, de 19 de julio, sobre una derivación administrativa de responsabilidad tributaria, se señala que, “estamos ya en disposición de dar respuesta a la alegada vulneración del derecho a la tutela judicial efectiva sin indefensión (art. 24.1 CE) que la parte actora hace depender de la negativa judicial a permitirle cuestionar las deudas tributarias que le han sido derivadas. Pues bien, sobre esta cuestión ya hemos tenido ocasión de pronunciarnos para reconocer a los responsables el derecho de defensa contradictoria mediante la oportunidad de alegar y probar procesalmente sus derechos e intereses, de manera que, como consecuencia de la resolución de los recursos o reclamaciones que aquellos interpongan, pueda revisarse el importe de la obligación del responsable, considerando este Tribunal la negativa del órgano judicial a controlar las liquidaciones de las que traía causa la responsabilidad derivada una vulneración del derecho a la tutela judicial efectiva (art. 24.1 CE), causante de una auténtica indefensión (STC 85/2006, de 27 de marzo, FJ 7). Y ello porque al responsable no se le deriva una liquidación firme y consentida por el obligado principal $\mathrm{y}$, en consecuencia, inimpugnable al momento de la derivación, sino que lo que se le deriva es la responsabilidad de pago de una deuda, frente a la cual y desde el mismo instante en que 
se le traslada, se le abre la oportunidad, no sólo de efectuar el pago en período voluntario, sino también de reaccionar frente a la propia derivación de responsabilidad, así como frente a la deuda cuya responsabilidad de pago se le exige. No hay que olvidar que una conducta pasiva del deudor principal frente a las pretensiones liquidatorias o recaudatorias administrativas, haciendo dejación de su derecho a reaccionar en tiempo y forma contra los actos de liquidación, dejaría inerme al responsable solidario o subsidiario, al condicionar el ejercicio de su derecho fundamental de acceso a la jurisdicción en petición de nulidad de la deuda que se le deriva de la actitud procesal diligente del deudor principal que la deja impagada (STC 39/2010, de 19 de julio, FJ 4)."

Motivos de oposición plenos del administrador para impugnar el acto de derivación, la deuda de Seguridad Social o ambas cuestiones, que el TS admite y que podemos ver de modo indirecto, cuando a efectos de la procedencia del recurso de casación en función de la cuantía objeto de la litis, se distinguía entre recurrirse el acto administrativo de derivación, o la propia liquidación de la deuda derivada, ya que en la doctrina jurisprudencial precedente ${ }^{1477}$ a la actual, en el primer caso, de recurrirse la derivación administrativa de la responsabilidad, era suficiente con que la suma de todas las deudas excediesen del importe fijado para el recurso, mientras que para recurrirse la concreta reclamación de deuda ésta debía ser de importe igual o superior al fijado en la ley procesal para la viabilidad del recurso. Doctrina jurisprudencial que se ha modificado ${ }^{1478}$ para dar el mismo tratamiento a efectos de la cuantía del recurso, tanto se recurra la deuda como el acto de derivación, exigiendo que el acto recurrido, sea la derivación o una concreta deuda, deba ser de importe superior al establecido para la admisión del recurso, para que no tenga distinto tratamiento procesal el deudor principal o el administrador social.

El administrador social podrá oponerse a la derivación administrativa de la responsabilidad alegando:

\footnotetext{
${ }^{1477}$ SSTS, Sala Contencioso-Administrativa 1060/2018, de 20 de junio -Rec. 553/2016-; y 262/2019, de 28 de febrero -Rec. 2342/2016-.

1478 SSTS, Sala Contencioso-Administrativa 1849/2019, de 18 de diciembre -Rec. 1098/2017-; 1717/2019, de 12 de diciembre -Rec. 3005/2017-; 7/2020, de 14 de enero -Rec. 5164/2017-; y 560/2020, de 25 de mayo -Rec. 3120/2018-.
} 
1. ${ }^{\circ}$ Vicios en el acto administrativo de derivación de responsabilidad que motiven la nulidad o anulabilidad del mismo, por infracciones de la norma reguladora del procedimiento (arts. 47 y 48 de la LPACAP, en relación con el RGRSS y RISOS).

2. Podrá oponerse al presupuesto de hecho determinante de la responsabilidad por deudas $^{1479}$, cuestionando que concurran los presupuestos normativos establecido para esa clase de responsabilidad, como sería cuestionar que exista causa de disolución, o cuando de existir se alegue que no incumplió los deberes de promover la disolución o de solicitud del concurso. En este sentido, se ha anulado la derivación de responsabilidad por no existir prueba suficiente de que el patrimonio ha quedado reducido a menos de la mitad del capital social ${ }^{1480}$; o por quedar acreditado que el patrimonio neto es superior al capital social ${ }^{1481}$.

3. Podrá alegar causas de exoneración de su responsabilidad por no serle imputable los hechos del presupuesto normativo de la responsabilidad derivada, como, por ejemplo, alguna de las circunstancias que exoneran de responsabilidad del art. 237 de la LSC, o por haber cesado en el cargo con anterioridad a la concurrencia de la causa determinante de la responsabilidad. En la Sentencia del TSJ de Andalucía con sede en Sevilla, Sala Contencioso-Administrativa, de 10 de junio de 2011 -Aranzadi JUR 2011\350114-, se anuló la derivación de responsabilidad porque cesó en el cargo antes de la concurrencia de la posible causa de disolución.

4..$^{\circ}$ Podrá alegar prescripción tanto de la deuda como de la acción para derivar la responsabilidad $^{1482}$ (art. 24 TRLGSS y arts. 241 bis y 949 del Código de Comercio).

5. Podrá cuestionar la deuda, su procedencia, su cuantía, etc.

6. Podrá alegar en definitiva cuantos hechos o fundamentos de derecho estime pertinente en defensa de sus derechos para que no se declare su responsabilidad derivada (arts. 33 y 34 del TRLGSS, arts. 13.4 y 46 del RGRSS y arts. 32 y 33 del RISOS).

${ }^{1479}$ GALA DURÁN, C.: La responsabilidad laboral y de seguridad social de los administradores de las sociedades mercantiles, op. cit. p. 200.

1480 Sentencia del TSJ de Andalucía/Sevilla, Sala Contencioso-Administrativa, 10 junio 2011 -Aranzadi JUR 2011\350114-; y TSJ de Galicia, misma Sala, 424/2018, de 19 julio -Aranzadi JUR 2018\25545419-.

1481 Sentencia del TSJ Sevilla Contencioso-Administrativa, de 10 junio 2011 -Aranzadi JUR 20111350114-; y TSJ Madrid, Sala Contencioso-Administrativa, 67/2018, de 31 enero -Aranzadi JUR 2018193619-.

1482 GALA DURÁN, C.: La responsabilidad laboral y de seguridad social de los administradores de las sociedades mercantiles, op. cit. p. 200. 
Solamente cuando se abra la vía de apremio, sea ante el deudor principal (la sociedad) o ante el responsable (el administrador), por no haberse efectuado el pago en el plazo de ingreso establecido en la reclamación de deuda o en la resolución del acta de liquidación, firmes en vía administrativa, los motivos de oposición a la providencia de apremio mediante el recurso de alzada, estarán tasados y limitados, a los siguientes: a) pago, b) prescripción, c) error material o aritmético en la determinación de la deuda, d) condonación, aplazamiento de la deuda o suspensión del procedimiento, e) falta de notificación de la reclamación de deuda o del acta de liquidación, o de las resoluciones de las que esas procedan (art. 38.3 TRLGSS y art. 86.1 del RGRSS) ${ }^{1483}$.

Si consecuencia de los motivos de oposición se declarase la nulidad de pleno derecho de la derivación de responsabilidad por alguna de las causas del art. 47 de la LPACAP (lesión de derechos fundamentales, resolución dictada prescindiendo total y absolutamente del procedimiento administrativo, etc.), se dejará sin efecto la misma y las medidas cautelares, restableciéndose la situación patrimonial anterior, afectando la nulidad a los actos posteriores que se hubieren producido (Sentencia del TS, Sala Contencioso-Administrativa, de 14 de diciembre de 2009 -Rec. 307/2008-).

Relacionado con los motivos de oposición a la derivación de responsabilidad, está otra cuestión distinta pero conexa, y es cómo afecta a ese derecho de defensa del administrador la existencia de una previa sentencia firme que haya puesto fin al proceso en que la sociedad de capital impugnó el acto administrativo inicial de reclamación de la deuda, cuando esa reclamación administrativa inicial se dirigió sólo contra el deudor principal, la sociedad de capital, sin haberse apreciado la responsabilidad solidaria del administrador social.

En este supuesto, de haberse fijado la deuda en sentencia firme al haberse debatido y aportado pruebas acerca del alcance de la misma, en un proceso en el que fue parte la empresa, pero no el administrador social, la cuestión a dilucidar será si esa sentencia firme tiene la fuerza de cosa juzgada material para la posterior derivación de la deuda al administrador social.

${ }^{1483}$ La STC 160/2020, de 16 de noviembre, considera que el acto liquidatorio tributario no ha sido notificado correctamente, no interrumpiendo la prescripción, si se envió a un domicilio en que ya no reside el administrado, por lo que éste no pudo impugnarlo, pese a que la providencia de apremio sí se remitió a su nuevo domicilio que constaba en otros registros públicos, como DNI, Padrón Municipal, o en declaraciones fiscales. 
En principio, hemos de indicar que en puridad no puede hablarse de cosa juzgada material, ya que no hay identidad de sujetos litigantes, y podría incluso no haber identidad de causa de pedir. No hay identidad de litigantes porque en el primer proceso fueron parte la Administración de la Seguridad Social y la sociedad de capital, aunque ésta estuviere representada por el administrador, mientras que en la derivación administrativa de la deuda al administrador, es parte un sujeto distinto a la empresa, y no necesariamente será la misma la causa de pedir entre el primer proceso y el segundo proceso contencioso administrativo, ya que en el primer proceso contencioso la causa de pedir fue el incumplimiento de la obligación de Seguridad Social por la sociedad, y en el segundo proceso contencioso será la procedencia de la derivación, la que obviamente, de proceder, será por una deuda fijada en un proceso anterior.

Para responder a esta cuestión habrá de partirse del concepto de la cosa juzgada material y sus dos efectos positivo y negativo. En virtud del efecto negativo o excluyente, previsto en el art. 222.1 de la LEC, se impide que en un nuevo proceso se entre a conocer sobre la misma cuestión de un proceso anterior finalizado con sentencia firme, cuando concurra la triple identidad de sujetos, de objeto y de causa de pedir. En virtud del efecto positivo o prejudicial de la cosa juzgada material del art. 222.4 de la LEC, el proceso anterior vincula al posterior, siempre y cuando el primero sea antecedente lógico del segundo, y haya identidad de litigantes. En ese artículo 222.4 se establece que "lo resuelto con fuerza de cosa juzgada en la sentencia firme que haya puesto fin a un proceso vinculará al tribunal de un proceso posterior cuando en éste aparezca como antecedente lógico de lo que sea su objeto, siempre que los litigantes de ambos procesos sean los mismos o la cosa juzgada se extienda a ellos por disposición legal".

De no extenderse la cosa juzgada por disposición legal, que no es el caso, y siendo distintos los litigantes de ambos procesos, al no concurrir la triple identidad no existiría la cosa juzgada material. Por otro lado, es regla general en la solidaridad en las deudas, que el deudor solidario puede utilizar contra el acreedor todas las excepciones que se deriven de la naturaleza de la obligación, a parte de las excepciones personales (art. 1148 del Código Civil). Si a esto se añaden las exigencias del derecho constitucional de tutela judicial efectiva y la doctrina del TC antes referida acerca del pleno derecho del administrador social a cuestionar la deuda, aunque haya devenido firme frente al deudor principal, debemos concluir que al no haber tenido el administrador la condición de parte procesal del proceso precedente, puede cuestionar la procedencia y cuantía de la 
deuda derivada, ya que el anterior proceso no produce efectos positivos de la cosa juzgada material.

En virtud del derecho a la tutela judicial efectiva, no se puede causar indefensión al administrador social que no ha sido parte procesal en un proceso anterior, limitando su derecho de alegar y probar lo pertinente en defensa de su derecho. El derecho de tutela judicial efectiva se satisface mediante el acceso de las partes al proceso, "sin limitación de garantías ni impedimento alguno para alegar y demostrar en el proceso los propios derechos" (Sentencias del TC 40/1994, de 15 de febrero -Aranzadi RTC 1994/40-; y 198/2000, de 24 de julio -RTC 2000/198-), con la finalidad de no causarse indefensión, lo que tendría lugar si se priva a una de las partes de los medios de defensa oportunos y suficientes (Sentencia del TS, Sala Civil, 14 de diciembre de 2007 -Rec. 4824/2000-; y 307/2010, de 25 mayo -Rec. 931/2005-).

La Sentencia del TS, Sala Civil, núm. 307/2010, de 25 mayo -Rec. 931/2005-, ${ }^{1484}$ sobre la prejudicialidad, señala lo siguiente, "el efecto prejudicial de la cosa juzgada. A) Junto al llamado efecto negativo o excluyente de la cosa juzgada material, la sentencia firme tiene también un efecto positivo o prejudicial, que impide que en un proceso ulterior se resuelva un concreto tema o punto litigioso de manera distinta a como ya quedó decidido en un proceso anterior entre las mismas partes. El hecho de que los objetos de dos procesos difieran o no sean plenamente coincidentes no es óbice para extender al segundo pleito lo resuelto en el primero respecto a cuestiones o puntos concretos controvertidos que constan como debatidos, aunque tan sólo con carácter prejudicial, y no impide que el órgano judicial del segundo pleito decida sin sujeción en todo lo restante que constituye la litis (SSTS, 1 de diciembre de 1997 -RC n. ${ }^{\circ}$ 2936/1993- y 12 de junio de 2008 -RC n. ${ }^{\circ}$ 1073/2001-). El efecto prejudicial de la cosa juzgada se vincula al fallo, pero también a los razonamientos de la sentencia cuando constituyan la razón decisoria (SSTS de 28 de febrero de 1991, 7 de mayo de 2007, RC 2069/2000). La jurisprudencia de esta Sala admite que la sentencia firme, con independencia de la cosa juzgada, produzca efectos indirectos, entre ellos el de constituir en un ulterior proceso un medio de prueba de los hechos en aquella contemplados y valorados, en el caso de que sean determinantes del fallo (SSTS, de 18 de marzo de 1987, 3 de

${ }^{1484}$ En igual sentido SSTS, Sala Civil, 855/2010, de 30 de diciembre; 826/2011, de 23 de noviembre; 777/2012, de 17 de diciembre; 123/2013, de 11 de marzo; 631/2013, de 18 de octubre; 698/2013, de 7 de noviembre; 377/2014, de 14 de julio -Rec. 2416/2012-; y 650/2014, de 27 de noviembre -Rec. $623 / 2013-$, entre otras muchas. 
noviembre de 1993, 27 de mayo de 2003, 7 de mayo de 2007, RC n. ${ }^{\circ}$ 2069/2000). Este criterio se funda en que la existencia de pronunciamientos contradictorios en las resoluciones judiciales de los que resulte que unos mismos hechos ocurrieron o no ocurrieron es incompatible con el principio de seguridad jurídica y con el derecho a una tutela judicial efectiva que reconoce el artículo 24.1 CE (STC 34/2003, de 25 de febrero). B) Esta doctrina, desarrollada por esta Sala durante la vigencia de la LEC 1881, en interpretación del hoy derogado, artículo 1252 CC, es de aplicación a los procesos seguidos bajo la vigencia de la LEC, que, en el artículo 222.4, contempla los efectos positivos de la cosa juzgada". La cursiva es nuestra.

Por otro lado, en la Sentencia del TS, Sala Civil, 618/2012, de 15 de octubre -Rec. 909/2010-, partiendo de los anteriores fundamentos de derecho, se analiza la prejudicialidad impropia, los efectos de la prejudicialidad civil en un posterior proceso, cuando no haya identidad de partes, existiendo conexión con lo resuelto en el proceso anterior. En esa sentencia sobre la prejudicialidad impropia se argumenta lo siguiente, (si) “declara el art. 222.3 LEC que la cosa juzgada afectará a las partes del proceso en que se dicte y a sus herederos y causahabientes. Es más aunque no hubiese identidad de partes no podemos olvidar la existencia de prejudicialidad impropia sobre la que esta Sala ha declarado que: Se trata de la llamada litispendencia impropia o prejudicialidad civil, que se produce, como ha dicho la Sentencia, de 22 de marzo de 2006, cuando hay conexión entre el objeto de los dos procesos, de modo que lo que en uno de ellos se decida resulte antecedente lógico de la decisión de otro (SSTS, 20 de noviembre de 2000, 31 de mayo, 1 de junio y 20 de diciembre de 2005) aun cuando no concurran todas las identidades que exigía el artículo 1252 del Código Civil. STS, Civil, Sección $1^{\text {a }}$, del 29 de diciembre del 2011 -Rec. 1725/2008-." La cursiva es nuestra.

En la Sentencia núm. 460/2010, de 14 de julio -Rec. 945/2006-, de la misma Sala Civil del TS, se insiste en esa línea argumental desde una perspectiva constitucional, al señalarse, (sic) "no cabe afirmar la infracción del apartado cuarto del artículo 222 de la Ley de Enjuiciamiento Civil cuando los litigantes de ambos procesos no son los mismos y la cosa juzgada no se extiende a ellos por disposición legal. Por otro lado, llevada la cuestión al plano constitucional -el de la efectividad de la tutela judicial que consagra el artículo 24, apartado uno, de la Constitución Española-, hemos de recordar con las Sentencias del Tribunal Constitucional números 231/2006, de 17 de julio, y 208/2009, de 26 de agosto, que la carencia de efectividad de la protección judicial que supone la 
desatención a la eficacia de la cosa juzgada, puede producirse no sólo con el desconocimiento por un órgano judicial de lo resuelto por otro en supuestos en que concurran las identidades propias de aquélla, sino también cuando hay un desconocimiento de lo resuelto por sentencia firme en el marco de procesos que examinan cuestiones que guardan con aquélla una relación de estricta dependencia, aunque no sea posible apreciar el efecto mencionado en las normas procesales. Se busca salvaguardar la eficacia de una resolución judicial que, habiendo adquirido firmeza, ha conformado la realidad jurídica de una forma cualificada que no puede desconocerse por otros órganos juzgadores sin reducir a la nada la propia eficacia de aquélla”.

En esta sentencia no se aprecia cosa juzgada cuando se reclamó la responsabilidad solidaria del actual art. 367 de la LSC a un miembro del Consejo de Administración de una sociedad anónima deportiva, con relación a un proceso anterior firme en que se había recabado la responsabilidad por los mismos hechos de otros administradores de la misma sociedad.

Por todo lo anterior, el administrador social podrá alegar y probar lo que a su derecho de defensa convenga, para no ver vulnerado su derecho a la tutela judicial efectiva, pudiendo aportar hechos probatorios que estime pertinentes, y que, si son hechos nuevos, impiden apreciar respecto de ellos la cosa juzgada (art. 222.2 de la LEC). En todo caso, para evitar desconocer totalmente una sentencia firme, cuando sea presupuesto lógico del proceso de reclamación posterior de la responsabilidad solidaria, el Tribunal Supremo, Sala Civil, ha venido señalando que el primer proceso podrá producir efectos indirectos en el segundo proceso, en virtud del derecho a la tutela judicial efectiva que se materializó con el primer proceso, y esos efectos indirectos serían considerar el proceso anterior como medio probatorio de los hechos que fueron comprobados y valorados en el anterior juicio (Sentencias núm. 307/2010, de 25 mayo Rec. 931/2005-; 460/2010, de 14 de julio; y 618/2012, de 15 de octubre -Rec. 909/2010) .

Señalar que en la derivación de responsabilidad al administrador, la sociedad no estaría legitimada para impugnar la resolución administrativa que declara la responsabilidad de aquel en las deudas de Seguridad Social de la mercantil, al no tener ésta legitimación “ad causam” (TSJ de Murcia, Sala Contencioso-Administrativa, Sentencia 385/2018, de 28 de septiembre de 2018 -Rec. 199/2017, Aranzadi JUR 2018/298290-). Legitimación "ad causam” que es la aptitud para ser parte en un proceso determinado, 
lo que implica una relación especial entre una persona y una situación jurídica objeto del litigio, por virtud de la cual, sólo el administrador social podría impugnar la derivación de responsabilidad efectuada contra él, pero no la sociedad de capital.

\section{Prejudicialidad penal. Efectos del proceso penal en la derivación de deudas.}

El procedimiento administrativo de derivación de responsabilidad al administrador social no se paraliza por el hecho de seguirse causa penal contra la sociedad de capital o el administrador social, a diferencia de las sanciones e infracciones administrativas, en que si el hecho es constitutivo de delito se paraliza el procedimiento administrativo sancionador hasta que se resuelva la causa penal, en virtud del principio non bis in ídem”, para evitar ser sancionado dos veces por el mismo hecho (art. 5 del TRLISOS).

Las causas de suspensión del procedimiento administrativo de recaudación se recogen en el art. 6.3 del RGRSS, donde se señala que "el procedimiento de recaudación se impulsará de oficio en todos sus trámites y sólo se suspenderá en los términos establecidos en los artículos 129 y siguientes de la LJCA, y en aquellos otros casos en que así se establezca en este reglamento, por ley o en ejecución de ella y en las condiciones y con los efectos que en ellos se determinen". El art. 129 de la Ley reguladora de la Jurisdicción Contencioso-Administrativa contempla la posibilidad de que el administrador social, como parte recurrente, pueda solicitar la suspensión cautelar de la ejecución de la reclamación de la deuda derivada, correspondiendo al juzgado o tribunal resolver sobre su procedencia, ya que la interposición del recurso contencioso no suspende la ejecución del acto impugnado.

Suspensión del procedimiento que no se produce tampoco cuando se recurra en vía administrativa la derivación de responsabilidad, salvo que se garantice el pago con aval suficiente o se consigne el importe de la deuda y del recargo (arts. 33.5 y 34.3 del TRLGSS, art. 66 del RGRSS y art. 33.3 del RISOS).

En ese precepto no se exige que el procedimiento recaudatorio deba paralizarse por seguirse por los mismos hechos causa penal, al no ser aplicable el principio non bis in ídem, ya que la reclamación administrativa de responsabilidad no es constitutiva de un procedimiento sancionador.

Se prevé expresamente la no paralización de la reclamación de la responsabilidad mediante el acta de liquidación por la concurrencia de causa penal, en el art. 36 del 
RISOS, donde se establece que, "cuando en el ejercicio de su función los Inspectores o Subinspectores comprobasen deudas por cuotas a la Seguridad Social y conceptos asimilados, o por disfrute indebido de prestaciones sociales o subvenciones públicas, si se apreciase la concurrencia de indicios racionales de posible comisión de delito, se procederá en la forma dispuesta en el artículo 5 de este Reglamento en cuanto a dación de cuenta al Ministerio Fiscal. Tal comunicación no suspenderá la tramitación y finalización de los expedientes liquidatorios o de exigencia de devolución de cantidades indebidamente percibidas en el ámbito de los sistemas públicos de protección social, ni a las eventuales actuaciones administrativas posteriores para su exacción". De darse cuenta al Ministerio Fiscal acerca de hechos constitutivos de delito, se paralizará el procedimiento administrativo sancionador, pero para evitar que la reclamación de la deuda por acta de liquidación se pudiera ver afectada por esa paralización, se prevé expresamente que en esos casos no puede acumularse el acta de liquidación y el acta de infracción ante unos mismos hechos, siendo objeto de tramitación diferenciada ambas actas (art. 34.5 del RISOS). De igual modo, en el art. 5.2 del RISOS, que prevé la paralización del expediente sancionador ante la concurrencia de causa penal por los mismos hechos, exceptúa de la suspensión la reclamación de deudas de Seguridad Social.

En el Código Penal, en la regulación de los delitos contra la Seguridad Social, se prevé como regla general la no paralización de la reclamación administrativa de la deuda ante la tramitación de la causa penal, al prescribirse en el art. 307.4 del Código Penal, que, "la existencia de un procedimiento penal por delito contra la Seguridad Social no paralizará el procedimiento administrativo para la liquidación y cobro de la deuda contraída con la Seguridad Social, salvo que el Juez lo acuerde previa prestación de garantía. En el caso de que no se pudiese prestar garantía en todo o en parte, el Juez, con carácter excepcional, podrá acordar la suspensión con dispensa total o parcial de las garantías, en el caso de que apreciara que la ejecución pudiera ocasionar daños irreparables o de muy difícil reparación. La liquidación administrativa se ajustará finalmente a lo que se decida en el proceso penal".

No obstante, en el ámbito de la derivación de responsabilidad tributaria, en el supuesto de que se derive a un tercero que haya colaborado en la comisión de la infracción, la liquidación tributaria y la sanción administrativa del deudor principal (arts. 42.1.a), 174.5 y 180.1 LGT), si se siguiese causa penal contra el deudor principal por presuntos 
hechos delictivos que fuesen el presupuesto de la derivación de esa responsabilidad, la jurisprudencia ha admitido que el procedimiento tributario de derivación al responsable solidario de la sanción y de la deuda, deberán paralizarse hasta que se dicte sentencia firme en la causa penal (Sentencia del TS, Sala Contencioso-Administrativa núm. 218/2019, de 21 de febrero de 2019 -Rec. 3780/2017-). En esa sentencia se fija la siguiente doctrina, "teniendo en consideración que la cuestión suscitada en el auto de admisión, consiste en determinar si es procedente acudir al procedimiento de derivación de responsabilidad tributaria solidaria del artículo 42.1.a) LGT (responsabilidad de quienes sean causantes o colaboradores activos en la realización de una infracción tributaria) en aquellos casos en los que, en relación con los mismos elementos fácticos pero respecto a un concepto impositivo distinto, la determinación de la conducta como punible se está desarrollando en el ámbito penal procede, en función de todo lo razonado declarar los siguiente: La interpretación conjunta de los artículos 42.1.a), 174.5 y 180.1 LGT, determina que la prejudicialidad penal derivada de las actuaciones penales seguidas contra el obligado principal por el concepto IVA produce todos sus efectos con relación a la derivación de responsabilidad solidaria al recurrente por el concepto tributario del Impuesto sobre Sociedades".

Doctrina que no es trasladable automáticamente al ámbito de la Seguridad Social, ya que la derivación de responsabilidad al administrador social en esta rama jurídica es sólo de las deudas, no de sanciones administrativas, terreno de las sanciones administrativa donde es de plena aplicación el principio non bis in ídem. En la derivación de deudas de Seguridad Social, ante la existencia de causa penal, el juez o tribunal penal puede adoptar como medida cautelar la paralización del procedimiento administrativo, cuando los hechos objeto del pleito penal puedan ser determinantes de la responsabilidad derivada, especialmente ante actuaciones fraudulentas constitutivas de delito, en cuyo caso, sería conveniente saber si el hecho fraudulento se ha producido y quién es el sujeto causante o responsable del mismo, para partiendo de esos hechos probados en la causa penal, seguir con el procedimiento de derivación de la deuda o archivarlo. Situación que con carácter general no concurrirá ante derivaciones de deudas por incumplimientos de los administradores de los deberes de promover la disolución de la sociedad de capital, de hallarse la mercantil en causa legal de disolución.

El principio non bis in ídem se aplica plenamente al procedimiento administrativo sancionador del orden social -que no es el caso del procedimiento de derivación de 
deudas de Seguridad Social-, por lo que, si por los mismos hechos se incoa causa penal, aunque ésta no sea contra la sociedad sino contra sus gestores o administradores, debe paralizarse la tramitación del acta de infracción extendida a la sociedad de capital para evitar pronunciamientos distintos sobre unos mismos hechos (Sentencia del TS, Sala Contencioso-Administrativa 174/2019, de 6 de marzo -Rec. 3648/2016- ${ }^{1485}$ ).

\section{La caducidad del procedimiento administrativo de derivación de responsabilidad.}

Como todo procedimiento iniciado de oficio con efectos desfavorables o de gravamen, si transcurre el plazo máximo para dictarse y notificarse la resolución administrativa al sujeto responsable -al administrador social-, el procedimiento administrativo de derivación de responsabilidad caduca. Caducidad que ha de ser declarada mediante resolución expresa de la Administración, ordenando el archivo de las actuaciones, sin que el mero transcurso del plazo máximo del procedimiento genere de modo automático la caducidad, y sin que pese al transcurso de ese plazo pueda iniciarse un nuevo procedimiento si no hay resolución expresa de caducidad del anterior procedimiento (art. 25.1 de la LPACAP, y Sentencia del TS, Sala Contencioso-Administrativa 1667/2020, de 3 de diciembre de 2020 -Rec. 8332/2019-). La caducidad tiene el efecto de no producir por sí misma la prescripción de la acción para reclamar la derivación administrativa de la responsabilidad, pero en cambio, ese procedimiento caducado no habrá interrumpido la prescripción de la acción de la derivación administrativa de la responsabilidad (art. 95.3 de la LPACAP). Por otro lado, si la acción no ha prescrito podrá iniciarse un nuevo procedimiento administrativo de derivación de responsabilidad, pudiéndose incorporar a éste los actos y trámites cuyo contenido se hubieren mantenido igual, debiéndose cumplimentar nuevamente los trámites de alegaciones, proposición de prueba y audiencia al interesado (art. 95.3 segundo párrafo de la LPACAP).

\subsection{Caducidad de la derivación de la TGSS.}

Si la derivación de responsabilidad es realizada por la TGSS, ésta reclamará la responsabilidad a los administradores mediante la reclamación de deuda por derivación

\footnotetext{
1485 Para una visión crítica de esa Sentencia, véase DÍAZ RODRÍGUEZ, J. M.: "La concurrencia lícita entre sanciones penales y administrativas para personas físicas y jurídicas en una misma empresa (a pesar de la STS 174/2019)", Trabajo y Derecho, № 61, Sección Jurisprudencia/Observatorio temático de jurisprudencia, enero 2020, Wolters Kluwer, Ref. La Ley 15230/2019.
} 
de responsabilidad, pero se precisa que antes de dictarse esa reclamación de deuda se inicie el procedimiento mediante la adopción del acuerdo de inicio, acuerdo que debe ser notificado a los sujetos responsable para darles trámite de audiencia, salvo que la reclamación de deuda se base en los mismos hechos y fundamentos de derecho que motivaron una previa reclamación de deuda por derivación al mismo sujeto responsable. Incoado el procedimiento con el acuerdo de inicio, la TGSS debe dictar y notificar la resolución declarando la responsabilidad de los administradores en el plazo máximo de seis meses a computar desde el día siguiente al de la fecha de ese acuerdo de inicio (arts. 13.4 y 14.1 del RGRSS). En esos preceptos se establece que, el plazo máximo para notificar la reclamación de deuda por derivación será de seis meses, a contar desde el día siguiente a la fecha del acuerdo de iniciación.

\subsection{La caducidad de la actividad previa de comprobación de la ITSS.}

Si la derivación de responsabilidad se realiza mediante acta de liquidación por derivación de responsabilidad de la ITSS, a efectos de la caducidad debemos distinguir, por un lado, la caducidad de la actividad previa de comprobación, y, por otro lado, la caducidad del procedimiento administrativo de derivación de responsabilidad en sentido estricto, que se inicia con el acta de liquidación. Analicemos brevemente ambas caducidades.

La caducidad de la actividad previa de comprobación de la ITSS se regula en los artículos 21.4 de la LOISS, art. 8.2 del RISOS y art. 17 del ROFITSS, con el siguiente régimen jurídico:

La actuación previa de comprobación de la ITSS tiene lugar en un momento o fase anterior al procedimiento liquidatorio. Fase de investigación que entronca con lo que en la LPACAP se denominan "actuaciones previas", que son aquellas que el órgano competente puede abrir con anterioridad al inicio del procedimiento, con el fin de conocer las circunstancias del caso concreto y la conveniencia de iniciar el procedimiento, que de ser un procedimiento sancionador o liquidatorio, esas actuaciones se dirigirán a constatar los hechos y los posibles sujetos responsables, en nuestro caso, a investigar los hechos determinantes de la responsabilidad del administrador social, identificando a los sujetos responsables, el alcance de la responsabilidad y demás 
circunstancias relevantes para la derivación de las deudas de Seguridad Social (art. 55 de la LPACAP, art. 21 de la LOITSS y arts. 8, 29 y ss del RISOS) ${ }^{1486}$.

Fase de comprobación previa que al implicar cierta actividad instructora, conlleva una serie de obligaciones o cargas para la sociedad y el administrador social, en cuanto sujetos sometidos a investigación, ya que los Inspectores de Trabajo y Seguridad Social y los Subinspectores Laborales de Empleo y Seguridad Social están autorizados para entrar libremente en el centro de trabajo, recabar información presencial de los trabajadores, de los representantes legales o sindicales de los trabajadores, así como de los representantes de la empresa, pudiendo requerir la aportación de todo tipo de documentación con transcendencia en la hechos objeto de investigación, sea documentación laboral, de Seguridad Social, fiscal, contable, mercantil etc. (arts. 19 y 21 apartados 1, 2, 3, 5, y 6 de la LOITSS).

Actividad previa de comprobación que al someter al administrador y a la sociedad de capital a una actividad de fiscalización, al ser una actuación de gravamen, para garantizar los derechos del ciudadano, en virtud de las exigencias del principio de seguridad jurídica, no podrá mantenerse en el tiempo ilimitadamente, sino que tiene establecida una duración máxima total ${ }^{1487}$.

- En primer lugar, estas actuaciones previas comprobatorias no se dilatarán por tiempo superior a nueve meses desde su inicio, salvo que la dilación sea imputable al sujeto investigado o a las personas dependientes del mismo ${ }^{1488}$. Plazo de nueve meses que podrá ser ampliado por otros nueve meses como máximo, cuando concurran las siguientes circunstancias: a) cuando las actividades de inspección revistan especial dificultad y complejidad, entendiéndose concurrente esa dificultad o complejidad en

${ }^{1486}$ En el art. 8.1 del RISOS se establece que la actividad inspectora previa al procedimiento sancionador o liquidatorio, "es el conjunto de actuaciones realizadas por la ITSS destinadas a comprobar el cumplimiento de las disposiciones legales, reglamentarias y convenidas en el orden social". Las actuaciones previas de comprobación recogidas en el art. 8 del RISOS conllevan, "las más amplias potestades de investigación y prueba de la Administración" (Sentencia del TS, Sala ContenciosoAdministrativo, de 6 noviembre de 2012 -Rec. 3558/2011-).

${ }^{1487}$ Art. 21.4 de la LOITSS; art. 8.2 del RISOS; y art. 17 del Real Decreto 138/2000, de 4 de febrero, por el que se aprueba el Reglamento de Organización y Funcionamiento de la Inspección de Trabajo y Seguridad Social -ROFITSS-, BOE del 16.2.2000; y Criterio Técnico núm. 35/2003, de 19 de mayo de 2003, de la DGITSS, sobre los plazos del procedimiento administrativo sancionador y liquidatorio, así como de las actuaciones previas de comprobación -Ref.: La Ley 807/2003-.

${ }^{1488}$ La duración máxima se amplía por igual tiempo en que se vio paralizada la actuación por no comparecer la empresa aportando la documentación complementaria en las fechas señalas por el funcionario actuante, cuando esa documentación tuviere transcendencia en la comprobación (Sentencia del TS, Sala Social, de 8 de septiembre de 2020 -Rec. 25/2019-). 
función del volumen de operaciones de la persona o de la entidad, o por la dispersión geográfica de sus actividades; b) cuando en el transcurso de las mismas se descubra que el sujeto inspeccionado ha obstruido u ocultado al órgano inspector alguna de sus actividades o de las personas que las desempeñen; c) cuando la actuación inspectora requiera de cooperación administrativa internacional.

Se entenderá que concurre especial dificultad y complejidad de la actuación de comprobación, a efecto de ampliación de los plazos de conformidad con el art. 17.1 del ROFITSS, cuando concurran las siguientes circunstancias: a) cuando por el volumen de documentación a analizar y el número de las personas que deben ser investigadas o entrevistadas así lo requieran; b) cuando se esté ante un grupo de empresas vinculadas entre sí y sea preciso realizar actuaciones sobre las diversas empresas que componen dicho grupo o estructura empresarial, o ante supuestos de sucesión de empresa; c) cuando se trate de hechos, actos, elementos, actividades, explotaciones y otras circunstancias que se lleven a cabo fuera del territorio donde radique el órgano actuante, y le exija a éste la realización de actuaciones de comprobación fuera de dicho ámbito territorial; d) por el incumplimiento de las obligaciones laborales, fiscales, contables, registrales o de seguridad social, o por la desaparición o falta de los libros o registros que supongan una mayor dificultad de comprobación e investigación; e) cuando se lleven a cabo actuaciones e investigaciones a los sujetos responsables de obligaciones laborales o de seguridad social basadas en su posible intervención en redes, tramas o actuaciones tendentes a la defraudación al Sistema de la Seguridad Social, en aras a la obtención de bonificaciones, subvenciones, prestaciones así como a la simulación de la relación laboral o la obtención fraudulenta de autorizaciones de residencia y trabajo de extranjeros no comunitarios; y f) cuando en la comprobación se constate la presencia de empresas que están vinculadas entre sí y que participen en la producción, ejecución o distribución de un determinado bien o servicio, teniendo presente que la actuación inspectora se dirige a la comprobación de las distintas fases que intervienen en la producción, ejecución o distribución.

- En segundo lugar, la ampliación del plazo máximo podrá llevarse a cabo una vez que hayan transcurrido cuatro meses desde el inicio de las actuaciones de inspección, debiéndose notificar al sujeto objeto de inspección, a quien se le otorgará un plazo de quince días, para que efectúe, si lo estima pertinente, las alegaciones oportunas. 
Concluido este trámite, se notificará al sujeto investigado la resolución pertinente, no cabiendo recurso alguno contra dicho acto, todo ello sin perjuicio de las alegaciones y recursos que puedan efectuarse posteriormente, tanto en vía administrativa como jurisdiccional, en el caso de que se iniciase procedimiento liquidatorio de derivación de responsabilidad. En la resolución a notificar se indicará el periodo de tiempo por el que se amplía el plazo, que no podrá exceder de nueve meses, y deberá motivarse adecuadamente la ampliación del plazo (STS, Contencioso-Administrativa, 1519/2017, de 5 de octubre -Rec. 3043/2016-, sobre ampliación del plazo en procedimiento tributario que establece la necesidad de acreditar que por las circunstancias concurrentes el plazo inicial era insuficiente para concluir la actividad investigadora).

- En tercer lugar, la competencia para la ampliación de la duración máxima de la actuación inspectora previa de comprobación, corresponderá en función del ámbito de actuación, al Director de la Dirección Especial de Inspección, al Director Territorial de la Inspección de Trabajo y Seguridad Social de la Comunidad Autónoma, o al Jefe de la Inspección Provincial de Trabajo y Seguridad Social, u órgano equivalente en aquellas Comunidades Autónomas que hayan recibido un traspaso de funciones y servicios en materia de Función Pública Inspectora.

- En cuarto lugar, con independencia del plazo máximo de la actuación previa de comprobación, ésta no podrá interrumpirse por más de cinco meses, salvo que la interrupción sea causada por el sujeto inspeccionado o personas de él dependientes, o cuando se constate la imposibilidad de proseguir la actuación inspectora por la pendencia de un pronunciamiento judicial que pueda condicionar el resultado de la misma. Si para evitar que caduque la actuación inspectora por inactividad durante cinco meses, se solicitase en los últimos días por el funcionario actuante documentación sin relevancia en la comprobación inspectora o documentación ya aportada, con la mera pretensión de paralizar la caducidad, al no tener justificación y hacerse con esa finalidad, al ser acto en fraude de ley debería de aplicarse el precepto tratado de eludir, con la consiguiente caducidad de la actividad por el transcurso de los cinco meses ${ }^{1489}$. Deberá motivarse la paralización por causa imputable al sujeto

1489 Las SSTS, Sala Contencioso-Administrativa 650/2018, de 23 de abril de 2018 -Rec. 608/2016-, y 1389/2020, de 22 de octubre de 2020 -Rec. 4388/2019-, ha rechazado las suspensiones ficticias, aquellas que se utilizan "como un mero ardid para eludir la caducidad de un procedimiento concreto. $\mathrm{Si}$ así ocurre, la suspensión así acordada (y el plazo suspensivo que de ella deriva) habrá de 
responsable, así como su incidencia en la actividad inspectora de comprobación para la derivación administrativa de responsabilidad, sin que sea suficiente emplear fórmulas estereotipadas como la de que la persona o entidad inspeccionada "no aporta documentación" sin especificar qué documentación y su importancia en la actividad investigadora llevada a cabo (Sentencia del TS, Sala ContenciosoAdministrativa 1928/2017, de 11 de diciembre -Rec. 3175/2016-, en materia de derivación tributaria).

En Consulta de la DGITSS de 22.12.2015 "sobre el alcance del art. 20.6 de la Ley 23/2015, Ordenadora del Sistema de Inspección de Trabajo y Seguridad Social en lo que respecta a la actuación inspectora" ${ }^{1490}$, se estima que pese a recogerse en el art. 21.4 de la LOITSS, en relación con el art. 20.6 de la LOITSS, que la paralización de la actuación previa de comprobación por seguirse sobre los mismos hechos una demanda ante la Jurisdicción Social, suspende el cómputo del plazo de cinco meses de la actuación comprobatoria, sin decirse nada acerca de si se suspende también el plazo máximo de nueve o dieciocho meses, concluye en sentido afirmativo, señalando que la actuación inspectora paralizada por demanda judicial, suspende ambos plazos, el de cinco y el de nueve o dieciocho meses ${ }^{1491}$. Artículo 20.6 que tiene como finalidad iniciar actuaciones inspectoras a los únicos efectos de

considerarse fraudulenta y por tanto no impedirá la aplicación de la norma que se ha tratado de eludir (ex art. $6.4 \mathrm{CC}$ ), de forma que esa suspensión no podrá impedir la producción y declaración de la caducidad".

${ }^{1490}$ Ref.: La Ley 4206/2015

${ }^{1491} \mathrm{Al}$ respecto se señala "en este sentido, debemos tener en cuenta que tanto el artículo 20.6 como el artículo 21.4 de la Ley 23/2015 de 21 de julio prevén la iniciación de actuaciones y paralización de las mismas o interrupción de actuaciones previas de comprobación en los supuestos de pendencia de un pronunciamiento judicial del asunto sobre el que verse la actuación inspectora. Se trata de una causa justificada de inactividad de la Administración prevista legalmente, como no puede ser de otro modo, dada la imposibilidad de proseguir actuaciones hasta que se resuelva el procedimiento judicial que determinará o no la iniciación del procedimiento correspondiente o por el contrario el archivo de dichas actuaciones. Por ello, obviamente, la interrupción del plazo de cinco meses contemplada en el art. 21.4 puede extenderse más allá del plazo de nueve meses de duración de las actuaciones comprobatorias, lo que lejos de constituir un supuesto excepcional será, además, lo más normal, dada la previsible mayor duración de un procedimiento judicial hasta alcanzar la firmeza de la sentencia. En definitiva, la interrupción justificada por un tiempo superior a cinco meses (sin establecerse límite máximo para dicho período) necesariamente afecta al cómputo del plazo de los nueve meses (...) Por lo anterior, debemos llegar a la conclusión de que en el supuesto previsto en el artículo 20.6. de la LOITSS, de producirse la firmeza del pronunciamiento judicial una vez transcurridos más de nueve meses desde el inicio de la actuaciones inspectoras, esto no supondrá la declaración de caducidad de las actuaciones previas de comprobación, procediéndose una vez comunicada la sentencia firme en la forma prevista en dicho artículo, es decir, se practicará el acta de liquidación, y en su caso de infracción, o en caso contrario, procediendo al archivo definitivo de actuaciones." 
interrumpir la prescripción de las deudas de Seguridad Social, actuación que estará a resultas del contenido de la sentencia firme del orden social ${ }^{1492}$.

- En quinto lugar, para el cómputo de esos dos plazos de caducidad de la actividad previa de comprobación, se aplican las siguientes reglas ${ }^{1493}$.

a) El cómputo de los plazos referidos se iniciará a partir de la fecha de la visita efectuada (Sentencia del Tribunal Supremo, Sala de lo ContenciosoAdministrativa, 1064/2020, de 21 julio -Rec. 2982/2018- ${ }^{1494}$ ), fecha de la visita que ha de hacerse constar en la diligencia de la actuación inspectora. Si iniciada visita de inspección a un centro o lugar de trabajo, no fuese posible concluir la comprobación por falta de aportación de los antecedentes necesarios, o por ausencia o negativa a declarar de la persona afectada por las comprobaciones, el funcionario actuante podrá requerir la comparecencia en la oficina pública que se señale, en cuyo caso, el cómputo se iniciará desde el momento de la comparecencia aportando toda la documentación (Sentencia del TS, Sala Social, de 8 de septiembre de 2020 -Rec. 25/2019-). Será día inicial del cómputo desde la visita o de la posterior comparecencia aportando toda la documentación que recoge el Criterio Técnico 35/2003 de la DGITSS. Si se estimase que el inicio de la actuación ante una empresa o sujeto a inspección,

1492 SACRISTÁN ENCISO, J. I.: "La nueva Ley 23/2015, de 21 de julio, Ordenadora del Sistema de Inspección de Trabajo y Seguridad Social. La reforma de un servicio público comprometido con la

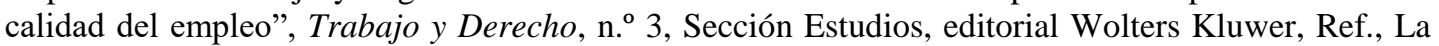
Ley 3426/2016, edición digital,

https://laleydigital-laleynext-es.ponton.uva.es/Content/Documento.aspx?params, p. 25, quien señala que, (sic) "de acuerdo con lo dispuesto en el artículo 20.6 de la Ley, en que la Inspección podrá iniciar y concluir las actuaciones previas de comprobación, comunicándolo a la empresa, si bien no podrá extender acta de infracción y/o de liquidación de cuotas hasta que no sea firme la sentencia y ésta sea comunicada a la ITSS, momento en el que de resultar procedente se iniciará el procedimiento administrativo sancionador y liquidatorio. El inicio de estas actuaciones implica, por ministerio de la Ley, la interrupción de la prescripción del pago de las cotizaciones sociales. Las actuaciones estarán dirigidas a comprobar los hechos denunciados o los solicitados por la autoridad que haya ordenado la inspección, siendo por tanto indiferente cuál sea el origen de la actuación inspectora. Se quiere con ello evitar que opere el instituto de la prescripción en el pago de las cuotas de Seguridad Social, cuando los trabajadores reclaman ante la jurisdicción competente por diferencias salariales, despido con ausencia de reconocimiento de relación laboral o encuadramiento indebido, entre otros supuestos. Pero también cuando la Inspección inicia procedimientos de derivación de responsabilidad por el impago de las cuotas en supuestos de sucesión de empresas o declaración de grupo de empresas a efectos laborales, a pesar de que sobre ello esté conociendo un órgano judicial. La Ley suple de esta forma el carácter no interruptivo que tienen las demandas cuando el objeto del petitum no concreta la regularización del pago de las cotizaciones de Seguridad Social".

${ }^{1493} \mathrm{El}$ art. 17.3 del ROFITSS sobre la forma de cómputo de los plazos, alude sólo al plazo de nueve o dieciocho meses, pero no al de cinco meses, considerando la DGITSS en Consulta de la DGITSS de 22.12.2015 que es aplicable también al plazo de cinco meses sobre la no interrupción de una actuación previa de comprobación.

${ }^{1494}$ En igual sentido STS, Sala Social, 65/2021, de 19 de enero-Rec. 3/2020-. 
debe ser mediante entrada en un domicilio particular, al estar éste protegido por el derecho constitucional a la inviolabilidad del domicilio, deberá obtenerse la previa autorización judicial, por lo que el período comprendido entre la solicitud judicial de entrada en el domicilio y la fecha de la visita, no deberá computarse dentro de la duración de la actividad previa de comprobación (en este sentido se ha pronunciado la Sentencia del TS, Sala ContenciosoAdministrativa 935/2020, de 7 de julio -Rec. 641/2018-, con relación a una actuación inspectora tributaria, que resulta aplicable en materia de inspección de Seguridad Social, por ser esa actividad un trámite judicial necesario para la visita, la que inicia propiamente la actividad de comprobación ante la empresa).

b) En segundo lugar, en caso de haberse iniciado la actuación mediante requerimiento de comparecencia del sujeto inspeccionado, es dies a quo la fecha efectiva de la comparecencia, siempre que haya aportado la totalidad de la documentación requerida con trascendencia en la actuación inspectora (art. 17.3 letra b), del ROFITSS y Criterio Técnico 35/2003 de la DGITSS). No obstante, en Sentencia del TSJ de Andalucía/Sevilla, Sala ContenciosoAdministrativa, 13 de junio de 2013 -Auto $\mathrm{n}^{\circ} 17 / 2011^{-1495}$, sitúa el dies a quo o fecha de inicio para el cómputo del plazo máximo de las actuaciones de comprobación, no en la fecha de la comparecencia, sino en la fecha de la orden

${ }^{1495}$ La Sentencia del TSJ declara que, "En el recurso de apelación se pretende por la Administración dar a entender que es de aplicación el art. 17.3.b) del Real Decreto 138/2000, de 4 de febrero, pues las actuaciones comenzaron por requerimiento de comparecencia, de ahí que el cómputo de nueves (sic) meses se debe iniciar desde la fecha de la efectiva comparecencia del sujeto obligado, con aportación en su caso de la totalidad de al (sic) documentación requerida, con trascendencia en la actuación inspectora, circunstancia que se reseñará en el Libro de Vistas. No es procedente la alegación pues el requerimiento por comparecencia, es una modalidad de actuación de la Inspección de Trabajo, de conformidad con lo dispuesto en el art. 14 de la Ley 42/1997, de 14 de noviembre, sin que en el supuesto que se enjuicia pueda estimarse como causa de iniciación de actuación inspectora previa, pues sólo podría asimilarse al supuesto del apartado e) del art. 9 del Real Decreto 928/1998, es decir, por propia iniciativa del Inspector de Trabajo. Sin embargo acierta la sentencia apelada al afirmar que la actuación inspectora previa se inició, por orden de servicio de la Jefatura de la Inspección Provincial, a tenor de lo dispuesto en el apartado b) del art. 9 del Real Decreto 928/1998. Si con posterioridad al inicio mediante las referidas órdenes de servicio de 12 de mayo y 2 de julio de 2009, se procedió a efectuar un requerimiento de comparecencia para el día 23 de julio de 2009, no se puede dotar al susodicho requerimiento de comparecencia del contenido de acto de inicio de actividad inspectora previa, pues ha de repetirse que fue iniciada por órdenes de servicio de 12 mayo y 2 de julio de 2009. Por tanto, ha de coincidirse con la sentencia apelada en que transcurrió el período de nueve meses, desde que se dictaron las referidas órdenes de ejecución y el acta de liquidación de 22 de abril de 2010, por lo que se produjo la caducidad de actuación inspectora, sin que pueda confundirse las modalidades de actuación de la Inspección de Trabajo del art. 15 del Real Decreto 138/2000, con la (sic) causas de iniciación de la actuación inspectora del art. 9 del Real Decreto 928/1998, que en el supuesto presente lo fue por orden de ejecución". 
de servicio, porque, según señala, no debe confundirse la forma de inicio de la actuación de la ITSS del art. 9 del RISOS (y art. 20.3 de la LOITSS) -por orden de servicio, orden superior, denuncia etc.-, con una de las modalidades de actuación de la Inspección (art. 21.1 de la LOITSS), como es el requerimiento de comparecencia, que según esa sentencia no es una forma de inicio de las actuaciones inspectoras. Impugnada esa sentencia mediante recurso de casación en interés de ley por la TGSS, el TS, Sala ContenciosoAdministrativa, en Sentencia, de 24 octubre 2014 -Rec. 3432/2013, RJ 2014/5403-, desestima el recurso interpuesto, declarando que no existe interés casacional $^{1496}$.

${ }^{1496}$ En esa Sentencia del TS, se señala para rechazar el recurso de la TGSS en interés de ley, "conviene advertir que no resulta compatible con la naturaleza de este recurso que se postule una doctrina legal respecto de una pluralidad de normas, como se hace en este caso, pues se ha realizado una agrupación normativa en torno al artículo 17 del Reglamento de Organización y Funcionamiento de la Inspección de Trabajo y Seguridad Social, aprobado por Real Decreto 138/2000, de 4 de febrero, para extraer, de todas ellas, la doctrina que favorece el mejor funcionamiento, a juicio de la recurrente, de la inspección de trabajo. Conviene tener en cuenta que la naturaleza de este singular recurso de casación en interés de la ley, precisa que la doctrina legal se deduzca de la correcta interpretación de una norma concreta y determinada, debiendo mediar, por tanto, entre dicha norma y la doctrina legal una conexión directa, y no genérica y difusa como acontece en este caso, por referencia a todo un grupo normativo. Pero es que, además, la doctrina legal que se postula, en el Fundamento Tercero, del escrito de interposición es, esencialmente, una mera transcripción de lo dispuesto en el artículo 17 del Reglamento que aprueba el RD 138/2000, que aunque efectivamente, como señala el Ayuntamiento recurrido y el Ministerio Fiscal, ha sido modificado mediante Ley 13/2012, de 26 de diciembre, esa reforma no afecta al contenido de la norma que ocasiona la controversia esgrimida en casación. Prueba de lo que decimos, respecto de la copia del texto de la norma, es que se pretende que se fije como doctrina legal, tras la cita del grupo de preceptos de aplicación antes citado, que "el inicio del cómputo del plazo de nueve meses de caducidad de las actuaciones comprobatorias de la Inspección de Trabajo y Seguridad Social, cuando la actuación comience por requerimiento de comparecencia, se iniciará desde la fecha de la efectiva comparecencia del sujeto obligado requerido con aportación, en su caso, de la totalidad de la documentación requerida". Y el mentado artículo 17 señala que para el cómputo del plazo de nueve meses se aplicarán las reglas siguientes: "b) si la actuación comienza por requerimiento de comparecencia, el computo se iniciará desde la efectiva comparecencia del sujeto obligado requerido con aportación, en su caso, de la totalidad de la documentación requerida, circunstancia que se reseñara en el Libro de Visitas". En todo caso, la doctrina legal que se postula no declara lo que la recurrente defiende que es, en definitiva, que la orden de servicio no es un acto de iniciación del procedimiento, pues éste comienza con el requerimiento por comparecencia, lo que determina que la doctrina postulada carece de la necesaria relevancia para el fallo. De modo que dicha doctrina legal propuesta no impediría interpretaciones como la que ahora combate. Repárese, a estos efectos, que la recurrente considera que la doctrina contenida en la Sentencia de instancia es gravemente dañosa para el interés general, porque entorpece la función de la inspección de trabajo. Sin embargo, el grave daño para el interés general que alega no está en la aplicación e interpretación de los artículos 17 del Reglamento que aprueba el RD 138/2000, y 8 del Reglamento que aprueba el RD 928/1998, pues no se discute la determinación de la fecha de inicio, dies a quo, para el cómputo del plazo de "nueve meses continuados ", sino que la discrepancia con la sentencia radica en la determinación de la naturaleza de las órdenes de servicio de la Inspección, si tienen o no el carácter de actuación inspectora, y si cursada una de esas órdenes, el procedimiento no puede entenderse iniciado hasta que tiene lugar el requerimiento de comparecencia. Recordemos que la sentencia impugnada, al confirmar otra dictada en apelación, señala que la actuación inspectora se inició por "por orden de servicio de la Jefatura de la Inspección Provincial", y si posteriormente se procedió a realizar un "requerimiento de comparecencia" ello no dota a dicho requerimiento del carácter de acto 
Discrepamos de la doctrina del TSJ de Andalucía, ya que, en primer lugar, el art. 17.3 letra b) del ROFITSS, señala claramente que el día inicial del cómputo del plazo de nueve meses tiene lugar en la fecha de comparecencia de la empresa aportando la documentación requerida, cuando la modalidad de inicio de la actuación haya sido mediante requerimiento de comparecencia; y en segundo lugar, porque no debe confundirse el origen de la actuación inspectora, o la forma de promoverse el posterior inicio de actuaciones inspectoras, con el inicio propiamente dicho de la actuación inspectora ante la empresa. En el art. 20.3 de la LOITSS, se regula el origen o forma de encomienda de las actuaciones inspectoras, y señala que, "la Inspección de Trabajo y Seguridad Social actuará de oficio siempre, como consecuencia, de orden superior, de orden de servicio (...)”. De este modo, la orden de servicio, la denuncia, etc., son formas de promover el inicio de las actuaciones, la causa próxima de una posterior actuación comprobatoria ante una empresa, en definitiva, formas de promover internamente una posterior actuación inspectora en la empresa. La orden de servicio no es, "per se", inicio alguno de una concreta actuación comprobatoria o inspectora ante la empresa, de modo que ha podido impartirse una orden de servicio, y posteriormente darse de baja o anularse sin haberse iniciado comprobación alguna. No puede confundirse la orden de servicio con el inicio de las actuaciones inspectoras. La orden de servicio es la forma de asignar internamente servicios o actuaciones a los funcionarios de la Inspección (art. 23.1 del ROFITSS ${ }^{1497}$ ), mientras que la

de inicio de la actividad inspectora. Por el contrario, la Letrada de la Tesorería General de la Seguridad Social recurrente considera que el procedimiento se inicia "como consecuencia de ordenes de servicios de inspección de 12 de mayo y 2 de julio de 2009, como consecuencia de las cuales se citó a la empresa Ayuntamiento de Cádiz requiriéndole la presentación de la correspondiente documentación a comparecencia en julio de 2009". No basta, en definitiva, para avalar la naturaleza errónea y gravemente dañosa al interés general de la doctrina sentada por la sentencia recurrida que la misma perjudique o dificulte, a juicio de la recurrente, la actividad de la inspección de trabajo. Ni resulta procedente, al socaire de este remedio procesal extraordinario, que mediante el mismo se formule, como aquí sucede, un replanteamiento global del razonamiento en virtud del cual la sentencia termina desestimando el recurso de apelación, y confirmando la sentencia de instancia, como si de un recurso ordinario se tratara, pues ello desborda los contornos propios de esta modalidad de recurso de casación. Por cuanto antecede, debemos desestimar el presente recurso de casación interés de la ley".

1497 “Artículo 23. Órdenes de servicio.

1. El señalamiento de actuaciones concretas a los inspectores y a los equipos de Inspección se materializará en órdenes de servicio, en los supuestos a que se refiere el apartado 2 del artículo anterior".

El art. 22.2, establece "La actuación por orden superior se formalizará mediante orden emitida conforme al artículo siguiente, y se expedirá en todos los supuestos a que se refiere el artículo 9.1 del Reglamento General sobre procedimientos para la imposición de sanciones por infracciones de orden 
actuación inspectora ante la empresa se inicia mediante visita, requerimiento de comparecencia aportando documentación, o en virtud de expediente administrativo, por lo que en esa visita $o$ en ese requerimiento de comparecencia ha de situarse la fecha inicial del cómputo del plazo de caducidad de la actuación, ya que la finalidad de ese plazo es una garantía de la empresa de no tener que soportar indefinidamente la carga de hallarse sujeta a actuaciones de comprobación, con independencia de la fecha en que se haya registrado la orden de servicio en el sistema informático de la de ITSS, ya que esta fecha no tiene efectos jurídicos en el inicio de la actuación ante la empresa. En el ámbito tributario, la jurisprudencia no incluye las actividades de programación de las actuaciones inspectoras, como la selección de los sujetos que van a ser objeto de investigación o la asignación interna de actuaciones a los inspectores, dentro del cómputo de duración de la actuación inspectora de comprobación, al no formar parte propiamente esos actos internos de una actuación inspectora ante la empresa o sujeto investigado (Sentencia del TS, Sala Contencioso-Administrativa, núm. 935/2020, de 7 de julio -Rec. 641/2018-).

Cuestión que ha sido resuelta por el Tribunal Supremo, Sala ContenciosoAdministrativa en Sentencia 1064/2020, de 21 julio -Rec. 2982/2018-, al señalar que la actuación inspectora, a efectos del cómputo del plazo de caducidad, no la inicia la orden de servicio, sino la visita, el requerimiento o el expediente administrativo ${ }^{1498}$. Tampoco se inicia en la fecha en que la TGSS

social y para los expedientes liquidatorios de cuotas de la Seguridad Social aprobado por Real Decreto 928/1998, de 14 de mayo."

${ }^{1498}$ En esa Sentencia se señala expresamente que "la finalidad del art. 9 del RD 928/1998, es clasificar las formas en que se puede dar lugar la actividad de comprobación previa de la inspección, pero no regula el acto iniciador del procedimiento. Es así porque ninguno de estos actos o hechos son actos de iniciación del procedimiento. Basta observar que en catálogo del art. 9 se hace mención a formas de promover la actividad de inspección, como son la denuncia o la petición derivada de un procedimiento judicial que, como se comprenderá, no determinan por sí mismas el inicio de procedimiento alguno. Tampoco lo hace la orden de servicio, que tiene por objeto ordenar la actividad de los servicios de inspección como estructura, pero en modo alguno tiene trascendencia externa alguna de cara a considerar iniciado el procedimiento", para añadir, "todas estas formas de promover la actividad previa de comprobación son independientes del acto iniciador del procedimiento de comprobación, que será, según los casos, la visita de inspección, el requerimiento previo, o el expediente administrativo cuando el contenido de su actuación permita iniciar y finalizar aquélla" concluyendo que, "la orden de servicio es el medio organizativo utilizado por la jefatura de inspección para asignar tareas determinadas, pero en modo alguno dicha orden de servicio puede ser considerada, pues ninguna norma lo establece así, como día inicial en el cómputo del plazo máximo de duración del procedimiento en cuestión”. En esta Sentencia 1064/2020, de 21 julio -Rec. 2982/2018-, se fija como doctrina de interés casacional que "la doctrina jurisprudencial que fijamos es que el cómputo del plazo 
solicita la actuación inspectora, sino cuando consecuencia de esa solicitud se efectúa la visita de inspección o se comparece aportando toda la documentación (Sentencia del TS, Sala Social, 65/2021, de 19 de enero -Rec. 3/2020-).

c) En tercer lugar, no se considerará incluido, en ningún caso, en el cómputo de los plazos, el tiempo transcurrido durante el aplazamiento concedido al sujeto obligado en los supuestos de formularse requerimientos de subsanación de incumplimientos previos por parte del órgano inspector.

d) En cuarto lugar, la fecha final o dies ad quem del pazo de duración de la actividad previa de investigación, será la fecha en que finalicen las comprobaciones extendiéndose alguna de las medidas previstas en el art. 22 de la LOITSS. Extensión de medidas que ponen el punto final a esa labor de comprobación, por lo que deben tener lugar dentro de la duración máxima de esa actividad previa de investigación ${ }^{1499}$.

Señalar que el período del 14.3.2020 al 31.5.2020 queda excluido del cómputo del de los plazos de duración de las actuaciones comprobatorias de la Inspección de Trabajo y Seguridad Social, con la excepción de aquellas actuaciones comprobatorias derivadas de situaciones estrechamente vinculadas a los hechos justificativos del estado de alarma, o aquellas que por su gravedad o urgencia resulten indispensables para la protección del interés general

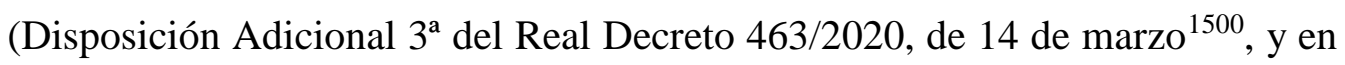
el art. 9 del Real Decreto 537/2020, de 22 de mayo, por el que se prorrogó el estado de alarma ${ }^{1501}$, y Disposición Adicional $2^{\text {a }}$ del Real Decreto-Ley

de nueve meses establecido para las actuaciones de comprobación de la Inspección de Trabajo y Seguridad Social no se inicia, en caso de que exista orden de servicio y posterior visita de inspección, cuando se dicta la orden de servicio, sino cuando se produce la visita de inspección que, en tal supuesto, es el día inicial para el cómputo del plazo de caducidad de nueve meses previsto en el artículo 17 del Reglamento de Organización y Funcionamiento de la Inspección de Trabajo y Seguridad Social, aprobado por Real Decreto 138/2000, de 4 de febrero".

${ }^{1499}$ En el Criterio Técnico 22/1999, de 13 de julio de 1999, de la DGITSS, interpretativo sobre los requisitos de las Actas de Infracción y de Liquidación -Ref.: La Ley 311/1999-, se pronuncia acerca de si las actuaciones comprobatorias deben considerarse finalizadas cuando se extiendas las actas o cuando el funcionario ha reunido todo el material probatorio, concluyendo que finalizan con la extensión de las actas.

A igual conclusión se llega en el Criterio Técnico 35/2003, de la DGITSS, que las actuaciones comprobatorias deben considerarse finalizadas en la fecha del acta.

${ }^{1500}$ BOE del 14.3.2020, según la redacción del Real Decreto 465/2020, de 17 de marzo -BOE del 18.3.2020-

${ }^{1501}$ BOE del 23.5.2020. 
15/2020, de 21 de abril, de medidas urgentes complementarias para apoyar la economía y el empleo).

- En sexto lugar, si se incumplen los plazos de cinco meses de interrupción de actividad, o de nueve meses máximos de duración o el de su prórroga, se produce la caducidad de la actividad inspectora previa de comprobación. Caducidad que ha de ser declarada mediante resolución administrativa expresa en la que se ordenará el archivo de las actuaciones practicadas, frente a la que cabe recurso de alzada ante el superior jerárquico ${ }^{1502}$, sin que quepa iniciarse nuevo procedimiento por el mero transcurso del plazo máximo si no hay resolución expresa declarando la caducidad (Sentencia del TS, Sala Contencioso-Administrativa 1667/2020, de 3 de diciembre Rec. 8332/2019-).

En la Sentencia del TS, Sala Contencioso-Administrativa, de 6 de noviembre de 2012 -Rec. 3558/2011- ${ }^{1503}$, sobre la caducidad de la actuación previa de comprobación, se estableció que si transcurren los plazos máximos de la actuación previa, ésta caducará, determinando la nulidad del acta de infracción o de liquidación, ya que en el art. 8.2 del RISOS, se establece, por un lado, que expirado el plazo de esas actuaciones, “decae el derecho a extender el acta”, y, por otro lado, se habla de "actuaciones previas caducadas". Caducidad que debe ser declarada de modo expreso y formal en una resolución administrativa que debe dictarse, y en la

1502 STS, Sala Contencioso-Administrativa, de 6 de noviembre de 2012 -Rec. 3558/2011-.

En la Consulta de la DGITSS, de 13 de marzo de 2015, "sobre la necesidad de dictar resolución declarando la caducidad de las actuaciones previas de comprobación, Sentencia del TS de 6 de noviembre de 2012" -Ref.: La Ley 754/2015-, acerca de la competencia para dictar esa resolución, se señala que, "ante el vacío legal sobre quién debe dictar tal acto se razona en el cuerpo de este informe que corresponde a quien tiene la competencia para valorar los efectos del resultado de la fase previa (normalmente el Jefe Provincial de la Inspección). El acto será recurrible en alzada, ante el superior jerárquico". Por otro lado, en la nota informativa de la DGITSS -actual dirección del OEITSS-, sobre la necesidad de dictar resolución administrativa declarando la caducidad de las actuaciones comprobatorias previas, emitida en el año 2015, tras la sentencia referida del TS, y dirigida a las Inspecciones Provinciales y Direcciones Territoriales, se indicaba con mayor rigor, y en función del ámbito territorial y competencial de la actuación inspectora, que "la competencia para dictar la resolución de caducidad correspondería al Jefe de la Inspección Provincial, o en su caso Director de la Dirección Especial o Director Territorial", por ser los superiores jerárquicos de los inspectores o Subinspectores en función del ámbito territorial de la actuación inspectora (arts. 22, 24.2, 27, 28 y 30 del Real Decreto 192/2018, de 6 de abril, por el que se aprueban los estatutos del Organismo Autónomo Estatal Inspección de Trabajo y Seguridad Social -BOE del 7.4.2018-).

1503 En el Fundamento de Derecho Quinto de la Sentencia de 6 noviembre de 2012, se señala, "la superación del plazo máximo de paralización previsto en el art. 8.2 del Real Decreto 928/1998, ha de tener por fuerza las siguientes consecuencias: a) la Administración debe declarar la caducidad de las actuaciones previas de comprobación que está tramitando, b) debe proceder también a acordar el archivo de las mismas, c) sin perjuicio de lo anterior, si no ha prescrito la infracción presuntamente cometida, puede incoar unas " nuevas actuaciones de comprobación referentes a los mismos hechos". 
que se ordenará también el subsiguiente archivo de las actuaciones, resolución impugnable en alzada ante el superior jerárquico.

De exceder la actuación previa de comprobación su duración máxima legal, o de incumplirse el plazo máximo de paralización, opera la caducidad, que ha de declarase expresamente por acto administrativo, y que podrá ser objeto de recurso, a diferencia de la propia actividad investigadora ante la que no cabe recurso alguno, pudiendo ser objeto de impugnación el acta de liquidación de derivación de producirse irregularidades en su desarrollo que afecten a las garantías, derechos o intereses del administrador. La Sentencia del TS, de 6 de noviembre de 2012, asimila la fase de comprobación previa a una especie de instrucción previa del procedimiento sancionador o liquidatorio.

La caducidad de la actividad previa de comprobación no interrumpirá el cómputo de la prescripción, y decaerá la posibilidad de extender acta de liquidación como consecuencia de tales actuaciones previas, siendo nulas las actas extendidas (art. 8.2 del RISOS). En esos supuestos de caducidad de la actividad previa de comprobación, la ITSS podrá promover nuevas actuaciones de investigación y comprobación referentes a los mismos sujetos y hechos, extendiendo, en su caso, las actas correspondientes si la deuda y la responsabilidad no han prescrito (art. 8.2 del RISOS). Actuaciones que para que sean nuevas no bastará con aludir sin más a las diligencias practicadas antes de la paralización, sino que es necesario que en la nueva acta extendida se cumplan los siguientes requisitos ${ }^{1504}: 1^{\circ}$ que se deje constancia de la paralización y archivo producido y de la incoación de unas nuevas actuaciones previas de comprobación; $2^{\circ}$ que se exterioricen las razones de la incorporación, es decir, se explique por qué no es necesario, conveniente o posible repetir las concretas diligencias que se incorporan a ese nuevo procedimiento; y $3^{\circ}$ que se justifique también que la traída e incorporación de esas diligencias al nuevo procedimiento, y su toma en consideración, no menoscaban los derechos del presunto responsable de la deuda derivada.

\subsection{Caducidad del procedimiento de derivación iniciado con acta de liquidación.}

Concluida la actividad inspectora previa de comprobación y extendida acta de liquidación por derivación de responsabilidad, con el acta se inicia en sentido estricto el

${ }^{1504}$ STS, Sala Contencioso-Administrativa, de 6 de noviembre de 2012 -Rec. 3558/2011-. 
procedimiento administrativo de derivación de responsabilidad, que tienen un plazo máximo de seis meses para dictarse y notificarse la resolución administrativa, ya que, en otro caso, el procedimiento caducará y deberá anularse el acta de liquidación (arts. 20 y 33 del RISOS). Plazo seis meses que se computa desde la fecha del acta de liquidación hasta la notificación de la resolución que eleva a definitiva la liquidación o derivación de responsabilidad, comprendiendo a estos efectos como notificación su intento (art. 40.4 de la LPACAP, 20.3 y 33.2 del RISOS, y STS, Contencioso-Administrativa, Sentencia 423/2018, de 15 de marzo -Rec. 1121/2017- ${ }^{1505}$ ). Es dies ad quem la fecha de notificación de la resolución o intento válido de notificación, por ser de aplicación supletoria los arts. 21 y 40.4 de la LPACAP y la doctrina de las Sentencias del TS, Sala Contencioso-Administrativa, de 23 de febrero de 2010 -Rec. 243/2008- y 7 de febrero de 2014 -Rec. 4607/2012-, dictadas en recurso de casación en interés de ley ${ }^{1506}$.

Ante esas Sentencias, por la DGITSS -actual Dirección del OEITSS- en nota interna de fecha 14 de octubre de 2015, se concluye, previo informe de la Abogacía del Estado, que el dies a quo del plazo es la fecha del acta, no la fecha de la visita de inspección, y, que el dies ad quem del cómputo del plazo máximo para resolver, "será el de la notificación de la resolución, no el del día en que se dicte".

Sorprendentemente, ante esa jurisprudencia reiterada de la Sala ContenciosoAdministrativa del TS, que es la competente para conocer sobre las derivaciones de responsabilidad a los administradores sociales de deudas por cotizaciones, en una

${ }^{1505}$ En igual sentido SSTS, misma Sala, 7 de octubre de 2011 -Rec. 40/2010-; 3 de diciembre de 2013 Rec. 557/2011-; y 14 de octubre de 2016 -Rec. 2109/2015-, entre otras.

${ }^{1506}$ Las Sentencias del TS, Sala Contencioso-Administrativa, de 23 de febrero de 2010 -Rec. 243/2008- y de 7 de febrero de 2014 -Rec. 4607/2012- (dictadas en Recurso de casación en interés de ley), consideran que es de aplicación la regulación de la LPACAP, entendiendo que prevalece esa disposición legal frente a la disposición reglamentaria del RISOS, disposición legal que fija el día final del cómputo del plazo, en la fecha de la notificación de la resolución que eleva o no a definitiva el acta de liquidación. Según la Sentencia, de 23 de febrero de 2010, esa es, "nuestra propia jurisprudencia, pues en la Sentencia, de 12 de noviembre de 2001, dictada en el recurso de casación en interés de la ley núm. 256/2000, fijamos como dies ad quem (día final) del plazo de caducidad el de la notificación de la resolución del expediente", para añadir más adelante que, "tras aquella Sentencia, aquel criterio sobre el día final se ha reiterado, entre otras, en las Sentencias de 24 de octubre de 2007 (Recurso de Casación para la unificación de doctrina, núm. 174/2006) y 25 de marzo de 2009 (Recurso de Casación en interés de la ley, núm. 7/2008 ). Además, ese criterio que reiteramos y mantenemos se sustenta también: en la consideración del carácter supletorio de la Ley 30/1992 en la materia que nos ocupa". La referencia a la Ley 30/1992, debe entenderse a la actual LPACAP (Ley 39/2015, de 1 de octubre). Los argumentos de la Sentencia son contundentes, por haber desconocido el legislador la doctrina que ya venía fijando reiteradamente ese Alto Tribunal desde el año 2001, pese a lo cual, en la última reforma de los artículos 20 y 33 del RISOS del año 2011, se seguía recogiendo la fecha de la resolución como fecha final de cómputo del plazo de caducidad, terminando la sentencia indicando que, si la fecha de la resolución operase como fecha final, podría dar lugar a alteraciones de la misma para soslayar la caducidad, con la subsiguiente indefensión del interesado. 
reciente sentencia de la Sala Social (Sentencia del TS 527/2020, de 24 de junio -Rec. 3/2018-), resolviendo un recurso contra un acta de infracción en materia de falta de cotización a la Seguridad Social, que no iba acompañada de acta de liquidación conjunta por los mismos hechos, aplica literalmente el art. 33.2 del RISOS, esto es, que el dies ad quem es la fecha de la resolución y no de la notificación, sin mayor argumentación jurídica, ni sin cita de la jurisprudencia dictada en sentido contrario por la sala contenciosa, ni sin argumentar por qué no sería de la aplicación la LPACAP, lo que sería lo pertinente si se pretende fijar doctrina distinta y discrepar de la línea mantenida por la Sala Contencioso-Administrativa.

Señalar que durante el período del 14.3.2020 al 31.5.2020, como consecuencia del estado de alarma por la crisis sanitaria del COVID-19, se suspendieron los plazos del procedimiento administrativo liquidatorio (Disposición Adicional 3a del Real Decreto 463/2020, de 14 de marzo, Disposición Final 2a apartados 2 y 3 del Real Decreto-Ley 15/2020, de 21 de abril ${ }^{1507}$, y artículo 9 del Real Decreto 537/2020, de 22 de mayo ${ }^{1508}$ ).

Producida la caducidad del procedimiento administrativo, ha de ordenarse el archivo del expediente, con la anulación del acta, sin perjuicio de poder iniciarse un nuevo procedimiento de derivación de responsabilidad (art. 7.5 del RISOS), pero éste sólo podrá iniciarse si hay previa resolución expresa de caducidad, no siendo suficiente que haya transcurrido el plazo máximo para resolver y notificar el acta previa de derivación (Sentencia del TS, Sala Contencioso-Administrativa 1667/2020, de 3 de diciembre Rec. 8332/2019-).

\section{La ejecutividad y la no suspensión del pago de la deuda objeto de la derivación administrativa de responsabilidad.}

Si la ejecutividad es nota distintiva de toda resolución administrativa, en el pago de las deudas de Seguridad Social esa nota toma su máximo protagonismo, ya que una vez se

\footnotetext{
1507 “Disposición Adicional Segunda. Suspensión de plazos en el ámbito de actuación de la Inspección de Trabajo y Seguridad Social (...):

2. Durante el periodo de vigencia del estado de alarma, declarado por el Real Decreto 463/2020, de 14 de marzo, y sus posibles prórrogas, quedan suspendidos los plazos de prescripción de las acciones para exigir responsabilidades en lo que se refiere al cumplimiento de la normativa de orden social y de Seguridad Social.

3. Todos los plazos relativos a los procedimientos regulados en el Reglamento General sobre procedimientos para la imposición de sanciones por infracciones de orden social y para los expedientes liquidatorios de cuotas de la Seguridad Social, aprobado por Real Decreto 928/1998, de 14 de mayo, están afectados por la suspensión de plazos administrativos prevista en la Disposición Adicional Tercera del Real Decreto 463/2020, de 14 de marzo”.

${ }^{1508}$ BOE del 23.5.2020.
} 
dicta la resolución administrativa, sea la resolución de la TGSS declarando al responsabilidad derivada y la reclamación de deuda por derivación en la que se recoge la deuda objeto de responsabilidad derivada, o la resolución que eleva a definitiva el acta de liquidación, el sujeto responsable tiene un plazo para ingresar el importe de la deuda, salvo que garantice o consigne su importe, sin que deba esperarse a que sea firme en vía administrativa la resolución del acta o la reclamación de deuda ${ }^{1509}$ (arts. 33 apartados 3 y 4, y 34.3 del TRLGSS, arts. 64 y 66 del RGRSS y arts. 33.3 y 34.3 del RISOS). Esta ejecutividad es una manifestación de la presunción de legitimidad y validez de los actos administrativos ${ }^{1510}$

De derivarse la deuda a los administradores por la TGSS mediante reclamación de deuda, en caso de ser deudas por cuotas y conceptos de recaudación conjunta con éstas, incluidos recargos sobre unas y otros, impugnadas o no, deberán hacerse efectivos dentro de los plazos siguientes ${ }^{1511}$ : a) Las notificadas entre los días 1 y 15 de cada mes, desde la fecha de la notificación hasta el día 5 del mes siguiente o el inmediato hábil posterior; y b) las notificadas entre los días 16 y último de cada mes, desde la fecha de notificación hasta el día 20 del mes siguiente o el inmediato hábil posterior.

Contra la reclamación de deuda se podrá interponer recurso administrativo de alzada, y contra la resolución de éste, recurso contencioso-administrativo (art. 46.1 del RGRSS). El procedimiento recaudatorio sólo se suspenderá, de interponerse recurso administrativo, si el recurrente garantiza con aval o consigna a disposición de la Tesorería General de la Seguridad Social el importe de la deuda exigible, incluidos los recargos, intereses y las costas del procedimiento.

Si la derivación de responsabilidad es por deudas por prestaciones de responsabilidad de la sociedad de capital, una vez declarada la responsabilidad de la sociedad en el pago de la prestación, nos hallamos ante una deuda por prestaciones cuya gestión recaudatoria compete a la TGSS, que tiene encomendada la actividad administrativa conducente a la realización de los créditos y derechos de la Seguridad Social, entre los que se incluyen

1509 Sobre la no suspensión del procedimiento recaudatorio por la interposición de recursos administrativos, véase, MARTÍNEZ LUCAS, J. A.: "La suspensión del procedimiento recaudatorio de la Seguridad Social como consecuencia de la interposición de los recursos administrativos y reclamaciones previas", Actualidad Administrativa, Sección Doctrina, 2000, p. 649, Tomo 2, Editorial La Ley, Ref. La Ley 1482/2001.

1510 TRILLO GARCÍA, A. R.: "Artículo 30. Reclamaciones de deudas", en AA.VV. (Dir.: GARCÍAPERROTE ESCARTÍN, I. y MERCADER UGUINA, J. R.): Comentarios a la Ley General de la Seguridad Social, editorial Lex Nova- Thomson Reuters, $1^{a}$ edición, julio 2015, p. 189.

${ }^{1511}$ Art. 33.3 del TRLGSS y art. 64 del RGRSS. 
las prestaciones de responsabilidad empresarial (arts. 1.d), 69 y 70 del RGRSS), siendo competente también para derivar la deuda a los administradores sociales (art. 12.2 del RGRSS). De ser prestaciones de desempleo de responsabilidad de la empresa sociedad de capital, la competencia para reclamar a ésta el pago en el período voluntario de ingreso, no es de la TGSS, sino que corresponde a la entidad gestora de esa prestación SEPE o ISM-, correspondiendo la recaudación ejecutiva a la TGSS (art. 295 del TRLGSS y art. 32 del Real Decreto 625/1985, de 2 de abril, por el que se desarrolla la Ley $31 / 1984$, de 2 de agosto, de Protección por Desempleo ${ }^{1512}$ ).

Las deudas por prestaciones de responsabilidad de la sociedad de capital, podrán reclamarse a los administradores sociales por la TGSS mediante el procedimiento administrativo de derivación de responsabilidad, en cuanto pasan a ser deudas o recursos de Seguridad Social objeto de la gestión de recaudación (art. 18.3 TRLGSS y art. 12 RGRSS). Deuda derivada, cuyo plazo reglamentario de ingreso será dentro del mes siguiente a la notificación de la reclamación administrativa, ya que al no hallarnos ante deudas por cuotas, no son aplicables los plazos del art. 33.3 del TRLGSS y art. 64 del RGRSS, sino que de conformidad con el art. 33.4 del TRLGSS, será de aplicación el plazo establecido en los arts. 55.2 y 70 del RGRSS para el ingreso de otros recursos de Seguridad Social distinto a las cuotas.

De haberse derivado la responsabilidad a los administradores sociales mediante acta de liquidación de cuotas, los importes de las cuotas de Seguridad Social y demás cuotas de recaudación conjunta reclamadas, sean o no objeto de recurso de alzada, deberán hacerse efectivos en la Tesorería General de la Seguridad Social hasta el último día del mes siguiente al de la notificación de la resolución que eleva a definitiva la liquidación, iniciándose, en otro caso, el procedimiento de apremio a que se refieren los artículos 33 y siguientes del Texto Refundido de la Ley General de la Seguridad Social, salvo que se garantice con aval bancario suficiente o se consigne el importe en la Tesorería General de la Seguridad Social (art. 33.3 párrafo 1 del RISOS y art. 66 del RGRSS).

Finalmente señalar que si el administrador social responsable de las deudas de Seguridad Social de la sociedad de capital, residiere en un Estado miembro de la Unión Europea y/o tuviere bienes en ese Estado con los que poder hacer frente a la responsabilidad derivada, una vez no haya podido hacerse efectivo en España la

1512 BOE 7.5.1985, según redacción dada a ese precepto por Real Decreto-Ley 16/2014, de 19 de diciembre, por el que se regula el Programa de Activación para el Empleo -BOE del 20.12.2014-. 
totalidad de la responsabilidad contraída con la Seguridad Social, en el Reglamento (CE) 987/2009, del Parlamento Europeo y del Consejo, de 16 de septiembre de 2009, por el que se adoptan las normas de aplicación del Reglamento (CE) 883/2004, sobre la coordinación de los sistemas de Seguridad Social ${ }^{1513}$, se prevé la colaboración entre las instituciones de Seguridad Social españolas y las instituciones o autoridades competentes del otro Estado miembro, mediante la recaudación por las autoridades competentes del otro estado miembro en el que reside o tuviere bienes el deudor, de los títulos ejecutivos emitidos en España por la Seguridad Social o los tribunales (arts. 75 a 85 del Reglamento CE- 987/2009, de 16 de septiembre de 2009).

En virtud de esos preceptos del Reglamento Comunitario la Seguridad Social Española solicitará la colaboración a la Institución competente del otro Estado para que proceda a ejecutar el título emitido en España, reconociendo el Estado requerido directamente ese título ejecutivo, para proceder a dar la misma tramitación que daría de ser un título ejecutivo propio. Obtenido el cobro del crédito el Estado procederá a su transferencia a la Seguridad Social española. Para que la Seguridad Social española puede requerir al otro Estado miembro la colaboración en el cobro del crédito, deben cumplirse tres condiciones. En primer lugar, que el crédito o el instrumento que permite su ejecución no hayan sido impugnados en España, o si impugnado se prevea su inmediata ejecución - caso de la legislación interna española- y la Seguridad Social española haya comunicado esos efectos y la voluntad de que se proceda a la no suspensión de la ejecución (art. 78.2.a) y 81.2 del Reglamento). En segundo lugar, que previamente se haya seguido el procedimiento recaudatorio en España sin haberse logrado el pago íntegro del crédito. Y, en tercer lugar, que el crédito no esté prescrito.

Son créditos de Seguridad Social objeto de esta colaboración en la gestión recaudatoria, según el art. 75.1 del Reglamento Comunitario, los créditos por cotizaciones o por prestaciones indebidamente abonadas ${ }^{1514}$.

\footnotetext{
${ }^{1513}$ DOUE, Serie L, de 30.10.2009.

1514 Artículo 75. Definiciones y disposiciones comunes.

1. A efectos de la presente sección se entenderá por: -«crédito», cualquier crédito en relación con las cotizaciones o prestaciones pagadas o abonadas indebidamente, incluidos los intereses, multas, sanciones administrativas y cualesquiera otras cargas y gastos relacionados con el crédito de acuerdo con la legislación del Estado miembro que reclame el crédito en cuestión. (...)
} 


\section{Suspensión del procedimiento de derivación de responsabilidad por aplazamiento de la deuda de la sociedad de capital.}

La sociedad de capital podrá solicitar la concesión de aplazamiento en el pago de las deudas con la Seguridad Social, cuando las dificultades económico-financieras le impidan cumplir en plazo reglamentario con el pago de esos débitos (art. 23 del TRLGSS y art. 31.1 del RGRSS).

La concesión por la TGSS del aplazamiento de las deudas de Seguridad Social a la sociedad de capital, tendrá tres grandes efectos relacionados con la derivación administrativa de responsabilidad. En primer lugar, la concesión del aplazamiento de las deudas de Seguridad Social de la sociedad de capital suspende el procedimiento recaudatorio que estuviere en tramitación de las deudas aplazadas (art. 23.1 del TRLGSS y art. 31.3 del RGRSS). En segundo lugar, en virtud de la concesión del aplazamiento y siempre que la empresa cumpla las condiciones establecidas en el mismo, con relación a las deudas aplazadas se considera que la sociedad se halla al corriente en el cumplimiento de esas obligaciones (art. 31.3 del RGRSS), por lo que no podrá derivarse la responsabilidad a otros sujetos responsables, o de haberse iniciado, deberá suspenderse su tramitación. En tercer lugar, que para que se mantenga la suspensión del procedimiento recaudatorio y en su caso de la derivación administrativa de responsabilidad, la sociedad de capital no sólo debe cumplir las condiciones pactadas en el mismo, y entre ellas, ingresar dentro del mes siguiente a la concesión las cuotas inaplazables ${ }^{1515}$, asegurando ${ }^{1516}$ con aval suficiente u otra garantía autorizada, en su

1515 Son deudas inaplazables, las cuotas correspondientes a las contingencias de accidentes de trabajo y enfermedades profesionales a cargo de la empresa, y la aportación de los trabajadores correspondiente a las cuotas aplazadas (art. 23.2 del TRLGSS y art. 32.1 del RGRSS).

${ }^{1516}$ De conformidad con el art. 33.4 del RGRSS, no será necesaria la constitución de garantías, en los siguientes supuestos: a) Cuando el solicitante sea la Administración General del Estado, una comunidad autónoma, una entidad de la Administración local u organismos o entidades de derecho público con personalidad jurídica propia vinculados o dependientes de cualquiera de tales Administraciones, siempre que no actúen en el tráfico jurídico bajo forma societaria mercantil. b) Cuando el total de la deuda aplazable sea igual o inferior a 30.000 euros, o cuando, siendo la deuda aplazable inferior a 90.000 euros, se acuerde que se ingrese al menos un tercio de esta última antes de que hayan transcurrido 10 días desde la notificación de la concesión y el resto en los dos años siguientes. Estas cantidades podrán ser modificadas por resolución del Director General de la Tesorería General de la Seguridad Social. c) Cuando se trate de deuda correspondiente a prestaciones indebidamente percibidas que no hubieran sido satisfechas dentro del plazo o de los plazos reglamentarios fijados al efecto, siempre que el sujeto responsable de su reintegro mantenga su condición de pensionista de la Seguridad Social. d) En los aplazamientos en que, por concurrir causas de carácter extraordinario que así lo aconsejen, el Secretario de Estado de la Seguridad Social autorice expresamente la exención de garantías, previa propuesta favorable del Director General de la Tesorería General de la Seguridad Social". Los importes del apartado b) del art 33.4 del RGSS, se han elevado mediante Resolución de 6 de abril de 2020 -BOE del 9.4.2020-, de la Tesorería General de la 
caso, la deuda aplazada, los recargos, intereses y costas, sino que deberá igualmente la sociedad cumplir en plazo con las nuevas obligaciones con la Seguridad Social que se vayan devengando (arts. 23.7 del TRLGSS y 36.2 del RGRSS), ya que si se incumplen las nuevas obligaciones, se produce la falta de pago de alguna deuda aplazada o cualquier otra de condición del aplazamiento, se reanuda la tramitación del procedimiento recaudatorio que se hubiere suspendido, prosiguiendo, sin más trámite el procedimiento de apremio que se hubiera iniciado antes de su concesión, con respecto a la sociedad de capital (art. 23.6 del TRLGSS y art. 36.1 del RGRSS), e iniciándose o, en su caso, reanudándose la tramitación del procedimiento de derivación de responsabilidad ante los demás sujetos responsables solidarios -los administradores-.

Igualmente, señalar que la suspensión o terminación del procedimiento recaudatorio seguido contra un responsable solidario, suspende o pone fin al procedimiento que se siga contra el resto de los responsables solidarios, a no ser que se produzcan con motivo de impugnaciones o revisiones fundadas en causas que sólo concurran en alguno de ellos (art. 13.5 del RGRSS).

\section{IV.- DERIVACIÓN ADMINISTRATIVA DE RESPONSABILIDAD SOLIDARIA Y SUBSIDIARIA.}

La responsabilidad del administrador en las deudas de Seguridad Social prevista en la legislación de sociedades, es con carácter general una responsabilidad solidaria, estemos ante la responsabilidad por causa de disolución de pleno derecho o causa legal de disolución (arts. 360 y 367 de la LSC), responsabilidad en la sociedad en formación (arts. 36 a 38 de la LSC), o en la sociedad unipersonal sobrevenida, en este caso del socio único, que podrá ser o no el administrador (art. 14 de la LSC). Los supuestos de responsabilidad subsidiaria son más excepcionales, que fundamentalmente se reconducen a los supuestos de responsabilidad de los socios en la sociedad irregular y

\footnotetext{
Seguridad Social, al establecerse que "en el supuesto previsto en el artículo 33.4.b) del Reglamento General de Recaudación de la Seguridad Social, aprobado por el Real Decreto 1415/2004, de 11 de junio, no será necesaria la constitución de garantías para asegurar el cumplimiento del aplazamiento en el pago de deudas con la Seguridad Social cuando el total de la deuda aplazable sea igual o inferior a $150.000 €$ o cuando, siendo la deuda aplazable inferior a $250.000 €$, se acuerde que se ingrese al menos un tercio de esta última antes de que hayan transcurrido diez días desde la notificación de la concesión y el resto en los dos años siguientes".

Mediante Resolución, de 16 de julio de 2004 -BOE del 14.8.2004-, de la Tesorería General de la Seguridad Social, se determinan las funciones en materia de aplazamientos de pago de deudas, reintegros de prestaciones indebidamente percibidas, compensación, desistimiento, convenios o acuerdos en procedimientos concursales y anuncios de subastas en Boletines Oficiales, dentro de los distingos órganos de la TGSS. Resolución que ha tenido diversas modificaciones, la última, de fecha 6 de abril de 2020 -BOE del 9.4.2020-.
} 
en las transformaciones societarias (art. 39 de la LSC y art. 21 de la Ley 3/2009, de 3 de abril, en relación con los arts. 127, 128, 148 y 237 del Código de Comercio).

La responsabilidad solidaria o subsidiaria tiene sus consecuencias jurídicas en la derivación administrativa de responsabilidad, y en el procedimiento administrativo de derivación, siendo sus rasgos distintivos y diferenciadores los siguientes:

- En primer lugar, en caso de responsabilidad solidaria el administrador responde del importe de la deuda de la sociedad, de los recargos, intereses y costas del procedimiento (arts. 33.2 y 34.1.c), del TRLGSS). Por el contrario, de ser una responsabilidad subsidiaria, el responsable sólo responde del principal de la deuda, pero no de los recargos, intereses o costas que pudieran exigirse a la sociedad de capital (art. 33.2 del TRLGSS y art. 14.2 del RGRSS), salvo que no ingrese la deuda en el plazo reglamentario establecido para él, en cuyo caso comenzará el devengo de los recargos, intereses y costas.

- En segundo lugar, en la responsabilidad solidaria se adquiere la condición de sujeto responsable y de sujeto obligado al pago de la deuda una vez haya expirado el plazo reglamentario de ingreso de la sociedad de capital.

Los responsables solidarios a los que podrá exigirse el pago de la deuda mediante la reclamación de deuda por derivación de la TGSS, deben constar previamente identificados en la resolución de derivación de responsabilidad que ha de emitir ese Servicio Común. De igual modo, cuando la responsabilidad solidaria sea declarada en acta de liquidación de cuotas por la ITSS, tanto en el acta como en la resolución que eleva a definitiva la misma, deberán ser identificados los responsables solidarios, para que posteriormente el procedimiento recaudatorio del acta se pueda dirigir contra todos ellos (art. 34 del TRLGSS, art. 13.2 RGRSS, y arts. 32.1.b), 33.1 y 33.2 del RISOS). De no haberse declarado la responsabilidad solidaria de alguno de los administradores en el acta o en la reclamación de deuda, a éste no podría dirigirse el procedimiento recaudatorio, debiendo emitirse nueva acta de liquidación para la declaración de su responsabilidad solidaria, o bien iniciarse respecto a él la derivación de responsabilidad la TGSS.

La deuda podrá exigirse administrativamente a todos los sujetos responsables, tanto al sujeto directo -la sociedad de capital-, como a todos los responsables solidarios los administradores sociales-, una vez haya expirado el plazo reglamentario de 
ingreso de la sociedad de capital; y sin que las reclamaciones efectuadas contra alguno de ellos, sean impedimento para las reclamaciones de la deuda contra el resto de responsables mientras no sea satisfecha íntegramente la misma (art. 13.1 del RGRSS, art. 34.1.c) del TRLGSS y art. 33.2 del RISOS). En el art. 34.1 del TRLGSS y en el art. 13.1 del RGRSS, se indica que podrá dirigirse reclamación de deuda o acta de liquidación contra todos o contra cualquiera de los responsables solidarios, y que el procedimiento recaudatorio seguido contra un responsable solidario no suspenderá ni impedirá que pueda seguirse contra otro, hasta la total extinción del crédito. Esta es una concreción de la regla prevista en la responsabilidad solidaria en el art. 1144 del Código Civil.

La deuda de Seguridad Social deberá ingresarse por los administradores responsables solidarios en el plazo reglamentario establecido en los arts. 33.2 y 34.3 del TRLGSS, sin que la interposición de los pertinentes recursos administrativos suspenda el pago, salvo que se garantice con aval o se consigne el importe de la deuda exigible, incluidos los recargos, intereses y las costas del procedimiento (arts. 33.5, 34 apartados 3 y 4 del TRLGSS, arts. 46.2 y 66 del RGRSS, y art. 33.3 del RISOS). De no efectuarse el pago en ese plazo legalmente establecido, y una vez firme en vía administrativa la resolución del acta o la reclamación de deuda por derivación, se abre la vía ejecutiva, el procedimiento de apremio contra el o los administradores dictándose la providencia de apremio (art. 33.4 del TRLGSS y arts. 46 y 85.2 del RGRSS).

- En tercer lugar, en la responsabilidad subsidiaria, a diferencia de la responsabilidad solidaria, no puede exigirse el pago de la deuda tras la expiración del plazo reglamentario de ingreso de la sociedad de capital, sino que debe esperarse a que se haya emitido la declaración de insolvencia de la sociedad (art. 14.1 del RGRSS). La insolvencia de la sociedad de capital puede ser la declarada en el propio procedimiento de recaudación de la Seguridad Social, o en otro procedimiento administrativo o judicial, teniendo los mismos efectos la declaración de concurso en el que se haya producido la apertura de la fase de liquidación (art. 14.3 del RGRSS). En la responsabilidad subsidiaria, puede el administrador social en el curso del procedimiento de derivación de responsabilidad que se siga contra él, alegar que, pese a la posible declaración de insolvencia la sociedad, ésta dispone de bienes realizable con los que atender, en todo o en parte, el pago de la deuda, señalando los 
mismos, teniendo como efecto esa declaración la paralización de la ejecución forzosa sobre el patrimonio de aquél, hasta tanto se realicen dichos bienes (art. 14.4 párrafo primero del RGRSS). Para que se acuerde esta suspensión se requerirá, con carácter general, que no se hubiera autorizado ya la enajenación de los bienes del responsable subsidiario, y que los bienes señalados se identifiquen suficientemente para proceder a su traba, siempre que radiquen en territorio nacional y alcancen una valoración que, en relación con la deuda y descontadas las cargas, justifique su enajenación forzosa (art. 14.4 párrafo segundo del RGRSS).

En la responsabilidad subsidiaria, la condición de sujeto responsable y sujeto obligado al pago se adquiere en el mismo acto cuando la derivación de responsabilidad se emita por la TGSS, al dictar ésta la resolución de declaración de responsabilidad subsidiaria y expedir la reclamación de deuda por derivación exigiendo su pago (art. 14.1 del RGRSS). Comoquiera que la reclamación del pago de la deuda al responsable subsidiario no puede exigirse mientras no conste la insolvencia de la sociedad, para evitar la caducidad del procedimiento de derivación, la TGSS sólo podrá iniciarlo una vez se haya declarado la insolvencia de la sociedad (art. 14.1 del RGRSS).

Al tenerse que declarar la responsabilidad subsidiaria una vez conste la insolvencia de la sociedad, eso podría tener como efecto nocivo o perverso que hubiese prescrito la acción de derivación o declaración de la responsabilidad subsidiaria, si el administrador cesó en el cargo cuatro años antes de la declaración de la insolvencia (art. 949 del Código de Comercio), al no ser aplicable el art. 1974 del Código Civil a la responsabilidad subsidiaria.

En cambio, si la declaración de responsabilidad subsidiaria se declarase por la ITSS en acta de liquidación de cuotas, la condición de sujeto responsable y sujeto obligado al pago, no se produce simultáneamente en el mismo acto administrativo. En la actual regulación se permite extender el acta de liquidación con declaración de responsabilidad subsidiaria una vez haya expirado el plazo reglamentario de la sociedad para ingresar la deuda, sin necesidad de que conste previamente la declaración de insolvencia. Cuestión distinta será que esa deuda no pueda ser exigida al responsable subsidiario hasta que conste la insolvencia de la sociedad, debiendo paralizarse la reclamación del acta por la TGSS, lo que plantea problemas en la posible caducidad y prescripción. Nada impide extender un acta de liquidación a la 
sociedad de capital con declaración de responsabilidad subsidiaria, sea un acta de liquidación por faltas de alta de los trabajadores, por diferencias de cotización, etc., ya que en los arts. 32.1.b) y 33.1 del RISOS se prevé que de existir responsables solidarios o subsidiarios, deben ser identificados y ser declarada su responsabilidad en el acta de liquidación, así como en la resolución que eleve a definitiva la liquidación, notificándose tanto el acta como su resolución a todos los sujetos responsables subsidiarios, quienes tendrán el derecho a realizar alegaciones al acta y a interponer recursos pertinentes contra la resolución de la misma (art. 33 apartados 1 a 3 del RISOS). Acta de liquidación que en todo caso interrumpiría la prescripción tanto de la deuda como de la acción de derivación de la responsabilidad (art. 24 del TRLGSS y art. 43 del RGRSS, en relación con el art. 949 del Código de Comercio y arts. 1973 y 1974 del Código Civil).

Para solventar las disfunciones que presentan las actas de liquidación con responsables subsidiarios, el legislador debería establecer expresamente que la declaración de la responsabilidad subsidiaria y la reclamación del pago de la deuda, debe ser competencia de la TGSS una vez conste la insolvencia del deudor. De este modo, la ITSS, ante supuestos de responsabilidad subsidiaria, no debería extender acta de liquidación sino emitir informe a la TGSS para que sea ésta la que inicie el procedimiento de derivación de responsabilidad.

La DGITSS -actual Dirección del OEITSS- en el Criterio Técnico 29/2000 ${ }^{1517}$, ante los problemas que plantea la actual regulación, estima más oportuno, de facto, emitir informe a la TGSS y no extender acta de liquidación en los supuestos de responsabilidad subsidiaria, al afirmar que "también procederá informar cuando, a propia iniciativa la Inspección compruebe la concurrencia de responsabilidad subsidiaria de un tercero, habida cuenta que la exigencia de responsabilidad derivada a dicho tercero subsidiario viene condicionada por decisiones a adoptar respecto al sujeto responsable". Se está recomendando no extender acta de liquidación, sino emitir un informe a la TGSS para que sea ésta la que inicie el procedimiento de derivación de responsabilidad, tanto para declarar la responsabilidad derivada subsidiaria, como para iniciar el acto recaudatorio de la deuda.

${ }^{1517}$ Ref.: La Ley 2878/2009. 
Paralelamente en la Consulta de la Dirección General de la Inspección de Trabajo y Seguridad Social, de 9 de junio de $2014^{1518}$, y en coherencia con ese criterio de declarar la responsabilidad subsidiaria tras la insolvencia, señala que el plazo de prescripción de 4 años del art. 24 del TRLGS para declarar la responsabilidad subsidiaria, se inicia desde que se ha declarado la insolvencia de la sociedad de capital, al no ser exigible con anterioridad la deuda al mismo. Este criterio administrativo resulta insuficiente, no sólo por carencia de rango normativo, sino porque no resuelve satisfactoriamente el problema de la posible prescripción de la acción de derivación cuando el cese del administrador responsable se ha producido con más de cuatro años de antelación a la declaración de insolvencia de la sociedad, porque la reclamación de la deuda ante la sociedad interrumpe la prescripción de la deuda ante los demás responsables solidarios o subsidiarios (art. 43.3 del RGRSS), pero no interrumpe la prescripción de la acción para reclamar la responsabilidad subsidiaria del administrador social del art. 949 del Código de Comercio, al no ser de aplicación el art. 1974 del código Civil a la responsabilidad subsidiaria.

La exigibilidad del pago de la deuda del responsable subsidiario se condiciona sólo a la declaración de insolvencia de la sociedad de capital (art. 14.1 del RGRSS) ${ }^{1519}$. En el Derecho tributario (art. 176 LGT), la declaración y exigibilidad del pago del responsable subsidiario se emite una vez se haya declarado la insolvencia del deudor principal y de los responsables solidarios En el Derecho Tributario nos dirá VILLAR EZCURRA $^{1520}$, que la Administración sólo puede actuar contra el responsable subsidiario si antes ha dirigido la acción de cobro contra el deudor principal y los responsables solidarios, y si ambos han sido declarados previamente fallidos (art. 176 de la LGT). Regla tributaria que se cohonesta mejor con la naturaleza jurídica de la responsabilidad subsidiaria, en cuanto es exigible cuando no existan antes otros responsables inmediatos de pago, sea el principal o terceros solidarios.

\footnotetext{
${ }^{1518}$ Ref. La Ley 1368/2014.

En esa Consulta se establece que, "prescribirán a los cuatro años tanto el derecho de la Administración de la Seguridad Social para determinar las deudas con la misma cuyo objeto esté constituido por cuotas, mediante las oportunas liquidaciones, como la acción para exigir el pago de las deudas por cuotas de la Seguridad Social, se considera que el inicio del cómputo del plazo de prescripción para el ejercicio de la acción de derivación al responsable subsidiario se efectúa desde que la TGSS declara dicha situación de insolvencia a través del correspondiente acto".

1519 Actualmente el art. 14.1 del RGRSS sólo exige la insolvencia del deudor principal, no de los responsables solidarios.

${ }^{1520}$ VILLAR EZCURRA, M.: “La responsabilidad tributaria”, op. cit. p. 598.
} 
Por la propia naturaleza de la responsabilidad subsidiaria, para exigir el pago al responsable subsidiario deberá haberse declarado previamente la insolvencia del deudor principal y de los responsables solidarios, por ser la responsabilidad subsidiaria una responsabilidad de segundo grado respecto del deudor principal y de los responsables solidarios, ya que éstos están en el primer escalón o grado de exigibilidad de la deuda, y sería adulterar el carácter solidario de la responsabilidad, exigir sólo el pago al deudor principal, y ante su insolvencia ir directamente contra el responsable subsidiario, sin antes tener que reclamar la deuda a otros responsables solidarios, por lo que de facto estaríamos situando a los responsables subsidiarios en un nivel igual o superior al de los responsables solidarios.

- En cuarto lugar, en la responsabilidad solidaria la suspensión o terminación del procedimiento recaudatorio seguido contra un responsable solidario, suspende o finaliza respectivamente el procedimiento frente al resto de responsables solidarios, a no ser que esa suspensión se hubiere producido con motivo de impugnaciones o revisiones fundadas en causas que sólo concurran en alguno de ellos (art. 13.5 del RGRSS); y sin perjuicio de que el administrador responsable solidario que efectuó el pago pueda reclamar la parte que corresponda al resto de responsables solidarios o a la empresa (art. 1145 del Código Civil).

En cambio, en la responsabilidad subsidiaria sólo el pago por deudor o la prescripción de la deuda, impide que se inicie el procedimiento administrativo de derivación de responsabilidad, ya que la declaración de insolvencia del deudor es el presupuesto del inicio de ese procedimiento administrativo de derivación de responsabilidad, siempre que la deuda no hubiere prescrito ante el deudor principal.

Concluimos señalando como propuesta de lege ferenda que la competencia para declarar la responsabilidad subsidiaria en general y, en particular, del administrador en los supuestos de responsabilidad en deudas de la sociedad establecidos en la legislación mercantil y de sociedades, sea de la TGSS, quien podrá iniciar el procedimiento administrativo de declaración de la responsabilidad derivada, una vez se haya declarado la insolvencia de la sociedad de capital y del resto de sujetos responsables solidarios.

Paralelamente, deberá establecerse que la reclamación de la deuda a la sociedad de capital interrumpe la prescripción de la acción para derivar la responsabilidad 
solidaria a terceros responsables, y que la reclamación a la sociedad y a los responsables solidarios interrumpe la prescripción de los responsables subsidiarios, para cerrar el círculo del art. 43.3 del RGRSS y suplir la insuficiencia de los arts. 1974 y 1975 del Código Civil en la derivación de la responsabilidad subsidiaria.

De este modo, el plazo de prescripción de la acción para derivar la responsabilidad subsidiaria y para exigir el pago de la deuda al administrador social del art. 949 del Código de Comercio se computaría desde la declaración de insolvencia. Con esta propuesta se evitará la prescripción de la acción de derivación si se ha producido el cese del administrador responsable subsidiario en los cuatro años anteriores a la declaración de insolvencia de la sociedad, ya que la reclamación de la deuda ante la sociedad interrumpe la prescripción de la deuda ante los demás responsables solidarios o subsidiarios (art. 43.3 del RGRSS), pero no interrumpe la prescripción de la acción para reclamar la responsabilidad subsidiaria del administrador social del art. 949 del Código de Comercio, al no ser de aplicación el art. 1974 del Código Civil a la responsabilidad subsidiaria.

\section{V.- PROCEDIMIENTO DERIVACIÓN DE RESPONSABILIDAD DE DEUDAS POR LA TESORERÍA DE LA SEGURIDAD SOCIAL.}

Antes de analizar el procedimiento administrativo de derivación a los administradores sociales de las deudas por cuotas y prestaciones de la sociedad de capital, debemos realizar una breve introducción sobre los títulos jurídicos y la forma de reclamación de las deudas por cuotas y por prestaciones al sujeto deudor principal, a la sociedad de capital.

Con carácter general debemos empezar recordando que corresponde a la Tesorería General de la Seguridad Social, como caja única del Sistema de la Seguridad Social, la gestión liquidatoria y recaudatoria de los recursos económicos de ésta, sean cuotas de Seguridad Social y de recaudación conjunta, o prestaciones de responsabilidad empresarial, emitiendo la reclamación de deuda por cotizaciones o por prestaciones a la sociedad de capital (arts. 21.1 y 33 del TRLGSS y arts. 1 apartados a), d), g), m), 2, 69, 70, 75 y 80 del RGRSS).

La Tesorería General de la Seguridad Social llevará a cabo dicha gestión recaudatoria, tanto en período voluntario como en vía ejecutiva, a través sus Administraciones y de sus Direcciones Provinciales (art. 2.2 del RGRSS), correspondiendo a las Unidades de 
Recaudación Ejecutiva (URES) la vía de apremio o la ejecución forzosa sobre el patrimonio del deudor y los sujetos responsables (arts. 2.3, 84 y siguientes del RGRSS). En ejercicio de esa función podrá requerir a las empresas y demás sujetos responsables la aportación de datos, antecedentes o justificantes con trascendencia en materia de liquidación y recaudación (art. 40.1 del TRLGSS).

La terminación del procedimiento recaudatorio, tanto en período voluntario como en vía ejecutiva, se producirá, en todo caso, en los supuestos en que se anule o se extinga por cualquier causa la deuda (art. 6.4 del RGRSS).

Una vez ha nacido la deuda de Seguridad Social de la sociedad de capital, y haya transcurrido el plazo reglamentario de ingreso sin atenderse su pago, la gestión encaminada a la realización de esos derechos de crédito forma parte de la función recaudadora que tiene atribuida la TGSS, en la que colabora la ITSS cuando sean determinado tipo de deudas por cotizaciones (arts. 21, 33, 34 y 37 del TRLGSS, y arts. $1,2,3,62$ y ss del RGRSS).

Nacida la deuda de Seguridad Social de la sociedad de capital por expiación de su plazo reglamentario de ingreso, la competencia para la derivación de responsabilidad al administrador social de las deudas por prestaciones corresponde a la TGSS (arts. 1 apartados d) y m), y 12.2 del RGRSS), con la excepción del recargo de prestaciones que no podrá derivarse esa deuda a terceros por la TGSS, salvo que conste la declaración expresa de responsabilidad del tercero en resolución expresa de la entidad gestora declarando el recargo de prestaciones -INSS, ISM- (art.12.4 del RGRSS), al tener el recargo de la prestación, como causa o fundamento, el incumplimiento de la normativa de prevención de riesgos laborales, lo que exige la existencia de imputabilidad de la conducta causante del daño de la empresa (art. 164.2 del TRLGSS), de terceras empresas o personas determinadas.

Si la deuda de la sociedad de capital es por cotizaciones, la derivación administrativa de responsabilidad podrá efectuarla tanto la TGSS como la ITSS. La derivación por la TGSS se practicará mediante la reclamación de deuda por derivación, que se emitirá simultánea o posteriormente a la resolución administrativa de declaración de la responsabilidad derivada (arts. 18.3, 33.2, 164.1 y 168 apartados 1 y 2 del TRLGSS, en relación con los arts. 12.2, 13 y 64.2 del RGRSS). 
Para que la Tesorería General de la Seguridad Social pueda derivar al administrador social las deudas de la sociedad de capital, debe iniciar el procedimiento administrativo de derivación, adoptando previamente el acuerdo de inicio, en el que deberán expresarse los hechos determinantes de la responsabilidad del administrador social -determinar si ha habido causa de disolución, así como los deberes incumplidos por los administradores ante la concurrencia de la causa-, y los fundamentos jurídicos que avalan la declaración de la responsabilidad derivada al administrador. Para LLOMPART BENNÀSSAR ${ }^{1521}$ en el acuerdo de inicio deben constar (sic) "las causas de declaración de responsabilidad solidaria, esto es, de las normas específicas de Seguridad Social, laborales, civiles, administrativas o mercantiles que, a juicio de los órganos de recaudación, van a determinar la declaración de responsabilidad solidaria del administrador", para evitar que se cause indefensión. MARTÍNEZ LUCAS ${ }^{1522}$, estima que el acuerdo de inicio deberá recoger el presupuesto de la responsabilidad solidaria y el importe objeto de la reclamación con la finalidad de lograr interrumpir la prescripción de las cuotas de la Seguridad Social.

Acuerdo de inicio que debe ser notificado a los administradores sociales, dándoles trámite de audiencia por un plazo de 15 días a partir del siguiente a su notificación para que efectúen alegaciones y presente los documentos y justificantes que estimen pertinentes (arts. 13.4 y 14.2 del RGSS), todo ello para evitar indefensión del administrador social que sería causa de anulación del acto administrativo (art. 48 de la LPACAP). Plazo de audiencia de quince días del art. 13.4 del RGRSS que es de aplicación directa en virtud de lo prescrito en la Disposición Adicional $1^{\text {a }}$ de la LPACAP, y no el plazo de diez a quince días fijado con carácter general para todo procedimiento administrativo en el art. 82.2 de la LPACAP, no sólo por la aplicación preferente del RGRSS, sino también porque estando dentro de los límites de la LPACAP es más favorable para el administrador. No obstante lo cual, MERCADER UGUINA y SUÁREZ CORUJO ${ }^{1523}$, defendían que el plazo de alegaciones será el de diez a quince días de la LPACAP. El administrador podrá aducir alegaciones cuyo

${ }^{1521}$ LLOMPART BENNÀSSAR, M.: "La responsabilidad en el ámbito laboral y de Seguridad Social”, op. cit., edición digital, p. 19 de 44.

1522 MARTÍNEZ LUCAS, J. A.: "Responsabilidad de los administradores por cuotas de la Seguridad Social", op. cit., edición digital p. 4 de 13.

${ }^{1523}$ MERCADER UGUINA, J. R y SUÁREZ CORUJO, B.: "La responsabilidad laboral y de Seguridad Social de los Administradores Sociales", p. 583. 
contenido según MARTÍNEZ LUCAS ${ }^{1524}$, podrá ser (sic) "la prescripción de la deuda, bien el cese en el cargo de administrador, bien la falta de concurrencia de alguna de las anteriores causas de disolución”. Para MERCADER UGUINA y SUÁREZ CORUJO $^{1525}$ las causas de oposición serán la prescripción de la deuda, el cese en el cargo del administrador, o la falta de concurrencia de alguna de las causas de disolución.

Alegaciones del administrador social que reconducimos a las siguientes: la falta de concurrencia de la causa que fundamente su responsabilidad, la falta de imputabilidad del incumplimiento por las causas del art. 237 de la LSC o por haber cesado en el cargo con anterioridad al incumplimiento determinante de la responsabilidad, la prescripción de la acción de responsabilidad, nulidad o improcedencia de la deuda de la sociedad de capital o su prescripción

Cumplido el trámite de audiencia, se presenten o no alegaciones, la TGSS en el plazo máximo de seis meses dictará y notificará la resolución declarando si procede o no la derivación de responsabilidad.

Esa resolución administrativa de derivación de responsabilidad deberá tener el siguiente contenido: a) se deberá identificar a los distintos administradores o sujetos responsables y a la sociedad de capital -con indicación del nombre, razón social, número de identificación fiscal y domicilio-; b) los hechos determinantes de la responsabilidad -la concurrencia de una causa de disolución, con descripción suficiente de la misma y la fecha de efectos-; c) los incumplimientos de los deberes de los administradores que dan lugar a su responsabilidad; d) los fundamentos jurídicos de la derivación de responsabilidad, con apreciación de la responsabilidad solidaria o subsidiaria aplicada; e) las deudas derivadas -naturaleza, período, e importe total de la deuda, con inclusión en su caso de los recargos, intereses y costas de ser una responsabilidad solidaria por cuotas-; f) declaración expresa de ser las deudas derivadas de fecha posterior a la causa de disolución; g) indicación de no ser firme, pudiéndose interponer dentro del plazo del

${ }^{1524}$ MARTÍNEZ LUCAS, J. A.: "Responsabilidad de los administradores por cuotas de la Seguridad Social", op. cit., edición digital p. 4 de 13; En similares términos, LLOMPART BENNÀSSAR, M.: "La responsabilidad en el ámbito laboral y de Seguridad Social", op. cit., edición digital, p. 19 de 44, para quien "el administrador podrá aducir alguna de las siguientes argumentaciones: la falta de concurrencia de alguna de las causas que pueden determinar su responsabilidad, su cese en el cargo de administrador, o la prescripción de la deuda o de la acción de responsabilidad solidaria del administrador".

${ }^{1525}$ MERCADER UGUINA, J. R. y SUÁREZ CORUJO, B.: "La responsabilidad laboral y de Seguridad Social de los Administradores Sociales", p. 583. 
mes siguiente a la notificación, recurso administrativo de alzada ante el superior jerárquico, con indicación expresa de cuál es el órgano superior competente para conocer y resolver el recurso, con la advertencia legal de que la interposición del recurso no suspende el pago de la deuda, salvo que se avale o se garantice su importe (art. 33.5 del TRLGSS y art. 46.2 del RGRSS).

La deuda objeto de derivación de responsabilidad se detallará en la "reclamación de deuda por derivación de responsabilidad", que la TGSS expedirá conjuntamente con la resolución administrativa de declaración de responsabilidad. La reclamación de deuda por derivación contendrá todos los elementos propios de toda reclamación de deuda, y, además, la identificación de los responsables solidarios contra los que se sigan actuaciones, así como los hechos y fundamentos de derecho en que se funda la responsabilidad derivada (arts. 13.4 y 14.2 del RGRSS).

De ser deudas por cotizaciones, la reclamación de deuda por derivación deberá recoger los siguientes datos: a) identificación de los administradores responsables, con su domicilio social a efecto de notificaciones, y su DNI o NIF de ser persona jurídica, b) identidad del sujeto deudor principal -la sociedad de capital-, con su código de cuenta de cotización e identificación fiscal; c) el origen de la deuda de la sociedad de capital, con identificación del documento administrativo anterior de reclamación a la sociedad de capital; d) período reclamado; e) naturaleza de la deuda (si es descubierto total, parcial, diferencias, etc.); f) el acto administrativo del que trae causa directa, que es la resolución de derivación de responsabilidad; g) la responsabilidad solidaria o subsidiaria apreciada; h) período de la deuda derivada; i) importe total de la deuda con mención de las bases de cotización, tipos y cuotas resultantes, con inclusión de los recargos, costas e interés de demora de ser una responsabilidad solidaria ${ }^{1526}$.

1526 MARTÍNEZ LUCAS, J. A.: "Responsabilidad de los administradores por cuotas de la Seguridad Social", op. cit., edición digital p. 5 de 13, considera que la reclamación de deuda por derivación ha de recoger los siguientes datos, a parte de los propios de toda reclamación de deuda "1. ${ }^{\circ}$ ) la identificación del responsable solidario contra el que se dirige la reclamación, es decir, el administrador o administradores de la sociedad que hayan incumplido la obligación de convocar la Junta General o, en su caso, solicitado la disolución judicial; $2^{\circ}$ ) la expresión de los hechos y fundamentos de derecho en que se funda su responsabilidad, que deben ser alguno de los incumplimientos de las citadas obligaciones por parte del administrador; $3^{\circ}$ ) pronunciamiento expreso de la existencia de responsabilidad solidaria; $4^{\circ}$ ) alcance de la deuda objeto de reclamación, con mención de los elementos de la liquidación".

MERCADER UGUINA, J. R. y SUÁREZ CORUJO, B.: "La responsabilidad laboral y de Seguridad Social de los Administradores Sociales”, op. cit., p. 583, para quienes la reclamación de deuda deberá incluir "los datos necesarios para la determinación de la deuda con indicación del importe reclamado, así como la cuantía del recargo aplicado, y con expresión, en su caso, del número de trabajadores a 
De ser deudas por prestaciones, la reclamación de deuda por derivación deberá recoger cuando menos los siguientes datos: a) la identificación de los administradores responsables, con su domicilio, DNI o NIF de ser persona jurídica; b) identidad del sujeto deudor principal -la sociedad de capital con su código de cuenta de cotización y número de identificación fiscal-; c) el origen de la deuda de la sociedad de capital, con identificación del documento administrativo anterior de reclamación de deuda emitido a la sociedad de capital; d) la resolución firme en vía administrativa de la entidad gestora en la que se declara la responsabilidad empresarial de la sociedad, con la fecha de su notificación, así como la resolución de la TGSS de derivación de responsabilidad a los administradores; e) naturaleza de la deuda por prestaciones; f) importe del capital coste de la pensión o prestación, o de la prestación de pago único, con los intereses de capitalización, y el recargo del cinco por cierto por falta de aseguramiento, de proceder, así como los recargos demora, intereses y costas del procedimiento devengados en la reclamación de la deuda emitida previamente a la sociedad de capital.

Los plazos de ingreso de las reclamaciones de deuda por derivación de responsabilidad, emitidas por la TGSS a los administradores sociales, serán los establecidos en el art. 64 del RGRSS y art. 33.3 del TRLGSS, si son deudas por cotizaciones, o los fijados en los arts. 70 y 80 del RGRSS, si son deudas por prestaciones.

Contra la reclamación de deuda y la resolución administrativa de derivación cabe recurso administrativo de alzada ante la Dirección Provincial de la TGSS (art. 46 del RGRSS). En el recurso de alzada el administrador social podrá cuestionar la procedencia de la deuda, de la responsabilidad derivada, así como la prescripción de la deuda o de la acción de derivación ${ }^{1527}$.

que se refiere la reclamación y de las bases y tipos de cotización", que es sólo uno de los requisitos de toda reclamación de deudas por cuota según el art. 63 apartado c) del RGRSS.

${ }^{1527}$ LLOMPART BENNÀSSAR, M.: "La responsabilidad en el ámbito laboral y de Seguridad Social", op. cit., edición digital, p. 20 de 44, para quien pueden ser causas del recurso de alzada la "inexistencia de la deuda, ausencia del presupuesto de hecho de derivación de la responsabilidad, prescripción de las cuotas reclamadas por defectos de notificación de los actos administrativos a la sociedad deudora principal o al administrado o, en fin, prescripción de la acción para exigir la responsabilidad al administrador"; MARTÍNEZ LUCAS, J. A.: "Responsabilidad de los administradores por cuotas de la Seguridad Social”, op. cit., edición digital pp. 5-6 de 13. Señala que "las causas de impugnación pueden ser variadas, entre las que destacamos las siguientes: prescripción de las cuotas por defectos de notificación de los actos administrativos al deudor principal o al administrador; prescripción de la acción para exigir la responsabilidad del administrador, por haber transcurrido más de cuatro años desde que cesó en el cargo; ausencia del presupuesto de hecho de derivación de la responsabilidad, esto es, bien porque no se han producido ninguna de las causas legales de disolución de la sociedad, para cuya operatividad sea preciso el acuerdo de la Junta General o bien porque el administrador ha cumplido la obligación legal de convocar la Junta General a los 
La interposición del recurso de alzada no suspende el procedimiento recaudatorio, salvo que se consigne o se garantice con aval el importe total de la deuda, incluidos los recargos, intereses y costas del procedimiento (art. 33.5 del TRLGSS y art. 46.2 RGRSS). La resolución del recurso de alzada puede ser estimatoria en todo -en cuyo caso se anulará la reclamación de deuda por derivación-, o en parte -en cuyo supuesto se modificará el alcance de la derivación-, o bien desestimatoria, continuándose con el procedimiento recaudatorio contra el administrador.

Desestimado el recurso administrativo, si el responsable de pago no realizase el ingreso de la deuda en el plazo concedido en la reclamación o, en su caso, dentro de los 15 días siguientes a aquel en que se notifique la resolución del recurso o en que pueda entenderse desestimado por silencio administrativo ${ }^{1528}$, la TGSS aplicará lo consignado al pago de la deuda o ejecutará el aval (art. 46.2 del RGRSS).

Si frente a la resolución administrativa firme en vía administrativa, los administradores sociales, en el plazo de 15 días acreditan haber interpuesto recurso contenciosoadministrativo, y haber solicitado la suspensión del procedimiento, se mantendrá esa suspensión con el aval o la consignación efectuada ante la TGSS, hasta que el órgano judicial resuelva sobre dicha solicitud (art. 46.2 del RGRSS). Recurso contenciosoadministrativo que podrá interponerse en el plazo de dos meses desde la notificación de la resolución del recurso de alzada (arts. 1, 2 y 45 a 48 de la LJCA en relación con el art. 3 letra f) LRJS ${ }^{1529}$ ). Resuelto el recurso en sentencia firme, si se suspendió el pago, los administradores disponen de un nuevo plazo de 15 días desde la notificación de la

fines de adoptar el acuerdo de disolución o, en su caso, por haber solicitado judicialmente la disolución; inexistencia de la deuda por cuotas, etc.".

1528 Señalar que, con vocación de formar doctrina general el TS, Sala Contencioso-Administrativa, en Sentencia 586/2020, de 28 de mayo -Rec. 5751/2017-, ha establecido que la Administración -era la Administración Tributaria-, no puede dictar una providencia de apremio si está aún pendiente de resolverse de modo expreso un recurso administrativo, en nuestro caso el recurso de alzada, porque la Administración no puede entender que existe ya la resolución administrativa firme y desestimatoria por silencio negativo, una vez ha expirado el plazo para resolver, ya que está obligada a dictar resolución expresa, al ser el silencio negativo una ficción jurídica un "no acto", doctrina que sería igualmente aplicable en el procedimiento recaudatorio de Seguridad Social.

1529 Hemos de distinguir entre impugnación de la resolución de la entidad gestora que declara la responsabilidad empresarial en el pago de una prestación, que es impugnable ante la Jurisdicción Social, y el acto posterior de gestión recaudatorio de la TGSS, reclamando el pago del capital coste, que es recurrible en vía Contencioso-Administrativa y la, correspondiendo a la Jurisdicción Social la facultad exclusiva de pronunciarse sobre la declaración de responsabilidad empresarial, y a la contenciosa-administrativa todo lo relativo a la impugnación del acto de liquidación, derivación de responsabilidad y recaudación ante el administrador social (SSTS, Sala Contencioso-Administrativa, de 31 de enero de 2000 -Rec. 6603/1997 y 4886/1997-; y de 1 de febrero de 2000 -Rec. 1311/1998 y 1369/1998-; 22 de marzo de 2002 -Rec. 9037/1996-; 12 de marzo del 2001; 25 de septiembre del 2002; y 18 de marzo del 2003 -Rec. 1128/1998-). 
sentencia para efectuar el ingreso de la liquidación antes de dictarse la providencia de apremio $^{1530}$.

De no efectuarse el pago por los administradores en esos plazos reglamentarios, se dictará la providencia de apremio para iniciarse la recaudación en vía ejecutiva. Contra la providencia de apremio el administrador puede interponer recurso de alzada (art. 86 del RGRSS $)^{1531}$. La interposición de recurso suspenderá el procedimiento de apremio hasta la notificación de su resolución (art. 86.2 del RGRSS). Contra la resolución del recurso de alzada podrá interponerse el pertinente recurso contencioso-administrativo.

De haberse derivado la responsabilidad a varios administradores responsables solidarios, el pago por uno de ellos extingue la deuda, sin perjuicio de poder resarcirse ante los demás utilizando la vía judicial de regreso.

El procedimiento recaudatorio seguido contra un responsable solidario no suspenderá ni impedirá que pueda seguirse contra otro, hasta la total extinción del crédito (art. 13.1 del RGRSS). La derivación de responsabilidad solidaria puede dirigirse contra todos los administradores responsables, o contra alguno de ellos. De haberse solicitado y obtenido un aplazamiento en el pago de la deuda, mientras se cumplan las condiciones del mismo, se suspende la tramitación del procedimiento recaudatorio ante todos los responsables (art. 23.3 del TRLGSS y art. 31.3 del RGRSS) ${ }^{1532}$, por dos razones. En primer lugar porque el aplazamiento suspende el procedimiento recaudatorio de la deuda (art. 31.3 del RGRSS), y esa suspensión afecta consiguientemente a todos sus responsables del pago, y en segundo lugar, porque con el aplazamiento han de otorgarse garantías o avales para cubrir el importe de la deuda, recargos, intereses y costas, salvo que por la menor cuantía de la deuda no fueren exigibles (art. 33.4.b), del RGRSS), garantías que serán las inmediatamente ejecutadas de incumplirse el aplazamiento.

\footnotetext{
${ }^{1530}$ SSTS, Sala Contencioso-Administrativa 705/2019, de 27 de mayo -Rec. 111/2017-; 1023/2019, de 10 de julio -Rec. 858/2017-; 1197/2019, de 19 de septiembre -Rec. 588/2017-; y 1793/2019, de 17 de diciembre -Rec. 3087/2017-.

${ }^{1531}$ Los motivos de oposición a la providencia de apremio en alzada están tasados: a) Pago, b) prescripción, c) error material o aritmético en la determinación de la deuda, d) condonación, aplazamiento de la deuda o suspensión del procedimiento, y e) falta de notificación de la reclamación de deuda, cuando ésta proceda, del acta de liquidación o de las resoluciones que éstas o las autoliquidaciones de cuotas originen.

${ }^{1532}$ LLOMPART BENNÀSSAR, M.: "La responsabilidad en el ámbito laboral y de Seguridad Social", op. cit., p. 21 de 44; MARTÍNEZ LUCAS, J. A.: "Responsabilidad de los administradores por cuotas de la Seguridad Social", op. cit., edición digital, p. 6 de 13.
} 
De incumplirse el aplazamiento continuará el procedimiento recaudatorio, reabriéndose el procedimiento de apremio que se hubiera suspendido, o de no haberse iniciado éste, se dictará sin más trámite la providencia de apremio, sin perjuicio de que en dicho procedimiento de apremio se proceda en primer lugar a ejecutar las garantías que se hubieran constituido (art. 36 del RGRSS). De igual modo, podrá exigirse el pago al resto de los administradores al haberse levantado la suspensión del procedimiento.

\section{VI.- DERIVACIÓN DE RESPONSABILIDAD DE DEUDAS POR CUOTAS POR LA INSPECCIÓN DE TRABAJO Y SEGURIDAD SOCIAL: ACTAS DE LIQUIDACIÓN, REQUERIMIENTOS DE CUOTAS E INFORMES.}

Si bien la TGSS tiene reconocida la competencia liquidadora y recaudadora de los recursos económicos de la Seguridad Social, tanto en período voluntario como en vía ejecutiva, no obstante, en esas funciones de liquidación y recaudación en período voluntario colabora con la misma el Organismo Estatal Inspección de Trabajo y Seguridad Social -OEITSS- (arts. 21, 34 y 133 del TRLGSS, arts. 12 apartado 1.c) y 22 apartados 6 y 7 de la LOITSS, arts. 2 y 3 del RGCSS, arts. 65 y 66 del RGRSS). Organismo que tiene la naturaleza jurídica de organismo autónomo estatal con personalidad jurídica propia adscrito al Ministerio de Trabajo y Economía Social (art. 27 de la LOITSS, arts. 1 y 2 del Real Decreto 192/2018, de 6 de abril, por el que se aprueban los estatutos del Organismo Autónomo Organismo Estatal Inspección de Trabajo y Seguridad Social ${ }^{1533}$, y art. 2.4 del Real Decreto 499/2020, de 28 de abril, por el que se desarrolla la estructura orgánica básica del Ministerio de Trabajo y Economía Social $\left.^{1534}\right)$.

\section{Actuaciones de la Inspección de Trabajo y Seguridad Social en materia de liquidación de cuotas de Seguridad Social.}

El OEITSS tiene atribuida la función inspectora en materia de Seguridad Social, que será desempeñada por funcionarios del Cuerpo Superior de Inspectores de Trabajo y Seguridad Social, y del Cuerpo de Subinspectores Laborales de la Escala de Empleo y Seguridad Social. Función inspectora cuyo contenido esencial, entre otros, será la vigilancia y exigencia del cumplimiento de las normas legales, reglamentarias, en materias de Seguridad Social, especialmente en los aspectos relativos al campo de

\footnotetext{
${ }^{1533}$ BOE del 27.4.2018.
}

1534 BOE del 01.5.2020. 
aplicación, inscripción, afiliación, altas y bajas de trabajadores, cotización y recaudación de cuotas del Sistema de la Seguridad Social, la obtención y disfrute de las prestaciones de la Seguridad Social, o los sistemas de mejoras voluntarias de la acción protectora de la Seguridad Social (arts. 12, apartado 1.c), $1^{\circ}, 2^{\circ}, 3^{\circ}$ y 22 apartados 6, 7 , 8, 9, 10, 11 y 16 de la LOITSS, arts. 33, 34 y 133 del TRLGSS, arts. 29 a 36 del RISOS).

Labor de vigilancia del cumplimiento de las obligaciones de las empresas con la Seguridad Social, que podrá desarrollarse directamente en los centros de trabajo de la sociedad de capital, accediendo libremente a los mismos, o bien en las oficinas públicas de la Administración, requiriendo a las empresas y demás sujetos responsables del cumplimiento de las obligaciones con la Seguridad Social, para que comparezcan aportando la documentación pertinente (arts. 13, 14, 19 y 21 de la LOITSS).

Consecuencia de esas funciones de vigilancia del cumplimiento de las obligaciones de cotización con la Seguridad Social de las empresas, y entre ellas, de la sociedad de capital, la ITSS podrá practicar las siguientes actuaciones en materia de Seguridad Social:

$1^{\text {o }}$ Iniciar expedientes liquidatorios de deudas por cuotas a la Seguridad Social y conceptos de recaudación conjunta, o por bonificaciones indebidas, mediante la extensión de actas de liquidación (art. 22.6 de la LOITSS, art. 34 del TRLGSS y arts. 29 y 31 del RISOS).

$2^{\circ}$ Efectuar requerimientos de pago de deudas a la Seguridad Social, con carácter previo a la extensión de actas de liquidación (art. 22.6 de la LOITSS, art. 34.1 del TRLGSS, y arts. 29 y 35 del RISOS).

$3^{\circ}$ Emitir propuestas de liquidación a la TGSS en los supuestos de incumplimientos de obligaciones de cotizar por el deudor principal, cuando la reclamación de las cuotas sea competencia de la TGSS (art. 36 del TRLGSS y arts. 29 y 30 del RISOS).

$4^{\circ}$ Emitir informes a la TGSS para identificar a posibles sujetos responsables del pago de deudas por cuotas a la Seguridad Social y demás contingencias de recaudación conjunta, cuando concurran supuestos de responsabilidad solidaria, subsidiaria, o mortis causa (arts. 22.16 de la LOITSS y 33.2 del TRLGSS). 
$5^{\circ}$ Emitir, a través del Jefe de la Inspección de Trabajo y Seguridad Social, del Director Territorial o del Director de la Dirección Especial, informe dirigido al Ministerio Fiscal si los hechos de fraude a la Seguridad Social fueren constitutivos de un ilícito penal (art. 3 del TRLISOS, en relación con los arts. 5 y 36 del RISOS).

$6^{\circ}$ Promover el inicio de procedimientos de oficio ante la TGSS para la inscripción de empresas, afiliación, altas y bajas de trabajadores en Seguridad Social, así como para el correcto encuadramiento de empresas y trabajadores en el Sistema de la Seguridad Social (art. 22.7 de la LOITSS, en relación con los arts. 20, 26 y 35 del RGIASS).

$7^{\circ}$ Instar de las entidades gestoras o colaboradoras con la Seguridad Social la suspensión o cese en la percepción de prestaciones sociales, si se constatase su obtención o disfrute indebido (art. 22.8 de la LOITSS).

$8^{\circ}$ Instar ante la entidad gestora de prestaciones de Seguridad Social, el inicio del procedimiento administrativo para la declaración del recargo de las prestaciones económicas derivadas de un accidente de trabajo o enfermedad profesional, si han sido causadas por falta de medidas de seguridad y salud laboral (art. 22. 9 de la LOITSS y art. 27 del RISOS).

$9^{\circ}$ Proponer recargos o reducciones en las primas de cuotas por accidentes de trabajo y enfermedades profesionales a las empresas, en función de su participación en el cumplimiento o incumplimiento de la normativa de prevención de riesgos laborales (art. 22.10 de la LOITSS).

$10^{\circ}$ Iniciar el procedimiento para la correcta aplicación o para la devolución de cantidades indebidamente aplicadas en los casos de colaboración en la gestión de la Seguridad Social (art. 22.11 de la LOITSS).

Del conjunto de esas posibles medidas en materia de liquidación o reclamación de deudas por cuotas, la ITSS podrá adoptar cuatro medidas o institutos jurídicos distintos. En primer lugar, podrá extender acta de liquidación de cuotas ${ }^{1535}$. En segundo lugar, expedir requerimiento de pago de cuotas ${ }^{1536}$. En tercer lugar, formular propuesta de liquidación ante la TGSS ${ }^{1537}$ en aquellos supuestos en que la reclamación de la deuda al

\footnotetext{
${ }^{1535}$ Art. 34 apartado 1 del TRLGSS, art. 65 apartado 1.c) del RGRSS y art. 31 apartado 1.c) del RISOS. ${ }^{1536}$ Art. 34.1 penúltimo párrafo del TRLGSS, art. 22.6 de la LOITSS, arts. 29.1 y 35 del RISOS y art. 65.1 párrafo segundo del RGRSS.

${ }^{1537}$ Art. 33.1 del TRLGSS, arts. 29.1 y 30 del RISOS.
} 
sujeto responsable directo sea competencia de la TGSS, esto es, cuando ésta emite la reclamación de deuda por descubiertos totales o parciales de trabajadores en alta, o por diferencias de cotización que resultaren de las autoliquidaciones de la empresa (art. 33. 1 del RGRSS y arts. 29 y 30 del RISOS). En cuarto lugar, elevar un informe de derivación de responsabilidad a la TGSS para que sea ésta la que inicie el procedimiento administrativo de reclamación o derivación de responsabilidad (arts. 33 apartados 1 y 2 , 34 y 133 del TRLGSS, art. 22.16 de la LOITSS, arts. 29 a 36 del RISOS y art. 65 del RGRSS).

A efectos de la derivación administrativa de responsabilidad a los administradores de las deudas de la sociedad de capital, nos interesan: a) el acta de liquidación por derivación de responsabilidad, b) el requerimiento de pago de cuotas, c) el informe a la TGSS para que sea ésta la que inicie el procedimiento administrativo de derivación de responsabilidad, y d) el informe al Ministerio Fiscal de ser los hechos constitutivos de delito. En cambio, no tendrá interés la propuesta de liquidación, que está concebida para comunicar a la TGSS las bases reales de cotización, en los supuestos en que procede la reclamación de deuda a la empresa por ese Servicio Común, para que éste emita la reclamación de deuda por bases reales de cotización, y no por bases estimadas (arts. 33.1 apartados a) y b) y 35.1.b), del TRLGSS).

\section{Actividad inspectora previa de comprobación, naturaleza jurídica y contenido.}

Antes de analizar los instrumentos jurídicos con que cuenta la ITSS para reclamar la responsabilidad derivada de los administradores sociales, conviene examinar brevemente la naturaleza jurídica de la actividad previa de comprobación, para determinar cómo se inserta dentro del procedimiento administrativo de derivación de responsabilidad, en la medida en que esa actividad previa de comprobación permitirá constatar el cumplimiento de las obligaciones con la Seguridad Social y acceder a las pruebas pertinentes para imputar la responsabilidad derivada a los administradores sociales.

Es preciso conocer tanto la naturaleza jurídica de esa actividad previa, como su contenido, por los efectos que podrá tener en el procedimiento administrativo de derivación de responsabilidad, tanto cuando éste se inicie directamente por la Inspección mediante acta de liquidación, como cuando se inicie por la TGGSS como consecuencia de esa previa actuación. 
Se entiende por actividad inspectora previa al procedimiento liquidatorio o sancionador, el conjunto de actuaciones realizadas por la Inspección de Trabajo y Seguridad Social destinadas a comprobar el cumplimiento de las disposiciones legales, reglamentarias y convenidas en el orden social (art. 8.1 del RISOS). Actividad inspectora previa cuya finalidad es comprobar el cumplimiento de las obligaciones empresariales del orden social, y, a nuestros efectos, de las obligaciones en materia de Seguridad Social.

Para MERCADER UGUINA y SÁNCHEZ GRANDE ${ }^{1538}$ esta actividad previa puede tener un contenido amplio y diverso (sic) "mediante las cuales el órgano o unidad que tenga atribuidas las funciones de investigación, averiguación o inspección de las infracciones administrativas, o la persona u órgano designado al efecto, intenta proveerse de los datos, indicios, elementos o conocimientos necesarios en orden a que la autoridad competente para la iniciación del procedimiento sancionador cuente con ellos de cara a formar su convicción sobre la procedencia o improcedencia de llevar a cabo dicha incoación".

Actividad previa que se inicia mediante visita de inspección al centro de trabajo de las empresas, mediante requerimiento de comparecencia en las oficinas de la Administración, o en virtud de expediente administrativo cuando el contenido del mismo permita iniciar y finalizar la actuación (art. 21 apartado 1 y 2 de la LOITSS). Actividad que concluirá con la práctica de alguna de las medidas indicadas en el art. 22 de la LOITSS ${ }^{1539}$ y en el RISOS, requerimiento de pago de cuotas, actas de liquidación, o la emisión de un informe de derivación de responsabilidad dirigido a la TGSS.

Con relación al contenido de esa actividad inspectora de comprobación, sea mediante visita o mediante requerimiento de aportación de documentación ante las empresas y sujetos responsables de cotizar a la Seguridad Social, los Inspectores y Subinspectores podrán practicar cualquier diligencia de investigación, examen, reconstrucción o prueba que consideren necesario, con la finalidad de constatar o comprobar el cumplimiento de las obligaciones empresariales con la Seguridad Social, pudiendo para ello (art. 13 apartados 3 y 4 de la LOITSS): a) recabar información al empresario o al personal de la empresa, entre ellos al administrador social sobre cuestiones que pueden motivar una

1538 MERCADER UGUINA, J. R. y SÁNCHEZ GRANDE, A.: “Anotaciones al Reglamento general sobre procedimiento sancionador y liquidatorio del orden social (Novedades del RD 928/1998, de 14 de mayo)", op. cit., edición digital, p. 6.

${ }^{1539}$ En ese precepto se señala que "los Inspectores de Trabajo y Seguridad Social, finalizada la actividad inspectora, podrá adoptar las siguientes medidas: a)....". Precepto al que se remite en alguno de sus apartados, el art. 14.5 de la LOITSS para los Subinspectores Laborales. 
derivación administrativa de responsabilidad; b) exigir la comparecencia del empresario, administrador social o trabajadores en el centro inspeccionado o en las oficinas públicas de la Inspección; c) examinar o requerir la aportación de todo tipo de documentación con trascendencia en la posible derivación de responsabilidad, tales como: libros, registros, incluidos los programas informáticos y archivos en soporte electrónico, declaraciones oficiales y contabilidad; documentos de inscripción, afiliación, altas, bajas, justificantes del abono de cuotas o prestaciones de Seguridad Social; documentos justificativos de retribuciones, y cualesquiera otros relacionados con las materias sujetas a inspección; d) adoptar, en cualquier momento del desarrollo de las actuaciones, las medidas cautelares que estimen oportunas y sean proporcionadas a su fin, para impedir la destrucción, desaparición o alteración de la documentación objeto de comprobación.

Con relación a la naturaleza jurídica de la actividad inspectora previa de comprobación, ha sido criterio administrativo reiterado de la antigua DGITSS -actual Dirección del OEITSS-, que la actividad inspectora previa de comprobación no constituía un procedimiento administrativo, sino que era una fase de investigación anterior y por lo tanto no incluida en el mismo (Criterio Técnico 50/2007 1540 , y, entre otras, Consultas de 29.9.2009 ${ }^{1541}$ y de 22.12.2015 $5^{1542}$ ). Procedimiento que según esa DGITSS sólo se inicia cuando se extienda acta de liquidación de cuotas o acta de infracción, porque de conformidad con el art. 52.1 apartado a) del TRLISOS, el procedimiento de la ITSS "se inicia de oficio por acta de la Inspección de Trabajo y Seguridad Social en virtud de actuaciones practicadas de oficio, por iniciativa propia o mediante denuncia, o a instancia de persona interesada" ${ }^{1543}$.

Si el procedimiento de la Inspección sólo se inicia por acta, los informes de la Inspección y sus actuaciones previas no serán actos administrativos, y no cabe contra

1540 Criterio Técnico núm. 50/2007, de 28 de junio de 2007, sobre recurribilidad de las advertencias y requerimientos formulados por la Inspección de Trabajo y Seguridad Social -Ref.: La Ley 3001/2007-.

1541 Consulta, de 29 de septiembre de 2009, de la Dirección General de la Inspección de Trabajo y Seguridad Social, sobre Inspección y procedimiento y sobre si la documentación obrante en la orden de servicio con las actuaciones previas a la incoación de procedimiento sancionador o liquidatorio puede ser objeto de vista y obtención de copias, -Ref.: La Ley 3565/2009-.

1542 Consulta, de 22 de diciembre de 2015, de la Dirección General de la ITSS, sobre el alcance del art. 20.6 de la Ley 23/2015, Ordenadora del Sistema de Inspección de Trabajo y Seguridad Social en lo que respecta a la actuación inspectora -Ref.: La Ley 4206/2015-.

${ }^{1543}$ En igual sentido el art. 13.1 del RISOS, donde se señala que "el procedimiento sancionador se inicia de oficio, como consecuencia de la actividad inspectora previa, por acta de infracción de la Inspección de Trabajo y Seguridad Social, que se extenderá y tramitará de acuerdo con lo establecido en este capítulo". 
ellos recursos administrativos, ni se tendría derecho al examen de su contenido, salvo que sean consecuencia de denuncia y afecten a los derechos o intereses del denunciante, en cuyo caso, éste podrá tener derecho a acceder a su contenido, debiendo ser informado del resultado de las actuaciones.

Al no ser la actividad previa de comprobación finalizada sin actas de la inspección un procedimiento administrativo ${ }^{1544}$, sobre la misma no existiría el "derecho a acceder y a obtener copias de los documentos contenidos en los procedimientos administrativos", derecho recogido en el art. 53.1.a) de la LPACAP. Por la misma razón tampoco quedaría esa actividad previa incluida en los procedimientos finalizados con derecho acceder a su contenido, ya que en el artículo 18 de la Ley 19/2013, de 9 de diciembre, de transparencia, acceso a la información pública y buen Gobierno ${ }^{1545}$, se excluyen del acceso a todas aquellas solicitudes "referidas a información que tenga carácter auxiliar o de apoyo, como la contenida en notas, borradores, opiniones, resúmenes, comunicaciones, informes internos, o entre órganos o entidades administrativas".

Si ésta ha venido siendo la doctrina interna administrativa del OEITSS, para la Sentencia del TS, Sala Contencioso-Administrativa, de 6 de noviembre de 2012 -Rec. 3558/2011- ${ }^{1546}$, la actividad previa de comprobación tiene naturaleza de instrucción del

${ }^{1544}$ DURÉNDEZ SÁEZ, I.: "Modificaciones recientes que afectan a la Inspección de Trabajo y Seguridad Social y al Procedimiento administrativo sancionador del orden social", op. cit., edición digital, p. 11 de 19.

1545 BOE del 10.12.2013.

1546 Para esa Sentencia, "esta naturaleza instructora de las "actuaciones previas de comprobación" no se extrae tan solo de su ubicación temporal. Se extrae, sobre todo, de su regulación material contenida en el Real Decreto 928/1998, que prevé que su objeto es "comprobar el cumplimiento de las disposiciones legales, reglamentarias y convenidas en el orden social" (art. 8.1), regula en su seno las más amplias potestades de investigación y prueba de la Administración (art. 10) y establece que, si como consecuencia de las diligencias practicadas se constatan hechos constitutivos de infracción, se extenderá la correspondiente acta (art. 12.1) como "resultado" de la actividad inspectora previa (art. 13.1). Esta es la razón por la que siendo el acta de infracción el acto que formalmente "inicia" el expediente sancionador, tenga en realidad un contenido más propio de una propuesta de resolución que de un simple acuerdo de incoación (cfr.: arts. 13 y 18 del Reglamento de Procedimiento Administrativo Sancionador General). Al igual que una propuesta de resolución, el acta de infracción debe contener, según el art. 14 del Real Decreto 928/1998: (1) la identificación del sujeto infractor; (2) un relato de hechos probados con expresión motivada de los medios utilizados para su comprobación; (3) la calificación jurídica de la infracción o infracciones presuntamente cometidas; y, por último, (4) la propuesta de sanción. Consecuencia de todo lo anterior es que deben aplicarse con todo su rigor las consecuencias previstas por la norma para el caso de superarse el plazo máximo de duración o paralización de las actuaciones previas de comprobación. De la misma manera que se aplicarían esas consecuencias en caso de producirse esa paralización en la fase de instrucción del procedimiento sancionador general. Porque éste es en puridad el papel que desempeñan las actuaciones previas de comprobación en el procedimiento especial para la imposición de sanciones por infracciones del orden social. En este sentido, es doctrina de esta Sala que la especialidad de este específico procedimiento y la consiguiente "supletoriedad" de las normas generales del procedimiento sancionador establecida por la Disposición Adicional Séptima de la Ley 30/1992, no excluye que puedan y deban tenerse en 
procedimiento administrativo propiamente dicho, procedimiento que se inicia con la extensión del acta de liquidación, al señalar que la fase de instrucción de este específico procedimiento liquidador, no es que no exista, es que está desgajada del procedimiento de liquidación stricto sensu, y que se desarrolla con anterioridad al mismo, en las llamadas actuaciones previas de comprobación".

Al ser esa actividad previa de comprobación una fase instructora del procedimiento administrativo, de no extenderse el acta no se integrará en un procedimiento administrativo, por lo que en sí misma no podrá ser objeto de impugnación directa en vía judicial o administrativa, pudiendo sólo ser objeto de impugnación indirecta a través de los recursos administrativos o judiciales impugnatorios del acto administrativo de derivación de responsabilidad del que pudiera traer causa -el acta de liquidación de cuotas, o la resolución y la reclamación de deuda por derivación de la TGSS consecuencia del informe de la ITSS-, donde podrán impugnarse o cuestionarse los hechos imputables constitutivos de la responsabilidad derivada, la validez de las pruebas obtenidas, su valoración, los defectos esenciales de la actividad comprobatoria si han podido vulnerarse derechos fundamentales o garantías procedimentales, etc.

Concluimos remitiéndonos al apartado III. 7 de este Capítulo, en que se analizó la duración máxima de las actuaciones previas de comprobación y su caducidad.

\section{Acta de liquidación de cuotas de derivación de responsabilidad.}

El acta de liquidación de cuotas es un documento de carácter administrativo extendido por la ITSS en el que de modo provisional se determina una deuda de Seguridad Social, o una responsabilidad derivada en la misma, tras la realización de actividades de investigación o comprobación ${ }^{1547}$.

Las deudas por cuotas que pueden reclamarse mediante actas de liquidación de cuotas se recogen en el art. 34.1 del TRLGSS. Cuando la ITSS compruebe hechos determinantes de la responsabilidad del administrador social en las deudas de Seguridad Social de la sociedad de capital, como sería el supuesto de haberse incurrido en responsabilidad solidaria por acaecer una causa de disolución prevista en los arts. 360 y

cuenta a efectos interpretativos los principios que dimanan de ésta (Sentencias ya citadas de 12 de noviembre de 2001 y 21 de julio de 2004, y otras, como la de 23 de febrero de 2010, dictada en el Rec. 243/2008)". Doctrina aplicable igualmente a las actas de liquidación de cuotas.

1547 TRILLO GARCÍA, A. R.: “Artículo 31. Actas de liquidación de cuotas”, en AA.VV. (Dir.: GARCÍAPERROTE ESCARTÍN, I. y MERCADER UGUINA, J. R.): Comentarios a la Ley General de la Seguridad Social, editorial Lex Nova-Thomson Reuters, , 1ª edición, julio 2015, p. 191. 
363 de la LSC, sin haberse cumplido con las obligaciones previstas en los arts. 360, 365, 366 y 367 de la LSC; podrá extender acta de liquidación de cuotas por derivación de responsabilidad o emitir informe a la TGSS.

Como hemos señalado el apartado II de este Capítulo, legalmente no se limita el acta de liquidación por derivación de responsabilidad prevista en el art. 34 apartado 1.c) del TRLGSS, sólo a aquellos supuestos en los que proceda la extensión de un acta de liquidación de cuotas a la sociedad de capital, esto es, a los supuestos de falta de afiliación o de alta, de diferencias de cotización, o por bonificaciones indebidas (art. 34.1 apartados a), b), y d), del TRLGSS).

Sería válida el acta de liquidación de derivación de responsabilidad si se reclamase a los administradores la responsabilidad solidaria ante deudas por descubiertos totales de la sociedad, que hubiere reclamado a ésta previamente la TGSS (art. 33.1.a), del TRLGSS, ya que no habría óbice jurídico alguno para exigir a aquéllos mediante acta de liquidación la deuda impagada por la sociedad. El acta no estaría afectada de vicio de legalidad alguno, por lo que no podemos compartir la opinión de MARTÍN JIMÉNEZ y MATEOS BEATO ${ }^{1548}$, quienes señalan que esa acta no sería válida. Cuestión distinta es que, en aras de una mejor coordinación con la TGSS, cuando haya sido ésta quien hubiese reclamado la deuda a la sociedad, sea más oportuno emitir un informe para que la TGSS inicie el procedimiento administrativo de derivación de responsabilidad, y de este modo, centralizar en un mismo órgano administrativo toda la gestión recaudatoria, tanto ante el sujeto deudor principal -la sociedad-, como ante los responsables solidarios o subsidiarios -los administradores-. Pero, que ello sea más oportuno y eficaz, no significa que de no hacerse haya vicio de ilegalidad en la extensión del acta de liquidación.

Por lo mismo, y en sentido contrario, si se extendiese a la sociedad de capital un acta de liquidación de cuotas por falta de alta o afiliación de algún trabajador, por diferencias de cotización o por bonificaciones indebidas, y concurriesen hechos determinantes de la responsabilidad solidaria de los administradores, en el acta de liquidación se apreciará la responsabilidad de los mismos.

\footnotetext{
1548 MARTÍN JIMÉNEZ, R. y MATEOS BEATO, A.: La responsabilidad de empresas y
} Administradores con la Seguridad Social, op. cit., p. 271. 
El procedimiento para la extensión y tramitación de las actas de liquidación de cuotas se regirán por el RISOS, que es la disposición normativa de aplicación principal, y, supletoriamente en defecto de la anterior, será de aplicación: en primer lugar, la LPACAP; y en segundo lugar, como norma supletoria última de cierre el RGRSS, para todo lo relativo a la gestión recaudatoria de las actas, de modo esencial el procedimiento de recaudación ejecutiva de las mismas (art. 29.2 del RISOS ${ }^{1549}$, en relación con Disposición Adicional $1^{\text {a }}$ apartado 2.b) de la LPACAP ${ }^{1550}$ y art. 12.5 del RGRSS ${ }^{1551}$ ).

\subsection{Requisitos generales de las actas de liquidación.}

Como se ha indicado, el acta de liquidación inicia el procedimiento administrativo liquidatorio. Acta de liquidación que no es propiamente una resolución administrativa definitiva, sino que es una propuesta que contiene una liquidación provisional de cuotas adeudadas o una derivación de responsabilidad de carácter provisional, y que ha de ser notificada a los sujetos responsables, quienes podrán presentar alegaciones frente a la misma, para, una vez concluido el trámite de alegaciones, dictarse resolución administrativa por la Dirección Provincial de la TGSS, que podrá tener un triple contenido: a) elevar a definitiva el acta de liquidación, b) modificar la liquidación, y c) anular el acta si incurriese en algún vicio de ilegalidad, ser improcedente la deuda reclamada, la responsabilidad o haber prescrito la deuda o la responsabilidad.

El acta de liquidación es un acto administrativo provisional, que pasará a ser definitivo cuando se dicte la resolución administrativa pertinente por el órgano competente de la Administración o Dirección Provincial de la TGSS (art. 34.2 del TRLGSS), o cuando el

${ }^{1549}$ El art. 29.2 del Real Decreto 928/1998, de 14 de mayo, establece “2. El procedimiento administrativo para la práctica de actas de liquidación y demás documentos liquidatorios de cuotas a la Seguridad Social y conceptos de ingreso conjunto, se ajustará a las disposiciones del presente capítulo y, subsidiariamente, a lo dispuesto en la Ley 30/1992, de 26 de noviembre, de Régimen Jurídico de las Administraciones Públicas y del Procedimiento Administrativo Común. Serán sujetos responsables quienes así resulten por aplicación de las normas reguladoras del Sistema de Seguridad Social". La referencia a la Ley 39071992, debe entenderse a la Ley 39/2015, de 1 de octubre -LPACAP-.

${ }^{1550}$ La Disposición Adicional $1^{\text {a }}$ apartado 2.b) de la Ley 39/2015, de 1 de octubre, señala “ 2. Las siguientes actuaciones y procedimientos se regirán por su normativa específica y supletoriamente por lo dispuesto en esta ley; a) (...), b) las actuaciones y procedimientos de gestión, inspección, liquidación, recaudación, impugnación y revisión en materia de Seguridad Social y Desempleo."

1551 El art. 12.5 del Real Decreto 1415/2004, de 11 de junio -RGRSS-, establece "Sin perjuicio de las especialidades contenidas en la normativa específica reguladora de las actuaciones de la Inspección de Trabajo y Seguridad Social, lo previsto en este reglamento para el procedimiento recaudatorio seguido en relación con reclamaciones de deuda por derivación de responsabilidad solidaria, subsidiaria o mortis causa, será de aplicación al que se siga en virtud de actas de liquidación emitidas por derivación de responsabilidad." 
responsable ingrese su importe dentro del plazo para presentar alegaciones (art. 33.1 del RISOS).

El acta de liquidación por derivación de responsabilidad es una modalidad específica de acta de liquidación (art. 34 apartado 1.c) del TRLGSS, art. 65 apartado 1.c) del RGRSS y art. 31.1.c) del RISOS).

Examinemos brevemente los requisitos generales de las actas de liquidación, para posteriormente analizar el acta de liquidación por derivación de responsabilidad.

Los requisitos mínimos de toda acta de liquidación se enumeran en el art. 32.1 del RISOS, y con independencia de los relativos a la identidad de los sujetos responsables, régimen de Seguridad Social aplicable, o de los funcionarios actuantes, destacamos como especialmente relevantes, lo siguientes:

a) Los hechos comprobados por el funcionario actuante que motivan el acta, que deben ser descritos con precisión, con mención de los medios utilizados para su esclarecimiento, señalándose los elementos de convicción de que se ha dispuesto en la labor inspectora (art. 32.1.c), del RISOS).

b) "Los datos que hayan servido de base para el cálculo del débito: período de descubierto, relación nominal y grupo de cotización de los trabajadores afectados o, en su caso, relaciones contenidas en las declaraciones oficiales formuladas por el presunto responsable, referencia suficientemente identificadora del contenido de tales declaraciones, o relaciones nominales y de datos facilitadas y suscritas por el sujeto responsable; bases y tipos de cotización aplicados; y cuantos otros datos pueda el funcionario actuante obtener o deducir a los fines indicados. En los supuestos en que los datos de los documentos de cotización discreparan de los contenidos en las comunicaciones de inscripción de empresa, afiliación, altas y bajas de trabajadores y variaciones de datos, el acta de liquidación se calculará a partir de los datos de estas comunicaciones, salvo que quedara probado en el expediente la validez de los datos contenidos en los documentos de cotización" (según redacción literal del art. 32, apartado 1, letra d), párrafo primero, del RISOS).

c) Los fundamentos jurídicos de la liquidación de cuotas extendida, con mención expresa del precepto o preceptos vulnerados de las disposiciones legales y reglamentarias del orden social (art. 32.1.c), del RISOS). 
d) El importe principal de la deuda, y, en los supuestos que fueran procedentes, los recargos, intereses y costas devengadas hasta la fecha en que se extienda el acta, y la suma total de dichos conceptos.

e) Indicación expresa de la posibilidad de alegaciones a las que se podrán acompañar las pruebas de que se disponga.

f) Fecha del acta de liquidación.

En las actas de liquidación por bonificaciones indebidas, se flexibilizan los requisitos generales de los datos para determinar la deuda exigidos en el art. 32 apartado 1.d), ya que en su párrafo cuarto, se señala que, "en las actas de liquidación por aplicación indebida de las bonificaciones en las cotizaciones a la Seguridad Social para la financiación de acciones formativas del subsistema de formación profesional continua, previstas en el artículo 31.1.d) del Texto Refundido de la Ley General de la Seguridad Social, se hará constar la cuantía de la bonificación practicada y el periodo al que corresponda. En los restantes supuestos de actas de liquidación por bonificaciones y reducciones en las cuotas y/ o conceptos de recaudación conjunta, bastará con consignar el periodo de descubierto, el trabajador afectado y la cuantía de la bonificación o reducción practicada".

Pese a no indicarse nada en el art. 32.1 del RISOS, en el acta de liquidación deberán constar igualmente los siguientes datos. En primer lugar, la fecha de inicio de la actividad previa de investigación, ya que es un dato necesario a efectos de una eventual anulación de la misma por caducidad de la actividad inspectora previa de comprobación, y porque esa fecha es determinante a efectos de la interrupción de la prescripción, de acuerdo con el art. 43.1.b) del RGRSS. Igualmente, deberán recogerse las fechas de las sucesivas comprobaciones realizadas en la actividad previa de investigación, a efectos de la duración máxima de la misma, para que pueda ser objeto de fiscalización judicial (art. 20.4 LOITSS). En segundo lugar, deberá hacerse constar la modalidad de actuación inspectora, con sus respectivas fechas. Si ha sido mediante visita de inspección, en cuyo caso, habrá de identificarse el lugar, si ha sido por requerimiento de comparecencia, o por ambos medios, visita y comparecencia, o finalmente, si ha sido por expediente administrativo, reseñando el expediente en el que constan los hechos probados -sentencia judicial firme, etc.- (art. 21 de la LOITSS), al ser datos relevantes a efectos de la duración e interrupción de la actividad previa. 
Elementos esenciales del acta de liquidación ante una eventual impugnación por el sujeto responsable, son los recogidos en el artículo 32 apartados 1, letras c) y d), del RISOS, relativos a los hechos determinantes de la deuda liquidada, los hechos comprobados, y los medios de convicción de que ha dispuesto el Inspector o Subinspector.

Los hechos motivadores del acta de liquidación y los medios de convicción deben detallarse con precisión, ya que la insuficiencia en su relato ha llevado a numerosas sentencias a no tener por acreditados los hechos que originan la extensión del acta ${ }^{1552}$. La omisión o insuficiencia de los hechos que origina la reclamación administrativa, además de enervar la presunción de certeza del acta, puede dar lugar a la anulación de la misma por falta de acreditación o de prueba de los hechos que motivan la extensión del acta. Una detallada relación de hechos probados permitirá que el sujeto responsable pueda ejercitar su derecho a la defensa permitiendo el control jurisdiccional, porque la actividad inspectora debe, en todo caso, respetar las garantías y derechos constitucionales (Sentencia del TS, Sala Contencioso-Administrativa, de 10 de marzo de 1994 -Rec 3029/1990-).

Como se señala en los Criterios Técnicos 3/1997, y 22/1999, los hechos motivadores del acta de liquidación de cuotas, "es una de las cuestiones cuyo incumplimiento provoca un mayor número de anulaciones de Actas", y para evitar sentencias anulatorias, según el Criterio Técnico 3/1997, las actas deberán recoger todos "los factores de convicción que sustenten su procedencia y que permitan la contradicción al presunto deudor”.

Abunda en la necesidad de ser muy preciso en la exposición de los datos que han servido para determinar la deuda, el Criterio Técnico 22/1999, de 13 de julio de 1999, de la DGITSS, al señalar que, "los hechos motivadores deberán figurar suficientemente descritos y determinados, en especial, los cuantificadores de las bases de liquidación, tipos, epígrafes de accidentes y enfermedades profesionales aplicables a cada trabajador y primas, coeficientes reductores, etc. Suficiencia que también es necesaria respecto a los elementos de convicción de que ha dispuesto el funcionario inspector para concluir los probados y la valoración de los mismos si las circunstancias del caso lo requieren, y la cita del precepto o preceptos incumplidos".

1552 En el Criterio Técnico 3/1997 de la DGITSS, se indica, (sic) "La efectiva y correcta cumplimentación de tales requisitos es motivo de atenta y reiterada atención por parte de la jurisprudencia (TS, Sentencias de 27-9-88, 27-12-88, 29-3-89, 2-2-90, 19-2-90, 2-3-91, 10-12-92, 6-5-93, 19-1-94, 10-394, 21-6-95, y otras)". 
Con relación a la deuda, en el acta deberán recogerse "las bases de cotización y los tipos, siendo muy exigente la jurisprudencia al respecto (TS, Sala ContenciosoAdministrativa, Sentencias 5-4-90 y 4-5-90), con mención expresa de los períodos reclamados por cada uno de los trabajadores, independientemente del período total al que se extienda el acta de liquidación" ${ }^{1553}$. Las bases de cotización estarán en función de las retribuciones que los trabajadores tiene derecho a percibir, o de las realmente percibidas de ser superiores (art. 35.2 párrafo primero del TRLGSS). Si la Inspección de Trabajo y Seguridad Social se viese en la imposibilidad de conocer el importe de las remuneraciones percibidas por el trabajador, se estimará como base de cotización la media entre la base mínima y máxima correspondiente al último grupo de cotización conocido en que estuviese encuadrado el grupo o categoría profesional de los trabajadores, salvo en aquellos supuestos en que resulten de aplicación bases únicas (art. 35.2 párrafo segundo del TRLGSS).

Finalmente, es también elemento esencial del acta la mención de las "disposiciones infringidas, con expresión del precepto o preceptos vulnerados" (art. 32.1.c) del RISOS). Esta exigencia implica, según el Criterio Técnico 3/1997 de la DGITSS, reseñar "expresamente el precepto o preceptos vulnerados en que jurídicamente se basa la liquidación que se practica, debiendo existir correspondencia entre los hechos o circunstancias reseñados y el contenido de dicho fundamento jurídico en cada Acta de Liquidación; a tal efecto, se estima válido aplicar expresamente las relaciones y remisiones normativas que procedan, en la medida que técnicamente se estimen oportunas o necesarias al respecto (TS, Sentencia, 15-6-1993)".

\subsection{Requisitos particulares de las actas de derivación de responsabilidad.}

El art 31.1.c) del TRLGSS prevé el acta de liquidación por derivación de responsabilidad, como modalidad de acta de liquidación de cuotas, al establecerse que "procederá la formulación de actas de liquidación en las deudas por cuotas originadas por: (...) c) derivación de la responsabilidad del sujeto obligado al pago, cualquiera que sea su causa y régimen de la Seguridad Social aplicable, y con base en cualquier norma con rango de ley que no excluya la responsabilidad por deudas de Seguridad Social. En los casos de responsabilidad solidaria legalmente previstos, la Inspección de Trabajo y Seguridad Social podrá extender acta a todos los sujetos responsables o a

\footnotetext{
${ }^{1553}$ Según señala expresamente el Criterio Técnico 3/1997 de la DGITSS.
} 
alguno de ellos, en cuyo caso el acta de liquidación comprenderá el principal de la deuda a que se extienda la responsabilidad solidaria, los recargos, intereses y costas devengadas hasta la fecha en que se extienda el acta". Nos hallamos ante lo que un sector de la doctrina ha llamado responsabilidad derivada ${ }^{1554}$

Los requisitos específicos de las actas de liquidación por derivación de responsabilidad son los recogidos en con el art. 32.1, d) párrafo segundo del RISOS ${ }^{1555}$, a parte del resto de requisitos generales del acta de liquidación referidos a la sociedad de capital.

Serán requisitos del acta de liquidación por derivación de responsabilidad:

a) En primer lugar, en las actas de liquidación por derivación de responsabilidad, se harán constar todos los datos generales de las actas de liquidación referidos a la sociedad de capital cuya deuda es objeto de derivación de responsabilidad (razón social, número de identificación fiscal, código de cuenta de cotización de la mercantil, Régimen de Seguridad Social, actividad de la sociedad, domicilio, entidad de cobertura de las contingencias profesionales, etc.). La necesidad de identificar al responsable con nombre, apellidos y número de identificación, son necesarios y no vulneran la Ley Orgánica de Protección de Datos ${ }^{1556}$ ni el Reglamento comunitario ${ }^{1557}$, según Nota Informativa del año 2020 del OEITSS $^{1558}$.

b) En segundo lugar, la identificación de los responsables solidarios, mencionándose el nombre o razón social de los administradores responsables, el documento nacional de identidad de ser personas físicas, o el número de identificación fiscal de ser personas jurídicas, así como domicilio de los mismos a efectos de su notificación. La necesidad de identificar al responsable solidario o subsidiario con

${ }^{1554}$ Por todos, ALARCÓN CARACUEL, M. R. y GONZÁLEZ ORTEGA, S.: Compendio de Seguridad Social, op. cit., p.128.

${ }^{1555}$ En ese precepto se establecen como requisitos propios del acta por derivación de responsabilidad: "las actas de liquidación por derivación de responsabilidad, con excepción de las extendidas en los supuestos de contratas y subcontratas, contendrán los datos referentes al período de deuda al que se contrae el acto de derivación, el número total de los trabajadores que se encuentran afectados por la derivación, y el importe de la deuda que se deriva, diferenciando por cada uno de los meses de deuda imputados la cuantía de la deuda principal, y los recargos, intereses y costas, en los supuestos que fueran procedentes. En este supuesto, se adjuntará al acta la documentación anterior que acredite la preexistencia de la deuda".

${ }^{1556}$ Ley Orgánica 3/2018, de 5 diciembre, de Protección de Datos Personales y garantía de los derechos digitales -BOE 6.12.2018-

1557 Reglamento (UE) 2016/679 del Parlamento Europeo y del Consejo, de 27 de abril de 2016 (Ref.: La Ley 6637/2016), relativo a la protección de las personas físicas en lo que respecta al tratamiento de sus datos personales y a la libre circulación de estos datos -DOUE Serie L, 4.5.2016-.

${ }^{1558}$ Ref.: La Ley 1512/2020. 
nombre, apellidos y número de identificación, son necesarios y no vulneran la Ley Orgánica de Protección de Datos ni el Reglamento comunitario de protección de datos, según Nota Informativa del OEITSS ${ }^{1559}$

c) En tercer lugar, la concurrencia de la causa de la concreta responsabilidad derivada, sea de carácter solidaria o subsidiaria, que ha motivado la extensión del acta.

d) En cuarto lugar, deberán recogerse los hechos comprobados por el funcionario actuante que motiva el nacimiento de la deuda de la sociedad (falta de alta, diferencias de cotización, descubierto total de cuotas, etc.), y los hechos que fundamenten la responsabilidad derivada (concurrencia de causa de disolución, con acreditación suficiente de la causa, incumplimiento de los deberes de los administradores, con acreditación de los deberes se incumplidos, etc.), describiendo con la suficiente precisión ambos hechos, y reseñando los elementos de convicción de que ha dispuesto, las pruebas obtenidas y los medios utilizados para el esclarecimiento de esos hechos. Los hechos así consignados gozarán de presunción de certeza, salvo prueba en contrario.

e) En quinto lugar, deberá hacerse una exposición de las disposiciones infringidas que han determinado el nacimiento de la deuda de la sociedad de capital, con expresión del precepto o preceptos vulnerados, así como los preceptos que fundamental la responsabilidad derivada en las deudas por cuotas de Seguridad Social.

f) En sexto lugar, los datos objetivos sobre la deuda derivada. Con relación a los datos necesarios para la determinación de la deuda derivada, hay una mayor flexibilidad o permisibilidad, y ésta es la nota característica propia de las actas de liquidación por derivación de responsabilidad, ya que no se exige la concurrencia de todos y cada uno de los requisitos que para calcular la deuda se impone en general a las actas de liquidación en el art. 32 apartado 1.d) primer párrafo del RISOS. Así, en el segundo párrafo de este art. 32.1.d), con relación a los datos que han servido de base para el cálculo de la deuda, se indica que, "las actas de liquidación por derivación de responsabilidad, con excepción de las extendidas en los supuestos de contratas y subcontratas, contendrán los datos referentes al

${ }^{1559}$ Ref. La Ley 1512/2020, y publicada en el foro interno del conocimiento de la ITSS. 
período de deuda al que se contrae el acto de derivación, el número total de los trabajadores que se encuentran afectados por la derivación, y el importe de la deuda que se deriva, diferenciando por cada uno de los meses de deuda imputados la cuantía de la deuda principal, y los recargos, intereses y costas, en los supuestos que fueran procedentes. En este supuesto, se adjuntará al acta la documentación anterior que acredite la preexistencia de la deuda". En definitiva, está exigiendo que conste el período de la deuda derivada, el número de trabajadores afectados, sin precisarse su identificación, y la deuda derivada, con especificación de los importes mensuales del principal de la deuda, recargos, intereses y costas.

De este precepto se desprende que en las actas de derivación de responsabilidad no sería necesario que recojan todos los datos necesarios para llegar a obtener el cálculo de la deuda, porque en el supuesto de derivación de responsabilidad al administrador social ya existirá una deuda previa de la sociedad que habrá sido liquidada (salvo que sea un acta por falta de alta, diferencias de cotización o bonificaciones indebidas con apreciación de la responsabilidad solidaria de los administradores, en cuyo caso, se detallará la deuda en el acta). No sería necesario en las actas de derivación de responsabilidad del art. 34 apartado 1.c) del TRLGSS -en las que se deriven deudas por descubiertos totales o parciales ya liquidadas por la TGSS o autoliquidadas por la propia sociedad deudora-, determinar las bases de cotizaciones individualizadas de los trabajadores, ni la relación nominal de esos trabajadores, ya que sólo se exige concretar "el período de deuda al que se contrae el acto de derivación, el número total de los trabajadores, y el importe total de la deuda que se deriva, diferenciando por cada uno de los meses de deuda imputada el importe de la deuda principal, los recargos, intereses y costas, pudiendo sustituirse esas menciones por la documentación que acredite la existencia de la deuda".

Al no exigirse la relación nominativa de trabajadores, ni las bases de cotización individualizadas por empleados, a diferencia del resto de actas de liquidación en que nos hallamos ante una deuda no liquidada o declarada (faltas de altas, diferencias, bonificaciones indebidas); para las actas de liquidación por derivación de responsabilidad se permite que pueda adjuntarse la documentación que acredite la preexistencia de la deuda, que podrán ser, o bien las liquidaciones mensuales 
impagadas de la empresa, o bien las reclamaciones de deuda o las providencias de apremio de la TGSS, en función de que la sociedad hubiere o no comunicado a la Tesorería los datos para las liquidaciones mensuales. En este sentido, se pronuncia también CAMINO FRÍAS ${ }^{1560}$, para quien en este tipo de actas por derivación, a diferencia de las actas por falta de alta o diferencias de liquidación, no se está liquidando "ex novo" una deuda, sino derivando una deuda previa que se habrá reclamado por la TGSS, de modo que sería suficiente con la (sic) "referencia suficientemente identificadora al contenido de tales declaraciones, para esto servirían perfectamente, en mi opinión, las copias de los documentos de deuda del sujeto originario, tal y como aparecen en el Fichero General de Recaudación (Transacción RCU05) ya que en ellas figura el número de trabajadores, la base global de cotización del periodo de descubierto y la deuda por conceptos, total, y recargo, elementos todos ellos suficientemente identificadores del débito cuya satisfacción se está exigiendo", todo ello, porque, en definitiva, según este autor, “el objeto esencial de estas actas se desplaza de la identificación de la deuda a la del sujeto obligado a su pago".

Ahora bien, cuando esa documentación adjuntada o referenciada que liquidó la deuda de la sociedad fuese la llamada "reclamación de deuda" emitida por la TGSS, la misma se habrá extendido por bases estimadas, salvo que hubiere mediado una previa propuesta de liquidación de la ITSS (arts. 33. 1 letras a) y b) y 35.1 del TRLGSS). Y esa reclamación de deuda según el art. 63 apartado 1.c) del RGSS, sólo incluirá "los datos necesarios para la determinación de la deuda con indicación del importe reclamado, así como de la cuantía del recargo aplicado, y con expresión, en su caso, del número de trabajadores a que se refiere la reclamación y de las bases y tipos de cotización aplicados". En definitiva, la reclamación de deuda no exige que se determinen las bases individualizadas de los trabajadores, sólo las bases totales del mes, ni la relación nominativa de los trabajadores, sólo su número total, en cuyo caso, a los administradores no se les estará dando traslado de todos los datos necesarios para conocer cómo se ha determinado la deuda reclamada. Al no recogerse las bases individualizadas ni la

${ }^{1560}$ CAMINO FRÍAS, J. J.: "El procedimiento para extender las actas de liquidación y los supuestos de derivación de responsabilidad: algunas cuestiones", edición digital,

http://itss.laley.es/Content/Documento.aspx?params, publicado en el Foro del Conocimiento del OEITSS. Ref.: La Ley 13909/2009. 
relación de los trabajadores afectados, se podría afectar el derecho de los administradores a no sufrir indefensión, ya que si quieran cuestionar el importe de la deuda reclamada, deberían acreditar que las bases de cotización reales de los trabajadores son inferiores, o que se reclaman deudas por un número mayor a los trabajadores en alta en los períodos reclamados, y ello podría ser una carga desproporcionada para aquellos administradores que ya no están en el ejercicio del cargo y sin posible acceso a la documentación de Seguridad Social de la empresa, por lo que para evitarse su indefensión, tienen el derecho a pedir que por la TGSS se les determine la relación de trabajadores, y por la empresa las bases reales de cotización de los mismos, al estar legitimados para oponerse no sólo al acto de derivación, sino también a la procedencia de la deuda.

De opinión contraria es CAMINO FRÍAS ${ }^{1561}$, para quien, "en este tipo de actas, referidas a deuda ya declarada, la identificación del débito ha de efectuarse con la suficiente remisión a los documentos que reflejan la deuda originaria, añadiendo ahora los referentes a recargos, costas e intereses, sin que quepa incurrir por parte de las autoridades administrativas o judiciales con funciones revisoras en la materia, en interpretaciones en extremo formalistas y, a mi juicio, alejadas de la finalidad, a la vez garantizadora de los derechos de los administrados, y encauzadora de la actuación administrativa, propia de las normas de procedimiento".

g) En séptimo lugar, ha de constar el importe total derivado, los recargos, intereses y costas, de ser una responsabilidad solidaria, ya que de ser responsabilidad subsidiaria, sólo responde el sujeto responsable subsidiario del principal de la deuda (art. 33.2 del TRLGSS y art. 14.2 del RGRSS), por lo que, en el modelaje de actas de liquidación por derivación de responsabilidad subsidiaria no deberá recogerse el recargo en la deuda derivada al responsable subsidiario, y si costase en el cuerpo del acta la deuda, recargo e intereses, por haberse extendido a la sociedad de capital con derivación de la responsabilidad al responsable subsidiario, deberá determinarse claramente en la propia acta que la deuda que se deriva al responsable subsidiario es sólo el principal de la deuda, en el que no se incluirán los importes del recargo ni los intereses. Son estas disfunciones las que

${ }^{1561}$ CAMINO FRÍAS, J. J.: "El procedimiento para extender las actas de liquidación y los supuestos de derivación de responsabilidad: algunas cuestiones", op. cit. 
han llevado al OEITSS a estimar más oportuno emitir un informe de derivación de responsabilidad dirigido a la TGSS, y no un acta de liquidación de derivación, cuando concurran supuestos de responsabilidad subsidiaria:

- Entidad que cubre las contingencias profesionales de la sociedad de capital.

- Indicación si se extiende acta de infracción conjunta por los mismos hechos. Este dato sólo será para las actas extendidas a la sociedad de capital, pero no para las actas de liquidación por derivación de responsabilidad al administrador social ${ }^{1562}$, ya que éste no es responsable de las infracciones del orden social (art. 2 del TRLISOS). Si se apreciase la derivación de responsabilidad de los administradores en el acta de liquidación de cuotas extendida a la sociedad por faltas de alta en Seguridad Social o por diferencias de cotización, y se hubiere extendido acta de infracción por los mismos hechos a la sociedad de capital, el acta de infracción se extenderá y notificará sólo a la mercantil, pese a tener que tramitarse conjuntamente ambas actas por el mismo cauce procedimental, y dictarse sendas resoluciones unificadas de las mismas (art. 34.4 del TRLGSS y art. 34 del RISOS), ya que no se ha excluido este supuesto de la tramitación conjunta procedimiento conjunto o unificado-, como se ha hecho en otros supuestos, como cuando se extiende acta de liquidación y acta de infracción por los mismos hechos, y se comunican éstos al Ministerio Fiscal, en cuyo caso, no se tramitan conjuntamente las actas, y no se resuelven en un mismo procedimiento unificado el acta de liquidación y el acta de infracción (art.

\section{5 del RISOS).}

- Funcionario o funcionarios actuantes que extienden el acta de liquidación con su firma y, en su caso, firma del inspector que la conforme con su visado.

\footnotetext{
${ }^{1562}$ No cabe que el acta de liquidación por derivación de responsabilidad extendida a los administradores, vaya acompañada, con relación a ellos, de un acta de infracción conjunta por los mismos hechos. Al respecto en la consulta de 21 de enero de 2011, de la DGITSS, sobre la "posibilidad de levantar acta de infracción y liquidación coordinadas al administrador social de conglomerado empresarial. La aplicación de la teoría del levantamiento del velo al ámbito laboral sólo puede ser efectuada si se cumplen los requisitos establecidos a través de la reiterada doctrina del Tribunal Supremo", se señala, acerca de la responsabilidad solidaria del administrador en las cuotas de una sociedad, partiendo de la doctrina del levantamiento del velo, que "en el supuesto de que se cumplieran dichos requisitos, desde un punto de vista jurídico, la extensión de responsabilidad sería solidaria y no directa, según la configuración jurisprudencial de la misma, por lo que se podría extender acta de liquidación por derivación de responsabilidad, pero no acta de infracción por la imposibilidad de extender la responsabilidad a las sanciones, "dado el carácter personalísimo de las mismas."
} 
- Indicación expresa del derecho a presentar alegaciones ante el Jefe de la Unidad Especializada de la Seguridad Social.

- Fecha del acta.

En las actuaciones de la ITSS de derivación de responsabilidad ${ }^{1563}$, según el Criterio Técnico 31/2000 de la DGITSS, se indica que "sea por acta o mediante informe a TGSS, ha de contener los hechos y los fundamentos jurídicos que amparen la extensión de responsabilidad, de forma que pruebe la responsabilidad correspondiente que se imputa; ha de tener en cuenta, además de la general, la prescripción específica de responsabilidad en los supuestos que se aplicable".

Con relación a los hechos determinantes de la derivación de responsabilidad, en el Criterio Técnico 89/2011, de la DGITSS, sobre derivación de responsabilidad a los administradores de sociedades mercantiles capitalistas en materia de deudas por cuotas de Seguridad Social, se declara que "el acta de liquidación o el informe en el que se derive la responsabilidad a los administradores por las deudas sociales deberá hacer constar en todo caso la existencia de una causa legal de disolución de la sociedad de las contempladas en el art. 363.1 de la LSC, que deberá justificarse por los medios apropiados. En particular, la existencia de las pérdidas deberá considerarse acreditada mediante el examen del balance. En el muy frecuente supuesto de que ese examen no sea posible (por no haber sido localizada la empresa o los administradores, por incomparecencia de éstos o por falta de depósito de las cuentas en el Registro), la insuficiencia patrimonial deberá justificarse por vías indirectas, bien por haber sido declarado el crédito incobrable por la Tesorería o bien acudiendo a lo declarado por los tribunales (así, Sentencia del Tribunal Superior de Justicia de Extremadura de 25 de enero de 2000, Sentencia de la Audiencia Provincial de Madrid, de 7 de junio de 2005, y Sentencia de la Audiencia Provincial de La Coruña, de 23 de marzo de 2006), y exponiendo las circunstancias relevantes a estos efectos que hubieran podido observarse durante las actuaciones de comprobación".

Con relación al contenido mínimo de las actas, en la Nota Informativa de la DGITSS “sobre los datos mínimos de las actas de liquidación e informes a TGSS en el caso de derivación de deudas de Seguridad Social a los administradores sociales", de fecha 4 de

1563 Criterio Técnico 31/2000, de 18 de mayo de 2000, de la DGITSS, relativo a la derivación de la responsabilidad del sujeto responsable principal del pago de cuotas a la Seguridad Social y a otros Ref.: La Ley 283/2000-. 
febrero de 2016, se establece que deberán recogerse, al menos, los siguientes datos: a) especificar la concreta causa legal de disolución de la sociedad que concurre, de las previstas en el art. 363.1 de la LSC, debiendo justificarse adecuadamente -debemos puntualizar nosotros, que si la causa fuere la disolución de pleno derecho por reducción del capital por debajo del mínimo legal del art. 360.1.b) de la LSC, deberá especificarse la concurrencia de la misma y el transcurso del plazo de un año sin haberse removido-; b) fecha de concurrencia de la causa de disolución; y c) fecha a partir de la cual procede la derivación de la deuda, que en el caso de pérdidas cualificadas será desde el día siguiente a la concurrencia de la causa legal.

Como señalábamos en el apartado II de este capítulo, acerca de la distribución de competencias entre la TGSS y la ITSS en materia de derivación de responsabilidad, siendo competencia de la ITSS la extensión de actas de liquidación por derivación de responsabilidad, ello no obstante en el propio funcionamiento del OEITSS se venía optando en las actuaciones inspectoras por el informe emitido a la TGSS, en lugar de extender directamente el acta de liquidación por derivación de responsabilidad, especialmente por las dificultades técnicas debidas la ausencia de una aplicación informática que permitiese el cálculo de las liquidaciones por derivación y su inmediata grabación en el fichero de recaudación de la TGSS, y porque, si se optaba por el informe, todo el proceso de gestión recaudatoria se llevaría desde su origen por la TGSS, lo que le permitiría una mayor eficiencia en la recaudación. Con relación al primer aspecto, sobre la insuficiencia de medios técnicos de la ITSS, en la Guía de actuación sobre actas de liquidación de la DGITSS, de 2014, se señalaba expresamente (sic), "la elaboración de las Actas de Liquidación por derivación de responsabilidad a través de la aplicación INTEGRA no tiene el mismo funcionamiento que el establecido para la confección de las Actas de Liquidación para el resto de descubiertos, toda vez que para las primeras la TGSS no realiza su cálculo y grabación inmediata de la deuda en su Fichero General de Recaudación, que sí sucede con las segundas. Una vez aclarado este aspecto, se informa que la elaboración de esta tipología de Actas de Liquidación en la aplicación INTEGRA se realizará mediante la generación, en primer lugar, de un producto Acta de Liquidación, con la clave correspondiente y dicha naturaleza de descubierto; en segundo lugar, será necesario introducir la deuda a derivar en el módulo Liquidaciones Parciales, bien en cada uno de los meses que integran el periodo liquidatorio del Acta, o bien en uno de esos meses imputar toda la deuda. De 
esta forma la aplicación INTEGRA realiza el cálculo del Acta de Liquidación, aplicando a la deuda derivada el recargo del $20 \%$. Una vez terminado este proceso (o antes), y como en todas las Actas habrá que cumplimentar el Anexo de los hechos. También existe la posibilidad de realizar estos expedientes a través de un Informe a remitir a la TGSS, con la deuda que se deriva".

Como puede observarse ante las insuficiencias de medios técnicos para la gestión de la elaboración del acta de liquidación por derivación de responsabilidad, se recordaba la posibilidad de emitir el informe a la TGSS, como alternativa al acta de liquidación, reconociendo que con el informe se salvaban las dificultades que entrañaba la extensión de acta, pese a tener la competencia plena para emitir actas por derivación de responsabilidad, sin que jurídicamente estuvieren limitadas o condicionadas sólo a los supuestos en que cupiese un acta de liquidación por otras causas -faltas de alta a la Seguridad Social de trabajadores, diferencias de cotización, o bonificaciones indebidas-

Aunque en el art. 34.1.c) del TRLGSS se señala que, "en los casos de responsabilidad solidaria legalmente previstos, la Inspección de Trabajo y Seguridad Social podrá extender acta a todos los sujetos responsables o a alguno de ellos", en el acta de liquidación deberá identificarse y determinarse todos los administradores responsables (art. 32.1 letra a) del RISOS), porque si no se declarase la responsabilidad de alguno de ellos, no podría exigirse a éstos el pago de las cuotas recogidas en el acta. Lo que se quiere indicar con esa deficiente redacción, es que una vez declarada la responsabilidad solidaria de todos los administradores, podría exigirse el pago en el procedimiento recaudatorio a todos o a alguno de ellos, sin que la falta de pago de alguno de ellos sea obstáculo para seguir el procedimiento recaudatorio frente al resto (art. 1144 del Código Civil). Si no constase la declaración de responsabilidad de todos los administradores en el acta de liquidación, para poder reclamar la deuda al resto de los administradores, debería emitirse una nueva acta de liquidación, o, en su caso, una reclamación de deuda acompañada de la pertinente resolución de declaración de responsabilidad de la TGSS, ya que, para exigirse el pago de la deuda por derivación de responsabilidad es requisito previo la identificación de todos y cada uno de los responsables solidarios (art. 32.1.a) del RISOS), siendo en un momento procedimental posterior, en la vía ejecutiva, cuando podría pretenderse el ingreso coactivo a todos o a alguno de ellos.

De extenderse acta de liquidación y acta de infracción por los mismos hechos a la sociedad de capital, con apreciación de la responsabilidad solidaria (piénsese en una 
falta de alta en Seguridad Social o diferencias de cotización), el acta de infracción tendrá efectos únicamente ante la sociedad, no ante el administrador, por lo que éste tendrá derecho a la audiencia y a efectuar alegaciones acerca del acta de liquidación, y en las resoluciones unificadas de ambas actas se determinará que la responsabilidad del administrador será, de proceder, en el pago de la liquidación. Téngase en cuenta que no se ha excluido este supuesto de la tramitación unificada de ambas actas -procedimiento unificado-, a diferencia de lo previsto en el art. 34.5 del RISOS cuando los hechos sean constitutivos de delito, ya que en ese caso ha de suspenderse la tramitación del acta de infracción. Igualmente no procede el procedimiento unificado cuando por los mismos hechos deban resolver autoridades distintas el acta de infracción y el de liquidación (piénsese en un supuesto de falta de alta de un trabajador perceptor de prestaciones, en que el acta de liquidación por falta de alta la resuelve la TGSS y el acta de infracción por el ilícito muy grave se resuelve por el jefe de la Inspección, estando previsto que en el futuro se resuelva por la entidad gestora -SEPE- en virtud de la Disposición Transitoria $2^{\text {a }}$ del Real Decreto 72/2011, de 3 de junio ${ }^{1564}$, que reforma el RISOS).

Este es otro factor que contribuye a que no se extiendan actas de liquidación por derivación de responsabilidad, optándose por la emisión de un informe a la TGSS, cuando las deudas a la sociedad de capital se exijan mediante reclamación de deuda de la TGSS.

\subsection{Presunción de certeza de las actas de la Inspección.}

En el art. 53.2 del TRLISOS y en el art. 23 de la LOITSS se recoge el principio de la presunción de certeza de los hechos constatados en la actividad inspectora previa de comprobación, al establecerse que los hechos constatados por los funcionarios de la Inspección de Trabajo y Seguridad Social, que se formalicen en las actas de infracción y de liquidación, observando los requisitos legales pertinentes, "tendrán presunción de certeza", sin perjuicio de las pruebas que en defensa de los respectivos derechos o

\footnotetext{
${ }^{1564}$ BOE del 21.6.2011,

"Disposición Transitoria Segunda. Asunción de competencias sancionadoras por el Servicio Público de Empleo Estatal.

Las competencias sancionadoras atribuidas a las Direcciones Provinciales del Servicio Público de Empleo Estatal respecto de las infracciones reguladas en la Sección Primera del Capítulo III del Texto Refundido de la Ley de Infracciones y Sanciones en el Orden Social relativas a las prestaciones por desempleo serán de aplicación una vez que el Servicio Público de Empleo Estatal disponga de los recursos necesarios para ello y así se establezca por Orden del Ministerio de Trabajo e Inmigración. Hasta entonces, la competencia para sancionar las infracciones mencionadas corresponderá a los Jefes de las Inspecciones Provinciales de Trabajo y Seguridad Social de la Administración General del Estado".
} 
intereses puedan aportar los interesado. Privilegio de presunción de certeza que se extiende a los hechos recogidos en las actas de liquidación de cuotas (art. 23 de la LOITS y art. 32.1.c) del RISOS) y en los informes emitidos por la Inspección (art. 23 párrafo segundo de la LOITSS).

Presunción de certeza que no se ve afectada por el hecho de haber sido sustituido el funcionario o funcionarios actuantes en el transcurso de la actividad previa de comprobación, exigiéndose que se comunique esa circunstancia a los interesados con anterioridad a la finalización de las actuaciones (art. 23 párrafo tercero de la LOITSS). Se impone la obligación de comunicar al sujeto sometido a la actividad de comprobación o inspección la sustitución del funcionario actuante, en garantía de sus derechos. Sustitución que no tiene fijado un plazo para su comunicación al interesado, siempre que se haga antes de finalizar las actuaciones, pero pese a esa laxitud, entendemos que deberá comunicarse cuanto antes, sin dilaciones. El relevo del funcionario actuante podrá tener causas objetivas como el cese, traslado, enfermedad u otra causa de fuerza mayor, o bien razones procedimentales de concurrir causas de abstención, o, por último, razones internas de insuficiente diligencia en la actividad investigadora, cuando incurra el funcionario actuante en demoras injustificadas o se separare manifiestamente de las normas e instrucciones que rigen la función inspectora (art. 18 del ROFITSS).

Esta presunción de certeza es una presunción "iuris tantum", frente a la que cabe la prueba en contrario de la empresa o sujeto responsable, ya que esta presunción de veracidad no es prueba tasada, pudiendo ser desvirtuada por otras pruebas de descargo de la parte afectada, que serán valoradas conjunta y libremente por los órganos jurisdiccionales (Sentencia del TS, Sala Contencioso-Administrativa, de 10 de marzo de 1994 -Rec. 3029/1990-).

La presunción de certeza no libera al Inspector o Subinspector de la carga de reflejar en el acta las pruebas o elementos de convicción de que se ha servido para dar por acreditados los hechos determinantes del acta de liquidación, en definitiva, de la actividad probatoria desplegada en el curso de las actuaciones comprobatorias. Al ser el acta de infracción parte del procedimiento administrativo sancionador, debe aplicarse a ese procedimiento sancionador, con ciertas matizaciones, las garantías y derechos de defensa previstos en el art. 24 de la CE (Sentencia del TC 77/1983, de 3 de octubre, ponente Díez Picazo), por ser el procedimiento administrativo sancionador 
manifestación del "ius puniendi" del Estado (Sentencia del TC, 18/1981, de 8 de junio), por lo que serán de aplicación, tanto los principios sustantivos del art. 25.1 CE como de las garantías procedimentales del art. 24.2 CE, entre las que se encuentra el derecho a la defensa y a ser informado de los hechos imputados, pero sin ser aplicable al procedimiento liquidatorio, al acta de liquidación, la presunción de inocencia por no ser un procedimiento sancionador (Sentencia del TS, Sala Contencioso-Administrativa, de 20 de abril de 1992 -ES:TS:1992:11970-, ponente Conde Martín de Hijas, Vicente). Esto obliga a la Administración a seguir un procedimiento en el que el interesado tenga oportunidad de aportar y proponer las pruebas que estime pertinentes y de alegar lo que a su derecho convenga ${ }^{1565}$.

La presunción de certeza de los hechos constatados y recogidos en las actas de Inspección, como ha señalado la jurisprudencia ${ }^{1566}$, tiene su fundamento "en la imparcialidad y especialización" que, en principio, debe reconocerse al Inspector o subinspector actuante, porque estamos ante la comprobación de unos hechos objetivos realizada por órganos especializados de la Administración. Presunción de certeza que es perfectamente compatible con el derecho fundamental a la presunción de inocencia, en el caso de las actas de infracción (artículo 24.2 CE), ya que los citados preceptos se limitan a atribuir a tales actas el carácter de prueba de cargo, dejando abierta la posibilidad de practicar prueba en contrario ${ }^{1567}$. Es también reiterada la jurisprudencia que ha limitado el valor atribuible a las Actas de la Inspección, limitando la presunción de certeza sólo a los hechos que por su objetividad son susceptibles de percepción directa por el Inspector o Subinspector, o a los inmediatamente deducibles de aquéllos o acreditados por medios de prueba consignados en la propia acta, como pueden ser documentos o declaraciones incorporadas a la misma ${ }^{1568}$. Por el contrario, es nutrida la

${ }^{1565}$ SSTC, 32/2009, de 9 de febrero; 59/2014, de 5 de mayo; 93/2018, de 17 de septiembre; y 82/2019, de 17 de junio, entre otras muchas.

1566 SSTS, Sala Contencioso-Administrativa, de 18 de enero de 1991 -Aranzadi RJ 1991\15081-; 18 de marzo de 1991; de 12 de enero de 1996 -Rec. 788/1991-; 18 de enero de 1996 -Rec. 2450/1991-; de 19 de enero de 1996 -Rec. 1298/1991-; de 21 de marzo de 1997 -Rec. 604/1991-; 4 de diciembre de 2009 -Aranzadi RJ 2010/1885-; 28 de febrero de 2012 -Rec. 1616/2010-; y 10 diciembre 2014 -RJ 2015/42-, entre otras muchas.

1567 STC, 77/1983, de 3 de octubre; y SSTS, Sala Contencioso-Administrativa, de 10 de marzo de 1994 Rec. 3029/1990-; de 19 de enero de 1996 -Rec. 1298/1991-; de 23 de julio de1996; de 24 de septiembre de 1996 -Rec. 738/1992-; de 29 de noviembre de 1996 -Rec. 3460/1992; de 13 de enero de 1997; 20 de mayo de 1997 -Rec. 10366/1990-; de 15 de julio de 1997 -Rec. 10357/1990-; de 10 de octubre de 1997 -Rec. 4331/1991-; y de 10 diciembre 2014 -RJ 2015/42-, entre otras muchas.

1568 STC, 76/1990, de 20 de abril; y SSTS, Sala Contencioso-Administrativa, de 24 de junio de 1991 -RJ 1991/7578-; de 6 de mayo de 1993 -Aranzadi RJ 1993/8738-; de 19 de enero de 1996 -Rec. 
jurisprudencia ${ }^{1569}$ que no reconoce presunción de certeza a las simples apreciaciones globales, juicios de valor o calificaciones jurídicas.

La presunción de certeza es destruible por prueba en contrario, de modo que es el administrador quien debe acreditar con las pruebas que aporte, que los hechos reflejados en las actas no se ajustan a la realidad ${ }^{1570}$. En puridad, la presunción de veracidad o certeza de las actas no supone, en sentido estricto, que se invierta la carga de la prueba, sino la necesidad de actuar contra el medio de prueba aportado por la Administración ${ }^{1571}$, la que deberá acreditar la infracción ${ }^{1572}$ o los hechos determinantes de la liquidación. La presunción de certeza no otorga a las actas de la Inspección de Trabajo una veracidad absoluta e indiscutible, lo que no sería constitucionalmente admisible, sino que el valor probatorio que de ellas se deduce puede ser enervado por otras pruebas que conduzcan a conclusiones distintas, ya que nada impide que frente a las actas se puedan utilizar los medios de defensa oportunos ${ }^{1573}$.

En vía judicial, las actas de la Inspección no poseen mayor relevancia, respecto a otros medios de prueba admitidos en Derecho, y, por ello, ni han de prevalecer frente a otras pruebas que conduzcan a conclusiones distintas, ni pueden impedir que los tribunales formen su convicción sobre la base de una valoración o apreciación razonada de las pruebas practicadas ${ }^{1574}$.

1298/1991-; de 5 de mayo de 1997 -Rec. 8754/1990-; de 28 de febrero de 2012 -Rec. 1616/2010-; y de 10 diciembre 2014 -RJ 2015/42-, entre otras muchas.

${ }^{1569}$ De las que son exponentes, STC, 76/1990, de 26 de abril; y SSTS, Sala Contencioso-Administrativa, de fechas de 18 marzo 1980 -Aranzadi RJ 1980\2266-; 10 julio 1981; 7 abril 1982 -Aranzadi RJ

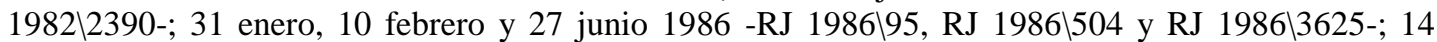
abril, 17 y 29 junio y 1 diciembre 1987 -RJ 1987\4207, RJ 1987\4404 y RJ 1987\9261-; 23 febrero, 4 y 21 abril, 4 y 18 mayo y 25 octubre 1988 -RJ 1988\1454, RJ 1988\2347, RJ 1988\3390, RJ 1988\4037, RJ 1988\4181 y RJ 1988\7867-; 2 enero, 5, 15 y 19 marzo, 23 abril y 25 mayo 1990-RJ 1990\146, RJ 1990\2017, RJ 1990\1828, RJ 1990\2022 y RJ 1990\3138-; y 28 de febrero de 2012 Rec. 1616/2010-, entre otras muchas.

${ }^{1570}$ SSTS, Sala Contencioso Administrativo de esta Sala, de 9 de julio de 1991 -ECLI: ES:TS:1991:3980; y 19 de enero de 1996 -Rec. 1298/1991-, entre otras muchas.

1571 SSTS, Sala Contencioso-Administrativa, de 29 de junio de 1998 -Rec. 4717/1992-; 27 de abril de 1998; y 23 de abril de 2001 -Rec. 6230/1995-.

1572 TOLOSA TRIBIÑO, C.: "La aplicación de los principios de la potestad sancionadora a las infracciones del orden social”, Actualidad Laboral, Sección Doctrina, 1999, Ref. XLIII, p. 681, Tomo 3, Editorial La Ley, Ref. La Ley 3030/2001, edición digital Smarteca, p. 13.

1573 SSTS, Sala Contencioso-Administrativa, de 29 de junio de 1998 -Rec. 4717/1992-; de 27 de abril de 1998 -Aranzadi RJ 1998, 3066-; de 10 de noviembre de 2016 -Aranzadi RJ 2016, 6230-; y de 22 de octubre de 2001 -RJ 2002, 9878-, entre otras.

1574 SSTC, 76/1990, de 26 de abril; de 23/1995, de 30 de enero; y de 69/1998, de 30 de marzo; así como SSTS, Sala Contencioso-Administrativa, 22 de noviembre de 2001 -Aranzadi RL 2002, 9878-; y 10 de noviembre de 2016 -RJ 2106, 6230-. 
Cuestión diversa a la presunción de certeza es la posibilidad jurídica de que la Inspección, en sus actas, y como un medio probatorio, se sirva de la prueba de indicios o de presunciones, siempre que entre un hecho o hechos demostrados -que han de constar en el acta-, y aquél o aquéllos de los que se trate de deducir otros, haya un enlace preciso y directo según las reglas del recto criterio humano (art. 386 de La LEC). En las actas de la Inspección se ha admitido esta prueba de presunciones o por indicios $^{1575}$, cuando los hechos constitutivos de la liquidación o infracción -caso de la connivencia- difícilmente puedan ser objeto de prueba directa, por lo que para su apreciación ha de partirse de indicios o datos objetivos, según las normas del recto criterio humano. Es admisible la prueba indiciaria, siempre que ésta cumpla las condiciones señaladas por la jurisprudencia constitucional, que los indicios estén plenamente probados, no puede tratarse de meras sospechas, y que se explicite el razonamiento en virtud del cual, partiendo de los hechos probados indiciarios, se ha llegado a la conclusión de haberse realizado la conducta tipificada (Sentencia del Tribunal Constitucional 229/1988, de 1 de diciembre, Fundamento Jurídico Segundo, y Sentencia del TS, Sala Contencioso-Administrativa, de 26 de octubre de 1992 -ponente García Carrero-). El Tribunal Constitucional tuvo ocasión de examinar si ese medio probatorio vulnera el derecho a la presunción de inocencia, indicando en su Auto 7/1989, de 13 de enero, que la doctrina de ese Tribunal era reiterada en la admisión constitucional de la prueba indiciaria, siempre que cumpla unos requisitos de derivación lógica.

\subsection{Tramitación del acta de liquidación, resolución y recursos.}

\subsubsection{Tramitación del acta de liquidación.}

Extendida el acta de liquidación de cuotas por derivación de responsabilidad por el Inspector de Trabajo y Seguridad Social o por el Subinspector Laboral de Empleo y Seguridad Social ${ }^{1576}$, la misma será notificada por el OEITSS a todos los sujetos responsables (art. 33.1 del RISOS), en nuestro caso a la sociedad de capital y a todos los administradores declarados responsables, haciéndoles saber que podrán formular alegaciones en el plazo de quince días ante el Jefe de la Unidad Especializada de la

\footnotetext{
1575 SSTS, Sala Contencioso-Administrativo, de 18 de octubre de 1988 -ponente García Estartús-; 26 de octubre de 1992 -ponente García Carrero-; de 11 de abril de 1995 -ECLI: ES:TS:1995:8992-; y 23 de abril de 2001 -Rec. 6230/1995-, entre otras.

1576 Arts. 14.5 y 22.6 de la LOITSS, en relación con el art. 12 del RISOS y arts. 25 y 27 apartado d) del ROFITSS.
} 
Seguridad Social del OEITSS. Acta de liquidación que será notificada, en función de cuál haya sido el ámbito de actuación inspectora -infra o supra autonómica-, por la Inspección Provincial de Trabajo y Seguridad Social, por la Dirección Territorial, o por la Dirección Especial adscrita a la Dirección del OEITSS (art. 33.3 del ROFITSS).

En los supuestos de responsabilidad solidaria, las actas se tramitarán en el mismo expediente administrativo liquidatorio (art. 33.1 del RISOS).

Con relación a la notificación de las actas por el OEITSS, se ha declarado que la notificación es nula cuando realizado un primer intento, no fue recibida por la empresa en el centro de trabajo o domicilio de la misma, constando en la diligencia del servicio de correos "ausente", ante lo que se procedió posteriormente a practicar una segunda notificación, pero no en el mismo domicilio, sino en otro distinto, señalando el Tribunal Supremo, en Sentencia de la Sala Contencioso-Administrativa, 1370/2019, de 15 de octubre -Rec. 714/2018- ${ }^{1577}$ que, “en estas condiciones, no se puede tener por cumplido cuanto prescriben los artículos 42.2 y 44 de la Ley 39/2015 ya que no se han practicado los dos intentos de notificación del acta de infracción en el mismo domicilio de la interesada". Para tenerse por practicada la notificación, el segundo intento ha de repetirse en el domicilio en que tuvo lugar el primero, dentro de los tres días siguientes y con una separación de, al menos, tres horas respecto de aquella en que se hizo la anterior (art. 42.2 de la LPACAP).

Las actas de liquidación se comunicarán de inmediato a la TGSS (art. 33.1, segundo párrafo "in fine" del RISOS).

Acta de liquidación que tendrá el carácter de reclamación provisional de la responsabilidad, ya que la declaración definitiva de la misma con la determinación de la

1577 En esa Sentencia se indicaba que, "Es verdad que en la copia de la escritura notarial de constitución de la sociedad X de 11 de junio de 1996, se deja constancia de que el domicilio de uno de los otorgantes, el designado presidente de la misma, es el de la calle José Abascal 57 de Madrid y que en él se fija por los estatutos que la acompañan el domicilio social. Ahora bien, dejando al margen que eso sucedió más de veinte años antes, no se sabe por qué se practicó la notificación en esas señas en vez de en la calle Montemar, s/n de Torremolinos y, en todo caso, resulta que intentar aquí la notificación por segunda vez no es lo que exige el artículo 42.2 de la Ley 39/2015. De acuerdo con este precepto, el segundo intento ha de repetirse en el domicilio en que tuvo lugar el primero, dentro de los tres días siguientes y con una separación de, al menos, tres horas respecto de aquella en que se hizo la anterior. Al haberse utilizado un domicilio distinto, debió reiterarse el intento en él, antes de acudir a la vía del artículo 44. Por tanto, no se da el requisito de que hubiera dos intentos infructuosos de notificación antes de que se hiciera por anuncio publicado en el Boletín Oficial del Estado. Es tan reiterada la jurisprudencia sobre la exigencia de notificación personal de las resoluciones administrativas siempre que se conozca o se pueda conocer sin dificultad excesiva el domicilio del interesado que bastará con recordar ahora la sentencia del Tribunal Constitucional n. ${ }^{\circ}$ 219/2007 y las que en ella se citan". 
deuda derivada, se recogerá en la resolución administrativa emitida por el órgano competente orgánica y territorialmente de la TGSS, en virtud de la cual se elevará o no a definitiva el acta de liquidación, una vez concluidos los trámites de las primeras o segundas alegaciones de los administradores responsables.

Según la Instrucción de 25 de junio de 1998, de la DGITSS, sobre las normas de aplicación del Real Decreto 928/1998 ${ }^{1578}$, la notificación del acta se hará “al sujeto responsable, a los trabajadores interesados y a la Tesorería General de la Seguridad Social por la Inspección Provincial de Trabajo y Seguridad Social o por la unidad correspondiente de la Dirección General de la Inspección de Trabajo y Seguridad Social cuando el acta de liquidación se haya extendido en el ejercicio de las competencias de ámbito supraautonómico. Cuando se haya practicado por derivación de la responsabilidad del sujeto obligado al pago, la notificación del acta o actas, en su caso, se hará también al responsable subsidiario o solidario. En la notificación se informará al sujeto responsable que de formular alegaciones y transcurrido su término, se le dará vista y audiencia por plazo de los diez días hábiles siguientes" ${ }^{\text {"1579. }}$.

La tramitación del acta de liquidación tendrá las siguientes fases administrativas tras su notificación:

- En primer lugar, los sujetos responsables del acta, tanto la sociedad como los administradores, podrán presentar alegaciones a la misma, en el plazo de quince días siguientes a la notificación, ante el Jefe de la Unidad especializada de la Seguridad Social del OEITSS (art. 33.1 del RISOS).

Para poder presentar las alegaciones, los administradores tendrán derecho a la vista de expediente administrativo y a obtener copias, con acceso a toda la documentación obrante en el mismo, excepto a aquella que tenga el carácter de documentación confidencial como ocurre con las denuncias cuando éstas hayan sido el origen de la actuación inspectora (art. 10.1 de la LOITS, arts. 17.4 y 33 del RISOS y art. 10 del ROFITSS).

\footnotetext{
1578 Ref.: La Ley 2314/2009.

${ }^{1579}$ La referencia al artículo 18.3.9 de la Ley 42/1997, debe entenderse actualmente, al art. 30.3 letra c) de la LOITSS, en relación con los artículos 8 apartado 3.e) y 24 del Real Decreto 192/2018, de 6 de abril, por el que se aprueban los estatutos del Organismo Autónomo Organismo Estatal Inspección de Trabajo y Seguridad Social -BOE del 7.4.2018-.
} 
Con relación al contenido del derecho a la vista del expediente, en Consulta de la DGITSS, de 29 de septiembre de 2009, sobre si la documentación obrante en la orden de servicio con las actuaciones previas a la incoación de procedimiento sancionador o liquidatorio puede ser objeto de vista y obtención de copias, se señala que (sic) "la documentación obtenida o elaborada en las actuaciones previas de comprobación en principio no forman parte del expediente sancionador. Las mismas consideraciones hechas respecto del procedimiento sancionador cabe trasladarlas al liquidatorio que se inicia con el acta de liquidación. En consecuencia, la documentación derivada de la actuación inspectora que pueda ser conservada junto con la orden de servicio no debe ser puesta de manifiesto". Esta conclusión podría ser de difícil aplicación teniendo en cuenta que tras la Sentencia del TS, Sala Tercera, de lo Contencioso-Administrativo, Sección 4 ${ }^{\mathrm{a}}$, de 6 de noviembre de 2012 Rec. 3558/2011-, la actividad previa de comprobación se inserta en la fase de instrucción del procedimiento administrativo liquidatorio, una vez se emita el acta de liquidación, por lo que no se podrá negar el acceso al expediente. Otra cuestión distinta será que, por el principio de confidencialidad, se tenga la obligación o carga de evitarse por el OEITSS el acceso a la denuncia (art. 10 de la LOITSS, arts. 17.4 y 33 del RISOS y art. 10 del ROFITSS). Tampoco se podrá acceder, según el art. 18 apartado b) de la Ley 19/2013, de 9 de diciembre, de transparencia, acceso a la información pública y buen gobierno ${ }^{1580}$, a la información "que tenga carácter de auxiliar o de apoyo de la actuación inspectora de comprobación, como la contenida en notas, borradores, opiniones, resúmenes".

- En segundo lugar, si se presentan alegaciones al acta por los administradores y/o la sociedad de capital, el Jefe de la Unidad Especializada de la Seguridad Social del OEITSS, en cuanto órgano instructor, podrá recabar informe ampliatorio de los funcionarios que han extendido el acta, informe que ha de emitirse en el plazo de diez días (art. 80.2 de la LPACAP), plazo éste que no es preclusivo, ya que su demora en la emisión del informe no invalida el trámite (art. 80.4 de la LPACAP). Informe ampliatorio que será preceptivo en las actas de infracción si en las alegaciones se invocan hechos distintos a los recogidos en el acta, si el relato de hechos del acta es insuficiente o si se alega indefensión, como se establece en el art. 18 bis RISOS. Petición de informe ampliatorio que no se establece con carácter

1580 BOE del 10.12.2013. 
preceptivo en el art. 32 del RISOS para las actas de liquidación, pero ante la aportación de hechos nuevos por el administrador social, deberá darse traslado de esas alegaciones a los actuantes por el carácter contradictorio del procedimiento en su fase de instrucción, para que antes de redactarse la propuesta de resolución puedan pronunciarse sobre las alegaciones del sujeto responsable acerca de los hechos nuevos, o para aclarar o precisar el relato insuficiente de hechos del acta, o para argumentar sobre la eventual indefensión, siendo ésta la práctica administrativa según se establece por la DGITSS en Consulta, de fecha 5 de octubre de $2004^{1581}$ y en el Criterio Técnico 27/2000 ${ }^{1582}$. De no ser emitido el informe ampliatorio continuará la tramitación del procedimiento administrativo (art. 80.3 de la LPACAP). Emitido ese informe ampliatorio se dará nueva vista y audiencia a los administradores y/o sociedad de capital, en un plazo de diez días para presentar nuevas alegaciones y pruebas sobre el contenido del informe ampliatorio.

Antes de concluir el plazo para presentar las alegaciones, cualquiera de los administradores responsables o la sociedad de capital, podrían proceder a ingresar el importe del acta de liquidación, justificando su pago, en cuyo caso la liquidación provisional adquiere el carácter de liquidación definitiva (art. 33.1 último párrafo del

${ }^{1581}$ En la Consulta de 5 de octubre de 2004. Dirección General de la Inspección de Trabajo y Seguridad Social. Inspección y procedimiento. Procedimiento de tramitación de los expedientes sancionadores y liquidatorios en materia de Seguridad Social. La Ley 3573/2004. Exp. 586/2004; se señala:

"En opinión de este centro directivo la regulación del trámite de alegaciones y, en su caso, segundas alegaciones en los procedimientos sancionadores es la siguiente: Si se trata de actas de infracción si el interesado formulase alegaciones, el órgano competente para resolver, o en su caso elevar a definitivas las actas podrá recabar informe ampliatorio del Inspector o Subinspector que practicó el acta, dicha petición de informe es preceptiva para el órgano competente para resolver si en las alegaciones se invocan hechos o circunstancias distintos a los consignados en el acta, insuficiencia del relato fáctico de la misma, o indefensión por cualquier causa, en tanto que respecto de las actas de liquidación no se establece tales supuestos imperativos de exigencia de informe ampliatorio al Inspector o Subinspector actuante, en ambos casos habrá que proceder a dar un nuevo trámite de audiencia al interesado que podrá generar unas segundas alegaciones. Por lo que se refiere a la tramitación de las actas de liquidación, en la regulación de este trámite hay básicamente la diferencia fundamental, no existen supuestos tasados en los que el órgano competente para elevar a definitivas las actas deba pedir informe al Inspector o Subinspector actuante, ahora bien si se ha solicitado tal informe habrá que dar nueva vista y audiencia al interesado que podrá formular nuevas alegaciones. Por el contrario si no existen circunstancias nuevas, como es el precitado informe adicional, no tendría sentido dar nueva audiencia al interesado para formular nuevas alegaciones sobre la base de los mismos documentos que obraron en el primer trámite de alegaciones". La cursiva es nuestra.

${ }^{1582}$ En el Criterio Técnico 7/2000, de 2 de marzo de 2000, sobre respeto y garantía de los derechos de los ciudadanos ante la Inspección de Trabajo y Seguridad Social, Ref. La Ley 286/2000, se señala "entre la notificación del acta de liquidación y su elevación a definitiva, media el correspondiente procedimiento. Por supuesto que el seno del mismo, especialmente cuando median alegaciones, han de respetarse los derechos de defensa del interesado (art. 33.2 RISOS), que derivan de la Ley 30/1992 (Ref.: La Ley 3279/1992) y del RISOS (art. 29.2 RISOS), que alcanza a las pruebas que sean pertinentes y relevantes al caso, al derecho a vista y nuevas alegaciones cuando corresponda $\mathrm{y}$, a su finalización, a un acto fundamentado con la decisión definitiva". La cursiva es nuestra. 
RISOS), sin perjuicio de que el administrador que abonó la totalidad de la deuda exija por vía civil de regreso el pago a los demás responsables solidarios o a la sociedad de capital (art. 1145 del Código Civil).

- En tercer lugar, agotado el trámite de primeras o segundas alegaciones, el Jefe de la Unidad especializada de Seguridad Social del OEITSS, redactará la propuesta de liquidación. Propuesta cuyo contenido podrá ser que se eleve a definitiva el acta de liquidación, que se anule la misma, que se modifique el alcance de la derivación de responsabilidad o el importe de la deuda derivada. Esa propuesta de resolución deberá exponer con claridad los hechos que se estiman acreditados y los fundamentos de derecho (art. 33.2 del RISOS), lo que implica cuando menos, identificar a los sujetos responsables, determinando el carácter solidario o subsidiario de la responsabilidad, y la deuda derivada. Se elevará la propuesta al órgano competente para dictar la resolución administrativa, junto con los antecedentes del expediente, con una antelación mínima de quince días al vencimiento del plazo de seis meses para dictar y notificar la resolución (arts. 17.1 y 33.2 del RISOS).

- En cuarto lugar, si en el trámite de alegaciones al acta, especialmente si ésta ha sido por falta de alta en Seguridad Social de los trabajadores, con derivación de responsabilidad a los administradores, y en las alegaciones presentadas o en las pruebas propuestas se ha cuestionado que hubiere relación laboral, el instructor pondrá proponer al órgano que debe dictar la resolución que paralice el procedimiento administrativo y promueva el proceso de oficio ante la Jurisdicción Social, con la finalidad que se determine por ésta, como cuestión previa y en cuanto jurisdicción competente en la calificación de la relación jurídica, si hay o no relación laboral, para en función del contenido de la sentencia, continuar posteriormente con la tramitación administrativa del acta de liquidación, sabiendo que la sentencia firme vinculará a la autoridad competente para resolver el acta y a los órganos del orden jurisdiccional contencioso-administrativo ante los que se impugne (art. 148 apartado d) de la LRJS ${ }^{1583}$, en relación con los artículos 6, 19 y 33 del RISOS).

${ }^{1583}$ Art. $148(\ldots)$ “d) De las comunicaciones de la autoridad laboral cuando cualquier acta de infracción o de liquidación levantada por la Inspección de Trabajo y de Seguridad Social, relativa a las materias de Seguridad Social excluidas del conocimiento del orden social en la letra f) del artículo 3 , haya sido impugnada por el sujeto responsable con base en alegaciones y pruebas que, a juicio de la autoridad laboral, puedan desvirtuar la naturaleza laboral de la relación jurídica objeto de la actuación inspectora. A la demanda de oficio a la que se refiere el párrafo anterior, la autoridad laboral acompañará copia del expediente administrativo. La admisión de la demanda producirá la 
La finalidad del proceso judicial de oficio ante el orden social es dar primacía a este orden sobre el contencioso-administrativo que tiene competencia para resolver la demanda de impugnación de la resolución del acta de liquidación de cuotas, y evitar pronunciamientos contradictorios entre ambos órdenes jurisdiccionales. Con el proceso de oficio se pretenden evitar pronunciamientos dispares entre dos órdenes jurisdiccionales distintos, dando prevalencia al orden social cuando se trata de calificar una relación laboral que es presupuesto de una liquidación de cuotas de Seguridad Social. El proceso de oficio como apunta TOLOSA TRIBIÑO ${ }^{1584}$ (sic) “introduce un mecanismo muy próximo a la cuestión prejudicial devolutiva excluyente, pero no en el seno del proceso jurisdiccional contencioso-administrativo, sino en el seno mismo del procedimiento administrativo sancionador", añadiendo nosotros no sólo en el procedimiento sancionador, sino también en el de liquidación de cuotas de Seguridad Social. Según GONZÁLEZ ORTEGA ${ }^{1585}$ el proceso de oficio (sic) "es una regla de reparto de modo que el presupuesto o los hechos determinantes de la liquidación, como es la existencia de la relación no se vea excluido del conocimiento de la jurisdicción inicialmente competente para ello, la laboral, por lo que, la sentencia firme que se dicte será vinculante para la autoridad laboral y la jurisdicción contencioso-administrativa que resuelva la impugnación del acta de liquidación, pero sólo acerca de si hay o no relación laboral, no sobre otros aspectos"

La comunicación de inicio del procedimiento de oficio no sería facultativa para la autoridad laboral, sino preceptiva, según MERCADER UGUINA y SÁNCHEZ

suspensión del expediente administrativo. A este proceso de oficio le serán aplicables las reglas de las letras a) y d) del apartado 2 del artículo 150. Cuando se entienda que las alegaciones o actuación del sujeto responsable pretenden la dilación de la actuación administrativa, el órgano judicial impondrá la multa que señalan los apartados 4 del artículo 75 y 3 del artículo 97, así como cuando tal conducta la efectuara el empresario, deberá abonar también los honorarios de los abogados y graduados sociales de la parte contraria que hubieren intervenido, dentro de los límites establecidos para la instancia, suplicación y casación. La sentencia firme se comunicará a la autoridad laboral y vinculará en los extremos en ella resueltos a la autoridad laboral y a los órganos de la Jurisdicción Contencioso-Administrativa ante los que se impugne el acta de infracción o de liquidación".

1584 TOLOSA TRIBIÑO, C.: "Una nueva perspectiva en las relaciones entre la jurisdicción laboral y la contencioso-administrativa”, Actualidad Laboral, Sección Doctrina, 1998, Ref. XLIII, pp. 685 y ss, Tomo 3, Editorial La Ley, Ref. La Ley 2996/2001, edición digital, https://laleydigital-laleynextes.ponton.uva.es/Content/Documento.aspx?params, p. 10.

1585 GONZÁLEZ ORTEGA, S.: "La extensión de la jurisdicción social en materia de Seguridad Social y otras afines", Relaciones Laborales, Sección Doctrina, 1990, p. 351, Tomo 2, Editorial La Ley Ref. 405/2001, edición digital, https://laleydigital-laleynext-es.ponton.uva.es/Content/Documento.aspx?params, p. 15. 
GRANDE $^{1586}$, quienes señalan que pese a utilizarse en el art. 19 del RISOS la expresión «podrá», en lugar de "procederá" que se empleaba en anterior reglamento derogado RD 396/1996 (sic) "ha de seguirse el criterio marcado mayoritariamente por doctrina y jurisprudencia de acuerdo con el cual se mantiene la obligatoriedad para la Autoridad laboral de plantear, cuando proceda, la correspondiente demandada de oficio". Pudiera pensarse que no confiere naturaleza preceptiva a la demanda de oficio el art. 148 de la LRJS cuando establece que "el proceso podrá iniciarse de oficio", lo que no nos debe llevar a la conclusión de que es potestativo someter a esa jurisdicción la demanda cuando se aleguen y aduzca elementos que desvirtúen la relación laboral (art. 148 apartado d) de la LRJS), sino que la autoridad laboral deberá presentar la demanda de oficio, ya que cuando se alude que "el proceso podrá iniciarse de oficio", es para prever una nueva forma de inicio del proceso a instancias de la Administración, pese a no pretender ésta la defensa de sus derechos o intereses como es lo propio de toda demanda, sin que ello signifique que deje la presentación de la demanda a la discrecionalidad de la autoridad laboral.

Demanda de oficio que, pese a aludirse sólo a la autoridad laboral, puede presentarla también el órgano competente de la TGSS para resolver el acta de liquidación de cuotas por derivación de responsabilidad (Sentencias del TS, Sala Social de 16 de mayo de 2018 -Rec. 3976/2016-, 28 de junio de 2018 -Rec. 3713/2016-).

\subsubsection{Resolución.}

El órgano competente para resolver el acta será el órgano de la Dirección Provincial de la TGSS o de la Dirección General de la TGSS establecido en la disposición reglamentaria de atribución de competencia (art. 34.2 del TRLGSS). Competencia territorial del órgano que estará en función del ámbito de la actuación inspectora que dio origen al acta de liquidación, en función de que haya sido la Inspección Provincial, la Dirección Territorial, o la Dirección Especial de la ITSS.

Para las actas extendidas por la Inspección Provincial de Trabajo y Seguridad Social tiene la competencia para dictar la resolución la Unidad de Impugnaciones de la Dirección Provincial de la TGSS (artículo único de la Orden TIN/2076/2010, de 27 de julio, por la que se determina el ejercicio de funciones en materia de actas de

${ }^{1586}$ MERCADER UGUINA, J. R. y SÁNCHEZ GRANDE, A: “Anotaciones al Reglamento general sobre procedimiento sancionador y liquidatorio del orden social (Novedades del RD 928/1998, de 14 de mayo)", op. cit., edición digital, p. 9. 
liquidación y de imposición de sanciones por infracciones de Seguridad Social en el ámbito de las Direcciones Provinciales de la Tesorería General de la Seguridad Social $\left.{ }^{1587}\right)$. Si el acta de liquidación se ha extendido por funcionarios adscritos a la Dirección Territorial, será competente la Unidad de Impugnaciones de la Dirección Provincial de la TGSS donde tiene su sede la Dirección Territorial que programó la actuación, que ordinariamente es la capital de la Comunidad Autónoma. Si el acta de liquidación se extendió por la Dirección Especial del OEITSS, la competencia para resolver el acta es de la Subdirección General de Ordenación e Impugnaciones de la Dirección General de la TGSS (arts. 1 letra m), y 5 letra c) del Real Decreto 1314/1984, de 20 de junio, por el que se regula la estructura y competencias de la Tesorería General de la Seguridad Social ${ }^{1588}$ ).

La resolución administrativa elevará a definitiva la derivación de responsabilidad, la dejará sin efecto o modificará su alcance (art. 33.2 del RISOS). La resolución administrativa del acta puede variar la calificación jurídica de la propuesta de resolución, efectuando otra distinta, siempre partiendo de los hechos probados que consten en la fase de instrucción y en la propuesta de resolución, no de hechos nuevos, y siempre que se garantice el derecho de audiencia, por lo que podría imponerse una sanción pese a ordenarse el archivo del expediente en la propuesta, lo que trasladado al ámbito liquidatorio se traduce en que puede incrementarse la liquidación, previo trámite de audiencia al interesado para evitar su indefensión, cuando ese nuevo importe superior liquidatorio sea consecuencia de la correcta valoración o calificación jurídica de los hechos (Sentencia del TS, Sala Contencioso-Administrativa, núm. 1382/2020, de 22 de octubre de 2020 -Rec. 4535/2019- ${ }^{1589}$ ). En todo caso, cuando la resolución se separe de

1587 BOE del 31.7.2010.

${ }^{1588}$ BOE del 11.7.1984.

${ }^{1589}$ En esa Sentencia se analiza si la resolución administrativa sancionadora puede imponer una sanción cuando en la propuesta de resolución se instaba a su anulación ordenándose el archivo de las actuaciones, por lo que entra a analizar el alcance del principio acusatorio del Derecho penal en el procedimiento administrativo sancionador, señalando como doctrina de interés casacional que, ese principio acusatorio, vinculado al derecho de defensa, al derecho a un proceso con todas las garantías y al derecho a ser informado de la acusación, "debe modularse cuando se trate de su aplicación en el procedimiento administrativo sancionador, de modo que, a diferencia de la transcendencia que tiene en el proceso penal, en este ámbito no comporta que el órgano competente para resolver un expediente sancionador no pueda imponer una sanción, modificando, para ello, la calificación jurídica efectuada por el órgano instructor, siempre que no se base en la consideración de hechos distintos de los hechos determinados en la fase de instrucción (salvo en el supuesto en que se hayan practicado actuaciones complementarias para su concreción definitiva en la ulterior fase decisoria), y se respete el derecho de defensa". Doctrina aplicable al procedimiento sancionador, pero que será aplicable en el procedimiento liquidatorio, con lo que puede la resolución modificar la liquidación, partiendo de los hechos probados, en función de una correcta valoración jurídica de los hechos probados, para minorar 
la propuesta de resolución, imponiendo una sanción o liquidación superior a la propuesta, debe darse previa audiencia al interesado, como expresamente se establece actualmente en el art. 90.2 de la LPAC, ya que la Sentencia 1382/2020 partía del Real Decreto 1398/1993, de 4 de agosto, disposición ésta derogada expresamente por la LPACAP.

En la resolución se deberá determinar el deudor principal -la sociedad de capital-, y quiénes son los sujetos responsables -los administradores sociales- así como la naturaleza de esa responsabilidad, si son solidariamente responsables, en cuyo supuesto, desde ese momento adquieren la condición de sujetos obligados al pago, o si son responsables subsidiarios, en cuyo supuesto, no nace su obligación de pago en ese acto, sino una vez conste la insolvencia de la sociedad de capital. Debe distinguirse entre la declaración de responsabilidad y la exigibilidad de la responsabilidad, ya que en la responsabilidad subsidiaria si su declaración consta en la resolución, en cambio su exigibilidad se iniciará con la insolvencia de la sociedad, a diferencia de la responsabilidad solidaria en que la declaración y la exigibilidad tienen efectividad desde que se dicta la resolución.

Se deberá dictar y notificar la pertinente resolución en el plazo máximo de seis meses desde la fecha del acta (arts. 20.3 y 33.2 del RISOS, en interpretación jurisprudencial según Sentencias del TS, Sala Contencioso-Administrativa, de 23 de febrero de 2010 Rec. 243/2008- y 7 de febrero de 2014 -Rec. 4607/2012-, dictadas en Recurso de Casación en interés de ley) ${ }^{1590}$.

La resolución debe dictarse y notificarse dentro del plazo de seis meses a computar desde la fecha del acta de liquidación, ya que en otro caso el procedimiento habrá caducado, y en la resolución administrativa deberá dejarse sin efecto el acta de liquidación, sin perjuicio de volverse a extender nueva acta mediante la práctica de nuevas actuaciones inspectoras, siempre que las deudas por cuotas y la responsabilidad

la misma o incrementarla respecto a la propuesta del instructor, previo nuevo trámite de audiencia para no causarse indefensión al interesado.

${ }^{1590}$ Esas Sentencias estiman, con buen criterio, que es de aplicación la regulación del artículo 21 de la LPACAP, por lo que la fecha final del plazo de seis meses para concluir el procedimiento administrativo, no será la fecha de la resolución del acta de liquidación, sino la fecha de notificación de esa resolución, entendiendo que prevalece esa disposición legal frente a la disposición reglamentaria. Doctrina jurisprudencial que ya se venía fijando en Sentencias del TS, Sala Contencioso-Administrativo, de 12 de noviembre de 2001 -Rec. en interés de la Ley 256/2000-; de 24 de octubre de 2007 -Rec. de casación para la 174/2006-; y de 25 de marzo de 2009 -Rec. en interés de la Ley 7/2008-. 
no hayan prescrito, ya que la caducidad no produce por sí sola la prescripción de las acciones, pero el procedimiento caducado no interrumpe los plazos de prescripción (art. 95.3 de la LPACAP).

Con relación a la notificación de los actos o resoluciones administrativas, cuando para su práctica se utilicen dos medios, notificación personal en el domicilio y notificación electrónica, se entenderá efectuada la notificación en la fecha en que se reciba o se acceda a su contenido en primer lugar (Sentencia del TS, Sala ContenciosoAdministrativa, 177/2020, de 12 de febrero -Rec. 2587/2016-), ya que para los supuestos de notificación de un mismo acto administrativo utilizando diversos cauces, en el artículo 41.7 de la LPACAP, se establece que "cuando el interesado fuera notificado por distintos cauces, se tomará como fecha de notificación la de aquella que se hubiera producido en primer lugar". Igual criterio, como no podía ser de otro modo, se establece para las notificaciones de Seguridad Social en el art. 8 apartados 2 y 3 de la Orden ESS/485/2013, de 26 de marzo, por la que se regulan las notificaciones y comunicaciones por medios electrónicos en el ámbito de la Seguridad Social ${ }^{1591}$. Fecha de notificación que será a todos los efectos, tanto para la determinación de la caducidad del procedimiento, como para el cómputo del plazo para la presentación de los recursos administrativos o judiciales.

Se impone la obligación de ser notificados en la Dirección Electrónica Habilitada única y/o de modo complementario en la sede electrónica a las empresas responsables de la obligación de cotizar incorporadas al sistema RED -remisión electrónica de datos- (art. 3.2 de la Orden ESS/485/2013, de 26 de marzo, en relación con el art. 42 del Real Decreto 203/2021, de 30 de marzo), que son todas las empresas con trabajadores por

${ }^{1591}$ BOE del 28.3.2013.

Artículo 8. Ámbito de aplicación objetivo. (..)

“2. Sin perjuicio de lo establecido en el apartado anterior, la Administración de la Seguridad Social podrá practicar las notificaciones y comunicaciones por medios no electrónicos, en los términos previstos en el artículo 59 de la Ley 30/1992, de 26 de noviembre, de Régimen Jurídico de las Administraciones Públicas y del Procedimiento Administrativo Común, en los siguientes supuestos: a) Cuando la notificación o comunicación se practique con ocasión de la comparecencia espontánea del interesado o de su representante en las dependencias de la Administración de la Seguridad Social en que se tramite el procedimiento de que se trate y solicite la notificación o comunicación personal en ese momento. b) Cuando la notificación o comunicación electrónica resulte incompatible con la inmediatez o celeridad que requiera la actuación administrativa para asegurar su eficacia. En este caso, el interesado no podrá optar por la notificación en la SEDESS.

3. Cuando en los supuestos referidos en el apartado anterior, la Administración de la Seguridad Social hubiera practicado la notificación o comunicación por medios electrónicos y no electrónicos, se entenderán producidos todos los efectos administrativos del acto de que se trate a partir de la primera de las notificaciones o comunicaciones correctamente efectuada". 
cuenta ajena (art. 2 de la Orden ESS/484/2013, de 26 de marzo, por la que se regula el Sistema de remisión electrónica de datos en el ámbito de la Seguridad Social ${ }^{1592}$ ).

La notificación en la Dirección Electrónica Habilitada única y/o en la sede electrónica se extiende a las notificaciones y comunicaciones efectuadas por la Administración de la Seguridad Social en todas las actuaciones y procedimientos en materia de Seguridad Social, incluidos los correspondientes a la recaudación de los recursos a que se refiere el artículo 1 del RGRSS (arts. 3.1 y 8.1 de la Orden ESS/485/2013, de 26 de marzo).

No están obligados a ser notificados en la Dirección Electrónica Habilitada única y/o en la sede electrónica otros sujetos personas físicas responsables que no tengan la condición de empresarios respecto de las cuotas reclamadas, como los administradores sociales, quienes quedan excluidos del sistema de notificación por comparecencia en la sede electrónica, salvo que hayan optado por ser notificados por este medio (arts. 3.3, 6.3 y Disposición Adicional Única apartado 4 de la Orden ESS/485/2013, de 26 de $\left.\operatorname{marzo}^{1593}\right)$.

Las notificaciones en sede electrónica a la sociedad de capital, en su condición de sujeto responsable de la obligación de cotizar e ingresar sus liquidaciones, se entenderá rechazada si no se accede a la misma en el plazo de diez días naturales desde la puesta a disposición en la sede, dándose por cumplido dicho trámite y continuándose con el

1592 BOE del 28.3.2013.

1593 "Artículo 3 Ámbito de aplicación subjetivo. (...)

2. Estarán obligados a recibir por medios electrónicos las notificaciones y comunicaciones que en el ejercicio de sus competencias les dirija la Administración de la Seguridad Social: a) Las empresas, agrupaciones de empresas y demás sujetos responsables del cumplimiento de la obligación de cotizar que estén obligados a incorporarse al Sistema de remisión electrónica de datos (en adelante Sistema RED), según lo previsto en la Orden ESS/484/2013, de 26 de marzo, reguladora de dicho sistema. b) Las empresas, agrupaciones de empresas y demás sujetos responsables del cumplimiento de la obligación de cotizar que, sin estar obligados a incorporarse al Sistema RED, se hayan adherido voluntariamente al mismo, en tanto se mantenga su incorporación al citado sistema.

Los sujetos responsables señalados en los párrafos anteriores quedarán obligados a comparecer en la SEDESS, a efectos de recibir las notificaciones y comunicaciones electrónicas a que se refiere esta orden, desde el momento en que deban estar incorporados al Sistema RED, en el supuesto previsto en el párrafo a), y desde el momento de su incorporación a dicho sistema, en el supuesto previsto en el párrafo $b$ ).

3. Las personas, físicas o jurídicas, o entes sin personalidad jurídica no incluidos en el apartado anterior podrán manifestar su voluntad de recibir las notificaciones y comunicaciones de la Administración de la Seguridad Social por medios electrónicos, a través del servicio correspondiente de la SEDESS, quedando automáticamente obligados a recibirlas mediante comparecencia en dicha sede electrónica desde que hayan ejercitado su opción por esa forma de notificación".

Art. 6 (...) "3. Las personas, físicas o jurídicas, o entes sin personalidad jurídica, a que se refiere el artículo 3.3 podrán quedar excluidos del sistema de notificación por comparecencia en la SEDESS cuando así lo soliciten. El sistema generará el correspondiente justificante de la transmisión efectuada, así como del día y la hora de la solicitud formulada". 
procedimiento (art. 132.3 del TRLGSS y art. 9 de la Orden ESS/485/2013, de 26 de marzo), salvo que por causas imputables a la Administración de la Seguridad Social se compruebe la imposibilidad técnica o material del acceso (art. 9.3 de la Orden ESS/485/2013, de 26 de marzo).

La notificación electrónica en la sede acreditará la fecha y hora en que tenga lugar la puesta a disposición del interesado del acto objeto de notificación, así como la fecha y hora del acceso a su contenido y dejará constancia de la concreta actuación administrativa comunicada o notificada y de su contenido. Datos éstos que podrán ser certificados por la sede electrónica. Certificación que incluirá la identidad del destinatario y del receptor, así como, en su caso, la fecha en que la notificación se consideró rechazada por haber transcurrido el plazo de 10 días naturales sin haberse accedido a la misma, o si se rechazó expresamente (art. 9.3 de la Orden ESS/485/2013, de 26 de marzo).

Notificación en sede electrónica de las resoluciones elevando o no a definitivas las actas de liquidación que para las empresas se aplica a partir del 19 de enero de 2018, fecha de la entrada en vigor de la Resolución de 3 de enero de 2018, de la Secretaría de Estado de la Seguridad Social ${ }^{1594}$. Se notificarán a las empresas incluidas en el sistema RED en la sede electrónica los siguientes actos administrativos. En primer lugar, las resoluciones sobre la elevación a definitivas de las actas de liquidación de cuotas de la Seguridad Social, así como de las actas de liquidación conjuntas con las actas de infracción levantadas por la Inspección de Trabajo y Seguridad Social. En segundo lugar, las resoluciones sobre imposición de sanciones por infracciones en materia de Seguridad Social que afecten al ámbito de competencia de la Tesorería General de la Seguridad Social. En tercer lugar, las resoluciones de las impugnaciones administrativas formuladas frente a los actos dictados por la Tesorería General de la Seguridad Social en las materias de su competencia, como son las resoluciones de los recursos de alzada frente a las reclamaciones de deuda o frente a las resoluciones de las actas de liquidación.

1594 Resolución publicada en el BOE del 18.1.2018 que lleva como título: "por la que se fija la fecha a partir de la cual se notificarán electrónicamente las resoluciones sobre la elevación a definitivas de las actas de liquidación de cuotas de la Seguridad Social, así como de las actas de liquidación conjuntas con las actas de infracción levantadas por la Inspección de Trabajo y Seguridad Social; las resoluciones sobre imposición de sanciones por infracciones en materia de Seguridad Social competencia de la Tesorería General de la Seguridad Social; y las resoluciones de las impugnaciones administrativas formuladas frente a los actos dictados por la Tesorería General de la Seguridad Social en las materias de su competencia, salvo en materia de recursos humanos". 
No es de aplicación a los administradores sociales la notificación de esas resoluciones de actas de liquidación de derivación de responsabilidad, en cuanto sujetos responsables solidarios de deudas, ya que al no ser empresa responsable directa de sus cotizaciones, para ellos la notificación en la sede electrónica sólo es exigible cuando hayan optado por este medio de notificación (arts. 3.3, 6.3 y Disposición Adicional Única apartado 4 de la Orden ESS/485/2013, de 26 de marzo ${ }^{1595}$, en relación con la Resolución de 3 de enero de 2018 de la Secretaria de Estado de la Seguridad Social). En la Resolución de 3 de enero de 2018 se establece que "a partir de la fecha de efectos de esta resolución la Tesorería General de la Seguridad Social notificará a través del sistema de notificación electrónica, mediante comparecencia en la sede electrónica de la Secretaría de Estado de la Seguridad Social, a los sujetos responsables a que se refiere el artículo 3 de la Orden ESS/485/2013, de 26 de marzo, por la que se regulan las notificaciones y comunicaciones por medios electrónicos en el ámbito de la Seguridad Social, en los términos previstos tanto en el citado artículo 3 como en su Disposición Adicional Única", lo que implica que para terceros que no sean empresas con obligación de cotizar a la Seguridad Social, para la validez de la notificación en sede electrónica se precisa que se haya optado por este medio.

Para finalizar, señalar que durante el período del 14.3.2020 al 31.5.2020, como consecuencia del estado de alarma por la crisis sanitaria del Covid-19, se suspendieron los plazos del procedimiento administrativo liquidatorio (Disposición Adicional $3^{\mathrm{a}}$ del Real Decreto 463/2020, de 14 de marzo ${ }^{1596}$, Disposición Adicional 2a apartado 2 y 3 del Real Decreto-Ley 15/2020, de 21 de abril ${ }^{1597}$ y Real Decreto 537/2020, de 22 de mayo $^{1598}$ ).

1595 Disposición Adicional Única. Efectividad inicial de la obligación de recibir las notificaciones y comunicaciones de la Administración de la Seguridad Social mediante el sistema de notificación electrónica (...) 4. Por resoluciones de la Secretaría de Estado de la Seguridad Social se fijarán las fechas a partir de las cuales las distintas actuaciones y procedimientos en materia de Seguridad Social se notificarán o comunicarán a través del sistema de notificación electrónica. Sin perjuicio de lo previsto en el párrafo anterior, a partir de la entrada en vigor de esta orden las reclamaciones de deuda, las providencias de apremio y las comunicaciones de inicio del procedimiento de deducción frente a entidades públicas emitidas por la Tesorería General de la Seguridad Social, serán notificadas electrónicamente mediante comparecencia en la SEDESS tanto a los sujetos a que se refiere el artículo 3, apartados 2 y 4, una vez que queden inicialmente obligados en los términos indicados en el apartado 1 de esta disposición adicional, como a los sujetos a que se refiere el artículo 3.3, una vez que opten por esa forma de notificación".

${ }^{1596}$ BOE del 14.3.2020.

${ }^{1597}$ Disposición Adicional Segunda. Suspensión de plazos en el ámbito de actuación de la Inspección de Trabajo y Seguridad Social (...): 


\subsubsection{Recursos.}

Ante la resolución administrativa del acta de liquidación por derivación de responsabilidad cabe recurso de alzada ante el superior jerárquico (art. 46 del RGRSS y art. 121 de la LPACAP), que en el caso de haberse dictado esa resolución por la Unidad de Impugnaciones de la Dirección Provincial de la TGSS, la competencia para conocer y resolver el recurso de alzada será del Director/a Provincial de la Tesorería General de la Seguridad Social, y en caso de haber sido dictada la resolución por la Subdirección General de Ordenación e Impugnaciones de la Dirección General de la TGSS, el órgano competente para conocer el recurso de alzada será la Dirección General de la Tesorería General de la Seguridad Social (arts. 5.c) y 7 del Real Decreto 1314/1984, de 20 de junio, y artículo único de la Orden TIN/2076/2010, de 27 de julio).

Dictada la resolución elevando a definitiva el acta por el órgano competente de la TGSS, el importe de la deuda exigible, incluidos los recargos, intereses y las costas del procedimiento reclamados a los administradores sociales, sean o no objeto de recurso de alzada, deberán hacerse efectivos en la Tesorería General de la Seguridad Social hasta el último día del mes siguiente al de la notificación de la resolución que eleva a definitiva la derivación, iniciándose, en otro caso, el procedimiento de apremio a que se refieren los artículos 33 y siguientes del Texto Refundido de la Ley General de la Seguridad Social. No sería exigible la deuda, si interpuesto recurso administrativo, se garantiza con aval bancario suficiente o se consigna su importe en la Tesorería General de la Seguridad Social (art. 33.3 párrafo 1 del RISOS y arts. 46 y 66 del RGRSS). Si al interponerse el recurso de alzada se hubiese garantizado el importe reclamado con aval suficiente o consignado el mismo, se suspenderá el procedimiento recaudatorio hasta los quince días siguientes a aquel en que se notifique la resolución del recurso de alzada (art. 33.1, párrafo segundo del RISOS).

2. Durante el periodo de vigencia del estado de alarma, declarado por el Real Decreto 463/2020, de 14 de marzo y sus posibles prórrogas, quedan suspendidos los plazos de prescripción de las acciones para exigir responsabilidades en lo que se refiere al cumplimiento de la normativa de orden social y de Seguridad Social.

3. Todos los plazos relativos a los procedimientos regulados en el Reglamento general sobre procedimientos para la imposición de sanciones por infracciones de orden social y para los expedientes liquidatorios de cuotas de la Seguridad Social, aprobado por Real Decreto 928/1998, de 14 de mayo, están afectados por la suspensión de plazos administrativos prevista en la Disposición Adicional Tercera del Real Decreto 463/2020, de 14 de marzo.

1598 BOE del 23.5.2020. 
Una cosa es que, si se garantiza o consigna el importe se suspende la ejecución de la resolución del acta de liquidación, y otra cosa distinta es que se establezca como requisito para interponer el recurso de alzada que se consigne o se garantice con aval la deuda, como se hacía en la redacción originaria del art. 33.3 del RISOS. En la Sentencia del TS, Sala Contencioso-Administrativa, de 21 de julio de 2010 -Rec. 397/2000-, se anuló esa exigencia por vicio de legalidad, al declarar que no era conforme a Derecho la frase del artículo 33, "no admitiéndose a trámite los recursos en que no concurran tales requisitos", porque en definitiva, además del vicio de falta de cobertura legal, comportaba esa exigencia una vulneración del derecho a la defensa, que se integra en el derecho a la tutela judicial efectiva, realizando una interpretación del artículo 24.1 de la Constitución en el sentido más favorable al ejercicio de las acciones, para evitar la falta de control de las actuaciones administrativas y la indefensión del interesado.

Desestimado el recurso de alzada, de haberse suspendido el pago por haberse garantizado su importe, la deuda deberá ingresarse dentro del plazo de los quince días siguientes a su notificación (art. 33.3 del RISOS). Si el responsable de pago -los administradores- no realizasen el ingreso de la deuda en el plazo de los 15 días siguientes a la notificación de la resolución del recurso, o en el plazo de los 15 días siguientes a la fecha en que deba entenderse desestimado el recurso por silencio administrativo $^{1599}$, la Tesorería General de la Seguridad Social aplicará lo consignado al pago de la deuda o ejecutará el aval (art. 46.2 del RGRSS), aplicándose las siguientes reglas:

a) No procedería el pago si en ese plazo de 15 días, el interesado (administrador/es declarados responsables) acredita la interposición de recurso contenciosoadministrativo, y haber solicitado judicialmente la suspensión del procedimiento, en cuyo caso, se mantendrá tal suspensión hasta que el órgano judicial resuelva sobre dicha solicitud (art 46.2 párrafo tercero del RGRSS).

\footnotetext{
1599 Señalar que, con vocación de formar doctrina general el TS, Sala Contencioso-Administrativa, en sentencia 586/2020, de 28 de mayo -Rec. 5751/2017-, ha establecido que la Administración -era la Administración Tributaria-, no puede dictar una providencia de apremio si está aún pendiente de resolverse de modo expreso un recurso administrativo, en nuestro caso el recurso de alzada, porque la Administración no puede entender que existe ya la resolución administrativa firme y desestimatoria por silencio negativo, una vez ha expirado el plazo para resolver, ya que está obligada a dictar resolución expresa, al ser el silencio negativo una ficción jurídica un "no acto", doctrina que sería igualmente aplicable en el procedimiento recaudatorio de Seguridad Social.
} 
b) La suspensión de la obligación de pagar el importe del acta se mantendrá si el órgano judicial confirma la suspensión solicitada, lo que determina la suspensión de ejecutividad del acto administrativo impugnado y, con ello, la obligación de pago.

c) Que la medida cautelar judicial estará en vigor hasta que recaiga sentencia firme que ponga fin al procedimiento en el que se hayan acordado, o hasta que éste finalice por cualquiera de las causas previstas en la LJCA.

La resolución del recurso de alzada agota la vía administrativa, y es susceptible de recurso ante la Jurisdicción Contencioso-Administrativa (art. 114.1. a) de la LPACAP; art. 33.3 párrafo tercero del RISOS; art. 3 apartado f) de la LRJS; y arts. 1, 2 y 3 de la LJCA).

El recurso contencioso-administrativo se interpondrá dentro del plazo de dos meses siguientes a la notificación de la resolución firme en vía administrativa, de los dos meses siguientes a la notificación de la resolución del recurso o desde que se produjo la desestimación del recurso de alzada por silencio administrativo (art. 122 de la LPACAP y art. 46 de LJCA).

Dictada sentencia firme por la Jurisdicción Contencioso-Administrativa, se abre un nuevo plazo de quince días desde la notificación de la sentencia para proceder al pago del acta de liquidación, y si no se atiende su pago en ese plazo se emitirá la providencia de apremio $^{1600}$. De conformidad con la nueva jurisprudencia interpretativa del art. 46 del

1600 Art. 46 RGRSS, en interpretación del TS, Sala Contencioso-Administrativa, en Sentencias, entre otras, de 705/2019, de 27 de mayo -Rec. 111/2017-; 1023/2019, de 10 de julo -Rec. 858/2017-; 1183/2019, de 16 de septiembre de 2019 -Rec. 2991/2017-; 1197/2019, de 19 de septiembre -Rec. 588/2017-; y 1793/2019, de 17 de diciembre -Rec. 3807/2017-, que estiman aplicable ese precepto reglamentario y no el art. 132.1 LJCA. Esas Sentencias establecieron lo siguiente: "1 $1^{\text {a }}$ que las deudas definitivamente liquidadas han de ser abonadas en periodo voluntario dentro del plazo legalmente establecido por el artículo 31.3 del Texto Refundido de 1994 (art. 32.4 del Texto Refundido de 2015). $2^{a}$ ) que, en caso de impugnación administrativa presentando aval en garantía de la deuda, la obligación de pago queda suspendida y, desestimado el recurso, el pago deberá realizarse dentro de 15 días siguientes a la notificación de la resolución que lo desestima. $3^{\mathrm{a}}$ ) que, si dentro de ese plazo de 15 días se acredita la interposición de recurso contencioso administrativo y la solicitud, en sus trámites, de la suspensión del procedimiento, se mantendrá tal suspensión hasta que el órgano judicial resuelva sobre dicha solicitud. $4^{\text {a }}$ ) que esa suspensión se mantendrá si el órgano judicial confirma la suspensión solicitada, lo que determina la suspensión de ejecutividad del acto administrativo impugnado y, con ello, de la obligación de pago. $5^{\text {a }}$ ) que la medida cautelar judicial estará en vigor hasta que recaiga sentencia firme que ponga fin al procedimiento en el que se hayan acordado, o hasta que éste finalice por cualquiera de las causas previstas en esta Ley. $6^{a}$ ) que no puede entenderse concurrente una falta de pago de la deuda hasta que, levantada la medida de suspensión administrativa o jurisdiccional, el administrado tenga ocasión de efectuar el pago de la deuda reclamada y definitivamente exigible. $7^{\mathrm{a}}$ ) que ese plazo será el de los 15 días siguientes a la notificación de la resolución administrativa que desestimó el recurso de alzada, que es la afectada por la suspensión de su ejecutividad, tanto en vía administrativa como en la posterior jurisdiccional. $8^{\text {a }}$ ) que no cabe admitir una posible suspensión y 
RGRSS, una vez notificada la sentencia firme que desestima el recurso contenciosoadministrativo interpuesto contra el acta de liquidación definitiva, cuya efectividad se suspendió en vía administrativa y jurisdiccional, tiene el deudor derecho a disponer del período de pago voluntario de quince días antes de que la Administración pueda dictar la correspondiente providencia de apremio, siendo el día inicial para el cómputo del plazo de quince días de pago voluntario, el de la fecha en que se notifique al deudor la sentencia.

Ante la sentencia de instancia cabe recurso de apelación, y en su caso, de casación. Para la admisibilidad del recurso de apelación se precisa que la cuantía litigiosa sea igual o superior a 30.000 euros (art. 81 de la LJCA).

La Ley de la Jurisdicción Contencioso-Administrativa al regular la cuantía del recurso en los artículos 40 y siguientes, establece, en el artículo 41 que " la cuantía del asunto vendrá determinada por el valor económico de la pretensión objeto del mismo" (apartado 1); y que en "los supuestos de acumulación o ampliación, la cuantía vendrá determinada por la suma del valor económico de las pretensiones objeto de aquéllas", pero advirtiendo que "no comunicará a las de cuantía inferior la posibilidad de casación o apelación" (apartado 3). Por otro lado, en el artículo 42.1.a) de la LJCA se matiza que, a efectos de fijar el valor de la pretensión, ha de tenerse en cuenta el débito principal, pero no los recargos, las costas, ni cualquier otra clase de responsabilidad como los intereses-, salvo que cualquiera de éstos fuera de importe superior a aquél.

Ante ese importe mínimo para el recurso de apelación, se plantean tres cuestiones acerca de la cuantía del recurso. En primer lugar, cuál debe ser la cuantía del recurso

reanudación de ese plazo de 15 días (i) ni desde la fecha en que se interpone el recurso de alzada, pues la norma reglamentaria contempla la fijación e inicio de ese plazo con la resolución del recurso, (ii) ni desde la fecha de interposición del recurso contencioso-administrativo, pues esa misma norma no lo contempla expresamente y el plazo no puede reducirse sin causa prevista. $9^{\mathrm{a}}$ ) que solo el impago de la deuda dentro del plazo reglamentario de ingreso establecido -15 días- determinará la aplicación del recargo, el devengo de los intereses de demora, y el inicio de la recaudación ejecutiva. En consecuencia, concluyeron, siempre con la sentencia n. $705 / 2019$ que, una vez notificada la sentencia firme que desestima el recurso contencioso-administrativo interpuesto contra el acta de liquidación definitiva por deudas contraídas con la Seguridad Social, cuya efectividad se suspendió en vía administrativa y jurisdiccional, tiene el deudor derecho a disponer del período de pago voluntario de 15 días que fija el artículo 46 del Real Decreto 1415/2004 antes de que la Administración pueda dictar la correspondiente providencia de apremio. Y, sobre si el dies a quo del período de pago voluntario es el de la fecha de la notificación de aquella sentencia al deudor o el de la fecha en que se declare su firmeza, en esas sentencias se ha concluido que debe resolverse aplicando, no el artículo 132.1 de la Ley de la Jurisdicción, como defiende la Tesorería General de la Seguridad Social, sino el propio artículo 46 del Reglamento de Recaudación. En concreto, se ha dicho en ellas que el artículo 132.1 de la Ley de la Jurisdicción fija el final de la vigencia de las medidas cautelares pero no dice cuándo debe iniciarse el cómputo del plazo de pago de la deuda en periodo voluntario". 
cuando sólo se impugna la conformidad o disconformidad a Derecho de la resolución administrativa de derivación de responsabilidad, sin cuestionarse la cuantía de la deuda derivada. En segundo lugar, cuando se discute tanto la cuantía de las cuotas reclamadas como la legalidad de la derivación. Y, en tercer lugar, cuando la impugnación se sustenta exclusivamente en la invalidez de las cuotas reclamadas, sea de una, de varias o de todas, si deben considerarse individualmente los importes de cada una de las liquidaciones impugnadas, o el importe global de todas las impugnadas.

Para responder a esta cuestión, el TS distinguía entre impugnación de la procedencia de la derivación, en cuyo caso, si se impugnaba la improcedencia de la derivación de responsabilidad, era suficiente que el importe total de la derivación excediese el importe mínimo fijado para la admisibilidad del recurso, pero en cambio, si se impugnaban la validez de las liquidaciones debería estarse a los importes de las liquidaciones impugnadas a efectos de la admisibilidad del recurso ${ }^{1601}$. Pues bien, esta doctrina ha sido rectificada recientemente, para establecerse ${ }^{1602}$ que, "si bien este Tribunal ha mantenido, durante un tiempo, la admisión del recurso de casación cuando lo que se discute no son las liquidaciones concretas que integran el acuerdo de derivación de responsabilidad, sino la procedencia de dicho acuerdo como acto único, siempre que el importe total derivado superase el límite legal para acceder al recurso (de casación), ahora reconsiderando la cuestión, se llega a la conclusión contraria, al entender que, con carácter previo al examen del acto único de derivación de responsabilidad, ha de examinarse cada acto administrativo de liquidación y, en consecuencia, únicamente podrán acceder al recurso de casación, por razón de la cuantía, las liquidaciones derivadas cuyo débito principal supere el límite legal, en este caso los 30.000 euros del recurso de apelación del artículo 81.1.a) de la LJCA" (Sentencia del TS, ContenciosoAdministrativa, 7/2020, de 14 de enero -Rec. 5164/2017-).

Esta nueva doctrina jurisprudencial para llegar a esa conclusión señala, por un lado, que no puede prescindirse de la independencia intelectual y jurídica de cada acto administrativo derivado, y por otro lado, que de no hacerse esa interpretación se produciría, sin justificación alguna, una diferente trato procesal en función de que el

\footnotetext{
${ }^{1601}$ Sentencias del TS, Sala Contencioso-Administrativa, 1060/2018, de 20 de junio -Rec. 553/2016-; 88/2019, de 29 de enero -Rec. 1978/2016-; y 262/2019, de 28 de febrero -Rec. 2342/2016-.

1602 Sentencias del TS, Sala Contencioso-Administrativa, 1717/2019, de 12 de diciembre -Rec. 3005/2017-; 1849/2019, de 18 de diciembre -Rec. 1098/2017-; 7/2020, de 14 de enero -Rec. 5164/2017-; y 560/2020, de 25 de mayo -Rec. 3120/2018-.
} 
recurrente fuese el deudor principal o un tercero responsable solidario o subsidio, ya que el deudor principal sólo podría recurrir de tener la deuda un importe igual o superior al establecido para el recurso, pero en cambio, los responsables solidarios o subsidiarios podrían acceder al recurso agrupando las cuantías de todas las dudas derivadas de impugnar el acto de derivación (Fundamento de Derecho Tercero de la Sentencia del TS, Sala Contencioso-Administrativa, de 1717/2019, de 12 de diciembre -Rec. 3005/2017-).

\section{Requerimiento de pago de deudas por cuotas.}

La ITSS antes de extender el acta de liquidación de cuotas está facultada para requerir el pago de esas deudas extendiendo previamente el pertinente requerimiento de pago de la deuda por cotizaciones al sujeto responsable directo, y, por ende, si estamos ante hechos susceptibles de un acta de liquidación por derivación de responsabilidad, al sujeto responsable solidario (art. 34.1 del TRLGSS, arts. 14.5 y 22.6 de la LOITSS, art. 35 del RISOS, art. 65 RGRSS, y arts. 25 y 27.1 apartado d) del ROFITSS), pero no al subsidiario, ya que para poder requerir el pago al responsable subsidiario, deberá haberse declarado previamente la insolvencia de la sociedad (art. 34.1 del TRLGSS, art. 35 del RISOS, en relación con el art. 14.3 del RGRSS).

En el art. 34.1 párrafo segundo del TRLGSS se señala que "en los casos a los que se refieren las letras a), b) y c), la Inspección de Trabajo y Seguridad Social podrá formular requerimientos a los sujetos obligados al pago de cuotas adeudadas por cualquier causa, previo reconocimiento de la deuda por aquéllos ante el funcionario actuante. En este caso, el ingreso de la deuda por cuotas contenida en el requerimiento será hecho efectivo en el plazo que determine la Inspección de Trabajo y Seguridad Social, que no será inferior a un mes ni superior a cuatro meses. En caso de incumplimiento del requerimiento, se procederá a extender acta de liquidación y de infracción por impago de cuotas". Las referencias a las letras a), b), c), es para aludir a las actas de liquidación por falta de alta, diferencias de cotización y de derivación de responsabilidad, respectivamente. 
El requerimiento de cuotas es una especificación o concreción ${ }^{1603}$ en materia de deudas por cuotas de Seguridad Social de la potestad general de la ITSS de emitir requerimientos ante el incumplimiento de obligaciones del orden social. El requerimiento se ha calificado como un acto de trámite discrecional por el que la ITSS insta al deudor a satisfacer una deuda ${ }^{1604}$.

En virtud de este precepto legal, cuando el Inspector o Subinspector compruebe la existencia de deudas por cuotas a la Seguridad Social, especialmente cuando proceda extender acta de liquidación (supuestos de falta de alta, diferencias de cotización que no resulten del sistema de liquidación directa, y derivación de responsabilidad), en lugar de extender acta de liquidación, está facultado para requerir su ingreso al sujeto responsable, previo reconocimiento de la deuda por éste, absteniéndose de iniciar expediente liquidatorio de haberse cumplido el requerimiento emitido. Trámite del requerimiento de pago que según MERCADER UGUINA y SÁNCHEZ GRANDE ${ }^{1605}$ (sic) "debe añadirse al procedimiento recaudatorio y que contribuye, en alguna medida, a facilitar el pago voluntario retrasando la puesta en marcha de la vía de apremio”.

La decisión de formular el requerimiento en lugar de extender directamente el acta de liquidación, entra dentro de los actos discrecionales administrativos, ya que el funcionario actuante valora libremente extender o no el requerimiento, sin estar tasados reglamentariamente las circunstancias para su obligada formulación ${ }^{1606}$. Pero una vez emitido el requerimiento tiene que estar suficientemente justificado y fundamentado en cuanto es una compulsión de hacer dirigida al administrado.

Uno de los supuestos legales en los que se admite el requerimiento es cuando proceda un acta de liquidación por derivación de responsabilidad. Cabe consiguientemente, el requerimiento de cuotas a los administradores como responsables solidarios de las

${ }^{1603}$ MERCADER UGUINA, J. R. y SÁNCHEZ GRANDE, A: “Anotaciones al Reglamento general sobre procedimiento sancionador y liquidatorio del orden social (Novedades del RD 928/1998, de 14 de mayo)", op. cit., edición digital, p. 11.

${ }^{1604}$ TRILLO GARCÍA, A. R.: "Artículo 31. Actas de liquidación de cuotas", en AA.VV. (Dir.: GARCÍAPERROTE ESCARTÍN, I. y MERCADER UGUINA, J. R.): Comentarios a la Ley General de la Seguridad Social, op. cit., p. 191.

${ }^{1605}$ MERCADER UGUINA, J. R. y SÁNCHEZ GRANDE, A: “Anotaciones al Reglamento general sobre procedimiento sancionador y liquidatorio del orden social (Novedades del RD 928/1998, de 14 de mayo)", op. cit., edición digital, p. 11.

${ }^{1606}$ FERNÁNDEZ ORRICO, F. J.: "Las actuaciones de advertencia y los requerimientos de la Inspección de Trabajo y Seguridad Social”, Revista del Ministerio de Trabajo y Asuntos Sociales, n. ${ }^{\circ}$ 78, 2008, recogida en el Foro del Conocimiento del OEITSS, edición digital, http://itss.laley.es/Content/Documento.aspx?params=, p. 9 de 29. 
deudas por cuotas al amparo de los arts. 360 y 367 de la LSC, como medio para obtener el pago, antes de extender el acta de liquidación por derivación de responsabilidad.

Vía del requerimiento de pago de dudosa eficacia en la derivación administrativa de responsabilidad de deudas al administrador social, ya que el requerimiento puede tener su razón de ser en los supuestos de exigirse el pago de las cuotas al sujeto responsable directo, a la sociedad de capital que, como sujeto responsable de infracciones del orden social podría tener cierto interés en atender el requerimiento de ingreso, para evitar la sanción administrativa, ya que éste es, en definitiva, el beneficio del requerimiento, eludir la sanción (art. 34.2 del TRLGSS y art. 35.3 del RISOS), pero como sabemos, los administradores no son responsables de las infracciones de Seguridad Social que haya cometido la sociedad y por las que proceda la extensión del acta de liquidación de cuotas (art. 2 del TRLISOS).

Podrá emitirse el requerimiento de ingreso de las cuotas siempre que se cumplan dos requisitos. En primer lugar, que el sujeto responsable dé su conformidad a la liquidación, en nuestro caso, a la derivación de responsabilidad y al importe de la deuda exigida. En segundo lugar, que se formalice por escrito, bien en la diligencia de la actuación inspectora con destino a la empresa, o bien mediante escrito ordinario notificado a los interesados, formalización en escrito específico que será lo más oportuno cuando se emite a los administradores sociales, pese a no haberse excluido expresamente su formalización en la diligencia a entregar en la sociedad de capital (art. 35.2 del RISOS y art. 2.3 de la Orden ESS/1452/2016, de 10 de junio, por la que se regula el modelo de diligencia de actuación de la Inspección de Trabajo y Seguridad Social), porque la diligencia de la actuación inspectora está pensada para su entrega a la empresa objeto de inspección (Orden ESS/1452/2016, de 10 de junio). Diligencia que no será el cauce más idóneo para formalizar el requerimiento cuando éste se emite a un tercero distinto de la sociedad de capital, como son los administradores sociales, y especialmente cuando ya no están en el ejercicio del cargo, en cuyo supuesto, lo pertinente sería formalizarlo en una en comunicación "ad hoc" dirigida a los mismos, con una mención al mismo en la diligencia.

El requerimiento de ingreso de las cuotas deberá recoger, cuando menos, la determinación de los elementos esenciales de la deuda, el plazo o plazos para su ingreso efectivo en la Seguridad Social, y la obligación de justificación documental ante la 
Inspección de cada uno de los ingresos efectuados en los plazos establecidos al efecto en el requerimiento (art. 35.2 del RISOS).

Consideramos que el requerimiento deberá tener el siguiente contenido: a) Identificación de los sujetos responsables, tanto de la sociedad de capital deudora, como de los administradores responsables solidarios, constando la conformidad de los sujetos responsables con la derivación de la responsabilidad y con la deuda, así como la forma y la fecha en que se presta esa conformidad; b) fechas de inicio y de las sucesivas actuaciones de comprobación de la ITSS, tanto ante la sociedad de capital, como en su caso, ante los administradores sociales; c) origen de la deuda, su naturaleza (si es descubierto total de cotización, diferencias de cotización, faltas de alta, etc.); d) importe total de la deuda derivada, incluyendo en la responsabilidad solidaria el importe de las cuotas, de los recargos, los intereses y las costas del procedimiento; e) período de la deuda; f) preceptos legales que facultan al funcionario a extender el requerimiento; g) fundamentación jurídica de la procedencia de la liquidación de la deuda, y de la derivación administrativa de responsabilidad; h) plazo o plazos establecidos para el ingreso de la deuda; i) documentación que debe aportar el administrador social para acreditar el pago de la deuda y, en su caso, plazo y medio de entrega; y j) advertencia expresa de que en caso de incumplirse el requerimiento, se procederá a extender acta de liquidación de cuotas por derivación de responsabilidad.

En ese requerimiento se permite que pueda aplazarse o fraccionarse el pago de la deuda, sin que esos plazos de pago puedan ser inferiores a un mes, ni extenderse más allá de cuatro meses (art. 34.2 del TRLGSS). De la duración de los plazos fijados en el requerimiento, se ha de excluir el período del 14.3.2020 al 31.5.2020, del estado alarma por la crisis sanitaria del Covid-19, (Disposición Adicional 3 ${ }^{\mathrm{a}}$ del Real Decreto 463/2020, de 14 de marzo ${ }^{1607}$, Disposición Adicional 2a del Real Decreto-Ley 15/2020, de 21 de abril ${ }^{1608}$, y art. 9 del Real Decreto 537/2020, de 22 de mayo ${ }^{1609}$ ). Si se

\footnotetext{
1607 BOE del 14.3.2020.

1608 “Disposición Adicional Segunda. Suspensión de plazos en el ámbito de actuación de la Inspección de Trabajo y Seguridad Social (...):

2. Durante el periodo de vigencia del estado de alarma, declarado por el Real Decreto 463/2020, de 14 de marzo y sus posibles prórrogas, quedan suspendidos los plazos de prescripción de las acciones para exigir responsabilidades en lo que se refiere al cumplimiento de la normativa de orden social y de Seguridad Social.

3. Todos los plazos relativos a los procedimientos regulados en el Reglamento general sobre procedimientos para la imposición de sanciones por infracciones de orden social y para los expedientes liquidatorios de cuotas de la Seguridad Social, aprobado por Real Decreto 928/1998,
} 
acordasen plazos superiores a los cuatros meses, de incumplirse los mismos, esa circunstancia no tendría efectos invalidantes de la posterior acta de liquidación que se extendiese ante la falta de pago de la totalidad de la deuda requerida.

Con relación a la naturaleza jurídica de estos requerimientos, indicar que estaríamos ante "una especie de procedimiento abreviado de conformidad con efecto preclusivo de un procedimiento sancionador y liquidatorio ulterior" (Criterio 50/2007, de 28 de junio de 2007, de la DGITSS - actual Dirección del OEITSS-, sobre recurribilidad de las advertencias y requerimientos formulados por la Inspección de Trabajo y Seguridad Social ${ }^{1610}$ ). A efectos de los administradores tendrá sólo efectos excluyentes del procedimiento liquidatorio.

Requerimiento de pago de cuotas, que, con independencia de la discusión doctrinal sobre la posibilidad de recurrir los actos de conformidad y los motivos de los recursos, no está previsto recurso alguno ante el mismo, a diferencia de lo que sucede con las actas de conformidad levantadas por la Inspección Tributaria. El reconocimiento de la deuda "no sería, por lo tanto, recurrible y si, tras efectuar el ingreso el sujeto responsable, se observara error en el cálculo de la deuda o cualquier otra circunstancia relevante, todo lo más podrá reclamar la devolución de cuotas indebidamente ingresadas" (Criterio Técnico 50/2007 de la DGITSS). Cuestión distinta será que, incumplido el requerimiento, no cabría extender acta de infracción al administrador social al no ser sujeto responsable de las infracciones del orden social (art. 2 del TRLISOS), y menos aún, permitiría considerar el incumplimiento de requerimiento como circunstancia agravante de la responsabilidad si se hubiere emitido a la sociedad de capital, ya que sería una intimidación o coacción que lesionaría el derecho a la defensa. Según el Criterio Técnico 50/2007 de la DGITSS, cuando el art. 39 del TRLISOS alude al incumplimiento de requerimientos de la Inspección, como circunstancias agravantes de la responsabilidad por infracciones administrativas, no se han de incluir estos requerimientos de pago de cuotas.

En la Sentencia del Tribunal Supremo, Sala Contencioso-Administrativa, de 11 de mayo de 2006 -Aranzadi RJ 200613949-, analizando las garantías del administrado del art. 24 de la $\mathrm{CE}$ en el procedimiento sancionador, y, en especial, el derecho de defensa, señala

de 14 de mayo, están afectados por la suspensión de plazos administrativos prevista en la Disposición Adicional Tercera del Real Decreto 463/2020, de 14 de marzo". 
que ese precepto no es aplicable a un requerimiento de la Administración (en sentido similar, la Sentencia del TS, misma sala, de 10 de noviembre de 2005 -RJ 20061492-), porque el requerimiento no es una resolución administrativa que imponga una sanción, sino una conminación a realizar un acto, ya que si con posterioridad a su incumplimiento, se iniciase un procedimiento sancionador, contra la resolución del mismo el interesado siempre podría ejercer sus derechos de defensa.

No puede confundirse este tipo de requerimientos de ingreso de cuotas del art. 22.6 de la LOITSS y art. 34.1 del TRLGSS, con el requerimiento o advertencia ante incumplimientos de la normativa del orden social (art. 22.1 de la LOITSS), previsto para los supuestos de incumplimientos empresariales del orden social que no entrañen perjuicio a los trabajadores, en que el Inspector actuante podrá requerir la subsanación de esos incumplimientos, en lugar de promover actas de infracción (art. 49 del TRLISOS). Requerimientos de subsanación de incumplimientos sociales que tienen su fundamento en el art 17.2 del Convenio 81 de la OIT y en el art. 22.2 del Convenio 129 dela OIT. El artículo 22.2 del Convenio 129 de la OIT relativo a la Inspección del Trabajo en la agricultura, utiliza una terminología que se ha recogido en nuestro Derecho interno, al señalar que "los Inspectores del trabajo tendrán la facultad de advertir y de aconsejar, en vez de iniciar o recomendar el procedimiento correspondiente".

\section{Informe a la TGSS en materia de derivación de responsabilidad.}

El informe a la TGSS es otra de las formas o posibilidades jurídicas de finalización de las actuaciones previas de comprobación de la Inspección de Trabajo y Seguridad Social, y que de facto, se ha convertido en la forma ordinaria de conclusión de la actuación inspectora en las derivación administrativas de responsabilidad de los administradores en las deudas de la sociedad de capital, para que sea la Tesorería quien inicie el procedimiento administrativo de derivación dictando la resolución y la reclamación de deuda pertinente.

Se puede decir, que tanto el requerimiento de pago de la deuda, como la extensión de actas de liquidación por derivación de responsabilidad, se han convertido en la excepción, quedando reducidos ambos instrumentos prácticamente a aquellos supuestos en los que procede extender a la sociedad de capital un acta de liquidación por falta de afiliación o de alta de los trabajadores en Seguridad Social, por diferencias de cotización 
o por bonificaciones indebidas con apreciación de la responsabilidad solidaria de los administradores sociales.

No se extienden actas de derivación de responsabilidad por la Inspección ante descubiertos totales o parciales de cotización, cuando la competencia para reclamar la deuda a la sociedad de capital es de la TGSS (art. 33.1 del TRLGSS). En estos supuestos, la ITSS viene emitiendo directamente el informe a ese Servicio Común, por ser el medio más idóneo de coordinación entre ambos organismos y de mayor eficiencia en el control y gestión de la reclamación de la deuda a todos los deudores y responsables, tanto a la sociedad de capital como a los administradores sociales.

Informe de derivación de responsabilidad reconocido jurídicamente en el art. 33.2 del TRLGSS, cuando prevé expresamente que la Tesorería General de la Seguridad Social pueda iniciar el procedimiento de derivación administrativa de la responsabilidad en virtud de los datos comunicados por la Inspección, y en los arts. 22.16 y 14.5 de la LOITSS $^{1611}$, donde se establece que los Inspectores de Trabajo y Seguridad Social o Subinspectores Laborales de Empleo y Seguridad Social, finalizada la actividad inspectora comprobatoria, podrán informar al órgano competente acerca de la identificación de los distintos sujetos responsables ante supuestos de hechos constitutivos de una responsabilidad solidaria o subsidiaria.

Al recoger ese informe las pruebas obtenidas en la actividad inspectora de comprobación acerca de los hechos objetivos determinantes de la responsabilidad del administrador, y que va a servir de fundamento a la TGSS para dictar la resolución de derivación y la reclamación de deuda de derivación, es esencial que en el mismo se expliciten suficientemente los siguientes datos: forma de comprobación de los hechos y fechas de las actuaciones inspectoras, concurrencia de la causa de disolución, y fecha de acaecimiento, identificación de los administradores responsables, deberes legales incumplidos por los administradores y fechas de los incumplimientos, fecha a partir de la cual nace la responsabilidad de los administradores y a partir de la que procede la derivación de las deudas, período de las deudas derivadas, con mención de las circunstancias que pudieran tener efectos en las deudas objeto de su responsabilidad, como la fecha de la aceptación del nombramiento o la fecha del cese en el cargo y de su

${ }^{1611}$ En igual sentido los arts. 25 y 27 apartado g) del ROFITSS. 
inscripción registral, etc., así como los fundamentos jurídicos de la derivación de la responsabilidad de la deuda a los administradores sociales.

La DGITSS -actual Dirección del OEITSS- en Nota Interna, de fecha 4 de febrero de 2016, señala que los informes dirigidos a la TGSS en materia de derivación de responsabilidad a administradores sociales por deudas en cuotas de la Seguridad Social, deben recoger al menos los siguientes extremos, por considerarse indispensables para acreditar la existencia de responsabilidad del administrador social y para poder determinarse las deudas por cuotas derivadas:

" $1{ }^{\circ}$ Causa legal de disolución de la sociedad que concurra en cada caso concreto, debiendo realizarse una remisión a alguna de las contenidas en el artículo 363.1 del RD Legislativo 1/2010, Ley de Sociedades de Capital. La citada causa legal de disolución deberá además justificarse por medios apropiados.

$2^{\circ}$ En el caso en que la causa legal de disolución fuera la del art. 363.1.e) de la Ley de Sociedades de Capital, deberá indicarse la fecha de concurrencia de la causa legal de disolución. Esta será la de fecha de cierre del ejercicio contable en que las pérdidas hayan reducido el patrimonio a una cantidad inferior a la mitad del capital social (normalmente el 31 de diciembre), salvo que se acredite dicha circunstancia en otra fecha distinta, y así se haga constar en el informe.

$3^{\circ}$ Fecha a partir de la cual procede la derivación de la deuda. En el supuesto en que la causa legal de disolución fuera la del art. 363.1.e), la citada fecha será la del día siguiente a la de la concurrencia de la causa legal de disolución. A modo de ejemplo, si concurre la causa legal de disolución el 31 de diciembre de 2012, procede la derivación de las cuotas devengadas a partir del 1 de enero de 2013 que se encuentren en estado de deuda vigente".

Los hechos constatados en las actuaciones inspectoras de comprobación que se recojan en los informes emitidos por la ITSS tienen el valor de la presunción de certeza, al igual que ocurre con los hechos recogidos en las actas de liquidación de cuotas o de infracción (art. 23 de la LOITSS). Presunción "iuris tantum" que admite prueba en contrario por los interesados, por la sociedad de capital o los administradores sociales, como hemos reseñado al analizar la presunción de certeza en el apartado VI.3.3 de este Capítulo al que nos remitimos. 
Presunción de certeza de los hechos recogidos en los informes, prevista expresamente en el art. 23 de la LOITSS, que admitió el TS en Sentencia, de la Sala de lo Contencioso-Administrativa, de 9 de julio de 2015 -Rec. 3623/2013-, en que se analizó el valor probatorio de los informes de la Inspección de Trabajo y Seguridad Social, con motivo de una propuesta de alta de oficio en el Régimen General de la Seguridad Social, comunicada por la Inspección a la TGSS por medios telemáticos, a través de la aplicación "Integra". Para el TS los hechos descritos en el informe tras la visita de la inspección gozan de presunción de certeza, atendida la tradicional dificultad probatoria que se presenta cuando se abordan incumplimientos laborales, lo que conlleva la necesidad de que el recurrente acredite los hechos con los que pretende refutar los constatados por el funcionario actuante, si pretende desvirtuar la presunción legal de certeza. Concluye el TS que "la estimación del motivo procede, por tanto, cuando comprobamos que en el expediente administrativo se documenta la visita, realizada por el servicio de inspección, a la sede de la asociación donde se estaban impartiendo cursos de formación, sin haber dado de alta a los trabajadores identificados". Finalmente, señala el TS que el medio informático de elaboración del informe no es lo relevante para despojar del valor de presunción de certeza a los hechos constatados en visita de inspección y comunicados a la TGSS.

Igualmente, en Sentencia del TS, Sala Social, de 17 de marzo de 2016 -Rec. 178/2015dictada en proceso de oficio ante un acta de la ITSS, se declara que la presunción «iuris tantum» de veracidad que corresponde a las actuaciones de la Inspección de Trabajo, no solamente alcanza a las Actas de infracción sino que también se extiende a los informes, refiriéndose el privilegio probatorio únicamente a los «hechos» constatados por el Inspector actuante, no a la valoración que éste haga de los mismos, por lo que en la valoración del juez los hechos del informe serán un medio probatorio más conjuntamente con el resto de pruebas admitidas, sin que tengan una relevancia mayor a la del resto de las pruebas admitidas.

\section{Informe al Ministerio Fiscal.}

Cuando con motivo de las actuaciones previas de comprobación los funcionarios de la Inspección de Trabajo y Seguridad Social constaten o comprueben hechos que pudieran ser constitutivos de ilícito penal, y especialmente en materia de fraude a la Seguridad Social, remitirá al Jefe de la Inspección de Trabajo y Seguridad Social informe con expresión de los hechos, circunstancias y sujetos que pudieran resultar afectados. Si se 
hubiere iniciado un procedimiento sancionador mediante la extensión de un acta de infracción y los hechos pudieran ser constitutivos de infracción penal, el Jefe de la Inspección de Trabajo y Seguridad Social lo comunicará al órgano competente para resolver, acordando éste, en su caso, la remisión del expediente al Ministerio Fiscal y se abstendrá de seguir el procedimiento administrativo sancionador por los mismos hechos hasta que el Ministerio Fiscal, en su caso, resuelva no interponer acción o le sea notificada la firmeza de la sentencia o auto de sobreseimiento que dicte la autoridad judicial (art. 3.2 del TRLISOS, art. 17.3 de la LOITSS y art. 5 del RISOS). También se suspenderá el procedimiento administrativo sancionador cuando no mediando dicha comunicación, se venga en conocimiento de la existencia de actuaciones penales por los mismos hechos y fundamento en relación al mismo presunto responsable (arts. 5.1 y 36 del RISOS).

Pese a aludirse en esos preceptos al Jefe de la Inspección Provincial, cuando la actuación inspectora sea de ámbito territorial de una Comunidad Autónoma, realizada bajo las órdenes de la Dirección Territorial, será el Director Territorial el que tendrá la competencia para comunicar los hechos al Ministerio Fiscal (art. 28. 4, en relación con el art. 30.2, letra f) del Real Decreto 192/2018, de 6 de abril, por el que se aprueban los estatutos del Organismo Autónomo Organismo Estatal Inspección de Trabajo y Seguridad Social ${ }^{1612}$ ).

De haberse extendido acta de liquidación de cuotas o emitido informe a la TGSS, con independencia de ponerse los presuntos hechos constitutivo de ilícito penal en conocimiento del Ministerio Fiscal, el procedimiento de recaudación del acta de liquidación no se paraliza, salvo que lo acordase el juzgado o tribunal penal que conozcan los hechos delictivos del presunto fraude a la Seguridad Social (art. 36 del RISOS y art. 307.4 del Código Penal ${ }^{1613}$, e Instrucción Cuarta de la Instrucción conjunta, de 4 de marzo de 2013, de la Dirección General de la ITSS y la Dirección del

1612 BOE del 7.4.2018.

1613 Art. 307. 4. "La existencia de un procedimiento penal por delito contra la Seguridad Social no paralizará el procedimiento administrativo para la liquidación y cobro de la deuda contraída con la Seguridad Social, salvo que el Juez lo acuerde previa prestación de garantía. En el caso de que no se pudiese prestar garantía en todo o en parte, el Juez, con carácter excepcional, podrá acordar la suspensión con dispensa total o parcial de las garantías, en el caso de que apreciara que la ejecución pudiera ocasionar daños irreparables o de muy difícil reparación. La liquidación administrativa se ajustará finalmente a lo que se decida en el proceso penal". 
Servicio Jurídico de la Administración de la Seguridad Social, para establecer un marco de coordinación en el ámbito de los ilícitos penales contra la Seguridad Social ${ }^{1614}$ ).

Para una mejor coordinación de las actuaciones inspectoras encaminadas a combatir el fraude a la Seguridad Social, en la Instrucción Conjunta del OEITSS y los Servicios Jurídicos de la Seguridad Social, de 4 de marzo de 2013, se procedió a constituir un Grupo de trabajo en los Servicios Centrales y Provinciales. Grupo de trabajo que tendría como cometido, "la elaboración de un documento en el que se efectuará una valoración de las diferentes conductas susceptibles de ser tipificadas como delito, con la finalidad de establecer criterios sobre el contenido de las actas de infracción y liquidación que vayan a iniciar el proceso penal, así como la homogeneización de estrategias y criterios en materia de persecución de los delitos contra la Seguridad Social y su revisión periódica de acuerdo con la doctrina y jurisprudencia que vaya recayendo".

Estos grupos de trabajo tendrían como objetivos y cometidos esenciales, los siguientes:

a) Mejorar la coordinación entre las actuaciones administrativas y procesales, con la participación de los Letrados de la Seguridad Social en los expedientes administrativos de mayor complejidad o repercusión social o económica.

b) Facilitar que la ITSS conozca el estado de tramitación de las causas penales en que tenga intervención el Letrado de la Administración de la Seguridad Social, cuando tengan su origen en la actuación inspectora o puedan afectar a ésta.

c) Impulsar el ejercicio por los Letrados de la Administración de la Seguridad Social de la acusación particular, prestando el apoyo necesario a lo largo del proceso de cara a la acreditación del hecho delictivo y su autoría, aseguramiento de responsabilidades, especialmente civiles, y efectiva ejecución de la sentencia.

d) Cuando la actuación de la ITSS culmine con la remisión del expediente al Ministerio Fiscal en materias competencia del Servicio Jurídico de la Seguridad Social, lo comunicará también a ese Servicio Jurídico remitiendo los informes y antecedentes necesarios.

e) Con relación a aquellos expedientes donde se aprecie la posible existencia de delitos a la Seguridad Social, los órganos competentes de la ITSS podrán solicitar informe no vinculante del Servicio Jurídico provincial de la Seguridad Social. Éste podrá 
proponer la interposición directa de denuncia o querella ante el órgano jurisdiccional competente, cuando hubiera riesgo de prescripción inminente del delito, cuando urja la adopción de medidas cautelares, o cuando concurra otra razón que lo aconseje. En ese caso, de acordarse la interposición de la querella, se efectuará por los Servicios Jurídicos de la Seguridad Social

f) El Servicio Jurídico provincial informará a la ITSS sobre todas las incidencias del proceso penal que resulten relevantes, así como sobre la adopción de medidas cautelares, y comunicará los autos de sobreseimiento, la apertura del juicio oral, y las sentencias que pongan fin a al proceso, indicando su carácter firme o la susceptibilidad de recurso.

Para concluir, señalar que con la finalidad de potenciar una mejor coordinación administrativa en la lucha contra el fraude a la Seguridad Social, se ha creado el Observatorio para la lucha contra el fraude a la Seguridad Social, que se ha adscrito a la Dirección General de la TGSS, como órgano de participación, cooperación y colaboración entre la Tesorería General de la Seguridad Social, el Instituto Nacional de la Seguridad Social, el Instituto Social de la Marina, el Organismo Estatal Inspección de Trabajo y Seguridad Social, el Servicio Jurídico de la Administración de la Seguridad Social y las organizaciones sindicales y empresariales más representativas (Orden TMS/667/2019, de 5 de junio, por la que se crea el Observatorio para la lucha contra el fraude a la Seguridad Social ${ }^{1615}$ ).

1615 -BOE 19.6.2019-, modificada por la Orden TMS/1066/2019, de 24 de octubre -BOE del 30.10.2019-. Para un conocimiento del control del fraude de Seguridad Social mediante los Big Data por la TGSS, véase AIBAR BERNAD, J.: "El Big Data y el análisis de datos aplicados por la Tesorería General de la Seguridad Social como medio de lucha contra el fraude en la Seguridad Social", Trabajo y Derecho, No 11, Sección Estudios, editorial Wolters Kluwer, Ref. La Ley 7213/2020, Smarteca, edición digital. 


\section{CONCLUSIONES Y PROPUESTA DE LEGE FERENDA}

\section{Conclusiones.}

1.- En nuestro Derecho de la Seguridad Social no existe una regulación específica de la responsabilidad de los administradores sociales en las deudas de Seguridad Social de la sociedad de capital, por incumplimientos imputables de los mismos, a diferencia de otros sectores normativos como en el Derecho Tributario, y ello, pese a ser los administradores quienes, en último término dirigen y organizan y son responsables, directa o indirectamente, del desarrollo de las relaciones laborales en el ámbito de la empresa, con lo que, en buena medida, determinados incumplimientos laborales y de seguridad social de la sociedad de capital serán atribuibles a la actuación orgánica de aquéllos.

2.- Con carácter general el administrador social actualmente puede responder del pago de las deudas con la Seguridad Social de la sociedad de capital, en cuatro situaciones, de las cuales, tres están reguladas en el Derecho Mercantil. En primer lugar, cuando en el Derecho de Sociedades se le imponga legalmente una responsabilidad por deudas, sea solidaria o subsidiaria - responsabilidad ex lege por deudas ajenas-. En segundo lugar, cuando en actuación orgánica el administrador social cause un daño directo al derecho de crédito de la Seguridad Social - responsabilidad por daños-, exigible a través de la acción individual de responsabilidad, (arts. 236 a 241 bis de la LSC). En tercer lugar, cuando en la sentencia de calificación del concurso de acreedores de la sociedad se le condene a cubrir el déficit patrimonial de la masa activa del concurso - responsabilidad concursal- (art. 456 del TRLC). Un cuarto y último posible supuesto de responsabilidad tiene lugar cuando pueda atribuirse al administrador social la condición de verdadero empresario a efectos laborales y de seguridad social, por uso abusivo de la personalidad jurídico-societaria (levantamiento del velo).

3.- De esos cuatro posibles supuestos de responsabilidad sólo procederá la derivación administrativa de responsabilidad dentro del procedimiento de recaudación autotutela administrativa-, en la responsabilidad ex lege en deuda ajena (art. 18.3 del 
TRLGSS), y cuando pueda calificarse al administrador social como verdadero empresario (art. 18.4 del TRLGSS), siendo la responsabilidad ex lege la que tendrá mayor relevancia y eficacia recaudatoria.

4.- La derivación de responsabilidad al administrador de las deudas de la sociedad en virtud de la responsabilidad ex lege prevista en el art. 18.3 del TRLGSS, tendrá lugar cuando incumpla los deberes orgánicos establecidos en la legislación de sociedades, en primer lugar, ante la concurrencia de una causa de disolución, sea causa de disolución de pleno derecho o causa legal de disolución (arts. 360 y 367 de la LSC), $y$, en segundo lugar, de menor relevancia, en los supuestos de la sociedad de capital en formación (arts. 36 a 38 de la LSC), de sociedad de capital irregular (art. 39 de la LSC), de sociedad unipersonal sobrevenida (art. 14 de la LSC), o como consecuencia de las transformaciones societarias (art. 21 de la Ley 3/2009, de 3 de abril), aunque en la sociedad unipersonal y en las transformaciones societarias, la responsabilidad no será tanto del administrador, sino del socio, ostentando éste habitualmente en la sociedad unipersonal el cargo de administrador, salvo que se nombre a un mero testaferro para eludir responsabilidades.

5.- La derivación de responsabilidad al administrador social cuando concurran causa legal de disolución de la sociedad en aplicación de los arts. 18.3 del TRLGSS y artículos 360 y 367 de la LSC, no se extiende al personal ejecutivo no consejero (alta dirección y apoderados generales), salvo que pudieran ser calificados como administradores de hecho. En primer lugar, porque no han sido incluidos expresamente en los arts. 360 y 367 de la LSC, a diferencia de la responsabilidad por daños del art. 236 de la LSC y, en segundo lugar, porque las facultades de convocar la Junta General no pueden ser delegadas por el Consejo de Administración (art. 249 bis apartado j) de la LSC), de modo que no podrán imputarse la responsabilidad a quien no tiene la obligación de cumplir con el deber determinante de la misma. En cambio, ese personal ejecutivo no consejero sí podrá incurrir en la responsabilidad por daños de la acción individual de responsabilidad (art. 236.4 LSC) y en la responsabilidad concursal (art. 456 TRLC).

A la sociedad matriz o a los administradores de la sociedad dominante se les podrá derivar la responsabilidad en las deudas de la filial si se les puede atribuir la condición de administradores de hecho de la sociedad dominada, y sin que, el hecho 
de haber seguido los administradores de la sociedad dominada las instrucciones de la sociedad matriz les exonere de responsabilidad ya que gozan de autonomía para cumplir con sus deberes legales, no existiendo obediencia debida a la matriz, ni un interés del grupo prevalente y absoluto, hallándose sometidos al deber de diligencia con la sociedad filial.

En las sociedades mercantiles estatales, cuando el órgano de administración adopta la forma de Consejo de Administración, y el cargo de consejero designado por la Administración General del Estado lo asuma un empleado público, la responsabilidad de éste se atribuye ope legis a la Administración del Estado que lo designó (art. 115 de la LRJSP), porque el legislador ha querido que siga sometido al régimen de responsabilidad administrativa patrimonial y disciplinaria. Responsabilidad por deudas imputable a la Administración exigible por el procedimiento administrativo de derivación de responsabilidad (arts. 12, 13 y 39 del RGRSS), sin tener que acudirse recabar la responsabilidad patrimonial de la Administración.

Es discriminatorio no haberse incluido a los administradores solidarios o mancomunados empleados públicos, existiendo identidad de razón.

6.- No resulta de aplicación la derivación administrativa de responsabilidad del art. 18.3 del TRLGSS, para exigir la responsabilidad por daños del art. 241 de la LSC, ni para la responsabilidad concursal del art. 456 del TRLC, en primer lugar, porque han de ser reconocidas y declaradas en una resolución judicial, y, en segundo lugar, porque en el art. 241 de la LSC y en el art. 456 del TRLC no se impone una responsabilidad ex lege, solidaria o subsidiaria, del administrador social en las deudas de la sociedad de capital (art. 18.3 del TRLGS), sino que nos encontramos ante una responsabilidad de naturaleza reparadora o indemnizatoria.

7.- La derivación administrativa de responsabilidad al administrador social al amparo del art. 18.3 del TRLGSS, será la vía preferente de reclamación de deudas de Seguridad Social al administrador social, principalmente ante el incumplimiento de sus deberes orgánicos concurriendo causas de disolución, teniendo carácter residual el ejercicio de la acción procesal individual de responsabilidad del art. 241 de la LSC por la TGSS y/o entidades gestoras, que de facto quedaría reducida para una eventual reclamación de deudas anteriores al acaecimiento de una causa de 
disolución, para incumplimientos dolosos de obligaciones de Seguridad Social, para las situaciones de cierre de hecho, o en caso de preterición de créditos de Seguridad Social.

8.- La competencia para derivar la responsabilidad al administrador al amparo del art. 18.3 del TRLGSS, cuando sean deudas por cotizaciones corresponde a la TGSS, mediante el acuerdo de derivación y la reclamación de deuda de derivación (art. 33.2 del TRLGSS y arts. 13, 14 y 62.2 del RGRSS), y a la ITSS mediante el acta de liquidación de cuotas por derivación de responsabilidad (art. 34.1.c) del TRLGSS y art. 31.1 letra c) del RISOS), mediante el requerimiento del pago al administrador antes de extender el acta (art. 34.1 párrafo segundo del TRLGSS, arts. 22.6 de la LOITSS y 35 del RISOS), o finalmente emitiendo un informe recogiendo los hechos y fundamentos de derecho para que sea la TGSS quien inicie el procedimiento administrativo de derivación (art. 22.16 de la LOITSS).

Las actas de liquidación por derivación de responsabilidad (art. 31.1.c) del TRLGSS) no están limitadas jurídicamente a los supuestos de faltas de alta, diferencias de cotización o bonificaciones subsistema de formación profesional para el empleo (art. 34 apartado 1), letras a), b), y d) del TRLGSS). Cuestión diversa será que, ante deudas por descubiertos de cotización cuya competencia ostenta la TGSS para su reclamación a la sociedad (art. 33.1 del TRLGSS), la ITSS, como criterio de mejor coordinación y eficacia, emita un informe a la TGSS para que sea ésta la que proceda a la derivación de responsabilidad.

Si la ITSS tuviere que extender a la sociedad de capital actas de liquidación por faltas de alta o de afiliación de los trabajadores, por diferencias de cotización o por bonificaciones indebidas (art. 33.1 letras a), b), y d) del TRLGSS), en esas actas declarará la responsabilidad solidaria o subsidiaria del administrador social de concurrir hechos determinantes de esa responsabilidad.

Por el contrario, la competencia para la derivación de responsabilidad solidaria o subsidiaria al administrador social en las deudas por prestaciones de responsabilidad de la sociedad de capital al amparo del art. 18.3 del TRLGSS, corresponde a la TGSS dentro del procedimiento de recaudación, cuando estemos ante una responsabilidad ex lege en deuda ajena de los arts. 36 a 39, 360 y 367 de la LSC, por encontrarnos ante una función de gestión recaudatoria de deudas previamente existentes. 
Será competencia de la entidad gestora de prestaciones (INSS/ISM/SEPE), declarar la responsabilidad del administrador social cuando, en ejercicio de la función de gestión de prestaciones le impute la responsabilidad por atribuirle la condición de empresario real (doctrina del levantamiento del velo), así como para derivarle la responsabilidad en el recargo de prestaciones (art. 12.4 del RGRSS), que cobra verdadero sentido en los supuestos en que pudiera serle imputable el incumplimiento de las disposiciones de prevención de riesgos laborales -función de gestión de prestaciones-, pero que no tendrá la misma justificación jurídica cuando se pretenda derivarle una deuda previa del recargo en supuestos de responsabilidad ex lege en deuda ajena -función de gestión recaudadora-, que debería corresponder a la TGSS, siendo procedente atribuirle expresamente esta competencia reformando al respecto el art. 12.4 del RGRSS.

9.- De los dos actuales supuestos de derivación de responsabilidad de deudas de Seguridad Social de la sociedad al administrador social, sólo en uno de ellos se declara la responsabilidad en aplicación directa y exclusiva de la normativa reguladora de la responsabilidad en Seguridad Social, cual es el art. 18.4 del TRLGSS, cuando pueda ser calificado como el verdadero empresario real, cuando se haya servido del ropaje jurídico de la sociedad para eludir su responsabilidad patrimonial persona e ilimitada. Supuesto éste de difícil apreciación y con verdaderas dificultades probatorias, que no genera prácticamente derivaciones de responsabilidad al administrador social.

El segundo supuesto que permite exigir la responsabilidad del administrador social en las deudas de Seguridad Social de la sociedad es el art. 18.3 del TRLGSS, precepto de declaración de responsabilidad derivada por remisión legal expresa a otros órdenes normativos. Norma de remisión en blanco de responsabilidad y medio indirecto de determinación de la responsabilidad del administrador social. La responsabilidad solidaria o subsidiaria del administrador en las deudas de Seguridad Social, en virtud de este precepto, tendrá como disposición habilitante una ley de Seguridad Social, que operará como la causa o fuente próxima de la responsabilidad siendo su causa o fuente remota la legislación de sociedades.

En virtud del art. 18.3 del TRLGSS podremos llegar a recabar la responsabilidad del administrador cuando en la legislación mercantil, y más concretamente en la legislación de sociedades, se le imponga una responsabilidad en el pago de las 
deudas de la sociedad, sin haberse excluido las deudas de Seguridad Social. Es una responsabilidad por incumplimiento de los deberes orgánicos societarios del administrador. No estamos ante una responsabilidad del administrador por incumplir la mercantil sus obligaciones con la Seguridad Social por causa imputable al mismo.

Estos dos supuestos de derivación de responsabilidad de las deudas de la sociedad al administrador social, a la altura de nuestros días, se muestran claramente insuficientes, siendo preciso disponer también de un sistema específico de responsabilidad del administrador en las deudas de Seguridad Social de la sociedad por conducta imputable, teniendo en cuenta que éstas se generen en gran medida por conducta orgánica de los administradores, al ser en última instancia los responsables de muchos los incumplimientos con la Seguridad Social que se producen en las sociedades mercantiles.

Esa insuficiencia del actual artículo 18.3 del TRLGSS nos permiten concluir que ha llegado ya el momento de recogerse, de modo expreso y sin complejos, en la legislación de Seguridad Social un sistema específico de responsabilidad del administrador en las deudas de la Seguridad Social de la mercantil por sus incumplimientos imputables. Sistema de responsabilidad propio y específico de Seguridad Social que tendrá dos grandes beneficios. En primer lugar, será un medio de garantizar el cobro de esas deudas de Seguridad Social, en cuanto las entidades de la Seguridad Social dispondrán de un sujeto adicional al que poder exigir el pago de la deuda, sujeto que ha tenido su responsabilidad en los incumplimientos, bien por conducta activa o pasiva de no haber hecho lo necesario para el cumplimiento de esas obligaciones (función de garantía). En segundo lugar, porque será un medio de incentivar a los administradores sociales para que la sociedad cumpla más diligentemente con las obligaciones con la Seguridad Social (función de prevención), especialmente ante deudas que se generan por incumplimientos groseros e inadmisibles en un orden jurídico avanzado, como serían las deudas por falta de alta en Seguridad Social de los trabajadores, por actividades empresariales sumergidas o no declaradas (falta de inscripción de la empresa en Seguridad Social), por la obtención fraudulenta de deducciones, reducciones, bonificaciones de cotizaciones al aportarse datos falsos, por la retención de cuota obrera sin ingresarse su importe en la TGSS, etc. 
Este sistema específico de responsabilidad por incumplimientos de las obligaciones con la Seguridad Social, sería complementario del actual sistema de responsabilidad aplicable en virtud del artículo 18.3 del TRLGSS para la responsabilidad por deudas impuesta en la legislación mercantil y de sociedades.

\section{Propuestas de lege ferenda en la responsabilidad del administrador y en la derivación de responsabilidad.}

Para cubrir vacíos normativos y clarificar dudas existentes en la regulación de la responsabilidad del administrador en las deudas de Seguridad Social y en el procedimiento administrativo de derivación, como propuestas de lege ferenda abogamos por:

$1^{\circ}$. Debería establecerse un régimen jurídico propio de responsabilidad del administrador en el pago de deudas de Seguridad Social de la sociedad de capital, por incumplimientos de los mismos de las obligaciones con la Seguridad Social de la sociedad de capital, rigiendo como regla general la responsabilidad subsidiaria, cuando el incumplimiento les fuere imputable, bien por no haber realizado los actos necesarios que fuesen de su incumbencia para que la sociedad cumpliese con sus obligaciones, bien por haber consentido el incumplimiento de quienes de ellos dependan, o bien por haber adoptado acuerdos que posibilitasen las infracciones.

Procedería sólo la responsabilidad solidaria en supuesto tasados de mayor gravedad cuando la deuda sea debida a actuaciones fraudulentas por conducta orgánica imputable.

Responsabilidad que será en deudas por cotizaciones y por prestaciones de responsabilidad empresarial, incluido al recargo de prestaciones, pero que inicialmente no se extendería a las sanciones administrativas.

En las deudas por cotizaciones con responsabilidad solidaria del administrador el plazo de prescripción de la acción para derivarle la responsabilidad, se computará desde que finalizó el plazo reglamentario de ingreso de las cuotas de Seguridad Social y otras de recaudación conjunta. En caso de la responsabilidad subsidiaria el plazo de prescripción para declarar la responsabilidad y exigir el pago de la deuda será de 4 años que se debería computar desde la declaración de la insolvencia de la sociedad y del resto de responsables solidarios. 
En deudas por prestaciones el plazo de prescripción para declarar la entidad gestora la responsabilidad derivada subsidiaria del administrador social en las deudas por prestaciones será el mismo plazo establecido para el reconocimiento de la prestación de Seguridad Social, a computar desde el acaecimiento del hecho causante. En cambio, el plazo de prescripción para exigir la TGSS al administrador social el pago de la deuda subsidiaria de la prestación, mediante reclamación de deuda, será de cuatro años desde la declaración de la insolvencia de la sociedad y del resto de los responsables solidarios. Nos encontraremos ante dos procedimientos administrativos distintos, el primero es la declaración de responsabilidad subsidiaria por la entidad gestora, y segundo es el procedimiento recaudatorio de la TGSS ante el responsable directo -la empresa- y ante el responsable subsidiario -el administrador social-, que en el caso del administrador ese procedimiento recaudatorio no se iniciaría mientras no conste la insolvencia de la sociedad y otros responsables solidarios.

La competencia para declarar la responsabilidad solidaria del administrador en el pago de deudas por cotizaciones, dentro del procedimiento de liquidación y recaudación de Seguridad Social, correspondería a la TGSS, y a la ITSS en los términos establecidos en el arts. 33 y 34 del TRLGSS. La declaración y reclamación de la responsabilidad subsidiaria en deudas por cotizaciones debería ser competencia de la TGSS, limitándose la ITSS a emitir el pertinente informe acerca de los hechos determinantes de la responsabilidad subsidiaria. Los actos administrativos de derivación de la responsabilidad serán recurribles ante la Jurisdicción Contencioso-Administrativa, una vez firmes en vía administrativa.

Por el contrario, de hallarnos ante una responsabilidad imputable del administrador social por el incumplimiento de disposiciones propias y específicas de Seguridad Social, la competencia para la declaración de la responsabilidad subsidiaria de aquél en las deudas por prestaciones, debería ser de la entidad gestora, y no de la TGSS, por ser un acto de gestión de prestaciones, y no un acto de gestión recaudatoria de una deuda preexistente, al tenerse que aplicar la legislación de Seguridad Social reguladora de la responsabilidad en las prestaciones, al haber nacido la responsabilidad por incumplimientos imputables del administrador de las obligaciones de Seguridad Social. Resolución de la entidad gestora que será recurrible ante la Jurisdicción Social (art. 2 apartado o) de la LRJS). Una vez firme 
en vía administrativa la resolución de la entidad gestora, ésta lo comunicará a la TGSS, para que por ese Servicio Común inicie el procedimiento administrativo de recaudación de la deuda por prestaciones ante la sociedad de capital. En cambio, el procedimiento recaudatorio de la responsabilidad subsidiaria del administrador social, emitiendo la TGSS la reclamación de la deuda, no podrá iniciarse hasta que no se haya declarado la insolvencia de la sociedad u otros responsables solidarios.

$2^{\text {o. }}$ Debería declarase que el administrador social responderá de las deudas de Seguridad Social de la sociedad de capital, sean deudas por cotizaciones o por prestaciones de responsabilidad empresarial, en todos los supuestos en que en la legislación mercantil y de sociedades se declare la responsabilidad del administrador en las deudas de la sociedad, siempre que no se hayan excluido a las deudas de Seguridad Social. Responsabilidad ex lege en deuda ajena del administrador por remisión expresa al Derecho mercantil, que debe recogerse en la legislación de Seguridad Social por la conveniencia de regularse con vocación totalizadora los supuestos de responsabilidad del administrador en las deudas de Seguridad Social de la sociedad. Responsabilidad del administrador social a la que sería aplicable el plazo de prescripción del art. 949 del Código de Comercio.

Igualmente, de modo paralelo, debería establecerse que en la responsabilidad por causa de disolución, sea por causa legal o disolución de pleno derecho, la responsabilidad se extenderá a las deudas posteriores al acaecimiento de la causa de disolución, con el mismo alcance para los nuevos administradores si tras la aceptación del cargo no cumplen en plazo, a computar desde la fecha de acceso al cargo, con los deberes de promover la disolución.

Norma de responsabilidad por remisión que complementaría al actual art. 18.3 del TRLGSS, precepto éste que quedaría para responsabilidades ex lege distintas a las del administrador social impuestas un orden jurídico ajeno al social (socios, responsabilidad en los supuestos de la Agrupación de Interés Económico, en las Uniones Temporales de Empresas, etc.).

$3^{\text {. }}$. Debería declararse expresamente la responsabilidad solidaria de los administradores en todas las deudas de Seguridad Social no prescritas que quedasen pendientes de la sociedad en los supuestos de cierre de hecho sin ordenada liquidación. Responsabilidad distinta y específica a la prevista en el art. 367 de la LSC, ya que, 
ante el cierre de hecho el administrador respondería de todas las deudas pendientes de Seguridad Social, aunque pudieran ser de un período anterior a una teórica concurrencia de una causa de disolución, todo ello, para instarles a cumplir con los deberes de ordenada disolución, aunque sea extemporáneamente.

$4^{\circ}$. Debería declararse la responsabilidad solidaria del administrador social en las deudas por cotizaciones o por prestaciones, si incumple las obligaciones de solicitar en plazo el concurso o medidas preconcursales, de hallarse la sociedad en causa de insolvencia, responsabilidad solidaria que ha de extenderse a las deudas posteriores a la concurrencia de la insolvencia con el mismo régimen jurídico que la responsabilidad por causa de disolución. Responsabilidad ex lege que podría igualmente recogerse en la legislación concursal para su aplicabilidad general, operando como un medio indirecto adicional para que los administradores cumpliesen diligentemente con la obligación de solicitar en plazo el concurso, en aras de la adecuada protección de los acreedores. Derivación de responsabilidad admitida en algunas sentencias de los TSJ y que se ha visto revisada a partir de la nueva jurisprudencia dictada en unificación de doctrina en el año 2019 por la Sala Tercera del TS. Con esta propuesta legislativa se establecería una responsabilidad ex lege por deudas distinta de la responsabilidad concursal, ante la insuficiencia de ésta.

$5^{\circ}$. Debería establecerse que los liquidadores y administradores concursales responderán de modo solidario de las deudas de Seguridad Social conocidas en el procedimiento liquidatorio, cuando consecuencia del incumplimiento de sus obligaciones no se hubiesen satisfecho aquéllas, en todo o en parte. Responsabilidad sujeta al plazo de prescripción del art. 949 del Código de Comercio.

$6^{\circ}$. Debería preverse claramente en la legislación de Seguridad Social que, en los supuestos de sociedad disuelta los socios responden con la cuota de liquidación de las deudas por prestaciones, y no sólo de las deudas por cotizaciones como se establece en el art. 142.1 del TRLGSS.

$7^{\circ}$. Igualmente, ante la insuficiencia del art. 18.4 del TRLGSS, que limita la responsabilidad sólo a deudas por cotizaciones, debería extenderse la 
responsabilidad solidaria del empresario real a las deudas por prestaciones de responsabilidad empresarial, reformándose el art. 168 del TRLGSS.

$8^{\circ}$. Deberían reformarse los arts. 164.2 del TRLGSS y 12.4 del RGRSS, para permitir expresamente la derivación administrativa de responsabilidad de la deuda del recargo de prestaciones partiendo de la doctrina jurisprudencial que prima el carácter indemnizatorio-prestacional del recargo frente al carácter sancionadorpreventivo.

Con esta propuesta la entidad gestora podría seguir declarando la responsabilidad solidaria en el recargo cuando se impute esa responsabilidad aplicando la normativa de Seguridad Social reguladora de la responsabilidad en prestaciones.

$9^{\circ}$. Determinar que es competencia de la entidad gestora declarar la responsabilidad derivada, solidaria o subsidiaria, del administrador social o de terceros, en prestaciones de responsabilidad empresarial, incluido el recargo de prestaciones, cuando se imponga en aplicación de la normativa de Seguridad Social reguladora de la responsabilidad en prestaciones, (acto de gestión de prestaciones). Por el contrario, cuando la declaración de responsabilidad del tercero en las prestaciones de Seguridad Social o en el recargo, sea una responsabilidad en deuda ajena establecida en disposiciones legales de otro orden jurídico al amparo del art. 18.3 del TRLGSS, como la responsabilidad del administrador social establecida en la legislación de sociedades (arts. 14, 36 a 39, 360 y 367 de la LSC), al ser una responsabilidad en una deuda ajena preexistente, y no una responsabilidad en aplicación de la normativa reguladora de las prestaciones, la competencia para derivar la responsabilidad será de la TGSS, por ser un acto de gestión recaudadora.

$10^{\circ}$. Que se declare de modo expreso en el TRLGSS que la derivación administrativa de la responsabilidad solidaria del administrador social en las deudas de Seguridad Social de la sociedad de capital declarada en concurso de acreedores, no se suspende por la declaración judicial del concurso de la mercantil. Igualmente, debería establecerse la obligación de la TGSS de comunicar al juez del concurso el inicio del procedimiento administrativo de derivación, para que pueda ser tenido en cuenta su resultado por el juez del concurso si se declara la responsabilidad concursal del administrador, para no vulnerarse el principio non bis in ídem. 
$11^{\circ}$. Debería determinarse que la competencia para derivar la responsabilidad subsidiaria en el procedimiento de recaudación es de la TGSS, en deudas por cotizaciones, una vez se haya declarado la insolvencia del deudor principal y del resto de responsables solidarios declarados, con lo que quedarían incluidos los supuestos de responsabilidad ex lege del administrador establecidos en la legislación mercantil y societaria.

$12^{\circ}$. Debería establecerse que la reclamación de la deuda al deudor -a la sociedad de capital- interrumpe la prescripción de la acción para derivar la responsabilidad solidaria, y que la reclamación a la sociedad y a los responsables solidarios interrumpe la prescripción de la acción de derivación a los responsables subsidiarios, para cerrar el círculo del art. 43.3 del RGRSS y suplir la insuficiencia de los arts. 1974 y 1975 del Código Civil en la derivación de la responsabilidad subsidiaria.

De este modo, el plazo de prescripción de la acción para derivar la responsabilidad subsidiaria y para exigir el pago de la deuda al administrador social del art. 949 del Código de Comercio se computaría desde la declaración de insolvencia. Con esta propuesta legislativa se evitará la prescripción de la acción de derivación si se ha producido el cese del administrador responsable subsidiario en los cuatro años anteriores a la declaración de insolvencia de la sociedad o del resto de responsables solidarios, ya que la reclamación de la deuda ante la sociedad interrumpe la prescripción de la deuda ante los demás responsables solidarios o subsidiarios (art. 43.3 del RGRSS), pero no interrumpe la prescripción de la acción para reclamar la responsabilidad subsidiaria del administrador social del art. 949 del Código de Comercio, no siendo tampoco de aplicación el art. 1974 del Código Civil a la responsabilidad subsidiaria.

$13^{\circ}$. Reconocimiento expreso de la competencia de la ITSS para proponer a la TGSS la adopción de medidas cautelares en el informe final de derivación dirigido a la misma o en el acta de liquidación, cuando existan indicios racionales de que de no adoptarse se pudiera eludir la responsabilidad derivada. Medidas cautelares como proponer embargos preventivos, retención de devolución de ingresos indebidos, etc. De proponerse en el acta de liquidación, la resolución que eleve a definitiva la misma podrá decretar su levantamiento o su mantenimiento hasta que se ingrese la 
deuda dentro del plazo reglamentario de ingreso o se garantice el pago mediante aval o con otra garantía suficiente.

$14^{\circ}$. Debería establecerse que el procedimiento administrativo de derivación no se paraliza por seguirse por los mismos hechos causa penal, al no ser aplicable el principio non bis in ídem, ya que la reclamación administrativa de responsabilidad no es constitutiva de un procedimiento sancionador. Declaración legal que consta para las actas de liquidación en los arts. 5.2 y 36 del RISOS, y que debe extenderse expresamente a la derivación de responsabilidad declarada por la TGSS, salvo que el juez que conozca de la causa penal declare la suspensión del procedimiento recaudatorio, previa prestación de garantía, como se establece en el art. 307.4 del Código Penal.

$15^{\circ}$. Debería establecerse que la caducidad de la actividad previa de comprobación de la ITSS ha de ser declarada expresamente mediante resolución administrativa de la jefatura de la ITSS, de la Dirección Territorial o de la Dirección Especial, en función del ámbito territorial de actuación, resolución frente a la que podrá interponerse recurso de alzada ante el superior jerárquico.

$16^{\circ}$. Debería establecerse que en la derivación administrativa de responsabilidad el sujeto responsable solidario o subsidiario podrá oponerse tanto a la procedencia jurídica del acto administrativo de derivación como a la procedencia de la deuda, haya sido o no objeto de impugnación la deuda por el sujeto responsable principal, sin perjuicio de los eventuales efectos de la litispendencia impropia o prejudicialidad civil. Sólo podrán limitarse los motivos de oposición cuando lo impugnado ya no sea el acto de derivación de responsabilidad, sino la providencia de apremio, siendo los motivos tasados, tanto para el responsable directo como para los responsables derivados. 



\section{JURISPRUDENCIA SELECCIONADA}

\section{Tribunal de Justicia de la Unión Europea:}

- $\quad$ STJUE, de 5 de marzo de 2015 -Asunto C-343/13-.

- STJUE, de 14 de diciembre de 2017 -Asunto C-243/16-.

\section{Tribunal Constitucional:}

- $\quad$ STC 18/1981, de 8 de junio.

- $\quad$ STC 77/1983, de 3 de octubre.

- $\quad$ STC 22/1984, de 17 de febrero.

- STC 65/1987, de 21 de mayo.

- STC 66/1984, de 6 de junio.

- $\quad$ STC 76/1990, de 26 de abril.

- $\quad$ STC 119/1991, de 3 de junio.

- $\quad$ STC 246/1991, de 19 de diciembre.

- $\quad$ STC 37/1994, de 10 de febrero.

- STC 40/1994, de 15 de febrero.

- STC 146/1994, de 12 de mayo.

- $\quad$ STC 23/1995, de 30 de enero.

- $\quad$ STC 77/1995, de 22 de mayo.

- $\quad$ STC 164/1995, de 13 de noviembre.

- $\quad$ STC 78/1996, de 20 de mayo.

- $\quad$ STC 120/1996, de 8 de julio.

- $\quad$ STC 69/1998, de 30 de marzo.

- $\quad$ STC 14/1999, de 22 de febrero.

- $\quad$ STC 198/2000, de 24 de julio.

- $\quad$ STC 218/2005, de 12 de septiembre.

- $\quad$ STC 85/2006, de 27 de marzo.

- $\quad$ STS 32/2009, de 9 de febrero.

- $\quad$ STC 39/2010, de 19 de julio. 
- $\quad$ STC 121/2010, de 29 de noviembre.

- $\quad$ STC 140/2010, de 21 de diciembre.

- $\quad$ STC 93/2018, de 17 de septiembre.

- $\quad$ STC 59/2014, de 5 de mayo.

- STC 55/2018, de 24 de mayo.

- $\quad$ STC 93/2018, de 17 de septiembre.

- $\quad$ STC 110/2018, de 17 de octubre.

- $\quad$ STC 82/2019, de 17 de junio.

- STC 106/2020, de 16 de noviembre.

\section{Tribunal Supremo, Sala Civil:}

- $\quad$ STS, de 28 de mayo de 1984 (ECLI:ES:TS:1984:1196).

- $\quad$ STS 435/1995, de 9 de mayo -Rec. 485/1992-.

- $\quad$ STS, de 23 de mayo de 1995 -Rec. 789/1992-.

- $\quad$ STS 567/1995, de 8 de junio -Rec. 531/1992-.

- STS 651/1997, de 15 de julio -Rec. 2388/1993-

- STS 1113/1998, de 27 de noviembre-Rec. 3350/1995-.

- STS 588/1999, de 2 de julio -Rec. 3594/1994-.

- $\quad$ STS 741/1999, de 21 de septiembre -Rec. 438/1995-.

- STS 1092/1999, de 22 de diciembre -Rec. 2659/1995-

- STS, de 24 de febrero de 2000 -Rec. 526/1998-.

- $\quad$ STS 386/2000, de 13 de abril -Rec. 2143/1995-.

- STS 507/2000, de 15 de mayo -Rec. 2231/1995-.

- $\quad$ STS 977/2000, de 30 de octubre -Rec. 3341/1995-.

- $\quad$ STS 989/2000, de 4 de noviembre -Rec. 3083/1995-.

- STS 1194/2000, de 29 de diciembre -Rec. 3393/1995-.

- STS 323/2001, de 28 de marzo -Rec. 872/1996-.

- $\quad$ STS 388/2001, de 19 de abril -Rec. 3931/1997-.

- $\quad$ STS 397/2001, de 19 de abril -Rec. 301/1996-.

- $\quad$ STS 749/2001, de 20 de julio -Rec. 1495/1996-

- $\quad$ STS 828/2001, de 24 de septiembre -Rec. 1895/1996-.

- $\quad$ STS 760/2002, de 16 de julio -Rec. 304/1997-. 
- $\quad$ STS 766/2002, de 18 de julio -Rec. 328/1997-.

- $\quad$ STS 981/2002, de 24 de octubre -Rec. 1030/1997-.

- $\quad$ STS 1003/2002, de 28 de octubre -Rec. 1085/1997-.

- $\quad$ STS 516/2003, de 26 de mayo -Rec. 3144/1997-.

- $\quad$ STS 556/2003, de 5 de junio -Rec. 3162/1997-.

- $\quad$ STS 1080/2003 de 17 de noviembre -Rec. 144/1998-.

- STS 1124/2003, de 20 de noviembre -Rec. 302/1998-.

- $\quad$ STS 1191/2003, de 15 de diciembre -Rec. 348/1998-.

- $\quad$ STS 1178/2003, de 17 de diciembre -Rec. 280/1998-.

- $\quad$ STS 2/2004, de 22 de enero -Rec. 2280/1998-.

- $\quad$ STS 110/2004, de 23 de febrero -Rec. 1041/1998-.

- $\quad$ STS 222/2004, de 22 de marzo -Rec. 1556/1998-.

- $\quad$ STS 286/2005, de 26 de abril -Rec. 4282/1998-.

- STS 540/2004, de 17 de junio -Rec. 2329/1998-

- STS 937/2004, de 5 de octubre -Rec. 2607/1998-.

- $\quad$ STS 1200/2004, de 7 de diciembre -Rec. 3349/1998-.

- STS 1207/2004, de 13 de diciembre-Rec. 3367/1998-.

- STS 1219/2004, de 16 de diciembre -Rec. 3375/1998-.

- $\quad$ STS 307/2010, de 25 de mayo -Rec. 931/2005-.

- $\quad$ STS 416/2005, de 28 de mayo -Rec. 4720/1998-.

- $\quad$ STS 467/2005, de 20 de junio -Rec. 183/1999-.

- $\quad$ STS 540/2005, de 7 de julio -Rec. 43/1999-.

- STS 794/2005, de 25 de octubre -Rec. 1218/1999-.

- STS 1014/2005, de 13 de diciembre -Rec. 1638/1999-.

- $\quad$ STS 1055/2006, de 9 de enero -Rec. 2048/1999-.

- $\quad$ STS 195/2006, de 9 de marzo -Rec. 2325/1999-.

- $\quad$ STS 227/2006, de 9 de marzo -Rec. 2418/1999-.

- $\quad$ STS 313/2006, de 3 de abril -Rec. 2702/1999-.

- $\quad$ STS 314/2006, de 23 de marzo -Rec. 2643/1999-.

- $\quad$ STS 416/2006, de 28 de abril -Rec. 4187/2000-.

- $\quad$ STS 417/2006, de 28 de abril -Rec. 3287/1999-.

- $\quad$ STS 441/2006, de 11 de mayo -Rec. 2875/1999-. 
- $\quad$ STS 497/2006, de 26 de mayo -Rec. 4020/1999-.

- $\quad$ STS 647/2006, de 23 de junio -Rec. 4192/1999-.

- $\quad$ STS 664/2006, de 26 de junio -Rec. 4434/1999-.

- STS 1280/2006, de 19 de diciembre -Rec. 342/2000-.

- $\quad$ STS 61/2007, de 31 de enero -Rec. 2442/2000-

- $\quad$ STS 103/2007, de 7 de febrero -Rec. 362/2000-.

- $\quad$ STS 235/2007, de 8 de marzo -Rec. 2036/2000-.

- STS 261/2007, de 14 de marzo -Rec. 262/2000-.

- STS 272/2007, de 9 de marzo - Rec. 2226/2000-.

- $\quad$ STS 341/2007, de 22 de marzo -Rec. 3447/2000-.

- $\quad$ STS 501/2007, de 7 de mayo -Rec. 2225/2000-.

- $\quad$ STS 674/2007, de 14 de junio -Rec. 1959/2000-.

- STS 760/2007, de 4 de julio -Rec. 4503/2000-.

- $\quad$ STS 771/2007, de 5 de julio -Rec. 3063/2000-.

- $\quad$ STS 951/2007, de 25 de septiembre -Rec. 4052/2000-.

- $\quad$ STS 55/2008, de 8 de febrero -Rec. 5168/2000-.

- $\quad$ STS 76/2008, de 5 de febrero -Rec. 5783/2000-.

- $\quad$ STS 205/2008, de 1 de diciembre -Rec. 80/2001-.

- $\quad$ STS 201/2008, de 28 de febrero -Rec. 5713/2000-.

- STS 226/2008, de 24 de marzo -Rec. 366/2001-.

- $\quad$ STS 228/2008, de 25 de marzo -Rec. 219/2001-.

- $\quad$ STS 207/2008, de 14 de marzo -Rec. 74/2001-.

- $\quad$ STS 408/2008, de 14 de mayo -Rec. 187/2001-.

- $\quad$ STS 457/2008, de 30 de mayo -Rec. 1040/2001-.

- $\quad$ STS 583/2008, de 24 de junio -Rec. 3077/2001-.

- $\quad$ STS 669/2008, de 3 de julio -Rec. 4186/2001-.

- STS 1049/2008, de 11 de noviembre -Rec. 974/2004-.

- STS 1145/2008, de 27 de noviembre -Rec. 1050/2003-.

- $\quad$ STS 1168/2008, de 27 de noviembre -Rec.815/2004-.

- $\quad$ STS 205/2008, de 1 de diciembre -Rec. 80/2001-.

- $\quad$ STS 409/2008, de 14 de mayo -rec. 251/2001-.

- $\quad$ STS 986/2008, de 23 de octubre -rec. 102/2004-. 
- $\quad$ STS 208/2009, de 1 de abril -Rec. 2198/2003-.

- $\quad$ STS 240/2009, de 14 de abril -Rec. 1504/2004-.

- $\quad$ STS 298/2009, de 14 de mayo -Rec. 1926/2004-.

- $\quad$ STS 338/2009, de 29 de mayo -Rec. 2106/2004-.

- $\quad$ STS 402/2009, de 12 de junio -Rec. 2352/2004-.

- $\quad$ STS 415/2009, de 18 de junio -Rec. 2760/2004-.

- $\quad$ STS 667/2009, de 23 de octubre -Rec. 199/2005-.

- $\quad$ STS 43/2010, de 12 de febrero -Rec. 1850/2005-.

- STS 100/2012, de 7 de marzo -Rec. 674/2009-.

- STS 123/2010, de 11 de marzo -Rec. 1239/2005-.

- STS 124/2010, de 12 de marzo -Rec. 1435/2005-.

- $\quad$ STS 206/2010, de 15 de abril -Rec. 470/2006-.

- $\quad$ STS 291/2010, de 18 de mayo -Rec. 738/2006-.

- $\quad$ STS 307/2010, de 25 de mayo -Rec. 931/2005-.

- $\quad$ STS 373/2010, de 15 de junio -Rec. 358/2006-.

- $\quad$ STS 458/2010, de 30 de junio -Rec. 1337/2006-.

- $\quad$ STS 460/2010, de 14 de julio -Rec. 945/2006-.

- $\quad$ STS 521/2010, de 23 de julio -Rec. 1633/2006-.

- STS 557/2010, de 27 de septiembre -Rec. 2194/2006-.

- STS 630/2010, de 14 de octubre -Rec. 2253/2006-.

- STS 670/2010, de 4 de noviembre -Rec. 422/2007-.

- $\quad$ STS 680/2010, de 10 de noviembre -Rec. 791/2007-.

- $\quad$ STS 740/2010, de 24 de noviembre-Rec. 876/2007-.

- $\quad$ STS 784/2010, de 9 de diciembre -Rec. 903/2007-.

- $\quad$ STS 96/2011, de 15 de febrero -Rec. 1963/2007-.

- STS 173/2011, de 17 de marzo -Rec. 1408/2007-.

- $\quad$ STS 184/2011, de 21 de marzo -Rec. 1456/2007-.

- $\quad$ STS 185/2011, de 28 de marzo -Rec. 333/2007-.

- $\quad$ STS 229/2011, de 11 de abril -Rec. 2289/2007-.

- $\quad$ STS 242/2011, de 4 de abril -Rec. 1820/2006-.

- $\quad$ STS 286/2011, de 23 de noviembre -Rec. 90/2008-.

- $\quad$ STS 328/2011, de 19 de mayo -Rec. 1691/2007-. 
- $\quad$ STS 826/2011, de 23 de noviembre-Rec. 1753/2007-.

- $\quad$ STS 919/2011, de 23 de diciembre -Rec. 1659/2008-

- $\quad$ STS 923/2011, de 26 de noviembre -Rec. 1769/2008-.

- STS 942/2011, de 29 de diciembre -Rec. 1725/2008-

- $\quad$ STS 100/2012, de 7 de marzo -Rec. 674/2009-.

- STS 145/2012, de 21 de marzo -Rec. 272/2009-.

- STS 161/2012, de 21 de marzo -Rec. 473/2009-.

- STS 225/2012, de 13 de abril -Rec. 1018/2009-.

- $\quad$ STS 371/2012, de 13 de junio -Rec. 326/2010-.

- STS 395/2012, de 18 de junio -Rec. 1852/2009-.

- STS 721/2012, de 4 de diciembre -Rec. 1139/2010-.

- $\quad$ STS 414/2013, de 21 de junio -Rec. 809/2011-.

- STS 539/2012, de 18 de septiembre -Rec. 2149/2009-.

- $\quad$ STS 618/2012, de 15 de octubre -Rec. 909/2010-.

- $\quad$ STS 485/2012, de 18 de julio -Rec. 990/2009-.

- STS 326/2013, de 16 de mayo -Rec. 1892/2010-.

- $\quad$ STS 505/2013, de 24 de julio -Rec. 2178/2011-.

- $\quad$ STS 721/2012, de 4 de diciembre -Rec. 1139/2010-.

- $\quad$ STS 818/2012, de 11 de enero -Rec. 2236/2010-.

- STS 326/2013, de 16 de mayo -Rec. 1892/2010-.

- $\quad$ STS 409/2013, de 20 de junio -Rec. 302/2011-.

- $\quad$ STS 414/2013, de 21 de junio -Rec. 809/2011-.

- $\quad$ STS 560/2013, de 7 de octubre -Rec. 1087/2011-.

- STS 585/2013, de 14 de octubre -Rec. 1192/2011-.

- STS 590/2013, de 15 de octubre-Rec. 1268/2011-.

- $\quad$ STS 731/2013, de 2 de diciembre -Rec. 1444/2011-

- $\quad$ STS 733/2013, de 4 de diciembre -Rec. 1694/2011-

- $\quad$ STS 367/2014, de 10 de julio -Rec. 1858/2012-.

- $\quad$ STS 396/2013, de 20 de junio -Rec 1421/2011-.

- $\quad$ STS 122/2014, de 1 de abril -Rec. 541/2012-.

- STS 242/2014, de 23 de mayo -Rec. 1423/2012-.

- $\quad$ STS 377/2014, de 14 de julio -Rec. 2416/2012-. 
- $\quad$ STS 446/2014, de 3 de septiembre -Rec. 2681/2012-.

- $\quad$ STS 505/2014, de 8 de octubre -Rec. 237/2013-.

- $\quad$ STS 650/2014, de 27 de noviembre -Rec. 623/2013-.

- STS 653/2014, de 26 de noviembre -Rec. 745/2013-.

- $\quad$ STS 737/2014, de 22 de diciembre -Rec. 1261/2013-

- $\quad$ STS 772/2014, de 12 de enero -Rec. 473/2013-.

- STS 108/2015, de 11 de marzo -Rec. 1020/2013-.

- $\quad$ STS 127/2015, de 17 de marzo -Rec. 767/2013-.

- $\quad$ STS 246/2015, de 14 de mayo -Rec.1121/2013-.

- $\quad$ STS 327/2015, de 1 de junio -Rec. 1449/2013-.

- $\quad$ STS 421/2015, de 22 de julio -Rec. 1701/2013-.

- $\quad$ STS 456/2015, de 4 de septiembre -Rec. 2414/2013-.

- $\quad$ STS 695/2015, de 11 de diciembre -Rec. 2141/2013-.

- $\quad$ STS 728/2015, de 30 de diciembre -Rec. 2002/2013-.

- STS 131/2016, de 3 de marzo -Rec. 2320/2013-.

- STS 151/2016, de 10 de marzo -Rec. 2421/2013-.

- STS 203/2016, de 1 de abril -Rec. 2616/2013-.

- $\quad$ STS 224/2016, de 8 de abril -Rec. 2535/2013-.

- $\quad$ STS 253/2016, de 18 de abril - Rec. 2754/2013-.

- STS 363/2016, de 1 de junio -Rec. 142/2014-.

- $\quad$ STS 389/2016, de 8 de junio -Rec. 79/2014-.

- $\quad$ STS 472/2016, de 13 de julio -Rec. 2307/2013-.

- $\quad$ STS 499/2016, de 19 de julio -Rec. 449/2014-.

- $\quad$ STS 696/2016, de 24 de noviembre -Rec. 871/2014-.

- $\quad$ STS 27/2017, de 18 de enero -Rec. 1422/2014-

- $\quad$ STS 129/2017, de 27 de febrero -Rec. 2604/2014-.

- $\quad$ STS 144/2017, de 1 de marzo -Rec. 2198/2014-.

- $\quad$ STS 150/2017, de 2 de marzo -Rec. 2118/2014-.

- STS 203/2017, de 29 de marzo -Rec. 1579/2014-.

- $\quad$ STS 274/2017, de 5 de mayo -Rec. 3298/2014-.

- STS 324/2017, de 24 mayo -Rec. 197/2015-.

- $\quad$ STS 455/2017, de 18 de julio -Rec. 1589/2014-. 
- $\quad$ STS 616/2017, de 12 de julio -Rec. 1849/2015-.

- STS 650/2017, de 29 de noviembre-Rec. 1418/2015-

- STS 693/2017, de 20 diciembre -Rec. 2469/2015-.

- STS 14/2018, de 12 de enero -Rec. 751/2015-.

- $\quad$ STS 207/2018, de 11 de abril -Rec. 2647/2015-.

- $\quad$ STS 221/2018, de 16 de abril -Rec. 3050/2015-.

- STS 485/2018, de 11 de septiembre -Rec. 2365/2015-.

- $\quad$ STS 716/2018, de 19 de diciembre -Rec. 3648/2015-.

- STS 45/2019, de 23 de enero -Rec. 243/2016-.

- $\quad$ STS 60/2019, de 29 de enero -Rec. 506/2016-.

- $\quad$ STS 62/2019, de 31 de enero -Rec. 1932/2016-.

- $\quad$ STS 213/2019, de 29 de mayo -Rec. 1700/2017-.

- $\quad$ STS 225/2019, de 10 de abril -Rec. 4146/2016-.

- STS 279/2019, de 22 de mayo -Rec. 1073/2016-.

- $\quad$ STS 420/2019, de 15 de julio -Rec. 3654/2016-.

- $\quad$ STS 424/2019, de 16 de julio -Rec. 3784/2016-.

- $\quad$ STS 571/2019, de 4 de noviembre -Rec. 4162/2016-.

- $\quad$ STS 601/2019, de 8 de noviembre-Rec. 596/2017-.

- $\quad$ STS 571/2019, de 4 de noviembre -Rec. 4162/2016-.

- $\quad$ STS 580/2019, de 5 de noviembre -Rec. 579/2017-.

- $\quad$ STS 601/2019, de 8 de noviembre -Rec. 596/2017-.

- $\quad$ STS 612/2019, de 14 de noviembre -Rec. 1318/2017-.

- STS 670/2019, de 16 de diciembre -rec. 178/2017-.

- $\quad$ STS 5/2020, de 8 de enero -Rec. 1011/2017-.

- STS 22/2020, de 16 de enero -Rec. 520/2017-.

- $\quad$ STS 193/2020, de 25 de mayo -Rec. 2077/2017-.

- $\quad$ STS 202/2020, de 28 de mayo -Rec. 3365/2017-.

- STS 212/2020, de 29 de mayo -Rec. 4544/2017-.

- $\quad$ STS 213/2020, de 29 de mayo -Rec. 1700/2017-.

- $\quad$ STS 214/2020, de 29 de mayo -Rec. 1706/2017-.

- $\quad$ STS 215/2020, de 1 de junio -Rec. 2849/2017-.

- $\quad$ STS 256/2020, de 5 de junio -Rec. 3001/2017-. 
- $\quad$ STS 258/2020, de 5 de junio -Rec. 3653/2017-.

- $\quad$ STS 315/2020, de 17 de junio -Rec. 4186/2017-.

- $\quad$ STS 316/2020, de 17 de junio -Rec. 4270/2017-.

- $\quad$ STS 350/2020, de 24 de junio -Rec. 4442/2017-.

- $\quad$ STS 316/2020, de 17 de junio -Rec. 4270/2017-.

\section{Tribunal Supremo, Sala Contencioso-Administrativa:}

- $\quad$ STS de 10 de noviembre de 1986 -ECLI:ES:TS:1986:13954-.

- $\quad$ STS de 22 febrero de 1989 -ECLI:ES:TS:1989:1291-.

- $\quad$ STS de 27 de marzo de 1991 -Rec. 1014/1990; ECLI: ES:TS:1991:1911-.

- $\quad$ STS de 9 de julio de 1991 -ECLI: ES:TS:1991:3980-.

- STS de 20 de abril de 1992 -ECLI:ES:TS:1992:11970, ponente: Conde Martín de Hijas-.

- $\quad$ STS de 10 de marzo de 1994 -Rec. 3029/1990-.

- $\quad$ STS de 11 de abril de 1995 -ECLI: ES:TS:1995:8992-.

- $\quad$ STS de 12 de enero de 1996 -Rec. 788/1991-.

- $\quad$ STS de 18 de enero de 1996 -Rec. 2450/1991-.

- $\quad$ STS de 19 de enero de 1996 -Rec. 1298/1991-.

- $\quad$ STS de 24 de septiembre de 1996 -Rec. 738/1992-.

- $\quad$ STS de 7 de marzo de 1997 -Rec. 8204/1990-,

- $\quad$ STS de 21 de marzo de 1997 -Rec. 604/1991-

- $\quad$ STS de 5 de mayo de 1997 -rec. 8754/1990-.

- $\quad$ STS de 10 de octubre de 1997 -Rec. 4331/1991-.

- $\quad$ STS de 29 de junio de 1998 -Rec. 4717/1992-.

- $\quad$ STS de 3 de diciembre de 1999 -Rec. 1543/1994-.

- $\quad$ STS de 31 de enero de 2000 -Rec. 6603/1997-.

- $\quad$ STS de 31 de enero de 2000 -Rec. 4886/1997-.

- $\quad$ STS de 1 de febrero de 2000 -Rec. 1311/1998-.

- $\quad$ STS de 1 de febrero de 2000 -Rec. 369/1998-.

- $\quad$ STS de 23 de abril de 2001 -Rec. 6230/1995-.

- $\quad$ STS de 22 de marzo de 2002 -Rec. 9037/1996-.

- $\quad$ STS de 18 de junio de 2002 -Rec. interés de ley 3424/2001-. 
- $\quad$ STS de 18 de marzo de 2003 -Rec. 35/2002-.

- $\quad$ STS de 18 de marzo de 2003 -Rec. 1128/1998-.

- $\quad$ STS de 31 de marzo de 2003 -Rec. 11159/1998-.

- $\quad$ STS de 15 de octubre de 2003 -Rec. 95/2002-

- $\quad$ STS de 21 de julio de 2003 -Rec. 88/2002-.

- $\quad$ STS de 18 de mayo de 2004 -Rec. 73/2002-.

- $\quad$ STS de 22 de junio de 2004 -Rec. 9/2003-.

- STS de 15 de septiembre de 2004 -Rec. 122/2003-.

- $\quad$ STS de 14 de diciembre de 2009 -Rec. 307/2008-.

- $\quad$ STS de 23 de febrero de 2010 -Rec. 243/2008-.

- $\quad$ STS de 18 de octubre de 2010 -Rec. 2733/2006-.

- $\quad$ STS de 8 de noviembre de 2010 -rec. 4941/2007-.

- $\quad$ STS de 7 de octubre de 2011 -Rec. 40/2010-.

- $\quad$ STS de 28 de febrero de 2011-Rec. 1616/2010-.

- $\quad$ STS de 1 de octubre de 2012 -Rec. 310/2012-.

- $\quad$ STS de 1 de octubre de 2012 -Rec. 342/2012-.

- $\quad$ STS de 1 de octubre de 2012 -Rec. 882/2011-.

- $\quad$ STS de 6 de noviembre de 2012 -Rec. 3558/2011-.

- $\quad$ STS de 12 de diciembre de 2012 -Rec. 887/2011-.

- $\quad$ STS de 18 de noviembre de 2013 -Rec. 4486/2012-.

- $\quad$ STS de 7 de febrero de 2014 -Rec. 4607/2012-.

- $\quad$ STS de 8 de julio de 2014 -Rec. 3416/2012-.

- $\quad$ STS de 24 de octubre 2014 -Rec 3432/2013-.

- $\quad$ STS de 9 de julio de 2015 -Rec. 3623/2013-.

- $\quad$ STS 1292/2016, de 2 de junio -Rec. 2890/2014-.

- STS 1421/2016, de 15 de junio -Rec. 1916/2015-.

- $\quad$ STS de 6 de julio de 2015 -Rec. 3418/2013-.

- $\quad$ STS 1673/2016, de 8 de julio -Rec. 3831/2014-.

- $\quad$ STS 2023/2017, de 19 de diciembre -Rec. 3052/2015-.

- STS 2213/2016, de 11 de octubre -Rec. 673/2015-.

- $\quad$ STS 88/2017, de 24 de enero de 2017 -Rec. 3034/2015-.

- $\quad$ STS 509/2017, de 23 de marzo -Rec. 1486/2015-. 
- $\quad$ STS 619/2017, de 5 de abril -Rec. 1594/2015-.

- $\quad$ STS 1098/2017, de 20 de junio -Rec. 2765/2016-.

- STS 1421/2016, de 15 de junio -Rec. 1916/2015-.

- $\quad$ STS 1673/2016, de 8 de julio -Rec. 3831/2014-.

- $\quad$ STS 1141/2017, de 27 de junio -Rec. 433/2016-.

- STS 1519/2017, de 5 de octubre -Rec. 3043/2016-.

- $\quad$ STS 1807/2017, de 23 noviembre -Rec. 2012/2015-

- STS 1928/2017, de 11 de diciembre -Rec. 3175/2016-.

- STS 263/2018, de 20 de febrero -Rec. 3257/2016-.

- $\quad$ STS 282/2018, de 21 de febrero -Rec. 17/2017-.

- STS 423/2018, de 15 de marzo -Rec. 1121/2017-.

- $\quad$ STS 539/2018, de 3 de abril -Rec. 427/2017-.

- STS 650/2018, de 23 de abril -Rec. 608/2016-.

- $\quad$ STS 1060/2018, de 20 de junio -Rec. 553/2016-.

- STS 1661/2018, de 22 de noviembre -Rec. 2507/2016-.

- $\quad$ STS 74/2019, de 29 de enero -Rec. 2972/2016-.

- $\quad$ STS 88/2019, de 29 de enero - Rec. 1978/2016-.

- $\quad$ STS 218/2019, de 21 de febrero de 2019 -Rec. 3780/2017-.

- $\quad$ STS 262/2019, de 28 de febrero -Rec. 2342/2016-.

- STS 551/2019, de 24 de abril -Rec. 157/2017-.

- $\quad$ STS 586/2020, de 28 de mayo -Rec. 5751/2017-.

- $\quad$ STS 705/2019, de 27 de mayo -Rec. 111/2017-.

- $\quad$ STS 874/2019, de 24 de junio -Rec. 2765/2018-.

- $\quad$ STS 875/2019, de 24 de junio -Rec. 2902/2018-.

- STS 897/2019, de 25 de junio -Rec. 3689/2018-.

- STS 915/2019, de 26 de junio -Rec. 2165/2017-

- $\quad$ STS 935/2020, de 7 de julio -Rec. 641/2018-.

- $\quad$ STS 1008/2019, de 8 de julio -Rec. 220/2017-.

- $\quad$ STS 1033/2019, de 10 de julio -Rec. 4540/2017-.

- $\quad$ STS 1023/2019, de 10 de julio -Rec. 858/2017-.

- STS 1717/2019, de 12 de diciembre -Rec. 3005/2017-.

- $\quad$ STS 1849/2019, de 18 de diciembre -Rec. 1098/2017-. 
- $\quad$ STS 1064/2020, de 21 julio -Rec. 2982/2018-.

- STS 1181/2019, de 16 de septiembre -Rec. 22/2016-.

- STS 1182/2019, de 16 de septiembre -Rec. 9/2017-.

- $\quad$ STS 1183/2019, de 16 de septiembre -Rec. 2991/2017-.

- STS 1197/2019, de 19 de septiembre -Rec. 588/2017-.

- STS 1197/2019, de 19 de septiembre-Rec. 588/2017-

- STS 1370/2019, de 15 de octubre-Rec. 714/2018-.

- $\quad$ STS 1384/2019, de 16 de octubre -Rec. 2064/2017-.

- $\quad$ STS 1542/2019, de 7 de noviembre -Rec. 4234/2017-.

- STS 1717/2019, de 12 de diciembre -Rec. 3005/2017-.

- $\quad$ STS 1793/2019, de 17 de diciembre -Rec. 3807/2017-.

- STS 1197/2019, de 19 de septiembre -Rec. 588/2017-.

- STS 1793/2019, de 17 de diciembre -Rec. 3087/2017-.

- $\quad$ STS 1849/2019, de 18 de diciembre -Rec. 1098/2017-.

- $\quad$ STS 7/2020, de 14 de enero -Rec. 5164/2017-.

- $\quad$ STS 177/2020, de 12 de febrero -Rec. 2587/2016-.

- STS 338/2020, de 6 de marzo -Rec. 7827/2018-.

- STS 560/2020, de 25 de mayo -Rec. 3120/2018-.

- $\quad$ STS 586/2020, de 28 de mayo -Rec. 5751/2017-.

- $\quad$ STS 656/2020, de 3 de junio -Rec. 5020/2017-.

- $\quad$ STS 1064/2020, de 21 de julio -Rec. 2982/2018-.

- $\quad$ STS 935/2020, de 7 de julio -Rec. 641/2018-.

- STS 1244/2020, de 1 de octubre-Rec. 4525/2018-.

- $\quad$ STS 1346/2020, de 19 de octubre -Rec. 7410/2018-.

- $\quad$ STS 1389/2020, de 22 de octubre -Rec. 4388/2019-.

- STS 1382/2020, de 22 de octubre -Rec. 4535/2019-.

- $\quad$ STS 1400/2020, de 26 de octubre -Rec. 5951/2018-.

- STS 1411/2020, de 27 de octubre -Rec. 3759/2018-.

- $\quad$ STS 1654/2020, de 3 de diciembre -Rec. 730/2019-.

- $\quad$ STS 1667/2020, de 3 de diciembre -Rec. 8332/2019-.

- STS 1713/2020, de 14 de diciembre -Rec. 1987/2019-.

- $\quad$ STS 83/2021, de 27 de enero -Rec. 2046/2019-. 
- $\quad$ STS 117/2021, de 1 de febrero -Rec. 6149/2019-.

- $\quad$ STS 120/2021, de 2 de febrero -Rec. 4284/2019-.

- $\quad$ STS 128/2021, de 3 de febrero -Rec. 4110/2019-.

\section{Tribunal Supremo, Sala Social:}

- $\quad$ STS de 9 de junio 1987 -ECLI: ES:TS:1987:12092-.

- $\quad$ STS de 26 de febrero 1990 -ECLI: ES:TS:1990:17276-.

- $\quad$ STS de 8 de marzo de 1993 -rcud. 953/1992-.

- $\quad$ STS de 29 de marzo de 1993 -rcud. 298/1992-.

- $\quad$ STS de 10 de diciembre de 1993 -rcud. 3113/1992-.

- $\quad$ STS de 1 de junio de 1994 -rcud. 3415/1993-.

- $\quad$ STS de 20 de julio de 1995 -Rec. 3795/1994-.

- $\quad$ STS de 29 de septiembre de 1994 -Rec. 2552/1993-.

- $\quad$ STS de 8 de marzo de 1995 -rcud. 843/1994-.

- $\quad$ STS de 20 de julio de 1995 -Rec. 3795/1994-.

- $\quad$ STS de 28 de septiembre de 1995 -rcud. 3000/1994-.

- $\quad$ STS de 27 de febrero de 1996 -rcud. 1896/1995-.

- $\quad$ STS de 16 de julio de 1996 -rcud. 2389/1995-.

- $\quad$ STS de 22 de octubre de 1996 -rcud. 686/1996-.

- $\quad$ STS de 31 de enero de 1997 -Rec. 820/1996-.

- $\quad$ STS de 28 de febrero de 1997 -Rec. 2928/1996-.

- $\quad$ STS de 20 de marzo de 1997 -Rec. 2730/1996-.

- $\quad$ STS de 8 de mayo de 1997 -Rec. 3824/1996-.

- $\quad$ STS de 11 de julio de 1997 -Rec. 719/1997-.

- $\quad$ STS de 28 de octubre de 1997-Rec. 3485/1996-.

- $\quad$ STS de 31 de diciembre de 1997 -Rec. 1858/1997-.

- $\quad$ STS de 17 de enero de 1998 -rcud. 3083/1992-.

- $\quad$ STS de 13 de abril de 1998 - rcud. 925/1997-.

- $\quad$ STS de 21 de julio de 1998 -rcud. 102/1998-.

- $\quad$ STS de 10 de diciembre de 1998 -rcud. 4078/1997-.

- $\quad$ STS de 25 de enero de 1999 -rcud. 500/1998-.

- $\quad$ STS de 31 de marzo de 1999 -rcud. 3073/1998-. 
- $\quad$ STS de 5 de mayo de 1999 -Rec. 3656/1997-.

- $\quad$ STS de 26 de diciembre de 2001 -Rec. 139/2001-.

- $\quad$ STS de 20 de septiembre de 1999 -rcud. 1339/1998-.

- $\quad$ STS de 9 de noviembre de 1999 - rcud. 2252/1998-.

- $\quad$ STS de 7 de enero de 2000 -rcud. 3973/1998-.

- $\quad$ STS de 1 de febrero de 2000 -rcud. 694/1999-.

- $\quad$ STS de 12 de abril de 2000 -rcud. 4605/1998-.

- $\quad$ STS de 25 de mayo de 2000 -Rec. 895/1999-.

- $\quad$ STS de 23 de mayo de 2000 -rcud. 3039/1999-.

- $\quad$ STS de 9 de junio de 2000 -rcud. 601/1999-.

- $\quad$ STS de 14 de junio de 2000 -rcud. 3096/1999-.

- $\quad$ STS de 26 de junio de 2000 -rcud. 4169/1999-.

- $\quad$ STS de 21 de diciembre de 2000 -Rec. 4383/1999-.

- $\quad$ STS de 14 de febrero de 2001 -rcud. 130/2000-.

- $\quad$ STS de 22 de febrero de 2001 -rcud. 3033/2000-

- $\quad$ STS de 19 de marzo de 2001 -rcud. 3095/2000-.

- $\quad$ STS de 9 de abril de 2001 -rcud. 3860/1999-.

- $\quad$ STS de 24 de marzo de 2001 -rcud. 794/2000-.

- STS de 15 de mayo de 2001 -rcud. 3546/2000-.

- $\quad$ STS de 22 de mayo de 2001 -rcud. 4093/2000-.

- $\quad$ STS de 9 de julio de 2001 -rcud. 4378/1999-.

- $\quad$ STS de 17 de septiembre de 2001 -Rec. 1904/2000-.

- $\quad$ STS de 9 de octubre de 2001 -rcud. 159/2001-.

- $\quad$ STS de 29 de octubre de 2001 -rcud. 146/2001-.

- $\quad$ STS de 29 de octubre de 2001 -Rec. 199/2001-.

- $\quad$ STS de 26 de diciembre de 2001 -rec. 139/2001-.

- STS de 20 de enero de 2003 -Rec. 1524/2002-.

- $\quad$ STS de 21 de febrero de 2002 -rcud. 2239/2001-.

- $\quad$ STS de 8 de mayo de 2002 -rec. 3079/2001-.

- $\quad$ STS de 13 de mayo de 2002 -rcud. 2568/2001-.

- $\quad$ STS de 3 de julio de 2002 -rcud. 2901/2001-.

- $\quad$ STS de 30 de septiembre de 2002 -rcud. 223/2002-. 
- $\quad$ STS de 16 de octubre de 2012 -rcud. 4343/2010-.

- $\quad$ STS de 30 de junio de 2003 -rcud. 2403/2002-.

- $\quad$ STS de 17 de mayo de 2004 -Rec. 3259/2003-.

- $\quad$ STS de 30 de septiembre de 2005 -rcud. 3824/2004-.

- $\quad$ STS de 17 de noviembre de 2004 -rcud. 5997/2003-.

- $\quad$ STS de 26 de enero de 2004 -rcud. 4535/2002-.

- $\quad$ STS de 27 de mayo de 2004 - rcud. 2843/2003-.

- $\quad$ STS de 22 de julio de 2004 -rcud. 4037/2003-.

- $\quad$ STS de 8 de octubre de 2004 -rcud. 4552/2003-.

- $\quad$ STS de 17 de noviembre de 2004 -rcud. 5997/2003-

- $\quad$ STS de 14 de diciembre de 2004 -rcud. 5291/2003-.

- $\quad$ STS de 16 de junio de 2005 -rcud. 3332/2003-.

- $\quad$ STS de 25 de octubre de 2005 -Rec. 3552/2004-.

- $\quad$ STS de 3 de noviembre de 2005 -Rec. 3400 /2004-.

- $\quad$ STS de 18 de noviembre de 2005 -rcud. 5352/2004-.

- $\quad$ STS de 16 de enero de 2006 -rcud. 3970/2004-.

- $\quad$ STS de 9 de febrero de 2006 -rcud. 4100/2004-.

- $\quad$ STS de 17 de marzo de 2006 -rcud. 832/2005-.

- $\quad$ STS de 1 de junio de 2006 -rcud. 5458/2004-.

- $\quad$ STS de 5 de julio de 2006 -rcud. 1090/2005-.

- $\quad$ STS de 21 de julio de 2006 -rcud. 2031/2005-.

- $\quad$ STS de 4 de octubre de 2006 -rcud. 1798/2005-.

- $\quad$ STS de 9 de octubre de 2006 -rcud. 3279/2005-.

- $\quad$ STS de 8 de noviembre de 2006 -rcud. 3392/2005-

- $\quad$ STS de 21 de noviembre de 2006 -rcud. 1079/2005-.

- $\quad$ STS de 22 de noviembre de 2006 -rcud. 2792/2001-.

- $\quad$ STS de 5 de diciembre de 2006 -rcud. 2531/2005-.

- $\quad$ STS de 12 de febrero de 2007 -rcud. 5542/2005-.

- $\quad$ STS de 27 de marzo de 2007 -rcud. 639/2006-.

- $\quad$ STS de 9 de abril de 2007 -rcud. 143/2006-.

- $\quad$ STS de 14 de abril de 2007 -rcud. 756/2006-.

- $\quad$ STS de 16 de mayo de 2007 -rcud. 4263/2005-. 
- $\quad$ STS de 2 de julio de 2007 -rcud. 686/2006-.

- $\quad$ STS de 3 de julio de 2007 -rcud. 1330/2006-.

- $\quad$ STS de 10 de julio de 2007 -rcud. 4168/2006-.

- $\quad$ STS de 12 de julio de 2007 -rcud. 1145/2006-.

- $\quad$ STS de 18 de octubre de 2007 -Rec. 2812/2006-.

- $\quad$ STS de 26 de septiembre de 2007 -rcud. 2573/2006-.

- $\quad$ STS de 15 de enero de 2008 -rcud. 3964/2006-

- $\quad$ STS de 13 de febrero de 2008 -Rec. 163/2007-.

- STS de 14 de mayo de 2008 -Rec. 4016/2006-.

- $\quad$ STS de 18 de febrero de 2008 -rcud. 1263/2007-.

- $\quad$ STS de 26 de febrero de 2008 -rcud. 2341/2006-.

- $\quad$ STS de 26 de febrero de 2008 -rcud. 3383/2006-.

- $\quad$ STS de 27 de febrero de 2008 -rcud. 21/2007-.

- $\quad$ STS de 9 de mayo de 2008 -rcud. 605/2007-.

- $\quad$ STS de 26 de mayo de 2008 -rcud. 4755/2006-.

- $\quad$ STS de 28 de mayo de 2008 -rcud. 814/2007-.

- $\quad$ STS de 30 de junio de 2008 -rcud. 4162/2006-.

- STS de 22 de septiembre de 2008 -rcud. 189/2008-.

- $\quad$ STS de 25 de septiembre de 2008 -rcud. 2914/2007-.

- $\quad$ STS de 7 de octubre de 2008 -rcud. 2426/2007-.

- $\quad$ STS de 11 de diciembre de 2008 -rcud. 4408/2007-.

- $\quad$ STS de 23 de diciembre de 2008 -rcud. 2284/2007-.

- $\quad$ STS de 22 de enero de 2009 -rcud. 3858/2007-.

- $\quad$ STS de 11 de febrero de 2009 -rcud. 4439/2007-.

- $\quad$ STS de 17 de febrero de 2009 -rcud. 4230/2007-.

- $\quad$ STS de 21 de mayo de 2009 -rcud. 1515/2008-.

- $\quad$ STS de 7 de julio de 2009 -rcud. 2612/2008-.

- STS de 15 de septiembre de 2009 -rcud. 171/2009-.

- $\quad$ STS de 13 de octubre de 2009 -rcud. 4063/2008-.

- $\quad$ STS de 29 de octubre de 2009 -rcud. 4447/2008-.

- STS de 11 de noviembre de 2009 -rcud. 513/2009-.

- $\quad$ STS de 15 de noviembre de 2009 -rcud. 2864/2006-. 
- $\quad$ STS de 16 de diciembre de 2009 -rcud. 650/2009-.

- $\quad$ STS de 16 de diciembre de 2009 -rcud. 4356/2008-.

- $\quad$ STS de 18 de enero de 2010 -rcud. 3237/2007-.

- $\quad$ STS de 28 de enero de 2010 -rcud. 1136/2009-.

- $\quad$ STS de 23 de febrero de 2010 -Rec. 243/2008-.

- $\quad$ STS de 27 de abril de 2010 -rcud.1756/2009-.

- STS de 22 de diciembre de 2010 -rcud. 1136/2009-.

- $\quad$ STS de 4 de abril de 2011 -rcud. 556/2010-.

- STS de 30 de enero de 2012 -rcud. 2720/2010-.

- $\quad$ STS de 20 de marzo de 2012 -rcud. 1470/2011-.

- $\quad$ STS de 10 de julio de 2012 -rcud. 2828/2011-.

- $\quad$ STS de 20 de marzo de 2013 -Rec. 81/2012-.

- $\quad$ STS de 27 de mayo de 2013 -Rec. 78/2012-.

- $\quad$ STS de 17 de julio de 2013 -rcud. 1023/2012-.

- $\quad$ STS de 19 de julio de 2013 -rcud. 2730/2012-.

- $\quad$ STS de 25 de septiembre de 2013 -Rec. 3/2013-.

- $\quad$ STS de 12 de noviembre de 2013 -rcud. 3117/2012-.

- $\quad$ STS de 7 de febrero de 2014 -Rec. 4607/2012-.

- STS de 14 de mayo de 2014 -rcud. 1467/2013-.

- $\quad$ STS de 4 de febrero de 2015 -rcud. 96/2014-.

- $\quad$ STS de 4 de marzo de 2014 -rcud. 788/2013-.

- $\quad$ STS de 23 de junio de 2014 -rcud. 1257/2013-.

- $\quad$ STS de 26 de junio de 2014 -Rec. 219/2013-.

- $\quad$ STS de 23 de septiembre de 2014 -Rec. 309/2013-.

- $\quad$ STS de 15 de octubre de 2014 -rcud. 3164/2013-.

- $\quad$ STS de 3 de diciembre de 2014 -Rec. 201/2013-.

- STS de 10 de febrero de 2015 -rcud. 33/2014-.

- $\quad$ STS de 23 de marzo de 2015 -rcud. 2057/2014-.

- $\quad$ STS de 14 de abril de 2015 -rcud. 962/2014-.

- $\quad$ STS de 5 de mayo de 2015 -rcud. 1075/2014-.

- STS de 12 de mayo de 2014 -rcud. 635/2013-.

- $\quad$ STS de 13 de octubre de 2015 -rcud. 2166/2014-. 
- $\quad$ STS de 23 de marzo de 2015 -rcud. 2057/2014-.

- $\quad$ STS de 14 de abril de 2015 -rcud. 962/2014-.

- $\quad$ STS de 5 de mayo de 2015 -rcud. 1075/2014-.

- $\quad$ STS de 20 de octubre de 2015 -Rec. 172/2014-.

- $\quad$ STS de 2 de noviembre de 2015 -rcud. 3426/2014-.

- $\quad$ STS de 2 de noviembre de 2015 -rcud. 3426/2014-.

- $\quad$ STS de 10 de diciembre de 2015 -rcud. 1012/2014-.

- $\quad$ STS de 15 de diciembre de 2015 -Rec.1258/2014-.

- $\quad$ STS de 22 de enero de 2016 -rcud.1931/2014-.

- $\quad$ STS de 25 de febrero de 2016 -rcud. 846/2014-.

- $\quad$ STS de 17 de marzo de 2016 -Rec. 178/2015-.

- $\quad$ STS de 26 de abril de 2016 -rcud. 149/2015-.

- $\quad$ STS 390/2016, de 9 de mayo -rcud. 3535/2014-.

- $\quad$ STS de 18 de mayo de 2016 -rcud. 1042/2014-.

- $\quad$ STS de 8 de junio de 2016 -rcud. 1103/2015-.

- $\quad$ STS de 13 de septiembre de 2016 -rcud. 3770/2015-

- $\quad$ STS de 14 de septiembre de 2016 -rcud. 90/2015-.

- STS de 14 de septiembre de 2016 -rcud. 846/2015-.

- $\quad$ STS de 15 de septiembre de 2016 -rcud. 3272/2015-.

- $\quad$ STS de 21 de diciembre de 2016 -rcud. 3373/2015-.

- $\quad$ STS de 8 de marzo de 2017 -rcud. 2686/2015-.

- $\quad$ STS de 14 de marzo de 2017 -rcud. 1083/2015-.

- $\quad$ STS de 20 de abril de 2017 -rcud. 1826/2015-.

- STS de 18 de mayo de 2017 -rcud. 1720/2015-.

- $\quad$ STS de 4 de julio de 2017 -rcud. 913/2016-.

- $\quad$ STS 10 de julio de 2017 -rcud. 1652/2016-.

- $\quad$ STS 616/2017, de 12 de julio -Rec. 32/2017-.

- $\quad$ STS 850/2017, de 31 de octubre -Rec. 115/2017-.

- $\quad$ STS de 10 de noviembre de 2017 -rcud. 3049/2015-.

- $\quad$ STS 90/2018, de 2 de febrero -rcud. 679/2016-.

- $\quad$ STS de 20 de febrero de 2018 -rcud. 1845/2016-.

- $\quad$ STS 212/2018, de 27 de febrero -rcud. 3448/2015-. 
- $\quad$ STS de 11 de mayo de 2018 -rcud. 3012/2016-.

- $\quad$ STS de 16 de mayo de 2018 -Rec. 3976/2016-.

- $\quad$ STS de 20 de junio de 2018 -rec. 168/2017-.

- $\quad$ STS de 28 de junio de 2018 -Rec. 3713/2016-.

- $\quad$ STS de 18 de septiembre de 2018 -rcud. 2367/2016-.

- $\quad$ STS de 18 de septiembre de 2018 -rcud. 144/2017-.

- $\quad$ STS de 25 de septiembre de 2018 -rcud. 761/2017-.

- $\quad$ STS de 23 de octubre de 2018 -rcud. 3599/2016-.

- $\quad$ STS de 7 de noviembre de 2018 -rcud. 3549/2016-.

- STS 1043/2018, de 12 de diciembre -rcud. 4142/2016-.

- $\quad$ STS de 7 de febrero de 2019 -rcud. 1680/2016-.

- $\quad$ STS de 28 de febrero de 2019 -rcud. 508/2017-.

- $\quad$ STS de 21 de marzo de 2019 -rcud. 3901/2017-.

- $\quad$ STS de 27 de marzo de 2019 -rcud. 2137/2017-.

- $\quad$ STS de 2 de abril de 2019 -rcud. 2885/2017-.

- $\quad$ STS 691/2019, de 8 de octubre -Rec. 2/2017-.

- $\quad$ STS 750/2019, de 5 de noviembre -rcud. 1610/2017-.

- $\quad$ STS de 7 de mayo de 2020 -rcud. 169/2018-.

- $\quad$ STS 402/2020, de 22 de mayo -Rec. 3/2019-.

- $\quad$ STS 500/2020, de 23 de junio -rcud. 4375/2017-.

- $\quad$ STS 527/2020, de 24 de junio -Rec. 3/2018-.

- $\quad$ STS de 22 de julio de 2020 -rcud. 102/2018-.

- $\quad$ STS de 22 de julio de 2020 -rcud. 737/2018-.

- $\quad$ STS de 8 de septiembre de 2020 -Rec. 25/2019-.

- $\quad$ STS de 17 de septiembre de 2020 -rcud. 723/2018-.

- $\quad$ STS de 13 de octubre de 2020 -rcud. 3270/2018-.

- $\quad$ STS de 13 de octubre de 2020 -rcud. 3947/2017-.

- $\quad$ STS 1382/2020, de 22 de octubre -Rec. 4535/2019-.

- $\quad$ STS 65/2021, de 19 de enero -Rec. 3/2020-. 


\section{Tribunal Supremo, Sala Especial:}

- $\quad$ Auto 4/1996, de 8 de marzo de 1996 -Rec. 7/1995-.

- Auto 36/1998, de 3 de noviembre-Rec. 13/1998-.

- Auto 39/2013, de 19 de diciembre de 2013 -Rec. 35/2013-.

- $\quad$ Auto 2/2015, de 10 de febrero de 2013 -Rec. 33/2014-.

- $\quad$ Auto 4/2019, de 19 de febrero de 2019 -Rec. 18/2018-.

- Auto 13/2020, de 15 de junio de 2020 -Rec. 21/2019-.

- $\quad$ STS de 9 de mayo de 1995 -Rec. 17/1991-.

- $\quad$ STS 3/2013, de 9 de abril -Rec. 1/2013-.

- $\quad$ STS 2/2018, de 21 de marzo -Rec. 1/2018-.

- $\quad$ STS 1/2019, de 29 de abril -Rec. 1/2019-.

\section{Tribunales Superiores de Justicia. Sala Contencioso-Administrativa:}

- STSJ de Andalucía con sede en Sevilla, Sección 2a , no 240/2018, de 15 de marzo -Rec. 148/201515-.

- STSJ de Castila y León, con sede en Valladolid, n $^{\circ}$ 859/2018, de 27 de septiembre -Rec. 902/2016-.

- STSJ de Castila y León, con sede en Valladolid, nº 172/2017, de 15 septiembre -Rec. 43/2016 y acumulado 51/2016-.

- STSJ de Galicia, con sede en La Coruña, no 150/2016, de 6 de abril -Rec. $15083 / 2015-$.

- $\quad$ STSJ de Murcia, no 385/2018, de 28 de septiembre -Rec. 199/2017-.

\section{Tribunales Superiores de Justicia, Sala Social:}

- STSJ de Canarias, con sede en Tenerife, $n^{\circ}$ 714/2016, de 4 de octubre -Rec. 171/2016-.

- STSJ de Castilla y León, con sede en Burgos, n 394/2013, de 23 de julio -Rec. 362/2013-.

- STSJ de Castilla y León, con sede en Burgos, Sala Social, nº 120/2014, de 5 de marzo -Rec. 83/2014-. 
- TSJ de Cataluña, con sede en Barcelona, $\mathrm{n}^{\circ}$ 1123/2011, de 11 de febrero -Rec. 6702/2009-.

- STSJ de Cataluña, con sede en Barcelona, n 4628/2019, de 4 de octubre -Rec. 2811/2019-.

\section{Audiencias Provinciales, Sala civil:}

- Sentencia Audiencia Provincial de Barcelona, $n^{\circ}$ 335/2018, de 17 de mayo Rec. 465/2017-.

- Sentencia Audiencia Provincial de Barcelona, no 251/2017, de 15 de junio Rec. 23/2016-.

- Sentencia de la Audiencia Provincial de Valencia, nº 297 /2018, de 18 de abril Rec. 426/2018-.

- Sentencia de la Audiencia Provincial de Salamanca, nº 332/2018, de 17 de julio -Rec. 203/2018-

- Sentencia de la Audiencia Provincial de Valladolid, no 314/2016, de 11 de noviembre -Rec. 352/2016-.

- Sentencia de la Audiencia Provincial de Alicante, $\mathrm{n}^{\circ}$ 190/2019, de 20 de febrero -Rec. 611/2018-.

- Sentencias de la Audiencia Provincial de Pontevedra, n 164/2017, de 6 de abril -Rec. 82/2017-.

- Sentencias de la Audiencia Provincial de Pontevedra, n 162/2016, de 31 de marzo -Rec. 50/2016-.

- Sentencia de la Audiencia Provincial de la Coruña, no 142/2019, de 10 abril Rec. 53/2019-. 



\section{BIBLIOGRAFÍA}

AA.VV. (GARRIGUES, J. y URÍA GONZÁLEZ, R.): Comentario a la Ley de Sociedades Anónimas, Tomo II, $3^{\mathrm{a}}$ edición revisada y puesta a día por MENÉNDEZ MENÉNDEZ, A. y OLIVENCIA RUIZ, M., Madrid, 1976.

AA.VV. (DÍEZ PICAZO, L. y GULLÓN BALLESTEROS, A.): Sistema de Derecho Civil, Vol. II, $2^{\text {a }}$ edición, editorial Tecnos, 1979.

AA.VV. (Dir.: URÍA GONZÁLEZ, R.; MENÉNDEZ MENÉNDEZ, A.; y OLIVENCIA RUIZ, M.): Comentario al régimen legal de las sociedades mercantiles, Tomo VI, editorial Cívitas, Madrid, 1992.

AA.VV. (Dir.: SÁNCHEZ CALERO, F.): Comentarios a la Ley de Sociedades Anónimas, Madrid. 1993.

AA.VV. (Coord.: BAYLOS GRAU, A. y COLLADO GARCÍA, L.): Grupos de empresas y Derecho del Trabajo, Madrid, Editorial Trotta, 1994.

AA.VV. (Coord.: ESTEBAN VELASCO, G.): El gobierno de sociedades cotizadas, Madrid, 1999.

AA.VV. (Coord.: GALÁN CORONA, E. y GARCÍA CRUCES, J. A.): La responsabilidad de los administradores de las sociedades de capital, Tecnos, Madrid 1999.

AA.VV. (DESDENTADO BONETE, A. y DESDENTADO DAROCA, E.): Administradores sociales, altos directivos y socios trabajadores. Calificación y concurrencia de relaciones profesionales, responsabilidad laboral y encuadramiento en la Seguridad Social, Editorial Lex Nova, Valladolid, 2000.

AA.VV. (Coord.: ARROYO MARTÍNEZ, I. y EMBID IRUJO, J. M.): Comentarios a la Ley de Sociedades anónimas, Tecnos, Madrid, 2001.

AA.VV. (Dir.: GARCÍA VILLAVERDE, R.; ALONSO UREBA, A.; y PULGAR EZQUERRA, J.): Derecho concursal. Estudio Sistemático de la Ley 22/2003 y de la Ley 8/2003 para la reforma concursal, Editorial Dilex, Madrid, 2003. 
AA.VV. (Dir.: SÁNCHEZ-CALERO GUILARTE, J. y GUILARTE GUTIÉRREZ, V.): Comentarios a la Legislación Concursal, Lex Nova, Valladolid, 2004.

AA.VV. (SEMPERE NAVARRO, A. V. y ARETA MARTÍNEZ, M.): "El Derecho del Trabajo y los Grupos de Empresas: inventario", en Revista del Ministerio de Trabajo y Asuntos Sociales, № 48, 2004, edición digital en el foro del conocimiento de la ITSS, http://itss.laley.es/Content/Documento.aspx?params.

AA.VV. (Dir.: RODRÍGUEZ ARTIGAS, F.; ALONSO UREBA, A.; FERNÁNDEZ DE LA GÁNDARA, L.; VELASCO SAN PEDRO, L. A.; QUIJANO GONZÁLEZ, J.; y ESTEBAN VELASCO, G.): Derecho de sociedades anónimas cotizadas, -Vol. II, Elcano, 2005.

AA.VV. (RODRÍGUEZ ARTIGAS, F. y MARÍN DE LA BÁRCENA GARCIMARTÍN, F.): “Algunas cuestiones sobre la responsabilidad de los administradores de la Sociedad a por no promoción de la disolución en caso de pérdidas (art. 265.2 LSA). STS 16 de diciembre de 2004”, en $R d S$, n 24, 2005, pp. 295 y ss.

AA.VV. (Coord.: RODRÍGUEZ ARTIGAS, F.): Derecho de sociedades anónimas cotizadas: estructura de gobierno y mercados, Thomson Reuters Aranzadi, Vol. II, 2006.

AA.VV. (FERNÁNDEZ DOMÍNGUEZ, J. J. y FERNÁNDEZ FERNÁNDEZ, R.): Incumplimientos empresariales en los actos de encuadramiento y responsabilidad de las mutuas, Laboral Prácticos Abdón Pedrajas, Tirant Lo Blanch, 2007.

AA.VV. (Dir.: BORRAJO DACRUZ, E.): Accidentes de Trabajo y Mutuas, La ley, Madrid, 2008.

AA.VV. (MARTÍN JIMÉNEZ, R. y MATEOS BEATO, A.): La responsabilidad de empresas y Administradores con la Seguridad Social, Editorial Aranzadi Thomson Reuters, 2009.

AA.VV. (PEDRAJAS MORENO, A.; SALA FRANCO, T.; y VALLEJO ORTE, A.): La incapacidad permanente y las lesiones no invalidantes, ed. Tirant Lo Blanch, 2010.

AA.VV. (Coord.: GUERRA MARTÍN, G.): La responsabilidad de los administradores de sociedades de capital, Madrid, 2011. 
AA.VV. (Coord.: ROJO FERNÁNDEZ-RÍO, A. et altri.): Comentario de la Ley de Sociedades de Capital, Tomo II, Civitas Thomson Reuters, 2011.

AA.VV. (Coord.: SEMPERE NAVARRO, A. V.): Comentarios a la Ley de la Jurisdicción Social, Thomson Reuters Aranzadi, 3ª edición, marzo 2013.

AA.VV. (DE LA PUEBLA PINILLA, A. et altri): Análisis de la nueva Ley Reguladora de la Jurisdicción Social, 1ª edición, Tirant Lo Blanch, 2014.

AA.VV. (SALA FRANCO, T.; BLASCO PELlICER, A. A.; y SALCEDO BELTRÁn, M. ${ }^{\mathrm{a}}$ C.): Derecho de Prevención de Riesgos Laborales, Tirant Lo Blanch, 9a edición, 2014.

AA.VV. (Dir.: MARTÍNEZ-ECHEVERRÍA Y GARCÍA DE DUEÑAS, A.): Gobierno Corporativo: la Estructura del órgano de Gobierno y la Responsabilidad de los Administradores, ed. Aranzadi Thomson Reuters, $1^{\text {a }}$ edición, 2015.

AA.VV. (Coord.: JUSTE MENCÍA, J.): Comentario de la reforma del régimen de sociedades de capital en materia de gobierno corporativo (Ley 31/2014), Thomson Reuters, Navarra, 2015.

AA.VV. (Dir.: GARCÍA-PERROTE ESCARTÍN, I. y MERCADER UGUINA, J. R.): Comentarios a la Ley General de la Seguridad Social, editorial Lex Nova-Thomson Reuters, $1^{\text {a }}$ edición, julio 2015.

AA.VV. (Coord.: HERNANDO CEBRIÁ, L.): Régimen de Deberes y Responsabilidades de los administradores en las sociedades de capital, ed. Bosch, 2015.

AA.VV. (Coord.: ROJO FERNÁNDEZ-RÍO, A. y BELTRÁN SÁNCHEZ, E. M.): La responsabilidad de los administradores de las Sociedades Mercantiles, $6^{\text {a }}$ edición, Tirant Lo Blanch, Valencia, 2016.

AA.VV. (Dir.: NOGUEIRA GUASTAVINO, M. y GARCÍA BECEDAS, G.): Lecciones de Jurisdicción Social, Tirant Lo Blanch, 2016, edición digital, https://biblioteca-tirant-com.ponton.uva.es.

AA.VV. (BROSETA PONT, M. y MARTÍNEZ SANZ, F.): Manual de Derecho Mercantil, ed. Tecnos, 23ª edición, Vol. I, 2016. 
AA.VV. (BLASCO LAHOZ, J. F. y LÓPEZ GANDÍA, J.): Curso de Seguridad Social, Tirant Lo Blanch, $10^{a}$ edición, 2018, edición digital, https://biblioteca-tirantcom.ponton.uva.es/cloudLibrary/ebook/info/9788491906575.

AA.VV. (CRUZ VILLALÓN, J. y DOMÍNGUEZ MORALES, A.): “El Empresario", Revista Española de Derecho del Trabajo, núm. 215, 2018, Thomson Reuters, ed. digital, https://insignis-aranzadidigital-es.ponton.uva.es/maf/app/document?srguid

AA.VV. (Coord.: BRENES CORTÉS, J.; Dir.: DÍAZ MORENO, A.; y VÁZQUEZ CUETO, J. C.): Estudios sobre la responsabilidad de los administradores de las sociedades de capital a la luz de sus recientes reformas legislativas y pronunciamientos judiciales, Thomson Reuters Aranzadi, 2018, 1ª edición.

AA.VV. (Coord.: EMBID IRUJO, J. M. y NIETO CAROL, U.): Estudios de Derechos de Sociedades, Tirant Lo Blanch, Valencia, 2019.

AA.VV. (MONEREO PÉREZ, J. L., et altri): Manual de Seguridad Social, ed. Tecnos, $16^{\text {a }}$ edición, 2020.

AIBAR BERNAD, J.: "El Big Data y el análisis de datos aplicados por la Tesorería General de la Seguridad Social como medio de lucha contra el fraude en la Seguridad Social", Trabajo y Derecho, № 11, Sección Estudios, editorial Wolters Kluwer, Ref. La Ley 7213/2020, edición digital.

ALARCÓN CARACUEL, M. R. y GONZÁLEZ ORTEGA, S.: Compendio de Seguridad Social, ed. Tecnos, Madrid, 1991, p. 128.

AlBERT EMBUENA, V.: La Incapacidad Permanente Contributiva. Aspectos Sustantivos y Procesales, ed. Tirant Lo Blanch, 2017, edición digital https://biblioteca-tirant-com.ponton.uva.es/cloudLibrary/ebook/search.

ALCALÁ DÍAZ, M. a A.: “Acción individual de responsabilidad frente a los administradores (STS de 21 de mayo de 1992)”, $R d S$, núm. 1, 1993.

ALCÁNTARA Y COLÓN, J. M.: “Incumplimiento de los reconocimientos médicos laborales previos y periódicos. Los efectos de los artículos 196 y 197 de la LGSS: Responsabilidad empresarial. Algunas notas", Revista de Información Laboral, núm. 12/2015, Aranzadi, BIB 2015\18183, ed. digitalhttps://insignis$\underline{\text { aranzadidigital- }}$ 
es.ponton.uva.es/maf/app/document?srguid=i0ad6adc60000017588e2d51baaebcf59 \&marginal=BIB $\backslash 2015 \backslash 18183 \&$ docguid, pp. 1 a 12.

ALCOVER GARAU, G.: "El ámbito de responsabilidad de los administradores en los nuevos artículos 262.5 de la Ley de Sociedades Anónimas y 105.5 de la Ley de Sociedades de Responsabilidad Limitada", en $R d S \mathrm{n}^{\mathrm{o}} 1,2006$, pp. 85 y ss.

ALCOVER GARAU, G.: “Aproximación al régimen jurídico de los artículos 8 a 18 del Capítulo II (medidas concursales y societarias) del Real Decreto-Ley 16/2020, de 28 de abril, de medidas procesales y organizativas para hacer frente al COVID19 en el ámbito de la Administración de Justicia”, en Diario La Ley, N 9634, Tribuna, 18 de mayo de 2020, edición digital.

ALFONSO SÁNCHEZ, R.: “Obligaciones básicas derivadas del deber de lealtad”, en AA.VV. (Coord.: HERNANDO CEBRIÁ, L.): Régimen de Deberes y Responsabilidades de los administradores en las sociedades de capital, ed. Bosch, 2015.

ALMANSA PASTOR, J. M.: Derecho de la Seguridad Social, ed. Tecnos, 6 a edición, Madrid, 1989.

ALONSO UREBA, A.: "Presupuestos de responsabilidad social de los administradores de una sociedad anónima", RDM, núm. 198, octubre-diciembre 1990.

ALONSO UREBA, A.: "La responsabilidad concursal de los administradores de una sociedad de capital en situación concursal (el art. 172.3 de la Ley Concursal y sus relaciones con las acciones societarias de responsabilidad", en AA.VV.: Derecho Concursal. Estudio sistemático de la Ley 22/2003 y de la Ley 8/2003, para la reforma concursal, editorial Dilex, Madrid, 2003.

ALVÁREZ ROYO-VILLANOVA, S.: "La necesaria revisión de la doctrina del levantamiento del velo", en AA.VV. (Dir.: MARTÍNEZ-ECHEVERRÍA Y GARCÍA DE DUEÑAS, A.): Gobierno Corporativo: la Estructura del órgano de Gobierno y la Responsabilidad de los Administradores, ed. Aranzadi Thomson Reuters, $1^{\text {a }}$ edición, 2015.

ARANGUREN URRIZA, F. J.: La sociedad de Responsabilidad Limitada, Tomo II, Editorial Trivium, Madrid, 1998. 
ARETA MARTÍNEZ, M.: en AA.VV. (SEMPERE NAVARRO, A. V. y ARETA MARTÍNEZ, M.): "El Derecho del Trabajo y los Grupos de Empresas: inventario", en Revista del Ministerio de Trabajo y Asuntos Sociales, No 48, 2004, edición digital en el foro del conocimiento de la ITSS, http://itss.laley.es/Content/Documento.aspx?params.

BATALLER GRAU, J.: "Disolución y Liquidación”, AA.VV. (Coord.: ROJO FERNÁNDEZ-RÍO, A. et altri.): Comentario de la Ley de Sociedades de Capital, Tomo II, Vol. 2, Civitas, Madrid, 2011, pp. 2531-2590.

BAYLOS GRAU, A. y COLLADO GARCÍA, L.: Grupos de empresas y Derecho del Trabajo, Madrid, Editorial Trotta, 1994.

BEJARANO HERNÁNDEZ, A.: "Responsabilidad empresarial por falta de alta del trabajador y anticipo de prestaciones de la Seguridad Social”, Relaciones Laborales, N²0, Sección Doctrina, Quincena del 16 al 31 octubre 1996, p. 340, Tomo 2, Editorial La Ley, edición digital, https://laleydigital-laleynextes.ponton.uva.es/Content/Documento.aspx?params.

BELLO MARTÍN-CRESPO, M. ${ }^{a}$ P.: "Responsabilidad civil de administradores de sociedades de capital y Ley Concursal", en Estudios sobre la Ley concursal (Libro Homenaje a Manuel Olivencia), Tomo II, editorial Marcial Pons, Madrid, 2005.

BELTRÁN SÁNCHEZ, E. M.: "La liquidación”, Comentario a los arts. 371 a 394, en AA.VV. (Coord.: ROJO FERNÁNDEZ-RÍO, A. et altri.): Comentario de la Ley de Sociedades de Capital, Tomo II, Cívitas Thomson Reuters, 2011, pp. 2591-2704.

BELTRÁN SÁNCHEZ, E. M.: "La responsabilidad de los administradores por obligaciones sociales”, en AA.VV. (Coord.: ROJO FERNÁNDEZ-RÍO, A. y BELTRÁN SÁNCHEZ, E. M.): La responsabilidad de los administradores de las sociedades mercantiles, 6 $6^{\text {a }}$ edición, Tirant Lo Blanch, Valencia, 2016, pp. 301-444. Trabajo revisado y actualizado por SÁNCHEZ PAREDES, L.

BERCOVITZ RODRÍGUEZ-CANO, A.: "Régimen general de la responsabilidad civil de los administradores de las sociedades de capital", en AA.VV. (Coord.: GALÁN CORONA, E. y GARCÍA CRUCES, J. A.): La responsabilidad de los administradores de las sociedades de capital, Tecnos, Madrid 1999 
BERTRÁN MEDIZÁBAL, F.: "Las sociedades en pérdidas: Especial referencia a la Normativa del Mercado de Valores", en Estudios de Derecho Bancario y bursátil en Homenaje a Evelio Verdera y Tuells, Tomo I, La Ley, Madrid, 1994.

BLASCO LAHOZ, J. F.: Las Contingencias Profesionales de la Seguridad Social, ed. Tirant lo Blanch, 2019.

BLASCO LAHOZ, J. F y LÓPEZ GANDÍA, J.: Curso de Seguridad Social, Tirant Lo Blanch, $10^{\mathrm{a}}$ edición, 2018, edición digital https://biblioteca-tirantcom.ponton.uva.es/cloudLibrary/ebook/info/9788491906575

BLASCO LAHOZ, J. F. y LÓPEZ GANDÍA, J.: Curso de Seguridad Social, Tirant Lo Blanch, $12^{\mathrm{a}}$ edición, 2020, edición digital,https://biblioteca-tirantcom.ponton.uva.es/cloudLibrary/ebook/show/9788491693185\#ulNotai nformativaTitle.

BLASCO PELLICER, A. A.: La responsabilidad empresarial en el pago de Prestaciones de Seguridad Social, editorial Aranzadi Thomson Reuters, 2005, pp. 123-128.

BORRAJO DACRUZ, E.: «El contenido de la relación jurídica de seguro social», Revista de Derecho Mercantil, núm. 76, abril-junio 1960, pp. 301 a 342, y núm. 77, julio-septiembre 1960, pp. 57 a 116.

BRENES CORTÉS, J.: "Responsabilidad del representante persona física del administrador persona jurídica y su posible configuración como administrador de hecho", Revista Derecho Mercantil, no 310, 2018, Aranzadi, Comentarios de jurisprudencia, edición digital, https://insignis-aranzadidigitales.ponton.uva.es/maf/app/document?srguid.

BROSETA PONT, M.: Manual de Derecho Mercantil, 4ª edición, Tecnos, 1981.

BROSETA PONT, M. y MARTÍNEZ SANZ, F.: Manual de Derecho Mercantil, ed. Tecnos, $23^{\text {a }}$ edición, Vol. I, 2016.

CABANAS TREJO, R.: "Sobre el nuevo sistema de cómputo de las acciones de responsabilidad contra los administradores", Diario La Ley, abril de 2015, nº 8513.

CABEZA PEREIRO, J.: "Sobre el recargo, a la luz de la moderna jurisprudencia", en AA.VV. (Dir.: BORRAJO DACRUZ, E.): Accidentes de Trabajo y Mutuas, La Ley, Madrid, 2008. 
BIBLIOGRAFÍA

CALBACHO LOSADA, F.: El ejercicio de las acciones de responsabilidad contra los administradores de la sociedad anónima, ed. Tirant Lo Blanch, Valencia, 1999.

CAMINO FRÍAS, J. J.: "El procedimiento para extender las actas de liquidación y los supuestos de derivación de responsabilidad: algunas cuestiones", edición digital, http://itss.laley.es/Content/Documento.aspx?params, publicado en el Foro del Conocimiento del OEITSS. Ref. La Ley 13909/2009.

CAMINO FRÍAS, J. J.: "Un fenómeno emergente del fraude social: las empresas ficticias. Actuación de la Inspección de Trabajo y Seguridad Social”, Trabajo y Derecho, N ${ }^{o}$ 3, Sección Práctica Jurídica y Despachos Profesionales, editorial Wolters Kluwer, Ref. La Ley, edición digital https://laleydigital-laleynextes.ponton.uva.es/Content/Documento.aspx?params.

CAÑABATE POZO, R.: “Jurisdicción competente para determinar la responsabilidad de los administradores de una sociedad de responsabilidad limitada derivada del despido de un trabajador. (Comentario a la STSJ de Navarra de 18 junio 1999)", Revista Doctrinal Aranzadi Social vol. II, paraf. 40, BIB 1999\1542, edición digital, https://insignis-aranzadidigital-es.ponton.uva.es/maf/app/document?redirect=true\&srguid.

CARPENA NIÑO, J. M.: "La responsabilidad empresarial en materia de Seguridad Social por infracotizaciones", Revista del Ministerio de Trabajo y Asuntos Sociales, núm. 74, 2008.

CARRIÓN GARCÍA DE PARADA, P.: "De la disolución y Liquidación", La Sociedad de Responsabilidad Limitada, Tomo I, Colegios Notariales de España, Madrid, 1995, pp. 455-503.

CASAS BAAMONDE, M. ${ }^{a}$ E.: "Jurisdicción y competencia del orden social", en AA.VV. (Dir.: NOGUEIRA GUASTAVINO, M. y GARCÍA BECEDAS, G.): Lecciones de Jurisdicción Social, Tirant Lo Blanch, 2016, edición digital, https://biblioteca-tirant-com.ponton.uva.es.

CASTÁN TOBEÑAS, J.: Derecho Civil Español Común y Foral, Tomo 1º, $12^{\mathrm{a}}$ edición, editorial Reus, Madrid, 1978.

CAVAS MARTÍNEZ, F.: "Jurisdicción competente para determinar la responsabilidad solidaria de los administradores sociales por débitos laborales y de Seguridad Social”, Revista Doctrinal Aranzadi Social, Vol. II paraf. 30, 1998, BIB 
1998\1260, edición digital, https://insignis-aranzadidigitales.ponton.uva.es/maf/app/document?redirect=true\&srguid.

CAVAS MARTÍNEZ, F.: "La responsabilidad patrimonial de los socios y administradores sociales en el ámbito laboral”, Revista Doctrinal Aranzadi Social núm. 9/2002, edición digital, https://insignis-aranzadidigitales.ponton.uva.es/maf/app/document?redirect=true\&srguid.

CERDÁ ALBERO, F.: Administradores, insolvencia y disolución por pérdidas, ed. Tirant lo Blanch, Valencia, 2000.

CRUZ VILLALÓN, J.: "Notas acerca del régimen contractual en los grupos de empresa", en Temas Laborales, 1996, nº 38.

CRUZ VILLALÓN, J.: "El Empresario", en AA.VV. (CRUZ VILLALÓN, J. y DOMÍNGUEZ MORALES, A.), Revista Española de Derecho del Trabajo, núm. 215, 2018, Thomson Reuters, edición digital, https://insignis-aranzadidigitales.ponton.uva.es/maf/app/document?srguid.

CUADRADO RODRÍGUEZ, J. I.: La denuncia en el Derecho Tributario, ed. Marcial Pons, Madrid, 1995.

CUYÁS PRAT, D. y FAVÀ FERRÉ, I.: "Derivaciones de responsabilidad de deudas tributarias: cuestiones de actualidad", Actualidad Jurídica Aranzadi, núm. 958/2020 parte Artículo, Editorial Aranzadi, S.A.U., Cizur Menor. 2020, edición digital, https://insignis-aranzadidigital-es.ponton.uva.es/maf/app/document?srguid

DEL VAL TALENS, P.: El administrador persona jurídica en las sociedades de capital, Editorial Marcial Pons, Madrid, 2017.

DE LA CÁMARA ÁlVAREZ, M.: “La Administración de la Sociedad Anónima”, RJN, 1992, núm. 4.

DE ALCÁNTARA Y COLÓN, J. M.: "El recargo de prestaciones. Un análisis práctico”. Jurisprudencia de Información Laboral, Estudios nº 7, 2007.

DESDENTADO BONETE, A.: Administradores sociales, altos directivos y socios trabajadores. Calificación y concurrencia de relaciones profesionales, responsabilidad laboral y encuadramiento en la Seguridad Social, en AA.VV. (DESDENTADO BONETE, A. y DESDENTADO DAROCA, E.), Editorial Lex Nova, Valladolid, 2000. 
DESDENTADO BONETE, A.: "Responsabilidades por el incumplimiento de las obligaciones en materia de actos de encuadramiento en la Seguridad Social", Actualidad Laboral, núm. 4, quincena del 16 al 29 febrero de 2004, pp. 395 y ss, y núm. 5 quincena del 1 al 15 marzo 2004, pp. 523 y ss, editorial La Ley, ed. digital https://laleydigital-laleynext-es.ponton.uva.es/Content/Documento.aspx?params, ref. La Ley 313/2004.

DESDENTADO DAROCA E.: Administradores sociales, altos directivos y socios trabajadores. Calificación y concurrencia de relaciones profesionales, responsabilidad laboral y encuadramiento en la Seguridad Social, en AA.VV. (DESDENTADO BONETE, A. y DESDENTADO DAROCA, E.), Editorial Lex Nova, Valladolid, 2000.

DÍAZ ECHEGARAY, J. L.: La responsabilidad civil de los administradores de la sociedad anónima, editorial Montecorvo, Madrid, 1995.

DÍAZ ECHEGARAY, J. L.: Deberes y responsabilidades de los Administradores de Sociedades de Capital, editorial Thomson Aranzadi, 2a edición, 2006.

DÍAZ RODRÍGUEZ, J. M.: "La concurrencia lícita entre sanciones penales y administrativas para personas físicas y jurídicas en una misma empresa (a pesar de la STS 174/2019)", Trabajo y Derecho, Nº 61, Sección Jurisprudencia/Observatorio temático de jurisprudencia, enero 2020, Wolters Kluwer, Ref. La Ley 15230/2019.

DÍEZ-PICAZO Y PONCE DE LEÓN, L.: Sistema de Derecho Civil, en AA.VV. (DÍEZ-PICAZO Y PONCE DE LEÓN, L. y GULLÓN BALLESTEROS, A.), Vol. II, $2^{\mathrm{a}}$ edición, editorial Tecnos, 1979.

DUQUE GONZÁLEZ, M.: "El recargo de prestaciones como manifestación de la acción de regreso de la Seguridad Social (I): su incardinación en el sistema de protección social y su coordinación con el sistema de responsabilidad civil", Revista Española de Derecho del Trabajo, núm. 220/2019, edición digital https://insignisaranzadidigital-es.ponton.uva.es/maf/app/document?srguid.

DURÉNDEZ SÁEZ, I.: "Modificaciones recientes que afectan a la Inspección de Trabajo y Seguridad Social y al Procedimiento administrativo sancionador del orden social", Revista española de Derecho del Trabajo, núm. 151/2011 parte Estudios, editorial Civitas, Pamplona, 2011, BIB 2011\1083, edición digital https://insignis-aranzadidigital-es.ponton.uva.es/maf/app/document?srguid. 
DOMÍNGUEZ MORALES, A.: "El Empresario”, en AA.VV. (CRUZ VILLALÓN, J. y DOMÍNGUEZ MORALES, A.), Revista Española de Derecho del Trabajo, núm. 215, 2018, Thomson Reuters, edición digital, https://insignis-aranzadidigitales.ponton.uva.es/maf/app/document?srguid

EIZAGUIRRE BERMEJO, J. M.: "Disolución y liquidación: obligaciones", en AA.VV. (Dir.: SÁNCHEZ-CALERO GUILARTE, J.): Comentarios a la Ley de Sociedades Anónimas, Madrid. 1993.

ENTRENA CUESTA, R.: Curso de Derecho Administrativo, $5^{\circ}$ edición, ed. Tecnos, 1976.

ESTEBAN MONASTERIO, I.: "Responsabilidad de los administradores sociales por deuda pública", Revista Aranzadi Doctrinal, núm. 2/2020, parte Jurisprudencia, edición digital, https://insignis-aranzadidigital-es.ponton.uva.es/maf/app/document?redirect=true\&srguid.

ESTEBAN VELASCO, G.: “Algunas reflexiones sobre la Responsabilidad de los Administradores frente a los Socios y los Terceros: Acción individual y acción por no Promoción o Remoción de la disolución”, Revista Derecho de Sociedades, núm. 5, 1995, pp. 47-78.

ESTEBAN VELASCO, G.: "La acción individual de responsabilidad", en AA.VV. (Coord.: ROJO FERNÁNDEZ-RÍO, A. y BELTRÁN SÁNCHEZ, E. M.): La responsabilidad de los administradores de las sociedades mercantiles, Tirant Lo Blanch, $6^{\text {a }}$ edición, 2016, Valencia.

ESTEVE-SEGARRA, A.: "Responsabilidad de los administradores y directivos de la empresa por deudas laborales y de Seguridad Social por la crisis económica del coronavirus", en $R D S$, núm. 90, 2020.

FERNÁNDEZ DE LA GÁNDARA, L.: Derecho de Sociedades, Tirant Lo Blanch, Biblioteca Virtual, 2010, Vol. I, edición digital, https://biblioteca-tirantcom.ponton.uva.es/cloudLibrary/ebook/show.

FERNÁNDEZ DÍEZ, A. : "Prescripción de la responsabilidad del administrador por deudas de Seguridad Social de la sociedad", en Revista General de Derecho del Trabajo y de la Seguridad Social, n 56, julio 2020, pp. 430 a 488. 
FERNÁNDEZ DOMÍNGUEZ, J. J. y FERNÁNDEZ FERNÁNDEZ, R.: Incumplimientos empresariales en los actos de encuadramiento y responsabilidad de la mutua, Laboral Prácticos Abdón Pedrajas, ed. Tirant Lo Blanch, 2007.

FERNÁNDEZ ORRICO, F. J.: "Las actuaciones de advertencia y los requerimientos de la Inspección de Trabajo y Seguridad Social", Revista del Ministerio de Trabajo y Asuntos Sociales, № 78, 2008, recogida en el Foro del Conocimiento del OEITSS, edición digital http://itss.laley.es/Content/Documento.aspx?params=.

FERNÁNDEZ SEIJO, J. M.: “La prescripción de las acciones de responsabilidad”, en AA.VV. (Coord.: ROJO FERNÁNDEZ-RÍO, A. y BELTRÁN SÁNCHEZ, E. M.): La responsabilidad de los administradores de las sociedades mercantiles, $6^{\mathrm{a}}$ edición, 2016, ed. Tirant Lo Blanch, Valencia.

FERNÁNDEZ-COSTALES MUÑIZ, J.: Prevención de riesgos laborales y empresa: obligaciones y responsabilidades, editorial Aranzadi Thomson Reuters, 2019.

GALA DURÁN, C.: La responsabilidad empresarial por incumplimiento de las obligaciones de afiliación, alta y cotización a la Seguridad Social, editorial Aranzadi, Pamplona, 1997.

GALA DURÁN, C.: La responsabilidad laboral y de seguridad social de los administradores de las sociedades mercantiles, Editorial Bosch, 2007.

GARCÍA CRUCES, J. A.: "La responsabilidad concursal”, en AA.VV. (Coord.: ROJO FERNÁNDEZ-RÍO, A. y BELTRÁN SÁNCHEZ, E. M.): La responsabilidad de los administradores de las sociedades mercantiles, 6 a edición, ed. Tirant Lo Blanch, Valencia, 2016.

GARCÍA CRUCES, J. A.: Derecho de Sociedades Mercantiles, Tirant Lo Blanch, 2a edición, Valencia, 2019.

GARCÍA DE ENTERRÍA, E.: Curso de Derecho Administrativo, Volumen I, Cívitas, $2^{\circ}$ edición, y $2^{\mathrm{a}}$ reimpresión, Madrid, 1978.

GARCÍA FERNÁNDEZ, E.: Las declaraciones administrativas de responsabilidad. Derivación de deudas tributarias y de Seguridad Social, editorial Bosch, 2005.

GARCÍA-PITA Y LASTRES, J. L.: "La disolución de las Sociedad Anónima: Aspectos Generales", Cuadernos de Derecho y Comercio, núm. 6, diciembre de 1989, pp. 97-174. 
GARRETA SUCH, J. M.: La responsabilidad civil, fiscal y penal de los administradores de sociedades, Editorial Marcial Pons, $3^{\text {a }}$ edición, Madrid, 1996.

GARRIGUES, J.: Curso de Derecho Mercantil, Tomo I, 7ª edición, Madrid 1976.

GARRIGUES, J. y OLIVENCIA RUIZ, M.: en AA.VV. (GARRIGUES, J. y URÍA GONZÁlEZ, R.): Comentario a la Ley de Sociedades Anónimas, Tomo II, $3^{\mathrm{a}}$ edición revisada y puesta a día por MENÉNDEZ MENÉNDEZ, A. y OLIVENCIA RUIZ, M., Madrid, 1976.

GIRÓN TENA, J.: Derecho de Sociedades Anónimas, Valladolid, 1952.

GONZÁLEZ ORTEGA, S.: "La extensión de la jurisdicción social en materia de Seguridad Social y otras afines", Relaciones Laborales, Sección Doctrina, 1990, p. 351, Tomo 2, Editorial La Ley Ref. 405/2001, edición digital https://laleydigitallaleynext-es.ponton.uva.es/Content/Documento.aspx?params.

GUINOT BARONA, M.: "La naturaleza de los acuerdos de derivación de responsabilidad. Doctrina jurisprudencial. Consecuencias jurídicas sobre la recaudación de las deudas", Tribuna Fiscal, № 258, Sección Brújula, abril 2012, ed. digital https://aleydigital-laleynext-es.ponton.uva.es/Content/Documento.aspx?params, editorial CISS.

GUllón BALleSteros, A.: Sistema de Derecho Civil, en AA.VV. (DÍEZPICAZO Y PONCE DE LEÓN, L. y GULLÓN BALLESTEROS, A.), Vol. II, $2^{\text {a }}$ edición, editorial Tecnos, 1979.

GRIMALDOS GARCÍA, M. I.: "Presupuestos y extensión subjetiva de la responsabilidad. Solidaridad: artículos 236 y 237. Otras acciones por infracción del deber de lealtad: artículos 227.2 y 232", en AA.VV. (Coord.: HERNANDO CEBRIÁ, L.): Régimen de Deberes y Responsabilidades de los administradores en las sociedades de capital, ed. Bosch, 2015.

HERNÁNDEZ SAINZ, E.: La Administración de sociedades de capital por personas jurídicas. Régimen jurídico y responsabilidad, Aranzadi, 2014, edición digital, https://insignis-aranzadidigital-

es.ponton.uva.es/maf/app/document?start Chunk=1\&endChunk=2\&nsti $\underline{\mathrm{d}=\text { marginal \& } \mathrm{stid}=\text { marginal\&infoty } \mathrm{pe}=\text { biblos \& } \operatorname{marginal}=\mathrm{B} I \mathrm{~B} \backslash 2014 \backslash 9}$. 
HERNÁNDEZ SAINZ, E. : "El nuevo régimen de responsabilidad de los consejeros de sociedades mercantiles estatales: ¿hacia la irresponsabilidad por la gestión de sociedades públicas?”, RdS, núm. 47, 2016, edición digital, https://insignisaranzadidigital-es.ponton.uva.es/maf/app/document?srguid=

HERNANDO CEBRIÁ, L.: “¿Sociedad dominante administradora de hecho? Más allá del velo corporativo", Revista de Derecho Mercantil, núm. 280, 2011, parte Varia, editorial digital https://insignis-aranzadidigitales.ponton.uva.es/maf/app/document?srguid=.

HERRERA CUEVAS, E. J.: "La autotutela administrativa respecto de los actos de encuadramiento", Actualidad Laboral, Sección Doctrina, 1999, Ref. XII, p. 189, Tomo 1, La Ley, edición digital, https://laleydigital-laleynextes.ponton.uva.es/Content/Documento.aspx?params,

IGLESIAS PRADA, J. L.: Administración y delegación de facultades en la Sociedad Anónima, Editorial Tecnos, 1971.

JIMÉNEZ ROJAS, F.: La relación individual de trabajo en los grupos de empresa, ed. Editum, Murcia, 2014.

JIMÉNEZ SÁNCHEZ, G. J.: Lecciones de Derecho Mercantil, editorial Tecnos, 1992.

JIMÉNEZ SÁNCHEZ, J. J: “Algunas reflexiones, desde el punto de vista del Derecho del Trabajo, acerca de las acciones de responsabilidad frente a los administradores de las sociedades mercantiles; las cuestiones competencial material y procedimental”, Actualidad Laboral, núm. 40, 1996, pp. 765-778.

JUSTE MENCÍA, J.: “La posición del equipo directivo en la estructura de gobierno de la sociedad cotizada: la responsabilidad de los Consejeros ejecutivos y miembros de la Alta Dirección", en AA.VV. (Dir.: RODRÍGUEZ ARTIGAS, F.; ALONSO UREBA, A.; FERNÁNDEZ DE LA GÁNDARA, L.; VELASCO SAN PEDRO, L. A.; QUIJANO GONZÁlEZ, J.; y ESTEBAN VELASCO, G.): Derecho de Sociedades Anónimas cotizadas, Vol. II, Elcano, 2005.

LLEBOT MAJÓ, J. O.: “El sistema de la responsabilidad de los administradores”, en $R d S, \mathrm{n}^{\circ} 7,1996$.

LLEBOT MAJÓ, J. O.: “Deberes y Responsabilidades de los Administradores", en AA.VV. (Coord.: ROJO FERNÁNDEZ-RÍO, A. y BELTRÁN SÁNCHEZ, E. M.): 
La Responsabilidad de los Administradores de las Sociedades Mercantiles, $6^{\mathrm{a}}$ edición, 2016, ed. Tirant Lo Blanch, Valencia.

LLOMPART BENNÀSSAR, M.: "La responsabilidad en el ámbito laboral y de Seguridad Social", publicado en la monografía La responsabilidad de los administradores de sociedades de capital, $1^{\mathrm{a}}$ edición, editorial La Ley, Madrid, marzo 2011, Ref. La Ley 22232/2011, edición digital https://laleydigital-laleynextes.ponton.uva.es/Content/Documento.aspx?params.

LLUIS Y NAVAS, J.: "La extensión de reclamación de deudas a la Seguridad Social”, Actualidad Laboral, No 15, Sección Estudios, Quincena del 1 al 14 septiembre 2006, p. 1794, Tomo 2, editorial La Ley, Ref. La Ley 2250/2006, edición digital, https://laleydigital-laleynext-es.ponton.uva.es/Content/Documento.aspx?params

LÓPEZ GANDÍA, J.: Curso de Seguridad Social, en AA.VV. (BLASCO LAHOZ, J. F. y LÓPEZ GANDÍA, J.), Tirant Lo Blanch, 10ª edición, 2018, edición digital, https://biblioteca-tirant-com.ponton.uva.es/cloudLibrary/ebook/info/9788491906575.

LÓPEZ MEDRANO, F.: "Las acciones de daños y de cobertura del pasivo en el concurso de acreedores", Anuario de Derecho Concursal, nº 12 (2007-3).

MACHADO PLAZAS, J.: Pérdida del capital social y responsabilidad de los administradores por deudas sociales, Civitas, Madrid, 1997.

MANRIQUE LÓPEZ, F.: Manual de Derecho de la Seguridad Social, Universidad de Deusto, 1984, Bilbao.

MARÍN DE LA BÁRCENA GARCIMARTÍN, F.: "La acción individual de responsabilidad de los administradores de sociedad anónima frente a socios y terceros (artículo 135)”, RdS, núm 13, 1999.

MARÍN DE LA BÁRCENA GARCIMARTÍN, F.: La acción individual de responsabilidad de los administradores de las sociedades de capital (art. 135 LSA), editorial Marcial Pons, Madrid, 2005.

MARÍN DE LA BÁRCENA GARCIMARTÍN, F.: "Deberes y responsabilidades de los administradores ante la insolvencia de las sociedades de capital”. $R d S$, núm. 24, 2005, edición digital, https://insignis-aranzadidigitales.ponton.uva.es/maf/app/document?srguid=i0ad82d9b000001742f355 $\underline{b 4068993575 \& \text { marginal }=B I B \backslash 2005 \backslash 750 \& \text { doc guid }=I 5 b 4 f 746090}$. 
MARÍN DE LA BÁRCENA GARCIMARTÍN, F.: "Deberes de contabilidad y acción individual de responsabilidad. (STS $1^{\text {a }}$ de 22 de diciembre de 2014)", $R d S$, núm. 44, 2015, versión digital, https://insignis-aranzadidigitales.ponton.uva.es/maf/app/document?redirect=true\&srguid

MARTÍN JIMÉNEZ, R.: La responsabilidad de empresas y Administradores con la Seguridad Social, AA.VV. (MARTÍN JIMÉNEZ, R. y MATEOS BEATO, A.), Editorial Aranzadi Thomson Reuters, 2009.

MARTÍN JIMÉNEZ, R. y MATEOS BEATO, A.: La responsabilidad de empresas y Administradores con la Seguridad Social, Editorial Aranzadi Thomson Reuters, 2009.

MARTÍNEZ LUCAS, J. A.: "La configuración jurídica de la responsabilidad empresarial en orden a las prestaciones de la Seguridad Social”, Revista Española del Derecho del Trabajo, Cívitas, núm. 78, 1996.

MARTÍNEZ LUCAS, J. A.: "Las medidas cautelares para asegurar el cobro de las deudas con la Seguridad Social”, Actualidad Laboral, Sección Doctrina, 1999, p. 263, Tomo 1, editorial La Ley, Ref. La Ley 2570/2001, edición digital, https://laleydigital-laleynext-es.ponton.uva.es/Content/Documento.aspx?params.

MARTÍNEZ LUCAS, J. A.: "La suspensión del procedimiento recaudatorio de la Seguridad Social como consecuencia de la interposición de los recursos administrativos y reclamaciones previas”, Actualidad Administrativa, Sección Doctrina, 2000, pp. 649 y ss, Tomo 2, editorial La Ley, Ref. La Ley 1482/2001.

MARTÍNEZ LUCAS, J. A.: “Análisis del nuevo Reglamento General de Recaudación de la Seguridad Social: el Real Decreto 1415/2004, de 11 de junio", Actualidad Laboral, No 21, Sección Estudios, Quincena del 1 al 15 diciembre 2004, p. 2541, Tomo 2, editorial La Ley, Ref. La Ley 2444/2004, edición digital https://laleydigital-laleynext-es.ponton.uva.es/Content/Documento.aspx?params.

MARTÍNEZ LUCAS, J. A.: "Responsabilidad de los administradores por cuotas de la Seguridad Social", Actualidad Laboral, $\mathrm{n}^{\mathbf{0}}$ 1, 2005, edición digital https://laleydigital-laleynext-es.ponton.uva.es/Content/Documento.aspx?params .

MARTÍNEZ SANZ, F. y BARTLE AGUSTÍN, M.: "Los administradores responsables", en AA.VV. (Coord.: ROJO FERNÁNDEZ-RÍO, A. y BELTRÁN 
SÁNCHEZ, E. M.): La responsabilidad de los administradores de las sociedades mercantiles, $6^{\text {a }}$ edición, 2016, ed. Tirant Lo Blanch, Valencia.

MARTÍNEZ-GIRÓN MACHUCA, P.: “Algunas reflexiones sobre la responsabilidad de los administradores en los grupos de sociedades tras la Sentencia del Tribunal Supremo de 11 de diciembre de 2015", en AA.VV. (Coord.: BRENES CORTÉS, J.; Dir.: DÍAZ MORENO, A.; y VÁZQUEZ CUETO, J. C.): Estudios sobre la responsabilidad de los administradores de las sociedades de capital a la luz de sus recientes reformas legislativas y pronunciamientos judiciales, Thomson Reuters Aranzadi, 2018, $1^{\text {a }}$ edición.

MAS-GUINDAL GARCÍA, J.: "La responsabilidad de los administradores sociales. Una aproximación al régimen del artículo 241 de la Ley de Sociedades de Capital”, en AA.VV. (Dir.: MARTÍNEZ-ECHEVERRÍA Y GARCÍA DE DUEÑAS, A.): Gobierno Corporativo: la Estructura del órgano de Gobierno y la Responsabilidad de los Administradores, Aranzadi Thomson Reuters, $1^{\text {a }}$ edición, 2015.

MASSAGUER FUENTES, J.: “Artículo 241 bis. Prescripción de las acciones de responsabilidad", en AA.VV. (Coord.: JUSTE MENCÍA, J.): Comentario de la reforma del régimen de sociedades de capital en materia de gobierno corporativo (ley 31/2014), Thomson Reuters, Navarra 2015.

MATEOS BEATO, A.: La responsabilidad de empresas y Administradores con la Seguridad Social, en AA.VV. (MARTÍN JIMÉNEZ, R. y MATEOS BEATO, A.), Editorial Aranzadi Thomson Reuters, 2009.

MÉNDEZ SEBASTIÁN, P.: "La cuadratura del círculo procesal de las responsabilidades por accidente de trabajo. En particular, la vinculación entre las decisiones judiciales sobre recargo, sanción e indemnización por daños”, Trabajo y Derecho, núm. 55, julio 2019, Smarteca, edición digital https://laleydigitallaleynext-es.ponton.uva.es/Content/Documento.aspx?params, pp. 1-21.

MERCADER UGUINA, J. R.: Los Procedimientos Administrativos en materia de Seguridad Social, Aranzadi Thomson Reuters, 2017.

MERCADER UGUINA, J. R. y SÁNCHEZ GRANDE, A.: “Anotaciones al Reglamento general sobre procedimiento sancionador y liquidatorio del orden social (Novedades del RD 928/1998, de 14 de mayo)”, Relaciones Laborales, ${ }^{\circ}$ 20, Sección Legislación, Quincena del 16 al 31 octubre 1998, p. 1109, Tomo 2, 
editorial La Ley, edición digital,

https://laleydigital-laleynextes.ponton.uva.es/Content/Documento.aspx?params.

MERCADER UGUINA, J. R. y SÁNCHEZ GRANDE, A.: "Nuevas adaptaciones del Reglamento General de Recaudación de Recursos del Sistema de Seguridad Social: el Real Decreto 2032/1998, de 25 de septiembre", Relaciones Laborales, № 22, Sección Legislación, Quincena del 16 al 30 noviembre 1998, p. 1129, Tomo 2, editorial La Ley, edición digital, $\quad$ https://laleydigital-laleynextes.ponton.uva.es/Content/Documento.aspx?params.

MERCADER UGUINA, J. R. y SÁNCHEZ GRANDE, A.: "La Ley Ordenadora de la Inspección de Trabajo y Seguridad Social (Consideraciones en torno a la Ley 42/1997, de 14 de noviembre)”, Relaciones Laborales, N 3, Sección Legislación, Quincena del 1 al 15 febrero 1998, p. 865, Tomo 1, editorial La Ley, Ref. La Ley 6481/2002, edición digital https://laleydigital-laleynextes.ponton.uva.es/Content/Documento.aspx?params.

MERCADER UGUINA, J. R. y TOLOSA TRIBIÑO, C.: "Notas al Reglamento de ordenación y funcionamiento de la Inspección de Trabajo y Seguridad Social", Relaciones Laborales, № 13, Sección Legislación, Quincena del 1 al 15 julio 2000, p. 1043, Tomo 2, editorial La Ley, Ref. La Ley 6467/2002, edición digital https://laleydigital-laleynext-es.ponton.uva.es/Content/Documento.aspx?params.

MERCADER UGUINA, J. R. y DE LA PUEBLA PINILLA, A.: "Reflexiones en torno al Reglamento General de Recaudación de los recursos de la Seguridad Social: el RD 1415/2004, de 11 de junio", Relaciones Laborales, № 22, Sección Legislación, Quincena del 23 noviembre al 8 diciembre 2004, Año XX, p. 1131, Tomo 2, editorial La Ley, edición digital https://laleydigital-laleynextes.ponton.uva.es/Content/Documento.aspx?params.

MERCADER UGUINA, J. R. y SUÁREZ CORUJO, B.: “La responsabilidad laboral y de Seguridad Social de los Administradores Sociales", en AA.VV. (Coord.: ROJO FERNÁNDEZ-RÍO, A. y BELTRÁN SÁNCHEZ, E. M.): La responsabilidad de los administradores de las sociedades mercantiles, $6^{\text {a }}$ edición, 2016, Tirant Lo Blanch, Valencia.

MOLINA NAVARRETE, C.: Persona jurídica y disciplina de los grupos de empresa, Ed. Publicaciones del Real Colegio de España, Bolonia, 1995. 
MOLINA NAVARRETE, C.: “Otra vez a vueltas con el problema de la configuración jurídica del recargo de prestaciones por omisión de las medidas sobre prevención de riesgos: la nueva modernidad de una institución jurídica clásica”. Revista Española de Derecho del Trabajo, $\mathrm{n}^{\circ}$ 79, septiembre/octubre 1996.

MOLINA NAVARRETE, C.: "Capítulo 3. Especialidades procesales en materia de prestaciones de la seguridad social y acumulación de acciones en procesos sobre contingencias profesionales", en AA.VV. (DE LA PUEBLA PINILLA, A. et altri): Análisis de la nueva Ley Reguladora de la Jurisdicción Social, 1 1 edición, Tirant Lo Blanch, 2014.

MOLINS GARCÍA-ATANCE, J.: "El grupo de empresas con efectos laborales", Trabajo y Derecho, ed. La Ley, № 4, abril 2015, edición digital.

MONEREO PÉREZ, J. L. “Aspectos laborales de los grupos de empresas”, Revista Española Derecho del Trabajo, núm. 21, 1985.

MONEREO PÉREZ, J. L.: "El recargo de prestaciones por incumplimiento de las medidas de seguridad e higiene en el trabajo", Cívitas, 1992, Madrid.

MONEREO PÉREZ, J. L.: Teoría jurídica de los grupos de empresas y Derecho del Trabajo, Editorial Comares, 1997.

MONEREO PÉREZ, J. L. y SÁNCHEZ PÉREZ, J.: ’El recargo de prestaciones y la nueva doctrina jurisprudencial. Una reflexión crítica a propósito de las sentencias del Tribunal Supremo de 4 y de 23 de marzo de 2015", Trabajo y Derecho, № 12 , diciembre 2015, Editorial Wolters Kluwer, edición digital https://aleydigitallaleynext-es.ponton.uva.es/Content/Documento.aspx?params

MONTOYA MELGAR, A.: "El poder de dirección del empresario en las estructuras empresariales complejas", Revista del Ministerio de Trabajo y Asuntos Sociales, $\mathrm{N}^{\circ}$ 48, 2004, edición digital, http://itss.laley.es/Content/Documento.aspx?params.

MONTOYA MELGAR, A.: “Capítulo I. De la Jurisdicción”, en AA.VV. (SEMPERE NAVARRO, A. V.): Comentarios a la Ley de la Jurisdicción Social, Thomson Reuters Aranzadi, $3^{\text {a }}$ edición, marzo 2013.

MORALES BARCELÓ, J.: la responsabilidad de los administradores de las sociedades mercantiles en situación de pérdidas y de insolvencia, editorial Tirant Lo Blanch, 2013, edición digital,

https://biblioteca-tirant- 
com.ponton.uva.es/cloudLibrary/ebook/show/9788490330821\#ulNotai nformativaTitle.

MORENO SERRANO, E.: "La responsabilidad de la sociedad matriz como administrador de hecho", en AA.VV. (Coord.: BRENES CORTÉS, J.): Estudios sobre la responsabilidad de los administradores de las sociedades de capital a la luz de sus recientes reformas legislativas y pronunciamientos judiciales, Thomson Reuters Aranzadi, 2018, $1^{\text {a }}$ edición.

MOYA BALLESTER, J.: la responsabilidad de los administradores de sociedades en situaciones de crisis, editorial La Ley, Madrid, 2010.

MOYA JIMÉNEZ, A.: la responsabilidad de los administradores de empresas insolventes, editorial Bosch, 10ª edición, 2015.

MUÑOZ MARTíN, N.: "Pérdidas de la Sociedad de Responsabilidad Limitada", en Estudios de Derecho Mercantil, Homenaje al profesor Justino F. Duque, Valladolid, 1998, pp. 511 y ss.

MUÑOZ MOLINA, J.: Responsabilidad empresarial en materia de prestaciones de la Seguridad Social, ed. Tirant Lo Blanch, 1999.

MUÑOZ PAREDES, A.: La responsabilidad de los administradores societarios, Editorial Thomson Reuters Aranzadi, $1^{\text {a }}$ edición, 2018.

MUÑOZ PAREDES, A.: Tratado judicial de la responsabilidad de los administradores. La responsabilidad societaria. Editorial Thomson Reuters Aranzadi, Vol. I, $1^{\text {a }}$ edición, 2015.

NAVARRO FRÍAS, I.: "Sociedades públicas: Derecho mercantil vs Derecho administrativo. En particular, deberes y responsabilidad de los administradores de sociedades públicas estatales", $R d S$, núm. 56, 2019, edición digital - https://insignisaranzadidigital-es.ponton.uva.es/maf/app/document?srguid-

NICOLÁS BERNAD, J. A.: "La responsabilidad de los administradores sociales ante la Inspección de Trabajo”, Revista de Derecho Social, núm. 17/2002.

NICOLÁS BERNAD, J. A.: “Un obstáculo para la derivación administrativa de responsabilidad por deudas sociales a entes societario por incumplimiento de la normativa mercantil”, Boletín Aranzadi Laboral, núm. 4/2003 parte Boletín, 
editorial Aranzadi, S.A.U., Cizur Menor. 2003, edición digital, https://insignisaranzadidigital-es.ponton.uva.es/maf/app/document?srguid.

NICOLÁS BERNAD, J. A.: "'Acciones por subrogación del FOGASA en supuestos de despatrimonialización empresarial”, Revista General Del Derecho del Trabajo y Seguridad Social, n 48, 2018, pp. 33-69.

PÁRAMO MONTERO, P.: "Prueba e instrucción de las actas de la Inspección de Trabajo y Seguridad Social”, Diario La Ley, Sección Doctrina, 1998, Ref. D-208, Tomo 4, editorial La Ley, Ref. La Ley 11702/2001, edición digital https://laleydigital-laleynext-es.ponton.uva.es/Content/Documento.aspx?params.

PAZ-ARES RODRÍGUEZ, J. C.: "Sobre la Infracapitalización de las Sociedades", en Anuario de Derecho Civil, Tomo XXXVI, Fascículo III, julio-septiembre de 1983, pp. 1587-1639.

PEÑA LÓPEZ, F.: La culpabilidad en la responsabilidad civil extracontractual, Ed. Comares, Granada, 2002.

PÉREZ CAPITÁN, L.: “Una aproximación al estudio de la responsabilidad derivada en materia de cotización a la Seguridad Social”, Revista Doctrinal Aranzadi Social, Vol. V, editorial Aranzadi, BIB 1998\1190, edición digital https://insignisaranzadidigital-es.ponton.uva.es/maf/app/document?srguid.

PÉREZ DE LOS COBOS ORIHUEL, F.: “Filialización. Grupos de empresa", en Descentralización productiva y nuevas formas organizativas del trabajo, $\mathrm{X}^{\mathrm{o}}$ Congreso Nacional de Derecho del Trabajo y de la Seguridad Social, Ministerio de Trabajo y Asuntos Sociales, Madrid, 2000.

PÉREZ CARRILLO, E. F.: "El deber de diligencia de los administradores de sociedades", $R d S$, núm. 14, 2000.

PIÑOLETA ALONSO, L. M.: "La extinción de la sociedad”, Comentario a los arts. $395 a$ 397, en AA.VV. (Coord.: ROJO FERNÁNDEZ-RÍO, A. et altri.): Comentario de la Ley de Sociedades de Capital, Tomo II, Civitas Thomson Reuters, 2011, pp. 2704-2729.

PIÑOLETA ALONSO, L. M. “Activo y pasivo sobrevenido", Comentario a arts. 398 a 400, en AA.VV. (Coord.: ROJO FERNÁNDEZ-RÍO, A. et altri.): Comentario de 
la Ley de Sociedades de Capital, Tomo II, Civitas Thomson Reuters, 2011, pp. 2730-2750.

POLO SÁNCHEZ, E.: "Los administradores y el Consejo de Administración de la Sociedad Anónima (arts. 123 a 143 de la LSA)", en AA.VV. (Dir.: URÍA GONZÁLEZ, R.; MENÉNDEZ MENÉNDEZ, A.; y OLIVENCIA RUIZ, M.): Comentario al Régimen Legal de las Sociedades Mercantiles, T. VI, editorial Civitas, Madrid, 1992.

PULGAR EZQUERRA, J.: "El presupuesto objetivo de apertura del concurso de acreedores", en AA.VV. (Dir.: GARCÍA VILLAVERDE, R.; ALONSO UREBA, A.; y PULGAR EZQUERRA, J.): Derecho concursal. Estudio Sistemático de la Ley 22/2003 y de la Ley 8/2003 para la reforma concursal, Editorial Dilex, Madrid, 2003.

PRADES CUTILLAS, D.: La responsabilidad del administrador en las sociedades de capital en la jurisprudencia del Tribunal Supremo, Ed. Tirant Lo Blanch, 2014, ed. digital, https://biblioteca-tirant-com.ponton.uva.es/cloudLibrary/ebook/show/9788490338469.

QUIJANO GONZÁLEZ, J.: La responsabilidad civil de los administradores de la Sociedad Anónima, aspectos sustantivos, ed. Universidad de Valladolid, 1985.

QUIJANO GONZÁLEZ, J.: "La responsabilidad civil de los administradores de la sociedad anónima en el Texto Refundido de 22 de diciembre de 1989”, Boletín Informativo del Colegio de Abogados de Valladolid, 1990, núm. 4.

QUIJANO GONZÁLEZ, J.: "Principales aspectos del estatuto jurídico de los administradores: nombramiento, duración, retribución, conflicto de intereses separación; los suplentes", RdS, número extraordinario, 1994, La Reforma del Derecho de Sociedades de Responsabilidad Limitada,Tomo I, pp. 642-676.

QUIJANO GONZÁLEZ, J.: "Responsabilidad de los administradores por no disolución de la sociedad (art. 262.5 TRLSA) (Sentencia de la Audiencia Provincial de Burgos de 24 de julio de 1995)", RdS, n 5, 1995, pp. 265-282.

QUIJANO GONZALEZ, J.: "La responsabilidad de los administradores por la no disolución de la sociedad y las causas de exoneración”, $R d S$, n 19, año 2002, pp. 73 a 87. 
QUIJANO GONZÁLEZ, J.: "Responsabilidad societaria y concursal de administradores: de nuevo sobre la coordinación y el marco de relaciones", $R D C P$, núm. 10/2009, pp. 19 a 48 y edición digital.

QUIJANO GONZÁLEZ, J.: “La responsabilidad concursal tras la Ley 38/2011 de reforma de la Ley Concursal”, RDCP, núm. 18/2013, edición digital.

QUIJANO GONZÁLEZ, J.: “Coordinación de acciones societarias (social, individual y por deudas) y concursales de responsabilidad", $R D C P, \mathrm{n}^{\circ} 22,2015$, edición digital.

QUIJANO GONZÁLEZ, J., "Los deberes de los administradores sociales y la calificación del concurso (Comentario de la sentencia del Tribunal Supremo, Sala $1^{\mathrm{a}}$, de 20 de diciembre de 2017)", Anuario de Derecho Concursal, $\mathrm{n}^{\mathrm{o}}$ 44/2018, comentarios de jurisprudencia, edición digital, https://insignis-aranzadidigitales.ponton.uva.es/maf/app/document?srguid=i0ad6adc500000174448924f9bb5681c $\underline{\mathrm{b} \& \text { marginal }=\mathrm{BIB} \backslash 2018 \backslash 9378 \& \text { docguid }=\mathrm{Ibbfd} 8 \mathrm{fc} 05 \mathrm{f}}$.

QUIJANO GONZÁLEZ, J.: “Capital social y pérdidas cualificadas: Deberes y responsabilidades de los administradores”, $R D C P, \mathrm{n}^{\circ} 31$, 2019, edición digital, pp. $1-13$.

QUIJANO GONZÁLEZ, J.: “Acción individual de responsabilidad de Administradores e ilícito orgánico (a propósito de la Sentencia del Tribunal Supremo, de 4 de noviembre de 2019)", RDCP, n 32, enero 2020, edición digital en Smarteca, pp. 1 a 16.

QUIJANO GONZÁLEZ, J.: "Los órganos societarios y el Estado de Alarma", Diario la Ley, $\mathrm{N}^{\mathrm{o}}$ 9675, Sección Tribuna, 16 de julio de 2020, edición digital https://diariolaley.laleynext.es/Content/Documento.aspx?params.

QUIJANO GONZÁLEZ, J. y MAMBRILLA RIVERA, V.: "Los deberes fiduciarios de diligencia y lealtad, en particular los conflictos de interés y las operaciones vinculadas", en AA.VV. (Coord.: RODRÍGUEZ ARTIGAS, F.): Derecho de sociedades anónimas cotizadas: estructura de gobierno y mercados, Thomson Reuters Aranzadi, Vol. II, 2006.

RODRÍGUEZ ARTIGAS, F.: Consejeros delegados, Comisiones Ejecutivas y Consejos de Administración, Madrid 1978. 
RODRÍGUEZ ARTIGAS, F.: "El deber de diligencia", en AA.VV. (Coord.: ESTEBAN VELASCO, G.): El gobierno de sociedades cotizadas, Madrid, 1999.

RODRÍGUEZ ARTIGAS, F. y MARÍN DE LA BÁRCENA GARCIMARTÍN, F.: “Algunas cuestiones sobre la responsabilidad de los administradores de la Sociedad a por no promoción de la disolución en caso de pérdidas (art. 265.2 LSA). STS 16 de diciembre de 2004”, $R d S, \mathrm{n}^{\circ} 24,2005$, pp. 295 y ss.

RODRÍGUEZ ARTIGAS, F. y MARÍN DE LA BÁRCENA GARCIMARTÍN, F.: 'La acción social de responsabilidad", en AA.VV. (Coord.: GUERRA MARTÍN, G.): La responsabilidad de los administradores de sociedades de capital, Madrid, 2011.

RODRÍGUEZ DÍAZ, I.: “Cómo opera la responsabilidad solidaria del representante con el administrador persona jurídica”, Diario La Ley, $N^{\circ}$ 9304, Sección Tribuna, 22 de noviembre de 2018, edición digital, https://diariolaley.laleynext.es/Content/Documento.aspx?params=H4sIAAAAAAA EAMtMSbF1CTEAAiMLE0sTY7Wy1KLizPw8WyMDQwtDQwMjtbz81NQQF2f b0ryU1LTMvNQUkJLMtEqX_OSQyoJU25Ki01S11KT8_GwUg-LhBqSm.

RODRÍGUEZ-SAÑUDO GUTIÉRREZ, F.: “Garantías jurídicas para el empresario ante la actuación sancionadora de la Inspección de Trabajo". Actualidad Laboral, $\mathrm{N}^{\mathrm{o}}$ 6, Sección Estudios, Quincena del 16 al 31 marzo 2007, p. 684, Tomo 1, editorial La Ley, Ref. La Ley 1015/2007, edición digital, https://laleydigital-laleynext-es.ponton.uva.es/Content/Documento.aspx?params.

RODRÍGUEZ RUIZ DE LA VILLA, D. y HUERTA VIESCA, M. I.: La responsabilidad de los administradores por las deudas de las Sociedades de Capital (en las Leyes de Sociedades Anónimas, de Sociedades de Responsabilidad Limitada, de Sociedad Limitada Nueva Empresa, Concursal, General Tributaria y de Responsabilidad Medioambiental), 2a edición, Aranzadi, 2008.

RODRÍGUEZ RUIZ DE LA VILLA, D. y HUERTA VIESCA, M. I.: "La responsabilidad por deudas de los nuevos administradores sociales de la sociedad de capital en causa legal de disolución”, Diario La Ley, núm. 9556, Sección Tribuna, 20 de enero de 2020, edición digital, https://diariolaley.laleynext.es/Content/Documento.aspx?params=H4sIAAAAAAA 


\section{EAFXMsQqEMBCE4acx9WYVxCKVeYT0x-mOsAhZ8aLg2xubA6f4q-} FTkRAT1bXUMvXuxP5Ty4HJD549uWyCFMdwZMGiGfJcdLmizenaEMp-wGE

RODRÍGUEZ SÁNCHEZ, S.: "La delimitación de la figura del administrador de hecho", $R d S$, núm. 301, 2016, edición digital, https://insignis-aranzadidigitales.ponton.uva.es/maf/app/document?srguid=i0ad82d9b0000017448ff865bd89df112 \&marginal=BIB $2016185617 \&$ docguid=I06c70da0.

ROJO FERNÁNDEZ-RÍO, A.: "Los deberes legales de los administradores en orden a la disolución de la sociedad de capital como consecuencia de pérdidas", en Derecho de Sociedades, Estudio en Homenaje a Sánchez Calero, Vol. II. Madrid, 2002, pp. 1437 y ss.

RUBIO GARDA-MINA, J.: Curso de Derecho de sociedades Anónimas S.A, Madrid, 1964.

RUIZ GONZÁLEZ, M. A.: “Análisis del Real Decreto-Ley 16/2020, de 28 de abril, de medidas procesales y organizativas para hacer frente al Covid-19 en el ámbito de la Administración de Justicia”, Diario La Ley, № 9640, Tribuna, 26 de mayo de 2020, edición digital.

RUIZ MUÑOZ, M.: "Fundamento y naturaleza jurídica de la responsabilidad de los administradores del artículo 262.5 LSA (artículo 105 LSRL): análisis contractualrepresentativo", Revista de Derecho Mercantil, n 24, abril-junio 2002.

SACRISTÁN ENCISO, J. I.: "La nueva Ley 23/2015, de 21 de julio, Ordenadora del Sistema de Inspección de Trabajo y Seguridad Social. La reforma de un servicio público comprometido con la calidad del empleo", Trabajo y Derecho, $\mathrm{N}^{\mathrm{o}} 3$, Sección Estudios, editorial Wolters Kluwer, Ref. La Ley 3426/2016, edición digital https://laleydigital-laleynext-es.ponton.uva.es/Content/Documento.aspx?params.

SALDAÑA VILLOLDO, B.: La acción individual de responsabilidad. Su significado en el sistema de responsabilidad de los administradores sociales (estudio jurisprudencial). $1^{\text {a }}$ edición 2009, Tirant Lo Blanch, Valencia.

SALDAÑA VILLOLDO, B.: "Nuevos problemas de la responsabilidad de los administradores: la acción social y la responsabilidad por deudas tras la Ley 3/2014”, en AA.VV. (Coord.: EMBID IRUJO, J. M. y NIETO CAROL, U.): 
BIBLIOGRAFÍA

Estudios de Derechos de Sociedades, Tirant Lo Blanch, Valencia, 2019, pp. 123165.

SALINAS ADELANTADO, C.: "El nuevo escenario preconcursal y concursal después del RDL 16/2020 y el TRLC: ¿Realmente hay que esperar a 2021 para tomar decisiones?”, en Diario La Ley, No 9652, Tribuna, 12 de junio de 2020, edición digital.

SÁNCHEZ ÁLVAREZ, M. M.: “Grupos de Sociedades y responsabilidad de los administradores”, Revista de Derecho Mercantil, no 227, 1998, pp. 117-154.

SÁNCHEZ-BARRIGA PEÑAS, R.: "Reserva de Ley y cotización a la Seguridad Social (Especial referencia a la cotización adicional por horas extraordinarias)", Relaciones Laborales, Sección Comentarios de Jurisprudencia, 1992, p. 460, Tomo I, editorial La Ley, Ref. La Ley 905/2001, edición digital https://laleydigitallaleynext-es.ponton.uva.es/Content/Documento.aspx?params

SÁNCHEZ-BUSTAMANTE Y DE LA HERRÁN, J. M.: "Declaración de responsabilidad de los administradores societarios por la Tesorería General de la Seguridad Social: una competencia por resolver", Diario La Ley, No 5896, 19 de noviembre de 2003, editorial La Ley, edición digital, https://laleydigital-laleynextes.ponton.uva.es/Content/Documento.aspx?param.

SÁNCHEZ CALERO, F.: Los administradores en las sociedades de capital, 2a edición, Aranzadi Thomson Cívitas, Pamplona, 2007.

SÁNCHEZ CALERO, F.: “Administradores (arts. 123 a 143)”, en AA.VV. (Dir.: SÁNCHEZ CALERO, F.): Comentarios a la Ley de Sociedades Anónimas, Editoriales de Derecho Reunidas, Madrid, T. IV, 1994.

SÁNCHEZ-CALERO GUILARTE, J.: "Deber de solicitar la declaración de concurso (Artículo 5)", en AA.VV. (Dir.: SÁNCHEZ-CALERO GUILARTE, J. y GUILARTE GUTIÉRREZ, V.): Comentarios a la Legislación Concursal, Tomo I, Lex Nova, Valladolid, 2004.

SÁNCHEZ PUERTA, D. A.: Jurisdicción y Seguridad Social. La competencia jurisdiccional en materia de Seguridad Social, ediciones Laborum, Murcia, 2020.

SANTAELLA SÁEZ, O.: "Cuestiones prácticas de la responsabilidad del administrador societario para responder de las deudas sociales", en Diario La Ley, 
$\mathrm{n}^{\circ} 9403$, de 25 de abril de 2019 ,

edición digital, https://diariolaley.laleynext.es/Content/Documento.aspx?params=H4sIAAAAAAA EAMtMSbF1CTEAAiNLI0sLA7Wy1KLizPw8WyMDQ0sDYyNTtbz81NQQF2fb OryU1LTMvNQUkJLMtEqX_OSQyoJU25Ki01S11KT8_GwUg-LhBqSm, pp. 1 a 24.

SELMA PENALVA, A.: "La relación laboral encubierta. La "sociedad unipersonal" como forma de simulación”, Revista española de Derecho del Trabajo, núm. 143, 2009, editorial Cívitas, BIB 20091794.

SEMPERE NAVARRO, A. V.: "La responsabilidad empresarial en contingencias profesionales tras la STS 1 febrero 2000”, Aranzadi Social, núm. 4/2000, BIB 2000\349, edición digital https://insignis-aranzadidigitales.ponton.uva.es/maf/app/document?srguid.

SEMPERE NAVARRO, A. V. y ARETA MARTÍNEZ, M.: "El Derecho del Trabajo y los Grupos de Empresas: inventario", Revista del Ministerio de Trabajo y Asuntos Sociales, No 48, 2004, edición digital, en El foro del conocimiento de la ITSS, http://itss.laley.es/Content/Documento.aspx?params.

SEMPERE NAVARRO, A. V. y MARTÍN JIMÉNEZ, R.: "El recargo de prestaciones: puntos críticos", Revista del Ministerio de Trabajo y Asuntos Sociales, $\mathrm{N}^{\mathrm{o}}$ 53, 2004, publicado en el foro del conocimiento de la ITSS, https://itss.laley.es/Content/DocumentoTDC.aspx?params, editorial La Ley, Ref. La Ley $14641 / 2009$.

SEQUEIRA MARTÍN, A.: "De la disolución y Liquidación", en AA.VV. (Coord.: ARROYO MARTÍNEZ, I. e EMBID IRUJO, J. M.): Comentarios a la Ley de Sociedades anónimas, Tecnos, Madrid, 2001.

SUÁREZ-LLANOS GÓMEZ, L.: "Responsabilidad de los administradores en la sociedad anónima", Anuario de Derecho Civil, Vol. 15, n 4, 1962.

SUÁREZ-LLANOS GÓMEZ, L.: "La responsabilidad por deudas de los administradores de la sociedad anónima”, en Estudios jurídicos en homenaje del profesor Aurelio Menéndez, Vol. II, Madrid, 1996.

TOLOSA TRIBIÑO, C.: "Una nueva perspectiva en las relaciones entre la jurisdicción Laboral y la Contencioso-Administrativa", Actualidad Laboral, Sección Doctrina, 
1998, Ref. XLIII, pp. 685 y ss, Tomo 3, editorial La Ley, Ref. La Ley 2996/2001, ed. digital, https://aleydigital-laleynext-es.ponton.uvaes/Content/Documento.aspx?params.

TOLOSA TRIBIÑO, C.: "La aplicación de los principios de la potestad sancionadora a las infracciones del orden social”, Actualidad Laboral, Sección Doctrina, 1999, Ref. XLIII, p. 681, Tomo 3, editorial La Ley, Ref. La Ley 3030/2001, edición digital Smarteca.

TRILLO GARCÍA, A. R.: “Artículo 30. Reclamaciones de deudas”, en AA.VV. (Dir.: GARCÍA-PERROTE ESCARTÍN, I. y MERCADER UGUINA, J. R.): Comentarios a la Ley General de la Seguridad Social, editorial Lex NovaThomson Reuters, $1^{\text {a }}$ edición, julio 2015.

TRILLO GARCÍA, A. R.: "Artículo 31. Actas de liquidación de cuotas”, en AA.VV. (Dir.: GARCÍA-PERROTE ESCARTÍN, I. y MERCADER UGUINA, J. R.): Comentarios a la Ley General de la Seguridad Social, editorial Lex Nova-Thomson Reuters, $1^{\text {a }}$ edición, julio 2015.

VALPUESTA GASTAMINZA, E.: Comentarios a la Ley de Sociedades de Capital, $3^{\mathrm{a}}$ edición, editorial Bosch Wolters Kluwer, Madrid, 2018

VICENT CHULIÁ, F.: “Compendio Crítico del Derecho Mercantil”, Madrid, 1991.

VICENT CHULIÁ, F.: La Responsabilidad de los administradores en sociedades no operativas”, Derecho de los negocios, Año no 4, No 28, 1993, pp. 1-10.

VICENT CHULIÁ, F.: "La responsabilidad de los administradores en el concurso", $R D C P, \mathrm{n}^{\circ} 4,2006$, pp. 15 y ss.

VICENT CHULIÁ, F.: “Grupos de sociedades y conflictos de intereses”, Revista de Derecho Mercantil, núm. 280, 2011, pp. 19-43, edición digital https://insignisaranzadidigital-

es.ponton.uva.es/maf/app/document?srguid=i0ad82d9a000001744955ae86ecf341d3

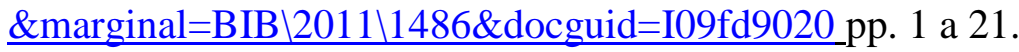

VILLAR EZCURRA, M.: "La responsabilidad tributaria", en AA.VV. (Coord.: ROJO FERNÁNDEZ-RÍO, A. y BELTRÁN SÁNCHEZ, E. M.): La responsabilidad de los administradores de las sociedades mercantiles, $6^{\text {a }}$ edición, ed. Tirant Lo Blanch, Valencia, 2016, pp. 589-649. 
VINUESA ALADRO, A.: "La Inspección de Trabajo y Seguridad Social: Ley 42/1997, de 14 de noviembre", Actualidad Laboral, Sección Doctrina, 1998, Ref. XII, p. 157, Tomo 1, editorial La Ley, Ref. La Ley 2547/2001, edición digital https://laleydigital-laleynext-es.ponton.uva.es/Content/Documento.aspx?params.

ZABALA RODRÍGUEZ-FORNOS, A.: "Responsabilidad tributaria y responsables del tributo", en Comentarios a la Ley General Tributaria, coordinado por HERRERO DE EGAÑA Y ESPINOSA DE LOS MONTEROS, J. M., Ed. Thomson-Aranzadi, $1^{\circ}$ edición, 2008, p. 333 y ss. 